\title{
Bibliography of Ground-Water References for All 254 Counties in Texas, 1886-2001
}

Open-File Report 2005-1270 
Blank Page 


\section{Bibliography of Ground-Water References for All 254 Counties in Texas, 1886-2001}

Compiled By E.T. Baker, Jr.

Open-File Report 2005-1270

U.S. Department of the Interior

U.S. Geological Survey 


\section{U.S. Department of the Interior Gale A. Norton, Secretary}

\section{U.S. Geological Survey \\ P. Patrick Leahy, Acting Director}

\section{U.S. Geological Survey, Reston, Virginia: 2005}

For sale by U.S. Geological Survey, Information Services

Box 25286, Denver Federal Center

Denver, CO 80225

For more information about the USGS and its products:

Telephone: 1-888-ASK-USGS

World Wide Web: http://www.usgs.gov/

Any use of trade, product, or firm names in this publication is for descriptive purposes only and does not imply endorsement by the U.S. Government.

Although this report is in the public domain, permission must be secured from the individual copyright owners to reproduce any copyrighted materials contained within this report.

Suggested citation:

Baker, E.T., Jr., comp., 2005, Bibliography of ground-water references for all 254 counties in Texas, 1886-2001: U.S. Geological Survey Open-File Report 2005-1270, 321 p. 


\title{
Bibliography of Ground-Water References for All 254 Counties in Texas, 1886-2001
}

\author{
Compiled by E.T. Baker, Jr.
}

U.S. Geological Survey (Retired)

\section{Preface}

This bibliography comprises more than 10,000 citations of ground-water references involving all 254 counties in Texas. The reference citations date from 1886 and extend into 2001. Publications and reports from more than 30 agencies, universities, water districts, geological societies, cities, consultants, and private publication outlets are included in the bibliography. The bibliographic listing is, first, alphabetical by county and, second, chronological by date of the report, from oldest to most recent.

The passing years have seen a proliferation in both published and unpublished reports, and such proliferation continues to expand at an accelerating pace. All 254 counties have had groundwater studies, either cursory or detailed. Investigation and development of the ground-water resources of the State of Texas resulted in reports that appear in a variety of formats, including Federal, State, and local agency reports; scholarly, professional, and trade journals; conference proceedings; guidebooks; maps; and theses and dissertations. The end result for the person seeking ground-water information about specific Texas counties is the increasing difficulty in locating pertinent data among the many and diverse ground-water reports in which the information is recorded. This bibliography, covering a span of 115 years, should have considerable utility in guiding those individuals seeking ground-water information. 
Blank Page 


\section{Contents}

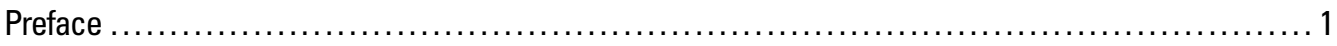

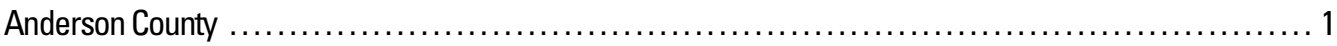

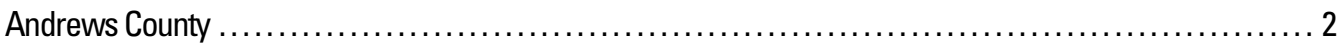

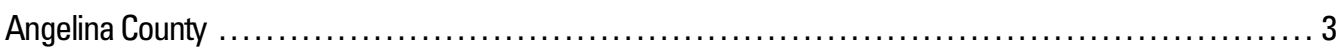

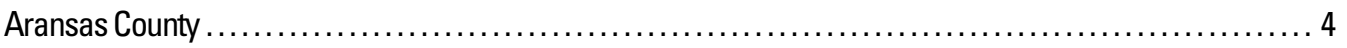

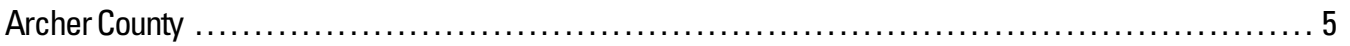

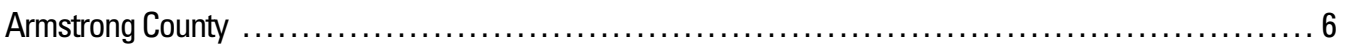

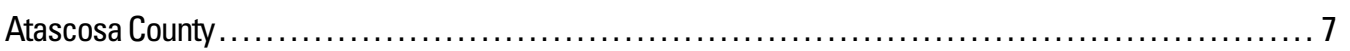

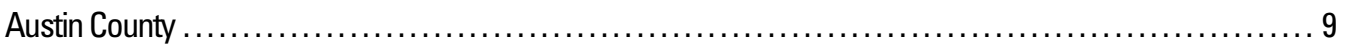

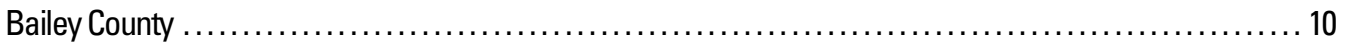

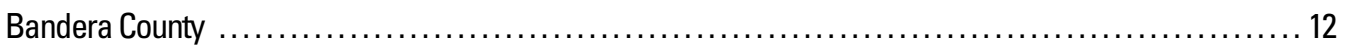

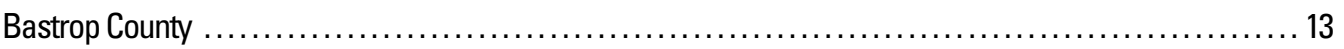

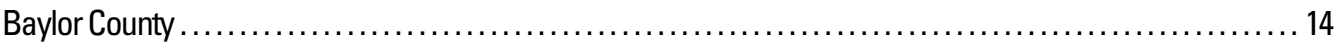

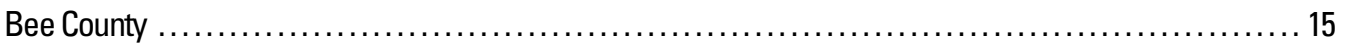

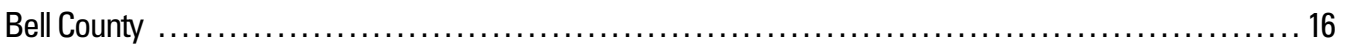

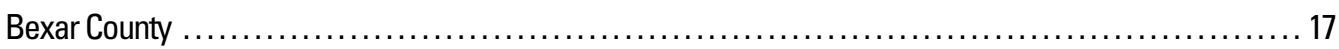

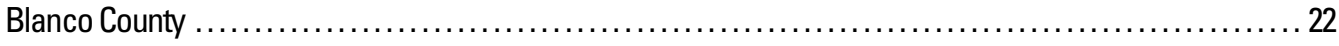

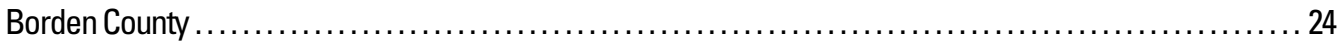

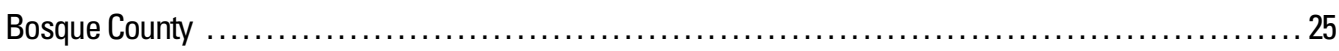

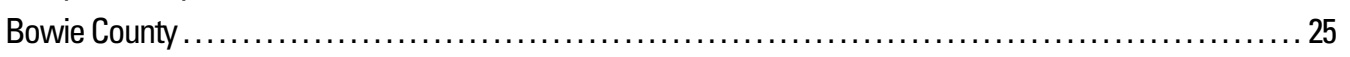

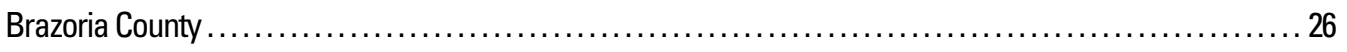

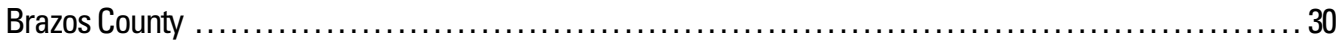

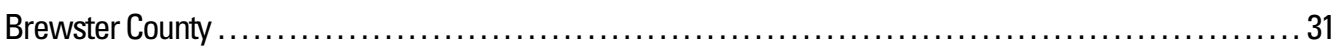

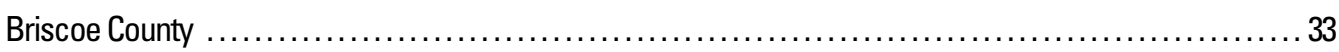

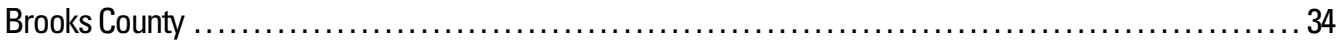

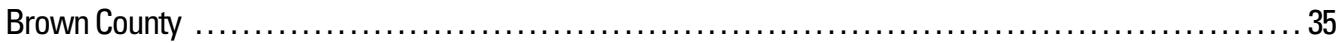

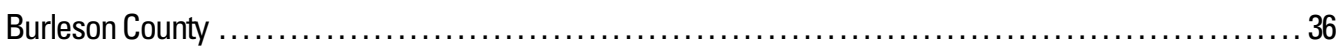

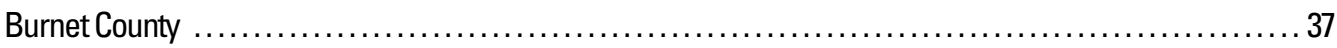

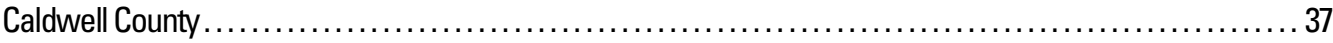

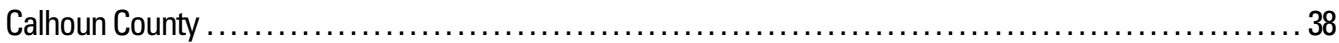

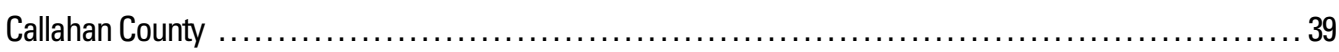

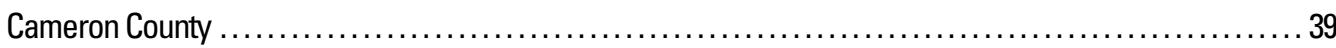

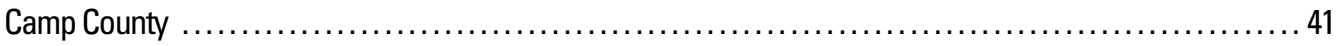

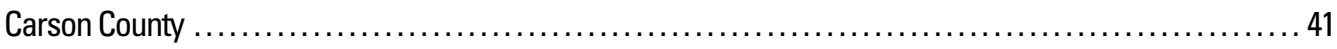

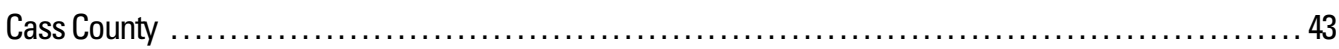

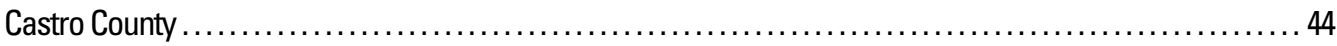

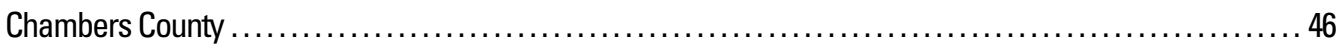

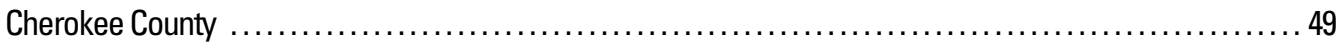

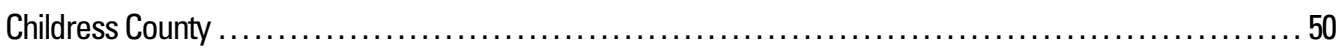

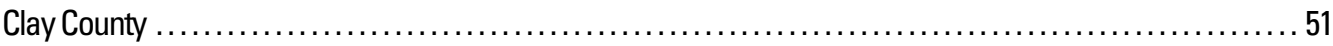

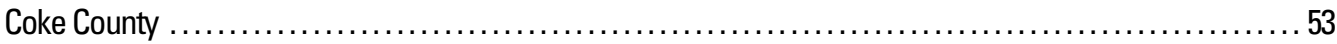

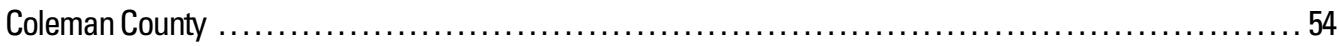




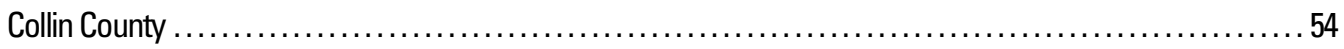

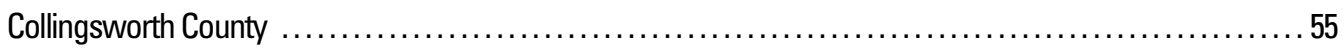

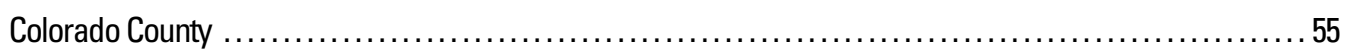

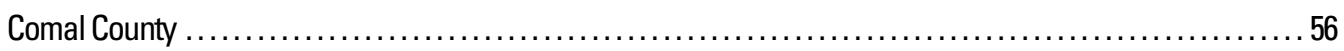

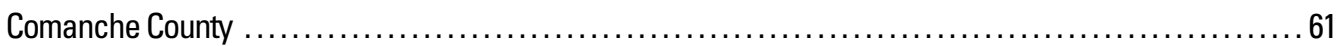

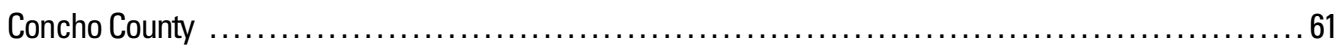

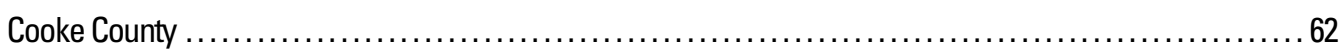

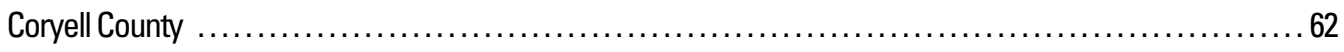

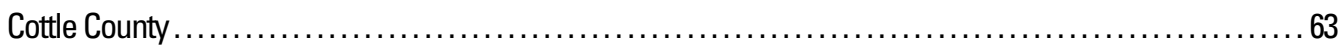

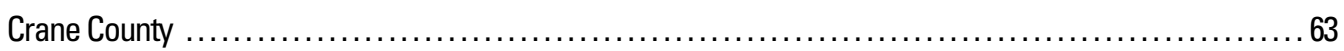

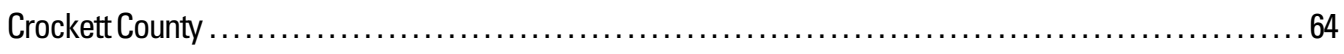

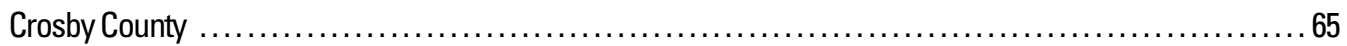

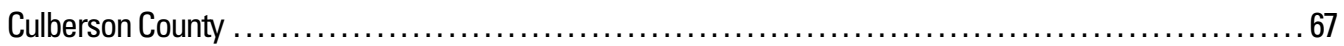

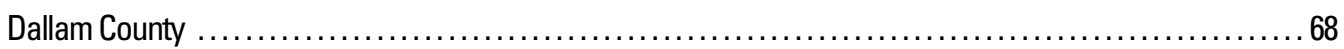

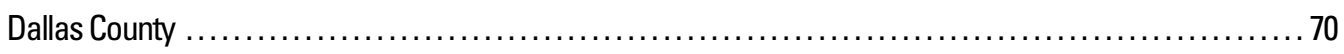

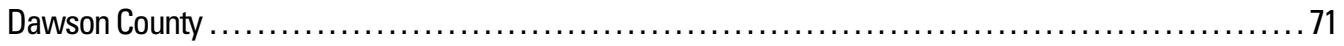

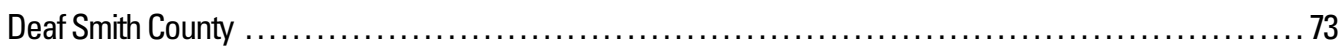

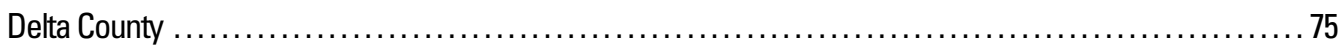

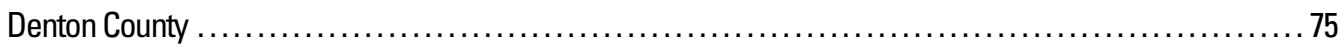

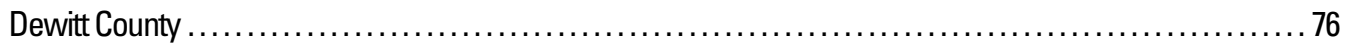

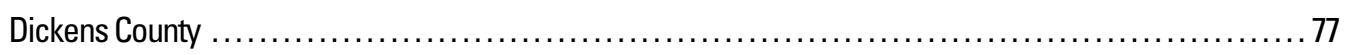

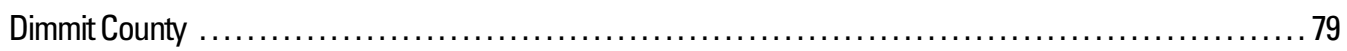

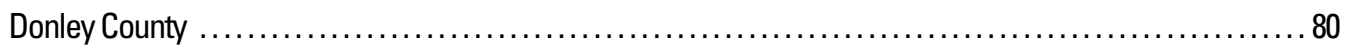

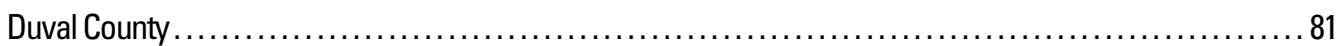

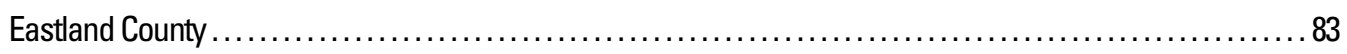

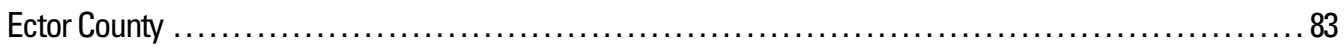

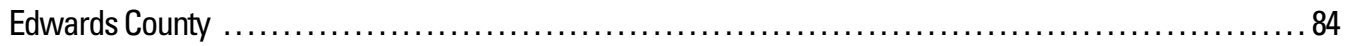

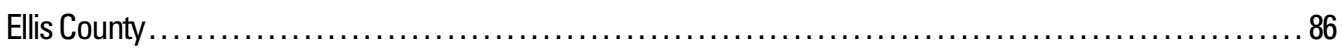

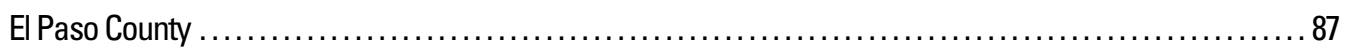

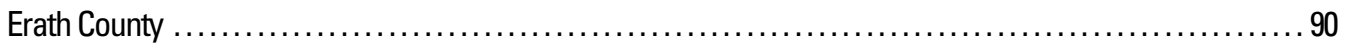

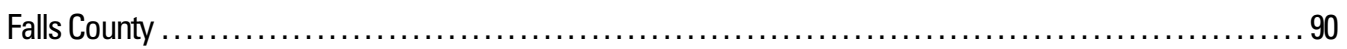

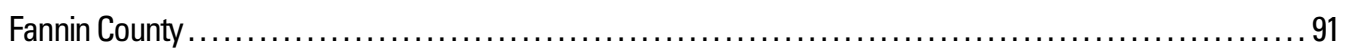

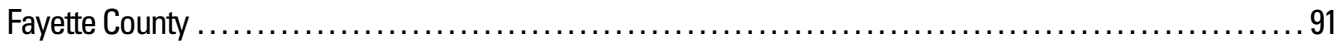

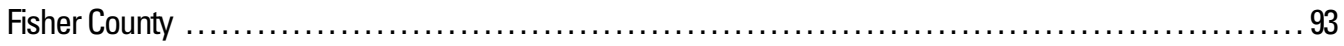

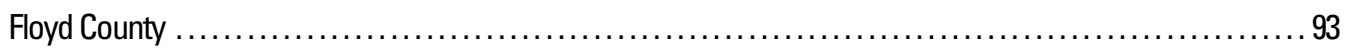

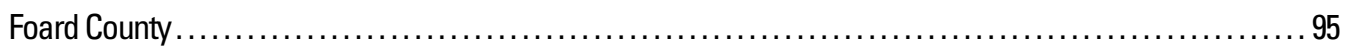

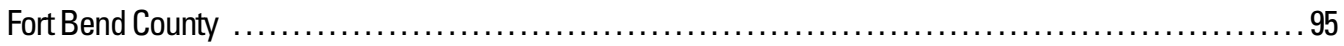

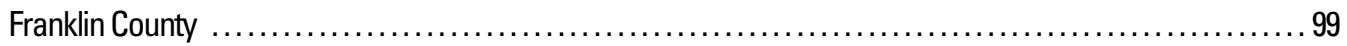

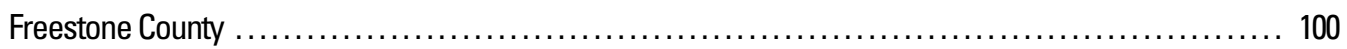

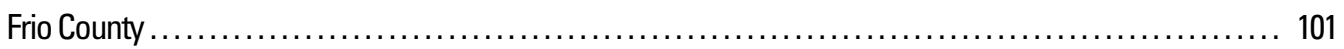

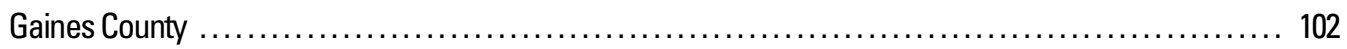

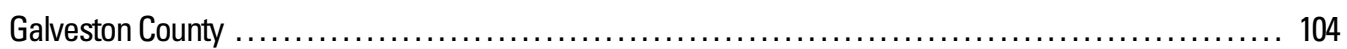

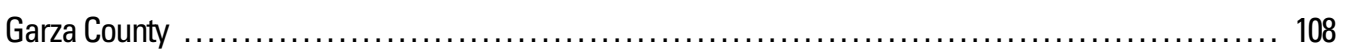

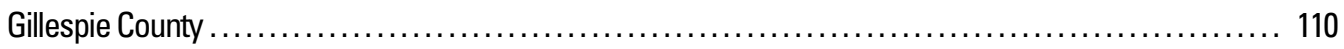

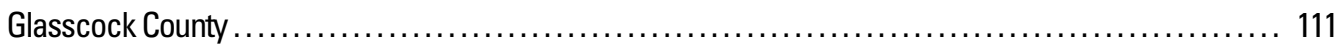




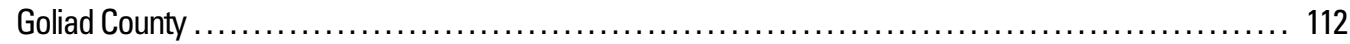

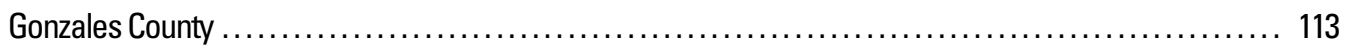

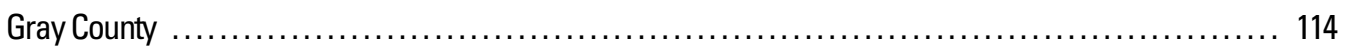

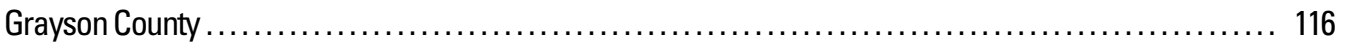

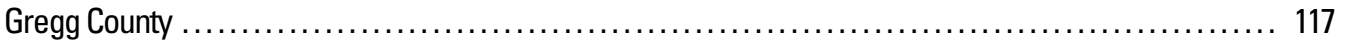

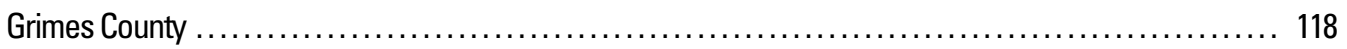

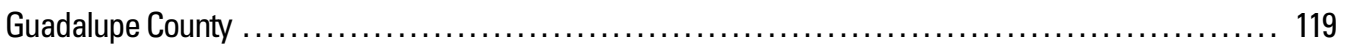

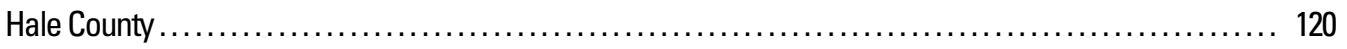

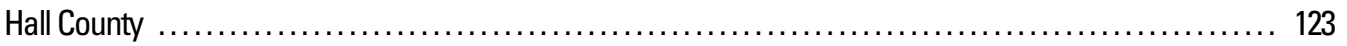

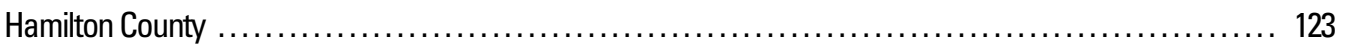

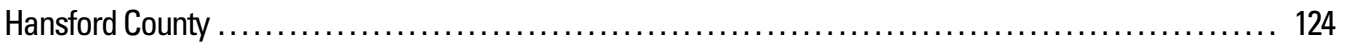

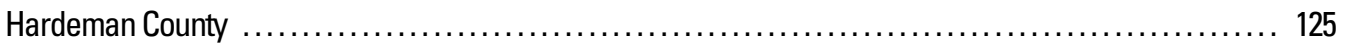

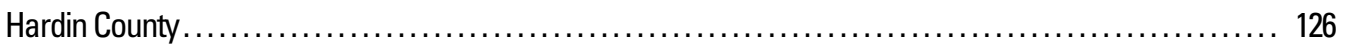

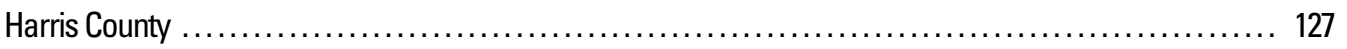

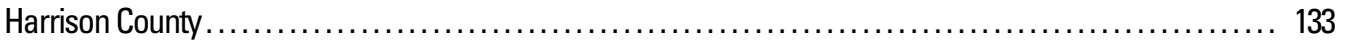

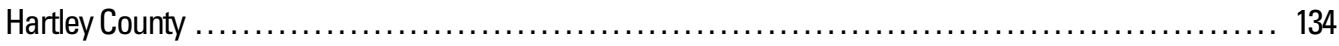

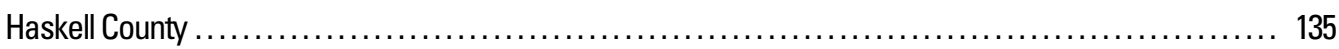

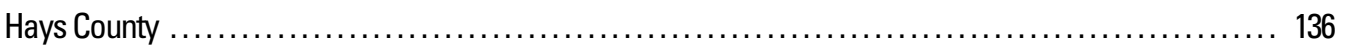

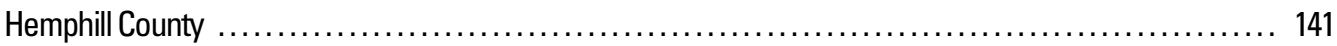

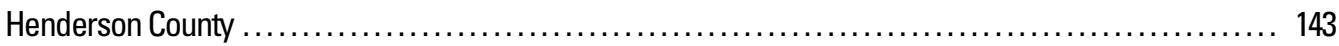

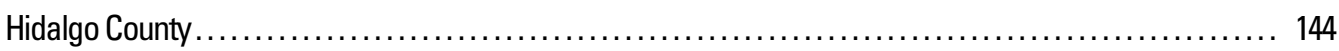

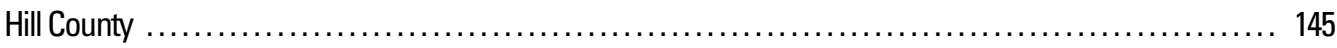

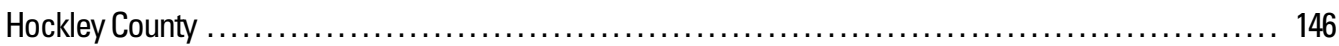

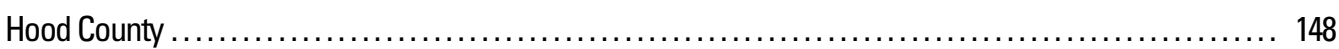

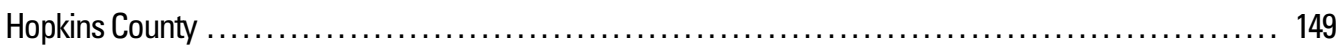

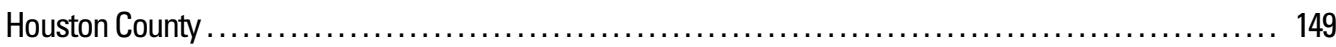

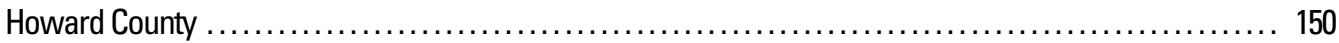

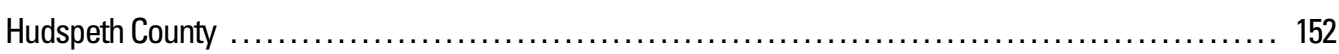

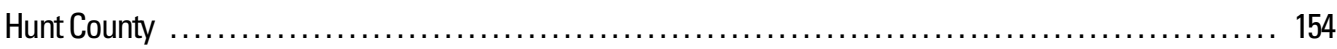

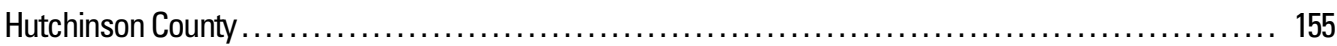

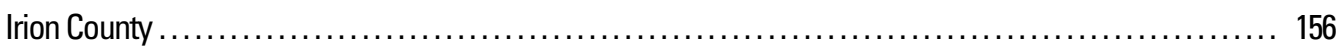

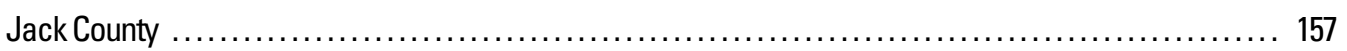

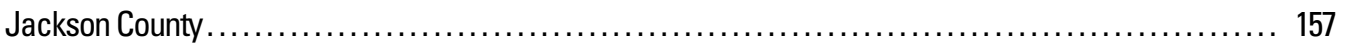

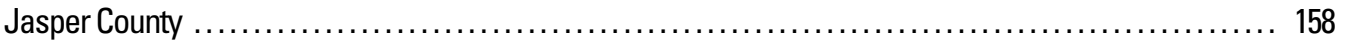

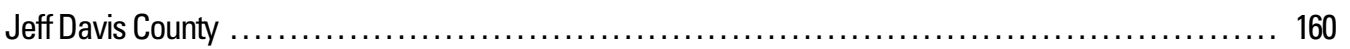

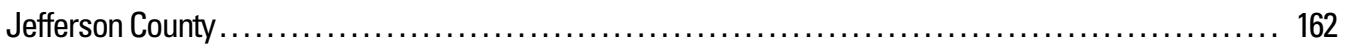

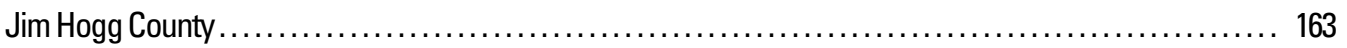

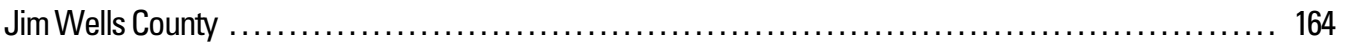

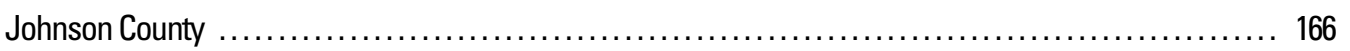

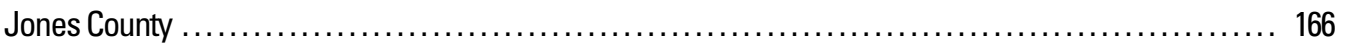

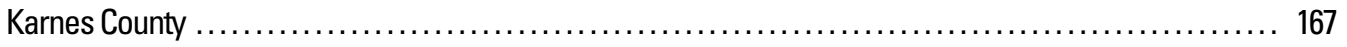

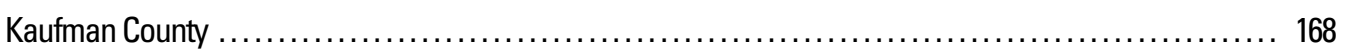

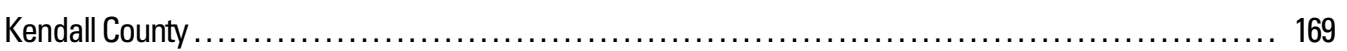

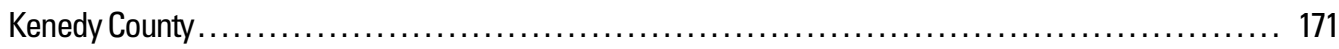

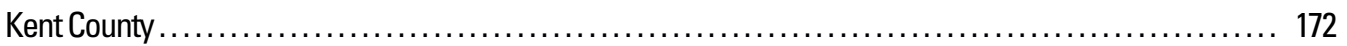




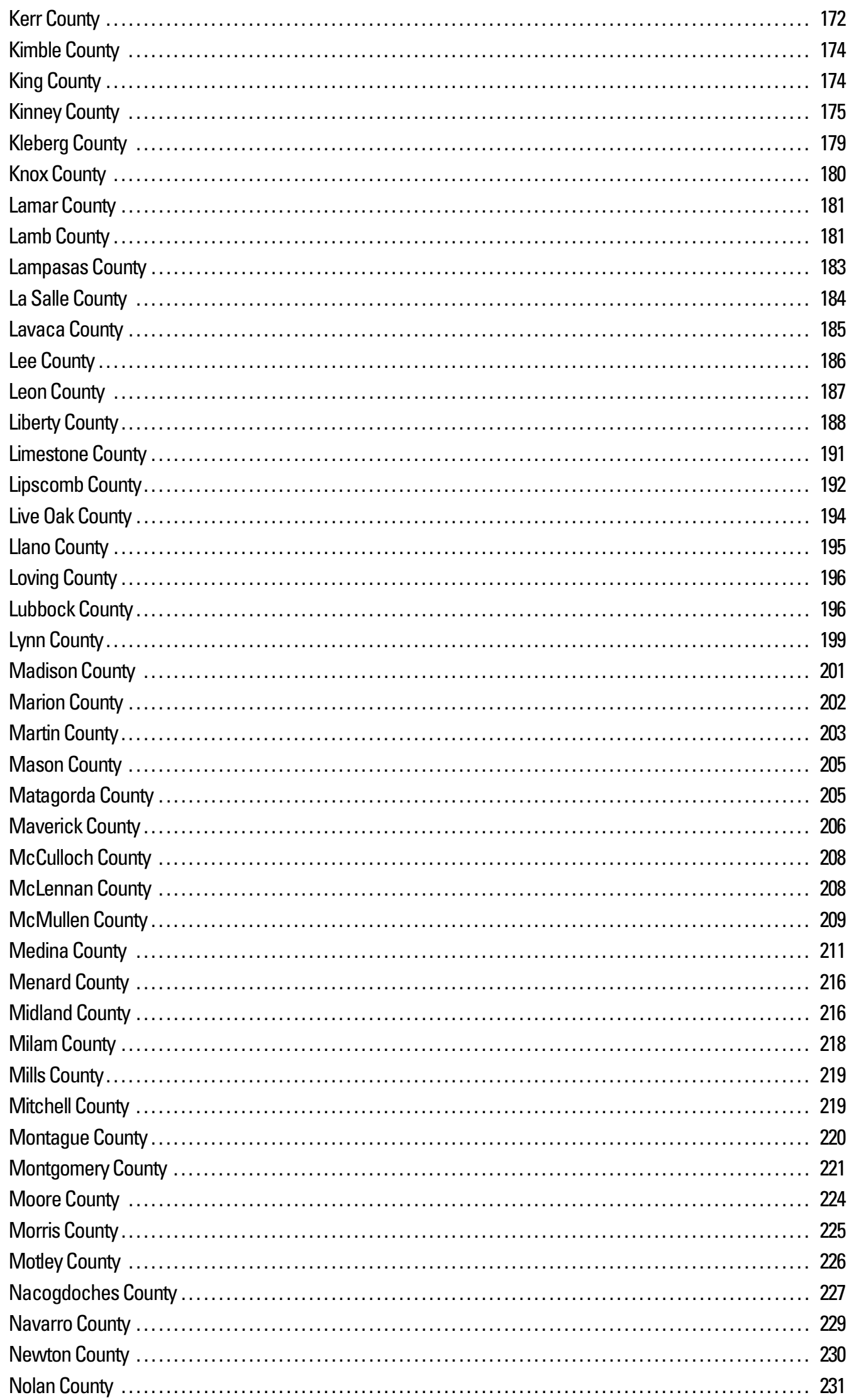




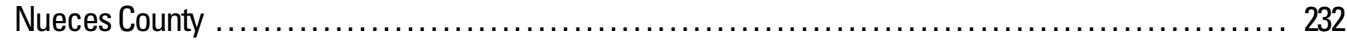

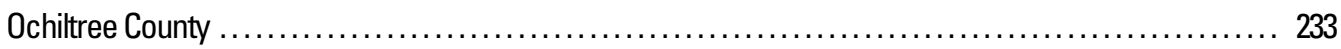

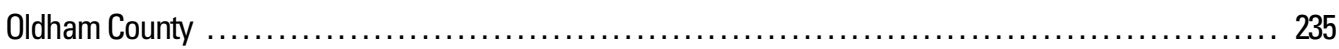

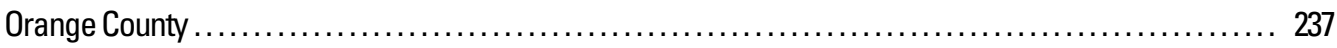

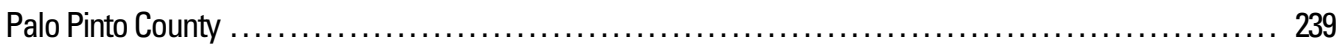

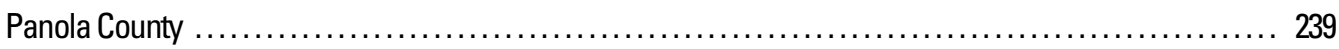

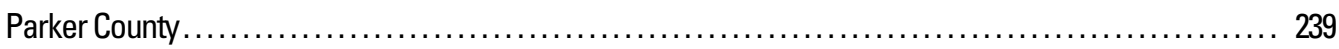

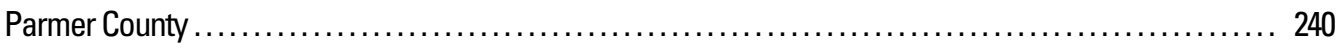

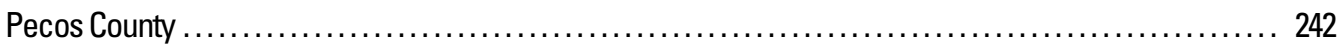

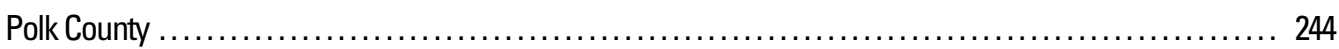

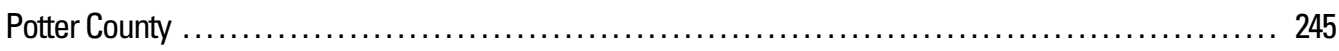

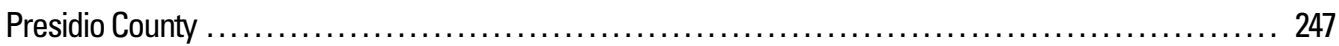

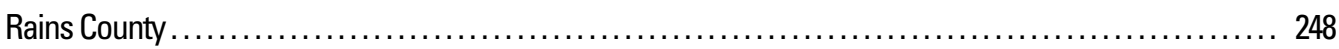

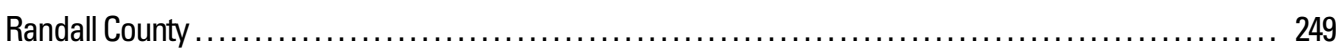

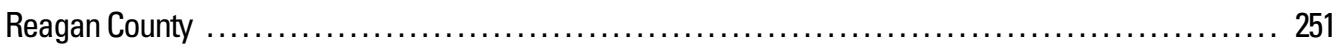

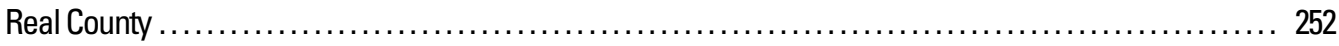

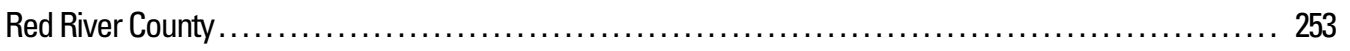

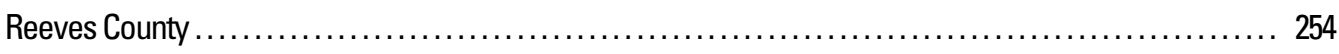

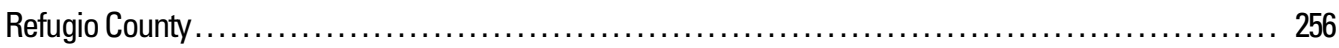

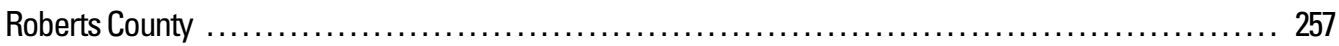

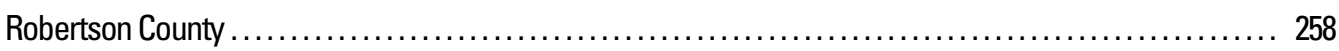

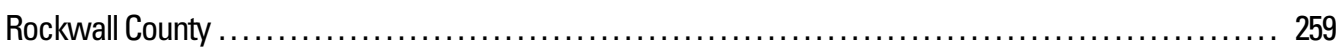

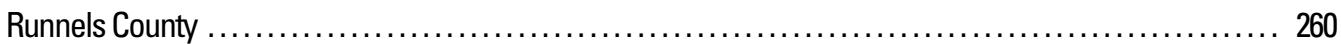

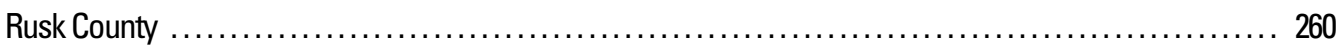

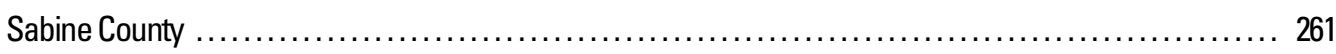

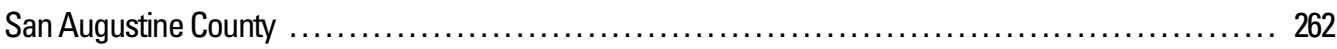

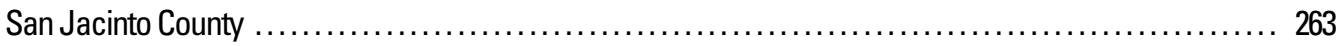

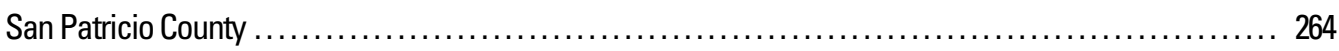

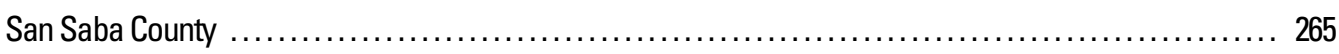

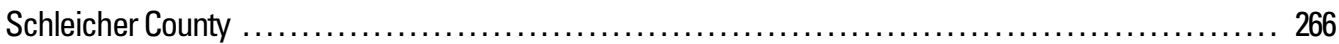

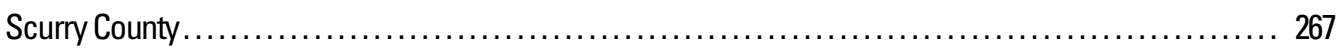

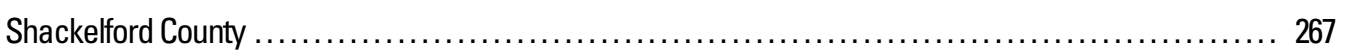

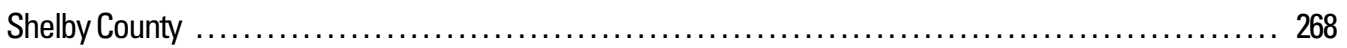

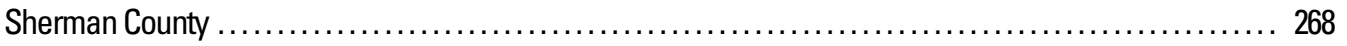

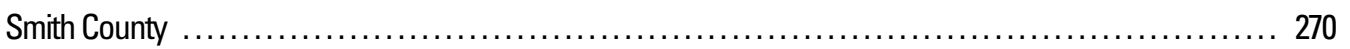

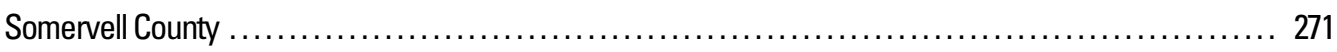

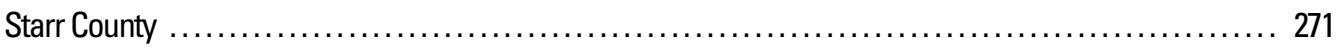

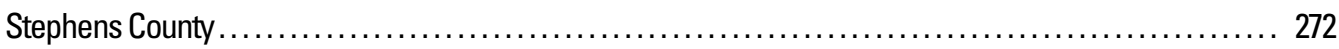

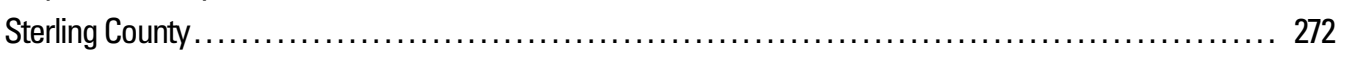

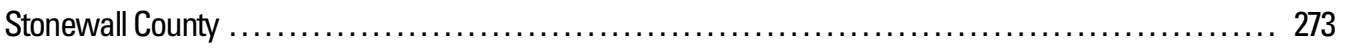

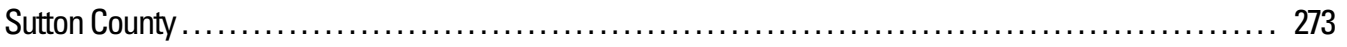

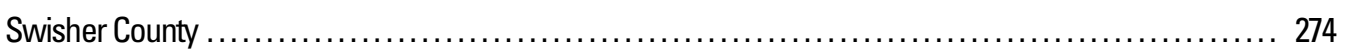

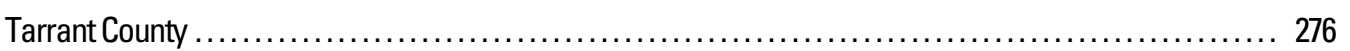

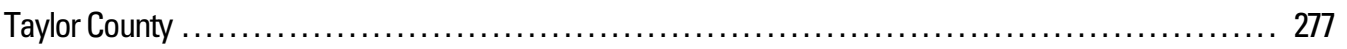

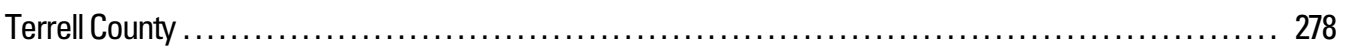




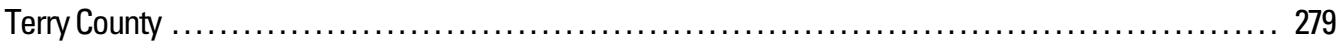

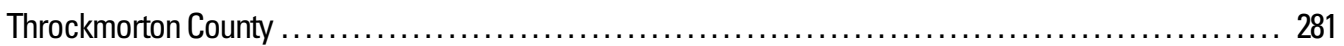

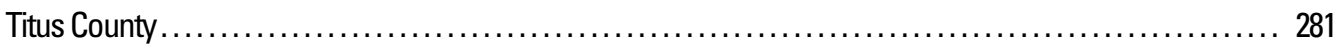

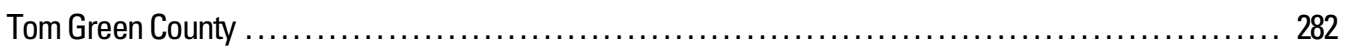

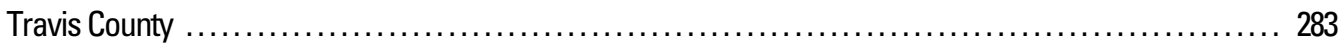

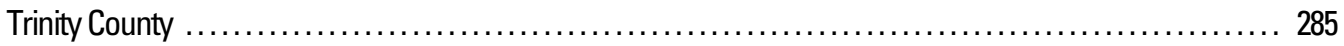

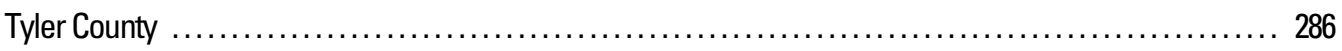

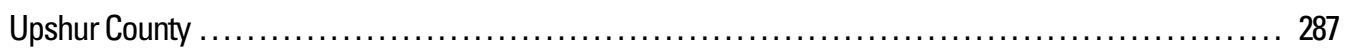

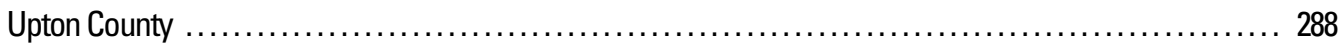

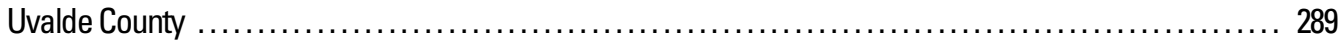

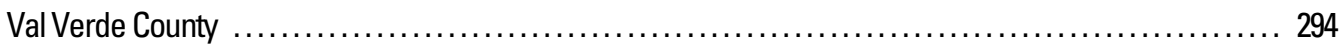

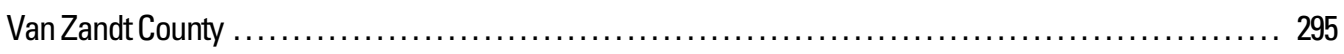

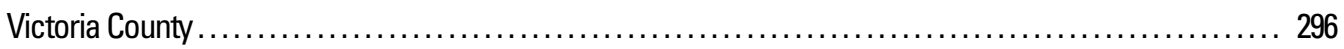

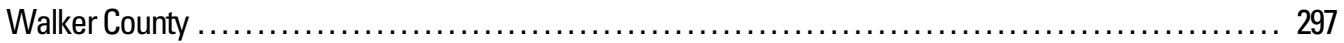

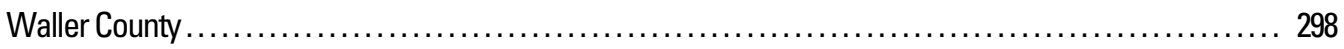

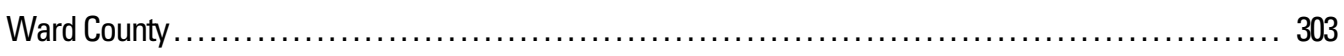

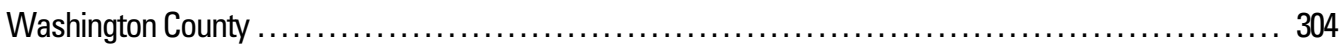

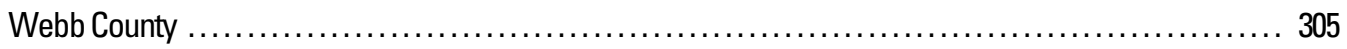

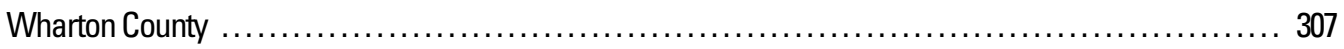

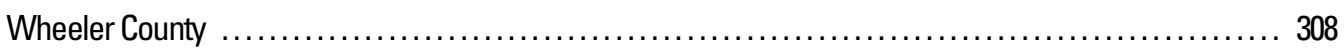

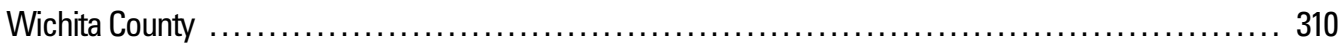

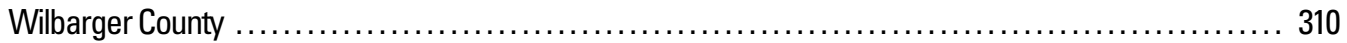

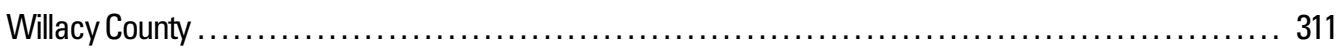

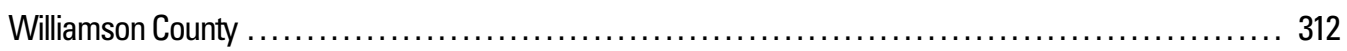

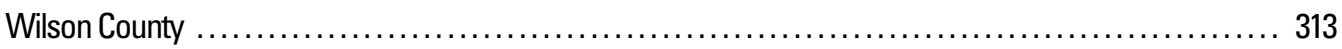

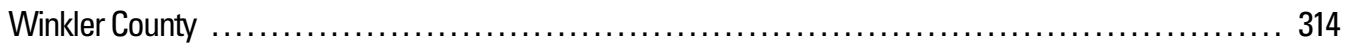

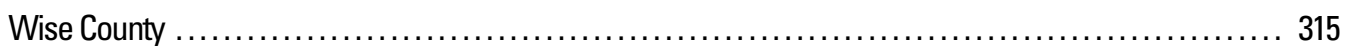

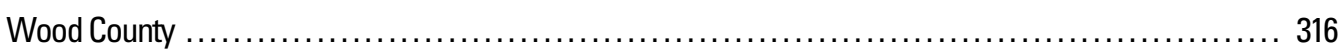

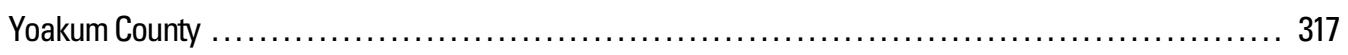

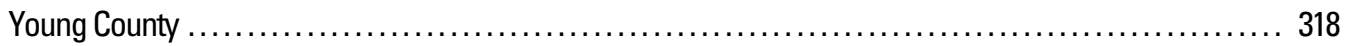

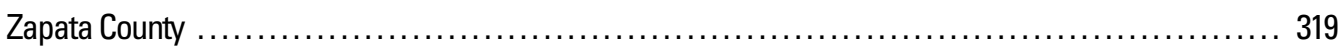

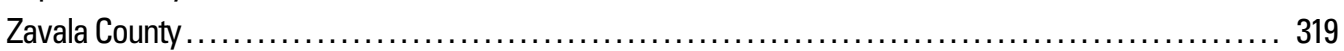




\title{
Bibliography of Ground-Water References for All 254 Counties in Texas, 1886-2001
}

\author{
Compiled By E.T. Baker, Jr.
}

\section{ANDERSON COUNTY}

UNDERGROUND WATERS OF THE COASTAL PLAIN OF TEXAS: USGS WATER-SUPPLY PAPER 190, 1907.

GEOLOGY AND UNDERGROUND WATERS OF THE SOUTHEASTERN PART OF THE TEXAS COASTAL PLAIN: USGS WATER-SUPPLY PAPER 335, 1914.

MEMORANDUM REGARDING WATER SUPPLY OF PALESTINE, TEXAS: USGS OPEN-FILE REPORT (UNNUMBERED), 1940.

MEMORANDUM TO MR. C.S. CLARK REGARDING CORES AND LOGS OF TEST HOLES AT BLACKBURN RIDGE DAM SITE ON THE NECHES RIVER IN CHEROKEE AND ANDERSON COUNTIES, TEXAS: USGS OPEN-FILE REPORT (UNNUMBERED), 1941.

GROUND-WATER RESOURCES IN THE VICINITY OF PALESTINE, TEXAS: USGS OPEN-FILE REPORT (UNNUMBERED), 1942.

POSSIBILITIES OF IRRIGATION FROM WELLS IN THE CARRIZO SAND IN SOUTHERN HENDERSON AND NORTHERN ANDERSON COUNTIES: USGS OPEN-FILE REPORT (UNNUMBERED), 1948.

PUBLIC WATER SUPPLIES IN EASTERN TEXAS: USGS WATERSUPPLY PAPER 1047, 1948.

ARTESIAN WATER IN THE ELKHART AREA, SOUTHERN ANDERSON COUNTY, TEXAS: TEXAS BOARD OF WATER ENGINEERS MISCELLANEOUS PUBLICATION 2, 1956.

HYDROLOGIC SIGNIFICANCE OF THE LITHOFACIES OF THE SPARTA SAND IN ARKANSAS, LOUISIANA, MISSISSIPPI, AND TEXAS: USGS PROFESSIONAL PAPER 569-A, 1968.

GEOHYDROLOGIC SIGNIFICANCE OF LITHOFACIES OF THE COCKFIELD FORMATION OF LOUISIANA AND MISSISSIPPI AND OF THE YEGUA FORMATION OF TEXAS: USGS PROFESSIONAL PAPER 569-B, 1970.

COMPILATION OF RESULTS OF AQUIFER TESTS IN TEXAS: TEXAS WATER DEVELOPMENT BOARD REPORT 98, 1969.

GROUND-WATER CONDITIONS IN ANDERSON, CHEROKEE, FREESTONE, AND HENDERSON COUNTIES, TEXAS: TEXAS WATER DEVELOPMENT BOARD REPORT 150, 1972.

GEOLOGIC AND HYDROLOGIC SUMMARY OF SALT DOMES IN GULF COAST REGION OF TEXAS, LOUISIANA, AND ALABAMA: USGS OPEN-FILE REPORT 73-07, 1973.

PROJECTED EFFECTS OF THE PROPOSED TENNESSEE COLONY RESERVOIR ON GROUND-WATER CONDITIONS IN THE CARRIZO-
WILCOX AQUIFER AND TRINITY RIVER ALLUVIUM, TRINIDADOAKWOOD AREA, TEXAS: USGS OPEN-FILE REPORT 74-297, 1974

GEOHYDROLOGIC SIGNIFICANCE OF LITHOFACIES OF THE CARRIZO SAND OF ARKANSAS, LOUISIANA, AND TEXAS AND THE MERIDIAN SAND OF MISSISSIPPI: USGS PROFESSIONAL PAPER 569-D, 1975.

WATER-QUALITY DATA FOR AQUIFERS, STREAMS, AND LAKES IN THE VICINITY OF KEECHI, MOUNT SYLVAN, OAKWOOD, AND PALESTINE SALT DOMES, NORTHEAST TEXAS SALT-DOME BASIN: USGS OPEN-FILE REPORT 80-2037, 1980

GEOHYDROLOGY OF THE KEECHI, MOUNT SYLVAN, OAKWOOD, AND PALESTINE SALT DOMES IN THE NORTHEAST TEXAS SALTDOME BASIN: USGS OPEN-FILE REPORT 80-2044, 1980.

GEOLOGY AND GEOHYDROLOGY OF THE EAST TEXAS BASIN-A REPORT ON THE PROGRESS OF NUCLEAR WASTE ISOLATION FEASIBILITY STUDIES (1979): UNIVERSITY OF TEXAS, BUREAU OF ECONOMIC GEOLOGY GEOLOGICAL CIRCULAR 80-12, 1980.

GEOLOGY AND GEOHYDROLOGY OF THE EAST TEXAS BASIN-A REPORT ON THE PROGRESS OF NUCLEAR WASTE ISOLATION FEASIBILITY STUDIES (1980): UNIVERSITY OF TEXAS, BUREAU OF ECONOMIC GEOLOGY GEOLOGICAL CIRCULAR 81-7, 1981.

TEXAS GROUND-WATER RESOURCES, in NATIONAL WATER SUMMARY 1984: USGS WATER-SUPPLY PAPER 2275, 1985.

APPROXIMATE POTENTIOMETRIC SURFACES FOR THE AQUIFERS OF THE TEXAS COASTAL UPLANDS SYSTEM, 1980: USGS HYDROLOGIC INVESTIGATIONS ATLAS HA-704, 1987.

GEOHYDROLOGIC FRAMEWORK OF THE GULF COASTAL PLAIN: USGS HYDROLOGIC INVESTIGATIONS ATLAS HA-695, 1988.

NATIONAL WATER-QUALITY ASSESSMENT PROGRAM-THE TRINITY RIVER BASIN: USGS OPEN-FILE REPORT 91-158, 1991.

PROPERTIES AND CHEMICAL CONSTITUENTS IN GROUND WATER FROM THE LOWER CLAIBORNE-UPPER WILCOX AQUIFER, GULF COAST REGIONAL AQUIFER SYSTEMS, SOUTH-CENTRAL UNITED STATES: USGS WATER-RESOURCES INVESTIGATIONS REPORT 92-4102, 1993.

PROPERTIES AND CHEMICAL CONSTITUENTS IN GROUND WATER FROM THE MIDDLE CLAIBORNE AQUIFER, GULF COAST REGIONAL AQUIFER SYSTEMS, SOUTH-CENTRAL UNITED STATES: USGS WATER-RESOURCES INVESTIGATIONS REPORT 92-4104, 1993.

PROPERTIES AND CHEMICAL CONSTITUENTS IN GROUND WATER FROM THE MIDDLE WILCOX AQUIFER, GULF COAST REGIONAL 


\section{Bibliography of Ground-Water References for All 254 Counties in Texas, 1886-2001}

AQUIFER SYSTEMS, SOUTH-CENTRAL UNITED STATES: USGS WATER-RESOURCES INVESTIGATIONS REPORT 93-4070, 1993.

STRATIGRAPHIC NOMENCLATURE AND GEOLOGIC SECTIONS OF THE GULF COASTAL PLAIN OF TEXAS: USGS OPEN-FILE REPORT 94-461, 1995.

NATIONAL WATER-QUALITY ASSESSMENT PROGRAM-PESTICIDES IN THE TRINITY RIVER BASIN STUDY UNIT, TEXAS, 1968-91: USGS FACT SHEET FS-088-95, 1995.

WATER-QUALITY ASSESSMENT OF THE TRINITY RIVER BASIN, TEXAS-DATA COLLECTION, 1992-95: USGS FACT SHEET FS-095-95, 1995.

WATER-QUALITY ASSESSMENT OF THE TRINITY RIVER BASIN, TEXAS-PESTICIDES IN A SUBURBAN WATERSHED, ARLINGTON, 1993-94: USGS FACT SHEET FS-159-95, 1995.

AQUIFERS OF TEXAS: TEXAS WATER DEVELOPMENT BOARD REPORT 345, 1995.

WATER QUALITY IN THE SPARTA AQUIFER, EAST TEXAS: TEXAS WATER DEVELOPMENT BOARD HYDROLOGIC ATLAS NO. 5, 1996.

WATER QUALITY IN THE QUEEN CITY AQUIFER, EAST TEXAS: TEXAS WATER DEVELOPMENT BOARD HYDROLOGIC ATLAS NO. 6, 1996

TRANSMISSIVITY, HYDRAULIC CONDUCTIVITY, AND STORATIVITY OF THE CARRIZO-WILCOX AQUIFER IN TEXAS, DATA AND ANALYSIS: UNIVERSITY OF TEXAS, BUREAU OF ECONOMIC GEOLOGY, CD-ROM, 2000

\section{ANDREWS COUNTY}

RECORDS OF WELLS, TEST WELLS AND DRILLERS' LOGS, WATER ANALYSES, AND MAP SHOWING LOCATION OF WELLS IN ANDREWS COUNTY (SOUTH HALF), TEXAS: TEXAS BOARD OF WATER ENGINEERS MISCELLANEOUS PUBLICATION 3, 1937.

RECORDS OF WELLS, TEST WELLS, DRILLERS' LOGS, CHEMICAL ANALYSES OF WATER, AND MAP SHOWING LOCATIONS OF WELLS IN ANDREWS COUNTY, TEXAS: TEXAS BOARD OF WATER ENGINEERS MISCELLANEOUS PUBLICATION 4, 1940.

MEMORANDUM CONCERNING GROUND-WATER CONDITIONS IN THE ANDREWS AREA, TEXAS: USGS OPEN-FILE REPORT (UNNUMBERED), 1945.

SHALLOW FORMATIONS AND AQUIFERS OF THE WEST TEXAS AREA: WEST TEXAS GEOLOGICAL SOCIETY PUBLICATION 61-45 AND PERMIAN BASIN GEOPHYSICAL SOCIETY, MIDLAND, TEXAS, 1961

A SUMMARY OF THE OCCURRENCE AND DEVELOPMENT OF GROUND WATER IN THE SOUTHERN HIGH PLAINS OF TEXAS: TEXAS BOARD OF WATER ENGINEERS BULLETIN 6107, 1961.

A SUMMARY OF THE OCCURRENCE AND DEVELOPMENT OF GROUND WATER IN THE SOUTHERN HIGH PLAINS OF TEXAS, WITH A SECTION ON ARTIFICIAL RECHARGE STUDIES: USGS WATER-SUPPLY PAPER 1693, 1964

WATER-LEVEL DATA FROM OBSERVATION WELLS IN THE SOUTHERN HIGH PLAINS OF TEXAS: TEXAS WATER DEVELOPMENT BOARD REPORT 21, 1966.
GROUND WATER IN THE OGALLALA FORMATION IN THE SOUTHERN HIGH PLAINS OF TEXAS AND NEW MEXICO: USGS HYDROLOGIC INVESTIGATIONS ATLAS HA-330, 1969.

WATER-LEVEL DATA FROM OBSERVATION WELLS IN THE SOUTHERN HIGH PLAINS OF TEXAS, 1965-70: TEXAS WATER DEVELOPMENT BOARD REPORT 121, 1970.

RECONNAISSANCE INVESTIGATION OF GROUND WATER IN THE RIO GRANDE DRAINAGE BASIN—WITH SPECIAL EMPHASIS ON SALINE GROUND-WATER RESOURCES: USGS HYDROLOGIC INVESTIGATIONS ATLAS HA-510, 1974

WATER-LEVEL DATA FROM OBSERVATION WELLS IN THE SOUTHERN HIGH PLAINS OF TEXAS, 1971-77: TEXAS DEPARTMENT OF WATER RESOURCES REPORT 228, 1979.

OCCURRENCE, AVAILABILITY, AND CHEMICAL QUALITY OF GROUND WATER IN THE EDWARDS PLATEAU REGION OF TEXAS: TEXAS DEPARTMENT OF WATER RESOURCES REPORT 235,1979

PRELIMINARY DATA DESCRIBING THE DISTRIBUTION OF FLUORIDE AND SILICA IN THE OGALLALA AQUIFER ON THE HIGH PLAINS OF TEXAS: USGS OPEN-FILE REPORT 80-349, 1980.

EVALUATING THE GROUND-WATER RESOURCES OF THE HIGH PLAINS OF TEXAS: RESULTS OF TEST HOLE DRILLING: TEXAS DEPARTMENT OF WATER RESOURCES LIMITED PRINTING REPORT LP-129, 1980.

SPRINGS OF TEXAS, VOLUME 1: (BY GUNNAR BRUNE), BRANCHSMITH, INC., FORT WORTH, TEXAS, 1981.

BEDROCK GEOLOGY, ALTITUDE OF BASE, AND 1980 SATURATED THICKNESS OF THE HIGH PLAINS AQUIFER IN PARTS OF COLORADO, KANSAS, NEBRASKA, NEW MEXICO, OKLAHOMA, SOUTH DAKOTA, TEXAS, AND WYOMING: USGS HYDROLOGIC INVESTIGATIONS ATLAS HA-648, 1981

WATER LEVEL AND SATURATED THICKNESS CHANGES, PREDEVELOPMENT TO 1980, IN THE HIGH PLAINS AQUIFER IN PARTS OF COLORADO, KANSAS, NEBRASKA, NEW MEXICO, OKLAHOMA, SOUTH DAKOTA, TEXAS, AND WYOMING: USGS HYDROLOGIC INVESTIGATIONS ATLAS HA-652, 1981.

DISSOLVED SOLIDS AND SODIUM IN WATER FROM THE HIGH PLAINS AQUIFER IN PARTS OF COLORADO, KANSAS, NEBRASKA, NEW MEXICO, OKLAHOMA, SOUTH DAKOTA, TEXAS, AND WYOMING: USGS HYDROLOGIC INVESTIGATIONS ATLAS HA-658, 1982.

EVALUATING THE GROUND-WATER RESOURCES OF THE HIGH PLAINS OF TEXAS, VOLUME 1: TEXAS DEPARTMENT OF WATER RESOURCES REPORT 288, V. 1, 1984

EVALUATING THE GROUND-WATER RESOURCES OF THE HIGH PLAINS OF TEXAS, VOLUME 4, RECORDS OF WELLS AND MAPS SHOWING WELL LOCATIONS, BASE OF AQUIFER, WATER LEVELS, AND SATURATED THICKNESS (ANDREWS, BORDEN, COCHRAN, DAWSON, ECTOR, GAINES, GARZA, GLASSCOCK, HOWARD, HOCKLEY, LUBBOCK, LYNN, MARTIN, MIDLAND, TERRY, AND YOAKUM COUNTIES: TEXAS DEPARTMENT OF WATER RESOURCES REPORT 288 V. 4, 1984.

GEOHYDROLOGY OF THE HIGH PLAINS AQUIFER IN PARTS OF COLORADO, KANSAS, NEBRASKA, NEW MEXICO, OKLAHOMA, SOUTH DAKOTA, TEXAS, AND WYOMING: USGS PROFESSIONAL PAPER 1400-B, 1984. 
TEXAS GROUND-WATER RESOURCES, in NATIONAL WATER SUMMARY 1984: USGS WATER-SUPPLY PAPER 2275, 1985.

DIGITAL SIMULATION OF GROUND-WATER FLOW IN THE HIGH PLAINS AQUIFER IN PARTS OF COLORADO, KANSAS, NEBRASKA, NEW MEXICO, OKLAHOMA, SOUTH DAKOTA, TEXAS, AND WYOMING: USGS PROFESSIONAL PAPER 1400-D, 1986.

HYDROGEOLOGY AND HYDROCHEMISTRY OF CRETACEOUS AQUIFERS, TEXAS PANHANDLE AND EASTERN NEW MEXICO: UNIVERSITY OF TEXAS, BUREAU OF ECONOMIC GEOLOGY GEOLOGICAL CIRCULAR 88-3, 1988.

SUMMARY OF THE HIGH PLAINS REGIONAL AQUIFER-SYSTEM ANALYSIS IN PARTS OF COLORADO, KANSAS, NEBRASKA, NEW MEXICO, OKLAHOMA, SOUTH DAKOTA, TEXAS, AND WYOMING: USGS PROFESSIONAL PAPER 1400-A, 1988.

HYDROGEOLOGY OF LOWER CRETACEOUS STRATA UNDER THE SOUTHERN HIGH PLAINS OF TEXAS AND NEW MEXICO: TEXAS WATER DEVELOPMENT BOARD REPORT 314, 1989.

PUBLIC SUPPLY GROUND-WATER USE IN THE SOUTHERN HIGH PLAINS OF TEXAS: TEXAS WATER DEVELOPMENT BOARD REPORT 328, 1990.

POTENTIOMETRIC SURFACE OF THE EDWARDS-TRINITY AQUIFER SYSTEM AND CONTIGUOUS HYDRAULICALLY CONNECTED UNITS, WEST-CENTRAL TEXAS, WINTER 1974-75: USGS WATERRESOURCES INVESTIGATIONS REPORT 89-4208, 1990.

WITHDRAWALS FROM THE EDWARDS-TRINITY AQUIFER SYSTEM AND CONTIGUOUS HYDRAULICALLY CONNECTED UNITS, WEST-CENTRAL TEXAS, DECEMBER 1974 THROUGH MARCH 1977: USGS WATER-RESOURCES INVESTIGATIONS REPORT 91-4021, 1991.

EVALUATION OF GROUND-WATER RESOURCES IN THE SOUTHERN HIGH PLAINS OF TEXAS: TEXAS WATER DEVELOPMENT BOARD REPORT 330, 1991.

WATER-LEVEL CHANGES IN THE HIGH PLAINS AQUIFER OF TEXAS, 1980-1990: TEXAS WATER DEVELOPMENT BOARD HYDROLOGIC ATLAS NO. 1, 1991.

CONFIGURATION OF THE BASE OF THE EDWARDS-TRINITY AQUIFER SYSTEM AND HYDROGEOLOGY OF THE UNDERLYING PRECRETACEOUS ROCKS, WEST-CENTRAL TEXAS: USGS WATERRESOURCES INVESTIGATIONS REPORT 91-4071, 1992.

HISTORICAL POTENTIOMETRIC SURFACE OF THE EDWARDS-TRINITY AQUIFER SYSTEM AND CONTIGUOUS HYDRAULICALLY CONNECTED UNITS, WEST-CENTRAL TEXAS: USGS WATERRESOURCES INVESTIGATIONS REPORT 92-4055, 1993.

HISTORICAL SATURATED THICKNESS OF THE EDWARDS-TRINITY AQUIFER SYSTEM AND SELECTED CONTIGUOUS HYDRAULICALLY CONNECTED UNITS, WEST-CENTRAL TEXAS: USGS WATER-RESOURCES INVESTIGATIONS REPORT 92-4125, 1993.

THE HIGH PLAINS AQUIFER SYSTEM OF TEXAS, 1980-1990-OVERVIEW AND PROJECTIONS: TEXAS WATER DEVELOPMENT BOARD REPORT 341, 1993.

WATER-QUALITY EVALUATION OF THE OGALLALA AQUIFER, TEXAS: TEXAS WATER DEVELOPMENT BOARD REPORT 342 , 1993.

SIMULATIONS OF FLOW IN THE EDWARDS-TRINITY AQUIFER SYSTEM AND CONTIGUOUS HYDRAULICALLY CONNECTED
UNITS, WEST-CENTRAL TEXAS: USGS WATER-RESOURCES INVESTIGATIONS REPORT 93-4039, 1994.

DISSOLVED-SOLIDS CONCENTRATIONS AND HYDROCHEMICAL FACIES IN WATER OF THE EDWARDS-TRINITY AQUIFER SYSTEM, WEST-CENTRAL TEXAS: USGS WATER-RESOURCES INVESTIGATIONS REPORT 93-4126, 1994.

WATER-LEVEL CHANGES IN THE HIGH PLAINS AQUIFER-PREDEVELOPMENT TO 1992: USGS WATER-RESOURCES INVESTIGATIONS REPORT 94-4027, 1994.

GEOLOGIC HISTORY AND HYDROGEOLOGIC SETTING OF THE EDWARDS-TRINITY AQUIFER SYSTEM, WEST-CENTRAL TEXAS: USGS WATER-RESOURCES INVESTIGATIONS REPORT 94-4039, 1994.

WATER QUALITY IN THE EDWARDS-TRINITY (PLATEAU) AQUIFER, EDWARDS PLATEAU AND TRANS-PECOS TEXAS: TEXAS WATER DEVELOPMENT BOARD HYDROLOGIC ATLAS NO. 3, 1995.

WATER-LEVEL CHANGES IN THE HIGH PLAINS AQUIFER, 1980 TO 1994: USGS FACT SHEET FS-215-95, 1995.

AQUIFERS OF TEXAS: TEXAS WATER DEVELOPMENT BOARD REPORT 345, 1995.

WATER-LEVEL CHANGES IN THE HIGH PLAINS AQUIFER, 1980 TO 1995: USGS FACT SHEET FS-068-97, 1997.

WATER-LEVEL CHANGES IN THE HIGH PLAINS AQUIFER-PREDEVELOPMENT TO 1995: USGS WATER-RESOURCES INVESTIGATIONS REPORT 97-4081, 1997.

UPDATED WATER-QUALITY EVALUATION OF THE OGALLALA AQUIFER INCLUDING SELECTED METALLIC AND NON-METALLIC INORGANIC CONSTITUENTS: TEXAS WATER DEVELOPMENT BOARD HYDROLOGIC ATLAS NO. 10, 1998.

AN OVERVIEW OF THE EDWARDS-TRINITY AQUIFER SYSTEM, CENTRAL-WEST TEXAS, CHAPTER 8, in AQUIFERS OF WEST TEXAS: TEXAS WATER DEVELOPMENT BOARD REPORT 356, 2001.

\section{ANGELNA COUNTY}

UNDERGROUND WATERS OF THE COASTAL PLAIN OF TEXAS: USGS WATER-SUPPLY PAPER 190, 1907.

GEOLOGY AND UNDERGROUND WATERS OF THE SOUTHEASTERN PART OF THE TEXAS COASTAL PLAIN: USGS WATER-SUPPLY PAPER 335, 1914.

MEMORANDUM ON THE GROUND-WATER DEVELOPMENTS IN THE LUFKIN AREA SINCE THE RELEASE OF THE LUFKIN REPORT (WSP 849-A): USGS OPEN-FILE REPORT (UNNUMBERED), 1940.

GEOLOGY AND GROUND-WATER RESOURCES OF THE LUFKIN AREA, TEXAS: USGS WATER-SUPPLY PAPER 849-A, 1941.

GROUND-WATER RESOURCES IN THE BURKE AREA, ANGELINA COUNTY, TEXAS: USGS OPEN-FILE REPORT (UNNUMBERED), 1942.

MEMORANDUM OF CONFERENCE OF JULY 7, 1942 ON GROUNDWATER INVESTIGATION OF SPARTA SAND NORTH OF SOUTHLAND PAPER MILL: USGS OPEN-FILE REPORT (UNNUMBERED), 1942. 


\section{Bibliography of Ground-Water References for All 254 Counties in Texas, 1886-2001}

DECLINE IN WATER LEVELS IN CITY WELLS AT NACOGDOCHES, TEXAS, AS A RESULT OF PUMPING FROM WELLS OF SOUTHLAND PAPER MILL NEAR LUFKIN: USGS OPEN-FILE REPORT (UNNUMBERED), 1942.

MEMORANDUM ON THE CARRIZO WATER WELL SUPPLYING CITY OF LUFKIN: USGS OPEN-FILE REPORT (UNNUMBERED), 1942.

RESULTS OF PUMPING TESTS OF THE CARRIZO SAND IN THE LUFKIN AREA, TEXAS: AM. GEOPHYSICAL UNION TRANS., PART 2, P. 40-48, 1942.

PROGRESS REPORT ON TEST DRILLING AND PUMPING IN THE SPARTA SAND IN THE LUFKIN AREA, TEXAS: USGS OPEN-FILE REPORT (UNNUMBERED), 1943.

GROUND-WATER CONDITIONS AT PLANT OF SOUTHLAND PAPER MILLS, INC., LUFKIN, TEXAS, A PROGRESS REPORT: USGS OPENFILE REPORT (UNNUMBERED), 1945.

THEORETICAL EFFECT OF INCREASING PRESENT WITHDRAWALS OF GROUND WATER IN LUFKIN AREA, TEXAS: USGS OPEN-FILE REPORT (UNNUMBERED), 1946.

VALUE OF THE ELECTRICAL LOG FOR ESTIMATING GROUNDWATER SUPPLIES AND THE QUALITY OF THE GROUND WATER: AM. GEOPHYSICAL UNION TRANS., V. 28, NO. 6, P. 903-911, 1947.

PUBLIC WATER SUPPLIES IN EASTERN TEXAS: USGS WATERSUPPLY PAPER 1047, 1948

DECLINE OF WATER LEVELS IN WELLS AT NACOGDOCHES CAUSED BY PUMPING BY SOUTHLAND PAPER MILLS: USGS OPEN-FILE REPORT (UNNUMBERED), 1948.

HYDROLOGIC SIGNIFICANCE OF THE LITHOFACIES OF THE SPARTA SAND IN ARKANSAS, LOUISIANA, MISSISSIPPI, AND TEXAS: USGS PROFESSIONAL PAPER 569-A, 1968.

COMPILATION OF RESULTS OF AQUIFER TESTS IN TEXAS: TEXAS WATER DEVELOPMENT BOARD REPORT 98, 1969.

GEOHYDROLOGIC SIGNIFICANCE OF LITHOFACIES OF THE COCKFIELD FORMATION OF LOUISIANA AND MISSISSIPPI AND OF THE YEGUA FORMATION OF TEXAS: USGS PROFESSIONAL PAPER 569-B, 1970.

GROUND-WATER CONDITIONS IN ANGELINA AND NACOGDOCHES COUNTIES, TEXAS: TEXAS WATER DEVELOPMENT BOARD REPORT 110, 1970.

HYDROLOGIC SIGNIFICANCE OF LITHOFACIES OF THE CANE RIVER FORMATION OR EQUIVALENTS OF ARKANSAS, LOUISIANA, MISSISSIPPI, AND TEXAS: USGS PROFESSIONAL PAPER 569-C, 1972.

GEOHYDROLOGIC SIGNIFICANCE OF LITHOFACIES OF THE CARRIZO SAND OF ARKANSAS, LOUISIANA, AND TEXAS AND THE MERIDIAN SAND OF MISSISSIPPI: USGS PROFESSIONAL PAPER 569-D, 1975.

GEOLOGY AND GEOHYDROLOGY OF THE EAST TEXAS BASIN-A REPORT ON THE PROGRESS OF NUCLEAR WASTE ISOLATION FEASIBILITY STUDIES (1979): UNIVERSITY OF TEXAS, BUREAU OF ECONOMIC GEOLOGY GEOLOGICAL CIRCULAR 80-12, 1980.

GEOLOGY AND GEOHYDROLOGY OF THE EAST TEXAS BASIN-A REPORT ON THE PROGRESS OF NUCLEAR WASTE ISOLATION FEASIBILITY STUDIES (1980): UNIVERSITY OF TEXAS, BUREAU OF ECONOMIC GEOLOGY GEOLOGICAL CIRCULAR 81-7, 1981.
TEXAS GROUND-WATER RESOURCES, in NATIONAL WATER SUMMARY 1984: USGS WATER-SUPPLY PAPER 2275, 1985.

APPROXIMATE POTENTIOMETRIC SURFACES FOR THE AQUIFERS OF THE TEXAS COASTAL UPLANDS SYSTEM, 1980: USGS HYDROLOGIC INVESTIGATIONS ATLAS HA-704, 1987.

GEOHYDROLOGIC FRAMEWORK OF THE GULF COASTAL PLAIN: USGS HYDROLOGIC INVESTIGATIONS ATLAS HA-695, 1988.

EVALUATION OF GROUND-WATER RESOURCES IN THE VICINITY OF THE CITIES OF HENDERSON, JACKSONVILLE, KILGORE, LUFKIN, NACOGDOCHES, RUSK, AND TYLER IN EAST TEXAS: TEXAS WATER DEVELOPMENT BOARD REPORT 327, 1991.

PROPERTIES AND CHEMICAL CONSTITUENTS IN GROUND WATER FROM THE UPPER CLAIBORNE AQUIFER, GULF COAST REGIONAL AQUIFER SYSTEMS, SOUTH-CENTRAL UNITED STATES: USGS WATER-RESOURCES INVESTIGATIONS REPORT 91-4150, 1993.

PROPERTIES AND CHEMICAL CONSTITUENTS IN GROUND WATER FROM THE LOWER CLAIBORNE-UPPER WILCOX AQUIFER, GULF COAST REGIONAL AQUIFER SYSTEMS, SOUTH-CENTRAL UNITED STATES: USGS WATER-RESOURCES INVESTIGATIONS REPORT 92-4102, 1993.

PROPERTIES AND CHEMICAL CONSTITUENTS IN GROUND WATER FROM PERMEABLE ZONE E (LOWER MIOCENE-UPPER OLIGOCENE DEPOSITS), COASTAL LOWLANDS AQUIFER SYSTEM, SOUTH-CENTRAL UNITED STATES: USGS WATER-RESOURCES INVESTIGATIONS REPORT 92-4103, 1993.

PROPERTIES AND CHEMICAL CONSTITUENTS IN GROUND WATER FROM THE MIDDLE CLAIBORNE AQUIFER, GULF COAST REGIONAL AQUIFER SYSTEMS, SOUTH-CENTRAL UNITED STATES: USGS WATER-RESOURCES INVESTIGATIONS REPORT 92-4104, 1993.

PROPERTIES AND CHEMICAL CONSTITUENTS IN GROUND WATER FROM THE MIDDLE WILCOX AQUIFER, GULF COAST REGIONAL AQUIFER SYSTEMS, SOUTH-CENTRAL UNITED STATES: USGS WATER-RESOURCES INVESTIGATIONS REPORT 93-4070, 1993.

STRATIGRAPHIC NOMENCLATURE AND GEOLOGIC SECTIONS OF THE GULF COASTAL PLAIN OF TEXAS: USGS OPEN-FILE REPORT 94-461, 1995.

AQUIFERS OF TEXAS: TEXAS WATER DEVELOPMENT BOARD REPORT 345, 1995.

WATER QUALITY IN THE SPARTA AQUIFER, EAST TEXAS: TEXAS WATER DEVELOPMENT BOARD HYDROLOGIC ATLAS NO. 5, 1996.

WATER QUALITY IN THE QUEEN CITY AQUIFER, EAST TEXAS: TEXAS WATER DEVELOPMENT BOARD HYDROLOGIC ATLAS NO. 6, 1996.

TRANSMISSIVITY, HYDRAULIC CONDUCTIVITY, AND STORATIVITY OF THE CARRIZO-WILCOX AQUIFER IN TEXAS, DATA AND ANALYSIS: UNIVERSITY OF TEXAS, BUREAU OF ECONOMIC GEOLOGY, CD-ROM, 2000.

\section{ARANSAS COUNTY}

UNDERGROUND WATERS OF THE COASTAL PLAIN OF TEXAS: USGS WATER-SUPPLY PAPER 190, 1907. 
GROUND-WATER SUPPLY OF LIVE OAK RIDGE, SOUTHWEST OF ARANSAS PASS, TEXAS: USGS OPEN-FILE REPORT (UNNUMBERED), [NO DATE, PROBABLY 1930S].

RECORDS OF WELLS AND SPRINGS, DRILLERS' LOGS, WATER ANALYSES, CROSS SECTIONS AND MAP SHOWING LOCATION OF WELLS AND SPRINGS IN ARANSAS COUNTY, TEXAS: TEXAS BOARD OF WATER ENGINEERS MISCELLANEOUS PUBLICATION $5,1940$.

GROUND-WATER RESOURCES OF LIVE OAK RIDGE IN SAN PATRICIO AND ARANSAS COUNTIES: USGS OPEN-FILE REPORT (UNNUMBERED), 1941?

ROCKPORT WATER SUPPLY: USGS OPEN-FILE REPORT (UNNUMBERED), 1941.

PUBLIC WATER SUPPLIES IN SOUTHERN TEXAS: USGS WATERSUPPLY PAPER 1070, 1950.

AVAILABILITY OF GROUND WATER IN THE GULF COAST REGION OF TEXAS: USGS OPEN-FILE REPORT, 1956.

RECORDS OF WATER LEVELS IN ARANSAS AND SAN PATRICIO COUNTIES, TEXAS, 1938 THROUGH DECEMBER 1956: TEXAS BOARD OF WATER ENGINEERS BULLETIN 5703, 1957.

COMPILATION OF AQUIFER TESTS IN TEXAS: TEXAS WATER DEVELOPMENT BOARD REPORT 98, 1969.

GROUND-WATER RESOURCES OF ARANSAS COUNTY, TEXAS: TEXAS WATER DEVELOPMENT BOARD REPORT 124, 1970.

LAND AND WATER RESOURCES OF THE CORPUS CHRISTI AREA, TEXAS: UNIVERSITY OF TEXAS, BUREAU OF ECONOMIC GEOLOGY REPORT OF INVESTIGATIONS NO. 95, 1978.

STRATIGRAPHIC AND HYDROGEOLOGIC FRAMEWORK OF PART OF THE COASTAL PLAIN OF TEXAS: TEXAS DEPARTMENT OF WATER RESOURCES REPORT 236, 1979.

LAND-SURFACE SUBSIDENCE IN THE TEXAS COASTAL REGION: USGS OPEN-FILE REPORT 80-969, 1980.

SPRINGS OF TEXAS, VOLUME 1: (BY GUNNAR BRUNE), BRANCHSMITH, INC., FORT WORTH, TEXAS, 1981.

TEXAS GROUND-WATER RESOURCES, in NATIONAL WATER SUMMARY 1984: USGS WATER-SUPPLY PAPER 2275, 1985.

GEOHYDROLOGIC FRAMEWORK OF THE GULF COASTAL PLAIN: USGS HYDROLOGIC INVESTIGATIONS ATLAS HA-695, 1988.

PROPERTIES AND CHEMICAL CONSTITUENTS IN GROUND WATER FROM THE MISSISSIPPI RIVER VALLEY ALLUVIAL AQUIFER AND PERMEABLE ZONE A (HOLOCENE-UPPER PLEISTOCENE DEPOSITS), SOUTH-CENTRAL UNITED STATES: USGS WATERRESOURCES INVESTIGATIONS REPORT 91-4149, 1992.

PROPERTIES AND CHEMICAL CONSTITUENTS IN GROUND WATER FROM THE UPPER CLAIBORNE AQUIFER, GULF COAST REGIONAL AQUIFER SYSTEMS, SOUTH-CENTRAL UNITED STATES: USGS WATER-RESOURCES INVESTIGATIONS REPORT 91-4150, 1993.

PROPERTIES AND CHEMICAL CONSTITUENTS IN GROUND WATER FROM PERMEABLE ZONE C (LOWER PLIOCENE-UPPER MIOCENE DEPOSITS), COASTAL LOWLANDS AQUIFER SYSTEM, SOUTHCENTRAL UNITED STATES: USGS WATER-RESOURCES INVESTIGATIONS REPORT 91-4151, 1993.
PROPERTIES AND CHEMICAL CONSTITUENTS IN GROUND WATER FROM PERMEABLE ZONE B (LOWER PLEISTOCENE-UPPER PLIOCENE DEPOSITS), COASTAL LOWLANDS AQUIFER SYSTEM, SOUTH-CENTRAL UNITED STATES: USGS WATER-RESOURCES INVESTIGATIONS REPORT 91-4152, 1993.

PROPERTIES AND CHEMICAL CONSTITUENTS IN GROUND WATER FROM PERMEABLE ZONE E (LOWER MIOCENE-UPPER OLIGOCENE DEPOSITS), COASTAL LOWLANDS AQUIFER SYSTEM, SOUTH-CENTRAL UNITED STATES: USGS WATER-RESOURCES INVESTIGATIONS REPORT 92-4103, 1993.

PROPERTIES AND CHEMICAL CONSTITUENTS IN GROUND WATER FROM PERMEABLE ZONE D (MIDDLE MIOCENE DEPOSITS), COASTAL LOWLANDS AQUIFER SYSTEM, SOUTH-CENTRAL UNITED STATES: USGS WATER-RESOURCES INVESTIGATIONS REPORT 92-4105, 1993.

STRATIGRAPHIC NOMENCLATURE AND GEOLOGIC SECTIONS OF THE GULF COASTAL PLAIN OF TEXAS: USGS OPEN-FILE REPORT 94-461, 1995.

\section{ARCHER COUNTY}

GEOLOGY AND UNDERGROUND WATERS OF THE WICHITA REGION, NORTH-CENTRAL TEXAS: USGS WATER-SUPPLY PAPER $317,1913$.

MEMORANDUM REGARDING INSPECTION OF DAM SITE ON LITTLE WICHITA RIVER, ARCHER COUNTY, TEXAS: USGS OPEN-FILE REPORT (UNNUMBERED), 1945.

PUBLIC WATER SUPPLIES IN CENTRAL AND NORTH-CENTRAL TEXAS: USGS WATER-SUPPLY PAPER 1069, 1949.

OCCURRENCE AND QUALITY OF GROUND WATER IN ARCHER COUNTY, TEXAS: TEXAS WATER DEVELOPMENT BOARD REPORT 52, 1967.

TEXAS GROUND-WATER RESOURCES, in NATIONAL WATER SUMMARY 1984: USGS WATER-SUPPLY PAPER 2275, 1985.

OCCURRENCE AND QUALITY OF WATER IN JACK COUNTY, TEXAS: TEXAS WATER DEVELOPMENT BOARD REPORT 308, 1988.

NATIONAL WATER-QUALITY ASSESSMENT PROGRAM-THE TRINITY RIVER BASIN: USGS OPEN-FILE REPORT 91-158, 1991.

EVALUATION OF WATER RESOURCES IN PARTS OF THE ROLLING PRAIRIES REGION OF NORTH-CENTRAL TEXAS: TEXAS WATER DEVELOPMENT BOARD REPORT 337, 1992.

NATIONAL WATER-QUALITY ASSESSMENT PROGRAM-PESTICIDES IN THE TRINITY RIVER BASIN STUDY UNIT, TEXAS, 1968-91: USGS FACT SHEET FS-088-95, 1995.

WATER-QUALITY ASSESSMENT OF THE TRINITY RIVER BASIN, TEXAS-DATA COLLECTION, 1992-95: USGS FACT SHEET FS-095-95, 1995.

WATER-QUALITY ASSESSMENT OF THE TRINITY RIVER BASIN, TEXAS-PESTICIDES IN A SUBURBAN WATERSHED, ARLINGTON, 1993-94: USGS FACT SHEET FS-159-95, 1995.

AQUIFERS OF TEXAS: TEXAS WATER DEVELOPMENT BOARD REPORT 345, 1995. 


\section{Bibliography of Ground-Water References for All 254 Counties in Texas, 1886-2001}

\section{ARMSTRONG COUNTY}

THE GEOLOGY AND WATER RESOURCES OF THE EASTERN PORTION OF THE PANHANDLE OF TEXAS: USGS WATER-SUPPLY PAPER 154, 1906

RECORDS OF WELLS AND SPRINGS, DRILLERS' LOGS, WATER ANALYSES, AND MAP SHOWING LOCATIONS OF WELLS AND SPRINGS IN ARMSTRONG COUNTY, TEXAS: TEXAS BOARD OF WATER ENGINEERS MISCELLANEOUS PUBLICATION 6, 1940.

GROUND WATER IN THE HIGH PLAINS OF TEXAS, PROGRESS REPORT (1944): TEXAS BOARD OF WATER ENGINEERS OPEN-FILE REPORT, 1944.

GROUND WATER IN THE HIGH PLAINS OF TEXAS, PROGRESS REPORT NO. 5: TEXAS BOARD OF WATER ENGINEERS OPEN-FILE REPORT, 1945.

GROUND WATER IN THE HIGH PLAINS OF TEXAS, PROGRESS REPORT NO. 6: TEXAS BOARD OF WATER ENGINEERS OPEN-FILE REPORT, 1947.

GEOLOGY AND GROUND WATER IN THE IRRIGATED REGION OF THE SOUTHERN HIGH PLAINS IN TEXAS, PROGRESS REPORT NO 7: TEXAS BOARD OF WATER ENGINEERS OPEN-FILE REPORT, 1949.

PUBLIC WATER SUPPLIES IN WESTERN TEXAS: USGS WATERSUPPLY PAPER 1106, 1951

COST OF PUMPING WATER FOR IRRIGATION, TEXAS HIGH PLAINS FIELD INVESTIGATIONS-1947 IRRIGATION SEASON: TEXAS BOARD OF WATER ENGINEERS MISCELLANEOUS PUBLICATION 124, 1951.

WATER-LEVEL DECLINE MAPS, 1956 TO 1957, AND WATER LEVELS IN OBSERVATION WELLS IN 20 COUNTIES IN THE SOUTHERN HIGH PLAINS, TEXAS: TEXAS BOARD OF WATER ENGINEERS BULLETIN 5705, 1957.

WATER-LEVEL MEASUREMENTS AND MAPS, SOUTHERN HIGH PLAINS, TEXAS, 1958-1959: TEXAS BOARD OF WATER ENGINEERS BULLETIN 5908, 1959

WATER LEVELS IN OBSERVATION WELLS, SOUTHERN HIGH PLAINS, TEXAS, 1959 AND 1960: TEXAS BOARD OF WATER ENGINEERS BULLETIN 6011, 1960.

WATER LEVELS IN OBSERVATION WELLS, SOUTHERN HIGH PLAINS, TEXAS, 1960 AND 1961: TEXAS BOARD OF WATER ENGINEERS BULLETIN 6101, 1961.

A SUMMARY OF THE OCCURRENCE AND DEVELOPMENT OF GROUND WATER IN THE SOUTHERN HIGH PLAINS OF TEXAS: TEXAS BOARD OF WATER ENGINEERS BULLETIN 6107, 1961.

WATER-LEVEL MEASUREMENTS THROUGH 1962 IN SELECTED OBSERVATION WELLS, SOUTHERN HIGH PLAINS, TEXAS: TEXAS WATER COMMISSION BULLETIN 6207, 1962.

RECONNAISSANCE INVESTIGATION OF THE GROUND-WATER RESOURCES OF THE RED RIVER, SULPHUR RIVER, AND CYPRESS CREEK BASINS, TEXAS: TEXAS WATER COMMISSION BULLETIN 6306, 1963.

A SUMMARY OF THE OCCURRENCE AND DEVELOPMENT OF GROUND WATER IN THE SOUTHERN HIGH PLAINS OF TEXAS, WITH A SECTION ON ARTIFICIAL RECHARGE STUDIES: USGS WATER-SUPPLY PAPER 1693, 1964.
WATER-LEVEL DATA FROM OBSERVATION WELLS IN THE SOUTHERN HIGH PLAINS OF TEXAS: TEXAS WATER DEVELOPMENT BOARD REPORT 21, 1966.

GROUND WATER IN THE OGALLALA FORMATION IN THE SOUTHERN HIGH PLAINS OF TEXAS AND NEW MEXICO: USGS HYDROLOGIC INVESTIGATIONS ATLAS HA-330, 1969.

COMPILATION OF RESULTS OF AQUIFER TESTS IN TEXAS: TEXAS WATER DEVELOPMENT BOARD REPORT 98, 1969.

WATER-LEVEL DATA FROM OBSERVATION WELLS IN THE SOUTHERN HIGH PLAINS OF TEXAS, 1965-70: TEXAS WATER DEVELOPMENT BOARD REPORT 121, 1970.

AN EVALUATION OF THE USE OF DRILLERS' LOGS IN LITHOLOGIC STUDIES OF THE OGALLALA FORMATION OF THE SOUTHERN HIGH PLAINS OF TEXAS: USGS OPEN-FILE REPORT 72-451, 1972.

ARTIFICIAL-RECHARGE EXPERIMENTS AND OPERATIONS ON THE SOUTHERN HIGH PLAINS OF TEXAS AND NEW MEXICO: USGS WATER-RESOURCES INVESTIGATIONS REPORT 10-73, 1973.

WATER-LEVEL DATA FROM OBSERVATION WELLS IN THE SOUTHERN HIGH PLAINS OF TEXAS, 1971-77: TEXAS DEPARTMENT OF WATER RESOURCES REPORT 228, 1979.

PRELIMINARY DATA DESCRIBING THE DISTRIBUTION OF FLUORIDE AND SILICA IN THE OGALLALA AQUIFER ON THE HIGH PLAINS OF TEXAS: USGS OPEN-FILE REPORT 80-349, 1980.

ANALYTICAL STUDY OF THE OGALLALA AQUIFER IN ARMSTRONG COUNTY, TEXAS-PROJECTIONS OF SATURATED THICKNESS, VOLUME OF WATER IN STORAGE, PUMPAGE RATES, PUMPING LIFTS, AND WELL YIELDS: TEXAS DEPARTMENT OF WATER RESOURCES REPORT 251, 1980.

EVALUATING THE GROUND-WATER RESOURCES OF THE HIGH PLAINS OF TEXAS: RESULTS OF TEST HOLE DRILLING: TEXAS DEPARTMENT OF WATER RESOURCES LIMITED PRINTING REPORT LP-129, 1980.

EVALUATING THE GROUND-WATER RESOURCES OF THE HIGH PLAINS OF TEXAS: RESULTS OF SURFACE ELECTRICAL RESISTIVITY SURVEYS: TEXAS DEPARTMENT OF WATER RESOURCES LIMITED PRINTING REPORT LP-130, 1980.

SPRINGS OF TEXAS, VOLUME 1: (BY GUNNAR BRUNE), BRANCHSMITH, INC., FORT WORTH, TEXAS, 1981.

BEDROCK GEOLOGY, ALTITUDE OF BASE, AND 1980 SATURATED THICKNESS OF THE HIGH PLAINS AQUIFER IN PARTS OF COLORADO, KANSAS, NEBRASKA, NEW MEXICO, OKLAHOMA, SOUTH DAKOTA, TEXAS, AND WYOMING: USGS HYDROLOGIC INVESTIGATIONS ATLAS HA-648, 1981

WATER LEVEL AND SATURATED THICKNESS CHANGES, PREDEVELOPMENT TO 1980, IN THE HIGH PLAINS AQUIFER IN PARTS OF COLORADO, KANSAS, NEBRASKA, NEW MEXICO, OKLAHOMA, SOUTH DAKOTA, TEXAS, AND WYOMING: USGS HYDROLOGIC INVESTIGATIONS ATLAS HA-652, 1981

DISSOLVED SOLIDS AND SODIUM IN WATER FROM THE HIGH PLAINS AQUIFER IN PARTS OF COLORADO, KANSAS, NEBRASKA, NEW MEXICO, OKLAHOMA, SOUTH DAKOTA, TEXAS, AND WYOMING: USGS HYDROLOGIC INVESTIGATIONS ATLAS HA-658, 1982

EVALUATING THE GROUND-WATER RESOURCES OF THE HIGH PLAINS OF TEXAS, VOLUME 1: TEXAS DEPARTMENT OF WATER RESOURCES REPORT 288, V. 1, 1984 
EVALUATING THE GROUND-WATER RESOURCES OF THE HIGH PLAINS OF TEXAS, VOLUME 2, RECORDS OF WELLS, AND MAPS SHOWING WELL LOCATIONS, BASE OF AQUIFER, WATER LEVELS, AND SATURATED THICKNESS (ARMSTRONG, CARSON, DALLAS, DONLEY, GRAY, HANSFORD, HARTLEY, HEMPHILL, HUTCHINSON, LIPSCOMB, MOORE, OCHILTREE, POTTER, ROBERTS, SHERMAN, AND WHEELER COUNTIES): TEXAS DEPARTMENT OF WATER RESOURCES REPORT 288, V. 2, 1984.

TEXAS GROUND-WATER RESOURCES, in NATIONAL WATER SUMMARY 1984: USGS WATER-SUPPLY PAPER 2275, 1985.

WATER-LEVEL CHANGES IN THE HIGH PLAINS AQUIFER OF TEXAS, 1980-1990: TEXAS WATER DEVELOPMENT BOARD HYDROLOGIC ATLAS NO. 1, 1991.

PUBLIC SUPPLY GROUND-WATER USE IN THE NORTHERN HIGH PLAINS OF TEXAS: TEXAS WATER DEVELOPMENT BOARD REPORT 336, 1992.

EVALUATION OF WATER RESOURCES IN PARTS OF THE ROLLING PRAIRIES REGION OF NORTH-CENTRAL TEXAS: TEXAS WATER DEVELOPMENT BOARD REPORT 337, 1992.

THE HIGH PLAINS AQUIFER SYSTEM OF TEXAS, 1980 TO 1990OVERVIEW AND PROJECTIONS: TEXAS WATER DEVELOPMENT BOARD REPORT 341, 1993.

WATER-QUALITY EVALUATION OF THE OGALLALA AQUIFER, TEXAS: TEXAS WATER DEVELOPMENT BOARD REPORT 342, 1993.

WATER-LEVEL CHANGES IN THE HIGH PLAINS AQUIFER-PREDEVELOPMENT TO 1992: USGS WATER-RESOURCES INVESTIGATIONS REPORT 94-4027, 1994.

WATER-LEVEL CHANGES IN THE HIGH PLAINS AQUIFER, 1980 TO 1994: USGS FACT SHEET FS-215-95, 1995.

AQUIFERS OF TEXAS: TEXAS WATER DEVELOPMENT BOARD REPORT 345, 1995.

HYDROLOGIC ATLAS FOR ARMSTRONG COUNTY, TEXAS: HIGH PLAINS UNDERGROUND WATER CONSERVATION DISTRICT NO. 1, LUBBOCK, TEXAS, 1996.

WATER-LEVEL CHANGES IN THE HIGH PLAINS AQUIFER, 1980 TO 1995: USGS FACT SHEET FS-068-97, 1997.

WATER-LEVEL CHANGES IN THE HIGH PLAINS AQUIFER-PREDEVELOPMENT TO 1995: USGS WATER-RESOURCES INVESTIGATIONS REPORT 97-4081, 1997.

PLAYAS AND RECHARGE OF THE OGALLALA AQUIFER ON THE SOUTHERN HIGH PLAINS OF TEXAS-AN EXAMINATION USING NUMERICAL TECHNIQUES: UNIVERSITY OF TEXAS, BUREAU OF ECONOMIC GEOLOGY REPORT OF INVESTIGATIONS NO. 242, 1997.

SPATIAL VARIABILITY IN UNSATURATED FLOW BENEATH PLAYA AND ADJACENT INTERPLAYA SETTINGS AND IMPLICATIONS FOR CONTAMINANT TRANSPORT, SOUTHERN HIGH PLAINS, TEXAS: UNIVERSITY OF TEXAS, BUREAU OF ECONOMIC GEOLOGY REPORT OF INVESTIGATIONS NO. 243, 1997.

UPDATED WATER-QUALITY EVALUATION OF THE OGALLALA AQUIFER INCLUDING SELECTED METALLIC AND NON-METALLIC INORGANIC CONSTITUENTS: TEXAS DEPARTMENT OF WATER RESOURCES HYDROLOGIC ATLAS NO. 10, 1998.

\section{ATASCOSA COUNTY}

ARTESIAN WELLS OF THE COASTAL PRAIRIE REGION AND TERTIARY BELT OF TEXAS: GEOLOGICAL SURVEY OF TEXAS, CHAPTER 2, 1893.

UNDERGROUND WATERS OF THE COASTAL PLAIN OF TEXAS: USGS WATER-SUPPLY PAPER 190, 1907.

GROUND WATER IN THE WINTER GARDEN AND ADJACENT DISTRICTS IN SOUTHWESTERN TEXAS: USGS OPEN-FILE REPORT (UNNUMBERED), 1931.

GEOLOGY AND GROUND-WATER RESOURCES OF ATASCOSA AND FRIO COUNTIES, TEXAS: USGS WATER-SUPPLY PAPER 676, 1935.

GROUND-WATER RESOURCES OF ATASCOSA COUNTY, TEXAS, PROGRESS REPORT: TEXAS BOARD OF WATER ENGINEERS MISCELLANEOUS PUBLICATION 7, 1945.

GROUND-WATER RESOURCES OF ATASCOSA COUNTY, TEXAS: USGS WATER-SUPPLY PAPER 1079-C, 1950.

PUBLIC WATER SUPPLIES IN SOUTHERN TEXAS: USGS WATERSUPPLY PAPER 1070, 1950

RECHARGE TO THE CARRIZO SAND IN ATASCOSA COUNTY AND ADJACENT AREAS: USGS OPEN-FILE REPORT (UNNUMBERED), 1951.

RECORDS OF WATER-LEVEL MEASUREMENTS IN ATASCOSA AND FRIO COUNTIES, TEXAS: TEXAS BOARD OF WATER ENGINEERS BULLETIN 5416, 1954.

DEVELOPMENT OF GROUND WATER FROM THE CARRIZO SAND AND WILCOX GROUP IN DIMMIT, ZAVALA, MAVERICK, FRIO, ATASCOSA, MEDINA, BEXAR, LIVE OAK, McMULLEN, LA SALLE, AND WEBB COUNTIES, TEXAS: USGS OPEN-FILE REPORT 57-77, 1957.

WATER LEVELS IN OBSERVATION WELLS IN ATASCOSA AND FRIO COUNTIES, TEXAS, 1955-1960: TEXAS BOARD OF WATER ENGINEERS BULLETIN 6015, 1960.

RECONNAISSANCE INVESTIGATION OF THE GROUND-WATER RESOURCES OF THE GUADALUPE, SAN ANTONIO, AND NUECES RIVER BASINS, TEXAS: TEXAS WATER COMMISSION BULLETIN 6409, 1964.

CHEMICAL ANALYSES OF WATER FROM OBSERVATION WELLS IN THE EDWARDS AND ASSOCIATED LIMESTONES, SAN ANTONIO AREA, TEXAS, 1964: EDWARDS UNDERGROUND WATER DISTRICT BULLETIN 7, 1965.

GROUND-WATER DISCHARGE FROM THE EDWARDS AND ASSOCIATED LIMESTONES, SAN ANTONIO AREA, TEXAS, 1964: EDWARDS UNDERGROUND WATER DISTRICT BULLETIN 8, 1965.

GROUND-WATER RECHARGE TO THE EDWARDS AND ASSOCIATED LIMESTONES, SAN ANTONIO AREA, TEXAS, 1964: EDWARDS UNDERGROUND WATER DISTRICT BULLETIN 9, 1965.

CHEMICAL ANALYSES FROM OBSERVATION WELLS IN THE EDWARDS AND ASSOCIATED LIMESTONES, SAN ANTONIO AREA, TEXAS, 1965: EDWARDS UNDERGROUND WATER DISTRICT BULLETIN 10, 1966.

GROUND-WATER RESOURCES OF ATASCOSA AND FRIO COUNTIES, TEXAS: TEXAS WATER DEVELOPMENT BOARD REPORT 32, 1966. 


\section{Bibliography of Ground-Water References for All 254 Counties in Texas, 1886-2001}

CHEMICAL ANALYSES OF WATER FROM OBSERVATION WELLS IN THE EDWARDS AND ASSOCIATED LIMESTONES, SAN ANTONIO AREA, TEXAS, 1966: EDWARDS UNDERGROUND WATER DISTRICT BULLETIN 13, 1967.

CHEMICAL ANALYSES OF WATER FROM OBSERVATION WELLS IN THE EDWARDS AND ASSOCIATED LIMESTONES, SAN ANTONIO AREA, TEXAS, 1967: EDWARDS UNDERGROUND WATER DISTRICT BULLETIN 16, 1968.

WATER-LEVEL DATA FROM OBSERVATION WELLS IN THE NORTHWESTERN GULF COASTAL PLAIN OF TEXAS: TEXAS WATER DEVELOPMENT BOARD REPORT 70, 1968.

HYDROLOGIC SIGNIFICANCE OF THE LITHOFACIES OF THE SPARTA SAND IN ARKANSAS, LOUISIANA, MISSISSIPPI, AND TEXAS: USGS PROFESSIONAL PAPER 569-A, 1968.

COMPILATION OF AQUIFER TESTS IN TEXAS: TEXAS WATER DEVELOPMENT BOARD REPORT 98, 1969.

GEOHYDROLOGIC SIGNIFICANCE OF LITHOFACIES OF THE COCKFIELD FORMATION OF LOUISIANA AND MISSISSIPPI AND OF THE YEGUA FORMATION OF TEXAS: USGS PROFESSIONAL PAPER 569-B, 1970.

HYDROLOGIC SIGNIFICANCE OF LITHOFACIES OF THE CANE RIVER FORMATION OR EQUIVALENTS OF ARKANSAS, LOUISIANA, MISSISSIPPI, AND TEXAS: USGS PROFESSIONAL PAPER 569-C, 1972.

GEOHYDROLOGIC SIGNIFICANCE OF LITHOFACIES OF THE CARRIZO SAND OF ARKANSAS, LOUISIANA, AND TEXAS AND THE MERIDIAN SAND OF MISSISSIPPI: USGS PROFESSIONAL PAPER 569-D, 1975.

GROUND-WATER RESOURCES OF THE CARRIZO AQUIFER IN THE WINTER GARDEN AREA OF TEXAS, VOLUME 1: TEXAS WATER DEVELOPMENT BOARD REPORT 210, V. 1, 1976.

GROUND-WATER RESOURCES OF THE CARRIZO AQUIFER IN THE WINTER GARDEN AREA OF TEXAS, VOLUME 2: TEXAS WATER DEVELOPMENT BOARD REPORT 210, V. 2, 1977.

RESULTS OF AN INFILTRATION STUDY ON THE CARRIZO SAND OUTCROP IN ATASCOSA COUNTY, TEXAS: TEXAS DEPARTMENT OF WATER RESOURCES LIMITED PRINTING REPORT LP-61, 1978.

VARIATIONS IN SPECIFIC YIELD IN THE OUTCROP OF THE CARRIZO SAND IN SOUTH TEXAS AS ESTIMATED BY SEISMIC REFRACTION: TEXAS DEPARTMENT OF WATER RESOURCES REPORT 229, 1979.

GROUND-WATER RESOURCES AND MODEL APPLICATIONS FOR THE EDWARDS (BALCONES FAULT ZONE) AQUIFER IN THE SAN ANTONIO REGION: TEXAS DEPARTMENT OF WATER RESOURCES REPORT 239, 1979.

HYDROCHEMICAL DATA FOR THE EDWARDS AQUIFER IN THE SAN ANTONIO AREA, TEXAS: TEXAS DEPARTMENT OF WATER RESOURCES LIMITED PRINTING REPORT LP-131, 1980.

WATER LEVEL, RECHARGE, DISCHARGE, SPECIFIC-CAPACITY, WELL-YIELD, AND AQUIFER-TEST DATA FOR THE EDWARDS AQUIFER IN THE SAN ANTONIO AREA, TEXAS: TEXAS DEPARTMENT OF WATER RESOURCES LIMITED PRINTING REPORT LP-133, 1980.

APPLICATION AND ANALYSIS OF BOREHOLE DATA FOR THE EDWARDS AQUIFER IN THE SAN ANTONIO AREA, TEXAS: TEXAS
DEPARTMENT OF WATER RESOURCES LIMITED PRINTING REPORT LP-139, 1981.

TEXAS GROUND-WATER RESOURCES, in NATIONAL WATER SUMMARY 1984: USGS WATER-SUPPLY PAPER 2275, 1985

APPROXIMATE POTENTIOMETRIC SURFACES FOR THE AQUIFERS OF THE TEXAS COASTAL UPLANDS SYSTEM, 1980: USGS HYDROLOGIC INVESTIGATIONS ATLAS HA-704, 1987.

DEPOSITIONAL AND GROUND-WATER FLOW SYSTEMS OF THE CARRIZO-UPPER WILCOX, SOUTH TEXAS: UNIVERSITY OF TEXAS, BUREAU OF ECONOMIC GEOLOGY REPORT OF INVESTIGATIONS NO. 175, 1988.

GEOHYDROLOGIC FRAMEWORK OF THE GULF COASTAL PLAIN: USGS HYDROLOGIC INVESTIGATIONS ATLAS HA-695, 1988.

GROUND-WATER QUALITY MONITORING RESULTS IN THE WINTER GARDEN AREA, 1990: TEXAS WATER DEVELOPMENT BOARD REPORT 335, 1992.

PROPERTIES AND CHEMICAL CONSTITUENTS IN GROUND WATER FROM THE UPPER CLAIBORNE AQUIFER, GULF COAST REGIONAL AQUIFER SYSTEMS, SOUTH-CENTRAL UNITED STATES: USGS WATER-RESOURCES INVESTIGATIONS REPORT 91-4150, 1993.

PROPERTIES AND CHEMICAL CONSTITUENTS IN GROUND WATER FROM THE LOWER CLAIBORNE-UPPER WILCOX AQUIFER, GULF COAST REGIONAL AQUIFER SYSTEMS, SOUTH-CENTRAL UNITED STATES: USGS WATER-RESOURCES INVESTIGATIONS REPORT 92-4102, 1993

PROPERTIES AND CHEMICAL CONSTITUENTS IN GROUND WATER FROM THE MIDDLE CLAIBORNE AQUIFER, GULF COAST REGIONAL AQUIFER SYSTEMS, SOUTH-CENTRAL UNITED STATES: USGS WATER-RESOURCES INVESTIGATIONS REPORT 92-4104, 1993.

PROPERTIES AND CHEMICAL CONSTITUENTS IN GROUND WATER FROM THE MIDDLE WILCOX AQUIFER, GULF COAST REGIONAL AQUIFER SYSTEMS, SOUTH-CENTRAL UNITED STATES: USGS WATER-RESOURCES INVESTIGATIONS REPORT 93-4070, 1993.

DEFINING THE EDWARDS AQUIFER FRESHWATER/SALINE-WATER INTERFACE WITH GEOPHYSICAL LOGS AND MEASURED DATA (SAN ANTONIO TO KYLE, TEXAS): EDWARDS UNDERGROUND WATER DISTRICT REPORT 93-06, 1993.

1994 REVIEW AND UPDATE OF THE POSITION OF THE EDWARDS AQUIFER FRESHWATER/SALINE-WATER INTERFACE FROM UVALDE TO KYLE, TEXAS: EDWARDS UNDERGROUND WATER DISTRICT REPORT 94-05, 1994.

STRATIGRAPHIC NOMENCLATURE AND GEOLOGIC SECTIONS OF THE GULF COASTAL PLAIN OF TEXAS: USGS OPEN-FILE REPORT 94-461, 1995.

AQUIFERS OF TEXAS: TEXAS WATER DEVELOPMENT BOARD REPORT 345, 1995.

REGIONAL DISTRIBUTION OF PERMEABILITY IN THE EDWARDS AQUIFER: EDWARDS UNDERGROUND WATER DISTRICT REPORT 95-02, 1995.

WATER QUALITY IN THE SPARTA AQUIFER, EAST TEXAS: TEXAS WATER DEVELOPMENT BOARD HYDROLOGIC ATLAS NO. 5, 1996. 
WATER QUALITY IN THE QUEEN CITY AQUIFER, EAST TEXAS: TEXAS WATER DEVELOPMENT BOARD HYDROLOGIC ATLAS NO. 6, 1996

EDWARDS AQUIFER GROUND-WATER RESOURCES: GEOLOGIC CONTROLS ON POROSITY DEVELOPMENT IN PLATFORM CARBONATES, SOUTH TEXAS: UNIVERSITY OF TEXAS, BUREAU OF ECONOMIC GEOLOGY REPORT OF INVESTIGATIONS NO. 238, 1996.

HYDROGEOLOGIC FRAMEWORK AND GEOCHEMISTRY OF THE EDWARDS AQUIFER SALINE-WATER ZONE, SOUTH-CENTRAL TEXAS: USGS WATER-RESOURCES INVESTIGATIONS REPORT 97-4133, 1997.

TRANSMISSIVITY, HYDRAULIC CONDUCTIVITY, AND STORATIVITY OF THE CARRIZO-WILCOX AQUIFER IN TEXAS, DATA AND ANALYSIS: UNIVERSITY OF TEXAS, BUREAU OF ECONOMIC GEOLOGY, CD-ROM, 2000

WATER QUALITY IN SOUTH-CENTRAL TEXAS-TEXAS, 1996-98: USGS CIRCULAR 1212, 2000.

\section{AUSTIN COUNTY}

UNDERGROUND WATERS OF THE COASTAL PLAIN OF TEXAS: USGS WATER-SUPPLY PAPER 190, 1907.

RECORDS OF WELLS AND SPRINGS, DRILLERS' LOGS, WATER ANALYSES, AND MAP SHOWING LOCATION OF WELLS AND SPRINGS IN AUSTIN COUNTY, TEXAS: TEXAS BOARD OF WATER ENGINEERS MISCELLANEOUS PUBLICATION 8, 1938.

PUBLIC WATER SUPPLIES IN EASTERN TEXAS: USGS WATERSUPPLY PAPER 1047, 1948.

AVAILABILITY OF GROUND WATER IN THE GULF COAST REGION OF TEXAS: USGS OPEN-FILE REPORT (UNNUMBERED), 1956.

RECONNAISSANCE INVESTIGATION OF THE GROUND-WATER RESOURCES OF THE GULF COAST REGION, TEXAS: TEXAS WATER COMMISSION BULLETIN 6305, 1963.

GROUND WATER IN THE FLOOD-PLAIN ALLUVIUM OF THE BRAZOS RIVER, WHITNEY DAM TO VICINITY OF RICHMOND, TEXAS: TEXAS WATER DEVELOPMENT BOARD REPORT 41, 1967.

GROUND-WATER RESOURCES OF AUSTIN AND WALLER COUNTIES, TEXAS: TEXAS WATER DEVELOPMENT BOARD REPORT 68, 1967.

GEOHYDROLOGIC SIGNIFICANCE OF LITHOFACIES OF THE COCKFIELD FORMATION OF LOUISIANA AND MISSISSIPPI AND OF THE YEGUA FORMATION OF TEXAS: USGS PROFESSIONAL PAPER 569-B, 1970

HYDROLOGIC SIGNIFICANCE OF LITHOFACIES OF THE CANE RIVER FORMATION OR EQUIVALENTS OF ARKANSAS, LOUISIANA, MISSISSIPPI, AND TEXAS: USGS PROFESSIONAL PAPER 569-C, 1972

SUMMARY APPRAISALS OF THE NATION'S GROUND-WATER RESOURCES-TEXAS-GULF REGION: USGS PROFESSIONAL PAPER 813-F, 1976.

APPROXIMATE AREAS OF RECHARGE TO THE CHICOT AND EVANGELINE AQUIFER SYSTEMS IN THE HOUSTON-GALVESTON AREA, TEXAS: USGS OPEN-FILE REPORT 77-754, 1977.
LAND AND WATER RESOURCES OF THE CORPUS CHRISTI AREA, TEXAS: UNIVERSITY OF TEXAS, BUREAU OF ECONOMIC GEOLOGY REPORT OF INVESTIGATIONS NO. 95, 1978.

STRATIGRAPHIC AND HYDROGEOLOGIC FRAMEWORK OF PART OF THE COASTAL PLAIN OF TEXAS: USGS OPEN-FILE REPORT 77-712, 1978. ALSO PUBLISHED AS TEXAS DEPARTMENT OF WATER RESOURCES REPORT 236, 1979.

SPRINGS OF TEXAS, VOLUME 1: (BY GUNNAR BRUNE), BRANCHSMITH, INC., FORT WORTH, TEXAS, 1981.

REGIONAL HYDRODYNAMICS AND HYDROCHEMISTRY OF THE URANIUM-BEARING OAKVILLE AQUIFER (MIOCENE) OF SOUTH TEXAS: UNIVERSITY OF TEXAS, BUREAU OF ECONOMIC GEOLOGY REPORT OF INVESTIGATIONS NO. 124, 1982.

TEXAS GROUND-WATER RESOURCES, in NATIONAL WATER SUMMARY 1984: USGS WATER-SUPPLY PAPER 2275, 1985.

DIGITAL MODELS FOR SIMULATION OF GROUND-WATER HYDROLOGY OF THE CHICOT AND EVANGELINE AQUIFERS ALONG THE GULF COAST OF TEXAS: TEXAS DEPARTMENT OF WATER RESOURCES REPORT 289, 1985.

GEOHYDROLOGIC FRAMEWORK OF THE GULF COASTAL PLAIN: USGS HYDROLOGIC INVESTIGATIONS ATLAS HA-695, 1988

PROPERTIES AND CHEMICAL CONSTITUENTS IN GROUND WATER FROM THE MISSISSIPPI RIVER VALLEY ALLUVIAL AQUIFER AND PERMEABLE ZONE A (HOLOCENE-UPPER PLEISTOCENE DEPOSITS), SOUTH-CENTRAL UNITED STATES: USGS WATERRESOURCES INVESTIGATIONS REPORT 91-4149, 1992.

PROPERTIES AND CHEMICAL CONSTITUENTS IN GROUND WATER FROM THE UPPER CLAIBORNE AQUIFER, GULF COAST REGIONAL AQUIFER SYSTEMS, SOUTH-CENTRAL UNITED STATES: USGS WATER-RESOURCES INVESTIGATIONS REPORT 91-4150, 1993.

PROPERTIES AND CHEMICAL CONSTITUENTS IN GROUND WATER FROM PERMEABLE ZONE C (LOWER PLIOCENE-UPPER MIOCENE DEPOSITS), COASTAL LOWLANDS AQUIFER SYSTEM, SOUTHCENTRAL UNITED STATES: USGS WATER-RESOURCES INVESTIGATIONS REPORT 91-4151, 1993.

PROPERTIES AND CHEMICAL CONSTITUENTS IN GROUND WATER FROM PERMEABLE ZONE E (LOWER MIOCENE-UPPER OLIGOCENE DEPOSITS), COASTAL LOWLANDS AQUIFER SYSTEM, SOUTH-CENTRAL UNITED STATES: USGS WATER-RESOURCES INVESTIGATIONS REPORT 92-4103, 1993.

PROPERTIES AND CHEMICAL CONSTITUENTS IN GROUND WATER FROM THE MIDDLE CLAIBORNE AQUIFER, GULF COAST REGIONAL AQUIFER SYSTEMS, SOUTH-CENTRAL UNITED STATES: USGS WATER-RESOURCES INVESTIGATIONS REPORT 92-4104, 1993.

PROPERTIES AND CHEMICAL CONSTITUENTS IN GROUND WATER FROM PERMEABLE ZONE D (MIDDLE MIOCENE DEPOSITS), COASTAL LOWLANDS AQUIFER SYSTEM, SOUTH-CENTRAL UNITED STATES: USGS WATER-RESOURCES INVESTIGATIONS REPORT 92-4105, 1993.

PROPERTIES AND CHEMICAL CONSTITUENTS IN GROUND WATER FROM THE MIDDLE WILCOX AQUIFER, GULF COAST REGIONAL AQUIFER SYSTEMS, SOUTH-CENTRAL UNITED STATES: USGS WATER-RESOURCES INVESTIGATIONS REPORT 93-4070, 1993.

AQUIFERS OF TEXAS: TEXAS WATER DEVELOPMENT BOARD REPORT 345, 1995. 
STRATIGRAPHIC NOMENCLATURE AND GEOLOGIC SECTIONS OF THE GULF COASTAL PLAIN OF TEXAS: USGS OPEN-FILE REPORT 94-461, 1995.

\section{BAILEY COUNTY}

RECORDS OF WELLS, DRILLERS' LOGS, AND WATER ANALYSES, AND MAP SHOWING LOCATION OF WELLS IN BAILEY COUNTY, TEXAS (NORTHEAST PART): TEXAS BOARD OF WATER ENGINEERS MISCELLANEOUS PUBLICATION 9, 1936.

RECORDS OF WELLS, DRILLERS' LOGS, WATER LEVEL MEASUREMENTS, WATER ANALYSES, AND MAP SHOWING LOCATION OF WELLS IN BAILEY COUNTY, TEXAS: TEXAS BOARD OF WATER ENGINEERS MISCELLANEOUS PUBLICATION 10, 1937.

GROUND WATER IN THE HIGH PLAINS IN TEXAS, PROGRESS REPORT (1940): TEXAS BOARD OF WATER ENGINEERS OPEN-FILE REPORT, 1940.

GROUND WATER IN THE HIGH PLAINS IN TEXAS, PROGRESS REPORT (1943): TEXAS BOARD OF WATER ENGINEERS OPEN-FILE REPORT, 1943.

GROUND WATER IN THE HIGH PLAINS IN TEXAS, PROGRESS REPORT (1944): TEXAS BOARD OF WATER ENGINEERS OPEN-FILE REPORT, 1944.

GROUND WATER IN THE HIGH PLAINS IN TEXAS, PROGRESS REPORT NO. 5: TEXAS BOARD OF WATER ENGINEERS OPEN-FILE REPORT, 1945.

GROUND WATER IN THE HIGH PLAINS OF TEXAS: USGS WATERSUPPLY PAPER 889-F, 1946.

GROUND WATER IN THE HIGH PLAINS IN TEXAS, PROGRESS REPORT NO. 6: TEXAS BOARD OF WATER ENGINEERS OPEN-FILE REPORT, 1947.

GEOLOGY AND GROUND WATER IN THE IRRIGATED REGION OF THE SOUTHERN HIGH PLAINS IN TEXAS, PROGRESS REPORT NO. 7: TEXAS BOARD OF WATER ENGINEERS OPEN-FILE REPORT, 1949.

DEVELOPMENT OF WELLS FOR IRRIGATION AND FLUCTUATION OF WATER LEVELS IN THE HIGH PLAINS OF TEXAS TO JANUARY 1951: TEXAS BOARD OF WATER ENGINEERS BULLETIN 5104, 1951.

COST OF PUMPING WATER FOR IRRIGATION, TEXAS HIGH PLAINS FIELD INVESTIGATIONS-1947 IRRIGATION SEASON: TEXAS BOARD OF WATER ENGINEERS MEMORANDUM REPORT 124 , 1951.

SUMMARY OF GROUND-WATER DEVELOPMENT IN THE SOUTHERN HIGH PLAINS, TEXAS: TEXAS BOARD OF WATER ENGINEERS BULLETIN 5402, 1954

RECORDS OF WATER-LEVEL MEASUREMENTS IN BAILEY, BRISCOE, CASTRO, PARMER, POTTER, AND RANDALL COUNTIES, TEXAS: TEXAS BOARD OF WATER ENGINEERS BULLETIN 5406, 1954.

GROUND-WATER DEVELOPMENT IN THE SOUTHERN HIGH PLAINS OF TEXAS: TEXAS BOARD OF WATER ENGINEERS BULLETIN 5410, 1954.
WATER-LEVEL DECLINE MAPS OF 17 COUNTIES IN THE SOUTHERN HIGH PLAINS, TEXAS, JANUARY 1955 TO JANUARY 1956: TEXAS BOARD OF WATER ENGINEERS BULLETIN 5607, 1956.

WATER-LEVEL DECLINE MAPS, 1956 TO 1957, AND WATER LEVELS IN OBSERVATION WELLS IN 20 COUNTIES IN THE SOUTHERN HIGH PLAINS, TEXAS: TEXAS BOARD OF WATER ENGINEERS BULLETIN 5705, 1957.

WATER-LEVEL MEASUREMENTS AND MAPS, SOUTHERN HIGH PLAINS, TEXAS, 1958 AND 1959: TEXAS BOARD OF WATER ENGINEERS BULLETIN 5908, 1959.

WATER LEVELS IN OBSERVATION WELLS, SOUTHERN HIGH PLAINS, TEXAS,1959 AND 1960: TEXAS BOARD OF WATER ENGINEERS BULLETIN 6011, 1960

WATER LEVELS IN OBSERVATION WELLS, SOUTHERN HIGH PLAINS, TEXAS, 1960 AND 1961: TEXAS BOARD OF WATER ENGINEERS BULLETIN 6101, 1961.

A SUMMARY OF THE OCCURRENCE AND DEVELOPMENT OF GROUND WATER IN THE SOUTHERN HIGH PLAINS OF TEXAS: TEXAS BOARD OF WATER ENGINEERS BULLETIN 6107, 1961.

WATER-LEVEL MEASUREMENTS THROUGH 1962 IN SELECTED OBSERVATION WELLS, SOUTHERN HIGH PLAINS, TEXAS: TEXAS WATER COMMISSION BULLETIN 6207, 1962.

A SUMMARY OF THE OCCURRENCE AND DEVELOPMENT OF GROUND WATER IN THE SOUTHERN HIGH PLAINS OF TEXAS: USGS WATER-SUPPLY PAPER 1693, 1964.

PUBLIC WATER SUPPLIES OF THE 100 LARGEST CITIES IN THE UNITED STATES: USGS WATER-SUPPLY PAPER 1812, 1964.

WATER-LEVEL DATA FROM OBSERVATION WELLS IN THE SOUTHERN HIGH PLAINS OF TEXAS: TEXAS WATER DEVELOPMENT BOARD REPORT 21, 1966.

COMPILATION OF RESULTS OF AQUIFER TESTS IN TEXAS: TEXAS WATER DEVELOPMENT BOARD REPORT 98, 1969

GROUND WATER IN THE OGALLALA FORMATION IN THE SOUTHERN HIGH PLAINS OF TEXAS AND NEW MEXICO: USGS HYDROLOGIC INVESTIGATIONS ATLAS HA-330, 1969.

WATER-LEVEL DATA FROM OBSERVATION WELLS IN THE SOUTHERN HIGH PLAINS OF TEXAS, 1965-70: TEXAS WATER DEVELOPMENT BOARD REPORT 121, 1970.

AN EVALUATION OF THE USE OF DRILLERS' LOGS IN LITHOLOGIC STUDIES OF THE OGALLALA FORMATION OF THE SOUTHERN HIGH PLAINS OF TEXAS: USGS OPEN-FILE REPORT 72-451, 1972.

ARTIFICIAL RECHARGE EXPERIMENTS AND OPERATIONS ON THE SOUTHERN HIGH PLAINS OF TEXAS AND NEW MEXICO: USGS WATER-RESOURCES INVESTIGATIONS REPORT 10-73, 1973.

ANALYTICAL STUDY OF THE OGALLALA AQUIFER IN BAILEY COUNTY, TEXAS—PROJECTIONS OF SATURATED THICKNESS, VOLUME OF WATER IN STORAGE, PUMPAGE RATES, PUMPING LIFTS, AND WELL YIELDS: TEXAS WATER DEVELOPMENT BOARD REPORT 207, 1976.

WATER-LEVEL DATA FROM OBSERVATION WELLS IN THE SOUTHERN HIGH PLAINS OF TEXAS, 1971-77: TEXAS DEPARTMENT OF WATER RESOURCES REPORT 228, 1979.

PRELIMINARY DATA DESCRIBING THE DISTRIBUTION OF FLUORIDE AND SILICA IN THE OGALLALA AQUIFER ON THE HIGH PLAINS OF TEXAS: USGS OPEN-FILE REPORT 80-349, 1980. 
EVALUATING THE GROUND-WATER RESOURCES OF THE HIGH PLAINS OF TEXAS: RESULTS OF TEST HOLE DRILLING: TEXAS DEPARTMENT OF WATER RESOURCES LIMITED PRINTING REPORT LP-129, 1980

EVALUATING THE GROUND-WATER RESOURCES OF THE HIGH PLAINS OF TEXAS: RESULTS OF SURFACE ELECTRICAL RESISTIVITY SURVEYS: TEXAS DEPARTMENT OF WATER RESOURCES LIMITED PRINTING REPORT LP-130, 1980.

EVALUATING THE GROUND-WATER RESOURCES OF THE HIGH PLAINS OF TEXAS: NEUTRON-PROBE MEASUREMENTS OF DEEP SOIL MOISTURE AS AN INDICATION OF AQUIFER RECHARGE: TEXAS DEPARTMENT OF WATER RESOURCES LIMITED PRINTING REPORT LP-142, 1981.

SPRINGS OF TEXAS, VOLUME 1: (BY GUNNAR BRUNE), BRANCHSMITH, INC., FORT WORTH, TEXAS, 1981.

BEDROCK GEOLOGY, ALTITUDE OF BASE, AND 1980 SATURATED THICKNESS OF THE HIGH PLAINS AQUIFER IN PARTS OF COLORADO, KANSAS, NEBRASKA, NEW MEXICO, OKLAHOMA, SOUTH DAKOTA, TEXAS, AND WYOMING: USGS HYDROLOGIC INVESTIGATIONS ATLAS HA-648, 1981.

WATER LEVEL AND SATURATED THICKNESS CHANGES, PREDEVELOPMENT TO 1980, IN THE HIGH PLAINS AQUIFER IN PARTS OF COLORADO, KANSAS, NEBRASKA, NEW MEXICO, OKLAHOMA, SOUTH DAKOTA, TEXAS, AND WYOMING: USGS HYDROLOGIC INVESTIGATIONS ATLAS HA-652, 1981.

DISSOLVED SOLIDS AND SODIUM IN WATER FROM THE HIGH PLAINS AQUIFER IN PARTS OF COLORADO, KANSAS, NEBRASKA, NEW MEXICO, OKLAHOMA, SOUTH DAKOTA, TEXAS, AND WYOMING: USGS HYDROLOGIC INVESTIGATIONS ATLAS HA-658, 1982.

INVESTIGATION OF SECONDARY RECOVERY OF GROUND WATER FROM THE OGALLALA FORMATION, HIGH PLAINS OF TEXASSUMMARY OF STUDY: HIGH PLAINS UNDERGROUND WATER CONSERVATION DISTRICT NO. 1, LUBBOCK, TEXAS, 1982.

EVALUATING THE GROUND-WATER RESOURCES OF THE HIGH PLAINS OF TEXAS, VOLUME 1: TEXAS DEPARTMENT OF WATER RESOURCES REPORT 288, V. 1, 1984.

EVALUATING THE GROUND-WATER RESOURCES OF THE HIGH PLAINS OF TEXAS, VOLUME 3, RECORDS OF WELLS AND MAPS SHOWING WELL LOCATIONS, BASE OF AQUIFER, WATER LEVELS, AND SATURATED THICKNESS (BAILEY, BRISCOE, CASTRO, CROSBY, DEAF SMITH, DICKENS, FLOYD, HALE, LAMB, MOTLEY, OLDHAM, PARMER, RANDALL, AND SWISHER COUNTIES): TEXAS DEPARTMENT OF WATER RESOURCES REPORT 288 V. 3 , 1984.

GEOHYDROLOGY OF THE HIGH PLAINS AQUIFER IN PARTS OF COLORADO, KANSAS, NEBRASKA, NEW MEXICO, OKLAHOMA, SOUTH DAKOTA, TEXAS, AND WYOMING: USGS PROFESSIONAL PAPER 1400-B, 1984.

TEXAS GROUND-WATER RESOURCES, in NATIONAL WATER SUMMARY 1984: USGS WATER-SUPPLY PAPER 2275, 1985.

DIGITAL SIMULATION OF GROUND-WATER FLOW IN THE HIGH PLAINS AQUIFER IN PARTS OF COLORADO, KANSAS, NEBRASKA, NEW MEXICO, OKLAHOMA, SOUTH DAKOTA, TEXAS, AND WYOMING: USGS PROFESSIONAL PAPER 1400-D, 1986.

HYDROLOGIC ATLAS FOR BAILEY COUNTY, TEXAS: HIGH PLAINS UNDERGROUND WATER CONSERVATION DISTRICT NO. 1, 1987.
HYDROGEOLOGY AND HYDROCHEMISTRY OF CRETACEOUS AQUIFERS, TEXAS PANHANDLE AND EASTERN NEW MEXICO: UNIVERSITY OF TEXAS, BUREAU OF ECONOMIC GEOLOGY GEOLOGICAL CIRCULAR 88-3, 1988.

SUMMARY OF THE HIGH PLAINS REGIONAL AQUIFER-SYSTEM ANALYSIS IN PARTS OF COLORADO, KANSAS, NEBRASKA, NEW MEXICO, OKLAHOMA, SOUTH DAKOTA, TEXAS, AND WYOMING: USGS PROFESSIONAL PAPER 1400-A, 1988.

HYDROGEOLOGY OF LOWER CRETACEOUS STRATA UNDER THE SOUTHERN HIGH PLAINS OF TEXAS AND NEW MEXICO: TEXAS WATER DEVELOPMENT BOARD REPORT 314, 1989.

PUBLIC SUPPLY GROUND-WATER USE IN THE SOUTHERN HIGH PLAINS OF TEXAS: TEXAS WATER DEVELOPMENT BOARD REPORT 328, 1990.

WATER-LEVEL CHANGES IN THE HIGH PLAINS AQUIFER OF TEXAS, 1980-1990: TEXAS WATER DEVELOPMENT BOARD HYDROLOGIC ATLAS NO. 1, 1991.

WATER-RESOURCES DATA, TEXAS, WATER YEAR 1991, VOLUME 4, GROUND-WATER DATA: USGS WATER-DATA REPORT TX-91-4, 1992.

THE HIGH PLAINS AQUIFER SYSTEM OF TEXAS, 1980 TO 1990OVERVIEW AND PROJECTIONS: TEXAS WATER DEVELOPMENT BOARD REPORT 341, 1993.

WATER-QUALITY EVALUATION OF THE OGALLALA AQUIFER, TEXAS: TEXAS WATER DEVELOPMENT BOARD REPORT 342 , 1993.

WATER-RESOURCES DATA, TEXAS, WATER YEAR 1992, VOLUME 4, GROUND-WATER DATA: USGS WATER-DATA REPORT TX-92-4, 1993.

WATER-LEVEL CHANGES IN THE HIGH PLAINS AQUIFER-PREDEVELOPMENT TO 1992: USGS WATER-RESOURCES INVESTIGATIONS REPORT 94-4027, 1994.

WATER-RESOURCES DATA, TEXAS, WATER YEAR 1993, VOLUME 4, GROUND-WATER DATA: USGS WATER-DATA REPORT TX-93-4, 1994.

WATER-LEVEL CHANGES IN THE HIGH PLAINS AQUIFER, 1980 TO 1994: USGS FACT SHEET FS-215-95, 1995.

WATER-RESOURCES DATA, TEXAS, WATER YEAR 1994, VOLUME 4, GROUND-WATER DATA: USGS WATER-DATA REPORT TX-94-4, 1995.

HYDROLOGIC ATLAS FOR BAILEY COUNTY, TEXAS: HIGH PLAINS UNDERGROUND WATER CONSERVATION DISTRICT NO. 1, LUBBOCK, TEXAS, 1996.

WATER-RESOURCES DATA, TEXAS, WATER YEAR 1995, VOLUME 4, GROUND-WATER DATA: USGS WATER-DATA REPORT TX-95-4, 1996.

WATER-LEVEL CHANGES IN THE HIGH PLAINS AQUIFER, 1980 TO 1995: USGS FACT SHEET FS-068-97, 1997.

WATER-LEVEL CHANGES IN THE HIGH PLAINS AQUIFER-PREDEVELOPMENT TO 1995: USGS WATER-RESOURCES INVESTIGATIONS REPORT 97-4081, 1997.

WATER-RESOURCES DATA, TEXAS, WATER YEAR 1996, VOLUME 4 , GROUND-WATER DATA: USGS WATER-DATA REPORT TX-96-4, 1997. 
UPDATED WATER-QUALITY EVALUATION OF THE OGALLALA AQUIFER INCLUDING SELECTED METALLIC AND NON-METALLIC INORGANIC CONSTITUENTS: TEXAS WATER DEVELOPMENT BOARD HYDROLOGIC ATLAS HA-10, 1998.

WATER-RESOURCES DATA, TEXAS, WATER YEAR 1997, VOLUME 4, GROUND-WATER DATA: USGS WATER-DATA REPORT TX-97-4, 1998.

WATER-RESOURCES DATA, TEXAS, WATER YEAR 1998, VOLUME 4 , GROUND-WATER DATA: USGS WATER-DATA REPORT TX-98-4, 1999.

WATER-RESOURCES DATA, TEXAS, WATER YEAR 1999, VOLUME 6, GROUND-WATER DATA: USGS WATER-DATA REPORT TX-99-6, 2000 .

\section{BANDERA COUNTY}

PUBLIC WATER SUPPLIES IN SOUTHERN TEXAS: USGS WATERSUPPLY PAPER 1070, 1950.

SUPPLEMENTARY REPORT ON SURFACE-WATER AND GROUNDWATER SURVEYS, NUECES RIVER BASIN, TEXAS: USGS OPENFILE REPORT (UNNUMBERED), 1950.

GROUND-WATER RESOURCES OF THE SAN ANTONIO AREA, TEXAS, A PROGRESS REPORT OF CURRENT STUDIES: TEXAS BOARD OF WATER ENGINEERS BULLETIN 5412, 1954.

GROUND-WATER GEOLOGY OF BANDERA COUNTY, TEXAS: TEXAS WATER COMMISSION BULLETIN 6210, 1962.

GROUND-WATER GEOLOGY OF BANDERA COUNTY, TEXAS: SOUTH TEXAS GEOLOGICAL SOCIETY BULLETIN V. 4, NO. 2, FEBRUARY 6, 1964.

RECONNAISSANCE INVESTIGATION OF THE GROUND-WATER RESOURCES OF THE GUADALUPE, SAN ANTONIO, AND NUECES RIVER BASINS, TEXAS: TEXAS WATER COMMISSION BULLETIN 6409, 1964.

COMPILATION OF RESULTS OF AQUIFER TESTS IN TEXAS: TEXAS WATER DEVELOPMENT BOARD REPORT 98, 1969.

CHEMICAL AND BACTERIOLOGICAL QUALITY OF WATER AT SELECTED SITES IN THE SAN ANTONIO AREA, TEXAS, AUGUST 1968-APRIL 1972: EDWARDS UNDERGROUND WATER DISTRICT, 1972.

RELATION OF PRECIPITATION TO ANNUAL GROUND-WATER RECHARGE IN THE EDWARDS AQUIFER, SAN ANTONIO AREA, TEXAS: USGS OPEN-FILE REPORT 75-298, 1975.

MAJOR AND HISTORICAL SPRINGS OF TEXAS: TEXAS WATER DEVELOPMENT BOARD REPORT 189, 1975.

METHOD OF ESTIMATING NATURAL RECHARGE TO THE EDWARDS AQUIFER IN THE SAN ANTONIO AREA, TEXAS: USGS WATERRESOURCES INVESTIGATIONS REPORT 78-10, 1978.

REGIONAL DISTRIBUTION OF FRACTURES IN THE SOUTHERN EDWARDS PLATEAU AND THEIR RELATIONSHIP TO TECTONICS AND CAVES: UNIVERSITY OF TEXAS, BUREAU OF ECONOMIC GEOLOGY GEOLOGICAL CIRCULAR 78-2, 1978.

RECORDS OF GROUND-WATER RECHARGE AND DISCHARGE FOR THE EDWARDS AQUIFER IN THE SAN ANTONIO AREA, TEXAS,
1934-77: EDWARDS UNDERGROUND WATER DISTRICT BULLETIN 37, 1979.

OCCURRENCE, AVAILABILITY, AND CHEMICAL QUALITY OF GROUND WATER IN THE EDWARDS PLATEAU REGION OF TEXAS: TEXAS DEPARTMENT OF WATER RESOURCES REPORT 235,1979

RECORDS OF GROUND-WATER RECHARGE, DISCHARGE, WATER LEVELS, AND CHEMICAL QUALITY OF WATER FOR THE EDWARDS AQUIFER IN THE SAN ANTONIO AREA, TEXAS, 1934-78: EDWARDS UNDERGROUND WATER DISTRICT BULLETIN 38, 1980.

RECORDS OF GROUND-WATER RECHARGE, DISCHARGE, WATER LEVELS, AND CHEMICAL QUALITY OF WATER FOR THE EDWARDS AQUIFER IN THE SAN ANTONIO AREA, TEXAS, 1934-79: EDWARDS UNDERGROUND WATER DISTRICT BULLETIN 39, 1981.

RECORDS OF GROUND-WATER RECHARGE, DISCHARGE, WATER LEVELS, AND CHEMICAL QUALITY OF WATER FOR THE EDWARDS AQUIFER IN THE SAN ANTONIO AREA, TEXAS, 1934-80: EDWARDS UNDERGROUND WATER DISTRICT BULLETIN 40, 1982.

GROUND-WATER AVAILABILITY OF THE LOWER CRETACEOUS FORMATIONS IN THE HILL COUNTRY OF SOUTH-CENTRAL TEXAS: TEXAS DEPARTMENT OF WATER RESOURCES REPORT 273, 1983.

RECORDS OF GROUND-WATER RECHARGE, DISCHARGE, WATER LEVELS, AND CHEMICAL QUALITY OF WATER FOR THE EDWARDS AQUIFER IN THE SAN ANTONIO AREA, TEXAS, 1934-81: EDWARDS UNDERGROUND WATER DISTRICT BULLETIN 41, 1984.

CARBONATE GEOLOGY AND HYDROLOGY OF THE EDWARDS AQUIFER IN THE SAN ANTONIO AREA, TEXAS: USGS OPEN-FILE REPORT 83-537, 1984.

RECORDS OF GROUND-WATER RECHARGE, DISCHARGE, WATER LEVELS, AND CHEMICAL QUALITY OF WATER FOR THE EDWARDS AQUIFER IN THE SAN ANTONIO AREA, TEXAS, 1934-82: EDWARDS UNDERGROUND WATER DISTRICT BULLETIN 42, 1985.

TEXAS GROUND-WATER RESOURCES, in NATIONAL WATER SUMMARY 1984: USGS WATER-SUPPLY PAPER 2275, 1985.

COMPILATION OF HYDROLOGIC DATA FOR THE EDWARDS AQUIFER, SAN ANTONIO AREA, TEXAS, 1983-84, WITH 1934-84 SUMMARY: EDWARDS UNDERGROUND WATER DISTRICT BULLETIN 43-44, 1986.

CARBONATE GEOLOGY AND HYDROLOGY OF THE EDWARDS AQUIFER IN THE SAN ANTONIO AREA, TEXAS: TEXAS WATER DEVELOPMENT BOARD REPORT 296, 1986.

COMPILATION OF HYDROLOGIC DATA FOR THE EDWARDS AQUIFER, SAN ANTONIO AREA, TEXAS, 1985, WITH 1934-85 SUMMARY: EDWARDS UNDERGROUND WATER DISTRICT BULLETIN 45, 1987.

COMPILATION OF HYDROLOGIC DATA FOR THE EDWARDS AQUIFER, SAN ANTONIO AREA, TEXAS, 1986, WITH 1934-86 SUMMARY: EDWARDS UNDERGROUND WATER DISTRICT BULLETIN 46, 1988.

COMPILATION OF HYDROLOGIC DATA FOR THE EDWARDS AQUIFER, SAN ANTONIO AREA, TEXAS, 1987, WITH 1934-87 SUM- 
MARY: EDWARDS UNDERGROUND WATER DISTRICT BULLETIN 47, 1988.

COMPILATION OF HYDROLOGIC DATA FOR THE EDWARDS AQUIFER, SAN ANTONIO AREA, TEXAS, 1988, WITH 1934-88 SUMMARY: EDWARDS UNDERGROUND WATER DISTRICT BULLETIN 48, 1989

POTENTIOMETRIC SURFACE OF THE EDWARDS-TRINITY AQUIFER SYSTEM AND CONTIGUOUS HYDRAULICALLY CONNECTED UNITS, WEST-CENTRAL TEXAS, WINTER 1974-75: USGS WATERRESOURCES INVESTIGATIONS REPORT 89-4208, 1990.

COMPILATION OF HYDROLOGIC DATA FOR THE EDWARDS AQUIFER, SAN ANTONIO AREA, TEXAS, 1989, WITH 1934-89 SUMMARY: EDWARDS UNDERGROUND WATER DISTRICT BULLETIN 49, 1990.

WITHDRAWALS FROM THE EDWARDS-TRINITY AQUIFER SYSTEM AND CONTIGUOUS HYDRAULICALLY CONNECTED UNITS, WEST-CENTRAL TEXAS, DECEMBER 1974 THROUGH MARCH 1977: USGS WATER-RESOURCES INVESTIGATIONS REPORT 91-4021, 1991.

EDWARDS AQUIFER, A TEXAS TREASURE-A TEACHERS GUIDE, SECONDARY, GRADES 7-12: EDWARDS UNDERGROUND WATER DISTRICT, 1991.

COMPILATION OF HYDROLOGIC DATA FOR THE EDWARDS AQUIFER, SAN ANTONIO AREA, TEXAS, 1990, WITH 1934-90 SUMMARY: EDWARDS UNDERGROUND WATER DISTRICT BULLETIN $50,1991$.

INSIDE THE EDWARDS AQUIFER-A THREE-PART TECHNICAL FILM, HIGH-SCHOOL LEVEL TEACHER'S GUIDE: EDWARDS UNDERGROUND WATER DISTRICT, 1992.

CONFIGURATION OF THE BASE OF THE EDWARDS-TRINITY AQUIFER SYSTEM AND HYDROGEOLOGY OF THE UNDERLYING PRECRETACEOUS ROCKS, WEST-CENTRAL TEXAS: USGS WATERRESOURCES INVESTIGATIONS REPORT 91-4071, 1992.

EVALUATION OF THE GROUND-WATER RESOURCES OF THE PALEOZOIC AND CRETACEOUS AQUIFERS IN THE HILL COUNTRY OF CENTRAL TEXAS: TEXAS WATER DEVELOPMENT BOARD REPORT 339, 1992

COMPILATION OF HYDROLOGIC DATA FOR THE EDWARDS AQUIFER, SAN ANTONIO AREA, TEXAS, 1991, WITH 1934-91 SUMMARY: EDWARDS UNDERGROUND WATER DISTRICT BULLETIN $51,1992$.

HISTORICAL POTENTIOMETRIC SURFACE OF THE EDWARDS-TRINITY AQUIFER SYSTEM AND CONTIGUOUS HYDRAULICALLY CONNECTED UNITS, WEST-CENTRAL TEXAS: USGS WATERRESOURCES INVESTIGATIONS REPORT 92-4055, 1993.

HISTORICAL SATURATED THICKNESS OF THE EDWARDS-TRINITY AQUIFER SYSTEM AND SELECTED CONTIGUOUS HYDRAULICALLY CONNECTED UNITS, WEST-CENTRAL TEXAS: USGS WATER-RESOURCES INVESTIGATIONS REPORT 92-4125, 1993.

EDWARDS AQUIFER HYDROGEOLOGIC STATUS REPORT FOR 1992: EDWARDS UNDERGROUND WATER DISTRICT REPORT 93-05, 1993.

SIMULATIONS OF FLOW IN THE EDWARDS-TRINITY AQUIFER SYSTEM AND CONTIGUOUS HYDRAULICALLY CONNECTED UNITS, WEST-CENTRAL TEXAS: USGS WATER-RESOURCES INVESTIGATIONS REPORT 93-4039, 1994.
DISSOLVED-SOLIDS CONCENTRATIONS AND HYDROCHEMICAL FACIES IN WATER OF THE EDWARDS-TRINITY AQUIFER SYSTEM, WEST-CENTRAL TEXAS: USGS WATER-RESOURCES INVESTIGATIONS REPORT 93-4126, 1994.

NATIONAL WATER-QUALITY ASSESSMENT PROGRAM-SOUTHCENTRAL TEXAS: USGS FACT SHEET FS-94-048, 1994.

GEOLOGIC HISTORY AND HYDROGEOLOGIC SETTING OF THE EDWARDS-TRINITY AQUIFER SYSTEM, WEST-CENTRAL TEXAS: USGS WATER-RESOURCES INVESTIGATIONS REPORT 94-4039, 1994.

WATER QUALITY IN THE EDWARDS-TRINITY (PLATEAU) AQUIFER, EDWARDS PLATEAU AND TRANS-PECOS, TEXAS: TEXAS WATER DEVELOPMENT BOARD HYDROLOGIC ATLAS NO. 3, 1995.

AQUIFERS OF TEXAS: TEXAS WATER DEVELOPMENT BOARD REPORT 345, 1995.

HYDROGEOLOGIC FRAMEWORK OF THE EDWARDS-TRINITY AQUIFER SYSTEM, WEST-CENTRAL TEXAS: USGS PROFESSIONAL PAPER 1421-B, 1996.

GEOLOGIC FRAMEWORK AND HYDROGEOLOGIC CHARACTERISTICS OF THE OUTCROPS OF THE EDWARDS AND TRINITY AQUIFERS, MEDINA LAKE AREA, TEXAS: USGS WATER-RESOURCES INVESTIGATIONS REPORT 97-4290, 1998.

WATER-RESOURCES DATA, TEXAS, WATER YEAR 1997, VOLUME 4 GROUND-WATER DATA: USGS WATER-DATA REPORT TX-97-4, 1998.

GEOLOGIC FRAMEWORK AND HYDROGEOLOGIC PROPERTIES OF THE SECO CREEK WATERSHED, TEXAS: USGS FACT SHEET FS-104-98, 1999 .

WATER-RESOURCES DATA, TEXAS, WATER YEAR 1998, VOLUME 4 , GROUND-WATER DATA: USGS WATER-DATA REPORT TX-98-4, 1999.

GROUNDWATER AVAILABILITY OF THE TRINITY AQUIFER, HILL COUNTRY AREA, TEXAS: NUMERICAL SIMULATIONS THROUGH 2050: TEXAS WATER DEVELOPMENT BOARD REPORT 353, 2000.

HYDROGEOLOGY, HYDROLOGIC BUDGET, AND WATER CHEMISTRY OF THE MEDINA LAKE AREA, TEXAS: USGS WATERRESOURCES INVESTIGATIONS REPORT 00-4148, 2000.

WATER QUALITY IN SOUTH-CENTRAL TEXAS-TEXAS, 1996-98: USGS CIRCULAR 1212, 2000.

AN OVERVIEW OF THE EDWARDS-TRINITY AQUIFER SYSTEM, CENTRAL-WEST TEXAS, CHAPTER 8, in AQUIFERS OF WEST TEXAS: TEXAS WATER DEVELOPMENT BOARD REPORT 356, 2001

\section{BASTROP COUNTY}

ARTESIAN WELLS OF THE COASTAL PRAIRIE REGION AND TERTIARY BELT OF TEXAS: GEOLOGICAL SURVEY OF TEXAS, CHAPTER 2, 1893.

GEOLOGIC ATLAS OF THE UNITED STATES-AUSTIN FOLIO, TEXAS: USGS GEOLOGIC FOLIO, 1902

UNDERGROUND WATERS OF THE COASTAL PLAIN OF TEXAS: USGS WATER-SUPPLY PAPER 190, 1907. 
RESULTS OF PUMPING TESTS OF WELLS AT CAMP SWIFT, TEXAS USGS OPEN-FILE REPORT (UNNUMBERED) 1942

PUBLIC WATER SUPPLIES IN EASTERN TEXAS: USGS WATERSUPPLY PAPER 1047, 1948.

RECORDS OF WELLS IN BASTROP COUNTY, TEXAS: TEXAS BOARD OF WATER ENGINEERS BULLETIN 5413, 1954.

RECORDS OF WATER LEVELS IN BASTROP AND CALDWELL COUNTIES, TEXAS, 1937 THROUGH DECEMBER 1956: TEXAS BOARD OF WATER ENGINEERS BULLETIN 5702, 1957.

HYDROLOGIC SIGNIFICANCE OF THE LITHOFACIES OF THE SPARTA SAND IN ARKANSAS, LOUISIANA, MISSISSIPPI, AND TEXAS: USGS PROFESSIONAL PAPER 569-A, 1968.

GROUND-WATER RESOURCES OF BASTROP COUNTY, TEXAS: TEXAS WATER DEVELOPMENT BOARD REPORT 109, 1970.

GEOHYDROLOGIC SIGNIFICANCE OF LITHOFACIES OF THE CARRIZO SAND OF ARKANSAS, LOUISIANA, AND TEXAS AND THE MERIDIAN SAND OF MISSISSIPPI: USGS PROFESSIONAL PAPER 569-D, 1975.

PRELIMINARY HYDROGEOLOGIC INVESTIGATION RELATED TO POSSIBLE MINING OPERATIONS, BASTROP COUNTY, TEXAS: HYDRO-SEARCH, INC., CONSULTANTS, AUSTIN, TEXAS, 1981.

WATER-RESOURCES APPRAISAL OF THE CAMP SWIFT LIGNITE AREA, CENTRAL TEXAS: USGS WATER-RESOURCES INVESTIGATIONS REPORT 84-4333, 1985.

TEXAS GROUND-WATER RESOURCES, in NATIONAL WATER SUMMARY 1984: USGS WATER-SUPPLY PAPER 2275, 1985.

APPROXIMATE POTENTIOMETRIC SURFACES FOR THE AQUIFERS OF THE TEXAS COASTAL UPLANDS SYSTEM, 1980: USGS HYDROLOGIC ATLAS HA-704, 1987.

GEOHYDROLOGIC FRAMEWORK OF THE GULF COASTAL PLAIN: USGS HYDROLOGIC ATLAS HA-695, 1988.

FLOW PATTERN IN REGIONAL AQUIFERS AND FLOW RELATIONS BETWEEN THE LOWER COLORADO RIVER VALLEY AND REGIONAL AQUIFERS IN SIX COUNTIES OF SOUTHEASTERN TEXAS: USGS WATER-RESOURCES INVESTIGATIONS REPORT 88-4154, 1989.

A DIGITAL MODEL OF THE CARRIZO-WILCOX AQUIFER WITHIN THE COLORADO RIVER BASIN OF TEXAS: TEXAS WATER DEVELOPMENT BOARD LIMITED PUBLICATION REPORT LP-208, 1989.

GROUND-WATER RESOURCES OF THE CARRIZO-WILCOX AQUIFER IN THE CENTRAL TEXAS REGION: TEXAS WATER DEVELOPMENT BOARD REPORT 332, 1991.

STREAM-GROUNDWATER INTERACTION OF THE LOWER COLORADO RIVER AND ITS ALLUVIAL AQUIFER: TEXAS STATE SECTION OF THE AMERICAN WATER RESOURCES ASSOCIATION, TRIGG TWICHELL SYMPOSIUM, FALL MEETING, NOVEMBER 8, 1991, AUSTIN, TEXAS, 1991.

EVALUATION OF WATER RESOURCES IN PARTS OF THE ROLLING PRAIRIES REGION OF NORTH-CENTRAL TEXAS: TEXAS WATER DEVELOPMENT BOARD REPORT 337, 1992.

PROPERTIES AND CHEMICAL CONSTITUENTS IN GROUND WATER FROM THE UPPER CLAIBORNE AQUIFER, GULF COAST REGIONAL AQUIFER SYSTEMS, SOUTH-CENTRAL UNITED STATES: USGS WATER-RESOURCES INVESTIGATIONS REPORT 91-4150, 1993.
PROPERTIES AND CHEMICAL CONSTITUENTS IN GROUND WATER FROM THE LOWER CLAIBORNE-UPPER WILCOX AQUIFER, GULF COAST REGIONAL AQUIFER SYSTEMS, SOUTH-CENTRAL UNITED STATES: USGS WATER-RESOURCES INVESTIGATIONS REPORT 92-4102, 1993.

PROPERTIES AND CHEMICAL CONSTITUENTS IN GROUND WATER FROM THE MIDDLE CLAIBORNE AQUIFER, GULF COAST REGIONAL AQUIFER SYSTEMS, SOUTH-CENTRAL UNITED STATES: USGS WATER-RESOURCES INVESTIGATIONS REPORT 92-4104, 1993.

PROPERTIES AND CHEMICAL CONSTITUENTS IN GROUND WATER FROM THE MIDDLE WILCOX AQUIFER, GULF COAST REGIONAL AQUIFER SYSTEMS, SOUTH-CENTRAL UNITED STATES: USGS WATER-RESOURCES INVESTIGATIONS REPORT 93-4070, 1993.

DEFINING THE EDWARDS AQUIFER FRESHWATER/SALINE-WATER INTERFACE WITH GEOPHYSICAL LOGS AND MEASURED DATA (SAN ANTONIO TO KYLE, TEXAS): EDWARDS UNDERGROUND WATER DISTRICT REPORT 93-06, 1993.

STRATIGRAPHIC NOMENCLATURE AND GEOLOGIC SECTIONS OF THE GULF COASTAL PLAIN OF TEXAS: USGS OPEN-FILE REPORT 94-461, 1995.

WATER QUALITY IN THE SPARTA AQUIFER, EAST TEXAS: TEXAS WATER DEVELOPMENT BOARD HYDROLOGIC ATLAS NO. 5, 1996.

WATER QUALITY IN THE QUEEN CITY AQUIFER, EAST TEXAS: TEXAS WATER DEVELOPMENT BOARD HYDROLOGIC ATLAS NO. 6, 1996.

HYDROGEOLOGIC FRAMEWORK AND GEOCHEMISTRY OF THE EDWARDS AQUIFER SALINE-WATER ZONE, SOUTH-CENTRAL TEXAS: USGS WATER-RESOURCES INVESTIGATIONS REPORT 97-4133, 1997.

GROUND-WATER AVAILABILITY IN THE CARRIZO-WILCOX AQUIFER IN CENTRAL TEXAS-NUMERICAL SIMULATIONS OF 2000 THROUGH 2050 WITHDRAWAL PROJECTIONS: UNIVERSITY OF TEXAS, BUREAU OF ECONOMIC GEOLOGY REPORT OF INVESTIGATIONS NO. 256, 1999.

CHANGES IN GROUNDWATER CONDITIONS IN THE EDWARDS AND TRINITY AQUIFERS, 1987-1997, FOR PORTIONS OF BASTROP, BELL, BURNET, LEE, MILAM, TRAVIS, AND WILLIAMSON COUNTIES, TEXAS: TEXAS WATER DEVELOPMENT BOARD REPORT $350,1999$.

TRANSMISSIVITY, HYDRAULIC CONDUCTIVITY, AND STORATIVITY OF THE CARRIZO-WILCOX AQUIFER IN TEXAS, DATA AND ANALYSIS: UNIVERSITY OF TEXAS, BUREAU OF ECONOMIC GEOLOGY, CD-ROM, 2000

\section{BAYLOR COUNTY}

GEOLOGY AND UNDERGROUND WATERS OF THE WICHITA REGION, NORTH-CENTRAL TEXAS: USGS WATER-SUPPLY PAPER 317,1913

PUBLIC WATER SUPPLIES IN CENTRAL AND NORTH-CENTRAL TEXAS: USGS WATER-SUPPLY PAPER 1069, 1949.

RECONNAISSANCE INVESTIGATION OF THE GROUND-WATER RESOURCES OF THE RED RIVER, SULPHUR RIVER, AND CYPRESS 
CREEK BASINS, TEXAS: TEXAS WATER COMMISSION BULLETIN 6306, 1963.

RECONNAISSANCE INVESTIGATION OF THE GROUND-WATER RESOURCES OF THE BRAZOS RIVER BASIN, TEXAS: TEXAS WATER COMMISSION BULLETIN 6310, 1963.

MAJOR AND HISTORICAL SPRINGS OF TEXAS: TEXAS WATER DEVELOPMENT BOARD REPORT 189, 1975.

OCCURRENCE AND QUALITY OF GROUND WATER IN BAYLOR COUNTY, TEXAS: TEXAS DEPARTMENT OF WATER RESOURCES REPORT 218, 1978

SPRINGS OF TEXAS, VOLUME 1: (BY GUNNAR BRUNE), BRANCHSMITH, INC., FORT WORTH, TEXAS, 1981.

TEXAS GROUND-WATER RESOURCES, in NATIONAL WATER SUMMARY 1984: USGS WATER-SUPPLY PAPER 2275, 1985.

AQUIFERS OF TEXAS: TEXAS WATER DEVELOPMENT BOARD REPORT 345, 1995.

\section{BEE COUNTY}

UNDERGROUND WATERS OF THE COASTAL PLAIN OF TEXAS: USGS WATER-SUPPLY PAPER 190, 1907.

RECORDS OF WELLS, WATER ANALYSES, AND MAP SHOWING LOCATION OF WELLS IN BEE COUNTY, TEXAS: USGS OPEN-FILE REPORT (UNNUMBERED, 1935.

RESULTS OF GROUND-WATER INVESTIGATION IN BEE COUNTY, TEXAS: USGS OPEN-FILE REPORT (UNNUMBERED), 1935.

SUPPLEMENTARY REPORT ON SURFACE-WATER AND GROUNDWATER SURVEYS, NUECES RIVER BASIN, TEXAS: USGS OPENFILE REPORT (UNNUMBERED), 1935

RECORDS OF WELLS, TEST WELLS, DRILLERS' LOGS, CHEMICAL ANALYSES OF WATER AND MAP SHOWING LOCATION OF WELLS IN BEE COUNTY, TEXAS: TEXAS BOARD OF WATER ENGINEERS MISCELLANEOUS PUBLICATION 12, 1940.

RECORDS OF WELLS, TEST WELLS, DRILLERS' LOGS, CHEMICAL ANALYSES OF WATER, AND MAP SHOWING LOCATION OF WELLS IN BEE COUNTY, TEXAS: TEXAS BOARD OF WATER ENGINEERS OPEN-FILE REPORT, 1941

PUBLIC WATER SUPPLIES IN SOUTHERN TEXAS: USGS WATERSUPPLY PAPER 1070, 1950

AVAILABILITY OF GROUND WATER IN THE GULF COAST REGION OF TEXAS: USGS OPEN-FILE REPORT (UNNUMBERED), 1956.

RECONNAISSANCE INVESTIGATION OF THE GROUND-WATER RESOURCES OF THE GULF COAST REGION, TEXAS: TEXAS WATER COMMISSION BULLETIN 6305, 1963.

RECONNAISSANCE INVESTIGATION OF THE GROUND-WATER RESOURCES OF THE GUADALUPE, SAN ANTONIO, AND NUECES RIVER BASINS, TEXAS: TEXAS WATER COMMISSION BULLETIN 6409, 1964.

GROUND-WATER RESOURCES OF BEE COUNTY, TEXAS: TEXAS WATER DEVELOPMENT BOARD REPORT 17, 1966.

GEOHYDROLOGIC SIGNIFICANCE OF LITHOFACIES OF THE COCKFIELD FORMATION OF LOUISIANA AND MISSISSIPPI AND OF THE
YEGUA FORMATION OF TEXAS: USGS PROFESSIONAL PAPER 569-B, 1970.

HYDROLOGIC SIGNIFICANCE OF LITHOFACIES OF THE CANE RIVER FORMATION OR EQUIVALENTS OF ARKANSAS, LOUISIANA, MISSISSIPPI, AND TEXAS: USGS PROFESSIONAL PAPER 569-C, 1972.

GEOHYDROLOGIC SIGNIFICANCE OF LITHOFACIES OF THE CARRIZO SAND OF ARKANSAS, LOUISIANA, AND TEXAS AND THE MERIDIAN SAND OF MISSISSIPPI: USGS PROFESSIONAL PAPER 569-D, 1975.

SUMMARY APPRAISALS OF THE NATION'S GROUND-WATER RESOURCES-TEXAS-GULF REGION: USGS PROFESSIONAL PAPER 813-F, 1976.

STRATIGRAPHIC AND HYDROGEOLOGIC FRAMEWORK OF PART OF THE COASTAL PLAIN OF TEXAS: TEXAS DEPARTMENT OF WATER RESOURCES REPORT 236, 1979.

SPRINGS OF TEXAS, VOLUME 1: (BY GUNNAR BRUNE), BRANCHSMITH, INC., FORT WORTH, TEXAS, 1981.

REGIONAL HYDRODYNAMICS AND HYDROCHEMISTRY OF THE URANIUM-BEARING OAKVILLE AQUIFER (MIOCENE) OF SOUTH TEXAS: UNIVERSITY OF TEXAS, BUREAU OF ECONOMIC GEOLOGY REPORT OF INVESTIGATIONS NO. 124, 1982.

TEXAS GROUND-WATER RESOURCES, in NATIONAL WATER SUMMARY 1984: USGS WATER-SUPPLY PAPER 2275, 1985.

DIGITAL MODELS FOR SIMULATION OF GROUND-WATER HYDROLOGY OF THE CHICOT AND EVANGELINE AQUIFERS ALONG THE GULF COAST OF TEXAS: TEXAS DEPARTMENT OF WATER RESOURCES REPORT 289, 1985.

HYDROGEOLOGY AND PREDEVELOPMENT FLOW IN THE TEXAS GULF COAST AQUIFER SYSTEMS: USGS WATER-RESOURCES INVESTIGATIONS SYSTEMS REPORT 87-4248, 1988.

DEPOSITIONAL AND GROUND-WATER FLOW SYSTEMS OF THE CARRIZO-UPPER WILCOX, SOUTH TEXAS: UNIVERSITY OF TEXAS, BUREAU OF ECONOMIC GEOLOGY REPORT OF INVESTIGATIONS NO. 175, 1988.

GEOHYDROLOGIC FRAMEWORK OF THE GULF COASTAL PLAIN: USGS HYDROLOGIC ATLAS HA-695, 1988.

GROUND-WATER FLOW IN THE GULF COAST AQUIFER SYSTEMS, SOUTH CENTRAL UNITED STATES-A PRELIMINARY ANALYSIS: USGS WATER-RESOURCES INVESTIGATIONS REPORT 89-4071, 1990.

HYDROLOGY OF THE TEXAS GULF COAST AQUIFER SYSTEMS: USGS OPEN-FILE REPORT 91-64, 1991.

PROPERTIES AND CHEMICAL CONSTITUENTS IN GROUND WATER FROM THE MISSISSIPPI RIVER VALLEY ALLUVIAL AQUIFER AND PERMEABLE ZONE A (HOLOCENE-UPPER PLEISTOCENE DEPOSITS), SOUTH-CENTRAL UNITED STATES: USGS WATERRESOURCES INVESTIGATIONS REPORT 91-4149, 1992.

PROPERTIES AND CHEMICAL CONSTITUENTS IN GROUND WATER FROM PERMEABLE ZONE C (LOWER PLIOCENE-UPPER MIOCENE DEPOSITS), COASTAL LOWLANDS AQUIFER SYSTEM, SOUTHCENTRAL UNITED STATES: USGS WATER-RESOURCES INVESTIGATIONS REPORT 91-4151, 1993.

PROPERTIES AND CHEMICAL CONSTITUENTS IN GROUND WATER FROM PERMEABLE ZONE B (LOWER PLEISTOCENE-UPPER PLIOCENE DEPOSITS), COASTAL LOWLANDS AQUIFER SYSTEM, 
SOUTH-CENTRAL UNITED STATES: USGS WATER-RESOURCES INVESTIGATIONS REPORT 91-4152, 1993.

PROPERTIES AND CHEMICAL CONSTITUENTS IN GROUND WATER FROM THE LOWER CLAIBORNE-UPPER WILCOX AQUIFER, GULF COAST REGIONAL AQUIFER SYSTEMS, SOUTH-CENTRAL UNITED STATES: USGS WATER-RESOURCES INVESTIGATIONS REPORT 92-4102, 1993.

PROPERTIES AND CHEMICAL CONSTITUENTS IN GROUND WATER FROM PERMEABLE ZONE E (LOWER MIOCENE-UPPER OLIGOCENE DEPOSITS), COASTAL LOWLANDS AQUIFER SYSTEM, SOUTH-CENTRAL UNITED STATES: USGS WATER-RESOURCES INVESTIGATIONS REPORT 92-4103, 1993.

PROPERTIES AND CHEMICAL CONSTITUENTS IN GROUND WATER FROM PERMEABLE ZONE D (MIDDLE MIOCENE DEPOSITS), COASTAL LOWLANDS AQUIFER SYSTEM, SOUTH-CENTRAL UNITED STATES: USGS WATER-RESOURCES INVESTIGATIONS REPORT 92-4105, 1993.

PROPERTIES AND CHEMICAL CONSTITUENTS IN GROUND WATER FROM THE MIDDLE WILCOX AQUIFER, GULF COAST REGIONAL AQUIFER SYSTEMS, SOUTH-CENTRAL UNITED STATES: USGS WATER-RESOURCES INVESTIGATIONS REPORT 93-4070, 1993.

GEOLOGY AND HYDROGEOLOGY OF NAVAL AIR STATION CHASE FIELD AND NAVAL AUXILIARY LANDING FIELD GOLIAD, BEE AND GOLIAD COUNTIES, TEXAS: USGS WATER-RESOURCES INVESTIGATIONS REPORT 95-4038, 1995.

HYDROGEOLOGIC FRAMEWORK AND GEOCHEMISTRY OF THE EDWARDS AQUIFER SALINE-WATER ZONE, SOUTH-CENTRAL TEXAS: USGS WATER-RESOURCES INVESTIGATIONS REPORT 97-4133, 1997.

TRANSMISSIVITY, HYDRAULIC CONDUCTIVITY, AND STORATIVITY OF THE CARRIZO-WILCOX AQUIFER IN TEXAS, DATA AND ANALYSIS: UNIVERSITY OF TEXAS, BUREAU OF ECONOMIC GEOLOGY, CD-ROM, 2000.

\section{BELL COUNTY}

GEOGRAPHY AND GEOLOGY OF THE BLACK AND GRAND PRAIRIES OF TEXAS, WITH DETAILED DESCRIPTIONS OF THE CRETACEOUS FORMATIONS AND SPECIAL REFERENCE TO ARTESIAN WATERS: USGS 21ST ANNUAL REPORT, PART 7, 1901.

GROUND WATER IN THE VICINITY OF KILLEEN, TEXAS: USGS OPEN-FILE REPORT (UNNUMBERED), 1941.

MEMORANDUM ON GROUND WATER IN THE AREA ABOUT 8 MILES NORTH OF BELTON: USGS OPEN-FILE REPORT (UNNUMBERED), 1942.

PROGRESS REPORT, KILLEEN, BELL COUNTY, TEXAS: USGS OPENFILE REPORT, 1942.

WATER IN SHALLOW GRAVELS IN THE VICINITY OF KILLEEN, TEXAS: USGS OPEN-FILE REPORT (UNNUMBERED), 1942.

RESULTS OF PUMPING TESTS OF A WELL (ED HUESS NO. 1) 3.7 MILES NORTHEAST OF KILLEEN, BELL COUNTY, TEXAS: USGS OPEN-FILE REPORT (UNNUMBERED), 1943.

MEMORANDUM ON THE POSSIBILITY OF FINDING NATURAL FILTRATION BEDS ALONG THE LAMPASAS RIVER NEAR THE CAMP
HOOD WELL FIELD: USGS OPEN-FILE REPORT (UNNUMBERED), 1943.

PUMPING TEST OF ABANDONED WELL IN TRAVIS PEAK SANDS AT TEMPLE, TEXAS: USGS OPEN-FILE REPORT (UNNUMBERED), 1943.

RESULTS OF PUMPING TESTS OF WELLS AT CAMP HOOD, TEXAS: TEXAS BOARD OF WATER ENGINEERS MISCELLANEOUS PUBLICATION 31, 1943.

PUBLIC WATER SUPPLIES IN CENTRAL AND NORTH-CENTRAL TEXAS: USGS WATER-SUPPLY PAPER 1069, 1949.

RECORDS OF WATER-LEVEL MEASUREMENTS IN BELL, McLENNAN, AND SOMERVELL COUNTIES, TEXAS, 1930 THROUGH 1957: TEXAS BOARD OF WATER ENGINEERS BULLETIN 5902, 1959.

GROUND-WATER RESOURCES OF PART OF CENTRAL TEXAS WITH EMPHASIS ON THE ANTLERS AND TRAVIS PEAK FORMATIONS: TEXAS WATER DEVELOPMENT BOARD REPORT 195, V. 1, 1975.

GROUND-WATER RESOURCES OF PART OF CENTRAL TEXAS WITH EMPHASIS ON THE ANTLERS AND TRAVIS PEAK FORMATIONS: TEXAS WATER DEVELOPMENT BOARD REPORT 195, V. 2, 1976.

SUMMARY APPRAISALS OF THE NATION'S GROUND-WATER RESOURCES-TEXAS-GULF REGION: USGS PROFESSIONAL PAPER 813-F, 1976.

WATER USE, PROJECTED WATER REQUIREMENTS, AND RELATED DATA AND INFORMATION FOR THE METROPOLITAN STATISTICAL AREAS IN TEXAS: TEXAS DEPARTMENT OF WATER RESOURCES LIMITED PRINTING REPORT LP-201, 1985.

TEXAS GROUND-WATER RESOURCES, in NATIONAL WATER SUMMARY 1984: USGS WATER-SUPPLY PAPER 2275, 1985.

EDWARDS AQUIFER-NORTHERN SEGMENT, TRAVIS, WILLIAMSON, AND BELL COUNTIES, TEXAS: AUSTIN GEOLOGICAL SOCIETY GUIDEBOOK 8, 1985.

GEOHYDROLOGY OF THE EDWARDS AQUIFER IN THE AUSTIN AREA, TEXAS: TEXAS WATER DEVELOPMENT BOARD REPORT 293, 1986.

HYDROGEOLOGY OF THE EDWARDS AQUIFER, NORTHERN BALCONES AND WASHITA PRAIRIE SEGMENTS: AUSTIN GEOLOGICAL SOCIETY GUIDEBOOK 11, 1987.

A HYDROGEOLOGIC ASSESSMENT OF THE AUSTIN CHALK OUTCROP BELT, CENTRAL TEXAS: BAYLOR GEOLOGICAL STUDIES (THESIS ABSTRACTS), BAYLOR UNIVERSITY, WACO, TEXAS, 1989.

HYDROGEOLOGY OF THE NORTHERN SEGMENT OF THE EDWARDS AQUIFER, AUSTIN REGION: UNIVERSITY OF TEXAS, BUREAU OF ECONOMIC GEOLOGY REPORT OF INVESTIGATIONS NO. 192, 1990.

EVALUATION OF WATER RESOURCES IN PART OF CENTRAL TEXAS: TEXAS WATER DEVELOPMENT BOARD REPORT 319 , 1990.

TEST WELL DRILLING INVESTIGATION TO DELINEATE THE DOWNDIP LIMITS OF USABLE-QUALITY GROUND WATER IN THE EDWARDS AQUIFER IN THE AUSTIN REGION, TEXAS: TEXAS WATER DEVELOPMENT BOARD REPORT 325, 1990.

EVALUATION OF WATER RESOURCES IN BELL, BURNET, TRAVIS, WILLIAMSON, AND PARTS OF ADJACENT COUNTIES, TEXAS: TEXAS WATER DEVELOPMENT BOARD REPORT 326, 1991. 
HYDROGEOLOGIC ASSESSMENT OF SHALLOW GROUNDWATER FLOW SYSTEMS OF THE WALNUT FORMATION, CENTRAL TEXAS: (MASTER'S THESIS), BAYLOR GEOLOGICAL STUDIES (THESIS ABSTRACTS), BULLETIN 56, BAYLOR UNIVERSITY, WACO, TEXAS, 1995.

WATER BUDGET IN AN EAGLE FORD SHALE SUB-WATERSHED, BLACKLAND PRAIRIES, CENTRAL TEXAS: (MASTER'S THESIS), BAYLOR GEOLOGICAL STUDIES (THESIS ABSTRACTS), BULLETIN 56, BAYLOR UNIVERSITY, WACO, TEXAS, 1995.

AQUIFERS OF TEXAS: TEXAS WATER DEVELOPMENT BOARD REPORT 345, 1995.

CHANGES IN GROUNDWATER CONDITIONS IN THE EDWARDS AND TRINITY AQUIFERS, 1987-1997, FOR PORTIONS OF BASTROP, BELL, BURNET, LEE, MILAM, TRAVIS, AND WILLIAMSON COUNTIES, TEXAS: TEXAS WATER DEVELOPMENT BOARD REPORT $350,1999$.

\section{BEXAR COUNTY}

REPORT OF PROGRESS OF THE DIVISION OF HYDROGRAPHY FOR THE CALENDAR YEAR 1895: USGS BULLETIN 140, 1896.

GEOLOGY OF THE EDWARDS PLATEAU AND RIO GRANDE PLAIN ADJACENT TO AUSTIN AND SAN ANTONIO, TEXAS, WITH REFERENCE TO THE OCCURRENCE OF UNDERGROUND WATERS: USGS 18TH ANNUAL REPORT, PART 2, 1898.

UNDERGROUND WATERS OF THE COASTAL PLAIN OF TEXAS: USGS WATER-SUPPLY PAPER 190, 1907.

LARGE SPRINGS IN THE UNITED STATES: USGS WATER-SUPPLY PAPER 557, 1927.

THE WATER SUPPLY AT RANDOLPH FIELD NEAR SAN ANTONIO, TEXAS: USGS OPEN-FILE REPORT (UNNUMBERED), 1933.

WATER RESOURCES OF THE EDWARDS LIMESTONE IN THE SAN ANTONIO AREA, TEXAS: USGS WATER-SUPPLY PAPER 773-B, 1936.

SOME GROUND-WATER PROBLEMS OF UVALDE, MEDINA, AND BEXAR COUNTIES: USGS OPEN-FILE REPORT (UNNUMBERED), 1938.

TEST ON A FLOWING WELL OF SAN ANTONIO PUBLIC SERVICE CO. NEAR ROOSEVELT PARK IN SAN ANTONIO, TEXAS: USGS OPENFILE REPORT (UNNUMBERED), 1939.

A FEW INTERESTING FACTS REGARDING THE NATURAL FLOW FROM ARTESIAN WELL 4 OWNED BY THE SAN ANTONIO PUBLIC SERVICE CO., SAN ANTONIO, TEXAS: USGS OPEN-FILE REPORT (UNNUMBERED), 1942.

SUPPLY OF GROUND WATER AT RANDOLPH FIELD: USGS OPENFILE REPORT (UNNUMBERED), 1942.

GROUND-WATER RESOURCES OF LEON SPRINGS MILITARY RESERVATION AND VICINITY: USGS OPEN-FILE REPORT (UNNUMBERED, 1943

KELLY FIELD, BEXAR COUNTY, TEXAS, WELL LOCATIONS: USGS OPEN-FILE REPORT (UNNUMBERED), 1943.

GROUND-WATER RESOURCES OF BEXAR COUNTY, TEXAS: TEXAS BOARD OF WATER ENGINEERS MISCELLANEOUS PUBLICATION 13,1947
MISCELLANEOUS FIELD NOTES ON SAN ANTONIO AREA, TEXAS: USGS OPEN-FILE REPORT (UNNUMBERED), 1950.

PUBLIC WATER SUPPLIES IN SOUTHERN TEXAS: USGS WATERSUPPLY PAPER 1070, 1950.

RECHARGE TO THE CARRIZO SAND IN ATASCOSA COUNTY AND ADJACENT AREAS: USGS OPEN-FILE REPORT (UNNUMBERED), 1951.

GROUND-WATER CONDITIONS IN THE LACOSTE-MACDONA AREA, TEXAS: USGS OPEN-FILE REPORT (UNNUMBERED), 1951.

GROUND WATER IN THE TRINITY GROUP IN THE SAN ANTONIO AREA, TEXAS: USGS OPEN-FILE REPORT 53-150, 1953.

MISCELLANEOUS FIELD NOTES ON THE GEOLOGY OF THE SAN ANTONIO AREA, TEXAS 1950-53: USGS OPEN-FILE REPORT (UNNUMBERED), 1953.

GROUND-WATER RESOURCES OF THE SAN ANTONIO AREA, TEXAS, A PROGRESS REPORT OF CURRENT STUDIES: TEXAS BOARD OF WATER ENGINEERS BULLETIN 5412, 1954.

MEMORANDUM ON IRRIGATION BY GROUND WATER FROM THE EDWARDS AND ASSOCIATED LIMESTONES IN THE SAN ANTONIO-HONDO-UVALDE AREA, TEXAS: USGS OPEN-FILE REPORT $56-93,1956$.

RECORDS OF WATER-LEVEL MEASUREMENTS IN BEXAR COUNTY, TEXAS: TEXAS BOARD OF WATER ENGINEERS BULLETIN 5606, 1956.

GROUND-WATER RESOURCES OF THE SAN ANTONIO AREA, TEXAS, VOLUME 1, A PROGRESS REPORT ON CURRENT STUDIES: TEXAS BOARD OF WATER ENGINEERS BULLETIN 5608, V. 1, 1956.

GROUND-WATER RESOURCES OF THE SAN ANTONIO AREA, TEXAS, VOLUME 2, PART 1, RECORDS OF WELLS AND SPRINGS: TEXAS BOARD OF WATER ENGINEERS BULLETIN 5608, V. 2, PART 1, 1956.

GROUND-WATER RESOURCES OF THE SAN ANTONIO AREA, TEXAS, VOLUME 2, PART 2, RECORDS OF DRILLERS' LOGS: TEXAS BOARD OF WATER ENGINEERS BULLETIN 5608, V. 2, PART 2, 1956.

GROUND-WATER RESOURCES OF THE SAN ANTONIO AREA, TEXAS, VOLUME 2, PART 3, WATER LEVELS IN WELLS, CHEMICAL ANALYSES OF WATER, RECORDS OF STREAMFLOW AND RESERVOIR CONTENTS, DISCHARGE MEASUREMENTS, AND PRECIPITATION IN THE SAN ANTONIO AREA, TEXAS: TEXAS BOARD OF WATER ENGINEERS BULLETIN 5608, V. 2, PART 3, 1956.

DEVELOPMENT OF GROUND WATER FROM THE CARRIZO SAND AND WILCOX GROUP IN DIMMIT, ZAVALA, MAVERICK, FRIO, ATASCOSA, MEDINA, BEXAR, LIVE OAK, McMULLEN, LA SALLE, AND WEBB COUNTIES, TEXAS: USGS OPEN-FILE REPORT 57-77, 1957.

GROUND-WATER GEOLOGY OF BEXAR COUNTY, TEXAS: TEXAS BOARD OF WATER ENGINEERS BULLETIN 5911, 1959.

RECHARGE, DISCHARGE, AND CHANGES IN GROUND-WATER STORAGE IN THE EDWARDS AND ASSOCIATED LIMESTONES, SAN ANTONIO AREA, TEXAS, A PROGRESS REPORT ON STUDIES 1955-59: TEXAS WATER COMMISSION BULLETIN 6201, 1962.

CHEMICAL ANALYSES OF WATER FROM OBSERVATION WELLS IN THE EDWARDS AND ASSOCIATED LIMESTONES, SAN ANTONIO AREA, TEXAS: EDWARDS UNDERGROUND WATER DISTRICT BULLETIN 1, 1962. 
NOTES ON GEOLOGY OF PROPOSED BAT CAVE RESERVOIR AND VICINITY, BEXAR AND COMAL COUNTIES, TEXAS: USGS OPENFILE REPORT (UNNUMBERED), 1963

GROUND-WATER DISCHARGE FROM THE EDWARDS AND ASSOCIATED LIMESTONES, 1955-62, SAN ANTONIO AREA, TEXAS: EDWARDS UNDERGROUND WATER DISTRICT BULLETIN 2, 1963.

GROUND-WATER GEOLOGY OF BEXAR COUNTY, TEXAS: USGS WATER-SUPPLY PAPER 1588, 1963.

RECORDS OF PRECIPITATION, AQUIFER HEAD, AND GROUNDWATER DISCHARGE TO THE EDWARDS AND ASSOCIATED LIMESTONES, 1960-62, SAN ANTONIO AREA, TEXAS: EDWARDS UNDERGROUND WATER DISTRICT BULLETIN 3, 1963.

GROUND-WATER GEOLOGY OF BEXAR COUNTY, TEXAS: SOUTH TEXAS GEOLOGICAL SOCIETY BULLETIN V. 3, NO. 13, OCTOBER 7, 1963.

CHEMICAL ANALYSES OF WATER FROM OBSERVATION WELLS IN THE EDWARDS AND ASSOCIATED LIMESTONES, SAN ANTONIO AREA, TEXAS, 1963: EDWARDS UNDERGROUND WATER DISTRICT BULLETIN 4, 1964

GROUND-WATER DISCHARGE FROM THE EDWARDS AND ASSOCIATED LIMESTONES, SAN ANTONIO AREA, TEXAS, 1963: EDWARDS UNDERGROUND WATER DISTRICT BULLETIN 5, 1964.

RECORDS OF PRECIPITATION, AQUIFER HEAD, AND GROUNDWATER RECHARGE TO THE EDWARDS AND ASSOCIATED LIMESTONES, SAN ANTONIO AREA, TEXAS, 1963: EDWARDS UNDERGROUND WATER DISTRICT BULLETIN 6, 1964.

PUBLIC WATER SUPPLIES OF THE 100 LARGEST CITIES IN THE UNITED STATES: USGS WATER-SUPPLY PAPER 1812, 1964.

RECONNAISSANCE INVESTIGATION OF THE GROUND-WATER RESOURCES OF THE GUADALUPE, SAN ANTONIO, AND NUECES RIVER BASINS, TEXAS: TEXAS WATER COMMISSION BULLETIN 6409, 1964.

CHEMICAL ANALYSES OF WATER FROM OBSERVATION WELLS IN THE EDWARDS AND ASSOCIATED LIMESTONES, SAN ANTONIO AREA, TEXAS, 1964: EDWARDS UNDERGROUND WATER DISTRICT BULLETIN 7, 1965.

GROUND-WATER DISCHARGE FROM THE EDWARDS AND ASSOCIATED LIMESTONES, SAN ANTONIO AREA, TEXAS, 1964: EDWARDS UNDERGROUND WATER DISTRICT BULLETIN 8, 1965.

GROUND-WATER RECHARGE TO THE EDWARDS AND ASSOCIATED LIMESTONES, SAN ANTONIO AREA, TEXAS, 1964: EDWARDS UNDERGROUND WATER DISTRICT BULLETIN 9, 1965.

CHEMICAL ANALYSES FROM OBSERVATION WELLS IN THE EDWARDS AND ASSOCIATED LIMESTONES, SAN ANTONIO AREA, TEXAS, 1965: EDWARDS UNDERGROUND WATER DISTRICT BULLETIN 10, 1966

GROUND-WATER DISCHARGE FROM THE EDWARDS AND ASSOCIATED LIMESTONES, SAN ANTONIO AREA, TEXAS, 1965: EDWARDS UNDERGROUND WATER DISTRICT BULLETIN 11, 1966.

RECORDS OF PRECIPITATION, AQUIFER HEAD, AND GROUNDWATER RECHARGE TO THE EDWARDS AND ASSOCIATED LIMESTONES, SAN ANTONIO AREA, TEXAS, 1965: EDWARDS UNDERGROUND WATER DISTRICT BULLETIN 12, 1966.

GROUND-WATER RESOURCES OF THE SAN ANTONIO AREA, TEXAS, A PROGRESS REPORT ON STUDIES, 1960-64: TEXAS WATER DEVELOPMENT BOARD REPORT 34, 1966.
CHEMICAL ANALYSES OF WATER FROM OBSERVATION WELLS IN THE EDWARDS AND ASSOCIATED LIMESTONES, SAN ANTONIO AREA, TEXAS, 1966: EDWARDS UNDERGROUND WATER DISTRICT BULLETIN 13, 1967.

GROUND-WATER DISCHARGE FROM THE EDWARDS AND ASSOCIATED LIMESTONES, SAN ANTONIO AREA, TEXAS, 1966 EDWARDS UNDERGROUND WATER DISTRICT BULLETIN 14, 1967.

RECORDS OF PRECIPITATION, AQUIFER HEAD, AND GROUNDWATER RECHARGE TO THE EDWARDS AND ASSOCIATED LIMESTONES, SAN ANTONIO AREA, TEXAS, 1966: EDWARDS UNDERGROUND WATER DISTRICT BULLETIN 15, 1967.

CHEMICAL ANALYSES OF WATER FROM OBSERVATION WELLS IN THE EDWARDS AND ASSOCIATED LIMESTONES, SAN ANTONIO AREA, TEXAS, 1967: EDWARDS UNDERGROUND WATER DISTRICT BULLETIN 16, 1968.

HYDROLOGIC EFFECTS OF THE EARTHQUAKE OF MARCH 27, 1964 OUTSIDE ALASKA: USGS PROFESSIONAL PAPER 544-C, 1968.

GROUND-WATER DISCHARGE FROM THE EDWARDS AND ASSOCIATED LIMESTONES, SAN ANTONIO AREA, TEXAS, 1967: EDWARDS UNDERGROUND WATER DISTRICT BULLETIN 17, 1968.

RECORDS OF PRECIPITATION, AQUIFER HEAD, AND GROUNDWATER RECHARGE TO THE EDWARDS AND ASSOCIATED LIMESTONES, SAN ANTONIO AREA, TEXAS, 1967: EDWARDS UNDERGROUND WATER DISTRICT BULLETIN 18, 1968.

RECORDS OF WELLS AND SPRINGS, SAN ANTONIO AREA, TEXAS: EDWARDS UNDERGROUND WATER DISTRICT, 1969.

GROUND-WATER DISCHARGE FROM THE EDWARDS AND ASSOCIATED LIMESTONES, SAN ANTONIO AREA, TEXAS, 1968: EDWARDS UNDERGROUND WATER DISTRICT BULLETIN 20, 1969.

RECORDS OF PRECIPITATION, AQUIFER HEAD, AND GROUNDWATER RECHARGE TO THE EDWARDS AND ASSOCIATED LIMESTONES, SAN ANTONIO AREA, TEXAS, 1968: EDWARDS UNDERGROUND WATER DISTRICT BULLETIN 21, 1969.

GEOLOGY AND WATER QUALITY AT SELECTED LOCATIONS IN THE SAN ANTONIO AREA, TEXAS, PROGRESS REPORT, 1969: USGS OPEN-FILE REPORT 70-272, 1970.

GEOLOGY AND WATER QUALITY AT SELECTED LOCATIONS IN THE SAN ANTONIO AREA, TEXAS, PROGRESS REPORT, 1969: EDWARDS UNDERGROUND WATER DISTRICT, 1970.

GROUND-WATER DISCHARGE FROM THE EDWARDS AND ASSOCIATED LIMESTONES, SAN ANTONIO AREA, TEXAS, 1969: EDWARDS UNDERGROUND WATER DISTRICT BULLETIN 23, 1970.

RECORDS OF PRECIPITATION, WATER LEVELS, AND GROUNDWATER RECHARGE TO THE EDWARDS AND ASSOCIATED LIMESTONES, SAN ANTONIO AREA, TEXAS, 1969: EDWARDS UNDERGROUND WATER DISTRICT BULLETIN 24, 1970.

GROUND-WATER DISCHARGE FROM THE EDWARDS AND ASSOCIATED LIMESTONES, SAN ANTONIO AREA, TEXAS, 1970: EDWARDS UNDERGROUND WATER DISTRICT BULLETIN 26, 1971

RECORDS OF PRECIPITATION, WATER LEVELS, AND GROUNDWATER RECHARGE TO THE EDWARDS AND ASSOCIATED LIMESTONES, SAN ANTONIO AREA, TEXAS, 1970: EDWARDS UNDERGROUND WATER DISTRICT BULLETIN 27, 1971.

MAPS SHOWING OUTCROPS OF THE EDWARDS AND ASSOCIATED LIMESTONES IN THE PRINCIPAL RECHARGE AREA OF THE 
EDWARDS AQUIFER IN BEXAR COUNTY, TEXAS: USGS OPENFILE REPORT 72-310, 1972.

GROUND-WATER DISCHARGE FROM THE EDWARDS AND ASSOCIATED LIMESTONES, SAN ANTONIO AREA, TEXAS, 1971: EDWARDS UNDERGROUND WATER DISTRICT BULLETIN 29, 1972.

RECORDS OF PRECIPITATION, WATER LEVELS, AND GROUNDWATER RECHARGE TO THE EDWARDS AND ASSOCIATED LIMESTONES, SAN ANTONIO AREA, TEXAS, 1971: EDWARDS UNDERGROUND WATER DISTRICT BULLETIN 30, 1972.

CHEMICAL AND BACTERIOLOGICAL QUALITY OF WATER AT SELECTED SITES IN THE SAN ANTONIO AREA, TEXAS, AUGUST 1968-APRIL 1972: EDWARDS UNDERGROUND WATER DISTRICT, 1972.

GROUND-WATER DISCHARGE FROM THE EDWARDS AND ASSOCIATED LIMESTONES, SAN ANTONIO AREA, TEXAS, 1972: EDWARDS UNDERGROUND WATER DISTRICT BULLETIN 31, 1973

REGIONAL SPECIFIC YIELD OF THE EDWARDS AND ASSOCIATED LIMESTONES IN THE SAN ANTONIO, TEXAS, AREA: EDWARDS UNDERGROUND WATER DISTRICT, 1973.

GROUND-WATER DISCHARGE FROM THE EDWARDS AND ASSOCIATED LIMESTONES, SAN ANTONIO AREA, TEXAS, 1973: EDWARDS UNDERGROUND WATER DISTRICT BULLETIN 32, 1974.

RECORDS OF PRECIPITATION, WATER LEVELS, AND GROUNDWATER RECHARGE TO THE EDWARDS AND ASSOCIATED LIMESTONES, SAN ANTONIO AREA, TEXAS, 1972-73: EDWARDS UNDERGROUND WATER DISTRICT BULLETIN 33, 1974.

SUMMARY APPRAISALS OF THE NATIONS GROUND-WATER RESOURCES-TEXAS GULF REGION: USGS OPEN-FILE REPORT 74-331, 1974.

ENVIRONMENTAL TRITIUM IN THE EDWARDS AQUIFER, CENTRAL TEXAS, 1963-71: USGS OPEN-FILE REPORT 74-362, 1975.

THE EDWARDS UNDERGROUND RESERVOIR AND THE EDWARDS UNDERGROUND WATER DISTRICT: SOUTH TEXAS GEOLOGICAL SOCIETY BULLETIN V. 15, NO. 7, 1975.

RECORDS OF PRECIPITATION, WATER LEVELS, AND GROUNDWATER RECHARGE TO THE EDWARDS AND ASSOCIATED LIMESTONES, SAN ANTONIO AREA, TEXAS, 1972-73: SOUTH TEXAS GEOLOGICAL SOCIETY BULLETIN V. 15, NO. 7, 1975.

GROUND-WATER DISCHARGE FROM THE EDWARDS AND ASSOCIATED LIMESTONES, SAN ANTONIO AREA, TEXAS, 1974: EDWARDS UNDERGROUND WATER DISTRICT BULLETIN 34, 1975

RELATION OF PRECIPITATION TO ANNUAL GROUND-WATER RECHARGE IN THE EDWARDS AQUIFER, SAN ANTONIO AREA, TEXAS: USGS OPEN-FILE REPORT 75-298, 1975.

GEOHYDROLOGIC SIGNIFICANCE OF LITHOFACIES OF THE CARRIZO SAND OF ARKANSAS, LOUISIANA, AND TEXAS AND THE MERIDIAN SAND OF MISSISSIPPI: USGS PROFESSIONAL PAPER 569-D, 1975.

GEOCHEMICAL AND ISOTOPIC ANALYSES OF WATERS ASSOCIATED WITH THE EDWARDS LIMESTONE AQUIFER, CENTRAL TEXAS: EDWARDS UNDERGROUND WATER DISTRICT, 1976.

SUMMARY APPRAISALS OF THE NATION'S GROUND-WATER RESOURCES-TEXAS-GULF REGION: USGS PROFESSIONAL PAPER 813-F, 1976.
GROUND-WATER DISCHARGE FROM THE EDWARDS AND ASSOCIATED LIMESTONES, SAN ANTONIO AREA, TEXAS, 1975: EDWARDS UNDERGROUND WATER DISTRICT BULLETIN 35, 1976

STATISTICAL ANALYSIS OF WATER-LEVEL, SPRINGFLOW, AND STREAMFLOW DATA FOR THE EDWARDS AQUIFER IN SOUTHCENTRAL TEXAS: USGS OPEN-FILE REPORT 76-393, 1976.

STATISTICAL ANALYSIS OF WATER-LEVEL, SPRINGFLOW, AND STREAMFLOW DATA FOR THE EDWARDS AQUIFER IN SOUTHCENTRAL TEXAS: EDWARDS UNDERGROUND WATER DISTRICT, 1976.

CHEMICAL AND BACTERIOLOGICAL QUALITY OF WATER AT SELECTED SITES IN THE SAN ANTONIO AREA, TEXAS, AUGUST 1968-JANUARY 1975: USGS OPEN-FILE REPORT 76-574, 1976

CHEMICAL AND BACTERIOLOGICAL QUALITY OF WATER AT SELECTED SITES IN THE SAN ANTONIO AREA, TEXAS, AUGUST 1968-JANUARY 1975: EDWARDS UNDERGROUND WATER DISTRICT, 1976

PROGRESS REPORT ON GEOLOGY OF THE EDWARDS AQUIFER, SAN ANTONIO AREA, TEXAS, AND PRELIMINARY INTERPRETATION OF BOREHOLE GEOPHYSICAL AND LABORATORY DATA ON CARBONATE ROCKS: USGS OPEN-FILE REPORT 76-627, 1976.

GROUND-WATER RESOURCES OF THE CARRIZO AQUIFER IN THE WINTER GARDEN AREA OF TEXAS, VOLUME 1: TEXAS WATER DEVELOPMENT BOARD REPORT 210, V. 1, 1976.

GROUND-WATER RESOURCES OF THE CARRIZO AQUIFER IN THE WINTER GARDEN AREA OF TEXAS, VOLUME 2: TEXAS WATER DEVELOPMENT BOARD REPORT 210, V. 2, 1977.

GROUND-WATER DISCHARGE FROM THE EDWARDS AND ASSOCIATED LIMESTONES, SAN ANTONIO AREA, TEXAS, 1976: EDWARDS UNDERGROUND WATER DISTRICT, 1977.

SOURCE OF NITRATE IN WATER OF THE EDWARDS AQUIFER, SOUTH-CENTRAL TEXAS: UNIVERSITY OF TEXAS AT AUSTIN MASTER'S THESIS, 1977.

METHOD OF ESTIMATING NATURAL RECHARGE TO THE EDWARDS AQUIFER IN THE SAN ANTONIO AREA, TEXAS: USGS WATERRESOURCES INVESTIGATIONS REPORT 78-10, 1978.

REGIONAL DISTRIBUTION OF FRACTURES IN THE SOUTHERN EDWARDS PLATEAU AND THEIR RELATIONSHIP TO TECTONICS AND CAVES: UNIVERSITY OF TEXAS, BUREAU OF ECONOMIC GEOLOGY GEOLOGICAL CIRCULAR 78-2, 1978.

CHEMICAL AND BACTERIOLOGICAL QUALITY OF WATER AT SELECTED SITES IN THE SAN ANTONIO AREA, TEXAS, FEBRUARY 1975-SEPTEMBER 1977: EDWARDS UNDERGROUND WATER DISTRICT, 1978

RECORDS OF GROUND-WATER RECHARGE AND DISCHARGE FOR THE EDWARDS AQUIFER IN THE SAN ANTONIO AREA, TEXAS, 1934-77: EDWARDS UNDERGROUND WATER DISTRICT BULLETIN 37, 1979.

VARIATIONS IN SPECIFIC YIELD IN THE OUTCROP OF THE CARRIZO SAND IN SOUTH TEXAS AS ESTIMATED BY SEISMIC REFRACTION: TEXAS DEPARTMENT OF WATER RESOURCES REPORT 229, 1979.

RECORDS OF WELLS, CHEMICAL ANALYSES, AND WATER LEVELS OF SELECTED EDWARDS WELLS, BEXAR COUNTY, TEXAS: TEXAS DEPARTMENT OF WATER RESOURCES REPORT 237, 1979. 
GROUND-WATER RESOURCES AND MODEL APPLICATIONS FOR THE EDWARDS (BALCONES FAULT ZONE) AQUIFER IN THE SAN ANTONIO REGION: TEXAS DEPARTMENT OF WATER RESOURCES REPORT 239, 1979.

HYDROCHEMICAL DATA FOR THE EDWARDS AQUIFER IN THE SAN ANTONIO AREA, TEXAS: TEXAS DEPARTMENT OF WATER RESOURCES LIMITED PRINTING REPORT LP-131, 1980.

RECORDS OF GROUND-WATER RECHARGE, DISCHARGE, WATER LEVELS, AND CHEMICAL QUALITY OF WATER FOR THE EDWARDS AQUIFER IN THE SAN ANTONIO AREA, TEXAS, 1934-78: EDWARDS UNDERGROUND WATER DISTRICT BULLETIN 38, 1980.

WATER-LEVEL, RECHARGE, DISCHARGE, SPECIFIC CAPACITY, WELL-YIELD, AND AQUIFER-TEST DATA FOR THE EDWARDS AQUIFER IN THE SAN ANTONIO AREA, TEXAS: TEXAS DEPARTMENT OF WATER RESOURCES LIMITED PRINTING REPORT LP-133, 1980.

APPLICATION AND ANALYSIS OF BOREHOLE DATA FOR THE EDWARDS AQUIFER IN THE SAN ANTONIO AREA, TEXAS: TEXAS DEPARTMENT OF WATER RESOURCES LIMITED PRINTING REPORT LP-139, 1981.

RECORDS OF GROUND-WATER RECHARGE, DISCHARGE, WATER LEVELS, AND CHEMICAL QUALITY OF WATER FOR THE EDWARDS AQUIFER IN THE SAN ANTONIO AREA, TEXAS, 1934-79: EDWARDS UNDERGROUND WATER DISTRICT BULLETIN 39, 1981.

TEST-HOLE DATA FOR THE EDWARDS AQUIFER IN THE SAN ANTONIO AREA, TEXAS: TEXAS DEPARTMENT OF WATER RESOURCES LIMITED PRINTING REPORT LP-171, 1982.

RECORDS OF GROUND-WATER RECHARGE, DISCHARGE, WATER LEVELS, AND CHEMICAL QUALITY OF WATER FOR THE EDWARDS AQUIFER IN THE SAN ANTONIO AREA, TEXAS, 1934-80: EDWARDS UNDERGROUND WATER DISTRICT BULLETIN 40, 1982.

GROUND-WATER AVAILABILITY OF THE LOWER CRETACEOUS FORMATIONS IN THE HILL COUNTRY OF SOUTH-CENTRAL TEXAS: TEXAS DEPARTMENT OF WATER RESOURCES REPORT $273,1983$.

RECORDS OF GROUND-WATER RECHARGE, DISCHARGE, WATER LEVELS, AND CHEMICAL QUALITY OF WATER FOR THE EDWARDS AQUIFER IN THE SAN ANTONIO AREA, TEXAS, 1934-81: EDWARDS UNDERGROUND WATER DISTRICT BULLETIN 41, 1984.

CARBONATE GEOLOGY AND HYDROLOGY OF THE EDWARDS AQUIFER IN THE SAN ANTONIO AREA, TEXAS: USGS OPEN-FILE REPORT 83-537, 1984.

IDENTIFICATION AND TABULATION OF GEOLOGICAL CONTACTS IN THE EDWARDS AQUIFER, SAN ANTONIO AREA, TEXAS: USGS OPEN-FILE REPORT 84-075, 1984.

PROPOSED 10-YEAR PLAN FOR CONTINUATION OF HYDROLOGIC STUDIES OF THE EDWARDS AQUIFER, SAN ANTONIO AREA, TEXAS: USGS OPEN-FILE REPORT 84-817, 1984.

RECORDS OF GROUND-WATER RECHARGE, DISCHARGE, WATER LEVELS, AND CHEMICAL QUALITY OF WATER FOR THE EDWARDS AQUIFER IN THE SAN ANTONIO AREA, TEXAS, 1934-82: EDWARDS UNDERGROUND WATER DISTRICT BULLETIN 42, 1985.
TEXAS GROUND-WATER RESOURCES, in NATIONAL WATER SUMMARY 1984: USGS WATER-SUPPLY PAPER 2275, 1985.

IDENTIFICATION AND TABULATION OF GEOLOGICAL CONTACTS IN THE EDWARDS AQUIFER, SAN ANTONIO AREA, TEXAS: TEXAS DEPARTMENT OF WATER RESOURCES LIMITED PRINTING REPORT LP-199, 1985.

STATISTICAL SUMMARY OF WATER-QUALITY DATA COLLECTED FROM SELECTED WELLS AND SPRINGS IN THE EDWARDS AQUIFER NEAR SAN ANTONIO, TEXAS: USGS OPEN-FILE REPORT 85-182, 1985.

WATER USE, PROJECTED WATER REQUIREMENTS, AND RELATED DATA AND INFORMATION FOR THE METROPOLITAN STATISTICAL AREAS IN TEXAS: TEXAS DEPARTMENT OF WATER RESOURCES LIMITED PRINTING REPORT LP-201, 1985.

COMPILATION OF HYDROLOGIC DATA FOR THE EDWARDS AQUIFER, SAN ANTONIO AREA, TEXAS, 1983-84, WITH 1934-84 SUMMARY: EDWARDS UNDERGROUND WATER DISTRICT BULLETIN 43-44, 1986.

HYDROGEOLOGIC SECTIONS OF THE EDWARDS AQUIFER AND ITS CONFINING UNITS IN THE SAN ANTONIO AREA, TEXAS: USGS WATER-RESOURCES INVESTIGATIONS REPORT 85-4259, 1986.

CARBONATE GEOLOGY AND HYDROLOGY OF THE EDWARDS AQUIFER IN THE SAN ANTONIO AREA, TEXAS: TEXAS WATER DEVELOPMENT BOARD REPORT 296, 1986.

POTENTIAL FOR UPDIP MOVEMENT OF SALINEWATER IN THE EDWARDS AQUIFER, SAN ANTONIO, TEXAS: USGS WATERRESOURCES INVESTIGATIONS REPORT 86-4032, 1986.

THE EDWARDS AQUIFER; EXTREMELY PRODUCTIVE, BUT....A SOLE-SOURCE WATER SUPPLY FOR SAN ANTONIO AND SURROUNDING COUNTIES IN SOUTH-CENTRAL TEXAS: EDWARDS UNDERGROUND WATER DISTRICT, 1986.

SIMULATION OF FLOW IN THE EDWARDS AQUIFER, SAN ANTONIO REGION, TEXAS, AND REFINEMENT OF STORAGE AND FLOW CONCEPTS: USGS OPEN-FILE REPORT 86-532, 1987.

HYDROGEOLOGIC DATA FROM A STUDY OF THE FRESHWATER ZONE/SALINEWATER ZONE INTERFACE IN THE EDWARDS AQUIFER, SAN ANTONIO REGION, TEXAS: USGS OPEN-FILE REPORT 87-389, 1987.

COMPILATION OF HYDROLOGIC DATA FOR THE EDWARDS AQUIFER, SAN ANTONIO AREA, TEXAS, 1985, WITH 1934-85 SUMMARY: EDWARDS UNDERGROUND WATER DISTRICT BULLETIN 45, 1987.

RELATION OF WATER CHEMISTRY OF THE EDWARDS AQUIFER TO HYDROGEOLOGY AND LAND USE, SAN ANTONIO AREA, TEXAS: USGS WATER-RESOURCES INVESTIGATIONS REPORT 87-4116, 1987.

APPROXIMATE POTENTIOMETRIC SURFACES FOR THE AQUIFERS OF THE TEXAS COASTAL UPLANDS SYSTEM, 1980: USGS HYDROLOGIC ATLAS HA-704, 1987.

SUGGESTED DESIGN AND CONSTRUCTION OF EDWARDS AQUIFER WELLS: EDWARDS UNDERGROUND WATER DISTRICT, 1987?

COMPILATION OF HYDROLOGIC DATA FOR THE EDWARDS AQUIFER, SAN ANTONIO AREA, TEXAS, 1986, WITH 1934-86 SUMMARY: EDWARDS UNDERGROUND WATER DISTRICT BULLETIN 46, 1988. 
SIMULATION OF FLOW IN THE EDWARDS AQUIFER, SAN ANTONIO REGION, TEXAS, AND REFINEMENT OF STORAGE AND FLOW CONCEPTS: USGS WATER-SUPPLY PAPER 2336-A, 1988.

DEPOSITIONAL AND GROUND-WATER FLOW SYSTEMS OF THE CARRIZO-UPPER WILCOX, SOUTH TEXAS: UNIVERSITY OF TEXAS, BUREAU OF ECONOMIC GEOLOGY REPORT OF INVESTIGATIONS NO. 175, 1988.

GEOHYDROLOGIC FRAMEWORK OF THE GULF COASTAL PLAIN: USGS HYDROLOGIC ATLAS HA-695, 1988.

COMPILATION OF HYDROLOGIC DATA FOR THE EDWARDS AQUIFER, SAN ANTONIO AREA, TEXAS, 1987, WITH 1934-87 SUMMARY: EDWARDS UNDERGROUND WATER DISTRICT BULLETIN 47, 1988.

COMPILATION OF HYDROLOGIC DATA FOR THE EDWARDS AQUIFER, SAN ANTONIO AREA, TEXAS, 1988, WITH 1934-88 SUMMARY: EDWARDS UNDERGROUND WATER DISTRICT BULLETIN 48, 1989

POTENTIOMETRIC SURFACE OF THE EDWARDS-TRINITY AQUIFER SYSTEM AND CONTIGUOUS HYDRAULICALLY CONNECTED UNITS, WEST-CENTRAL TEXAS, WINTER 1974-75: USGS WATERRESOURCES INVESTIGATIONS REPORT 89-4208, 1990.

COMPILATION OF HYDROLOGIC DATA FOR THE EDWARDS AQUIFER, SAN ANTONIO AREA, TEXAS, 1989, WITH 1934-89 SUMMARY: EDWARDS UNDERGROUND WATER DISTRICT BULLETIN 49, 1990.

WITHDRAWALS FROM THE EDWARDS-TRINITY AQUIFER SYSTEM AND CONTIGUOUS HYDRAULICALLY CONNECTED UNITS, WEST-CENTRAL TEXAS, DECEMBER 1974 THROUGH MARCH 1977: USGS WATER-RESOURCES INVESTIGATIONS REPORT 91-4021, 1991.

COMPARATIVE PETROLOGY OF CORES FROM TWO TEST WELLS IN THE EASTERN PART OF THE EDWARDS AQUIFER, SOUTH-CENTRAL TEXAS: USGS WATER-RESOURCES INVESTIGATIONS REPORT 87-4266, 1991.

EDWARDS AQUIFER, A TEXAS TREASURE-A TEACHERS GUIDE, SECONDARY, GRADES 7-12: EDWARDS UNDERGROUND WATER DISTRICT, 1991.

COMPILATION OF HYDROLOGIC DATA FOR THE EDWARDS AQUIFER, SAN ANTONIO AREA, TEXAS, 1990, WITH 1934-90 SUMMARY: EDWARDS UNDERGROUND WATER DISTRICT BULLETIN 50, 1991

WORLDS LARGEST FLOWING WELL: TEXAS STATE SECTION OF THE AMERICAN WATER RESOURCES ASSOCIATION, TRIGG TWICHELL SYMPOSIUM, FALL MEETING, NOVEMBER 8, 1991, AUSTIN, TEXAS, 1991.

INSIDE THE EDWARDS AQUIFER-A THREE-PART TECHNICAL FILM, HIGH-SCHOOL LEVEL TEACHER'S GUIDE: EDWARDS UNDERGROUND WATER DISTRICT, 1992.

CONFIGURATION OF THE BASE OF THE EDWARDS-TRINITY AQUIFER SYSTEM AND HYDROGEOLOGY OF THE UNDERLYING PRECRETACEOUS ROCKS, WEST-CENTRAL TEXAS: USGS WATERRESOURCES INVESTIGATIONS REPORT 91-4071, 1992.

GROUND-WATER QUALITY MONITORING RESULTS IN THE WINTER GARDEN AREA, 1990: TEXAS WATER DEVELOPMENT BOARD REPORT 335, 1992.
MODEL REFINEMENT AND APPLICATION FOR THE EDWARDS (BALCONES FAULT ZONE) AQUIFER IN THE SAN ANTONIO AREA, TEXAS: TEXAS WATER DEVELOPMENT BOARD REPORT 340, 1992.

WATER QUALITY IN THE EDWARDS AQUIFER AND STREAMS RECHARGING THE AQUIFER IN THE SAN ANTONIO REGION, TEXAS: USGS HYDROLOGIC INVESTIGATIONS ATLAS HA-723, 1992.

USING GEOPHYSICAL LOGS IN THE EDWARDS AQUIFER TO ESTIMATE WATER QUALITY ALONG THE FRESHWATER/SALINEWATER INTERFACE (UVALDE TO SAN ANTONIO, TEXAS): EDWARDS UNDERGROUND WATER DISTRICT REPORT 92-03, 1992.

COMPILATION OF HYDROLOGIC DATA FOR THE EDWARDS AQUIFER, SAN ANTONIO AREA, TEXAS, 1991, WITH 1934-91 SUMMARY: EDWARDS UNDERGROUND WATER DISTRICT BULLETIN $51,1992$.

WATER-RESOURCES DATA, TEXAS, WATER YEAR 1991, VOLUME 4 , GROUND-WATER DATA: USGS WATER-DATA REPORT TX-91-4, 1992.

HISTORICAL POTENTIOMETRIC SURFACE OF THE EDWARDS-TRINITY AQUIFER SYSTEM AND CONTIGUOUS HYDRAULICALLY CONNECTED UNITS, WEST-CENTRAL TEXAS: USGS WATERRESOURCES INVESTIGATIONS REPORT 92-4055, 1993.

PROPERTIES AND CHEMICAL CONSTITUENTS IN GROUND WATER FROM THE LOWER CLAIBORNE-UPPER WILCOX AQUIFER, GULF COAST REGIONAL AQUIFER SYSTEMS, SOUTH-CENTRAL UNITED STATES: USGS WATER-RESOURCES INVESTIGATIONS REPORT 92-4102, 1993

HISTORICAL SATURATED THICKNESS OF THE EDWARDS-TRINITY AQUIFER SYSTEM AND SELECTED CONTIGUOUS HYDRAULICALLY CONNECTED UNITS, WEST-CENTRAL TEXAS: USGS WATER-RESOURCES INVESTIGATIONS REPORT 92-4125, 1993.

RECONNAISSANCE INVESTIGATION OF THE GEOLOGY AND HYDROGEOLOGY OF LACKLAND AIR FORCE BASE, SAN ANTONIO, TEXAS: USGS WATER-RESOURCES INVESTIGATIONS REPORT 93-4037, 1993.

PROPERTIES AND CHEMICAL CONSTITUENTS IN GROUND WATER FROM THE MIDDLE WILCOX AQUIFER, GULF COAST REGIONAL AQUIFER SYSTEMS, SOUTH-CENTRAL UNITED STATES: USGS WATER-RESOURCES INVESTIGATIONS REPORT 93-4070, 1993.

GOVERNMENT CANYON GEOLOGIC AND HYDROLOGIC ASSESSMENT: EDWARDS UNDERGROUND WATER DISTRICT REPORT 93-10, 1993.

DEFINING THE EDWARDS AQUIFER FRESHWATER/SALINE-WATER INTERFACE WITH GEOPHYSICAL LOGS AND MEASURED DATA (SAN ANTONIO TO KYLE, TEXAS): EDWARDS UNDERGROUND WATER DISTRICT REPORT 93-06, 1993.

EDWARDS AQUIFER HYDROGEOLOGIC STATUS REPORT FOR 1992: EDWARDS UNDERGROUND WATER DISTRICT REPORT 93-05, 1993.

WATER-RESOURCES DATA, TEXAS, WATER YEAR 1992, VOLUME 4 GROUND-WATER DATA: USGS WATER-DATA REPORT TX-92-4, 1993.

SIMULATIONS OF FLOW IN THE EDWARDS-TRINITY AQUIFER SYSTEM AND CONTIGUOUS HYDRAULICALLY CONNECTED 
UNITS, WEST-CENTRAL TEXAS: USGS WATER-RESOURCES INVESTIGATIONS REPORT 93-4039, 1994.

ANALYSIS OF DATA FROM TEST-WELL SITES ALONG THE DOWNDIP LIMIT OF FRESHWATER IN THE EDWARDS AQUIFER, SAN ANTONIO, TEXAS, 1985-87: USGS WATER-RESOURCES INVESTIGATIONS REPORT 93-4100, 1994.

DISSOLVED-SOLIDS CONCENTRATIONS AND HYDROCHEMICAL FACIES IN WATER OF THE EDWARDS-TRINITY AQUIFER SYSTEM, WEST-CENTRAL TEXAS: USGS WATER-RESOURCES INVESTIGATIONS REPORT 93-4126, 1994.

NATIONAL WATER-QUALITY ASSESSMENT PROGRAM-SOUTHCENTRAL TEXAS: USGS FACT SHEET FS-94-048, 1994.

GEOLOGIC HISTORY AND HYDROGEOLOGIC SETTING OF THE EDWARDS-TRINITY AQUIFER SYSTEM, WEST-CENTRAL TEXAS: USGS WATER-RESOURCES INVESTIGATIONS REPORT 94-4039, 1994.

1994 REVIEW AND UPDATE OF THE POSITION OF THE EDWARDS AQUIFER FRESHWATER/SALINE-WATER INTERFACE FROM UVALDE TO KYLE, TEXAS: EDWARDS UNDERGROUND WATER DISTRICT REPORT 94-05, 1994.

WATER-RESOURCES DATA, TEXAS, WATER YEAR 1993, VOLUME 4, GROUND-WATER DATA: USGS WATER-DATA REPORT TX-93-4, 1994.

GEOLOGY AND HYDROLOGY OF THE EDWARDS AQUIFER IN THE SAN ANTONIO AREA, TEXAS: USGS WATER-RESOURCES INVESTIGATIONS REPORT 95-4186, 1995.

STRATIGRAPHIC NOMENCLATURE AND GEOLOGIC SECTIONS OF THE GULF COASTAL PLAIN OF TEXAS: USGS OPEN-FILE REPORT 94-461, 1995.

REGIONAL DISTRIBUTION OF PERMEABILITY IN THE EDWARDS AQUIFER: EDWARDS UNDERGROUND WATER DISTRICT REPORT 95-02, 1995.

GEOLOGIC FRAMEWORK AND HYDROGEOLOGIC CHARACTERISTICS OF THE EDWARDS AQUIFER RECHARGE ZONE, BEXAR COUNTY, TEXAS: USGS WATER-RESOURCES INVESTIGATIONS REPORT 95-4030, 1995 [1996].

RECHARGE TO AND DISCHARGE FROM THE EDWARDS AQUIFER IN THE SAN ANTONIO AREA, TEXAS, 1995: USGS OPEN-FILE REPORT 96-181, 1996.

HYDROGEOLOGIC FACTORS THAT AFFECT THE FLOWPATH OF WATER IN SELECTED ZONES OF THE EDWARDS AQUIFER, SAN ANTONIO REGION, TEXAS: USGS WATER-RESOURCES INVESTIGATIONS REPORT 96-4046, 1996.

EDWARDS AQUIFER GROUND-WATER RESOURCES: GEOLOGIC CONTROLS ON POROSITY DEVELOPMENT IN PLATFORM CARBONATES, SOUTH TEXAS: UNIVERSITY OF TEXAS, BUREAU OF ECONOMIC GEOLOGY REPORT OF INVESTIGATIONS NO. 238, 1996.

WATER-QUALITY ASSESSMENT OF SOUTH-CENTRAL TEXASOCCURRENCE AND DISTRIBUTION OF VOLATILE ORGANIC COMPOUNDS IN SURFACE WATER AND GROUND WATER, 1983-94, AND IMPLICATIONS FOR FUTURE MONITORING: USGS WATER-RESOURCES INVESTIGATIONS REPORT 97-4028, 1997.

HYDROGEOLOGIC FRAMEWORK AND GEOCHEMISTRY OF THE EDWARDS AQUIFER SALINE-WATER ZONE, SOUTH-CENTRAL
TEXAS: USGS WATER-RESOURCES INVESTIGATIONS REPORT 97-4133, 1997.

GEOLOGIC FRAMEWORK AND HYDROGEOLOGIC CHARACTERISTICS OF THE OUTCROPS OF THE EDWARDS AND TRINITY AQUIFERS, MEDINA LAKE AREA, TEXAS: USGS WATER-RESOURCES INVESTIGATIONS REPORT 97-4290, 1998.

MONITORING OF SELECTED WATER-QUALITY CONSTITUENTS NEAR THE FRESHWATER/SALINE-WATER INTERFACE OF THE EDWARDS AQUIFER, JULY 1996-DECEMBER 1997: USGS FACT SHEET FS-103-98, 1998.

WATER-RESOURCES DATA, TEXAS, WATER YEAR 1997, VOLUME 4, GROUND-WATER DATA: USGS WATER-DATA REPORT TX-97-4, 1998.

WATER-RESOURCES DATA, TEXAS, WATER YEAR 1998, VOLUME 4, GROUND-WATER DATA: USGS WATER-DATA REPORT TX-98-4, 1999.

VULNERABILITY OF GROUND WATER TO CONTAMINATION, EDWARDS AQUIFER RECHARGE ZONE, BEXAR COUNTY, TEXAS, 1998: USGS WATER-RESOURCES INVESTIGATIONS REPORT $00-4149,2000$.

GROUNDWATER AVAILABILITY OF THE TRINITY AQUIFER, HILL COUNTRY AREA, TEXAS: NUMERICAL SIMULATIONS THROUGH 2050: TEXAS WATER DEVELOPMENT BOARD REPORT 353, 2000.

TRANSMISSIVITY, HYDRAULIC CONDUCTIVITY, AND STORATIVITY OF THE CARRIZO-WILCOX AQUIFER IN TEXAS, DATA AND ANALYSIS: UNIVERSITY OF TEXAS, BUREAU OF ECONOMIC GEOLOGY, CD-ROM, 2000.

WATER QUALITY IN SOUTH-CENTRAL TEXAS-TEXAS, 1996-98: USGS CIRCULAR 1212, 2000.

WATER-RESOURCES DATA, TEXAS, WATER YEAR 1999, VOLUME 6, GROUND-WATER DATA: USGS WATER-DATA REPORT TX-99-6, 2000.

WATER-RESOURCES DATA, TEXAS, WATER YEAR 2000, VOLUME 6, GROUND-WATER DATA: USGS WATER-DATA REPORT TX-00-6, 2001.

\section{BLANCO COUNTY}

GEOGRAPHY AND GEOLOGY OF THE BLACK AND GRAND PRAIRIES OF TEXAS, WITH DETAILED DESCRIPTIONS OF THE CRETACEOUS FORMATIONS AND SPECIAL REFERENCE TO ARTESIAN WATERS: USGS 21ST ANNUAL REPORT, PART 7, 1901.

MEMORANDUM TO DIRECTORS OF THE GIRL SCOUTS OF THE AUSTIN AREA REGARDING A PRELIMINARY REPORT ON INVESTIGATION OF THE AVAILABILITY OF GROUND WATER FOR A CAMP SUPPLY, BLANCO COUNTY, TEXAS: USGS OPEN-FILE REPORT (UNNUMBERED), 1938.

RECORDS OF WELLS AND SPRINGS, DRILLERS' LOGS, WATER ANALYSES, AND MAP SHOWING LOCATIONS OF WELLS AND SPRINGS IN BLANCO COUNTY, TEXAS: TEXAS BOARD OF WATER ENGINEERS MISCELLANEOUS PUBLICATION 14, 1942.

MEMORANDUM ON WATER SUPPLIES OF THE CITY OF BLANCO, TEXAS: USGS OPEN-FILE REPORT (UNNUMBERED), 1948.

PUBLIC WATER SUPPLIES IN CENTRAL AND NORTH-CENTRAL TEXAS: USGS WATER-SUPPLY PAPER 1069, 1949. 
RECONNAISSANCE INVESTIGATION OF THE GROUND-WATER RESOURCES OF THE GUADALUPE, SAN ANTONIO, AND NUECES RIVER BASINS, TEXAS: TEXAS WATER COMMISSION BULLETIN 6409, 1964.

RECONNAISSANCE INVESTIGATION OF THE GROUND-WATER RESOURCES OF THE COLORADO RIVER BASIN, TEXAS: TEXAS WATER DEVELOPMENT BOARD REPORT 51, 1967.

GROUND-WATER RESOURCES OF BLANCO COUNTY, TEXAS: TEXAS WATER DEVELOPMENT BOARD REPORT 174, 1973.

RELATION OF PRECIPITATION TO ANNUAL GROUND-WATER RECHARGE IN THE EDWARDS AQUIFER, SAN ANTONIO AREA, TEXAS: USGS OPEN-FILE REPORT 75-298, 1975.

MAJOR AND HISTORICAL SPRINGS OF TEXAS: TEXAS WATER DEVELOPMENT BOARD REPORT 189, 1975.

REGIONAL DISTRIBUTION OF FRACTURES IN THE SOUTHERN EDWARDS PLATEAU AND THEIR RELATIONSHIP TO TECTONICS AND CAVES: UNIVERSITY OF TEXAS, BUREAU OF ECONOMIC GEOLOGY GEOLOGICAL CIRCULAR 78-2, 1978.

RECORDS OF GROUND-WATER RECHARGE AND DISCHARGE FOR THE EDWARDS AQUIFER IN THE SAN ANTONIO AREA, TEXAS, 1934-77: EDWARDS UNDERGROUND WATER DISTRICT BULLETIN 37, 1979.

RECORDS OF GROUND-WATER RECHARGE, DISCHARGE, WATER LEVELS, AND CHEMICAL QUALITY OF WATER FOR THE EDWARDS AQUIFER IN THE SAN ANTONIO AREA, TEXAS, 1934-78: EDWARDS UNDERGROUND WATER DISTRICT BULLETIN 38, 1980.

SPRINGS OF TEXAS, VOLUME 1: (BY GUNNAR BRUNE), BRANCHSMITH, INC., FORT WORTH, TEXAS, 1981.

RECORDS OF GROUND-WATER RECHARGE, DISCHARGE, WATER LEVELS, AND CHEMICAL QUALITY OF WATER FOR THE EDWARDS AQUIFER IN THE SAN ANTONIO AREA, TEXAS, 1934-79: EDWARDS UNDERGROUND WATER DISTRICT BULLETIN 39, 1981.

RECORDS OF GROUND-WATER RECHARGE, DISCHARGE, WATER LEVELS, AND CHEMICAL QUALITY OF WATER FOR THE EDWARDS AQUIFER IN THE SAN ANTONIO AREA, TEXAS, 1934-80: EDWARDS UNDERGROUND WATER DISTRICT BULLETIN 40, 1982.

GROUND-WATER AVAILABILITY OF THE LOWER CRETACEOUS FORMATIONS IN THE HILL COUNTRY OF SOUTH-CENTRAL TEXAS: TEXAS DEPARTMENT OF WATER RESOURCES REPORT $273,1983$.

RECORDS OF GROUND-WATER RECHARGE, DISCHARGE, WATER LEVELS, AND CHEMICAL QUALITY OF WATER FOR THE EDWARDS AQUIFER IN THE SAN ANTONIO AREA, TEXAS, 1934-81: EDWARDS UNDERGROUND WATER DISTRICT BULLETIN 41, 1984.

CARBONATE GEOLOGY AND HYDROLOGY OF THE EDWARDS AQUIFER IN THE SAN ANTONIO AREA, TEXAS: USGS OPEN-FILE REPORT 83-537, 1984.

RECORDS OF GROUND-WATER RECHARGE, DISCHARGE, WATER LEVELS, AND CHEMICAL QUALITY OF WATER FOR THE EDWARDS AQUIFER IN THE SAN ANTONIO AREA, TEXAS, 1934-82: EDWARDS UNDERGROUND WATER DISTRICT BULLETIN 42, 1985.
TEXAS GROUND-WATER RESOURCES, in NATIONAL WATER SUMMARY 1984: USGS WATER-SUPPLY PAPER 2275, 1985.

COMPILATION OF HYDROLOGIC DATA FOR THE EDWARDS AQUIFER, SAN ANTONIO AREA, TEXAS, 1983-84, WITH 1934-84 SUMMARY: EDWARDS UNDERGROUND WATER DISTRICT BULLETIN 43-44, 1986.

CARBONATE GEOLOGY AND HYDROLOGY OF THE EDWARDS AQUIFER IN THE SAN ANTONIO AREA, TEXAS: TEXAS WATER DEVELOPMENT BOARD REPORT 296, 1986.

COMPILATION OF HYDROLOGIC DATA FOR THE EDWARDS AQUIFER, SAN ANTONIO AREA, TEXAS, 1985, WITH 1934-85 SUMMARY: EDWARDS UNDERGROUND WATER DISTRICT BULLETIN 45, 1987.

COMPILATION OF HYDROLOGIC DATA FOR THE EDWARDS AQUIFER, SAN ANTONIO AREA, TEXAS, 1986, WITH 1934-86 SUMMARY: EDWARDS UNDERGROUND WATER DISTRICT BULLETIN 46, 1988.

COMPILATION OF HYDROLOGIC DATA FOR THE EDWARDS AQUIFER, SAN ANTONIO AREA, TEXAS, 1987, WITH 1934-87 SUMMARY: EDWARDS UNDERGROUND WATER DISTRICT BULLETIN 47, 1988.

COMPILATION OF HYDROLOGIC DATA FOR THE EDWARDS AQUIFER, SAN ANTONIO AREA, TEXAS, 1988, WITH 1934-88 SUMMARY: EDWARDS UNDERGROUND WATER DISTRICT BULLETIN 48, 1989.

POTENTIOMETRIC SURFACE OF THE EDWARDS-TRINITY AQUIFER SYSTEM AND CONTIGUOUS HYDRAULICALLY CONNECTED UNITS, WEST-CENTRAL TEXAS, WINTER 1974-75: USGS WATERRESOURCES INVESTIGATIONS REPORT 89-4208, 1990.

COMPILATION OF HYDROLOGIC DATA FOR THE EDWARDS AQUIFER, SAN ANTONIO AREA, TEXAS, 1989, WITH 1934-89 SUMMARY: EDWARDS UNDERGROUND WATER DISTRICT BULLETIN 49, 1990.

WITHDRAWALS FROM THE EDWARDS-TRINITY AQUIFER SYSTEM AND CONTIGUOUS HYDRAULICALLY CONNECTED UNITS, WEST-CENTRAL TEXAS, DECEMBER 1974 THROUGH MARCH 1977: USGS WATER-RESOURCES INVESTIGATIONS REPORT 91-4021, 1991.

EDWARDS AQUIFER, A TEXAS TREASURE-A TEACHERS GUIDE, SECONDARY, GRADES 7-12: EDWARDS UNDERGROUND WATER DISTRICT, 1991.

COMPILATION OF HYDROLOGIC DATA FOR THE EDWARDS AQUIFER, SAN ANTONIO AREA, TEXAS, 1990, WITH 1934-90 SUMMARY: EDWARDS UNDERGROUND WATER DISTRICT BULLETIN 50, 1991.

INSIDE THE EDWARDS AQUIFER-A THREE-PART TECHNICAL FILM, HIGH-SCHOOL LEVEL TEACHER'S GUIDE: EDWARDS UNDERGROUND WATER DISTRICT, 1992.

CONFIGURATION OF THE BASE OF THE EDWARDS-TRINITY AQUIFER SYSTEM AND HYDROGEOLOGY OF THE UNDERLYING PRECRETACEOUS ROCKS, WEST-CENTRAL TEXAS: USGS WATERRESOURCES INVESTIGATIONS REPORT 91-4071, 1992.

EVALUATION OF THE GROUND-WATER RESOURCES OF THE PALEOZOIC AND CRETACEOUS AQUIFERS IN THE HILL COUNTRY OF CENTRAL TEXAS: TEXAS WATER DEVELOPMENT BOARD REPORT 339, 1992. 
COMPILATION OF HYDROLOGIC DATA FOR THE EDWARDS AQUIFER, SAN ANTONIO AREA, TEXAS, 1991, WITH 1934-91 SUMMARY: EDWARDS UNDERGROUND WATER DISTRICT BULLETIN 51, 1992.

HISTORICAL POTENTIOMETRIC SURFACE OF THE EDWARDS-TRINITY AQUIFER SYSTEM AND CONTIGUOUS HYDRAULICALLY CONNECTED UNITS, WEST-CENTRAL TEXAS: USGS WATERRESOURCES INVESTIGATIONS REPORT 92-4055, 1993.

HISTORICAL SATURATED THICKNESS OF THE EDWARDS-TRINITY AQUIFER SYSTEM AND SELECTED CONTIGUOUS HYDRAULICALLY CONNECTED UNITS, WEST-CENTRAL TEXAS: USGS WATER-RESOURCES INVESTIGATIONS REPORT 92-4125, 1993.

EDWARDS AQUIFER HYDROGEOLOGIC STATUS REPORT FOR 1992: EDWARDS UNDERGROUND WATER DISTRICT REPORT 93-05, 1993.

SIMULATIONS OF FLOW IN THE EDWARDS-TRINITY AQUIFER SYSTEM AND CONTIGUOUS HYDRAULICALLY CONNECTED UNITS, WEST-CENTRAL TEXAS: USGS WATER-RESOURCES INVESTIGATIONS REPORT 93-4039, 1994.

DISSOLVED-SOLIDS CONCENTRATIONS AND HYDROCHEMICAL FACIES IN WATER OF THE EDWARDS-TRINITY AQUIFER SYSTEM, WEST-CENTRAL TEXAS: USGS WATER-RESOURCES INVESTIGATIONS REPORT 93-4126, 1994.

NATIONAL WATER-QUALITY ASSESSMENT PROGRAM-SOUTHCENTRAL TEXAS: USGS FACT SHEET FS-94-048, 1994.

GEOLOGIC HISTORY AND HYDROGEOLOGIC SETTING OF THE EDWARDS-TRINITY AQUIFER SYSTEM, WEST-CENTRAL TEXAS: USGS WATER-RESOURCES INVESTIGATIONS REPORT 94-4039, 1994.

THE PALEOZOIC AND RELATED AQUIFERS OF CENTRAL TEXAS: TEXAS WATER DEVELOPMENT BOARD REPORT 346, 1996.

WATER-RESOURCES DATA, TEXAS, WATER YEAR 1997, VOLUME 4, GROUND-WATER DATA: USGS WATER-DATA REPORT TX-97-4, 1998.

WATER-RESOURCES DATA, TEXAS, WATER YEAR 1998, VOLUME 4, GROUND-WATER DATA: USGS WATER-DATA REPORT TX-98-4, 1999.

GROUNDWATER AVAILABILITY OF THE TRINITY AQUIFER, HILL COUNTRY AREA, TEXAS: NUMERICAL SIMULATIONS THROUGH 2050: TEXAS WATER DEVELOPMENT BOARD REPORT 353, 2000.

WATER QUALITY IN SOUTH-CENTRAL TEXAS-TEXAS, 1996-98: USGS CIRCULAR 1212, 2000.

AN OVERVIEW OF THE EDWARDS-TRINITY AQUIFER SYSTEM, CENTRAL-WEST TEXAS, CHAPTER 8, in AQUIFERS OF WEST TEXAS: TEXAS WATER DEVELOPMENT BOARD REPORT 356, 2001.

\section{BORDEN COUNTY}

GROUND-WATER RESOURCES OF BORDEN COUNTY, TEXAS: TEXAS BOARD OF WATER ENGINEERS MISCELLANEOUS PUBLICATION 16, 1949.

RECONNAISSANCE INVESTIGATION OF THE GROUND-WATER RESOURCES OF THE BRAZOS RIVER BASIN, TEXAS: TEXAS WATER COMMISSION BULLETIN 6310, 1963.
INVESTIGATION OF GROUND-WATER CONTAMINATION IN THE VEALMOOR OIL FIELD, HOWARD AND BORDEN COUNTIES, TEXAS: TEXAS WATER COMMISSION LIMITED DISTRIBUTION REPORT LD-265, 1965.

RECONNAISSANCE INVESTIGATION OF THE GROUND-WATER RESOURCES OF THE COLORADO RIVER BASIN, TEXAS: TEXAS WATER DEVELOPMENT BOARD REPORT 51, 1967.

WATER-LEVEL DATA FROM OBSERVATION WELLS IN THE SOUTHERN HIGH PLAINS OF TEXAS, 1965-70: TEXAS WATER DEVELOPMENT BOARD REPORT 121, 1970.

WOODY PHREATOPHYTES ALONG THE COLORADO RIVER FROM SOUTHEAST RUNNELS COUNTY TO THE HEADWATERS IN BORDEN COUNTY, TEXAS: TEXAS WATER DEVELOPMENT BOARD REPORT 182, 1974.

SUMMARY APPRAISALS OF THE NATION'S GROUND-WATER RESOURCES-TEXAS-GULF REGION: USGS PROFESSIONAL PAPER 813-F, 1976.

METHOD OF ESTIMATING NATURAL RECHARGE TO THE EDWARDS AQUIFER IN THE SAN ANTONIO AREA, TEXAS: USGS WATERRESOURCES INVESTIGATIONS REPORT 78-10, 1978.

ANALYTICAL STUDY OF THE OGALLALA AQUIFER IN DAWSON AND BORDEN COUNTIES, TEXAS-PROJECTIONS OF SATURATED THICKNESS, VOLUME OF WATER IN STORAGE, PUMPAGE RATES, PUMPING LIFTS, AND WELL YIELDS: TEXAS DEPARTMENT OF WATER RESOURCES REPORT 225, 1978.

WATER-LEVEL DATA FROM OBSERVATION WELLS IN THE SOUTHERN HIGH PLAINS OF TEXAS, 1971-77: TEXAS DEPARTMENT OF WATER RESOURCES REPORT 228, 1979.

EVALUATING THE GROUND-WATER RESOURCES OF THE HIGH PLAINS OF TEXAS: RESULTS OF TEST-HOLE DRILLING: TEXAS DEPARTMENT OF WATER RESOURCES LIMITED PRINTING REPORT LP-129, 1980.

SOURCE AREAS OF SALINITY AND TRENDS OF SALT LOADS IN STREAMFLOW IN THE UPPER COLORADO RIVER, TEXAS: USGS OPEN-FILE REPORT 80-224, 1980

BEDROCK GEOLOGY, ALTITUDE OF BASE, AND 1980 SATURATED THICKNESS OF THE HIGH PLAINS AQUIFER IN PARTS OF COLORADO, KANSAS, NEBRASKA, NEW MEXICO, OKLAHOMA, SOUTH DAKOTA, TEXAS, AND WYOMING: USGS HYDROLOGIC INVESTIGATIONS ATLAS HA-648, 1981.

WATER LEVEL AND SATURATED THICKNESS CHANGES, PREDEVELOPMENT TO 1980, IN THE HIGH PLAINS AQUIFER IN PARTS OF COLORADO, KANSAS, NEBRASKA, NEW MEXICO, OKLAHOMA, SOUTH DAKOTA, TEXAS, AND WYOMING: USGS HYDROLOGIC INVESTIGATIONS ATLAS HA-652, 1981.

DISSOLVED SOLIDS AND SODIUM IN WATER FROM THE HIGH PLAINS AQUIFER IN PARTS OF COLORADO, KANSAS, NEBRASKA, NEW MEXICO, OKLAHOMA, SOUTH DAKOTA, TEXAS, AND WYOMING: USGS HYDROLOGIC INVESTIGATIONS ATLAS HA-658, 1982.

EVALUATING THE GROUND-WATER RESOURCES OF THE HIGH PLAINS OF TEXAS, VOLUME 1: TEXAS DEPARTMENT OF WATER RESOURCES REPORT 288, V. 1, 1984.

EVALUATING THE GROUND-WATER RESOURCES OF THE HIGH PLAINS OF TEXAS, VOLUME 4, RECORDS OF WELLS AND MAPS SHOWING WELL LOCATIONS, BASE OF AQUIFER, WATER LEVELS, AND SATURATED THICKNESS (ANDREWS, BORDEN, 
COCHRAN, DAWSON, ECTOR, GAINES, GARZA, GLASSCOCK, HOWARD, HOCKLEY, LUBBOCK, LYNN, MARTIN, MIDLAND, TERRY, AND YOAKUM COUNTIES: TEXAS DEPARTMENT OF WATER RESOURCES REPORT 288 V. 4, 1984.

GEOHYDROLOGY OF THE HIGH PLAINS AQUIFER IN PARTS OF COLORADO, KANSAS, NEBRASKA, NEW MEXICO, OKLAHOMA, SOUTH DAKOTA, TEXAS, AND WYOMING: USGS PROFESSIONAL PAPER 1400-B, 1984.

TEXAS GROUND-WATER RESOURCES, in NATIONAL WATER SUMMARY 1984: USGS WATER-SUPPLY PAPER 2275, 1985.

DIGITAL SIMULATION OF GROUND-WATER FLOW IN THE HIGH PLAINS AQUIFER IN PARTS OF COLORADO, KANSAS, NEBRASKA, NEW MEXICO, OKLAHOMA, SOUTH DAKOTA, TEXAS, AND WYOMING: USGS PROFESSIONAL PAPER 1400-D, 1986.

HYDROGEOLOGY AND HYDROCHEMISTRY OF CRETACEOUS AQUIFERS, TEXAS PANHANDLE AND EASTERN NEW MEXICO: UNIVERSITY OF TEXAS, BUREAU OF ECONOMIC GEOLOGY GEOLOGICAL CIRCULAR 88-3, 1988.

SUMMARY OF THE HIGH PLAINS REGIONAL AQUIFER-SYSTEM ANALYSIS IN PARTS OF COLORADO, KANSAS, NEBRASKA, NEW MEXICO, OKLAHOMA, SOUTH DAKOTA, TEXAS, AND WYOMING: USGS PROFESSIONAL PAPER 1400-A, 1988.

HYDROGEOLOGY OF LOWER CRETACEOUS STRATA UNDER THE SOUTHERN HIGH PLAINS OF TEXAS AND NEW MEXICO: TEXAS WATER DEVELOPMENT BOARD REPORT 314, 1989.

PUBLIC SUPPLY GROUND-WATER USE IN THE SOUTHERN HIGH PLAINS OF TEXAS: TEXAS WATER DEVELOPMENT BOARD REPORT 328, 1990.

EVALUATION OF GROUND-WATER RESOURCES IN THE SOUTHERN HIGH PLAINS OF TEXAS: TEXAS WATER DEVELOPMENT BOARD REPORT 330, 1991.

WATER-LEVEL CHANGES IN THE HIGH PLAINS AQUIFER OF TEXAS, 1980-1990: TEXAS WATER DEVELOPMENT BOARD HYDROLOGIC ATLAS NO. 1, 1991.

THE HIGH PLAINS AQUIFER SYSTEM OF TEXAS, 1980-1990. OVERVIEW AND PROJECTIONS: TEXAS WATER DEVELOPMENT BOARD REPORT 341, 1993.

WATER-QUALITY EVALUATION OF THE OGALLALA AQUIFER, TEXAS: TEXAS WATER DEVELOPMENT BOARD REPORT 342, 1993.

WATER-LEVEL CHANGES IN THE HIGH PLAINS AQUIFER, 1980 TO 1994: USGS FACT SHEET FS-215-95, 1995.

AQUIFERS OF TEXAS: TEXAS WATER DEVELOPMENT BOARD REPORT 345, 1995

WATER-LEVEL CHANGES IN THE HIGH PLAINS AQUIFER, 1980 TO 1995: USGS FACT SHEET FS-068-97, 1997.

UPDATED WATER-QUALITY EVALUATION OF THE OGALLALA AQUIFER INCLUDING SELECTED METALLIC AND NON-METALLIC INORGANIC CONSTITUENTS: TEXAS WATER DEVELOPMENT BOARD HYDROLOGIC ATLAS HA-10, 1998.

\section{BOSQUE COUNTY}

GEOGRAPHY AND GEOLOGY OF THE BLACK AND GRAND PRAIRIES OF TEXAS, WITH DETAILED DESCRIPTIONS OF THE CRETACEOUS FORMATIONS AND SPECIAL REFERENCE TO ARTESIAN WATERS: USGS 21ST ANNUAL REPORT, PART 7, 1901.

PUBLIC WATER SUPPLIES IN BOSQUE COUNTY, TEXAS: USGS CONFIDENTIAL REPORT, 1943.

PUBLIC WATER SUPPLIES IN CENTRAL AND NORTH-CENTRAL TEXAS: USGS WATER-SUPPLY PAPER 1069, 1949.

GROUND WATER IN THE FLOOD-PLAIN ALLUVIUM OF THE BRAZOS RIVER, WHITNEY DAM TO VICINITY OF RICHMOND, TEXAS: TEXAS WATER DEVELOPMENT BOARD REPORT 41, 1967.

GROUND-WATER RESOURCES OF PART OF CENTRAL TEXAS WITH EMPHASIS ON THE ANTLERS AND TRAVIS PEAK FORMATIONS: TEXAS WATER DEVELOPMENT BOARD REPORT 195, V. 1, 1975.

GROUND-WATER RESOURCES OF PART OF CENTRAL TEXAS WITH EMPHASIS ON THE ANTLERS AND TRAVIS PEAK FORMATIONS: TEXAS WATER DEVELOPMENT BOARD REPORT 195, V. 2, 1976.

TEXAS GROUND-WATER RESOURCES, in NATIONAL WATER SUMMARY 1984: USGS WATER-SUPPLY PAPER 2275, 1985.

AQUIFER-STREAM INTERACTIONS IN NON-KARSTIC LIMESTONES: WASHITA PRAIRIE, CENTRAL TEXAS: BAYLOR GEOLOGICAL STUDIES (THESIS ABSTRACTS), BAYLOR UNIVERSITY, WACO, TEXAS, 1989.

EVALUATION OF WATER RESOURCES IN PART OF CENTRAL TEXAS: TEXAS WATER DEVELOPMENT BOARD REPORT 319 , 1990.

GROUND-WATER MONITORING OF THE TRINITY AQUIFER IN THE VICINITY OF ERATH COUNTY: TEXAS WATER DEVELOPMENT BOARD REPORT 331, 1991

HYDROGEOLOGIC ASSESSMENT OF SHALLOW GROUNDWATER FLOW SYSTEMS OF THE WALNUT FORMATION, CENTRAL TEXAS: (MASTER'S THESIS), BAYLOR GEOLOGICAL STUDIES (THESIS ABSTRACTS), BULLETIN 56, BAYLOR UNIVERSITY, WACO, TEXAS, 1995.

WATER-RESOURCES DATA, TEXAS, WATER YEAR 2000, VOLUME 6 , GROUND-WATER DATA: USGS WATER-DATA REPORT TX-00-6, 2001.

\section{BOWIE COUNTY}

GEOLOGY AND UNDERGROUND WATERS OF NORTHEASTERN TEXAS: USGS WATER-SUPPLY PAPER 276, 1911.

MEMORANDUM FOR THE FEDERAL PRISON BUREAU ON A GROUND-WATER SUPPLY FOR THE TEXARKANA SITE: USGS OPEN-FILE REPORT (UNNUMBERED), 1938.

MEMORANDUM TO MR. CLARK REGARDING WATER SUPPLY FOR THE TOWN OF HOOKS, BOWIE COUNTY, TEXAS: USGS OPEN-FILE REPORT (UNNUMBERED), AUGUST 1939.

MEMORANDUM TO MR. CLARK REGARDING WATER SUPPLY FOR THE TOWN OF HOOKS, BOWIE COUNTY, TEXAS: USGS OPEN-FILE REPORT (UNNUMBERED), SEPTEMBER 1939. 
TEXARKANA AND VICINITY WATER SUPPLY: USGS OPEN-FILE REPORT (UNNUMBERED), 1941.

WATER SUPPLY IN THE VICINITY OF NEW BOSTON, HOOKS, AND LEARY, BOWIE COUNTY, TEXAS: USGS OPEN-FILE REPORT (UNNUMBERED), 1941.

GROUND-WATER CONDITIONS AT De KALB, BOWIE COUNTY, TEXAS: USGS OPEN-FILE REPORT (UNNUMBERED), 1945.

PUBLIC WATER SUPPLIES IN EASTERN TEXAS: USGS WATERSUPPLY PAPER 1047, 1948.

GEOHYDROLOGY OF THE PRINCIPAL WATER-BEARING FORMATIONS OF THE MISSISSIPPI EMBAYMENT (GEOLOGIC PHASE) TEXAS SECTION: USGS OPEN-FILE REPORT (UNNUMBERED), 1960.

GENERAL GEOLOGY OF THE MISSISSIPPI EMBAYMENT: USGS PROFESSIONAL PAPER 448-B, 1964.

CRETACEOUS AQUIFERS OF THE MISSISSIPPI EMBAYMENT, WITH DISCUSSIONS OF QUALITY OF THE WATER: USGS PROFESSIONAL PAPER 448-C, 1965.

TERTIARY AQUIFERS IN THE MISSISSIPPI EMBAYMENT, WITH DISCUSSIONS OF THE QUALITY OF THE WATER: USGS PROFESSIONAL PAPER 448-D, 1968.

QUATERNARY AQUIFERS IN THE MISSISSIPPI EMBAYMENT WITH A DISCUSSION OF THE QUALITY OF THE WATER: USGS PROFESSIONAL PAPER 448-E, 1968.

WATER USE, PROJECTED WATER REQUIREMENTS, AND RELATED DATA AND INFORMATION FOR THE METROPOLITAN STATISTICAL AREAS IN TEXAS: TEXAS DEPARTMENT OF WATER RESOURCES LIMITED PRINTING REPORT LP-201, 1985.

TEXAS GROUND-WATER RESOURCES, in NATIONAL WATER SUMMARY 1984: USGS WATER-SUPPLY PAPER 2275, 1985.

HYDROGEOLOGY OF THE EDWARDS AQUIFER, NORTHERN BALCONES AND WASHITA PRAIRIE SEGMENTS: AUSTIN GEOLOGICAL SOCIETY GUIDEBOOK 11, 1987.

APPROXIMATE POTENTIOMETRIC SURFACES FOR THE AQUIFERS OF THE TEXAS COASTAL UPLANDS SYSTEM, 1980: USGS HYDROLOGIC ATLAS HA-704, 1987.

GROUND-WATER RESOURCES OF THE NACATOCH AQUIFER TEXAS WATER DEVELOPMENT BOARD REPORT 305, 1988.

GEOHYDROLOGIC FRAMEWORK OF THE GULF COASTAL PLAIN: USGS HYDROLOGIC ATLAS HA-695, 1988.

OCCURRENCE, AVAILABILITY, AND CHEMICAL QUALITY OF GROUND WATER IN THE BLOSSOM SAND AQUIFER: TEXAS WATER DEVELOPMENT BOARD REPORT 307, 1988.

SIMULATION OF GROUND-WATER FLOW IN THE ANTLERS AQUIFER IN SOUTHEASTERN OKLAHOMA AND NORTHEASTERN TEXAS: USGS WATER-RESOURCES INVESTIGATIONS REPORT 88-4208, 1992.

PROPERTIES AND CHEMICAL CONSTITUENTS IN GROUND WATER FROM THE MIDDLE WILCOX AQUIFER, GULF COAST REGIONAL AQUIFER SYSTEMS, SOUTH-CENTRAL UNITED STATES: USGS WATER-RESOURCES INVESTIGATIONS REPORT 93-4070, 1993.

TRANSMISSIVITY, HYDRAULIC CONDUCTIVITY, AND STORATIVITY OF THE CARRIZO-WILCOX AQUIFER IN TEXAS, DATA AND
ANALYSIS: UNIVERSITY OF TEXAS, BUREAU OF ECONOMIC GEOLOGY, CD-ROM, 2000

\section{BRAZORIA COUNTY}

ARTESIAN WELLS OF THE COASTAL PRAIRIE REGION AND TERTIARY BELT OF TEXAS: GEOLOGICAL SURVEY OF TEXAS, CHAPTER 2, 1893.

UNDERGROUND WATERS OF THE COASTAL PLAIN OF TEXAS: USGS WATER-SUPPLY PAPER 190, 1907.

GEOLOGY AND UNDERGROUND WATERS OF THE SOUTHEASTERN PART OF THE TEXAS COASTAL PLAIN: USGS WATER-SUPPLY PAPER 335, 1914.

GROUND-WATER RESOURCES OF THE HOUSTON-GALVESTON AREA, TEXAS: USGS OPEN-FILE REPORT, (UNNUMBERED), (PRESS RELEASE ONLY), 1932.

GROUND-WATER RESOURCES OF THE HOUSTON DISTRICT, TEXAS: USGS OPEN-FILE REPORT (UNNUMBERED), 1933.

RECORDS OF WELLS IN HARRIS, GALVESTON, WALLER, FORT BEND, BRAZORIA, AND GRIMES COUNTY, TEXAS: USGS OPENFILE REPORT (UNNUMBERED), 1935

PROGRESS REPORT ON THE GROUND-WATER RESOURCES OF THE HOUSTON DISTRICT, TEXAS: USGS OPEN-FILE REPORT (UNNUMBERED), 1937.

RECORDS OF WELLS, DRILLERS' LOGS, WATER ANALYSES, AND MAP SHOWING LOCATION OF WELLS WEST OF THE BRAZOS RIVER, BRAZORIA COUNTY, TEXAS: TEXAS BOARD OF WATER ENGINEERS MISCELLANEOUS PUBLICATION 17, 1937.

RESULTS OF INVESTIGATION IN BRAZORIA COUNTY, TEXAS: USGS OPEN-FILE REPORT (UNNUMBERED), 1937

PROGRESS REPORT ON THE GROUND-WATER RESOURCES OF THE HOUSTON DISTRICT, TEXAS: TEXAS BOARD OF WATER ENGINEERS MISCELLANEOUS PUBLICATION 129, 1938.

RECORDS OF WELLS, DRILLERS' LOGS, WATER ANALYSES, AND MAP SHOWING LOCATION OF WELLS EAST OF THE BRAZOS RIVER, BRAZORIA COUNTY, TEXAS: TEXAS BOARD OF WATER ENGINEERS MISCELLANEOUS PUBLICATION 18, 1939.

GROUND-WATER RESOURCES OF THE HOUSTON-GALVESTON AREA AND ADJACENT REGION: TEXAS BOARD OF WATER ENGINEERS MISCELLANEOUS PUBLICATION 130, 1939.

PROGRESS REPORT ON THE GROUND-WATER RESOURCES OF THE HOUSTON DISTRICT, TEXAS: TEXAS BOARD OF WATER ENGINEERS MISCELLANEOUS PUBLICATION 131, 1939.

WATER RESOURCES IN THE VICINITY OF FREEPORT, TEXAS: USGS OPEN-FILE REPORT (UNNUMBERED), 1941.

FREEPORT WATER SUPPLY: USGS OPEN-FILE REPORT (UNNUMBERED), 1941

BRAZORIA, BRAZORIA COUNTY, TEXAS: USGS OPEN-FILE REPORT (UNNUMBERED), 1941

FREEPORT AND VICINITY: USGS OPEN-FILE REPORT (UNNUMBERED), 1941 
RESULTS OF PUMPING TEST AT THE ABERCROMBIE-HARRISON GASOLINE PLANT: USGS OPEN-FILE REPORT (UNNUMBERED), 1943.

GROUND-WATER RESOURCES OF BRAZORIA COUNTY, TEXAS: TEXAS BOARD OF WATER ENGINEERS MISCELLANEOUS PUBLICATION 19, 1947.

PUBLIC WATER SUPPLIES IN EASTERN TEXAS: USGS WATERSUPPLY PAPER 1047, 1948

GEOLOGY AND GROUND-WATER RESOURCES OF THE HOUSTON DISTRICT, TEXAS: TEXAS BOARD OF WATER ENGINEERS BULLETIN 5001, 1950

WATER SUPPLY OF THE HOUSTON GULF COAST REGION: TEXAS BOARD OF WATER ENGINEERS BULLETIN 5101, 1951.

AVAILABILITY OF GROUND WATER IN THE GULF COAST REGION OF TEXAS: USGS OPEN-FILE REPORT (UNNUMBERED), 1956.

RECORDS OF WATER-LEVEL MEASUREMENTS IN BRAZORIA, FORT BEND, AND WALLER COUNTIES, TEXAS, 1931 THROUGH JUNE 1958: TEXAS WATER COMMISSION BULLETIN 5904, 1959.

INVESTIGATION OF CONTAMINATION COMPLAINT, CLEMENS PRISON FARM, BRAZORIA COUNTY, TEXAS (CONTAMINATION REPORT NO. 9): TEXAS BOARD OF WATER ENGINEERS MISCELLANEOUS PUBLICATION 20, 1960.

RECONNAISSANCE INVESTIGATION OF THE GROUND-WATER RESOURCES OF THE GULF COAST REGION, TEXAS: TEXAS WATER COMMISSION BULLETIN 6305, 1963.

ANALOG MODEL STUDY OF GROUND WATER IN THE HOUSTON DISTRICT, TEXAS: TEXAS WATER COMMISSION BULLETIN 6508, 1965.

DEVELOPMENT OF GROUND WATER IN THE HOUSTON DISTRICT, TEXAS, 1961-65: TEXAS WATER DEVELOPMENT BOARD REPORT 63, 1967.

LAND-SURFACE SUBSIDENCE IN THE HOUSTON-GALVESTON REGION, TEXAS: USGS OPEN-FILE REPORT 69-61, 1969.

COMPILATION OF RESULTS OF AQUIFER TESTS IN TEXAS: TEXAS WATER DEVELOPMENT BOARD REPORT 98, 1969.

DEVELOPMENT OF GROUND WATER IN THE HOUSTON DISTRICT, TEXAS, 1966-69: TEXAS WATER DEVELOPMENT BOARD REPORT $152,1972$.

GROUND-WATER RESOURCES OF BRAZORIA COUNTY, TEXAS: TEXAS WATER DEVELOPMENT BOARD REPORT 163, 1973.

LAND-SURFACE SUBSIDENCE IN THE HOUSTON-GALVESTON REGION, TEXAS: USGS OPEN-FILE REPORT 74-123, 1974.

LAND-SURFACE SUBSIDENCE IN THE HOUSTON-GALVESTON REGION, TEXAS: TEXAS: TEXAS WATER DEVELOPMENT BOARD REPORT 188, 1975.

SUMMARY APPRAISALS OF THE NATION'S GROUND-WATER RESOURCES-TEXAS-GULF REGION: USGS PROFESSIONAL PAPER 813-F, 1976.

RECORDS OF WELLS, DRILLERS' LOGS, WATER-LEVEL MEASUREMENTS, AND CHEMICAL ANALYSES OF GROUND WATER IN BRAZORIA, FORT BEND, AND WALLER COUNTIES, TEXAS, 1966-74: TEXAS WATER DEVELOPMENT BOARD REPORT 201, 1976.
APPROXIMATE AREAS OF RECHARGE TO THE CHICOT AND EVANGELINE AQUIFER SYSTEMS IN THE HOUSTON-GALVESTON AREA, TEXAS: USGS OPEN-FILE REPORT 77-754, 1977.

HYDROGEOLOGY OF GULF COAST AQUIFERS, HOUSTONGALVESTON AREA, TEXAS: UNIVERSITY OF TEXAS, BUREAU OF ECONOMIC GEOLOGY GEOLOGICAL CIRCULAR 77-4, 1977.

MAP SHOWING SURFACE FAULTS IN THE SOUTHEASTERN HOUSTON METROPOLITAN AREA, TEXAS: USGS OPEN-FILE REPORT 78-797, 1978

STRATIGRAPHIC AND HYDROGEOLOGIC FRAMEWORK OF PART OF THE COASTAL PLAIN OF TEXAS: TEXAS DEPARTMENT OF WATER RESOURCES REPORT 236, 1979.

A DIGITAL MODEL FOR SIMULATION OF GROUND-WATER HYDROLOGY IN THE HOUSTON AREA, TEXAS: TEXAS DEPARTMENT OF WATER RESOURCES LIMITED PRINTING LP-103, 1979.

APPROXIMATE ALTITUDE OF WATER LEVELS IN WELLS IN THE CHICOT AND EVANGELINE AQUIFERS IN THE HOUSTON AREA, TEXAS, SPRING 1977 AND SPRING 1978: USGS OPEN-FILE REPORT 79-334, 1979.

APPROXIMATE WATER-LEVEL CHANGES IN WELLS IN THE CHICOT AND EVANGELINE AQUIFERS, 1977-79, AND MEASURED COMPACTION 1973-79, IN HARRIS AND GALVESTON COUNTIES, TEXAS: USGS OPEN-FILE REPORT 79-693, 1979.

APPROXIMATE WATER-LEVEL CHANGES IN WELLS IN THE CHICOT AND EVANGELINE AQUIFERS IN THE HOUSTON-GALVESTON REGION, TEXAS, 1977-80 AND 1979-80: USGS OPEN-FILE REPORT 80-337, 1980.

APPROXIMATE ALTITUDE OF WATER LEVELS IN WELLS IN THE CHICOT AND EVANGELINE AQUIFERS IN THE HOUSTON AREA, TEXAS, SPRING 1979 AND SPRING 1980: USGS OPEN-FILE REPORT $80-579,1980$

APPROXIMATE LAND-SURFACE SUBSIDENCE IN THE HOUSTONGALVESTON REGION, TEXAS, 1906-78, 1943-78, AND 1973-78: USGS OPEN-FILE REPORT 80-338, 1980.

HYDROGEOLOGY OF THE BEAUMONT FORMATION (PLEISTOCENE), BRAZORIA COUNTY, TEXAS: UNIVERSITY OF TEXAS AT AUSTIN MASTER'S THESIS, 1980

LAND-SURFACE SUBSIDENCE IN THE TEXAS COASTAL REGION: USGS OPEN-FILE REPORT 80-969, 1980.

DEVELOPMENT OF GROUND WATER IN THE HOUSTONGALVESTON DISTRICT, TEXAS, 1970-74: TEXAS DEPARTMENT OF WATER RESOURCES REPORT 241, 1980.

APPROXIMATE WATER-LEVEL CHANGES IN WELLS IN THE CHICOT AND EVANGELINE AQUIFERS, 1977-81 AND 1980-81, AND MEASURED COMPACTION, 1973-81, IN THE HOUSTON-GALVESTON REGION, TEXAS: USGS OPEN-FILE REPORT 81-341, 1981.

SPRINGS OF TEXAS, VOLUME 1: (BY GUNNAR BRUNE), BRANCHSMITH, INC., FORT WORTH, TEXAS, 1981.

APPROXIMATE ALTITUDE OF WATER LEVELS IN THE CHICOT AND EVANGELINE AQUIFERS IN THE HOUSTON AREA, TEXAS, SPRING 1981: USGS OPEN-FILE REPORT 81-676, 1981.

LAND-SURFACE SUBSIDENCE IN THE TEXAS COASTAL REGION: TEXAS DEPARTMENT OF WATER RESOURCES REPORT 272, 1982.

APPROXIMATE WATER-LEVEL CHANGES IN WELLS IN THE CHICOT AND EVANGELINE AQUIFERS, 1977-82 AND 1981-82, AND MEA- 
SURED COMPACTION, 1973-82, IN THE HOUSTON-GALVESTON REGION, TEXAS: USGS OPEN-FILE REPORT 82-328, 1982.

GROUND-WATER WITHDRAWALS AND CHANGES IN WATER LEVELS IN THE HOUSTON DISTRICT, 1975-79: USGS OPEN-FILE REPORT 82-431, 1982.

APPROXIMATE ALTITUDE OF WATER LEVELS IN WELLS IN THE CHICOT AND EVANGELINE AQUIFERS IN THE HOUSTON AREA, TEXAS, SPRING 1982: USGS OPEN-FILE REPORT 82-559, 1982.

APPROXIMATE WATER-LEVEL CHANGES IN WELLS IN THE CHICOT AND EVANGELINE AQUIFERS, 1977-83 AND 1982-83, AND MEASURED COMPACTION, 1973-83, IN THE HOUSTON-GALVESTON REGION, TEXAS: USGS OPEN-FILE REPORT 83-150, 1983.

RECORDS OF WELLS, DRILLERS' LOGS, WATER-LEVEL MEASUREMENTS, AND CHEMICAL ANALYSES OF GROUND-WATER IN BRAZORIA, FORT BEND, AND WALLER COUNTIES, TEXAS, 1975-79: TEXAS DEPARTMENT OF WATER RESOURCES REPORT $277,1983$.

APPROXIMATE ALTITUDE OF WATER LEVELS IN WELLS IN THE CHICOT AND EVANGELINE AQUIFERS IN THE HOUSTON AREA, TEXAS, SPRING 1983: USGS OPEN-FILE REPORT 83-529, 1983.

APPROXIMATE WATER-LEVEL CHANGES IN WELLS IN THE CHICOT AND EVANGELINE AQUIFERS, 1977-84 AND 1983-84, AND MEASURED COMPACTION, 1973-84, IN THE HOUSTON-GALVESTON REGION, TEXAS: USGS OPEN-FILE REPORT 84-140, 1984.

APPROXIMATE ALTITUDE OF WATER LEVELS IN WELLS IN THE CHICOT AND EVANGELINE AQUIFERS IN THE HOUSTON AREA, TEXAS, SPRING, 1984: USGS OPEN-FILE REPORT 84-436, 1984.

GROUND-WATER WITHDRAWALS AND CHANGES IN WATER LEVELS IN THE HOUSTON DISTRICT, TEXAS, 1975-79: TEXAS DEPARTMENT OF WATER RESOURCES REPORT 286, 1984.

GROUND-WATER WITHDRAWALS AND LAND-SURFACE SUBSIDENCE IN THE HOUSTON-GALVESTON REGION, TEXAS, 1906-80: TEXAS DEPARTMENT OF WATER RESOURCES REPORT 287, 1984.

DIGITAL MODELS FOR SIMULATION OF GROUND-WATER HYDROLOGY OF THE CHICOT AND EVANGELINE AQUIFERS ALONG THE GULF COAST OF TEXAS: TEXAS DEPARTMENT OF WATER RESOURCES REPORT 289, 1985.

TEXAS GROUND-WATER RESOURCES, in NATIONAL WATER SUMMARY 1984: USGS WATER-SUPPLY PAPER 2275, 1985.

WATER USE, PROJECTED WATER REQUIREMENTS, AND RELATED DATA AND INFORMATION FOR THE METROPOLITAN STATISTICAL AREAS IN TEXAS: TEXAS DEPARTMENT OF WATER RESOURCES LIMITED PRINTING REPORT LP-201, 1985.

APPROXIMATE WATER-LEVEL CHANGES IN WELLS IN THE CHICOT AND EVANGELINE AQUIFERS, 1977-85 AND 1984-85, AND MEASURED COMPACTION, 1973-85, IN THE HOUSTON-GALVESTON REGION, TEXAS: USGS OPEN-FILE REPORT 85-158, 1985.

RECORDS OF WELLS, DRILLERS' LOGS, WATER-LEVEL MEASUREMENTS, AND CHEMICAL ANALYSES OF GROUND WATER IN BRAZORIA, FORT BEND, AND WALLER COUNTIES, TEXAS, 1980-84: USGS OPEN-FILE REPORT 86-68, 1986.

APPROXIMATE CHANGES IN WATER LEVELS IN THE CHICOT AND EVANGELINE AQUIFERS, 1977-86 AND 1985-86, AND MEASURED COMPACTION, 1973-86, IN THE HOUSTON-GALVESTON REGION, TEXAS: USGS OPEN-FILE REPORT 86-135, 1986.
APPROXIMATE ALTITUDE OF WATER LEVELS IN WELLS IN THE CHICOT AND EVANGELINE AQUIFERS IN THE HOUSTON AREA, TEXAS, SPRING 1986: USGS OPEN-FILE REPORT 86-306, 1986.

HYDROLOGY OF THE JASPER AQUIFER IN THE SOUTHEAST TEXAS COASTAL PLAIN: TEXAS WATER DEVELOPMENT BOARD REPORT 295, 1986.

RECORDS OF WELLS, DRILLERS' LOGS, WATER-LEVEL MEASUREMENTS, AND CHEMICAL ANALYSES OF GROUND WATER IN BRAZORIA, FORT BEND, AND WALLER COUNTIES, TEXAS, 1980-84: TEXAS WATER DEVELOPMENT BOARD REPORT 303, 1987.

APPROXIMATE WATER-LEVEL CHANGES IN WELLS COMPLETED IN THE CHICOT AND EVANGELINE AQUIFERS, 1977-87 AND 1986-87, AND MEASURED COMPACTION, 1973-87, IN THE HOUSTONGALVESTON REGION, TEXAS: USGS OPEN-FILE REPORT 87-108, 1987.

APPROXIMATE ALTITUDE OF WATER-LEVELS IN WELLS IN THE CHICOT AND EVANGELINE AQUIFERS IN THE HOUSTON AREA, TEXAS, SPRING 1987: USGS OPEN-FILE REPORT 87-233, 1987.

GEOHYDROLOGIC FRAMEWORK OF THE GULF COASTAL PLAIN: USGS HYDROLOGIC ATLAS HA-695, 1988.

HYDROGEOLOGY AND PREDEVELOPMENT FLOW IN THE TEXAS GULF COAST AQUIFER SYSTEMS: USGS WATER-RESOURCES INVESTIGATIONS REPORT 87-4248, 1988.

APPROXIMATE WATER-LEVEL CHANGES IN WELLS COMPLETED IN THE CHICOT AND EVANGELINE AQUIFERS, 1977-88 AND 1987-88, AND MEASURED COMPACTION, 1973-88, IN THE HOUSTONGALVESTON REGION, TEXAS: USGS OPEN-FILE REPORT 88-168, 1988.

APPROXIMATE ALTITUDE OF WATER LEVELS IN WELLS IN THE CHICOT AND EVANGELINE AQUIFERS IN THE HOUSTON AREA, TEXAS, SPRING 1988: USGS OPEN-FILE REPORT 88-334, 1988.

APPROXIMATE ALTITUDE OF WATER LEVELS IN WELLS IN THE CHICOT AND EVANGELINE AQUIFERS IN THE HOUSTON AREA, TEXAS, SPRING 1989: USGS OPEN-FILE REPORT 89-237, 1989.

APPROXIMATE WATER-LEVEL CHANGE IN WELLS COMPLETED IN THE CHICOT AND EVANGELINE AQUIFERS, 1977-89 AND 1988-89, AND MEASURED COMPACTION, 1973-89, IN THE HOUSTONGALVESTON REGION, TEXAS: USGS OPEN-FILE REPORT 89-057, 1989.

APPROXIMATE WATER-LEVEL CHANGES IN WELLS COMPLETED IN THE CHICOT AND EVANGELINE AQUIFERS, 1977-90 AND 1989-90, AND MEASURED COMPACTION, 1973-DECEMBER 1989, IN THE HOUSTON-GALVESTON REGION, TEXAS: USGS OPEN-FILE REPORT 90-132, 1990.

GROUND-WATER FLOW IN THE GULF COAST AQUIFER SYSTEMS, SOUTH-CENTRAL UNITED STATES-A PRELIMINARY ANALYSIS: USGS WATER-RESOURCES INVESTIGATIONS REPORT 89-4071, 1990.

SALT-DOME LOCATIONS IN THE GULF COASTAL PLAIN, SOUTHCENTRAL UNITED STATES: USGS WATER-RESOURCES INVESTIGATIONS REPORT 90-4060, 1990.

LAND-SURFACE SUBSIDENCE RESULTING FROM GROUND-WATER WITHDRAWALS IN THE HOUSTON-GALVESTON REGION, TEXAS, THROUGH 1987: HARRIS-GALVESTON COASTAL SUBSIDENCE DISTRICT REPORT OF INVESTIGATIONS NO. 90-01, 1990. 
RECORDS OF WELLS, DRILLERS' LOGS, WATER-LEVEL MEASUREMENTS, AND CHEMICAL ANALYSES OF GROUND WATER IN BRAZORIA, FORT BEND, AND WALLER COUNTIES, TEXAS, 1985-89: USGS OPEN-FILE REPORT 90-588, 1991.

APPROXIMATE ALTITUDE OF WATER LEVELS IN WELLS IN THE CHICOT AND EVANGELINE AQUIFERS IN THE HOUSTON AREA, TEXAS, JANUARY-FEBRUARY 1990: USGS OPEN-FILE REPORT 91-240, 1991.

HYDROLOGY OF THE TEXAS GULF COAST AQUIFER SYSTEMS: USGS OPEN-FILE REPORT 91-64, 1991.

DEWATERING OF AQUIFER SANDS: TREE DAMAGE LINKED TO SAND MINING: TEXAS STATE SECTION OF THE AMERICAN WATER RESOURCES ASSOCIATION, TRIGG TWICHELL SYMPOSIUM, FALL MEETING, NOVEMBER 8, 1991, AUSTIN, TEXAS, 1991.

APPROXIMATE WATER-LEVEL CHANGES IN WELLS COMPLETED IN THE CHICOT AND EVANGELINE AQUIFERS, 1991-92, IN FORT BEND COUNTY AND ADJACENT AREAS, TEXAS: USGS OPEN-FILE REPORT 92-53, 1992.

APPROXIMATE CHANGES IN WATER LEVELS IN WELLS COMPLETED IN THE CHICOT AND EVANGELINE AQUIFERS, 1977-92 AND 1991-92, AND MEASURED COMPACTION, 1973-91, IN THE HOUSTON-GALVESTON REGION, TEXAS: USGS OPEN-FILE REPORT 92-66, 1992.

PROPERTIES AND CHEMICAL CONSTITUENTS IN GROUND WATER FROM THE MISSISSIPPI RIVER VALLEY ALLUVIAL AQUIFER AND PERMEABLE ZONE A (HOLOCENE-UPPER PLEISTOCENE DEPOSITS), SOUTH-CENTRAL UNITED STATES: USGS WATERRESOURCES INVESTIGATIONS REPORT 91-4149, 1992.

WATER-RESOURCES DATA, TEXAS, WATER YEAR 1991, VOLUME 4, GROUND-WATER DATA: USGS WATER-DATA REPORT TX-91-4, 1992.

PROPERTIES AND CHEMICAL CONSTITUENTS IN GROUND WATER FROM THE UPPER CLAIBORNE AQUIFER, GULF COAST REGIONAL AQUIFER SYSTEMS, SOUTH-CENTRAL UNITED STATES: USGS WATER-RESOURCES INVESTIGATIONS REPORT 91-4150, 1993.

PROPERTIES AND CHEMICAL CONSTITUENTS IN GROUND WATER FROM PERMEABLE ZONE C (LOWER PLIOCENE-UPPER MIOCENE DEPOSITS), COASTAL LOWLANDS AQUIFER SYSTEM, SOUTHCENTRAL UNITED STATES: USGS WATER-RESOURCES INVESTIGATIONS REPORT 91-4151, 1993.

PROPERTIES AND CHEMICAL CONSTITUENTS IN GROUND WATER FROM PERMEABLE ZONE B (LOWER PLEISTOCENE-UPPER PLIOCENE DEPOSITS), COASTAL LOWLANDS AQUIFER SYSTEM, SOUTH-CENTRAL UNITED STATES: USGS WATER-RESOURCES INVESTIGATIONS REPORT 91-4152, 1993.

PROPERTIES AND CHEMICAL CONSTITUENTS IN GROUND WATER FROM PERMEABLE ZONE E (LOWER MIOCENE-UPPER OLIGOCENE DEPOSITS), COASTAL LOWLANDS AQUIFER SYSTEM, SOUTH-CENTRAL UNITED STATES: USGS WATER-RESOURCES INVESTIGATIONS REPORT 92-4103, 1993.

PROPERTIES AND CHEMICAL CONSTITUENTS IN GROUND WATER FROM PERMEABLE ZONE D (MIDDLE MIOCENE DEPOSITS), COASTAL LOWLANDS AQUIFER SYSTEM, SOUTH-CENTRAL UNITED STATES: USGS WATER-RESOURCES INVESTIGATIONS REPORT 92-4105, 1993.

GROUND-WATER WITHDRAWALS, WATER LEVELS, AND GROUNDWATER QUALITY IN THE HOUSTON DISTRICT, TEXAS, WITH
EMPHASIS ON 1985-89: USGS WATER-RESOURCES INVESTIGATIONS REPORT 92-4180, 1993.

APPROXIMATE ALTITUDE OF WATER LEVELS IN WELLS COMPLETED IN THE CHICOT AND EVANGELINE AQUIFERS IN FORT BEND COUNTY AND ADJACENT AREAS, TEXAS, JANUARY-FEBRUARY 1991: USGS OPEN-FILE REPORT 93-62, 1993.

WATER-RESOURCES DATA, TEXAS, WATER YEAR 1992, VOLUME 4 , GROUND-WATER DATA: USGS WATER-DATA REPORT TX-92-4, 1993.

APPROXIMATE CHANGES IN WATER LEVELS IN WELLS COMPLETED IN THE CHICOT AND EVANGELINE AQUIFERS, 1977-94 AND 1993-94, AND MEASURED COMPACTION, 1973-93, IN THE HOUSTON-GALVESTON REGION, TEXAS: USGS OPEN-FILE REPORT 94-346, 1994.

WATER-RESOURCES DATA, TEXAS, WATER YEAR 1993, VOLUME 4, GROUND-WATER DATA: USGS WATER-DATA REPORT TX-93-4, 1994.

STRATIGRAPHIC NOMENCLATURE AND GEOLOGIC SECTIONS OF THE GULF COASTAL PLAIN OF TEXAS: USGS OPEN-FILE REPORT 94-461, 1995.

WATER-LEVEL ALTITUDES 1995, WATER-LEVEL CHANGES 1977-95 AND 1994-95, AND COMPACTION 1973-94 IN THE CHICOT AND EVANGELINE AQUIFERS, HOUSTON-GALVESTON REGION, TEXAS: USGS OPEN-FILE REPORT 95-182, 1995.

WATER-LEVEL ALTITUDES 1995 AND WATER-LEVEL CHANGES 1990-95 AND 1994-95 IN THE CHICOT AND EVANGELINE AQUIFERS, FORT BEND COUNTY AND ADJACENT AREAS, TEXAS: USGS OPEN-FILE REPORT 95-183, 1995.

AQUIFERS OF TEXAS: TEXAS WATER DEVELOPMENT BOARD REPORT 345, 1995.

WATER-RESOURCES DATA, TEXAS, WATER YEAR 1994, VOLUME 4 GROUND-WATER DATA: USGS WATER-DATA REPORT TX-94-4, 1995.

WATER-LEVEL ALTITUDES 1996, WATER-LEVEL CHANGES 1977-96 AND 1995-96, AND COMPACTION 1973-95 IN THE CHICOT AND EVANGELINE AQUIFERS, HOUSTON-GALVESTON REGION, TEXAS: USGS OPEN-FILE REPORT 96-163, 1996.

WATER-LEVEL ALTITUDES 1996 AND WATER-LEVEL CHANGES 1990-96 AND 1995-96 IN THE CHICOT AND EVANGELINE AQUIFERS, FORT BEND COUNTY AND ADJACENT AREAS, TEXAS: USGS OPEN-FILE REPORT 96-164, 1996.

WATER-RESOURCES DATA, TEXAS, WATER YEAR 1995, VOLUME 4 GROUND-WATER DATA: USGS WATER-DATA REPORT TX-95-4, 1996.

WATER-LEVEL ALTITUDES 1997 AND WATER-LEVEL CHANGES 1990-97 AND 1996-97 IN THE CHICOT AND EVANGELINE AQUIFERS, FORT BEND COUNTY AND ADJACENT AREAS, TEXAS: USGS OPEN-FILE REPORT 97-180, 1997.

WATER-LEVEL ALTITUDES 1997, WATER-LEVEL CHANGES 1977-97 AND 1996-97, AND COMPACTION 1973-96 IN THE CHICOT AND EVANGELINE AQUIFERS, HOUSTON-GALVESTON REGION, TEXAS: USGS OPEN-FILE REPORT 97-181, 1997.

WATER-LEVEL ALTITUDES IN WELLS COMPLETED IN THE CHICOT AND EVANGELINE AQUIFERS, FORT BEND COUNTY AND ADJACENT AREAS, TEXAS, JANUARY-FEBRUARY 1990: USGS OPENFILE REPORT 97-784, 1997. 
WATER-LEVEL ALTITUDES IN WELLS COMPLETED IN THE CHICOT AND EVANGELINE AQUIFERS, FORT BEND COUNTY AND ADJACENT AREAS, JANUARY-FEBRUARY 1992, 1993, AND 1994: USGS OPEN-FILE REPORT 97-785, 1997.

WATER-LEVEL ALTITUDES IN WELLS COMPLETED IN THE CHICOT AND EVANGELINE AQUIFERS, HOUSTON-GALVESTON REGION, TEXAS, JANUARY-FEBRUARY 1992, 1993, AND 1994: USGS OPENFILE REPORT 97-786, 1997.

WATER-RESOURCES DATA, TEXAS, WATER YEAR 1996, VOLUME 4, GROUND-WATER DATA: USGS WATER-DATA REPORT TX-96-4, 1997.

WATER-LEVEL ALTITUDES 1998 AND WATER-LEVEL CHANGES 1990-98 AND 1997-98 IN THE CHICOT AND EVANGELINE AQUIFERS, FORT BEND COUNTY AND ADJACENT AREAS, TEXAS: USGS OPEN-FILE REPORT 98-095, 1998.

WATER-LEVEL ALTITUDES 1998, WATER-LEVEL CHANGES 1977-98 AND 1997-98, AND COMPACTION IN THE CHICOT AND EVANGELINE AQUIFERS, HOUSTON-GALVESTON REGION, TEXAS: USGS OPEN-FILE REPORT 98-096, 1998.

APPROXIMATE LAND-SURFACE SUBSIDENCE IN FORT BEND COUNTY, TEXAS, 1943-87 AND 1973-87: USGS OPEN-FILE REPORT 98-383, 1998.

WATER-RESOURCES DATA, TEXAS, WATER YEAR 1997, VOLUME 4, GROUND-WATER DATA: USGS WATER-DATA REPORT TX-97-4, 1998.

WATER-LEVEL ALTITUDES 1999 AND WATER-LEVEL CHANGES 1990-99 AND 1998-99 IN THE CHICOT AND EVANGELINE AQUIFERS, FORT BEND COUNTY AND ADJACENT AREAS, TEXAS: USGS OPEN-FILE REPORT 99-177, 1999.

WATER-LEVEL ALTITUDES 1999, WATER-LEVEL CHANGES 1977-99 AND 1998-99, AND COMPACTION 1973-98 IN THE CHICOT AND EVANGELINE AQUIFERS, HOUSTON-GALVESTON REGION, TEXAS: USGS OPEN-FILE REPORT 99-178, 1999.

WATER-RESOURCES DATA, TEXAS, WATER YEAR 1998, VOLUME 4 GROUND-WATER DATA: USGS WATER-DATA REPORT TX-98-4, 1999.

WATER-LEVEL ALTITUDES 2000 AND WATER-LEVEL CHANGES 1990-2000 AND 1999-2000 IN THE CHICOT AND EVANGELINE AQUIFERS, FORT BEND COUNTY AND ADJACENT AREAS, TEXAS: USGS OPEN-FILE REPORT 00-093, 2000.

WATER-LEVEL ALTITUDES 2000, WATER-LEVEL CHANGES 1977-2000 AND 1999-2000, AND COMPACTION 1973-99 IN THE CHICOT AND EVANGELINE AQUIFERS, HOUSTON-GALVESTON REGION, TEXAS: USGS OPEN-FILE REPORT 00-094, 2000.

WATER-RESOURCES DATA, TEXAS, WATER YEAR 1999, VOLUME 6, GROUND-WATER DATA: USGS WATER-DATA REPORT TX-99-6, 2000 .

WATER-RESOURCES DATA, TEXAS, WATER YEAR 2000, VOLUME 6 , GROUND-WATER DATA: USGS WATER-DATA REPORT TX-00-6, 2001.

\section{BRAZOS COUNTY}

ARTESIAN WELLS OF THE COASTAL PRAIRIE REGION AND TERTIARY BELT OF TEXAS: GEOLOGICAL SURVEY OF TEXAS, CHAPTER 2, 1893.

UNDERGROUND WATERS OF THE COASTAL PLAIN OF TEXAS: USGS WATER-SUPPLY PAPER 190, 1907.

GEOLOGY AND UNDERGROUND WATERS OF THE SOUTHEASTERN PART OF THE TEXAS COASTAL PLAIN: USGS WATER-SUPPLY PAPER 335, 1914.

GROUND WATER IN THE VICINITY OF BRYAN AND COLLEGE STATION, TEXAS: TEXAS BOARD OF WATER ENGINEERS MISCELLANEOUS PUBLICATION 24, 1938.

GROUND WATER AT BRYAN AIRPORT, BRAZOS COUNTY, TEXAS: USGS OPEN-FILE REPORT (UNNUMBERED), 1942.

GROUND-WATER SUPPLY OF BRYAN, TEXAS: TEXAS BOARD OF WATER ENGINEERS MISCELLANEOUS PUBLICATION 25, 1944.

PUBLIC WATER SUPPLIES IN EASTERN TEXAS: USGS WATERSUPPLY PAPER 1047, 1948.

RECONNAISSANCE INVESTIGATION OF THE GROUND-WATER RESOURCES OF THE BRAZOS RIVER BASIN, TEXAS: TEXAS WATER COMMISSION BULLETIN 6310, 1963.

GROUND WATER IN THE FLOOD-PLAIN ALLUVIUM OF THE BRAZOS RIVER, WHITNEY DAM TO VICINITY OF RICHMOND, TEXAS: TEXAS WATER DEVELOPMENT BOARD REPORT 41, 1967.

HYDROLOGIC SIGNIFICANCE OF THE LITHOFACIES OF THE SPARTA SAND IN ARKANSAS, LOUISIANA, MISSISSIPPI, AND TEXAS: USGS PROFESSIONAL PAPER 569-A, 1968.

COMPILATION OF RESULTS OF AQUIFER TESTS IN TEXAS: TEXAS WATER DEVELOPMENT BOARD REPORT 98, 1969.

GEOHYDROLOGIC SIGNIFICANCE OF LITHOFACIES OF THE COCKFIELD FORMATION OF LOUISIANA AND MISSISSIPPI AND OF THE YEGUA FORMATION OF TEXAS: USGS PROFESSIONAL PAPER 569-B, 1970.

HYDROLOGIC SIGNIFICANCE OF LITHOFACIES OF THE CANE RIVER FORMATION OR EQUIVALENTS OF ARKANSAS, LOUISIANA, MISSISSIPPI, AND TEXAS: USGS PROFESSIONAL PAPER 569-C, 1972.

GROUND-WATER RESOURCES OF BRAZOS AND BURLESON COUNTIES, TEXAS: TEXAS WATER DEVELOPMENT BOARD REPORT $185,1974$.

GEOHYDROLOGIC SIGNIFICANCE OF LITHOFACIES OF THE CARRIZO SAND OF ARKANSAS, LOUISIANA, AND TEXAS AND THE MERIDIAN SAND OF MISSISSIPPI: USGS PROFESSIONAL PAPER 569-D, 1975.

TEXAS GROUND-WATER RESOURCES, in NATIONAL WATER SUMMARY 1984: USGS WATER-SUPPLY PAPER 2275, 1985.

APPROXIMATE POTENTIOMETRIC SURFACES FOR THE AQUIFERS OF THE TEXAS COASTAL UPLANDS SYSTEM, 1980: USGS HYDROLOGIC ATLAS HA-704, 1987.

GEOHYDROLOGIC FRAMEWORK OF THE GULF COASTAL PLAIN: USGS HYDROLOGIC ATLAS HA-695, 1988. 
GROUND-WATER RESOURCES OF THE CARRIZO-WILCOX AQUIFER IN THE CENTRAL TEXAS REGION: TEXAS WATER DEVELOPMENT BOARD REPORT 332, 1991.

PROPERTIES AND CHEMICAL CONSTITUENTS IN GROUND WATER FROM THE UPPER CLAIBORNE AQUIFER, GULF COAST REGIONAL AQUIFER SYSTEMS, SOUTH-CENTRAL UNITED STATES: USGS WATER-RESOURCES INVESTIGATIONS REPORT 91-4150, 1993.

PROPERTIES AND CHEMICAL CONSTITUENTS IN GROUND WATER FROM THE LOWER CLAIBORNE-UPPER WILCOX AQUIFER, GULF COAST REGIONAL AQUIFER SYSTEMS, SOUTH-CENTRAL UNITED STATES: USGS WATER-RESOURCES INVESTIGATIONS REPORT 92-4102, 1993

PROPERTIES AND CHEMICAL CONSTITUENTS IN GROUND WATER FROM PERMEABLE ZONE E (LOWER MIOCENE-UPPER OLIGOCENE DEPOSITS), COASTAL LOWLANDS AQUIFER SYSTEM, SOUTH-CENTRAL UNITED STATES: USGS WATER-RESOURCES INVESTIGATIONS REPORT 92-4103, 1993.

PROPERTIES AND CHEMICAL CONSTITUENTS IN GROUND WATER FROM THE MIDDLE CLAIBORNE AQUIFER, GULF COAST REGIONAL AQUIFER SYSTEMS, SOUTH-CENTRAL UNITED STATES: USGS WATER-RESOURCES INVESTIGATIONS REPORT 92-4104, 1993.

PROPERTIES AND CHEMICAL CONSTITUENTS IN GROUND WATER FROM PERMEABLE ZONE D (MIDDLE MIOCENE DEPOSITS), COASTAL LOWLANDS AQUIFER SYSTEM, SOUTH-CENTRAL UNITED STATES: USGS WATER-RESOURCES INVESTIGATIONS REPORT 92-4105, 1993.

PROPERTIES AND CHEMICAL CONSTITUENTS IN GROUND WATER FROM THE MIDDLE WILCOX AQUIFER, GULF COAST REGIONAL AQUIFER SYSTEMS, SOUTH-CENTRAL UNITED STATES: USGS WATER-RESOURCES INVESTIGATIONS REPORT 93-4070, 1993.

STRATIGRAPHIC NOMENCLATURE AND GEOLOGIC SECTIONS OF THE GULF COASTAL PLAIN OF TEXAS: USGS OPEN-FILE REPORT 94-461, 1995.

WATER QUALITY IN THE SPARTA AQUIFER, EAST TEXAS: TEXAS WATER DEVELOPMENT BOARD HYDROLOGIC ATLAS NO. 5 , 1996.

WATER QUALITY IN THE QUEEN CITY AQUIFER, EAST TEXAS: TEXAS WATER DEVELOPMENT BOARD HYDROLOGIC ATLAS NO. 6, 1996.

GROUND-WATER AVAILABILITY IN THE CARRIZO-WILCOX AQUIFER IN CENTRAL TEXAS-NUMERICAL SIMULATIONS OF 2000 THROUGH 2050 WITHDRAWAL PROJECTIONS: UNIVERSITY OF TEXAS, BUREAU OF ECONOMIC GEOLOGY REPORT OF INVESTIGATIONS NO. 256, 1999.

TRANSMISSIVITY, HYDRAULIC CONDUCTIVITY, AND STORATIVITY OF THE CARRIZO-WILCOX AQUIFER IN TEXAS, DATA AND ANALYSIS: UNIVERSITY OF TEXAS, BUREAU OF ECONOMIC GEOLOGY, CD-ROM, 2000.

\section{BREWSTER COUNTY}

GROUND WATER IN THE VICINITY OF ALPINE, BREWSTER COUNTY, TEXAS: USGS OPEN-FILE REPORT (UNNUMBERED, 1947
GROUND WATER IN THE ALPINE AREA AND ADJACENT TERRITORY, BREWSTER COUNTY, TEXAS: USGS OPEN-FILE REPORT (UNNUMBERED), 1949.

PUBLIC WATER SUPPLIES IN WESTERN TEXAS: USGS WATERSUPPLY PAPER 1106, 1951.

MEMORANDUM CONCERNING A PERFORMANCE TEST OF PANTHER JUNCTION WELL NO. 2 IN BIG BEND NATIONAL PARK, BREWSTER COUNTY, TEXAS: USGS OPEN-FILE REPORT (UNNUMBERED), 1954.

GROUND-WATER SUPPLY FROM TORNILLO CREEK DOWNSTREAM FROM HIGHWAY CROSSING, BIG BEND NATIONAL PARK, TEXAS: USGS OPEN-FILE REPORT (UNNUMBERED), 1954.

INTEROFFICE MEMORANDUM FROM CHRIS GARD, TBWE, TO E.A. MOULDER, USGS, REGARDING MARATHON PUMPING TESTS ( 7 GRAPHS ATTACHED): USGS OPEN-FILE REPORT (UNNUMBERED), 1957.

MEMORANDUM CONCERNING PUMPING TEST ON A CITY TEST WELL ON THE ROGERS PROPERTY, SUNNY GLEN AREA, NORTHWEST OF ALPINE, TEXAS: USGS OPEN-FILE REPORT (UNNUMBERED), 1957.

MEMORANDUM CONCERNING PUMPING TEST ON WELL T-7 ON THE ROBERTS PROPERTY, SUNNY GLEN AREA, NORTHWEST OF ALPINE TEXAS: USGS OPEN-FILE REPORT (UNNUMBERED), 1957.

GROUND-WATER GEOLOGY OF THE ALPINE AREA, BREWSTER, JEFF DAVIS, AND PRESIDIO COUNTIES, TEXAS: TEXAS BOARD OF WATER ENGINEERS BULLETIN 5712, 1957.

MEMORANDUM CONCERNING PUMPING TESTS ON BIG BEND NATIONAL PARK WELLS (PANTHER JUNCTION WELL NO. 3 AND K-BAR WELL): USGS OPEN-FILE REPORT (UNNUMBERED), 1958.

A RECONNAISSANCE OF THE GROUND-WATER RESOURCES OF THE MARATHON AREA, BREWSTER COUNTY, TEXAS: TEXAS BOARD OF WATER ENGINEERS BULLETIN 6111, 1961.

RECONNAISSANCE INVESTIGATION OF THE GROUND-WATER RESOURCES OF THE BRAZOS RIVER BASIN, TEXAS: TEXAS WATER COMMISSION BULLETIN 6310, 1963.

QUALITY OF WATER FROM TEST WELLS IN THE CASTOLON AREA, BIG BEND NATIONAL PARK, BREWSTER COUNTY, TEXAS: USGS OPEN-FILE REPORT 63-113, 1963.

RECONNAISSANCE INVESTIGATION OF THE GROUND-WATER RESOURCES OF THE RIO GRANDE BASIN, TEXAS: TEXAS WATER COMMISSION BULLETIN 6502, 1965.

WATER-LEVEL DATA FROM OBSERVATION WELLS IN CULBERSON, JEFF DAVIS, PRESIDIO, AND BREWSTER COUNTIES, TEXAS: TEXAS WATER DEVELOPMENT BOARD REPORT 16, 1966.

COMPILATION OF AQUIFER TESTS IN TEXAS: TEXAS WATER DEVELOPMENT BOARD REPORT 98, 1969

RECORDS OF WATER LEVELS AND CHEMICAL ANALYSES FROM SELECTED WELLS IN PARTS OF THE TRANS-PECOS REGION, TEXAS, 1965-68: TEXAS WATER DEVELOPMENT BOARD REPORT 114,1970

WATER SUPPLY STUDY, TERLINGUA DISTRICT, BREWSTER COUNTY, TEXAS: ED L, REED AND ASSOCIATES, MIDLAND, TEXAS, 1972. 
RECONNAISSANCE INVESTIGATION OF GROUND WATER IN THE RIO GRANDE DRAINAGE BASIN-WITH SPECIAL EMPHASIS ON SALINE GROUND-WATER RESOURCES: USGS HYDROLOGIC ATLAS HA-510, 1974.

MAJOR AND HISTORICAL SPRINGS OF TEXAS: TEXAS WATER DEVELOPMENT BOARD REPORT 189, 1975.

OCCURRENCE AND QUALITY OF GROUND WATER IN THE EDWARDS-TRINITY (PLATEAU) AQUIFER IN THE TRANS PECOS REGION OF TEXAS: TEXAS DEPARTMENT OF WATER RESOURCES REPORT 255, 1980.

SPRINGS OF TEXAS, VOLUME 1: (BY GUNNAR BRUNE), BRANCHSMITH, INC., FORT WORTH, TEXAS, 1981.

A HYDROGEOLOGICAL EVALUATION OF ALLUVIAL FANS IN NORTHERN BIG BEND NATIONAL PARK, TEXAS, USING GEOPHYSICAL METHODS: TEXAS A\&M UNIVERSITY AT COLLEGE STATION, MASTERS THESIS, 1982.

BEDROCK AQUIFER GEOMETRY IN THE PANTHER JUNCTION AREA OF BIG BEND NATIONAL PARK, TEXAS: TEXAS A\&M UNIVERSITY AT COLLEGE STATION, MASTERS THESIS, 1983.

GROUND-WATER HYDROLOGY OF THE PANTHER JUNCTION AREA OF BIG BEND NATIONAL PARK, TEXAS: TEXAS A\&M UNIVERSITY AT COLLEGE STATION, MASTERS THESIS, 1983.

ENVIRONMENTAL ISOTOPE AND GEOCHEMICAL INVESTIGATION OF GROUND WATER IN BIG BEND NATIONAL PARK, TEXAS: TEXAS A\&M UNIVERSITY AT COLLEGE STATION, MASTERS THESIS, 1984

APPLICATION OF REMOTE SENSING TO THE GROUND-WATER HYDROLOGY STUDY OF BIG BEND NATIONAL PARK, TEXAS: TEXAS A\&M UNIVERSITY AT COLLEGE STATION, MASTERS THESIS, 1984

SEISMIC MAPPING OF ALLUVIAL FANS AND SUB-FAN BEDROCK IN BIG BEND NATIONAL PARK, TEXAS: TEXAS A\&M UNIVERSITY AT COLLEGE STATION, MASTERS THESIS, 1984.

MAPS SHOWING GROUND-WATER UNITS AND WITHDRAWAL, BASIN AND RANGE PROVINCE, TEXAS: USGS WATERRESOURCES INVESTIGATIONS REPORT 83-4121-A, 1984.

MAPS SHOWING GROUND-WATER LEVELS, SPRINGS, AND DEPTH TO GROUND WATER, BASIN AND RANGE PROVINCE, TEXAS: USGS WATER-RESOURCES INVESTIGATIONS REPORT 83-4121-B, 1984

MAPS SHOWING DISTRIBUTION OF DISSOLVED SOLIDS AND DOMINANT CHEMICAL TYPE IN GROUND WATER, BASIN AND RANGE PROVINCE, TEXAS: USGS WATER-RESOURCES INVESTIGATIONS REPORT 83-4121-C, 1984.

TEXAS GROUND-WATER RESOURCES, in NATIONAL WATER SUMMARY 1984: USGS WATER-SUPPLY PAPER 2275, 1985.

GEOHYDROLOGY AND POTENTIAL FOR CONTAMINATION OF OAK SPRING, BIG BEND NATIONAL PARK, TEXAS, PROGRESS REPORT, 1987: USGS OPEN-FILE REPORT (UNNUMBERED), 1987.

RECORDS OF WELLS, WATER LEVELS, PUMPAGE, AND CHEMICAL ANALYSES FROM SELECTED WELLS IN PARTS OF THE TRANSPECOS REGION, TEXAS, 1968-1980: TEXAS WATER DEVELOPMENT BOARD REPORT 301, 1987.

PUBLIC SUPPLY GROUND-WATER USE IN WESTERN TEXAS: TEXAS WATER DEVELOPMENT BOARD REPORT 311, 1989.
POTENTIOMETRIC SURFACE OF THE EDWARDS-TRINITY AQUIFER SYSTEM AND CONTIGUOUS HYDRAULICALLY CONNECTED UNITS, WEST-CENTRAL TEXAS, WINTER 1974-75: USGS WATERRESOURCES INVESTIGATIONS REPORT 89-4208, 1990.

HYDROLOGY OF THE TERLINGUA AREA, TEXAS: TEXAS WATER DEVELOPMENT BOARD REPORT 323, 1990.

WITHDRAWALS FROM THE EDWARDS-TRINITY AQUIFER SYSTEM AND CONTIGUOUS HYDRAULICALLY CONNECTED UNITS, WEST-CENTRAL TEXAS, DECEMBER 1974 THROUGH MARCH 1977: USGS WATER-RESOURCES INVESTIGATIONS REPORT 91-4021, 1991.

CONFIGURATION OF THE BASE OF THE EDWARDS-TRINITY AQUIFER SYSTEM AND HYDROGEOLOGY OF THE UNDERLYING PRECRETACEOUS ROCKS, WEST-CENTRAL TEXAS: USGS WATERRESOURCES INVESTIGATIONS REPORT 91-4071, 1992.

HISTORICAL POTENTIOMETRIC SURFACE OF THE EDWARDS-TRINITY AQUIFER SYSTEM AND CONTIGUOUS HYDRAULICALLY CONNECTED UNITS, WEST-CENTRAL TEXAS: USGS WATERRESOURCES INVESTIGATIONS REPORT 92-4055, 1993.

HISTORICAL SATURATED THICKNESS OF THE EDWARDS-TRINITY AQUIFER SYSTEM AND SELECTED CONTIGUOUS HYDRAULICALLY CONNECTED UNITS, WEST-CENTRAL TEXAS: USGS WATER-RESOURCES INVESTIGATIONS REPORT 92-4125, 1993.

HYDROGEOLOGY, GEOCHEMISTRY, AND QUALITY OF WATER OF THE BASIN AND OAK SPRING AREAS OF THE CHISOS MOUNTAINS, BIG BEND NATIONAL PARK, TEXAS: USGS WATERRESOURCES INVESTIGATIONS REPORT 93-4112, 1993.

SIMULATIONS OF FLOW IN THE EDWARDS-TRINITY AQUIFER SYSTEM AND CONTIGUOUS HYDRAULICALLY CONNECTED UNITS, WEST-CENTRAL TEXAS: USGS WATER-RESOURCES INVESTIGATIONS REPORT 93-4039, 1994.

DISSOLVED-SOLIDS CONCENTRATIONS AND HYDROCHEMICAL FACIES IN WATER OF THE EDWARDS-TRINITY AQUIFER SYSTEM, WEST-CENTRAL TEXAS: USGS WATER-RESOURCES INVESTIGATIONS REPORT 93-4126, 1994.

GEOLOGIC HISTORY AND HYDROGEOLOGIC SETTING OF THE EDWARDS-TRINITY AQUIFER SYSTEM, WEST-CENTRAL TEXAS: USGS WATER-RESOURCES INVESTIGATIONS REPORT 94-4039, 1994.

AQUIFERS OF TEXAS: TEXAS WATER DEVELOPMENT BOARD REPORT 345, 1995.

WATER QUALITY IN THE EDWARDS-TRINITY (PLATEAU) AQUIFER, EDWARDS PLATEAU AND TRANS-PECOS, TEXAS: TEXAS WATER DEVELOPMENT BOARD HYDROLOGIC ATLAS NO. 3, 1995.

WATER QUALITY IN THE CAPITAN REEF AQUIFER: TEXAS WATER DEVELOPMENT BOARD HYDROLOGIC ATLAS NO. 8, 1997.

HYDROGEOLOGY OF THE GREATER LAJITAS AREA, WEST TEXAS: JANUS INTERNATIONAL, BOULDER, COLORADO, 2001.

IGNEOUS AQUIFER SYSTEM OF BREWSTER, JEFF DAVIS, AND PRESIDIO COUNTIES, TEXAS: LBG-GUYTON ASSOCIATES, WATER PROSPECTING AND RESOURCE CONSULTING, LLC., AND SUL ROSS UNIVERSITY, 2001.

AQUIFERS OF WEST TEXAS: TEXAS WATER DEVELOPMENT BOARD REPORT 356, 2001 
AN OVERVIEW OF THE EDWARDS-TRINITY AQUIFER SYSTEM, CENTRAL-WEST TEXAS, CHAPTER 8, in AQUIFERS OF WEST TEXAS: TEXAS WATER DEVELOPMENT BOARD REPORT 356, 2001.

THE GEOLOGY AND HYDROGEOLOGY OF THE CAPITAN AQUIFER: A BRIEF OVERVIEW, CHAPTER 11, in AQUIFERS OF WEST TEXAS: TEXAS WATER DEVELOPMENT BOARD REPORT 356, 2001.

IGNEOUS AQUIFERS OF FAR WEST TEXAS, CHAPTER 13, in AQUIFERS OF WEST TEXAS: TEXAS WATER DEVELOPMENT BOARD REPORT 356, 2001.

HYDROGEOLOGY OF THE MARATHON BASIN, BREWSTER COUNTY, TEXAS, CHAPTER 14, in AQUIFERS OF WEST TEXAS: TEXAS WATER DEVELOPMENT BOARD REPORT 356, 2001.

HYDROGEOLOGY OF THE RUSTLER AQUIFER, TRANS-PECOS TEXAS, CHAPTER 15, in AQUIFERS OF WEST TEXAS: TEXAS WATER DEVELOPMENT BOARD REPORT 356, 2001.

\section{BRISCOE COUNTY}

GEOLOGY AND GROUND-WATER RESOURCES OF THE SOUTHERN HIGH PLAINS: USGS OPEN-FILE REPORT (UNNUMBERED), 1935.

GROUND WATER IN THE SOUTHERN HIGH PLAINS: USGS OPENFILE REPORT (UNNUMBERED), 1937.

GROUND WATER IN THE HIGH PLAINS IN TEXAS (1940): TEXAS BOARD OF WATER ENGINEERS MISCELLANEOUS PUBLICATIONS REPORT M119, 1940

GROUND WATER NEAR CHILDRESS, QUITAQUE, AND TURKEY, TEXAS: USGS OPEN-FILE REPORT (UNNUMBERED), 1942.

GROUND WATER IN THE HIGH PLAINS IN TEXAS, PROGRESS REPORT (1943): TEXAS BOARD OF WATER ENGINEERS MISCELLANEOUS PUBLICATIONS REPORT M120, 1943.

GROUND WATER IN THE HIGH PLAINS IN TEXAS, PROGRESS REPORT (1944): TEXAS BOARD OF WATER ENGINEERS MISCELLANEOUS PUBLICATIONS REPORT M121, 1944.

GROUND WATER IN THE HIGH PLAINS IN TEXAS, PROGRESS REPORT NO. 5: TEXAS BOARD OF WATER ENGINEERS MISCELLANEOUS PUBLICATIONS REPORT M122, 1945.

RECORDS OF WELLS, DRILLERS' LOGS, WATER ANALYSES, AND MAP SHOWING LOCATIONS OF WELLS IN BRISCOE COUNTY, TEXAS: TEXAS BOARD OF WATER ENGINEERS MISCELLANEOUS PUBLICATION 21, 1946.

GROUND WATER IN THE HIGH PLAINS OF TEXAS: USGS WATERSUPPLY PAPER 889-F, 1946.

GROUND WATER IN THE HIGH PLAINS IN TEXAS, PROGRESS REPORT NO. 6: TEXAS BOARD OF WATER ENGINEERS MISCELLANEOUS PUBLICATIONS REPORT M123, 1947.

COST OF PUMPING WATER FOR IRRIGATION, TEXAS HIGH PLAINS, FIELD INVESTIGATION_1947 IRRIGATION SEASON: TEXAS BOARD OF WATER ENGINEERS MISCELLANEOUS PUBLICATIONS REPORT M124, 1951.

DEVELOPMENT OF WELLS FOR IRRIGATION AND FLUCTUATION OF WATER LEVELS IN THE HIGH PLAINS OF TEXAS TO JANUARY 1951: TEXAS BOARD OF WATER ENGINEERS BULLETIN 5104, 1951.
PUBLIC WATER SUPPLIES IN WESTERN TEXAS: USGS WATERSUPPLY PAPER 1106, 1951 [1952].

SUMMARY OF GROUND-WATER DEVELOPMENT IN THE SOUTHERN HIGH PLAINS, TEXAS: TEXAS BOARD OF WATER ENGINEERS BULLETIN 5402, 1954

RECORDS OF WATER-LEVEL MEASUREMENTS IN BAILEY, BRISCOE, CASTRO, PARMER, POTTER, AND RANDALL COUNTIES, TEXAS: TEXAS BOARD OF WATER ENGINEERS BULLETIN $5406,1954$.

GROUND-WATER DEVELOPMENT IN THE SOUTHERN HIGH PLAINS OF TEXAS, 1953: TEXAS BOARD OF WATER ENGINEERS BULLETIN 5410, 1954

WATER-LEVEL DECLINE MAPS OF 16 COUNTIES IN THE SOUTHERN HIGH PLAINS, TEXAS: (BAILEY, BRISCOE, CASTRO, COCHRAN, CROSBY, DEAF SMITH, FLOYD, GAINES, HALE, HOCKLEY, LAMB, LUBBOCK, PARMER, RANDALL, SWISHER, TERRY): USGS OPENFILE REPORT (UNNUMBERED), 1955.

WATER-LEVEL DECLINE MAPS OF 17 COUNTIES IN THE SOUTHERN HIGH PLAINS, TEXAS, JANUARY 1955 TO JANUARY 1956: TEXAS BOARD OF WATER ENGINEERS BULLETIN 5607, 1956.

WATER-LEVEL DECLINE MAPS, 1956 TO 1957, AND WATER LEVELS IN OBSERVATION WELLS IN 20 COUNTIES IN THE SOUTHERN HIGH PLAINS, TEXAS: TEXAS BOARD OF WATER ENGINEERS BULLETIN 5705, 1957.

WATER-LEVEL MEASUREMENTS AND MAPS, SOUTHERN HIGH PLAINS, TEXAS, 1958 AND 1959: TEXAS BOARD OF WATER ENGINEERS BULLETIN 5908, 1959.

WATER LEVELS IN OBSERVATION WELLS, SOUTHERN HIGH PLAINS, TEXAS, 1959 AND 1960: TEXAS BOARD OF WATER ENGINEERS BULLETIN 6011, 1960.

WATER LEVELS IN OBSERVATION WELLS, SOUTHERN HIGH PLAINS, TEXAS, 1960 AND 1961: TEXAS BOARD OF WATER ENGINEERS BULLETIN 6101, 1961

A SUMMARY OF THE OCCURRENCE AND DEVELOPMENT OF GROUND WATER IN THE SOUTHERN HIGH PLAINS OF TEXAS: TEXAS BOARD OF WATER ENGINEERS BULLETIN 6107, 1961.

WATER-LEVEL MEASUREMENTS THROUGH 1962 IN SELECTED OBSERVATION WELLS, SOUTHERN HIGH PLAINS, TEXAS: TEXAS WATER COMMISSION BULLETIN 6207, 1962.

RECONNAISSANCE INVESTIGATION OF THE GROUND-WATER RESOURCES OF THE RED RIVER, SULPHUR RIVER, AND CYPRESS CREEK BASINS, TEXAS: TEXAS WATER COMMISSION BULLETIN 6306, 1963.

A SUMMARY OF THE OCCURRENCE AND DEVELOPMENT OF GROUND WATER IN THE SOUTHERN HIGH PLAINS OF TEXAS: USGS WATER-SUPPLY PAPER 1693, 1964.

WATER-LEVEL DATA FROM OBSERVATION WELLS IN THE SOUTHERN HIGH PLAINS OF TEXAS: TEXAS WATER DEVELOPMENT BOARD REPORT 21, 1966.

GROUND WATER IN THE OGALLALA FORMATION IN THE SOUTHERN HIGH PLAINS OF TEXAS AND NEW MEXICO: USGS HYDROLOGIC INVESTIGATIONS ATLAS HA-330, 1969.

WATER-LEVEL DATA FROM OBSERVATION WELLS IN THE SOUTHERN HIGH PLAINS OF TEXAS, 1956-70: TEXAS WATER DEVELOPMENT BOARD REPORT 121, 1970. 
AN EVALUATION OF THE USE OF DRILLERS' LOGS IN LITHOLOGIC STUDIES OF THE OGALLALA FORMATION OF THE SOUTHERN HIGH PLAINS OF TEXAS: USGS OPEN-FILE REPORT 72-451, 1972.

GROUND-WATER RESOURCES OF HALL AND EASTERN BRISCOE COUNTIES, TEXAS: TEXAS WATER DEVELOPMENT BOARD REPORT 167, 1973.

MAJOR AND HISTORICAL SPRINGS OF TEXAS: TEXAS WATER DEVELOPMENT BOARD REPORT 189, 1975.

ANALYTICAL STUDY OF THE OGALLALA AQUIFER IN BRISCOE COUNTY, TEXAS—PROJECTIONS OF SATURATED THICKNESS, VOLUME OF WATER IN STORAGE, PUMPAGE RATES, PUMPING LIFTS, AND WELL YIELDS: TEXAS WATER DEVELOPMENT BOARD REPORT 212, 1977.

WATER-LEVEL DATA FROM OBSERVATION WELLS IN THE SOUTHERN HIGH PLAINS OF TEXAS, 1971-77: TEXAS DEPARTMENT OF WATER RESOURCES REPORT 228, 1979.

PRELIMINARY DATA DESCRIBING THE DISTRIBUTION OF FLUORIDE AND SILICA IN THE OGALLALA AQUIFER ON THE HIGH PLAINS OF TEXAS: USGS OPEN-FILE REPORT 80-349, 1980.

EVALUATING THE GROUND-WATER RESOURCES OF THE HIGH PLAINS OF TEXAS: RESULTS OF SURFACE ELECTRICAL RESISTIVITY SURVEYS: TEXAS DEPARTMENT OF WATER RESOURCES LIMITED PRINTING REPORT 130, 1980.

SPRINGS OF TEXAS, VOLUME 1: (BY GUNNAR BRUNE), BRANCHSMITH, INC., FORT WORTH, TEXAS, 1981.

BEDROCK GEOLOGY, ALTITUDE OF BASE, AND 1980 SATURATED THICKNESS OF THE HIGH PLAINS AQUIFER IN PARTS OF COLORADO, KANSAS, NEBRASKA, NEW MEXICO, OKLAHOMA, SOUTH DAKOTA, TEXAS, AND WYOMING: USGS HYDROLOGIC INVESTIGATIONS ATLAS HA-648, 1981.

WATER LEVEL AND SATURATED THICKNESS CHANGES, PREDEVELOPMENT TO 1980, IN THE HIGH PLAINS AQUIFER IN PARTS OF COLORADO, KANSAS, NEBRASKA, NEW MEXICO, OKLAHOMA, SOUTH DAKOTA, TEXAS, AND WYOMING: USGS HYDROLOGIC INVESTIGATIONS ATLAS HA-652, 1981.

DISSOLVED SOLIDS AND SODIUM IN WATER FROM THE HIGH PLAINS AQUIFER IN PARTS OF COLORADO, KANSAS, NEBRASKA, NEW MEXICO, OKLAHOMA, SOUTH DAKOTA, TEXAS, AND WYOMING: USGS HYDROLOGIC INVESTIGATIONS ATLAS HA-658, 1982.

EVALUATING THE GROUND-WATER RESOURCES OF THE HIGH PLAINS OF TEXAS, VOLUME 1: TEXAS DEPARTMENT OF WATER RESOURCES REPORT 288, V. 1, 1984.

EVALUATING THE GROUND-WATER RESOURCES OF THE HIGH PLAINS OF TEXAS, VOLUME 3, RECORDS OF WELLS, AND MAPS SHOWING WELL LOCATIONS, BASE OF AQUIFER, WATER LEVELS, AND SATURATED THICKNESS: TEXAS DEPARTMENT OF WATER RESOURCES REPORT 288, V. 3, 1984.

GEOHYDROLOGY OF THE HIGH PLAINS AQUIFER IN PARTS OF COLORADO, KANSAS, NEBRASKA, NEW MEXICO, OKLAHOMA, SOUTH DAKOTA, TEXAS, AND WYOMING: USGS PROFESSIONAL PAPER 1400-B, 1984

TEXAS GROUND-WATER RESOURCES, in NATIONAL WATER SUMMARY 1984: USGS WATER-SUPPLY PAPER 2275, 1985.

DIGITAL SIMULATION OF GROUND-WATER FLOW IN THE HIGH PLAINS AQUIFER IN PARTS OF COLORADO, KANSAS,
NEBRASKA, NEW MEXICO, OKLAHOMA, SOUTH DAKOTA, TEXAS, AND WYOMING: USGS PROFESSIONAL PAPER 1400-D, 1986.

SUMMARY OF THE HIGH PLAINS REGIONAL AQUIFER-SYSTEM ANALYSIS IN PARTS OF COLORADO, KANSAS, NEBRASKA, NEW MEXICO, OKLAHOMA, SOUTH DAKOTA, TEXAS, AND WYOMING: USGS PROFESSIONAL PAPER 1400-A, 1988.

EVALUATION OF GROUND-WATER RESOURCES IN BRISCOE, HALE, AND SWISHER COUNTIES, TEXAS: TEXAS WATER DEVELOPMENT BOARD REPORT 313, 1989.

PUBLIC-SUPPLY GROUND-WATER USE IN THE SOUTHERN HIGH PLAINS OF TEXAS: TEXAS WATER DEVELOPMENT BOARD REPORT 328, 1990.

WATER-LEVEL CHANGES IN THE HIGH PLAINS AQUIFER OF TEXAS, 1980-1990: TEXAS WATER DEVELOPMENT BOARD HYDROLOGIC ATLAS NO. 1, 1991.

EVALUATION OF WATER RESOURCES IN PARTS OF THE ROLLING PRAIRIES REGION OF NORTH-CENTRAL TEXAS: TEXAS WATER DEVELOPMENT BOARD REPORT 337, 1992.

THE HIGH PLAINS AQUIFER SYSTEM OF TEXAS, 1980 TO 1990. OVERVIEW AND PROJECTIONS: TEXAS WATER DEVELOPMENT BOARD REPORT 341, 1993.

WATER-QUALITY EVALUATION OF THE OGALLALA AQUIFER, TEXAS: TEXAS WATER DEVELOPMENT BOARD REPORT 342 , 1993.

WATER-LEVEL CHANGES IN THE HIGH PLAINS AQUIFER, 1980 TO 1994: USGS FACT SHEET FS-215-95, 1995.

AQUIFERS OF TEXAS: TEXAS WATER DEVELOPMENT BOARD REPORT 345, 1995.

WATER-LEVEL CHANGES IN THE HIGH PLAINS AQUIFER, 1980 TO 1995: USGS FACT SHEET FS-068-97, 1997.

WATER-LEVEL CHANGES IN THE HIGH PLAINS AQUIFER-PREDEVELOPMENT TO 1995: USGS WATER-RESOURCES INVESTIGATIONS REPORT 97-4081, 1997.

UPDATED WATER-QUALITY EVALUATION OF THE OGALLALA AQUIFER INCLUDING SELECTED METALLIC AND NON-METALLIC INORGANIC CONSTITUENTS: TEXAS WATER DEVELOPMENT BOARD HYDROLOGIC ATLAS NO. 10, 1998.

\section{BROOKS COUNTY}

UNDERGROUND WATERS OF COASTAL PLAIN OF TEXAS: USGS WATER-SUPPLY AND IRRIGATION PAPER 190, 1907.

MEMORANDUM CONCERNING QUALITY OF WATER TO WHICH WELL CASING IS EXPOSED IN JIM WELLS, BROOKS, AND KENEDY COUNTIES, TEXAS: USGS OPEN-FILE REPORT (UNNUMBERED), 1935.

RECORDS OF WELLS, DRILLERS' LOGS, WATER ANALYSES, AND MAP SHOWING LOCATION OF WELLS IN BROOKS COUNTY, TEXAS: TEXAS BOARD OF WATER ENGINEERS MISCELLANEOUS PUBLICATION 22, 1940.

MEMORANDUM ON THE PUBLIC WATER SUPPLY OF FALFURRIAS, BROOKS COUNTY, TEXAS: USGS OPEN-FILE REPORT (UNNUMBERED), 1940. 
GROUND-WATER CONDITIONS IN PREMONT-LAGLORIA-FALFURRIAS DISTRICT: TEXAS BOARD OF WATER ENGINEERS MISCELLANEOUS PUBLICATION 212, 1944.

PUBLIC WATER SUPPLIES IN SOUTHERN TEXAS: USGS WATERSUPPLY PAPER 1070, 1950

AVAILABILITY OF GROUND WATER IN THE GULF COAST REGION OF TEXAS: USGS OPEN-FILE REPORT (UNNUMBERED), 1956.

RECONNAISSANCE INVESTIGATION OF THE GROUND-WATER RESOURCES OF THE GULF COAST REGION, TEXAS: TEXAS WATER COMMISSION BULLETIN 6305, 1963.

GROUND-WATER RESOURCES OF BROOKS COUNTY, TEXAS: TEXAS WATER DEVELOPMENT BOARD REPORT 61, 1967.

COMPILATION OF AQUIFER TESTS IN TEXAS: TEXAS WATER DEVELOPMENT BOARD REPORT 98, 1969.

GEOLOGIC AND HYDROLOGIC SUMMARY OF SALT DOMES IN GULF COAST REGION OF TEXAS, LOUISIANA, AND ALABAMA: USGS OPEN-FILE REPORT 73-07, 1973.

SUMMARY APPRAISALS OF THE NATION'S GROUND-WATER RESOURCES-TEXAS-GULF REGION: USGS PROFESSIONAL PAPER 813-F, 1976.

STRATIGRAPHIC AND HYDROGEOLOGIC FRAMEWORK OF PART OF THE COASTAL PLAIN OF TEXAS: TEXAS DEPARTMENT OF WATER RESOURCES REPORT 236, 1979.

LAND-SURFACE SUBSIDENCE IN THE TEXAS COASTAL REGION: USGS OPEN-FILE REPORT 80-969, 1980.

SPRINGS OF TEXAS, VOLUME 1: (BY GUNNAR BRUNE), BRANCHSMITH, INC., FORT WORTH, TEXAS, 1981.

WATER LEVELS AND SALINITIES OF WATER WITHIN THE EVANGELINE AQUIFER IN AN AREA SOUTHWEST OF CORPUS CHRISTI, TEXAS: USGS OPEN-FILE REPORT 82-174, 1983.

SIMULATED EFFECTS OF PROJECTED PUMPING ON THE AVAILABILITY OF FRESHWATER IN THE EVANGELINE AQUIFER IN AN AREA SOUTHWEST OF CORPUS CHRISTI, TEXAS: USGS WATERRESOURCES INVESTIGATIONS REPORT 85-4182, 1985.

TEXAS GROUND-WATER RESOURCES, in NATIONAL WATER SUMMARY 1984: USGS WATER-SUPPLY PAPER 2275, 1985.

DIGITAL MODELS FOR SIMULATION OF GROUND-WATER HYDROLOGY OF THE CHICOT AND EVANGELINE AQUIFERS ALONG THE GULF COAST OF TEXAS: TEXAS DEPARTMENT OF WATER RESOURCES REPORT 289, 1985.

GEOHYDROLOGIC FRAMEWORK OF THE GULF COASTAL PLAIN: USGS HYDROLOGIC ATLAS HA-695, 1988.

PROPERTIES AND CHEMICAL CONSTITUENTS IN GROUND WATER FROM THE MISSISSIPPI RIVER VALLEY ALLUVIAL AQUIFER AND PERMEABLE ZONE A (HOLOCENE-UPPER PLEISTOCENE DEPOSITS), SOUTH-CENTRAL UNITED STATES: USGS WATERRESOURCES INVESTIGATIONS REPORT 91-4149, 1992.

PROPERTIES AND CHEMICAL CONSTITUENTS IN GROUND WATER FROM THE UPPER CLAIBORNE AQUIFER, GULF COAST REGIONAL AQUIFER SYSTEMS, SOUTH-CENTRAL UNITED STATES: USGS WATER-RESOURCES INVESTIGATIONS REPORT 91-4150, 1993.

PROPERTIES AND CHEMICAL CONSTITUENTS IN GROUND WATER FROM PERMEABLE ZONE C (LOWER PLIOCENE-UPPER MIOCENE
DEPOSITS), COASTAL LOWLANDS AQUIFER SYSTEM, SOUTHCENTRAL UNITED STATES: USGS WATER-RESOURCES INVESTIGATIONS REPORT 91-4151, 1993.

PROPERTIES AND CHEMICAL CONSTITUENTS IN GROUND WATER FROM PERMEABLE ZONE B (LOWER PLEISTOCENE-UPPER PLIOCENE DEPOSITS), COASTAL LOWLANDS AQUIFER SYSTEM, SOUTH-CENTRAL UNITED STATES: USGS WATER-RESOURCES INVESTIGATIONS REPORT 91-4152, 1993.

PROPERTIES AND CHEMICAL CONSTITUENTS IN GROUND WATER FROM PERMEABLE ZONE E (LOWER MIOCENE-UPPER OLIGOCENE DEPOSITS), COASTAL LOWLANDS AQUIFER SYSTEM, SOUTH-CENTRAL UNITED STATES: USGS WATER-RESOURCES INVESTIGATIONS REPORT 92-4103, 1993.

PROPERTIES AND CHEMICAL CONSTITUENTS IN GROUND WATER FROM PERMEABLE ZONE D (MIDDLE MIOCENE DEPOSITS), COASTAL LOWLANDS AQUIFER SYSTEM, SOUTH-CENTRAL UNITED STATES: USGS WATER-RESOURCES INVESTIGATIONS REPORT 92-4105, 1993.

AQUIFERS OF TEXAS: TEXAS WATER DEVELOPMENT BOARD REPORT 345, 1995.

\section{BROWN COUNTY}

GEOGRAPHY AND GEOLOGY OF THE BLACK AND GRAND PRAIRIES OF TEXAS, WITH DETAILED DESCRIPTIONS OF THE CRETACEOUS FORMATIONS AND SPECIAL REFERENCE TO ARTESIAN WATERS: USGS 21ST ANNUAL REPORT, PART 7, 1901.

RECORDS OF WELLS, DRILLERS' LOGS, AND WATER ANALYSES, AND MAP SHOWING LOCATION OF WELLS IN BROWN COUNTY: TEXAS BOARD OF WATER ENGINEERS MISCELLANEOUS PUBLICATION 23, 1938.

BROWNWOOD WATER SUPPLY: USGS OPEN-FILE REPORT (UNNUMBERED), 1941.

MEMORANDUM REGARDING CORE DRILLING BY THE U.S. ENGINEERS AT BROWNWOOD LAKE DAM, NEAR BROWNWOOD, TEXAS: USGS OPEN-FILE REPORT (UNNUMBERED), 1944.

PUBLIC WATER SUPPLIES IN CENTRAL AND NORTH-CENTRAL TEXAS: USGS WATER-SUPPLY PAPER 1069, 1949.

OCCURRENCE AND QUALITY OF GROUND WATER IN BROWN COUNTY, TEXAS: TEXAS WATER DEVELOPMENT BOARD REPORT 46, 1967.

RECONNAISSANCE INVESTIGATION OF THE GROUND-WATER RESOURCES OF THE COLORADO RIVER BASIN, TEXAS: TEXAS WATER DEVELOPMENT BOARD REPORT 51, 1967.

GROUND-WATER RESOURCES OF PART OF CENTRAL TEXAS WITH EMPHASIS ON THE ANTLERS AND TRAVIS PEAK FORMATIONS, VOLUME 1: TEXAS WATER DEVELOPMENT BOARD REPORT 195 , V. 1, 1975.

GROUND-WATER RESOURCES OF PART OF CENTRAL TEXAS WITH EMPHASIS ON THE ANTLERS AND TRAVIS PEAK FORMATIONS, VOLUME 2, RECORDS OF WELLS; DRILLERS' LOGS; WATER LEVELS IN WELLS; CHEMICAL ANALYSES OF GROUND WATER; CHEMICAL ANALYSES OF OIL-FIELD BRINES; AND WELL LOCA TION MAPS: TEXAS WATER DEVELOPMENT BOARD REPORT 195, V. 2, 1976 
TEXAS GROUND-WATER RESOURCES, in NATIONAL WATER SUMMARY 1984: USGS WATER-SUPPLY PAPER 2275, 1985.

GROUND-WATER RESOURCES OF THE ANTLERS AND TRAVIS PEAK FORMATIONS IN THE OUTCROP AREA OF NORTH-CENTRAL TEXAS: TEXAS WATER DEVELOPMENT BOARD REPORT 298, 1987.

EVALUATION OF WATER RESOURCES IN PART OF CENTRAL TEXAS: TEXAS WATER DEVELOPMENT BOARD REPORT 319, 1990.

AQUIFERS OF TEXAS: TEXAS WATER DEVELOPMENT BOARD REPORT 345, 1995.

THE PALEOZOIC AND RELATED AQUIFERS OF CENTRAL TEXAS: TEXAS WATER DEVELOPMENT BOARD REPORT 346, 1996.

\section{BURLESON COUNTY}

ARTESIAN WELLS OF THE COASTAL PRAIRIE REGION AND TERTIARY BELT OF TEXAS: GEOLOGICAL SURVEY OF TEXAS, CHAPTER 2, 1893.

UNDERGROUND WATERS OF THE COASTAL PLAIN OF TEXAS: USGS WATER-SUPPLY PAPER 190, 1907.

GEOLOGY AND UNDERGROUND WATERS OF THE SOUTHEASTERN PART OF THE TEXAS COASTAL PLAIN: USGS WATER-SUPPLY PAPER 335, 1914.

GROUND WATER CONDITIONS IN BURLESON COUNTY: USGS OPEN-FILE REPORT (UNNUMBERED), (NO DATE, OLD)

RECORDS OF WELLS, DRILLERS' LOGS, WATER ANALYSES, AND MAP SHOWING LOCATION OF WELLS IN BURLESON COUNTY, TEXAS: TEXAS BOARD OF WATER ENGINEERS MISCELLANEOUS PUBLICATION 26, 1937

MEMORANDUM ON THE GROUND-WATER SUPPLY OF SOMERVILLE, TEXAS: USGS OPEN-FILE REPORT (UNNUMBERED), 1939.

PUBLIC WATER SUPPLIES IN EASTERN TEXAS: USGS WATERSUPPLY PAPER 1047, 1948.

RECONNAISSANCE INVESTIGATION OF THE GROUND-WATER RESOURCES OF THE BRAZOS RIVER BASIN, TEXAS: TEXAS WATER COMMISSION BULLETIN 6310, 1963.

GROUND WATER IN THE FLOOD-PLAIN ALLUVIUM OF THE BRAZOS RIVER, WHITNEY DAM TO VICINITY OF RICHMOND, TEXAS: TEXAS WATER DEVELOPMENT BOARD REPORT 41, 1967.

HYDROLOGIC SIGNIFICANCE OF THE LITHOFACIES OF THE SPARTA SAND IN ARKANSAS, LOUISIANA, MISSISSIPPI, AND TEXAS: USGS PROFESSIONAL PAPER 569-A, 1968.

GEOHYDROLOGIC SIGNIFICANCE OF LITHOFACIES OF THE COCKFIELD FORMATION OF LOUISIANA AND MISSISSIPPI AND OF THE YEGUA FORMATION OF TEXAS: USGS PROFESSIONAL PAPER 569-B, 1970.

HYDROLOGIC SIGNIFICANCE OF LITHOFACIES OF THE CANE RIVER FORMATION OR EQUIVALENTS OF ARKANSAS, LOUISIANA, MISSISSIPPI, AND TEXAS: USGS PROFESSIONAL PAPER 569-C, 1972.
GROUND-WATER RESOURCES OF BRAZOS AND BURLESON COUNTIES, TEXAS: TEXAS WATER DEVELOPMENT BOARD REPORT $185,1974$.

GEOHYDROLOGIC SIGNIFICANCE OF LITHOFACIES OF THE CARRIZO SAND OF ARKANSAS, LOUISIANA, AND TEXAS AND THE MERIDIAN SAND OF MISSISSIPPI: USGS PROFESSIONAL PAPER 569-D, 1975.

MAJOR AND HISTORICAL SPRINGS OF TEXAS: TEXAS WATER DEVELOPMENT BOARD REPORT 189, 1975.

SUMMARY APPRAISALS OF THE NATION'S GROUND-WATER RESOURCES-TEXAS-GULF REGION: USGS PROFESSIONAL PAPER 813-F, 1976.

STRATIGRAPHIC AND HYDROGEOLOGIC FRAMEWORK OF PART OF THE COASTAL PLAIN OF TEXAS: USGS OPEN-FILE REPORT 77-712, 1978. ALSO PUBLISHED AS TEXAS DEPARTMENT OF WATER RESOURCES REPORT 236, 1979.

TEXAS GROUND-WATER RESOURCES, in NATIONAL WATER SUMMARY 1984: USGS WATER-SUPPLY PAPER 2275, 1985.

APPROXIMATE POTENTIOMETRIC SURFACES FOR THE AQUIFERS OF THE TEXAS COASTAL UPLANDS SYSTEM, 1980: USGS HYDROLOGIC ATLAS HA-704, 1987.

GEOHYDROLOGIC FRAMEWORK OF THE GULF COASTAL PLAIN: USGS HYDROLOGIC ATLAS HA-695, 1988.

GROUND-WATER RESOURCES OF THE CARRIZO-WILCOX AQUIFER IN THE CENTRAL TEXAS REGION: TEXAS WATER DEVELOPMENT BOARD REPORT 332, 1991

PROPERTIES AND CHEMICAL CONSTITUENTS IN GROUND WATER FROM THE UPPER CLAIBORNE AQUIFER, GULF COAST REGIONAL AQUIFER SYSTEMS, SOUTH-CENTRAL UNITED STATES: USGS WATER-RESOURCES INVESTIGATIONS REPORT 91-4150, 1993.

PROPERTIES AND CHEMICAL CONSTITUENTS IN GROUND WATER FROM THE LOWER CLAIBORNE-UPPER WILCOX AQUIFER, GULF COAST REGIONAL AQUIFER SYSTEMS, SOUTH-CENTRAL UNITED STATES: USGS WATER-RESOURCES INVESTIGATIONS REPORT 92-4102, 1993

PROPERTIES AND CHEMICAL CONSTITUENTS IN GROUND WATER FROM PERMEABLE ZONE E (LOWER MIOCENE-UPPER OLIGOCENE DEPOSITS), COASTAL LOWLANDS AQUIFER SYSTEM, SOUTH-CENTRAL UNITED STATES: USGS WATER-RESOURCES INVESTIGATIONS REPORT 92-4103, 1993.

PROPERTIES AND CHEMICAL CONSTITUENTS IN GROUND WATER FROM THE MIDDLE CLAIBORNE AQUIFER, GULF COAST REGIONAL AQUIFER SYSTEMS, SOUTH-CENTRAL UNITED STATES: USGS WATER-RESOURCES INVESTIGATIONS REPORT 92-4104, 1993.

PROPERTIES AND CHEMICAL CONSTITUENTS IN GROUND WATER FROM THE MIDDLE WILCOX AQUIFER, GULF COAST REGIONAL AQUIFER SYSTEMS, SOUTH-CENTRAL UNITED STATES: USGS WATER-RESOURCES INVESTIGATIONS REPORT 93-4070, 1993.

STRATIGRAPHIC NOMENCLATURE AND GEOLOGIC SECTIONS OF THE GULF COASTAL PLAIN OF TEXAS: USGS OPEN-FILE REPORT 94-461, 1995

WATER QUALITY IN THE SPARTA AQUIFER, EAST TEXAS: TEXAS WATER DEVELOPMENT BOARD HYDROLOGIC ATLAS NO. 5, 1996. 
WATER QUALITY IN THE QUEEN CITY AQUIFER, EAST TEXAS: TEXAS WATER DEVELOPMENT BOARD HYDROLOGIC ATLAS NO. 6, 1996

GROUND-WATER AVAILABILITY IN THE CARRIZO-WILCOX AQUIFER IN CENTRAL TEXAS-NUMERICAL SIMULATIONS OF 2000 THROUGH 2050 WITHDRAWAL PROJECTIONS: UNIVERSITY OF TEXAS, BUREAU OF ECONOMIC GEOLOGY REPORT OF INVESTIGATIONS NO. 256, 1999.

TRANSMISSIVITY, HYDRAULIC CONDUCTIVITY, AND STORATIVITY OF THE CARRIZO-WILCOX AQUIFER IN TEXAS, DATA AND ANALYSIS: UNIVERSITY OF TEXAS, BUREAU OF ECONOMIC GEOLOGY, CD-ROM, 2000.

\section{BURNET COUNTY}

GEOGRAPHY AND GEOLOGY OF THE BLACK AND GRAND PRAIRIES OF TEXAS, WITH DETAILED DESCRIPTIONS OF THE CRETACEOUS FORMATIONS AND SPECIAL REFERENCE TO ARTESIAN WATERS: USGS 21ST ANNUAL REPORT, PART 7, 1901.

GEOLOGIC ATLAS OF THE UNITED STATES-LLANO-BURNET FOLIO, TEXAS: USGS GEOLOGIC FOLIO, 1912.

GROUND WATER IN THE VICINITY OF BURNET AND BERTRAM, BURNET COUNTY, TEXAS: USGS OPEN-FILE REPORT (UNNUMBERED), 1942.

PUBLIC WATER SUPPLIES IN CENTRAL AND NORTH-CENTRAL TEXAS: USGS WATER-SUPPLY PAPER 1069, 1949.

GROUND-WATER CONDITIONS IN THE VICINITY OF BURNET, TEXAS: TEXAS WATER COMMISSION MEMORANDUM REPORT MR 62-01, 1962.

RECONNAISSANCE INVESTIGATION OF THE GROUND-WATER RESOURCES OF THE BRAZOS RIVER BASIN, TEXAS: TEXAS WATER COMMISSION BULLETIN 6310, 1963.

RECONNAISSANCE INVESTIGATION OF THE GROUND-WATER RESOURCES OF THE COLORADO RIVER BASIN, TEXAS: TEXAS WATER DEVELOPMENT BOARD REPORT 51, 1967.

COMPILATION OF AQUIFER TESTS IN TEXAS: TEXAS WATER DEVELOPMENT BOARD REPORT 98, 1969.

MAJOR AND HISTORICAL SPRINGS OF TEXAS: TEXAS WATER DEVELOPMENT BOARD REPORT 189, 1975.

GROUND-WATER RESOURCES OF PART OF CENTRAL TEXAS WITH EMPHASIS ON THE ANTLERS AND TRAVIS PEAK FORMATIONS, VOLUME 1: TEXAS WATER DEVELOPMENT BOARD REPORT 195, V. 1, 1975.

GROUND-WATER RESOURCES OF PART OF CENTRAL TEXAS WITH EMPHASIS ON THE ANTLERS AND TRAVIS PEAK FORMATIONS, VOLUME 2, RECORDS OF WELLS; DRILLERS' LOGS; WATER LEVELS IN WELLS; CHEMICAL ANALYSES OF GROUND WATER; CHEMICAL ANALYSES OF OIL-FIELD BRINES; AND WELL LOCATION MAPS: TEXAS WATER DEVELOPMENT BOARD REPORT 195, V. 2, 1976.

SPRINGS OF TEXAS, VOLUME 1: (BY GUNNAR BRUNE), BRANCHSMITH, INC., FORT WORTH, TEXAS, 1981.

TEXAS GROUND-WATER RESOURCES, in NATIONAL WATER SUMMARY 1984: USGS WATER-SUPPLY PAPER 2275, 1985.
EVALUATION OF WATER RESOURCES IN PART OF CENTRAL TEXAS: TEXAS WATER DEVELOPMENT BOARD REPORT 319 , 1990.

EVALUATION OF WATER RESOURCES IN BELL, BURNET, TRAVIS, WILLIAMSON, AND PARTS OF ADJACENT COUNTIES, TEXAS: TEXAS WATER DEVELOPMENT BOARD REPORT 326, 1991.

AQUIFERS OF TEXAS: TEXAS WATER DEVELOPMENT BOARD REPORT 345, 1995.

THE PALEOZOIC AND RELATED AQUIFERS OF CENTRAL TEXAS: TEXAS WATER DEVELOPMENT BOARD REPORT 346, 1996.

CHANGES IN GROUNDWATER CONDITIONS IN THE EDWARDS AND TRINITY AQUIFERS, 1987-1997, FOR PORTIONS OF BASTROP, BELL, BURNET, LEE, MILAM, TRAVIS, AND WILLIAMSON COUNTIES, TEXAS: TEXAS WATER DEVELOPMENT BOARD REPORT $350,1999$.

\section{CALDWELL COUNTY}

GEOLOGIC ATLAS OF THE UNITED STATES-AUSTIN FOLIO, TEXAS: USGS GEOLOGIC FOLIO, 1902.

UNDERGROUND WATERS OF THE COASTAL PLAIN OF TEXAS: USGS WATER-SUPPLY PAPER 190, 1907.

OCCURRENCE OF GROUND WATER IN TERRACE GRAVELS ALONG SAN MARCOS RIVER: USGS OPEN-FILE REPORT (UNNUMBERED) (MEMORANDUM), 1942.

CONTAMINATION OF SURFACE STREAMS FROM OIL-FIELD WASTE IN THE VICINITY OF LULING, TEXAS: USGS OPEN-FILE REPORT (UNNUMBERED), 1944.

GEOLOGY AND GROUND-WATER RESOURCES OF CALDWELL COUNTY, TEXAS: TEXAS BOARD OF WATER ENGINEERS MISCELLANEOUS PUBLICATION 27, 1947.

PUBLIC WATER SUPPLIES IN SOUTHERN TEXAS: USGS WATERSUPPLY PAPER 1070, 1950.

MEMORANDUM ON VISIT TO LOCKHART: USGS OPEN-FILE REPORT (UNNUMBERED), 1952

RECORDS OF WATER LEVELS IN BASTROP AND CALDWELL COUNTIES, TEXAS, 1937 THROUGH 1947: TEXAS BOARD OF WATER ENGINEERS BULLETIN 5702, 1957.

RECONNAISSANCE INVESTIGATION OF THE GROUND-WATER RESOURCES OF THE GUADALUPE, SAN ANTONIO, AND NUECES RIVER BASINS, TEXAS: TEXAS WATER COMMISSION BULLETIN 6409, 1964.

GROUND-WATER RESOURCES OF CALDWELL COUNTY, TEXAS: TEXAS WATER DEVELOPMENT BOARD REPORT 12, 1966.

COMPILATION OF RESULTS OF AQUIFER TEST IN TEXAS: TEXAS WATER DEVELOPMENT BOARD REPORT 98, 1969

HYDROLOGIC SIGNIFICANCE OF LITHOFACIES OF THE CANE RIVER FORMATION OR EQUIVALENTS OF ARKANSAS, LOUISIANA, MISSISSIPPI, AND TEXAS: USGS PROFESSIONAL PAPER 569-C, 1972.

GEOHYDROLOGIC SIGNIFICANCE OF LITHOFACIES OF THE CARRIZO SAND OF ARKANSAS, LOUISIANA, AND TEXAS AND THE 
MERIDIAN SAND OF MISSISSIPPI: USGS PROFESSIONAL PAPER 569-D, 1975.

SUMMARY APPRAISALS OF THE NATION'S GROUND-WATER RESOURCES-TEXAS-GULF REGION: USGS PROFESSIONAL PAPER 813-F, 1976.

GROUND-WATER RESOURCES OF THE CARRIZO AQUIFER IN THE WINTER GARDEN AREA OF TEXAS, VOLUME 1: TEXAS WATER DEVELOPMENT BOARD REPORT 210, V. 1, 1976.

GROUND-WATER RESOURCES OF THE CARRIZO AQUIFER IN THE WINTER GARDEN AREA OF TEXAS, VOLUME 2: TEXAS DEPARTMENT OF WATER RESOURCES REPORT 210, V. 2, 1977.

SPRINGS OF TEXAS, VOLUME 1: (BY GUNNAR BRUNE), BRANCHSMITH, INC., FORT WORTH, TEXAS, 1981.

TEXAS GROUND-WATER RESOURCES, in NATIONAL WATER SUMMARY 1984: USGS WATER-SUPPLY PAPER 2275, 1985.

APPROXIMATE POTENTIOMETRIC SURFACES FOR THE AQUIFERS OF THE TEXAS COASTAL UPLANDS SYSTEM, 1980: USGS HYDROLOGIC INVESTIGATIONS ATLAS HA-704, 1987.

GEOHYDROLOGIC FRAMEWORK OF THE GULF COASTAL PLAIN: USGS HYDROLOGIC ATLAS HA-695, 1988.

A DIGITAL MODEL OF THE CARRIZO-WILCOX AQUIFER WITHIN THE COLORADO RIVER BASIN OF TEXAS: TEXAS WATER DEVELOPMENT REPORT LIMITED PRINTING REPORT LP-208, 1989.

GROUND-WATER RESOURCES OF THE CARRIZO-WILCOX AQUIFER IN THE CENTRAL TEXAS REGION: TEXAS WATER DEVELOPMENT BOARD REPORT 332, 1991.

PROPERTIES AND CHEMICAL CONSTITUENTS IN GROUND WATER FROM THE LOWER CLAIBORNE-UPPER WILCOX AQUIFER, GULF COAST REGIONAL AQUIFER SYSTEMS, SOUTH-CENTRAL UNITED STATES: USGS WATER-RESOURCES INVESTIGATIONS REPORT 92-4102, 1993

PROPERTIES AND CHEMICAL CONSTITUENTS IN GROUND WATER FROM THE MIDDLE CLAIBORNE AQUIFER, GULF COAST REGIONAL AQUIFER SYSTEMS, SOUTH-CENTRAL UNITED STATES: USGS WATER-RESOURCES INVESTIGATIONS REPORT 92-4104, 1993.

DEFINING THE EDWARDS AQUIFER FRESHWATER/SALINE-WATER INTERFACE WITH GEOPHYSICAL LOGS AND MEASURED DATA (SAN ANTONIO TO KYLE, TEXAS): EDWARDS UNDERGROUND WATER DISTRICT REPORT 93-06, 1993

1994 REVIEW AND UPDATE OF THE POSITION OF THE EDWARDS AQUIFER FRESHWATER/SALINE-WATER INTERFACE FROM UVALDE TO KYLE, TEXAS: EDWARDS UNDERGROUND WATER DISTRICT REPORT 94-05, 1994.

WATER QUALITY IN THE QUEEN CITY AQUIFER, EAST TEXAS: TEXAS WATER DEVELOPMENT BOARD HYDROLOGIC ATLAS NO. 6, 1996

EDWARDS AQUIFER GROUND-WATER RESOURCES: GEOLOGIC CONTROLS ON POROSITY DEVELOPMENT IN PLATFORM CARBONATES, SOUTH TEXAS: UNIVERSITY OF TEXAS, BUREAU OF ECONOMIC GEOLOGY REPORT OF INVESTIGATIONS NO. 238, 1996.

HYDROGEOLOGIC FRAMEWORK AND GEOCHEMISTRY OF THE EDWARDS AQUIFER SALINE-WATER ZONE, SOUTH-CENTRAL TEXAS: USGS WATER-RESOURCES INVESTIGATIONS REPORT 97-4133, 1997.
TRANSMISSIVITY, HYDRAULIC CONDUCTIVITY, AND STORATIVITY OF THE CARRIZO-WILCOX AQUIFER IN TEXAS, DATA AND ANALYSIS: UNIVERSITY OF TEXAS, BUREAU OF ECONOMIC GEOLOGY, CD-ROM, 2000

WATER QUALITY IN SOUTH-CENTRAL TEXAS-TEXAS, 1996-98: USGS CIRCULAR 1212, 2000.

\section{CALHOUN COUNTY}

UNDERGROUND WATERS OF THE COASTAL PLAIN OF TEXAS: USGS WATER-SUPPLY PAPER 190, 1907.

MEMORANDUM ON THE GROUND-WATER RESOURCES OF SEADRIFT, TEXAS: USGS OPEN-FILE REPORT (UNNUMBERED), 1938.

RECORDS OF WELLS, DRILLERS' LOGS, WATER ANALYSES, AND MAP SHOWING LOCATION OF WELLS IN CALHOUN COUNTY, TEXAS: TEXAS BOARD OF WATER ENGINEERS MISCELLANEOUS PUBLICATION 28, 1941.

GROUND WATER IN THE VICINITY OF PORT O'CONNOR, CALHOUN COUNTY, TEXAS: USGS OPEN-FILE REPORT (UNNUMBERED), 1941.

MEMORANDUM ON GROUND-WATER SUPPLY OF MATAGORDA ISLAND FLYING FIELD: USGS OPEN-FILE REPORT (UNNUMBERED), 1943.

PUBLIC WATER SUPPLIES IN SOUTHERN TEXAS: USGS WATERSUPPLY PAPER 1070, 1950.

MEMORANDUM ON FRESH WATER IN BEACH SAND, MATAGORDA ISLAND, CALHOUN COUNTY, TEXAS: USGS OPEN-FILE REPORT (UNNUMBERED), 1951.

AVAILABILITY OF GROUND WATER IN THE GULF COAST REGION OF TEXAS: USGS OPEN-FILE REPORT (UNNUMBERED), 1956.

GROUND-WATER RESOURCES OF VICTORIA AND CALHOUN COUNTIES, TEXAS: TEXAS WATER COMMISSION BULLETIN 6202, 1962.

RECONNAISSANCE INVESTIGATION OF THE GROUND-WATER RESOURCES OF THE GULF COAST REGION, TEXAS: TEXAS WATER COMMISSION BULLETIN 6305, 1963.

SUMMARY APPRAISALS OF THE NATION'S GROUND-WATER RESOURCES-TEXAS-GULF REGION: USGS PROFESSIONAL PAPER 813-F, 1976.

STRATIGRAPHIC AND HYDROGEOLOGIC FRAMEWORK OF PART OF THE COASTAL PLAIN OF TEXAS: USGS OPEN-FILE REPORT $77-712,1978$

STRATIGRAPHIC AND HYDROGEOLOGIC FRAMEWORK OF PART OF THE COASTAL PLAIN OF TEXAS: TEXAS DEPARTMENT OF WATER RESOURCES REPORT 236, 1979.

LAND-SURFACE SUBSIDENCE IN THE TEXAS COASTAL REGION: USGS OPEN-FILE REPORT 80-969, 1980.

SPRINGS OF TEXAS, VOLUME 1: (BY GUNNAR BRUNE), BRANCHSMITH, INC., FORT WORTH, TEXAS, 1981.

LAND-SURFACE SUBSIDENCE IN THE TEXAS COASTAL REGION: TEXAS DEPARTMENT OF WATER RESOURCES REPORT 272, 1982.

DIGITAL MODELS FOR SIMULATION OF GROUND-WATER HYDROLOGY OF THE CHICOT AND EVANGELINE AQUIFERS ALONG THE 
GULF COAST OF TEXAS: TEXAS DEPARTMENT OF WATER RESOURCES REPORT 289, 1985.

TEXAS GROUND-WATER RESOURCES, in NATIONAL WATER SUMMARY 1984: USGS WATER-SUPPLY PAPER 2275, 1985.

GEOHYDROLOGIC FRAMEWORK OF THE GULF COASTAL PLAIN: USGS HYDROLOGIC ATLAS HA-695, 1988.

PROPERTIES AND CHEMICAL CONSTITUENTS IN GROUND WATER FROM THE MISSISSIPPI RIVER VALLEY ALLUVIAL AQUIFER AND PERMEABLE ZONE A (HOLOCENE-UPPER PLEISTOCENE DEPOSITS), SOUTH-CENTRAL UNITED STATES: USGS WATERRESOURCES INVESTIGATIONS REPORT 91-4149, 1992.

PROPERTIES AND CHEMICAL CONSTITUENTS IN GROUND WATER FROM THE UPPER CLAIBORNE AQUIFER, GULF COAST REGIONAL AQUIFER SYSTEMS, SOUTH-CENTRAL UNITED STATES: USGS WATER-RESOURCES INVESTIGATIONS REPORT 91-4150, 1993.

PROPERTIES AND CHEMICAL CONSTITUENTS IN GROUND WATER FROM PERMEABLE ZONE C (LOWER PLIOCENE-UPPER MIOCENE DEPOSITS), COASTAL LOWLANDS AQUIFER SYSTEM, SOUTHCENTRAL UNITED STATES: USGS WATER-RESOURCES INVESTIGATIONS REPORT 91-4151, 1993.

PROPERTIES AND CHEMICAL CONSTITUENTS IN GROUND WATER FROM PERMEABLE ZONE B (LOWER PLEISTOCENE-UPPER PLIOCENE DEPOSITS), COASTAL LOWLANDS AQUIFER SYSTEM, SOUTH-CENTRAL UNITED STATES: USGS WATER-RESOURCES INVESTIGATIONS REPORT 91-4152, 1993.

PROPERTIES AND CHEMICAL CONSTITUENTS IN GROUND WATER FROM PERMEABLE ZONE E (LOWER MIOCENE-UPPER OLIGOCENE DEPOSITS), COASTAL LOWLANDS AQUIFER SYSTEM, SOUTH-CENTRAL UNITED STATES: USGS WATER-RESOURCES INVESTIGATIONS REPORT 92-4103, 1993.

PROPERTIES AND CHEMICAL CONSTITUENTS IN GROUND WATER FROM PERMEABLE ZONE D (MIDDLE MIOCENE DEPOSITS), COASTAL LOWLANDS AQUIFER SYSTEM, SOUTH-CENTRAL UNITED STATES: USGS WATER-RESOURCES INVESTIGATIONS REPORT 92-4105, 1993.

AQUIFERS OF TEXAS: TEXAS WATER DEVELOPMENT BOARD REPORT 345, 1995.

\section{CALLAHAN COUNTY}

MEMORANDUM ON THE CITY WATER SUPPLY OF BAIRD, TEXAS: USGS OPEN-FILE REPORT (UNNUMBERED), 1939.

RECORDS OF WELLS AND SPRINGS, DRILLERS' LOGS, WATER ANALYSES, AND MAP SHOWING LOCATIONS OF WELLS AND SPRINGS IN CALLAHAN COUNTY, TEXAS: TEXAS BOARD OF WATER ENGINEERS MISCELLANEOUS PUBLICATION 29, 1940.

MEMORANDUM ON THE GROUND-WATER CONDITIONS IN THE VICINITY OF BAIRD, TEXAS: USGS OPEN-FILE REPORT (UNNUMBERED), 1940.

PUBLIC WATER SUPPLIES IN CENTRAL AND NORTH-CENTRAL TEXAS: USGS WATER-SUPPLY PAPER 1069, 1949.

RECONNAISSANCE INVESTIGATION OF THE GROUND-WATER RESOURCES OF THE BRAZOS RIVER BASIN, TEXAS: TEXAS WATER COMMISSION BULLETIN 6310, 1963.
RECONNAISSANCE INVESTIGATION OF THE GROUND-WATER RESOURCES OF THE COLORADO RIVER BASIN, TEXAS: TEXAS WATER DEVELOPMENT BOARD REPORT 51, 1967.

COMPILATION OF RESULTS OF AQUIFER TESTS IN TEXAS: TEXAS WATER DEVELOPMENT BOARD REPORT 98, 1969.

GROUND-WATER RESOURCES OF PART OF CENTRAL TEXAS WITH EMPHASIS ON THE ANTLERS AND TRAVIS PEAK FORMATIONS, VOLUME 1: TEXAS WATER DEVELOPMENT BOARD REPORT 195, V. 1, 1975.

GROUND-WATER RESOURCES OF PART OF CENTRAL TEXAS WITH EMPHASIS ON THE ANTLERS AND TRAVIS PEAK FORMATIONS, VOLUME 2: TEXAS WATER DEVELOPMENT BOARD REPORT 195, V. 2, 1976.

SPRINGS OF TEXAS, VOLUME 1: (BY GUNNAR BRUNE), BRANCHSMITH, INC., FORT WORTH, TEXAS, 1981.

OCCURRENCE, QUALITY, AND AVAILABILITY OF GROUND WATER IN CALLAHAN COUNTY, TEXAS: TEXAS DEPARTMENT OF WATER RESOURCES REPORT 278, 1983.

TEXAS GROUND-WATER RESOURCES, in NATIONAL WATER SUMMARY 1984: USGS WATER-SUPPLY PAPER 2275, 1985.

GROUND-WATER RESOURCES OF THE ANTLERS AND TRAVIS PEAK FORMATIONS IN THE OUTCROP AREA OF NORTH-CENTRAL TEXAS: TEXAS WATER DEVELOPMENT BOARD REPORT 298, 1987.

EVALUATION OF WATER RESOURCES IN PART OF CENTRAL TEXAS: TEXAS WATER DEVELOPMENT BOARD REPORT 319, 1990.

EVALUATION OF WATER RESOURCES IN PARTS OF THE ROLLING PRAIRIES REGION OF NORTH-CENTRAL TEXAS: TEXAS WATER DEVELOPMENT BOARD REPORT 337, 1992.

\section{CAMERON COUNTY}

UNDERGROUND WATERS OF THE COASTAL PLAIN OF TEXAS: USGS WATER-SUPPLY PAPER 190, 1907.

WATER TABLE SURVEY IN THE LOWER RIO GRANDE VALLEY, PART 9, SEC. 1-CAMERON COUNTY W.I.D. NO. 6 (WPA PROJ. 1759): TEXAS BOARD OF WATER ENGINEERS MISCELLANEOUS PUBLICATION 165, 1937.

WATER TABLE SURVEY IN THE LOWER RIO GRANDE VALLEY, PART 9, SEC. 2-CAMERON COUNTY W.I.D. NO. 6 (WPA PROJ. 1759): TEXAS BOARD OF WATER ENGINEERS MISCELLANEOUS PUBLICATION 165A, 1937.

WATER TABLE SURVEY IN THE LOWER RIO GRANDE VALLEY, PART 8-CAMERON COUNTY W.I.D. NO. 1 AND CAMERON COUNTY W.I.D. NO. 15 (WPA PROJ. 1759): TEXAS BOARD OF WATER ENGINEERS MISCELLANEOUS PUBLICATION 166, 1937.

WATER TABLE SURVEY IN THE LOWER RIO GRANDE VALLEY, PART 7, SEC. 2-HIDALGO AND CAMERON COUNTIES W.C.I.D. NO. 9 (WPA PROJ. 1759): TEXAS BOARD OF WATER ENGINEERS MISCELLANEOUS PUBLICATION 167, 1937.

WATER TABLE SURVEY IN THE LOWER RIO GRANDE VALLEY, PART 6-CAMERON COUNTY W.C.I.D. NO. 5 (WPA PROJ. 1759): TEXAS BOARD OF WATER ENGINEERS MISCELLANEOUS PUBLICATION 169, 1937. 
WATER TABLE SURVEY IN THE LOWER RIO GRANDE VALLEY, PART 7, SEC. 1-HIDALGO AND CAMERON COUNTIES W.C.I.D. NO. 9 (WPA PROJ. 1759): TEXAS BOARD OF WATER ENGINEERS MISCELLANEOUS PUBLICATION 169, 1937.

WATER TABLE SURVEY IN THE LOWER RIO GRANDE VALLEY, PART 4-LAFERIA W.C.I.D. CAMERON COUNTY NO 3 (WPA PROJ. 1759): TEXAS BOARD OF WATER ENGINEERS MISCELLANEOUS PUBLICATION 171, 1937.

WATER TABLE SURVEY IN THE LOWER RIO GRANDE VALLEY, PART 2-CAMERON COUNTY W.I.D. NO. 2 (WPA PROJ. 1759): TEXAS BOARD OF WATER ENGINEERS MISCELLANEOUS PUBLICATION 173, 1937.

A FEW NOTES REGARDING GROUND WATER IN BROWNSVILLESAN BENITO-LA FERIA DISTRICT, TEXAS: USGS OPEN-FILE REPORT (UNNUMBERED), 1941.

WATER SUPPLY OF BROWNSVILLE, CAMERON COUNTY, TEXAS: USGS OPEN-FILE REPORT (UNNUMBERED), 1941.

SUPPLEMENTAL REPORT ON WATER SUPPLY OF BROWNSVILLE, CAMERON COUNTY, TEXAS; USGS OPEN-FILE REPORT (UNNUMBERED), 1941.

GROUND WATER IN LOWER RIO GRANDE VALLEY: USGS OPENFILE REPORT (UNNUMBERED), 1945.

GROUND-WATER DEVELOPMENT IN CAMERON COUNTY-BELT OF GOOD WATER ALONG RIO GRANDE: USGS OPEN-FILE REPORT (UNNUMBERED), 1945.

PUBLIC WATER SUPPLIES IN SOUTHERN TEXAS: USGS WATERSUPPLY PAPER 1070, 1950.

INVESTIGATION OF GROUND-WATER CONDITIONS IN HIDALGO, CAMERON, AND WILLACY COUNTIES IN THE LOWER RIO GRANDE VALLEY OF TEXAS: CONSULTING REPORT BY NICHOLAS A. ROSE, HOUSTON, TEXAS, 1954.

AVAILABILITY OF GROUND WATER IN THE GULF COAST REGION OF TEXAS: USGS OPEN-FILE REPORT (UNNUMBERED), 1956.

MEMORANDUM ON PUMPING TESTS CONDUCTED ON WELLS OWNED BY THE CITY OF HARLINGEN, TEXAS: USGS OPEN-FILE REPORT (UNNUMBERED), 1957.

RECONNAISSANCE INVESTIGATION OF THE GROUND-WATER RESOURCES OF THE GULF COAST REGION, TEXAS: TEXAS WATER COMMISSION BULLETIN 6305, 1963.

SUMMARY OF THE GROUND-WATER AQUIFERS IN THE RIO GRANDE BASIN: TEXAS WATER COMMISSION CIRCULAR 63-05, 1963.

GROUND-WATER RESOURCES OF THE LOWER RIO GRANDE VALLEY AREA, TEXAS: USGS WATER-SUPPLY PAPER 1653, 1964.

RECONNAISSANCE INVESTIGATIONS OF THE GROUND-WATER RESOURCES OF THE RIO GRANDE BASIN, TEXAS: TEXAS WATER COMMISSION BULLETIN 6502, 1965.

GROUND-WATER RESOURCES OF CAMERON COUNTY, TEXAS: TEXAS BOARD OF WATER ENGINEERS BULLETIN 5403, 1954.

AVAILABILITY OF GROUND WATER IN THE GULF COAST REGION OF TEXAS: USGS OPEN-FILE REPORT (UNNUMBERED), 1956.

WATER LEVELS IN OBSERVATION WELLS IN CAMERON, HIDALGO, AND STARR COUNTIES, TEXAS, 1950-1959, 1960.
GROUND-WATER RESOURCES OF THE LOWER RIO GRANDE VALLEY AREA, TEXAS, VOLUME 1: TEXAS BOARD OF WATER ENGINEERS BULLETIN 6014, V. 1, 1961.

GROUND-WATER RESOURCES OF THE LOWER RIO GRANDE VALLEY AREA, TEXAS, VOLUME 2, RECORDS OF WELLS, DRILLERS' LOGS, WATER LEVELS IN WELLS, AND CHEMICAL ANALYSES OF WATER: TEXAS BOARD OF WATER ENGINEERS BULLETIN 6014, V. 2, 1961.

WATER-SUPPLY LIMITATIONS ON IRRIGATION FROM THE RIO GRANDE IN STARR, HIDALGO, CAMERON AND WILLACY COUNTIES, TEXAS: TEXAS WATER COMMISSION BULLETIN 6413, 1964.

APPENDICES TO BULLETIN 6413, WATER-SUPPLY LIMITATIONS ON IRRIGATION FROM THE RIO GRANDE IN STARR, HIDALGO, CAMERON, AND WILLACY COUNTIES, TEXAS, TEXAS: TEXAS WATER COMMISSION BULLETIN 6413A, 1965.

COMPILATION OF RESULTS OF AQUIFER TESTS IN TEXAS: TEXAS WATER DEVELOPMENT BOARD REPORT 98, 1969.

RECONNAISSANCE INVESTIGATION OF GROUND WATER IN THE RIO GRANDE DRAINAGE BASIN-WITH SPECIAL EMPHASIS ON SALINE GROUND-WATER RESOURCES: USGS HYDROLOGIC ATLAS HA-510, 1974.

STRATIGRAPHIC AND HYDROGEOLOGIC FRAMEWORK OF PART OF THE COASTAL PLAIN OF TEXAS: TEXAS DEPARTMENT OF WATER RESOURCES REPORT 236, 1979.

LAND-SURFACE SUBSIDENCE IN THE TEXAS COASTAL REGION: USGS OPEN-FILE REPORT 80-969, 1980.

SPRINGS OF TEXAS, VOLUME 1: (BY GUNNAR BRUNE), BRANCHSMITH, INC., FORT WORTH, TEXAS, 1981.

LAND-SURFACE SUBSIDENCE IN THE TEXAS COASTAL REGION: TEXAS DEPARTMENT OF WATER RESOURCES REPORT 272, 1982

OCCURRENCE AND QUALITY OF GROUND WATER IN THE VICINITY OF BROWNSVILLE, TEXAS: TEXAS DEPARTMENT OF WATER RESOURCES REPORT 279, 1983.

WATER USE, PROJECTED WATER REQUIREMENTS, AND RELATED DATA AND INFORMATION FOR THE METROPOLITAN STATISTICAL AREAS IN TEXAS: TEXAS DEPARTMENT OF WATER RESOURCES LIMITED PRINTING REPORT LP-201, 1985.

TEXAS GROUND-WATER RESOURCES, in NATIONAL WATER SUMMARY 1984: USGS WATER-SUPPLY PAPER 2275, 1985.

GEOHYDROLOGIC FRAMEWORK OF THE GULF COASTAL PLAIN: USGS HYDROLOGIC ATLAS HA-695, 1988.

EVALUATION OF GROUND-WATER RESOURCES IN THE LOWER RIO GRANDE VALLEY, TEXAS: TEXAS WATER DEVELOPMENT BOARD REPORT 316, 1990.

PROPERTIES AND CHEMICAL CONSTITUENTS IN GROUND WATER FROM THE MISSISSIPPI RIVER VALLEY ALLUVIAL AQUIFER AND PERMEABLE ZONE A (HOLOCENE-UPPER PLEISTOCENE DEPOSITS), SOUTH-CENTRAL UNITED STATES: USGS WATERRESOURCES INVESTIGATIONS REPORT 91-4149, 1992.

PROPERTIES AND CHEMICAL CONSTITUENTS IN GROUND WATER FROM PERMEABLE ZONE C (LOWER PLIOCENE-UPPER MIOCENE DEPOSITS), COASTAL LOWLANDS AQUIFER SYSTEM, SOUTHCENTRAL UNITED STATES: USGS WATER-RESOURCES INVESTIGATIONS REPORT 91-4151, 1993. 
PROPERTIES AND CHEMICAL CONSTITUENTS IN GROUND WATER FROM PERMEABLE ZONE B (LOWER PLEISTOCENE-UPPER PLIOCENE DEPOSITS), COASTAL LOWLANDS AQUIFER SYSTEM, SOUTH-CENTRAL UNITED STATES: USGS WATER-RESOURCES INVESTIGATIONS REPORT 91-4152, 1993.

PROPERTIES AND CHEMICAL CONSTITUENTS IN GROUND WATER FROM PERMEABLE ZONE E (LOWER MIOCENE-UPPER OLIGOCENE DEPOSITS), COASTAL LOWLANDS AQUIFER SYSTEM, SOUTH-CENTRAL UNITED STATES: USGS WATER-RESOURCES INVESTIGATIONS REPORT 92-4103, 1993.

PROPERTIES AND CHEMICAL CONSTITUENTS IN GROUND WATER FROM PERMEABLE ZONE D (MIDDLE MIOCENE DEPOSITS), COASTAL LOWLANDS AQUIFER SYSTEM, SOUTH-CENTRAL UNITED STATES: USGS WATER-RESOURCES INVESTIGATIONS REPORT 92-4105, 1993.

AQUIFERS OF TEXAS: TEXAS WATER DEVELOPMENT BOARD REPORT 345, 1995.

\section{CAMP COUNTY}

GEOLOGY AND UNDERGROUND WATERS OF NORTHEASTERN TEXAS: USGS WATER-SUPPLY PAPER 276, 1911.

RECORDS OF WELLS, SPRINGS, DRILLERS' LOGS, WATER ANALYSES, AND MAP SHOWING LOCATIONS OF WELLS AND SPRINGS IN CAMP, FRANKLIN, AND TITUS COUNTIES, TEXAS: TEXAS BOARD OF WATER ENGINEERS MISCELLANEOUS PUBLICATION $30,1943$.

PUBLIC WATER SUPPLIES IN EASTERN TEXAS: USGS WATERSUPPLY PAPER 1047, 1948.

RECONNAISSANCE INVESTIGATION OF THE GROUND-WATER RESOURCES OF THE RED RIVER, SULPHUR RIVER, AND CYPRESS CREEK BASINS, TEXAS: TEXAS WATER COMMISSION BULLETIN 6306, 1963.

GROUND-WATER RESOURCES OF CAMP, FRANKLIN, MORRIS, AND TITUS COUNTIES, TEXAS: TEXAS WATER COMMISSION BULLETIN 6517, 1965.

COMPILATION OF RESULTS OF AQUIFER TESTS IN TEXAS: TEXAS WATER DEVELOPMENT BOARD REPORT 98, 1969.

WATER-QUALITY DATA FOR AQUIFERS, STREAMS, AND LAKES IN THE VICINITY OF KEECHI, MOUNT SYLVAN, OAKWOOD, AND PALESTINE SALT DOMES, NORTHEAST TEXAS SALT-DOME BASIN: USGS OPEN-FILE REPORT 80-2037, 1980

GEOHYDROLOGY OF THE KEECHI, MOUNT SYLVAN, OAKWOOD, AND PALESTINE SALT DOMES IN THE NORTHEAST TEXAS SALTDOME BASIN: USGS OPEN-FILE REPORT 80-2044, 1980.

GEOLOGY AND GEOHYDROLOGY OF THE EAST TEXAS BASIN-A REPORT ON THE PROGRESS OF NUCLEAR WASTE ISOLATION FEASIBILITY STUDIES (1979): UNIVERSITY OF TEXAS, BUREAU OF ECONOMIC GEOLOGY GEOLOGICAL CIRCULAR 80-12, 1980.

GEOLOGY AND GEOHYDROLOGY OF THE EAST TEXAS BASIN-A REPORT ON THE PROGRESS OF NUCLEAR WASTE ISOLATION FEASIBILITY STUDIES (1980): UNIVERSITY OF TEXAS, BUREAU OF ECONOMIC GEOLOGY GEOLOGICAL CIRCULAR 81-7, 1981.

SPRINGS OF TEXAS, VOLUME 1: (BY GUNNAR BRUNE), BRANCHSMITH, INC., FORT WORTH, TEXAS, 1981.
TEXAS GROUND-WATER RESOURCES, in NATIONAL WATER SUMMARY 1984: USGS WATER-SUPPLY PAPER 2275, 1985.

APPROXIMATE POTENTIOMETRIC SURFACES FOR THE AQUIFERS OF THE TEXAS COASTAL UPLANDS SYSTEM, 1980: USGS HYDROLOGIC ATLAS HA-704, 1987.

GEOHYDROLOGIC FRAMEWORK OF THE GULF COASTAL PLAIN: USGS HYDROLOGIC ATLAS HA-695, 1988.

PROPERTIES AND CHEMICAL CONSTITUENTS IN GROUND WATER FROM THE LOWER CLAIBORNE-UPPER WILCOX AQUIFER, GULF COAST REGIONAL AQUIFER SYSTEMS, SOUTH-CENTRAL UNITED STATES: USGS WATER-RESOURCES INVESTIGATIONS REPORT 92-4102, 1993

PROPERTIES AND CHEMICAL CONSTITUENTS IN GROUND WATER FROM THE MIDDLE CLAIBORNE AQUIFER, GULF COAST REGIONAL AQUIFER SYSTEMS, SOUTH-CENTRAL UNITED STATES: USGS WATER-RESOURCES INVESTIGATIONS REPORT 92-4104, 1993.

PROPERTIES AND CHEMICAL CONSTITUENTS IN GROUND WATER FROM THE MIDDLE WILCOX AQUIFER, GULF COAST REGIONAL AQUIFER SYSTEMS, SOUTH-CENTRAL UNITED STATES: USGS WATER-RESOURCES INVESTIGATIONS REPORT 93-4070, 1993.

WATER-RESOURCES DATA, TEXAS, WATER YEAR 1992, VOLUME 4, GROUND-WATER DATA: USGS WATER-DATA REPORT TX-92-4, 1993.

AQUIFERS OF TEXAS: TEXAS WATER DEVELOPMENT BOARD REPORT 345, 1995.

STRATIGRAPHIC NOMENCLATURE AND GEOLOGIC SECTIONS OF THE GULF COASTAL PLAIN OF TEXAS: USGS OPEN-FILE REPORT 94-461, 1995.

WATER QUALITY IN THE QUEEN CITY AQUIFER, EAST TEXAS: TEXAS WATER DEVELOPMENT BOARD HYDROLOGIC ATLAS NO. 6, 1996.

\section{CARSON COUNTY}

THE GEOLOGY AND WATER RESOURCES OF THE EASTERN PORTION OF THE PANHANDLE OF TEXAS: USGS WATER-SUPPLY PAPER 154, 1906.

GEOLOGY AND GROUND-WATER RESOURCES OF THE SOUTHERN HIGH PLAINS: USGS OPEN-FILE REPORT (UNNUMBERED), 1935.

GROUND WATER IN THE SOUTHERN HIGH PLAINS: USGS OPENFILE REPORT (UNNUMBERED), 1937.

GROUND WATER IN THE HIGH PLAINS OF TEXAS: TEXAS BOARD OF WATER ENGINEERS MISCELLANEOUS PUBLICATION (UNNUMBERED), 1938.

RECORDS OF WELLS, DRILLERS' LOGS, WATER ANALYSES, AND MAP SHOWING LOCATION OF WELLS AND SPRINGS IN CARSON COUNTY, TEXAS: TEXAS BOARD OF WATER ENGINEERS MISCELLANEOUS PUBLICATION 32, 1939.

GROUND WATER IN THE HIGH PLAINS OF TEXAS: TEXAS BOARD OF WATER ENGINEERS MISCELLANEOUS PUBLICATION 119, 1940.

PROGRESS REPORT ON GROUND WATER IN THE HIGH PLAINS OF TEXAS: TEXAS BOARD OF WATER ENGINEERS MISCELLANEOUS PUBLICATION (UNNUMBERED), 1942. 
PROGRESS REPORT ON GROUND WATER IN THE HIGH PLAINS OF TEXAS: TEXAS BOARD OF WATER ENGINEERS MISCELLANEOUS PUBLICATION 120, 1943.

PROGRESS REPORT ON GROUND WATER IN THE HIGH PLAINS OF TEXAS: TEXAS BOARD OF WATER ENGINEERS MISCELLANEOUS PUBLICATION 121, 1944.

GROUND WATER IN THE HIGH PLAINS OF TEXAS, PROGRESS REPORT NO. 5: TEXAS BOARD OF WATER ENGINEERS MISCELLANEOUS PUBLICATION 122, 1945.

GROUND WATER IN THE HIGH PLAINS OF TEXAS: USGS WATERSUPPLY PAPER 889-F, 1946.

GROUND WATER IN HIGH PLAINS OF TEXAS, PROGRESS REPORT NO. 6: TEXAS BOARD OF WATER ENGINEERS MISCELLANEOUS PUBLICATION 123, 1947.

GEOLOGY AND GROUND WATER IN THE IRRIGATED REGION OF THE SOUTHERN HIGH PLAINS IN TEXAS, PROGRESS REPORT NO 7: TEXAS BOARD OF WATER ENGINEERS MISCELLANEOUS PUBLICATION 125, 1949.

COST OF PUMPING WATER FOR IRRIGATION, TEXAS HIGH PLAINS, FIELD INVESTIGATIONS-1947 IRRIGATION SEASON: TEXAS BOARD OF WATER ENGINEERS MISCELLANEOUS PUBLICATION 124,1951

PUBLIC WATER SUPPLIES IN WESTERN TEXAS: USGS WATERSUPPLY PAPER 1106, 1951 [1952].

DEVELOPMENT OF WELLS FOR IRRIGATION AND FLUCTUATION OF WATER LEVELS IN THE HIGH PLAINS OF TEXAS TO JANUARY 1951: TEXAS BOARD OF WATER ENGINEERS BULLETIN 5104, 1951.

SUMMARY OF GROUND-WATER DEVELOPMENT IN THE SOUTHERN HIGH PLAINS, TEXAS: TEXAS BOARD OF WATER ENGINEERS BULLETIN 5402, 1954.

GROUND-WATER DEVELOPMENT IN THE SOUTHERN HIGH PLAINS OF TEXAS, 1953: TEXAS BOARD OF WATER ENGINEERS BULLETIN 5410, 1954.

WATER-LEVEL DECLINE MAPS, 1956 TO 1957, AND WATER LEVELS IN OBSERVATION WELLS IN 20 COUNTIES IN THE SOUTHERN HIGH PLAINS OF TEXAS: TEXAS BOARD OF WATER ENGINEERS BULLETIN 5705, 1957.

GROUND-WATER CONDITIONS IN CARSON COUNTY, TEXAS: TEXAS BOARD OF WATER ENGINEERS BULLETIN 5802, 1958.

WATER-LEVEL MEASUREMENTS AND MAPS, SOUTHERN HIGH PLAINS, TEXAS, 1958 AND 1959: TEXAS BOARD OF WATER ENGINEERS BULLETIN 5908, 1959.

WATER LEVELS IN OBSERVATION WELLS, SOUTHERN HIGH PLAINS, TEXAS, 1959 AND 1960: TEXAS BOARD OF WATER ENGINEERS BULLETIN 6011, 1960.

RECONNAISSANCE INVESTIGATION OF THE GROUND-WATER RESOURCES OF THE CANADIAN RIVER BASIN, TEXAS: TEXAS BOARD OF WATER ENGINEERS BULLETIN 6016, 1960.

WATER LEVELS IN OBSERVATION WELLS, SOUTHERN HIGH PLAINS, TEXAS, 1960 AND 1961: TEXAS BOARD OF WATER ENGINEERS BULLETIN 6101, 1961.

GEOLOGY AND GROUND-WATER RESOURCES OF CARSON COUNTY AND PART OF GRAY COUNTY, TEXAS, PROGRESS
REPORT NO. 1: TEXAS BOARD OF WATER ENGINEERS BULLETIN 6102, 1961.

A SUMMARY OF THE OCCURRENCE AND DEVELOPMENT OF GROUND WATER IN THE SOUTHERN HIGH PLAINS OF TEXAS: TEXAS BOARD OF WATER ENGINEERS BULLETIN 6107, 1961.

WATER-LEVEL MEASUREMENTS THROUGH 1962 IN SELECTED OBSERVATION WELLS, SOUTHERN HIGH PLAINS, TEXAS: TEXAS WATER COMMISSION BULLETIN 6207, 1962.

RECONNAISSANCE INVESTIGATION OF THE GROUND-WATER RESOURCES OF THE RED RIVER, SULPHUR RIVER, AND CYPRESS CREEK BASINS, TEXAS: TEXAS WATER COMMISSION BULLETIN 6306, 1963.

A SUMMARY OF THE OCCURRENCE AND DEVELOPMENT OF GROUND WATER IN THE SOUTHERN HIGH PLAINS OF TEXAS: USGS WATER-SUPPLY PAPER 1693, 1964.

PUBLIC WATER SUPPLIES OF THE 100 LARGEST CITIES IN THE UNITED STATES: USGS WATER-SUPPLY PAPER 1812, 1964

GEOLOGY AND GROUND-WATER RESOURCES OF CARSON AND PART OF GRAY COUNTY, TEXAS, PROGRESS REPORT NO. 2: TEXAS WATER COMMISSION BULLETIN 6402, 1964.

WATER-LEVEL DATA FROM OBSERVATION WELLS IN THE SOUTHERN HIGH PLAINS OF TEXAS: TEXAS WATER DEVELOPMENT BOARD REPORT 21, 1966.

GROUND WATER IN THE OGALLALA FORMATION IN THE SOUTHERN HIGH PLAINS OF TEXAS AND OKLAHOMA: USGS HYDROLOGIC INVESTIGATIONS ATLAS HA-330, 1969.

WATER-LEVEL DATA FROM OBSERVATION WELLS IN THE SOUTHERN HIGH PLAINS OF TEXAS, 1965-70: TEXAS WATER DEVELOPMENT BOARD REPORT 121, 1970 .

ARTIFICIAL-RECHARGE EXPERIMENTS AND OPERATIONS ON THE SOUTHERN HIGH PLAINS OF TEXAS AND NEW MEXICO: USGS WATER-RESOURCES INVESTIGATIONS REPORT 10-73, 1973

WATER-LEVEL DATA FROM OBSERVATION WELLS IN THE SOUTHERN HIGH PLAINS OF TEXAS, 1971-77, 1979.

ANALYTICAL STUDY OF THE OGALLALA AQUIFER IN CARSON COUNTY, TEXAS_PROJECTIONS OF SATURATED THICKNESS, VOLUME OF WATER IN STORAGE, PUMPAGE RATES, PUMPING LIFTS, AND WELL YIELDS: TEXAS DEPARTMENT OF WATER RESOURCES REPORT 242, 1979.

PRELIMINARY DATA DESCRIBING THE DISTRIBUTION OF FLUORIDE AND SILICA IN THE OGALLALA AQUIFER ON THE HIGH PLAINS OF TEXAS: USGS OPEN-FILE REPORT 80-349, 1980.

WATER TABLE IN THE HIGH PLAINS AQUIFER IN 1978 IN PARTS OF COLORADO, KANSAS, NEBRASKA, NEW MEXICO, OKLAHOMA, SOUTH DAKOTA, TEXAS, AND WYOMING: USGS HYDROLOGIC INVESTIGATIONS ATLAS HA-642, 1980.

EVALUATING THE GROUND-WATER RESOURCES OF THE HIGH PLAINS OF TEXAS: RESULTS OF TEST HOLE DRILLING: TEXAS DEPARTMENT OF WATER RESOURCES LIMITED PRINTING REPORT LP-129, 1980.

EVALUATING THE GROUND-WATER RESOURCES OF THE HIGH PLAINS OF TEXAS: RESULTS OF SURFACE ELECTRICAL RESISTIVITY: TEXAS DEPARTMENT OF WATER RESOURCES LIMITED PRINTING REPORT LP-130, 1980. 
EVALUATING THE GROUND-WATER RESOURCES OF THE HIGH PLAINS OF TEXAS: NEUTRON-PROBE MEASUREMENTS OF DEEP SOIL MOISTURE AS AN INDICATION OF AQUIFER RECHARGE RATES: TEXAS DEPARTMENT OF WATER RESOURCES REPORT LP-142, 1981.

SPRINGS OF TEXAS, VOLUME 1: (BY GUNNAR BRUNE), BRANCHSMITH, INC., FORT WORTH, TEXAS, 1981.

BEDROCK GEOLOGY, ALTITUDE OF BASE, AND 1980 SATURATED THICKNESS OF THE HIGH PLAINS AQUIFER IN PARTS OF COLORADO, KANSAS, NEBRASKA, NEW MEXICO, OKLAHOMA, SOUTH DAKOTA, TEXAS, AND WYOMING: USGS HYDROLOGIC INVESTIGATIONS ATLAS HA-648, 1981.

WATER-LEVEL AND SATURATED-THICKNESS CHANGES, PREDEVELOPMENT TO 1980, IN THE HIGH PLAINS AQUIFER IN PARTS OF COLORADO, KANSAS, NEBRASKA, NEW MEXICO, OKLAHOMA, SOUTH DAKOTA, TEXAS, AND WYOMING: USGS HYDROLOGIC INVESTIGATIONS ATLAS HA-652, 1981.

DISSOLVED SOLIDS AND SODIUM IN WATER FROM THE HIGH PLAINS AQUIFER IN PARTS OF COLORADO, KANSAS, NEBRASKA, NEW MEXICO, OKLAHOMA, SOUTH DAKOTA, TEXAS, AND WYOMING: USGS HYDROLOGIC INVESTIGATIONS ATLAS HA-658, 1982.

INVESTIGATION OF SECONDARY RECOVERY OF GROUND WATER FROM THE OGALLALA FORMATION, HIGH PLAINS OF TEXASSUMMARY OF STUDY: HIGH PLAINS UNDERGROUND WATER CONSERVATION DISTRICT NO. 1, LUBBOCK, TEXAS, 1982.

GEOHYDROLOGY OF THE HIGH PLAINS AQUIFER IN PARTS OF COLORADO, KANSAS, NEBRASKA, NEW MEXICO, OKLAHOMA, SOUTH DAKOTA, TEXAS, AND WYOMING: USGS PROFESSIONAL PAPER 1400-B, 1984.

EVALUATING THE GROUND-WATER RESOURCES OF THE HIGH PLAINS OF TEXAS, VOLUME 1: TEXAS DEPARTMENT OF WATER RESOURCES REPORT 288, V. 1, 1984.

EVALUATING THE GROUND-WATER RESOURCES OF THE HIGH PLAINS OF TEXAS, VOLUME 2, RECORDS OF WELLS, AND MAPS SHOWING WELL LOCATIONS, BASE OF AQUIFER, WATER LEVELS, AND SATURATED THICKNESS (ARMSTRONG, CARSON, DALLAS, DONLEY, GRAY, HANSFORD, HARTLEY, HEMPHILL, HUTCHINSON, LIPSCOMB, MOORE, OCHILTREE, POTTER, ROBERTS, SHERMAN, AND WHEELER COUNTIES): TEXAS DEPARTMENT OF WATER RESOURCES REPORT 288, V. 2, 1984.

TEXAS GROUND-WATER RESOURCES, in NATIONAL WATER SUMMARY 1984: USGS WATER-SUPPLY PAPER 2275, 1985.

DIGITAL SIMULATION OF GROUND-WATER FLOW IN THE HIGH PLAINS AQUIFER IN PARTS OF COLORADO, KANSAS, NEBRASKA, NEW MEXICO, OKLAHOMA, SOUTH DAKOTA, TEXAS, AND WYOMING: USGS PROFESSIONAL PAPER 1400-D, 1986.

SUMMARY OF THE HIGH PLAINS REGIONAL AQUIFER-SYSTEM ANALYSIS IN PARTS OF COLORADO, KANSAS, NEBRASKA, NEW MEXICO, OKLAHOMA, SOUTH DAKOTA, TEXAS, AND WYOMING: USGS PROFESSIONAL PAPER 1400-A, 1988.

PUBLIC SUPPLY GROUND-WATER USE IN THE SOUTHERN HIGH PLAINS OF TEXAS: TEXAS WATER DEVELOPMENT BOARD REPORT 328, 1990.

WATER-LEVEL CHANGES IN THE HIGH PLAINS AQUIFER OF TEXAS, 1980-1990: TEXAS WATER DEVELOPMENT BOARD HYDROLOGIC ATLAS NO. 1, 1991.
PUBLIC-SUPPLY GROUND-WATER USE IN THE NORTHERN HIGH PLAINS OF TEXAS: TEXAS WATER DEVELOPMENT BOARD REPORT 336, 1992.

THE HIGH PLAINS AQUIFER SYSTEM OF TEXAS, 1980-1990. OVERVIEW AND PROJECTIONS: TEXAS WATER DEVELOPMENT BOARD REPORT 341, 1993.

WATER-QUALITY EVALUATION OF THE OGALLALA AQUIFER, TEXAS: TEXAS WATER DEVELOPMENT BOARD REPORT 342, 1993.

WATER-LEVEL CHANGES IN THE HIGH PLAINS AQUIFER-PREDEVELOPMENT TO 1992: USGS WATER-RESOURCES INVESTIGATIONS REPORT 94-4027, 1994.

WATER-LEVEL CHANGES IN THE HIGH PLAINS AQUIFER, 1980 TO 1994: USGS FACT SHEET FS-215-95, 1995.

AQUIFERS OF TEXAS: TEXAS WATER DEVELOPMENT BOARD REPORT 345, 1995.

WATER-LEVEL CHANGES IN THE HIGH PLAINS AQUIFER, 1980 TO 1995: USGS FACT SHEET FS-068-97, 1997.

WATER-LEVEL CHANGES IN THE HIGH PLAINS AQUIFER-PREDEVELOPMENT TO 1995: USGS WATER-RESOURCES INVESTIGATIONS REPORT 97-4081, 1997.

PLAYAS AND RECHARGE OF THE OGALLALA AQUIFER ON THE SOUTHERN HIGH PLAINS OF TEXAS-AN EXAMINATION USING NUMERICAL TECHNIQUES: UNIVERSITY OF TEXAS, BUREAU OF ECONOMIC GEOLOGY REPORT OF INVESTIGATIONS NO. 242, 1997.

SPATIAL VARIABILITY IN UNSATURATED FLOW BENEATH PLAYA AND ADJACENT INTERPLAYA SETTINGS AND IMPLICATIONS FOR CONTAMINANT TRANSPORT, SOUTHERN HIGH PLAINS, TEXAS: UNIVERSITY OF TEXAS, BUREAU OF ECONOMIC GEOLOGY REPORT OF INVESTIGATIONS NO. 243, 1997.

UPDATED WATER-QUALITY EVALUATION OF THE OGALLALA AQUIFER INCLUDING SELECTED METALLIC AND NON-METALLIC INORGANIC CONSTITUENTS: TEXAS WATER DEVELOPMENT BOARD HYDROLOGIC ATLAS NO. 10, 1998.

\section{CASS COUNTY}

LISTS AND ANALYSES OF MINERAL SPRINGS OF THE UNITED STATES; A PRELIMINARY STUDY: USGS BULLETIN 32, 1886.

GEOLOGY AND UNDERGROUND WATERS OF NORTHEASTERN TEXAS: USGS WATER-SUPPLY PAPER 276, 1911.

WATER SUPPLY IN THE VICINITY OF HUGHES SPRINGS, CASS COUNTY, TEXAS, AND DAINGERFIELD, MORRIS COUNTY, TEXAS: USGS OPEN-FILE REPORT (UNNUMBERED, 1941.

RECORDS OF WELLS AND SPRINGS, DRILLERS' LOGS, WATER ANALYSES, AND MAP SHOWING LOCATIONS OF WELLS AND SPRINGS IN CASS COUNTY, TEXAS: TEXAS BOARD OF WATER ENGINEERS MISCELLANEOUS PUBLICATION 33, 1942.

PUBLIC WATER SUPPLIES IN EASTERN TEXAS: USGS WATERSUPPLY PAPER 1047, 1948.

GEOHYDROLOGY OF THE PRINCIPAL WATER-BEARING FORMATIONS OF THE MISSISSIPPI EMBAYMENT (GEOLOGIC PHASE) TEXAS SECTION: USGS OPEN-FILE REPORT, 1960. 
RECONNAISSANCE INVESTIGATION OF THE RED RIVER, SULPHUR RIVER, AND CYPRESS CREEK BASINS, TEXAS: TEXAS WATER COMMISSION BULLETIN 6306, 1963.

GENERAL GEOLOGY OF THE MISSISSIPPI EMBAYMENT: USGS PROFESSIONAL PAPER 448-B, 1964.

CRETACEOUS AQUIFERS OF THE MISSISSIPPI EMBAYMENT, WITH DISCUSSIONS OF QUALITY OF THE WATER: USGS PROFESSIONAL PAPER 448-C, 1965

TERTIARY AQUIFERS OF THE MISSISSIPPI EMBAYMENT, WITH DISCUSSIONS OF QUALITY OF THE WATER: USGS PROFESSIONAL PAPER 448-D, 1968.

QUATERNARY AQUIFERS IN THE MISSISSIPPI EMBAYMENT, WITH A DISCUSSION OF QUALITY OF THE WATER: USGS PROFESSIONAL PAPER 448-E, 1968.

COMPILATION OF RESULTS OF AQUIFER TESTS IN TEXAS: TEXAS WATER DEVELOPMENT BOARD REPORT 98, 1969.

GROUND-WATER RESOURCES OF CASS AND MARION COUNTIES, TEXAS: TEXAS WATER DEVELOPMENT BOARD REPORT 135, 1971.

MAJOR AND HISTORICAL SPRINGS OF TEXAS: TEXAS WATER DEVELOPMENT BOARD REPORT 189, 1975.

SUMMARY APPRAISALS OF THE NATION'S GROUND-WATER RESOURCES-TEXAS-GULF REGION: USGS PROFESSIONAL PAPER 813-F, 1976.

SPRINGS OF TEXAS, VOLUME 1: (BY GUNNAR BRUNE), BRANCHSMITH, INC., FORT WORTH, TEXAS, 1981.

TEXAS GROUND-WATER RESOURCES, in NATIONAL WATER SUMMARY 1984: USGS WATER-SUPPLY PAPER 2275, 1985.

APPROXIMATE POTENTIOMETRIC SURFACES FOR THE AQUIFERS OF THE TEXAS COASTAL UPLANDS SYSTEM, 1980: USGS HYDROLOGIC ATLAS HA-704, 1987.

GEOHYDROLOGIC FRAMEWORK OF THE GULF COASTAL PLAIN: USGS HYDROLOGIC ATLAS HA-695, 1988.

PROPERTIES AND CHEMICAL CONSTITUENTS IN GROUND WATER FROM THE LOWER CLAIBORNE-UPPER WILCOX AQUIFER, GULF COAST REGIONAL AQUIFER SYSTEMS, SOUTH-CENTRAL UNITED STATES: USGS WATER-RESOURCES INVESTIGATIONS REPORT 92-4102, 1993

PROPERTIES AND CHEMICAL CONSTITUENTS IN GROUND WATER FROM THE MIDDLE CLAIBORNE AQUIFER, GULF COAST REGIONAL AQUIFER SYSTEMS, SOUTH-CENTRAL UNITED STATES: USGS WATER-RESOURCES INVESTIGATIONS REPORT 92-4104, 1993.

PROPERTIES AND CHEMICAL CONSTITUENTS IN GROUND WATER FROM THE MIDDLE WILCOX AQUIFER, GULF COAST REGIONAL AQUIFER SYSTEMS, SOUTH-CENTRAL UNITED STATES: USGS WATER-RESOURCES INVESTIGATIONS REPORT 93-4070, 1993.

STRATIGRAPHIC NOMENCLATURE AND GEOLOGIC SECTIONS OF THE GULF COASTAL PLAIN OF TEXAS: USGS OPEN-FILE REPORT 94-461, 1995.

AQUIFERS OF TEXAS: TEXAS WATER DEVELOPMENT BOARD REPORT 345, 1995.
WATER QUALITY IN THE QUEEN CITY AQUIFER, EAST TEXAS: TEXAS WATER DEVELOPMENT BOARD HYDROLOGIC ATLAS NO. 6, 1996.

\section{CASTRO COUNTY}

GEOLOGY AND GROUND-WATER RESOURCES OF THE SOUTHERN HIGH PLAINS: USGS OPEN-FILE REPORT (UNNUMBERED), 1935.

GROUND WATER IN THE SOUTHERN HIGH PLAINS: USGS OPENFILE REPORT (UNNUMBERED), 1937.

GROUND WATER IN THE HIGH PLAINS OF TEXAS: TEXAS BOARD OF WATER ENGINEERS MISCELLANEOUS PUBLICATION (UNNUMBERED), 1938.

RECORDS OF WELLS, DRILLERS' LOGS, AND WATER ANALYSES AND MAP SHOWING LOCATION OF WELLS IN CASTRO COUNTY, TEXAS: TEXAS BOARD OF WATER ENGINEERS MISCELLANEOUS PUBLICATION 34, 1939

GROUND WATER IN THE HIGH PLAINS OF TEXAS: TEXAS BOARD OF WATER ENGINEERS MISCELLANEOUS PUBLICATION 119, 1940.

PROGRESS REPORT ON GROUND WATER IN THE HIGH PLAINS OF TEXAS: TEXAS BOARD OF WATER ENGINEERS MISCELLANEOUS PUBLICATION (UNNUMBERED), 1942.

PROGRESS REPORT ON GROUND WATER IN THE HIGH PLAINS OF TEXAS: TEXAS BOARD OF WATER ENGINEERS MISCELLANEOUS PUBLICATION 120, 1943

PROGRESS REPORT ON GROUND WATER IN THE HIGH PLAINS OF TEXAS: TEXAS BOARD OF WATER ENGINEERS MISCELLANEOUS PUBLICATION 121, 1944

GROUND WATER IN THE HIGH PLAINS OF TEXAS, PROGRESS REPORT NO. 5: TEXAS BOARD OF WATER ENGINEERS MISCELLANEOUS PUBLICATION 122, 1945.

GROUND WATER IN THE HIGH PLAINS OF TEXAS: USGS WATERSUPPLY PAPER 889-F, 1946

GROUND WATER IN HIGH PLAINS IN TEXAS, PROGRESS REPORT NO. 6: TEXAS BOARD OF WATER ENGINEERS MISCELLANEOUS PUBLICATION 123, 1947.

GEOLOGY AND GROUND WATER IN THE IRRIGATED REGION OF THE SOUTHERN HIGH PLAINS IN TEXAS, PROGRESS REPORT NO. 7: TEXAS BOARD OF WATER ENGINEERS MISCELLANEOUS PUBLICATION 125, 1949.

COST OF PUMPING WATER FOR IRRIGATION, TEXAS HIGH PLAINS, FIELD INVESTIGATIONS-1947 IRRIGATION SEASON: TEXAS BOARD OF WATER ENGINEERS MISCELLANEOUS PUBLICATION 124,1951

PUBLIC WATER SUPPLIES IN WESTERN TEXAS: USGS WATERSUPPLY PAPER 1106, 1951 [1952].

DEVELOPMENT OF WELLS FOR IRRIGATION AND FLUCTUATION OF WATER LEVELS IN THE HIGH PLAINS OF TEXAS TO JANUARY 1951: TEXAS BOARD OF WATER ENGINEERS BULLETIN 5104, 1951.

SUMMARY OF GROUND-WATER DEVELOPMENT IN THE SOUTHERN HIGH PLAINS, TEXAS: TEXAS BOARD OF WATER ENGINEERS BULLETIN 5402, 1954 
RECORDS OF WATER-LEVEL MEASUREMENTS IN BAILEY, BRISCOE, CASTRO, PARMER, POTTER, AND RANDALL COUNTIES, TEXAS: TEXAS BOARD OF WATER ENGINEERS BULLETIN 5406, 1954.

GROUND-WATER DEVELOPMENT IN THE SOUTHERN HIGH PLAINS OF TEXAS, 1953: TEXAS BOARD OF WATER ENGINEERS BULLETIN 5410, 1954.

WATER-LEVEL DECLINE MAPS OF 17 COUNTIES IN THE SOUTHERN HIGH PLAINS, TEXAS, JANUARY 1955 TO JANUARY 1956: TEXAS BOARD OF WATER ENGINEERS BULLETIN 5607, 1956.

WATER-LEVEL DECLINE MAPS, 1956 TO 1957, AND WATER LEVELS IN OBSERVATION WELLS IN 20 COUNTIES IN THE SOUTHERN HIGH PLAINS, TEXAS: TEXAS BOARD OF WATER ENGINEERS BULLETIN 5705, 1957.

WATER-LEVEL MEASUREMENTS AND MAPS, SOUTHERN HIGH PLAINS, TEXAS, 1958 AND 1959: TEXAS BOARD OF WATER ENGINEERS BULLETIN 5908, 1959.

WATER LEVELS IN OBSERVATION WELLS, SOUTHERN HIGH PLAINS, TEXAS, 1959 AND 1960, TEXAS BOARD OF WATER ENGINEERS BULLETIN 6011, 1960.

WATER LEVELS IN OBSERVATION WELLS, SOUTHERN HIGH PLAINS, TEXAS, 1960 AND 1961: TEXAS BOARD OF WATER ENGINEERS BULLETIN 6101, 1961.

A SUMMARY OF THE OCCURRENCE AND DEVELOPMENT OF GROUND WATER IN THE SOUTHERN HIGH PLAINS OF TEXAS: TEXAS BOARD OF WATER ENGINEERS BULLETIN 6107, 1961.

WATER-LEVEL MEASUREMENTS THROUGH 1962 IN SELECTED OBSERVATION WELLS, SOUTHERN HIGH PLAINS, TEXAS: TEXAS WATER COMMISSION BULLETIN 6207, 1962.

RECONNAISSANCE INVESTIGATION OF THE GROUND-WATER RESOURCES OF THE RED RIVER, SULPHUR RIVER, AND CYPRESS CREEK BASINS, TEXAS: TEXAS WATER COMMISSION BULLETIN 6306, 1963.

RECONNAISSANCE INVESTIGATION OF THE GROUND-WATER RESOURCES OF THE BRAZOS RIVER BASIN, TEXAS: TEXAS WATER COMMISSION BULLETIN 6310, 1963.

A SUMMARY OF THE OCCURRENCE AND DEVELOPMENT OF GROUND WATER IN THE SOUTHERN HIGH PLAINS OF TEXAS: USGS WATER-SUPPLY PAPER 1693, 1964.

WATER-LEVEL DATA FROM OBSERVATION WELLS IN THE SOUTHERN HIGH PLAINS OF TEXAS: TEXAS WATER DEVELOPMENT BOARD REPORT 21, 1966.

COMPILATION OR RESULTS OF AQUIFER TESTS IN TEXAS: TEXAS WATER DEVELOPMENT BOARD REPORT 98, 1969.

GROUND WATER IN THE OGALLALA FORMATION IN THE SOUTHERN HIGH PLAINS OF TEXAS AND NEW MEXICO: USGS HYDROLOGIC INVESTIGATIONS ATLAS HA-330, 1969.

WATER-LEVEL DATA FROM OBSERVATION WELLS IN THE SOUTHERN HIGH PLAINS OF TEXAS, 1965-70: TEXAS WATER DEVELOPMENT BOARD REPORT 121, 1970.

AN EVALUATION OF THE USE OF DRILLERS' LOGS IN LITHOLOGIC STUDIES OF THE OGALLALA FORMATION OF THE SOUTHERN HIGH PLAINS OF TEXAS: USGS OPEN-FILE REPORT 72-451, 1972.

ANALYTICAL STUDY OF THE OGALLALA AQUIFER IN CASTRO COUNTY, TEXAS—PROJECTIONS OF SATURATED THICKNESS,
VOLUME OF WATER IN STORAGE, PUMPAGE RATES, PUMPAGE LIFTS, AND WELL YIELDS: TEXAS WATER DEVELOPMENT BOARD REPORT 206, 1976.

WATER-LEVEL DATA FROM OBSERVATION WELLS IN THE SOUTHERN HIGH PLAINS OF TEXAS, 1971-77: TEXAS DEPARTMENT OF WATER RESOURCES REPORT 228, 1979.

PRELIMINARY DATA DESCRIBING THE DISTRIBUTION OF FLUORIDE AND SILICA IN THE OGALLALA AQUIFER ON THE HIGH PLAINS OF TEXAS: USGS OPEN-FILE REPORT 80-349, 1980.

EVALUATING THE GROUND-WATER RESOURCES OF THE HIGH PLAINS OF TEXAS: RESULTS OF TEST HOLE DRILLING: TEXAS DEPARTMENT OF WATER RESOURCES LIMITED PRINTING REPORT LP-129, 1980.

EVALUATING THE GROUND-WATER RESOURCES OF THE HIGH PLAINS OF TEXAS: RESULTS OF SURFACE ELECTRICAL RESISTIVITY SURVEYS: TEXAS DEPARTMENT OF WATER RESOURCES LIMITED PRINTING REPORT LP-130, 1980.

EVALUATING THE GROUND-WATER RESOURCES OF THE HIGH PLAINS OF TEXAS: NEUTRON-PROBE MEASUREMENTS OF DEEP SOIL MOISTURE AS AN INDICATION OF AQUIFER RECHARGE RATES: TEXAS DEPARTMENT OF WATER RESOURCES LIMITED PRINTING REPORT LP-142, 1981.

SPRINGS OF TEXAS, VOLUME 1: (BY GUNNAR BRUNE), BRANCHSMITH, INC., FORT WORTH, TEXAS, 1981.

BEDROCK GEOLOGY, ALTITUDE OF BASE, AND 1980 SATURATED THICKNESS OF THE HIGH PLAINS AQUIFER IN PARTS OF COLORADO, KANSAS, NEBRASKA, NEW MEXICO, OKLAHOMA, SOUTH DAKOTA, TEXAS, AND WYOMING: USGS HYDROLOGIC INVESTIGATIONS ATLAS HA-648, 1981.

WATER LEVEL AND SATURATED THICKNESS CHANGES, PREDEVELOPMENT TO 1980, IN THE HIGH PLAINS AQUIFER IN PARTS OF COLORADO, KANSAS, NEBRASKA, NEW MEXICO, OKLAHOMA, SOUTH DAKOTA, TEXAS, AND WYOMING: USGS HYDROLOGIC INVESTIGATIONS ATLAS HA-652, 1981.

DISSOLVED SOLIDS AND SODIUM IN WATER FROM THE HIGH PLAINS AQUIFER IN PARTS OF COLORADO, KANSAS, NEBRASKA, NEW MEXICO, OKLAHOMA, SOUTH DAKOTA, TEXAS, AND WYOMING: USGS HYDROLOGIC INVESTIGATIONS ATLAS HA-658, 1982.

EVALUATING THE GROUND-WATER RESOURCES OF THE HIGH PLAINS OF TEXAS, VOLUME 1: TEXAS DEPARTMENT OF WATER RESOURCES REPORT 288, V. 1, 1984.

EVALUATING THE GROUND-WATER RESOURCES OF THE HIGH PLAINS OF TEXAS, VOLUME 3, RECORDS OF WELLS, AND MAPS SHOWING WELL LOCATIONS, BASE OF AQUIFER, WATER LEVELS, AND SATURATED THICKNESS (BAILEY, BRISCOE, CASTRO, CROSBY, DEAF SMITH, DICKENS, FLOYD, HALE, LAMB, MOTLEY, OLDHAM, PARMER, RANDALL, AND SWISHER COUNTIES): TEXAS DEPARTMENT OF WATER RESOURCES REPORT 288, V. 3 , 1984.

GEOHYDROLOGY OF THE HIGH PLAINS AQUIFER IN PARTS OF COLORADO, KANSAS, NEBRASKA, NEW MEXICO, OKLAHOMA, SOUTH DAKOTA, TEXAS, AND WYOMING: USGS PROFESSIONAL PAPER 1400-B, 1984.

TEXAS GROUND-WATER RESOURCES, in NATIONAL WATER SUMMARY 1984: USGS WATER-SUPPLY PAPER 2275, 1985. 
IRRIGATION DATA FROM CASTRO AND PARMER COUNTIES, TEXAS, 1983-84: USGS OPEN-FILE REPORT 85-699, 1986.

DIGITAL SIMULATION OF GROUND-WATER FLOW IN THE HIGH PLAINS AQUIFER IN PARTS OF COLORADO, KANSAS, NEBRASKA, NEW MEXICO, OKLAHOMA, SOUTH DAKOTA, TEXAS, AND WYOMING: USGS PROFESSIONAL PAPER 1400-D, 1986.

HYDROLOGIC ATLAS FOR CASTRO COUNTY, TEXAS: HIGH PLAINS UNDERGROUND WATER CONSERVATION DISTRICT NO. 1, LUBBOCK, TEXAS, 1987.

COMPARISON OF IRRIGATION PUMPAGE AND CHANGE IN WATER STORAGE OF THE HIGH PLAINS AQUIFER IN CASTRO AND PARMER COUNTIES, TEXAS, 1975-83: USGS WATER-RESOURCES INVESTIGATIONS REPORT 87-4032, 1987.

SUMMARY OF THE HIGH PLAINS REGIONAL AQUIFER-SYSTEM ANALYSIS IN PARTS OF COLORADO, KANSAS, NEBRASKA, NEW MEXICO, OKLAHOMA, SOUTH DAKOTA, TEXAS, AND WYOMING: USGS PROFESSIONAL PAPER 1400-A, 1988.

PUBLIC SUPPLY GROUND-WATER USE IN THE SOUTHERN HIGH PLAINS OF TEXAS: TEXAS WATER DEVELOPMENT BOARD REPORT 328, 1990

WATER-LEVEL CHANGES IN THE HIGH PLAINS AQUIFER OF TEXAS, 1980-1990: TEXAS WATER DEVELOPMENT BOARD HYDROLOGIC ATLAS NO. 1, 1991.

THE HIGH PLAINS AQUIFER SYSTEM OF TEXAS, 1980 TO 1990. OVERVIEW AND PROJECTIONS: TEXAS WATER DEVELOPMENT BOARD REPORT 341, 1993.

WATER-QUALITY EVALUATION OF THE OGALLALA AQUIFER, TEXAS: TEXAS WATER DEVELOPMENT BOARD REPORT 342, 1993.

WATER-LEVEL CHANGES IN THE HIGH PLAINS AQUIFER-PREDEVELOPMENT TO 1992: USGS WATER-RESOURCES INVESTIGATIONS REPORT 94-4027, 1994.

AQUIFERS OF TEXAS: TEXAS WATER DEVELOPMENT BOARD REPORT 345, 1995.

WATER-LEVEL CHANGES IN THE HIGH PLAINS AQUIFER, 1980 TO 1995: USGS FACT SHEET FS-068-97, 1997.

WATER-LEVEL CHANGES IN THE HIGH PLAINS AQUIFER-PREDEVELOPMENT TO 1995: USGS WATER-RESOURCES INVESTIGATIONS REPORT 97-4081, 1997.

UPDATED WATER-QUALITY EVALUATION OF THE OGALLALA AQUIFER INCLUDING SELECTED METALLIC AND NON-METALLIC INORGANIC CONSTITUENTS: TEXAS WATER DEVELOPMENT BOARD HYDROLOGIC ATLAS NO. 10, 1998.

WATER-RESOURCES DATA, TEXAS, WATER YEAR 2000, VOLUME 6 , GROUND-WATER DATA: USGS WATER-DATA REPORT TX-00-6, 2001.

\section{CHAMBERS COUNTY}

UNDERGROUND WATERS OF COASTAL PLAIN OF TEXAS: USGS WATER SUPPLY AND IRRIGATION PAPER 190, 1907.
GEOLOGY AND UNDERGROUND WATERS OF THE SOUTHEASTERN PART OF THE TEXAS COASTAL PLAIN: USGS WATER-SUPPLY PAPER 335, 1914.

RECORDS OF WELLS, DRILLERS' LOGS, WATER ANALYSES, AND MAP SHOWING LOCATIONS OF WELLS AND TEST HOLES IN CHAMBERS COUNTY, TEXAS: TEXAS BOARD OF WATER ENGINEERS MISCELLANEOUS PUBLICATION 35, 1942.

RESULTS OF PUMPING TEST AT THE McCARTHY GASOLINE ABSORPTION PLANT AT WINNIE, TEXAS: USGS OPEN-FILE REPORT (UNNUMBERED), 1945

PUBLIC WATER SUPPLIES IN EASTERN TEXAS: USGS WATERSUPPLY PAPER 1047, 1948.

WATER SUPPLY OF THE HOUSTON GULF COAST REGION: TEXAS BOARD OF WATER ENGINEERS BULLETIN 5101, 1951.

BASIC DATA AND SUMMARY OF GROUND-WATER RESOURCES OF CHAMBERS COUNTY, TEXAS: TEXAS BOARD OF WATER ENGINEERS BULLETIN 5605, 1956.

AVAILABILITY OF GROUND WATER IN THE GULF COAST REGION OF TEXAS: USGS OPEN-FILE REPORT (UNNUMBERED), 1956.

RECORDS OF WATER-LEVEL MEASUREMENTS IN CHAMBERS, LIBERTY, AND MONTGOMERY COUNTIES, TEXAS, 1931 THROUGH APRIL 1958: TEXAS BOARD OF WATER ENGINEERS BULLETIN $5901,1959$.

RECONNAISSANCE INVESTIGATION OF THE GROUND-WATER RESOURCES OF THE GULF COAST REGION, TEXAS: TEXAS WATER COMMISSION BULLETIN 6305, 1963.

ANALOG MODEL STUDY OF GROUND WATER IN THE HOUSTON DISTRICT, TEXAS: TEXAS WATER COMMISSION BULLETIN 6508, 1965.

DEVELOPMENT OF GROUND WATER IN THE HOUSTON DISTRICT, TEXAS, 1961-65: TEXAS WATER DEVELOPMENT BOARD REPORT 63, 1967.

LAND-SURFACE SUBSIDENCE IN THE HOUSTON-GALVESTON REGION, TEXAS: USGS OPEN-FILE REPORT 69-61, 1969.

COMPILATION OF RESULTS OF AQUIFER TESTS IN TEXAS: TEXAS WATER DEVELOPMENT BOARD REPORT 98, 1969.

GROUND-WATER RESOURCES OF CHAMBERS AND JEFFERSON COUNTIES, TEXAS: TEXAS WATER DEVELOPMENT BOARD REPORT 133, 1971.

GROUND-WATER CONDITIONS IN THE GALVESTON BAY AREAHARRIS, GALVESTON, AND CHAMBERS COUNTIES, TEXAS: WILLIAM F. GUYTON \& ASSOCIATES, AUSTIN AND HOUSTON, TEXAS, 1972.

DEVELOPMENT OF GROUND WATER IN THE HOUSTON DISTRICT, TEXAS, 1966-69: TEXAS WATER DEVELOPMENT BOARD REPORT 152,1972

LAND-SURFACE SUBSIDENCE IN THE HOUSTON-GALVESTON REGION, TEXAS: USGS OPEN-FILE REPORT 74-123, 1974.

LAND-SURFACE SUBSIDENCE IN THE HOUSTON-GALVESTON REGION, TEXAS: TEXAS: TEXAS WATER DEVELOPMENT BOARD REPORT 188, 1975.

RECORDS OF WELLS, DRILLERS' LOGS, WATER-LEVEL MEASUREMENTS, AND CHEMICAL ANALYSES OF GROUND WATER IN CHAMBERS, LIBERTY, AND MONTGOMERY COUNTIES, TEXAS, 
1966-74: TEXAS WATER DEVELOPMENT BOARD REPORT 202, 1976.

SUMMARY APPRAISALS OF THE NATION'S GROUND-WATER RESOURCES-TEXAS GULF REGION: USGS PROFESSIONAL PAPER 813-F, 1976.

APPROXIMATE AREAS OF RECHARGE TO THE CHICOT AND EVANGELINE AQUIFER SYSTEMS IN THE HOUSTON-GALVESTON AREA, TEXAS: USGS OPEN-FILE REPORT 77-754, 1977.

HYDROGEOLOGY OF GULF COAST AQUIFERS, HOUSTONGALVESTON AREA, TEXAS: UNIVERSITY OF TEXAS, BUREAU OF ECONOMIC GEOLOGY GEOLOGICAL CIRCULAR 77-4, 1977.

STRATIGRAPHIC AND HYDROGEOLOGIC FRAMEWORK OF PART OF THE COASTAL PLAIN OF TEXAS: USGS OPEN-FILE REPORT 77-712, 1978.

STRATIGRAPHIC AND HYDROGEOLOGIC FRAMEWORK OF PART OF THE COASTAL PLAIN OF TEXAS: TEXAS DEPARTMENT OF WATER RESOURCES REPORT 236, 1979.

APPROXIMATE ALTITUDE OF WATER LEVELS IN WELLS IN THE CHICOT AND EVANGELINE AQUIFERS IN THE HOUSTON AREA, TEXAS, SPRING 1977 AND SPRING 1978: USGS OPEN-FILE REPORT 79-334, 1979.

APPROXIMATE WATER-LEVEL CHANGES IN WELLS IN THE CHICOT AND EVANGELINE AQUIFERS, 1977-79, AND MEASURED COMPACTION 1973-79, IN HARRIS AND GALVESTON COUNTIES, TEXAS: USGS OPEN-FILE REPORT 79-693, 1979.

APPROXIMATE WATER-LEVEL CHANGES IN WELLS IN THE CHICOT AND EVANGELINE AQUIFERS IN THE HOUSTON-GALVESTON REGION, TEXAS, 1977-80 AND 1979-80: USGS OPEN-FILE REPORT 80-337, 1980.

APPROXIMATE ALTITUDE OF WATER LEVELS IN WELLS IN THE CHICOT AND EVANGELINE AQUIFERS IN THE HOUSTON AREA, TEXAS, SPRING 1979 AND SPRING 1980: USGS OPEN-FILE REPORT 80-579, 1980.

APPROXIMATE LAND-SURFACE SUBSIDENCE IN THE HOUSTONGALVESTON REGION, TEXAS, 1906-78, 1943-78, AND 1973-78: USGS OPEN-FILE REPORT 80-338, 1980.

LAND-SURFACE SUBSIDENCE IN THE TEXAS COASTAL REGION: USGS OPEN-FILE REPORT 80-969, 1980.

DEVELOPMENT OF GROUND WATER IN THE HOUSTONGALVESTON DISTRICT, TEXAS, 1970-74: TEXAS DEPARTMENT OF WATER RESOURCES REPORT 241, 1980.

APPROXIMATE WATER-LEVEL CHANGES IN WELLS IN THE CHICOT AND EVANGELINE AQUIFERS, 1977-81 AND 1980-81, AND MEASURED COMPACTION, 1973-81, IN THE HOUSTON-GALVESTON REGION, TEXAS: USGS OPEN-FILE REPORT 81-341, 1981.

SPRINGS OF TEXAS, VOLUME 1: (BY GUNNAR BRUNE), BRANCHSMITH, INC., FORT WORTH, TEXAS, 1981.

APPROXIMATE ALTITUDE OF WATER LEVELS IN THE CHICOT AND EVANGELINE AQUIFERS IN THE HOUSTON AREA, TEXAS, SPRING 1981: USGS OPEN-FILE REPORT 81-676, 1981.

APPROXIMATE WATER-LEVEL CHANGES IN WELLS IN THE CHICOT AND EVANGELINE AQUIFERS, 1977-82 AND 1981-82, AND MEASURED COMPACTION, 1973-82, IN THE HOUSTON-GALVESTON REGION, TEXAS: USGS OPEN-FILE REPORT 82-328, 1982.
GROUND-WATER WITHDRAWALS AND CHANGES IN WATER LEVELS IN THE HOUSTON DISTRICT, 1975-79: USGS OPEN-FILE REPORT 82-431, 1982.

APPROXIMATE ALTITUDE OF WATER LEVELS IN WELLS IN THE CHICOT AND EVANGELINE AQUIFERS IN THE HOUSTON AREA, TEXAS, SPRING 1982: USGS OPEN-FILE REPORT 82-559, 1982.

LAND-SURFACE SUBSIDENCE IN THE TEXAS COASTAL REGION: TEXAS DEPARTMENT OF WATER RESOURCES REPORT 272, 1982.

APPROXIMATE WATER-LEVEL CHANGES IN WELLS IN THE CHICOT AND EVANGELINE AQUIFERS, 1977-83 AND 1982-83, AND MEASURED COMPACTION, 1973-83, IN THE HOUSTON-GALVESTON REGION, TEXAS: USGS OPEN-FILE REPORT 83-150, 1983.

RECORDS OF WELLS, DRILLERS' LOGS, WATER-LEVEL MEASUREMENTS, AND CHEMICAL ANALYSES OF GROUND WATER IN CHAMBERS, LIBERTY, AND MONTGOMERY COUNTIES, TEXAS, 1975-79: TEXAS DEPARTMENT OF WATER RESOURCES REPORT $280,1983$.

APPROXIMATE ALTITUDE OF WATER LEVELS IN WELLS IN THE CHICOT AND EVANGELINE AQUIFERS IN THE HOUSTON AREA, TEXAS, SPRING 1983: USGS OPEN-FILE REPORT 83-529, 1983.

APPROXIMATE WATER-LEVEL CHANGES IN WELLS IN THE CHICOT AND EVANGELINE AQUIFERS, 1977-84 AND 1983-84, AND MEASURED COMPACTION, 1973-84, IN THE HOUSTON-GALVESTON REGION, TEXAS: USGS OPEN-FILE REPORT 84-140, 1984.

APPROXIMATE ALTITUDE OF WATER LEVELS IN WELLS IN THE CHICOT AND EVANGELINE AQUIFERS IN THE HOUSTON AREA, TEXAS, SPRING, 1984: USGS OPEN-FILE REPORT 84-436, 1984.

DIGITAL MODELS FOR SIMULATION OF GROUND-WATER HYDROLOGY OF THE CHICOT AND EVANGELINE AQUIFERS ALONG THE GULF COAST OF TEXAS: TEXAS DEPARTMENT OF WATER RESOURCES REPORT 289, 1985.

TEXAS GROUND-WATER RESOURCES, in NATIONAL WATER SUMMARY 1984: USGS WATER-SUPPLY PAPER 2275, 1985.

APPROXIMATE WATER-LEVEL CHANGES IN WELLS IN THE CHICOT AND EVANGELINE AQUIFERS, 1977-85 AND 1984-85, AND MEASURED COMPACTION, 1973-85, IN THE HOUSTON-GALVESTON REGION, TEXAS: USGS OPEN-FILE REPORT 85-158, 1985.

APPROXIMATE CHANGES IN WATER LEVELS IN THE CHICOT AND EVANGELINE AQUIFERS, 1977-86 AND 1985-86, AND MEASURED COMPACTION, 1973-86, IN THE HOUSTON-GALVESTON REGION, TEXAS: USGS OPEN-FILE REPORT 86-135, 1986.

APPROXIMATE ALTITUDE OF WATER LEVELS IN WELLS IN THE CHICOT AND EVANGELINE AQUIFERS IN THE HOUSTON AREA, TEXAS, SPRING 1986: USGS OPEN-FILE REPORT 86-306, 1986.

HYDROLOGY OF THE JASPER AQUIFER IN THE SOUTHEAST TEXAS COASTAL PLAIN: TEXAS WATER DEVELOPMENT BOARD REPORT 295, 1986.

RECORDS OF WELLS, DRILLERS' LOGS, WATER-LEVEL MEASUREMENTS, AND CHEMICAL ANALYSES OF GROUND WATER IN CHAMBERS, LIBERTY, AND MONTGOMERY COUNTIES, TEXAS, 1980-84: USGS OPEN-FILE REPORT 86-57, 1986.

RECORDS OF WELLS, DRILLERS' LOGS, WATER-LEVEL MEASUREMENTS, AND CHEMICAL ANALYSES OF GROUND WATER IN CHAMBERS, LIBERTY, AND MONTGOMERY COUNTIES, TEXAS, 1980-84: TEXAS WATER DEVELOPMENT BOARD REPORT 304, 1987. 
APPROXIMATE WATER-LEVEL CHANGES IN WELLS COMPLETED IN THE CHICOT AND EVANGELINE AQUIFERS, 1977-87 AND 1986-87, AND MEASURED COMPACTION, 1973-87, IN THE HOUSTONGALVESTON REGION, TEXAS: USGS OPEN-FILE REPORT 87-108, 1987.

APPROXIMATE ALTITUDE OF WATER-LEVELS IN WELLS IN THE CHICOT AND EVANGELINE AQUIFERS IN THE HOUSTON AREA, TEXAS, SPRING 1987: USGS OPEN-FILE REPORT 87-233, 1987.

GEOHYDROLOGIC FRAMEWORK OF THE GULF COASTAL PLAIN: USGS HYDROLOGIC ATLAS HA-695, 1988.

HYDROGEOLOGY AND PREDEVELOPMENT FLOW IN THE TEXAS GULF COAST AQUIFER SYSTEMS: USGS WATER-RESOURCES INVESTIGATIONS REPORT 87-4248, 1988.

APPROXIMATE WATER-LEVEL CHANGES IN WELLS COMPLETED IN THE CHICOT AND EVANGELINE AQUIFERS, 1977-88 AND 1987-88, AND MEASURED COMPACTION, 1973-88, IN THE HOUSTONGALVESTON REGION, TEXAS: USGS OPEN-FILE REPORT 88-168, 1988.

APPROXIMATE ALTITUDE OF WATER LEVELS IN WELLS IN THE CHICOT AND EVANGELINE AQUIFERS IN THE HOUSTON AREA, TEXAS, SPRING 1988: USGS OPEN-FILE REPORT 88-334, 1988.

HYDROGEOLOGY OF BARBERS HILL SALT DOME, TEXAS COASTAL PLAIN: UNIVERSITY OF TEXAS, BUREAU OF ECONOMIC GEOLOGY REPORT OF INVESTIGATIONS NO. 176, 1988.

APPROXIMATE ALTITUDE OF WATER LEVELS IN WELLS IN THE CHICOT AND EVANGELINE AQUIFERS IN THE HOUSTON AREA, TEXAS, SPRING 1989: USGS OPEN-FILE REPORT 89-237, 1989.

APPROXIMATE WATER-LEVEL CHANGE IN WELLS COMPLETED IN THE CHICOT AND EVANGELINE AQUIFERS, 1977-89 AND 1988-89, AND MEASURED COMPACTION, 1973-89, IN THE HOUSTONGALVESTON REGION, TEXAS: USGS OPEN-FILE REPORT 89-057, 1989.

APPROXIMATE WATER-LEVEL CHANGES IN WELLS COMPLETED IN THE CHICOT AND EVANGELINE AQUIFERS, 1977-90 AND 1989-90, AND MEASURED COMPACTION, 1973-DECEMBER 1989, IN THE HOUSTON-GALVESTON REGION, TEXAS: USGS OPEN-FILE REPORT 90-132, 1990.

GROUND-WATER FLOW IN THE GULF COAST AQUIFER SYSTEMS, SOUTH-CENTRAL UNITED STATES-A PRELIMINARY ANALYSIS: USGS WATER-RESOURCES INVESTIGATIONS REPORT 89-4071, 1990.

SALT-DOME LOCATIONS IN THE GULF COASTAL PLAIN, SOUTHCENTRAL UNITED STATES: USGS WATER-RESOURCES INVESTIGATIONS REPORT 90-4060, 1990.

RECORDS OF WELLS, DRILLERS' LOGS, WATER-WELL MEASUREMENTS, AND CHEMICAL ANALYSES OF GROUND WATER IN CHAMBERS, LIBERTY, AND MONTGOMERY COUNTIES, TEXAS, 1985-89: USGS OPEN-FILE REPORT 90-594, 1991.

NATIONAL WATER-QUALITY ASSESSMENT PROGRAM-THE TRINITY RIVER BASIN: USGS OPEN-FILE REPORT 91-158, 1991.

HYDROLOGY OF THE TEXAS GULF COAST AQUIFER SYSTEMS: USGS OPEN-FILE REPORT 91-64, 1991.

APPROXIMATE WATER-LEVEL CHANGES IN WELLS COMPLETED IN THE CHICOT AND EVANGELINE AQUIFERS, 1977-91 AND 1990-91, AND MEASURED COMPACTION, 1973-90, IN THE HOUSTON-
GALVESTON REGION, TEXAS: USGS OPEN-FILE REPORT 91-094, 1991.

APPROXIMATE ALTITUDE OF WATER LEVELS IN WELLS IN THE CHICOT AND EVANGELINE AQUIFERS IN THE HOUSTON AREA, TEXAS, JANUARY-FEBRUARY 1990: USGS OPEN-FILE REPORT 91-240, 1991.

PROPERTIES AND CHEMICAL CONSTITUENTS IN GROUND WATER FROM THE MISSISSIPPI RIVER VALLEY ALLUVIAL AQUIFER AND PERMEABLE ZONE A (HOLOCENE-UPPER PLEISTOCENE DEPOSITS), SOUTH-CENTRAL UNITED STATES: USGS WATERRESOURCES INVESTIGATIONS REPORT 91-4149, 1992.

APPROXIMATE CHANGE IN WATER LEVELS IN WELLS COMPLETED IN THE CHICOT AND EVANGELINE AQUIFERS, 1977-92 AND 1991-92, AND MEASURED COMPACTION, 1973-91, IN THE HOUSTON-GALVESTON REGION, TEXAS: USGS OPEN-FILE REPORT 92-066, 1992.

WATER-RESOURCES DATA, TEXAS, WATER YEAR 1991, VOLUME 4 GROUND-WATER DATA: USGS WATER-DATA REPORT TX-91-4, 1992.

PROPERTIES AND CHEMICAL CONSTITUENTS IN GROUND WATER FROM THE UPPER CLAIBORNE AQUIFER, GULF COAST REGIONAL AQUIFER SYSTEMS, SOUTH-CENTRAL UNITED STATES: USGS WATER-RESOURCES INVESTIGATIONS REPORT 91-4150, 1993.

PROPERTIES AND CHEMICAL CONSTITUENTS IN GROUND WATER FROM PERMEABLE ZONE C (LOWER PLIOCENE-UPPER MIOCENE DEPOSITS), COASTAL LOWLANDS AQUIFER SYSTEM, SOUTHCENTRAL UNITED STATES: USGS WATER-RESOURCES INVESTIGATIONS REPORT 91-4151, 1993.

PROPERTIES AND CHEMICAL CONSTITUENTS IN GROUND WATER FROM PERMEABLE ZONE B (LOWER PLEISTOCENE-UPPER PLIOCENE DEPOSITS), COASTAL LOWLANDS AQUIFER SYSTEM, SOUTH-CENTRAL UNITED STATES: USGS WATER-RESOURCES INVESTIGATIONS REPORT 91-4152, 1993.

PROPERTIES AND CHEMICAL CONSTITUENTS IN GROUND WATER FROM PERMEABLE ZONE E (LOWER MIOCENE-UPPER OLIGOCENE DEPOSITS), COASTAL LOWLANDS AQUIFER SYSTEM, SOUTH-CENTRAL UNITED STATES: USGS WATER-RESOURCES INVESTIGATIONS REPORT 92-4103, 1993.

PROPERTIES AND CHEMICAL CONSTITUENTS IN GROUND WATER FROM PERMEABLE ZONE D (MIDDLE MIOCENE DEPOSITS), COASTAL LOWLANDS AQUIFER SYSTEM, SOUTH-CENTRAL UNITED STATES: USGS WATER-RESOURCES INVESTIGATIONS REPORT 92-4105, 1993.

GROUND-WATER WITHDRAWALS, WATER LEVELS, AND GROUNDWATER QUALITY IN THE HOUSTON DISTRICT, TEXAS, WITH EMPHASIS ON 1985-89: USGS WATER-RESOURCES INVESTIGATIONS REPORT 92-4180, 1993

APPROXIMATE ALTITUDE OF WATER LEVELS IN WELLS COMPLETED IN THE CHICOT AND EVANGELINE AQUIFERS IN THE HOUSTON AREA, TEXAS, JANUARY-FEBRUARY 1991: USGS OPEN-FILE REPORT 93-075, 1993.

APPROXIMATE CHANGE IN WATER LEVELS IN WELLS COMPLETED IN THE CHICOT AND EVANGELINE AQUIFERS, 1977-93 AND 1992-93, AND MEASURED COMPACTION, 1973-92, IN THE HOUSTON-GALVESTON REGION, TEXAS: USGS OPEN-FILE REPORT 93-086, 1993. 
WATER-RESOURCES DATA, TEXAS, WATER YEAR 1992, VOLUME 4, GROUND-WATER DATA: USGS WATER-DATA REPORT TX-92-4, 1993.

APPROXIMATE CHANGE IN WATER LEVELS IN WELLS COMPLETED IN THE CHICOT AND EVANGELINE AQUIFERS, 1977-94 AND 1993-94, AND MEASURED COMPACTION, 1973-93, IN THE HOUSTON-GALVESTON REGION, TEXAS: USGS OPEN-FILE REPORT 94-346, 1994.

WATER-RESOURCES DATA, TEXAS, WATER YEAR 1993, VOLUME 4, GROUND-WATER DATA: USGS WATER-DATA REPORT TX-93-4, 1994.

NATIONAL WATER-QUALITY ASSESSMENT PROGRAM-PESTICIDES IN THE TRINITY RIVER BASIN STUDY UNIT, TEXAS, 1968-91: USGS FACT SHEET FS-088-95, 1995.

WATER-QUALITY ASSESSMENT OF THE TRINITY RIVER BASIN, TEXAS-DATA COLLECTION, 1992-95: USGS FACT SHEET FS-095-95, 1995.

WATER-QUALITY ASSESSMENT OF THE TRINITY RIVER BASIN, TEXAS-PESTICIDES IN A SUBURBAN WATERSHED, ARLINGTON, 1993-94: USGS FACT SHEET FS-159-95, 1995.

STRATIGRAPHIC NOMENCLATURE AND GEOLOGIC SECTIONS OF THE GULF COASTAL PLAIN OF TEXAS: USGS OPEN-FILE REPORT 94-461, 1995.

WATER-LEVEL ALTITUDES 1995, WATER-LEVEL CHANGES 1977-95 AND 1994-95, AND COMPACTION 1973-94 IN THE CHICOT AND EVANGELINE AQUIFERS, HOUSTON-GALVESTON REGION, TEXAS: USGS OPEN-FILE REPORT 95-182, 1995.

AQUIFERS OF TEXAS: TEXAS WATER DEVELOPMENT BOARD REPORT 345, 1995.

WATER-RESOURCES DATA, TEXAS, WATER YEAR 1994, VOLUME 4, GROUND-WATER DATA: USGS WATER-DATA REPORT TX-94-4, 1995.

WATER-LEVEL ALTITUDES 1996, WATER-LEVEL CHANGES 1977-96 AND 1995-96, AND COMPACTION 1973-95 IN THE CHICOT AND EVANGELINE AQUIFERS, HOUSTON-GALVESTON REGION, TEXAS: USGS OPEN-FILE REPORT 96-163, 1996.

WATER-RESOURCES DATA, TEXAS, WATER YEAR 1995, VOLUME 4, GROUND-WATER DATA: USGS WATER-DATA REPORT TX-95-4, 1996.

WATER-LEVEL ALTITUDES 1997, WATER-LEVEL CHANGES 1977-97 AND 1996-97, AND COMPACTION 1973-96 IN THE CHICOT AND EVANGELINE AQUIFERS, HOUSTON-GALVESTON REGION, TEXAS: USGS OPEN-FILE REPORT 97-181, 1997.

WATER-LEVEL ALTITUDES IN WELLS COMPLETED IN THE CHICOT AND EVANGELINE AQUIFERS, HOUSTON-GALVESTON REGION, TEXAS, JANUARY-FEBRUARY 1992, 1993, AND 1994: USGS OPENFILE REPORT 97-786, 1997.

WATER-RESOURCES DATA, TEXAS, WATER YEAR 1996, VOLUME 4, GROUND-WATER DATA: USGS WATER-DATA REPORT TX-96-4, 1997.

WATER-LEVEL ALTITUDES 1998, WATER-LEVEL CHANGES 1977-98 AND 1997-98, AND COMPACTION IN THE CHICOT AND EVANGELINE AQUIFERS, HOUSTON-GALVESTON REGION, TEXAS: USGS OPEN-FILE REPORT 98-096, 1998.
WATER-RESOURCES DATA, TEXAS, WATER YEAR 1997, VOLUME 4, GROUND-WATER DATA: USGS WATER-DATA REPORT TX-97-4, 1998.

WATER-LEVEL ALTITUDES 1999, WATER-LEVEL CHANGES 1977-99 AND 1998-99, AND COMPACTION 1973-98 IN THE CHICOT AND EVANGELINE AQUIFERS, HOUSTON-GALVESTON REGION, TEXAS: USGS OPEN-FILE REPORT 99-178, 1999.

WATER-RESOURCES DATA, TEXAS, WATER YEAR 1998, VOLUME 4, GROUND-WATER DATA: USGS WATER-DATA REPORT TX-98-4, 1999.

WATER-LEVEL ALTITUDES 2000, WATER-LEVEL CHANGES 1977-2000 AND 1999-2000, AND COMPACTION 1973-99 IN THE CHICOT AND EVANGELINE AQUIFERS, HOUSTON-GALVESTON REGION, TEXAS: USGS OPEN-FILE REPORT 00-094, 2000.

WATER-QUALITY ASSESSMENT OF THE TRINITY RIVER BASIN, TEXAS-GROUND-WATER QUALITY OF THE TRINITY, CARRIZOWILCOX, AND GULF COAST AQUIFERS, FEBRUARY-AUGUST 1994: USGS WATER-RESOURCES INVESTIGATIONS REPORT 99-4233, 2000.

WATER-RESOURCES DATA, TEXAS, WATER YEAR 1999, VOLUME 6, GROUND-WATER DATA: USGS WATER-DATA REPORT TX-99-6, 2000 .

WATER-RESOURCES DATA, TEXAS, WATER YEAR 2000, VOLUME 6, GROUND-WATER DATA: USGS WATER-DATA REPORT TX-00-6, 2001.

\section{CHEROKEE COUNTY}

UNDERGROUND WATERS OF COASTAL PLAIN OF TEXAS: USGS WATER-SUPPLY AND IRRIGATION PAPER 190, 1907.

GEOLOGY AND UNDERGROUND WATERS OF THE SOUTHEASTERN PART OF THE TEXAS COASTAL PLAIN: USGS WATER-SUPPLY PAPER 335, 1914.

RECORDS OF WELLS, DRILLERS' LOGS, AND WATER ANALYSES, AND MAP SHOWING LOCATION OF WELLS IN CHEROKEE COUNTY, TEXAS: TEXAS BOARD OF WATER ENGINEERS MISCELLANEOUS PUBLICATION 49, 1936.

GROUND WATER IN CHEROKEE COUNTY, TEXAS: USGS OPEN-FILE REPORT (UNNUMBERED), 1936.

REPORT OF INVESTIGATION MADE FOR AN ADDITIONAL WATER SUPPLY FOR THE CITY OF RUSK, TEXAS: USGS OPEN-FILE REPORT (UNNUMBERED), 1940.

MEMORANDUM TO MR. C.S. CLARK REGARDING CORES AND LOGS OF TEST HOLES AT BLACKBURN BRIDGE DAM SITE ON THE NECHES RIVER IN CHEROKEE AND ANDERSON COUNTIES, TEXAS: USGS OPEN-FILE REPORT (UNNUMBERED), 1941.

PUBLIC WATER SUPPLIES IN EASTERN TEXAS: USGS WATERSUPPLY PAPER 1047, 1948

RECONNAISSANCE INVESTIGATION OF THE GROUND-WATER RESOURCES OF THE NECHES RIVER BASIN, TEXAS: TEXAS WATER COMMISSION BULLETIN 6308, 1963.

HYDROLOGIC SIGNIFICANCE OF THE LITHOFACIES OF THE SPARTA SAND IN ARKANSAS, LOUISIANA, MISSISSIPPI, AND TEXAS: USGS PROFESSIONAL PAPER 569-A, 1968 
COMPILATION OF RESULTS OF AQUIFER TESTS IN TEXAS: TEXAS WATER DEVELOPMENT BOARD REPORT 98, 1969

SALT-WATER DISPOSAL AND POTENTIAL FOR POLLUTION IN THE EAST TEXAS OIL FIELD: USGS OPEN-FILE REPORT (UNNUMBERED) (MEMORANDUM), 1971

GROUND-WATER CONDITIONS IN ANDERSON, CHEROKEE, FREESTONE, AND HENDERSON COUNTIES, TEXAS: TEXAS WATER DEVELOPMENT BOARD REPORT 150, 1972.

MAJOR AND HISTORICAL SPRINGS OF TEXAS: TEXAS WATER DEVELOPMENT BOARD REPORT 189, 1975.

GROUND-WATER PROGRAM (PROPOSED BY CARTER OIL COMPANY) FOR STRIP MINING OF LIGNITE IN N.E. TEXAS AND OTHER ITEMS OF INTEREST: USGS OPEN-FILE REPORT (UNNUMBERED), 1978.

WATER-QUALITY DATA FOR AQUIFERS, STREAMS, AND LAKES IN THE VICINITY OF KEECHI, MOUNT SYLVAN, OAKWOOD, AND PALESTINE SALT DOMES, NORTHEAST TEXAS SALT-DOME BASIN: USGS OPEN-FILE REPORT 80-2037, 1980

GEOHYDROLOGY OF THE KEECHI, MOUNT SYLVAN, OAKWOOD, AND PALESTINE SALT DOMES IN THE NORTHEAST TEXAS SALTDOME BASIN: USGS OPEN-FILE REPORT 80-2044, 1980.

GEOLOGY AND GEOHYDROLOGY OF THE EAST TEXAS BASIN-A REPORT ON THE PROGRESS OF NUCLEAR WASTE ISOLATION FEASIBILITY STUDIES (1979): UNIVERSITY OF TEXAS, BUREAU OF ECONOMIC GEOLOGY GEOLOGICAL CIRCULAR 80-12, 1980.

GEOLOGY AND GEOHYDROLOGY OF THE EAST TEXAS BASIN-A REPORT ON THE PROGRESS OF NUCLEAR WASTE ISOLATION FEASIBILITY STUDIES (1980): UNIVERSITY OF TEXAS, BUREAU OF ECONOMIC GEOLOGY GEOLOGICAL CIRCULAR 81-7, 1981.

SPRINGS OF TEXAS, VOLUME 1: (BY GUNNAR BRUNE), BRANCHSMITH, INC., FORT WORTH, TEXAS, 1981.

REGIONAL AQUIFER CHARACTERIZATION FOR DEEP-BASIN LIGNITE MINING, SABINE UPLIFT AREA, NORTHEAST TEXAS: UNIVERSITY OF TEXAS, BUREAU OF ECONOMIC GEOLOGY GEOLOGICAL CIRCULAR 83-3, 1983.

TEXAS GROUND-WATER RESOURCES, in NATIONAL WATER SUMMARY 1984: USGS WATER-SUPPLY PAPER 2275, 1985.

APPROXIMATE POTENTIOMETRIC SURFACES FOR THE AQUIFERS OF THE TEXAS COASTAL UPLANDS SYSTEM, 1980: USGS HYDROLOGIC ATLAS HA-704, 1987.

GEOHYDROLOGIC FRAMEWORK OF THE GULF COASTAL PLAIN: USGS HYDROLOGIC ATLAS HA-695, 1988.

EVALUATION OF GROUND-WATER RESOURCES IN THE VICINITY OF THE CITIES OF HENDERSON, JACKSONVILLE, KILGORE, LUFKIN, NACOGDOCHES, RUSK, AND TYLER IN EAST TEXAS: TEXAS WATER DEVELOPMENT BOARD REPORT 327, 1991.

PROPERTIES AND CHEMICAL CONSTITUENTS IN GROUND WATER FROM THE LOWER CLAIBORNE-UPPER WILCOX AQUIFER, GULF COAST REGIONAL AQUIFER SYSTEMS, SOUTH-CENTRAL UNITED STATES: USGS WATER-RESOURCES INVESTIGATIONS REPORT 92-4102, 1993

PROPERTIES AND CHEMICAL CONSTITUENTS IN GROUND WATER FROM THE MIDDLE CLAIBORNE AQUIFER, GULF COAST REGIONAL AQUIFER SYSTEMS, SOUTH-CENTRAL UNITED STATES: USGS WATER-RESOURCES INVESTIGATIONS REPORT 92-4104, 1993.
PROPERTIES AND CHEMICAL CONSTITUENTS IN GROUND WATER FROM THE MIDDLE WILCOX AQUIFER, GULF COAST REGIONAL AQUIFER SYSTEMS, SOUTH-CENTRAL UNITED STATES: USGS WATER-RESOURCES INVESTIGATIONS REPORT 93-4070, 1993.

AQUIFERS OF TEXAS: TEXAS WATER DEVELOPMENT BOARD REPORT 345, 1995.

STRATIGRAPHIC NOMENCLATURE AND GEOLOGIC SECTIONS OF THE GULF COASTAL PLAIN OF TEXAS: USGS OPEN-FILE REPORT 94-461, 1995.

WATER QUALITY IN THE SPARTA AQUIFER, EAST TEXAS: TEXAS WATER DEVELOPMENT BOARD HYDROLOGIC ATLAS NO. 5, 1996.

WATER QUALITY IN THE QUEEN CITY AQUIFER, EAST TEXAS: TEXAS WATER DEVELOPMENT BOARD HYDROLOGIC ATLAS NO. 6, 1996

\section{CHILDRESS COUNTY}

GEOLOGY OF THE SOUTH PORTION OF CHILDRESS COUNTY, TEXAS: USGS OPEN-FILE REPORT (UNNUMBERED), 1940.

RECORDS OF WELLS, DRILLERS' LOGS, WATER ANALYSES, AND MAP SHOWING LOCATIONS OF WELLS IN CHILDRESS COUNTY, TEXAS: TEXAS BOARD OF WATER ENGINEERS MISCELLANEOUS PUBLICATION 50, 1942.

GROUND-WATER CONDITIONS IN THE MEMPHIS AREA, TEXAS: USGS OPEN-FILE REPORT (UNNUMBERED), 1943.

EXPLORATION FOR GROUND WATER AT CHILDRESS, TEXAS: USGS OPEN-FILE REPORT (UNNUMBERED), 1945

EXPLORATION OF THE MICHIE SANDHILLS AREA, CHILDRESS COUNTY, TEXAS: USGS OPEN-FILE REPORT (UNNUMBERED), 1946.

PUBLIC WATER SUPPLIES IN WESTERN TEXAS: USGS WATERSUPPLY PAPER 1106, 1951.

RECORDS OF WATER-LEVEL MEASUREMENTS IN CHILDRESS, COTTLE, HARDEMAN, AND KING COUNTIES, TEXAS, 1940 TO JANUARY 1956: TEXAS BOARD OF WATER ENGINEERS BULLETIN 5613, 1956.

THE USE OF GROUND WATER FOR IRRIGATION IN CHILDRESS COUNTY, TEXAS: TEXAS BOARD OF WATER ENGINEERS BULLETIN 5706, 1957.

RECONNAISSANCE INVESTIGATION OF THE GROUND-WATER RESOURCES OF THE RED RIVER, SULPHUR RIVER, AND CYPRESS CREEK BASINS, TEXAS: TEXAS WATER COMMISSION BULLETIN 6306, 1963.

SPRINGS OF TEXAS, VOLUME 1: (BY GUNNAR BRUNE), BRANCHSMITH, INC., FORT WORTH, TEXAS, 1981.

WATER-LEVEL CHANGES IN THE HIGH PLAINS AQUIFER OF TEXAS, 1980-1990: TEXAS WATER DEVELOPMENT BOARD HYDROLOGIC ATLAS NO. 1, 1991.

EVALUATION OF WATER RESOURCES IN PARTS OF THE ROLLING PRAIRIES REGION OF NORTH-CENTRAL TEXAS: TEXAS WATER DEVELOPMENT BOARD REPORT 337, 1992. 
AQUIFERS OF TEXAS: TEXAS WATER DEVELOPMENT BOARD REPORT 345, 1995.

STRATIGRAPHIC NOMENCLATURE AND GEOLOGIC SECTIONS OF THE GULF COASTAL PLAIN OF TEXAS: USGS OPEN-FILE REPORT 94-461, 1995.

UPDATED WATER-QUALITY EVALUATION OF THE OGALLALA AQUIFER INCLUDING SELECTED METALLIC AND NON-METALLIC INORGANIC CONSTITUENTS: TEXAS WATER DEVELOPMENT BOARD HYDROLOGIC ATLAS NO. 10, 1998.

\section{CLAY COUNTY}

GEOLOGY AND UNDERGROUND WATERS OF THE WICHITA REGION, NORTH-CENTRAL TEXAS: USGS WATER-SUPPLY PAPER $317,1913$.

PUBLIC WATER SUPPLIES IN CENTRAL AND NORTH-CENTRAL TEXAS: USGS WATER-SUPPLY PAPER 1069, 1949.

RECONNAISSANCE INVESTIGATION OF THE GROUND-WATER RESOURCES OF THE RED RIVER, SULPHUR RIVER, AND CYPRESS CREEK BASINS, TEXAS: TEXAS WATER COMMISSION BULLETIN 6306, 1963.

RECONNAISSANCE INVESTIGATION OF THE GROUND-WATER RESOURCES OF THE TRINITY RIVER BASIN, TEXAS: TEXAS WATER COMMISSION BULLETIN 6309, 1963.

MAJOR AND HISTORICAL SPRINGS OF TEXAS: TEXAS WATER DEVELOPMENT BOARD REPORT 189, 1975.

SPRINGS OF TEXAS, VOLUME 1: (BY GUNNAR BRUNE), BRANCHSMITH, INC., FORT WORTH, TEXAS, 1981.

TEXAS GROUND-WATER RESOURCES, in NATIONAL WATER SUMMARY 1984: USGS WATER-SUPPLY PAPER 2275, 1985.

OCCURRENCE AND QUALITY OF GROUND WATER IN JACK COUNTY, TEXAS: TEXAS WATER DEVELOPMENT BOARD REPORT 308, 1988.

EVALUATION OF WATER RESOURCES IN PARTS OF THE ROLLING PRAIRIES REGION OF NORTH-CENTRAL TEXAS: TEXAS WATER DEVELOPMENT BOARD REPORT 337, 1992.

NATIONAL WATER-QUALITY ASSESSMENT PROGRAM-PESTICIDES IN THE TRINITY RIVER BASIN STUDY UNIT, TEXAS, 1968-91: USGS FACT SHEET FS-088-95, 1995.

WATER-QUALITY ASSESSMENT OF THE TRINITY RIVER BASIN, TEXAS-DATA COLLECTION, 1992-95: USGS FACT SHEET FS-095-95, 1995.

WATER-QUALITY ASSESSMENT OF THE TRINITY RIVER BASIN, TEXAS-PESTICIDES IN A SUBURBAN WATERSHED, ARLINGTON, 1993-94: USGS FACT SHEET FS-159-95, 1995.

AQUIFERS OF TEXAS: TEXAS WATER DEVELOPMENT BOARD REPORT 345, 1995.

COCHRAN COUNTY

GEOLOGY AND GROUND-WATER RESOURCES OF THE SOUTHERN HIGH PLAINS: USGS OPEN-FILE REPORT (UNNUMBERED), 1935.

GROUND WATER IN THE SOUTHERN HIGH PLAINS: USGS OPENFILE REPORT (UNNUMBERED, 1937.
GROUND WATER IN THE HIGH PLAINS OF TEXAS: TEXAS BOARD OF WATER ENGINEERS MISCELLANEOUS PUBLICATION (UNNUMBERED), 1938.

GROUND WATER IN THE HIGH PLAINS OF TEXAS: TEXAS BOARD OF WATER ENGINEERS MISCELLANEOUS PUBLICATION 119, 1940.

PROGRESS REPORT ON GROUND WATER IN THE HIGH PLAINS OF TEXAS: TEXAS BOARD OF WATER ENGINEERS MISCELLANEOUS PUBLICATION (UNNUMBERED), 1942.

PROGRESS REPORT ON GROUND WATER IN THE HIGH PLAINS OF TEXAS: TEXAS BOARD OF WATER ENGINEERS MISCELLANEOUS PUBLICATION 120, 1943

PROGRESS REPORT ON GROUND WATER IN THE HIGH PLAINS OF TEXAS: TEXAS BOARD OF WATER ENGINEERS MISCELLANEOUS PUBLICATION 121, 1944.

GROUND WATER IN HIGH PLAINS OF TEXAS, PROGRESS REPORT NO. 5: TEXAS BOARD OF WATER ENGINEERS MISCELLANEOUS PUBLICATION 122, 1945.

GROUND WATER IN THE HIGH PLAINS OF TEXAS: USGS WATERSUPPLY PAPER 889-F, 1946.

GROUND WATER IN HIGH PLAINS OF TEXAS, PROGRESS REPORT NO. 6: TEXAS BOARD OF WATER ENGINEERS MISCELLANEOUS PUBLICATION 123, 1947.

GEOLOGY AND GROUND WATER IN THE IRRIGATED REGION OF THE SOUTHERN HIGH PLAINS IN TEXAS, PROGRESS REPORT NO. 7: TEXAS BOARD OF WATER ENGINEERS MISCELLANEOUS PUBLICATION 125, 1949.

COST OF PUMPING WATER FOR IRRIGATION, TEXAS HIGH PLAINS, FIELD INVESTIGATIONS-1947 IRRIGATION SEASON: TEXAS BOARD OF WATER ENGINEERS MISCELLANEOUS PUBLICATION $124,1951$.

DEVELOPMENT OF WELLS FOR IRRIGATION AND FLUCTUATION OF WATER LEVELS IN THE HIGH PLAINS OF TEXAS TO JANUARY 1951: TEXAS BOARD OF WATER ENGINEERS BULLETIN 5104, 1951.

PUBLIC WATER SUPPLIES IN WESTERN TEXAS: USGS WATERSUPPLY PAPER 1106, 1951 [1952].

SUMMARY OF GROUND-WATER DEVELOPMENT IN THE SOUTHERN HIGH PLAINS, TEXAS: TEXAS BOARD OF WATER ENGINEERS BULLETIN 5402, 1954

RECORDS OF WATER-LEVEL MEASUREMENTS IN COCHRAN, CROSBY, GAINES, HOCKLEY, LYNN, AND TERRY COUNTIES, TEXAS: TEXAS BOARD OF WATER ENGINEERS BULLETIN 5407, 1954.

GROUND-WATER DEVELOPMENT IN THE SOUTHERN HIGH PLAINS OF TEXAS, 1953: TEXAS BOARD OF WATER ENGINEERS BULLETIN 5410, 1954

WATER-LEVEL DECLINE MAPS OF 17 COUNTIES IN THE SOUTHERN HIGH PLAINS, TEXAS, JANUARY 1955 TO JANUARY 1956: TEXAS BOARD OF WATER ENGINEERS BULLETIN 5607, 1956.

WATER-LEVEL DECLINE MAPS, 1956 TO 1957, AND WATER LEVELS IN OBSERVATION WELLS IN 20 COUNTIES IN THE SOUTHERN HIGH PLAINS, TEXAS: TEXAS BOARD OF WATER ENGINEERS BULLETIN 5705, 1957 
WATER-LEVEL MEASUREMENTS AND MAPS, SOUTHERN HIGH PLAINS, TEXAS, 1958 AND 1959: TEXAS BOARD OF WATER ENGINEERS BULLETIN 5908, 1959.

WATER LEVELS IN OBSERVATION WELLS, SOUTHERN HIGH PLAINS, TEXAS, 1959 AND 1960: TEXAS BOARD OF WATER ENGINEERS BULLETIN 6011, 1960.

WATER LEVELS IN OBSERVATION WELLS, SOUTHERN HIGH PLAINS, TEXAS, 1960 AND 1961: TEXAS BOARD OF WATER ENGINEERS BULLETIN 6101, 1961.

A SUMMARY OF THE OCCURRENCE AND DEVELOPMENT OF GROUND WATER IN THE SOUTHERN HIGH PLAINS OF TEXAS: TEXAS BOARD OF WATER ENGINEERS BULLETIN 6107, 1961.

WATER-LEVEL MEASUREMENTS THROUGH 1962 IN SELECTED OBSERVATION WELLS, SOUTHERN HIGH PLAINS, TEXAS: TEXAS WATER COMMISSION BULLETIN 6207, 1962.

RECONNAISSANCE INVESTIGATION OF THE GROUND-WATER RESOURCES OF THE BRAZOS RIVER BASIN, TEXAS: TEXAS WATER COMMISSION BULLETIN 6310, 1963.

A SUMMARY OF THE OCCURRENCE AND DEVELOPMENT OF GROUND WATER IN THE SOUTHERN HIGH PLAINS OF TEXAS, WITH A SECTION ON ARTIFICIAL RECHARGE STUDIES: USGS WATER-SUPPLY PAPER 1693, 1964.

WATER-LEVEL DATA FROM OBSERVATION WELLS IN THE SOUTHERN HIGH PLAINS OF TEXAS: TEXAS WATER DEVELOPMENT BOARD REPORT 21, 1966.

RECONNAISSANCE INVESTIGATION OF THE GROUND-WATER RESOURCES OF THE COLORADO RIVER BASIN, TEXAS: TEXAS WATER DEVELOPMENT BOARD REPORT 51, 1967.

GROUND WATER IN THE OGALLALA FORMATION IN THE SOUTHERN HIGH PLAINS OF TEXAS AND NEW MEXICO: USGS HYDROLOGIC INVESTIGATIONS ATLAS HA-330, 1969.

COMPILATION OF RESULTS OF AQUIFER TESTS IN TEXAS: TEXAS WATER DEVELOPMENT BOARD REPORT 98, 1969.

WATER-LEVEL DATA FROM OBSERVATION WELLS IN THE SOUTHERN HIGH PLAINS OF TEXAS, 1965-70: TEXAS WATER DEVELOPMENT BOARD REPORT 121, 1970.

MAJOR AND HISTORICAL SPRINGS OF TEXAS: TEXAS WATER DEVELOPMENT BOARD REPORT 189, 1975.

ANALYTICAL STUDY OF THE OGALLALA AQUIFER IN COCHRAN COUNTY, TEXAS-PROJECTIONS OF SATURATED THICKNESS, VOLUME OF WATER IN STORAGE, PUMPAGE RATES, PUMPING LIFTS, AND WELL YIELDS: TEXAS DEPARTMENT OF WATER RESOURCES REPORT 217, 1978.

WATER-LEVEL DATA FROM OBSERVATION WELLS IN THE SOUTHERN HIGH PLAINS OF TEXAS, 1971-77: TEXAS DEPARTMENT OF WATER RESOURCES REPORT 228, 1979.

PRELIMINARY DATA DESCRIBING THE DISTRIBUTION OF FLUORIDE AND SILICA IN THE OGALLALA AQUIFER ON THE HIGH PLAINS OF TEXAS: USGS OPEN-FILE REPORT 80-349, 1980.

EVALUATING THE GROUND-WATER RESOURCES OF THE HIGH PLAINS OF TEXAS: RESULTS OF TEST HOLE DRILLING: TEXAS DEPARTMENT OF WATER RESOURCES LIMITED PRINTING REPORT LP-129, 1980.

EVALUATING THE GROUND-WATER RESOURCES OF THE HIGH PLAINS OF TEXAS: NEUTRON-PROBE MEASUREMENTS OF DEEP
SOIL MOISTURE AS AN INDICATION OF AQUIFER RECHARGE RATES: TEXAS DEPARTMENT OF WATER RESOURCES LIMITED PRINTING REPORT LP-142, 1981.

SPRINGS OF TEXAS, VOLUME 1: (BY GUNNAR BRUNE), BRANCHSMITH, INC., FORT WORTH, TEXAS, 1981.

BEDROCK GEOLOGY, ALTITUDE OF BASE, AND 1980 SATURATED THICKNESS OF THE HIGH PLAINS AQUIFER IN PARTS OF COLORADO, KANSAS, NEBRASKA, NEW MEXICO, OKLAHOMA, SOUTH DAKOTA, TEXAS, AND WYOMING: USGS HYDROLOGIC INVESTIGATIONS ATLAS HA-648, 1981.

WATER LEVEL AND SATURATED THICKNESS CHANGES, PREDEVELOPMENT TO 1980, IN THE HIGH PLAINS AQUIFER IN PARTS OF COLORADO, KANSAS, NEBRASKA, NEW MEXICO, OKLAHOMA, SOUTH DAKOTA, TEXAS, AND WYOMING: USGS HYDROLOGIC INVESTIGATIONS ATLAS HA-652, 1981.

DISSOLVED SOLIDS AND SODIUM IN WATER FROM THE HIGH PLAINS AQUIFER IN PARTS OF COLORADO, KANSAS, NEBRASKA, NEW MEXICO, OKLAHOMA, SOUTH DAKOTA, TEXAS, AND WYOMING: USGS HYDROLOGIC INVESTIGATIONS ATLAS HA-658, 1982

EVALUATING THE GROUND-WATER RESOURCES OF THE HIGH PLAINS OF TEXAS, VOLUME 1: TEXAS DEPARTMENT OF WATER RESOURCES REPORT 288, V. 1, 1984

EVALUATING THE GROUND-WATER RESOURCES OF THE HIGH PLAINS OF TEXAS, VOLUME 4, RECORDS OF WELLS, AND MAPS SHOWING WELL LOCATIONS, BASE OF AQUIFER, WATER LEVELS, AND SATURATED THICKNESS (ANDREWS, BORDEN, COCHRAN, DAWSON, ECTOR, GAINES, GARZA, GLASSCOCK, HOWARD, HOCKLEY, LUBBOCK, LYNN, MARTIN, MIDLAND, TERRY, AND YOAKUM COUNTIES: TEXAS DEPARTMENT OF WATER RESOURCES REPORT 288 V. 4, 1984.

GEOHYDROLOGY OF THE HIGH PLAINS AQUIFER IN PARTS OF COLORADO, KANSAS, NEBRASKA, NEW MEXICO, OKLAHOMA, SOUTH DAKOTA, TEXAS, AND WYOMING: USGS PROFESSIONAL PAPER 1400-B, 1984.

TEXAS GROUND-WATER RESOURCES, in NATIONAL WATER SUMMARY 1984: USGS WATER-SUPPLY PAPER 2275, 1985.

DIGITAL SIMULATION OF GROUND-WATER FLOW IN THE HIGH PLAINS AQUIFER IN PARTS OF COLORADO, KANSAS, NEBRASKA, NEW MEXICO, OKLAHOMA, SOUTH DAKOTA, TEXAS, AND WYOMING: USGS PROFESSIONAL PAPER 1400-D, 1986.

HYDROGEOLOGY AND HYDROCHEMISTRY OF CRETACEOUS AQUIFERS, TEXAS PANHANDLE AND EASTERN NEW MEXICO: UNIVERSITY OF TEXAS, BUREAU OF ECONOMIC GEOLOGY GEOLOGICAL CIRCULAR 88-3, 1988.

SUMMARY OF THE HIGH PLAINS REGIONAL AQUIFER-SYSTEM ANALYSIS IN PARTS OF COLORADO, KANSAS, NEBRASKA, NEW MEXICO, OKLAHOMA, SOUTH DAKOTA, TEXAS, AND WYOMING USGS PROFESSIONAL PAPER 1400-A, 1988.

HYDROGEOLOGY OF LOWER CRETACEOUS STRATA UNDER THE SOUTHERN HIGH PLAINS OF TEXAS AND NEW MEXICO: TEXAS WATER DEVELOPMENT BOARD REPORT 314, 1989.

PUBLIC SUPPLY GROUND-WATER USE IN THE SOUTHERN HIGH PLAINS OF TEXAS: TEXAS WATER DEVELOPMENT BOARD REPORT 328, 1990. 
NATIONAL WATER-QUALITY ASSESSMENT PROGRAM-THE TRINITY RIVER BASIN: USGS OPEN-FILE REPORT 91-158, 1991.

WATER-LEVEL CHANGES IN THE HIGH PLAINS AQUIFER OF TEXAS, 1980-1990: TEXAS WATER DEVELOPMENT BOARD HYDROLOGIC ATLAS NO. 1, 1991.

WATER-RESOURCES DATA, TEXAS, WATER YEAR 1991, VOLUME 4 , GROUND-WATER DATA: USGS WATER-DATA REPORT TX-91-4, 1992.

THE HIGH PLAINS AQUIFER SYSTEM OF TEXAS, 1980-1990. OVERVIEW AND PROJECTIONS: TEXAS WATER DEVELOPMENT BOARD REPORT 341, 1993.

WATER-QUALITY EVALUATION OF THE OGALLALA AQUIFER, TEXAS: TEXAS WATER DEVELOPMENT BOARD REPORT 342, 1993.

WATER-RESOURCES DATA, TEXAS, WATER YEAR 1992, VOLUME 4, GROUND-WATER DATA: USGS WATER-DATA REPORT TX-92-4, 1993.

WATER-LEVEL CHANGES IN THE HIGH PLAINS AQUIFER-PREDEVELOPMENT TO 1992: USGS WATER-RESOURCES INVESTIGATIONS REPORT 94-4027, 1994.

WATER-RESOURCES DATA, TEXAS, WATER YEAR 1993, VOLUME 4 , GROUND-WATER DATA: USGS WATER-DATA REPORT TX-93-4, 1994.

WATER-LEVEL CHANGES IN THE HIGH PLAINS AQUIFER, 1980 TO 1994: USGS FACT SHEET FS-215-95, 1995.

AQUIFERS OF TEXAS: TEXAS WATER DEVELOPMENT BOARD REPORT 345, 1995.

WATER-RESOURCES DATA, TEXAS, WATER YEAR 1994, VOLUME 4, GROUND-WATER DATA: USGS WATER-DATA REPORT TX-94-4, 1995.

HYDROLOGIC ATLAS FOR COCHRAN COUNTY, TEXAS: HIGH PLAINS UNDERGROUND WATER CONSERVATION DISTRICT NO. 1, LUBBOCK, TEXAS, 1996.

WATER-RESOURCES DATA, TEXAS, WATER YEAR 1995, VOLUME 4, GROUND-WATER DATA: USGS WATER-DATA REPORT TX-95-4, 1996.

WATER-LEVEL CHANGES IN THE HIGH PLAINS AQUIFER, 1980 TO 1995: USGS FACT SHEET FS-068-97, 1997.

WATER-LEVEL CHANGES IN THE HIGH PLAINS AQUIFER-PREDEVELOPMENT TO 1995: USGS WATER-RESOURCES INVESTIGATIONS REPORT 97-4081, 1997.

WATER-RESOURCES DATA, TEXAS, WATER YEAR 1996, VOLUME 4, GROUND-WATER DATA: USGS WATER-DATA REPORT TX-96-4, 1997.

UPDATED WATER-QUALITY EVALUATION OF THE OGALLALA AQUIFER INCLUDING SELECTED METALLIC AND NON-METALLIC INORGANIC CONSTITUENTS: TEXAS WATER DEVELOPMENT BOARD HYDROLOGIC ATLAS NO. 10, 1998.

WATER-RESOURCES DATA, TEXAS, WATER YEAR 1997, VOLUME 4, GROUND-WATER DATA: USGS WATER-DATA REPORT TX-97-4, 1998.

WATER-RESOURCES DATA, TEXAS, WATER YEAR 1998, VOLUME 4, GROUND-WATER DATA: USGS WATER-DATA REPORT TX-98-4, 1999.
WATER-RESOURCES DATA, TEXAS, WATER YEAR 1999, VOLUME 6, GROUND-WATER DATA: USGS WATER-DATA REPORT TX-99-6, 2000.

WATER-RESOURCES DATA, TEXAS, WATER YEAR 2000, VOLUME 6 , GROUND-WATER DATA: USGS WATER-DATA REPORT TX-00-6, 2001.

\section{COKE COUNTY}

GROUND-WATER RECONNAISSANCE IN THE VICINITY OF BRONTE, COKE COUNTY, TEXAS: USGS OPEN-FILE REPORT (UNNUMBERED), 1946.

PUBLIC WATER SUPPLIES IN WESTERN TEXAS: USGS WATERSUPPLY PAPER 1106, 1951 [1952].

RECONNAISSANCE INVESTIGATION OF THE GROUND-WATER RESOURCES OF THE COLORADO RIVER BASIN, TEXAS: TEXAS WATER DEVELOPMENT BOARD REPORT 51, 1967.

GROUND-WATER RESOURCES OF COKE COUNTY, TEXAS: TEXAS WATER DEVELOPMENT BOARD REPORT 166, 1973.

WOODY PHREATOPHYTES ALONG THE COLORADO RIVER FROM SOUTHEAST RUNNELS COUNTY TO THE HEADWATERS IN BORDEN COUNTY, TEXAS: TEXAS WATER DEVELOPMENT BOARD REPORT 182, 1974.

OCCURRENCE, AVAILABILITY, AND CHEMICAL QUALITY OF GROUND WATER IN THE EDWARDS PLATEAU REGION OF TEXAS: TEXAS DEPARTMENT OF WATER RESOURCES REPORT $235,1979$.

SOURCE AREAS OF SALINITY AND TRENDS OF SALT LOADS IN STREAMFLOW IN THE UPPER COLORADO RIVER, TEXAS: USGS OPEN-FILE REPORT 80-224, 1980.

TEXAS GROUND-WATER RESOURCES, in NATIONAL WATER SUMMARY 1984: USGS WATER-SUPPLY PAPER 2275, 1985.

PUBLIC SUPPLY GROUND-WATER USE IN WESTERN TEXAS: TEXAS WATER DEVELOPMENT BOARD REPORT 311, 1989.

POTENTIOMETRIC SURFACE OF THE EDWARDS-TRINITY AQUIFER SYSTEM AND CONTIGUOUS HYDRAULICALLY CONNECTED UNITS, WEST-CENTRAL TEXAS, WINTER 1974-75: USGS WATERRESOURCES INVESTIGATIONS REPORT 89-4208, 1990.

WITHDRAWALS FROM THE EDWARDS-TRINITY AQUIFER SYSTEM AND CONTIGUOUS HYDRAULICALLY CONNECTED UNITS, WEST-CENTRAL TEXAS, DECEMBER 1974 THROUGH MARCH 1977: USGS WATER-RESOURCES INVESTIGATIONS REPORT 91-4021, 1991.

CONFIGURATION OF THE BASE OF THE EDWARDS-TRINITY AQUIFER SYSTEM AND HYDROGEOLOGY OF THE UNDERLYING PRECRETACEOUS ROCKS, WEST-CENTRAL TEXAS: USGS WATERRESOURCES INVESTIGATIONS REPORT 91-4071, 1992.

HISTORICAL POTENTIOMETRIC SURFACE OF THE EDWARDS-TRINITY AQUIFER SYSTEM AND CONTIGUOUS HYDRAULICALLY CONNECTED UNITS, WEST-CENTRAL TEXAS: USGS WATERRESOURCES INVESTIGATIONS REPORT 92-4055, 1993.

HISTORICAL SATURATED THICKNESS OF THE EDWARDS-TRINITY AQUIFER SYSTEM AND SELECTED CONTIGUOUS HYDRAULICALLY CONNECTED UNITS, WEST-CENTRAL TEXAS: USGS WATER-RESOURCES INVESTIGATIONS REPORT 92-4125, 1993. 
SIMULATIONS OF FLOW IN THE EDWARDS-TRINITY AQUIFER SYSTEM AND CONTIGUOUS HYDRAULICALLY CONNECTED UNITS, WEST-CENTRAL TEXAS: USGS WATER-RESOURCES INVESTIGATIONS REPORT 93-4039, 1994.

DISSOLVED-SOLIDS CONCENTRATIONS AND HYDROCHEMICAL FACIES IN WATER OF THE EDWARDS-TRINITY AQUIFER SYSTEM, WEST-CENTRAL TEXAS: USGS WATER-RESOURCES INVESTIGATIONS REPORT 93-4126, 1994.

CHARACTERISTICS OF STREAMS AND AQUIFERS AND PROCESSES AFFECTING THE SALINITY OF WATER IN THE UPPER COLORADO RIVER BASIN, TEXAS: USGS WATER-RESOURCES INVESTIGATIONS REPORT 94-4036, 1994.

GEOLOGIC HISTORY AND HYDROGEOLOGIC SETTING OF THE EDWARDS-TRINITY AQUIFER SYSTEM, WEST-CENTRAL TEXAS: USGS WATER-RESOURCES INVESTIGATIONS REPORT 94-4039, 1994.

WATER QUALITY IN THE EDWARDS-TRINITY (PLATEAU) AQUIFER AND TRANS-PECOS, TEXAS: TEXAS WATER DEVELOPMENT BOARD HYDROLOGIC ATLAS NO. 3, 1995.

AQUIFERS OF TEXAS: TEXAS WATER DEVELOPMENT BOARD REPORT 345, 1995

\section{COLEMAN COUNTY}

RECORDS OF WELLS AND SPRINGS, DRILLERS' LOGS, TEST WELL LOGS, RECORDS OF STREAMS AND LAKES, ANALYSES OF WATER FROM WELLS, SPRINGS, STREAMS, AND LAKES, AND MAP SHOWING LOCATIONS IN COLEMAN COUNTY, TEXAS: TEXAS BOARD OF WATER ENGINEERS MISCELLANEOUS PUBLICATION 55, 1938.

GROUND WATER AT COLEMAN, TEXAS: USGS OPEN-FILE REPORT (UNNUMBERED), 1944.

PUBLIC WATER SUPPLIES IN CENTRAL AND NORTH-CENTRAL TEXAS: USGS WATER-SUPPLY PAPER, 1949.

CITY OF VALERA, COLEMAN COUNTY, TEXAS: TEXAS WATER COMMISSION LIMITED DISTRIBUTION REPORT LD-0362-MR, 1962.

OCCURRENCE AND QUALITY OF GROUND WATER IN COLEMAN COUNTY, TEXAS: TEXAS WATER DEVELOPMENT BOARD REPORT 57, 1967.

RECONNAISSANCE INVESTIGATION OF THE GROUND-WATER RESOURCES OF THE COLORADO RIVER BASIN, TEXAS: TEXAS WATER DEVELOPMENT BOARD REPORT 51, 1967.

TEXAS GROUND-WATER RESOURCES, in NATIONAL WATER SUMMARY 1984: USGS WATER-SUPPLY PAPER 2275, 1985.

CHARACTERISTICS OF STREAMS AND AQUIFERS AND PROCESSES AFFECTING THE SALINITY OF WATER IN THE UPPER COLORADO RIVER BASIN, TEXAS: USGS WATER-RESOURCES INVESTIGATIONS REPORT 94-4036, 1994.

AQUIFERS OF TEXAS: TEXAS WATER DEVELOPMENT BOARD REPORT 345, 1995.

THE PALEOZOIC AND RELATED AQUIFERS OF CENTRAL TEXAS: TEXAS WATER DEVELOPMENT BOARD REPORT 346, 1996.
AN OVERVIEW OF THE EDWARDS-TRINITY AQUIFER SYSTEM, CENTRAL-WEST TEXAS, CHAPTER 8 , in AQUIFERS OF WEST TEXAS: TEXAS WATER DEVELOPMENT BOARD REPORT 356, 2001

\section{COLLIN COUNTY}

GEOGRAPHY AND GEOLOGY OF THE BLACK AND GRAND PRAIRIES OF TEXAS, WITH DETAILED DESCRIPTIONS OF THE CRETACEOUS FORMATIONS AND SPECIAL REFERENCE TO ARTESIAN WATERS: USGS 21ST ANNUAL REPORT, PART 7, 1901.

WATER SUPPLY OF McKINNEY, TEXAS: USGS OPEN-FILE REPORT (UNNUMBERED), 1943

PUBLIC WATER SUPPLIES IN EASTERN TEXAS: USGS WATERSUPPLY PAPER 1047, 1948.

RECONNAISSANCE INVESTIGATION OF THE GROUND-WATER RESOURCES OF THE SABINE RIVER BASIN, TEXAS: TEXAS WATER COMMISSION BULLETIN 6307, 1963.

RECONNAISSANCE INVESTIGATION OF THE GROUND-WATER RESOURCES OF THE TRINITY RIVER BASIN, TEXAS: TEXAS WATER COMMISSION BULLETIN 6309, 1963.

SUMMARY APPRAISALS OF THE NATION'S GROUND-WATER RESOURCES-TEXAS-GULF REGION: USGS PROFESSIONAL PAPER 813-F, 1976.

WATER-LEVEL AND WATER-QUALITY DATA FROM OBSERVATION WELLS IN NORTHEAST TEXAS: TEXAS WATER DEVELOPMENT BOARD REPORT 198, 1976

SPRINGS OF TEXAS, VOLUME 1: (BY GUNNAR BRUNE), BRANCHSMITH, INC., FORT WORTH, TEXAS, 1981

OCCURRENCE, AVAILABILITY, AND CHEMICAL QUALITY OF GROUND WATER IN THE CRETACEOUS AQUIFERS OF NORTHCENTRAL TEXAS: TEXAS DEPARTMENT OF WATER RESOURCES REPORT 269, V. 1, 1982.

OCCURRENCE, AVAILABILITY, AND CHEMICAL QUALITY OF GROUND WATER IN THE CRETACEOUS AQUIFERS OF NORTHCENTRAL TEXAS: TEXAS DEPARTMENT OF WATER RESOURCES REPORT 269, V. 2, 1982.

TEXAS GROUND-WATER RESOURCES, in NATIONAL WATER SUMMARY 1984: USGS WATER-SUPPLY PAPER 2275, 1985

EVALUATION OF WATER RESOURCES IN PART OF NORTH-CENTRAL TEXAS: TEXAS WATER DEVELOPMENT BOARD REPORT $318,1990$.

NATIONAL WATER-QUALITY ASSESSMENT PROGRAM-THE TRINITY RIVER BASIN: USGS OPEN-FILE REPORT 91-158, 1991.

NATIONAL WATER-QUALITY ASSESSMENT PROGRAM-PESTICIDES IN THE TRINITY RIVER BASIN STUDY UNIT, TEXAS, 1968-91: USGS FACT SHEET FS-088-95, 1995.

WATER-QUALITY ASSESSMENT OF THE TRINITY RIVER BASIN, TEXAS-DATA COLLECTION, 1992-95: USGS FACT SHEET FS-095-95, 1995.

WATER-QUALITY ASSESSMENT OF THE TRINITY RIVER BASIN, TEXAS-PESTICIDES IN A SUBURBAN WATERSHED, ARLINGTON, 1993-94: USGS FACT SHEET FS-159-95, 1995. 
AQUIFERS OF TEXAS: TEXAS WATER DEVELOPMENT BOARD REPORT 345, 1995.

WATER QUALITY IN THE WOODBINE AQUIFER, NORTH-CENTRAL TEXAS: TEXAS WATER DEVELOPMENT BOARD HYDROLOGIC ATLAS NO. 4, 1996.

UPDATED EVALUATION OF WATER RESOURCES IN PART OF NORTH-CENTRAL TEXAS, 1990-1999: TEXAS WATER DEVELOPMENT BOARD REPORT 349, 1999.

WATER-RESOURCES DATA, TEXAS, WATER YEAR 2000, VOLUME 6, GROUND-WATER DATA: USGS WATER-DATA REPORT TX-00-6, 2001.

\section{COLLINGSWORTH COUNTY}

THE GEOLOGY AND WATER RESOURCES OF THE EASTERN PORTION OF THE PANHANDLE OF TEXAS: USGS WATER-SUPPLY PAPER 154, 1906

RECORDS OF WELLS AND SPRINGS, DRILLERS' LOGS, WATER ANALYSES, AND MAP SHOWING LOCATION OF WELLS AND SPRINGS IN COLLINGSWORTH COUNTY, TEXAS: TEXAS BOARD OF WATER ENGINEERS MISCELLANEOUS PUBLICATION 39, 1939.

GROUND-WATER CONDITIONS IN THE MEMPHIS AREA, TEXAS: USGS OPEN-FILE REPORT (UNNUMBERED), 1943.

PUBLIC WATER SUPPLIES IN WESTERN TEXAS: USGS WATERSUPPLY PAPER 1106, 1951.

RECORDS OF WATER-LEVEL MEASUREMENTS IN COLLINGSWORTH, HEMPHILL, ROBERTS, AND WHEELER COUNTIES, TEXAS: TEXAS BOARD OF WATER ENGINEERS BULLETIN 5806, 1958.

GROUND-WATER RESOURCES OF COLLINGSWORTH COUNTY, TEXAS: TEXAS WATER DEVELOPMENT BOARD REPORT 119, 1970.

MAJOR AND HISTORICAL SPRINGS OF TEXAS: TEXAS WATER DEVELOPMENT BOARD REPORT 189, 1975.

SPRINGS OF TEXAS, VOLUME 1: (BY GUNNAR BRUNE), BRANCHSMITH, INC., FORT WORTH, TEXAS, 1981.

TEXAS GROUND-WATER RESOURCES, in NATIONAL WATER SUMMARY 1984: USGS WATER-SUPPLY PAPER 2275, 1985.

WATER USE, PROJECTED WATER REQUIREMENTS, AND RELATED DATA AND INFORMATION FOR THE METROPOLITAN STATISTICAL AREAS IN TEXAS: TEXAS DEPARTMENT OF WATER RESOURCES LIMITED PRINTING REPORT LP-201, 1985.

WATER-LEVEL CHANGES IN THE HIGH PLAINS AQUIFER OF TEXAS 1980-1990: TEXAS WATER DEVELOPMENT BOARD HYDROLOGIC ATLAS NO. 1, 1991.

EVALUATION OF WATER RESOURCES IN PARTS OF THE ROLLING PRAIRIES REGION OF NORTH-CENTRAL TEXAS: TEXAS WATER DEVELOPMENT BOARD REPORT 337, 1992.

AQUIFERS OF TEXAS: TEXAS WATER DEVELOPMENT BOARD REPORT 345, 1995.

UPDATED WATER-QUALITY EVALUATION OF THE OGALLALA AQUIFER INCLUDING SELECTED METALLIC AND NON-METAL-
LIC INORGANIC CONSTITUENTS: TEXAS WATER DEVELOPMENT BOARD HYDROLOGIC ATLAS NO. 10, 1998.

\section{COLORADO COUNTY}

UNDERGROUND WATERS OF THE COASTAL PLAIN OF TEXAS: USGS WATER-SUPPLY PAPER 190, 1907.

RECORDS OF WELLS AND SPRINGS, DRILLERS' LOGS, AND WATER ANALYSES, AND MAP SHOWING LOCATION OF WELLS AND SPRINGS IN COLORADO COUNTY, TEXAS: TEXAS BOARD OF WATER ENGINEERS MISCELLANEOUS PUBLICATION 57, 1938.

PUBLIC WATER SUPPLIES IN EASTERN TEXAS: USGS WATERSUPPLY PAPER 1047, 1948

AVAILABILITY OF GROUND WATER IN THE GULF COAST REGION OF TEXAS: USGS OPEN-FILE REPORT (UNNUMBERED), 1956.

RECONNAISSANCE INVESTIGATION OF THE GROUND-WATER RESOURCES OF THE GULF COAST REGION, TEXAS: TEXAS WATER COMMISSION BULLETIN 6305, 1963.

HYDROLOGIC SIGNIFICANCE OF THE LITHOFACIES OF THE SPARTA SAND IN ARKANSAS, LOUISIANA, MISSISSIPPI, AND TEXAS: USGS PROFESSIONAL PAPER 569-A, 1968.

GEOHYDROLOGIC SIGNIFICANCE OF LITHOFACIES OF THE COCKFIELD FORMATION OF LOUISIANA AND MISSISSIPPI AND OF THE YEGUA FORMATION OF TEXAS: USGS PROFESSIONAL PAPER 569-B, 1970.

HYDROLOGIC SIGNIFICANCE OF LITHOFACIES OF THE CANE RIVER FORMATION OR EQUIVALENTS OF ARKANSAS, LOUISIANA, MISSISSIPPI, AND TEXAS: USGS PROFESSIONAL PAPER 569-C, 1972.

GEOHYDROLOGIC SIGNIFICANCE OF LITHOFACIES OF THE CARRIZO SAND OF ARKANSAS, LOUISIANA, AND TEXAS AND THE MERIDIAN SAND OF MISSISSIPPI: USGS PROFESSIONAL PAPER 569-D, 1975.

SUMMARY APPRAISALS OF THE NATION'S GROUND-WATER RESOURCES-TEXAS-GULF REGION: USGS PROFESSIONAL PAPER 813-F, 1976

STRATIGRAPHIC AND HYDROGEOLOGIC FRAMEWORK OF PART OF THE COASTAL PLAIN OF TEXAS: USGS OPEN-FILE REPORT 77-712, 1978. ALSO PUBLISHED AS TEXAS DEPARTMENT OF WATER RESOURCES REPORT 236, 1979.

GROUND-WATER RESOURCES OF COLORADO, LAVACA, AND WHARTON COUNTIES, TEXAS: USGS OPEN-FILE REPORT 79-212, 1979.

SPRINGS OF TEXAS, VOLUME 1: (BY GUNNAR BRUNE), BRANCHSMITH, INC., FORT WORTH, TEXAS, 1981.

GROUND-WATER RESOURCES OF COLORADO, LAVACA, AND WHARTON COUNTIES, TEXAS: TEXAS DEPARTMENT OF WATER RESOURCES REPORT 270, 1982.

REGIONAL HYDRODYNAMICS AND HYDROCHEMISTRY OF THE URANIUM-BEARING OAKVILLE AQUIFER (MIOCENE) OF SOUTH TEXAS: UNIVERSITY OF TEXAS, BUREAU OF ECONOMIC GEOLOGY REPORT OF INVESTIGATIONS NO. 124, 1982.

TEXAS GROUND-WATER RESOURCES, in NATIONAL WATER SUMMARY 1984: USGS WATER-SUPPLY PAPER 2275, 1985. 
DIGITAL MODELS FOR SIMULATION OF GROUND-WATER HYDROLOGY OF THE CHICOT AND EVANGELINE AQUIFERS ALONG THE GULF COAST OF TEXAS: TEXAS DEPARTMENT OF WATER RESOURCES REPORT 289, 1985.

GEOHYDROLOGIC FRAMEWORK OF THE GULF COASTAL PLAIN: USGS HYDROLOGIC ATLAS HA-695, 1988.

FLOW PATTERN IN REGIONAL AQUIFERS AND FLOW RELATIONS BETWEEN THE LOWER COLORADO RIVER VALLEY AND REGIONAL AQUIFERS IN SIX COUNTIES OF SOUTHEASTERN TEXAS: USGS WATER-RESOURCES INVESTIGATIONS REPORT 88-4154, 1989.

PROPERTIES AND CHEMICAL CONSTITUENTS IN GROUND WATER FROM THE MISSISSIPPI RIVER VALLEY ALLUVIAL AQUIFER AND PERMEABLE ZONE A (HOLOCENE-UPPER PLEISTOCENE DEPOSITS), SOUTH-CENTRAL UNITED STATES: USGS WATERRESOURCES INVESTIGATIONS REPORT 91-4149, 1992.

PROPERTIES AND CHEMICAL CONSTITUENTS IN GROUND WATER FROM THE UPPER CLAIBORNE AQUIFER, GULF COAST REGIONAL AQUIFER SYSTEMS, SOUTH-CENTRAL UNITED STATES: USGS WATER-RESOURCES INVESTIGATIONS REPORT 91-4150, 1993.

PROPERTIES AND CHEMICAL CONSTITUENTS IN GROUND WATER FROM PERMEABLE ZONE C (LOWER PLIOCENE-UPPER MIOCENE DEPOSITS), COASTAL LOWLANDS AQUIFER SYSTEM, SOUTHCENTRAL UNITED STATES: USGS WATER-RESOURCES INVESTIGATIONS REPORT 91-4151, 1993.

PROPERTIES AND CHEMICAL CONSTITUENTS IN GROUND WATER FROM PERMEABLE ZONE B (LOWER PLEISTOCENE-UPPER PLIOCENE DEPOSITS), COASTAL LOWLANDS AQUIFER SYSTEM, SOUTH-CENTRAL UNITED STATES: USGS WATER-RESOURCES INVESTIGATIONS REPORT 91-4152, 1993.

PROPERTIES AND CHEMICAL CONSTITUENTS IN GROUND WATER FROM PERMEABLE ZONE E (LOWER MIOCENE-UPPER OLIGOCENE DEPOSITS), COASTAL LOWLANDS AQUIFER SYSTEM, SOUTH-CENTRAL UNITED STATES: USGS WATER-RESOURCES INVESTIGATIONS REPORT 92-4103, 1993.

PROPERTIES AND CHEMICAL CONSTITUENTS IN GROUND WATER FROM THE MIDDLE CLAIBORNE AQUIFER, GULF COAST REGIONAL AQUIFER SYSTEMS, SOUTH-CENTRAL UNITED STATES: USGS WATER-RESOURCES INVESTIGATIONS REPORT 92-4104, 1993.

PROPERTIES AND CHEMICAL CONSTITUENTS IN GROUND WATER FROM PERMEABLE ZONE D (MIDDLE MIOCENE DEPOSITS), COASTAL LOWLANDS AQUIFER SYSTEM, SOUTH-CENTRAL UNITED STATES: USGS WATER-RESOURCES INVESTIGATIONS REPORT 92-4105, 1993.

PROPERTIES AND CHEMICAL CONSTITUENTS IN GROUND WATER FROM THE MIDDLE WILCOX AQUIFER, GULF COAST REGIONAL AQUIFER SYSTEMS, SOUTH-CENTRAL UNITED STATES: USGS WATER-RESOURCES INVESTIGATIONS REPORT 93-4070, 1993.

AQUIFERS OF TEXAS: TEXAS WATER DEVELOPMENT BOARD REPORT 345, 1995.

\section{COMALCOUNTY}

REPORT OF PROGRESS OF THE DIVISION OF HYDROGRAPHY FOR THE CALENDAR YEAR 1895: USGS BULLETIN 140, 1896.
GEOLOGY OF THE EDWARDS PLATEAU AND RIO GRANDE PLAIN ADJACENT TO AUSTIN AND SAN ANTONIO, TEXAS, WITH REFERENCE TO THE OCCURRENCE OF UNDERGROUND WATERS: USGS 18TH ANNUAL REPORT, PART 2, 1898.

REPORT OF PROGRESS OF STREAM MEASUREMENTS FOR THE CALENDAR YEAR 1904: USGS WATER-SUPPLY AND IRRIGATION PAPER 132, 1905.

LARGE SPRINGS IN THE UNITED STATES: USGS WATER-SUPPLY PAPER 557, 1927.

WATER RESOURCES OF THE EDWARDS LIMESTONE IN THE SAN ANTONIO AREA, TEXAS: USGS WATER-SUPPLY PAPER 773-B, 1936.

RECORDS OF WELLS, DRILLERS' LOGS, AND WATER ANALYSES, AND MAP SHOWING LOCATION OF WELLS IN COMAL COUNTY, TEXAS: TEXAS BOARD OF WATER ENGINEERS MISCELLANEOUS PUBLICATION 58, 1937.

MEMORANDUM TO THE TEXAS BOARD OF WATER ENGINEERS REGARDING THE NEED FOR SURFACE-WATER GAGING STATIONS ON CIBOLO CREEK IN COMAL COUNTY: USGS OPEN-FILE REPORT (UNNUMBERED), 1944.

GEOLOGY AND GROUND-WATER RESOURCES OF COMAL COUNTY, TEXAS: TEXAS BOARD OF WATER ENGINEERS MISCELLANEOUS PUBLICATION 59, 1947.

PUBLIC WATER SUPPLIES IN SOUTHERN TEXAS: USGS WATERSUPPLY PAPER 1070, 1950.

GEOLOGY AND GROUND-WATER RESOURCES OF COMAL COUNTY, TEXAS: USGS WATER-SUPPLY PAPER 1138, 1952.

MISCELLANEOUS FIELD NOTES ON THE GEOLOGY OF THE SAN ANTONIO AREA, TEXAS: USGS CONFIDENTIAL REPORT, 1953.

GROUND-WATER RESOURCES OF THE SAN ANTONIO AREA, TEXAS, A PROGRESS REPORT ON CURRENT STUDIES: TEXAS BOARD OF WATER ENGINEERS BULLETIN 5412, 1954.

GEOLOGY OF THE CANYON RESERVOIR SITE ON THE GUADALUPE RIVER, COMAL COUNTY, TEXAS: USGS OPEN-FILE REPORT (UNNUMBERED), 1955.

RECORDS OF TEST WELLS AT CANYON RESERVOIR SITE IN COMAL COUNTY, TEXAS: USGS OPEN-FILE REPORT (UNNUMBERED), 1955.

GROUND-WATER RESOURCES OF THE SAN ANTONIO AREA, TEXAS, VOLUME 1, A PROGRESS REPORT ON CURRENT STUDIES: TEXAS BOARD OF WATER ENGINEERS BULLETIN 5608, V. 1, 1956.

GROUND-WATER RESOURCES OF THE SAN ANTONIO AREA, TEXAS, VOLUME 2, PART 1, RECORDS OF WELLS AND SPRINGS: TEXAS BOARD OF WATER ENGINEERS BULLETIN 5608, V. 2, PART 1, 1956.

GROUND-WATER RESOURCES OF THE SAN ANTONIO AREA, TEXAS, VOLUME 2, PART 2, RECORDS OF DRILLERS' LOGS: TEXAS BOARD OF WATER ENGINEERS BULLETIN 5608, V. 2, PART 2, 1956.

GROUND-WATER RESOURCES OF THE SAN ANTONIO AREA, TEXAS, VOLUME 2, PART 3, WATER LEVELS IN WELLS, CHEMICAL ANALYSES OF WATER, RECORDS OF STREAMFLOW AND RESERVOIR CONTENTS, DISCHARGE MEASUREMENTS, AND PRECIPITATION IN THE SAN ANTONIO AREA, TEXAS: TEXAS BOARD OF WATER ENGINEERS BULLETIN 5608, V. 2, PART 3, 1956. 
RECORDS OF WATER-LEVEL MEASUREMENTS IN COMAL AND GUADALUPE COUNTIES, TEXAS, 1933-MARCH 1956: TEXAS BOARD OF WATER ENGINEERS BULLETIN 5610, 1956.

RECHARGE, DISCHARGE, AND CHANGES IN GROUND-WATER STORAGE IN THE EDWARDS AND ASSOCIATED LIMESTONES, SAN ANTONIO AREA, TEXAS, A PROGRESS REPORT ON STUDIES 1955-59: TEXAS WATER COMMISSION BULLETIN 6201, 1962.

CHEMICAL ANALYSES OF WATER FROM OBSERVATION WELLS IN THE EDWARDS AND ASSOCIATED LIMESTONES, SAN ANTONIO AREA, TEXAS: EDWARDS UNDERGROUND WATER DISTRICT BULLETIN 1, 1962.

NOTES ON GEOLOGY OF PROPOSED BAT CAVE RESERVOIR AND VICINITY, BEXAR AND COMAL COUNTIES, TEXAS: USGS OPENFILE REPORT (NO NUMBER), 1963.

GROUND-WATER DISCHARGE FROM THE EDWARDS AND ASSOCIATED LIMESTONES, 1955-62, SAN ANTONIO AREA, TEXAS: EDWARDS UNDERGROUND WATER DISTRICT BULLETIN 2, 1963.

RECORDS OF PRECIPITATION, AQUIFER HEAD, AND GROUNDWATER DISCHARGE TO THE EDWARDS AND ASSOCIATED LIMESTONES, 1960-62, SAN ANTONIO AREA, TEXAS: EDWARDS UNDERGROUND WATER DISTRICT BULLETIN 3, 1963.

CHEMICAL ANALYSES OF WATER FROM OBSERVATION WELLS IN THE EDWARDS AND ASSOCIATED LIMESTONES, SAN ANTONIO AREA, TEXAS, 1963: EDWARDS UNDERGROUND WATER DISTRICT BULLETIN 4, 1964.

GROUND-WATER DISCHARGE FROM THE EDWARDS AND ASSOCIATED LIMESTONES, SAN ANTONIO AREA, TEXAS, 1963: EDWARDS UNDERGROUND WATER DISTRICT BULLETIN 5, 1964.

RECORDS OF PRECIPITATION, AQUIFER HEAD, AND GROUNDWATER RECHARGE TO THE EDWARDS AND ASSOCIATED LIMESTONES, SAN ANTONIO AREA, TEXAS, 1963: EDWARDS UNDERGROUND WATER DISTRICT BULLETIN 6, 1964.

RECONNAISSANCE INVESTIGATION OF THE GROUND-WATER RESOURCES OF THE GUADALUPE, SAN ANTONIO, AND NUECES RIVER BASINS, TEXAS: TEXAS WATER COMMISSION BULLETIN 6409, 1964.

BASE-FLOW STUDIES, GUADALUPE RIVER, COMAL COUNTY, TEXAS-QUANTITY, MARCH 1962: TEXAS WATER COMMISSION BULLETIN 6503, 1965.

CHEMICAL ANALYSES OF WATER FROM OBSERVATION WELLS IN THE EDWARDS AND ASSOCIATED LIMESTONES, SAN ANTONIO AREA, TEXAS, 1964: EDWARDS UNDERGROUND WATER DISTRICT BULLETIN 7, 1965.

GROUND-WATER DISCHARGE FROM THE EDWARDS AND ASSOCIATED LIMESTONES, SAN ANTONIO AREA, TEXAS, 1964: EDWARDS UNDERGROUND WATER DISTRICT BULLETIN 8, 1965

GROUND-WATER RECHARGE TO THE EDWARDS AND ASSOCIATED LIMESTONES, SAN ANTONIO AREA, TEXAS, 1964: EDWARDS UNDERGROUND WATER DISTRICT BULLETIN 9, 1965.

CHEMICAL ANALYSES FROM OBSERVATION WELLS IN THE EDWARDS AND ASSOCIATED LIMESTONES, SAN ANTONIO AREA, TEXAS, 1965: EDWARDS UNDERGROUND WATER DISTRICT BULLETIN 10, 1966.

GROUND-WATER DISCHARGE FROM THE EDWARDS AND ASSOCIATED LIMESTONES, SAN ANTONIO AREA, TEXAS, 1965: EDWARDS UNDERGROUND WATER DISTRICT BULLETIN 11, 1966.
RECORDS OF PRECIPITATION, AQUIFER HEAD, AND GROUNDWATER RECHARGE TO THE EDWARDS AND ASSOCIATED LIMESTONES, SAN ANTONIO AREA, TEXAS, 1965: EDWARDS UNDERGROUND WATER DISTRICT BULLETIN 12, 1966.

GROUND-WATER RESOURCES OF THE SAN ANTONIO AREA, TEXAS, A PROGRESS REPORT ON STUDIES, 1960-64: TEXAS WATER DEVELOPMENT BOARD REPORT 34, 1966.

CHEMICAL ANALYSES OF WATER FROM OBSERVATION WELLS IN THE EDWARDS AND ASSOCIATED LIMESTONES, SAN ANTONIO AREA, TEXAS, 1966: EDWARDS UNDERGROUND WATER DISTRICT BULLETIN 13, 1967.

GROUND-WATER DISCHARGE FROM THE EDWARDS AND ASSOCIATED LIMESTONES, SAN ANTONIO AREA, TEXAS, 1966: EDWARDS UNDERGROUND WATER DISTRICT BULLETIN 14, 1967.

RECORDS OF PRECIPITATION, AQUIFER HEAD, AND GROUNDWATER RECHARGE TO THE EDWARDS AND ASSOCIATED LIMESTONES, SAN ANTONIO AREA, TEXAS, 1966: EDWARDS UNDERGROUND WATER DISTRICT BULLETIN 15, 1967.

CHEMICAL ANALYSES OF WATER FROM OBSERVATION WELLS IN THE EDWARDS AND ASSOCIATED LIMESTONES, SAN ANTONIO AREA, TEXAS, 1967: EDWARDS UNDERGROUND WATER DISTRICT BULLETIN 16, 1968.

HYDROLOGIC EFFECTS OF THE EARTHQUAKE OF MARCH 27, 1964 OUTSIDE ALASKA: USGS PROFESSIONAL PAPER 544-C, 1968.

GROUND-WATER DISCHARGE FROM THE EDWARDS AND ASSOCIATED LIMESTONES, SAN ANTONIO AREA, TEXAS, 1967: EDWARDS UNDERGROUND WATER DISTRICT BULLETIN 17, 1968

RECORDS OF PRECIPITATION, AQUIFER HEAD, AND GROUNDWATER RECHARGE TO THE EDWARDS AND ASSOCIATED LIMESTONES, SAN ANTONIO AREA, TEXAS, 1967: EDWARDS UNDERGROUND WATER DISTRICT BULLETIN 18, 1968.

RECORDS OF WELLS AND SPRINGS, SAN ANTONIO AREA, TEXAS: EDWARDS UNDERGROUND WATER DISTRICT, 1969.

GROUND-WATER DISCHARGE FROM THE EDWARDS AND ASSOCIATED LIMESTONES, SAN ANTONIO AREA, TEXAS, 1968: EDWARDS UNDERGROUND WATER DISTRICT BULLETIN 20, 1969

RECORDS OF PRECIPITATION, AQUIFER HEAD, AND GROUNDWATER RECHARGE TO THE EDWARDS AND ASSOCIATED LIMESTONES, SAN ANTONIO AREA, TEXAS, 1968: EDWARDS UNDERGROUND WATER DISTRICT BULLETIN 21, 1969.

GEOLOGY AND WATER QUALITY AT SELECTED LOCATIONS IN THE SAN ANTONIO AREA, TEXAS, PROGRESS REPORT, 1969: USGS OPEN-FILE REPORT 70-272, 1970.

GEOLOGY AND WATER QUALITY AT SELECTED LOCATIONS IN THE SAN ANTONIO AREA, TEXAS, PROGRESS REPORT, 1969: EDWARDS UNDERGROUND WATER DISTRICT, 1970.

GROUND-WATER DISCHARGE FROM THE EDWARDS AND ASSOCIATED LIMESTONES, SAN ANTONIO AREA, TEXAS, 1969: EDWARDS UNDERGROUND WATER DISTRICT BULLETIN 23, 1970.

RECORDS OF PRECIPITATION, WATER LEVELS, AND GROUNDWATER RECHARGE TO THE EDWARDS AND ASSOCIATED LIMESTONES, SAN ANTONIO AREA, TEXAS, 1969: EDWARDS UNDERGROUND WATER DISTRICT BULLETIN 24, 1970.

GROUND-WATER DISCHARGE FROM THE EDWARDS AND ASSOCIATED LIMESTONES, SAN ANTONIO AREA, TEXAS, 1970: EDWARDS UNDERGROUND WATER DISTRICT BULLETIN 26, 1971 
RECORDS OF PRECIPITATION, WATER LEVELS, AND GROUNDWATER RECHARGE TO THE EDWARDS AND ASSOCIATED LIMESTONES, SAN ANTONIO AREA, TEXAS, 1970: EDWARDS UNDERGROUND WATER DISTRICT BULLETIN 27, 1971.

GROUND-WATER DISCHARGE FROM THE EDWARDS AND ASSOCIATED LIMESTONES, SAN ANTONIO AREA, TEXAS, 1971:

EDWARDS UNDERGROUND WATER DISTRICT BULLETIN 29, 1972.

RECORDS OF PRECIPITATION, WATER LEVELS, AND GROUNDWATER RECHARGE TO THE EDWARDS AND ASSOCIATED LIMESTONES, SAN ANTONIO AREA, TEXAS, 1971: EDWARDS UNDERGROUND WATER DISTRICT BULLETIN 30, 1972.

CHEMICAL AND BACTERIOLOGICAL QUALITY OF WATER AT SELECTED SITES IN THE SAN ANTONIO AREA, TEXAS, AUGUST 1968-APRIL 1972: EDWARDS UNDERGROUND WATER DISTRICT, 1972.

GROUND-WATER DISCHARGE FROM THE EDWARDS AND ASSOCIATED LIMESTONES, SAN ANTONIO AREA, TEXAS, 1972: EDWARDS UNDERGROUND WATER DISTRICT BULLETIN 31, 1973.

REGIONAL SPECIFIC YIELD OF THE EDWARDS AND ASSOCIATED LIMESTONES IN THE SAN ANTONIO, TEXAS, AREA: EDWARDS UNDERGROUND WATER DISTRICT, 1973.

GROUND-WATER DISCHARGE FROM THE EDWARDS AND ASSOCIATED LIMESTONES, SAN ANTONIO AREA, TEXAS, 1973: EDWARDS UNDERGROUND WATER DISTRICT BULLETIN 32, 1974

RECORDS OF PRECIPITATION, WATER LEVELS, AND GROUNDWATER RECHARGE TO THE EDWARDS AND ASSOCIATED LIMESTONES, SAN ANTONIO AREA, TEXAS, 1972-73: EDWARDS UNDERGROUND WATER DISTRICT BULLETIN 33, 1974.

RELATION OF PRECIPITATION TO ANNUAL GROUND-WATER RECHARGE IN THE EDWARDS AQUIFER, SAN ANTONIO AREA, TEXAS: USGS OPEN-FILE REPORT 75-298, 1975

THE EDWARDS UNDERGROUND RESERVOIR AND THE EDWARDS UNDERGROUND WATER DISTRICT: SOUTH TEXAS GEOLOGICAL SOCIETY BULLETIN V. 15, NO. 7, 1975

RECORDS OF PRECIPITATION, WATER LEVELS, AND GROUNDWATER RECHARGE TO THE EDWARDS AND ASSOCIATED LIMESTONES, SAN ANTONIO AREA, TEXAS, 1972-73: SOUTH TEXAS GEOLOGICAL SOCIETY BULLETIN V. 15, NO. 7, 1975.

GROUND-WATER DISCHARGE FROM THE EDWARDS AND ASSOCIATED LIMESTONES, SAN ANTONIO AREA, TEXAS, 1974: EDWARDS UNDERGROUND WATER DISTRICT BULLETIN 34, 1975.

MAJOR AND HISTORICAL SPRINGS OF TEXAS: TEXAS WATER DEVELOPMENT BOARD REPORT 189, 1975.

GEOCHEMICAL AND ISOTOPIC ANALYSES OF WATERS ASSOCIATED WITH THE EDWARDS LIMESTONE AQUIFER, CENTRAL TEXAS: EDWARDS UNDERGROUND WATER DISTRICT, 1976.

GROUND-WATER DISCHARGE FROM THE EDWARDS AND ASSOCIATED LIMESTONES, SAN ANTONIO AREA, TEXAS, 1975: EDWARDS UNDERGROUND WATER DISTRICT BULLETIN 35, 1976.

STATISTICAL ANALYSIS OF WATER-LEVEL, SPRINGFLOW, AND STREAMFLOW DATA FOR THE EDWARDS AQUIFER IN SOUTHCENTRAL TEXAS: USGS OPEN-FILE REPORT 76-393, 1976.

STATISTICAL ANALYSIS OF WATER-LEVEL, SPRINGFLOW, AND STREAMFLOW DATA FOR THE EDWARDS AQUIFER IN SOUTHCENTRAL TEXAS: EDWARDS UNDERGROUND WATER DISTRICT, 1976.
CHEMICAL AND BACTERIOLOGICAL QUALITY OF WATER AT SELECTED SITES IN THE SAN ANTONIO AREA, TEXAS, AUGUST 1968-JANUARY 1975: USGS OPEN-FILE REPORT 76-574, 1976.

CHEMICAL AND BACTERIOLOGICAL QUALITY OF WATER AT SELECTED SITES IN THE SAN ANTONIO AREA, TEXAS, AUGUST 1968-JANUARY 1975: EDWARDS UNDERGROUND WATER DISTRICT, 1976

PROGRESS REPORT ON GEOLOGY OF THE EDWARDS AQUIFER, SAN ANTONIO AREA, TEXAS, AND PRELIMINARY INTERPRETATION OF BOREHOLE GEOPHYSICAL AND LABORATORY DATA ON CARBONATE ROCKS: USGS OPEN-FILE REPORT 76-627, 1976.

GROUND-WATER DISCHARGE FROM THE EDWARDS AND ASSOCIATED LIMESTONES, SAN ANTONIO AREA, TEXAS, 1976: EDWARDS UNDERGROUND WATER DISTRICT, 1977.

METHOD OF ESTIMATING NATURAL RECHARGE TO THE EDWARDS AQUIFER IN THE SAN ANTONIO AREA, TEXAS: USGS WATERRESOURCES INVESTIGATIONS REPORT 78-10, 1978.

REGIONAL DISTRIBUTION OF FRACTURES IN THE SOUTHERN EDWARDS PLATEAU AND THEIR RELATIONSHIP TO TECTONICS AND CAVES: UNIVERSITY OF TEXAS, BUREAU OF ECONOMIC GEOLOGY GEOLOGICAL CIRCULAR 78-2, 1978.

CHEMICAL AND BACTERIOLOGICAL QUALITY OF WATER AT SELECTED SITES IN THE SAN ANTONIO AREA, TEXAS, FEBRUARY 1975-SEPTEMBER 1977: EDWARDS UNDERGROUND WATER DISTRICT, 1978.

RECORDS OF GROUND-WATER RECHARGE AND DISCHARGE FOR THE EDWARDS AQUIFER IN THE SAN ANTONIO AREA, TEXAS, 1934-77: EDWARDS UNDERGROUND WATER DISTRICT BULLETIN 37, 1979.

GEOHYDROLOGY OF COMAL, SAN MARCOS, AND HUECO SPRINGS TEXAS DEPARTMENT OF WATER RESOURCES REPORT 234, 1979.

GROUND-WATER RESOURCES AND MODEL APPLICATIONS FOR THE EDWARDS (BALCONES FAULT SYSTEM) AQUIFER IN THE SAN ANTONIO REGION: TEXAS DEPARTMENT OF WATER RESOURCES REPORT 239, 1979.

HYDROCHEMICAL DATA FOR THE EDWARDS AQUIFER IN THE SAN ANTONIO AREA, TEXAS: TEXAS DEPARTMENT OF WATER RESOURCES LIMITED PRINTING REPORT LP-131, 1980.

RECORDS OF GROUND-WATER RECHARGE, DISCHARGE, WATER LEVELS, AND CHEMICAL QUALITY OF WATER FOR THE EDWARDS AQUIFER IN THE SAN ANTONIO AREA, TEXAS, 1934-78: EDWARDS UNDERGROUND WATER DISTRICT BULLETIN 38, 1980

WATER-LEVEL, RECHARGE, DISCHARGE, SPECIFIC CAPACITY, WELL-YIELD, AND AQUIFER-TEST DATA FOR THE EDWARDS AQUIFER IN THE SAN ANTONIO AREA, TEXAS: TEXAS DEPARTMENT OF WATER RESOURCES LIMITED PRINTING REPORT LP-133, 1980

SPRINGS OF TEXAS, VOLUME 1: (BY GUNNAR BRUNE), BRANCHSMITH, INC., FORT WORTH, TEXAS, 1981.

APPLICATION AND ANALYSIS OF BOREHOLE DATA FOR THE EDWARDS AQUIFER IN THE SAN ANTONIO AREA, TEXAS: TEXAS DEPARTMENT OF WATER RESOURCES LIMITED PRINTING REPORT LP-139, 1981.

RECORDS OF GROUND-WATER RECHARGE, DISCHARGE, WATER LEVELS, AND CHEMICAL QUALITY OF WATER FOR THE 
EDWARDS AQUIFER IN THE SAN ANTONIO AREA, TEXAS, 1934-79: EDWARDS UNDERGROUND WATER DISTRICT BULLETIN 39, 1981.

TEST-HOLE DATA FOR THE EDWARDS AQUIFER IN THE SAN ANTONIO AREA, TEXAS: TEXAS DEPARTMENT OF WATER RESOURCES LIMITED PRINTING REPORT LP-171, 1982.

RECORDS OF GROUND-WATER RECHARGE, DISCHARGE, WATER LEVELS, AND CHEMICAL QUALITY OF WATER FOR THE EDWARDS AQUIFER IN THE SAN ANTONIO AREA, TEXAS, 1934-80: EDWARDS UNDERGROUND WATER DISTRICT BULLETIN 40, 1982.

GROUND-WATER AVAILABILITY OF THE LOWER CRETACEOUS FORMATIONS IN THE HILL COUNTRY OF SOUTH-CENTRAL TEXAS: TEXAS DEPARTMENT OF WATER RESOURCES REPORT $273,1983$.

RECORDS OF GROUND-WATER RECHARGE, DISCHARGE, WATER LEVELS, AND CHEMICAL QUALITY OF WATER FOR THE EDWARDS AQUIFER IN THE SAN ANTONIO AREA, TEXAS, 1934-81: EDWARDS UNDERGROUND WATER DISTRICT BULLETIN 41, 1984.

CARBONATE GEOLOGY AND HYDROLOGY OF THE EDWARDS AQUIFER IN THE SAN ANTONIO AREA, TEXAS: USGS OPEN-FILE REPORT 83-537, 1984.

IDENTIFICATION AND TABULATION OF GEOLOGICAL CONTACTS IN THE EDWARDS AQUIFER, SAN ANTONIO AREA, TEXAS: USGS OPEN-FILE REPORT 84-075, 1984.

PROPOSED 10-YEAR PLAN FOR CONTINUATION OF HYDROLOGIC STUDIES OF THE EDWARDS AQUIFER, SAN ANTONIO AREA, TEXAS: USGS OPEN-FILE REPORT 84-817, 1984.

RECORDS OF GROUND-WATER RECHARGE, DISCHARGE, WATER LEVELS, AND CHEMICAL QUALITY OF WATER FOR THE EDWARDS AQUIFER IN THE SAN ANTONIO AREA, TEXAS, 1934-82: EDWARDS UNDERGROUND WATER DISTRICT BULLETIN 42, 1985.

IDENTIFICATION AND TABULATION OF GEOLOGICAL CONTACTS IN THE EDWARDS AQUIFER, SAN ANTONIO AREA, TEXAS: TEXAS DEPARTMENT OF WATER RESOURCES LIMITED PRINTING REPORT LP-199, 1985.

TEXAS GROUND-WATER RESOURCES, in NATIONAL WATER SUMMARY 1984: USGS WATER-SUPPLY PAPER 2275, 1985.

STATISTICAL SUMMARY OF WATER-QUALITY DATA COLLECTED FROM SELECTED WELLS AND SPRINGS IN THE EDWARDS AQUIFER NEAR SAN ANTONIO, TEXAS: USGS OPEN-FILE REPORT 85-182, 1985.

WATER USE, PROJECTED WATER REQUIREMENTS, AND RELATED DATA AND INFORMATION FOR THE METROPOLITAN STATISTICAL AREAS IN TEXAS: TEXAS DEPARTMENT OF WATER RESOURCES LIMITED PRINTING REPORT LP-201, 1985.

COMPILATION OF HYDROLOGIC DATA FOR THE EDWARDS AQUIFER, SAN ANTONIO AREA, TEXAS, 1983-84, WITH 1934-84 SUMMARY: EDWARDS UNDERGROUND WATER DISTRICT BULLETIN 43-44, 1986.

HYDROGEOLOGIC SECTIONS OF THE EDWARDS AQUIFER AND ITS CONFINING UNITS IN THE SAN ANTONIO AREA, TEXAS: USGS WATER-RESOURCES INVESTIGATIONS REPORT 85-4259, 1986.
CARBONATE GEOLOGY AND HYDROLOGY OF THE EDWARDS AQUIFER IN THE SAN ANTONIO AREA, TEXAS: TEXAS WATER DEVELOPMENT BOARD REPORT 296, 1986.

THE EDWARDS AQUIFER: EXTREMELY PRODUCTIVE, BUT....A SOLE-SOURCE WATER SUPPLY FOR SAN ANTONIO AND SURROUNDING COUNTIES IN SOUTH-CENTRAL TEXAS: EDWARDS UNDERGROUND WATER DISTRICT, 1986.

POTENTIAL FOR UPDIP MOVEMENT OF SALINEWATER IN THE EDWARDS AQUIFER, SAN ANTONIO, TEXAS: USGS WATERRESOURCES INVESTIGATIONS REPORT 86-4032, 1986.

HYDROCHEMISTRY OF THE COMAL, HUECO, AND SAN MARCOS SPRINGS, EDWARDS AQUIFER, TEXAS, in BALCONES ESCARPMENT: PUBLISHED FOR GEOLOGICAL SOCIETY OF AMERICA ANNUAL MEETING, SAN ANTONIO, TEXAS, NOVEMBER, 1986.

SIMULATION OF FLOW IN THE EDWARDS AQUIFER, SAN ANTONIO REGION, TEXAS, AND REFINEMENT OF STORAGE AND FLOW CONCEPTS: USGS OPEN-FILE REPORT 86-532, 1987.

RELATION OF WATER CHEMISTRY OF THE EDWARDS AQUIFER TO HYDROGEOLOGY AND LAND USE, SAN ANTONIO AREA, TEXAS: USGS WATER-RESOURCES INVESTIGATIONS REPORT 87-4116, 1987.

COMPILATION OF HYDROLOGIC DATA FOR THE EDWARDS AQUIFER, SAN ANTONIO AREA, TEXAS, 1985, WITH 1934-85 SUMMARY: EDWARDS UNDERGROUND WATER DISTRICT BULLETIN 45, 1987.

HYDROGEOLOGIC DATA FROM A STUDY OF THE FRESHWATER ZONE/SALINEWATER ZONE INTERFACE IN THE EDWARDS AQUIFER, SAN ANTONIO REGION, TEXAS: USGS OPEN-FILE REPORT 87-389, 1987.

WATER QUALITY OF CANYON LAKE, CENTRAL TEXAS: TEXAS WATER DEVELOPMENT BOARD REPORT 302, 1987.

SUGGESTED DESIGN AND CONSTRUCTION OF EDWARDS AQUIFER WELLS: EDWARDS UNDERGROUND WATER DISTRICT, 1987?

COMPILATION OF HYDROLOGIC DATA FOR THE EDWARDS AQUIFER, SAN ANTONIO AREA, TEXAS, 1986, WITH 1934-86 SUMMARY: EDWARDS UNDERGROUND WATER DISTRICT BULLETIN 46, 1988.

SIMULATION OF FLOW IN THE EDWARDS AQUIFER, SAN ANTONIO REGION, TEXAS, AND REFINEMENT OF STORAGE AND FLOW CONCEPTS: USGS WATER-SUPPLY PAPER 2336-A, 1988.

COMPILATION OF HYDROLOGIC DATA FOR THE EDWARDS AQUIFER, SAN ANTONIO AREA, TEXAS, 1987, WITH 1934-87 SUMMARY: EDWARDS UNDERGROUND WATER DISTRICT BULLETIN 47, 1988.

COMPILATION OF HYDROLOGIC DATA FOR THE EDWARDS AQUIFER, SAN ANTONIO AREA, TEXAS, 1988, WITH 1934-88 SUMMARY: EDWARDS UNDERGROUND WATER DISTRICT BULLETIN 48, 1989.

POTENTIOMETRIC SURFACE OF THE EDWARDS-TRINITY AQUIFER SYSTEM AND CONTIGUOUS HYDRAULICALLY CONNECTED UNITS, WEST-CENTRAL TEXAS, WINTER 1974-75: USGS WATERRESOURCES INVESTIGATIONS REPORT 89-4208, 1990.

COMPILATION OF HYDROLOGIC DATA FOR THE EDWARDS AQUIFER, SAN ANTONIO AREA, TEXAS, 1989, WITH 1934-89 SUMMARY: EDWARDS UNDERGROUND WATER DISTRICT BULLETIN 49, 1990. 
WITHDRAWALS FROM THE EDWARDS-TRINITY AQUIFER SYSTEM AND CONTIGUOUS HYDRAULICALLY CONNECTED UNITS, WEST-CENTRAL TEXAS, DECEMBER 1974 THROUGH MARCH 1977: USGS WATER-RESOURCES INVESTIGATIONS REPORT 91-4021, 1991.

EDWARDS AQUIFER, A TEXAS TREASURE-A TEACHERS GUIDE, SECONDARY, GRADES 7-12: EDWARDS UNDERGROUND WATER DISTRICT, 1991.

COMPILATION OF HYDROLOGIC DATA FOR THE EDWARDS AQUIFER, SAN ANTONIO AREA, TEXAS, 1990, WITH 1934-90 SUMMARY: EDWARDS UNDERGROUND WATER DISTRICT BULLETIN 50, 1991.

INSIDE THE EDWARDS AQUIFER-A THREE-PART TECHNICAL FILM, HIGH-SCHOOL LEVEL TEACHER'S GUIDE: EDWARDS UNDERGROUND WATER DISTRICT, 1992.

CONFIGURATION OF THE BASE OF THE EDWARDS-TRINITY AQUIFER SYSTEM AND HYDROGEOLOGY OF THE UNDERLYING PRECRETACEOUS ROCKS, WEST-CENTRAL TEXAS: USGS WATERRESOURCES INVESTIGATIONS REPORT 91-4071, 1992.

EVALUATION OF THE GROUND-WATER RESOURCES OF THE PALEOZOIC AND CRETACEOUS AQUIFERS IN THE HILL COUNTRY OF CENTRAL TEXAS: TEXAS WATER DEVELOPMENT BOARD REPORT 339, 1992

INVESTIGATION OF THE FRESH/SALINE-WATER INTERFACE IN THE EDWARDS AQUIFER IN NEW BRAUNFELS AND SAN MARCOS, TEXAS: EDWARDS UNDERGROUND WATER DISTRICT REPORT 92-02, 1992.

MODEL REFINEMENT AND APPLICATIONS FOR THE EDWARDS (BALCONES FAULT ZONE) AQUIFER IN THE SAN ANTONIO REGION, TEXAS: TEXAS WATER DEVELOPMENT BOARD REPORT 340, 1992.

WATER QUALITY IN THE EDWARDS AQUIFER AND STREAMS RECHARGING THE AQUIFER IN THE SAN ANTONIO REGION, TEXAS: USGS HYDROLOGIC INVESTIGATIONS ATLAS HA-723, 1992

COMPILATION OF HYDROLOGIC DATA FOR THE EDWARDS AQUIFER, SAN ANTONIO AREA, TEXAS, 1991, WITH 1934-91 SUMMARY: EDWARDS UNDERGROUND WATER DISTRICT BULLETIN $51,1992$.

WATER-RESOURCES DATA, TEXAS, WATER YEAR 1991, VOLUME 4, GROUND-WATER DATA: USGS WATER-DATA REPORT TX-91-4, 1992.

HISTORICAL POTENTIOMETRIC SURFACE OF THE EDWARDS-TRINITY AQUIFER SYSTEM AND CONTIGUOUS HYDRAULICALLY CONNECTED UNITS, WEST-CENTRAL TEXAS: USGS WATERRESOURCES INVESTIGATIONS REPORT 92-4055, 1993.

HISTORICAL SATURATED THICKNESS OF THE EDWARDS-TRINITY AQUIFER SYSTEM AND SELECTED CONTIGUOUS HYDRAULICALLY CONNECTED UNITS, WEST-CENTRAL TEXAS: USGS WATER-RESOURCES INVESTIGATIONS REPORT 92-4125, 1993.

DEFINING THE EDWARDS AQUIFER FRESHWATER/SALINE-WATER INTERFACE WITH GEOPHYSICAL LOGS AND MEASURED DATA (SAN ANTONIO TO KYLE, TEXAS): EDWARDS UNDERGROUND WATER DISTRICT REPORT 93-06, 1993.

EDWARDS AQUIFER HYDROGEOLOGIC STATUS REPORT FOR 1992: EDWARDS UNDERGROUND WATER DISTRICT REPORT 93-05, 1993.
WATER-RESOURCES DATA, TEXAS, WATER YEAR 1992, VOLUME 4, GROUND-WATER DATA: USGS WATER-DATA REPORT TX-92-4, 1993.

SIMULATIONS OF FLOW IN THE EDWARDS-TRINITY AQUIFER SYSTEM AND CONTIGUOUS HYDRAULICALLY CONNECTED UNITS, WEST-CENTRAL TEXAS: USGS WATER-RESOURCES INVESTIGATIONS REPORT 93-4039, 1994.

DISSOLVED-SOLIDS CONCENTRATIONS AND HYDROCHEMICAL FACIES IN WATER OF THE EDWARDS-TRINITY AQUIFER SYSTEM, WEST-CENTRAL TEXAS: USGS WATER-RESOURCES INVESTIGATIONS REPORT 93-4126, 1994.

NATIONAL WATER-QUALITY ASSESSMENT PROGRAM-SOUTHCENTRAL TEXAS: USGS FACT SHEET FS-94-048, 1994.

GEOLOGIC HISTORY AND HYDROGEOLOGIC SETTING OF THE EDWARDS-TRINITY AQUIFER SYSTEM, WEST-CENTRAL TEXAS: USGS WATER-RESOURCES INVESTIGATIONS REPORT 94-4039, 1994.

GEOLOGIC FRAMEWORK AND HYDROGEOLOGIC CHARACTERISTICS OF THE EDWARDS AQUIFER OUTCROP, COMAL COUNTY, TEXAS: USGS WATER-RESOURCES INVESTIGATIONS REPORT 94-4117, 1994.

1994 REVIEW AND UPDATE OF THE POSITION OF THE EDWARDS AQUIFER FRESHWATER/SALINE-WATER INTERFACE FROM UVALDE TO KYLE, TEXAS: EDWARDS UNDERGROUND WATER DISTRICT REPORT 94-05, 1994.

WATER-RESOURCES DATA, TEXAS, WATER YEAR 1993, VOLUME 4, GROUND-WATER DATA: USGS WATER-DATA REPORT TX-93-4, 1994.

GEOLOGY AND HYDROLOGY OF THE EDWARDS AQUIFER IN THE SAN ANTONIO AREA, TEXAS: USGS WATER-RESOURCES INVESTIGATIONS REPORT 95-4186, 1995.

REGIONAL DISTRIBUTION OF PERMEABILITY IN THE EDWARDS AQUIFER: EDWARDS UNDERGROUND WATER DISTRICT REPORT 95-02, 1995.

AQUIFERS OF TEXAS: TEXAS WATER DEVELOPMENT BOARD REPORT 345, 1995.

GEOLOGIC FRAMEWORK AND HYDROGEOLOGIC CHARACTERISTICS OF THE EDWARDS AQUIFER RECHARGE ZONE, BEXAR COUNTY, TEXAS: USGS WATER-RESOURCES INVESTIGATIONS REPORT 95-4030, 1995 [1996].

RECHARGE TO AND DISCHARGE FROM THE EDWARDS AQUIFER IN THE SAN ANTONIO AREA, TEXAS, 1995: USGS OPEN-FILE REPORT 96-181, 1996.

HYDROGEOLOGIC FACTORS THAT AFFECT THE FLOWPATH OF WATER IN SELECTED ZONES OF THE EDWARDS AQUIFER, SAN ANTONIO REGION, TEXAS: USGS WATER-RESOURCES INVESTIGATIONS REPORT 96-4046, 1996.

EDWARDS AQUIFER GROUND-WATER RESOURCES: GEOLOGIC CONTROLS ON POROSITY DEVELOPMENT IN PLATFORM CARBONATES, SOUTH TEXAS: UNIVERSITY OF TEXAS, BUREAU OF ECONOMIC GEOLOGY REPORT OF INVESTIGATIONS NO. 238, 1996.

WATER-QUALITY ASSESSMENT OF SOUTH-CENTRAL TEXASOCCURRENCE AND DISTRIBUTION OF VOLATILE ORGANIC COMPOUNDS IN SURFACE WATER AND GROUND WATER, 
1983-94, AND IMPLICATIONS FOR FUTURE MONITORING: USGS WATER-RESOURCES INVESTIGATIONS REPORT 97-4028, 1997.

HYDROGEOLOGIC FRAMEWORK AND GEOCHEMISTRY OF THE EDWARDS AQUIFER SALINE-WATER ZONE, SOUTH-CENTRAL TEXAS: USGS WATER-RESOURCES INVESTIGATIONS REPORT 97-4133, 1997.

WATER-QUALITY ASSESSMENT OF THE COMAL SPRINGS RIVERINE SYSTEM, NEW BRAUNFELS, TEXAS, 1993-94: USGS FACT SHEET FS-099-97, 1997.

MONITORING OF SELECTED WATER-QUALITY CONSTITUENTS NEAR THE FRESHWATER/SALINE-WATER INTERFACE OF THE EDWARDS AQUIFER, JULY 1996-DECEMBER 1997: USGS FACT SHEET FS-103-98, 1998.

WATER-RESOURCES DATA, TEXAS, WATER YEAR 1997, VOLUME 4, GROUND-WATER DATA: USGS WATER-DATA REPORT TX-97-4, 1998.

WATER-RESOURCES DATA, TEXAS, WATER YEAR 1998, VOLUME 4, GROUND-WATER DATA: USGS WATER-DATA REPORT TX-98-4, 1999.

GROUNDWATER AVAILABILITY OF THE TRINITY AQUIFER, HILL COUNTRY AREA, TEXAS: NUMERICAL SIMULATIONS THROUGH 2050: TEXAS WATER DEVELOPMENT BOARD REPORT 353, 2000.

WATER QUALITY IN SOUTH-CENTRAL TEXAS-TEXAS, 1996-98: USGS CIRCULAR 1212, 2000.

WATER-RESOURCES DATA, TEXAS, WATER YEAR 1999, VOLUME 6 , GROUND-WATER DATA: USGS WATER-DATA REPORT TX-99-6, 2000 .

WATER-RESOURCES DATA, TEXAS, WATER YEAR 2000, VOLUME 6 , GROUND-WATER DATA: USGS WATER-DATA REPORT TX-00-6, 2001.

\section{COMANCHE COUNTY}

GEOGRAPHY AND GEOLOGY OF THE BLACK AND GRAND PRAIRIES OF TEXAS, WITH DETAILED DESCRIPTIONS OF THE CRETACEOUS FORMATIONS AND SPECIAL REFERENCE TO ARTESIAN WATERS: USGS 21ST ANNUAL REPORT, PART 7, 1901

MEMORANDUM TO THE BOARD OF WATER ENGINEERS, SUBJECT: CITY OF COMANCHE, GROUND WATER: USGS OPEN-FILE REPORT (UNNUMBERED), 1946.

PUBLIC WATER SUPPLIES IN CENTRAL AND NORTH-CENTRAL TEXAS: USGS WATER-SUPPLY PAPER 1069, 1949.

RECONNAISSANCE INVESTIGATION OF THE GROUND-WATER RESOURCES OF THE BRAZOS RIVER BASIN, TEXAS: TEXAS WATER COMMISSION BULLETIN 6310, 1963.

GROUND-WATER RESOURCES OF PART OF CENTRAL TEXAS WITH EMPHASIS ON THE ANTLERS AND TRAVIS PEAK FORMATIONS: TEXAS WATER DEVELOPMENT BOARD REPORT 195, V. 1, 1975.

GROUND-WATER RESOURCES OF PART OF CENTRAL TEXAS WITH EMPHASIS ON THE ANTLERS AND TRAVIS PEAK FORMATIONS: TEXAS WATER DEVELOPMENT BOARD REPORT 195, V. 2, 1976.

TEXAS GROUND-WATER RESOURCES, in NATIONAL WATER SUMMARY 1984: USGS WATER-SUPPLY PAPER 2275, 1985.
GROUND-WATER RESOURCES OF THE ANTLERS AND TRAVIS PEAK FORMATIONS IN THE OUTCROP AREA OF NORTH-CENTRAL TEXAS: TEXAS WATER DEVELOPMENT BOARD REPORT 298, 1987.

EVALUATION OF WATER RESOURCES IN PART OF CENTRAL TEXAS: TEXAS WATER DEVELOPMENT BOARD REPORT 319 , 1987.

GROUND-WATER QUALITY MONITORING OF THE TRINITY AQUIFER IN THE VICINITY OF ERATH COUNTY: TEXAS WATER DEVELOPMENT BOARD REPORT 331, 1991.

AQUIFERS OF TEXAS: TEXAS WATER DEVELOPMENT BOARD REPORT 345, 1995.

WATER-RESOURCES DATA, TEXAS, WATER YEAR 2000, VOLUME 6 , GROUND-WATER DATA: USGS WATER-DATA REPORT TX-00-6, 2001.

\section{CONCHO COUNTY}

PUBLIC WATER SUPPLIES IN CENTRAL AND NORTH-CENTRAL TEXAS: USGS WATER-SUPPLY PAPER 1069, 1949.

RECONNAISSANCE INVESTIGATION OF THE GROUND-WATER RESOURCES OF THE COLORADO RIVER BASIN, TEXAS: TEXAS WATER DEVELOPMENT BOARD REPORT 51, 1967.

OCCURRENCE, AVAILABILITY, AND CHEMICAL QUALITY OF GROUND WATER IN THE EDWARDS PLATEAU REGION OF TEXAS: TEXAS WATER DEVELOPMENT BOARD REPORT 235 , 1979.

POTENTIOMETRIC SURFACE OF THE EDWARDS-TRINITY AQUIFER SYSTEM AND CONTIGUOUS HYDRAULICALLY CONNECTED UNITS, WEST-CENTRAL TEXAS, WINTER 1974-75: USGS WATERRESOURCES INVESTIGATIONS REPORT 89-4208, 1990.

WITHDRAWALS FROM THE EDWARDS-TRINITY AQUIFER SYSTEM AND CONTIGUOUS HYDRAULICALLY CONNECTED UNITS, WEST-CENTRAL TEXAS, DECEMBER 1974 THROUGH MARCH 1977: USGS WATER-RESOURCES INVESTIGATIONS REPORT 91-4021, 1991.

CONFIGURATION OF THE BASE OF THE EDWARDS-TRINITY AQUIFER SYSTEM AND HYDROGEOLOGY OF THE UNDERLYING PRECRETACEOUS ROCKS, WEST-CENTRAL TEXAS: USGS WATERRESOURCES INVESTIGATIONS REPORT 91-4071, 1992.

HISTORICAL POTENTIOMETRIC SURFACE OF THE EDWARDS-TRINITY AQUIFER SYSTEM AND CONTIGUOUS HYDRAULICALLY CONNECTED UNITS, WEST-CENTRAL TEXAS: USGS WATERRESOURCES INVESTIGATIONS REPORT 92-4055, 1993.

HISTORICAL SATURATED THICKNESS OF THE EDWARDS-TRINITY AQUIFER SYSTEM AND SELECTED CONTIGUOUS HYDRAULICALLY CONNECTED UNITS, WEST-CENTRAL TEXAS: USGS WATER-RESOURCES INVESTIGATIONS REPORT 92-4125, 1993.

SIMULATIONS OF FLOW IN THE EDWARDS-TRINITY AQUIFER SYSTEM AND CONTIGUOUS HYDRAULICALLY CONNECTED UNITS, WEST-CENTRAL TEXAS: USGS WATER-RESOURCES INVESTIGATIONS REPORT 93-4039, 1994.

DISSOLVED-SOLIDS CONCENTRATIONS AND HYDROCHEMICAL FACIES IN WATER OF THE EDWARDS-TRINITY AQUIFER SYS- 
TEM, WEST-CENTRAL TEXAS: USGS WATER-RESOURCES INVESTIGATIONS REPORT 93-4126, 1994.

CHARACTERISTICS OF STREAMS AND AQUIFERS AND PROCESSES AFFECTING THE SALINITY OF WATER IN THE UPPER COLORADO RIVER BASIN, TEXAS: USGS WATER-RESOURCES INVESTIGATIONS REPORT 94-4036, 1994.

GEOLOGIC HISTORY AND HYDROGEOLOGIC SETTING OF THE EDWARDS-TRINITY AQUIFER SYSTEM, WEST-CENTRAL TEXAS: USGS WATER-RESOURCES INVESTIGATIONS REPORT 94-4039, 1994.

WATER QUALITY IN THE EDWARDS-TRINITY (PLATEAU) AQUIFER, EDWARDS PLATEAU AND TRANS-PECOS, TEXAS: TEXAS WATER DEVELOPMENT BOARD HYDROLOGIC ATLAS NO. 3, 1995

THE PALEOZOIC AND RELATED AQUIFERS OF CENTRAL TEXAS: TEXAS WATER DEVELOPMENT BOARD REPORT 346, 1996.

AQUIFERS OF TEXAS: TEXAS WATER DEVELOPMENT BOARD REPORT 345, 1995.

AN OVERVIEW OF THE EDWARDS-TRINITY AQUIFER SYSTEM, CENTRAL-WEST TEXAS, CHAPTER 8, in AQUIFERS OF WEST TEXAS: TEXAS WATER DEVELOPMENT BOARD REPORT 356, 2001.

\section{COOKE COUNTY}

GEOGRAPHY AND GEOLOGY OF THE BLACK AND GRAND PRAIRIES, TEXAS, WITH DETAILED DESCRIPTIONS OF THE CRETACEOUS FORMATIONS AND SPECIAL REFERENCE TO ARTESIAN WATERS: USGS 21ST ANNUAL REPORT, PART 7, 1901

PUBLIC WATER SUPPLIES IN CENTRAL AND NORTH-CENTRAL TEXAS: USGS WATER-SUPPLY PAPER 1069, 1949.

REPORT OF PRELIMINARY INVESTIGATION OF THE OCCURRENCE OF GROUND WATER IN THE TRINITY GROUP NEAR GAINSVILLE, COOKE COUNTY, TEXAS: TEXAS BOARD OF WATER ENGINEERS MISCELLANEOUS PUBLICATION 90, 1960.

RECONNAISSANCE INVESTIGATION OF THE GROUND-WATER RESOURCES OF THE RED RIVER, SULPHUR RIVER, AND CYPRESS CREEK BASINS, TEXAS: TEXAS WATER COMMISSION BULLETIN 6306, 1963.

RECONNAISSANCE INVESTIGATION OF THE GROUND-WATER RESOURCES OF THE TRINITY RIVER BASIN, TEXAS: TEXAS WATER COMMISSION BULLETIN 6309, 1963.

COMPILATION OF RESULTS OF AQUIFER TESTS IN TEXAS: TEXAS WATER DEVELOPMENT BOARD REPORT 98, 1969.

WATER-LEVEL AND WATER-QUALITY DATA FROM OBSERVATION WELLS IN NORTHEAST TEXAS: TEXAS WATER DEVELOPMENT BOARD REPORT 198, 1976.

SPRINGS OF TEXAS, VOLUME 1: (BY GUNNAR BRUNE), BRANCHSMITH, INC., FORT WORTH, TEXAS, 1981.

OCCURRENCE, AVAILABILITY, AND CHEMICAL QUALITY OF GROUND WATER IN THE CRETACEOUS AQUIFERS OF NORTHCENTRAL TEXAS: TEXAS DEPARTMENT OF WATER RESOURCES REPORT 269, V. 1, 1982.

OCCURRENCE, AVAILABILITY, AND CHEMICAL QUALITY OF GROUND WATER IN THE CRETACEOUS AQUIFERS OF NORTH-
CENTRAL TEXAS: TEXAS DEPARTMENT OF WATER RESOURCES REPORT 269, V. 2, 1982.

TEXAS GROUND-WATER RESOURCES, in NATIONAL WATER SUMMARY 1984: USGS WATER-SUPPLY PAPER 2275, 1985.

EVALUATION OF WATER RESOURCES IN PART OF NORTH-CENTRAL TEXAS: TEXAS WATER DEVELOPMENT BOARD REPORT $318,1990$.

NATIONAL WATER-QUALITY ASSESSMENT PROGRAM-THE TRINITY RIVER BASIN: USGS OPEN-FILE REPORT 91-158, 1991.

SIMULATION OF GROUND-WATER FLOW IN THE ANTLERS AQUIFER IN SOUTHEASTERN OKLAHOMA AND NORTHEASTERN TEXAS: USGS WATER-RESOURCES INVESTIGATIONS REPORT 88-4208, 1992.

AQUIFERS OF TEXAS: TEXAS WATER DEVELOPMENT BOARD REPORT 345, 1995.

NATIONAL WATER-QUALITY ASSESSMENT PROGRAM-PESTICIDES IN THE TRINITY RIVER BASIN STUDY UNIT, TEXAS, 1968-91: USGS FACT SHEET FS-088-95, 1995.

WATER-QUALITY ASSESSMENT OF THE TRINITY RIVER BASIN, TEXAS-DATA COLLECTION, 1992-95: USGS FACT SHEET FS-095-95, 1995.

WATER-QUALITY ASSESSMENT OF THE TRINITY RIVER BASIN, TEXAS-PESTICIDES IN A SUBURBAN WATERSHED, ARLINGTON, 1993-94: USGS FACT SHEET FS-159-95, 1995.

WATER QUALITY IN THE WOODBINE AQUIFER, NORTH-CENTRAL TEXAS: TEXAS WATER DEVELOPMENT BOARD HYDROLOGIC ATLAS NO. 4, 1996.

UPDATED EVALUATION OF WATER RESOURCES IN PART OF NORTH-CENTRAL TEXAS, 1990-1999: TEXAS WATER DEVELOPMENT BOARD REPORT 349, 1999.

\section{CORYELL COUNTY}

GEOGRAPHY AND GEOLOGY OF THE BLACK AND GRAND PRAIRIES, TEXAS, WITH DETAILED DESCRIPTIONS OF THE CRETACEOUS FORMATIONS AND SPECIAL REFERENCE TO ARTESIAN WATERS: USGS 21ST ANNUAL REPORT, PART 7, 1901.

GROUND WATER NEAR HICO, GATESVILLE, BRADY, KERRVILLE, AND PLAINVIEW, TEXAS: USGS OPEN-FILE REPORT (UNNUMBERED), 1942.

GROUND-WATER RESOURCES IN THE VICINITY OF GATESVILLE, TEXAS: USGS OPEN-FILE REPORT (UNNUMBERED), 1942.

TEST WELL AT PROPOSED ARMY CAMP 5 MILES SOUTHEAST OF GATESVILLE, TEXAS: USGS OPEN-FILE REPORT (UNNUMBERED), 1942.

RESULTS OF PUMPING TEST OF WELLS AT TANK DESTROYER CENTER, NORTH CAMP HOOD, NEAR GATESVILLE, TEXAS: USGS OPEN-FILE REPORT (UNNUMBERED), 1943.

PUBLIC WATER SUPPLIES IN CENTRAL AND NORTH-CENTRAL TEXAS: USGS WATER-SUPPLY PAPER 1069, 1949.

RECONNAISSANCE INVESTIGATION OF THE GROUND-WATER RESOURCES OF THE BRAZOS RIVER BASIN, TEXAS: TEXAS WATER COMMISSION BULLETIN 6310, 1963. 
COMPILATION OF RESULTS OF AQUIFER TESTS IN TEXAS: TEXAS WATER DEVELOPMENT BOARD REPORT 98, 1969.

GROUND-WATER RESOURCES OF PART OF CENTRAL TEXAS WITH EMPHASIS ON THE ANTLERS AND TRAVIS PEAK FORMATIONS: TEXAS WATER DEVELOPMENT BOARD REPORT 195, V. 1, 1975.

GROUND-WATER RESOURCES OF PART OF CENTRAL TEXAS WITH EMPHASIS ON THE ANTLERS AND TRAVIS PEAK FORMATIONS: TEXAS WATER DEVELOPMENT BOARD REPORT 195, V. 2, 1976.

EFFECTS OF GROUND-WATER DEVELOPMENT IN THE NORTH FORT HOOD AREA, CORYELL COUNTY, TEXAS: USGS WATERRESOURCES INVESTIGATIONS REPORT 83-4074, 1983

WATER USE, PROJECTED WATER REQUIREMENTS, AND RELATED DATA AND INFORMATION FOR THE METROPOLITAN STATISTICAL AREAS IN TEXAS: TEXAS DEPARTMENT OF WATER RESOURCES LIMITED PRINTING REPORT LP-201, 1985.

TEXAS GROUND-WATER RESOURCES, in NATIONAL WATER SUMMARY 1984: USGS WATER-SUPPLY PAPER 2275, 1985.

HYDROGEOLOGY OF THE EDWARDS AQUIFER, NORTHERN BALCONES AND WASHITA PRAIRIE SEGMENTS: AUSTIN GEOLOGICAL SOCIETY GUIDEBOOK 11, 1987.

GEOCHEMISTRY AND FLOW CHARACTERISTICS OF EDWARDS AQUIFER SPRINGS: WASHITA PRAIRIE, CENTRAL TEXAS: BAYLOR GEOLOGICAL STUDIES (THESIS ABSTRACTS), BAYLOR UNIVERSITY, WACO, TEXAS, 1989.

AQUIFER-STREAM INTERACTIONS IN NON-KARSTIC LIMESTONES: WASHITA PRAIRIE, CENTRAL TEXAS: BAYLOR GEOLOGICAL STUDIES (THESIS ABSTRACTS), BAYLOR UNIVERSITY, WACO, TEXAS, 1989

EVALUATION OF WATER RESOURCES IN PART OF CENTRAL TEXAS: TEXAS WATER DEVELOPMENT BOARD REPORT 319, 1990.

HYDROGEOLOGIC ASSESSMENT OF SHALLOW GROUNDWATER FLOW SYSTEMS OF THE WALNUT FORMATION, CENTRAL TEXAS: (MASTER'S THESIS), BAYLOR GEOLOGICAL STUDIES (THESIS ABSTRACTS), BULLETIN 56, BAYLOR UNIVERSITY, WACO, TEXAS, 1995.

AQUIFERS OF TEXAS: TEXAS WATER DEVELOPMENT BOARD REPORT 345, 1995.

WATER-RESOURCES DATA, TEXAS, WATER YEAR 2000, VOLUME 6, GROUND-WATER DATA: USGS WATER-DATA REPORT TX-00-6, 2001

\section{COTTLE COUNTY}

GROUND WATER IN THE VICINITY OF PADUCAH, COTTLE COUNTY: USGS OPEN-FILE REPORT (UNNUMBERED), 1945.

PROGRESS REPORT, GROUND WATER IN THE VICINITY OF PADUCAH, COTTLE COUNTY, TEXAS: USGS OPEN-FILE REPORT (UNNUMBERED), 1946.

PUBLIC WATER SUPPLIES IN WESTERN TEXAS: USGS WATERSUPPLY PAPER 1106, 1951.

RECORDS OF WATER-LEVEL MEASUREMENTS IN CHILDRESS, COTTLE, HARDEMAN, AND KING COUNTIES, TEXAS, 1940 TO JANU-
ARY 1956: TEXAS BOARD OF WATER ENGINEERS BULLETIN 5613, 1956.

RECONNAISSANCE INVESTIGATION OF THE GROUND-WATER RESOURCES OF THE RED RIVER, SULPHUR RIVER, AND CYPRESS CREEK BASINS, TEXAS: TEXAS WATER COMMISSION BULLETIN 6306, 1963.

COMPILATION OF RESULTS OF AQUIFER TESTS IN TEXAS: TEXAS WATER DEVELOPMENT BOARD REPORT 98, 1969.

SPRINGS OF TEXAS, VOLUME 1: (BY GUNNAR BRUNE), BRANCHSMITH, INC., FORT WORTH, TEXAS, 1981.

TEXAS GROUND-WATER RESOURCES, in NATIONAL WATER SUMMARY 1984: USGS WATER-SUPPLY PAPER 2275, 1985.

WATER-LEVEL CHANGES IN THE HIGH PLAINS AQUIFER OF TEXAS, 1980-1990: TEXAS WATER DEVELOPMENT BOARD HYDROLOGIC ATLAS NO. 1, 1991.

EVALUATION OF WATER RESOURCES IN PARTS OF THE ROLLING PRAIRIES REGION OF NORTH-CENTRAL TEXAS: TEXAS WATER DEVELOPMENT BOARD REPORT 337, 1992.

AQUIFERS OF TEXAS: TEXAS WATER DEVELOPMENT BOARD REPORT 345, 1995

UPDATED WATER-QUALITY EVALUATION OF THE OGALLALA AQUIFER INCLUDING SELECTED METALLIC AND NON-METALLIC INORGANIC CONSTITUENTS: TEXAS WATER DEVELOPMENT BOARD HYDROLOGIC ATLAS NO. 10, 1998.

\section{CRANE COUNTY}

WATER RESOURCES OF THE PECOS RIVER BASIN, VOLUME 1, PECOS RIVER JOINT INVESTIGATION—PART 3, REPORT B, GEOLOGY AND GROUND WATER: TEXAS BOARD OF WATER ENGINEERS MISCELLANEOUS PUBLICATION 209A, V. 1, 1941.

WATER RESOURCES OF THE PECOS RIVER BASIN, VOLUME 2, RECORDS OF WELLS AND SPRINGS AND ANALYSES OF WATER IN LOVING, WARD, REEVES, AND NORTHERN PECOS COUNTIES TEXAS BOARD OF WATER ENGINEERS MISCELLANEOUS PUBLICATION 209A, V. 2, 1941

WATER RESOURCES OF THE PECOS RIVER BASIN, VOLUME 3 , RECORDS OF AUGER HOLES INCLUDING LOGS, RECORDS OF FLUCTUATIONS OF WATER LEVELS, WATER ANALYSES, AND MAPS SHOWING LOCATIONS OF WELLS: TEXAS BOARD OF WATER ENGINEERS MISCELLANEOUS PUBLICATION 209A, V. 3, 1941.

PUBLIC WATER SUPPLIES IN WESTERN TEXAS: USGS WATERSUPPLY PAPER 1106, 1951

GROUND-WATER RESOURCES OF THE CRANE SANDHILLS, CRANE COUNTY, TEXAS: TEXAS BOARD OF WATER ENGINEERS BULLETIN 5604, 1956.

RECORDS OF WATER-LEVEL MEASUREMENTS IN CRANE AND MIDLAND COUNTIES, TEXAS: TEXAS BOARD OF WATER ENGINEERS BULLETIN 5906, 1959.

SHALLOW FORMATIONS AND AQUIFERS OF THE WEST TEXAS AREA: WEST TEXAS GEOLOGICAL SOCIETY PUBLICATION 61-45 AND PERMIAN BASIN GEOPHYSICAL SOCIETY, MIDLAND, TEXAS, 1961. 
RECONNAISSANCE INVESTIGATION OF GROUND WATER IN THE RIO GRANDE DRAINAGE BASIN—WITH SPECIAL EMPHASIS ON SALINE GROUND-WATER RESOURCES: USGS HYDROLOGIC ATLAS HA-510, 1974.

SPRINGS OF TEXAS, VOLUME 1: (BY GUNNAR BRUNE), BRANCHSMITH, INC., FORT WORTH, TEXAS, 1981.

TEXAS GROUND-WATER RESOURCES, in NATIONAL WATER SUMMARY 1984: USGS WATER-SUPPLY PAPER 2275, 1985.

PUBLIC SUPPLY GROUND-WATER USE IN WESTERN TEXAS: TEXAS WATER DEVELOPMENT BOARD REPORT 311, 1989.

POTENTIOMETRIC SURFACE OF THE EDWARDS-TRINITY AQUIFER SYSTEM AND CONTIGUOUS HYDRAULICALLY CONNECTED UNITS, WEST-CENTRAL TEXAS, WINTER 1974-75: USGS WATERRESOURCES INVESTIGATIONS REPORT 89-4208, 1990.

WITHDRAWALS FROM THE EDWARDS-TRINITY AQUIFER SYSTEM AND CONTIGUOUS HYDRAULICALLY CONNECTED UNITS, WEST-CENTRAL TEXAS, DECEMBER 1974 THROUGH MARCH 1977: USGS WATER-RESOURCES INVESTIGATIONS REPORT 91-4021, 1991

CONFIGURATION OF THE BASE OF THE EDWARDS-TRINITY AQUIFER SYSTEM AND HYDROGEOLOGY OF THE UNDERLYING PRECRETACEOUS ROCKS, WEST-CENTRAL TEXAS: USGS WATERRESOURCES INVESTIGATIONS REPORT 91-4071, 1992.

HISTORICAL POTENTIOMETRIC SURFACE OF THE EDWARDS-TRINITY AQUIFER SYSTEM AND CONTIGUOUS HYDRAULICALLY CONNECTED UNITS, WEST-CENTRAL TEXAS: USGS WATERRESOURCES INVESTIGATIONS REPORT 92-4055, 1993.

HISTORICAL SATURATED THICKNESS OF THE EDWARDS-TRINITY AQUIFER SYSTEM AND SELECTED CONTIGUOUS HYDRAULICALLY CONNECTED UNITS, WEST-CENTRAL TEXAS: USGS WATER-RESOURCES INVESTIGATIONS REPORT 92-4125, 1993.

SIMULATIONS OF FLOW IN THE EDWARDS-TRINITY AQUIFER SYSTEM AND CONTIGUOUS HYDRAULICALLY CONNECTED UNITS, WEST-CENTRAL TEXAS: USGS WATER-RESOURCES INVESTIGATIONS REPORT 93-4039, 1994.

DISSOLVED-SOLIDS CONCENTRATIONS AND HYDROCHEMICAL FACIES IN WATER OF THE EDWARDS-TRINITY AQUIFER SYSTEM, WEST-CENTRAL TEXAS: USGS WATER-RESOURCES INVESTIGATIONS REPORT 93-4126, 1994.

GEOLOGIC HISTORY AND HYDROGEOLOGIC SETTING OF THE EDWARDS-TRINITY AQUIFER SYSTEM, WEST-CENTRAL TEXAS: USGS WATER-RESOURCES INVESTIGATIONS REPORT 94-4039, 1994.

WATER QUALITY IN THE EDWARDS-TRINITY (PLATEAU) AQUIFER, EDWARDS PLATEAU AND TRANS-PECOS, TEXAS: TEXAS WATER DEVELOPMENT BOARD HYDROLOGIC ATLAS NO. 3, 1995.

AQUIFERS OF TEXAS: TEXAS WATER DEVELOPMENT BOARD REPORT 345, 1995.

CENOZOIC PECOS ALLUVIUM AQUIFER, CHAPTER 9, in AQUIFERS OF WEST TEXAS: TEXAS WATER DEVELOPMENT BOARD REPORT 356, 2001

THE DOCKUM AQUIFER IN WEST TEXAS, CHAPTER 12, in AQUIFERS OF WEST TEXAS: TEXAS WATER DEVELOPMENT BOARD REPORT 356, 2001.

\section{CROCKETT COUNTY}

PUBLIC WATER SUPPLIES IN WESTERN TEXAS: USGS WATERSUPPLY PAPER 1106, 1951.

RECORDS OF WATER-LEVEL MEASUREMENTS IN CROCKETT, GLASSCOCK, REAGAN, UPTON, AND TERRELL COUNTIES, TEXAS, 1937 THROUGH 1957: TEXAS BOARD OF WATER ENGINEERS BULLETIN 5903, 1959.

RECONNAISSANCE INVESTIGATION OF THE GROUND-WATER RESOURCES OF THE RIO GRANDE BASIN, TEXAS: TEXAS WATER COMMISSION BULLETIN 6502, 1965.

OCCURRENCE AND QUALITY OF GROUND WATER IN CROCKETT COUNTY, TEXAS: TEXAS WATER DEVELOPMENT BOARD REPORT 47, 1967.

RECONNAISSANCE INVESTIGATION OF THE GROUND-WATER RESOURCES OF THE COLORADO RIVER BASIN, TEXAS: TEXAS WATER DEVELOPMENT BOARD REPORT 51, 1967.

RECONNAISSANCE INVESTIGATION OF GROUND WATER IN THE RIO GRANDE DRAINAGE BASIN—WITH SPECIAL EMPHASIS ON SALINE GROUND-WATER RESOURCES: USGS HYDROLOGIC ATLAS HA-510, 1974.

MAJOR AND HISTORICAL SPRINGS OF TEXAS: TEXAS WATER DEVELOPMENT BOARD REPORT 189, 1975.

OCCURRENCE, AVAILABILITY, AND CHEMICAL QUALITY OF GROUND WATER IN THE EDWARDS PLATEAU REGION OF TEXAS: TEXAS DEPARTMENT OF WATER RESOURCES REPORT $235,1979$.

SPRINGS OF TEXAS, VOLUME 1: (BY GUNNAR BRUNE), BRANCHSMITH, INC., FORT WORTH, TEXAS, 1981.

TEXAS GROUND-WATER RESOURCES, in NATIONAL WATER SUMMARY 1984: USGS WATER-SUPPLY PAPER 2275, 1985.

POTENTIOMETRIC SURFACE OF THE EDWARDS-TRINITY AQUIFER SYSTEM AND CONTIGUOUS HYDRAULICALLY CONNECTED UNITS, WEST-CENTRAL TEXAS, WINTER 1974-75: USGS WATERRESOURCES INVESTIGATIONS REPORT 89-4208, 1990.

WITHDRAWALS FROM THE EDWARDS-TRINITY AQUIFER SYSTEM AND CONTIGUOUS HYDRAULICALLY CONNECTED UNITS, WEST-CENTRAL TEXAS, DECEMBER 1974 THROUGH MARCH 1977: USGS WATER-RESOURCES INVESTIGATIONS REPORT 91-4021, 1991.

CONFIGURATION OF THE BASE OF THE EDWARDS-TRINITY AQUIFER SYSTEM AND HYDROGEOLOGY OF THE UNDERLYING PRECRETACEOUS ROCKS, WEST-CENTRAL TEXAS: USGS WATERRESOURCES INVESTIGATIONS REPORT 91-4071, 1992.

HISTORICAL POTENTIOMETRIC SURFACE OF THE EDWARDS-TRINITY AQUIFER SYSTEM AND CONTIGUOUS HYDRAULICALLY CONNECTED UNITS, WEST-CENTRAL TEXAS: USGS WATERRESOURCES INVESTIGATIONS REPORT 92-4055, 1993.

HISTORICAL SATURATED THICKNESS OF THE EDWARDS-TRINITY AQUIFER SYSTEM AND SELECTED CONTIGUOUS HYDRAULICALLY CONNECTED UNITS, WEST-CENTRAL TEXAS: USGS WATER-RESOURCES INVESTIGATIONS REPORT 92-4125, 1993.

SIMULATIONS OF FLOW IN THE EDWARDS-TRINITY AQUIFER SYSTEM AND CONTIGUOUS HYDRAULICALLY CONNECTED 
UNITS, WEST-CENTRAL TEXAS: USGS WATER-RESOURCES INVESTIGATIONS REPORT 93-4039, 1994.

DISSOLVED-SOLIDS CONCENTRATIONS AND HYDROCHEMICAL FACIES IN WATER OF THE EDWARDS-TRINITY AQUIFER SYSTEM, WEST-CENTRAL TEXAS: USGS WATER-RESOURCES INVESTIGATIONS REPORT 93-4126, 1994.

GEOLOGIC HISTORY AND HYDROGEOLOGIC SETTING OF THE EDWARDS-TRINITY AQUIFER SYSTEM, WEST-CENTRAL TEXAS: USGS WATER-RESOURCES INVESTIGATIONS REPORT 94-4039, 1994.

WATER QUALITY IN THE EDWARDS-TRINITY (PLATEAU) AQUIFER, EDWARDS PLATEAU AND TRANS-PECOS, TEXAS: TEXAS WATER DEVELOPMENT BOARD HYDROLOGIC ATLAS NO. 3, 1995.

AQUIFERS OF TEXAS: TEXAS WATER DEVELOPMENT BOARD REPORT 345, 1995.

AN OVERVIEW OF THE EDWARDS-TRINITY AQUIFER SYSTEM, CENTRAL-WEST TEXAS, CHAPTER 8, in AQUIFERS OF WEST TEXAS: TEXAS WATER DEVELOPMENT BOARD REPORT 356, 2001.

\section{CROSBY COUNTY}

GEOLOGY AND GROUND-WATER RESOURCES OF THE SOUTHERN HIGH PLAINS: USGS OPEN-FILE REPORT (UNNUMBERED), 1935.

GROUND WATER IN THE SOUTHERN HIGH PLAINS: USGS OPENFILE REPORT (UNNUMBERED, 1937.

GROUND WATER IN THE HIGH PLAINS OF TEXAS: TEXAS BOARD OF WATER ENGINEERS MISCELLANEOUS PUBLICATION (UNNUMBERED), 1938.

RECORDS OF WELLS AND SPRINGS, DRILLERS' LOGS, WATER ANALYSES, AND MAP SHOWING LOCATIONS OF WELLS AND SPRINGS IN CROSBY COUNTY, TEXAS: TEXAS BOARD OF WATER ENGINEERS MISCELLANEOUS PUBLICATION 62, 1939.

GROUND WATER IN THE HIGH PLAINS OF TEXAS: TEXAS BOARD OF WATER ENGINEERS MISCELLANEOUS PUBLICATION 119, 1940.

PROGRESS REPORT ON GROUND WATER IN THE HIGH PLAINS OF TEXAS: TEXAS BOARD OF WATER ENGINEERS MISCELLANEOUS PUBLICATION (UNNUMBERED), 1942.

PROGRESS REPORT ON GROUND WATER IN THE HIGH PLAINS OF TEXAS: TEXAS BOARD OF WATER ENGINEERS MISCELLANEOUS PUBLICATION 120, 1943.

PROGRESS REPORT ON GROUND WATER IN THE HIGH PLAINS OF TEXAS: TEXAS BOARD OF WATER ENGINEERS MISCELLANEOUS PUBLICATION 121, 1944.

PROGRESS REPORT ON GROUND WATER IN THE HIGH PLAINS OF TEXAS: TEXAS BOARD OF WATER ENGINEERS MISCELLANEOUS PUBLICATION 122, 1945.

GROUND WATER IN THE HIGH PLAINS OF TEXAS: USGS WATERSUPPLY PAPER 889-F, 1946.

GROUND WATER IN HIGH PLAINS OF TEXAS, PROGRESS REPORT NO. 6: TEXAS BOARD OF WATER ENGINEERS MISCELLANEOUS PUBLICATION 123, 1947.

GEOLOGY AND GROUND WATER IN THE IRRIGATED REGION OF THE SOUTHERN HIGH PLAINS IN TEXAS, PROGRESS REPORT NO.
7: TEXAS BOARD OF WATER ENGINEERS MISCELLANEOUS PUBLICATION 125, 1949.

COST OF PUMPING WATER FOR IRRIGATION, TEXAS HIGH PLAINS, FIELD INVESTIGATIONS-1947 IRRIGATION SEASON: TEXAS BOARD OF WATER ENGINEERS MISCELLANEOUS PUBLICATION 124,1951

DEVELOPMENT OF WELLS FOR IRRIGATION AND FLUCTUATION OF WATER LEVELS IN THE HIGH PLAINS OF TEXAS TO JANUARY 1951: TEXAS BOARD OF WATER ENGINEERS BULLETIN 5104, 1951.

PUBLIC WATER SUPPLIES IN WESTERN TEXAS: USGS WATERSUPPLY PAPER 1106, 1951 [1952].

SUMMARY OF GROUND-WATER DEVELOPMENT IN THE SOUTHERN HIGH PLAINS, TEXAS: TEXAS BOARD OF WATER ENGINEERS BULLETIN 5402, 1954

RECORDS OF WATER-LEVEL MEASUREMENTS IN COCHRAN, CROSBY, GAINES, HOCKLEY, LYNN, AND TERRY COUNTIES, TEXAS: TEXAS BOARD OF WATER ENGINEERS BULLETIN 5407, 1954.

GROUND-WATER DEVELOPMENT IN THE SOUTHERN HIGH PLAINS OF TEXAS, 1953: TEXAS BOARD OF WATER ENGINEERS BULLETIN 5410, 1954

WATER-LEVEL DECLINE MAPS OF 17 COUNTIES IN THE SOUTHERN HIGH PLAINS, TEXAS, JANUARY 1955 TO JANUARY 1956: TEXAS BOARD OF WATER ENGINEERS BULLETIN 5607, 1956.

WATER-LEVEL DECLINE MAPS, 1956 TO 1957, AND WATER LEVELS IN OBSERVATION WELLS IN 20 COUNTIES IN THE SOUTHERN HIGH PLAINS, TEXAS: TEXAS BOARD OF WATER ENGINEERS BULLETIN 5705, 1957.

WATER-LEVEL MEASUREMENTS AND MAPS, SOUTHERN HIGH PLAINS, TEXAS, 1958 AND 1959: TEXAS BOARD OF WATER ENGINEERS BULLETIN 5908, 1959.

WATER LEVELS IN OBSERVATION WELLS, SOUTHERN HIGH PLAINS, TEXAS, 1959 AND 1960: TEXAS BOARD OF WATER ENGINEERS BULLETIN 6011, 1960.

SHALLOW FORMATIONS AND AQUIFERS OF THE WEST TEXAS AREA: WEST TEXAS GEOLOGICAL SOCIETY PUBLICATION 61-45 AND PERMIAN BASIN GEOPHYSICAL SOCIETY, MIDLAND, TEXAS, 1961

WATER LEVELS IN OBSERVATION WELLS, SOUTHERN HIGH PLAINS, TEXAS, 1960 AND 1961: TEXAS BOARD OF WATER ENGINEERS BULLETIN 6101, 1961.

A SUMMARY OF THE OCCURRENCE AND DEVELOPMENT OF GROUND WATER IN THE SOUTHERN HIGH PLAINS OF TEXAS: TEXAS BOARD OF WATER ENGINEERS BULLETIN 6107, 1961.

WATER-LEVEL MEASUREMENTS THROUGH 1962 IN SELECTED OBSERVATION WELLS, SOUTHERN HIGH PLAINS, TEXAS: TEXAS WATER COMMISSION BULLETIN 6207, 1962.

RECONNAISSANCE INVESTIGATION OF THE GROUND-WATER RESOURCES OF THE BRAZOS RIVER BASIN, TEXAS: TEXAS WATER COMMISSION BULLETIN 6310, 1963.

A SUMMARY OF THE OCCURRENCE AND DEVELOPMENT OF GROUND WATER IN THE SOUTHERN HIGH PLAINS OF TEXAS, WITH A SECTION ON ARTIFICIAL RECHARGE STUDIES: USGS WATER-SUPPLY PAPER 1693, 1964 
WATER-LEVEL DATA FROM OBSERVATION WELLS IN THE SOUTHERN HIGH PLAINS OF TEXAS: TEXAS WATER DEVELOPMENT BOARD REPORT 21, 1966

GROUND WATER IN THE OGALLALA FORMATION IN THE SOUTHERN HIGH PLAINS OF TEXAS AND NEW MEXICO: USGS HYDROLOGIC INVESTIGATIONS ATLAS HA-330, 1969.

COMPILATION OF RESULTS OF AQUIFER TESTS IN TEXAS: TEXAS WATER DEVELOPMENT BOARD REPORT 98, 1969.

WATER-LEVEL DATA FROM OBSERVATION WELLS IN THE SOUTHERN HIGH PLAINS OF TEXAS, 1965-70: TEXAS WATER DEVELOPMENT BOARD REPORT 121, 1970.

AN EVALUATION OF THE USE OF DRILLERS' LOGS IN LITHOLOGIC STUDIES OF THE OGALLALA FORMATION OF THE SOUTHERN HIGH PLAINS OF TEXAS: USGS OPEN-FILE REPORT 72-451, 1972.

ANALYTICAL STUDY OF THE OGALLALA AQUIFER IN CROSBY COUNTY, TEXAS-PROJECTIONS OF SATURATED THICKNESS, VOLUME OF WATER IN STORAGE, PUMPAGE RATES, PUMPING LIFTS, AND WELL YIELDS: TEXAS WATER DEVELOPMENT BOARD REPORT 209, 1976.

WATER-LEVEL DATA FROM OBSERVATION WELLS IN THE SOUTHERN HIGH PLAINS OF TEXAS, 1971-77: TEXAS DEPARTMENT OF WATER RESOURCES REPORT 228, 1979.

PRELIMINARY DATA DESCRIBING THE DISTRIBUTION OF FLUORIDE AND SILICA IN THE OGALLALA AQUIFER ON THE HIGH PLAINS OF TEXAS: USGS OPEN-FILE REPORT 80-349, 1980.

EVALUATING THE GROUND-WATER RESOURCES OF THE HIGH PLAINS OF TEXAS: RESULTS OF TEST HOLE DRILLING: TEXAS DEPARTMENT OF WATER RESOURCES LIMITED PRINTING REPORT LP-129, 1980.

EVALUATING THE GROUND-WATER RESOURCES OF THE HIGH PLAINS OF TEXAS: RESULTS OF SURFACE ELECTRICAL RESISTIVITY SURVEYS: TEXAS DEPARTMENT OF WATER RESOURCES LIMITED PRINTING REPORT LP-130, 1980

SPRINGS OF TEXAS, VOLUME 1: (BY GUNNAR BRUNE), BRANCHSMITH, INC., FORT WORTH, TEXAS, 1981.

BEDROCK GEOLOGY, ALTITUDE OF BASE, AND 1980 SATURATED THICKNESS OF THE HIGH PLAINS AQUIFER IN PARTS OF COLORADO, KANSAS, NEBRASKA, NEW MEXICO, OKLAHOMA, SOUTH DAKOTA, TEXAS, AND WYOMING: USGS HYDROLOGIC INVESTIGATIONS ATLAS HA-648, 1981.

WATER LEVEL AND SATURATED THICKNESS CHANGES, PREDEVELOPMENT TO 1980, IN THE HIGH PLAINS AQUIFER IN PARTS OF COLORADO, KANSAS, NEBRASKA, NEW MEXICO, OKLAHOMA, SOUTH DAKOTA, TEXAS, AND WYOMING: USGS HYDROLOGIC INVESTIGATIONS ATLAS HA-652, 1981.

DISSOLVED SOLIDS AND SODIUM IN WATER FROM THE HIGH PLAINS AQUIFER IN PARTS OF COLORADO, KANSAS, NEBRASKA, NEW MEXICO, OKLAHOMA, SOUTH DAKOTA, TEXAS, AND WYOMING: USGS HYDROLOGIC INVESTIGATIONS ATLAS HA-658, 1982.

EVALUATING THE GROUND-WATER RESOURCES OF THE HIGH PLAINS OF TEXAS, VOLUME 1: TEXAS DEPARTMENT OF WATER RESOURCES REPORT 288, V. 1, 1984.

EVALUATING THE GROUND-WATER RESOURCES OF THE HIGH PLAINS OF TEXAS, VOLUME 3, RECORDS OF WELLS, AND MAPS SHOWING WELL LOCATIONS, BASE OF AQUIFER, WATER LEV-
ELS, AND SATURATED THICKNESS (BAILEY, BRISCOE, CASTRO, CROSBY, DEAF SMITH, DICKENS, FLOYD, HALE, LAMB, MOTLEY, OLDHAM, PARMER, RANDALL, AND SWISHER COUNTIES): TEXAS DEPARTMENT OF WATER RESOURCES REPORT 288, V. 3 , 1984.

GEOHYDROLOGY OF THE HIGH PLAINS AQUIFER IN PARTS OF COLORADO, KANSAS, NEBRASKA, NEW MEXICO, OKLAHOMA, SOUTH DAKOTA, TEXAS, AND WYOMING: USGS PROFESSIONAL PAPER 1400-B, 1984.

TEXAS GROUND-WATER RESOURCES, in NATIONAL WATER SUMMARY 1984: USGS WATER-SUPPLY PAPER 2275, 1985.

DIGITAL SIMULATION OF GROUND-WATER FLOW IN THE HIGH PLAINS AQUIFER IN PARTS OF COLORADO, KANSAS, NEBRASKA, NEW MEXICO, OKLAHOMA, SOUTH DAKOTA, TEXAS, AND WYOMING: USGS PROFESSIONAL PAPER 1400-D, 1986.

SUMMARY OF THE HIGH PLAINS REGIONAL AQUIFER-SYSTEM ANALYSIS IN PARTS OF COLORADO, KANSAS, NEBRASKA, NEW MEXICO, OKLAHOMA, SOUTH DAKOTA, TEXAS, AND WYOMING: USGS PROFESSIONAL PAPER 1400-A, 1988.

HYDROGEOLOGY OF LOWER CRETACEOUS STRATA UNDER THE SOUTHERN HIGH PLAINS OF TEXAS AND NEW MEXICO: TEXAS WATER DEVELOPMENT BOARD REPORT 314, 1989.

PUBLIC SUPPLY GROUND-WATER USE IN THE SOUTHERN HIGH PLAINS OF TEXAS: TEXAS WATER DEVELOPMENT BOARD REPORT 328, 1990.

WATER-LEVEL CHANGES IN THE HIGH PLAINS AQUIFER OF TEXAS, 1980-1990: TEXAS WATER DEVELOPMENT BOARD HYDROLOGIC ATLAS NO. 1, 1991.

EVALUATION OF WATER RESOURCES IN PARTS OF THE ROLLING PRAIRIES REGION OF NORTH-CENTRAL TEXAS: TEXAS WATER DEVELOPMENT BOARD REPORT 337, 1992.

THE HIGH PLAINS AQUIFER SYSTEM OF TEXAS, 1980-1990. OVERVIEW AND PROJECTIONS: TEXAS WATER DEVELOPMENT BOARD REPORT 341, 1993.

WATER-QUALITY EVALUATION OF THE OGALLALA AQUIFER, TEXAS: TEXAS WATER DEVELOPMENT BOARD REPORT 342, 1993.

WATER-LEVEL CHANGES IN THE HIGH PLAINS AQUIFER-PREDEVELOPMENT TO 1992: USGS WATER-RESOURCES INVESTIGATIONS REPORT 94-4027, 1994.

WATER-LEVEL CHANGES IN THE HIGH PLAINS AQUIFER, 1980 TO 1994: USGS FACT SHEET FS-215-95, 1995.

AQUIFERS OF TEXAS: TEXAS WATER DEVELOPMENT BOARD REPORT 345, 1995.

HYDROLOGIC ATLAS FOR CROSBY COUNTY, TEXAS: HIGH PLAINS UNDERGROUND WATER CONSERVATION DISTRICT NO. 1, LUBBOCK, TEXAS, 1996.

WATER-LEVEL CHANGES IN THE HIGH PLAINS AQUIFER, 1980 TO 1995: USGS FACT SHEET FS-068-97, 1997.

WATER-LEVEL CHANGES IN THE HIGH PLAINS AQUIFER-PREDEVELOPMENT TO 1995: USGS WATER-RESOURCES INVESTIGATIONS REPORT 97-4081, 1997.

UPDATED WATER-QUALITY EVALUATION OF THE OGALLALA AQUIFER INCLUDING SELECTED METALLIC AND NON-METAL- 
LIC INORGANIC CONSTITUENTS: TEXAS WATER DEVELOPMENT BOARD HYDROLOGIC ATLAS NO. 10, 1998.

\section{CULBERSON COUNTY}

GEOLOGIC ATLAS OF THE UNITED STATES-VAN HORN FOLIO, TEXAS: USGS GEOLOGIC FOLIO, 1914.

PUBLIC WATER SUPPLIES IN WESTERN TEXAS: USGS WATERSUPPLY PAPER 1106, 1951.

PROPOSED 6-YEAR PROGRAM OF GROUND-WATER INVESTIGATIONS IN THE TEXAS PORTION OF THE RIO GRANDE BASIN ABOVE FORT QUITMAN, INCLUDING THE CLOSED SALT FLAT BASIN IN HUDSPETH AND CULBERSON COUNTIES, TEXAS: USGS OPEN-FILE REPORT (UNNUMBERED), 1949.

SUMMARY OF THE DEVELOPMENT OF GROUND WATER FOR IRRIGATION IN THE LOBO FLATS AREA, CULBERSON AND JEFF DAVIS COUNTIES, TEXAS: TEXAS BOARD OF WATER ENGINEERS BULLETIN 5102, 1951.

RECORDS OF WATER-LEVEL MEASUREMENTS IN CULBERSON, HUDSPETH, AND JEFF DAVIS COUNTIES, TEXAS: TEXAS BOARD OF WATER ENGINEERS BULLETIN 5415, 1954.

WATER-LEVEL MEASUREMENTS IN CULBERSON, HUDSPETH, AND JEFF DAVIS COUNTIES, TEXAS: TEXAS BOARD OF WATER ENGINEERS BULLETIN 6005, 1960.

WATER LEVELS AND CHEMICAL ANALYSES FROM OBSERVATION WELLS IN THE DELL CITY AREA, HUDSPETH AND CULBERSON COUNTIES, TEXAS, 1948 THROUGH 1964: TEXAS WATER COMMISSION CIRCULAR 64-01, 1964.

RECONNAISSANCE INVESTIGATIONS OF THE GROUND-WATER RESOURCES OF THE RIO GRANDE BASIN, TEXAS: TEXAS WATER COMMISSION BULLETIN 6502, 1965.

WATER-LEVEL DATA FROM OBSERVATION WELLS IN CULBERSON, JEFF DAVIS, PRESIDIO, AND BREWSTER COUNTIES, TEXAS: TEXAS WATER DEVELOPMENT BOARD REPORT 16, 1966.

COMPILATION OF RESULTS OF AQUIFER TESTS IN TEXAS: TEXAS WATER DEVELOPMENT BOARD REPORT 98, 1969.

RECORDS OF WATER LEVELS AND CHEMICAL ANALYSES FROM SELECTED WELLS IN PARTS OF THE TRANS-PECOS REGION, TEXAS, 1965-68: TEXAS WATER DEVELOPMENT BOARD REPORT $114,1970$.

RECONNAISSANCE INVESTIGATION OF GROUND WATER IN THE RIO GRANDE DRAINAGE BASIN—WITH SPECIAL EMPHASIS ON SALINE GROUND-WATER RESOURCES: USGS HYDROLOGIC ATLAS HA-510, 1974.

QUALITY AND AVAILABILITY OF WATER IN WESTERNMOST TEXAS: USGS OPEN-FILE REPORT 75-133, 1975.

EXPLORATION FOR FRESH GROUND WATER IN THE EAGLE MOUNTAINS AREA, HUDSPETH COUNTY AREA, TEXAS, in GEOLOGY OF THE EAGLE MOUNTAINS AND VICINITY: SOCIETY OF ECONOMIC PALEONTOLOGISTS AND MINERALOGISTS_PERMIAN BASIN SECTION, 1975.

MAJOR AND HISTORICAL SPRINGS OF TEXAS: TEXAS WATER DEVELOPMENT BOARD REPORT 189, 1975.
TEST DRILLING FOR GROUND WATER IN HUDSPETH, CULBERSON, AND PRESIDIO COUNTIES IN WESTERNMOST TEXAS: USGS OPEN-FILE REPORT 76-338, 1976.

AVAILABILITY OF FRESH AND SLIGHTLY SALINE GROUND WATER IN THE BASINS OF WESTERNMOST TEXAS: USGS OPEN-FILE REPORT 78-663, 1978.

OCCURRENCE AND QUALITY OF GROUND WATER IN THE EDWARDS-TRINITY (PLATEAU) AQUIFER IN THE TRANS-PECOS REGION OF TEXAS: TEXAS DEPARTMENT OF WATER RESOURCES REPORT 255, 1980.

AVAILABILITY OF FRESH AND SLIGHTLY SALINE GROUND WATER IN THE BASINS OF WESTERNMOST TEXAS: TEXAS DEPARTMENT OF WATER RESOURCES REPORT 256, 1980.

GROUND-WATER DATA FOR THE SALT BASIN, EAGLE FLAT, RED LIGHT DRAW, GREEN RIVER VALLEY, AND PRESIDIO BOLSON IN WESTERNMOST TEXAS: TEXAS DEPARTMENT OF WATER RESOURCES REPORT 259, 1980.

SPRINGS OF TEXAS, VOLUME 1: (BY GUNNAR BRUNE), BRANCHSMITH, INC., FORT WORTH, TEXAS, 1981.

MAPS SHOWING GROUND-WATER UNITS AND WITHDRAWAL, BASIN AND RANGE PROVINCE, TEXAS: USGS WATERRESOURCES INVESTIGATIONS REPORT 83-4121-A, 1984.

MAPS SHOWING GROUND-WATER LEVELS, SPRINGS, AND DEPTH TO GROUND WATER, BASIN AND RANGE PROVINCE, TEXAS: USGS WATER-RESOURCES INVESTIGATIONS REPORT 83-4121-B, 1984.

MAPS SHOWING DISTRIBUTION OF DISSOLVED SOLIDS AND DOMINANT CHEMICAL TYPE IN GROUND WATER, BASIN AND RANGE PROVINCE, TEXAS: USGS WATER-RESOURCES INVESTIGATIONS REPORT 83-4121-C, 1984.

GEOHYDROLOGY OF THE DELAWARE BASIN AND VICINITY, TEXAS AND NEW MEXICO: USGS WATER-RESOURCES INVESTIGATIONS REPORT 84-4077, 1985.

TEXAS GROUND-WATER RESOURCES, in NATIONAL WATER SUMMARY 1984: USGS WATER-SUPPLY PAPER 2275, 1985.

TECTONIC CONTROLS ON THE HYDROGEOLOGY OF THE SALT BASIN, TRANS-PECOS TEXAS, in STRUCTURE AND TECTONICS OF TRANS-PECOS TEXAS: WEST TEXAS GEOLOGICAL SOCIETY FIELD TRIP CONFERENCE, 85-81, 1985.

PUBLIC SUPPLY GROUND-WATER USE IN WESTERN TEXAS: TEXAS WATER DEVELOPMENT BOARD REPORT 311, 1989.

POTENTIOMETRIC SURFACE OF THE EDWARDS-TRINITY AQUIFER SYSTEM AND CONTIGUOUS HYDRAULICALLY CONNECTED UNITS, WEST-CENTRAL TEXAS, WINTER 1974-75: USGS WATERRESOURCES INVESTIGATIONS REPORT 89-4208, 1990.

WITHDRAWALS FROM THE EDWARDS-TRINITY AQUIFER SYSTEM AND CONTIGUOUS HYDRAULICALLY CONNECTED UNITS, WEST-CENTRAL TEXAS, DECEMBER 1974 THROUGH MARCH 1977: USGS WATER-RESOURCES INVESTIGATIONS REPORT 91-4021, 1991.

CONFIGURATION OF THE BASE OF THE EDWARDS-TRINITY AQUIFER SYSTEM AND HYDROGEOLOGY OF THE UNDERLYING PRECRETACEOUS ROCKS, WEST-CENTRAL TEXAS: USGS WATERRESOURCES INVESTIGATIONS REPORT 91-4071, 1992.

HISTORICAL POTENTIOMETRIC SURFACE OF THE EDWARDS-TRINITY AQUIFER SYSTEM AND CONTIGUOUS HYDRAULICALLY 
CONNECTED UNITS, WEST-CENTRAL TEXAS: USGS WATERRESOURCES INVESTIGATIONS REPORT 92-4055, 1993.

HISTORICAL SATURATED THICKNESS OF THE EDWARDS-TRINITY AQUIFER SYSTEM AND SELECTED CONTIGUOUS HYDRAULICALLY CONNECTED UNITS, WEST-CENTRAL TEXAS: USGS WATER-RESOURCES INVESTIGATIONS REPORT 92-4125, 1993.

SIMULATIONS OF FLOW IN THE EDWARDS-TRINITY AQUIFER SYSTEM AND CONTIGUOUS HYDRAULICALLY CONNECTED UNITS, WEST-CENTRAL TEXAS: USGS WATER-RESOURCES INVESTIGATIONS REPORT 93-4039, 1994.

DISSOLVED-SOLIDS CONCENTRATIONS AND HYDROCHEMICAL FACIES IN WATER OF THE EDWARDS-TRINITY AQUIFER SYSTEM, WEST-CENTRAL TEXAS: USGS WATER-RESOURCES INVESTIGATIONS REPORT 93-4126, 1994.

GEOLOGIC HISTORY AND HYDROGEOLOGIC SETTING OF THE EDWARDS-TRINITY AQUIFER SYSTEM, WEST-CENTRAL TEXAS: USGS WATER-RESOURCES INVESTIGATIONS REPORT 94-4039, 1994.

GROUND-WATER HYDROLOGY AND HYDROCHEMISTRY OF EAGLE FLAT AND SURROUNDING AREA: UNIVERSITY OF TEXAS, BUREAU OF ECONOMIC GEOLOGY CONTRACT REPORT, PREPARED FOR TEXAS LOW-LEVEL RADIOACTIVE WASTE DISPOSAL AUTHORITY, 1994.

WATER QUALITY IN THE EDWARDS-TRINITY (PLATEAU) AQUIFER, EDWARDS PLATEAU AND TRANS-PECOS, TEXAS: TEXAS WATER DEVELOPMENT BOARD HYDROLOGIC ATLAS NO. 3, 1995.

AQUIFERS OF TEXAS: TEXAS WATER DEVELOPMENT BOARD REPORT 345, 1995

WATER QUALITY IN THE CAPITAN REEF AQUIFER: TEXAS WATER DEVELOPMENT BOARD HYDROLOGIC ATLAS NO. 8, 1997.

DELINEATION OF THE GROUND-WATER FLOW SYSTEMS OF THE EAGLE FLAT AND RED LIGHT BASINS OF TRANS-PECOS TEXAS: THE UNIVERSITY OF TEXAS AT AUSTIN, DOCTORAL DISSERTATION, 1997.

WATER QUALITY IN THE RUSTLER AQUIFER: TEXAS WATER DEVELOPMENT BOARD HYDROLOGIC ATLAS NO. 9, 1998.

HYDROGEOLOGIC ANALYSIS AND GROUND-WATER FLOW MODEL OF THE WILDHORSE FLAT AREA, CULBERSON COUNTY, TEXAS: JOHN SCHOMAKER AND ASSOCIATES, INC., ALBUQUERQUE, NEW MEXICO, 2001.

AQUIFERS OF WEST TEXAS: TEXAS WATER DEVELOPMENT BOARD REPORT 356, 2001

EVALUATION OF GROUND-WATER RECHARGE IN BASINS OF TRANS-PECOS TEXAS, CHAPTER 3, in AQUIFERS OF WEST TEXAS: TEXAS WATER DEVELOPMENT BOARD REPORT 356, 2001.

REGIONAL GROUND-WATER FLOW SYSTEMS IN TRANS-PECOS TEXAS, CHAPTER 4, in AQUIFERS OF WEST TEXAS: TEXAS WATER DEVELOPMENT BOARD REPORT 356, 2001

AN OVERVIEW OF THE EDWARDS-TRINITY AQUIFER SYSTEM, CENTRAL-WEST TEXAS, CHAPTER 8, in AQUIFERS OF WEST TEXAS TEXAS WATER DEVELOPMENT BOARD REPORT 356, 2001.

THE GEOLOGY AND HYDROGEOLOGY OF THE CAPITAN AQUIFER: A BRIEF OVERVIEW, CHAPTER 11, in AQUIFERS OF WEST TEXAS: TEXAS WATER DEVELOPMENT BOARD REPORT 356, 2001.
IGNEOUS AQUIFERS OF FAR WEST TEXAS, CHAPTER 13, in AQUIFERS OF WEST TEXAS: TEXAS WATER DEVELOPMENT BOARD REPORT 356, 2001.

HYDROGEOLOGY OF THE RUSTLER AQUIFER, TRANS-PECOS TEXAS, CHAPTER 15, in AQUIFERS OF WEST TEXAS: TEXAS WATER DEVELOPMENT BOARD REPORT 356, 2001.

THE AQUIFERS OF RED LIGHT DRAW, GREEN RIVER VALLEY, AND EAGLE FLAT, CHAPTER 16, in AQUIFERS OF WEST TEXAS: TEXAS WATER DEVELOPMENT BOARD REPORT 356, 2001.

HYDROGEOLOGY OF THE SALT BASIN, CHAPTER 17, in AQUIFERS OF WEST TEXAS: TEXAS WATER DEVELOPMENT BOARD REPORT 356, 2001.

\section{DALLAM COUNTY}

THE GEOLOGY AND WATER RESOURCES OF THE WESTERN PORTION OF THE PANHANDLE OF TEXAS: USGS WATER-SUPPLY PAPER 191, 1907.

GEOLOGY AND GROUND-WATER RESOURCES OF THE SOUTHERN HIGH PLAINS: USGS OPEN-FILE REPORT (UNNUMBERED), 1935.

RECORDS OF WELLS, DRILLERS' LOGS, AND WATER ANALYSES, AND MAP SHOWING LOCATION OF WELLS IN DALLAM COUNTY, TEXAS: TEXAS BOARD OF WATER ENGINEERS MISCELLANEOUS PUBLICATION 64, 1937.

GROUND WATER IN THE HIGH PLAINS OF TEXAS: TEXAS BOARD OF WATER ENGINEERS MISCELLANEOUS PUBLICATION (UNNUMBERED), 1938.

GROUND WATER IN THE HIGH PLAINS OF TEXAS: TEXAS BOARD OF WATER ENGINEERS MISCELLANEOUS PUBLICATION 119, 1940.

ROGRESS REPORT ON GROUND WATER IN THE HIGH PLAINS OF TEXAS: TEXAS BOARD OF WATER ENGINEERS MISCELLANEOUS PUBLICATION (UNNUMBERED), 1942.

PROGRESS REPORT ON GROUND WATER IN THE HIGH PLAINS OF TEXAS: TEXAS BOARD OF WATER ENGINEERS MISCELLANEOUS PUBLICATION 120, 1943.

PROGRESS REPORT ON GROUND WATER IN THE HIGH PLAINS OF TEXAS: TEXAS BOARD OF WATER ENGINEERS MISCELLANEOUS PUBLICATION 121, 1944

PROGRESS REPORT NUMBER 5 ON GROUND WATER IN THE HIGH PLAINS OF TEXAS: TEXAS BOARD OF WATER ENGINEERS MISCELLANEOUS PUBLICATION 122, 1945.

GROUND WATER IN THE HIGH PLAINS OF TEXAS: USGS WATERSUPPLY PAPER 889-F, 1946.

GROUND WATER IN HIGH PLAINS OF TEXAS, PROGRESS REPORT NO. 6: TEXAS BOARD OF WATER ENGINEERS MISCELLANEOUS PUBLICATION 123, 1947.

COST OF PUMPING WATER FOR IRRIGATION, TEXAS HIGH PLAINS FIELD INVESTIGATIONS-1947 IRRIGATION SEASON: TEXAS BOARD OF WATER ENGINEERS MISCELLANEOUS PUBLICATION 124, 1951.

PUBLIC WATER SUPPLIES IN WESTERN TEXAS: USGS WATERSUPPLY PAPER 1106, 1951 [1952]. 
DEVELOPMENT OF WELLS FOR IRRIGATION AND FLUCTUATION OF WATER LEVELS IN THE HIGH PLAINS OF TEXAS TO JANUARY 1951: TEXAS BOARD OF WATER ENGINEERS BULLETIN 5104, 1951.

RECORDS OF WATER-LEVEL MEASUREMENTS IN DALLAM, HANSFORD, HARTLEY, HUTCHINSON, MOORE, OCHILTREE, AND SHERMAN COUNTIES, TEXAS: TEXAS BOARD OF WATER ENGINEERS BULLETIN 5404, 1954.

WATER-LEVEL MAPS AND WATER LEVELS IN OBSERVATION WELLS IN THE NORTH HIGH PLAINS, TEXAS: TEXAS BOARD OF WATER ENGINEERS BULLETIN 5707, 1957.

WATER-LEVEL MEASUREMENTS AND MAPS, NORTHERN HIGH PLAINS, TEXAS, 1958 AND 1959: TEXAS BOARD OF WATER ENGINEERS BULLETIN 5909, 1959.

WATER LEVELS IN OBSERVATION WELLS, NORTHERN HIGH PLAINS, TEXAS, 1958-1960: TEXAS BOARD OF WATER ENGINEERS BULLETIN 6012, 1960.

RECONNAISSANCE INVESTIGATION OF THE GROUND-WATER RESOURCES OF THE CANADIAN RIVER BASIN, TEXAS: TEXAS BOARD OF WATER ENGINEERS BULLETIN 6016, 1960.

ANNUAL WATER-LEVEL MEASUREMENTS IN OBSERVATION WELLS, NORTHERN HIGH PLAINS, TEXAS, 1960 AND 1961: TEXAS BOARD OF WATER ENGINEERS BULLETIN 6103, 1961.

GEOLOGY AND GROUND-WATER RESOURCES OF THE NORTHERN HIGH PLAINS OF TEXAS, PROGRESS REPORT NO. 1: TEXAS BOARD OF WATER ENGINEERS BULLETIN 6109, 1961.

ANNUAL WATER-LEVEL MEASUREMENTS IN OBSERVATION WELLS, NORTHERN HIGH PLAINS, TEXAS, 1961 AND 1962: TEXAS WATER COMMISSION BULLETIN 6213, 1962.

WATER-LEVEL DATA FROM OBSERVATION WELLS IN THE NORTHERN PANHANDLE OF TEXAS: TEXAS DEPARTMENT OF WATER RESOURCES REPORT 137, 1971.

ARTIFICIAL-RECHARGE EXPERIMENTS AND OPERATIONS ON THE SOUTHERN HIGH PLAINS OF TEXAS AND NEW MEXICO: USGS WATER-RESOURCES INVESTIGATIONS REPORT 10-73, 1973.

MAJOR AND HISTORICAL SPRINGS OF TEXAS: TEXAS WATER DEVELOPMENT BOARD REPORT 189, 1975.

GROUND-WATER RESOURCES OF THE PALO DURO CREEK BASIN, TEXAS AND OKLAHOMA: USGS OPEN-FILE REPORT 79-209, 1979.

PRELIMINARY DATA DESCRIBING THE DISTRIBUTION OF FLUORIDE AND SILICA IN THE OGALLALA AQUIFER ON THE HIGH PLAINS OF TEXAS: USGS OPEN-FILE REPORT 80-349, 1980.

WATER-LEVEL DATA FROM OBSERVATION WELLS IN THE NORTHERN PANHANDLE OF TEXAS, 1972-78: TEXAS DEPARTMENT OF WATER RESOURCES REPORT 248, 1980.

WATER TABLE IN THE HIGH PLAINS AQUIFER IN 1978 IN PARTS OF COLORADO, KANSAS, NEBRASKA, NEW MEXICO, OKLAHOMA, SOUTH DAKOTA, TEXAS, AND WYOMING: USGS HYDROLOGIC INVESTIGATIONS ATLAS HA-642, 1980.

EVALUATING THE GROUND-WATER RESOURCES OF THE HIGH PLAINS OF TEXAS: RESULTS OF TEST HOLE DRILLING: TEXAS DEPARTMENT OF WATER RESOURCES LIMITED PRINTING REPORT LP-129, 1980.

EVALUATING THE GROUND-WATER RESOURCES OF THE HIGH PLAINS OF TEXAS: RESULTS OF SURFACE ELECTRICAL RESIS-
TIVITY: TEXAS DEPARTMENT OF WATER RESOURCES LIMITED PRINTING REPORT LP-130, 1980.

SPRINGS OF TEXAS, VOLUME 1: (BY GUNNAR BRUNE), BRANCHSMITH, INC., FORT WORTH, TEXAS, 1981.

BEDROCK GEOLOGY, ALTITUDE OF BASE, AND 1980 SATURATED THICKNESS OF THE HIGH PLAINS AQUIFER IN PARTS OF COLORADO, KANSAS, NEBRASKA, NEW MEXICO, OKLAHOMA, SOUTH DAKOTA, TEXAS, AND WYOMING: USGS HYDROLOGIC INVESTIGATIONS ATLAS HA-648, 1981.

WATER-LEVEL AND SATURATED-THICKNESS CHANGES, PREDEVELOPMENT TO 1980, IN THE HIGH PLAINS AQUIFER IN PARTS OF COLORADO, KANSAS, NEBRASKA, NEW MEXICO, OKLAHOMA, SOUTH DAKOTA, TEXAS, AND WYOMING: USGS HYDROLOGIC INVESTIGATIONS ATLAS HA-652, 1981.

DISSOLVED SOLIDS AND SODIUM IN WATER FROM THE HIGH PLAINS AQUIFER IN PARTS OF COLORADO, KANSAS, NEBRASKA, NEW MEXICO, OKLAHOMA, SOUTH DAKOTA, TEXAS, AND WYOMING: USGS HYDROLOGIC INVESTIGATIONS ATLAS HA-658, 1982.

GEOHYDROLOGY OF THE HIGH PLAINS AQUIFER IN PARTS OF COLORADO, KANSAS, NEBRASKA, NEW MEXICO, OKLAHOMA, SOUTH DAKOTA, TEXAS, AND WYOMING: USGS PROFESSIONAL PAPER 1400-B, 1984.

EVALUATING THE GROUND-WATER RESOURCES OF THE HIGH PLAINS OF TEXAS, VOLUME 1: TEXAS DEPARTMENT OF WATER RESOURCES REPORT 288, V. 1, 1984.

EVALUATING THE GROUND-WATER RESOURCES OF THE HIGH PLAINS OF TEXAS, VOLUME 2, RECORDS OF WELLS, AND MAPS SHOWING WELL LOCATIONS, BASE OF AQUIFER, WATER LEVELS, AND SATURATED THICKNESS (ARMSTRONG, CARSON, DALLAS, DONLEY, GRAY, HANSFORD, HARTLEY, HEMPHILL, HUTCHINSON, LIPSCOMB, MOORE, OCHILTREE, POTTER, ROBERTS, SHERMAN, AND WHEELER COUNTIES): TEXAS DEPARTMENT OF WATER RESOURCES REPORT 288, V. 2, 1984.

TEXAS GROUND-WATER RESOURCES, in NATIONAL WATER SUMMARY 1984: USGS WATER-SUPPLY PAPER 2275, 1985.

DIGITAL SIMULATION OF GROUND-WATER FLOW IN THE HIGH PLAINS AQUIFER IN PARTS OF COLORADO, KANSAS, NEBRASKA, NEW MEXICO, OKLAHOMA, SOUTH DAKOTA, TEXAS, AND WYOMING: USGS PROFESSIONAL PAPER 1400-D, 1986.

SUMMARY OF THE HIGH PLAINS REGIONAL AQUIFER-SYSTEM ANALYSIS IN PARTS OF COLORADO, KANSAS, NEBRASKA, NEW MEXICO, OKLAHOMA, SOUTH DAKOTA, TEXAS, AND WYOMING: USGS PROFESSIONAL PAPER 1400-A, 1988.

EVALUATION OF GROUND-WATER RESOURCES IN DALLAM COUNTY, TEXAS: TEXAS WATER DEVELOPMENT BOARD REPORT 315, 1989.

WATER-LEVEL CHANGES IN THE HIGH PLAINS AQUIFER OF TEXAS, 1980-1990: TEXAS WATER DEVELOPMENT BOARD HYDROLOGIC ATLAS NO. 1, 1991.

PUBLIC-SUPPLY GROUND-WATER USE IN THE NORTHERN HIGH PLAINS OF TEXAS: TEXAS WATER DEVELOPMENT BOARD REPORT 336, 1992.

WATER-RESOURCES DATA, TEXAS, WATER YEAR 1991, VOLUME 4, GROUND-WATER DATA: USGS WATER-DATA REPORT TX-91-4, 1992. 
THE HIGH PLAINS AQUIFER SYSTEM OF TEXAS, 1980-1990. OVERVIEW AND PROJECTIONS: TEXAS WATER DEVELOPMENT BOARD REPORT 341, 1993.

WATER-QUALITY EVALUATION OF THE OGALLALA AQUIFER, TEXAS: TEXAS WATER DEVELOPMENT BOARD REPORT 342, 1993.

WATER-RESOURCES DATA, TEXAS, WATER YEAR 1992, VOLUME 4, GROUND-WATER DATA: USGS WATER-DATA REPORT TX-92-4, 1993.

WATER-LEVEL CHANGES IN THE HIGH PLAINS AQUIFER-PREDEVELOPMENT TO 1992: USGS WATER-RESOURCES INVESTIGATIONS REPORT 94-4027, 1994.

WATER-RESOURCES DATA, TEXAS, WATER YEAR 1993, VOLUME 4, GROUND-WATER DATA: USGS WATER-DATA REPORT TX-93-4, 1994.

WATER-LEVEL CHANGES IN THE HIGH PLAINS AQUIFER, 1980 TO 1994: USGS FACT SHEET FS-215-95, 1995.

AQUIFERS OF TEXAS: TEXAS WATER DEVELOPMENT BOARD REPORT 345, 1995

WATER-LEVEL CHANGES IN THE HIGH PLAINS AQUIFER, 1980 TO 1995: USGS FACT SHEET FS-068-97, 1997.

WATER-LEVEL CHANGES IN THE HIGH PLAINS AQUIFER-PREDEVELOPMENT TO 1995: USGS WATER-RESOURCES INVESTIGATIONS REPORT 97-4081, 1997.

UPDATED WATER-QUALITY EVALUATION OF THE OGALLALA AQUIFER INCLUDING SELECTED METALLIC AND NON-METALLIC INORGANIC CONSTITUENTS: TEXAS WATER DEVELOPMENT BOARD HYDROLOGIC ATLAS NO. 10, 1998.

\section{DALLAS COUNTY}

GEOGRAPHY AND GEOLOGY OF THE BLACK AND GRAND PRAIRIES, TEXAS, WITH DETAILED DESCRIPTIONS OF THE CRETACEOUS FORMATIONS AND SPECIAL REFERENCE TO ARTESIAN WATERS: USGS 21ST ANNUAL REPORT, PART 7, 1901.

THE GEOLOGY OF DALLAS COUNTY: UNIVERSITY OF TEXAS, UNIVERSITY OF TEXAS, BUREAU OF ECONOMIC GEOLOGY AND TECHNOLOGY BULLETIN 1818, 1918

MEMORANDUM ON GROUND-WATER SUPPLIES IN THE VICINITY OF THE SEAGOVILLE FEDERAL REFORMATORY FOR WOMEN IN DALLAS COUNTY, TEXAS: USGS OPEN-FILE REPORT (UNNUMBERED), 1941.

WATER RESOURCES OF GRAND PRAIRIE, DALLAS COUNTY, TEXAS USGS OPEN-FILE REPORT (UNNUMBERED), 1941.

WATER SUPPLY OF DALLAS: USGS OPEN-FILE REPORT (UNNUMBERED), 1941.

EMERGENCY WATER SUPPLY FOR NAVAL RESERVE AIR BASE NEAR GRAND PRAIRIE, TEXAS: USGS OPEN-FILE REPORT (UNNUMBERED), 1942.

WATER RESOURCES OF GARLAND, DALLAS COUNTY, TEXAS: USGS OPEN-FILE REPORT (UNNUMBERED), 1942.
MEMORANDUM ON TEST WELL DRILLING AT SEAGOVILLE REFORMATORY, DALLAS COUNTY, TEXAS: USGS OPEN-FILE REPORT (UNNUMBERED), 1942

DALLAS COUNTY: USGS OPEN-FILE REPORT (UNNUMBERED), 1943.

GROUND-WATER RESOURCES AT GRAND PRAIRIE, TEXAS AND VICINITY: USGS OPEN-FILE REPORT (UNNUMBERED), 1943.

RECORDS OF WELLS AND SPRINGS, DRILLERS' LOGS, WATER ANALYSES, AND MAP SHOWING LOCATIONS OF WELLS AND SPRINGS IN DALLAS COUNTY, TEXAS: TEXAS BOARD OF WATER ENGINEERS MISCELLANEOUS PUBLICATION 66, 1943.

SUPPLEMENTAL MEMORANDUM REGARDING THE DEVELOPMENT OF GROUND WATER FROM THE TRINITY SANDS AT GARLAND: USGS OPEN-FILE REPORT (UNNUMBERED), 1944.

MEMORANDUM ON WATER WELL NO. 2, FEDERAL REFORMATORY FOR WOMEN AT SEAGOVILLE, TEXAS: USGS OPEN-FILE REPORT (UNNUMBERED), 1944

PUBLIC WATER SUPPLIES IN EASTERN TEXAS: USGS WATERSUPPLY PAPER 1047, 1948.

RECORDS OF WELLS PRODUCING WATER FROM THE TRAVIS PEAK FORMATION IN THE DALLAS AREA, TEXAS: TEXAS BOARD OF WATER ENGINEERS MISCELLANEOUS PUBLICATION 065, 1957.

RECONNAISSANCE INVESTIGATION OF THE GROUND-WATER RESOURCES OF THE TRINITY RIVER BASIN, TEXAS: TEXAS WATER COMMISSION BULLETIN 6309, 1963.

HYDROLOGIC EFFECTS OF THE EARTHQUAKE OF MARCH 27, 1964, OUTSIDE ALASKA: USGS PROFESSIONAL PAPER 544-C, 1968.

COMPILATION OF RESULTS OF AQUIFER TESTS IN TEXAS: TEXAS WATER DEVELOPMENT BOARD REPORT 98, 1969.

LIQUID-WASTE DISPOSAL AT THE LINFIELD DISPOSAL SITE, DALLAS, TEXAS: USGS OPEN-FILE REPORT 72-228, 1972.

MAJOR AND HISTORICAL SPRINGS OF TEXAS: TEXAS WATER DEVELOPMENT BOARD REPORT 189, 1975.

WATER-LEVEL AND WATER-QUALITY DATA FROM OBSERVATION WELLS IN NORTHEAST TEXAS: TEXAS WATER DEVELOPMENT BOARD REPORT 198, 1976

OCCURRENCE, AVAILABILITY, AND CHEMICAL QUALITY OF GROUND WATER IN THE CRETACEOUS AQUIFERS OF NORTHCENTRAL TEXAS: TEXAS DEPARTMENT OF WATER RESOURCES REPORT 269, V. 1, 1982.

OCCURRENCE, AVAILABILITY, AND CHEMICAL QUALITY OF GROUND WATER IN THE CRETACEOUS AQUIFERS OF NORTHCENTRAL TEXAS: TEXAS DEPARTMENT OF WATER RESOURCES REPORT 269, V. 2, 1982

WATER USE, PROJECTED WATER REQUIREMENTS, AND RELATED DATA AND INFORMATION FOR THE METROPOLITAN STATISTICAL AREAS IN TEXAS: TEXAS DEPARTMENT OF WATER RESOURCES LIMITED PRINTING REPORT LP-201, 1985.

TEXAS GROUND-WATER RESOURCES, in NATIONAL WATER SUMMARY 1984: USGS WATER-SUPPLY PAPER 2275, 1985.

EVALUATION OF WATER RESOURCES IN PART OF NORTH-CENTRAL TEXAS: TEXAS WATER DEVELOPMENT BOARD REPORT 318,1990

NATIONAL WATER-QUALITY ASSESSMENT PROGRAM-THE TRINITY RIVER BASIN: USGS OPEN-FILE REPORT 91-158, 1991. 
AQUIFERS OF TEXAS: TEXAS WATER DEVELOPMENT BOARD REPORT 345, 1995.

NATIONAL WATER-QUALITY ASSESSMENT PROGRAM-PESTICIDES IN THE TRINITY RIVER BASIN STUDY UNIT, TEXAS, 1968-91: USGS FACT SHEET FS-088-95, 1995.

WATER-QUALITY ASSESSMENT OF THE TRINITY RIVER BASIN, TEXAS-DATA COLLECTION, 1992-95: USGS FACT SHEET FS-095-95, 1995.

WATER-QUALITY ASSESSMENT OF THE TRINITY RIVER BASIN, TEXAS-PESTICIDES IN A SUBURBAN WATERSHED, ARLINGTON, 1993-94: USGS FACT SHEET FS-159-95, 1995.

WATER QUALITY IN THE WOODBINE AQUIFER, NORTH-CENTRAL TEXAS: TEXAS WATER DEVELOPMENT BOARD HYDROLOGIC ATLAS NO. 4, 1996.

INTEGRITY OF PRODUCTION WELLS AND CONFINING UNIT AT THE NAVAL WEAPONS INDUSTRIAL RESERVE PLANT, DALLAS, TEXAS, 1995: USGS WATER-RESOURCES INVESTIGATIONS REPORT 97-4047, 1997.

UPDATED EVALUATION OF WATER RESOURCES IN PART OF NORTH-CENTRAL TEXAS, 1990-1999: TEXAS WATER DEVELOPMENT BOARD REPORT 349, 1999.

USE OF BOREHOLE GEOPHYSICAL LOGS FOR IMPROVED SITE CHARACTERIZATION AT NAVAL WEAPONS INDUSTRIAL RESERVE PLANT, DALLAS, TEXAS: USGS WATER-RESOURCES INVESTIGATIONS REPORT 00-4150, 2000.

COMPUTER-MODEL ANALYSIS OF GROUND-WATER FLOW AND SIMULATED EFFECTS OF CONTAMINANT REMEDIATION AT NAVAL WEAPONS INDUSTRIAL RESERVE PLANT, DALLAS, TEXAS: USGS WATER-RESOURCES INVESTIGATIONS REPORT 00-4197, 2000.

WATER-RESOURCES DATA, TEXAS, WATER YEAR 2000, VOLUME 6, GROUND-WATER DATA: USGS WATER-DATA REPORT TX-00-6, 2001.

\section{DAWSON COUNTY}

GEOLOGY AND GROUND-WATER RESOURCES OF THE SOUTHERN HIGH PLAINS: USGS OPEN-FILE REPORT (UNNUMBERED), 1935.

GROUND WATER IN THE SOUTHERN HIGH PLAINS: USGS OPENFILE REPORT (UNNUMBERED, 1937.

GROUND WATER IN THE HIGH PLAINS OF TEXAS: TEXAS BOARD OF WATER ENGINEERS MISCELLANEOUS PUBLICATION (UNNUMBERED), 1938.

RECORDS OF WELLS, DRILLERS' LOGS, WATER ANALYSES, AND MAP SHOWING LOCATIONS OF WELLS IN DAWSON COUNTY, TEXAS: TEXAS BOARD OF WATER ENGINEERS MISCELLANEOUS PUBLICATION 67, 1938.

ACKERLY, TEXAS: USGS OPEN-FILE REPORT, (NO DATE).

GROUND WATER IN THE HIGH PLAINS OF TEXAS: TEXAS BOARD OF WATER ENGINEERS MISCELLANEOUS PUBLICATION 119, 1940.

PROGRESS REPORT ON GROUND WATER IN THE HIGH PLAINS OF TEXAS: TEXAS BOARD OF WATER ENGINEERS MISCELLANEOUS PUBLICATION (UNNUMBERED), 1942.
PROGRESS REPORT ON GROUND WATER IN THE HIGH PLAINS OF TEXAS: TEXAS BOARD OF WATER ENGINEERS MISCELLANEOUS PUBLICATION 120, 1943.

PROGRESS REPORT ON GROUND WATER IN THE HIGH PLAINS OF TEXAS: TEXAS BOARD OF WATER ENGINEERS MISCELLANEOUS PUBLICATION 121, 1944.

GROUND WATER IN THE HIGH PLAINS OF TEXAS, PROGRESS REPORT NO. 5: TEXAS BOARD OF WATER ENGINEERS MISCELLANEOUS PUBLICATION 122, 1945.

GROUND WATER IN THE HIGH PLAINS OF TEXAS: USGS WATERSUPPLY PAPER 889-F, 1946.

GROUND WATER IN THE VICINITY OF LAMESA, DAWSON COUNTY, TEXAS: USGS OPEN-FILE REPORT (UNNUMBERED), 1946.

GROUND WATER IN HIGH PLAINS OF TEXAS, PROGRESS REPORT NO. 6: TEXAS BOARD OF WATER ENGINEERS MISCELLANEOUS PUBLICATION 123, 1947

GEOLOGY AND GROUND WATER IN THE IRRIGATED REGION OF THE SOUTHERN HIGH PLAINS IN TEXAS, PROGRESS REPORT NO 7: TEXAS BOARD OF WATER ENGINEERS MISCELLANEOUS PUBLICATION 125, 1949.

COST OF PUMPING WATER FOR IRRIGATION, TEXAS HIGH PLAINS, FIELD INVESTIGATIONS-1947 IRRIGATION SEASON: TEXAS BOARD OF WATER ENGINEERS MISCELLANEOUS PUBLICATION, 1951.

DEVELOPMENT OF WELLS FOR IRRIGATION AND FLUCTUATION OF WATER LEVELS IN THE HIGH PLAINS OF TEXAS TO JANUARY 1951: TEXAS BOARD OF WATER ENGINEERS BULLETIN 5104, 1951.

PUBLIC WATER SUPPLIES IN WESTERN TEXAS: USGS WATERSUPPLY PAPER 1106, 1951 [1952].

SUMMARY OF GROUND-WATER DEVELOPMENT IN THE SOUTHERN HIGH PLAINS, TEXAS: TEXAS BOARD OF WATER ENGINEERS BULLETIN 5402, 1954

GROUND-WATER DEVELOPMENT IN THE SOUTHERN HIGH PLAINS OF TEXAS, 1953: TEXAS BOARD OF WATER ENGINEERS BULLETIN 5410, 1954

WATER-LEVEL DECLINE MAPS OF 17 COUNTIES IN THE SOUTHERN HIGH PLAINS, TEXAS, JANUARY 1955 TO JANUARY 1956: TEXAS BOARD OF WATER ENGINEERS BULLETIN 5607, 1956.

WATER-LEVEL DECLINE MAPS, 1956 TO 1957, AND WATER LEVELS IN OBSERVATION WELLS IN 20 COUNTIES IN THE SOUTHERN HIGH PLAINS, TEXAS: TEXAS BOARD OF WATER ENGINEERS BULLETIN 5705, 1957.

WATER-LEVEL MEASUREMENTS AND MAPS, SOUTHERN HIGH PLAINS, TEXAS, 1958 AND 1959: TEXAS BOARD OF WATER ENGINEERS BULLETIN 5908, 1959.

WATER LEVELS IN OBSERVATION WELLS, SOUTHERN HIGH PLAINS, TEXAS, 1959 AND 1960: TEXAS BOARD OF WATER ENGINEERS BULLETIN 6011, 1960.

WATER LEVELS IN OBSERVATION WELLS, SOUTHERN HIGH PLAINS, TEXAS, 1960 AND 1961: TEXAS BOARD OF WATER ENGINEERS BULLETIN 6101, 1961.

A SUMMARY OF THE OCCURRENCE AND DEVELOPMENT OF GROUND WATER IN THE SOUTHERN HIGH PLAINS OF TEXAS: TEXAS BOARD OF WATER ENGINEERS BULLETIN 6107, 1961. 
WATER-LEVEL MEASUREMENTS THROUGH 1962 IN SELECTED OBSERVATION WELLS, SOUTHERN HIGH PLAINS, TEXAS: TEXAS WATER COMMISSION BULLETIN 6207, 1962.

RECONNAISSANCE INVESTIGATION OF THE GROUND-WATER RESOURCES OF THE BRAZOS RIVER BASIN, TEXAS: TEXAS WATER COMMISSION BULLETIN 6310, 1963.

A SUMMARY OF THE OCCURRENCE AND DEVELOPMENT OF GROUND WATER IN THE SOUTHERN HIGH PLAINS OF TEXAS, WITH A SECTION ON ARTIFICIAL RECHARGE STUDIES: USGS WATER-SUPPLY PAPER 1693, 1964.

WATER-LEVEL DATA FROM OBSERVATION WELLS IN THE SOUTHERN HIGH PLAINS OF TEXAS: TEXAS WATER DEVELOPMENT BOARD REPORT 21, 1966.

RECONNAISSANCE INVESTIGATION OF THE GROUND-WATER RESOURCES OF THE COLORADO RIVER BASIN, TEXAS: TEXAS WATER COMMISSION REPORT 51, 1967.

GROUND WATER IN THE OGALLALA FORMATION IN THE SOUTHERN HIGH PLAINS OF TEXAS AND NEW MEXICO: USGS HYDROLOGIC INVESTIGATIONS ATLAS HA-330, 1969.

WATER-LEVEL DATA FROM OBSERVATION WELLS IN THE SOUTHERN HIGH PLAINS OF TEXAS, 1965-70: TEXAS WATER DEVELOPMENT BOARD REPORT 121, 1970.

ANALYTICAL STUDY OF THE OGALLALA AQUIFER IN DAWSON AND BORDEN COUNTIES, TEXAS: TEXAS DEPARTMENT OF WATER RESOURCES REPORT 225, 1978.

WATER-LEVEL DATA FROM OBSERVATION WELLS IN THE SOUTHERN HIGH PLAINS OF TEXAS, 1971-77: TEXAS DEPARTMENT OF WATER RESOURCES REPORT 228, 1979.

PRELIMINARY DATA DESCRIBING THE DISTRIBUTION OF FLUORIDE AND SILICA IN THE OGALLALA AQUIFER ON THE HIGH PLAINS OF TEXAS: USGS OPEN-FILE REPORT 80-349, 1980.

EVALUATING THE GROUND-WATER RESOURCES OF THE HIGH PLAINS OF TEXAS: RESULTS OF TEST HOLE DRILLING: TEXAS DEPARTMENT OF WATER RESOURCES LIMITED PRINTING REPORT LP-129, 1980.

SPRINGS OF TEXAS, VOLUME 1: (BY GUNNAR BRUNE), BRANCHSMITH, INC., FORT WORTH, TEXAS, 1981.

BEDROCK GEOLOGY, ALTITUDE OF BASE, AND 1980 SATURATED THICKNESS OF THE HIGH PLAINS AQUIFER IN PARTS OF COLORADO, KANSAS, NEBRASKA, NEW MEXICO, OKLAHOMA, SOUTH DAKOTA, TEXAS, AND WYOMING: USGS HYDROLOGIC INVESTIGATIONS ATLAS HA-648, 1981.

WATER LEVEL AND SATURATED THICKNESS CHANGES, PREDEVELOPMENT TO 1980, IN THE HIGH PLAINS AQUIFER IN PARTS OF COLORADO, KANSAS, NEBRASKA, NEW MEXICO, OKLAHOMA, SOUTH DAKOTA, TEXAS, AND WYOMING: USGS HYDROLOGIC INVESTIGATIONS ATLAS HA-652, 1981.

DISSOLVED SOLIDS AND SODIUM IN WATER FROM THE HIGH PLAINS AQUIFER IN PARTS OF COLORADO, KANSAS, NEBRASKA, NEW MEXICO, OKLAHOMA, SOUTH DAKOTA, TEXAS, AND WYOMING: USGS HYDROLOGIC INVESTIGATIONS ATLAS HA-658, 1982.

EVALUATING THE GROUND-WATER RESOURCES OF THE HIGH PLAINS OF TEXAS, VOLUME 1: TEXAS DEPARTMENT OF WATER RESOURCES REPORT 288, V. 1, 1984.
EVALUATING THE GROUND-WATER RESOURCES OF THE HIGH PLAINS OF TEXAS, VOLUME 4, RECORDS OF WELLS, AND MAPS SHOWING WELL LOCATIONS, BASE OF AQUIFER, WATER LEVELS, AND SATURATED THICKNESS (ANDREWS, BORDEN, COCHRAN, DAWSON, ECTOR, GAINES, GARZA, GLASSCOCK, HOWARD, HOCKLEY, LUBBOCK, LYNN, MARTIN, MIDLAND, TERRY, AND YOAKUM COUNTIES: TEXAS DEPARTMENT OF WATER RESOURCES REPORT 288 V. 4, 1984.

GEOHYDROLOGY OF THE HIGH PLAINS AQUIFER IN PARTS OF COLORADO, KANSAS, NEBRASKA, NEW MEXICO, OKLAHOMA, SOUTH DAKOTA, TEXAS, AND WYOMING: USGS PROFESSIONAL PAPER 1400-B, 1984.

TEXAS GROUND-WATER RESOURCES, in NATIONAL WATER SUMMARY 1984: USGS WATER-SUPPLY PAPER 2275, 1985.

DIGITAL SIMULATION OF GROUND-WATER FLOW IN THE HIGH PLAINS AQUIFER IN PARTS OF COLORADO, KANSAS, NEBRASKA, NEW MEXICO, OKLAHOMA, SOUTH DAKOTA, TEXAS, AND WYOMING: USGS PROFESSIONAL PAPER 1400-D, 1986.

HYDROGEOLOGY AND HYDROCHEMISTRY OF CRETACEOUS AQUIFERS, TEXAS PANHANDLE AND EASTERN NEW MEXICO: UNIVERSITY OF TEXAS, BUREAU OF ECONOMIC GEOLOGY GEOLOGICAL CIRCULAR 88-3, 1988.

SUMMARY OF THE HIGH PLAINS REGIONAL AQUIFER-SYSTEM ANALYSIS IN PARTS OF COLORADO, KANSAS, NEBRASKA, NEW MEXICO, OKLAHOMA, SOUTH DAKOTA, TEXAS, AND WYOMING: USGS PROFESSIONAL PAPER 1400-A, 1988.

HYDROGEOLOGY OF LOWER CRETACEOUS STRATA UNDER THE SOUTHERN HIGH PLAINS OF TEXAS AND NEW MEXICO: TEXAS WATER DEVELOPMENT BOARD REPORT 314, 1989.

PUBLIC SUPPLY GROUND-WATER USE IN THE SOUTHERN HIGH PLAINS OF TEXAS: TEXAS WATER DEVELOPMENT BOARD REPORT 328, 1990.

WATER-LEVEL CHANGES IN THE HIGH PLAINS AQUIFER OF TEXAS, 1980-1990: TEXAS WATER DEVELOPMENT BOARD HYDROLOGIC ATLAS NO. 1, 1991.

WATER-RESOURCES DATA, TEXAS, WATER YEAR 1991, VOLUME 4, GROUND-WATER DATA: USGS WATER-DATA REPORT TX-91-4, 1992.

THE HIGH PLAINS AQUIFER SYSTEM OF TEXAS, 1980-1990. OVERVIEW AND PROJECTIONS: TEXAS WATER DEVELOPMENT BOARD REPORT 341, 1993.

WATER-QUALITY EVALUATION OF THE OGALLALA AQUIFER, TEXAS: TEXAS WATER DEVELOPMENT BOARD REPORT 342 , 1993.

WATER-LEVEL CHANGES IN THE HIGH PLAINS AQUIFER-PREDEVELOPMENT TO 1992: USGS WATER-RESOURCES INVESTIGATIONS REPORT 94-4027, 1994.

WATER-LEVEL CHANGES IN THE HIGH PLAINS AQUIFER, 1980 TO 1994: USGS FACT SHEET FS-215-95, 1995.

AQUIFERS OF TEXAS: TEXAS WATER DEVELOPMENT BOARD REPORT 345, 1995.

WATER-LEVEL CHANGES IN THE HIGH PLAINS AQUIFER, 1980 TO 1995: USGS FACT SHEET FS-068-97, 1997. 
WATER-LEVEL CHANGES IN THE HIGH PLAINS AQUIFER-PREDEVELOPMENT TO 1995: USGS WATER-RESOURCES INVESTIGATIONS REPORT 97-4081, 1997.

UPDATED WATER-QUALITY EVALUATION OF THE OGALLALA AQUIFER INCLUDING SELECTED METALLIC AND NON-METALLIC INORGANIC CONSTITUENTS: TEXAS WATER DEVELOPMENT BOARD HYDROLOGIC ATLAS NO. 10, 1998.

\section{DEAF SMITH COUNTY}

GEOLOGY AND GROUND-WATER RESOURCES OF THE SOUTHERN HIGH PLAINS: USGS OPEN-FILE REPORT (UNNUMBERED), 1935.

GROUND WATER IN THE SOUTHERN HIGH PLAINS: USGS OPENFILE REPORT (UNNUMBERED), 1937.

GROUND WATER IN THE HIGH PLAINS OF TEXAS: TEXAS BOARD OF WATER ENGINEERS MISCELLANEOUS PUBLICATION (UNNUMBERED), 1938.

RECORDS OF WELLS, DRILLERS' LOGS, WATER ANALYSES, AND MAP SHOWING LOCATION OF WELLS IN DEAF SMITH COUNTY, TEXAS: TEXAS BOARD OF WATER ENGINEERS MISCELLANEOUS PUBLICATION 68, 1938.

GROUND WATER IN THE HIGH PLAINS OF TEXAS: TEXAS BOARD OF WATER ENGINEERS MISCELLANEOUS PUBLICATION 119, 1940.

PROGRESS REPORT ON GROUND WATER IN THE HIGH PLAINS OF TEXAS: TEXAS BOARD OF WATER ENGINEERS MISCELLANEOUS PUBLICATION (UNNUMBERED), 1942.

PROGRESS REPORT ON GROUND WATER IN THE HIGH PLAINS OF TEXAS: TEXAS BOARD OF WATER ENGINEERS MISCELLANEOUS PUBLICATION 120, 1943.

PROGRESS REPORT ON GROUND WATER IN THE HIGH PLAINS OF TEXAS: TEXAS BOARD OF WATER ENGINEERS MISCELLANEOUS PUBLICATION 121, 1944.

PROGRESS REPORT ON GROUND WATER IN THE HIGH PLAINS OF TEXAS, PROGRESS REPORT NO. 5: TEXAS BOARD OF WATER ENGINEERS MISCELLANEOUS PUBLICATION 122, 1945.

RECORDS OF WELLS, DRILLERS' LOGS, WATER ANALYSES, AND MAP SHOWING LOCATIONS OF WELLS IN DEAF SMITH COUNTY, TEXAS: TEXAS BOARD OF WATER ENGINEERS MISCELLANEOUS PUBLICATION 69, 1946.

GROUND WATER IN THE HIGH PLAINS OF TEXAS: USGS WATERSUPPLY PAPER 889-F, 1946.

GROUND WATER IN HIGH PLAINS IN TEXAS, PROGRESS REPORT NO. 6: TEXAS BOARD OF WATER ENGINEERS MISCELLANEOUS PUBLICATION 123, 1947.

GEOLOGY AND GROUND WATER IN THE IRRIGATED REGION OF THE SOUTHERN HIGH PLAINS IN TEXAS, PROGRESS REPORT NO. 7: TEXAS BOARD OF WATER ENGINEERS MISCELLANEOUS PUBLICATION 125, 1949.

COST OF PUMPING WATER FOR IRRIGATION, TEXAS HIGH PLAINS, FIELD INVESTIGATIONS-1947 IRRIGATION SEASON: TEXAS BOARD OF WATER ENGINEERS MISCELLANEOUS PUBLICATION 124, 1951.

PUBLIC WATER SUPPLIES IN WESTERN TEXAS: USGS WATERSUPPLY PAPER 1106, 1951 [1952].
DEVELOPMENT OF WELLS FOR IRRIGATION AND FLUCTUATION OF WATER LEVELS IN THE HIGH PLAINS OF TEXAS TO JANUARY 1951: TEXAS BOARD OF WATER ENGINEERS BULLETIN 5104, 1951.

RECORDS OF WATER-LEVEL MEASUREMENTS IN DEAF SMITH COUNTY, TEXAS, 1914-1953: TEXAS BOARD OF WATER ENGINEERS BULLETIN 5305, 1953.

SUMMARY OF GROUND-WATER DEVELOPMENT IN THE SOUTHERN HIGH PLAINS, TEXAS: TEXAS BOARD OF WATER ENGINEERS BULLETIN 5402, 1954.

GROUND-WATER DEVELOPMENT IN THE SOUTHERN HIGH PLAINS OF TEXAS, 1953: TEXAS BOARD OF WATER ENGINEERS BULLETIN 5410, 1954.

WATER-LEVEL DECLINE MAPS OF 17 COUNTIES IN THE SOUTHERN HIGH PLAINS, TEXAS, JANUARY 1955 TO JANUARY 1956: TEXAS BOARD OF WATER ENGINEERS BULLETIN 5607, 1956.

WATER-LEVEL DECLINE MAPS, 1956 TO 1957, AND WATER LEVELS IN OBSERVATION WELLS IN 20 COUNTIES IN THE SOUTHERN HIGH PLAINS, TEXAS: TEXAS BOARD OF WATER ENGINEERS BULLETIN 5705, 1957.

WATER-LEVEL MEASUREMENTS AND MAPS, SOUTHERN HIGH PLAINS, TEXAS, 1958 AND 1959: TEXAS BOARD OF WATER ENGINEERS BULLETIN 5908, 1959.

WATER LEVELS IN OBSERVATION WELLS, SOUTHERN HIGH PLAINS, TEXAS, 1959 AND 1960, TEXAS BOARD OF WATER ENGINEERS BULLETIN 6011, 1960.

RECONNAISSANCE INVESTIGATION OF THE GROUND-WATER RESOURCES OF THE CANADIAN RIVER BASIN, TEXAS: TEXAS BOARD OF WATER ENGINEERS BULLETIN 6016, 1960.

WATER LEVELS IN OBSERVATION WELLS, SOUTHERN HIGH PLAINS, TEXAS, 1960 AND 1961: TEXAS BOARD OF WATER ENGINEERS BULLETIN 6101, 1961.

A SUMMARY OF THE OCCURRENCE AND DEVELOPMENT OF GROUND WATER IN THE SOUTHERN HIGH PLAINS OF TEXAS: TEXAS BOARD OF WATER ENGINEERS BULLETIN 6107, 1961.

WATER-LEVEL MEASUREMENTS THROUGH 1962 IN SELECTED OBSERVATION WELLS, SOUTHERN HIGH PLAINS, TEXAS: TEXAS WATER COMMISSION BULLETIN 6207, 1962.

RECONNAISSANCE INVESTIGATION OF THE GROUND-WATER RESOURCES OF THE RED RIVER, SULPHUR RIVER, AND CYPRESS CREEK BASINS, TEXAS: TEXAS WATER COMMISSION BULLETIN 6306, 1963.

A SUMMARY OF THE OCCURRENCE AND DEVELOPMENT OF GROUND WATER IN THE SOUTHERN HIGH PLAINS OF TEXAS: USGS WATER-SUPPLY PAPER 1693, 1964.

PUBLIC WATER SUPPLIES OF THE 100 LARGEST CITIES IN THE UNITED STATES: USGS WATER-SUPPLY PAPER 1812, 1964

WATER-LEVEL DATA FROM OBSERVATION WELLS IN THE SOUTHERN HIGH PLAINS OF TEXAS: TEXAS WATER DEVELOPMENT BOARD REPORT 21, 1966.

COMPILATION OR RESULTS OF AQUIFER TESTS IN TEXAS: TEXAS WATER DEVELOPMENT BOARD REPORT 98, 1969.

GROUND WATER IN THE OGALLALA FORMATION IN THE SOUTHERN HIGH PLAINS OF TEXAS AND NEW MEXICO: USGS HYDROLOGIC INVESTIGATIONS ATLAS HA-330, 1969. 
WATER-LEVEL DATA FROM OBSERVATION WELLS IN THE SOUTHERN HIGH PLAINS OF TEXAS, 1965-70: TEXAS WATER DEVELOPMENT BOARD REPORT 121, 1970.

ARTIFICIAL GROUND-WATER RECHARGE AS A WATER-MANAGEMENT TECHNIQUE ON THE SOUTHERN HIGH PLAINS OF TEXAS AND NEW MEXICO: USGS OPEN-FILE REPORT 76-730, 1976.

ANALYTICAL STUDY OF THE OGALLALA AQUIFER IN DEAF SMITH COUNTY, TEXAS-PROJECTIONS OF SATURATED THICKNESS, VOLUME OF WATER IN STORAGE, PUMPAGE RATES, PUMPING LIFTS, AND WELL YIELDS: TEXAS WATER DEVELOPMENT BOARD REPORT 213, 1977.

WATER-LEVEL DATA FROM OBSERVATION WELLS IN THE SOUTHERN HIGH PLAINS OF TEXAS, 1971-77: TEXAS DEPARTMENT OF WATER RESOURCES REPORT 228, 1979.

PRELIMINARY DATA DESCRIBING THE DISTRIBUTION OF FLUORIDE AND SILICA IN THE OGALLALA AQUIFER ON THE HIGH PLAINS OF TEXAS: USGS OPEN-FILE REPORT 80-349, 1980.

EVALUATING THE GROUND-WATER RESOURCES OF THE HIGH PLAINS OF TEXAS: RESULTS OF TEST HOLE DRILLING: TEXAS DEPARTMENT OF WATER RESOURCES LIMITED PRINTING REPORT LP-129, 1980.

EVALUATING THE GROUND-WATER RESOURCES OF THE HIGH PLAINS OF TEXAS: RESULTS OF SURFACE ELECTRICAL RESISTIVITY SURVEYS: TEXAS DEPARTMENT OF WATER RESOURCES LIMITED PRINTING REPORT LP-130, 1980.

EVALUATING THE GROUND-WATER RESOURCES OF THE HIGH PLAINS OF TEXAS: NEUTRON-PROBE MEASUREMENTS OF DEEP SOIL MOISTURE AS AN INDICATION OF AQUIFER RECHARGE RATES: TEXAS DEPARTMENT OF WATER RESOURCES LIMITED PRINTING REPORT LP-142, 1981.

SPRINGS OF TEXAS, VOLUME 1: (BY GUNNAR BRUNE), BRANCHSMITH, INC., FORT WORTH, TEXAS, 1981.

BEDROCK GEOLOGY, ALTITUDE OF BASE, AND 1980 SATURATED THICKNESS OF THE HIGH PLAINS AQUIFER IN PARTS OF COLORADO, KANSAS, NEBRASKA, NEW MEXICO, OKLAHOMA, SOUTH DAKOTA, TEXAS, AND WYOMING: USGS HYDROLOGIC INVESTIGATIONS ATLAS HA-648, 1981.

WATER LEVEL AND SATURATED THICKNESS CHANGES, PREDEVELOPMENT TO 1980, IN THE HIGH PLAINS AQUIFER IN PARTS OF COLORADO, KANSAS, NEBRASKA, NEW MEXICO, OKLAHOMA, SOUTH DAKOTA, TEXAS, AND WYOMING: USGS HYDROLOGIC INVESTIGATIONS ATLAS HA-652, 1981.

DISSOLVED SOLIDS AND SODIUM IN WATER FROM THE HIGH PLAINS AQUIFER IN PARTS OF COLORADO, KANSAS, NEBRASKA, NEW MEXICO, OKLAHOMA, SOUTH DAKOTA, TEXAS, AND WYOMING: USGS HYDROLOGIC INVESTIGATIONS ATLAS HA-658, 1982.

INVESTIGATION OF SECONDARY RECOVERY OF GROUND WATER FROM THE OGALLALA FORMATION, HIGH PLAINS OF TEXASSUMMARY OF STUDY: HIGH PLAINS UNDERGROUND WATER CONSERVATION DISTRICT NO. 1, LUBBOCK, TEXAS, 1982.

EVALUATING THE GROUND-WATER RESOURCES OF THE HIGH PLAINS OF TEXAS, VOLUME 1: TEXAS DEPARTMENT OF WATER RESOURCES REPORT 288, V. 1, 1984.

EVALUATING THE GROUND-WATER RESOURCES OF THE HIGH PLAINS OF TEXAS, VOLUME 3, RECORDS OF WELLS, AND MAPS SHOWING WELL LOCATIONS, BASE OF AQUIFER, WATER LEV-
ELS, AND SATURATED THICKNESS (BAILEY, BRISCOE, CASTRO, CROSBY, DEAF SMITH, DICKENS, FLOYD, HALE, LAMB, MOTLEY, OLDHAM, PARMER, RANDALL, AND SWISHER COUNTIES): TEXAS DEPARTMENT OF WATER RESOURCES REPORT 288, V. 3 , 1984.

GROUND-WATER CONDITIONS OF THE TRIASSIC AQUIFER IN DEAF SMITH AND SWISHER COUNTIES: TEXAS DEPARTMENT OF WATER RESOURCES LIMITED PRINTING REPORT LP-196, 1984.

GEOHYDROLOGY OF THE HIGH PLAINS AQUIFER IN PARTS OF COLORADO, KANSAS, NEBRASKA, NEW MEXICO, OKLAHOMA, SOUTH DAKOTA, TEXAS, AND WYOMING: USGS PROFESSIONAL PAPER 1400-B, 1984.

TEXAS GROUND-WATER RESOURCES, in NATIONAL WATER SUMMARY 1984: USGS WATER-SUPPLY PAPER 2275, 1985.

DIGITAL SIMULATION OF GROUND-WATER FLOW IN THE HIGH PLAINS AQUIFER IN PARTS OF COLORADO, KANSAS, NEBRASKA, NEW MEXICO, OKLAHOMA, SOUTH DAKOTA, TEXAS, AND WYOMING: USGS PROFESSIONAL PAPER 1400-D, 1986.

HYDROLOGIC ATLAS FOR DEAF SMITH COUNTY, TEXAS: HIGH PLAINS UNDERGROUND WATER CONSERVATION DISTRICT NO. $1,1987$.

SUMMARY OF THE HIGH PLAINS REGIONAL AQUIFER-SYSTEM ANALYSIS IN PARTS OF COLORADO, KANSAS, NEBRASKA, NEW MEXICO, OKLAHOMA, SOUTH DAKOTA, TEXAS, AND WYOMING: USGS PROFESSIONAL PAPER 1400-A, 1988.

WATER-LEVEL CHANGES IN THE HIGH PLAINS AQUIFER OF TEXAS, 1980-1990: TEXAS WATER DEVELOPMENT BOARD HYDROLOGIC ATLAS NO. 1, 1991.

PUBLIC SUPPLY GROUND-WATER USE IN THE NORTHERN HIGH PLAINS OF TEXAS: TEXAS WATER DEVELOPMENT BOARD REPORT 336, 1992.

WATER-RESOURCES DATA, TEXAS, WATER YEAR 1991, VOLUME 4, GROUND-WATER DATA: USGS WATER-DATA REPORT TX-91-4, 1992.

THE HIGH PLAINS AQUIFER SYSTEM OF TEXAS, 1980 TO 1990. OVERVIEW AND PROJECTIONS: TEXAS WATER DEVELOPMENT BOARD REPORT 341, 1993.

WATER-QUALITY EVALUATION OF THE OGALLALA AQUIFER, TEXAS: TEXAS WATER DEVELOPMENT BOARD REPORT 342, 1993.

WATER-LEVEL CHANGES IN THE HIGH PLAINS AQUIFER-PREDEVELOPMENT TO 1992: USGS WATER-RESOURCES INVESTIGATIONS REPORT 94-4027, 1994.

WATER-RESOURCES DATA, TEXAS, WATER YEAR 1993, VOLUME 4 , GROUND-WATER DATA: USGS WATER-DATA REPORT TX-93-4, 1994.

WATER-LEVEL CHANGES IN THE HIGH PLAINS AQUIFER, 1980 TO 1994: USGS FACT SHEET FS-215-95, 1995.

AQUIFERS OF TEXAS: TEXAS WATER DEVELOPMENT BOARD REPORT 345, 1995.

WATER-RESOURCES DATA, TEXAS, WATER YEAR 1994, VOLUME 4 , GROUND-WATER DATA: USGS WATER-DATA REPORT TX-94-4, 1995. 
HYDROLOGIC ATLAS FOR DEAF SMITH COUNTY, TEXAS: HIGH PLAINS UNDERGROUND WATER CONSERVATION DISTRICT NO. 1, LUBBOCK, TEXAS, 1996.

WATER-RESOURCES DATA, TEXAS, WATER YEAR 1995, VOLUME 4, GROUND-WATER DATA: USGS WATER-DATA REPORT TX-95-4, 1996.

WATER-LEVEL CHANGES IN THE HIGH PLAINS AQUIFER, 1980 TO 1995: USGS FACT SHEET FS-068-97, 1997.

WATER-LEVEL CHANGES IN THE HIGH PLAINS AQUIFER-PREDEVELOPMENT TO 1995: USGS WATER-RESOURCES INVESTIGATIONS REPORT 97-4081, 1997.

WATER-RESOURCES DATA, TEXAS, WATER YEAR 1996, VOLUME 4, GROUND-WATER DATA: USGS WATER-DATA REPORT TX-96-4, 1997.

UPDATED WATER-QUALITY EVALUATION OF THE OGALLALA AQUIFER INCLUDING SELECTED METALLIC AND NON-METALLIC INORGANIC CONSTITUENTS: TEXAS WATER DEVELOPMENT BOARD HYDROLOGIC ATLAS NO. 10, 1998.

WATER-RESOURCES DATA, TEXAS, WATER YEAR 1997, VOLUME 4 GROUND-WATER DATA: USGS WATER-DATA REPORT TX-97-4, 1998.

WATER-RESOURCES DATA, TEXAS, WATER YEAR 1998, VOLUME 4, GROUND-WATER DATA: USGS WATER-DATA REPORT TX-98-4, 1999.

WATER-RESOURCES DATA, TEXAS, WATER YEAR 1999, VOLUME 6, GROUND-WATER DATA: USGS WATER-DATA REPORT TX-99-6, 2000.

WATER-RESOURCES DATA, TEXAS, WATER YEAR 2000, VOLUME 6, GROUND-WATER DATA: USGS WATER-DATA REPORT TX-00-6, 2001.

\section{DELTA COUNTY}

GEOLOGY AND UNDERGROUND WATERS OF NORTHEASTERN TEXAS: USGS WATER-SUPPLY PAPER 276, 1911.

PUBLIC WATER SUPPLIES IN EASTERN TEXAS: USGS WATERSUPPLY PAPER 1047, 1948.

RECONNAISSANCE INVESTIGATION OF THE GROUND-WATER RESOURCES OF THE RED RIVER, SULPHUR RIVER, AND CYPRESS CREEK BASINS, TEXAS: TEXAS WATER COMMISSION BULLETIN 6306, 1963.

WATER-LEVEL AND WATER-QUALITY DATA FROM OBSERVATION WELLS IN NORTHEAST TEXAS: TEXAS WATER DEVELOPMENT BOARD REPORT 198, 1976

SPRINGS OF TEXAS, VOLUME 1: (BY GUNNAR BRUNE), BRANCHSMITH, INC., FORT WORTH, TEXAS, 1981.

OCCURRENCE, AVAILABILITY, AND CHEMICAL QUALITY OF GROUND WATER IN THE CRETACEOUS AQUIFERS OF NORTHCENTRAL TEXAS: TEXAS DEPARTMENT OF WATER RESOURCES REPORT 269, V. 1, 1982

OCCURRENCE, AVAILABILITY, AND CHEMICAL QUALITY OF GROUND WATER IN THE CRETACEOUS AQUIFERS OF NORTHCENTRAL TEXAS: TEXAS DEPARTMENT OF WATER RESOURCES REPORT 269, V. 2, 1982.
TEXAS GROUND-WATER RESOURCES, in NATIONAL WATER SUMMARY 1984: USGS WATER-SUPPLY PAPER 2275, 1985.

GROUND-WATER RESOURCES OF THE NACATOCH AQUIFER: TEXAS DEPARTMENT OF WATER RESOURCES REPORT 305, 1988

EVALUATION OF WATER RESOURCES IN PART OF NORTH-CENTRAL TEXAS: TEXAS WATER DEVELOPMENT BOARD REPORT $318,1990$.

SIMULATION OF GROUND-WATER FLOW IN THE ANTLERS AQUIFER IN SOUTHEASTERN OKLAHOMA AND NORTHEASTERN TEXAS: USGS WATER-RESOURCES INVESTIGATIONS REPORT 88-4208, 1992.

AQUIFERS OF TEXAS: TEXAS WATER DEVELOPMENT BOARD REPORT 345, 1995.

UPDATED EVALUATION OF WATER RESOURCES IN PART OF NORTH-CENTRAL TEXAS, 1990-1999: TEXAS WATER DEVELOPMENT BOARD REPORT 349, 1999.

\section{DENTON COUNTY}

GEOGRAPHY AND GEOLOGY OF THE BLACK AND GRAND PRAIRIES, TEXAS, WITH DETAILED DESCRIPTIONS OF THE CRETACEOUS FORMATIONS AND SPECIAL REFERENCE TO ARTESIAN WATERS: USGS 21ST ANNUAL REPORT, PART 7, 1901.

MEMORANDUM ON THE WATER SUPPLY FOR THE CITY OF DENTON, TEXAS: USGS OPEN-FILE REPORT (UNNUMBERED), 1944.

PUBLIC WATER SUPPLIES IN CENTRAL AND NORTH-CENTRAL TEXAS: USGS WATER-SUPPLY PAPER 1069, 1949.

RECONNAISSANCE INVESTIGATION OF THE GROUND-WATER RESOURCES OF THE TRINITY RIVER BASIN, TEXAS: TEXAS WATER COMMISSION BULLETIN 6309, 1963.

COMPILATION OF RESULTS OF AQUIFER TESTS IN TEXAS: TEXAS WATER DEVELOPMENT BOARD REPORT 98, 1969.

WATER-LEVEL AND WATER-QUALITY DATA FROM OBSERVATION WELLS IN NORTHEAST TEXAS: TEXAS WATER DEVELOPMENT BOARD REPORT 198, 1976.

SPRINGS OF TEXAS, VOLUME 1: (BY GUNNAR BRUNE), BRANCHSMITH, INC., FORT WORTH, TEXAS, 1981.

OCCURRENCE, AVAILABILITY, AND CHEMICAL QUALITY OF GROUND WATER IN THE CRETACEOUS AQUIFERS OF NORTHCENTRAL TEXAS: TEXAS DEPARTMENT OF WATER RESOURCES REPORT 269, V. 1, 1982.

OCCURRENCE, AVAILABILITY, AND CHEMICAL QUALITY OF GROUND WATER IN THE CRETACEOUS AQUIFERS OF NORTHCENTRAL TEXAS: TEXAS DEPARTMENT OF WATER RESOURCES REPORT 269, V. 2, 1982

WATER USE, PROJECTED WATER REQUIREMENTS, AND RELATED DATA AND INFORMATION FOR THE METROPOLITAN STATISTICAL AREAS IN TEXAS: TEXAS DEPARTMENT OF WATER RESOURCES LIMITED PRINTING REPORT LP-201, 1985.

TEXAS GROUND-WATER RESOURCES, in NATIONAL WATER SUMMARY 1984: USGS WATER-SUPPLY PAPER 2275, 1985. 
EVALUATION OF WATER RESOURCES IN PART OF NORTH-CENTRAL TEXAS: TEXAS WATER DEVELOPMENT BOARD REPORT 318,1990 .

NATIONAL WATER-QUALITY ASSESSMENT PROGRAM-THE TRINITY RIVER BASIN: USGS OPEN-FILE REPORT 91-158, 1991.

SIMULATION OF GROUND-WATER FLOW IN THE ANTLERS AQUIFER IN SOUTHEASTERN OKLAHOMA AND NORTHEASTERN TEXAS: USGS WATER-RESOURCES INVESTIGATIONS REPORT 88-4208, 1992.

AQUIFERS OF TEXAS: TEXAS WATER DEVELOPMENT BOARD REPORT 345, 1995.

NATIONAL WATER-QUALITY ASSESSMENT PROGRAM-PESTICIDES IN THE TRINITY RIVER BASIN STUDY UNIT, TEXAS, 1968-91: USGS FACT SHEET FS-088-95, 1995.

WATER-QUALITY ASSESSMENT OF THE TRINITY RIVER BASIN, TEXAS-DATA COLLECTION, 1992-95: USGS FACT SHEET FS-095-95, 1995.

WATER-QUALITY ASSESSMENT OF THE TRINITY RIVER BASIN, TEXAS-PESTICIDES IN A SUBURBAN WATERSHED, ARLINGTON, 1993-94: USGS FACT SHEET FS-159-95, 1995.

WATER QUALITY IN THE WOODBINE AQUIFER, NORTH-CENTRAL TEXAS: TEXAS WATER DEVELOPMENT BOARD HYDROLOGIC ATLAS NO. 4, 1996.

UPDATED EVALUATION OF WATER RESOURCES IN PART OF NORTH-CENTRAL TEXAS, 1990-1999: TEXAS WATER DEVELOPMENT BOARD REPORT 349, 1999.

\section{DEWITT COUNTY}

ARTESIAN WELLS OF THE COASTAL PRAIRIE REGION AND TERTIARY BELT OF TEXAS: GEOLOGICAL SURVEY OF TEXAS, CHAPTER 2, 1893

GEOGRAPHY AND GEOLOGY OF THE BLACK AND GRAND PRAIRIES, TEXAS, WITH DETAILED DESCRIPTIONS OF THE CRETACEOUS FORMATIONS AND SPECIAL REFERENCE TO ARTESIAN WATERS: USGS 21ST ANNUAL REPORT, PART 7, 1901

UNDERGROUND WATERS OF THE COASTAL PLAIN OF TEXAS: USGS WATER-SUPPLY PAPER 190, 1907.

RECORDS OF WELLS, DRILLERS' LOGS, AND WATER ANALYSES, AND MAP SHOWING LOCATION OF WELLS IN DEWITT COUNTY, TEXAS: TEXAS BOARD OF WATER ENGINEERS MISCELLANEOUS PUBLICATION 72, 1938

GROUND WATER IN THE VICINITY OF CUERO, TEXAS: USGS OPENFILE REPORT (UNNUMBERED), 1942.

MEMORANDUM REGARDING NEW WELL AT CUERO: USGS OPENFILE REPORT (UNNUMBERED), 1948

PUBLIC WATER SUPPLIES IN SOUTHERN TEXAS: USGS WATERSUPPLY PAPER 1070, 1950.

AVAILABILITY OF GROUND WATER IN THE GULF COAST REGION OF TEXAS: USGS OPEN-FILE REPORT (UNNUMBERED), 1956.

COMPILATION OF RESULTS OF AQUIFER TESTS IN TEXAS: TEXAS WATER DEVELOPMENT BOARD REPORT 98, 1969.
GEOHYDROLOGIC SIGNIFICANCE OF LITHOFACIES OF THE COCKFIELD FORMATION OF LOUISIANA AND MISSISSIPPI AND OF THE YEGUA FORMATION OF TEXAS: USGS PROFESSIONAL PAPER 569-B, 1970.

STRATIGRAPHIC AND HYDROGEOLOGIC FRAMEWORK OF PART OF THE COASTAL PLAIN OF TEXAS: USGS OPEN-FILE REPORT 77-712, 1978. ALSO PUBLISHED AS TEXAS DEPARTMENT OF WATER RESOURCES REPORT 236, 1979.

RECONNAISSANCE INVESTIGATION OF THE GROUND-WATER RESOURCES OF THE GULF COAST REGION, TEXAS: TEXAS WATER COMMISSION BULLETIN 6305, 1963.

RECONNAISSANCE INVESTIGATION OF THE GROUND-WATER RESOURCES OF THE GUADALUPE, SAN ANTONIO, AND NUECES RIVER BASINS, TEXAS: TEXAS WATER COMMISSION BULLETIN 6409, 1964.

GROUND-WATER RESOURCES OF DEWITT COUNTY, TEXAS: TEXAS WATER DEVELOPMENT BOARD BULLETIN 6518, 1965.

HYDROLOGIC SIGNIFICANCE OF THE LITHOFACIES OF THE SPARTA SAND IN ARKANSAS, LOUISIANA, MISSISSIPPI, AND TEXAS: USGS PROFESSIONAL PAPER 569-A, 1968.

HYDROLOGIC SIGNIFICANCE OF LITHOFACIES OF THE CANE RIVER FORMATION OR EQUIVALENTS OF ARKANSAS, LOUISIANA, MISSISSIPPI, AND TEXAS: USGS PROFESSIONAL PAPER 569-C, 1972.

GEOHYDROLOGIC SIGNIFICANCE OF LITHOFACIES OF THE CARRIZO SAND OF ARKANSAS, LOUISIANA, AND TEXAS AND THE MERIDIAN SAND OF MISSISSIPPI: USGS PROFESSIONAL PAPER 569-D, 1975.

SPRINGS OF TEXAS, VOLUME 1: (BY GUNNAR BRUNE), BRANCHSMITH, INC., FORT WORTH, TEXAS, 1981.

REGIONAL HYDRODYNAMICS AND HYDROCHEMISTRY OF THE URANIUM-BEARING OAKVILLE AQUIFER (MIOCENE) OF SOUTH TEXAS: UNIVERSITY OF TEXAS, BUREAU OF ECONOMIC GEOLOGY REPORT OF INVESTIGATIONS NO. 124, 1982.

TEXAS GROUND-WATER RESOURCES, in NATIONAL WATER SUMMARY 1984: USGS WATER-SUPPLY PAPER 2275, 1985.

DIGITAL MODELS FOR SIMULATION OF GROUND-WATER HYDROLOGY OF THE CHICOT AND EVANGELINE AQUIFERS ALONG THE GULF COAST OF TEXAS: TEXAS DEPARTMENT OF WATER RESOURCES REPORT 289, 1985.

GEOHYDROLOGIC FRAMEWORK OF THE GULF COASTAL PLAIN: USGS HYDROLOGIC INVESTIGATIONS ATLAS HA-695, 1988.

DEPOSITIONAL AND GROUND-WATER FLOW SYSTEMS OF THE CARRIZO-UPPER WILCOX, SOUTH TEXAS: UNIVERSITY OF TEXAS, BUREAU OF ECONOMIC GEOLOGY REPORT OF INVESTIGATIONS NO. 175, 1988.

HYDROGEOLOGY AND PREDEVELOPMENT FLOW IN THE TEXAS GULF COAST AQUIFER SYSTEMS: USGS WATER-RESOURCES INVESTIGATIONS REPORT 87-4248, 1988.

GROUND-WATER FLOW IN THE GULF COAST AQUIFER SYSTEMS, SOUTH CENTRAL UNITED STATES-A PRELIMINARY ANALYSIS: USGS WATER-RESOURCES INVESTIGATIONS REPORT 89-4071, 1990.

HYDROLOGY OF THE TEXAS GULF COAST AQUIFER SYSTEMS: USGS OPEN-FILE REPORT 91-64, 1991. 
PROPERTIES AND CHEMICAL CONSTITUENTS IN GROUND WATER FROM THE UPPER CLAIBORNE AQUIFER, GULF COAST REGIONAL AQUIFER SYSTEMS, SOUTH-CENTRAL UNITED STATES: USGS WATER-RESOURCES INVESTIGATIONS REPORT 91-4150, 1993.

PROPERTIES AND CHEMICAL CONSTITUENTS IN GROUND WATER FROM PERMEABLE ZONE C (LOWER PLIOCENE-UPPER MIOCENE DEPOSITS), COASTAL LOWLANDS AQUIFER SYSTEM, SOUTHCENTRAL UNITED STATES: USGS WATER-RESOURCES INVESTIGATIONS REPORT 91-4151, 1993.

PROPERTIES AND CHEMICAL CONSTITUENTS IN GROUND WATER FROM PERMEABLE ZONE B (LOWER PLEISTOCENE-UPPER PLIOCENE DEPOSITS), COASTAL LOWLANDS AQUIFER SYSTEM, SOUTH-CENTRAL UNITED STATES: USGS WATER-RESOURCES INVESTIGATIONS REPORT 91-4152, 1993.

PROPERTIES AND CHEMICAL CONSTITUENTS IN GROUND WATER FROM PERMEABLE ZONE E (LOWER MIOCENE-UPPER OLIGOCENE DEPOSITS), COASTAL LOWLANDS AQUIFER SYSTEM, SOUTH-CENTRAL UNITED STATES: USGS WATER-RESOURCES INVESTIGATIONS REPORT 92-4103, 1993.

PROPERTIES AND CHEMICAL CONSTITUENTS IN GROUND WATER FROM THE MIDDLE CLAIBORNE AQUIFER, GULF COAST REGIONAL AQUIFER SYSTEMS, SOUTH-CENTRAL UNITED STATES: USGS WATER-RESOURCES INVESTIGATIONS REPORT 92-4104, 1993.

PROPERTIES AND CHEMICAL CONSTITUENTS IN GROUND WATER FROM PERMEABLE ZONE D (MIDDLE MIOCENE DEPOSITS), COASTAL LOWLANDS AQUIFER SYSTEM, SOUTH-CENTRAL UNITED STATES: USGS WATER-RESOURCES INVESTIGATIONS REPORT 92-4105, 1993.

PROPERTIES AND CHEMICAL CONSTITUENTS IN GROUND WATER FROM THE MIDDLE WILCOX AQUIFER, GULF COAST REGIONAL AQUIFER SYSTEMS, SOUTH-CENTRAL UNITED STATES: USGS WATER-RESOURCES INVESTIGATIONS REPORT 93-4070, 1993.

AQUIFERS OF TEXAS: TEXAS WATER DEVELOPMENT BOARD REPORT 345, 1995.

HYDROGEOLOGIC FRAMEWORK AND GEOCHEMISTRY OF THE EDWARDS AQUIFER SALINE-WATER ZONE, SOUTH-CENTRAL TEXAS: USGS WATER-RESOURCES INVESTIGATIONS REPORT 97-4133, 1997.

WATER QUALITY IN SOUTH-CENTRAL TEXAS-TEXAS, 1996-98: USGS CIRCULAR 1212, 2000.

\section{DICKENS COUNTY}

GEOLOGY AND GROUND-WATER RESOURCES OF THE SOUTHERN HIGH PLAINS: USGS OPEN-FILE REPORT (UNNUMBERED), 1935.

GROUND WATER IN THE SOUTHERN HIGH PLAINS: USGS OPENFILE REPORT (UNNUMBERED, 1937.

GROUND WATER IN THE HIGH PLAINS OF TEXAS: TEXAS BOARD OF WATER ENGINEERS MISCELLANEOUS PUBLICATION (UNNUMBERED), 1938.

GROUND WATER IN THE HIGH PLAINS OF TEXAS: TEXAS BOARD OF WATER ENGINEERS MISCELLANEOUS PUBLICATION 119, 1940.
PROGRESS REPORT ON GROUND WATER IN THE HIGH PLAINS OF TEXAS: TEXAS BOARD OF WATER ENGINEERS MISCELLANEOUS PUBLICATION (UNNUMBERED), 1942.

PROGRESS REPORT ON GROUND WATER IN THE HIGH PLAINS OF TEXAS: TEXAS BOARD OF WATER ENGINEERS MISCELLANEOUS PUBLICATION 120, 1943.

PROGRESS REPORT ON GROUND WATER IN THE HIGH PLAINS OF TEXAS: TEXAS BOARD OF WATER ENGINEERS MISCELLANEOUS PUBLICATION 121, 1944.

PROGRESS REPORT ON GROUND WATER IN THE HIGH PLAINS OF TEXAS, PROGRESS REPORT NO. 5: TEXAS BOARD OF WATER ENGINEERS MISCELLANEOUS PUBLICATION 122, 1945.

GROUND WATER IN THE HIGH PLAINS OF TEXAS: USGS WATERSUPPLY PAPER 889-F, 1946.

GROUND WATER IN HIGH PLAINS OF TEXAS, PROGRESS REPORT NO. 6: TEXAS BOARD OF WATER ENGINEERS MISCELLANEOUS PUBLICATION 123, 1947.

GEOLOGY AND GROUND WATER IN THE IRRIGATED REGION OF THE SOUTHERN HIGH PLAINS IN TEXAS, PROGRESS REPORT NO. 7: TEXAS BOARD OF WATER ENGINEERS MISCELLANEOUS PUBLICATION 125, 1949.

COST OF PUMPING WATER FOR IRRIGATION, TEXAS HIGH PLAINS, FIELD INVESTIGATIONS-1947 IRRIGATION SEASON: TEXAS BOARD OF WATER ENGINEERS MISCELLANEOUS PUBLICATION 124, 1951.

DEVELOPMENT OF WELLS FOR IRRIGATION AND FLUCTUATION OF WATER LEVELS IN THE HIGH PLAINS OF TEXAS TO JANUARY 1951: TEXAS BOARD OF WATER ENGINEERS BULLETIN 5104, 1951.

PUBLIC WATER SUPPLIES IN WESTERN TEXAS: USGS WATERSUPPLY PAPER 1106, 1951 [1952].

SUMMARY OF GROUND-WATER DEVELOPMENT IN THE SOUTHERN HIGH PLAINS, TEXAS: TEXAS BOARD OF WATER ENGINEERS BULLETIN 5402, 1

GROUND-WATER DEVELOPMENT IN THE SOUTHERN HIGH PLAINS OF TEXAS, 1953: TEXAS BOARD OF WATER ENGINEERS BULLETIN 5410, 1954.

WATER-LEVEL DECLINE MAPS OF 17 COUNTIES IN THE SOUTHERN HIGH PLAINS, TEXAS, JANUARY 1955 TO JANUARY 1956: TEXAS BOARD OF WATER ENGINEERS BULLETIN 5607, 1956.

WATER-LEVEL DECLINE MAPS, 1956 TO 1957, AND WATER LEVELS IN OBSERVATION WELLS IN 20 COUNTIES IN THE SOUTHERN HIGH PLAINS, TEXAS: TEXAS BOARD OF WATER ENGINEERS BULLETIN 5705, 1957.

GROUND-WATER GEOLOGY IN THE VICINITY OF DOVE AND CROTON CREEKS, STONEWALL, KENT, DICKENS, AND KING COUNTIES, TEXAS: TEXAS BOARD OF WATER ENGINEERS BULLETIN 5801, 1958.

WATER-LEVEL MEASUREMENTS AND MAPS, SOUTHERN HIGH PLAINS, TEXAS, 1958 AND 1959: TEXAS BOARD OF WATER ENGINEERS BULLETIN 5908, 1959.

WATER LEVELS IN OBSERVATION WELLS, SOUTHERN HIGH PLAINS, TEXAS, 1959 AND 1960: TEXAS BOARD OF WATER ENGINEERS BULLETIN 6011, 1960. 
WATER LEVELS IN OBSERVATION WELLS, SOUTHERN HIGH PLAINS, TEXAS, 1960 AND 1961: TEXAS BOARD OF WATER ENGINEERS BULLETIN 6101, 1961.

A SUMMARY OF THE OCCURRENCE AND DEVELOPMENT OF GROUND WATER IN THE SOUTHERN HIGH PLAINS OF TEXAS: TEXAS BOARD OF WATER ENGINEERS BULLETIN 6107, 1961.

WATER-LEVEL MEASUREMENTS THROUGH 1962 IN SELECTED OBSERVATION WELLS, SOUTHERN HIGH PLAINS, TEXAS: TEXAS WATER COMMISSION BULLETIN 6207, 1962.

RECONNAISSANCE INVESTIGATION OF THE GROUND-WATER RESOURCES OF THE RED RIVER, SULPHUR RIVER, AND CYPRESS CREEK BASINS, TEXAS: TEXAS WATER COMMISSION BULLETIN 6306, 1963.

RECONNAISSANCE INVESTIGATION OF THE GROUND-WATER RESOURCES OF THE BRAZOS RIVER BASIN, TEXAS: TEXAS WATER COMMISSION BULLETIN 6310, 1963.

A SUMMARY OF THE OCCURRENCE AND DEVELOPMENT OF GROUND WATER IN THE SOUTHERN HIGH PLAINS OF TEXAS, WITH A SECTION ON ARTIFICIAL RECHARGE STUDIES: USGS WATER-SUPPLY PAPER 1693, 1964.

PRELIMINARY REPORT ON THE INVESTIGATION OF SALT SPRINGS AND SEEPS IN A PORTION OF THE PERMIAN BASIN IN TEXAS: USGS OPEN-FILE REPORT 65-153, 1965.

WATER-LEVEL DATA FROM OBSERVATION WELLS IN THE SOUTHERN HIGH PLAINS OF TEXAS: TEXAS WATER DEVELOPMENT BOARD REPORT 21, 1966.

GROUND WATER IN THE OGALLALA FORMATION IN THE SOUTHERN HIGH PLAINS OF TEXAS AND NEW MEXICO: USGS HYDROLOGIC INVESTIGATIONS ATLAS HA-330, 1969.

WATER-LEVEL DATA FROM OBSERVATION WELLS IN THE SOUTHERN HIGH PLAINS OF TEXAS, 1965-70: TEXAS WATER DEVELOPMENT BOARD REPORT 121, 1970.

GROUND WATER IN DICKENS AND KENT COUNTIES, TEXAS: TEXAS WATER DEVELOPMENT BOARD REPORT 158, 1972.

WATER-LEVEL DATA FROM OBSERVATION WELLS IN THE SOUTHERN HIGH PLAINS OF TEXAS, 1971-77: TEXAS DEPARTMENT OF WATER RESOURCES REPORT 228, 1979.

PRELIMINARY DATA DESCRIBING THE DISTRIBUTION OF FLUORIDE AND SILICA IN THE OGALLALA AQUIFER ON THE HIGH PLAINS OF TEXAS: USGS OPEN-FILE REPORT 80-349, 1980

SPRINGS OF TEXAS, VOLUME 1: (BY GUNNAR BRUNE), BRANCHSMITH, INC., FORT WORTH, TEXAS, 1981.

BEDROCK GEOLOGY, ALTITUDE OF BASE, AND 1980 SATURATED THICKNESS OF THE HIGH PLAINS AQUIFER IN PARTS OF COLORADO, KANSAS, NEBRASKA, NEW MEXICO, OKLAHOMA, SOUTH DAKOTA, TEXAS, AND WYOMING: USGS HYDROLOGIC INVESTIGATIONS ATLAS HA-648, 1981.

WATER LEVEL AND SATURATED THICKNESS CHANGES, PREDEVELOPMENT TO 1980, IN THE HIGH PLAINS AQUIFER IN PARTS OF COLORADO, KANSAS, NEBRASKA, NEW MEXICO, OKLAHOMA, SOUTH DAKOTA, TEXAS, AND WYOMING: USGS HYDROLOGIC INVESTIGATIONS ATLAS HA-652, 1981.

DISSOLVED SOLIDS AND SODIUM IN WATER FROM THE HIGH PLAINS AQUIFER IN PARTS OF COLORADO, KANSAS, NEBRASKA, NEW MEXICO, OKLAHOMA, SOUTH DAKOTA,
TEXAS, AND WYOMING: USGS HYDROLOGIC INVESTIGATIONS ATLAS HA-658, 1982.

PROJECTED EFFECTS OF PROPOSED SALINITY-CONTROL PROJECTS ON SHALLOW GROUND WATER-PRELIMINARY RESULTS FOR THE UPPER BRAZOS RIVER BASIN, TEXAS: USGS OPEN-FILE REPORT 82-908, 1982

EVALUATING THE GROUND-WATER RESOURCES OF THE HIGH PLAINS OF TEXAS, VOLUME 1: TEXAS DEPARTMENT OF WATER RESOURCES REPORT 288, V. 1, 1984

EVALUATING THE GROUND-WATER RESOURCES OF THE HIGH PLAINS OF TEXAS, VOLUME 3, RECORDS OF WELLS, AND MAPS SHOWING WELL LOCATIONS, BASE OF AQUIFER, WATER LEVELS, AND SATURATED THICKNESS (BAILEY, BRISCOE, CASTRO, CROSBY, DEAF SMITH, DICKENS, FLOYD, HALE, LAMB, MOTLEY, OLDHAM, PARMER, RANDALL, AND SWISHER COUNTIES): TEXAS DEPARTMENT OF WATER RESOURCES REPORT 288, V. 3, 1984.

GEOHYDROLOGY OF THE HIGH PLAINS AQUIFER IN PARTS OF COLORADO, KANSAS, NEBRASKA, NEW MEXICO, OKLAHOMA, SOUTH DAKOTA, TEXAS, AND WYOMING: USGS PROFESSIONAL PAPER 1400-B, 1984.

TEXAS GROUND-WATER RESOURCES, in NATIONAL WATER SUMMARY 1984: USGS WATER-SUPPLY PAPER 2275, 1985.

DIGITAL SIMULATION OF GROUND-WATER FLOW IN THE HIGH PLAINS AQUIFER IN PARTS OF COLORADO, KANSAS, NEBRASKA, NEW MEXICO, OKLAHOMA, SOUTH DAKOTA, TEXAS, AND WYOMING: USGS PROFESSIONAL PAPER 1400-D, 1986.

SUMMARY OF THE HIGH PLAINS REGIONAL AQUIFER-SYSTEM ANALYSIS IN PARTS OF COLORADO, KANSAS, NEBRASKA, NEW MEXICO, OKLAHOMA, SOUTH DAKOTA, TEXAS, AND WYOMING: USGS PROFESSIONAL PAPER 1400-A, 1988

HYDROGEOLOGY OF LOWER CRETACEOUS STRATA UNDER THE SOUTHERN HIGH PLAINS OF TEXAS AND NEW MEXICO: TEXAS WATER DEVELOPMENT BOARD REPORT 314, 1989.

PUBLIC SUPPLY GROUND-WATER USE IN THE SOUTHERN HIGH PLAINS OF TEXAS: TEXAS WATER DEVELOPMENT BOARD REPORT 328, 1990.

WATER-LEVEL CHANGES IN THE HIGH PLAINS AQUIFER OF TEXAS 1980-1990: TEXAS WATER DEVELOPMENT BOARD HYDROLOGIC ATLAS NO. 1, 1991.

EVALUATION OF WATER RESOURCES IN PARTS OF THE ROLLING PRAIRIES REGION OF NORTH-CENTRAL TEXAS: TEXAS WATER DEVELOPMENT BOARD REPORT 337, 1992.

THE HIGH PLAINS AQUIFER SYSTEM OF TEXAS, 1980-1990. OVERVIEW AND PROJECTIONS: TEXAS WATER DEVELOPMENT BOARD REPORT 341, 1993.

WATER-QUALITY EVALUATION OF THE OGALLALA AQUIFER, TEXAS: TEXAS WATER DEVELOPMENT BOARD REPORT 342 , 1993.

WATER-LEVEL CHANGES IN THE HIGH PLAINS AQUIFER-PREDEVELOPMENT TO 1992: USGS WATER-RESOURCES INVESTIGATIONS REPORT 94-4027, 1994.

WATER-LEVEL CHANGES IN THE HIGH PLAINS AQUIFER, 1980 TO 1994: USGS FACT SHEET FS-215-95, 1995. 
AQUIFERS OF TEXAS: TEXAS WATER DEVELOPMENT BOARD REPORT 345, 1995.

WATER-LEVEL CHANGES IN THE HIGH PLAINS AQUIFER, 1980 TO 1995: USGS FACT SHEET FS-068-97, 1997.

WATER-LEVEL CHANGES IN THE HIGH PLAINS AQUIFER-PREDEVELOPMENT TO 1995: USGS WATER-RESOURCES INVESTIGATIONS REPORT 97-4081, 1997.

UPDATED WATER-QUALITY EVALUATION OF THE OGALLALA AQUIFER INCLUDING SELECTED METALLIC AND NON-METALLIC INORGANIC CONSTITUENTS: TEXAS WATER DEVELOPMENT BOARD HYDROLOGIC ATLAS NO. 10, 1998.

\section{DIMMIT COUNTY}

UNDERGROUND WATERS OF COASTAL PLAIN OF TEXAS: USGS WATER-SUPPLY AND IRRIGATION PAPER 190, 1907.

GROUND WATER IN THE WINTER GARDEN AND ADJACENT DISTRICTS IN SOUTHWESTERN TEXAS: USGS OPEN-FILE REPORT, 1931.

GROUND WATER IN DIMMIT AND ZAVALA COUNTIES, TEXAS: USGS OPEN-FILE REPORT (UNNUMBERED) (PRESS RELEASE), 1934.

RECORDS OF WELLS AND WATER-LEVEL FLUCTUATIONS IN OBSERVATION WELLS IN DIMMIT, ZAVALA, AND EASTERN MAVERICK COUNTIES, TEXAS: USGS OPEN-FILE REPORT (UNNUMBERED), 1934.

WELLS IN WINTER GARDEN DISTRICT IN DIMMIT AND ZAVALA COUNTIES AND EASTERN MAVERICK COUNTY, TEXAS (RECORDS OF WELLS, DRILLERS' LOGS, WATER ANALYSES, AND MAPS SHOWING LOCATION OF WELLS): TEXAS BOARD OF WATER ENGINEERS MISCELLANEOUS PUBLICATION 302, 1940.

WATER SUPPLY IN THE CARRIZO SAND IN DIMMIT COUNTY, TEXAS: USGS OPEN-FILE REPORT (UNNUMBERED), 1948.

PUBLIC WATER SUPPLIES IN SOUTHERN TEXAS: USGS WATERSUPPLY PAPER 1070, 1950.

WINTER GARDEN DISTRICT DIMMIT AND ZAVALA COUNTIES AND EASTERN MAVERICK COUNTY, TEXAS (RECORDS OF WELLS, DRILLERS' LOGS, WATER ANALYSES, AND MAP SHOWING LOCATIONS OF WELLS): TEXAS BOARD OF WATER ENGINEERS BULLETIN 5203, 1952.

RECORDS OF WATER-LEVEL MEASUREMENTS IN DIMMIT, MAVERICK, AND ZAVALA COUNTIES, TEXAS, 1920, 1928 TO SEPTEMBER 1956: TEXAS BOARD OF WATER ENGINEERS BULLETIN 5617, 1956.

DEVELOPMENT OF GROUND WATER FROM THE CARRIZO SAND AND WILCOX GROUP IN DIMMIT, ZAVALA, MAVERICK, FRIO, ATASCOSA, MEDINA, BEXAR, LIVE OAK, McMULLEN, LA SALLE, AND WEBB COUNTIES, TEXAS: USGS OPEN-FILE REPORT 57-77, 1957.

GEOLOGY AND GROUND-WATER RESOURCES OF DIMMIT COUNTY, TEXAS: TEXAS BOARD OF WATER ENGINEERS BULLETIN 6003, 1960.

RECONNAISSANCE INVESTIGATION OF THE GROUND-WATER RESOURCES OF THE GUADALUPE, SAN ANTONIO, AND NUECES
RIVER BASINS, TEXAS: TEXAS WATER COMMISSION BULLETIN 6409, 1964.

RECONNAISSANCE INVESTIGATIONS OF THE GROUND-WATER RESOURCES OF THE RIO GRANDE BASIN, TEXAS: TEXAS WATER COMMISSION BULLETIN 6502, 1965.

WATER-LEVEL DATA FROM OBSERVATION WELLS IN THE NORTHWESTERN GULF COASTAL PLAIN OF TEXAS: TEXAS WATER DEVELOPMENT BOARD REPORT 70, 1968.

HYDROLOGIC SIGNIFICANCE OF THE LITHOFACIES OF THE SPARTA SAND IN ARKANSAS, LOUISIANA, MISSISSIPPI, AND TEXAS: USGS PROFESSIONAL PAPER 569-A, 1968.

COMPILATION OF RESULTS OF AQUIFER TESTS IN TEXAS: TEXAS WATER DEVELOPMENT BOARD REPORT 98, 1969.

RECONNAISSANCE INVESTIGATION OF GROUND WATER IN THE RIO GRANDE DRAINAGE BASIN-WITH SPECIAL EMPHASIS ON SALINE GROUND-WATER RESOURCES: USGS HYDROLOGIC INVESTIGATIONS ATLAS HA-510, 1974.

GEOHYDROLOGIC SIGNIFICANCE OF LITHOFACIES OF THE CARRIZO SAND OF ARKANSAS, LOUISIANA, AND TEXAS AND THE MERIDIAN SAND OF MISSISSIPPI: USGS PROFESSIONAL PAPER 569-D, 1975.

MAJOR AND HISTORICAL SPRINGS OF TEXAS: TEXAS WATER DEVELOPMENT BOARD REPORT 189, 1975.

GROUND-WATER RESOURCES OF THE CARRIZO AQUIFER IN THE WINTER GARDEN AREA OF TEXAS, VOLUME 1: TEXAS WATER DEVELOPMENT BOARD REPORT 210, V. 1, 1976.

GROUND-WATER RESOURCES OF THE CARRIZO AQUIFER IN THE WINTER GARDEN AREA OF TEXAS, VOLUME 2: TEXAS WATER DEVELOPMENT BOARD REPORT 210, V. 2, 1977.

VARIATIONS IN SPECIFIC YIELD IN THE OUTCROP OF THE CARRIZO SAND IN SOUTH TEXAS AS ESTIMATED BY SEISMIC REFRACTION: TEXAS DEPARTMENT OF WATER RESOURCES REPORT 229, 1979.

SPRINGS OF TEXAS, VOLUME 1: (BY GUNNAR BRUNE), BRANCHSMITH, INC., FORT WORTH, TEXAS, 1981.

STRUCTURE, TEMPERATURE, PRESSURE, AND SALINITY OF CENOZOIC AQUIFERS OF SOUTH TEXAS: USGS HYDROLOGIC INVESTIGATIONS ATLAS HA-654, 1983.

TEXAS GROUND-WATER RESOURCES, in NATIONAL WATER SUMMARY 1984: USGS WATER-SUPPLY PAPER 2275, 1985.

APPROXIMATE POTENTIOMETRIC SURFACES FOR THE AQUIFERS OF THE TEXAS COASTAL UPLANDS SYSTEM, 1980: USGS HYDROLOGIC INVESTIGATIONS ATLAS HA-704, 1987.

GEOHYDROLOGIC FRAMEWORK OF THE GULF COASTAL PLAIN: USGS HYDROLOGIC INVESTIGATIONS ATLAS HA-695, 1988.

DEPOSITIONAL AND GROUND-WATER FLOW SYSTEMS OF THE CARRIZO-UPPER WILCOX, SOUTH TEXAS: UNIVERSITY OF TEXAS, BUREAU OF ECONOMIC GEOLOGY REPORT OF INVESTIGATIONS NO. 175, 1988.

HYDROGEOLOGY AND PREDEVELOPMENT FLOW IN THE TEXAS GULF COAST AQUIFER SYSTEMS: USGS WATER-RESOURCES INVESTIGATIONS REPORT 87-4248, 1988.

GROUND-WATER FLOW IN THE GULF COAST AQUIFER SYSTEMS, SOUTH-CENTRAL UNITED STATES—A PRELIMINARY ANALYSIS 
USGS WATER-RESOURCES INVESTIGATIONS REPORT 89-4071, 1990.

HYDROLOGY OF THE TEXAS GULF COAST AQUIFER SYSTEMS: USGS OPEN-FILE REPORT 91-64, 1991.

EVALUATION OF THE GROUND-WATER RESOURCES IN THE WESTERN PORTION OF THE WINTER GARDEN AREA, TEXAS: TEXAS WATER DEVELOPMENT BOARD REPORT 334, 1991.

GROUND-WATER QUALITY MONITORING RESULTS IN THE WINTER GARDEN AREA, 1990: TEXAS WATER DEVELOPMENT BOARD REPORT 335, 1992

PROPERTIES AND CHEMICAL CONSTITUENTS IN GROUND WATER FROM THE LOWER CLAIBORNE-UPPER WILCOX AQUIFER, GULF COAST REGIONAL AQUIFER SYSTEMS, SOUTH-CENTRAL UNITED STATES: USGS WATER-RESOURCES INVESTIGATIONS REPORT 92-4102, 1993.

PROPERTIES AND CHEMICAL CONSTITUENTS IN GROUND-WATER FROM THE MIDDLE CLAIBORNE AQUIFER, GULF COAST REGIONAL AQUIFER SYSTEMS, SOUTH-CENTRAL UNITED STATES: USGS WATER-RESOURCES INVESTIGATIONS REPORT 92-4104, 1993.

PROPERTIES AND CHEMICAL CONSTITUENTS IN GROUND WATER FROM THE MIDDLE WILCOX AQUIFER, GULF COAST REGIONAL AQUIFER SYSTEMS, SOUTH-CENTRAL UNITED STATES: USGS WATER-RESOURCES INVESTIGATIONS REPORT 93-4070, 1993.

AQUIFERS OF TEXAS: TEXAS WATER DEVELOPMENT BOARD REPORT 345, 1995.

STRATIGRAPHIC NOMENCLATURE AND GEOLOGIC SECTIONS OF THE GULF COASTAL PLAIN OF TEXAS: USGS OPEN-FILE REPORT, 1995.

HYDROGEOLOGIC FRAMEWORK AND GEOCHEMISTRY OF THE EDWARDS AQUIFER SALINE-WATER ZONE, SOUTH-CENTRAL TEXAS: USGS WATER-RESOURCES INVESTIGATIONS REPORT 97-4133, 1997.

\section{DONLEY COUNTY}

THE GEOLOGY AND WATER RESOURCES OF THE EASTERN PORTION OF THE PANHANDLE OF TEXAS: USGS WATER-SUPPLY PAPER 154, 1906

RECORDS OF WELLS AND SPRINGS, DRILLERS' LOGS, WATER ANALYSES, AND MAP SHOWING LOCATIONS OF WELLS AND SPRINGS IN DONLEY COUNTY, TEXAS: TEXAS BOARD OF WATER ENGINEERS MISCELLANEOUS PUBLICATION 73, 1940.

GROUND-WATER RESOURCES IN BLOCK C-6, WEST OF CLARENDON, DONLEY COUNTY, TEXAS: USGS OPEN-FILE REPORT (UNNUMBERED), 1942

GROUND-WATER CONDITIONS IN THE MEMPHIS AREA, TEXAS: USGS OPEN-FILE REPORT (UNNUMBERED), 1943.

GROUND WATER IN THE HIGH PLAINS OF TEXAS, PROGRESS REPORT (1944): TEXAS BOARD OF WATER ENGINEERS MISCELLANEOUS PUBLICATION 121, 1944.

GROUND WATER IN THE HIGH PLAINS OF TEXAS, PROGRESS REPORT NO. 5: TEXAS BOARD OF WATER ENGINEERS MISCELLANEOUS PUBLICATION 122, 1945 .
GROUND WATER IN THE HIGH PLAINS OF TEXAS, PROGRESS REPORT NO. 6: TEXAS BOARD OF WATER ENGINEERS MISCELLANEOUS PUBLICATION 123, 1947.

GEOLOGY AND GROUND WATER IN THE IRRIGATED REGION OF THE SOUTHERN HIGH PLAINS IN TEXAS, PROGRESS REPORT NO. 7: TEXAS BOARD OF WATER ENGINEERS MISCELLANEOUS PUBLICATION 125, 1949.

PUBLIC WATER SUPPLIES IN WESTERN TEXAS: USGS WATERSUPPLY PAPER 1106, 1951

COST OF PUMPING WATER FOR IRRIGATION, TEXAS HIGH PLAINS FIELD INVESTIGATIONS-1947 IRRIGATION SEASON: TEXAS BOARD OF WATER ENGINEERS MISCELLANEOUS PUBLICATION 124, 1951.

WATER-LEVEL DECLINE MAPS, 1956 TO 1957, AND WATER LEVELS IN OBSERVATION WELLS IN 20 COUNTIES IN THE SOUTHERN HIGH PLAINS, TEXAS: TEXAS BOARD OF WATER ENGINEERS BULLETIN 5705, 1957.

WATER-LEVEL MEASUREMENTS AND MAPS, SOUTHERN HIGH PLAINS, TEXAS, 1958-1959: TEXAS BOARD OF WATER ENGINEERS BULLETIN 5908, 1959

WATER LEVELS IN OBSERVATION WELLS, SOUTHERN HIGH PLAINS, TEXAS, 1959 AND 1960: TEXAS BOARD OF WATER ENGINEERS BULLETIN 6011, 1960.

WATER LEVELS IN OBSERVATION WELLS, SOUTHERN HIGH PLAINS, TEXAS, 1960 AND 1961: TEXAS BOARD OF WATER ENGINEERS BULLETIN 6101, 1961.

A SUMMARY OF THE OCCURRENCE AND DEVELOPMENT OF GROUND WATER IN THE SOUTHERN HIGH PLAINS OF TEXAS: TEXAS BOARD OF WATER ENGINEERS BULLETIN 6107, 1961.

WATER-LEVEL MEASUREMENTS THROUGH 1962 IN SELECTED OBSERVATION WELLS, SOUTHERN HIGH PLAINS, TEXAS: TEXAS WATER COMMISSION BULLETIN 6207, 1962.

RECONNAISSANCE INVESTIGATION OF THE GROUND-WATER RESOURCES OF THE RED RIVER, SULPHUR RIVER, AND CYPRESS CREEK BASINS, TEXAS: TEXAS WATER COMMISSION BULLETIN 6306, 1963

A SUMMARY OF THE OCCURRENCE AND DEVELOPMENT OF GROUND WATER IN THE SOUTHERN HIGH PLAINS OF TEXAS, WITH A SECTION ON ARTIFICIAL RECHARGE STUDIES: USGS WATER-SUPPLY PAPER 1693, 1964.

WATER-LEVEL DATA FROM OBSERVATION WELLS IN THE SOUTHERN HIGH PLAINS OF TEXAS: TEXAS WATER DEVELOPMENT BOARD REPORT 21, 1966.

GROUND WATER IN THE OGALLALA FORMATION IN THE SOUTHERN HIGH PLAINS OF TEXAS AND NEW MEXICO: USGS HYDROLOGIC INVESTIGATIONS ATLAS HA-330, 1969.

WATER-LEVEL DATA FROM OBSERVATION WELLS IN THE SOUTHERN HIGH PLAINS OF TEXAS, 1965-70: TEXAS WATER DEVELOPMENT BOARD REPORT 121, 1970

GROUND-WATER RESOURCES OF DONLEY COUNTY, TEXAS: TEXAS WATER DEVELOPMENT BOARD REPORT 164, 1973.

MAJOR AND HISTORICAL SPRINGS OF TEXAS: TEXAS WATER DEVELOPMENT BOARD REPORT 189, 1975. 
WATER-LEVEL DATA FROM OBSERVATION WELLS IN THE SOUTHERN HIGH PLAINS OF TEXAS, 1971-77: TEXAS DEPARTMENT OF WATER RESOURCES REPORT 228, 1979.

PRELIMINARY DATA DESCRIBING THE DISTRIBUTION OF FLUORIDE AND SILICA IN THE OGALLALA AQUIFER ON THE HIGH PLAINS OF TEXAS: USGS OPEN-FILE REPORT 80-349, 1980.

EVALUATING THE GROUND-WATER RESOURCES OF THE HIGH PLAINS OF TEXAS: RESULTS OF TEST HOLE DRILLING: TEXAS DEPARTMENT OF WATER RESOURCES LIMITED PRINTING REPORT LP-129, 1980.

EVALUATING THE GROUND-WATER RESOURCES OF THE HIGH PLAINS OF TEXAS: RESULTS OF SURFACE ELECTRICAL RESISTIVITY SURVEYS: TEXAS DEPARTMENT OF WATER RESOURCES LIMITED PRINTING REPORT LP-130, 1980.

ANALYTICAL STUDY OF THE OGALLALA AQUIFER IN DONLEY COUNTY, TEXAS—PROJECTIONS OF SATURATED THICKNESS, VOLUME OF WATER IN STORAGE, PUMPAGE RATES, PUMPING LIFTS, AND WELL YIELDS: TEXAS DEPARTMENT OF WATER RESOURCES REPORT 260, 1981.

SPRINGS OF TEXAS, VOLUME 1: (BY GUNNAR BRUNE), BRANCHSMITH, INC., FORT WORTH, TEXAS, 1981.

BEDROCK GEOLOGY, ALTITUDE OF BASE, AND 1980 SATURATED THICKNESS OF THE HIGH PLAINS AQUIFER IN PARTS OF COLORADO, KANSAS, NEBRASKA, NEW MEXICO, OKLAHOMA, SOUTH DAKOTA, TEXAS, AND WYOMING: USGS HYDROLOGIC INVESTIGATIONS ATLAS HA-648, 1981.

WATER LEVEL AND SATURATED THICKNESS CHANGES, PREDEVELOPMENT TO 1980, IN THE HIGH PLAINS AQUIFER IN PARTS OF COLORADO, KANSAS, NEBRASKA, NEW MEXICO, OKLAHOMA, SOUTH DAKOTA, TEXAS, AND WYOMING: USGS HYDROLOGIC INVESTIGATIONS ATLAS HA-652, 1981.

DISSOLVED SOLIDS AND SODIUM IN WATER FROM THE HIGH PLAINS AQUIFER IN PARTS OF COLORADO, KANSAS, NEBRASKA, NEW MEXICO, OKLAHOMA, SOUTH DAKOTA, TEXAS, AND WYOMING: USGS HYDROLOGIC INVESTIGATIONS ATLAS HA-658, 1982.

EVALUATING THE GROUND-WATER RESOURCES OF THE HIGH PLAINS OF TEXAS, VOLUME 1: TEXAS DEPARTMENT OF WATER RESOURCES REPORT 288, V. 1, 1984.

EVALUATING THE GROUND-WATER RESOURCES OF THE HIGH PLAINS OF TEXAS, VOLUME 2, RECORDS OF WELLS, AND MAPS SHOWING WELL LOCATIONS, BASE OF AQUIFER, WATER LEVELS, AND SATURATED THICKNESS (ARMSTRONG, CARSON, DALLAS, DONLEY, GRAY, HANSFORD, HARTLEY, HEMPHILL, HUTCHINSON, LIPSCOMB, MOORE, OCHILTREE, POTTER, ROBERTS, SHERMAN, AND WHEELER COUNTIES): TEXAS DEPARTMENT OF WATER RESOURCES REPORT 288, V. 2, 1984.

GEOHYDROLOGY OF THE HIGH PLAINS AQUIFER IN PARTS OF COLORADO, KANSAS, NEBRASKA, NEW MEXICO, OKLAHOMA, SOUTH DAKOTA, TEXAS, AND WYOMING: USGS PROFESSIONAL PAPER 1400-B, 1984

TEXAS GROUND-WATER RESOURCES, in NATIONAL WATER SUMMARY 1984: USGS WATER-SUPPLY PAPER 2275, 1985.

DIGITAL SIMULATION OF GROUND-WATER FLOW IN THE HIGH PLAINS AQUIFER IN PARTS OF COLORADO, KANSAS, NEBRASKA, NEW MEXICO, OKLAHOMA, SOUTH DAKOTA, TEXAS, AND WYOMING: USGS PROFESSIONAL PAPER 1400-D, 1986.
SUMMARY OF THE HIGH PLAINS REGIONAL AQUIFER-SYSTEM ANALYSIS IN PARTS OF COLORADO, KANSAS, NEBRASKA, NEW MEXICO, OKLAHOMA, SOUTH DAKOTA, TEXAS, AND WYOMING: USGS PROFESSIONAL PAPER 1400-A, 1988.

WATER-LEVEL CHANGES IN THE HIGH PLAINS AQUIFER OF TEXAS, 1980-1990: TEXAS WATER DEVELOPMENT BOARD HYDROLOGIC ATLAS NO. 1, 1991.

PUBLIC SUPPLY GROUND-WATER USE IN THE NORTHERN HIGH PLAINS OF TEXAS: TEXAS WATER DEVELOPMENT BOARD REPORT 336, 1992

EVALUATION OF WATER RESOURCES IN PARTS OF THE ROLLING PRAIRIES REGION OF NORTH-CENTRAL TEXAS: TEXAS WATER DEVELOPMENT BOARD REPORT 337, 1992.

THE HIGH PLAINS AQUIFER SYSTEM OF TEXAS, 1980 TO 1990OVERVIEW AND PROJECTIONS: TEXAS WATER DEVELOPMENT BOARD REPORT 341, 1993.

WATER-QUALITY EVALUATION OF THE OGALLALA AQUIFER, TEXAS: TEXAS WATER DEVELOPMENT BOARD REPORT 342 , 1993.

WATER-LEVEL CHANGES IN THE HIGH PLAINS AQUIFER-PREDEVELOPMENT TO 1992: USGS WATER-RESOURCES INVESTIGATIONS REPORT 94-4027, 1994.

WATER-LEVEL CHANGES IN THE HIGH PLAINS AQUIFER, 1980 TO 1994: USGS FACT SHEET FS-215-95, 1995.

AQUIFERS OF TEXAS: TEXAS WATER DEVELOPMENT BOARD REPORT 345, 1995.

WATER-LEVEL CHANGES IN THE HIGH PLAINS AQUIFER, 1980 TO 1995: USGS FACT SHEET FS-068-97, 1997.

WATER-LEVEL CHANGES IN THE HIGH PLAINS AQUIFER-PREDEVELOPMENT TO 1995: USGS WATER-RESOURCES INVESTIGATIONS REPORT 97-4081, 1997.

PLAYAS AND RECHARGE OF THE OGALLALA AQUIFER ON THE SOUTHERN HIGH PLAINS OF TEXAS-AN EXAMINATION USING NUMERICAL TECHNIQUES: UNIVERSITY OF TEXAS, BUREAU OF ECONOMIC GEOLOGY REPORT OF INVESTIGATIONS NO. 242, 1997.

UPDATED WATER-QUALITY EVALUATION OF THE OGALLALA AQUIFER INCLUDING SELECTED METALLIC AND NON-METALLIC INORGANIC CONSTITUENTS: TEXAS DEPARTMENT OF WATER RESOURCES HYDROLOGIC ATLAS NO. 10, 1998.

\section{DUVAL COUNTY}

UNDERGROUND WATERS OF COASTAL PLAIN OF TEXAS: USGS WATER-SUPPLY AND IRRIGATION PAPER 190, 1907.

GROUND-WATER RESOURCES OF DUVAL COUNTY, TEXAS: USGS OPEN-FILE REPORT (UNNUMBERED) (PRESS RELEASE), 1933.

WATER RESOURCES OF DUVAL COUNTY, TEXAS: USGS WATERSUPPLY PAPER 776, 1937.

GROUND-WATER CONDITIONS IN PREMONT-LAGLORIA, FALFURRIAS DISTRICT, TEXAS: TEXAS BOARD OF WATER ENGINEERS MISCELLANEOUS PUBLICATION M212, 1944. 
PUBLIC WATER SUPPLIES IN SOUTHERN TEXAS: USGS WATERSUPPLY PAPER 1070, 1950.

SUPPLEMENTARY REPORT ON SURFACE-WATER AND GROUNDWATER SURVEYS, NUECES RIVER BASIN, TEXAS: USGS OPENFILE REPORT (UNNUMBERED) (PRESS RELEASE), 1950.

AVAILABILITY OF GROUND WATER IN THE GULF COAST REGION OF TEXAS: USGS OPEN-FILE REPORT (UNNUMBERED), 1956.

OCCURRENCE OF GROUND WATER IN THE PALANGANA BRINE FIELD, DUVAL COUNTY, TEXAS: TEXAS BOARD OF WATER ENGINEERS MISCELLANEOUS PUBLICATION M75, 1959.

AVAILABILITY OF GROUND WATER FROM THE GOLIAD SAND IN THE ALICE AREA, TEXAS: TEXAS WATER COMMISSION BULLETIN 6301, 1963.

RECONNAISSANCE INVESTIGATION OF THE GROUND-WATER RESOURCES OF THE GULF COAST REGION, TEXAS: TEXAS WATER COMMISSION BULLETIN 6305, 1963.

RECONNAISSANCE INVESTIGATION OF THE GROUND-WATER RESOURCES OF THE GUADALUPE, SAN ANTONIO, AND NUECES RIVER BASINS, TEXAS: TEXAS WATER COMMISSION BULLETIN 6409, 1964.

REPORT ON DEVELOPMENT OF GROUND WATER IN THE VICINITY OF PALANGANA DOME, DUVAL COUNTY, TEXAS: CONSULTING REPORT BY WILLIAM F. GUYTON AND ASSOCIATES, AUSTIN, TEXAS, 1966.

HYDROLOGIC SIGNIFICANCE OF THE LITHOFACIES OF THE SPARTA SAND IN ARKANSAS, LOUISIANA, MISSISSIPPI, AND TEXAS: USGS PROFESSIONAL PAPER 569-A, 1968.

GEOHYDROLOGIC SIGNIFICANCE OF LITHOFACIES OF THE COCKFIELD FORMATION OF LOUISIANA AND MISSISSIPPI AND OF THE YEGUA FORMATION OF TEXAS: USGS PROFESSIONAL PAPER 569-B, 1970.

HYDROLOGIC SIGNIFICANCE OF LITHOFACIES OF THE CANE RIVER FORMATION OR EQUIVALENTS OF ARKANSAS, LOUISIANA, MISSISSIPPI, AND TEXAS: USGS PROFESSIONAL PAPER 569-C, 1972.

GROUND-WATER RESOURCES OF DUVAL COUNTY, TEXAS: TEXAS WATER DEVELOPMENT BOARD REPORT 181, 1974.

GEOHYDROLOGIC SIGNIFICANCE OF LITHOFACIES OF THE CARRIZO SAND OF ARKANSAS, LOUISIANA, AND TEXAS AND THE MERIDIAN SAND OF MISSISSIPPI: USGS PROFESSIONAL PAPER 569-D, 1975.

STRATIGRAPHIC AND HYDROGEOLOGIC FRAMEWORK OF PART OF THE COASTAL PLAIN OF TEXAS: TEXAS DEPARTMENT OF WATER RESOURCES REPORT 236, 1979.

SPRINGS OF TEXAS, VOLUME 1: (BY GUNNAR BRUNE), BRANCHSMITH, INC., FORT WORTH, TEXAS, 1981.

REGIONAL HYDRODYNAMICS AND HYDROCHEMISTRY OF THE URANIUM-BEARING OAKVILLE AQUIFER (MIOCENE) OF SOUTH TEXAS: UNIVERSITY OF TEXAS, BUREAU OF ECONOMIC GEOLOGY REPORT OF INVESTIGATIONS NO. 124, 1982.

STRUCTURE, TEMPERATURE, PRESSURE, AND SALINITY OF CENOZOIC AQUIFERS OF SOUTH TEXAS: USGS HYDROLOGIC INVESTIGATIONS ATLAS HA-654, 1983.
WATER LEVELS AND SALINITIES OF WATER WITHIN THE EVANGELINE AQUIFER IN AN AREA SOUTHWEST OF CORPUS CHRISTI, TEXAS: USGS OPEN-FILE REPORT 82-174, 1983.

TEXAS GROUND-WATER RESOURCES, in NATIONAL WATER SUMMARY 1984: USGS WATER-SUPPLY PAPER 2275, 1985.

SIMULATED EFFECTS OF PROJECTED PUMPING ON THE AVAILABILITY OF FRESHWATER IN THE EVANGELINE AQUIFER IN AN AREA SOUTHWEST OF CORPUS CHRISTI, TEXAS: USGS WATERRESOURCES INVESTIGATIONS REPORT 85-4182, 1985.

GEOHYDROLOGIC FRAMEWORK OF THE GULF COASTAL PLAIN: USGS HYDROLOGIC INVESTIGATIONS ATLAS HA-695, 1988.

DEPOSITIONAL AND GROUND-WATER FLOW SYSTEMS OF THE CARRIZO-UPPER WILCOX, SOUTH TEXAS: UNIVERSITY OF TEXAS, BUREAU OF ECONOMIC GEOLOGY REPORT OF INVESTIGATIONS NO. 175, 1988.

PROPERTIES AND CHEMICAL CONSTITUENTS IN GROUND WATER FROM THE UPPER CLAIBORNE AQUIFER, GULF COAST REGIONAL AQUIFER SYSTEMS, SOUTH-CENTRAL UNITED STATES: USGS WATER-RESOURCES INVESTIGATIONS REPORT 91-4150, 1993.

PROPERTIES AND CHEMICAL CONSTITUENTS IN GROUND WATER FROM PERMEABLE ZONE C (LOWER PLIOCENE-UPPER MIOCENE DEPOSITS), COASTAL LOWLANDS AQUIFER SYSTEM, SOUTHCENTRAL UNITED STATES: USGS WATER-RESOURCES INVESTIGATIONS REPORT 91-4151, 1993.

PROPERTIES AND CHEMICAL CONSTITUENTS IN GROUND WATER FROM PERMEABLE ZONE B (LOWER PLEISTOCENE-UPPER PLIOCENE DEPOSITS), COASTAL LOWLANDS AQUIFER SYSTEM, SOUTH-CENTRAL UNITED STATES: USGS WATER-RESOURCES INVESTIGATIONS REPORT 91-4152, 1993.

PROPERTIES AND CHEMICAL CONSTITUENTS IN GROUND WATER FROM THE LOWER CLAIBORNE-UPPER WILCOX AQUIFER, GULF COAST REGIONAL AQUIFER SYSTEMS, SOUTH-CENTRAL UNITED STATES: USGS WATER-RESOURCES INVESTIGATIONS REPORT 92-4102, 1993

PROPERTIES AND CHEMICAL CONSTITUENTS IN GROUND WATER FROM PERMEABLE ZONE E (LOWER MIOCENE-UPPER OLIGOCENE DEPOSITS), COASTAL LOWLANDS AQUIFER SYSTEM, SOUTH-CENTRAL UNITED STATES: USGS WATER-RESOURCES INVESTIGATIONS REPORT 92-4103, 1993.

PROPERTIES AND CHEMICAL CONSTITUENTS IN GROUND WATER FROM THE MIDDLE CLAIBORNE AQUIFER, GULF COAST REGIONAL AQUIFER SYSTEMS, SOUTH-CENTRAL UNITED STATES: USGS WATER-RESOURCES INVESTIGATIONS REPORT 92-4104, 1993.

PROPERTIES AND CHEMICAL CONSTITUENTS IN GROUND WATER FROM PERMEABLE ZONE D (MIDDLE MIOCENE DEPOSITS), COASTAL LOWLANDS AQUIFER SYSTEM, SOUTH-CENTRAL UNITED STATES: USGS WATER-RESOURCES INVESTIGATIONS REPORT 92-4105, 1993.

PROPERTIES AND CHEMICAL CONSTITUENTS IN GROUND WATER FROM THE MIDDLE WILCOX AQUIFER, GULF COAST REGIONAL AQUIFER SYSTEMS, SOUTH-CENTRAL UNITED STATES: USGS WATER-RESOURCES INVESTIGATIONS REPORT 93-4070, 1993.

AQUIFERS OF TEXAS: TEXAS DEPARTMENT OF WATER RESOURCES REPORT 345, 1995. 
STRATIGRAPHIC NOMENCLATURE AND GEOLOGIC SECTIONS OF THE GULF COASTAL PLAIN OF TEXAS: USGS OPEN-FILE REPORT 94-461, 1995.

\section{EASTLAND COUNTY}

GEOGRAPHY AND GEOLOGY OF THE BLACK AND GRAND PRAIRIES, TEXAS, WITH DETAILED DESCRIPTIONS OF THE CRETACEOUS FORMATIONS AND SPECIAL REFERENCE TO ARTESIAN WATERS: USGS 21ST ANNUAL REPORT, PART 7, 1901.

RECORDS OF WELLS, DRILLERS' LOGS, WATER-LEVEL MEASUREMENTS, ANALYSES OF WATER FROM WELLS, STREAMS, AND LAKES, AND MAP SHOWING LOCATIONS IN EASTLAND COUNTY, TEXAS: TEXAS BOARD OF WATER ENGINEERS MISCELLANEOUS PUBLICATION 76, 1937.

PUBLIC WATER SUPPLIES IN CENTRAL AND NORTH-CENTRAL TEXAS: USGS WATER-SUPPLY PAPER 1069, 1949.

MAJOR AND HISTORICAL SPRINGS OF TEXAS: TEXAS WATER DEVELOPMENT BOARD REPORT 189, 1975.

GROUND-WATER RESOURCES OF PART OF CENTRAL TEXAS WITH EMPHASIS ON THE ANTLERS AND TRAVIS PEAK FORMATIONS: TEXAS WATER DEVELOPMENT BOARD REPORT 195, V. 1, 1975.

GROUND-WATER RESOURCES OF PART OF CENTRAL TEXAS WITH EMPHASIS ON THE ANTLERS AND TRAVIS PEAK FORMATIONS: TEXAS WATER DEVELOPMENT BOARD REPORT 195, V. 2, 1976.

TEXAS GROUND-WATER RESOURCES, in NATIONAL WATER SUMMARY 1984: USGS WATER-SUPPLY PAPER 2275, 1985.

GROUND-WATER RESOURCES OF THE ANTLERS AND TRAVIS PEAK FORMATIONS IN THE OUTCROP AREA OF NORTH-CENTRAL TEXAS: TEXAS WATER DEVELOPMENT BOARD REPORT 298, 1987.

EVALUATION OF WATER RESOURCES IN PART OF CENTRAL TEXAS: TEXAS WATER DEVELOPMENT BOARD REPORT 319, 1990.

GROUND-WATER QUALITY MONITORING OF THE TRINITY AQUIFER IN THE VICINITY OF ERATH COUNTY: TEXAS WATER DEVELOPMENT BOARD REPORT 331, 1991.

EVALUATION OF WATER RESOURCES IN PARTS OF THE ROLLING PRAIRIES REGION OF NORTH-CENTRAL TEXAS: TEXAS WATER DEVELOPMENT BOARD REPORT 337, 1992.

\section{ECTOR COUNTY}

RECORDS OF WELLS, DRILLERS' LOGS, AND WATER ANALYSES AND MAP SHOWING LOCATION OF WELLS IN ECTOR COUNTY, TEXAS: TEXAS BOARD OF WATER ENGINEERS MISCELLANEOUS PUBLICATION 37, 1937.

CARBON BLACK PLANT SITE NEAR ODESSA, TEXAS: USGS OPENFILE REPORT (UNNUMBERED), 1944.

MEMORANDUM REGARDING PUBLIC WATER SUPPLY AT ODESSA, TEXAS: USGS OPEN-FILE REPORT (UNNUMBERED), 1945.

PUBLIC WATER SUPPLIES IN WESTERN TEXAS: USGS WATERSUPPLY PAPER 1106, 1951.
GROUND-WATER RESOURCES OF ECTOR COUNTY, TEXAS: TEXAS BOARD OF WATER ENGINEERS BULLETIN 5210, 1952.

SHALLOW FORMATIONS AND AQUIFERS OF THE WEST TEXAS AREA: WEST TEXAS GEOLOGICAL SOCIETY PUBLICATION 61-45 AND PERMIAN BASIN GEOPHYSICAL SOCIETY, MIDLAND, TEXAS, 1961

RECONNAISSANCE INVESTIGATION OF THE GROUND-WATER RESOURCES OF THE RIO GRANDE BASIN, TEXAS: TEXAS WATER COMMISSION BULLETIN 6502, 1965.

RECONNAISSANCE INVESTIGATION OF THE GROUND-WATER RESOURCES OF THE COLORADO RIVER BASIN, TEXAS: TEXAS WATER DEVELOPMENT BOARD REPORT 51, 1967.

RECONNAISSANCE INVESTIGATION OF GROUND WATER IN THE RIO GRANDE DRAINAGE BASIN-WITH SPECIAL EMPHASIS ON SALINE GROUND-WATER RESOURCES: USGS HYDROLOGIC INVESTIGATIONS ATLAS HA-510, 1974.

SUMMARY APPRAISALS OF THE NATION'S GROUND-WATER RESOURCES-TEXAS-GULF REGION: USGS PROFESSIONAL PAPER 813-F, 1976.

OCCURRENCE, AVAILABILITY, AND CHEMICAL QUALITY OF GROUND WATER IN THE EDWARDS PLATEAU REGION OF TEXAS: TEXAS DEPARTMENT OF WATER RESOURCES REPORT 235,1979

SPRINGS OF TEXAS, VOLUME 1: (BY GUNNAR BRUNE), BRANCHSMITH, INC., FORT WORTH, TEXAS, 1981.

EVALUATING THE GROUND-WATER RESOURCES OF THE HIGH PLAINS OF TEXAS, VOLUME 1: TEXAS DEPARTMENT OF WATER RESOURCES REPORT 288, V. 1, 1984.

EVALUATING THE GROUND-WATER RESOURCES OF THE HIGH PLAINS OF TEXAS, VOLUME 4, RECORDS OF WELLS, AND MAPS SHOWING WELL LOCATIONS, BASE OF AQUIFER, WATER LEVELS, AND SATURATED THICKNESS (ANDREWS, BORDEN, COCHRAN, DAWSON, ECTOR, GAINES, GARZA, GLASSCOCK, HOWARD, HOCKLEY, LUBBOCK, LYNN, MARTIN, MIDLAND, TERRY, AND YOAKUM COUNTIES: TEXAS DEPARTMENT OF WATER RESOURCES REPORT 288 V. 4, 1984.

TEXAS GROUND-WATER RESOURCES, in NATIONAL WATER SUMMARY 1984: USGS WATER-SUPPLY PAPER 2275, 1985.

WATER USE, PROJECTED WATER REQUIREMENTS, AND RELATED DATA AND INFORMATION FOR THE METROPOLITAN STATISTICAL AREAS IN TEXAS: TEXAS DEPARTMENT OF WATER RESOURCES LIMITED PRINTING REPORT LP-201, 1985.

HYDROGEOLOGY AND HYDROCHEMISTRY OF CRETACEOUS AQUIFERS, TEXAS PANHANDLE AND EASTERN NEW MEXICO: UNIVERSITY OF TEXAS, BUREAU OF ECONOMIC GEOLOGY GEOLOGICAL CIRCULAR 88-3, 1988.

PUBLIC SUPPLY GROUND-WATER USE IN WESTERN TEXAS: TEXAS WATER DEVELOPMENT BOARD REPORT 311, 1989.

POTENTIOMETRIC SURFACE OF THE EDWARDS-TRINITY AQUIFER SYSTEM AND CONTIGUOUS HYDRAULICALLY CONNECTED UNITS, WEST-CENTRAL TEXAS, WINTER 1974-75: USGS WATERRESOURCES INVESTIGATIONS REPORT 89-4208, 1990.

WITHDRAWALS FROM THE EDWARDS-TRINITY AQUIFER SYSTEM AND CONTIGUOUS HYDRAULICALLY CONNECTED UNITS, WEST-CENTRAL TEXAS, DECEMBER 1974 THROUGH MARCH 
1977: USGS WATER-RESOURCES INVESTIGATIONS REPORT 91-4021, 1991.

EVALUATION OF GROUND-WATER RESOURCES IN THE SOUTHERN HIGH PLAINS OF TEXAS: TEXAS DEPARTMENT OF WATER RESOURCES REPORT 330, 1991.

WATER-LEVEL CHANGES IN THE HIGH PLAINS AQUIFER OF TEXAS, 1980-1990: TEXAS WATER DEVELOPMENT BOARD HYDROLOGIC ATLAS NO. 1, 1991.

CONFIGURATION OF THE BASE OF THE EDWARDS-TRINITY AQUIFER SYSTEM AND HYDROGEOLOGY OF THE UNDERLYING PRECRETACEOUS ROCKS, WEST-CENTRAL TEXAS: USGS WATERRESOURCES INVESTIGATIONS REPORT 91-4071, 1992.

HISTORICAL POTENTIOMETRIC SURFACE OF THE EDWARDS-TRINITY AQUIFER SYSTEM AND CONTIGUOUS HYDRAULICALLY CONNECTED UNITS, WEST-CENTRAL TEXAS: USGS WATERRESOURCES INVESTIGATIONS REPORT 92-4055, 1993.

HISTORICAL SATURATED THICKNESS OF THE EDWARDS-TRINITY AQUIFER SYSTEM AND SELECTED CONTIGUOUS HYDRAULICALLY CONNECTED UNITS, WEST-CENTRAL TEXAS: USGS WATER-RESOURCES INVESTIGATIONS REPORT 92-4125, 1993.

THE HIGH PLAINS AQUIFER SYSTEM OF TEXAS, 1980 TO 1990. OVERVIEW AND PROJECTIONS: TEXAS WATER DEVELOPMENT BOARD REPORT 341, 1993.

WATER-QUALITY EVALUATION OF THE OGALLALA AQUIFER, TEXAS: TEXAS WATER DEVELOPMENT BOARD REPORT 342, 1993.

SIMULATIONS OF FLOW IN THE EDWARDS-TRINITY AQUIFER SYSTEM AND CONTIGUOUS HYDRAULICALLY CONNECTED UNITS, WEST-CENTRAL TEXAS: USGS WATER-RESOURCES INVESTIGATIONS REPORT 93-4039, 1994.

DISSOLVED-SOLIDS CONCENTRATIONS AND HYDROCHEMICAL FACIES IN WATER OF THE EDWARDS-TRINITY AQUIFER SYSTEM, WEST-CENTRAL TEXAS: USGS WATER-RESOURCES INVESTIGATIONS REPORT 93-4126, 1994.

GEOLOGIC HISTORY AND HYDROGEOLOGIC SETTING OF THE EDWARDS-TRINITY AQUIFER SYSTEM, WEST-CENTRAL TEXAS: USGS WATER-RESOURCES INVESTIGATIONS REPORT 94-4039, 1994.

WATER-LEVEL CHANGES IN THE HIGH PLAINS AQUIFER, 1980 TO 1994: USGS FACT SHEET FS-215-95, 1995.

AQUIFERS OF TEXAS: TEXAS WATER DEVELOPMENT BOARD REPORT 345, 1995

WATER QUALITY IN THE EDWARDS-TRINITY (PLATEAU) AQUIFER, EDWARDS PLATEAU AND TRANS-PECOS, TEXAS: TEXAS WATER DEVELOPMENT BOARD HYDROLOGIC ATLAS NO. 3, 1995.

WATER-LEVEL CHANGES IN THE HIGH PLAINS AQUIFER, 1980 TO 1995: USGS FACT SHEET FS-068-97, 1997.

UPDATED WATER-QUALITY EVALUATION OF THE OGALLALA AQUIFER INCLUDING SELECTED METALLIC AND NON-METALLIC INORGANIC CONSTITUENTS: TEXAS WATER DEVELOPMENT BOARD HYDROLOGIC ATLAS NO. 10, 1998.

AN OVERVIEW OF THE EDWARDS-TRINITY AQUIFER SYSTEM, CENTRAL-WEST TEXAS, CHAPTER 8, in AQUIFERS OF WEST TEXAS: TEXAS WATER DEVELOPMENT BOARD REPORT 356, 2001.
CENOZOIC PECOS ALLUVIUM AQUIFER, CHAPTER 9, in AQUIFERS OF WEST TEXAS: TEXAS WATER DEVELOPMENT BOARD REPORT 356, 2001.

THE DOCKUM AQUIFER IN WEST TEXAS, CHAPTER 12, in AQUIFERS OF WEST TEXAS: TEXAS WATER DEVELOPMENT BOARD REPORT 356, 2001

\section{EDWARDS COUNTY}

GEOLOGY OF THE EDWARDS PLATEAU AND RIO GRANDE PLAIN ADJACENT TO AUSTIN AND SAN ANTONIO, TEXAS, WITH REFERENCE TO THE OCCURRENCE OF UNDERGROUND WATERS: USGS 18TH ANNUAL REPORT, PART 2, 1898.

GEOLOGIC ATLAS OF THE UNITED STATES-NUECES FOLIO, TEXAS: USGS GEOLOGIC FOLIO, 1898.

DATA ON TESTS ON CITY WATER WELLS AT ROCK SPRINGS, TEXAS: USGS OPEN-FILE REPORT (UNNUMBERED), 1935.

RECORDS OF WELLS AND SPRINGS, DRILLERS' LOGS, WATER ANALYSES, AND MAP SHOWING LOCATION OF WELLS AND SPRINGS IN EDWARDS COUNTY, TEXAS: TEXAS BOARD OF WATER ENGINEERS MISCELLANEOUS PUBLICATION 78, 1939.

SUPPLEMENTARY REPORT ON SURFACE-WATER AND GROUNDWATER SURVEYS, NUECES RIVER BASIN, TEXAS: USGS OPENFILE REPORT (UNNUMBERED), 1950.

PUBLIC WATER SUPPLIES IN WESTERN TEXAS: USGS WATERSUPPLY PAPER 1106, 1951.

GROUND-WATER RESOURCES OF THE SAN ANTONIO AREA, TEXAS, A PROGRESS REPORT OF CURRENT STUDIES: TEXAS BOARD OF WATER ENGINEERS BULLETIN 5412, 1954.

GROUND-WATER RESOURCES OF THE SAN ANTONIO AREA, TEXAS, VOLUME 1, A PROGRESS REPORT ON CURRENT STUDIES: TEXAS BOARD OF WATER ENGINEERS BULLETIN 5608, V. 1, 1956.

GROUND-WATER RESOURCES OF THE SAN ANTONIO AREA, TEXAS, VOLUME 2, PART 1, RECORDS OF WELLS AND SPRINGS: TEXAS BOARD OF WATER ENGINEERS BULLETIN 5608, V. 2, PART 1, 1956.

GROUND-WATER RESOURCES OF THE SAN ANTONIO AREA, TEXAS, VOLUME 2, PART 2, RECORDS OF DRILLERS' LOGS: TEXAS BOARD OF WATER ENGINEERS BULLETIN 5608, V. 2, PART 2, 1956.

GROUND-WATER RESOURCES OF THE SAN ANTONIO AREA, TEXAS, VOLUME 2, PART 3, WATER LEVELS IN WELLS, CHEMICAL ANALYSES OF WATER, RECORDS OF STREAMFLOW AND RESERVOIR CONTENTS, DISCHARGE MEASUREMENTS, AND PRECIPITATION IN THE SAN ANTONIO AREA, TEXAS: TEXAS BOARD OF WATER ENGINEERS BULLETIN 5608, V. 2, PART 3, 1956.

GROUND-WATER GEOLOGY OF EDWARDS COUNTY, TEXAS: TEXAS BOARD OF WATER ENGINEERS BULLETIN 6208, 1962.

RECONNAISSANCE INVESTIGATION OF THE GROUND-WATER RESOURCES OF THE GUADALUPE, SAN ANTONIO, AND NUECES RIVER BASINS, TEXAS: TEXAS WATER COMMISSION BULLETIN 6409, 1964.

RECONNAISSANCE INVESTIGATION OF THE GROUND-WATER RESOURCES OF THE RIO GRANDE BASIN, TEXAS: TEXAS WATER COMMISSION BULLETIN 6502, 1965 
RECONNAISSANCE INVESTIGATION OF THE GROUND-WATER RESOURCES OF THE COLORADO RIVER BASIN, TEXAS: TEXAS WATER DEVELOPMENT BOARD REPORT 51, 1967.

GEOLOGY AND WATER QUALITY AT SELECTED LOCATIONS IN THE SAN ANTONIO AREA, TEXAS, PROGRESS REPORT: USGS OPENFILE REPORT 70-272, 1970.

CHEMICAL AND BACTERIOLOGICAL QUALITY OF WATER AT SELECTED SITES IN THE SAN ANTONIO AREA, TEXAS, AUGUST 1968-APRIL 1972: EDWARDS UNDERGROUND WATER DISTRICT, 1972.

RECONNAISSANCE INVESTIGATION OF GROUND WATER IN THE RIO GRANDE DRAINAGE BASIN-WITH SPECIAL EMPHASIS ON SALINE GROUND-WATER RESOURCES: USGS HYDROLOGIC INVESTIGATIONS ATLAS HA-510, 1974.

RELATION OF PRECIPITATION TO ANNUAL GROUND-WATER RECHARGE IN THE EDWARDS AQUIFER, SAN ANTONIO AREA, TEXAS: USGS OPEN-FILE REPORT 75-298, 1975.

MAJOR AND HISTORICAL SPRINGS OF TEXAS: TEXAS WATER DEVELOPMENT BOARD REPORT 189, 1975.

METHOD OF ESTIMATING NATURAL RECHARGE TO THE EDWARDS AQUIFER IN THE SAN ANTONIO AREA, TEXAS: USGS WATERRESOURCES INVESTIGATIONS REPORT 78-10, 1978.

REGIONAL DISTRIBUTION OF FRACTURES IN THE SOUTHERN EDWARDS PLATEAU AND THEIR RELATIONSHIP TO TECTONICS AND CAVES: UNIVERSITY OF TEXAS, BUREAU OF ECONOMIC GEOLOGY GEOLOGICAL CIRCULAR 78-2, 1978.

RECORDS OF GROUND-WATER RECHARGE AND DISCHARGE FOR THE EDWARDS AQUIFER IN THE SAN ANTONIO AREA, TEXAS, 1934-77: EDWARDS UNDERGROUND WATER DISTRICT BULLETIN 37, 1979.

OCCURRENCE, AVAILABILITY, AND CHEMICAL QUALITY OF GROUND WATER IN THE EDWARDS PLATEAU REGION OF TEXAS: TEXAS DEPARTMENT OF WATER RESOURCES REPORT $235,1979$.

RECORDS OF GROUND-WATER RECHARGE, DISCHARGE, WATER LEVELS, AND CHEMICAL QUALITY OF WATER FOR THE EDWARDS AQUIFER IN THE SAN ANTONIO AREA, TEXAS, 1934-78: EDWARDS UNDERGROUND WATER DISTRICT BULLETIN 38, 1980.

SPRINGS OF TEXAS, VOLUME 1: (BY GUNNAR BRUNE), BRANCHSMITH, INC. FORT WORTH, TEXAS, 1981.

RECORDS OF GROUND-WATER RECHARGE, DISCHARGE, WATER LEVELS, AND CHEMICAL QUALITY OF WATER FOR THE EDWARDS AQUIFER IN THE SAN ANTONIO AREA, TEXAS, 1934-79: EDWARDS UNDERGROUND WATER DISTRICT BULLETIN 39, 1981.

RECORDS OF GROUND-WATER RECHARGE, DISCHARGE, WATER LEVELS, AND CHEMICAL QUALITY OF WATER FOR THE EDWARDS AQUIFER IN THE SAN ANTONIO AREA, TEXAS, 1934-80: EDWARDS UNDERGROUND WATER DISTRICT BULLETIN 40, 1982.

GROUND-WATER AVAILABILITY OF THE LOWER CRETACEOUS FORMATIONS IN THE HILL COUNTRY OF SOUTH-CENTRAL TEXAS: TEXAS DEPARTMENT OF WATER RESOURCES REPORT 273,1983
RECORDS OF GROUND-WATER RECHARGE, DISCHARGE, WATER LEVELS, AND CHEMICAL QUALITY OF WATER FOR THE EDWARDS AQUIFER IN THE SAN ANTONIO AREA, TEXAS, 1934-81: EDWARDS UNDERGROUND WATER DISTRICT BULLETIN 41, 1984.

CARBONATE GEOLOGY AND HYDROLOGY OF THE EDWARDS AQUIFER IN THE SAN ANTONIO AREA, TEXAS: USGS OPEN-FILE REPORT 83-537, 1984.

RECORDS OF GROUND-WATER RECHARGE, DISCHARGE, WATER LEVELS, AND CHEMICAL QUALITY OF WATER FOR THE EDWARDS AQUIFER IN THE SAN ANTONIO AREA, TEXAS, 1934-82: EDWARDS UNDERGROUND WATER DISTRICT BULLETIN 42, 1985

TEXAS GROUND-WATER RESOURCES, in NATIONAL WATER SUMMARY 1984: USGS WATER-SUPPLY PAPER 2275, 1985.

COMPILATION OF HYDROLOGIC DATA FOR THE EDWARDS AQUIFER, SAN ANTONIO AREA, TEXAS, 1983-84, WITH 1934-84 SUMMARY: EDWARDS UNDERGROUND WATER DISTRICT BULLETIN 43-44, 1986.

CARBONATE GEOLOGY AND HYDROLOGY OF THE EDWARDS AQUIFER IN THE SAN ANTONIO AREA, TEXAS: TEXAS WATER DEVELOPMENT BOARD REPORT 296, 1986.

COMPILATION OF HYDROLOGIC DATA FOR THE EDWARDS AQUIFER, SAN ANTONIO AREA, TEXAS, 1985, WITH 1934-85 SUMMARY: EDWARDS UNDERGROUND WATER DISTRICT BULLETIN 45, 1987.

COMPILATION OF HYDROLOGIC DATA FOR THE EDWARDS AQUIFER, SAN ANTONIO AREA, TEXAS, 1986, WITH 1934-86 SUMMARY: EDWARDS UNDERGROUND WATER DISTRICT BULLETIN 46, 1988.

COMPILATION OF HYDROLOGIC DATA FOR THE EDWARDS AQUIFER, SAN ANTONIO AREA, TEXAS, 1987, WITH 1934-87 SUMMARY: EDWARDS UNDERGROUND WATER DISTRICT BULLETIN 47, 1988.

COMPILATION OF HYDROLOGIC DATA FOR THE EDWARDS AQUIFER, SAN ANTONIO AREA, TEXAS, 1988, WITH 1934-88 SUMMARY: EDWARDS UNDERGROUND WATER DISTRICT BULLETIN 48, 1989.

POTENTIOMETRIC SURFACE OF THE EDWARDS-TRINITY AQUIFER SYSTEM AND CONTIGUOUS HYDRAULICALLY CONNECTED UNITS, WEST-CENTRAL TEXAS, WINTER 1974-75: USGS WATERRESOURCES INVESTIGATIONS REPORT 89-4208, 1990.

COMPILATION OF HYDROLOGIC DATA FOR THE EDWARDS AQUIFER, SAN ANTONIO AREA, TEXAS, 1989, WITH 1934-89 SUMMARY: EDWARDS UNDERGROUND WATER DISTRICT BULLETIN 49, 1990.

WITHDRAWALS FROM THE EDWARDS-TRINITY AQUIFER SYSTEM AND CONTIGUOUS HYDRAULICALLY CONNECTED UNITS, WEST-CENTRAL TEXAS, DECEMBER 1974 THROUGH MARCH 1977: USGS WATER-RESOURCES INVESTIGATIONS REPORT 91-4021, 1991.

EDWARDS AQUIFER, A TEXAS TREASURE-A TEACHERS GUIDE, SECONDARY, GRADES 7-12: EDWARDS UNDERGROUND WATER DISTRICT, 1991

COMPILATION OF HYDROLOGIC DATA FOR THE EDWARDS AQUIFER, SAN ANTONIO AREA, TEXAS, 1990, WITH 1934-90 SUM- 
MARY: EDWARDS UNDERGROUND WATER DISTRICT BULLETIN 50, 1991.

INSIDE THE EDWARDS AQUIFER-A THREE-PART TECHNICAL FILM, HIGH-SCHOOL LEVEL TEACHER'S GUIDE: EDWARDS UNDERGROUND WATER DISTRICT, 1992.

CONFIGURATION OF THE BASE OF THE EDWARDS-TRINITY AQUIFER SYSTEM AND HYDROGEOLOGY OF THE UNDERLYING PRECRETACEOUS ROCKS, WEST-CENTRAL TEXAS: USGS WATERRESOURCES INVESTIGATIONS REPORT 91-4071, 1992.

EVALUATION OF THE GROUND-WATER RESOURCES OF THE PALEOZOIC AND CRETACEOUS AQUIFERS IN THE HILL COUNTRY OF CENTRAL TEXAS: TEXAS WATER DEVELOPMENT BOARD REPORT 339, 1992.

COMPILATION OF HYDROLOGIC DATA FOR THE EDWARDS AQUIFER, SAN ANTONIO AREA, TEXAS, 1991, WITH 1934-91 SUMMARY: EDWARDS UNDERGROUND WATER DISTRICT BULLETIN $51,1992$.

HISTORICAL POTENTIOMETRIC SURFACE OF THE EDWARDS-TRINITY AQUIFER SYSTEM AND CONTIGUOUS HYDRAULICALLY CONNECTED UNITS, WEST-CENTRAL TEXAS: USGS WATERRESOURCES INVESTIGATIONS REPORT 92-4055, 1993.

HISTORICAL SATURATED THICKNESS OF THE EDWARDS-TRINITY AQUIFER SYSTEM AND SELECTED CONTIGUOUS HYDRAULICALLY CONNECTED UNITS, WEST-CENTRAL TEXAS: USGS WATER-RESOURCES INVESTIGATIONS REPORT 92-4125, 1993.

EDWARDS AQUIFER HYDROGEOLOGIC STATUS REPORT FOR 1992: EDWARDS UNDERGROUND WATER DISTRICT REPORT 93-05, 1993.

SIMULATIONS OF FLOW IN THE EDWARDS-TRINITY AQUIFER SYSTEM AND CONTIGUOUS HYDRAULICALLY CONNECTED UNITS, WEST-CENTRAL TEXAS: USGS WATER-RESOURCES INVESTIGATIONS REPORT 93-4039, 1994.

DISSOLVED-SOLIDS CONCENTRATIONS AND HYDROCHEMICAL FACIES IN WATER OF THE EDWARDS-TRINITY AQUIFER SYSTEM, WEST-CENTRAL TEXAS: USGS WATER-RESOURCES INVESTIGATIONS REPORT 93-4126, 1994.

NATIONAL WATER-QUALITY ASSESSMENT PROGRAM-SOUTHCENTRAL TEXAS: USGS FACT SHEET FS-94-048, 1994.

GEOLOGIC HISTORY AND HYDROGEOLOGIC SETTING OF THE EDWARDS-TRINITY AQUIFER SYSTEM, WEST-CENTRAL TEXAS: USGS WATER-RESOURCES INVESTIGATIONS REPORT 94-4039, 1994.

WATER QUALITY IN THE EDWARDS-TRINITY (PLATEAU) AQUIFER, EDWARDS PLATEAU AND TRANS-PECOS, TEXAS: TEXAS WATER DEVELOPMENT BOARD HYDROLOGIC ATLAS NO. 3, 1995.

AQUIFERS OF TEXAS: TEXAS WATER DEVELOPMENT BOARD REPORT 345, 1995

HYDROGEOLOGIC FRAMEWORK OF THE EDWARDS-TRINITY AQUIFER SYSTEM, WEST-CENTRAL TEXAS: USGS PROFESSIONAL PAPER 1421-B, 1996

WATER QUALITY IN SOUTH-CENTRAL TEXAS-TEXAS, 1996-98: USGS CIRCULAR 1212, 2000.

AN OVERVIEW OF THE EDWARDS-TRINITY AQUIFER SYSTEM, CENTRAL-WEST TEXAS, CHAPTER 8 , in AQUIFERS OF WEST TEXAS : TEXAS WATER DEVELOPMENT BOARD REPORT 356, 2001

\section{ELLIS COUNTY}

GEOGRAPHY AND GEOLOGY OF THE BLACK AND GRAND PRAIRIES, TEXAS, WITH DETAILED DESCRIPTIONS OF THE CRETACEOUS FORMATIONS AND SPECIAL REFERENCE TO ARTESIAN WATERS: USGS 21ST ANNUAL REPORT, PART 7, 1901.

MEMORANDUM REGARDING MUNICIPAL WELLS AT WAXAHACHIE, TEXAS: USGS OPEN-FILE REPORT (UNNUMBERED), 1945.

PUBLIC WATER SUPPLIES IN EASTERN TEXAS: USGS WATERSUPPLY PAPER 1047, 1948.

RESULTS OF PUMPING TEST AT WAXAHACHIE, TEXAS: TEXAS BOARD OF WATER ENGINEERS MISCELLANEOUS PUBLICATION 292,1948

GROUND-WATER RESOURCES OF ELLIS COUNTY, TEXAS: TEXAS WATER DEVELOPMENT BOARD REPORT 62, 1967.

PROJECTED EFFECTS OF THE PROPOSED TENNESSEE COLONY RESERVOIR ON GROUND-WATER CONDITIONS IN THE CARRIZOWILCOX AQUIFER AND TRINITY RIVER ALLUVIUM, TRINIDADOAKWOOD AREA, TEXAS: USGS OPEN-FILE REPORT 74-297, 1974.

GROUND-WATER RESOURCES OF PART OF CENTRAL TEXAS WITH EMPHASIS ON THE ANTLERS AND TRAVIS PEAK FORMATIONS: TEXAS WATER DEVELOPMENT BOARD REPORT 195, V. 1, 1975.

GROUND-WATER RESOURCES OF PART OF CENTRAL TEXAS WITH EMPHASIS ON THE ANTLERS AND TRAVIS PEAK FORMATIONS: TEXAS WATER DEVELOPMENT BOARD REPORT 195, V. 2, 1976.

WATER-LEVEL AND WATER-QUALITY DATA FROM OBSERVATION WELLS IN NORTHEAST TEXAS: TEXAS WATER DEVELOPMENT BOARD REPORT 198, 1976.

OCCURRENCE, AVAILABILITY, AND CHEMICAL QUALITY OF GROUND WATER IN THE CRETACEOUS AQUIFERS OF NORTHCENTRAL TEXAS: TEXAS DEPARTMENT OF WATER RESOURCES REPORT 269, V. 1, 1982.

OCCURRENCE, AVAILABILITY, AND CHEMICAL QUALITY OF GROUND WATER IN THE CRETACEOUS AQUIFERS OF NORTHCENTRAL TEXAS: TEXAS DEPARTMENT OF WATER RESOURCES REPORT 269, V. 2, 1982

TEXAS GROUND-WATER RESOURCES, in NATIONAL WATER SUMMARY 1984: USGS WATER-SUPPLY PAPER 2275, 1985.

WATER USE, PROJECTED WATER REQUIREMENTS, AND RELATED DATA AND INFORMATION FOR THE METROPOLITAN STATISTICAL AREAS IN TEXAS: TEXAS DEPARTMENT OF WATER RESOURCES LIMITED PRINTING REPORT LP-201, 1985.

EVALUATION OF WATER RESOURCES IN PART OF NORTH-CENTRAL TEXAS: TEXAS WATER DEVELOPMENT BOARD REPORT 318, 1990.

NATIONAL WATER-QUALITY ASSESSMENT PROGRAM-THE TRINITY RIVER BASIN: USGS OPEN-FILE REPORT 91-158, 1991.

NATIONAL WATER-QUALITY ASSESSMENT PROGRAM-PESTICIDES IN THE TRINITY RIVER BASIN STUDY UNIT, TEXAS, 1968-91: USGS FACT SHEET FS-088-95, 1995.

WATER-QUALITY ASSESSMENT OF THE TRINITY RIVER BASIN, TEXAS-DATA COLLECTION, 1992-95: USGS FACT SHEET FS-095-95, 1995 
WATER-QUALITY ASSESSMENT OF THE TRINITY RIVER BASIN, TEXAS-PESTICIDES IN A SUBURBAN WATERSHED, ARLINGTON, 1993-94: USGS FACT SHEET FS-159-95, 1995.

AQUIFERS OF TEXAS: TEXAS WATER DEVELOPMENT BOARD REPORT 345, 1995.

UPDATED EVALUATION OF WATER RESOURCES IN PART OF NORTH-CENTRAL TEXAS, 1990-1999: TEXAS WATER DEVELOPMENT BOARD REPORT 349, 1999.

\section{ELPASO COUNTY}

A PRELIMINARY REPORT ON THE SOILS AND WATERS OF THE UPPER RIO GRANDE AND PECOS VALLEYS: GEOLOGICAL SURVEY OF TEXAS BULLETIN NO. 2, 1890.

FIELD MEASUREMENTS OF THE RATE OF MOVEMENT OF UNDERGROUND WATERS: USGS WATER-SUPPLY PAPER 140, 1905.

OBSERVATIONS ON THE GROUND WATERS OF THE RIO GRANDE VALLEY: USGS WATER-SUPPLY PAPER 141, 1905.

GEOLOGIC ATLAS OF THE UNITED STATES-EL PASO FOLIO, TEXAS: USGS GEOLOGIC FOLIO, 1914.

PUMPING TEST OF WELL AT SITE OF PROPOSED FEDERAL DETENTION PRISON ABOUT ONE MILE SOUTH OF LA TUNA, FOR BUREAU OF PRISONS, DEPARTMENT OF JUSTICE: USGS OPENFILE REPORT (UNNUMBERED), 1930.

AN INVESTIGATION OF THE UNDERGROUND WATER SUPPLY FOR EL PASO, TEXAS: USGS OPEN-FILE REPORT (UNNUMBERED), 1931.

THE GROUND-WATER RESOURCES OF THE EL PASO, TEXAS, AREA: USGS OPEN-FILE REPORT (UNNUMBERED), 1937.

ACCEPTANCE TEST OF WATER WELL U.S. DETENTION FARM, LA TUNA, TEXAS, OCTOBER 12-13, 1937: USGS OPEN-FILE REPORT (UNNUMBERED), 1937,

ESTIMATING SAFE YIELD AS ILLUSTRATED BY THE EL PASO, TEXAS, GROUND-WATER INVESTIGATION: ECONOMIC GEOLOGY, V. 33, NO. 7, 1938.

QUALITY OF WATER OF THE RIO GRANDE BASIN ABOVE FORT QUITMAN, TEXAS-ANALYTICAL DATA: USGS WATER-SUPPLY PAPER 839, 1938.

MEMORANDUM REGARDING THE EL PASO WATER SUPPLY: USGS OPEN-FILE REPORT (UNNUMBERED), 1940.

GROUND-WATER SUPPLIES OF THE EL PASO AREA, TEXAS: USGS OPEN-FILE REPORT (UNNUMBERED), 1940.

EL PASO WATER SUPPLY: USGS OPEN-FILE REPORT (UNNUMBERED), 1941.

MEMORANDUM REGARDING DEVELOPMENT OF A NEW WATER SUPPLY IN THE EL PASO AREA, TEXAS: USGS OPEN-FILE REPORT (UNNUMBERED), 1942.

PROGRESS REPORT ON THE GROUND-WATER SUPPLY OF THE EL PASO AREA, TEXAS: USGS OPEN-FILE REPORT (UNNUMBERED), 1944.

MEMORANDUM ON REMOVAL OF WATER FROM STORAGE ON THE MESA IN THE EL PASO AREA, TEXAS: USGS OPEN-FILE REPORT (UNNUMBERED), 1945.
LETTER REGARDING WATER SUPPLY OF EL PASO AND HUDSPETH COUNTIES WITH PARTICULAR REFERENCE TO THE AREA EAST AND NORTHEAST OF FABINS: USGS OPEN-FILE REPORT (UNNUMBERED), 1945.

MEMORANDUM ON GROUND-WATER RESOURCES OF THE EL PASO, TEXAS, AREA, PROGRESS REPORT: USGS OPEN-FILE REPORT (UNNUMBERED), 1945.

GROUND-WATER RESOURCES OF THE EL PASO AREA, TEXAS: USGS OPEN-FILE REPORT (UNNUMBERED), 1945.

GROUND-WATER RESOURCES OF THE EL PASO AREA, TEXAS: USGS WATER-SUPPLY PAPER 919, 1945.

GROUND-WATER RESOURCES OF THE EL PASO AREA, TEXAS, PROGRESS REPORT NO, 6: TEXAS BOARD OF WATER ENGINEERS MISCELLANEOUS PUBLICATION 79, 1949.

PUBLIC WATER SUPPLIES IN WESTERN TEXAS: USGS WATERSUPPLY PAPER 1106, 1951

GROUND WATER FOR IRRIGATION AT THE FEDERAL CORRECTIONAL INSTITUTION, LA TUNA, TEXAS: USGS OPEN-FILE REPORT (UNNUMBERED), 1952.

RESULTS OF ARTIFICIAL RECHARGE OF THE GROUND-WATER RESERVOIR AT EL PASO, TEXAS: TEXAS BOARD OF WATER ENGINEERS BULLETIN 5206, 1952.

MEMORANDUM ON FORT BLISS WATER SUPPLY WELLS 10, 11, 12, AND 13: USGS CONFIDENTIAL REPORT, 1954.

RECORDS OF WATER-LEVEL MEASUREMENTS IN EL PASO COUNTY, TEXAS: TEXAS BOARD OF WATER ENGINEERS BULLETIN 5417, 1954.

GROUND-WATER RESOURCES OF THE EL PASO DISTRICT, TEXAS, PROGRESS REPORT NO. 7: TEXAS BOARD OF WATER ENGINEERS BULLETIN 5603, 1956.

GROUND-WATER RESOURCES OF THE HUECO BOLSON, NORTHEAST OF EL PASO, TEXAS: TEXAS BOARD OF WATER ENGINEERS BULLETIN 5615, 1956.

MEMORANDUM ON GROUND-WATER CONDITIONS AND SUGGESTIONS FOR TEST DRILLING IN LOGAN HEIGHTS AREA, EL PASO, TEXAS: USGS OPEN-FILE REPORT (UNNUMBERED), 1957.

SUMMARY OF TEST DRILLING AND GROUND-WATER CONDITIONS IN THE McGREGOR RANGE AREA, OTERO AND DONA ANA COUNTIES, NEW MEXICO, AND EL PASO COUNTY, TEXAS: USGS OPENFILE REPORT (UNNUMBERED), 1957.

MEMORANDUM ON THE WATER-SUPPLY WELLS AT BIGGS AIR FORCE BASE, EL PASO, TEXAS: USGS OPEN-FILE REPORT (UNNUMBERED), 1957.

PRELIMINARY GEOHYDROLOGICAL STUDY OF THE JUAREZ VALLEY AND SURROUNDING AREAS, STATE OF CHIHUAHUA: BY ALFONSO DE LA O CARRENO, ENGINEER AND CONSULTING GEOLOGIST, MEXICO CITY, FED, DIST., DEPARTMENT OF WATER RESOURCES TECHNICAL ADVISORY MEMORANDUM NO. 13.6-18, AUGUST 1957.

RECORDS OF WELLS AND RESULTS OF EXPLORATORY DRILLING IN THE EL PASO VALLEY AND HUECO BOLSON SOUTHEAST OF EL PASO, TEXAS: USGS OPEN-FILE REPORT (UNNUMBERED), 1959. 
MEMORANDUM ON GROUND-WATER CONDITIONS AND SUGGESTIONS FOR TEST DRILLING ON THE LOGAN HEIGHTS AREA, EL PASO, TEXAS: USGS OPEN-FILE REPORT 60-091, 1960.

MEMORANDUM ON THE WATER-SUPPLY WELLS AT BIGGS AIR FORCE BASE, EL PASO, TEXAS: USGS OPEN-FILE REPORT 60-092, 1960.

DEVELOPMENT OF GROUND WATER IN THE EL PASO DISTRICT, TEXAS, 1955-60, PROGRESS REPORT NO. 8: TEXAS WATER COMMISSION BULLETIN 6204, 1962.

GROUND-WATER RESOURCES OF THE LOWER MESSILA VALLEY, TEXAS AND NEW MEXICO: TEXAS WATER COMMISSION BULLETIN 6203, 1962.

GROUND-WATER RESOURCES OF THE LOWER MESSILA VALLEY, TEXAS AND NEW MEXICO: USGS WATER-SUPPLY PAPER 1669-AA, 1963.

PUBLIC WATER SUPPLIES OF THE 100 LARGEST CITIES IN THE UNITED STATES: USGS WATER-SUPPLY PAPER 1812, 1964.

DEVELOPMENT OF GROUND WATER IN THE EL PASO DISTRICT, TEXAS, 1960-63, PROGRESS REPORT NO. 9: TEXAS WATER COMMISSION BULLETIN 6514, 1965.

RECONNAISSANCE INVESTIGATION OF THE GROUND-WATER RESOURCES OF THE RIO GRANDE BASIN, TEXAS: TEXAS WATER COMMISSION BULLETIN 6502, 1965.

AVAILABILITY OF GROUND WATER IN TULAROSA BASIN AND ADJOINING AREAS, NEW MEXICO AND TEXAS: USGS HYDROLOGIC INVESTIGATIONS ATLAS HA-191, 1965.

ANALOG MODEL STUDY OF THE HUECO BOLSON NEAR EL PASO TEXAS: TEXAS WATER DEVELOPMENT BOARD REPORT 28, 1966.

RESULTS OF GROUND-WATER STUDY IN CHAMIZAL SETTLEMENT AREA, EL PASO, TEXAS-CIUDAD JUAREZ, MEXICO, MEXICO AREA: USGS OPEN-FILE REPORT (UNNUMBERED), 1967.

USE OF WELLS TO LOWER THE WATER TABLE ALONG RELOCATED CHANNEL OF RIO GRANDE IN THE EL PASO, TEXAS-CIUDAD JUAREZ, MEXICO AREA: USGS OPEN-FILE REPORT (UNNUMBERED), 1967.

PRELIMINARY RESULTS OF THE INVESTIGATION OF THE SALINEWATER RESOURCES IN THE HUECO BOLSON NEAR EL PASO, TEXAS: USGS OPEN-FILE REPORT 67-79, 1967.

MEMORANDUM ON AVAILABILITY OF WATER HAVING LESS THAN 2,500 PARTS PER MILLION DISSOLVED SOLIDS IN ALLUVIUM OF RIO GRANDE NEAR EL PASO, TEXAS: USGS OPEN-FILE REPORT 67-68, 1967

A SEISMIC AND GRAVITY PROFILE ACROSS THE HUECO BOLSON, TEXAS: IN USGS PROFESSIONAL PAPER 575-D, 1967.

HYDROLOGIC EFFECTS OF THE EARTHQUAKE OF MARCH 27, 1964, OUTSIDE ALASKA: USGS PROFESSIONAL PAPER 544-C, 1968.

COMPILATION OF RESULTS OF AQUIFER TESTS IN TEXAS: TEXAS WATER DEVELOPMENT BOARD REPORT 98, 1969.

THE USE OF SCHLUMBERGER AND EQUATORIAL SOUNDINGS IN GROUND-WATER INVESTIGATIONS NEAR EL PASO, TEXAS: GEOPHYSICS, V. 34, NO. 5, OCTOBER 1969.

A PRELIMINARY ANALYSIS OF THE WATER BUDGET FOR THE EL PASO VALLEY, TEXAS, UNDER 1968 HYDROLOGIC CONDITIONS: USGS OPEN-FILE REPORT (UNNUMBERED), 1970.
WATER REQUIREMENTS AND AVAILABLE RESOURCES OF EL PASO, TEXAS: JOHN T. HICKERSON, GENERAL MANAGER, EL PASO WATER UTILITIES, AUGUST 15, 1971.

DEVELOPMENT OF GROUND WATER IN THE EL PASO DISTRICT, TEXAS, 1963-70: TEXAS WATER DEVELOPMENT BOARD REPORT $153,1972$.

PRELIMINARY GROUND-WATER MODEL OFTHE MESILLA VALLEY: PROCEEDINGS OF THE SEVENTEENTH ANNUAL NEW MEXICO WATER CONFERENCE, NEW MEXICO STATE UNIVERSITY, LAS CRUCES, NEW MEXICO, APRIL 6-7, 1972.

WATER RESOURCES OF EL PASO COUNTY, TEXAS: U.S. BUREAU OF RECLAMATION OPEN-FILE REPORT (UNNUMBERED), 1973.

WATER-BUDGET STUDIES OF LOWER MESILLA VALLEY AND EL PASO VALLEY, EL PASO COUNTY, TEXAS: USGS OPEN-FILE REPORT 73-185, 1973.

RECONNAISSANCE INVESTIGATION OF GROUND WATER IN THE RIO GRANDE DRAINAGE BASIN—WITH SPECIAL EMPHASIS ON SALINE GROUND-WATER RESOURCES: USGS HYDROLOGIC INVESTIGATIONS ATLAS HA-510, 1974.

QUALITY AND AVAILABILITY OF WATER IN WESTERNMOST TEXAS: USGS OPEN-FILE REPORT 75-133, 1975.

SUMMARY APPRAISALS OF THE NATION'S GROUND-WATER RESOURCES-RIO GRANDE REGION: USGS PROFESSIONAL PAPER 813-D, 1975.

SELECTED WATER WELL AND GROUND-WATER CHEMICAL ANALYSIS DATA, CIUDAD JUAREZ, CHIHUAHUA, MEXICO: TEXAS WATER DEVELOPMENT BOARD LIMITED DISTRIBUTION REPORT (UNNUMBERED), 1975.

WATER SUPPLY PROBLEMS IN THE EL PASO AREA, TEXAS: ROBERT L. BLUNTZER, ASCE IRRIGATION AND DRAINAGE SPECIALTY CONFERENCE, LOGAN, UTAH, AUGUST 13-15, 1975.

DIGITAL MODEL FOR SIMULATED EFFECTS OF GROUND-WATER PUMPING IN THE HUECO BOLSON, EL PASO AREA, TEXAS, NEW MEXICO, AND MEXICO: USGS WATER-RESOURCES INVESTIGATIONS REPORT 58-75, 1976.

SCHLUMBERGER SOUNDINGS IN THE LOWER MESILLA VALLEY OF THE RIO GRANDE, TEXAS AND NEW MEXICO: USGS OPEN-FILE REPORT 76-324, 1976.

HYDROLOGIC INTERPRETATION OF GEOPHYSICAL DATA FROM THE SOUTHEASTERN HUECO BOLSON, EL PASO AND HUDSPETH COUNTIES, TEXAS: USGS OPEN-FILE REPORT 76-650, 1976.

AVAILABILITY OF FRESH AND SLIGHTLY SALINE GROUND WATER IN THE BASINS OF WESTERNMOST TEXAS: USGS OPEN-FILE REPORT 78-663, 1978

SIMULATED EFFECTS OF GROUND-WATER PUMPING IN PORTIONS OF THE HUECO BOLSON IN TEXAS AND NEW MEXICO DURING THE PERIOD 1973 THROUGH 2029: TEXAS DEPARTMENT OF WATER RESOURCES LIMITED PRINTING REPORT LP-104, 1979.

GROUND-WATER AVAILABILITY IN TEXAS-ESTIMATES AND PROJECTIONS THROUGH 2030: TEXAS DEPARTMENT OF WATER RESOURCES REPORT 238, 1979.

GROUND-WATER DEVELOPMENT IN THE EL PASO REGION, TEXAS, WITH EMPHASIS ON THE LOWER EL PASO VALLEY: TEXAS DEPARTMENT OF WATER RESOURCES REPORT 246, 1980. 
AVAILABILITY OF FRESH AND SLIGHTLY SALINE GROUND WATER IN THE BASINS OF WESTERNMOST TEXAS: TEXAS DEPARTMENT OF WATER RESOURCES REPORT 256, 1980.

SPECIAL REPORT ON ELEPHANT BUTTE RESERVOIR-FORT QUITMAN PROJECT, NEW MEXICO-TEXAS (RIO GRANDE REGIONAL ENVIRONMENTAL PROJECT): UNITED STATES DEPARTMENT OF THE INTERIOR, WATER AND POWER RESOURCES SERVICE, 1980.

PLANNING REPORT FOR THE SOUTHWEST ALLUVIAL BASINS (EAST) REGIONAL AQUIFER SYSTEM ANALYSIS IN PARTS OF COLORADO, NEW MEXICO, AND TEXAS: USGS OPEN-FILE REPORT 80-564, 1980.

APPRAISAL OF POTENTIAL FOR INJECTION-WELL RECHARGE OF THE HUECO BOLSON WITH TREATED SEWAGE EFFLUENT-PRELIMINARY STUDY OF THE NORTHEAST EL PASO AREA, TEXAS: USGS OPEN-FILE REPORT 80-1106, 1980.

DRAFT ENVIRONMENTAL IMPACT STATEMENT, WASTEWATER TREATMENT FACILITIES, NORTHEAST EL PASO, TEXAS: ENVIRONMENTAL PROTECTION AGENCY, 1980.

DEGRADATION OF GROUND-WATER QUALITY IN THE VICINITY OF THE OLD MESA WELL FIELD NORTHEAST OF EL PASO, TEXAS: USGS PRELIMINARY OPEN-FILE REPORT, 1981.

SPRINGS OF TEXAS, VOLUME 1: (BY GUNNAR BRUNE), BRANCHSMITH, INC., FORT WORTH, TEXAS, 1981.

SUMMARY OF HYDROLOGIC INFORMATION IN THE EL PASO, TEXAS, AREA, WITH EMPHASIS ON GROUND-WATER STUDIES, 1903-80: USGS OPEN-FILE REPORT 83-775, 1983.

MAPS SHOWING GROUND-WATER UNITS AND WITHDRAWAL, BASIN AND RANGE PROVINCE, TEXAS: USGS WATERRESOURCES INVESTIGATIONS REPORT 83-4121-A, 1984.

MAPS SHOWING GROUND-WATER LEVELS, SPRINGS, AND DEPTH TO GROUND WATER, BASIN AND RANGE PROVINCE, TEXAS: USGS WATER-RESOURCES INVESTIGATIONS REPORT 83-4121-B, 1984.

MAPS SHOWING DISTRIBUTION OF DISSOLVED SOLIDS AND DOMINANT CHEMICAL TYPE IN GROUND WATER, BASIN AND RANGE PROVINCE, TEXAS: USGS WATER-RESOURCES INVESTIGATIONS REPORT 83-4121-C, 1984.

PRELIMINARY STUDY OF THE AQUIFERS OF THE LOWER MESILLA VALLEY IN TEXAS AND NEW MEXICO BY MODEL SIMULATION: USGS WATER-RESOURCES INVESTIGATIONS REPORT 84-4317, 1984.

WATER USE, PROJECTED WATER REQUIREMENTS, AND RELATED DATA AND INFORMATION FOR THE METROPOLITAN STATISTICAL AREAS IN TEXAS: TEXAS DEPARTMENT OF WATER RESOURCES LIMITED PRINTING REPORT LP-201, 1985.

A PRELIMINARY ASSESSMENT OF LAND-SURFACE SUBSIDENCE IN THE EL PASO AREA, TEXAS: USGS WATER-RESOURCES INVESTIGATIONS REPORT 85-4155, 1985.

TEXAS GROUND-WATER RESOURCES, in NATIONAL WATER SUMMARY 1984: USGS WATER-SUPPLY PAPER 2275, 1985.

SOUTHWEST ALLUVIAL-BASIN REGIONAL AQUIFER-SYSTEM STUDY IN PARTS OF COLORADO, NEW MEXICO, AND TEXAS, in REGIONAL AQUIFER-SYSTEM ANALYSIS PROGRAM OF THE U.S. GEOLOGICAL SURVEY-SUMMARY OF PROJECTS, 1978-84: USGS CIRCULAR 1002, 1986.
GEOHYDROLOGY OF THE SOUTHWEST ALLUVIAL BASINS, REGIONAL AQUIFER-SYSTEM ANALYSIS IN PARTS OF COLORADO, NEW MEXICO, AND TEXAS: USGS WATER-RESOURCES INVESTIGATIONS REPORT 84-4224, 1986.

SUMMARY OF HYDROLOGIC INFORMATION IN THE EL PASO, TEXAS, AREA, WITH EMPHASIS ON GROUND-WATER STUDIES, 1903-80: TEXAS WATER DEVELOPMENT BOARD REPORT 300, 1987.

PUBLIC SUPPLY GROUND-WATER USE IN WESTERN TEXAS: TEXAS WATER DEVELOPMENT BOARD REPORT 311, 1989.

GROUND WATER CONDITIONS AND RESOURCES IN EL PASO/JUAREZ VALLEY: INTERNATIONAL BOUNDARY AND WATER COMMISSION, U.S. SECTION, NOVEMBER 1989.

INTEGRATION OF GROUND-WATER AND VADOSE-ZONE GEOCHEMISTRY TO INVESTIGATE HYDROCHEMICAL EVOLUTION-A CASE STUDY IN ARID LANDS OF THE NORTHERN CHIHUAHUAN DESERT, TRANS-PECOS TEXAS: UNIVERSITY OF TEXAS, BUREAU OF ECONOMIC GEOLOGY GEOLOGICAL CIRCULAR 90-5, 1990.

SUMMARY OF DATA FROM THE 1981-83 PILOT STUDY AND 1985-89 OPERATIONS OF THE HUECO BOLSON RECHARGE PROJECT, NORTHEAST EL PASO, TEXAS: USGS OPEN-FILE REPORT 90-175, 1990.

EVALUATION OF GROUND-WATER RESOURCES IN EL PASO COUNTY, TEXAS: TEXAS WATER DEVELOPMENT BOARD REPORT 324, 1990.

THE DRYING UP OF EL PASO: TEXAS STATE SECTION OF THE AMERICAN WATER RESOURCES ASSOCIATION, TRIGG TWICHELL SYMPOSIUM, FALL MEETING, NOVEMBER 8, 1991, AUSTIN, TEXAS, 1991.

SATURATED-ZONE HYDROLOGY AND HYDROCHEMISTRY OF THE NORTHERN CHIHUAHUAN DESERT, TRANS-PECOS TEXAS: WEST TEXAS GEOLOGICAL SOCIETY BULLETIN, V. 30, NO. 9, MAY 1991.

RESULTS OF SIMULATIONS BY A PRELIMINARY NUMERICAL MODEL OF LAND SUBSIDENCE IN THE EL PASO, TEXAS, AREA: USGS WATER-RESOURCES INVESTIGATIONS REPORT 92-4037, 1992.

GEOHYDROLOGY AND SIMULATION OF GROUND-WATER FLOW IN THE MESILLA BASIN, DONA ANA COUNTY, NEW MEXICO AND EL PASO COUNTY, TEXAS, WITH A SECTION ON WATER QUALITY AND GEOCHEMISTRY: USGS PROFESSIONAL PAPER 1407-C, 1992.

WATER-RESOURCES DATA, TEXAS, WATER YEAR 1991, VOLUME 4, GROUND-WATER DATA: USGS WATER-DATA REPORT TX-91-4, 1992.

WATER-RESOURCES DATA, TEXAS, WATER YEAR 1992, VOLUME 4, GROUND-WATER DATA: USGS WATER-DATA REPORT TX-92-4, 1993.

SIMULATION OF GROUND-WATER FLOW AND MOVEMENT OF SALINE WATER IN THE HUECO BOLSON AQUIFER, EL PASO, TEXAS, AND ADJACENT AREAS: USGS OPEN-FILE REPORT 92-171, 1994.

HYDROGEOLOGIC AND WATER-QUALITY DATA NEAR THE HUECO BOLSON RECHARGE PROJECT AREA, EL PASO, TEXAS, 1990 AND 1991: USGS OPEN-FILE REPORT 94-329, 1994. 
HYDROGEOLOGY AND SELECTED WATER-QUALITY ASPECTS OF THE HUECO BOLSON AQUIFER AT THE HUECO BOLSON RECHARGE PROJECT AREA, EL PASO, TEXAS: USGS WATERRESOURCES INVESTIGATIONS REPORT 94-4092, 1994.

WATER-RESOURCES DATA, TEXAS, WATER YEAR 1993, VOLUME 4, GROUND-WATER DATA: USGS WATER-DATA REPORT TX-93-4, 1994.

AQUIFERS OF TEXAS: TEXAS WATER DEVELOPMENT BOARD REPORT 345, 1995.

WATER-RESOURCES DATA, TEXAS, WATER YEAR 1994, VOLUME 4 , GROUND-WATER DATA: USGS WATER-DATA REPORT TX-94-4, 1995.

WATER-RESOURCES DATA, TEXAS, WATER YEAR 1995, VOLUME 4, GROUND-WATER DATA: USGS WATER-DATA REPORT TX-95-4, 1996.

HYDROLOGY OF THE SHALLOW AQUIFER AND UPPERMOST SEMICONFINED AQUIFER NEAR EL PASO, TEXAS: USGS WATERRESOURCES INVESTIGATIONS REPORT 97-4263, 1997.

WATER-RESOURCES DATA, TEXAS, WATER YEAR 1996, VOLUME 4, GROUND-WATER DATA: USGS WATER-DATA REPORT TX-96-4, 1997.

CHANGES IN GROUND-WATER CONDITIONS IN EL PASO COUNTY, TEXAS: TEXAS WATER DEVELOPMENT BOARD OPEN-FILE REPORT OFR98-02, 1998.

WATER-RESOURCES DATA, TEXAS, WATER YEAR 1997, VOLUME 4, GROUND-WATER DATA: USGS WATER-DATA REPORT TX-97-4, 1998.

WATER-RESOURCES DATA, TEXAS, WATER YEAR 1998, VOLUME 4, GROUND-WATER DATA: USGS WATER-DATA REPORT TX-98-4, 1999.

WATER-RESOURCES DATA, TEXAS, WATER YEAR 1999, VOLUME 6 , GROUND-WATER DATA: USGS WATER-DATA REPORT TX-99-6, 2000 .

AQUIFERS OF WEST TEXAS: TEXAS WATER DEVELOPMENT BOARD REPORT 356, 2001

EVALUATION OF GROUND-WATER RECHARGE IN BASINS OF TRANS-PECOS TEXAS, CHAPTER 3, in AQUIFERS OF WEST TEXAS: TEXAS WATER DEVELOPMENT BOARD REPORT 356, 2001.

REGIONAL GROUND-WATER FLOW SYSTEMS IN TRANS-PECOS TEXAS, CHAPTER 4, in AQUIFERS OF WEST TEXAS: TEXAS WATER DEVELOPMENT BOARD REPORT 356, 2001

THE HUECO BOLSON: AN AQUIFER AT THE CROSSROADS, CHAPTER 6, in AQUIFERS OF WEST TEXAS: TEXAS WATER DEVELOPMENT BOARD REPORT 356, 2001.

THE MESILLA BASIN AQUIFER SYSTEM OF NEW MEXICO, WEST TEXAS, AND CHIHUAHUA-AN OVERVIEW OF ITS HYDROGEOLOGIC FRAMEWORK AND RELATED ASPECTS OF GROUNDWATER FLOW AND CHEMISTRY, CHAPTER 7, in AQUIFERS OF WEST TEXAS: TEXAS WATER DEVELOPMENT BOARD REPORT 356,2001

WATER-RESOURCES DATA, TEXAS, WATER YEAR 2000, VOLUME 6, GROUND-WATER DATA: USGS WATER-DATA REPORT TX-00-6, 2001.

\section{ERATH COUNTY}

GEOGRAPHY AND GEOLOGY OF THE BLACK AND GRAND PRAIRIES, TEXAS, WITH DETAILED DESCRIPTIONS OF THE CRETACEOUS FORMATIONS AND SPECIAL REFERENCE TO ARTESIAN WATERS: USGS 21ST ANNUAL REPORT, PART 7, 1901.

GROUND-WATER RESOURCES IN SELECTED AREAS IN ERATH, HOOD, AND HAMILTON COUNTIES, TEXAS: USGS OPEN-FILE REPORT (UNNUMBERED), 1942

SUPPLEMENT, GROUND-WATER RESOURCES IN SELECTED AREAS IN ERATH, HOOD, AND HAMILTON COUNTIES, TEXAS: USGS OPEN-FILE REPORT (UNNUMBERED), 1942.

SUPPLEMENTARY MEMORANDUM, AREAS 2 AND 3, NORTH OF STEPHENVILLE, ERATH COUNTY, TEXAS: USGS OPEN-FILE REPORT (UNNUMBERED), 1942

PUBLIC WATER SUPPLIES IN CENTRAL AND NORTH-CENTRAL TEXAS: USGS WATER-SUPPLY PAPER 1069, 1949.

RECONNAISSANCE INVESTIGATION OF THE GROUND-WATER RESOURCES OF THE BRAZOS RIVER BASIN, TEXAS: TEXAS WATER COMMISSION BULLETIN 6310, 1963.

COMPILATION OF RESULTS OF AQUIFER TESTS IN TEXAS: TEXAS WATER DEVELOPMENT BOARD REPORT 98, 1969.

GROUND-WATER RESOURCES OF PART OF CENTRAL TEXAS WITH EMPHASIS ON THE ANTLERS AND TRAVIS PEAK FORMATIONS: TEXAS WATER DEVELOPMENT BOARD REPORT 195, V. 1, 1975.

GROUND-WATER RESOURCES OF PART OF CENTRAL TEXAS WITH EMPHASIS ON THE ANTLERS AND TRAVIS PEAK FORMATIONS: TEXAS WATER DEVELOPMENT BOARD REPORT 195, V. 2, 1976.

TEXAS GROUND-WATER RESOURCES, in NATIONAL WATER SUMMARY 1984: USGS WATER-SUPPLY PAPER 2275, 1985.

GROUND-WATER RESOURCES OF THE ANTLERS AND TRAVIS PEAK FORMATIONS IN THE OUTCROP OF NORTH-CENTRAL TEXAS: TEXAS WATER DEVELOPMENT BOARD REPORT 298, 1987.

EVALUATION OF WATER RESOURCES IN PART OF CENTRAL TEXAS: TEXAS WATER DEVELOPMENT BOARD REPORT 319 , 1990.

GROUND-WATER QUALITY MONITORING OF THE TRINITY AQUIFER IN THE VICINITY OF ERATH COUNTY: TEXAS WATER DEVELOPMENT BOARD REPORT 331, 1991.

EVALUATION OF WATER RESOURCES IN PARTS OF THE ROLLING PRAIRIES REGION OF NORTH-CENTRAL TEXAS: TEXAS WATER DEVELOPMENT BOARD REPORT 337, 1992.

AQUIFERS OF TEXAS: TEXAS WATER DEVELOPMENT BOARD REPORT 345, 1995.

WATER-RESOURCES DATA, TEXAS, WATER YEAR 2000, VOLUME 6, GROUND-WATER DATA: USGS WATER-DATA REPORT TX-00-6, 2001.

\section{FALLS COUNTY}

GEOGRAPHY AND GEOLOGY OF THE BLACK AND GRAND PRAIRIES, TEXAS, WITH DETAILED DESCRIPTIONS OF THE CRETA- 
CEOUS FORMATIONS AND SPECIAL REFERENCE TO ARTESIAN WATERS: USGS 21ST ANNUAL REPORT, PART 7, 1901.

GEOLOGY AND UNDERGROUND WATERS OF THE SOUTHEASTERN PART OF THE TEXAS COASTAL PLAIN: USGS WATER-SUPPLY PAPER 335, 1914.

PUBLIC WATER SUPPLIES IN EASTERN TEXAS: USGS WATERSUPPLY PAPER 1047, 1948.

GROUND-WATER RESOURCES OF THE FLOOD-PLAIN ALLUVIUM OF THE BRAZOS RIVER, WHITNEY DAM TO VICINITY OF RICHMOND, TEXAS: TEXAS WATER DEVELOPMENT BOARD REPORT 41, 1967.

GROUND-WATER RESOURCES OF PART OF CENTRAL TEXAS WITH EMPHASIS ON THE ANTLERS AND TRAVIS PEAK FORMATIONS: TEXAS WATER DEVELOPMENT BOARD REPORT 195, V. 1, 1975.

GROUND-WATER RESOURCES OF PART OF CENTRAL TEXAS WITH EMPHASIS ON THE ANTLERS AND TRAVIS PEAK FORMATIONS: TEXAS WATER DEVELOPMENT BOARD REPORT 195, V. 2, 1976.

TEXAS GROUND-WATER RESOURCES, in NATIONAL WATER SUMMARY 1984: USGS WATER-SUPPLY PAPER 2275, 1985.

APPROXIMATE POTENTIOMETRIC SURFACES FOR THE AQUIFERS OF THE TEXAS COASTAL UPLANDS SYSTEM, 1980: USGS HYDROLOGIC INVESTIGATIONS ATLAS HA-704, 1987.

GEOHYDROLOGIC FRAMEWORK OF THE GULF COASTAL PLAIN: USGS HYDROLOGIC INVESTIGATIONS ATLAS HA-695, 1988.

A HYDROGEOLOGIC ASSESSMENT OF THE OZAN FORMATION, CENTRAL TEXAS: BAYLOR GEOLOGICAL STUDIES (THESIS ABSTRACTS), BAYLOR UNIVERSITY, WACO, TEXAS, 1989.

EVALUATION OF WATER RESOURCES IN PART OF CENTRAL TEXAS: TEXAS WATER DEVELOPMENT BOARD REPORT 319, 1990.

GROUND-WATER RESOURCES OF THE CARRIZO-WILCOX AQUIFER IN THE CENTRAL TEXAS REGION: TEXAS WATER DEVELOPMENT BOARD REPORT 332, 1991.

PROPERTIES AND CHEMICAL CONSTITUENTS IN GROUND WATER FROM THE MIDDLE WILCOX AQUIFER, GULF COAST REGIONAL AQUIFER SYSTEMS, SOUTH-CENTRAL UNITED STATES: USGS WATER-RESOURCES INVESTIGATIONS REPORT 93-4070, 1993.

WATER QUALITY IN THE WOODBINE AQUIFER, NORTH-CENTRAL TEXAS: TEXAS WATER DEVELOPMENT BOARD HYDROLOGIC ATLAS NO. 4, 1996.

\section{FANNIN COUNTY}

GEOGRAPHY AND GEOLOGY OF THE BLACK AND GRAND PRAIRIES, TEXAS, WITH DETAILED DESCRIPTIONS OF THE CRETACEOUS FORMATIONS AND SPECIAL REFERENCE TO ARTESIAN WATERS: USGS 21ST ANNUAL REPORT, PART 7, 1901.

PUBLIC WATER SUPPLIES IN EASTERN TEXAS: USGS WATERSUPPLY PAPER 1047, 1948.

GROUND WATER IN NORTHWESTERN FANNIN COUNTY, TEXAS: USGS OPEN-FILE REPORT (UNNUMBERED), 1950.

RECONNAISSANCE INVESTIGATION OF THE GROUND-WATER RESOURCES OF THE RED RIVER, SULPHUR RIVER, AND CYPRESS
CREEK BASINS, TEXAS: TEXAS WATER COMMISSION BULLETIN 6306, 1963.

OCCURRENCE, AVAILABILITY, AND CHEMICAL QUALITY OF GROUND WATER IN THE CRETACEOUS AQUIFERS OF NORTHCENTRAL TEXAS: TEXAS DEPARTMENT OF WATER RESOURCES REPORT 269, V. 1, 1982.

OCCURRENCE, AVAILABILITY, AND CHEMICAL QUALITY OF GROUND WATER IN THE CRETACEOUS AQUIFERS OF NORTHCENTRAL TEXAS: TEXAS DEPARTMENT OF WATER RESOURCES REPORT 269, V. 2, 1982.

EVALUATION OF WATER RESOURCES IN PART OF NORTH-CENTRAL TEXAS: TEXAS WATER DEVELOPMENT BOARD REPORT 318, 1990.

COMPILATION OF RESULTS OF AQUIFER TESTS IN TEXAS: TEXAS WATER DEVELOPMENT BOARD REPORT 98, 1969.

WATER-LEVEL AND WATER-QUALITY DATA FROM OBSERVATION WELLS IN NORTHEAST TEXAS: TEXAS WATER DEVELOPMENT BOARD REPORT 198, 1976

SPRINGS OF TEXAS, VOLUME 1: (BY GUNNAR BRUNE), BRANCHSMITH, INC., FORT WORTH, TEXAS, 1981.

TEXAS GROUND-WATER RESOURCES, in NATIONAL WATER SUMMARY 1984: USGS WATER-SUPPLY PAPER 2275, 1985.

NATIONAL WATER-QUALITY ASSESSMENT PROGRAM-THE TRINITY RIVER BASIN: USGS OPEN-FILE REPORT 91-158, 1991.

SIMULATION OF GROUND-WATER FLOW IN THE ANTLERS AQUIFER IN SOUTHEASTERN OKLAHOMA AND NORTHEASTERN TEXAS: USGS WATER-RESOURCES INVESTIGATIONS REPORT 88-4208, 1992.

AQUIFERS OF TEXAS: TEXAS WATER DEVELOPMENT BOARD REPORT 345, 1995.

NATIONAL WATER-QUALITY ASSESSMENT PROGRAM-PESTICIDES IN THE TRINITY RIVER BASIN STUDY UNIT, TEXAS, 1968-91: USGS FACT SHEET FS-088-95, 1995.

WATER-QUALITY ASSESSMENT OF THE TRINITY RIVER BASIN, TEXAS-DATA COLLECTION, 1992-95: USGS FACT SHEET FS-095-95, 1995.

WATER-QUALITY ASSESSMENT OF THE TRINITY RIVER BASIN, TEXAS-PESTICIDES IN A SUBURBAN WATERSHED, ARLINGTON, 1993-94: USGS FACT SHEET FS-159-95, 1995.

WATER QUALITY IN THE WOODBINE AQUIFER, NORTH-CENTRAL TEXAS: TEXAS WATER DEVELOPMENT BOARD HYDROLOGIC ATLAS NO. 4, 1996.

UPDATED EVALUATION OF WATER RESOURCES IN PART OF NORTH-CENTRAL TEXAS, 1990-1999: TEXAS WATER DEVELOPMENT BOARD REPORT 349, 1999.

\section{FAYETTE COUNTY}

UNDERGROUND WATERS OF COASTAL PLAIN OF TEXAS: USGS WATER-SUPPLY AND IRRIGATION PAPER 190, 1907.

GROUND WATER IN WEST POINT-FLATONIA AREA, FAYETTE COUNTY, TEXAS: USGS OPEN-FILE REPORT (UNNUMBERED), 1942. 
RECORDS OF WELLS, DRILLERS' LOGS, WATER ANALYSES, AND MAP SHOWING LOCATIONS OF WELLS IN FAYETTE COUNTY, TEXAS: TEXAS BOARD WATER ENGINEERS MISCELLANEOUS PUBLICATION 80, 1943.

PUBLIC WATER SUPPLIES IN EASTERN TEXAS: USGS WATERSUPPLY PAPER 1047, 1948.

EXPLORATORY WELL DRILLING AT LA GRANGE: USGS OPEN-FILE REPORT (UNNUMBERED), 1951.

GEOLOGY AND GROUND-WATER CONDITIONS IN THE FLATONIA AREA, FAYETTE COUNTY, TEXAS: USGS OPEN-FILE REPORT (UNNUMBERED), 1951.

RECONNAISSANCE INVESTIGATION OF THE GROUND-WATER RESOURCES OF THE GUADALUPE, SAN ANTONIO, AND NUECES RIVER BASINS, TEXAS: TEXAS WATER COMMISSION BULLETIN 6409, 1964.

RECONNAISSANCE INVESTIGATION OF THE GROUND-WATER RESOURCES OF THE COLORADO RIVER BASIN, TEXAS: TEXAS WATER DEVELOPMENT BOARD REPORT 51, 1967.

AVAILABILITY AND QUALITY OF GROUND WATER IN FAYETTE COUNTY, TEXAS: TEXAS WATER DEVELOPMENT BOARD REPORT 56, 1967.

HYDROLOGIC SIGNIFICANCE OF THE LITHOFACIES OF THE SPARTA SAND IN ARKANSAS, LOUISIANA, MISSISSIPPI, AND TEXAS: USGS PROFESSIONAL PAPER 569-A, 1968.

GEOHYDROLOGIC SIGNIFICANCE OF LITHOFACIES OF THE COCKFIELD FORMATION OF LOUISIANA AND MISSISSIPPI AND OF THE YEGUA FORMATION OF TEXAS: USGS PROFESSIONAL PAPER 569-B, 1970.

HYDROLOGIC SIGNIFICANCE OF LITHOFACIES OF THE CANE RIVER FORMATION OR EQUIVALENTS OF ARKANSAS, LOUISIANA, MISSISSIPPI, AND TEXAS: USGS PROFESSIONAL PAPER 569-C, 1972.

MAJOR AND HISTORICAL SPRINGS OF TEXAS: TEXAS WATER DEVELOPMENT BOARD REPORT 189, 1975.

GEOHYDROLOGIC SIGNIFICANCE OF LITHOFACIES OF THE CARRIZO SAND OF ARKANSAS, LOUISIANA, AND TEXAS AND THE MERIDIAN SAND OF MISSISSIPPI: USGS PROFESSIONAL PAPER 569-D, 1975.

STRATIGRAPHIC AND HYDROGEOLOGIC FRAMEWORK OF PART OF THE COASTAL PLAIN OF TEXAS: TEXAS DEPARTMENT OF WATER RESOURCES REPORT 236, 1979.

SPRINGS OF TEXAS, VOLUME 1: (BY GUNNAR BRUNE), BRANCHSMITH, INC., FORT WORTH, TEXAS, 1981.

ALTITUDE OF THE WATER TABLE IN THE ALLUVIAL AND OTHER SHALLOW AQUIFERS ALONG THE COLORADO RIVER NEAR LA GRANGE, TEXAS, DECEMBER 1980: USGS OPEN-FILE REPORT 81-1063, 1981.

REGIONAL HYDRODYNAMICS AND HYDROCHEMISTRY OF THE URANIUM-BEARING OAKVILLE AQUIFER (MIOCENE) OF SOUTH TEXAS: UNIVERSITY OF TEXAS, BUREAU OF ECONOMIC GEOLOGY REPORT OF INVESTIGATIONS NO. 124, 1982.

TEXAS GROUND-WATER RESOURCES, in NATIONAL WATER SUMMARY 1984: USGS WATER-SUPPLY PAPER 2275, 1985.
APPROXIMATE POTENTIOMETRIC SURFACES FOR THE AQUIFERS OF THE TEXAS COASTAL UPLANDS SYSTEM, 1980: USGS HYDROLOGIC INVESTIGATIONS ATLAS HA-704, 1987.

GEOHYDROLOGIC FRAMEWORK OF THE GULF COASTAL PLAIN: USGS HYDROLOGIC INVESTIGATIONS ATLAS HA-695, 1988.

FLOW PATTERN IN REGIONAL AQUIFERS AND FLOW RELATIONS BETWEEN THE LOWER COLORADO RIVER VALLEY AND REGIONAL AQUIFERS IN SIX COUNTIES OF SOUTHEASTERN TEXAS: USGS WATER-RESOURCES INVESTIGATIONS REPORT 88-4154, 1989.

A DIGITAL MODEL OF THE CARRIZO-WILCOX AQUIFER WITHIN THE COLORADO RIVER BASIN OF TEXAS: TEXAS WATER DEVELOPMENT BOARD LIMITED PUBLICATION REPORT LP-208, 1989.

GROUND-WATER RESOURCES OF THE CARRIZO-WILCOX AQUIFER IN THE CENTRAL TEXAS REGION: TEXAS WATER DEVELOPMENT BOARD REPORT 332, 1991

PROPERTIES AND CHEMICAL CONSTITUENTS IN GROUND WATER FROM THE UPPER CLAIBORNE AQUIFER, GULF COAST REGIONAL AQUIFER SYSTEMS, SOUTH-CENTRAL UNITED STATES: USGS WATER-RESOURCES INVESTIGATIONS REPORT 91-4150, 1993.

PROPERTIES AND CHEMICAL CONSTITUENTS IN GROUND WATER FROM PERMEABLE ZONE C (LOWER PLIOCENE-UPPER MIOCENE DEPOSITS), COASTAL LOWLANDS AQUIFER SYSTEM, SOUTHCENTRAL UNITED STATES: USGS WATER-RESOURCES INVESTIGATIONS REPORT 91-4151, 1993.

PROPERTIES AND CHEMICAL CONSTITUENTS IN GROUND WATER FROM THE LOWER CLAIBORNE-UPPER WILCOX AQUIFER, GULF COAST REGIONAL AQUIFER SYSTEMS, SOUTH-CENTRAL UNITED STATES: USGS WATER-RESOURCES INVESTIGATIONS REPORT 92-4102, 1993

PROPERTIES AND CHEMICAL CONSTITUENTS IN GROUND WATER FROM PERMEABLE ZONE E (LOWER MIOCENE-UPPER OLIGOCENE DEPOSITS), COASTAL LOWLANDS AQUIFER SYSTEM, SOUTH-CENTRAL UNITED STATES: USGS WATER-RESOURCES INVESTIGATIONS REPORT 92-4103, 1993.

PROPERTIES AND CHEMICAL CONSTITUENTS IN GROUND WATER FROM THE MIDDLE CLAIBORNE AQUIFER, GULF COAST REGIONAL AQUIFER SYSTEMS, SOUTH-CENTRAL UNITED STATES: USGS WATER-RESOURCES INVESTIGATIONS REPORT 92-4104, 1993.

PROPERTIES AND CHEMICAL CONSTITUENTS IN GROUND WATER FROM PERMEABLE ZONE D (MIDDLE MIOCENE DEPOSITS), COASTAL LOWLANDS AQUIFER SYSTEM, SOUTH-CENTRAL UNITED STATES: USGS WATER-RESOURCES INVESTIGATIONS REPORT 92-4105, 1993.

PROPERTIES AND CHEMICAL CONSTITUENTS IN GROUND WATER FROM THE MIDDLE WILCOX AQUIFER, GULF COAST REGIONAL AQUIFER SYSTEMS, SOUTH-CENTRAL UNITED STATES: USGS WATER-RESOURCES INVESTIGATIONS REPORT 93-4070, 1993.

AQUIFERS OF TEXAS: TEXAS WATER DEVELOPMENT BOARD REPORT 345, 1995.

STRATIGRAPHIC NOMENCLATURE AND GEOLOGIC SECTIONS OF THE GULF COASTAL PLAIN OF TEXAS: USGS OPEN-FILE REPORT 94-461, 1995. 
WATER QUALITY IN THE SPARTA AQUIFER, EAST TEXAS: TEXAS WATER DEVELOPMENT BOARD HYDROLOGIC ATLAS NO. 5, 1996.

WATER QUALITY IN THE QUEEN CITY AQUIFER, EAST TEXAS: TEXAS WATER DEVELOPMENT BOARD HYDROLOGIC ATLAS NO. 6, 1996

HYDROGEOLOGIC FRAMEWORK AND GEOCHEMISTRY OF THE EDWARDS AQUIFER SALINE-WATER ZONE, SOUTH-CENTRAL TEXAS: USGS WATER-RESOURCES INVESTIGATIONS REPORT 97-4133, 1997.

GROUND-WATER AVAILABILITY IN THE CARRIZO-WILCOX AQUIFER IN CENTRAL TEXAS-NUMERICAL SIMULATIONS OF 2000 THROUGH 2050 WITHDRAWAL PROJECTIONS: UNIVERSITY OF TEXAS, BUREAU OF ECONOMIC GEOLOGY REPORT OF INVESTIGATIONS NO. 256, 1999.

\section{FISHER COUNTY}

GROUND-WATER CONDITIONS IN THE ROBY-CAMP SPRINGS AREA, TEXAS: USGS OPEN-FILE REPORT (UNNUMBERED), 1944.

PUBLIC WATER SUPPLIES IN WESTERN TEXAS: USGS WATERSUPPLY PAPER 1106, 1951

RECONNAISSANCE OF SOIL DAMAGE AND GROUND-WATER QUALITY, FISHER COUNTY, TEXAS: TEXAS WATER COMMISSION MEMORANDUM REPORT MR-63-02, 1963.

RECONNAISSANCE INVESTIGATION OF THE GROUND-WATER RESOURCES OF THE BRAZOS RIVER BASIN, TEXAS: TEXAS WATER COMMISSION BULLETIN 6310, 1963.

TEXAS GROUND-WATER RESOURCES, in NATIONAL WATER SUMMARY 1984: USGS WATER-SUPPLY PAPER 2275, 1985.

EVALUATION OF WATER RESOURCES IN PARTS OF THE ROLLING PRAIRIES REGION OF NORTH-CENTRAL TEXAS: TEXAS WATER DEVELOPMENT BOARD REPORT 337, 1992.

AQUIFERS OF TEXAS: TEXAS WATER DEVELOPMENT BOARD REPORT 345, 1995.

\section{FLOYD COUNTY}

GEOLOGY AND GROUND-WATER RESOURCES OF THE SOUTHERN HIGH PLAINS: USGS OPEN-FILE REPORT (UNNUMBERED), 1935.

GROUND WATER IN THE SOUTHERN HIGH PLAINS: USGS OPENFILE REPORT (UNNUMBERED), 1937.

RECORDS OF WELLS AND SPRINGS, DRILLERS' LOGS, AND WATER ANALYSES AND MAP SHOWING LOCATION OF WELLS AND SPRINGS IN FLOYD COUNTY, TEXAS: TEXAS BOARD OF WATER ENGINEERS MISCELLANEOUS PUBLICATION 82, 1938.

GROUND WATER IN THE HIGH PLAINS IN TEXAS (1940): TEXAS BOARD OF WATER ENGINEERS MISCELLANEOUS PUBLICATION M119, 1940

GROUND WATER IN THE HIGH PLAINS IN TEXAS, PROGRESS REPORT (1943): TEXAS BOARD OF WATER ENGINEERS MISCELLANEOUS PUBLICATION M120, 1943.
GROUND WATER IN THE HIGH PLAINS IN TEXAS, PROGRESS REPORT (1944): TEXAS BOARD OF WATER ENGINEERS MISCELLANEOUS PUBLICATION M121, 1944.

GROUND WATER IN THE HIGH PLAINS IN TEXAS, PROGRESS REPORT NO. 5: TEXAS BOARD OF WATER ENGINEERS MISCELLANEOUS PUBLICATION M122, 1945.

RECORDS OF WELLS, DRILLERS' LOGS, WATER ANALYSES, AND MAP SHOWING LOCATIONS OF WELLS IN FLOYD COUNTY, TEXAS: TEXAS BOARD OF WATER ENGINEERS MISCELLANEOUS PUBLICATION 83, 1946.

GROUND WATER IN THE HIGH PLAINS IN TEXAS, PROGRESS REPORT NO. 6: TEXAS BOARD OF WATER ENGINEERS MISCELLANEOUS PUBLICATION M123, 1947.

GEOLOGY AND GROUND WATER IN THE IRRIGATED REGION OF THE SOUTHERN HIGH PLAINS IN TEXAS, PROGRESS REPORT NO. 7: TEXAS BOARD OF WATER ENGINEERS MISCELLANEOUS PUBLICATION M125, 1949.

COST OF PUMPING WATER FOR IRRIGATION, TEXAS HIGH PLAINS, FIELD INVESTIGATION_1947 IRRIGATION SEASON: TEXAS BOARD OF WATER ENGINEERS MISCELLANEOUS PUBLICATION M124, 1951.

DEVELOPMENT OF WELLS FOR IRRIGATION AND FLUCTUATION OF WATER LEVELS IN THE HIGH PLAINS OF TEXAS TO JANUARY 1951: TEXAS BOARD OF WATER ENGINEERS BULLETIN 5104, 1951.

PUBLIC WATER SUPPLIES IN WESTERN TEXAS: USGS WATERSUPPLY PAPER 1106, 1951 [1952].

RECORDS OF WATER-LEVEL MEASUREMENTS IN FLOYD COUNTY, TEXAS, 1913-1953: TEXAS BOARD OF WATER ENGINEERS BULLETIN 5304, 1953

WATER-LEVEL DECLINE MAPS OF 6 COUNTIES IN THE SOUTHERN HIGH PLAINS, TEXAS, JANUARY 1953 TO JANUARY 1954: (DEAF SMITH, FLOYD, HALE, LAMB, LUBBOCK, AND SWISHER): USGS OPEN-FILE REPORT, 1954.

SUMMARY OF GROUND-WATER DEVELOPMENT IN THE SOUTHERN HIGH PLAINS, TEXAS: TEXAS BOARD OF WATER ENGINEERS BULLETIN 5402, 1954

GROUND-WATER DEVELOPMENT IN THE SOUTHERN HIGH PLAINS OF TEXAS, 1953: TEXAS BOARD OF WATER ENGINEERS BULLETIN 5410, 1954

WATER-LEVEL DECLINE MAPS OF 16 COUNTIES IN THE SOUTHERN HIGH PLAINS, TEXAS, JANUARY 1954 TO JANUARY 1955: (BAILEY, BRISCOE, CASTRO, COCHRAN, CROSBY, DEAF SMITH, FLOYD, GAINES, HALE, HOCKLEY, LAMB, LUBBOCK, PARMER, RANDALL, SWISHER, AND TERRY): USGS OPEN-FILE REPORT, 1955.

WATER-LEVEL DECLINE MAPS OF 17 COUNTIES IN THE SOUTHERN HIGH PLAINS, TEXAS, JANUARY 1955 TO JANUARY 1956: TEXAS BOARD OF WATER ENGINEERS BULLETIN 5607, 1956.

WATER-LEVEL DECLINE MAPS, 1956 TO 1957, AND WATER LEVELS IN OBSERVATION WELLS IN 20 COUNTIES IN THE SOUTHERN HIGH PLAINS, TEXAS: TEXAS BOARD OF WATER ENGINEERS BULLETIN 5705, 1957.

WATER-LEVEL MEASUREMENTS AND MAPS, SOUTHERN HIGH PLAINS, TEXAS, 1958 AND 1959: TEXAS BOARD OF WATER ENGINEERS BULLETIN 5908, 1959. 
WATER LEVELS IN OBSERVATION WELLS, SOUTHERN HIGH PLAINS, TEXAS, 1959 AND 1960: TEXAS BOARD OF WATER ENGINEERS BULLETIN 6011, 1960.

WATER LEVELS IN OBSERVATION WELLS, SOUTHERN HIGH PLAINS, TEXAS, 1960 AND 1961: TEXAS BOARD OF WATER ENGINEERS BULLETIN 6101, 1961

A SUMMARY OF THE OCCURRENCE AND DEVELOPMENT OF GROUND WATER IN THE SOUTHERN HIGH PLAINS OF TEXAS: TEXAS BOARD OF WATER ENGINEERS BULLETIN 6107, 1961.

WATER-LEVEL MEASUREMENTS THROUGH 1962 IN SELECTED OBSERVATION WELLS, SOUTHERN HIGH PLAINS, TEXAS: TEXAS WATER COMMISSION BULLETIN 6207, 1962.

RECONNAISSANCE INVESTIGATION OF THE GROUND-WATER RESOURCES OF THE RED RIVER, SULPHUR RIVER, AND CYPRESS CREEK BASINS, TEXAS: TEXAS WATER COMMISSION BULLETIN 6306, 1963.

RECONNAISSANCE INVESTIGATION OF THE GROUND-WATER RESOURCES OF THE BRAZOS RIVER BASIN, TEXAS: TEXAS WATER COMMISSION BULLETIN 6310, 1963.

A SUMMARY OF THE OCCURRENCE AND DEVELOPMENT OF GROUND WATER IN THE SOUTHERN HIGH PLAINS OF TEXAS: USGS WATER-SUPPLY PAPER 1693, 1964.

WATER-LEVEL DATA FROM OBSERVATION WELLS IN THE SOUTHERN HIGH PLAINS OF TEXAS: TEXAS WATER DEVELOPMENT BOARD REPORT 21, 1966.

COMPILATION OF RESULTS OF AQUIFER TESTS IN TEXAS: TEXAS WATER DEVELOPMENT BOARD REPORT 98, 1969.

GROUND WATER IN THE OGALLALA FORMATION IN THE SOUTHERN HIGH PLAINS OF TEXAS AND NEW MEXICO: USGS HYDROLOGIC INVESTIGATIONS ATLAS HA-330, 1969.

WATER-LEVEL DATA FROM OBSERVATION WELLS IN THE SOUTHERN HIGH PLAINS OF TEXAS, 1956-70: TEXAS WATER DEVELOPMENT BOARD REPORT 121, 1970.

AN EVALUATION OF THE USE OF DRILLERS' LOGS IN LITHOLOGIC STUDIES OF THE OGALLALA FORMATION OF THE SOUTHERN HIGH PLAINS OF TEXAS: USGS OPEN-FILE REPORT 72-451, 1972.

GROUND-WATER RESOURCES OF MOTLEY AND NORTHEASTERN FLOYD COUNTIES, TEXAS: TEXAS WATER DEVELOPMENT BOARD REPORT 165, 1973.

ANALYTICAL STUDY OF THE OGALLALA AQUIFER IN FLOYD COUNTY, TEXAS-PROJECTIONS OF SATURATED THICKNESS, VOLUME OF WATER IN STORAGE, PUMPAGE RATES, PUMPING LIFTS, AND WELL YIELDS: TEXAS WATER DEVELOPMENT BOARD REPORT 211, 1976.

ANALYTICAL STUDY OF THE OGALLALA AQUIFER IN BRISCOE COUNTY, TEXAS-PROJECTIONS OF SATURATED THICKNESS, VOLUME OF WATER IN STORAGE, PUMPAGE RATES, PUMPING LIFTS, AND WELL YIELDS: TEXAS WATER DEVELOPMENT BOARD REPORT 212, 1977

WATER-LEVEL DATA FROM OBSERVATION WELLS IN THE SOUTHERN HIGH PLAINS OF TEXAS, 1971-77: TEXAS DEPARTMENT OF WATER RESOURCES REPORT 228, 1979.

PRELIMINARY DATA DESCRIBING THE DISTRIBUTION OF FLUORIDE AND SILICA IN THE OGALLALA AQUIFER ON THE HIGH PLAINS OF TEXAS: USGS OPEN-FILE REPORT 80-349, 1980.
EVALUATING THE GROUND-WATER RESOURCES OF THE HIGH PLAINS OF TEXAS: RESULTS OF TEST-HOLE DRILLING: TEXAS DEPARTMENT OF WATER RESOURCES LIMITED PRINTING REPORT LP-129, 1980.

EVALUATING THE GROUND-WATER RESOURCES OF THE HIGH PLAINS OF TEXAS: RESULTS OF SURFACE ELECTRICAL SURVEYS: TEXAS DEPARTMENT OF WATER RESOURCES LIMITED PRINTING REPORT LP-130, 1980.

EVALUATING THE GROUND-WATER RESOURCES OF THE HIGH PLAINS OF TEXAS: NEUTRON-PROBE MEASUREMENTS OF DEEP SOIL MOISTURE AS AN INDICATION OF AQUIFER RECHARGE RATES: TEXAS DEPARTMENT OF WATER RESOURCES LIMITED PRINTING REPORT LP-142, 1981.

SPRINGS OF TEXAS, VOLUME 1: (BY GUNNAR BRUNE), BRANCHSMITH, INC., FORT WORTH, TEXAS, 1981.

BEDROCK GEOLOGY, ALTITUDE OF BASE, AND 1980 SATURATED THICKNESS OF THE HIGH PLAINS AQUIFER IN PARTS OF COLORADO, KANSAS, NEBRASKA, NEW MEXICO, OKLAHOMA, SOUTH DAKOTA, TEXAS, AND WYOMING: USGS HYDROLOGIC INVESTIGATIONS ATLAS HA-648, 1981.

WATER LEVEL AND SATURATED THICKNESS CHANGES, PREDEVELOPMENT TO 1980, IN THE HIGH PLAINS AQUIFER IN PARTS OF COLORADO, KANSAS, NEBRASKA, NEW MEXICO, OKLAHOMA, SOUTH DAKOTA, TEXAS, AND WYOMING: USGS HYDROLOGIC INVESTIGATIONS ATLAS HA-652, 1981.

DISSOLVED SOLIDS AND SODIUM IN WATER FROM THE HIGH PLAINS AQUIFER IN PARTS OF COLORADO, KANSAS, NEBRASKA, NEW MEXICO, OKLAHOMA, SOUTH DAKOTA, TEXAS, AND WYOMING: USGS HYDROLOGIC INVESTIGATIONS ATLAS HA-658, 1982

EVALUATING THE GROUND-WATER RESOURCES OF THE HIGH PLAINS OF TEXAS, VOLUME 1: TEXAS DEPARTMENT OF WATER RESOURCES REPORT 288, V. 1, 1984.

EVALUATING THE GROUND-WATER RESOURCES OF THE HIGH PLAINS OF TEXAS, VOLUME 3, RECORDS OF WELLS, AND MAPS SHOWING WELL LOCATIONS, BASE OF AQUIFER, WATER LEVELS, AND SATURATED THICKNESS: TEXAS DEPARTMENT OF WATER RESOURCES REPORT 288, V. 3, 1984.

GEOHYDROLOGY OF THE HIGH PLAINS AQUIFER IN PARTS OF COLORADO, KANSAS, NEBRASKA, NEW MEXICO, OKLAHOMA, SOUTH DAKOTA, TEXAS, AND WYOMING: USGS PROFESSIONAL PAPER 1400-B, 1984.

TEXAS GROUND-WATER RESOURCES, in NATIONAL WATER SUMMARY 1984: USGS WATER-SUPPLY PAPER 2275, 1985.

DIGITAL SIMULATION OF GROUND-WATER FLOW IN THE HIGH PLAINS AQUIFER IN PARTS OF COLORADO, KANSAS, NEBRASKA, NEW MEXICO, OKLAHOMA, SOUTH DAKOTA, TEXAS, AND WYOMING: USGS PROFESSIONAL PAPER 1400-D, 1986.

HYDROLOGIC ATLAS FOR FLOYD COUNTY, TEXAS: HIGH PLAINS UNDERGROUND WATER CONSERVATION DISTRICT NO. 1, 1987.

HYDROGEOLOGY AND HYDROCHEMISTRY OF CRETACEOUS AQUIFERS, TEXAS PANHANDLE AND EASTERN NEW MEXICO: UNIVERSITY OF TEXAS, BUREAU OF ECONOMIC GEOLOGY GEOLOGICAL CIRCULAR 88-3, 1988.

SUMMARY OF THE HIGH PLAINS REGIONAL AQUIFER-SYSTEM ANALYSIS IN PARTS OF COLORADO, KANSAS, NEBRASKA, NEW 
MEXICO, OKLAHOMA, SOUTH DAKOTA, TEXAS, AND WYOMING: USGS PROFESSIONAL PAPER 1400-A, 1988.

HYDROGEOLOGY OF LOWER CRETACEOUS STRATA UNDER THE SOUTHERN HIGH PLAINS OF TEXAS AND NEW MEXICO: TEXAS WATER DEVELOPMENT BOARD REPORT 314, 1989.

PUBLIC-SUPPLY GROUND-WATER USE IN THE SOUTHERN HIGH PLAINS OF TEXAS: TEXAS WATER DEVELOPMENT BOARD REPORT 328, 1990.

WATER-LEVEL CHANGES IN THE HIGH PLAINS AQUIFER OF TEXAS, 1980-1990: TEXAS WATER DEVELOPMENT BOARD HYDROLOGIC ATLAS NO. 1, 1991.

EVALUATION OF WATER RESOURCES IN PARTS OF THE ROLLING PRAIRIES REGION OF NORTH-CENTRAL TEXAS: TEXAS WATER DEVELOPMENT BOARD REPORT 337, 1992.

THE HIGH PLAINS AQUIFER SYSTEM OF TEXAS, 1980 TO 1990. OVER VIEW AND PROJECTIONS: TEXAS WATER DEVELOPMENT BOARD REPORT 341, 1993.

WATER-QUALITY EVALUATION OF THE OGALLALA AQUIFER, TEXAS: TEXAS WATER DEVELOPMENT BOARD REPORT 342, 1993.

WATER-LEVEL CHANGES IN THE HIGH PLAINS AQUIFER, 1980 TO 1994: USGS FACT SHEET FS-215-95, 1995.

AQUIFERS OF TEXAS: TEXAS WATER DEVELOPMENT BOARD REPORT 345, 1995.

WATER-LEVEL CHANGES IN THE HIGH PLAINS AQUIFER, 1980 TO 1995: USGS FACT SHEET FS-068-97, 1997.

WATER-LEVEL CHANGES IN THE HIGH PLAINS AQUIFER-PREDEVELOPMENT TO 1995: USGS WATER-RESOURCES INVESTIGATIONS REPORT 97-4081, 1997.

UPDATED WATER-QUALITY EVALUATION OF THE OGALLALA AQUIFER INCLUDING SELECTED METALLIC AND NON-METALLIC INORGANIC CONSTITUENTS: TEXAS WATER DEVELOPMENT BOARD HYDROLOGIC ATLAS NO. 10, 1998.

\section{FOARD COUNTY}

GEOLOGY AND UNDERGROUND WATERS OF THE WICHITA REGION, NORTH-CENTRAL TEXAS: USGS WATER-SUPPLY PAPER 317,1913 .

RECORDS OF WELLS, DRILLERS' LOGS, WATER ANALYSES, AND MAPS SHOWING LOCATION OF WELLS IN FOARD COUNTY, TEXAS: TEXAS BOARD OF WATER ENGINEERS MISCELLANEOUS PUBLICATION 84, 1936.

THE WATER SUPPLY OF CROWELL, FOARD COUNTY, TEXAS: USGS OPEN-FILE REPORT (UNNUMBERED), 1936.

MEMORANDUM ON GROUND-WATER RESOURCES IN THE VICINITY OF CROWELL, TEXAS: USGS OPEN-FILE REPORT (UNNUMBERED), 1941.

MEMORANDUM ON GROUND WATER SUPPLY AT CROWELL, TEXAS (CONFERENCE WITH N.H. ROBERTS, CONSULTING ENGINEER AND THE CROWELL CITY COUNCIL): USGS OPEN-FILE REPORT (UNNUMBERED), 1944.
MEMORANDUM; THE MARGARET WATER FIELD, CROWELL, TEXAS: USGS OPEN-FILE REPORT (UNNUMBERED), 1945.

MEMORANDUM TO THE TEXAS STATE BOARD OF WATER ENGINEERS REGARDING THE NEW MUNICIPAL WATER SUPPLY AT CROWELL, TEXAS: USGS OPEN-FILE REPORT (UNNUMBERED), 1945.

PUBLIC WATER SUPPLIES IN CENTRAL AND NORTH-CENTRAL TEXAS: USGS WATER-SUPPLY PAPER 1069, 1949.

RECORDS OF WATER-LEVEL MEASUREMENTS IN FOARD AND WILBARGER COUNTIES, TEXAS, 1936 TO JANUARY 1956: TEXAS BOARD OF WATER ENGINEERS BULLETIN 5614, 1956.

RECONNAISSANCE INVESTIGATION OF THE GROUND-WATER RESOURCES OF THE RED RIVER, SULPHUR RIVER, AND CYPRESS CREEK BASINS, TEXAS: TEXAS WATER COMMISSION BULLETIN 6306, 1963.

SPRINGS OF TEXAS, VOLUME 1: (BY GUNNAR BRUNE), BRANCHSMITH, INC., FORT WORTH, TEXAS, 1981.

TEXAS GROUND-WATER RESOURCES, in NATIONAL WATER SUMMARY 1984: USGS WATER-SUPPLY PAPER 2275, 1985.

EVALUATION OF WATER RESOURCES IN PARTS OF THE ROLLING PRAIRIES REGION OF NORTH-CENTRAL TEXAS: TEXAS WATER DEVELOPMENT BOARD REPORT 337, 1992.

AQUIFERS OF TEXAS: TEXAS WATER DEVELOPMENT BOARD REPORT 345, 1995.

\section{FORT BEND COUNTY}

ARTESIAN WELLS OF THE COASTAL PRAIRIE REGION AND TERTIARY BELT OF TEXAS: GEOLOGICAL SURVEY OF TEXAS, CHAPTER 2, 1893.

UNDERGROUND WATERS OF THE COASTAL PLAIN OF TEXAS: USGS WATER-SUPPLY PAPER 190, 1907.

GEOLOGY AND UNDERGROUND WATERS OF THE SOUTHEASTERN PART OF THE TEXAS COASTAL PLAIN: USGS WATER-SUPPLY PAPER 335, 1914.

GROUND-WATER RESOURCES OF THE HOUSTON-GALVESTON AREA, TEXAS: USGS OPEN-FILE REPORT (UNNUMBERED) (PRESS RELEASE), 1932

GROUND-WATER RESOURCES OF THE HOUSTON DISTRICT, TEXAS USGS OPEN-FILE REPORT (UNNUMBERED), 1933.

RECORDS OF WELLS IN HARRIS, GALVESTON, WALLER, FORT BEND, BRAZORIA, AND GRIMES COUNTY, TEXAS: USGS OPENFILE REPORT (UNNUMBERED), 1935.

PROGRESS REPORT ON THE GROUND-WATER RESOURCES OF THE HOUSTON DISTRICT, TEXAS: TEXAS BOARD OF WATER ENGINEERS MISCELLANEOUS PUBLICATION 128, 1937.

RECORDS OF WELLS, DRILLERS' LOGS, AND WATER ANALYSES, AND MAPS SHOWING LOCATION OF WELLS IN FORT BEND COUNTY (WEST OF BRAZOS RIVER), TEXAS: TEXAS BOARD OF WATER ENGINEERS MISCELLANEOUS PUBLICATION 85, 1937.

PROGRESS REPORT ON THE GROUND-WATER RESOURCES OF THE HOUSTON DISTRICT, TEXAS: TEXAS BOARD OF WATER ENGINEERS MISCELLANEOUS PUBLICATION 129, 1938 
RECORDS OF WELLS, DRILLERS' LOGS, WATER ANALYSES, AND MAP SHOWING LOCATION OF WELLS IN FORT BEND COUNTY (EAST OF BRAZOS RIVER), TEXAS: TEXAS BOARD OF WATER ENGINEERS MISCELLANEOUS PUBLICATION) 86, 1939.

GROUND-WATER RESOURCES OF THE HOUSTON-GALVESTON AREA AND ADJACENT REGION: TEXAS BOARD OF WATER ENGINEERS MISCELLANEOUS PUBLICATION 130, 1939.

PROGRESS REPORT ON THE GROUND-WATER RESOURCES OF THE HOUSTON DISTRICT, TEXAS: TEXAS BOARD OF WATER ENGINEERS MISCELLANEOUS PUBLICATION 131, 1939.

PROGRESS REPORT ON THE GROUND-WATER RESOURCES OF THE HOUSTON DISTRICT, TEXAS: TEXAS BOARD OF WATER ENGINEERS MISCELLANEOUS PUBLICATION 132, 1940.

GROUND WATER AND THE RELATION OF GEOLOGY TO ITS OCCURRENCE IN THE HOUSTON DISTRICT, TEXAS: USGS OPEN-FILE REPORT (UNNUMBERED), 1942.

GROUND-WATER RESOURCES OF THE HOUSTON DISTRICTPROGRESS REPORT WITH RECORDS OF WELLS, HARRIS COUNTY AND ADJOINING PARTS OF FORT BEND AND WALLER COUNTIES, TEXAS: TEXAS BOARD OF WATER ENGINEERS MISCELLANEOUS PUBLICATION 133, 1942.

PROGRESS REPORT ON THE GROUND-WATER RESOURCES OF THE HOUSTON DISTRICT, TEXAS: TEXAS BOARD OF WATER ENGINEERS MISCELLANEOUS PUBLICATION 134, 1942.

PUMP SETTINGS AND PUMPING LEVELS IN HOUSTON DISTRICT, TEXAS: TEXAS BOARD OF WATER ENGINEERS MISCELLANEOUS PUBLICATION 135, 1943.

PUBLIC WATER SUPPLIES IN EASTERN TEXAS: USGS WATERSUPPLY PAPER 1047, 1948.

GEOLOGY AND GROUND-WATER RESOURCES OF THE HOUSTON DISTRICT, TEXAS: TEXAS BOARD OF WATER ENGINEERS BULLETIN 5001, 1950

WATER SUPPLY OF THE HOUSTON GULF COAST REGION: TEXAS BOARD OF WATER ENGINEERS BULLETIN 5101, 1951.

AVAILABILITY OF GROUND WATER IN THE GULF COAST REGION OF TEXAS: USGS OPEN-FILE REPORT (UNNUMBERED), 1956.

RECORDS OF WATER-LEVEL MEASUREMENTS IN BRAZORIA, FORT BEND, AND WALLER COUNTIES, TEXAS, 1931 THROUGH JUNE 1958: TEXAS WATER COMMISSION BULLETIN 5904, 1959.

RECONNAISSANCE INVESTIGATION OF THE GROUND-WATER RESOURCES OF THE GULF COAST REGION, TEXAS: TEXAS WATER COMMISSION BULLETIN 6305, 1963.

ANALOG MODEL STUDY OF GROUND WATER IN THE HOUSTON DISTRICT, TEXAS: TEXAS WATER COMMISSION BULLETIN 6508, 1965.

GROUND WATER IN THE FLOOD-PLAIN ALLUVIUM OF THE BRAZOS RIVER, WHITNEY DAM TO VICINITY OF RICHMOND, TEXAS: TEXAS WATER DEVELOPMENT BOARD REPORT 41, 1967.

DEVELOPMENT OF GROUND WATER IN THE HOUSTON DISTRICT, TEXAS, 1961-65: TEXAS WATER DEVELOPMENT BOARD REPORT 63, 1967.

LAND-SURFACE SUBSIDENCE IN THE HOUSTON-GALVESTON REGION, TEXAS: USGS OPEN-FILE REPORT 69-61, 1969.
COMPILATION OF RESULTS OF AQUIFER TESTS IN TEXAS: TEXAS WATER DEVELOPMENT BOARD REPORT 98, 1969.

DEVELOPMENT OF GROUND WATER IN THE HOUSTON DISTRICT, TEXAS, 1966-69: TEXAS WATER DEVELOPMENT BOARD REPORT 152, 1972.

GROUND-WATER RESOURCES OF FORT BEND COUNTY, TEXAS: TEXAS WATER DEVELOPMENT BOARD REPORT 155, 1972.

GEOLOGIC AND HYDROLOGIC SUMMARY OF SALT DOMES IN GULF COAST REGION OF TEXAS, LOUISIANA, AND ALABAMA: USGS OPEN-FILE REPORT 73-07, 1973.

LAND-SURFACE SUBSIDENCE IN THE HOUSTON-GALVESTON REGION, TEXAS: USGS OPEN-FILE REPORT 74-123, 1974.

LAND-SURFACE SUBSIDENCE IN THE HOUSTON-GALVESTON REGION, TEXAS: TEXAS: TEXAS WATER DEVELOPMENT BOARD REPORT 188, 1975.

SUMMARY APPRAISALS OF THE NATION'S GROUND-WATER RESOURCES-TEXAS-GULF REGION: USGS PROFESSIONAL PAPER 813-F, 1976.

RECORDS OF WELLS, DRILLERS' LOGS, WATER-LEVEL MEASUREMENTS, AND CHEMICAL ANALYSES OF GROUND WATER IN BRAZORIA, FORT BEND, AND WALLER COUNTIES, TEXAS, 1966-74: TEXAS WATER DEVELOPMENT BOARD REPORT 201, 1976.

APPROXIMATE AREAS OF RECHARGE TO THE CHICOT AND EVANGELINE AQUIFER SYSTEMS IN THE HOUSTON-GALVESTON AREA, TEXAS: USGS OPEN-FILE REPORT 77-754, 1977.

HYDROGEOLOGY OF GULF COAST AQUIFERS, HOUSTONGALVESTON AREA, TEXAS: UNIVERSITY OF TEXAS, BUREAU OF ECONOMIC GEOLOGY GEOLOGICAL CIRCULAR 77-4, 1977.

STRATIGRAPHIC AND HYDROGEOLOGIC FRAMEWORK OF PART OF THE COASTAL PLAIN OF TEXAS: TEXAS DEPARTMENT OF WATER RESOURCES REPORT 236, 1979.

CLODINE FAULT, SOUTHWESTERN HOUSTON METROPOLITAN AREA, TEXAS: USGS OPEN-FILE REPORT 79-947, 1979.

A DIGITAL MODEL FOR SIMULATION OF GROUND-WATER HYDROLOGY IN THE HOUSTON AREA, TEXAS: TEXAS DEPARTMENT OF WATER RESOURCES LIMITED PRINTING LP-103, 1979.

APPROXIMATE ALTITUDE OF WATER LEVELS IN WELLS IN THE CHICOT AND EVANGELINE AQUIFERS IN THE HOUSTON AREA, TEXAS, SPRING 1977 AND SPRING 1978: USGS OPEN-FILE REPORT 79-334, 1979.

APPROXIMATE WATER-LEVEL CHANGES IN WELLS IN THE CHICOT AND EVANGELINE AQUIFERS, 1977-79, AND MEASURED COMPACTION, 1973-79, IN HARRIS AND GALVESTON COUNTIES, TEXAS: USGS OPEN-FILE REPORT 79-693, 1979.

APPROXIMATE WATER-LEVEL CHANGES IN WELLS IN THE CHICOT AND EVANGELINE AQUIFERS IN THE HOUSTON-GALVESTON REGION, TEXAS, 1977-80 AND 1979-80: USGS OPEN-FILE REPORT 80-337, 1980

APPROXIMATE ALTITUDE OF WATER LEVELS IN WELLS IN THE CHICOT AND EVANGELINE AQUIFERS IN THE HOUSTON AREA, TEXAS, SPRING 1979 AND SPRING 1980: USGS OPEN-FILE REPORT 80-579, 1980 
APPROXIMATE LAND-SURFACE SUBSIDENCE IN THE HOUSTONGALVESTON REGION, TEXAS, 1906-78, 1943-78, AND 1973-78: USGS OPEN-FILE REPORT 80-338, 1980.

LAND-SURFACE SUBSIDENCE IN THE TEXAS COASTAL REGION: USGS OPEN-FILE REPORT 80-969, 1980.

DEVELOPMENT OF GROUND WATER IN THE HOUSTONGALVESTON DISTRICT, TEXAS, 1970-74: TEXAS DEPARTMENT OF WATER RESOURCES REPORT 241, 1980.

APPROXIMATE WATER-LEVEL CHANGES IN WELLS IN THE CHICOT AND EVANGELINE AQUIFERS, 1977-81 AND 1980-81, AND MEASURED COMPACTION, 1973-81, IN THE HOUSTON-GALVESTON REGION, TEXAS: USGS OPEN-FILE REPORT 81-341, 1981.

SPRINGS OF TEXAS, VOLUME 1: (BY GUNNAR BRUNE), BRANCHSMITH, INC., FORT WORTH, TEXAS, 1981.

APPROXIMATE ALTITUDE OF WATER LEVELS IN THE CHICOT AND EVANGELINE AQUIFERS IN THE HOUSTON AREA, TEXAS, SPRING 1981: USGS OPEN-FILE REPORT 81-676, 1981.

LAND-SURFACE SUBSIDENCE IN THE TEXAS COASTAL REGION: TEXAS DEPARTMENT OF WATER RESOURCES REPORT 272, 1982.

APPROXIMATE WATER-LEVEL CHANGES IN WELLS IN THE CHICOT AND EVANGELINE AQUIFERS, 1977-82 AND 1981-82, AND MEASURED COMPACTION, 1973-82, IN THE HOUSTON-GALVESTON REGION, TEXAS: USGS OPEN-FILE REPORT 82-328, 1982.

GROUND-WATER WITHDRAWALS AND CHANGES IN WATER LEVELS IN THE HOUSTON DISTRICT, 1975-79: USGS OPEN-FILE REPORT 82-431, 1982.

APPROXIMATE ALTITUDE OF WATER LEVELS IN WELLS IN THE CHICOT AND EVANGELINE AQUIFERS IN THE HOUSTON AREA, TEXAS, SPRING 1982: USGS OPEN-FILE REPORT 82-559, 1982.

APPROXIMATE WATER-LEVEL CHANGES IN WELLS IN THE CHICOT AND EVANGELINE AQUIFERS, 1977-83 AND 1982-83, AND MEASURED COMPACTION, 1973-83, IN THE HOUSTON-GALVESTON REGION, TEXAS: USGS OPEN-FILE REPORT 83-150, 1983.

RECORDS OF WELLS, DRILLERS' LOGS, WATER-LEVEL MEASUREMENTS, AND CHEMICAL ANALYSES OF GROUND-WATER IN BRAZORIA, FORT BEND, AND WALLER COUNTIES, TEXAS, 1975-79: TEXAS DEPARTMENT OF WATER RESOURCES REPORT 277, 1983.

APPROXIMATE ALTITUDE OF WATER LEVELS IN WELLS IN THE CHICOT AND EVANGELINE AQUIFERS IN THE HOUSTON AREA, TEXAS, SPRING 1983: USGS OPEN-FILE REPORT 83-529, 1983.

APPROXIMATE WATER-LEVEL CHANGES IN WELLS IN THE CHICOT AND EVANGELINE AQUIFERS, 1977-84 AND 1983-84, AND MEASURED COMPACTION, 1973-84, IN THE HOUSTON-GALVESTON REGION, TEXAS: USGS OPEN-FILE REPORT 84-140, 1984.

APPROXIMATE ALTITUDE OF WATER LEVELS IN WELLS IN THE CHICOT AND EVANGELINE AQUIFERS IN THE HOUSTON AREA, TEXAS, SPRING, 1984: USGS OPEN-FILE REPORT 84-436, 1984.

GROUND-WATER WITHDRAWALS AND CHANGES IN WATER LEVELS IN THE HOUSTON DISTRICT, TEXAS, 1975-79: TEXAS DEPARTMENT OF WATER RESOURCES REPORT 286, 1984.

GROUND-WATER WITHDRAWALS AND LAND-SURFACE SUBSIDENCE IN THE HOUSTON-GALVESTON REGION, TEXAS, 1906-80: TEXAS DEPARTMENT OF WATER RESOURCES REPORT 287, 1984.
DIGITAL MODELS FOR SIMULATION OF GROUND-WATER HYDROLOGY OF THE CHICOT AND EVANGELINE AQUIFERS ALONG THE GULF COAST OF TEXAS: TEXAS DEPARTMENT OF WATER RESOURCES REPORT 289, 1985.

WATER USE, PROJECTED WATER REQUIREMENTS, AND RELATED DATA AND INFORMATION FOR THE METROPOLITAN STATISTICAL AREAS IN TEXAS: TEXAS DEPARTMENT OF WATER RESOURCES LIMITED PRINTING REPORT LP-201, 1985.

APPROXIMATE WATER-LEVEL CHANGES IN WELLS IN THE CHICOT AND EVANGELINE AQUIFERS, 1977-85 AND 1984-85, AND MEASURED COMPACTION, 1973-85, IN THE HOUSTON-GALVESTON REGION, TEXAS: USGS OPEN-FILE REPORT 85-158, 1985.

TEXAS GROUND-WATER RESOURCES, in NATIONAL WATER SUMMARY 1984: USGS WATER-SUPPLY PAPER 2275, 1985.

RECORDS OF WELLS, DRILLERS' LOGS, WATER-LEVEL MEASUREMENTS, AND CHEMICAL ANALYSES OF GROUND WATER IN BRAZORIA, FORT BEND, AND WALLER COUNTIES, TEXAS, 1980-84: USGS OPEN-FILE REPORT 86-68, 1986.

APPROXIMATE CHANGES IN WATER LEVELS IN THE CHICOT AND EVANGELINE AQUIFERS, 1977-86 AND 1985-86, AND MEASURED COMPACTION, 1973-86, IN THE HOUSTON-GALVESTON REGION, TEXAS: USGS OPEN-FILE REPORT 86-135, 1986.

APPROXIMATE ALTITUDE OF WATER LEVELS IN WELLS IN THE CHICOT AND EVANGELINE AQUIFERS IN THE HOUSTON AREA, TEXAS, SPRING 1986: USGS OPEN-FILE REPORT 86-306, 1986.

HYDROLOGY OF THE JASPER AQUIFER IN THE SOUTHEAST TEXAS COASTAL PLAIN: TEXAS WATER DEVELOPMENT BOARD REPORT 295, 1986.

RECORDS OF WELLS, DRILLERS' LOGS, WATER-LEVEL MEASUREMENTS, AND CHEMICAL ANALYSES OF GROUND WATER IN BRAZORIA, FORT BEND, AND WALLER COUNTIES, TEXAS, 1980-84: TEXAS WATER DEVELOPMENT BOARD REPORT 303, 1987.

APPROXIMATE WATER-LEVEL CHANGES IN WELLS COMPLETED IN THE CHICOT AND EVANGELINE AQUIFERS, 1977-87 AND 1986-87, AND MEASURED COMPACTION, 1973-87, IN THE HOUSTONGALVESTON REGION, TEXAS: USGS OPEN-FILE REPORT 87-108, 1987.

APPROXIMATE ALTITUDE OF WATER-LEVELS IN WELLS IN THE CHICOT AND EVANGELINE AQUIFERS IN THE HOUSTON AREA, TEXAS, SPRING 1987: USGS OPEN-FILE REPORT 87-233, 1987.

GEOHYDROLOGIC FRAMEWORK OF THE GULF COASTAL PLAIN: USGS HYDROLOGIC INVESTIGATIONS ATLAS HA-695, 1988

HYDROGEOLOGY AND PREDEVELOPMENT FLOW IN THE TEXAS GULF COAST AQUIFER SYSTEMS: USGS WATER-RESOURCES INVESTIGATIONS REPORT 87-4248, 1988.

APPROXIMATE WATER-LEVEL CHANGES IN WELLS COMPLETED IN THE CHICOT AND EVANGELINE AQUIFERS, 1977-88 AND 1987-88, AND MEASURED COMPACTION, 1973-88, IN THE HOUSTONGALVESTON REGION, TEXAS: USGS OPEN-FILE REPORT 88-168, 1988.

APPROXIMATE ALTITUDE OF WATER LEVELS IN WELLS IN THE CHICOT AND EVANGELINE AQUIFERS IN THE HOUSTON AREA, TEXAS, SPRING 1988: USGS OPEN-FILE REPORT 88-334, 1988. 
APPROXIMATE ALTITUDE OF WATER LEVELS IN WELLS IN THE CHICOT AND EVANGELINE AQUIFERS IN THE HOUSTON AREA, TEXAS, SPRING 1989: USGS OPEN-FILE REPORT 89-237, 1989.

APPROXIMATE WATER-LEVEL CHANGE IN WELLS COMPLETED IN THE CHICOT AND EVANGELINE AQUIFERS, 1977-89 AND 1988-89, AND MEASURED COMPACTION, 1973-89, IN THE HOUSTONGALVESTON REGION, TEXAS: USGS OPEN-FILE REPORT 89-057, 1989.

APPROXIMATE WATER-LEVEL CHANGES IN WELLS COMPLETED IN THE CHICOT AND EVANGELINE AQUIFERS, 1977-90 AND 1989-90, AND MEASURED COMPACTION, 1973-DECEMBER 1989, IN THE HOUSTON-GALVESTON REGION, TEXAS: USGS OPEN-FILE REPORT 90-132, 1990.

GROUND-WATER FLOW IN THE GULF COAST AQUIFER SYSTEMS, SOUTH-CENTRAL UNITED STATES-A PRELIMINARY ANALYSIS: USGS WATER-RESOURCES INVESTIGATIONS REPORT 89-4071, 1990.

GROUND-WATER WITHDRAWALS, WATER-LEVEL CHANGES, LAND-SURFACE SUBSIDENCE, AND GROUND-WATER QUALITY IN FORT BEND COUNTY, TEXAS, 1969-87: USGS WATERRESOURCES INVESTIGATIONS REPORT 90-4012, 1990.

SALT-DOME LOCATIONS IN THE GULF COASTAL PLAIN, SOUTHCENTRAL UNITED STATES: USGS WATER-RESOURCES INVESTIGATIONS REPORT 90-4060, 1990.

LAND-SURFACE SUBSIDENCE RESULTING FROM GROUND-WATER WITHDRAWALS IN THE HOUSTON-GALVESTON REGION, TEXAS, THROUGH 1987: HARRIS-GALVESTON COASTAL SUBSIDENCE DISTRICT REPORT OF INVESTIGATIONS NO. 90-01, 1990.

EVALUATION OF WATER RESOURCES OF FORT BEND COUNTY, TEXAS: TEXAS WATER DEVELOPMENT BOARD REPORT 321, 1990.

RECORDS OF WELLS, DRILLERS' LOGS, WATER-LEVEL MEASUREMENTS, AND CHEMICAL ANALYSES OF GROUND WATER IN BRAZORIA, FORT BEND, AND WALLER COUNTIES, TEXAS, 1985-89: USGS OPEN-FILE REPORT 90-588, 1991.

APPROXIMATE ALTITUDE OF WATER LEVELS IN WELLS IN THE CHICOT AND EVANGELINE AQUIFERS IN THE HOUSTON AREA, TEXAS, JANUARY-FEBRUARY 1990: USGS OPEN-FILE REPORT 91-240, 1991.

HYDROLOGY OF THE TEXAS GULF COAST AQUIFER SYSTEMS: USGS OPEN-FILE REPORT 91-64, 1991.

APPROXIMATE WATER-LEVEL CHANGES IN WELLS COMPLETED IN THE CHICOT AND EVANGELINE AQUIFERS, 1991-92, IN FORT BEND COUNTY AND ADJACENT AREAS, TEXAS: USGS OPEN-FILE REPORT 92-53, 1992.

APPROXIMATE CHANGES IN WATER LEVELS IN WELLS COMPLETED IN THE CHICOT AND EVANGELINE AQUIFERS, 1977-92 AND 1991-92, AND MEASURED COMPACTION, 1973-91, IN THE HOUSTON-GALVESTON REGION, TEXAS: USGS OPEN-FILE REPORT 92-66, 1992.

PROPERTIES AND CHEMICAL CONSTITUENTS IN GROUND WATER FROM THE MISSISSIPPI RIVER VALLEY ALLUVIAL AQUIFER AND PERMEABLE ZONE A (HOLOCENE-UPPER PLEISTOCENE DEPOSITS), SOUTH-CENTRAL UNITED STATES: USGS WATERRESOURCES INVESTIGATIONS REPORT 91-4149, 1992.
WATER-RESOURCES DATA, TEXAS, WATER YEAR 1991, VOLUME 4, GROUND-WATER DATA: USGS WATER-DATA REPORT TX-91-4, 1992.

PROPERTIES AND CHEMICAL CONSTITUENTS IN GROUND WATER FROM THE UPPER CLAIBORNE AQUIFER, GULF COAST REGIONAL AQUIFER SYSTEMS, SOUTH-CENTRAL UNITED STATES: USGS WATER-RESOURCES INVESTIGATIONS REPORT 91-4150, 1993.

PROPERTIES AND CHEMICAL CONSTITUENTS IN GROUND WATER FROM PERMEABLE ZONE C (LOWER PLIOCENE-UPPER MIOCENE DEPOSITS), COASTAL LOWLANDS AQUIFER SYSTEM, SOUTHCENTRAL UNITED STATES: USGS WATER-RESOURCES INVESTIGATIONS REPORT 91-4151, 1993.

PROPERTIES AND CHEMICAL CONSTITUENTS IN GROUND WATER FROM PERMEABLE ZONE B (LOWER PLEISTOCENE-UPPER PLIOCENE DEPOSITS), COASTAL LOWLANDS AQUIFER SYSTEM, SOUTH-CENTRAL UNITED STATES: USGS WATER-RESOURCES INVESTIGATIONS REPORT 91-4152, 1993.

PROPERTIES AND CHEMICAL CONSTITUENTS IN GROUND WATER FROM PERMEABLE ZONE E (LOWER MIOCENE-UPPER OLIGOCENE DEPOSITS), COASTAL LOWLANDS AQUIFER SYSTEM, SOUTH-CENTRAL UNITED STATES: USGS WATER-RESOURCES INVESTIGATIONS REPORT 92-4103, 1993.

PROPERTIES AND CHEMICAL CONSTITUENTS IN GROUND WATER FROM PERMEABLE ZONE D (MIDDLE MIOCENE DEPOSITS), COASTAL LOWLANDS AQUIFER SYSTEM, SOUTH-CENTRAL UNITED STATES: USGS WATER-RESOURCES INVESTIGATIONS REPORT 92-4105, 1993.

GROUND-WATER WITHDRAWALS, WATER LEVELS, AND GROUNDWATER QUALITY IN THE HOUSTON DISTRICT, TEXAS, WITH EMPHASIS ON 1985-89: USGS WATER-RESOURCES INVESTIGATIONS REPORT 92-4180, 1993.

APPROXIMATE ALTITUDE OF WATER LEVELS IN WELLS COMPLETED IN THE CHICOT AND EVANGELINE AQUIFERS IN FORT BEND COUNTY AND ADJACENT AREAS, TEXAS, JANUARY-FEBRUARY 1991: USGS OPEN-FILE REPORT 93-62, 1993.

APPROXIMATE CHANGES IN WATER LEVELS IN WELLS COMPLETED IN THE CHICOT AND EVANGELINE AQUIFERS, 1990-93 AND 1992-93, IN FORT BEND COUNTY AND ADJACENT AREAS, TEXAS: USGS OPEN-FILE REPORT 93-81, 1993.

WATER-RESOURCES DATA, TEXAS, WATER YEAR 1992, VOLUME 4 GROUND-WATER DATA: USGS WATER-DATA REPORT TX-92-4, 1993.

APPROXIMATE CHANGES IN WATER LEVELS IN WELLS COMPLETED IN THE CHICOT AND EVANGELINE AQUIFERS, 1990-94 AND 1993-94, IN FORT BEND COUNTY AND ADJACENT AREAS, TEXAS: USGS OPEN-FILE REPORT 94-345, 1994.

APPROXIMATE CHANGES IN WATER LEVELS IN WELLS COMPLETED IN THE CHICOT AND EVANGELINE AQUIFERS, 1977-94 AND 1993-94, AND MEASURED COMPACTION, 1973-93, IN THE HOUSTON-GALVESTON REGION, TEXAS: USGS OPEN-FILE REPORT 94-346, 1994.

WATER-RESOURCES DATA, TEXAS, WATER YEAR 1993, VOLUME 4 GROUND-WATER DATA: USGS WATER-DATA REPORT TX-93-4, 1994.

STRATIGRAPHIC NOMENCLATURE AND GEOLOGIC SECTIONS OF THE GULF COASTAL PLAIN OF TEXAS: USGS OPEN-FILE REPORT 94-461, 1995. 
WATER-LEVEL ALTITUDES 1995, WATER-LEVEL CHANGES 1977-95 AND 1994-95, AND COMPACTION 1973-94 IN THE CHICOT AND EVANGELINE AQUIFERS, HOUSTON-GALVESTON REGION, TEXAS: USGS OPEN-FILE REPORT 95-182, 1995.

WATER-LEVEL ALTITUDES 1995 AND WATER-LEVEL CHANGES 1990-95 AND 1994-95 IN THE CHICOT AND EVANGELINE AQUIFERS, FORT BEND COUNTY AND ADJACENT AREAS, TEXAS: USGS OPEN-FILE REPORT 95-183, 1995.

AQUIFERS OF TEXAS: TEXAS WATER DEVELOPMENT BOARD REPORT 345, 1995.

WATER-RESOURCES DATA, TEXAS, WATER YEAR 1994, VOLUME 4, GROUND-WATER DATA: USGS WATER-DATA REPORT TX-94-4, 1995.

WATER-LEVEL ALTITUDES 1996, WATER-LEVEL CHANGES 1977-96 AND 1995-96, AND COMPACTION 1973-95 IN THE CHICOT AND EVANGELINE AQUIFERS, HOUSTON-GALVESTON REGION, TEXAS: USGS OPEN-FILE REPORT 96-163, 1996.

WATER-LEVEL ALTITUDES 1996 AND WATER-LEVEL CHANGES 1990-96 AND 1995-96 IN THE CHICOT AND EVANGELINE AQUIFERS, FORT BEND COUNTY AND ADJACENT AREAS, TEXAS: USGS OPEN-FILE REPORT 96-164, 1996.

WATER-RESOURCES DATA, TEXAS, WATER YEAR 1995, VOLUME 4, GROUND-WATER DATA: USGS WATER-DATA REPORT TX-95-4, 1996.

WATER-LEVEL ALTITUDES 1997 AND WATER-LEVEL CHANGES 1990-97 AND 1996-97 IN THE CHICOT AND EVANGELINE AQUIFERS, FORT BEND COUNTY AND ADJACENT AREAS, TEXAS: USGS OPEN-FILE REPORT 97-180, 1997.

WATER-LEVEL ALTITUDES 1997, WATER-LEVEL CHANGES 1977-97 AND 1996-97, AND COMPACTION 1973-96 IN THE CHICOT AND EVANGELINE AQUIFERS, HOUSTON-GALVESTON REGION, TEXAS: USGS OPEN-FILE REPORT 97-181, 1997.

WATER-LEVEL ALTITUDES IN WELLS COMPLETED IN THE CHICOT AND EVANGELINE AQUIFERS, FORT BEND COUNTY AND ADJACENT AREAS, TEXAS, JANUARY-FEBRUARY 1990: USGS OPENFILE REPORT 97-784, 1997.

WATER-LEVEL ALTITUDES IN WELLS COMPLETED IN THE CHICOT AND EVANGELINE AQUIFERS, FORT BEND COUNTY AND ADJACENT AREAS, JANUARY-FEBRUARY 1992, 1993, AND 1994: USGS OPEN-FILE REPORT 97-785, 1997.

WATER-LEVEL ALTITUDES IN WELLS COMPLETED IN THE CHICOT AND EVANGELINE AQUIFERS, HOUSTON-GALVESTON REGION, TEXAS, JANUARY-FEBRUARY 1992, 1993, AND 1994: USGS OPENFILE REPORT 97-786, 1997.

WATER-RESOURCES DATA, TEXAS, WATER YEAR 1996, VOLUME 4, GROUND-WATER DATA: USGS WATER-DATA REPORT TX-96-4, 1997.

WATER-LEVEL ALTITUDES 1998 AND WATER-LEVEL CHANGES 1990-98 AND 1997-98 IN THE CHICOT AND EVANGELINE AQUIFERS, FORT BEND COUNTY AND ADJACENT AREAS, TEXAS: USGS OPEN-FILE REPORT 98-095, 1998.

WATER-LEVEL ALTITUDES 1998, WATER-LEVEL CHANGES 1977-98 AND 1997-98, AND COMPACTION IN THE CHICOT AND EVANGELINE AQUIFERS, HOUSTON-GALVESTON REGION, TEXAS: USGS OPEN-FILE REPORT 98-096, 1998.
APPROXIMATE LAND-SURFACE SUBSIDENCE IN FORT BEND COUNTY, TEXAS, 1943-87 AND 1973-87: USGS OPEN-FILE REPORT 98-383, 1998.

WATER-RESOURCES DATA, TEXAS, WATER YEAR 1997, VOLUME 4 GROUND-WATER DATA: USGS WATER-DATA REPORT TX-97-4, 1998.

WATER-LEVEL ALTITUDES 1999 AND WATER-LEVEL CHANGES 1990-99 AND 1998-99 IN THE CHICOT AND EVANGELINE AQUIFERS, FORT BEND COUNTY AND ADJACENT AREAS, TEXAS: USGS OPEN-FILE REPORT 99-177, 1999.

WATER-LEVEL ALTITUDES 1999, WATER-LEVEL CHANGES 1977-99 AND 1998-99, AND COMPACTION 1973-98 IN THE CHICOT AND EVANGELINE AQUIFERS, HOUSTON-GALVESTON REGION, TEXAS: USGS OPEN-FILE REPORT 99-178, 1999.

WATER-RESOURCES DATA, TEXAS, WATER YEAR 1998, VOLUME 4, GROUND-WATER DATA: USGS WATER-DATA REPORT TX-98-4, 1999.

WATER-LEVEL ALTITUDES 2000 AND WATER-LEVEL CHANGES 1990-2000 AND 1999-2000 IN THE CHICOT AND EVANGELINE AQUIFERS, FORT BEND COUNTY AND ADJACENT AREAS, TEXAS: USGS OPEN-FILE REPORT 00-093, 2000.

WATER-LEVEL ALTITUDES 2000, WATER-LEVEL CHANGES 1977-2000 AND 1999-2000, AND COMPACTION 1973-99 IN THE CHICOT AND EVANGELINE AQUIFERS, HOUSTON-GALVESTON REGION, TEXAS: USGS OPEN-FILE REPORT 00-094, 2000.

WATER-RESOURCES DATA, TEXAS, WATER YEAR 1999, VOLUME 6, GROUND-WATER DATA: USGS WATER-DATA REPORT TX-99-6, 2000 .

WATER-RESOURCES DATA, TEXAS, WATER YEAR 2000, VOLUME 6, GROUND-WATER DATA: USGS WATER-DATA REPORT TX-00-6, 2001.

\section{FRANKLIN COUNTY}

GEOLOGY AND UNDERGROUND WATERS OF NORTHEASTERN TEXAS: USGS WATER-SUPPLY PAPER 276, 1911.

RECORDS OF WELLS, SPRINGS, DRILLERS' LOGS, WATER ANALYSES, AND MAP SHOWING LOCATIONS OF WELLS AND SPRINGS IN CAMP, FRANKLIN, AND TITUS COUNTIES, TEXAS: TEXAS BOARD OF WATER ENGINEERS MISCELLANEOUS PUBLICATION 30, 1943.

PUBLIC WATER SUPPLIES IN EASTERN TEXAS: USGS WATERSUPPLY PAPER 1047, 1948.

RECONNAISSANCE INVESTIGATION OF THE GROUND-WATER RESOURCES OF THE RED RIVER, SULPHUR RIVER, AND CYPRESS CREEK BASINS, TEXAS: TEXAS WATER COMMISSION BULLETIN 6306, 1963.

GROUND-WATER RESOURCES OF CAMP, FRANKLIN, MORRIS, AND TITUS COUNTIES, TEXAS: TEXAS WATER DEVELOPMENT BOARD BULLETIN 6517, 1965.

COMPILATION OF RESULTS OF AQUIFER TESTS IN TEXAS: TEXAS WATER DEVELOPMENT BOARD REPORT 98, 1969.

WATER-QUALITY DATA FOR AQUIFERS, STREAMS, AND LAKES IN THE VICINITY OF KEECHI, MOUNT SYLVAN, OAKWOOD, AND 
PALESTINE SALT DOMES, NORTHEAST TEXAS SALT-DOME BASIN: USGS OPEN-FILE REPORT 80-2037, 1980

GEOHYDROLOGY OF THE KEECHI, MOUNT SYLVAN, OAKWOOD, AND PALESTINE SALT DOMES IN THE NORTHEAST TEXAS SALTDOME BASIN: USGS OPEN-FILE REPORT 80-2044, 1980.

GEOLOGY AND GEOHYDROLOGY OF THE EAST TEXAS BASIN-A REPORT ON THE PROGRESS OF NUCLEAR WASTE ISOLATION FEASIBILITY STUDIES (1979): UNIVERSITY OF TEXAS, BUREAU OF ECONOMIC GEOLOGY GEOLOGICAL CIRCULAR 80-12, 1980.

GEOLOGY AND GEOHYDROLOGY OF THE EAST TEXAS BASIN-A REPORT ON THE PROGRESS OF NUCLEAR WASTE ISOLATION FEASIBILITY STUDIES (1980): UNIVERSITY OF TEXAS, BUREAU OF ECONOMIC GEOLOGY GEOLOGICAL CIRCULAR 81-7, 1981.

SPRINGS OF TEXAS, VOLUME 1: (BY GUNNAR BRUNE), BRANCHSMITH, INC., FORT WORTH, TEXAS, 1981.

APPROXIMATE POTENTIOMETRIC SURFACES FOR THE AQUIFERS OF THE TEXAS COASTAL UPLANDS SYSTEM, 1980: USGS HYDROLOGIC INVESTIGATIONS ATLAS HA-704, 1987.

GROUND-WATER RESOURCES OF THE NACATOCH AQUIFER: TEXAS WATER DEVELOPMENT BOARD REPORT 305, 1988.

PROPERTIES AND CHEMICAL CONSTITUENTS IN GROUND WATER FROM THE LOWER CLAIBORNE-UPPER WILCOX AQUIFER, GULF COAST REGIONAL AQUIFER SYSTEMS, SOUTH-CENTRAL UNITED STATES: USGS WATER-RESOURCES INVESTIGATIONS REPORT 92-4102, 1993.

AQUIFERS OF TEXAS: TEXAS WATER DEVELOPMENT BOARD REPORT 345, 1995.

\section{FREESTONE COUNTY}

GEOLOGY AND UNDERGROUND WATERS OF THE SOUTHEASTERN PART OF THE TEXAS COASTAL PLAIN: USGS WATER-SUPPLY PAPER 335, 1914.

RECORDS OF WELLS, DRILLERS' LOGS, AND WATER ANALYSES, AND MAP SHOWING LOCATION OF WELLS IN FREESTONE COUNTY, TEXAS: TEXAS BOARD OF WATER ENGINEERS MISCELLANEOUS PUBLICATION 88, 1937.

PUBLIC WATER SUPPLIES IN EASTERN TEXAS: USGS WATERSUPPLY PAPER 1047, 1948.

RECONNAISSANCE INVESTIGATION OF THE GROUND-WATER RESOURCES OF THE TRINITY RIVER BASIN, TEXAS: TEXAS WATER COMMISSION BULLETIN 6309, 1963.

RECONNAISSANCE INVESTIGATION OF THE GROUND-WATER RESOURCES OF THE BRAZOS RIVER BASIN, TEXAS: TEXAS WATER COMMISSION BULLETIN 6310, 1963.

COMPILATION OF RESULTS OF AQUIFER TESTS IN TEXAS: TEXAS WATER DEVELOPMENT BOARD REPORT 98, 1969.

GROUND-WATER CONDITIONS IN ANDERSON, CHEROKEE, FREESTONE, AND HENDERSON COUNTIES, TEXAS: TEXAS WATER DEVELOPMENT BOARD REPORT 150, 1972.

PROJECTED EFFECTS OF THE PROPOSED TENNESSEE COLONY RESERVOIR ON GROUND-WATER CONDITIONS IN THE CARRIZOWILCOX AQUIFER AND TRINITY RIVER ALLUVIUM, TRINIDADOAKWOOD AREA, TEXAS: USGS OPEN-FILE REPORT 74-297, 1974.
GEOHYDROLOGIC SIGNIFICANCE OF LITHOFACIES OF THE CARRIZO SAND OF ARKANSAS, LOUISIANA, AND TEXAS AND THE MERIDIAN SAND OF MISSISSIPPI: USGS PROFESSIONAL PAPER 569-D, 1975.

ALTITUDE OF THE WATER TABLE IN THE ALLUVIAL AND WILCOX AQUIFERS IN THE VICINITY OF RICHLAND AND TEHUACANA CREEKS AND THE TRINITY RIVER, TEXAS, DECEMBER 1979: USGS OPEN-FILE REPORT 80-1007, 1980.

WATER-QUALITY DATA FOR AQUIFERS, STREAMS, AND LAKES IN THE VICINITY OF KEECHI, MOUNT SYLVAN, OAKWOOD, AND PALESTINE SALT DOMES, NORTHEAST TEXAS SALT-DOME BASIN: USGS OPEN-FILE REPORT 80-2037, 1980

GEOHYDROLOGY OF THE KEECHI, MOUNT SYLVAN, OAKWOOD, AND PALESTINE SALT DOMES IN THE NORTHEAST TEXAS SALTDOME BASIN: USGS OPEN-FILE REPORT 80-2044, 1980.

GEOLOGY AND GEOHYDROLOGY OF THE EAST TEXAS BASIN-A REPORT ON THE PROGRESS OF NUCLEAR WASTE ISOLATION FEASIBILITY STUDIES (1979): UNIVERSITY OF TEXAS, BUREAU OF ECONOMIC GEOLOGY GEOLOGICAL CIRCULAR 80-12, 1980.

GEOLOGY AND GEOHYDROLOGY OF THE EAST TEXAS BASIN-A REPORT ON THE PROGRESS OF NUCLEAR WASTE ISOLATION FEASIBILITY STUDIES (1980): UNIVERSITY OF TEXAS, BUREAU OF ECONOMIC GEOLOGY GEOLOGICAL CIRCULAR 81-7, 1981.

HYDROGEOCHEMISTRY OF THE UNSATURATED ZONES AT BIG BROWN LIGNITE MINE, EAST TEXAS: THE UNIVERSITY OF TEXAS AT AUSTIN, MASTER'S THESIS, 1982.

THREE-DIMENSIONAL GROUND-WATER MODELING IN DEPOSITIONAL SYSTEMS, WILCOX GROUP, OAKWOOD SALT DOME AREA, EAST TEXAS: UNIVERSITY OF TEXAS, BUREAU OF ECONOMIC GEOLOGY REPORT OF INVESTIGATIONS NO. 133, 1983.

HYDROLOGIC AND GEOCHEMICAL DATA FOR THE BIG BROWN LIGNITE MINE AREA, FREESTONE COUNTY, TEXAS: OPEN-FILE REPORT 85-338, 1985.

TEXAS GROUND-WATER RESOURCES, in NATIONAL WATER SUMMARY 1984: USGS WATER-SUPPLY PAPER 2275, 1985.

APPROXIMATE POTENTIOMETRIC SURFACES FOR THE AQUIFERS OF THE TEXAS COASTAL UPLANDS SYSTEM, 1980: USGS HYDROLOGIC INVESTIGATIONS ATLAS HA-704, 1987.

GEOHYDROLOGIC FRAMEWORK OF THE GULF COASTAL PLAIN: USGS HYDROLOGIC INVESTIGATIONS ATLAS HA-695, 1988.

GROUND-WATER RESOURCES OF THE CARRIZO-WILCOX AQUIFER IN THE CENTRAL TEXAS REGION: TEXAS WATER DEVELOPMENT BOARD REPORT 332, 1991

NATIONAL WATER-QUALITY ASSESSMENT PROGRAM-THE TRINITY RIVER BASIN: USGS OPEN-FILE REPORT 91-158, 1991

PROPERTIES AND CHEMICAL CONSTITUENTS IN GROUND WATER FROM THE LOWER CLAIBORNE-UPPER WILCOX AQUIFER, GULF COAST REGIONAL AQUIFER SYSTEMS, SOUTH-CENTRAL UNITED STATES: USGS WATER-RESOURCES INVESTIGATIONS REPORT 92-4102, 1993

PROPERTIES AND CHEMICAL CONSTITUENTS IN GROUND WATER FROM THE MIDDLE CLAIBORNE AQUIFER, GULF COAST REGIONAL AQUIFER SYSTEMS, SOUTH-CENTRAL UNITED STATES: USGS WATER-RESOURCES INVESTIGATIONS REPORT 92-4104, 1993. 
PROPERTIES AND CHEMICAL CONSTITUENTS IN GROUND WATER FROM THE MIDDLE WILCOX AQUIFER, GULF COAST REGIONAL AQUIFER SYSTEMS, SOUTH-CENTRAL UNITED STATES: USGS WATER-RESOURCES INVESTIGATIONS REPORT 93-4070, 1993.

NATIONAL WATER-QUALITY ASSESSMENT PROGRAM-PESTICIDES IN THE TRINITY RIVER BASIN STUDY UNIT, TEXAS, 1968-91: USGS FACT SHEET FS-088-95, 1995.

WATER-QUALITY ASSESSMENT OF THE TRINITY RIVER BASIN, TEXAS-DATA COLLECTION, 1992-95: USGS FACT SHEET FS-095-95, 1995.

WATER-QUALITY ASSESSMENT OF THE TRINITY RIVER BASIN, TEXAS-PESTICIDES IN A SUBURBAN WATERSHED, ARLINGTON, 1993-94: USGS FACT SHEET FS-159-95, 1995.

AQUIFERS OF TEXAS: TEXAS WATER DEVELOPMENT BOARD REPORT 345, 1995.

WATER QUALITY IN THE QUEEN CITY AQUIFER, EAST TEXAS: TEXAS WATER DEVELOPMENT BOARD HYDROLOGIC ATLAS NO. 6, 1996.

WATER-QUALITY ASSESSMENT OF THE TRINITY RIVER BASIN, TEXAS-GROUND-WATER QUALITY OF THE TRINITY, CARRIZOWILCOX, AND GULF COAST AQUIFERS, FEBRUARY-AUGUST 1994: USGS WATER-RESOURCES INVESTIGATIONS REPORT 99-4233, 2000.

\section{FRIO COUNTY}

ARTESIAN WELLS OF THE COASTAL PRAIRIE REGION AND TERTIARY BELT OF TEXAS: GEOLOGICAL SURVEY OF TEXAS, CHAPTER 2, 1893 .

UNDERGROUND WATERS OF THE COASTAL PLAIN OF TEXAS: USGS WATER-SUPPLY PAPER 190, 1907.

GROUND WATER IN THE WINTER GARDEN AND ADJACENT DISTRICTS IN SOUTHWESTERN TEXAS: USGS OPEN-FILE REPORT (UNNUMBERED), 1931.

UNDERGROUND WATER RESOURCES OF ATASCOSA AND FRIO COUNTIES, TEXAS: USGS OPEN-FILE REPORT (UNNUMBERED) (PRESS RELEASE), 1932.

GEOLOGY AND GROUND-WATER RESOURCES OF ATASCOSA AND FRIO COUNTIES, TEXAS: USGS WATER-SUPPLY PAPER 676, 1935.

PUBLIC WATER SUPPLIES IN SOUTHERN TEXAS: USGS WATERSUPPLY PAPER 1070, 1950.

SUPPLEMENTARY REPORT ON SURFACE-WATER AND GROUNDWATER SURVEYS, NUECES RIVER BASIN, TEXAS: USGS OPENFILE REPORT (UNNUMBERED), 1950.

RECORDS OF WATER-LEVEL MEASUREMENTS IN ATASCOSA AND FRIO COUNTIES, TEXAS: TEXAS BOARD OF WATER ENGINEERS BULLETIN 5416, 1954.

DEVELOPMENT OF GROUND WATER FROM THE CARRIZO SAND AND WILCOX GROUP IN DIMMIT, ZAVALA, MAVERICK, FRIO, ATASCOSA, MEDINA, BEXAR, LIVE OAK, McMULLEN, LA SALLE, AND WEBB COUNTIES, TEXAS: USGS OPEN-FILE REPORT 57-77, 1957.
WATER LEVELS IN OBSERVATION WELLS IN ATASCOSA AND FRIO COUNTIES, TEXAS: TEXAS WATER COMMISSION BULLETIN 6015, 1960.

RECONNAISSANCE INVESTIGATION OF THE GROUND-WATER RESOURCES OF THE GUADALUPE, SAN ANTONIO, AND NUECES RIVER BASINS, TEXAS: TEXAS WATER COMMISSION BULLETIN 6409, 1964.

GROUND-WATER RESOURCES OF ATASCOSA AND FRIO COUNTIES, TEXAS: TEXAS WATER DEVELOPMENT BOARD REPORT 32, 1966.

WATER-LEVEL DATA FROM OBSERVATION WELLS IN THE NORTHWESTERN GULF COASTAL PLAIN OF TEXAS: TEXAS WATER DEVELOPMENT BOARD REPORT 70, 1968.

HYDROLOGIC SIGNIFICANCE OF THE LITHOFACIES OF THE SPARTA SAND IN ARKANSAS, LOUISIANA, MISSISSIPPI, AND TEXAS: USGS PROFESSIONAL PAPER 569-A, 1968.

COMPILATION OF RESULTS OF AQUIFER TESTS IN TEXAS: TEXAS WATER DEVELOPMENT BOARD REPORT 98, 1969.

HYDROLOGIC SIGNIFICANCE OF LITHOFACIES OF THE CANE RIVER FORMATION OR EQUIVALENTS OF ARKANSAS, LOUISIANA, MISSISSIPPI, AND TEXAS: USGS PROFESSIONAL PAPER 569-C, 1972.

GEOHYDROLOGIC SIGNIFICANCE OF LITHOFACIES OF THE CARRIZO SAND OF ARKANSAS, LOUISIANA, AND TEXAS AND THE MERIDIAN SAND OF MISSISSIPPI: USGS PROFESSIONAL PAPER 569-D, 1975.

GROUND-WATER RESOURCES OF THE CARRIZO AQUIFER IN THE WINTER GARDEN AREA OF TEXAS, VOLUME 1: TEXAS WATER DEVELOPMENT BOARD REPORT 210, V. 1, 1976.

GROUND-WATER RESOURCES OF THE CARRIZO AQUIFER IN THE WINTER GARDEN AREA OF TEXAS, VOLUME 2: TEXAS WATER DEVELOPMENT BOARD REPORT 210, V. 2, 1977.

VARIATIONS IN SPECIFIC YIELD IN THE OUTCROP OF THE CARRIZO SAND IN SOUTH TEXAS AS ESTIMATED BY SEISMIC REFRACTION: TEXAS DEPARTMENT OF WATER RESOURCES REPORT 229, 1979.

TEXAS GROUND-WATER RESOURCES, in NATIONAL WATER SUMMARY 1984: USGS WATER-SUPPLY PAPER 2275, 1985.

APPROXIMATE POTENTIOMETRIC SURFACES FOR THE AQUIFERS OF THE TEXAS COASTAL UPLANDS SYSTEM, 1980: USGS HYDROLOGIC INVESTIGATIONS ATLAS HA-704, 1987.

GEOHYDROLOGIC FRAMEWORK OF THE GULF COASTAL PLAIN: USGS HYDROLOGIC INVESTIGATIONS ATLAS HA-695, 1988.

DEPOSITIONAL AND GROUND-WATER FLOW SYSTEMS OF THE CARRIZO-UPPER WILCOX, SOUTH TEXAS: UNIVERSITY OF TEXAS, BUREAU OF ECONOMIC GEOLOGY REPORT OF INVESTIGATIONS NO. 175, 1988.

GROUND-WATER QUALITY MONITORING RESULTS IN THE WINTER GARDEN AREA, 1990: TEXAS WATER DEVELOPMENT BOARD REPORT 335, 1992.

PROPERTIES AND CHEMICAL CONSTITUENTS IN GROUND WATER FROM THE LOWER CLAIBORNE-UPPER WILCOX AQUIFER, GULF COAST REGIONAL AQUIFER SYSTEMS, SOUTH-CENTRAL UNITED STATES: USGS WATER-RESOURCES INVESTIGATIONS REPORT 92-4102, 1993 
PROPERTIES AND CHEMICAL CONSTITUENTS IN GROUND WATER FROM THE MIDDLE CLAIBORNE AQUIFER, GULF COAST REGIONAL AQUIFER SYSTEMS, SOUTH-CENTRAL UNITED STATES: USGS WATER-RESOURCES INVESTIGATIONS REPORT 92-4104, 1993.

PROPERTIES AND CHEMICAL CONSTITUENTS IN GROUND WATER FROM THE MIDDLE WILCOX AQUIFER, GULF COAST REGIONAL AQUIFER SYSTEMS, SOUTH-CENTRAL UNITED STATES: USGS WATER-RESOURCES INVESTIGATIONS REPORT 93-4070, 1993.

DEFINING THE EDWARDS AQUIFER FRESHWATER/SALINE-WATER INTERFACE WITH GEOPHYSICAL LOGS AND MEASURED DATA (SAN ANTONIO TO KYLE, TEXAS): EDWARDS UNDERGROUND WATER DISTRICT REPORT 93-06, 1993.

1994 REVIEW AND UPDATE OF THE POSITION OF THE EDWARDS AQUIFER FRESHWATER/SALINE-WATER INTERFACE FROM UVALDE TO KYLE, TEXAS: EDWARDS UNDERGROUND WATER DISTRICT REPORT 94-05, 1994.

REGIONAL DISTRIBUTION OF PERMEABILITY IN THE EDWARDS AQUIFER: EDWARDS UNDERGROUND WATER DISTRICT REPORT 95-02, 1995.

AQUIFERS OF TEXAS: TEXAS WATER DEVELOPMENT BOARD REPORT 345, 1995.

STRATIGRAPHIC NOMENCLATURE AND GEOLOGIC SECTIONS OF THE GULF COASTAL PLAIN OF TEXAS: USGS OPEN-FILE REPORT 94-461, 1995.

WATER QUALITY IN THE SPARTA AQUIFER, EAST TEXAS: TEXAS WATER DEVELOPMENT BOARD HYDROLOGIC ATLAS NO. 5, 1996.

WATER QUALITY IN THE QUEEN CITY AQUIFER, EAST TEXAS: TEXAS WATER DEVELOPMENT BOARD HYDROLOGIC ATLAS, NO. 6, 1996.

EDWARDS AQUIFER GROUND-WATER RESOURCES: GEOLOGIC CONTROLS ON POROSITY DEVELOPMENT IN PLATFORM CARBONATES, SOUTH TEXAS: UNIVERSITY OF TEXAS, BUREAU OF ECONOMIC GEOLOGY REPORT OF INVESTIGATIONS NO. 238, 1996.

HYDROGEOLOGIC FRAMEWORK AND GEOCHEMISTRY OF THE EDWARDS AQUIFER SALINE-WATER ZONE, SOUTH-CENTRAL TEXAS: USGS WATER-RESOURCES INVESTIGATIONS REPORT 97-4133, 1997.

WATER QUALITY IN SOUTH-CENTRAL TEXAS-TEXAS, 1996-98: USGS CIRCULAR 1212, 2000.

WATER-RESOURCES DATA, TEXAS, WATER YEAR 2000, VOLUME 6, GROUND-WATER DATA: USGS WATER-DATA REPORT TX-00-6, 2001.

\section{GAINES COUNTY}

GEOLOGY AND GROUND-WATER RESOURCES OF THE SOUTHERN HIGH PLAINS: USGS OPEN-FILE REPORT (UNNUMBERED), 1935.

GROUND WATER IN THE SOUTHERN HIGH PLAINS: USGS OPENFILE REPORT (UNNUMBERED, 1937.

GROUND WATER IN THE HIGH PLAINS OF TEXAS: TEXAS BOARD OF WATER ENGINEERS MISCELLANEOUS PUBLICATION (UNNUMBERED), 1938.
GROUND WATER IN THE HIGH PLAINS OF TEXAS: TEXAS BOARD OF WATER ENGINEERS MISCELLANEOUS PUBLICATION 119, 1940.

PROGRESS REPORT ON GROUND WATER IN THE HIGH PLAINS OF TEXAS: TEXAS BOARD OF WATER ENGINEERS MISCELLANEOUS PUBLICATION (UNNUMBERED), 1942.

PROGRESS REPORT ON GROUND WATER IN THE HIGH PLAINS OF TEXAS: TEXAS BOARD OF WATER ENGINEERS MISCELLANEOUS PUBLICATION 120, 1943.

PROGRESS REPORT ON GROUND WATER IN THE HIGH PLAINS OF TEXAS: TEXAS BOARD OF WATER ENGINEERS MISCELLANEOUS PUBLICATION 121, 1944.

GROUND WATER IN THE HIGH PLAINS OF TEXAS, PROGRESS REPORT NO. 5: TEXAS BOARD OF WATER ENGINEERS MISCELLANEOUS PUBLICATION 122, 1945.

GROUND WATER IN THE HIGH PLAINS OF TEXAS: USGS WATERSUPPLY PAPER 889-F, 1946.

RECORDS OF WELLS, DRILLERS' LOGS, WATER ANALYSES, AND MAP SHOWING LOCATIONS OF WELLS IN GAINES COUNTY, TEXAS: TEXAS BOARD OF WATER ENGINEERS MISCELLANEOUS PUBLICATION 89, 1946.

GROUND WATER IN HIGH PLAINS OF TEXAS, PROGRESS REPORT NO. 6: TEXAS BOARD OF WATER ENGINEERS MISCELLANEOUS PUBLICATION 123, 1947.

GEOLOGY AND GROUND WATER IN THE IRRIGATED REGION OF THE SOUTHERN HIGH PLAINS IN TEXAS, PROGRESS REPORT NO. 7: TEXAS BOARD OF WATER ENGINEERS MISCELLANEOUS PUBLICATION 125, 1949.

COST OF PUMPING WATER FOR IRRIGATION, TEXAS HIGH PLAINS, FIELD INVESTIGATIONS-1947 IRRIGATION SEASON: TEXAS BOARD OF WATER ENGINEERS MISCELLANEOUS PUBLICATION 124,1951

DEVELOPMENT OF WELLS FOR IRRIGATION AND FLUCTUATION OF WATER LEVELS IN THE HIGH PLAINS OF TEXAS TO JANUARY 1951: TEXAS BOARD OF WATER ENGINEERS BULLETIN 5104, 1951.

PUBLIC WATER SUPPLIES IN WESTERN TEXAS: USGS WATERSUPPLY PAPER 1106, 1951 [1952].

SUMMARY OF GROUND-WATER DEVELOPMENT IN THE SOUTHERN HIGH PLAINS, TEXAS: TEXAS BOARD OF WATER ENGINEERS BULLETIN 5402, 1954.

RECORDS OF WATER-LEVEL MEASUREMENTS IN COCHRAN, CROSBY, GAINES, HOCKLEY, LYNN, AND TERRY COUNTIES, TEXAS: TEXAS BOARD OF WATER ENGINEERS BULLETIN 5407, 1954.

GROUND-WATER DEVELOPMENT IN THE SOUTHERN HIGH PLAINS OF TEXAS, 1953: TEXAS BOARD OF WATER ENGINEERS BULLETIN 5410, 1954.

WATER-LEVEL DECLINE MAPS OF 16 COUNTIES IN THE SOUTHERN HIGH PLAINS, TEXAS, JANUARY 1954 TO JANUARY 1955: (BAILEY, BRISCOE, CASTRO, COCHRAN, CROSBY, DEAF SMITH, FLOYD, GAINES, HALE, HOCKLEY, LAMB, LUBBOCK, PARMER, RANDALL, SWISHER, AND TERRY): USGS OPEN-FILE REPORT, 1955.

WATER-LEVEL DECLINE MAPS OF 17 COUNTIES IN THE SOUTHERN HIGH PLAINS, TEXAS, JANUARY 1955 TO JANUARY 1956: TEXAS BOARD OF WATER ENGINEERS BULLETIN 5607, 1956. 
WATER-LEVEL DECLINE MAPS, 1956 TO 1957, AND WATER LEVELS IN OBSERVATION WELLS IN 20 COUNTIES IN THE SOUTHERN HIGH PLAINS, TEXAS: TEXAS BOARD OF WATER ENGINEERS BULLETIN 5705, 1957.

WATER-LEVEL MEASUREMENTS AND MAPS, SOUTHERN HIGH PLAINS, TEXAS, 1958 AND 1959: TEXAS BOARD OF WATER ENGINEERS BULLETIN 5908, 1959.

WATER LEVELS IN OBSERVATION WELLS, SOUTHERN HIGH PLAINS, TEXAS, 1959 AND 1960: TEXAS BOARD OF WATER ENGINEERS BULLETIN 6011, 1960.

WATER LEVELS IN OBSERVATION WELLS, SOUTHERN HIGH PLAINS, TEXAS, 1960 AND 1961: TEXAS BOARD OF WATER ENGINEERS BULLETIN 6101, 1961.

A SUMMARY OF THE OCCURRENCE AND DEVELOPMENT OF GROUND WATER IN THE SOUTHERN HIGH PLAINS OF TEXAS: TEXAS BOARD OF WATER ENGINEERS BULLETIN 6107, 1961.

SHALLOW FORMATIONS AND AQUIFERS OF THE WEST TEXAS AREA: WEST TEXAS GEOLOGICAL SOCIETY PUBLICATION 61-45 AND PERMIAN BASIN GEOPHYSICAL SOCIETY, MIDLAND, TEXAS, 1961.

WATER-LEVEL MEASUREMENTS THROUGH 1962 IN SELECTED OBSERVATION WELLS, SOUTHERN HIGH PLAINS, TEXAS: TEXAS WATER COMMISSION BULLETIN 6207, 1962.

A SUMMARY OF THE OCCURRENCE AND DEVELOPMENT OF GROUND WATER IN THE SOUTHERN HIGH PLAINS OF TEXAS, WITH A SECTION ON ARTIFICIAL RECHARGE STUDIES: USGS WATER-SUPPLY PAPER 1693, 1964.

WATER-LEVEL DATA FROM OBSERVATION WELLS IN THE SOUTHERN HIGH PLAINS OF TEXAS: TEXAS WATER DEVELOPMENT BOARD REPORT 21, 1966.

GROUND-WATER RESOURCES OF GAINES COUNTY, TEXAS: TEXAS WATER DEVELOPMENT BOARD REPORT 15, 1966.

WATER-LEVEL DATA FROM OBSERVATION WELLS IN THE SOUTHERN HIGH PLAINS OF TEXAS: TEXAS WATER DEVELOPMENT BOARD REPORT 21, 1966.

RECONNAISSANCE INVESTIGATION OF THE GROUND-WATER RESOURCES OF THE COLORADO RIVER BASIN, TEXAS: TEXAS WATER COMMISSION REPORT 51, 1967.

COMPILATION OF RESULTS OF AQUIFER TESTS IN TEXAS: TEXAS WATER DEVELOPMENT BOARD REPORT 98, 1969.

GROUND WATER IN THE OGALLALA FORMATION IN THE SOUTHERN HIGH PLAINS OF TEXAS AND NEW MEXICO: USGS HYDROLOGIC INVESTIGATIONS ATLAS HA-330, 1969.

WATER-LEVEL DATA FROM OBSERVATION WELLS IN THE SOUTHERN HIGH PLAINS OF TEXAS, 1965-70: TEXAS WATER DEVELOPMENT BOARD REPORT 121, 1970.

ANALYTICAL STUDY OF THE OGALLALA AQUIFER IN GAINES COUNTY, TEXAS-PROJECTIONS OF SATURATED THICKNESS, VOLUME OF WATER IN STORAGE, PUMPAGE RATES, PUMPING LIFTS, AND WELL YIELDS: TEXAS DEPARTMENT OF WATER RESOURCES REPORT 227, 1979.

WATER-LEVEL DATA FROM OBSERVATION WELLS IN THE SOUTHERN HIGH PLAINS OF TEXAS, 1971-77: TEXAS DEPARTMENT OF WATER RESOURCES REPORT 228, 1979.
PRELIMINARY DATA DESCRIBING THE DISTRIBUTION OF FLUORIDE AND SILICA IN THE OGALLALA AQUIFER ON THE HIGH PLAINS OF TEXAS: USGS OPEN-FILE REPORT 80-349, 1980

EVALUATING THE GROUND-WATER RESOURCES OF THE HIGH PLAINS OF TEXAS: RESULTS OF TEST HOLE DRILLING: TEXAS DEPARTMENT OF WATER RESOURCES LIMITED PRINTING REPORT LP-129, 1980.

EVALUATING THE GROUND-WATER RESOURCES OF THE HIGH PLAINS OF TEXAS: NEUTRON-PROBE MEASUREMENTS OF DEEP SOIL MOISTURE AS AN INDICATION OF AQUIFER RECHARGE RATES: TEXAS DEPARTMENT OF WATER RESOURCES LIMITED PRINTING REPORT LP-142, 1981.

SPRINGS OF TEXAS, VOLUME 1: (BY GUNNAR BRUNE), BRANCHSMITH, INC., FORT WORTH, TEXAS, 1981.

BEDROCK GEOLOGY, ALTITUDE OF BASE, AND 1980 SATURATED THICKNESS OF THE HIGH PLAINS AQUIFER IN PARTS OF COLORADO, KANSAS, NEBRASKA, NEW MEXICO, OKLAHOMA, SOUTH DAKOTA, TEXAS, AND WYOMING: USGS HYDROLOGIC INVESTIGATIONS ATLAS HA-648, 1981.

WATER LEVEL AND SATURATED THICKNESS CHANGES, PREDEVELOPMENT TO 1980, IN THE HIGH PLAINS AQUIFER IN PARTS OF COLORADO, KANSAS, NEBRASKA, NEW MEXICO, OKLAHOMA, SOUTH DAKOTA, TEXAS, AND WYOMING: USGS HYDROLOGIC INVESTIGATIONS ATLAS HA-652, 1981

DISSOLVED SOLIDS AND SODIUM IN WATER FROM THE HIGH PLAINS AQUIFER IN PARTS OF COLORADO, KANSAS, NEBRASKA, NEW MEXICO, OKLAHOMA, SOUTH DAKOTA, TEXAS, AND WYOMING: USGS HYDROLOGIC INVESTIGATIONS ATLAS HA-658, 1982.

EVALUATING THE GROUND-WATER RESOURCES OF THE HIGH PLAINS OF TEXAS, VOLUME 1: TEXAS DEPARTMENT OF WATER RESOURCES REPORT 288, V. 1, 1984

EVALUATING THE GROUND-WATER RESOURCES OF THE HIGH PLAINS OF TEXAS, VOLUME 4, RECORDS OF WELLS, AND MAPS SHOWING WELL LOCATIONS, BASE OF AQUIFER, WATER LEVELS, AND SATURATED THICKNESS (ANDREWS, BORDEN, COCHRAN, DAWSON, ECTOR, GAINES, GARZA, GLASSCOCK, HOWARD, HOCKLEY, LUBBOCK, LYNN, MARTIN, MIDLAND, TERRY, AND YOAKUM COUNTIES: TEXAS DEPARTMENT OF WATER RESOURCES REPORT 288 V. 4, 1984.

GEOHYDROLOGY OF THE HIGH PLAINS AQUIFER IN PARTS OF COLORADO, KANSAS, NEBRASKA, NEW MEXICO, OKLAHOMA, SOUTH DAKOTA, TEXAS, AND WYOMING: USGS PROFESSIONAL PAPER 1400-B, 1984.

TEXAS GROUND-WATER RESOURCES, in NATIONAL WATER SUMMARY 1984: USGS WATER-SUPPLY PAPER 2275, 1985.

DIGITAL SIMULATION OF GROUND-WATER FLOW IN THE HIGH PLAINS AQUIFER IN PARTS OF COLORADO, KANSAS, NEBRASKA, NEW MEXICO, OKLAHOMA, SOUTH DAKOTA, TEXAS, AND WYOMING: USGS PROFESSIONAL PAPER 1400-D, 1986.

HYDROGEOLOGY AND HYDROCHEMISTRY OF CRETACEOUS AQUIFERS, TEXAS PANHANDLE AND EASTERN NEW MEXICO: UNIVERSITY OF TEXAS, BUREAU OF ECONOMIC GEOLOGY GEOLOGICAL CIRCULAR 88-3, 1988.

SUMMARY OF THE HIGH PLAINS REGIONAL AQUIFER-SYSTEM ANALYSIS IN PARTS OF COLORADO, KANSAS, NEBRASKA, NEW 
MEXICO, OKLAHOMA, SOUTH DAKOTA, TEXAS, AND WYOMING: USGS PROFESSIONAL PAPER 1400-A, 1988.

HYDROGEOLOGY OF LOWER CRETACEOUS STRATA UNDER THE SOUTHERN HIGH PLAINS OF TEXAS AND NEW MEXICO: TEXAS WATER DEVELOPMENT BOARD REPORT 314, 1989.

PUBLIC SUPPLY GROUND-WATER USE IN THE SOUTHERN HIGH PLAINS OF TEXAS: TEXAS WATER DEVELOPMENT BOARD REPORT 328, 1990.

WATER-LEVEL CHANGES IN THE HIGH PLAINS AQUIFER OF TEXAS, 1980-1990: TEXAS WATER DEVELOPMENT BOARD HYDROLOGIC ATLAS NO. 1, 1991.

EVALUATION OF GROUND-WATER RESOURCES IN THE SOUTHERN HIGH PLAINS OF TEXAS: TEXAS WATER DEVELOPMENT BOARD REPORT 330, 1991.

THE HIGH PLAINS AQUIFER SYSTEM OF TEXAS, 1980 TO 1990. OVERVIEW AND PROJECTIONS: TEXAS WATER DEVELOPMENT BOARD REPORT 341, 1993.

WATER-QUALITY EVALUATION OF THE OGALLALA AQUIFER, TEXAS: TEXAS WATER DEVELOPMENT BOARD REPORT 342 , 1993.

WATER-LEVEL CHANGES IN THE HIGH PLAINS AQUIFER-PREDEVELOPMENT TO 1992: USGS WATER-RESOURCES INVESTIGATIONS REPORT 94-4027, 1994.

WATER-LEVEL CHANGES IN THE HIGH PLAINS AQUIFER, 1980 TO 1994: USGS FACT SHEET FS-215-95, 1995.

AQUIFERS OF TEXAS: TEXAS WATER DEVELOPMENT BOARD REPORT 345, 1995

WATER-LEVEL CHANGES IN THE HIGH PLAINS AQUIFER, 1980 TO 1995: USGS FACT SHEET FS-068-97, 1997.

WATER-LEVEL CHANGES IN THE HIGH PLAINS AQUIFER-PREDEVELOPMENT TO 1995: USGS WATER-RESOURCES INVESTIGATIONS REPORT 97-4081, 1997.

UPDATED WATER-QUALITY EVALUATION OF THE OGALLALA AQUIFER INCLUDING SELECTED METALLIC AND NON-METALLIC INORGANIC CONSTITUENTS: TEXAS WATER DEVELOPMENT BOARD HYDROLOGIC ATLAS NO. 10, 1998.

\section{GALVESTON COUNTY}

ORGANIC REMAINS FROM THE DEEP WELL AT GALVESTON: GEOLOGICAL SURVEY OF TEXAS, CHAPTER 1, 1893.

ARTESIAN WELLS OF THE COASTAL PRAIRIE REGION AND TERTIARY BELT OF TEXAS: GEOLOGICAL SURVEY OF TEXAS, CHAPTER 2, 1893.

UNDERGROUND WATERS OF THE COASTAL PLAIN OF TEXAS: USGS WATER-SUPPLY PAPER 190, 1907

GEOLOGY AND UNDERGROUND WATERS OF THE SOUTHEASTERN PART OF THE TEXAS COASTAL PLAIN: USGS WATER-SUPPLY PAPER 335, 1914

GROUND-WATER RESOURCES OF THE HOUSTON-GALVESTON AREA, TEXAS: USGS OPEN-FILE REPORT (UNNUMBERED) (PRESS RELEASE), 1932.
GROUND-WATER RESOURCES OF THE HOUSTON DISTRICT, TEXAS USGS OPEN-FILE REPORT, 1933.

A STUDY OF SALT-WATER ENCROACHMENT IN THE GALVESTON AREA, TEXAS: AMERICAN GEOPHYSICAL UNION TRANSACTIONS, PART II, PUBLISHED BY THE NATIONAL RESEARCH COUNCIL OF THE NATIONAL ACADEMY OF SCIENCES, JUNE 1934.

RECORDS OF WELLS IN HARRIS, GALVESTON, WALLER, FORT BEND, BRAZORIA, AND GRIMES COUNTY, TEXAS: USGS OPENFILE REPORT (UNNUMBERED), 1935.

PROGRESS REPORT ON THE GROUND-WATER RESOURCES OF THE HOUSTON DISTRICT, TEXAS: USGS OPEN-FILE REPORT (UNNUMBERED), 1937.

PROGRESS REPORT ON THE GROUND-WATER RESOURCES OF THE HOUSTON DISTRICT, TEXAS: TEXAS BOARD OF WATER ENGINEERS MISCELLANEOUS PUBLICATION 129, 1938.

RECORDS OF WELLS, DRILLERS' LOGS, WATER ANALYSES, AND MAP SHOWING LOCATION OF WELLS IN GALVESTON COUNTY, TEXAS: TEXAS STATE BOARD OF WATER ENGINEERS MISCELLANEOUS PUBLICATION 91, 1939.

GROUND-WATER RESOURCES OF THE HOUSTON-GALVESTON AREA AND ADJACENT REGION: TEXAS BOARD OF WATER ENGINEERS MISCELLANEOUS PUBLICATION 130, 1939.

PROGRESS REPORT ON THE GROUND-WATER RESOURCES OF THE HOUSTON DISTRICT, TEXAS: TEXAS BOARD OF WATER ENGINEERS MISCELLANEOUS PUBLICATION 131, 1939

GROUND-WATER CONDITIONS IN THE LEAGUE CITY AREA, TEXAS: USGS OPEN-FILE REPORT (UNNUMBERED), 1939.

GROUND WATER IN GALVESTON COUNTY, TEXAS, OUTSTANDING FACTS: USGS OPEN-FILE REPORT (UNNUMBERED), 1939.

THE GALVESTON EXPLORATORY DRILLING PROGRAM: USGS OPEN-FILE REPORT (UNNUMBERED), 1940.

RESULTS OF TEST DRILLING BY CITY OF GALVESTON AND CONCLUSIONS: TEXAS BOARD OF WATER ENGINEERS MISCELLANEOUS PUBLICATION (UNNUMBERED), 1941.

WATER SUPPLY OF GALVESTON, GROUND WATER: USGS OPENFILE REPORT (UNNUMBERED), 1941.

GROUND-WATER INVESTIGATIONS IN THE VICINITY OF GALVESTON, TEXAS, WITH SPECIAL REFERENCE TO SALTWATER INTRUSION: CONFERENCE OF THE GROUND-WATER DIVISION, APRIL 28 TO MAY 3, 1941, WASHINGTON, D.C., USGS OPEN-FILE REPORT (UNNUMBERED), 1941.

GROUND-WATER INVESTIGATIONS IN THE VICINITY OF GALVESTON, TEXAS WITH SPECIAL REFERENCE TO SALTWATER INTRUSION: USGS OPEN-FILE REPORT (UNNUMBERED), 1941

RECORDS OF WELLS, DRILLERS' AND ELECTRICAL LOGS, WATERLEVEL MEASUREMENTS, WATER ANALYSES, AND MAP SHOWING LOCATION OF WELLS IN GALVESTON COUNTY, TEXAS: TEXAS STATE BOARD OF WATER ENGINEERS MISCELLANEOUS PUBLICATION 92, 1941

WATER SUPPLY OF LA MARQUE, GALVESTON COUNTY, TEXAS: USGS OPEN-FILE REPORT (UNNUMBERED), 1941.

WATER SUPPLY IN THE VICINITY OF TEXAS CITY, TEXAS: USGS OPEN-FILE REPORT (UNNUMBERED), 1941 
EMERGENCY WATER SUPPLY AVAILABLE ON GALVESTON ISLAND AND BOLIVAR PENINSULA, GALVESTON COUNTY, TEXAS: USGS OPEN-FILE REPORT (UNNUMBERED), 1942.

RESULTS OF TEST DRILLING BY CITY OF GALVESTON, NOV. 1941 TO JUNE 1942: USGS OPEN-FILE REPORT (UNNUMBERED), 1943.

PROGRESS REPORT ON THE GROUND-WATER RESOURCES OF THE TEXAS CITY AREA, TEXAS: USGS OPEN-FILE REPORT (UNNUMBERED), 1943.

ESTIMATED INCREASE OF PUMPAGE AND DECLINE OF WATER LEVELS IN WELLS IN HOUSTON DISTRICT DURING 1943: USGS OPEN-FILE REPORT (UNNUMBERED), 1943.

GROUND-WATER PROBLEMS IN THE TEXAS CITY-ALTA LOMABAYTOWN DISTRICT, TEXAS: USGS OPEN-FILE REPORT (UNNUMBERED), 1944.

MEMORANDUM CONCERNING CHLORIDE IN WATER FROM WELL 5 OF THE PAN AMERICAN REFINERY, TEXAS CITY, TEXAS: USGS OPEN-FILE REPORT (UNNUMBERED), 1944.

MEMORANDUM REGARDING GROUND-WATER CONDITIONS IN THE TEXAS CITY-GALVESTON AREA, TEXAS: USGS OPEN-FILE REPORT (UNNUMBERED), 1944.

GROUND-WATER CONDITIONS IN GALVESTON COUNTY, TEXAS: TEXAS BOARD OF WATER ENGINEERS MISCELLANEOUS PUBLICATION (UNNUMBERED), 1947.

MEMORANDUM ON GROUND-WATER CONDITIONS, MONSANTO CHEMICAL COMPANY PLANT, TEXAS CITY, TEXAS: USGS OPENFILE REPORT (UNNUMBERED), 1948

PUBLIC WATER SUPPLIES IN EASTERN TEXAS: USGS WATERSUPPLY PAPER 1047, 1948

GEOLOGY AND GROUND-WATER RESOURCES OF THE HOUSTON DISTRICT, TEXAS: TEXAS BOARD OF WATER ENGINEERS BULLETIN 5001, 1950.

WATER SUPPLY OF THE HOUSTON GULF COAST REGION: TEXAS BOARD OF WATER ENGINEERS BULLETIN 5101, 1951.

GEOLOGY AND GROUND-WATER RESOURCES OF GALVESTON COUNTY, TEXAS: TEXAS BOARD OF WATER ENGINEERS BULLETIN 5502, 1955.

AVAILABILITY OF GROUND WATER IN THE GULF COAST REGION OF TEXAS: USGS OPEN-FILE REPORT (UNNUMBERED), 1956.

PUMPAGE OF GROUND WATER AND CHANGES IN WATER LEVELS IN GALVESTON COUNTY, TEXAS, 1952-57: TEXAS BOARD OF WATER ENGINEERS BULLETIN 5808, 1958.

PUMPAGE OF GROUND WATER AND CHANGES IN WATER LEVELS IN GALVESTON COUNTY, TEXAS, 1958-62: TEXAS WATER COMMISSION BULLETIN 6303, 1963.

RECONNAISSANCE INVESTIGATION OF THE GROUND-WATER RESOURCES OF THE GULF COAST REGION, TEXAS: TEXAS WATER COMMISSION BULLETIN 6305, 1963

ANALOG MODEL STUDY OF GROUND WATER IN THE HOUSTON DISTRICT, TEXAS: TEXAS WATER COMMISSION BULLETIN 6508, 1965.

DEVELOPMENT OF GROUND WATER IN THE HOUSTON DISTRICT, TEXAS, 1961-65: TEXAS WATER DEVELOPMENT BOARD REPORT 63, 1967.
HYDROLOGIC EFFECTS OF THE EARTHQUAKE OF MARCH 27, 1964, OUTSIDE ALASKA: USGS PROFESSIONAL PAPER 544-C, 1968.

LAND-SURFACE SUBSIDENCE IN THE HOUSTON-GALVESTON REGION, TEXAS: USGS OPEN-FILE REPORT 69-61, 1969.

COMPILATION OF RESULTS OF AQUIFER TESTS IN TEXAS: TEXAS WATER DEVELOPMENT BOARD REPORT 98, 1969.

RECORDS OF WATER-LEVEL MEASUREMENTS IN WELLS IN GALVESTON COUNTY, TEXAS, 1894-1969: TEXAS WATER DEVELOPMENT BOARD REPORT 123, 1970.

RECORDS OF WELLS, DRILLERS' LOGS, AND CHEMICAL ANALYSES OF GROUND WATER IN GALVESTON COUNTY, TEXAS, 1952-1970: TEXAS WATER DEVELOPMENT BOARD REPORT 139, 1971.

GROUND-WATER CONDITIONS IN THE GALVESTON BAY AREAHARRIS, GALVESTON, AND CHAMBERS COUNTIES, TEXAS: WILLIAM F. GUYTON \& ASSOCIATES, AUSTIN AND HOUSTON, TEXAS, 1972

DEVELOPMENT OF GROUND WATER IN THE HOUSTON DISTRICT, TEXAS, 1966-69: TEXAS WATER DEVELOPMENT BOARD REPORT 152,1972

LAND-SURFACE SUBSIDENCE IN THE HOUSTON-GALVESTON REGION, TEXAS: USGS OPEN-FILE REPORT 74-123, 1974.

LAND-SURFACE SUBSIDENCE IN THE AREA OF MOSES LAKE NEAR TEXAS CITY, TEXAS: USGS OPEN-FILE REPORT 75-424, 1975.

LAND-SURFACE SUBSIDENCE IN THE HOUSTON-GALVESTON REGION, TEXAS: TEXAS: TEXAS WATER DEVELOPMENT BOARD REPORT 188, 1975

MAJOR AND HISTORICAL SPRINGS OF TEXAS: TEXAS WATER DEVELOPMENT BOARD REPORT 189, 1975.

LAND-SURFACE SUBSIDENCE IN THE AREA OF MOSES LAKE NEAR TEXAS CITY, TEXAS: USGS WATER-RESOURCES INVESTIGATIONS REPORT 76-32, 1975.

ANALOG-MODEL STUDIES OF GROUND-WATER HYDROLOGY IN THE HOUSTON DISTRICT, TEXAS: TEXAS WATER DEVELOPMENT BOARD REPORT 190, 1975.

SUMMARY APPRAISALS OF THE NATION'S GROUND-WATER RESOURCES-TEXAS-GULF REGION: USGS PROFESSIONAL PAPER 813-F, 1976.

RECORDS OF WELLS, DRILLERS' LOGS, WATER-LEVEL MEASUREMENTS, AND CHEMICAL ANALYSES OF GROUND WATER IN HARRIS AND GALVESTON COUNTIES, TEXAS, 1970-74: TEXAS WATER DEVELOPMENT BOARD REPORT 203, 1976.

DEVELOPMENT OF GROUND WATER IN THE HOUSTON DISTRICT, TEXAS, 1970-74: USGS OPEN-FILE REPORT 77-413, 1977.

APPROXIMATE AREAS OF RECHARGE TO THE CHICOT AND EVANGELINE AQUIFER SYSTEMS IN THE HOUSTON-GALVESTON AREA, TEXAS: USGS OPEN-FILE REPORT 77-754, 1977.

HYDROGEOLOGY OF GULF COAST AQUIFERS, HOUSTONGALVESTON AREA, TEXAS: UNIVERSITY OF TEXAS, BUREAU OF ECONOMIC GEOLOGY GEOLOGICAL CIRCULAR 77-4, 1977.

PROFILES SHOWING POTENTIOMETRIC SURFACES AND CHANGES IN EFFECTIVE STRESS IN AQUIFERS IN HARRIS AND GALVESTON COUNTIES, TEXAS, 1977-78, 1978. 
STRATIGRAPHIC AND HYDROGEOLOGIC FRAMEWORK OF PART OF THE COASTAL PLAIN OF TEXAS: TEXAS DEPARTMENT OF WATER RESOURCES REPORT 236, 1979.

A DIGITAL MODEL FOR SIMULATION OF GROUND-WATER HYDROLOGY IN THE HOUSTON AREA, TEXAS: TEXAS DEPARTMENT OF WATER RESOURCES LIMITED PRINTING LP-103, 1979.

APPROXIMATE ALTITUDE OF WATER LEVELS IN WELLS IN THE CHICOT AND EVANGELINE AQUIFERS IN THE HOUSTON AREA, TEXAS, SPRING 1977 AND SPRING 1978: USGS OPEN-FILE REPORT 79-334, 1979.

APPROXIMATE WATER-LEVEL CHANGES IN WELLS IN THE CHICOT AND EVANGELINE AQUIFERS, 1977-79, AND MEASURED COMPACTION, 1973-79, IN HARRIS AND GALVESTON COUNTIES, TEXAS: USGS OPEN-FILE REPORT 79-693, 1979.

APPROXIMATE WATER-LEVEL CHANGES IN WELLS IN THE CHICOT AND EVANGELINE AQUIFERS IN THE HOUSTON-GALVESTON REGION, TEXAS, 1977-80 AND 1979-80: USGS OPEN-FILE REPORT 80-337, 1980.

APPROXIMATE ALTITUDE OF WATER LEVELS IN WELLS IN THE CHICOT AND EVANGELINE AQUIFERS IN THE HOUSTON AREA, TEXAS, SPRING 1979 AND SPRING 1980: USGS OPEN-FILE REPORT 80-579, 1980

APPROXIMATE LAND-SURFACE SUBSIDENCE IN THE HOUSTONGALVESTON REGION, TEXAS, 1906-78, 1943-78, AND 1973-78: USGS OPEN-FILE REPORT 80-338, 1980.

LAND-SURFACE SUBSIDENCE IN THE TEXAS COASTAL REGION: USGS OPEN-FILE REPORT 80-969, 1980.

DEVELOPMENT OF GROUND WATER IN THE HOUSTONGALVESTON DISTRICT, TEXAS, 1970-74: TEXAS DEPARTMENT OF WATER RESOURCES REPORT 241, 1980.

APPROXIMATE WATER-LEVEL CHANGES IN WELLS IN THE CHICOT AND EVANGELINE AQUIFERS, 1977-81 AND 1980-81, AND MEASURED COMPACTION, 1973-81, IN THE HOUSTON-GALVESTON REGION, TEXAS: USGS OPEN-FILE REPORT 81-341, 1981.

SPRINGS OF TEXAS, VOLUME 1: (BY GUNNAR BRUNE), BRANCHSMITH, INC., FORT WORTH, TEXAS, 1981.

APPROXIMATE ALTITUDE OF WATER LEVELS IN THE CHICOT AND EVANGELINE AQUIFERS IN THE HOUSTON AREA, TEXAS, SPRING 1981: USGS OPEN-FILE REPORT 81-676, 1981.

LAND-SURFACE SUBSIDENCE IN THE TEXAS COASTAL REGION: TEXAS DEPARTMENT OF WATER RESOURCES REPORT 272, 1982.

APPROXIMATE WATER-LEVEL CHANGES IN WELLS IN THE CHICOT AND EVANGELINE AQUIFERS, 1977-82 AND 1981-82, AND MEASURED COMPACTION, 1973-82, IN THE HOUSTON-GALVESTON REGION, TEXAS: USGS OPEN-FILE REPORT 82-328, 1982.

GROUND-WATER WITHDRAWALS AND CHANGES IN WATER LEVELS IN THE HOUSTON DISTRICT, 1975-79: USGS OPEN-FILE REPORT 82-431, 1982.

APPROXIMATE ALTITUDE OF WATER LEVELS IN WELLS IN THE CHICOT AND EVANGELINE AQUIFERS IN THE HOUSTON AREA, TEXAS, SPRING 1982: USGS OPEN-FILE REPORT 82-559, 1982.

APPROXIMATE WATER-LEVEL CHANGES IN WELLS IN THE CHICOT AND EVANGELINE AQUIFERS, 1977-83 AND 1982-83, AND MEASURED COMPACTION, 1973-83, IN THE HOUSTON-GALVESTON REGION, TEXAS: USGS OPEN-FILE REPORT 83-150, 1983.
APPROXIMATE ALTITUDE OF WATER LEVELS IN WELLS IN THE CHICOT AND EVANGELINE AQUIFERS IN THE HOUSTON AREA, TEXAS, SPRING 1983: USGS OPEN-FILE REPORT 83-529, 1983.

APPROXIMATE WATER-LEVEL CHANGES IN WELLS IN THE CHICOT AND EVANGELINE AQUIFERS, 1977-84 AND 1983-84, AND MEASURED COMPACTION, 1973-84, IN THE HOUSTON-GALVESTON REGION, TEXAS: USGS OPEN-FILE REPORT 84-140, 1984.

APPROXIMATE ALTITUDE OF WATER LEVELS IN WELLS IN THE CHICOT AND EVANGELINE AQUIFERS IN THE HOUSTON AREA, TEXAS, SPRING, 1984: USGS OPEN-FILE REPORT 84-436, 1984.

RECORDS OF WELLS, DRILLERS' LOGS, WATER-LEVEL MEASUREMENTS, AND CHEMICAL ANALYSES OF GROUND WATER IN HARRIS AND GALVESTON COUNTIES, TEXAS, 1975-79: TEXAS DEPARTMENT OF WATER RESOURCES REPORT 285, 1984.

GROUND-WATER WITHDRAWALS AND CHANGES IN WATER LEVELS IN THE HOUSTON DISTRICT, TEXAS, 1975-79: TEXAS DEPARTMENT OF WATER RESOURCES REPORT 286, 1984.

GROUND-WATER WITHDRAWALS AND LAND-SURFACE SUBSIDENCE IN THE HOUSTON-GALVESTON REGION, TEXAS, 1906-80: TEXAS DEPARTMENT OF WATER RESOURCES REPORT 287, 1984.

DIGITAL MODELS FOR SIMULATION OF GROUND-WATER HYDROLOGY OF THE CHICOT AND EVANGELINE AQUIFERS ALONG THE GULF COAST OF TEXAS: TEXAS DEPARTMENT OF WATER RESOURCES REPORT 289, 1985

WATER USE, PROJECTED WATER REQUIREMENTS, AND RELATED DATA AND INFORMATION FOR THE METROPOLITAN STATISTICAL AREAS IN TEXAS: TEXAS DEPARTMENT OF WATER RESOURCES LIMITED PRINTING REPORT LP-201, 1985.

APPROXIMATE WATER-LEVEL CHANGES IN WELLS IN THE CHICOT AND EVANGELINE AQUIFERS, 1977-85 AND 1984-85, AND MEASURED COMPACTION, 1973-85, IN THE HOUSTON-GALVESTON REGION, TEXAS: USGS OPEN-FILE REPORT 85-158, 1985.

TEXAS GROUND-WATER RESOURCES, in NATIONAL WATER SUMMARY 1984: USGS WATER-SUPPLY PAPER 2275, 1985.

APPROXIMATE CHANGES IN WATER LEVELS IN THE CHICOT AND EVANGELINE AQUIFERS, 1977-86 AND 1985-86, AND MEASURED COMPACTION, 1973-86, IN THE HOUSTON-GALVESTON REGION, TEXAS: USGS OPEN-FILE REPORT 86-135, 1986.

APPROXIMATE ALTITUDE OF WATER LEVELS IN WELLS IN THE CHICOT AND EVANGELINE AQUIFERS IN THE HOUSTON AREA, TEXAS, SPRING 1986: USGS OPEN-FILE REPORT 86-306, 1986.

HYDROLOGY OF THE JASPER AQUIFER IN THE SOUTHEAST TEXAS COASTAL PLAIN: TEXAS WATER DEVELOPMENT BOARD REPORT 295, 1986.

APPROXIMATE WATER-LEVEL CHANGES IN WELLS COMPLETED IN THE CHICOT AND EVANGELINE AQUIFERS, 1977-87 AND 1986-87, AND MEASURED COMPACTION, 1973-87, IN THE HOUSTONGALVESTON REGION, TEXAS: USGS OPEN-FILE REPORT 87-108, 1987.

APPROXIMATE ALTITUDE OF WATER-LEVELS IN WELLS IN THE CHICOT AND EVANGELINE AQUIFERS IN THE HOUSTON AREA, TEXAS, SPRING 1987: USGS OPEN-FILE REPORT 87-233, 1987.

RECORDS OF WELLS, DRILLERS' LOGS, WATER-LEVEL MEASUREMENTS, AND CHEMICAL ANALYSES OF GROUND WATER IN HARRIS AND GALVESTON COUNTIES, TEXAS, 1980-84: USGS OPEN-FILE REPORT 87-378, 1987. 
GEOHYDROLOGIC FRAMEWORK OF THE GULF COASTAL PLAIN: USGS HYDROLOGIC INVESTIGATIONS ATLAS HA-695, 1988.

HYDROGEOLOGY AND PREDEVELOPMENT FLOW IN THE TEXAS GULF COAST AQUIFER SYSTEMS: USGS WATER-RESOURCES INVESTIGATIONS REPORT 87-4248, 1988.

RECORDS OF WELLS, DRILLERS' LOGS, WATER-LEVEL MEASUREMENTS, AND CHEMICAL ANALYSES OF GROUND WATER IN HARRIS AND GALVESTON COUNTIES, TEXAS, 1980-84: TEXAS WATER DEVELOPMENT BOARD REPORT 310, 1988.

APPROXIMATE WATER-LEVEL CHANGES IN WELLS COMPLETED IN THE CHICOT AND EVANGELINE AQUIFERS, 1977-88 AND 1987-88, AND MEASURED COMPACTION, 1973-88, IN THE HOUSTONGALVESTON REGION, TEXAS: USGS OPEN-FILE REPORT 88-168, 1988.

APPROXIMATE ALTITUDE OF WATER LEVELS IN WELLS IN THE CHICOT AND EVANGELINE AQUIFERS IN THE HOUSTON AREA, TEXAS, SPRING 1988: USGS OPEN-FILE REPORT 88-334, 1988.

APPROXIMATE ALTITUDE OF WATER LEVELS IN WELLS IN THE CHICOT AND EVANGELINE AQUIFERS IN THE HOUSTON AREA, TEXAS, SPRING 1989: USGS OPEN-FILE REPORT 89-237, 1989.

APPROXIMATE WATER-LEVEL CHANGE IN WELLS COMPLETED IN THE CHICOT AND EVANGELINE AQUIFERS, 1977-89 AND 1988-89, AND MEASURED COMPACTION, 1973-89, IN THE HOUSTONGALVESTON REGION, TEXAS: USGS OPEN-FILE REPORT 89-057, 1989.

APPROXIMATE WATER-LEVEL CHANGES IN WELLS COMPLETED IN THE CHICOT AND EVANGELINE AQUIFERS, 1977-90 AND 1989-90, AND MEASURED COMPACTION, 1973-DECEMBER 1989, IN THE HOUSTON-GALVESTON REGION, TEXAS: USGS OPEN-FILE REPORT 90-132, 1990.

GROUND-WATER FLOW IN THE GULF COAST AQUIFER SYSTEMS, SOUTH-CENTRAL UNITED STATES-A PRELIMINARY ANALYSIS: USGS WATER-RESOURCES INVESTIGATIONS REPORT 89-4071, 1990.

SALT-DOME LOCATIONS IN THE GULF COASTAL PLAIN, SOUTHCENTRAL UNITED STATES: USGS WATER-RESOURCES INVESTIGATIONS REPORT 90-4060, 1990.

LAND-SURFACE SUBSIDENCE RESULTING FROM GROUND-WATER WITHDRAWALS IN THE HOUSTON-GALVESTON REGION, TEXAS, THROUGH 1987: HARRIS-GALVESTON COASTAL SUBSIDENCE DISTRICT REPORT OF INVESTIGATIONS NO. 90-01, 1990.

RECORDS OF WELLS, DRILLERS' LOGS, WATER-LEVEL MEASUREMENTS, AND CHEMICAL ANALYSES OF GROUND WATER IN HARRIS AND GALVESTON COUNTIES, TEXAS, 1984-89: USGS OPEN-FILE REPORT 90-598, 1991.

APPROXIMATE ALTITUDE OF WATER LEVELS IN WELLS IN THE CHICOT AND EVANGELINE AQUIFERS IN THE HOUSTON AREA, TEXAS, JANUARY-FEBRUARY 1990: USGS OPEN-FILE REPORT 91-240, 1991.

HYDROLOGY OF THE TEXAS GULF COAST AQUIFER SYSTEMS: USGS OPEN-FILE REPORT 91-64, 1991.

APPROXIMATE CHANGES IN WATER LEVELS IN WELLS COMPLETED IN THE CHICOT AND EVANGELINE AQUIFERS, 1977-92 AND 1991-92, AND MEASURED COMPACTION, 1973-91, IN THE HOUSTON-GALVESTON REGION, TEXAS: USGS OPEN-FILE REPORT 92-66, 1992
PROPERTIES AND CHEMICAL CONSTITUENTS IN GROUND WATER FROM THE MISSISSIPPI RIVER VALLEY ALLUVIAL AQUIFER AND PERMEABLE ZONE A (HOLOCENE-UPPER PLEISTOCENE DEPOSITS), SOUTH-CENTRAL UNITED STATES: USGS WATERRESOURCES INVESTIGATIONS REPORT 91-4149, 1992.

WATER-RESOURCES DATA, TEXAS, WATER YEAR 1991, VOLUME 4, GROUND-WATER DATA: USGS WATER-DATA REPORT TX-91-4, 1992.

PROPERTIES AND CHEMICAL CONSTITUENTS IN GROUND WATER FROM THE UPPER CLAIBORNE AQUIFER, GULF COAST REGIONAL AQUIFER SYSTEMS, SOUTH-CENTRAL UNITED STATES: USGS WATER-RESOURCES INVESTIGATIONS REPORT 91-4150, 1993.

PROPERTIES AND CHEMICAL CONSTITUENTS IN GROUND WATER FROM PERMEABLE ZONE C (LOWER PLIOCENE-UPPER MIOCENE DEPOSITS), COASTAL LOWLANDS AQUIFER SYSTEM, SOUTHCENTRAL UNITED STATES: USGS WATER-RESOURCES INVESTIGATIONS REPORT 91-4151, 1993.

PROPERTIES AND CHEMICAL CONSTITUENTS IN GROUND WATER FROM PERMEABLE ZONE B (LOWER PLEISTOCENE-UPPER PLIOCENE DEPOSITS), COASTAL LOWLANDS AQUIFER SYSTEM, SOUTH-CENTRAL UNITED STATES: USGS WATER-RESOURCES INVESTIGATIONS REPORT 91-4152, 1993.

PROPERTIES AND CHEMICAL CONSTITUENTS IN GROUND WATER FROM PERMEABLE ZONE E (LOWER MIOCENE-UPPER OLIGOCENE DEPOSITS), COASTAL LOWLANDS AQUIFER SYSTEM, SOUTH-CENTRAL UNITED STATES: USGS WATER-RESOURCES INVESTIGATIONS REPORT 92-4103, 1993.

PROPERTIES AND CHEMICAL CONSTITUENTS IN GROUND WATER FROM PERMEABLE ZONE D (MIDDLE MIOCENE DEPOSITS), COASTAL LOWLANDS AQUIFER SYSTEM, SOUTH-CENTRAL UNITED STATES: USGS WATER-RESOURCES INVESTIGATIONS REPORT 92-4105, 1993.

GROUND-WATER WITHDRAWALS, WATER LEVELS, AND GROUNDWATER QUALITY IN THE HOUSTON DISTRICT, TEXAS, WITH EMPHASIS ON 1985-89: USGS WATER-RESOURCES INVESTIGATIONS REPORT 92-4180, 1993.

WATER-RESOURCES DATA, TEXAS, WATER YEAR 1992, VOLUME 4 , GROUND-WATER DATA: USGS WATER-DATA REPORT TX-92-4, 1993.

APPROXIMATE CHANGES IN WATER LEVELS IN WELLS COMPLETED IN THE CHICOT AND EVANGELINE AQUIFERS, 1977-94 AND 1993-94, AND MEASURED COMPACTION, 1973-93, IN THE HOUSTON-GALVESTON REGION, TEXAS: USGS OPEN-FILE REPORT 94-346, 1994.

WATER-RESOURCES DATA, TEXAS, WATER YEAR 1993, VOLUME 4, GROUND-WATER DATA: USGS WATER-DATA REPORT TX-93-4, 1994.

WATER-LEVEL ALTITUDES 1995, WATER-LEVEL CHANGES 1977-95 AND 1994-95, AND COMPACTION 1973-94 IN THE CHICOT AND EVANGELINE AQUIFERS, HOUSTON-GALVESTON REGION, TEXAS: USGS OPEN-FILE REPORT 95-182, 1995.

AQUIFERS OF TEXAS: TEXAS WATER DEVELOPMENT BOARD REPORT 345, 1995

WATER-RESOURCES DATA, TEXAS, WATER YEAR 1994, VOLUME 4 , GROUND-WATER DATA: USGS WATER-DATA REPORT TX-94-4, 1995. 
WATER-LEVEL ALTITUDES 1996, WATER-LEVEL CHANGES 1977-96 AND 1995-96, AND COMPACTION 1973-95 IN THE CHICOT AND EVANGELINE AQUIFERS, HOUSTON-GALVESTON REGION, TEXAS: USGS OPEN-FILE REPORT 96-163, 1996.

WATER-RESOURCES DATA, TEXAS, WATER YEAR 1995, VOLUME 4, GROUND-WATER DATA: USGS WATER-DATA REPORT TX-95-4, 1996.

WATER-LEVEL ALTITUDES 1997, WATER-LEVEL CHANGES 1977-97 AND 1996-97, AND COMPACTION 1973-96 IN THE CHICOT AND EVANGELINE AQUIFERS, HOUSTON-GALVESTON REGION, TEXAS: USGS OPEN-FILE REPORT 97-181, 1997.

WATER-LEVEL ALTITUDES IN WELLS COMPLETED IN THE CHICOT AND EVANGELINE AQUIFERS, HOUSTON-GALVESTON REGION, TEXAS, JANUARY-FEBRUARY 1992, 1993, AND 1994: USGS OPENFILE REPORT 97-786, 1997.

WATER-RESOURCES DATA, TEXAS, WATER YEAR 1996, VOLUME 4, GROUND-WATER DATA: USGS WATER-DATA REPORT TX-96-4, 1997.

WATER-LEVEL ALTITUDES 1998, WATER-LEVEL CHANGES 1977-98 AND 1997-98, AND COMPACTION IN THE CHICOT AND EVANGELINE AQUIFERS, HOUSTON-GALVESTON REGION, TEXAS: USGS OPEN-FILE REPORT 98-096, 1998.

WATER-RESOURCES DATA, TEXAS, WATER YEAR 1997, VOLUME 4, GROUND-WATER DATA: USGS WATER-DATA REPORT TX-97-4, 1998.

WATER-LEVEL ALTITUDES 1999, WATER-LEVEL CHANGES 1977-99 AND 1998-99, AND COMPACTION 1973-98 IN THE CHICOT AND EVANGELINE AQUIFERS, HOUSTON-GALVESTON REGION, TEXAS: USGS OPEN-FILE REPORT 99-178, 1999.

WATER-RESOURCES DATA, TEXAS, WATER YEAR 1998, VOLUME 4, GROUND-WATER DATA: USGS WATER-DATA REPORT TX-98-4, 1999.

WATER-LEVEL ALTITUDES 2000, WATER-LEVEL CHANGES 1977-2000 AND 1999-2000, AND COMPACTION 1973-99 IN THE CHICOT AND EVANGELINE AQUIFERS, HOUSTON-GALVESTON REGION, TEXAS: USGS OPEN-FILE REPORT 00-094, 2000.

WATER-RESOURCES DATA, TEXAS, WATER YEAR 1999, VOLUME 6, GROUND-WATER DATA: USGS WATER-DATA REPORT TX-99-6, 2000 .

WATER-RESOURCES DATA, TEXAS, WATER YEAR 2000, VOLUME 6, GROUND-WATER DATA: USGS WATER-DATA REPORT TX-00-6, 2001.

\section{GARZA COUNTY}

THE GEOLOGY AND WATER RESOURCES OF THE EASTERN PORTION OF THE PANHANDLE OF TEXAS: USGS WATER-SUPPLY PAPER 154, 1906.

GROUND WATER IN THE HIGH PLAINS OF TEXAS, PROGRESS REPORT (1944): TEXAS BOARD OF WATER ENGINEERS MISCELLANEOUS PUBLICATION 121, 1944.

GROUND WATER IN THE HIGH PLAINS OF TEXAS, PROGRESS REPORT NO. 5: TEXAS BOARD OF WATER ENGINEERS MISCELLANEOUS PUBLICATION 122, 1945.
GROUND WATER IN THE HIGH PLAINS OF TEXAS, PROGRESS REPORT NO. 6: TEXAS BOARD OF WATER ENGINEERS MISCELLANEOUS PUBLICATION 123, 1947.

GROUND WATER IN WESTERN PART OF GARZA COUNTY IN VICINITY OF POST, TEXAS: USGS OPEN-FILE REPORT (UNNUMBERED), 1947.

GEOLOGY AND GROUND WATER IN THE IRRIGATED REGION OF THE SOUTHERN HIGH PLAINS IN TEXAS, PROGRESS REPORT NO. 7: TEXAS BOARD OF WATER ENGINEERS MISCELLANEOUS PUBLICATION 125, 1949.

PUBLIC WATER SUPPLIES IN WESTERN TEXAS: USGS WATERSUPPLY PAPER 1106, 1951.

COST OF PUMPING WATER FOR IRRIGATION, TEXAS HIGH PLAINS FIELD INVESTIGATIONS-1947 IRRIGATION SEASON: TEXAS BOARD OF WATER ENGINEERS MISCELLANEOUS PUBLICATION 124, 1951.

WATER-LEVEL DECLINE MAPS, 1956 TO 1957, AND WATER LEVELS IN OBSERVATION WELLS IN 20 COUNTIES IN THE SOUTHERN HIGH PLAINS, TEXAS: TEXAS BOARD OF WATER ENGINEERS BULLETIN 5705, 1957.

WATER-LEVEL MEASUREMENTS AND MAPS, SOUTHERN HIGH PLAINS, TEXAS, 1958-1959: TEXAS BOARD OF WATER ENGINEERS BULLETIN 5908, 1959

WATER LEVELS IN OBSERVATION WELLS, SOUTHERN HIGH PLAINS, TEXAS, 1959 AND 1960: TEXAS BOARD OF WATER ENGINEERS BULLETIN 6011, 1960.

SHALLOW FORMATIONS AND AQUIFERS OF THE WEST TEXAS AREA: WEST TEXAS GEOLOGICAL SOCIETY PUBLICATION 61-45 AND PERMIAN BASIN GEOPHYSICAL SOCIETY, MIDLAND, TEXAS, 1961

WATER LEVELS IN OBSERVATION WELLS, SOUTHERN HIGH PLAINS, TEXAS, 1960 AND 1961:TEXAS BOARD OF WATER ENGINEERS BULLETIN 6101, 1961.

A SUMMARY OF THE OCCURRENCE AND DEVELOPMENT OF GROUND WATER IN THE SOUTHERN HIGH PLAINS OF TEXAS: TEXAS BOARD OF WATER ENGINEERS BULLETIN 6107, 1961.

WATER-LEVEL MEASUREMENTS THROUGH 1962 IN SELECTED OBSERVATION WELLS, SOUTHERN HIGH PLAINS, TEXAS: TEXAS WATER COMMISSION BULLETIN 6207, 1962.

A SUMMARY OF THE OCCURRENCE AND DEVELOPMENT OF GROUND WATER IN THE SOUTHERN HIGH PLAINS OF TEXAS, WITH A SECTION ON ARTIFICIAL RECHARGE STUDIES: USGS WATER-SUPPLY PAPER 1693, 1964.

INVESTIGATION OF GROUND-WATER CONTAMINATION, P.H.D., HACKBERRY, AND STORIE OIL FIELDS, GARZA COUNTY, TEXAS: TEXAS WATER COMMISSION LIMITED DISTRIBUTION REPORT LD-764, 1964.

WATER-LEVEL DATA FROM OBSERVATION WELLS IN THE SOUTHERN HIGH PLAINS OF TEXAS: TEXAS WATER DEVELOPMENT BOARD REPORT 21, 1966.

SOURCES OF SALINE WATER IN THE UPPER BRAZOS RIVER BASIN, TEXAS: USGS OPEN-FILE REPORT 68-108, 1968.

GROUND WATER IN THE OGALLALA FORMATION IN THE SOUTHERN HIGH PLAINS OF TEXAS AND NEW MEXICO: USGS HYDROLOGIC INVESTIGATIONS ATLAS HA-330, 1969. 
WATER-LEVEL DATA FROM OBSERVATION WELLS IN THE SOUTHERN HIGH PLAINS OF TEXAS, 1965-70: TEXAS WATER DEVELOPMENT BOARD REPORT 121, 1970.

AN EVALUATION OF THE USE OF DRILLERS' LOGS IN LITHOLOGIC STUDIES OF THE OGALLALA FORMATION OF THE SOUTHERN HIGH PLAINS OF TEXAS: USGS OPEN-FILE REPORT 72-451, 1972.

MAJOR AND HISTORICAL SPRINGS OF TEXAS: TEXAS WATER DEVELOPMENT BOARD REPORT 189, 1975.

ANALYTICAL STUDY OF THE OGALLALA AQUIFER IN LYNN AND GARZA COUNTIES, TEXAS-PROJECTIONS OF SATURATED THICKNESS, VOLUME OF WATER IN STORAGE, PUMPAGE RATES, PUMPAGE LIFTS, AND WELL YIELDS: TEXAS DEPARTMENT OF WATER RESOURCES REPORT 223, 1978.

WATER-LEVEL DATA FROM OBSERVATION WELLS IN THE SOUTHERN HIGH PLAINS OF TEXAS, 1971-77: TEXAS DEPARTMENT OF WATER RESOURCES REPORT 228, 1979.

PRELIMINARY DATA DESCRIBING THE DISTRIBUTION OF FLUORIDE AND SILICA IN THE OGALLALA AQUIFER ON THE HIGH PLAINS OF TEXAS: USGS OPEN-FILE REPORT 80-349, 1980.

EVALUATING THE GROUND-WATER RESOURCES OF THE HIGH PLAINS OF TEXAS: RESULTS OF TEST HOLE DRILLING: TEXAS DEPARTMENT OF WATER RESOURCES LIMITED PRINTING REPORT LP-129, 1980

EVALUATING THE GROUND-WATER RESOURCES OF THE HIGH PLAINS OF TEXAS: RESULTS OF SURFACE ELECTRICAL RESISTIVITY SURVEYS: TEXAS DEPARTMENT OF WATER RESOURCES LIMITED PRINTING REPORT LP-130, 1980.

ANALYTICAL STUDY OF THE OGALLALA AQUIFER IN DONLEY COUNTY, TEXAS-PROJECTIONS OF SATURATED THICKNESS, VOLUME OF WATER IN STORAGE, PUMPAGE RATES, PUMPING LIFTS, AND WELL YIELDS: TEXAS DEPARTMENT OF WATER RESOURCES REPORT 260, 1981.

SPRINGS OF TEXAS, VOLUME 1: (BY GUNNAR BRUNE), BRANCHSMITH, INC., FORT WORTH, TEXAS, 1981.

BEDROCK GEOLOGY, ALTITUDE OF BASE, AND 1980 SATURATED THICKNESS OF THE HIGH PLAINS AQUIFER IN PARTS OF COLORADO, KANSAS, NEBRASKA, NEW MEXICO, OKLAHOMA, SOUTH DAKOTA, TEXAS, AND WYOMING: USGS HYDROLOGIC INVESTIGATIONS ATLAS HA-648, 1981.

WATER LEVEL AND SATURATED THICKNESS CHANGES, PREDEVELOPMENT TO 1980, IN THE HIGH PLAINS AQUIFER IN PARTS OF COLORADO, KANSAS, NEBRASKA, NEW MEXICO, OKLAHOMA, SOUTH DAKOTA, TEXAS, AND WYOMING: USGS HYDROLOGIC INVESTIGATIONS ATLAS HA-652, 1981.

DISSOLVED SOLIDS AND SODIUM IN WATER FROM THE HIGH PLAINS AQUIFER IN PARTS OF COLORADO, KANSAS, NEBRASKA, NEW MEXICO, OKLAHOMA, SOUTH DAKOTA, TEXAS, AND WYOMING: USGS HYDROLOGIC INVESTIGATIONS ATLAS HA-658, 1982.

EVALUATING THE GROUND-WATER RESOURCES OF THE HIGH PLAINS OF TEXAS, VOLUME 1: TEXAS DEPARTMENT OF WATER RESOURCES REPORT 288, V. 1, 1984.

EVALUATING THE GROUND-WATER RESOURCES OF THE HIGH PLAINS OF TEXAS, VOLUME 4, RECORDS OF WELLS, AND MAPS SHOWING WELL LOCATIONS, BASE OF AQUIFER, WATER LEVELS, AND SATURATED THICKNESS (ANDREWS, BORDEN, COCHRAN, DAWSON, ECTOR, GAINES, GARZA, GLASSCOCK,
HOWARD, HOCKLEY, LUBBOCK, LYNN, MARTIN, MIDLAND, TERRY, AND YOAKUM COUNTIES: TEXAS DEPARTMENT OF WATER RESOURCES REPORT 288 V. 4, 1984.

GEOHYDROLOGY OF THE HIGH PLAINS AQUIFER IN PARTS OF COLORADO, KANSAS, NEBRASKA, NEW MEXICO, OKLAHOMA, SOUTH DAKOTA, TEXAS, AND WYOMING: USGS PROFESSIONAL PAPER 1400-B, 1984.

TEXAS GROUND-WATER RESOURCES, in NATIONAL WATER SUMMARY 1984: USGS WATER-SUPPLY PAPER 2275, 1985.

DIGITAL SIMULATION OF GROUND-WATER FLOW IN THE HIGH PLAINS AQUIFER IN PARTS OF COLORADO, KANSAS, NEBRASKA, NEW MEXICO, OKLAHOMA, SOUTH DAKOTA, TEXAS, AND WYOMING: USGS PROFESSIONAL PAPER 1400-D, 1986.

HYDROGEOLOGY AND HYDROCHEMISTRY OF CRETACEOUS AQUIFERS, TEXAS PANHANDLE AND EASTERN NEW MEXICO: UNIVERSITY OF TEXAS, BUREAU OF ECONOMIC GEOLOGY GEOLOGICAL CIRCULAR 88-3, 1988.

SUMMARY OF THE HIGH PLAINS REGIONAL AQUIFER-SYSTEM ANALYSIS IN PARTS OF COLORADO, KANSAS, NEBRASKA, NEW MEXICO, OKLAHOMA, SOUTH DAKOTA, TEXAS, AND WYOMING: USGS PROFESSIONAL PAPER 1400-A, 1988.

HYDROGEOLOGY OF LOWER CRETACEOUS STRATA UNDER THE SOUTHERN HIGH PLAINS OF TEXAS AND NEW MEXICO: TEXAS WATER DEVELOPMENT BOARD REPORT 314, 1989.

EVALUATION OF GROUND-WATER RESOURCES IN THE SOUTHERN HIGH PLAINS OF TEXAS: TEXAS WATER DEVELOPMENT BOARD REPORT 330, 1991.

WATER-LEVEL CHANGES IN THE HIGH PLAINS AQUIFER OF TEXAS, 1980-1990: TEXAS WATER DEVELOPMENT BOARD HYDROLOGIC ATLAS NO. 1, 1991.

PUBLIC SUPPLY GROUND-WATER USE IN THE NORTHERN HIGH PLAINS OF TEXAS: TEXAS WATER DEVELOPMENT BOARD REPORT 336, 1992.

EVALUATION OF WATER RESOURCES IN PARTS OF THE ROLLING PRAIRIES REGION OF NORTH-CENTRAL TEXAS: TEXAS WATER DEVELOPMENT BOARD REPORT 337, 1992.

THE HIGH PLAINS AQUIFER SYSTEM OF TEXAS, 1980 TO 1990OVERVIEW AND PROJECTIONS: TEXAS WATER DEVELOPMENT BOARD REPORT 341, 1993.

WATER-QUALITY EVALUATION OF THE OGALLALA AQUIFER, TEXAS: TEXAS WATER DEVELOPMENT BOARD REPORT 342, 1993.

WATER-LEVEL CHANGES IN THE HIGH PLAINS AQUIFER-PREDEVELOPMENT TO 1992: USGS WATER-RESOURCES INVESTIGATIONS REPORT 94-4027, 1994.

WATER-LEVEL CHANGES IN THE HIGH PLAINS AQUIFER, 1980 TO 1994: USGS FACT SHEET FS-215-95, 1995.

AQUIFERS OF TEXAS: TEXAS WATER DEVELOPMENT BOARD REPORT 345, 1995.

WATER-LEVEL CHANGES IN THE HIGH PLAINS AQUIFER, 1980 TO 1995: USGS FACT SHEET FS-068-97, 1997.

WATER-LEVEL CHANGES IN THE HIGH PLAINS AQUIFER-PREDEVELOPMENT TO 1995: USGS WATER-RESOURCES INVESTIGATIONS REPORT 97-4081, 1997. 
UPDATED WATER-QUALITY EVALUATION OF THE OGALLALA AQUIFER INCLUDING SELECTED METALLIC AND NON-METALLIC INORGANIC CONSTITUENTS: TEXAS DEPARTMENT OF WATER RESOURCES HYDROLOGIC ATLAS NO. 10, 1998.

\section{GILLESPIE COUNTY}

GEOLOGY OF THE EDWARDS PLATEAU AND RIO GRANDE PLAIN ADJACENT TO AUSTIN AND SAN ANTONIO, TEXAS, WITH REFERENCE TO THE OCCURRENCE OF UNDERGROUND WATERS: USGS 18TH ANNUAL REPORT, PART 2, 1898.

RECORDS OF WELLS, DRILLERS' LOGS, AND WATER ANALYSES, AND MAP SHOWING LOCATION OF WELLS IN GILLESPIE COUNTY, TEXAS: TEXAS BOARD OF WATER ENGINEERS MISCELLANEOUS PUBLICATION 93, 1937.

PUBLIC WATER SUPPLIES IN CENTRAL AND NORTH-CENTRAL TEXAS: USGS WATER-SUPPLY PAPER 1069, 1949.

INVESTIGATION OF GROUND-WATER RESOURCES NEAR FREDERICKSBURG, TEXAS: TEXAS WATER COMMISSION MEMORANDUM REPORT 63-03, 1963.

RECONNAISSANCE INVESTIGATION OF THE GROUND-WATER RESOURCES OF THE COLORADO RIVER BASIN, TEXAS: TEXAS WATER DEVELOPMENT BOARD REPORT 51, 1967.

COMPILATION OF RESULTS OF AQUIFER TESTS IN TEXAS: TEXAS WATER DEVELOPMENT BOARD REPORT 98, 1969.

RELATION OF PRECIPITATION TO ANNUAL GROUND-WATER RECHARGE IN THE EDWARDS AQUIFER, SAN ANTONIO AREA, TEXAS: USGS OPEN-FILE REPORT 75-298, 1975.

MAJOR AND HISTORICAL SPRINGS OF TEXAS: TEXAS WATER DEVELOPMENT BOARD REPORT 189, 1975.

REGIONAL DISTRIBUTION OF FRACTURES IN THE SOUTHERN EDWARDS PLATEAU AND THEIR RELATIONSHIP TO TECTONICS AND CAVES: UNIVERSITY OF TEXAS, BUREAU OF ECONOMIC GEOLOGY GEOLOGICAL CIRCULAR 78-2, 1978.

RECORDS OF GROUND-WATER RECHARGE AND DISCHARGE FOR THE EDWARDS AQUIFER IN THE SAN ANTONIO AREA, TEXAS, 1934-77: EDWARDS UNDERGROUND WATER DISTRICT BULLETIN 37, 1979.

OCCURRENCE, AVAILABILITY, AND CHEMICAL QUALITY OF GROUND WATER IN THE EDWARDS PLATEAU REGION OF TEXAS: TEXAS DEPARTMENT OF WATER RESOURCES REPORT 235,1979

RECORDS OF GROUND-WATER RECHARGE, DISCHARGE, WATER LEVELS, AND CHEMICAL QUALITY OF WATER FOR THE EDWARDS AQUIFER IN THE SAN ANTONIO AREA, TEXAS, 1934-78: EDWARDS UNDERGROUND WATER DISTRICT BULLETIN 38, 1980.

RECORDS OF GROUND-WATER RECHARGE, DISCHARGE, WATER LEVELS, AND CHEMICAL QUALITY OF WATER FOR THE EDWARDS AQUIFER IN THE SAN ANTONIO AREA, TEXAS, 1934-79: EDWARDS UNDERGROUND WATER DISTRICT BULLETIN 39, 1981.

RECORDS OF GROUND-WATER RECHARGE, DISCHARGE, WATER LEVELS, AND CHEMICAL QUALITY OF WATER FOR THE EDWARDS AQUIFER IN THE SAN ANTONIO AREA, TEXAS,
1934-80: EDWARDS UNDERGROUND WATER DISTRICT BULLETIN 40, 1982

GROUND-WATER AVAILABILITY OF THE LOWER CRETACEOUS FORMATIONS IN THE HILL COUNTRY OF SOUTH-CENTRAL TEXAS: TEXAS DEPARTMENT OF WATER RESOURCES REPORT 273,1983

RECORDS OF GROUND-WATER RECHARGE, DISCHARGE, WATER LEVELS, AND CHEMICAL QUALITY OF WATER FOR THE EDWARDS AQUIFER IN THE SAN ANTONIO AREA, TEXAS, 1934-81: EDWARDS UNDERGROUND WATER DISTRICT BULLETIN 41, 1984.

RECORDS OF GROUND-WATER RECHARGE, DISCHARGE, WATER LEVELS, AND CHEMICAL QUALITY OF WATER FOR THE EDWARDS AQUIFER IN THE SAN ANTONIO AREA, TEXAS, 1934-82: EDWARDS UNDERGROUND WATER DISTRICT BULLETIN 42, 1985

TEXAS GROUND-WATER RESOURCES, in NATIONAL WATER SUMMARY 1984: USGS WATER-SUPPLY PAPER 2275, 1985.

COMPILATION OF HYDROLOGIC DATA FOR THE EDWARDS AQUIFER, SAN ANTONIO AREA, TEXAS, 1983-84, WITH 1934-84 SUMMARY: EDWARDS UNDERGROUND WATER DISTRICT BULLETIN 43-44, 1986.

COMPILATION OF HYDROLOGIC DATA FOR THE EDWARDS AQUIFER, SAN ANTONIO AREA, TEXAS, 1985, WITH 1934-85 SUMMARY: EDWARDS UNDERGROUND WATER DISTRICT BULLETIN 45, 1987.

COMPILATION OF HYDROLOGIC DATA FOR THE EDWARDS AQUIFER, SAN ANTONIO AREA, TEXAS, 1986, WITH 1934-86 SUMMARY: EDWARDS UNDERGROUND WATER DISTRICT BULLETIN 46, 1988.

COMPILATION OF HYDROLOGIC DATA FOR THE EDWARDS AQUIFER, SAN ANTONIO AREA, TEXAS, 1987, WITH 1934-87 SUMMARY: EDWARDS UNDERGROUND WATER DISTRICT BULLETIN 47, 1988.

COMPILATION OF HYDROLOGIC DATA FOR THE EDWARDS AQUIFER, SAN ANTONIO AREA, TEXAS, 1988, WITH 1934-88 SUMMARY: EDWARDS UNDERGROUND WATER DISTRICT BULLETIN 48, 1989.

POTENTIOMETRIC SURFACE OF THE EDWARDS-TRINITY AQUIFER SYSTEM AND CONTIGUOUS HYDRAULICALLY CONNECTED UNITS, WEST-CENTRAL TEXAS, WINTER 1974-75: USGS WATERRESOURCES INVESTIGATIONS REPORT 89-4208, 1990.

COMPILATION OF HYDROLOGIC DATA FOR THE EDWARDS AQUIFER, SAN ANTONIO AREA, TEXAS, 1989, WITH 1934-89 SUMMARY: EDWARDS UNDERGROUND WATER DISTRICT BULLETIN 49, 1990.

WITHDRAWALS FROM THE EDWARDS-TRINITY AQUIFER SYSTEM AND CONTIGUOUS HYDRAULICALLY CONNECTED UNITS, WEST-CENTRAL TEXAS, DECEMBER 1974 THROUGH MARCH 1977: USGS WATER-RESOURCES INVESTIGATIONS REPORT 91-4021, 1991.

COMPILATION OF HYDROLOGIC DATA FOR THE EDWARDS AQUIFER, SAN ANTONIO AREA, TEXAS, 1990, WITH 1934-90 SUMMARY: EDWARDS UNDERGROUND WATER DISTRICT BULLETIN $50,1991$.

EVALUATION OF THE GROUND-WATER RESOURCES OF THE PALEOZOIC AND CRETACEOUS AQUIFERS IN THE HILL COUNTRY OF 
CENTRAL TEXAS: TEXAS WATER DEVELOPMENT BOARD REPORT 339, 1992.

CONFIGURATION OF THE BASE OF THE EDWARDS-TRINITY AQUIFER SYSTEM AND HYDROGEOLOGY OF THE UNDERLYING PRECRETACEOUS ROCKS, WEST-CENTRAL TEXAS: USGS WATERRESOURCES INVESTIGATIONS REPORT 91-4071, 1992.

COMPILATION OF HYDROLOGIC DATA FOR THE EDWARDS AQUIFER, SAN ANTONIO AREA, TEXAS, 1991, WITH 1934-91 SUMMARY: EDWARDS UNDERGROUND WATER DISTRICT BULLETIN 51,1992

HISTORICAL POTENTIOMETRIC SURFACE OF THE EDWARDS-TRINITY AQUIFER SYSTEM AND CONTIGUOUS HYDRAULICALLY CONNECTED UNITS, WEST-CENTRAL TEXAS: USGS WATERRESOURCES INVESTIGATIONS REPORT 92-4055, 1993.

HISTORICAL SATURATED THICKNESS OF THE EDWARDS-TRINITY AQUIFER SYSTEM AND SELECTED CONTIGUOUS HYDRAULICALLY CONNECTED UNITS, WEST-CENTRAL TEXAS: USGS WATER-RESOURCES INVESTIGATIONS REPORT 92-4125, 1993.

EDWARDS AQUIFER HYDROGEOLOGIC STATUS REPORT FOR 1992: EDWARDS UNDERGROUND WATER DISTRICT REPORT 93-05, 1993.

SIMULATIONS OF FLOW IN THE EDWARDS-TRINITY AQUIFER SYSTEM AND CONTIGUOUS HYDRAULICALLY CONNECTED UNITS, WEST-CENTRAL TEXAS: USGS WATER-RESOURCES INVESTIGATIONS REPORT 93-4039, 1994.

DISSOLVED-SOLIDS CONCENTRATIONS AND HYDROCHEMICAL FACIES IN WATER OF THE EDWARDS-TRINITY AQUIFER SYSTEM, WEST-CENTRAL TEXAS: USGS WATER-RESOURCES INVESTIGATIONS REPORT 93-4126, 1994.

GEOLOGIC HISTORY AND HYDROGEOLOGIC SETTING OF THE EDWARDS-TRINITY AQUIFER SYSTEM, WEST-CENTRAL TEXAS: USGS WATER-RESOURCES INVESTIGATIONS REPORT 94-4039, 1994.

AQUIFERS OF TEXAS: TEXAS WATER DEVELOPMENT BOARD REPORT 345, 1995.

WATER QUALITY IN THE EDWARDS-TRINITY (PLATEAU) AQUIFER, EDWARDS PLATEAU AND TRANS-PECOS, TEXAS: TEXAS WATER DEVELOPMENT BOARD HYDROLOGIC ATLAS NO. 3, 1995.

THE PALEOZOIC AND RELATED AQUIFERS OF CENTRAL TEXAS: TEXAS WATER DEVELOPMENT BOARD REPORT 346, 1996.

HYDROGEOLOGIC FRAMEWORK OF THE EDWARDS-TRINITY AQUIFER SYSTEM, WEST-CENTRAL TEXAS: USGS PROFESSIONAL PAPER 1421-B, 1996.

GROUNDWATER AVAILABILITY OF THE TRINITY AQUIFER, HILL COUNTRY AREA, TEXAS: NUMERICAL SIMULATIONS THROUGH 2050: TEXAS WATER DEVELOPMENT BOARD REPORT 353, 2000

AN OVERVIEW OF THE EDWARDS-TRINITY AQUIFER SYSTEM, CENTRAL-WEST TEXAS, CHAPTER 8, in AQUIFERS OF WEST TEXAS: TEXAS WATER DEVELOPMENT BOARD REPORT 356, 2001.

\section{GLASSCOCK COUNTY}

RECORDS OF WELLS, DRILLERS' LOGS, AND WATER ANALYSES, AND MAP SHOWING LOCATION OF WELLS IN GLASSCOCK
COUNTY, TEXAS: TEXAS BOARD OF WATER ENGINEERS MISCELLANEOUS PUBLICATION 94, 1937.

GEOLOGY AND GROUND-WATER RESOURCES OF THE BIG SPRING AREA, TEXAS: USGS WATER-SUPPLY PAPER 913, 1944.

PUBLIC WATER SUPPLIES IN WESTERN TEXAS: USGS WATERSUPPLY PAPER 1106, 1951.

RECORDS OF WATER-LEVEL MEASUREMENTS IN CROCKETT, GLASSCOCK, REAGAN, UPTON, AND TERRELL COUNTIES, TEXAS, 1937 THROUGH 1957: TEXAS BOARD OF WATER ENGINEERS BULLETIN 5903, 1959.

SHALLOW FORMATIONS AND AQUIFERS OF THE WEST TEXAS AREA: WEST TEXAS GEOLOGICAL SOCIETY PUBLICATION 61-45 AND PERMIAN BASIN GEOPHYSICAL SOCIETY, MIDLAND, TEXAS, 1961.

RECONNAISSANCE INVESTIGATION OF THE GROUND-WATER RESOURCES OF THE COLORADO RIVER BASIN, TEXAS: TEXAS WATER DEVELOPMENT BOARD REPORT 51, 1967.

WATER WELL AND GROUND-WATER CHEMICAL ANALYSIS DATA, GLASSCOCK COUNTY, TEXAS: TEXAS WATER DEVELOPMENT BOARD REPORT 143, 1972.

OCCURRENCE, AVAILABILITY, AND CHEMICAL QUALITY OF GROUND WATER IN THE EDWARDS PLATEAU REGION OF TEXAS: TEXAS DEPARTMENT OF WATER RESOURCES REPORT 235,1979 .

PRELIMINARY DATA DESCRIBING THE DISTRIBUTION OF FLUORIDE AND SILICA IN THE OGALLALA AQUIFER ON THE HIGH PLAINS OF TEXAS: USGS OPEN-FILE REPORT 80-349, 1980.

SPRINGS OF TEXAS, VOLUME 1: (BY GUNNAR BRUNE), BRANCHSMITH, INC., FORT WORTH, TEXAS, 1981.

EVALUATING THE GROUND-WATER RESOURCES OF THE HIGH PLAINS OF TEXAS, VOLUME 1: TEXAS DEPARTMENT OF WATER RESOURCES REPORT 288, V. 1, 1984.

EVALUATING THE GROUND-WATER RESOURCES OF THE HIGH PLAINS OF TEXAS, VOLUME 4, RECORDS OF WELLS, AND MAPS SHOWING WELL LOCATIONS, BASE OF AQUIFER, WATER LEVELS, AND SATURATED THICKNESS (ANDREWS, BORDEN, COCHRAN, DAWSON, ECTOR, GAINES, GARZA, GLASSCOCK, HOWARD, HOCKLEY, LUBBOCK, LYNN, MARTIN, MIDLAND, TERRY, AND YOAKUM COUNTIES: TEXAS DEPARTMENT OF WATER RESOURCES REPORT 288 V. 4, 1984

TEXAS GROUND-WATER RESOURCES, in NATIONAL WATER SUMMARY 1984: USGS WATER-SUPPLY PAPER 2275, 1985.

EVALUATION OF THE SANTA ROSA AQUIFER IN GLASSCOCK COUNTY: TEXAS WATER DEVELOPMENT BOARD LIMITED DISTRIBUTION REPORT LP-203, 1986.

HYDROGEOLOGY AND HYDROCHEMISTRY OF CRETACEOUS AQUIFERS, TEXAS PANHANDLE AND EASTERN NEW MEXICO: UNIVERSITY OF TEXAS, BUREAU OF ECONOMIC GEOLOGY GEOLOGICAL CIRCULAR 88-3, 1988.

PUBLIC SUPPLY GROUND-WATER USE IN WESTERN TEXAS: TEXAS WATER DEVELOPMENT BOARD REPORT 311, 1989.

POTENTIOMETRIC SURFACE OF THE EDWARDS-TRINITY AQUIFER SYSTEM AND CONTIGUOUS HYDRAULICALLY CONNECTED UNITS, WEST-CENTRAL TEXAS, WINTER 1974-75: USGS WATERRESOURCES INVESTIGATIONS REPORT 89-4208, 1990. 


\section{Bibliography of Ground-Water References for All 254 Counties in Texas, 1886-2001}

WITHDRAWALS FROM THE EDWARDS-TRINITY AQUIFER SYSTEM AND CONTIGUOUS HYDRAULICALLY CONNECTED UNITS, WEST-CENTRAL TEXAS, DECEMBER 1974 THROUGH MARCH 1977: USGS WATER-RESOURCES INVESTIGATIONS REPORT 91-4021, 1991.

EVALUATION OF GROUND-WATER RESOURCES IN THE SOUTHERN HIGH PLAINS OF TEXAS: TEXAS DEPARTMENT OF WATER RESOURCES REPORT 330, 1991.

WATER-LEVEL CHANGES IN THE HIGH PLAINS AQUIFER OF TEXAS, 1980-1990: TEXAS WATER DEVELOPMENT BOARD HYDROLOGIC ATLAS NO. 1, 1991.

GROUND-WATER QUALITY IN GARDEN CITY, TEXAS: TEXAS WATER DEVELOPMENT BOARD LIMITED PRINTING REPORT LP-210, 1991.

CONFIGURATION OF THE BASE OF THE EDWARDS-TRINITY AQUIFER SYSTEM AND HYDROGEOLOGY OF THE UNDERLYING PRECRETACEOUS ROCKS, WEST-CENTRAL TEXAS: USGS WATERRESOURCES INVESTIGATIONS REPORT 91-4071, 1992.

HISTORICAL POTENTIOMETRIC SURFACE OF THE EDWARDS-TRINITY AQUIFER SYSTEM AND CONTIGUOUS HYDRAULICALLY CONNECTED UNITS, WEST-CENTRAL TEXAS: USGS WATERRESOURCES INVESTIGATIONS REPORT 92-4055, 1993.

HISTORICAL SATURATED THICKNESS OF THE EDWARDS-TRINITY AQUIFER SYSTEM AND SELECTED CONTIGUOUS HYDRAULICALLY CONNECTED UNITS, WEST-CENTRAL TEXAS: USGS WATER-RESOURCES INVESTIGATIONS REPORT 92-4125, 1993.

THE HIGH PLAINS AQUIFER SYSTEM OF TEXAS, 1980 TO 1990. OVERVIEW AND PROJECTIONS: TEXAS WATER DEVELOPMENT BOARD REPORT 341, 1993.

WATER-QUALITY EVALUATION OF THE OGALLALA AQUIFER, TEXAS: TEXAS WATER DEVELOPMENT BOARD REPORT 342 , 1993.

SIMULATIONS OF FLOW IN THE EDWARDS-TRINITY AQUIFER SYSTEM AND CONTIGUOUS HYDRAULICALLY CONNECTED UNITS, WEST-CENTRAL TEXAS: USGS WATER-RESOURCES INVESTIGATIONS REPORT 93-4039, 1994.

DISSOLVED-SOLIDS CONCENTRATIONS AND HYDROCHEMICAL FACIES IN WATER OF THE EDWARDS-TRINITY AQUIFER SYSTEM, WEST-CENTRAL TEXAS: USGS WATER-RESOURCES INVESTIGATIONS REPORT 93-4126, 1994.

GEOLOGIC HISTORY AND HYDROGEOLOGIC SETTING OF THE EDWARDS-TRINITY AQUIFER SYSTEM, WEST-CENTRAL TEXAS: USGS WATER-RESOURCES INVESTIGATIONS REPORT 94-4039, 1994.

WATER-LEVEL CHANGES IN THE HIGH PLAINS AQUIFER, 1980 TO 1994: USGS FACT SHEET FS-215-95, 1995.

AQUIFERS OF TEXAS: TEXAS WATER DEVELOPMENT BOARD REPORT 345, 1995

WATER QUALITY IN THE EDWARDS-TRINITY (PLATEAU) AQUIFER, EDWARDS PLATEAU AND TRANS-PECOS, TEXAS: TEXAS WATER DEVELOPMENT BOARD HYDROLOGIC ATLAS NO. 3, 1995.

WATER-LEVEL CHANGES IN THE HIGH PLAINS AQUIFER, 1980 TO 1995: USGS FACT SHEET FS-068-97, 1997.

UPDATED WATER-QUALITY EVALUATION OF THE OGALLALA AQUIFER INCLUDING SELECTED METALLIC AND NON-METAL-
LIC INORGANIC CONSTITUENTS: TEXAS WATER DEVELOPMENT BOARD HYDROLOGIC ATLAS NO. 10, 1998.

AN OVERVIEW OF THE EDWARDS-TRINITY AQUIFER SYSTEM, CENTRAL-WEST TEXAS, CHAPTER 8, in AQUIFERS OF WEST TEXAS: TEXAS WATER DEVELOPMENT BOARD REPORT 356, 2001.

\section{GOLIAD COUNTY}

ARTESIAN WELLS OF THE COASTAL PRAIRIE REGION AND TERTIARY BELT OF TEXAS: GEOLOGICAL SURVEY OF TEXAS, CHAPTER 2, 1893.

UNDERGROUND WATERS OF THE COASTAL PLAIN OF TEXAS: USGS WATER-SUPPLY PAPER 190, 1907.

RECORDS OF WELLS, DRILLERS' LOGS, WATER ANALYSES, AND MAP SHOWING LOCATION OF WELLS IN REFUGIO COUNTY AND PART OF GOLIAD COUNTY, TEXAS: TEXAS BOARD OF WATER ENGINEERS MISCELLANEOUS PUBLICATION 228, 1938.

PUBLIC WATER SUPPLIES IN SOUTHERN TEXAS: USGS WATERSUPPLY PAPER 1070, 1950.

AVAILABILITY OF GROUND WATER IN THE GULF COAST REGION OF TEXAS: USGS OPEN-FILE REPORT (UNNUMBERED), 1956.

GROUND-WATER RESOURCES OF GOLIAD COUNTY, TEXAS: TEXAS BOARD OF WATER ENGINEERS BULLETIN 5711, 1957.

RECONNAISSANCE INVESTIGATION OF THE GROUND-WATER RESOURCES OF THE GULF COAST REGION, TEXAS: TEXAS WATER COMMISSION BULLETIN 6305, 1963.

RECONNAISSANCE INVESTIGATION OF THE GROUND-WATER RESOURCES OF THE GUADALUPE, SAN ANTONIO, AND NUECES RIVER BASINS, TEXAS: TEXAS WATER COMMISSION BULLETIN 6409, 1964.

GEOHYDROLOGIC SIGNIFICANCE OF LITHOFACIES OF THE COCKFIELD FORMATION OF LOUISIANA AND MISSISSIPPI AND OF THE YEGUA FORMATION OF TEXAS: USGS PROFESSIONAL PAPER 569-B, 1970.

GEOHYDROLOGIC SIGNIFICANCE OF LITHOFACIES OF THE CARRIZO SAND OF ARKANSAS, LOUISIANA, AND TEXAS AND THE MERIDIAN SAND OF MISSISSIPPI: USGS PROFESSIONAL PAPER 569-D, 1975.

SUMMARY APPRAISALS OF THE NATION'S GROUND-WATER RESOURCES-TEXAS-GULF REGION: USGS PROFESSIONAL PAPER 813-F, 1976.

STRATIGRAPHIC AND HYDROGEOLOGIC FRAMEWORK OF PART OF THE COASTAL PLAIN OF TEXAS: TEXAS DEPARTMENT OF WATER RESOURCES REPORT 236, 1979.

REGIONAL HYDRODYNAMICS AND HYDROCHEMISTRY OF THE URANIUM-BEARING OAKVILLE AQUIFER (MIOCENE) OF SOUTH TEXAS: UNIVERSITY OF TEXAS, BUREAU OF ECONOMIC GEOLOGY REPORT OF INVESTIGATIONS NO. 124, 1982.

TEXAS GROUND-WATER RESOURCES, in NATIONAL WATER SUMMARY 1984: USGS WATER-SUPPLY PAPER 2275, 1985.

DIGITAL MODELS FOR SIMULATION OF GROUND-WATER HYDROLOGY OF THE CHICOT AND EVANGELINE AQUIFERS ALONG THE GULF COAST OF TEXAS: TEXAS DEPARTMENT OF WATER RESOURCES REPORT 289, 1985. 
GEOHYDROLOGIC FRAMEWORK OF THE GULF COASTAL PLAIN: USGS HYDROLOGIC INVESTIGATIONS ATLAS HA-695, 1988.

DEPOSITIONAL AND GROUND-WATER FLOW SYSTEMS OF THE CARRIZO-UPPER WILCOX, SOUTH TEXAS: UNIVERSITY OF TEXAS, BUREAU OF ECONOMIC GEOLOGY REPORT OF INVESTIGATIONS NO. 175, 1988.

HYDROGEOLOGY AND PREDEVELOPMENT FLOW IN THE TEXAS GULF COAST AQUIFER SYSTEMS: USGS WATER-RESOURCES INVESTIGATIONS SYSTEMS REPORT 87-4248, 1988.

GROUND-WATER FLOW IN THE GULF COAST AQUIFER SYSTEMS, SOUTH CENTRAL UNITED STATES-A PRELIMINARY ANALYSIS: USGS WATER-RESOURCES INVESTIGATIONS REPORT 89-4071, 1990.

HYDROLOGY OF THE TEXAS GULF COAST AQUIFER SYSTEMS: USGS OPEN-FILE REPORT 91-64, 1991.

PROPERTIES AND CHEMICAL CONSTITUENTS IN GROUND WATER FROM THE MISSISSIPPI RIVER VALLEY ALLUVIAL AQUIFER AND PERMEABLE ZONE A (HOLOCENE-UPPER PLEISTOCENE DEPOSITS), SOUTH-CENTRAL UNITED STATES: USGS WATERRESOURCES INVESTIGATIONS REPORT 91-4149, 1992.

PROPERTIES AND CHEMICAL CONSTITUENTS IN GROUND WATER FROM THE UPPER CLAIBORNE AQUIFER, GULF COAST REGIONAL AQUIFER SYSTEMS, SOUTH-CENTRAL UNITED STATES: USGS WATER-RESOURCES INVESTIGATIONS REPORT 91-4150, 1993.

PROPERTIES AND CHEMICAL CONSTITUENTS IN GROUND WATER FROM PERMEABLE ZONE C (LOWER PLIOCENE-UPPER MIOCENE DEPOSITS), COASTAL LOWLANDS AQUIFER SYSTEM, SOUTHCENTRAL UNITED STATES: USGS WATER-RESOURCES INVESTIGATIONS REPORT 91-4151, 1993.

PROPERTIES AND CHEMICAL CONSTITUENTS IN GROUND WATER FROM PERMEABLE ZONE B (LOWER PLEISTOCENE-UPPER PLIOCENE DEPOSITS), COASTAL LOWLANDS AQUIFER SYSTEM, SOUTH-CENTRAL UNITED STATES: USGS WATER-RESOURCES INVESTIGATIONS REPORT 91-4152, 1993.

PROPERTIES AND CHEMICAL CONSTITUENTS IN GROUND WATER FROM PERMEABLE ZONE E (LOWER MIOCENE-UPPER OLIGOCENE DEPOSITS), COASTAL LOWLANDS AQUIFER SYSTEM, SOUTH-CENTRAL UNITED STATES: USGS WATER-RESOURCES INVESTIGATIONS REPORT 92-4103, 1993.

PROPERTIES AND CHEMICAL CONSTITUENTS IN GROUND WATER FROM PERMEABLE ZONE D (MIDDLE MIOCENE DEPOSITS), COASTAL LOWLANDS AQUIFER SYSTEM, SOUTH-CENTRAL UNITED STATES: USGS WATER-RESOURCES INVESTIGATIONS REPORT 92-4105, 1993.

PROPERTIES AND CHEMICAL CONSTITUENTS IN GROUND WATER FROM THE MIDDLE WILCOX AQUIFER, GULF COAST REGIONAL AQUIFER SYSTEMS, SOUTH-CENTRAL UNITED STATES: USGS WATER-RESOURCES INVESTIGATIONS REPORT 93-4070, 1993.

STRATIGRAPHIC NOMENCLATURE AND GEOLOGIC SECTIONS OF THE GULF COASTAL PLAIN OF TEXAS: USGS OPEN-FILE REPORT 94-461, 1995.

GEOLOGY AND HYDROGEOLOGY OF NAVAL AIR STATION CHASE FIELD AND NAVAL AUXILIARY LANDING FIELD GOLIAD, BEE AND GOLIAD COUNTIES, TEXAS: USGS WATER-RESOURCES INVESTIGATIONS REPORT 95-4038, 1995.

\section{GONZALES COUNTY}

ARTESIAN WELLS OF THE COASTAL PRAIRIE REGION AND TERTIARY BELT OF TEXAS: GEOLOGICAL SURVEY OF TEXAS, CHAPTER 2, 1893.

UNDERGROUND WATERS OF THE COASTAL PLAIN OF TEXAS: USGS WATER-SUPPLY PAPER 190, 1907.

RECORDS OF WELLS AND SPRINGS, DRILLERS' LOGS, WATER ANALYSES, AND MAP SHOWING LOCATION OF WELLS AND SPRINGS IN GONZALES COUNTY, TEXAS: TEXAS BOARD OF WATER ENGINEERS MISCELLANEOUS PUBLICATION 95, 1939.

MEMORANDUM, GROUND WATER NEAR GONZALES, TEXAS: USGS OPEN-FILE REPORT (UNNUMBERED), 1945.

MEMORANDUM REGARDING AVAILABILITY OF GROUND WATER IN THE AREA NORTH OF GONZALES, GONZALES COUNTY, TEXAS: USGS OPEN-FILE REPORT (UNNUMBERED), 1950.

PUBLIC WATER SUPPLIES IN SOUTHERN TEXAS: USGS WATERSUPPLY PAPER 1070, 1950.

RECONNAISSANCE INVESTIGATION OF THE GROUND-WATER RESOURCES OF THE GULF COAST REGION, TEXAS: TEXAS WATER COMMISSION BULLETIN 6305, 1963.

RECONNAISSANCE INVESTIGATION OF THE GROUND-WATER RESOURCES OF THE GUADALUPE, SAN ANTONIO, AND NUECES RIVER BASINS, TEXAS: TEXAS WATER COMMISSION BULLETIN 6409, 1964.

GROUND-WATER RESOURCES OF GONZALES COUNTY, TEXAS: TEXAS WATER DEVELOPMENT BOARD REPORT 4, 1965.

HYDROLOGIC SIGNIFICANCE OF THE LITHOFACIES OF THE SPARTA SAND IN ARKANSAS, LOUISIANA, MISSISSIPPI, AND TEXAS: USGS PROFESSIONAL PAPER 569-A, 1968.

GEOHYDROLOGIC SIGNIFICANCE OF LITHOFACIES OF THE COCKFIELD FORMATION OF LOUISIANA AND MISSISSIPPI AND OF THE YEGUA FORMATION OF TEXAS: USGS PROFESSIONAL PAPER 569-B, 1970.

HYDROLOGIC SIGNIFICANCE OF LITHOFACIES OF THE CANE RIVER FORMATION OR EQUIVALENTS OF ARKANSAS, LOUISIANA, MISSISSIPPI, AND TEXAS: USGS PROFESSIONAL PAPER 569-C, 1972.

SUMMARY APPRAISALS OF THE NATION'S GROUND-WATER RESOURCES-TEXAS-GULF REGION: USGS PROFESSIONAL PAPER 813-F, 1976.

GROUND-WATER RESOURCES OF THE CARRIZO AQUIFER IN THE WINTER GARDEN AREA OF TEXAS, VOLUME 1: TEXAS WATER DEVELOPMENT BOARD REPORT 210, V. 1, 1976.

GROUND-WATER RESOURCES OF THE CARRIZO AQUIFER IN THE WINTER GARDEN AREA OF TEXAS, VOLUME 2: TEXAS WATER DEVELOPMENT BOARD REPORT 210, V. 2, 1977.

STRATIGRAPHIC AND HYDROGEOLOGIC FRAMEWORK OF PART OF THE COASTAL PLAIN OF TEXAS: USGS OPEN-FILE REPORT $77-712,1978$.

VARIATIONS IN SPECIFIC YIELD IN THE OUTCROP OF THE CARRIZO SAND IN SOUTH TEXAS AS ESTIMATED BY SEISMIC REFRACTION: TEXAS DEPARTMENT OF WATER RESOURCES REPORT 229, 1979. 
STRATIGRAPHIC AND HYDROGEOLOGIC FRAMEWORK OF PART OF THE COASTAL PLAIN OF TEXAS: TEXAS DEPARTMENT OF WATER RESOURCES REPORT 236, 1979.

TEXAS GROUND-WATER RESOURCES, in NATIONAL WATER SUMMARY 1984: USGS WATER-SUPPLY PAPER 2275, 1985.

DIGITAL MODELS FOR SIMULATION OF GROUND-WATER HYDROLOGY OF THE CHICOT AND EVANGELINE AQUIFERS ALONG THE GULF COAST OF TEXAS: TEXAS DEPARTMENT OF WATER RESOURCES REPORT 289, 1985.

APPROXIMATE POTENTIOMETRIC SURFACES FOR THE AQUIFERS OF THE TEXAS COASTAL UPLANDS SYSTEM, 1980: USGS HYDROLOGIC INVESTIGATIONS ATLAS HA-704, 1987.

GEOHYDROLOGIC FRAMEWORK OF THE GULF COASTAL PLAIN: USGS HYDROLOGIC INVESTIGATIONS ATLAS HA-695, 1988.

DEPOSITIONAL AND GROUND-WATER FLOW SYSTEMS OF THE CARRIZO-UPPER WILCOX, SOUTH TEXAS: UNIVERSITY OF TEXAS, BUREAU OF ECONOMIC GEOLOGY REPORT OF INVESTIGATIONS NO. 175, 1988.

HYDROGEOLOGY AND PREDEVELOPMENT FLOW IN THE TEXAS GULF COAST AQUIFER SYSTEMS: USGS WATER-RESOURCES INVESTIGATIONS SYSTEMS REPORT 87-4248, 1988.

GROUND-WATER FLOW IN THE GULF COAST AQUIFER SYSTEMS, SOUTH CENTRAL UNITED STATES-A PRELIMINARY ANALYSIS: USGS WATER-RESOURCES INVESTIGATIONS REPORT 89-4071, 1990.

GROUND-WATER RESOURCES OF THE CARRIZO-WILCOX AQUIFER IN THE CENTRAL TEXAS REGION: TEXAS WATER DEVELOPMENT BOARD REPORT 332, 1991.

HYDROLOGY OF THE TEXAS GULF COAST AQUIFER SYSTEMS: USGS OPEN-FILE REPORT 91-64, 1991.

PROPERTIES AND CHEMICAL CONSTITUENTS IN GROUND WATER FROM THE UPPER CLAIBORNE AQUIFER, GULF COAST REGIONAL AQUIFER SYSTEMS, SOUTH-CENTRAL UNITED STATES: USGS WATER-RESOURCES INVESTIGATIONS REPORT 91-4150, 1993.

PROPERTIES AND CHEMICAL CONSTITUENTS IN GROUND WATER FROM THE LOWER CLAIBORNE-UPPER WILCOX AQUIFER, GULF COAST REGIONAL AQUIFER SYSTEMS, SOUTH-CENTRAL UNITED STATES: USGS WATER-RESOURCES INVESTIGATIONS REPORT 92-4102, 1993

PROPERTIES AND CHEMICAL CONSTITUENTS IN GROUND WATER FROM PERMEABLE ZONE E (LOWER MIOCENE-UPPER OLIGOCENE DEPOSITS), COASTAL LOWLANDS AQUIFER SYSTEM, SOUTH-CENTRAL UNITED STATES: USGS WATER-RESOURCES INVESTIGATIONS REPORT 92-4103, 1993.

PROPERTIES AND CHEMICAL CONSTITUENTS IN GROUND WATER FROM THE MIDDLE CLAIBORNE AQUIFER, GULF COAST REGIONAL AQUIFER SYSTEMS, SOUTH-CENTRAL UNITED STATES: USGS WATER-RESOURCES INVESTIGATIONS REPORT 92-4104, 1993.

PROPERTIES AND CHEMICAL CONSTITUENTS IN GROUND WATER FROM PERMEABLE ZONE D (MIDDLE MIOCENE DEPOSITS), COASTAL LOWLANDS AQUIFER SYSTEM, SOUTH-CENTRAL UNITED STATES: USGS WATER-RESOURCES INVESTIGATIONS REPORT 92-4105, 1993.
STRATIGRAPHIC NOMENCLATURE AND GEOLOGIC SECTIONS OF THE GULF COASTAL PLAIN OF TEXAS: USGS OPEN-FILE REPORT 94-461, 1995.

GROUND WATER ATLAS OF THE UNITED STATES-SEGMENT 4OKLAHOMA AND TEXAS: USGS HYDROLOGIC INVESTIGATIONS ATLAS 730-E, 1996.

WATER QUALITY IN THE SPARTA AQUIFER, EAST TEXAS: TEXAS WATER DEVELOPMENT BOARD HYDROLOGIC ATLAS NO. 5, 1996.

WATER QUALITY IN THE QUEEN CITY AQUIFER, EAST TEXAS: TEXAS WATER DEVELOPMENT BOARD HYDROLOGIC ATLAS NO. 6, 1996.

WATER QUALITY IN SOUTH-CENTRAL TEXAS-TEXAS, 1996-98: USGS CIRCULAR 1212, 2000.

\section{GRAY COUNTY}

THE GEOLOGY AND WATER RESOURCES OF THE EASTERN PORTION OF THE PANHANDLE OF TEXAS: USGS WATER-SUPPLY PAPER 154, 1906.

GEOLOGY AND GROUND-WATER RESOURCES OF THE SOUTHERN HIGH PLAINS: USGS OPEN-FILE REPORT (UNNUMBERED), 1935.

GROUND WATER IN THE SOUTHERN HIGH PLAINS: USGS OPENFILE REPORT (UNNUMBERED), 1937.

GROUND WATER IN THE HIGH PLAINS OF TEXAS: TEXAS BOARD OF WATER ENGINEERS MISCELLANEOUS PUBLICATION (UNNUMBERED), 1938.

GROUND WATER IN THE HIGH PLAINS OF TEXAS: TEXAS BOARD OF WATER ENGINEERS MISCELLANEOUS PUBLICATION 119, 1940.

PROGRESS REPORT ON GROUND WATER IN THE HIGH PLAINS OF TEXAS: TEXAS BOARD OF WATER ENGINEERS MISCELLANEOUS PUBLICATION (UNNUMBERED), 1942.

PROGRESS REPORT ON GROUND WATER IN THE HIGH PLAINS OF TEXAS: TEXAS BOARD OF WATER ENGINEERS MISCELLANEOUS PUBLICATION 120, 1943.

PROGRESS REPORT ON GROUND WATER IN THE HIGH PLAINS OF TEXAS: TEXAS BOARD OF WATER ENGINEERS MISCELLANEOUS PUBLICATION 121, 1944.

GROUND WATER IN THE HIGH PLAINS OF TEXAS, PROGRESS REPORT NO. 5: TEXAS BOARD OF WATER ENGINEERS MISCELLANEOUS PUBLICATION 122, 1945.

GROUND WATER IN THE HIGH PLAINS OF TEXAS: USGS WATERSUPPLY PAPER 889-F, 1946.

GROUND WATER IN HIGH PLAINS OF TEXAS, PROGRESS REPORT NO. 6: TEXAS BOARD OF WATER ENGINEERS MISCELLANEOUS PUBLICATION 123, 1947.

GEOLOGY AND GROUND WATER IN THE IRRIGATED REGION OF THE SOUTHERN HIGH PLAINS IN TEXAS, PROGRESS REPORT NO. 7: TEXAS BOARD OF WATER ENGINEERS MISCELLANEOUS PUBLICATION 125, 1949.

COST OF PUMPING WATER FOR IRRIGATION, TEXAS HIGH PLAINS, FIELD INVESTIGATIONS-1947 IRRIGATION SEASON: TEXAS 
BOARD OF WATER ENGINEERS MISCELLANEOUS PUBLICATION 124,1951

PUBLIC WATER SUPPLIES IN WESTERN TEXAS: USGS WATERSUPPLY PAPER 1106, 1951 [1952].

DEVELOPMENT OF WELLS FOR IRRIGATION AND FLUCTUATION OF WATER LEVELS IN THE HIGH PLAINS OF TEXAS TO JANUARY 1951: TEXAS BOARD OF WATER ENGINEERS BULLETIN 5104, 1951.

SUMMARY OF GROUND-WATER DEVELOPMENT IN THE SOUTHERN HIGH PLAINS, TEXAS: TEXAS BOARD OF WATER ENGINEERS BULLETIN 5402, 1954.

GROUND-WATER DEVELOPMENT IN THE SOUTHERN HIGH PLAINS OF TEXAS, 1953: TEXAS BOARD OF WATER ENGINEERS BULLETIN 5410, 1954

WATER-LEVEL DECLINE MAPS, 1956 TO 1957, AND WATER LEVELS IN OBSERVATION WELLS IN 20 COUNTIES IN THE SOUTHERN HIGH PLAINS OF TEXAS: TEXAS BOARD OF WATER ENGINEERS BULLETIN 5705, 1957.

WATER-LEVEL MEASUREMENTS AND MAPS, SOUTHERN HIGH PLAINS, TEXAS, 1958 AND 1959: TEXAS BOARD OF WATER ENGINEERS BULLETIN 5908, 1959.

WATER LEVELS IN OBSERVATION WELLS, SOUTHERN HIGH PLAINS, TEXAS, 1959 AND 1960: TEXAS BOARD OF WATER ENGINEERS BULLETIN 6011, 1960.

RECONNAISSANCE INVESTIGATION OF THE GROUND-WATER RESOURCES OF THE CANADIAN RIVER BASIN, TEXAS: TEXAS BOARD OF WATER ENGINEERS BULLETIN 6016, 1960.

WATER LEVELS IN OBSERVATION WELLS, SOUTHERN HIGH PLAINS, TEXAS, 1960 AND 1961: TEXAS BOARD OF WATER ENGINEERS BULLETIN 6101, 1961.

GEOLOGY AND GROUND-WATER RESOURCES OF CARSON COUNTY AND PART OF GRAY COUNTY, TEXAS, PROGRESS REPORT NO. 1: TEXAS BOARD OF WATER ENGINEERS BULLETIN $6102,1961$.

A SUMMARY OF THE OCCURRENCE AND DEVELOPMENT OF GROUND WATER IN THE SOUTHERN HIGH PLAINS OF TEXAS: TEXAS BOARD OF WATER ENGINEERS BULLETIN 6107, 1961.

WATER-LEVEL MEASUREMENTS THROUGH 1962 IN SELECTED OBSERVATION WELLS, SOUTHERN HIGH PLAINS, TEXAS: TEXAS WATER COMMISSION BULLETIN 6207, 1962.

RECONNAISSANCE INVESTIGATION OF THE GROUND-WATER RESOURCES OF THE RED RIVER, SULPHUR RIVER, AND CYPRESS CREEK BASINS, TEXAS: TEXAS WATER COMMISSION BULLETIN 6306, 1963.

A SUMMARY OF THE OCCURRENCE AND DEVELOPMENT OF GROUND WATER IN THE SOUTHERN HIGH PLAINS OF TEXAS: USGS WATER-SUPPLY PAPER 1693, 1964.

GEOLOGY AND GROUND-WATER RESOURCES OF CARSON AND PART OF GRAY COUNTY, TEXAS, PROGRESS REPORT NO. 2: TEXAS WATER COMMISSION BULLETIN 6402, 1964.

WATER-LEVEL DATA FROM OBSERVATION WELLS IN THE SOUTHERN HIGH PLAINS OF TEXAS: TEXAS WATER DEVELOPMENT BOARD REPORT 21, 1966
GROUND WATER IN THE OGALLALA FORMATION IN THE SOUTHERN HIGH PLAINS OF TEXAS AND OKLAHOMA: USGS HYDROLOGIC INVESTIGATIONS ATLAS HA-330, 1969.

WATER-LEVEL DATA FROM OBSERVATION WELLS IN THE SOUTHERN HIGH PLAINS OF TEXAS, 1965-70: TEXAS WATER DEVELOPMENT BOARD REPORT 121, 1970.

GROUND-WATER RESOURCES OF WHEELER AND EASTERN GRAY COUNTIES, TEXAS: TEXAS WATER DEVELOPMENT BOARD REPORT 170, 1973

ARTIFICIAL-RECHARGE EXPERIMENTS AND OPERATIONS ON THE SOUTHERN HIGH PLAINS OF TEXAS AND NEW MEXICO: USGS WATER-RESOURCES INVESTIGATIONS REPORT 10-73, 1973

WATER-LEVEL DATA FROM OBSERVATION WELLS IN THE SOUTHERN HIGH PLAINS OF TEXAS, 1971-77: TEXAS DEPARTMENT OF WATER RESOURCES REPORT 228, 1979.

ANALYTICAL STUDY OF THE OGALLALA AQUIFER IN GRAY COUNTY, TEXAS—PROJECTIONS OF SATURATED THICKNESS, VOLUME OF WATER IN STORAGE, PUMPAGE RATES, PUMPING LIFTS, AND WELL YIELDS: TEXAS DEPARTMENT OF WATER RESOURCES REPORT 243, 1979.

PRELIMINARY DATA DESCRIBING THE DISTRIBUTION OF FLUORIDE AND SILICA IN THE OGALLALA AQUIFER ON THE HIGH PLAINS OF TEXAS: USGS OPEN-FILE REPORT 80-349, 1980.

WATER TABLE IN THE HIGH PLAINS AQUIFER IN 1978 IN PARTS OF COLORADO, KANSAS, NEBRASKA, NEW MEXICO, OKLAHOMA, SOUTH DAKOTA, TEXAS, AND WYOMING: USGS HYDROLOGIC INVESTIGATIONS ATLAS HA-642, 1980.

EVALUATING THE GROUND-WATER RESOURCES OF THE HIGH PLAINS OF TEXAS: RESULTS OF TEST HOLE DRILLING: TEXAS DEPARTMENT OF WATER RESOURCES LIMITED PRINTING REPORT LP-129, 1980.

EVALUATING THE GROUND-WATER RESOURCES OF THE HIGH PLAINS OF TEXAS: RESULTS OF SURFACE ELECTRICAL RESISTIVITY: TEXAS DEPARTMENT OF WATER RESOURCES LIMITED PRINTING REPORT LP-130, 1980.

EVALUATING THE GROUND-WATER RESOURCES OF THE HIGH PLAINS OF TEXAS: NEUTRON-PROBE MEASUREMENTS OF DEEP SOIL MOISTURE AS AN INDICATION OF AQUIFER RECHARGE RATES: TEXAS DEPARTMENT OF WATER RESOURCES REPORT LP-142, 1981.

SPRINGS OF TEXAS, VOLUME 1: (BY GUNNAR BRUNE), BRANCHSMITH, INC., FORT WORTH, TEXAS, 1981.

BEDROCK GEOLOGY, ALTITUDE OF BASE, AND 1980 SATURATED THICKNESS OF THE HIGH PLAINS AQUIFER IN PARTS OF COLORADO, KANSAS, NEBRASKA, NEW MEXICO, OKLAHOMA, SOUTH DAKOTA, TEXAS, AND WYOMING: USGS HYDROLOGIC INVESTIGATIONS ATLAS HA-648, 1981.

WATER-LEVEL AND SATURATED-THICKNESS CHANGES, PREDEVELOPMENT TO 1980, IN THE HIGH PLAINS AQUIFER IN PARTS OF COLORADO, KANSAS, NEBRASKA, NEW MEXICO, OKLAHOMA, SOUTH DAKOTA, TEXAS, AND WYOMING: USGS HYDROLOGIC INVESTIGATIONS ATLAS HA-652, 1981.

DISSOLVED SOLIDS AND SODIUM IN WATER FROM THE HIGH PLAINS AQUIFER IN PARTS OF COLORADO, KANSAS, NEBRASKA, NEW MEXICO, OKLAHOMA, SOUTH DAKOTA, TEXAS, AND WYOMING: USGS HYDROLOGIC INVESTIGATIONS ATLAS HA-658, 1982. 
GEOHYDROLOGY OF THE HIGH PLAINS AQUIFER IN PARTS OF COLORADO, KANSAS, NEBRASKA, NEW MEXICO, OKLAHOMA, SOUTH DAKOTA, TEXAS, AND WYOMING: USGS PROFESSIONAL PAPER 1400-B, 1984.

EVALUATING THE GROUND-WATER RESOURCES OF THE HIGH PLAINS OF TEXAS, VOLUME 1: TEXAS DEPARTMENT OF WATER RESOURCES REPORT 288, V. 1, 1984.

EVALUATING THE GROUND-WATER RESOURCES OF THE HIGH PLAINS OF TEXAS, VOLUME 2, RECORDS OF WELLS, AND MAPS SHOWING WELL LOCATIONS, BASE OF AQUIFER, WATER LEVELS, AND SATURATED THICKNESS (ARMSTRONG, CARSON, DALLAS, DONLEY, GRAY, HANSFORD, HARTLEY, HEMPHILL, HUTCHINSON, LIPSCOMB, MOORE, OCHILTREE, POTTER, ROBERTS, SHERMAN, AND WHEELER COUNTIES): TEXAS DEPARTMENT OF WATER RESOURCES REPORT 288, V. 2, 1984.

TEXAS GROUND-WATER RESOURCES, in NATIONAL WATER SUMMARY 1984: USGS WATER-SUPPLY PAPER 2275, 1985.

DIGITAL SIMULATION OF GROUND-WATER FLOW IN THE HIGH PLAINS AQUIFER IN PARTS OF COLORADO, KANSAS, NEBRASKA, NEW MEXICO, OKLAHOMA, SOUTH DAKOTA, TEXAS, AND WYOMING: USGS PROFESSIONAL PAPER 1400-D, 1986.

SUMMARY OF THE HIGH PLAINS REGIONAL AQUIFER-SYSTEM ANALYSIS IN PARTS OF COLORADO, KANSAS, NEBRASKA, NEW MEXICO, OKLAHOMA, SOUTH DAKOTA, TEXAS, AND WYOMING: USGS PROFESSIONAL PAPER 1400-A, 1988.

PUBLIC SUPPLY GROUND-WATER USE IN THE SOUTHERN HIGH PLAINS OF TEXAS: TEXAS WATER DEVELOPMENT BOARD REPORT 328, 1990.

WATER-LEVEL CHANGES IN THE HIGH PLAINS AQUIFER OF TEXAS, 1980-1990: TEXAS WATER DEVELOPMENT BOARD HYDROLOGIC ATLAS NO. 1, 1991.

PUBLIC-SUPPLY GROUND-WATER USE IN THE NORTHERN HIGH PLAINS OF TEXAS: TEXAS WATER DEVELOPMENT BOARD REPORT 336, 1992

THE HIGH PLAINS AQUIFER SYSTEM OF TEXAS, 1980-1990. OVERVIEW AND PROJECTIONS: TEXAS WATER DEVELOPMENT BOARD REPORT 341, 1993.

WATER-QUALITY EVALUATION OF THE OGALLALA AQUIFER, TEXAS: TEXAS WATER DEVELOPMENT BOARD REPORT 342, 1993.

WATER-LEVEL CHANGES IN THE HIGH PLAINS AQUIFER-PREDEVELOPMENT TO 1992: USGS WATER-RESOURCES INVESTIGATIONS REPORT 94-4027, 1994.

WATER-LEVEL CHANGES IN THE HIGH PLAINS AQUIFER, 1980 TO 1994: USGS FACT SHEET FS-215-95, 1995.

AQUIFERS OF TEXAS: TEXAS WATER DEVELOPMENT BOARD REPORT 345, 1995.

WATER-LEVEL CHANGES IN THE HIGH PLAINS AQUIFER, 1980 TO 1995: USGS FACT SHEET FS-068-97, 1997.

WATER-LEVEL CHANGES IN THE HIGH PLAINS AQUIFER-PREDEVELOPMENT TO 1995: USGS WATER-RESOURCES INVESTIGATIONS REPORT 97-4081, 1997.

PLAYAS AND RECHARGE OF THE OGALLALA AQUIFER ON THE SOUTHERN HIGH PLAINS OF TEXAS-AN EXAMINATION USING NUMERICAL TECHNIQUES: UNIVERSITY OF TEXAS, BUREAU OF
ECONOMIC GEOLOGY REPORT OF INVESTIGATIONS NO. 242, 1997.

UPDATED WATER-QUALITY EVALUATION OF THE OGALLALA AQUIFER INCLUDING SELECTED METALLIC AND NON-METALLIC INORGANIC CONSTITUENTS: TEXAS WATER DEVELOPMENT BOARD HYDROLOGIC ATLAS NO. 10, 1998.

\section{GRAYSON COUNTY}

GEOGRAPHY AND GEOLOGY OF THE BLACK AND GRAND PRAIRIES, TEXAS, WITH DETAILED DESCRIPTIONS OF THE CRETACEOUS FORMATIONS AND SPECIAL REFERENCE TO ARTESIAN WATERS: USGS 21ST ANNUAL REPORT, PART 7, 1901.

PUBLIC WATER SUPPLIES IN EASTERN TEXAS: USGS WATERSUPPLY PAPER 1047, 1948.

GROUND-WATER RESOURCES AT SHERMAN, TEXAS: TEXAS BOARD OF WATER ENGINEERS MISCELLANEOUS PUBLICATION 249, 1945.

PROGRESS REPORT ON THE GEOLOGY AND GROUND-WATER RESOURCES OF GRAYSON COUNTY, TEXAS: USGS OPEN-FILE REPORT (UNNUMBERED), 1959.

GEOLOGY AND GROUND-WATER RESOURCES OF GRAYSON COUNTY, TEXAS: TEXAS BOARD OF WATER ENGINEERS BULLETIN 6013, 1960.

INVESTIGATION OF SALT-WATER CONTAMINATION IN A WOODBINE WELL NEAR SHERMAN, GRAYSON COUNTY, TEXAS: (CONTAMINATION REPORT NO. 10): TEXAS BOARD OF WATER ENGINEERS MISCELLANEOUS PUBLICATION 250, 1961.

RECONNAISSANCE INVESTIGATION OF THE GROUND-WATER RESOURCES OF THE RED RIVER, SULPHUR RIVER, AND CYPRESS CREEK BASINS, TEXAS: TEXAS WATER COMMISSION BULLETIN 6306, 1963

RECONNAISSANCE INVESTIGATION OF THE GROUND-WATER RESOURCES OF THE TRINITY RIVER BASIN, TEXAS: TEXAS WATER COMMISSION BULLETIN 6309, 1963.

COMPILATION OF RESULTS OF AQUIFER TESTS IN TEXAS: TEXAS WATER DEVELOPMENT BOARD REPORT 98, 1969.

WATER-LEVEL AND WATER-QUALITY DATA FROM OBSERVATION WELLS IN NORTHEAST TEXAS: TEXAS WATER DEVELOPMENT BOARD REPORT 198, 1976.

SPRINGS OF TEXAS, VOLUME 1: (BY GUNNAR BRUNE), BRANCHSMITH, INC., FORT WORTH, TEXAS, 1981.

OCCURRENCE, AVAILABILITY, AND CHEMICAL QUALITY OF GROUND WATER IN THE CRETACEOUS AQUIFERS OF NORTHCENTRAL TEXAS: TEXAS DEPARTMENT OF WATER RESOURCES REPORT 269, V. 1, 1982

OCCURRENCE, AVAILABILITY, AND CHEMICAL QUALITY OF GROUND WATER IN THE CRETACEOUS AQUIFERS OF NORTHCENTRAL TEXAS: TEXAS DEPARTMENT OF WATER RESOURCES REPORT 269, V. 2, 1982.

TEXAS GROUND-WATER RESOURCES, in NATIONAL WATER SUMMARY 1984: USGS WATER-SUPPLY PAPER 2275, 1985.

WATER USE, PROJECTED WATER REQUIREMENTS, AND RELATED DATA AND INFORMATION FOR THE METROPOLITAN STATISTI- 
CAL AREAS IN TEXAS: TEXAS DEPARTMENT OF WATER RESOURCES LIMITED PRINTING REPORT LP-201, 1985.

EVALUATION OF WATER RESOURCES IN PART OF NORTH-CENTRAL TEXAS: TEXAS WATER DEVELOPMENT BOARD REPORT $318,1990$.

NATIONAL WATER-QUALITY ASSESSMENT PROGRAM-THE TRINITY RIVER BASIN: USGS OPEN-FILE REPORT 91-158, 1991.

SIMULATION OF GROUND-WATER FLOW IN THE ANTLERS AQUIFER IN SOUTHEASTERN OKLAHOMA AND NORTHEASTERN TEXAS: USGS WATER-RESOURCES INVESTIGATIONS REPORT 88-4208, 1992.

NATIONAL WATER-QUALITY ASSESSMENT PROGRAM—PESTICIDES IN THE TRINITY RIVER BASIN STUDY UNIT, TEXAS, 1968-91: USGS FACT SHEET FS-088-95, 1995.

WATER-QUALITY ASSESSMENT OF THE TRINITY RIVER BASIN, TEXAS-DATA COLLECTION, 1992-95: USGS FACT SHEET FS-095-95, 1995.

WATER-QUALITY ASSESSMENT OF THE TRINITY RIVER BASIN, TEXAS-PESTICIDES IN A SUBURBAN WATERSHED, ARLINGTON, 1993-94: USGS FACT SHEET FS-159-95, 1995.

AQUIFERS OF TEXAS: TEXAS WATER DEVELOPMENT BOARD REPORT 345, 1995.

WATER QUALITY IN THE WOODBINE AQUIFER, NORTH-CENTRAL TEXAS: TEXAS WATER DEVELOPMENT BOARD HYDROLOGIC ATLAS NO. 4, 1996.

UPDATED EVALUATION OF WATER RESOURCES IN PART OF NORTH-CENTRAL TEXAS, 1990-1999: TEXAS WATER DEVELOPMENT BOARD REPORT 349, 1999.

\section{GREGG COUNTY}

UNDERGROUND WATERS OF THE COASTAL PLAIN OF TEXAS: USGS WATER-SUPPLY PAPER 190, 1907.

GEOLOGY AND UNDERGROUND WATERS OF THE SOUTHEASTERN PART OF THE TEXAS COASTAL PLAIN: USGS WATER-SUPPLY PAPER 335, 1914.

REPORT ON THE GROUND-WATER CONDITIONS IN THE EAST TEXAS OIL FIELD: USGS OPEN-FILE REPORT (UNNUMBERED), 1932.

RECORDS OF WELLS, DRILLERS' LOGS, WATER ANALYSES, AND MAP SHOWING LOCATION OF WELLS IN GREGG COUNTY, TEXAS: TEXAS BOARD OF WATER ENGINEERS MISCELLANEOUS PUBLICATION 97, 1937.

GROUND WATER IN THE GLADEWATER-BIG SANDY DISTRICT, TEXAS: USGS OPEN-FILE REPORT (UNNUMBERED), 1942.

RECORDS OF WELLS, DRILLERS' LOGS, WATER ANALYSES, AND MAP SHOWING LOCATIONS OF WELLS IN GREGG COUNTY, TEXAS: TEXAS BOARD OF WATER ENGINEERS MISCELLANEOUS PUBLICATION 98, 1943.

WATER RESOURCES OF GREGG COUNTY, TEXAS: TEXAS BOARD OF WATER ENGINEERS MISCELLANEOUS PUBLICATION 99, 1945.

PUBLIC WATER SUPPLIES IN EASTERN TEXAS: USGS WATERSUPPLY PAPER 1047, 1948.
GROUND-WATER RESOURCES OF GREGG COUNTY, TEXAS: USGS WATER-SUPPLY PAPER 1079-B, 1950.

RECONNAISSANCE INVESTIGATION OF THE GROUND-WATER RESOURCES OF THE RED RIVER, SULPHUR RIVER, AND CYPRESS CREEK BASINS, TEXAS: TEXAS WATER COMMISSION BULLETIN 6306, 1963.

RECONNAISSANCE INVESTIGATION OF THE GROUND-WATER RESOURCES OF THE SABINE RIVER BASIN, TEXAS: TEXAS WATER COMMISSION BULLETIN 6307, 1963.

INVESTIGATION OF ALLEGED GROUND-WATER CONTAMINATION NEAR KILGORE, GREGG COUNTY, TEXAS: TEXAS WATER COMMISSION LIMITED DISTRIBUTION REPORT LD-664, 1964.

BASE-FLOW STUDIES, LITTLE CYPRESS CREEK, UPSHUR, GREGG, AND HARRISON COUNTIES, TEXAS, QUANTITY AND QUALITY, JANUARY AND JUNE 1964: TEXAS WATER DEVELOPMENT BOARD REPORT 25, 1966.

COMPILATION OF RESULTS OF AQUIFER TESTS IN TEXAS: TEXAS WATER DEVELOPMENT BOARD REPORT 98, 1969.

GROUND-WATER RESOURCES OF GREGG AND UPSHUR COUNTIES, TEXAS: TEXAS WATER DEVELOPMENT BOARD REPORT 101, 1969.

SALT-WATER DISPOSAL AND POTENTIAL FOR POLLUTION IN THE EAST TEXAS OIL FIELD: USGS OPEN-FILE REPORT (UNNUMBERED) (MEMORANDUM), 1971

SUMMARY APPRAISALS OF THE NATION'S GROUND-WATER RESOURCES-TEXAS-GULF REGION: USGS PROFESSIONAL PAPER 813-F, 1976.

WATER-QUALITY DATA FOR AQUIFERS, STREAMS, AND LAKES IN THE VICINITY OF KEECHI, MOUNT SYLVAN, OAKWOOD, AND PALESTINE SALT DOMES, NORTHEAST TEXAS SALT-DOME BASIN: USGS OPEN-FILE REPORT 80-2037, 1980

GEOHYDROLOGY OF THE KEECHI, MOUNT SYLVAN, OAKWOOD, AND PALESTINE SALT DOMES IN THE NORTHEAST TEXAS SALTDOME BASIN: USGS OPEN-FILE REPORT 80-2044, 1980.

GEOLOGY AND GEOHYDROLOGY OF THE EAST TEXAS BASIN-A REPORT ON THE PROGRESS OF NUCLEAR WASTE ISOLATION FEASIBILITY STUDIES (1979): UNIVERSITY OF TEXAS, BUREAU OF ECONOMIC GEOLOGY GEOLOGICAL CIRCULAR 80-12, 1980.

SPRINGS OF TEXAS, VOLUME 1: (BY GUNNAR BRUNE), BRANCHSMITH, INC., FORT WORTH, TEXAS, 1981.

GEOLOGY AND GEOHYDROLOGY OF THE EAST TEXAS BASIN-A REPORT ON THE PROGRESS OF NUCLEAR WASTE ISOLATION FEASIBILITY STUDIES (1980): UNIVERSITY OF TEXAS, BUREAU OF ECONOMIC GEOLOGY GEOLOGICAL CIRCULAR 81-7, 1981.

REGIONAL AQUIFER CHARACTERIZATION FOR DEEP-BASIN LIGNITE MINING, SABINE UPLIFT AREA, NORTHEAST TEXAS: UNIVERSITY OF TEXAS, BUREAU OF ECONOMIC GEOLOGY GEOLOGICAL CIRCULAR 83-3, 1983.

WATER USE, PROJECTED WATER REQUIREMENTS, AND RELATED DATA AND INFORMATION FOR THE METROPOLITAN STATISTICAL AREAS IN TEXAS: TEXAS DEPARTMENT OF WATER RESOURCES LIMITED PRINTING REPORT LP-201, 1985.

TEXAS GROUND-WATER RESOURCES, in NATIONAL WATER SUMMARY 1984: USGS WATER-SUPPLY PAPER 2275, 1985. 
APPROXIMATE POTENTIOMETRIC SURFACES FOR THE AQUIFERS OF THE TEXAS COASTAL UPLANDS SYSTEM, 1980: USGS HYDROLOGIC INVESTIGATIONS ATLAS HA-704, 1987.

GEOHYDROLOGIC FRAMEWORK OF THE GULF COASTAL PLAIN: USGS HYDROLOGIC INVESTIGATIONS ATLAS HA-695, 1988.

EVALUATION OF GROUND-WATER RESOURCES IN THE VICINITY OF HENDERSON, JACKSONVILLE, KILGORE, LUFKIN, NACOGDOCHES, RUSK, AND TYLER IN EAST TEXAS: TEXAS WATER DEVELOPMENT BOARD REPORT 327, 1991.

PROPERTIES AND CHEMICAL CONSTITUENTS IN GROUND WATER FROM THE LOWER CLAIBORNE-UPPER WILCOX AQUIFER, GULF COAST REGIONAL AQUIFER SYSTEMS, SOUTH-CENTRAL UNITED STATES: USGS WATER-RESOURCES INVESTIGATIONS REPORT 92-4102, 1993.

PROPERTIES AND CHEMICAL CONSTITUENTS IN GROUND WATER FROM THE MIDDLE CLAIBORNE AQUIFER, GULF COAST REGIONAL AQUIFER SYSTEMS, SOUTH-CENTRAL UNITED STATES: USGS WATER-RESOURCES INVESTIGATIONS REPORT 92-4104, 1993.

PROPERTIES AND CHEMICAL CONSTITUENTS IN GROUND WATER FROM THE MIDDLE WILCOX AQUIFER, GULF COAST AQUIFER SYSTEMS, SOUTH-CENTRAL UNITED STATES: USGS WATERRESOURCES INVESTIGATIONS REPORT 93-4070, 1993.

AQUIFERS OF TEXAS: TEXAS WATER DEVELOPMENT BOARD REPORT 345, 1995.

\section{GRIMES COUNTY}

ARTESIAN WELLS OF THE COASTAL PRAIRIE REGION AND TERTIARY BELT OF TEXAS: GEOLOGICAL SURVEY OF TEXAS, CHAPTER 2, 1893.

UNDERGROUND WATERS OF THE COASTAL PLAIN OF TEXAS: USGS WATER-SUPPLY PAPER 190, 1907.

GEOLOGY AND UNDERGROUND WATERS OF THE SOUTHEASTERN PART OF THE TEXAS COASTAL PLAIN: USGS WATER-SUPPLY PAPER 335, 1914.

RECORDS OF WELLS IN HARRIS, GALVESTON, WALLER, FORT BEND, BRAZORIA, AND GRIMES COUNTIES, TEXAS: USGS OPENFILE REPORT (UNNUMBERED), 1935

RECORDS OF WELLS, DRILLERS' LOGS, WATER ANALYSES, AND MAP SHOWING LOCATION OF WELLS IN GRIMES COUNTY, TEXAS: TEXAS BOARD OF WATER ENGINEERS MISCELLANEOUS PUBLICATION 100, 1939.

RECORDS OF WELLS AND SPRINGS, DRILLERS' LOGS, WATER ANALYSES, AND MAP SHOWING LOCATIONS OF WELLS AND SPRINGS IN GRIMES COUNTY, TEXAS: TEXAS BOARD OF WATER ENGINEERS MISCELLANEOUS PUBLICATION 101, 1943.

PUBLIC WATER SUPPLIES IN EASTERN TEXAS: USGS WATERSUPPLY PAPER 1047, 1948.

WATER SUPPLY OF THE HOUSTON GULF COAST REGION: TEXAS BOARD OF WATER ENGINEERS BULLETIN 5101, 1951.

RECONNAISSANCE INVESTIGATION OF THE GROUND-WATER RESOURCES OF THE GULF COAST REGION OF TEXAS: TEXAS WATER COMMISSION BULLETIN 6305, 1963.
RECONNAISSANCE INVESTIGATION OF THE GROUND-WATER RESOURCES OF THE TRINITY RIVER BASIN, TEXAS: TEXAS WATER COMMISSION BULLETIN 6309, 1963.

RECONNAISSANCE INVESTIGATION OF THE GROUND-WATER RESOURCES OF THE BRAZOS RIVER BASIN, TEXAS: TEXAS WATER COMMISSION BULLETIN 6310, 1963.

GROUND WATER IN THE FLOOD-PLAIN ALLUVIUM OF THE BRAZOS RIVER, WHITNEY DAM TO VICINITY OF RICHMOND, TEXAS: TEXAS WATER DEVELOPMENT BOARD REPORT 41, 1967.

HYDROLOGIC SIGNIFICANCE OF THE LITHOFACIES OF THE SPARTA SAND IN ARKANSAS, LOUISIANA, MISSISSIPPI, AND TEXAS: USGS PROFESSIONAL PAPER 569-A, 1968.

GEOHYDROLOGIC SIGNIFICANCE OF LITHOFACIES OF THE COCKFIELD FORMATION OF LOUISIANA AND MISSISSIPPI AND OF THE YEGUA FORMATION OF TEXAS: USGS PROFESSIONAL PAPER 569-B, 1970.

HYDROLOGIC SIGNIFICANCE OF LITHOFACIES OF THE CANE RIVER FORMATION OR EQUIVALENTS OF ARKANSAS, LOUISIANA, MISSISSIPPI, AND TEXAS: USGS PROFESSIONAL PAPER 569-C, 1972.

GROUND-WATER RESOURCES OF GRIMES COUNTY, TEXAS: TEXAS WATER DEVELOPMENT BOARD REPORT 186, 1974.

GEOHYDROLOGIC SIGNIFICANCE OF LITHOFACIES OF THE CARRIZO SAND OF ARKANSAS, LOUISIANA, AND TEXAS AND THE MERIDIAN SAND OF MISSISSIPPI: USGS PROFESSIONAL PAPER 569-D, 1975.

MAJOR AND HISTORICAL SPRINGS OF TEXAS: TEXAS WATER DEVELOPMENT BOARD REPORT 189, 1975.

SUMMARY APPRAISALS OF THE NATION'S GROUND-WATER RESOURCES-TEXAS-GULF REGION: USGS PROFESSIONAL PAPER 813-F, 1976.

APPROXIMATE AREAS OF RECHARGE TO THE CHICOT AND EVANGELINE AQUIFER SYSTEMS IN THE HOUSTON-GALVESTON AREA, TEXAS: USGS OPEN-FILE REPORT 77-754, 1977.

STRATIGRAPHIC AND HYDROGEOLOGIC FRAMEWORK OF PART OF THE COASTAL PLAIN OF TEXAS: TEXAS DEPARTMENT OF WATER RESOURCES REPORT 236, 1979.

A DIGITAL MODEL FOR SIMULATION OF GROUND-WATER HYDROLOGY IN THE HOUSTON AREA, TEXAS: TEXAS DEPARTMENT OF WATER RESOURCES LIMITED PRINTING REPORT LP-103, 1979

REGIONAL HYDRODYNAMICS AND HYDROCHEMISTRY OF THE URANIUM-BEARING OAKVILLE AQUIFER (MIOCENE) OF SOUTH TEXAS: UNIVERSITY OF TEXAS, BUREAU OF ECONOMIC GEOLOGY REPORT OF INVESTIGATIONS NO. 124, 1982.

DIGITAL MODELS FOR SIMULATION OF GROUND-WATER HYDROLOGY OF THE CHICOT AND EVANGELINE AQUIFERS ALONG THE GULF COAST OF TEXAS: TEXAS DEPARTMENT OF WATER RESOURCES REPORT 289, 1985.

TEXAS GROUND-WATER RESOURCES, in NATIONAL WATER SUMMARY 1984: USGS WATER-SUPPLY PAPER 2275, 1985.

HYDROLOGY OF THE JASPER AQUIFER IN THE SOUTHEAST TEXAS COASTAL PLAIN: TEXAS WATER DEVELOPMENT BOARD REPORT 295, 1986. 
GEOHYDROLOGIC FRAMEWORK OF THE GULF COASTAL PLAIN: USGS HYDROLOGIC INVESTIGATIONS ATLAS HA-695, 1988.

GROUND-WATER RESOURCES OF THE CARRIZO-WILCOX AQUIFER IN THE CENTRAL TEXAS REGION: TEXAS WATER DEVELOPMENT BOARD REPORT 332, 1991.

NATIONAL WATER-QUALITY ASSESSMENT PROGRAM-THE TRINITY RIVER BASIN: USGS OPEN-FILE REPORT 91-158, 1991.

PROPERTIES AND CHEMICAL CONSTITUENTS IN GROUND WATER FROM THE UPPER CLAIBORNE AQUIFER, GULF COAST REGIONAL AQUIFER SYSTEMS, SOUTH-CENTRAL UNITED STATES: USGS WATER-RESOURCES INVESTIGATIONS REPORT 91-4150, 1993.

PROPERTIES AND CHEMICAL CONSTITUENTS IN GROUND WATER FROM PERMEABLE ZONE B (LOWER PLEISTOCENE-UPPER PLIOCENE DEPOSITS), COASTAL LOWLANDS AQUIFER SYSTEM, SOUTH-CENTRAL UNITED STATES: USGS WATER-RESOURCES INVESTIGATIONS REPORT 91-4152, 1993.

PROPERTIES AND CHEMICAL CONSTITUENTS IN GROUND WATER FROM THE LOWER CLAIBORNE-UPPER WILCOX AQUIFER, GULF COAST REGIONAL AQUIFER SYSTEMS, SOUTH-CENTRAL UNITED STATES: USGS WATER-RESOURCES INVESTIGATIONS REPORT 92-4102, 1993

PROPERTIES AND CHEMICAL CONSTITUENTS IN GROUND WATER FROM PERMEABLE ZONE E (LOWER MIOCENE-UPPER OLIGOCENE DEPOSITS), COASTAL LOWLANDS AQUIFER SYSTEM, SOUTH-CENTRAL UNITED STATES: USGS WATER-RESOURCES INVESTIGATIONS REPORT 92-4103, 1993.

PROPERTIES AND CHEMICAL CONSTITUENTS IN GROUND WATER FROM THE MIDDLE CLAIBORNE AQUIFER, GULF COAST REGIONAL AQUIFER SYSTEMS, SOUTH-CENTRAL UNITED STATES: USGS WATER-RESOURCES INVESTIGATIONS REPORT 92-4104, 1993.

PROPERTIES AND CHEMICAL CONSTITUENTS IN GROUND WATER FROM PERMEABLE ZONE D (MIDDLE MIOCENE DEPOSITS), COASTAL LOWLANDS AQUIFER SYSTEM, SOUTH-CENTRAL UNITED STATES: USGS WATER-RESOURCES INVESTIGATIONS REPORT 92-4105, 1993.

PROPERTIES AND CHEMICAL CONSTITUENTS IN GROUND WATER FROM THE MIDDLE WILCOX AQUIFER, GULF COAST REGIONAL AQUIFER SYSTEMS, SOUTH-CENTRAL UNITED STATES: USGS WATER-RESOURCES INVESTIGATIONS REPORT 93-4070, 1993.

NATIONAL WATER-QUALITY ASSESSMENT PROGRAM-PESTICIDES IN THE TRINITY RIVER BASIN STUDY UNIT, TEXAS, 1968-91: USGS FACT SHEET FS-088-95, 1995.

WATER-QUALITY ASSESSMENT OF THE TRINITY RIVER BASIN, TEXAS-DATA COLLECTION, 1992-95: USGS FACT SHEET FS-095-95, 1995.

WATER-QUALITY ASSESSMENT OF THE TRINITY RIVER BASIN, TEXAS—PESTICIDES IN A SUBURBAN WATERSHED, ARLINGTON, 1993-94: USGS FACT SHEET FS-159-95, 1995.

AQUIFERS OF TEXAS: TEXAS WATER DEVELOPMENT BOARD REPORT 345, 1995.

WATER QUALITY OF THE SPARTA AQUIFER, EAST TEXAS: TEXAS WATER DEVELOPMENT BOARD HYDROLOGIC ATLAS NO. 5 , 1996.
WATER QUALITY IN THE QUEEN CITY AQUIFER, EAST TEXAS: TEXAS WATER DEVELOPMENT BOARD HYDROLOGIC ATLAS NO. 6, 1996.

WATER-RESOURCES DATA, TEXAS, WATER YEAR 1999, VOLUME 6 , GROUND-WATER DATA: USGS WATER-DATA REPORT TX-99-6, 2000.

WATER-RESOURCES DATA, TEXAS, WATER YEAR 2000, VOLUME 6, GROUND-WATER DATA: USGS WATER-DATA REPORT TX-00-6, 2001.

\section{GUADALUPE COUNTY}

UNDERGROUND WATERS OF THE COASTAL PLAIN OF TEXAS: USGS WATER-SUPPLY PAPER 190, 1907.

RECORDS OF WELLS, DRILLERS' LOGS, AND WATER ANALYSES, AND MAP SHOWING LOCATION OF WELLS IN GUADALUPE COUNTY, TEXAS: TEXAS BOARD OF WATER ENGINEERS MISCELLANEOUS PUBLICATION 103, 1937.

PUBLIC WATER SUPPLIES IN SOUTHERN TEXAS: USGS WATERSUPPLY PAPER 1070, 1950

MISCELLANEOUS FIELD NOTES ON THE GEOLOGY OF THE SAN MARCOS AREA, TEXAS, 1950-53: USGS OPEN-FILE REPORT (UNNUMBERED), 1953

RECORDS OF WATER-LEVEL MEASUREMENTS IN COMAL AND GUADALUPE COUNTIES, TEXAS: TEXAS BOARD OF WATER ENGINEERS BULLETIN 5610, 1956.

RECONNAISSANCE INVESTIGATION OF THE GROUND-WATER RESOURCES OF THE GUADALUPE, SAN ANTONIO, AND NUECES RIVER BASINS, TEXAS: TEXAS WATER COMMISSION BULLETIN 6409, 1964.

CHEMICAL ANALYSES OF WATER FROM OBSERVATION WELLS IN THE EDWARDS AND ASSOCIATED LIMESTONES, SAN ANTONIO AREA, TEXAS, 1964: EDWARDS UNDERGROUND WATER DISTRICT BULLETIN 7, 1965.

GROUND-WATER DISCHARGE FROM THE EDWARDS AND ASSOCIATED LIMESTONES, SAN ANTONIO AREA, TEXAS, 1964: EDWARDS UNDERGROUND WATER DISTRICT BULLETIN 8, 1965

GROUND-WATER RECHARGE TO THE EDWARDS AND ASSOCIATED LIMESTONES, SAN ANTONIO AREA, TEXAS, 1964: EDWARDS UNDERGROUND WATER DISTRICT BULLETIN 9, 1965.

CHEMICAL ANALYSES FROM OBSERVATION WELLS IN THE EDWARDS AND ASSOCIATED LIMESTONES, SAN ANTONIO AREA, TEXAS, 1965: EDWARDS UNDERGROUND WATER DISTRICT BULLETIN 10, 1966.

GROUND-WATER RESOURCES OF GUADALUPE COUNTY, TEXAS TEXAS WATER DEVELOPMENT BOARD REPORT 19, 1966.

CHEMICAL ANALYSES OF WATER FROM OBSERVATION WELLS IN THE EDWARDS AND ASSOCIATED LIMESTONES, SAN ANTONIO AREA, TEXAS, 1966: EDWARDS UNDERGROUND WATER DISTRICT BULLETIN 13, 1967.

CHEMICAL ANALYSES OF WATER FROM OBSERVATION WELLS IN THE EDWARDS AND ASSOCIATED LIMESTONES, SAN ANTONIO AREA, TEXAS, 1967: EDWARDS UNDERGROUND WATER DISTRICT BULLETIN 16, 1968. 
COMPILATION OF RESULTS OF AQUIFER TESTS IN TEXAS: TEXAS WATER DEVELOPMENT BOARD REPORT 98, 1969.

GEOHYDROLOGIC SIGNIFICANCE OF LITHOFACIES OF THE CARRIZO SAND OF ARKANSAS, LOUISIANA, AND TEXAS AND THE MERIDIAN SAND OF MISSISSIPPI: USGS PROFESSIONAL PAPER 569-D, 1975.

MAJOR AND HISTORICAL SPRINGS OF TEXAS: TEXAS WATER DEVELOPMENT BOARD REPORT 189, 1975.

PROGRESS REPORT ON GEOLOGY OF THE EDWARDS AQUIFER, SAN ANTONIO AREA, TEXAS, AND PRELIMINARY INTERPRETATION OF BOREHOLE GEOPHYSICAL AND LABORATORY DATA ON CARBONATE ROCKS: USGS OPEN-FILE REPORT 76-627, 1976.

SUMMARY APPRAISALS OF THE NATION'S GROUND-WATER RESOURCES-TEXAS-GULF REGION: USGS PROFESSIONAL PAPER 813-F, 1976.

GROUND-WATER RESOURCES OF THE CARRIZO AQUIFER IN THE WINTER GARDEN AREA OF TEXAS, VOLUME 1: TEXAS WATER DEVELOPMENT BOARD REPORT 210, V. 1, 1976.

GROUND-WATER RESOURCES OF THE CARRIZO AQUIFER IN THE WINTER GARDEN AREA OF TEXAS, VOLUME 2: TEXAS WATER DEVELOPMENT BOARD REPORT 210, V. 2, 1977.

REGIONAL DISTRIBUTION OF FRACTURES IN THE SOUTHERN EDWARDS PLATEAU AND THEIR RELATIONSHIP TO TECTONICS AND CAVES: UNIVERSITY OF TEXAS, BUREAU OF ECONOMIC GEOLOGY GEOLOGICAL CIRCULAR 78-2, 1978.

VARIATIONS IN SPECIFIC YIELD IN THE OUTCROP OF THE CARRIZO SAND IN SOUTH TEXAS AS ESTIMATED BY SEISMIC REFRACTION: TEXAS DEPARTMENT OF WATER RESOURCES REPORT 229, 1979.

GROUND-WATER RESOURCES AND MODEL APPLICATIONS FOR THE EDWARDS (BALCONES FAULT ZONE) AQUIFER IN THE SAN ANTONIO REGION: TEXAS DEPARTMENT OF WATER RESOURCES REPORT 239, 1979.

HYDROCHEMICAL DATA FOR THE EDWARDS AQUIFER IN THE SAN ANTONIO AREA, TEXAS: TEXAS DEPARTMENT OF WATER RESOURCES LIMITED PRINTING REPORT LP-131, 1980.

WATER-LEVEL, RECHARGE, DISCHARGE, SPECIFIC-CAPACITY, WELL-YIELD, AND AQUIFER-TEST DATA FOR THE EDWARDS AQUIFER IN THE SAN ANTONIO AREA, TEXAS: TEXAS DEPARTMENT OF WATER RESOURCES LIMITED PRINTING REPORT LP-133, 1980.

APPLICATION AND ANALYSIS OF BOREHOLE DATA FOR THE EDWARDS AQUIFER IN THE SAN ANTONIO AREA, TEXAS: TEXAS DEPARTMENT OF WATER RESOURCES LIMITED PRINTING REPORT LP-139, 1981.

CARBONATE GEOLOGY AND HYDROLOGY OF THE EDWARDS AQUIFER IN THE SAN ANTONIO AREA, TEXAS: USGS OPEN-FILE REPORT 83-537, 1984.

IDENTIFICATION AND TABULATION OF GEOLOGICAL CONTACTS IN THE EDWARDS AQUIFER, SAN ANTONIO AREA, TEXAS: TEXAS DEPARTMENT OF WATER RESOURCES LIMITED PRINTING REPORT LP-199, 1985.

WATER USE, PROJECTED WATER REQUIREMENTS, AND RELATED DATA AND INFORMATION FOR THE METROPOLITAN STATISTICAL AREAS IN TEXAS: TEXAS DEPARTMENT OF WATER RESOURCES LIMITED PRINTING REPORT LP-201, 1985.
TEXAS GROUND-WATER RESOURCES, in NATIONAL WATER SUMMARY 1984: USGS WATER-SUPPLY PAPER 2275, 1985.

CARBONATE GEOLOGY AND HYDROLOGY OF THE EDWARDS AQUIFER IN THE SAN ANTONIO AREA, TEXAS: TEXAS WATER DEVELOPMENT BOARD REPORT 296, 1986.

APPROXIMATE POTENTIOMETRIC SURFACES FOR THE AQUIFERS OF THE TEXAS COASTAL UPLANDS SYSTEM, 1980: USGS HYDROLOGIC INVESTIGATIONS ATLAS HA-704, 1987.

DEPOSITIONAL AND GROUND-WATER FLOW SYSTEMS OF THE CARRIZO-UPPER WILCOX, SOUTH TEXAS: UNIVERSITY OF TEXAS, BUREAU OF ECONOMIC GEOLOGY REPORT OF INVESTIGATIONS NO. 175, 1988.

GEOHYDROLOGIC FRAMEWORK OF THE GULF COASTAL PLAIN: USGS HYDROLOGIC INVESTIGATIONS ATLAS HA-695, 1988.

EDWARDS AQUIFER, A TEXAS TREASURE-A TEACHERS GUIDE, SECONDARY, GRADES 7-12: EDWARDS UNDERGROUND WATER DISTRICT, 1991

INSIDE THE EDWARDS AQUIFER-A THREE-PART TECHNICAL FILM, HIGH-SCHOOL LEVEL TEACHER'S GUIDE: EDWARDS UNDERGROUND WATER DISTRICT, 1992.

PROPERTIES AND CHEMICAL CONSTITUENTS IN GROUND WATER FROM THE LOWER CLAIBORNE-UPPER WILCOX AQUIFER, GULF COAST REGIONAL AQUIFER SYSTEMS, SOUTH-CENTRAL UNITED STATES: USGS WATER-RESOURCES INVESTIGATIONS REPORT 92-4102, 1993

DEFINING THE EDWARDS AQUIFER FRESHWATER/SALINE-WATER INTERFACE WITH GEOPHYSICAL LOGS AND MEASURED DATA (SAN ANTONIO TO KYLE, TEXAS): EDWARDS UNDERGROUND WATER DISTRICT REPORT 93-06, 1993.

REGIONAL DISTRIBUTION OF PERMEABILITY IN THE EDWARDS AQUIFER: EDWARDS UNDERGROUND WATER DISTRICT REPORT 95-02, 1995.

AQUIFERS OF TEXAS: TEXAS WATER DEVELOPMENT BOARD REPORT 345, 1995.

EDWARDS AQUIFER GROUND-WATER RESOURCES: GEOLOGIC CONTROLS ON POROSITY DEVELOPMENT IN PLATFORM CARBONATES, SOUTH TEXAS: UNIVERSITY OF TEXAS, BUREAU OF ECONOMIC GEOLOGY REPORT OF INVESTIGATIONS NO. 238, 1996.

HYDROGEOLOGIC FRAMEWORK AND GEOCHEMISTRY OF THE EDWARDS AQUIFER SALINE-WATER ZONE, SOUTH-CENTRAL TEXAS: USGS WATER-RESOURCES INVESTIGATIONS REPORT 97-4133, 1997.

WATER QUALITY IN SOUTH-CENTRAL TEXAS-TEXAS, 1996-98: USGS CIRCULAR 1212, 2000.

\section{HALE COUNTY}

GEOLOGY AND GROUND-WATER RESOURCES OF THE SOUTHERN HIGH PLAINS: USGS OPEN-FILE REPORT (UNNUMBERED), 1935.

PRELIMINARY REPORT ON THE UNDERGROUND WATER SUPPLY OF THE PLAINVIEW, TEXAS PROJECT: USGS OPEN-FILE REPORT (UNNUMBERED), 1936 
GROUND WATER IN THE SOUTHERN HIGH PLAINS: USGS OPENFILE REPORT (UNNUMBERED), 1937.

RECORDS OF WELLS, DRILLERS' LOGS, WATER ANALYSES, AND MAP SHOWING LOCATIONS OF WELLS IN HALE COUNTY, TEXAS: TEXAS BOARD OF WATER ENGINEERS MISCELLANEOUS PUBLICATION 104, 1938.

GROUND WATER DISCHARGE ALONG RUNNING WATER DRAW UPSTREAM FROM PLAINVIEW: USGS OPEN-FILE REPORT (UNNUMBERED), 1939.

GROUND WATER IN THE HIGH PLAINS IN TEXAS (1940): TEXAS BOARD OF WATER ENGINEERS DUPLICATED REPORT M119, 1940.

GROUND WATER NEAR HICO, GATESVILLE, BRADY, KERRVILLE, AND PLAINVIEW, TEXAS: USGS OPEN-FILE REPORT (UNNUMBERED), 1942.

GROUND WATER IN THE HIGH PLAINS IN TEXAS, PROGRESS REPORT (1943): TEXAS BOARD OF WATER ENGINEERS DUPLICATED REPORT M120, 1943.

GROUND WATER IN THE HIGH PLAINS IN TEXAS, PROGRESS REPORT (1944): TEXAS BOARD OF WATER ENGINEERS DUPLICATED REPORT M121, 1944.

GROUND WATER IN THE HIGH PLAINS IN TEXAS, PROGRESS REPORT NO. 5: TEXAS BOARD OF WATER ENGINEERS DUPLICATED REPORT M122, 1945.

RECORDS OF WELLS, DRILLERS' LOGS, WATER ANALYSES, AND MAP SHOWING LOCATIONS OF WELLS IN HALE COUNTY, TEXAS: TEXAS BOARD OF WATER ENGINEERS MISCELLANEOUS PUBLICATION 105, 1946.

GROUND WATER IN THE HIGH PLAINS IN TEXAS, PROGRESS REPORT NO. 6: TEXAS BOARD OF WATER ENGINEERS DUPLICATED REPORT M123, 1947.

GEOLOGY AND GROUND WATER IN THE IRRIGATED REGION OF THE SOUTHERN HIGH PLAINS IN TEXAS, PROGRESS REPORT NO. 7: TEXAS BOARD OF WATER ENGINEERS DUPLICATED REPORT M125, 1949.

COST OF PUMPING WATER FOR IRRIGATION, TEXAS HIGH PLAINS, FIELD INVESTIGATION—1947 IRRIGATION SEASON: TEXAS BOARD OF WATER ENGINEERS DUPLICATED REPORT M124, 1951.

DEVELOPMENT OF WELLS FOR IRRIGATION AND FLUCTUATION OF WATER LEVELS IN THE HIGH PLAINS OF TEXAS TO JANUARY 1951: TEXAS BOARD OF WATER ENGINEERS BULLETIN 5104, 1951.

PUBLIC WATER SUPPLIES IN WESTERN TEXAS: USGS WATERSUPPLY PAPER 1106, 1951 [1952].

RECORDS OF WATER-LEVEL MEASUREMENTS IN HALE COUNTY, TEXAS, 1910-1953: TEXAS BOARD OF WATER ENGINEERS BULLETIN 5302, 1953.

WATER-LEVEL DECLINE MAPS OF 6 COUNTIES IN THE SOUTHERN HIGH PLAINS, TEXAS, JANUARY 1953 TO JANUARY 1954: (DEAF SMITH, FLOYD, HALE, LAMB, LUBBOCK, AND SWISHER): USGS OPEN-FILE REPORT (UNNUMBERED), 1954.

SUMMARY OF GROUND-WATER DEVELOPMENT IN THE SOUTHERN HIGH PLAINS, TEXAS: TEXAS BOARD OF WATER ENGINEERS BULLETIN 5402, 1954.
GROUND-WATER DEVELOPMENT IN THE SOUTHERN HIGH PLAINS OF TEXAS, 1953: TEXAS BOARD OF WATER ENGINEERS BULLETIN 5410, 1954.

WATER-LEVEL DECLINE MAPS OF 16 COUNTIES IN THE SOUTHERN HIGH PLAINS, TEXAS, JANUARY 1954 TO JANUARY 1955: (BAILEY, BRISCOE, CASTRO, COCHRAN, CROSBY, DEAF SMITH, FLOYD, GAINES, HALE, HOCKLEY, LAMB, LUBBOCK, PARMER, RANDALL, SWISHER, AND TERRY): USGS OPEN-FILE REPORT, 1955.

WATER-LEVEL DECLINE MAPS OF 17 COUNTIES IN THE SOUTHERN HIGH PLAINS, TEXAS, JANUARY 1955 TO JANUARY 1956: TEXAS BOARD OF WATER ENGINEERS BULLETIN 5607, 1956.

WATER-LEVEL DECLINE MAPS, 1956 TO 1957, AND WATER LEVELS IN OBSERVATION WELLS IN 20 COUNTIES IN THE SOUTHERN HIGH PLAINS, TEXAS: TEXAS BOARD OF WATER ENGINEERS BULLETIN 5705, 1957.

MEMORANDUM CONCERNING ARTIFICIAL RECHARGE TEST ON PROPERTY OF TEXAS RESEARCH FOUNDATION, 14 MILES WEST OF PLAINVIEW, TEXAS: USGS OPEN-FILE REPORT, 1957.

WATER-LEVEL MEASUREMENTS AND MAPS, SOUTHERN HIGH PLAINS, TEXAS, 1958 AND 1959: TEXAS BOARD OF WATER ENGINEERS BULLETIN 5908, 1959.

GEOLOGY AND GROUND-WATER RESOURCES OF HALE COUNTY, TEXAS: TEXAS BOARD OF WATER ENGINEERS BULLETIN 6010, 1960.

WATER LEVELS IN OBSERVATION WELLS, SOUTHERN HIGH PLAINS, TEXAS, 1959 AND 1960: TEXAS BOARD OF WATER ENGINEERS BULLETIN 6011, 1960.

WATER LEVELS IN OBSERVATION WELLS, SOUTHERN HIGH PLAINS, TEXAS, 1960 AND 1961: TEXAS BOARD OF WATER ENGINEERS BULLETIN 6101, 1961.

A SUMMARY OF THE OCCURRENCE AND DEVELOPMENT OF GROUND WATER IN THE SOUTHERN HIGH PLAINS OF TEXAS: TEXAS BOARD OF WATER ENGINEERS BULLETIN 6107, 1961.

WATER-LEVEL MEASUREMENTS THROUGH 1962 IN SELECTED OBSERVATION WELLS, SOUTHERN HIGH PLAINS, TEXAS: TEXAS WATER COMMISSION BULLETIN 6207, 1962.

RECONNAISSANCE INVESTIGATION OF THE GROUND-WATER RESOURCES OF THE RED RIVER, SULPHUR RIVER, AND CYPRESS CREEK BASINS, TEXAS: TEXAS WATER COMMISSION BULLETIN 6306, 1963.

RECONNAISSANCE INVESTIGATION OF THE GROUND-WATER RESOURCES OF THE BRAZOS RIVER BASIN, TEXAS: TEXAS WATER COMMISSION BULLETIN 6310, 1963.

A SUMMARY OF THE OCCURRENCE AND DEVELOPMENT OF GROUND WATER IN THE SOUTHERN HIGH PLAINS OF TEXAS: USGS WATER-SUPPLY PAPER 1693, 1964.

WATER-LEVEL DATA FROM OBSERVATION WELLS IN THE SOUTHERN HIGH PLAINS OF TEXAS: TEXAS WATER DEVELOPMENT BOARD REPORT 21, 1966.

COMPILATION OF RESULTS OF AQUIFER TESTS IN TEXAS: TEXAS WATER DEVELOPMENT BOARD REPORT 98, 1969.

GROUND WATER IN THE OGALLALA FORMATION IN THE SOUTHERN HIGH PLAINS OF TEXAS AND NEW MEXICO: USGS HYDROLOGIC INVESTIGATIONS ATLAS HA-330, 1969. 
WATER-LEVEL DATA FROM OBSERVATION WELLS IN THE SOUTHERN HIGH PLAINS OF TEXAS, 1956-70: TEXAS WATER DEVELOPMENT BOARD REPORT 121, 1970.

AN EVALUATION OF THE USE OF DRILLERS' LOGS IN LITHOLOGIC STUDIES OF THE OGALLALA FORMATION OF THE SOUTHERN HIGH PLAINS OF TEXAS: USGS OPEN-FILE REPORT 72-451, 1972.

SUMMARY APPRAISALS OF THE NATION'S GROUND-WATER RESOURCES-TEXAS-GULF REGION: USGS PROFESSIONAL PAPER 813-F, 1976.

ANALYTICAL STUDY OF THE OGALLALA AQUIFER IN HALE COUNTY, TEXAS—PROJECTIONS OF SATURATED THICKNESS, VOLUME OF WATER IN STORAGE, PUMPAGE RATES, PUMPING LIFTS, AND WELL YIELDS: TEXAS WATER DEVELOPMENT BOARD REPORT 200, 1976.

ARTIFICIAL GROUND-WATER RECHARGE AS A WATER-MANAGEMENT TECHNIQUE ON THE SOUTHERN HIGH PLAINS OF TEXAS AND NEW MEXICO: USGS OPEN-FILE REPORT 76-730, 1976.

WATER-LEVEL DATA FROM OBSERVATION WELLS IN THE SOUTHERN HIGH PLAINS OF TEXAS, 1971-77: TEXAS DEPARTMENT OF WATER RESOURCES REPORT 228, 1979.

PRELIMINARY DATA DESCRIBING THE DISTRIBUTION OF FLUORIDE AND SILICA IN THE OGALLALA AQUIFER ON THE HIGH PLAINS OF TEXAS: USGS OPEN-FILE REPORT 80-349, 1980.

EVALUATING THE GROUND-WATER RESOURCES OF THE HIGH PLAINS OF TEXAS: RESULTS OF TEST-HOLE DRILLING: TEXAS DEPARTMENT OF WATER RESOURCES LIMITED PRINTING REPORT LP-129, 1980.

EVALUATING THE GROUND-WATER RESOURCES OF THE HIGH PLAINS OF TEXAS: RESULTS OF SURFACE ELECTRICAL SURVEYS: TEXAS DEPARTMENT OF WATER RESOURCES LIMITED PRINTING REPORT LP-130, 1980.

EVALUATING THE GROUND-WATER RESOURCES OF THE HIGH PLAINS OF TEXAS: NEUTRON-PROBE MEASUREMENTS OF DEEP SOIL MOISTURE AS AN INDICATION OF AQUIFER RECHARGE RATES: TEXAS DEPARTMENT OF WATER RESOURCES LIMITED PRINTING REPORT LP-142, 1981.

SPRINGS OF TEXAS, VOLUME 1: (BY GUNNAR BRUNE), BRANCHSMITH, INC., FORT WORTH, TEXAS, 1981.

BEDROCK GEOLOGY, ALTITUDE OF BASE, AND 1980 SATURATED THICKNESS OF THE HIGH PLAINS AQUIFER IN PARTS OF COLORADO, KANSAS, NEBRASKA, NEW MEXICO, OKLAHOMA, SOUTH DAKOTA, TEXAS, AND WYOMING: USGS HYDROLOGIC INVESTIGATIONS ATLAS HA-648, 1981.

WATER LEVEL AND SATURATED THICKNESS CHANGES, PREDEVELOPMENT TO 1980, IN THE HIGH PLAINS AQUIFER IN PARTS OF COLORADO, KANSAS, NEBRASKA, NEW MEXICO, OKLAHOMA, SOUTH DAKOTA, TEXAS, AND WYOMING: USGS HYDROLOGIC INVESTIGATIONS ATLAS HA-652, 1981.

DISSOLVED SOLIDS AND SODIUM IN WATER FROM THE HIGH PLAINS AQUIFER IN PARTS OF COLORADO, KANSAS, NEBRASKA, NEW MEXICO, OKLAHOMA, SOUTH DAKOTA, TEXAS, AND WYOMING: USGS HYDROLOGIC INVESTIGATIONS ATLAS HA-658, 1982.

EVALUATING THE GROUND-WATER RESOURCES OF THE HIGH PLAINS OF TEXAS, VOLUME 1: TEXAS DEPARTMENT OF WATER RESOURCES REPORT 288, V. 1, 1984.
EVALUATING THE GROUND-WATER RESOURCES OF THE HIGH PLAINS OF TEXAS, VOLUME 3, RECORDS OF WELLS, AND MAPS SHOWING WELL LOCATIONS, BASE OF AQUIFER, WATER LEVELS, AND SATURATED THICKNESS: TEXAS DEPARTMENT OF WATER RESOURCES REPORT 288, V. 3, 1984.

GEOHYDROLOGY OF THE HIGH PLAINS AQUIFER IN PARTS OF COLORADO, KANSAS, NEBRASKA, NEW MEXICO, OKLAHOMA, SOUTH DAKOTA, TEXAS, AND WYOMING: USGS PROFESSIONAL PAPER 1400-B, 1984.

TEXAS GROUND-WATER RESOURCES, in NATIONAL WATER SUMMARY 1984: USGS WATER-SUPPLY PAPER 2275, 1985.

DIGITAL SIMULATION OF GROUND-WATER FLOW IN THE HIGH PLAINS AQUIFER IN PARTS OF COLORADO, KANSAS, NEBRASKA, NEW MEXICO, OKLAHOMA, SOUTH DAKOTA, TEXAS, AND WYOMING: USGS PROFESSIONAL PAPER 1400-D, 1986.

HYDROLOGIC ATLAS FOR HALE COUNTY, TEXAS: HIGH PLAINS UNDERGROUND WATER CONSERVATION DISTRICT NO. 1, 1987.

HYDROGEOLOGY AND HYDROCHEMISTRY OF CRETACEOUS AQUIFERS, TEXAS PANHANDLE AND EASTERN NEW MEXICO: UNIVERSITY OF TEXAS, BUREAU OF ECONOMIC GEOLOGY GEOLOGICAL CIRCULAR 88-3, 1988.

SUMMARY OF THE HIGH PLAINS REGIONAL AQUIFER-SYSTEM ANALYSIS IN PARTS OF COLORADO, KANSAS, NEBRASKA, NEW MEXICO, OKLAHOMA, SOUTH DAKOTA, TEXAS, AND WYOMING: USGS PROFESSIONAL PAPER 1400-A, 1988.

EVALUATION OF GROUND-WATER RESOURCES IN BRISCOE, HALE, AND SWISHER COUNTIES, TEXAS: TEXAS WATER DEVELOPMENT BOARD REPORT 313, 1989.

HYDROGEOLOGY OF LOWER CRETACEOUS STRATA UNDER THE SOUTHERN HIGH PLAINS OF TEXAS AND NEW MEXICO: TEXAS WATER DEVELOPMENT BOARD REPORT 314, 1989.

PUBLIC-SUPPLY GROUND-WATER USE IN THE SOUTHERN HIGH PLAINS OF TEXAS: TEXAS WATER DEVELOPMENT BOARD REPORT 328, 1990.

WATER-LEVEL CHANGES IN THE HIGH PLAINS AQUIFER OF TEXAS, 1980-1990: TEXAS WATER DEVELOPMENT BOARD HYDROLOGIC ATLAS NO. 1, 1991.

WATER-RESOURCES DATA, TEXAS, WATER YEAR 1991, VOLUME 4 GROUND-WATER DATA: USGS WATER-DATA REPORT TX-91-4, 1992.

THE HIGH PLAINS AQUIFER SYSTEM OF TEXAS, 1980 TO 1990. OVERVIEW AND PROJECTIONS: TEXAS WATER DEVELOPMENT BOARD REPORT 341, 1993.

WATER-QUALITY EVALUATION OF THE OGALLALA AQUIFER, TEXAS: TEXAS WATER DEVELOPMENT BOARD REPORT 342, 1993.

WATER-RESOURCES DATA, TEXAS, WATER YEAR 1992, VOLUME 4, GROUND-WATER DATA: USGS WATER-DATA REPORT TX-92-4, 1993.

WATER-RESOURCES DATA, TEXAS, WATER YEAR 1993, VOLUME 4, GROUND-WATER DATA: USGS WATER-DATA REPORT TX-93-4, 1994.

WATER-LEVEL CHANGES IN THE HIGH PLAINS AQUIFER, 1980 TO 1994: USGS FACT SHEET FS-215-95, 1995. 
AQUIFERS OF TEXAS: TEXAS WATER DEVELOPMENT BOARD REPORT 345, 1995.

WATER-RESOURCES DATA, TEXAS, WATER YEAR 1994, VOLUME 4 , GROUND-WATER DATA: USGS WATER-DATA REPORT TX-94-4, 1995.

WATER-RESOURCES DATA, TEXAS, WATER YEAR 1995, VOLUME 4, GROUND-WATER DATA: USGS WATER-DATA REPORT TX-95-4, 1996.

WATER-LEVEL CHANGES IN THE HIGH PLAINS AQUIFER, 1980 TO 1995: USGS FACT SHEET FS-068-97, 1997.

WATER-LEVEL CHANGES IN THE HIGH PLAINS AQUIFER-PREDEVELOPMENT TO 1995: USGS WATER-RESOURCES INVESTIGATIONS REPORT 97-4081, 1997.

WATER-RESOURCES DATA, TEXAS, WATER YEAR 1996, VOLUME 4, GROUND-WATER DATA: USGS WATER-DATA REPORT TX-96-4, 1997.

UPDATED WATER-QUALITY EVALUATION OF THE OGALLALA AQUIFER INCLUDING SELECTED METALLIC AND NON-METALLIC INORGANIC CONSTITUENTS: TEXAS WATER DEVELOPMENT BOARD HYDROLOGIC ATLAS NO. 10, 1998.

WATER-RESOURCES DATA, TEXAS, WATER YEAR 1997, VOLUME 4, GROUND-WATER DATA: USGS WATER-DATA REPORT TX-97-4, 1998.

WATER-RESOURCES DATA, TEXAS, WATER YEAR 1998, VOLUME 4, GROUND-WATER DATA: USGS WATER-DATA REPORT TX-98-4, 1999.

WATER-RESOURCES DATA, TEXAS, WATER YEAR 1999, VOLUME 6, GROUND-WATER DATA: USGS WATER-DATA REPORT TX-99-6, 2000.

WATER-RESOURCES DATA, TEXAS, WATER YEAR 2000, VOLUME 6, GROUND-WATER DATA: USGS WATER-DATA REPORT TX-00-6, 2001.

\section{HALL COUNTY}

GROUND-WATER CONDITIONS IN THE MEMPHIS AREA, TEXAS: TEXAS BOARD OF WATER ENGINEERS MISCELLANEOUS PUBLICATION 186, 1943

EXPLORATION FOR GROUND WATER AT CHILDRESS, TEXAS: USGS OPEN-FILE REPORT (UNNUMBERED), 1945.

PUBLIC WATER SUPPLIES IN WESTERN TEXAS: USGS WATERSUPPLY PAPER 1106, 1951.

RECONNAISSANCE INVESTIGATION OF THE GROUND-WATER RESOURCES OF THE RED RIVER, SULFUR RIVER, AND CYPRESS CREEK BASINS, TEXAS: TEXAS WATER COMMISSION BULLETIN 6306, 1963.

COMPILATION OF RESULTS OF AQUIFER TESTS IN TEXAS: TEXAS WATER DEVELOPMENT BOARD REPORT 98, 1969.

GROUND-WATER RESOURCES OF HALL AND EASTERN BRISCOE COUNTIES, TEXAS: TEXAS WATER DEVELOPMENT BOARD REPORT 167, 1973.

SPRINGS OF TEXAS, VOLUME 1: BY GUNNAR BRUNE, BRANCHSMITH, INC., FORT WORTH, TEXAS, 1981.
TEXAS GROUND-WATER RESOURCES, in NATIONAL WATER SUMMARY 1984: USGS WATER-SUPPLY PAPER 2275, 1985.

WATER-LEVEL CHANGES IN THE HIGH PLAINS AQUIFER OF TEXAS, 1980-1990: TEXAS WATER DEVELOPMENT BOARD HYDROLOGIC ATLAS NO. 1, 1991.

EVALUATION OF WATER RESOURCES IN PARTS OF THE ROLLING PRAIRIES REGION OF NORTH-CENTRAL TEXAS: TEXAS WATER DEVELOPMENT BOARD REPORT 337, 1992.

AQUIFERS OF TEXAS: TEXAS WATER DEVELOPMENT BOARD REPORT 345, 1995.

UPDATED WATER-QUALITY EVALUATION OF THE OGALLALA AQUIFER INCLUDING SELECTED METALLIC AND NON-METALLIC INORGANIC CONSTITUENTS: TEXAS WATER DEVELOPMENT BOARD HYDROLOGIC ATLAS NO. 10, 1998.

\section{HAMILTON COUNTY}

GEOGRAPHY AND GEOLOGY OF THE BLACK AND GRAND PRAIRIES, TEXAS, WITH DETAILED DESCRIPTIONS OF THE CRETACEOUS FORMATIONS AND SPECIAL REFERENCE TO ARTESIAN WATERS: USGS 21ST ANNUAL REPORT, PART 7, 1901.

GROUND WATER NEAR HICO, GATESVILLE, BRADY, KERRVILLE, AND PLAINVIEW, TEXAS: USGS OPEN-FILE REPORT (UNNUMBERED), 1942.

GROUND-WATER RESOURCES IN SELECTED AREAS IN ERATH, HOOD, AND HAMILTON COUNTIES, TEXAS: USGS OPEN-FILE REPORT (UNNUMBERED), 1942.

SUPPLEMENT TO GROUND-WATER RESOURCES IN SELECTED AREAS IN ERATH, HOOD, AND HAMILTON COUNTIES, TEXAS: USGS OPEN-FILE REPORT (UNNUMBERED), 1942.

PUBLIC WATER SUPPLIES IN CENTRAL AND NORTH-CENTRAL TEXAS: USGS WATER-SUPPLY PAPER 1069, 1949.

RECONNAISSANCE INVESTIGATION OF THE GROUND-WATER RESOURCES OF THE BRAZOS RIVER BASIN, TEXAS: TEXAS WATER COMMISSION BULLETIN 6310, 1963.

COMPILATION OF RESULTS OF AQUIFER TESTS IN TEXAS: TEXAS WATER DEVELOPMENT BOARD REPORT 98, 1969.

GROUND-WATER RESOURCES OF PART OF CENTRAL TEXAS WITH EMPHASIS ON THE ANTLERS AND TRAVIS PEAK FORMATIONS: TEXAS WATER DEVELOPMENT BOARD REPORT 195, V. 1, 1975.

GROUND-WATER RESOURCES OF PART OF CENTRAL TEXAS WITH EMPHASIS ON THE ANTLERS AND TRAVIS PEAK FORMATIONS: TEXAS WATER DEVELOPMENT BOARD REPORT 195, V. 2, 1976.

GROUND-WATER RESOURCES OF THE ANTLERS AND TRAVIS PEAK FORMATIONS IN THE OUTCROP AREA OF NORTH-CENTRAL TEXAS: TEXAS WATER DEVELOPMENT BOARD REPORT 298, 1987.

SUMMARY APPRAISALS OF THE NATION'S GROUND-WATER RESOURCES-TEXAS-GULF REGION: USGS PROFESSIONAL PAPER 813-F, 1976

EVALUATION OF WATER RESOURCES IN PART OF CENTRAL TEXAS: TEXAS WATER DEVELOPMENT BOARD REPORT 319, 1990. 
GROUND-WATER QUALITY MONITORING OF THE TRINITY AQUIFER IN THE VICINITY OF ERATH COUNTY: TEXAS WATER DEVELOPMENT BOARD REPORT 331, 1991.

HYDROGEOLOGIC ASSESSMENT OF SHALLOW GROUNDWATER FLOW SYSTEMS OF THE WALNUT FORMATION, CENTRAL TEXAS: (MASTER'S THESIS), BAYLOR GEOLOGICAL STUDIES (THESIS ABSTRACTS), BULLETIN 56, BAYLOR UNIVERSITY, WACO, TEXAS, 1995.

AQUIFERS OF TEXAS: TEXAS WATER DEVELOPMENT BOARD REPORT 345, 1995.

\section{HANSFORD COUNTY}

THE GEOLOGY AND WATER RESOURCES OF THE EASTERN PORTION OF THE PANHANDLE OF TEXAS: USGS WATER-SUPPLY PAPER 154, 1906.

GEOLOGY AND GROUND-WATER RESOURCES OF THE SOUTHERN HIGH PLAINS: USGS OPEN-FILE REPORT (UNNUMBERED), 1935.

RECORDS OF WELLS, DRILLERS' LOGS, AND WATER ANALYSES, AND MAP SHOWING LOCATION OF WELLS IN HANSFORD COUNTY, TEXAS: TEXAS BOARD OF WATER ENGINEERS MISCELLANEOUS PUBLICATION 106, 1936.

GROUND WATER IN HANSFORD COUNTY: USGS OPEN-FILE REPORT (UNNUMBERED), 1936.

GROUND WATER IN THE HIGH PLAINS OF TEXAS: TEXAS BOARD OF WATER ENGINEERS MISCELLANEOUS PUBLICATION (UNNUMBERED), 1938.

GROUND WATER IN THE HIGH PLAINS OF TEXAS: TEXAS BOARD OF WATER ENGINEERS MISCELLANEOUS PUBLICATION 119, 1940.

ROGRESS REPORT ON GROUND WATER IN THE HIGH PLAINS OF TEXAS: TEXAS BOARD OF WATER ENGINEERS MISCELLANEOUS PUBLICATION (UNNUMBERED), 1942.

PROGRESS REPORT ON GROUND WATER IN THE HIGH PLAINS OF TEXAS: TEXAS BOARD OF WATER ENGINEERS MISCELLANEOUS PUBLICATION 120, 1943.

PROGRESS REPORT ON GROUND WATER IN THE HIGH PLAINS OF TEXAS: TEXAS BOARD OF WATER ENGINEERS MISCELLANEOUS PUBLICATION 121, 1944.

PROGRESS REPORT NO. 5 ON GROUND WATER IN THE HIGH PLAINS OF TEXAS: TEXAS BOARD OF WATER ENGINEERS MISCELLANEOUS PUBLICATION 122, 1945.

GROUND WATER IN THE HIGH PLAINS OF TEXAS: USGS WATERSUPPLY PAPER 889-F, 1946.

GROUND WATER IN HIGH PLAINS OF TEXAS, PROGRESS REPORT NO. 6: TEXAS BOARD OF WATER ENGINEERS MISCELLANEOUS PUBLICATION 123, 1947.

COST OF PUMPING WATER FOR IRRIGATION, TEXAS HIGH PLAINS, FIELD INVESTIGATIONS-1947 IRRIGATION SEASON: TEXAS BOARD OF WATER ENGINEERS MISCELLANEOUS PUBLICATION 124, 1951.

PUBLIC WATER SUPPLIES IN WESTERN TEXAS: USGS WATERSUPPLY PAPER 1106, 1951 [1952].
DEVELOPMENT OF WELLS FOR IRRIGATION AND FLUCTUATION OF WATER LEVELS IN THE HIGH PLAINS OF TEXAS TO JANUARY 1951: TEXAS BOARD OF WATER ENGINEERS BULLETIN 5104, 1951.

RECORDS OF WATER-LEVEL MEASUREMENTS IN DALLAM, HANSFORD, HARTLEY, HUTCHINSON, MOORE, OCHILTREE, AND SHERMAN COUNTIES, TEXAS: TEXAS BOARD OF WATER ENGINEERS BULLETIN 5404, 1954.

PUMPING COSTS, SELECTED PUMPING PLANTS IN MOORE AND HANSFORD COUNTIES, TEXAS: TEXAS BOARD OF WATER ENGINEERS MISCELLANEOUS PUBLICATION 193, 1955.

WATER-LEVEL MAPS AND WATER LEVELS IN OBSERVATION WELLS IN THE NORTH HIGH PLAINS, TEXAS: TEXAS BOARD OF WATER ENGINEERS BULLETIN 5707, 1957.

WATER-LEVEL MEASUREMENTS AND MAPS, NORTHERN HIGH PLAINS, TEXAS, 1958 AND 1959: TEXAS BOARD OF WATER ENGINEERS BULLETIN 5909, 1959.

WATER LEVELS IN OBSERVATION WELLS, NORTHERN HIGH PLAINS, TEXAS, 1958-1960: TEXAS BOARD OF WATER ENGINEERS BULLETIN 6012, 1960.

RECONNAISSANCE INVESTIGATION OF THE GROUND-WATER RESOURCES OF THE CANADIAN RIVER BASIN, TEXAS: TEXAS BOARD OF WATER ENGINEERS BULLETIN 6016, 1960.

ANNUAL WATER-LEVEL MEASUREMENTS IN OBSERVATION WELLS, NORTHERN HIGH PLAINS, TEXAS, 1960 AND 1961: TEXAS BOARD OF WATER ENGINEERS BULLETIN 6103, 1961.

GEOLOGY AND GROUND-WATER RESOURCES OF THE NORTHERN HIGH PLAINS OF TEXAS, PROGRESS REPORT NO. 1: TEXAS BOARD OF WATER ENGINEERS BULLETIN 6109, 1961.

ANNUAL WATER-LEVEL MEASUREMENTS IN OBSERVATION WELLS, NORTHERN HIGH PLAINS, TEXAS, 1961 AND 1962: TEXAS WATER COMMISSION BULLETIN 6213, 1962.

WATER-LEVEL DATA FROM OBSERVATION WELLS IN THE NORTHERN PANHANDLE OF TEXAS: TEXAS DEPARTMENT OF WATER RESOURCES REPORT 137, 1971.

MAJOR AND HISTORICAL SPRINGS OF TEXAS: TEXAS WATER DEVELOPMENT BOARD REPORT 189, 1975.

GROUND-WATER RESOURCES OF THE PALO DURO CREEK BASIN, TEXAS AND OKLAHOMA: USGS OPEN-FILE REPORT 79-209, 1979.

ANALYTICAL STUDY OF THE OGALLALA AQUIFER IN CARSON COUNTY, TEXAS—PROJECTIONS OF SATURATED THICKNESS, VOLUME OF WATER IN STORAGE, PUMPAGE RATES, PUMPING LIFTS, AND WELL YIELDS: TEXAS DEPARTMENT OF WATER RESOURCES REPORT 242, 1979

PRELIMINARY DATA DESCRIBING THE DISTRIBUTION OF FLUORIDE AND SILICA IN THE OGALLALA AQUIFER ON THE HIGH PLAINS OF TEXAS: USGS OPEN-FILE REPORT 80-349, 1980.

WATER-LEVEL DATA FROM OBSERVATION WELLS IN THE NORTHERN PANHANDLE OF TEXAS, 1972-78: TEXAS DEPARTMENT OF WATER RESOURCES REPORT 248, 1980.

WATER TABLE IN THE HIGH PLAINS AQUIFER IN 1978 IN PARTS OF COLORADO, KANSAS, NEBRASKA, NEW MEXICO, OKLAHOMA, SOUTH DAKOTA, TEXAS, AND WYOMING: USGS HYDROLOGIC INVESTIGATIONS ATLAS HA-642, 1980. 
EVALUATING THE GROUND-WATER RESOURCES OF THE HIGH PLAINS OF TEXAS: RESULTS OF TEST HOLE DRILLING: TEXAS DEPARTMENT OF WATER RESOURCES LIMITED PRINTING REPORT LP-129, 1980.

EVALUATING THE GROUND-WATER RESOURCES OF THE HIGH PLAINS OF TEXAS: RESULTS OF SURFACE ELECTRICAL RESISTIVITY: TEXAS DEPARTMENT OF WATER RESOURCES LIMITED PRINTING REPORT LP-130, 1980.

ANALYTICAL STUDY OF THE OGALLALA AQUIFER IN HANSFORD COUNTY, TEXAS—PROJECTIONS OF SATURATED THICKNESS, VOLUME OF WATER IN STORAGE, PUMPAGE RATES, PUMPING LIFTS, AND WELL YIELDS: TEXAS DEPARTMENT OF WATER RESOURCES REPORT 257, 1980.

EVALUATING THE GROUND-WATER RESOURCES OF THE HIGH PLAINS OF TEXAS: NEUTRON-PROBE MEASUREMENTS OF DEEP SOIL MOISTURE AS AN INDICATION OF AQUIFER RECHARGE RATES: TEXAS DEPARTMENT OF WATER RESOURCES REPORT LP-142, 1981.

SPRINGS OF TEXAS, VOLUME 1: (BY GUNNAR BRUNE), BRANCHSMITH, INC., FORT WORTH, TEXAS, 1981.

BEDROCK GEOLOGY, ALTITUDE OF BASE, AND 1980 SATURATED THICKNESS OF THE HIGH PLAINS AQUIFER IN PARTS OF COLORADO, KANSAS, NEBRASKA, NEW MEXICO, OKLAHOMA, SOUTH DAKOTA, TEXAS, AND WYOMING: USGS HYDROLOGIC INVESTIGATIONS ATLAS HA-648, 1981.

WATER-LEVEL AND SATURATED-THICKNESS CHANGES, PREDEVELOPMENT TO 1980, IN THE HIGH PLAINS AQUIFER IN PARTS OF COLORADO, KANSAS, NEBRASKA, NEW MEXICO, OKLAHOMA, SOUTH DAKOTA, TEXAS, AND WYOMING: USGS HYDROLOGIC INVESTIGATIONS ATLAS HA-652, 1981.

DISSOLVED SOLIDS AND SODIUM IN WATER FROM THE HIGH PLAINS AQUIFER IN PARTS OF COLORADO, KANSAS, NEBRASKA, NEW MEXICO, OKLAHOMA, SOUTH DAKOTA, TEXAS, AND WYOMING: USGS HYDROLOGIC INVESTIGATIONS ATLAS HA-658, 1982.

GEOHYDROLOGY OF THE HIGH PLAINS AQUIFER IN PARTS OF COLORADO, KANSAS, NEBRASKA, NEW MEXICO, OKLAHOMA, SOUTH DAKOTA, TEXAS, AND WYOMING: USGS PROFESSIONAL PAPER 1400-B, 1984.

EVALUATING THE GROUND-WATER RESOURCES OF THE HIGH PLAINS OF TEXAS, VOLUME 1: TEXAS DEPARTMENT OF WATER RESOURCES REPORT 288, V. 1, 1984.

EVALUATING THE GROUND-WATER RESOURCES OF THE HIGH PLAINS OF TEXAS, VOLUME 2, RECORDS OF WELLS, AND MAPS SHOWING WELL LOCATIONS, BASE OF AQUIFER, WATER LEVELS, AND SATURATED THICKNESS (ARMSTRONG, CARSON, DALLAS, DONLEY, GRAY, HANSFORD, HARTLEY, HEMPHILL, HUTCHINSON, LIPSCOMB, MOORE, OCHILTREE, POTTER, ROBERTS, SHERMAN, AND WHEELER COUNTIES): TEXAS DEPARTMENT OF WATER RESOURCES REPORT 288, V. 2, 1984.

TEXAS GROUND-WATER RESOURCES, in NATIONAL WATER SUMMARY 1984: USGS WATER-SUPPLY PAPER 2275, 1985.

DIGITAL SIMULATION OF GROUND-WATER FLOW IN THE HIGH PLAINS AQUIFER IN PARTS OF COLORADO, KANSAS, NEBRASKA, NEW MEXICO, OKLAHOMA, SOUTH DAKOTA, TEXAS, AND WYOMING: USGS PROFESSIONAL PAPER 1400-D, 1986.
SUMMARY OF THE HIGH PLAINS REGIONAL AQUIFER-SYSTEM ANALYSIS IN PARTS OF COLORADO, KANSAS, NEBRASKA, NEW MEXICO, OKLAHOMA, SOUTH DAKOTA, TEXAS, AND WYOMING: USGS PROFESSIONAL PAPER 1400-A, 1988.

WATER-LEVEL CHANGES IN THE HIGH PLAINS AQUIFER OF TEXAS, 1980-1990: TEXAS WATER DEVELOPMENT BOARD HYDROLOGIC ATLAS NO. 1, 1991.

PUBLIC-SUPPLY GROUND-WATER USE IN THE NORTHERN HIGH PLAINS OF TEXAS: TEXAS WATER DEVELOPMENT BOARD REPORT 336, 1992.

THE HIGH PLAINS AQUIFER SYSTEM OF TEXAS, 1980-1990. OVERVIEW AND PROJECTIONS: TEXAS WATER DEVELOPMENT BOARD REPORT 341, 1993.

WATER-QUALITY EVALUATION OF THE OGALLALA AQUIFER, TEXAS: TEXAS WATER DEVELOPMENT BOARD REPORT 342, 1993.

WATER-LEVEL CHANGES IN THE HIGH PLAINS AQUIFER-PREDEVELOPMENT TO 1992: USGS WATER-RESOURCES INVESTIGATIONS REPORT 94-4027, 1994.

WATER-LEVEL CHANGES IN THE HIGH PLAINS AQUIFER, 1980 TO 1994: USGS FACT SHEET FS-215-95, 1995.

AQUIFERS OF TEXAS: TEXAS WATER DEVELOPMENT BOARD REPORT 345, 1995.

WATER-LEVEL CHANGES IN THE HIGH PLAINS AQUIFER, 1980 TO 1995: USGS FACT SHEET FS-068-97, 1997.

WATER-LEVEL CHANGES IN THE HIGH PLAINS AQUIFER-PREDEVELOPMENT TO 1995: USGS WATER-RESOURCES INVESTIGATIONS REPORT 97-4081, 1997.

UPDATED WATER-QUALITY EVALUATION OF THE OGALLALA AQUIFER INCLUDING SELECTED METALLIC AND NON-METALLIC INORGANIC CONSTITUENTS: TEXAS WATER DEVELOPMENT BOARD HYDROLOGIC ATLAS NO. 10, 1998.

\section{HARDEMAN COUNTY}

GEOLOGY AND UNDERGROUND WATERS OF THE WICHITA REGION, NORTH-CENTRAL TEXAS: USGS WATER-SUPPLY PAPER 317,1913

GROUND WATER IN WESTERN HARDEMAN COUNTY, TEXAS, AND SUPPLEMENTARY REPORT ON THE GROUND WATERS OF SOUTHEASTERN HARDEMAN COUNTY: USGS OPEN-FILE REPORT (UNNUMBERED), 1936.

RECORDS OF WELLS, DRILLERS' LOGS, WATER ANALYSES, AND MAP SHOWING LOCATION OF WELLS IN HARDEMAN COUNTY, TEXAS: TEXAS BOARD OF WATER ENGINEERS MISCELLANEOUS PUBLICATION 107, 1936.

MEMORANDUM ON GROUND-WATER RESOURCES IN THE ACME AREA, TEXAS: USGS OPEN-FILE REPORT (UNNUMBERED), 1945

PUBLIC WATER SUPPLIES IN CENTRAL AND NORTH-CENTRAL TEXAS: USGS WATER-SUPPLY PAPER 1069, 1949.

RECORDS OF WATER-LEVEL MEASUREMENTS IN CHILDRESS, COTTLE, HARDEMAN, AND KING COUNTIES, TEXAS, 1940 TO JANUARY 1956: TEXAS BOARD OF WATER ENGINEERS BULLETIN 5613, 1956. 
RECONNAISSANCE INVESTIGATION OF THE GROUND-WATER RESOURCES OF THE RED RIVER, SULFUR RIVER, AND CYPRESS CREEK BASINS, TEXAS: TEXAS WATER COMMISSION BULLETIN 6306, 1963.

GROUND-WATER RESOURCES OF HARDEMAN COUNTY, TEXAS: TEXAS WATER DEVELOPMENT BOARD REPORT 161, 1972.

SPRINGS OF TEXAS, VOLUME 1: (BY GUNNAR BRUNE), BRANCHSMITH, INC., FORT WORTH, TEXAS, 1981.

TEXAS GROUND-WATER RESOURCES, in NATIONAL WATER SUMMARY 1984: USGS WATER-SUPPLY PAPER 2275, 1985.

EVALUATION OF WATER RESOURCES IN PARTS OF THE ROLLING PRAIRIES REGION OF NORTH-CENTRAL TEXAS: TEXAS WATER DEVELOPMENT BOARD REPORT 337, 1992.

AQUIFERS OF TEXAS: TEXAS WATER DEVELOPMENT BOARD REPORT 345, 1995.

\section{HARDIN COUNTY}

UNDERGROUND WATERS OF THE COASTAL PLAIN OF TEXAS: USGS WATER-SUPPLY PAPER 190, 1907.

GEOLOGY AND UNDERGROUND WATERS OF THE SOUTHEASTERN PART OF THE TEXAS COASTAL PLAIN: USGS WATER-SUPPLY PAPER 335, 1914.

RECORDS OF WELLS, DRILLERS' LOGS, WATER ANALYSES, AND MAP SHOWING LOCATIONS OF WELLS IN HARDIN COUNTY, TEXAS: TEXAS BOARD OF WATER ENGINEERS MISCELLANEOUS PUBLICATION 108, 1942.

PUBLIC WATER SUPPLIES IN EASTERN TEXAS: USGS WATERSUPPLY PAPER 1047, 1948

AVAILABILITY OF GROUND WATER IN THE GULF COAST REGION OF TEXAS: USGS OPEN-FILE REPORT (UNNUMBERED), 1956.

RECONNAISSANCE INVESTIGATION OF THE GROUND-WATER RESOURCES OF THE GULF COAST REGION, TEXAS: TEXAS WATER COMMISSION BULLETIN 6305, 1963.

GEOLOGY AND GROUND-WATER RESOURCES OF HARDIN COUNTY, TEXAS: TEXAS WATER COMMISSION BULLETIN 6406, 1964.

GROUND-WATER DATA FOR ORANGE COUNTY AND VICINITY, TEXAS AND LOUISIANA, 1968: USGS OPEN-FILE REPORT 68-50, 1968.

GROUND-WATER DATA FOR ORANGE COUNTY AND VICINITY, TEXAS AND LOUISIANA, 1969: USGS OPEN-FILE REPORT 69-204, 1969.

COMPILATION OF RESULTS OF AQUIFER TESTS IN TEXAS: TEXAS WATER DEVELOPMENT BOARD REPORT 98, 1969.

GROUND-WATER DATA FOR ORANGE COUNTY AND VICINITY, TEXAS AND LOUISIANA, 1970: USGS OPEN-FILE REPORT 70-123, 1970.

GEOHYDROLOGIC SIGNIFICANCE OF LITHOFACIES OF THE COCKFIELD FORMATION OF LOUISIANA AND MISSISSIPPI AND OF THE YEGUA FORMATION OF TEXAS: USGS PROFESSIONAL PAPER 569-B, 1970.
DEVELOPMENT OF GROUND-WATER RESOURCES IN THE ORANGE COUNTY AREA, TEXAS AND LOUISIANA, 1963-71: USGS OPENFILE REPORT 72-243, 1972.

DEVELOPMENT OF GROUND-WATER RESOURCES IN THE ORANGE COUNTY AREA, TEXAS AND LOUISIANA, 1963-71: TEXAS WATER DEVELOPMENT BOARD REPORT 156, 1972.

GROUND-WATER DATA FOR ORANGE COUNTY AND VICINITY, TEXAS AND LOUISIANA, 1971-74: USGS OPEN-FILE REPORT $75-129,1975$.

GEOHYDROLOGIC SIGNIFICANCE OF LITHOFACIES OF THE CARRIZO SAND OF ARKANSAS, LOUISIANA, AND TEXAS AND THE MERIDIAN SAND OF MISSISSIPPI: USGS PROFESSIONAL PAPER 569-D, 1975.

SUMMARY APPRAISALS OF THE NATION'S GROUND-WATER RESOURCES-TEXAS-GULF REGION: USGS PROFESSIONAL PAPER 813-F, 1976.

STRATIGRAPHIC AND HYDROGEOLOGIC FRAMEWORK OF PART OF THE COASTAL PLAIN OF TEXAS: USGS OPEN-FILE REPORT $77-712,1978$.

STRATIGRAPHIC AND HYDROGEOLOGIC FRAMEWORK OF PART OF THE COASTAL PLAIN OF TEXAS: TEXAS DEPARTMENT OF WATER RESOURCES REPORT 236, 1979.

SPRINGS OF TEXAS, VOLUME 1: (BY GUNNAR BRUNE), BRANCHSMITH, INC., FORT WORTH, TEXAS, 1981.

LAND-SURFACE SUBSIDENCE IN THE TEXAS COASTAL REGION: TEXAS DEPARTMENT OF WATER RESOURCES REPORT 272, 1982.

TEXAS GROUND-WATER RESOURCES, in NATIONAL WATER SUMMARY 1984: USGS WATER-SUPPLY PAPER 2275, 1985.

DIGITAL MODELS FOR SIMULATION OF GROUND-WATER HYDROLOGY OF THE CHICOT AND EVANGELINE AQUIFERS ALONG THE GULF COAST OF TEXAS: TEXAS DEPARTMENT OF WATER RESOURCES REPORT 289, 1985.

WATER USE, PROJECTED WATER REQUIREMENTS, AND RELATED DATA AND INFORMATION FOR THE METROPOLITAN STATISTICAL AREAS IN TEXAS: TEXAS DEPARTMENT OF WATER RESOURCES LIMITED PRINTING REPORT LP-201, 1985.

HYDROLOGY OF THE JASPER AQUIFER IN THE SOUTHEAST TEXAS COASTAL PLAIN: TEXAS WATER DEVELOPMENT BOARD REPORT 295, 1986.

GEOHYDROLOGIC FRAMEWORK OF THE GULF COASTAL PLAIN USGS HYDROLOGIC INVESTIGATIONS ATLAS HA-695, 1988.

HYDROGEOLOGY AND PREDEVELOPMENT FLOW IN THE TEXAS GULF COAST AQUIFER SYSTEMS: USGS WATER-RESOURCES INVESTIGATIONS REPORT 87-4248, 1988.

GROUND-WATER FLOW IN THE GULF COAST AQUIFER SYSTEMS, SOUTH-CENTRAL UNITED STATES-A PRELIMINARY ANALYSIS USGS WATER-RESOURCES INVESTIGATIONS REPORT 89-4071, 1990.

SALT-DOME LOCATIONS IN THE GULF COASTAL PLAIN, SOUTHCENTRAL UNITED STATES: USGS WATER-RESOURCES INVESTIGATIONS REPORT 90-4060, 1990.

HYDROLOGY OF THE TEXAS GULF COAST AQUIFER SYSTEMS: USGS OPEN-FILE REPORT 91-64, 1991. 
PROPERTIES AND CHEMICAL CONSTITUENTS IN GROUND WATER FROM THE MISSISSIPPI RIVER VALLEY ALLUVIAL AQUIFER AND PERMEABLE ZONE A (HOLOCENE-UPPER PLEISTOCENE DEPOSITS), SOUTH-CENTRAL UNITED STATES: USGS WATERRESOURCES INVESTIGATIONS REPORT 91-4149, 1992.

PROPERTIES AND CHEMICAL CONSTITUENTS IN GROUND WATER FROM PERMEABLE ZONE C (LOWER PLIOCENE-UPPER MIOCENE DEPOSITS), COASTAL LOWLANDS AQUIFER SYSTEM, SOUTHCENTRAL UNITED STATES: USGS WATER-RESOURCES INVESTIGATIONS REPORT 91-4151, 1993.

PROPERTIES AND CHEMICAL CONSTITUENTS IN GROUND WATER FROM PERMEABLE ZONE B (LOWER PLEISTOCENE-UPPER PLIOCENE DEPOSITS), COASTAL LOWLANDS AQUIFER SYSTEM, SOUTH-CENTRAL UNITED STATES: USGS WATER-RESOURCES INVESTIGATIONS REPORT 91-4152, 1993.

PROPERTIES AND CHEMICAL CONSTITUENTS IN GROUND WATER FROM PERMEABLE ZONE E (LOWER MIOCENE-UPPER OLIGOCENE DEPOSITS), COASTAL LOWLANDS AQUIFER SYSTEM, SOUTH-CENTRAL UNITED STATES: USGS WATER-RESOURCES INVESTIGATIONS REPORT 92-4103, 1993.

PROPERTIES AND CHEMICAL CONSTITUENTS IN GROUND WATER FROM PERMEABLE ZONE D (MIDDLE MIOCENE DEPOSITS), COASTAL LOWLANDS AQUIFER SYSTEM, SOUTH-CENTRAL UNITED STATES: USGS WATER-RESOURCES INVESTIGATIONS REPORT 92-4105, 1993.

PROPERTIES AND CHEMICAL CONSTITUENTS IN GROUND WATER FROM THE MIDDLE WILCOX AQUIFER, GULF COAST REGIONAL AQUIFER SYSTEMS, SOUTH-CENTRAL UNITED STATES: USGS WATER-RESOURCES INVESTIGATIONS REPORT 93-4070, 1993.

WATER-RESOURCES DATA, TEXAS, WATER YEAR 1992, VOLUME 4, GROUND-WATER DATA: USGS WATER-DATA REPORT TX-92-4, 1993.

WATER-RESOURCES DATA, TEXAS, WATER YEAR 1993, VOLUME 4, GROUND-WATER DATA: USGS WATER-DATA REPORT TX-93-4, 1994.

STRATIGRAPHIC NOMENCLATURE AND GEOLOGIC SECTIONS OF THE GULF COASTAL PLAIN OF TEXAS: USGS OPEN-FILE REPORT 94-461, 1995.

AQUIFERS OF TEXAS: TEXAS WATER DEVELOPMENT BOARD REPORT 345, 1995.

WATER-RESOURCES DATA, TEXAS, WATER YEAR 1994, VOLUME 4, GROUND-WATER DATA: USGS WATER-DATA REPORT TX-94-4, 1995.

WATER-RESOURCES DATA, TEXAS, WATER YEAR 1995, VOLUME 4, GROUND-WATER DATA: USGS WATER-DATA REPORT TX-95-4, 1996.

WATER-RESOURCES DATA, TEXAS, WATER YEAR 1996, VOLUME 4, GROUND-WATER DATA: USGS WATER-DATA REPORT TX-96-4, 1997.

WATER-RESOURCES DATA, TEXAS, WATER YEAR 1997, VOLUME 4, GROUND-WATER DATA: USGS WATER-DATA REPORT TX-97-4, 1998.

GROUND-WATER DATA IN ORANGE COUNTY AND ADJACENT COUNTIES, TEXAS, 1985-90: USGS OPEN-FILE REPORT 99-603, 1999.
WATER-RESOURCES DATA, TEXAS, WATER YEAR 1998, VOLUME 4, GROUND-WATER DATA: USGS WATER-DATA REPORT TX-98-4, 1999.

WATER-RESOURCES DATA, TEXAS, WATER YEAR 1999, VOLUME 6, GROUND-WATER DATA: USGS WATER-DATA REPORT TX-99-6, 2000.

WATER-RESOURCES DATA, TEXAS, WATER YEAR 2000, VOLUME 6, GROUND-WATER DATA: USGS WATER-DATA REPORT TX-00-6, 2001.

\section{HARRIS COUNTY}

ARTESIAN WELLS OF THE COASTAL PRAIRIE REGION AND TERTIARY BELT OF TEXAS: GEOLOGICAL SURVEY OF TEXAS, CHAPTER 2, 1893.

UNDERGROUND WATERS OF THE COASTAL PLAIN OF TEXAS: USGS WATER-SUPPLY PAPER 190, 1907.

GEOLOGY AND UNDERGROUND WATERS OF THE SOUTHEASTERN PART OF THE TEXAS COASTAL PLAIN: USGS WATER-SUPPLY PAPER 335, 1914.

GROUND-WATER RESOURCES OF THE HOUSTON-GALVESTON AREA, TEXAS: USGS OPEN-FILE REPORT (UNNUMBERED) (PRESS RELEASE), 1932.

RECORDS OF WELLS IN HARRIS COUNTY, TEXAS: USGS OPEN-FILE REPORT (UNNUMBERED), 1933.

GROUND-WATER RESOURCES OF THE HOUSTON DISTRICT, TEXAS: USGS OPEN-FILE REPORT (UNNUMBERED), 1933.

RECORDS OF WELLS IN HARRIS, GALVESTON, WALLER, FORT BEND, BRAZORIA, AND GRIMES COUNTY, TEXAS: USGS OPENFILE REPORT (UNNUMBERED), 1935.

PROGRESS REPORT ON THE GROUND-WATER RESOURCES OF THE HOUSTON DISTRICT, TEXAS: USGS OPEN-FILE REPORT (UNNUMBERED), 1937.

PROGRESS REPORT ON THE GROUND-WATER RESOURCES OF THE HOUSTON DISTRICT, TEXAS: TEXAS BOARD OF WATER ENGINEERS MISCELLANEOUS PUBLICATION 129, 1938.

NOTES ON THE HOUSTON INVESTIGATION: USGS OPEN-FILE REPORT (UNNUMBERED), 1939.

CONSERVATION OF HOUSTON'S UNDERGROUND WATER: USGS OPEN-FILE REPORT (UNNUMBERED), 1939.

RECORDS OF WELLS, DRILLERS' LOGS, WATER ANALYSES, AND MAP SHOWING LOCATION OF WELLS IN HARRIS COUNTY, TEXAS: TEXAS STATE BOARD OF WATER ENGINEERS MISCELLANEOUS PUBLICATION 109, 1939.

GROUND-WATER RESOURCES OF THE HOUSTON-GALVESTON AREA AND ADJACENT REGION: TEXAS BOARD OF WATER ENGINEERS MISCELLANEOUS PUBLICATION 130, 1939.

PROGRESS REPORT ON THE GROUND-WATER RESOURCES OF THE HOUSTON DISTRICT, TEXAS: TEXAS BOARD OF WATER ENGINEERS MISCELLANEOUS PUBLICATION 131, 1939.

PROGRESS REPORT ON THE GROUND-WATER RESOURCES OF THE HOUSTON DISTRICT, TEXAS: TEXAS BOARD OF WATER ENGINEERS MISCELLANEOUS PUBLICATION 132, 1940. 
TEST DRILLING IN THE SAN JACINTO RIVER FLOOD PLAIN, TEXAS: USGS OPEN-FILE REPORT (UNNUMBERED), 1940.

SUMMARY OF RESULTS OF RECOVERY AND INTERFERENCE TESTS CONDUCTED BY THE GEOLOGICAL SURVEY IN COOPERATION WITH THE WATER DEPARTMENT OF THE CITY OF HOUSTON, TEXAS: USGS OPEN-FILE REPORT (UNNUMBERED), 1940.

COEFFICIENTS OF STORAGE AND TRANSMISSIBILITY OBTAINED FROM PUMPING TESTS IN THE HOUSTON DISTRICT, TEXAS: USGS OPEN-FILE REPORT (UNNUMBERED), 1941.

WATER SUPPLY OF BAYTOWN: USGS OPEN-FILE REPORT (UNNUMBERED), 1941.

OCCURRENCE OF SALT WATER IN THE HOUSTON DISTRICT, TEXAS: USGS OPEN-FILE REPORT (UNNUMBERED), 1941.

NOTES ON RECHARGE TEST WELLS, HOUSTON DISTRICT: USGS OPEN-FILE REPORT (UNNUMBERED), 1941.

WATER SUPPLY OF PASADENA: USGS OPEN-FILE REPORT (UNNUMBERED), 1941.

HOUSTON WATER SUPPLY, GROUND WATER: USGS OPEN-FILE REPORT (UNNUMBERED), 1941.

GROUND WATER AND THE RELATION OF GEOLOGY TO ITS OCCURRENCE IN THE HOUSTON DISTRICT, TEXAS: USGS OPEN-FILE REPORT (UNNUMBERED), 1942.

GROUND-WATER RESOURCES OF THE HOUSTON DISTRICT; PROGRESS REPORT WITH RECORDS OF WELLS, HARRIS COUNTY AND ADJOINING PARTS OF FORT BEND AND WALLER COUNTIES, TEXAS: TEXAS BOARD OF WATER ENGINEERS MISCELLANEOUS PUBLICATION 133, 1942.

PROGRESS REPORT ON GROUND-WATER RESOURCES OF THE HOUSTON DISTRICT, TEXAS: TEXAS BOARD OF WATER ENGINEERS MISCELLANEOUS PUBLICATION 134, 1942.

MEMORANDUM ON THE WATER SUPPLY AT THE BROWN SHIPBUILDING COMPANY PLANT, HOUSTON, TEXAS: USGS OPENFILE REPORT (UNNUMBERED), 1943

MEMORANDUM REGARDING PROPOSED NEW WELLS ALONG ALIEF-HOUSTON LINE, NEAR HOUSTON, TEXAS: USGS OPENFILE REPORT (UNNUMBERED), 1943.

WAR PRODUCTION BOARD, CASE NO. 25,357, MEMORANDUM REGARDING GROUND-WATER CONDITIONS AT HOUSTON: USGS OPEN-FILE REPORT (UNNUMBERED), 1943.

MEMORANDUM REGARDING RELATIVE MERITS OF VARIOUS PLANS OF PUMPING GROUND WATER BY THE CITY OF HOUSTON: USGS OPEN-FILE REPORT (UNNUMBERED), 1943.

ESTIMATED INCREASE OF PUMPAGE AND DECLINE OF WATER LEVELS IN WELLS IN HOUSTON DISTRICT DURING 1943: USGS OPEN-FILE REPORT (UNNUMBERED), 1943.

PUMP SETTINGS AND PUMPING LEVELS IN HOUSTON DISTRICT, TEXAS: TEXAS BOARD OF WATER ENGINEERS MISCELLANEOUS PUBLICATION 135, 1943.

GROUND WATER AND RELATION OF GEOLOGY TO ITS OCCURRENCE IN HOUSTON DISTRICT, TEXAS: AMERICAN ASSOCIATION OF PETROLEUM GEOLOGISTS, V. 27, NO. 8, P. 1081-1101, 1943.
EXPLORATORY WATER-WELL DRILLING IN THE HOUSTON DISTRICT, TEXAS: TEXAS BOARD OF WATER ENGINEERS MISCELLANEOUS PUBLICATION 136, 1943.

ESTIMATED INCREASE OF PUMPAGE AND DECLINE OF WATER LEVELS IN WELLS IN HOUSTON DISTRICT DURING 1943: USGS OPEN-FILE REPORT (UNNUMBERED), 1943.

GROUND WATER AND RELATION OF GEOLOGY TO ITS OCCURRENCE IN HOUSTON DISTRICT, TEXAS: AMERICAN ASSOCIATION OF PETROLEUM GEOLOGISTS BULLETIN, V. 27, NO. 8, P. 1081-1101, 1943.

MEMORANDUM ON THE WATER SUPPLY OF THE REFINERY OF THE SHELL OIL COMPANY, HOUSTON, TEXAS: USGS OPEN-FILE REPORT (UNNUMBERED), 1944.

MEMORANDUM ON THE WATER SUPPLY AT THE SHEFFIELD STEEL CORP., HOUSTON, TEXAS: USGS OPEN-FILE REPORT (UNNUMBERED), 1944.

GROUND-WATER RESOURCES OF THE HOUSTON DISTRICT, TEXAS: USGS WATER-SUPPLY PAPER 889-C, 1944.

PROGRESS REPORT ON THE GROUND-WATER RESOURCES OF THE HOUSTON DISTRICT, TEXAS: TEXAS BOARD OF WATER ENGINEERS MISCELLANEOUS PUBLICATION 137, 1944.

EXPLORATORY WATER-WELL DRILLING IN THE HOUSTON DISTRICT, TEXAS: USGS WATER-SUPPLY PAPER 889-D, 1944.

GROUND-WATER PROBLEMS IN THE TEXAS CITY-ALTA LOMABAYTOWN DISTRICT, TEXAS: USGS OPEN-FILE REPORT (UNNUMBERED), 1944.

RELATION OF PHENOMENAL RISE OF WATER LEVELS TO A DEFECTIVE GAS WELL, HARRIS COUNTY, TEXAS: AMERICAN ASSOCIATION OF PETROLEUM GEOLOGISTS BULLETIN V. 29, NO. 3, P. 253-279, 1945.

GROUND-WATER RESOURCES OF THE HOUSTON DISTRICT, TEXAS, PROGRESS REPORT FOR 1946, WITH SECTION ON RESULTS OF PUMPING TESTS AT NEW SOUTHWEST PUMPING PLANT: TEXAS BOARD OF WATER ENGINEERS MISCELLANEOUS PUBLICATION 138,1946

PUBLIC WATER SUPPLIES IN EASTERN TEXAS: USGS WATERSUPPLY PAPER 1047, 1948.

GROUND-WATER CONDITIONS IN THE VICINITY OF THE SOUTH HOUSTON OIL FIELD, AND NEED FOR PROTECTING FRESHWATER SANDS FROM CONTAMINATION: USGS OPEN-FILE REPORT 49-089, 1949.

MEMORANDUM ON MULTIPLE-STEP DRAWDOWN TEST, SOUTHWEST WELL FIELD, HOUSTON, TEXAS: USGS OPEN-FILE REPORT (UNNUMBERED), 1949

MEMORANDUM ON EFFECT OF INCREASE OF PUMPAGE IN CITY OF HOUSTON WELL FIELDS: USGS OPEN-FILE REPORT (UNNUMBERED), 1950

GEOLOGY AND GROUND-WATER RESOURCES OF THE HOUSTON DISTRICT, TEXAS: TEXAS BOARD OF WATER ENGINEERS BULLETIN 5001, 1950

INDUSTRIAL WATER REQUIREMENTS, BAYTOWN, TEXAS, REFINERY OF THE HUMBLE OIL AND REFINING CO.: USGS OPEN-FILE REPORT (UNNUMBERED), 1951.

WATER SUPPLY OF THE HOUSTON GULF COAST REGION: TEXAS BOARD OF WATER ENGINEERS BULLETIN 5101, 1951. 
THE HOUSTON DISTRICT, TEXAS, PUMPAGE AND DECLINE OF ARTESIAN PRESSURE DURING 1950-51: TEXAS BOARD OF WATER ENGINEERS BULLETIN 5201, 1952.

PUMPAGE OF GROUND WATER AND DECLINE OF ARTESIAN PRESSURE IN THE HOUSTON DISTRICT, TEXAS, DURING 1951 AND 1952: TEXAS BOARD OF WATER ENGINEERS BULLETIN 5401, 1954.

LAND-SURFACE SUBSIDENCE AND ITS RELATION TO THE WITHDRAWAL OF GROUND WATER IN THE HOUSTON-GALVESTON REGION, TEXAS: ECONOMIC GEOLOGY, V. 49, NO. 4, P. 413-422, 1954.

SALT WATER AND ITS RELATION TO FRESH GROUND WATER IN HARRIS COUNTY, TEXAS: TEXAS BOARD OF WATER ENGINEERS BULLETIN 5409, 1954.

PUMPAGE OF GROUND WATER AND CHANGES IN ARTESIAN PRESSURE IN THE HOUSTON DISTRICT AND BAYTOWN-LA PORTE AREA, TEXAS, 1953-55: TEXAS BOARD OF WATER ENGINEERS BULLETIN 5602, 1956.

AVAILABILITY OF GROUND WATER IN THE GULF COAST REGION OF TEXAS: USGS OPEN-FILE REPORT (UNNUMBERED), 1956.

SALT WATER AND ITS RELATION TO FRESH GROUND WATER IN HARRIS COUNTY, TEXAS: USGS WATER-SUPPLY PAPER 1360-F, 1957.

PUMPAGE OF GROUND WATER AND FLUCTUATIONS OF WATER LEVELS IN THE HOUSTON DISTRICT AND BAYTOWN-LA PORTE AREA, TEXAS, 1955-57, 1958.

PUMPAGE OF GROUND WATER AND FLUCTUATIONS OF WATER LEVELS IN THE HOUSTON DISTRICT AND THE BAYTOWN-LA PORTE AREA, TEXAS, 1957-61, 1962.

RECONNAISSANCE INVESTIGATION OF THE GROUND-WATER RESOURCES OF THE GULF COAST REGION, TEXAS: TEXAS WATER COMMISSION BULLETIN 6305, 1963.

PUBLIC WATER SUPPLIES OF THE 100 LARGEST CITIES IN THE UNITED STATES: USGS WATER-SUPPLY PAPER 1812, 1964.

ANALOG MODEL STUDY OF GROUND WATER IN THE HOUSTON DISTRICT, TEXAS: TEXAS WATER COMMISSION BULLETIN 6508, 1965.

DEVELOPMENT OF GROUND WATER IN THE HOUSTON DISTRICT, TEXAS, 1961-65: TEXAS WATER DEVELOPMENT BOARD REPORT 63, 1967.

HYDROLOGIC EFFECTS OF THE EARTHQUAKE OF MARCH 27, 1964 OUTSIDE ALASKA: USGS PROFESSIONAL PAPER 544-C, 1968.

LAND-SURFACE SUBSIDENCE IN THE HOUSTON-GALVESTON REGION, TEXAS: USGS OPEN-FILE REPORT 69-61, 1969.

COMPILATION OF RESULTS OF AQUIFER TESTS IN TEXAS: TEXAS WATER DEVELOPMENT BOARD REPORT 98, 1969.

RECORDS OF WATER-LEVEL MEASUREMENTS IN OBSERVATION WELLS IN HARRIS COUNTY, TEXAS: TEXAS WATER DEVELOPMENT BOARD REPORT 103, 1969.

GEOHYDROLOGIC SIGNIFICANCE OF LITHOFACIES OF THE COCKFIELD FORMATION OF LOUISIANA AND MISSISSIPPI AND OF THE YEGUA FORMATION OF TEXAS: USGS PROFESSIONAL PAPER 569-B, 1970.
RECORDS OF WATER-LEVEL MEASUREMENTS IN WELLS IN HARRIS COUNTY, TEXAS, 1966-69: TEXAS WATER DEVELOPMENT BOARD REPORT 122, 1970.

GROUND-WATER CONDITIONS IN THE GALVESTON BAY AREAHARRIS, GALVESTON, AND CHAMBERS COUNTIES, TEXAS: WILLIAM F. GUYTON \& ASSOCIATES, AUSTIN AND HOUSTON, TEXAS, 1972

CHEMICAL ANALYSES OF WATER FROM WELLS IN HARRIS COUNTY, TEXAS, 1922-71: USGS OPEN-FILE REPORT 72-225, 1972

RECORDS OF WELLS IN HARRIS COUNTY, TEXAS, 1892-1972: USGS OPEN-FILE REPORT 72-255, 1972.

DRILLERS' LOGS OF WELLS IN HARRIS COUNTY, TEXAS, 1905-71: USGS OPEN-FILE REPORT 72-274, 1972.

DEVELOPMENT OF GROUND WATER IN THE HOUSTON DISTRICT, TEXAS, 1966-69: TEXAS WATER DEVELOPMENT BOARD REPORT $152,1972$.

GEOLOGIC AND HYDROLOGIC SUMMARY OF SALT DOMES IN GULF COAST REGION OF TEXAS, LOUISIANA, AND ALABAMA: USGS OPEN-FILE REPORT 73-07, 1973.

PRELIMINARY REPORT ON LAND-SURFACE SUBSIDENCE IN THE AREA OF BURNETT, SCOTT, AND CRYSTAL BAYS NEAR BAYTOWN, TEXAS: USGS OPEN-FILE REPORT 73-101, 1973.

ANALOG-MODEL STUDIES OF THE EFFECTS OF RECHARGE WELLS ALONG THE HOUSTON SHIP CHANNEL ON POTENTIOMETRIC SURFACES OF THE CHICOT AND EVANGELINE AQUIFERS, HOUSTON, TEXAS: USGS OPEN-FILE REPORT, 73-138, 1973.

GROUND-WATER DATA FOR HARRIS COUNTY, TEXAS, VOLUME 1, DRILLERS' LOGS OF WELLS, 1905-71: TEXAS WATER DEVELOPMENT BOARD REPORT 178, V. 1, 1973.

GROUND-WATER DATA FOR HARRIS COUNTY, TEXAS, VOLUME 2, RECORDS OF WELLS, 1892-1972: TEXAS WATER DEVELOPMENT BOARD REPORT 178, V. 2, 1974.

GROUND-WATER DATA FOR HARRIS COUNTY, TEXAS, VOLUME 3 , CHEMICAL ANALYSES OF WATER FROM WELLS, 1922-71: TEXAS WATER DEVELOPMENT BOARD REPORT 178, V. 3, 1974.

LAND-SURFACE SUBSIDENCE IN THE AREA OF BURNETT, SCOTT, AND CRYSTAL BAYS NEAR BAYTOWN, TEXAS: USGS WATERRESOURCES INVESTIGATIONS REPORT 21-74, 1974.

LAND-SURFACE SUBSIDENCE IN THE HOUSTON-GALVESTON REGION, TEXAS: USGS OPEN-FILE REPORT 74-123, 1974.

SUMMARY APPRAISALS OF THE NATIONS GROUND-WATER RESOURCES-TEXAS GULF REGION: USGS OPEN-FILE REPORT 74-331, 1974.

LAND-SURFACE SUBSIDENCE AT SEABROOK, TEXAS: USGS OPENFILE REPORT 75-413, 1975.

GEOHYDROLOGIC SIGNIFICANCE OF LITHOFACIES OF THE CARRIZO SAND OF ARKANSAS, LOUISIANA, AND TEXAS AND THE MERIDIAN SAND OF MISSISSIPPI: USGS PROFESSIONAL PAPER 569-D, 1975.

LAND-SURFACE SUBSIDENCE AT SEABROOK, TEXAS: USGS WATER-RESOURCES INVESTIGATIONS REPORT 76-31, 1975.

LAND-SURFACE SUBSIDENCE IN THE HOUSTON-GALVESTON REGION, TEXAS: TEXAS: TEXAS WATER DEVELOPMENT BOARD REPORT 188, 1975. 
ANALOG-MODEL STUDIES OF GROUND-WATER HYDROLOGY IN THE HOUSTON DISTRICT, TEXAS: TEXAS WATER DEVELOPMENT BOARD REPORT 190, 1975.

SUMMARY APPRAISALS OF THE NATION'S GROUND-WATER RESOURCES-TEXAS-GULF REGION: USGS PROFESSIONAL PAPER 813-F, 1976.

RECORDS OF WELLS, DRILLERS' LOGS, WATER-LEVEL MEASUREMENTS, AND CHEMICAL ANALYSES OF GROUND WATER IN HARRIS AND GALVESTON COUNTIES, TEXAS, 1970-74: TEXAS WATER DEVELOPMENT BOARD REPORT 203, 1976.

SALT-WATER ENCROACHMENT IN AQUIFERS NEAR THE HOUSTON CHIP CHANNEL, TEXAS: USGS OPEN-FILE REPORT 76-781, 1977.

ARTIFICIAL RECHARGE FOR SUBSIDENCE ABATEMENT AT THE NASA-JOHNSON SPACE CENTER: USGS OPEN-FILE REPORT 77-219, 1977.

DEVELOPMENT OF GROUND WATER IN THE HOUSTON DISTRICT, TEXAS, 1970-74: USGS OPEN-FILE REPORT 77-413, 1977.

APPROXIMATE AREAS OF RECHARGE TO THE CHICOT AND EVANGELINE AQUIFER SYSTEMS IN THE HOUSTON-GALVESTON AREA, TEXAS: USGS OPEN-FILE REPORT 77-754, 1977.

HYDROGEOLOGY OF GULF COAST AQUIFERS, HOUSTONGALVESTON AREA, TEXAS: UNIVERSITY OF TEXAS, BUREAU OF ECONOMIC GEOLOGY GEOLOGICAL CIRCULAR 77-4, 1977.

PROFILES SHOWING POTENTIOMETRIC SURFACES AND CHANGES IN EFFECTIVE STRESS IN AQUIFERS IN HARRIS AND GALVESTON COUNTIES, TEXAS, 1977-78, 1978.

MAP SHOWING SURFACE FAULTS IN THE SOUTHEASTERN HOUSTON METROPOLITAN AREA, TEXAS: USGS OPEN-FILE REPORT 78-797, 1978.

STRATIGRAPHIC AND HYDROGEOLOGIC FRAMEWORK OF PART OF THE COASTAL PLAIN OF TEXAS: TEXAS DEPARTMENT OF WATER RESOURCES REPORT 236, 1979.

A DIGITAL MODEL FOR SIMULATION OF GROUND-WATER HYDROLOGY IN THE HOUSTON AREA, TEXAS: TEXAS DEPARTMENT OF WATER RESOURCES LIMITED PRINTING LP-103, 1979.

APPROXIMATE ALTITUDE OF WATER LEVELS IN WELLS IN THE CHICOT AND EVANGELINE AQUIFERS IN THE HOUSTON AREA, TEXAS, SPRING 1977 AND SPRING 1978: USGS OPEN-FILE REPORT 79-334, 1979.

APPROXIMATE WATER-LEVEL CHANGES IN WELLS IN THE CHICOT AND EVANGELINE AQUIFERS, 1977-79, AND MEASURED COMPACTION, 1973-79, IN HARRIS AND GALVESTON COUNTIES, TEXAS: USGS OPEN-FILE REPORT 79-693, 1979.

CLODINE FAULT, SOUTHWESTERN HOUSTON METROPOLITAN AREA, TEXAS: USGS OPEN-FILE REPORT 79-947, 1979.

APPROXIMATE WATER-LEVEL CHANGES IN WELLS IN THE CHICOT AND EVANGELINE AQUIFERS IN THE HOUSTON-GALVESTON REGION, TEXAS, 1977-80 AND 1979-80: USGS OPEN-FILE REPORT 80-337, 1980.

APPROXIMATE ALTITUDE OF WATER LEVELS IN WELLS IN THE CHICOT AND EVANGELINE AQUIFERS IN THE HOUSTON AREA, TEXAS, SPRING 1979 AND SPRING 1980: USGS OPEN-FILE REPORT 80-579, 1980
APPROXIMATE LAND-SURFACE SUBSIDENCE IN THE HOUSTONGALVESTON REGION, TEXAS, 1906-78, 1943-78, AND 1973-78: USGS OPEN-FILE REPORT 80-338, 1980.

LAND-SURFACE SUBSIDENCE IN THE TEXAS COASTAL REGION: USGS OPEN-FILE REPORT 80-969, 1980.

DEVELOPMENT OF GROUND WATER IN THE HOUSTONGALVESTON DISTRICT, TEXAS, 1970-74: TEXAS DEPARTMENT OF WATER RESOURCES REPORT 241, 1980.

APPROXIMATE WATER-LEVEL CHANGES IN WELLS IN THE CHICOT AND EVANGELINE AQUIFERS, 1977-81 AND 1980-81, AND MEASURED COMPACTION, 1973-81, IN THE HOUSTON-GALVESTON REGION, TEXAS: USGS OPEN-FILE REPORT 81-341, 1981.

SPRINGS OF TEXAS, VOLUME 1: (BY GUNNAR BRUNE), BRANCHSMITH, INC., FORT WORTH, TEXAS, 1981.

APPROXIMATE ALTITUDE OF WATER LEVELS IN THE CHICOT AND EVANGELINE AQUIFERS IN THE HOUSTON AREA, TEXAS, SPRING 1981: USGS OPEN-FILE REPORT 81-676, 1981.

LAND-SURFACE SUBSIDENCE IN THE TEXAS COASTAL REGION: TEXAS DEPARTMENT OF WATER RESOURCES REPORT 272, 1982

APPROXIMATE WATER-LEVEL CHANGES IN WELLS IN THE CHICOT AND EVANGELINE AQUIFERS, 1977-82 AND 1981-82, AND MEASURED COMPACTION, 1973-82, IN THE HOUSTON-GALVESTON REGION, TEXAS: USGS OPEN-FILE REPORT 82-328, 1982.

GROUND-WATER WITHDRAWALS AND CHANGES IN WATER LEVELS IN THE HOUSTON DISTRICT, 1975-79: USGS OPEN-FILE REPORT 82-431, 1982.

APPROXIMATE ALTITUDE OF WATER LEVELS IN WELLS IN THE CHICOT AND EVANGELINE AQUIFERS IN THE HOUSTON AREA, TEXAS, SPRING 1982: USGS OPEN-FILE REPORT 82-559, 1982.

REGIONAL HYDRODYNAMICS AND HYDROCHEMISTRY OF THE URANIUM-BEARING OAKVILLE AQUIFER (MIOCENE) OF SOUTH TEXAS: UNIVERSITY OF TEXAS, BUREAU OF ECONOMIC GEOLOGY REPORT OF INVESTIGATIONS NO. 124, 1982.

APPROXIMATE WATER-LEVEL CHANGES IN WELLS IN THE CHICOT AND EVANGELINE AQUIFERS, 1977-83 AND 1982-83, AND MEASURED COMPACTION, 1973-83, IN THE HOUSTON-GALVESTON REGION, TEXAS: USGS OPEN-FILE REPORT 83-150, 1983.

APPROXIMATE ALTITUDE OF WATER LEVELS IN WELLS IN THE CHICOT AND EVANGELINE AQUIFERS IN THE HOUSTON AREA, TEXAS, SPRING 1983: USGS OPEN-FILE REPORT 83-529, 1983.

APPROXIMATE WATER-LEVEL CHANGES IN WELLS IN THE CHICOT AND EVANGELINE AQUIFERS, 1977-84 AND 1983-84, AND MEASURED COMPACTION, 1973-84, IN THE HOUSTON-GALVESTON REGION, TEXAS: USGS OPEN-FILE REPORT 84-140, 1984.

APPROXIMATE ALTITUDE OF WATER LEVELS IN WELLS IN THE CHICOT AND EVANGELINE AQUIFERS IN THE HOUSTON AREA, TEXAS, SPRING, 1984: USGS OPEN-FILE REPORT 84-436, 1984.

RECORDS OF WELLS, DRILLERS' LOGS, WATER-LEVEL MEASUREMENTS, AND CHEMICAL ANALYSES OF GROUND WATER IN HARRIS AND GALVESTON COUNTIES, TEXAS, 1975-79: TEXAS DEPARTMENT OF WATER RESOURCES REPORT 285, 1984

GROUND-WATER WITHDRAWALS AND CHANGES IN WATER LEVELS IN THE HOUSTON DISTRICT, TEXAS, 1975-79: TEXAS DEPARTMENT OF WATER RESOURCES REPORT 286, 1984. 
GROUND-WATER WITHDRAWALS AND LAND-SURFACE SUBSIDENCE IN THE HOUSTON-GALVESTON REGION, TEXAS, 1906-80: TEXAS DEPARTMENT OF WATER RESOURCES REPORT 287, 1984.

DIGITAL MODELS FOR SIMULATION OF GROUND-WATER HYDROLOGY OF THE CHICOT AND EVANGELINE AQUIFERS ALONG THE GULF COAST OF TEXAS: TEXAS DEPARTMENT OF WATER RESOURCES REPORT 289, 1985.

WATER USE, PROJECTED WATER REQUIREMENTS, AND RELATED DATA AND INFORMATION FOR THE METROPOLITAN STATISTICAL AREAS IN TEXAS: TEXAS DEPARTMENT OF WATER RESOURCES LIMITED PRINTING REPORT LP-201, 1985.

APPROXIMATE WATER-LEVEL CHANGES IN WELLS IN THE CHICOT AND EVANGELINE AQUIFERS, 1977-85 AND 1984-85, AND MEASURED COMPACTION, 1973-85, IN THE HOUSTON-GALVESTON REGION, TEXAS: USGS OPEN-FILE REPORT 85-158, 1985.

TEXAS GROUND-WATER RESOURCES, in NATIONAL WATER SUMMARY 1984: USGS WATER-SUPPLY PAPER 2275, 1985.

APPROXIMATE CHANGES IN WATER LEVELS IN THE CHICOT AND EVANGELINE AQUIFERS, 1977-86 AND 1985-86, AND MEASURED COMPACTION, 1973-86, IN THE HOUSTON-GALVESTON REGION, TEXAS: USGS OPEN-FILE REPORT 86-135, 1986.

APPROXIMATE ALTITUDE OF WATER LEVELS IN WELLS IN THE CHICOT AND EVANGELINE AQUIFERS IN THE HOUSTON AREA, TEXAS, SPRING 1986: USGS OPEN-FILE REPORT 86-306, 1986.

HYDROLOGY OF THE JASPER AQUIFER IN THE SOUTHEAST TEXAS COASTAL PLAIN: TEXAS WATER DEVELOPMENT BOARD REPORT 295, 1986.

APPROXIMATE WATER-LEVEL CHANGES IN WELLS COMPLETED IN THE CHICOT AND EVANGELINE AQUIFERS, 1977-87 AND 1986-87, AND MEASURED COMPACTION, 1973-87, IN THE HOUSTONGALVESTON REGION, TEXAS: USGS OPEN-FILE REPORT 87-108, 1987.

APPROXIMATE ALTITUDE OF WATER-LEVELS IN WELLS IN THE CHICOT AND EVANGELINE AQUIFERS IN THE HOUSTON AREA, TEXAS, SPRING 1987: USGS OPEN-FILE REPORT 87-233, 1987.

RECORDS OF WELLS, DRILLERS' LOGS, WATER-LEVEL MEASUREMENTS, AND CHEMICAL ANALYSES OF GROUND WATER IN HARRIS AND GALVESTON COUNTIES, TEXAS, 1980-84: USGS OPEN-FILE REPORT 87-378, 1987.

HYDROGEOLOGY AND PREDEVELOPMENT FLOW IN THE TEXAS GULF COAST AQUIFER SYSTEMS: USGS WATER-RESOURCES INVESTIGATIONS REPORT 87-4248, 1988.

RECORDS OF WELLS, DRILLERS' LOGS, WATER-LEVEL MEASUREMENTS, AND CHEMICAL ANALYSES OF GROUND WATER IN HARRIS AND GALVESTON COUNTIES, TEXAS, 1980-84: TEXAS WATER DEVELOPMENT BOARD REPORT 310, 1988.

GEOHYDROLOGIC FRAMEWORK OF THE GULF COASTAL PLAIN: USGS HYDROLOGIC INVESTIGATIONS ATLAS HA-695, 1988.

APPROXIMATE WATER-LEVEL CHANGES IN WELLS COMPLETED IN THE CHICOT AND EVANGELINE AQUIFERS, 1977-88 AND 1987-88, AND MEASURED COMPACTION, 1973-88, IN THE HOUSTONGALVESTON REGION, TEXAS: USGS OPEN-FILE REPORT 88-168, 1988.

APPROXIMATE ALTITUDE OF WATER LEVELS IN WELLS IN THE CHICOT AND EVANGELINE AQUIFERS IN THE HOUSTON AREA, TEXAS, SPRING 1988: USGS OPEN-FILE REPORT 88-334, 1988.
HYDROGEOLOGY OF BARBERS HILL SALT DOME, TEXAS COASTAL PLAIN: UNIVERSITY OF TEXAS, BUREAU OF ECONOMIC GEOLOGY REPORT OF INVESTIGATIONS NO. 176, 1988.

APPROXIMATE ALTITUDE OF WATER LEVELS IN WELLS IN THE CHICOT AND EVANGELINE AQUIFERS IN THE HOUSTON AREA, TEXAS, SPRING 1989: USGS OPEN-FILE REPORT 89-237, 1989.

APPROXIMATE WATER-LEVEL CHANGE IN WELLS COMPLETED IN THE CHICOT AND EVANGELINE AQUIFERS, 1977-89 AND 1988-89, AND MEASURED COMPACTION, 1973-89, IN THE HOUSTONGALVESTON REGION, TEXAS: USGS OPEN-FILE REPORT 89-057, 1989.

APPROXIMATE WATER-LEVEL CHANGES IN WELLS COMPLETED IN THE CHICOT AND EVANGELINE AQUIFERS, 1977-90 AND 1989-90, AND MEASURED COMPACTION, 1973-DECEMBER 1989, IN THE HOUSTON-GALVESTON REGION, TEXAS: USGS OPEN-FILE REPORT 90-132, 1990.

GROUND-WATER FLOW IN THE GULF COAST AQUIFER SYSTEMS, SOUTH-CENTRAL UNITED STATES-A PRELIMINARY ANALYSIS: USGS WATER-RESOURCES INVESTIGATIONS REPORT 89-4071, 1990.

SALT-DOME LOCATIONS IN THE GULF COASTAL PLAIN, SOUTHCENTRAL UNITED STATES: USGS WATER-RESOURCES INVESTIGATIONS REPORT 90-4060, 1990.

LAND-SURFACE SUBSIDENCE RESULTING FROM GROUND-WATER WITHDRAWALS IN THE HOUSTON-GALVESTON REGION, TEXAS, THROUGH 1987: HARRIS-GALVESTON COASTAL SUBSIDENCE DISTRICT REPORT OF INVESTIGATIONS NO. 90-01, 1990.

RECORDS OF WELLS, DRILLERS' LOGS, WATER-LEVEL MEASUREMENTS, AND CHEMICAL ANALYSES OF GROUND WATER IN HARRIS AND GALVESTON COUNTIES, TEXAS, 1984-89: USGS OPEN-FILE REPORT 90-598, 1991.

APPROXIMATE ALTITUDE OF WATER LEVELS IN WELLS IN THE CHICOT AND EVANGELINE AQUIFERS IN THE HOUSTON AREA, TEXAS, JANUARY-FEBRUARY 1990: USGS OPEN-FILE REPORT 91-240, 1991.

HYDROLOGY OF THE TEXAS GULF COAST AQUIFER SYSTEMS: USGS OPEN-FILE REPORT 91-64, 1991.

APPROXIMATE WATER-LEVEL CHANGES IN WELLS COMPLETED IN THE CHICOT AND EVANGELINE AQUIFERS, 1991-92, IN FORT BEND COUNTY AND ADJACENT AREAS, TEXAS: USGS OPEN-FILE REPORT 92-53, 1992.

APPROXIMATE CHANGES IN WATER LEVELS IN WELLS COMPLETED IN THE CHICOT AND EVANGELINE AQUIFERS, 1977-92 AND 1991-92, AND MEASURED COMPACTION, 1973-91, IN THE HOUSTON-GALVESTON REGION, TEXAS: USGS OPEN-FILE REPORT 92-66, 1992.

PROPERTIES AND CHEMICAL CONSTITUENTS IN GROUND WATER FROM THE MISSISSIPPI RIVER VALLEY ALLUVIAL AQUIFER AND PERMEABLE ZONE A (HOLOCENE-UPPER PLEISTOCENE DEPOSITS), SOUTH-CENTRAL UNITED STATES: USGS WATERRESOURCES INVESTIGATIONS REPORT 91-4149, 1992.

WATER-RESOURCES DATA, TEXAS, WATER YEAR 1991, VOLUME 4, GROUND-WATER DATA: USGS WATER-DATA REPORT TX-91-4, 1992.

PROPERTIES AND CHEMICAL CONSTITUENTS IN GROUND WATER FROM THE UPPER CLAIBORNE AQUIFER, GULF COAST REGIONAL AQUIFER SYSTEMS, SOUTH-CENTRAL UNITED 
STATES: USGS WATER-RESOURCES INVESTIGATIONS REPORT 91-4150, 1993.

PROPERTIES AND CHEMICAL CONSTITUENTS IN GROUND WATER FROM PERMEABLE ZONE C (LOWER PLIOCENE-UPPER MIOCENE DEPOSITS), COASTAL LOWLANDS AQUIFER SYSTEM, SOUTHCENTRAL UNITED STATES: USGS WATER-RESOURCES INVESTIGATIONS REPORT 91-4151, 1993.

PROPERTIES AND CHEMICAL CONSTITUENTS IN GROUND WATER FROM PERMEABLE ZONE B (LOWER PLEISTOCENE-UPPER PLIOCENE DEPOSITS), COASTAL LOWLANDS AQUIFER SYSTEM, SOUTH-CENTRAL UNITED STATES: USGS WATER-RESOURCES INVESTIGATIONS REPORT 91-4152, 1993.

PROPERTIES AND CHEMICAL CONSTITUENTS IN GROUND WATER FROM PERMEABLE ZONE E (LOWER MIOCENE-UPPER OLIGOCENE DEPOSITS), COASTAL LOWLANDS AQUIFER SYSTEM, SOUTH-CENTRAL UNITED STATES: USGS WATER-RESOURCES INVESTIGATIONS REPORT 92-4103, 1993.

PROPERTIES AND CHEMICAL CONSTITUENTS IN GROUND WATER FROM PERMEABLE ZONE D (MIDDLE MIOCENE DEPOSITS), COASTAL LOWLANDS AQUIFER SYSTEM, SOUTH-CENTRAL UNITED STATES: USGS WATER-RESOURCES INVESTIGATIONS REPORT 92-4105, 1993.

GROUND-WATER WITHDRAWALS, WATER LEVELS, AND GROUNDWATER QUALITY IN THE HOUSTON DISTRICT, TEXAS, WITH EMPHASIS ON 1985-89: USGS WATER-RESOURCES INVESTIGATIONS REPORT 92-4180, 1993.

PROPERTIES AND CHEMICAL CONSTITUENTS IN GROUND WATER FROM THE MIDDLE WILCOX AQUIFER, GULF COAST AQUIFER SYSTEMS, SOUTH-CENTRAL UNITED STATES: USGS WATERRESOURCES INVESTIGATIONS REPORT 93-4070, 1993.

APPROXIMATE ALTITUDE OF WATER LEVELS IN WELLS COMPLETED IN THE CHICOT AND EVANGELINE AQUIFERS IN FORT BEND COUNTY AND ADJACENT AREAS, TEXAS, JANUARY-FEBRUARY 1991: USGS OPEN-FILE REPORT 93-62, 1993.

WATER-RESOURCES DATA, TEXAS, WATER YEAR 1992, VOLUME 4, GROUND-WATER DATA: USGS WATER-DATA REPORT TX-92-4, 1993.

APPROXIMATE CHANGES IN WATER LEVELS IN WELLS COMPLETED IN THE CHICOT AND EVANGELINE AQUIFERS, 1977-94 AND 1993-94, AND MEASURED COMPACTION, 1973-93, IN THE HOUSTON-GALVESTON REGION, TEXAS: USGS OPEN-FILE REPORT 94-346, 1994.

WATER-RESOURCES DATA, TEXAS, WATER YEAR 1993, VOLUME 4, GROUND-WATER DATA: USGS WATER-DATA REPORT TX-93-4, 1994.

AQUIFERS OF TEXAS: TEXAS WATER DEVELOPMENT BOARD REPORT 345, 1995.

WATER-LEVEL ALTITUDES 1995 AND WATER-LEVEL CHANGES 1990-95 AND 1994-95 IN THE CHICOT AND EVANGELINE AQUIFERS, FORT BEND COUNTY AND ADJACENT AREAS, TEXAS: USGS OPEN-FILE REPORT 95-183, 1995.

WATER-RESOURCES DATA, TEXAS, WATER YEAR 1994, VOLUME 4, GROUND-WATER DATA: USGS WATER-DATA REPORT TX-94-4, 1995.

WATER-LEVEL ALTITUDES 1996, WATER-LEVEL CHANGES 1977-96 AND 1995-96, AND COMPACTION 1973-95 IN THE CHICOT AND
EVANGELINE AQUIFERS, HOUSTON-GALVESTON REGION, TEXAS: USGS OPEN-FILE REPORT 96-163, 1996.

WATER-LEVEL ALTITUDES 1996 AND WATER-LEVEL CHANGES 1990-96 AND 1995-96 IN THE CHICOT AND EVANGELINE AQUIFERS, FORT BEND COUNTY AND ADJACENT AREAS, TEXAS: USGS OPEN-FILE REPORT 96-164, 1996.

ESTIMATED DEPTH TO THE WATER TABLE AND ESTIMATED RATE OF RECHARGE IN OUTCROPS OF THE CHICOT AND EVANGELINE AQUIFERS NEAR HOUSTON, TEXAS: USGS WATER-RESOURCES INVESTIGATIONS REPORT 96-4018, 1996.

WATER-RESOURCES DATA, TEXAS, WATER YEAR 1995, VOLUME 4 , GROUND-WATER DATA: USGS WATER-DATA REPORT TX-95-4, 1996.

WATER-LEVEL ALTITUDES 1997 AND WATER-LEVEL CHANGES 1990-97 AND 1996-97 IN THE CHICOT AND EVANGELINE AQUIFERS, FORT BEND COUNTY AND ADJACENT AREAS, TEXAS: USGS OPEN-FILE REPORT 97-180, 1997.

WATER-LEVEL ALTITUDES 1997, WATER-LEVEL CHANGES 1977-97 AND 1996-97, AND COMPACTION 1973-96 IN THE CHICOT AND EVANGELINE AQUIFERS, HOUSTON-GALVESTON REGION, TEXAS: USGS OPEN-FILE REPORT 97-181, 1997.

WATER-LEVEL ALTITUDES IN WELLS COMPLETED IN THE CHICOT AND EVANGELINE AQUIFERS, FORT BEND COUNTY AND ADJACENT AREAS, TEXAS, JANUARY-FEBRUARY 1990: USGS OPENFILE REPORT 97-784, 1997.

WATER-LEVEL ALTITUDES IN WELLS COMPLETED IN THE CHICOT AND EVANGELINE AQUIFERS, FORT BEND COUNTY AND ADJACENT AREAS, JANUARY-FEBRUARY 1992, 1993, AND 1994: USGS OPEN-FILE REPORT 97-785, 1997.

WATER-LEVEL ALTITUDES IN WELLS COMPLETED IN THE CHICOT AND EVANGELINE AQUIFERS, HOUSTON-GALVESTON REGION, TEXAS, JANUARY-FEBRUARY 1992, 1993, AND 1994: USGS OPENFILE REPORT 97-786, 1997.

ESTIMATED RATE OF RECHARGE IN OUTCROPS OF THE CHICOT AND EVANGELINE AQUIFERS NEAR HOUSTON, TEXAS: USGS FACT SHEET FS-179-97, 1997.

WATER-RESOURCES DATA, TEXAS, WATER YEAR 1996, VOLUME 4 , GROUND-WATER DATA: USGS WATER-DATA REPORT TX-96-4, 1997.

WATER-LEVEL ALTITUDES 1998 AND WATER-LEVEL CHANGES 1990-98 AND 1997-98 IN THE CHICOT AND EVANGELINE AQUIFERS, FORT BEND COUNTY AND ADJACENT AREAS, TEXAS: USGS OPEN-FILE REPORT 98-095, 1998.

WATER-LEVEL ALTITUDES 1998, WATER-LEVEL CHANGES 1977-98 AND 1997-98, AND COMPACTION IN THE CHICOT AND EVANGELINE AQUIFERS, HOUSTON-GALVESTON REGION, TEXAS: USGS OPEN-FILE REPORT 98-096, 1998.

APPROXIMATE LAND-SURFACE SUBSIDENCE IN FORT BEND COUNTY, TEXAS, 1943-87 AND 1973-87: USGS OPEN-FILE REPORT 98-383, 1998.

WATER-RESOURCES DATA, TEXAS, WATER YEAR 1997, VOLUME 4, GROUND-WATER DATA: USGS WATER-DATA REPORT TX-97-4, 1998.

WATER-LEVEL ALTITUDES 1999 AND WATER-LEVEL CHANGES 1990-99 AND 1998-99 IN THE CHICOT AND EVANGELINE AQUI- 
FERS, FORT BEND COUNTY AND ADJACENT AREAS, TEXAS: USGS OPEN-FILE REPORT 99-177, 1999.

WATER-LEVEL ALTITUDES 1999, WATER-LEVEL CHANGES 1977-99 AND 1998-99, AND COMPACTION 1973-98 IN THE CHICOT AND EVANGELINE AQUIFERS, HOUSTON-GALVESTON REGION, TEXAS: USGS OPEN-FILE REPORT 99-178, 1999.

WATER-RESOURCES DATA, TEXAS, WATER YEAR 1998, VOLUME 4, GROUND-WATER DATA: USGS WATER-DATA REPORT TX-98-4, 1999.

WATER-LEVEL ALTITUDES 2000 AND WATER-LEVEL CHANGES 1990-2000 AND 1999-2000 IN THE CHICOT AND EVANGELINE AQUIFERS, FORT BEND COUNTY AND ADJACENT AREAS, TEXAS: USGS OPEN-FILE REPORT 00-093, 2000.

WATER-LEVEL ALTITUDES 2000, WATER-LEVEL CHANGES 1977-2000 AND 1999-2000, AND COMPACTION 1973-99 IN THE CHICOT AND EVANGELINE AQUIFERS, HOUSTON-GALVESTON REGION, TEXAS: USGS OPEN-FILE REPORT 00-094, 2000.

ASSESSMENT OF POTENTIAL FOR NATURAL ATTENUATION OF CHLORINATED ETHENES AND ETHANES IN GROUND WATER AT A PETROCHEMICAL RECLAMATION SITE, HARRIS COUNTY, TEXAS: USGS WATER-RESOURCES INVESTIGATIONS REPORT 00-4121, 2000.

WATER-RESOURCES DATA, TEXAS, WATER YEAR 1999, VOLUME 6, GROUND-WATER DATA: USGS WATER-DATA REPORT TX-99-6, 2000.

WATER-LEVEL ALTITUDES IN WELLS COMPLETED IN THE JASPER AQUIFER, GREATER HOUSTON AREA, TEXAS, SPRING 2000: USGS OPEN-FILE REPORT 01-147, 2001.

WATER-RESOURCES DATA, TEXAS, WATER YEAR 2000, VOLUME 6, GROUND-WATER DATA: USGS WATER-DATA REPORT TX-00-6, 2001.

\section{HARRISON COUNTY}

ARTESIAN WELLS OF THE COASTAL PRAIRIE REGION AND TERTIARY BELT OF TEXAS: GEOLOGICAL SURVEY OF TEXAS, CHAPTER 2, 1893.

UNDERGROUND WATERS OF THE COASTAL PLAIN OF TEXAS: USGS WATER-SUPPLY PAPER 190, 1907.

GEOLOGY AND UNDERGROUND WATERS OF THE SOUTHEASTERN PART OF THE TEXAS COASTAL PLAIN: USGS WATER-SUPPLY PAPER 335, 1914.

RECORDS OF WELLS AND SPRINGS, DRILLERS' LOGS, WATER ANALYSES, AND MAP SHOWING LOCATIONS OF WELLS AND SPRINGS IN HARRISON COUNTY, TEXAS: TEXAS BOARD OF WATER ENGINEERS MISCELLANEOUS PUBLICATION 112, 1942.

WATER SUPPLY NEAR WOODALL, IN SOUTHWESTERN CORNER OF HARRISON COUNTY, TEXAS: USGS OPEN-FILE REPORT (UNNUMBERED), 1942.

WATER RESOURCES OF HARRISON COUNTY, TEXAS: TEXAS BOARD OF WATER ENGINEERS MISCELLANEOUS PUBLICATION 110, MAY 1943.

WATER RESOURCES OF HARRISON COUNTY, TEXAS: TEXAS BOARD OF WATER ENGINEERS MISCELLANEOUS PUBLICATION 111, SEPTEMBER 1943.
REPORT ON WATER SUPPLY FOR MARSHALL, TEXAS: FREESE AND NICHOLS CONSULTING ENGINEERS, 1946.

PUBLIC WATER SUPPLIES IN EASTERN TEXAS: USGS WATERSUPPLY PAPER 1047, 1948.

GEOHYDROLOGY OF THE PRINCIPAL WATER-BEARING FORMATIONS OF THE MISSISSIPPI EMBAYMENT (GEOLOGIC PHASE), TEXAS SECTION: USGS OPEN-FILE REPORT (UNNUMBERED), 1960.

RECONNAISSANCE INVESTIGATION OF THE GROUND-WATER RESOURCES OF THE RED RIVER, SULPHUR RIVER, AND CYPRESS CREEK BASINS, TEXAS: TEXAS WATER COMMISSION BULLETIN 6306, 1963.

RECONNAISSANCE INVESTIGATION OF THE GROUND-WATER RESOURCES OF THE SABINE RIVER BASIN, TEXAS: TEXAS WATER COMMISSION BULLETIN 6307, 1963.

GENERAL GEOLOGY OF THE MISSISSIPPI EMBAYMENT: USGS PROFESSIONAL PAPER 448-B, 1964.

CRETACEOUS AQUIFERS OF THE MISSISSIPPI EMBAYMENT, WITH DISCUSSIONS OF QUALITY OF THE WATER: USGS PROFESSIONAL PAPER 448-C, 1965.

BASE-FLOW STUDIES, LITTLE CYPRESS CREEK, UPSHUR, GREGG, AND HARRISON COUNTIES, TEXAS, QUANTITY AND QUALITY, JANUARY AND JUNE 1964: TEXAS WATER DEVELOPMENT BOARD REPORT 25, 1966.

GROUND-WATER RESOURCES OF HARRISON COUNTY, TEXAS: TEXAS WATER DEVELOPMENT BOARD REPORT 27, 1966.

TERTIARY AQUIFERS IN THE MISSISSIPPI EMBAYMENT, WITH DISCUSSIONS OF THE QUALITY OF THE WATER: USGS PROFESSIONAL PAPER 448-D, 1968

QUATERNARY AQUIFERS IN THE MISSISSIPPI EMBAYMENT WITH A DISCUSSION OF THE QUALITY OF THE WATER: USGS PROFESSIONAL PAPER 448-E, 1968.

COMPILATION OF RESULTS OF AQUIFER TESTS IN TEXAS: TEXAS WATER DEVELOPMENT BOARD REPORT 98, 1969.

MAJOR AND HISTORICAL SPRINGS OF TEXAS: TEXAS WATER DEVELOPMENT BOARD REPORT 189, 1975.

SUMMARY APPRAISALS OF THE NATION'S GROUND-WATER RESOURCES-TEXAS-GULF REGION: USGS PROFESSIONAL PAPER 813-F, 1976.

SPRINGS OF TEXAS, VOLUME 1: (BY GUNNAR BRUNE), BRANCHSMITH, INC., FORT WORTH, TEXAS, 1981.

REGIONAL AQUIFER CHARACTERIZATION FOR DEEP-BASIN LIGNITE MINING, SABINE UPLIFT AREA, NORTHEAST TEXAS: UNIVERSITY OF TEXAS, BUREAU OF ECONOMIC GEOLOGY GEOLOGICAL CIRCULAR 83-3, 1983.

TEXAS GROUND-WATER RESOURCES, in NATIONAL WATER SUMMARY 1984: USGS WATER-SUPPLY PAPER 2275, 1985.

WATER USE, PROJECTED WATER REQUIREMENTS, AND RELATED DATA AND INFORMATION FOR THE METROPOLITAN STATISTICAL AREAS IN TEXAS: TEXAS DEPARTMENT OF WATER RESOURCES LIMITED PRINTING REPORT LP-201, 1985.

APPROXIMATE POTENTIOMETRIC SURFACES FOR THE AQUIFERS OF THE TEXAS COASTAL UPLANDS SYSTEM, 1980: USGS HYDROLOGIC INVESTIGATIONS ATLAS HA-704, 1987. 
GEOHYDROLOGIC FRAMEWORK OF THE GULF COASTAL PLAIN: USGS HYDROLOGIC INVESTIGATIONS ATLAS HA-695, 1988.

PROPERTIES AND CHEMICAL CONSTITUENTS IN GROUND WATER FROM THE LOWER CLAIBORNE-UPPER WILCOX AQUIFER, GULF COAST REGIONAL AQUIFER SYSTEMS, SOUTH-CENTRAL UNITED STATES: USGS WATER-RESOURCES INVESTIGATIONS REPORT 92-4102, 1993

PROPERTIES AND CHEMICAL CONSTITUENTS IN GROUND WATER FROM THE MIDDLE CLAIBORNE AQUIFER, GULF COAST REGIONAL AQUIFER SYSTEMS, SOUTH-CENTRAL UNITED STATES: USGS WATER-RESOURCES INVESTIGATIONS REPORT 92-4104, 1993.

PROPERTIES AND CHEMICAL CONSTITUENTS IN GROUND WATER FROM THE MIDDLE WILCOX AQUIFER, GULF COAST REGIONAL AQUIFER SYSTEMS, SOUTH-CENTRAL UNITED STATES: USGS WATER-RESOURCES INVESTIGATIONS REPORT 93-4070, 1993.

WATER-RESOURCES DATA, TEXAS, WATER YEAR 1992, VOLUME 4, GROUND-WATER DATA: USGS WATER-DATA REPORT TX-92-4, 1993.

WATER-LEVEL ALTITUDES 1995, WATER-LEVEL CHANGES 1977-95 AND 1994-95, AND COMPACTION 1973-94 IN THE CHICOT AND EVANGELINE AQUIFERS, HOUSTON-GALVESTON REGION, TEXAS: USGS OPEN-FILE REPORT 95-182, 1995.

AQUIFERS OF TEXAS: TEXAS WATER DEVELOPMENT BOARD REPORT 345, 1995.

WATER QUALITY IN THE QUEEN CITY AQUIFER, EAST TEXAS TEXAS WATER DEVELOPMENT BOARD HYDROLOGIC ATLAS NO. 6, 1996

\section{HARTLEY COUNTY}

THE GEOLOGY AND WATER RESOURCES OF THE WESTERN PORTION OF THE PANHANDLE OF TEXAS: USGS WATER-SUPPLY PAPER 191, 1907.

GEOLOGY AND GROUND-WATER RESOURCES OF THE SOUTHERN HIGH PLAINS: USGS OPEN-FILE REPORT (UNNUMBERED), 1935

GROUND WATER IN THE HIGH PLAINS OF TEXAS: TEXAS BOARD OF WATER ENGINEERS MISCELLANEOUS PUBLICATION (UNNUMBERED), 1938.

RECORDS OF WELLS, SPRINGS, DRILLERS' LOGS, REPRESENTATIVE EARTHEN TANKS, AND WATER ANALYSES, AND MAP SHOWING LOCATION OF WELLS, SPRINGS, AND EARTHEN TANKS IN HARTLEY COUNTY, TEXAS: TEXAS BOARD OF WATER ENGINEERS MISCELLANEOUS PUBLICATION 113, 1938.

GROUND WATER IN THE HIGH PLAINS OF TEXAS: TEXAS BOARD OF WATER ENGINEERS MISCELLANEOUS PUBLICATION 119, 1940.

PROGRESS REPORT ON GROUND WATER IN THE HIGH PLAINS OF TEXAS: TEXAS BOARD OF WATER ENGINEERS MISCELLANEOUS PUBLICATION (UNNUMBERED), 1942.

PROGRESS REPORT ON GROUND WATER IN THE HIGH PLAINS OF TEXAS: TEXAS BOARD OF WATER ENGINEERS MISCELLANEOUS PUBLICATION 120, 1943.

PROGRESS REPORT ON GROUND WATER IN THE HIGH PLAINS OF TEXAS: TEXAS BOARD OF WATER ENGINEERS MISCELLANEOUS PUBLICATION 121, 1944.
GROUND WATER IN THE HIGH PLAINS OF TEXAS, PROGRESS REPORT NO. 5: TEXAS BOARD OF WATER ENGINEERS MISCELLANEOUS PUBLICATION 122, 1945.

GROUND WATER IN THE HIGH PLAINS OF TEXAS: USGS WATERSUPPLY PAPER 889-F, 1946.

GROUND WATER IN HIGH PLAINS OF TEXAS, PROGRESS REPORT NO. 6: TEXAS BOARD OF WATER ENGINEERS MISCELLANEOUS PUBLICATION 123, 1947.

COST OF PUMPING WATER FOR IRRIGATION, TEXAS HIGH PLAINS, FIELD INVESTIGATIONS-1947 IRRIGATION SEASON: TEXAS BOARD OF WATER ENGINEERS MISCELLANEOUS PUBLICATION $124,1951$.

PUBLIC WATER SUPPLIES IN WESTERN TEXAS: USGS WATERSUPPLY PAPER 1106, 1951 [1952].

DEVELOPMENT OF WELLS FOR IRRIGATION AND FLUCTUATION OF WATER LEVELS IN THE HIGH PLAINS OF TEXAS TO JANUARY 1951: TEXAS BOARD OF WATER ENGINEERS BULLETIN 5104, 1951.

RECORDS OF WATER-LEVEL MEASUREMENTS IN DALLAM, HANSFORD, HARTLEY, HUTCHINSON, MOORE, OCHILTREE, AND SHERMAN COUNTIES, TEXAS: TEXAS BOARD OF WATER ENGINEERS BULLETIN 5404, 1954

WATER-LEVEL MAPS AND WATER LEVELS IN OBSERVATION WELLS IN THE NORTH HIGH PLAINS, TEXAS: TEXAS BOARD OF WATER ENGINEERS BULLETIN 5707, 1957.

WATER-LEVEL MEASUREMENTS AND MAPS, NORTHERN HIGH PLAINS, TEXAS, 1958 AND 1959: TEXAS BOARD OF WATER ENGINEERS BULLETIN 5909, 1959.

WATER LEVELS IN OBSERVATION WELLS, NORTHERN HIGH PLAINS, TEXAS, 1958-1960: TEXAS BOARD OF WATER ENGINEERS BULLETIN 6012, 1960.

RECONNAISSANCE INVESTIGATION OF THE GROUND-WATER RESOURCES OF THE CANADIAN RIVER BASIN, TEXAS: TEXAS BOARD OF WATER ENGINEERS BULLETIN 6016, 1960.

ANNUAL WATER-LEVEL MEASUREMENTS IN OBSERVATION WELLS, NORTHERN HIGH PLAINS, TEXAS, 1960 AND 1961: TEXAS BOARD OF WATER ENGINEERS BULLETIN 6103, 1961.

GEOLOGY AND GROUND-WATER RESOURCES OF THE NORTHERN HIGH PLAINS OF TEXAS, PROGRESS REPORT NO. 1: TEXAS BOARD OF WATER ENGINEERS BULLETIN 6109, 1961.

ANNUAL WATER-LEVEL MEASUREMENTS IN OBSERVATION WELLS, NORTHERN HIGH PLAINS, TEXAS, 1961 AND 1962: TEXAS WATER COMMISSION BULLETIN 6213, 1962.

WATER-LEVEL DATA FROM OBSERVATION WELLS IN THE NORTHERN PANHANDLE OF TEXAS: TEXAS DEPARTMENT OF WATER RESOURCES REPORT 137, 1971

MAJOR AND HISTORICAL SPRINGS OF TEXAS: TEXAS WATER DEVELOPMENT BOARD REPORT 189, 1975.

GROUND-WATER RESOURCES OF THE PALO DURO CREEK BASIN, TEXAS AND OKLAHOMA: USGS OPEN-FILE REPORT 79-209, 1979.

PRELIMINARY DATA DESCRIBING THE DISTRIBUTION OF FLUORIDE AND SILICA IN THE OGALLALA AQUIFER ON THE HIGH PLAINS OF TEXAS: USGS OPEN-FILE REPORT 80-349, 1980. 
WATER-LEVEL DATA FROM OBSERVATION WELLS IN THE NORTHERN PANHANDLE OF TEXAS, 1972-78: TEXAS DEPARTMENT OF WATER RESOURCES REPORT 248, 1980.

WATER TABLE IN THE HIGH PLAINS AQUIFER IN 1978 IN PARTS OF COLORADO, KANSAS, NEBRASKA, NEW MEXICO, OKLAHOMA, SOUTH DAKOTA, TEXAS, AND WYOMING: USGS HYDROLOGIC INVESTIGATIONS ATLAS HA-642, 1980.

EVALUATING THE GROUND-WATER RESOURCES OF THE HIGH PLAINS OF TEXAS: RESULTS OF TEST HOLE DRILLING: TEXAS DEPARTMENT OF WATER RESOURCES LIMITED PRINTING REPORT LP-129, 1980.

EVALUATING THE GROUND-WATER RESOURCES OF THE HIGH PLAINS OF TEXAS: RESULTS OF SURFACE ELECTRICAL RESISTIVITY: TEXAS DEPARTMENT OF WATER RESOURCES LIMITED PRINTING REPORT LP-130, 1980.

ANALYTICAL STUDY OF THE OGALLALA AQUIFER IN HARTLEY COUNTY, TEXAS-PROJECTIONS OF SATURATED THICKNESS, VOLUME OF WATER IN STORAGE, PUMPAGE RATES, PUMPING LIFTS, AND WELL YIELDS: TEXAS DEPARTMENT OF WATER RESOURCES REPORT 261, 1981.

EVALUATING THE GROUND-WATER RESOURCES OF THE HIGH PLAINS OF TEXAS: NEUTRON-PROBE MEASUREMENTS OF DEEP SOIL MOISTURE AS AN INDICATION OF AQUIFER RECHARGE RATES: TEXAS DEPARTMENT OF WATER RESOURCES LIMITED PRINTING REPORT LP-142, 1981.

SPRINGS OF TEXAS, VOLUME 1: (BY GUNNAR BRUNE), BRANCHSMITH, INC., FORT WORTH, TEXAS, 1981.

BEDROCK GEOLOGY, ALTITUDE OF BASE, AND 1980 SATURATED THICKNESS OF THE HIGH PLAINS AQUIFER IN PARTS OF COLORADO, KANSAS, NEBRASKA, NEW MEXICO, OKLAHOMA, SOUTH DAKOTA, TEXAS, AND WYOMING: USGS HYDROLOGIC INVESTIGATIONS ATLAS HA-648, 1981.

WATER-LEVEL AND SATURATED-THICKNESS CHANGES, PREDEVELOPMENT TO 1980, IN THE HIGH PLAINS AQUIFER IN PARTS OF COLORADO, KANSAS, NEBRASKA, NEW MEXICO, OKLAHOMA, SOUTH DAKOTA, TEXAS, AND WYOMING: USGS HYDROLOGIC INVESTIGATIONS ATLAS HA-652, 1981.

DISSOLVED SOLIDS AND SODIUM IN WATER FROM THE HIGH PLAINS AQUIFER IN PARTS OF COLORADO, KANSAS, NEBRASKA, NEW MEXICO, OKLAHOMA, SOUTH DAKOTA, TEXAS, AND WYOMING: USGS HYDROLOGIC INVESTIGATIONS ATLAS HA-658, 1982.

INVESTIGATION OF SECONDARY RECOVERY OF GROUND WATER FROM THE OGALLALA FORMATION, HIGH PLAINS OF TEXASSUMMARY OF STUDY: HIGH PLAINS UNDERGROUND WATER CONSERVATION DISTRICT NO. 1, LUBBOCK, TEXAS, 1982.

GEOHYDROLOGY OF THE HIGH PLAINS AQUIFER IN PARTS OF COLORADO, KANSAS, NEBRASKA, NEW MEXICO, OKLAHOMA, SOUTH DAKOTA, TEXAS, AND WYOMING: USGS PROFESSIONAL PAPER 1400-B, 1984.

EVALUATING THE GROUND-WATER RESOURCES OF THE HIGH PLAINS OF TEXAS, VOLUME 1: TEXAS DEPARTMENT OF WATER RESOURCES REPORT 288, V. 1, 1984.

EVALUATING THE GROUND-WATER RESOURCES OF THE HIGH PLAINS OF TEXAS, VOLUME 2, RECORDS OF WELLS, AND MAPS SHOWING WELL LOCATIONS, BASE OF AQUIFER, WATER LEVELS, AND SATURATED THICKNESS (ARMSTRONG, CARSON, DALLAS, DONLEY, GRAY, HANSFORD, HARTLEY, HEMPHILL,
HUTCHINSON, LIPSCOMB, MOORE, OCHILTREE, POTTER, ROBERTS, SHERMAN, AND WHEELER COUNTIES): TEXAS DEPARTMENT OF WATER RESOURCES REPORT 288, V. 2, 1984.

TEXAS GROUND-WATER RESOURCES, in NATIONAL WATER SUMMARY 1984: USGS WATER-SUPPLY PAPER 2275, 1985.

DIGITAL SIMULATION OF GROUND-WATER FLOW IN THE HIGH PLAINS AQUIFER IN PARTS OF COLORADO, KANSAS, NEBRASKA, NEW MEXICO, OKLAHOMA, SOUTH DAKOTA, TEXAS, AND WYOMING: USGS PROFESSIONAL PAPER 1400-D, 1986.

SUMMARY OF THE HIGH PLAINS REGIONAL AQUIFER-SYSTEM ANALYSIS IN PARTS OF COLORADO, KANSAS, NEBRASKA, NEW MEXICO, OKLAHOMA, SOUTH DAKOTA, TEXAS, AND WYOMING: USGS PROFESSIONAL PAPER 1400-A, 1988.

WATER-LEVEL CHANGES IN THE HIGH PLAINS AQUIFER OF TEXAS, 1980-1990: TEXAS WATER DEVELOPMENT BOARD HYDROLOGIC ATLAS NO. 1, 1991.

PUBLIC-SUPPLY GROUND-WATER USE IN THE NORTHERN HIGH PLAINS OF TEXAS: TEXAS WATER DEVELOPMENT BOARD REPORT 336, 1992.

THE HIGH PLAINS AQUIFER SYSTEM OF TEXAS, 1980-1990. OVERVIEW AND PROJECTIONS: TEXAS WATER DEVELOPMENT BOARD REPORT 341, 1993.

WATER-QUALITY EVALUATION OF THE OGALLALA AQUIFER, TEXAS: TEXAS WATER DEVELOPMENT BOARD REPORT 342, 1993.

WATER-LEVEL CHANGES IN THE HIGH PLAINS AQUIFER-PREDEVELOPMENT TO 1992: USGS WATER-RESOURCES INVESTIGATIONS REPORT 94-4027, 1994.

WATER-LEVEL CHANGES IN THE HIGH PLAINS AQUIFER, 1980 TO 1994: USGS FACT SHEET FS-215-95, 1995.

AQUIFERS OF TEXAS: TEXAS WATER DEVELOPMENT BOARD REPORT 345, 1995.

WATER-LEVEL CHANGES IN THE HIGH PLAINS AQUIFER, 1980 TO 1995: USGS FACT SHEET FS-068-97, 1997.

WATER-LEVEL CHANGES IN THE HIGH PLAINS AQUIFER-PREDEVELOPMENT TO 1995: USGS WATER-RESOURCES INVESTIGATIONS REPORT 97-4081, 1997.

UPDATED WATER-QUALITY EVALUATION OF THE OGALLALA AQUIFER INCLUDING SELECTED METALLIC AND NON-METALLIC INORGANIC CONSTITUENTS: TEXAS WATER DEVELOPMENT BOARD HYDROLOGIC ATLAS NO. 10, 1998.

\section{HASKELL COUNTY}

GEOLOGY AND UNDERGROUND WATERS OF THE WICHITA REGION, NORTH-CENTRAL TEXAS: USGS WATER-SUPPLY PAPER 317,1913 .

PRELIMINARY REPORT OF THE GROUND-WATER RESOURCES NEAR STAMFORD IN JONES AND HASKELL COUNTIES, TEXAS: USGS OPEN-FILE REPORT (UNNUMBERED), 1944.

PUBLIC WATER SUPPLIES IN CENTRAL AND NORTH-CENTRAL TEXAS: USGS WATER-SUPPLY PAPER 1069, 1949. 
RECORDS OF WATER-LEVEL MEASUREMENTS IN HASKELL AND KNOX COUNTIES, TEXAS: TEXAS BOARD OF WATER ENGINEERS BULLETIN 5503, 1955

WATER LEVELS IN OBSERVATION WELLS IN HASKELL AND KNOX COUNTIES, TEXAS, 1956-60: TEXAS BOARD OF WATER ENGINEERS BULLETIN 6009, 1960.

GROUND-WATER RESOURCES OF HASKELL AND KNOX COUNTIES, TEXAS: TEXAS WATER COMMISSION BULLETIN 6209, 1962.

RECONNAISSANCE INVESTIGATION OF THE GROUND-WATER RESOURCES OF THE BRAZOS RIVER BASIN, TEXAS: TEXAS WATER COMMISSION BULLETIN 6310, 1963.

INVESTIGATION OF GROUND-WATER CONTAMINATION IN THE JULIANA AND WEST JUD OIL FIELDS, HASKELL AND STONEWALL COUNTIES, TEXAS: TEXAS WATER COMMISSION LIMITED DISTRIBUTION REPORT LD-364-MR, 1964.

COMPILATION OF RESULTS OF AQUIFER TESTS IN TEXAS: TEXAS WATER DEVELOPMENT BOARD REPORT 98, 1969.

SUMMARY APPRAISALS OF THE NATION'S GROUND-WATER RESOURCES-TEXAS-GULF REGION: USGS PROFESSIONAL PAPER 813-F, 1976.

THE SEYMOUR AQUIFER: GROUND-WATER QUALITY AND AVAILABILITY IN HASKELL AND KNOX COUNTIES, TEXAS: TEXAS DEPARTMENT OF WATER RESOURCES REPORT 226, V. 1, 1978.

THE SEYMOUR AQUIFER: GROUND-WATER QUALITY AND AVAILABILITY IN HASKELL AND KNOX COUNTIES, TEXAS: TEXAS DEPARTMENT OF WATER RESOURCES REPORT 226, V. 2, 1978.

SPRINGS OF TEXAS, VOLUME 1: (BY GUNNAR BRUNE), BRANCHSMITH, INC., FORT WORTH, TEXAS, 1981.

TEXAS GROUND-WATER RESOURCES, in NATIONAL WATER SUMMARY 1984: USGS WATER-SUPPLY PAPER 2275, 1985.

JOINT GROUND-WATER QUALITY PROJECT WITH THE TEXAS DEPARTMENT OF AGRICULTURE IN PARTS OF HASKELL, KNOX, AND STONEWALL COUNTIES: TEXAS WATER DEVELOPMENT BOARD REPORT 333, 1991

EVALUATION OF WATER RESOURCES IN PARTS OF THE ROLLING PRAIRIES REGION OF NORTH-CENTRAL TEXAS: TEXAS WATER DEVELOPMENT BOARD REPORT 337, 1992.

AQUIFERS OF TEXAS: TEXAS WATER DEVELOPMENT BOARD REPORT 345, 1995.

\section{HAYS COUNTY}

REPORT OF PROGRESS OF THE DIVISION OF HYDROGRAPHY FOR THE CALENDAR YEAR 1895: USGS BULLETIN 140, 1896.

GEOLOGY OF THE EDWARDS PLATEAU AND RIO GRANDE PLAIN ADJACENT TO AUSTIN AND SAN ANTONIO, TEXAS, WITH REFERENCE TO THE OCCURRENCE OF UNDERGROUND WATERS: USGS 18TH ANNUAL REPORT, PART 2, 1898.

LARGE SPRINGS IN THE UNITED STATES: USGS WATER-SUPPLY PAPER 557, 1927.

RECORDS OF WELLS AND SPRINGS, DRILLERS' LOGS, WATER ANALYSES AND MAP SHOWING LOCATION OF WELLS IN HAYS
COUNTY, TEXAS: TEXAS BOARD OF WATER ENGINEERS MISCELLANEOUS PUBLICATION 114, 1938.

GROUND-WATER RESOURCES IN THE AREA BETWEEN BUDA AND SAN MARCOS: USGS OPEN-FILE REPORT (UNNUMBERED), 1942.

OCCURRENCE OF GROUND WATER IN TERRACE GRAVELS ALONG SAN MARCOS RIVER: USGS OPEN-FILE REPORT (UNNUMBERED), 1942.

GROUND-WATER RESOURCES IN THE VICINITY OF KYLE, HAYS COUNTY, TEXAS: USGS OPEN-FILE REPORT (UNNUMBERED), 1945.

PUBLIC WATER SUPPLIES IN SOUTHERN TEXAS: USGS WATERSUPPLY PAPER 1070, 1950.

MISCELLANEOUS FIELD NOTES ON THE GEOLOGY OF THE SAN ANTONIO AREA, TEXAS: USGS OPEN-FILE REPORT (UNNUMBERED), 1953.

GROUND-WATER RESOURCES OF THE SAN ANTONIO AREA, TEXAS, A PROGRESS REPORT ON CURRENT STUDIES: TEXAS BOARD OF WATER ENGINEERS BULLETIN 5412, 1954.

RECORDS OF WELLS IN HAYS COUNTY, TEXAS: TEXAS BOARD OF WATER ENGINEERS BULLETIN 5501, 1955.

GROUND-WATER RESOURCES OF THE SAN ANTONIO AREA, TEXAS, VOLUME 1, A PROGRESS REPORT ON CURRENT STUDIES: TEXAS BOARD OF WATER ENGINEERS BULLETIN 5608, V. 1, 1956.

GROUND-WATER RESOURCES OF THE SAN ANTONIO AREA, TEXAS, VOLUME 2, PART 1, RECORDS OF WELLS AND SPRINGS: TEXAS BOARD OF WATER ENGINEERS BULLETIN 5608, V. 2, PART 1, 1956.

GROUND-WATER RESOURCES OF THE SAN ANTONIO AREA, TEXAS, VOLUME 2, PART 2, RECORDS OF DRILLERS' LOGS: TEXAS BOARD OF WATER ENGINEERS BULLETIN 5608, V. 2, PART 2, 1956.

GROUND-WATER RESOURCES OF THE SAN ANTONIO AREA, TEXAS, VOLUME 2, PART 3, WATER LEVELS IN WELLS, CHEMICAL ANALYSES OF WATER, RECORDS OF STREAMFLOW AND RESERVOIR CONTENTS, DISCHARGE MEASUREMENTS, AND PRECIPITATION IN THE SAN ANTONIO AREA, TEXAS: TEXAS BOARD OF WATER ENGINEERS BULLETIN 5608, V. 2 PART 3, 1956

RECORDS OF WATER-LEVEL MEASUREMENTS IN HAYS, TRAVIS, AND WILLIAMSON COUNTIES, TEXAS, 1937 TO MAY 1956: TEXAS BOARD OF WATER ENGINEERS BULLETIN 5612, 1956.

THREE MEASURED GEOLOGIC SECTIONS IN HAYS COUNTY, TEXAS: GULF COAST ASSOCIATION OF GEOLOGICAL SOCIETIES LOWER CRETACEOUS FIELD TRIP GUIDEBOOK, P. 18-20, 1956.

GEOLOGY OF SAN MARCOS SPRINGS QUADRANGLE, HAYS COUNTY, TEXAS: UNIVERSITY OF TEXAS AT AUSTIN MASTERS THESIS, 1956 [1957].

INVESTIGATION WITH DEEP-WELL CURRENT METER AT WELL H-72 AND NEW WELL AT U.S. FISH CULTURAL STATION, SAN MARCOS, HAYS COUNTY, TEXAS: USGS OPEN-FILE REPORT, 1957.

GEOLOGY AND GROUND-WATER RESOURCES OF HAYS COUNTY, TEXAS: TEXAS BOARD OF WATER ENGINEERS BULLETIN 6004, 1960.

RECHARGE, DISCHARGE, AND CHANGES IN GROUND-WATER STORAGE IN THE EDWARDS AND ASSOCIATED LIMESTONES, SAN ANTONIO AREA, TEXAS, A PROGRESS REPORT ON STUDIES 1955-59: TEXAS WATER COMMISSION BULLETIN 6201, 1962. 
CHEMICAL ANALYSES OF WATER FROM OBSERVATION WELLS IN THE EDWARDS AND ASSOCIATED LIMESTONES, SAN ANTONIO AREA, TEXAS: EDWARDS UNDERGROUND WATER DISTRICT BULLETIN 1, 1962.

GEOLOGY AND GROUND-WATER RESOURCES OF HAYS COUNTY, TEXAS: USGS WATER-SUPPLY PAPER 1612, 1963.

GROUND-WATER DISCHARGE FROM THE EDWARDS AND ASSOCIATED LIMESTONES, 1955-62, SAN ANTONIO AREA, TEXAS: EDWARDS UNDERGROUND WATER DISTRICT BULLETIN 2, 1963.

RECORDS OF PRECIPITATION, AQUIFER HEAD, AND GROUNDWATER DISCHARGE TO THE EDWARDS AND ASSOCIATED LIMESTONES, 1960-62, SAN ANTONIO AREA, TEXAS: EDWARDS UNDERGROUND WATER DISTRICT BULLETIN 3, 1963.

CHEMICAL ANALYSES OF WATER FROM OBSERVATION WELLS IN THE EDWARDS AND ASSOCIATED LIMESTONES, SAN ANTONIO AREA, TEXAS, 1963: EDWARDS UNDERGROUND WATER DISTRICT BULLETIN 4, 1964.

GROUND-WATER DISCHARGE FROM THE EDWARDS AND ASSOCIATED LIMESTONES, SAN ANTONIO AREA, TEXAS, 1963: EDWARDS UNDERGROUND WATER DISTRICT BULLETIN 5, 1964.

RECORDS OF PRECIPITATION, AQUIFER HEAD, AND GROUNDWATER RECHARGE TO THE EDWARDS AND ASSOCIATED LIMESTONES, SAN ANTONIO AREA, TEXAS, 1963: EDWARDS UNDERGROUND WATER DISTRICT BULLETIN 6, 1964.

RECONNAISSANCE INVESTIGATION OF THE GROUND-WATER RESOURCES OF THE GUADALUPE, SAN ANTONIO, AND NUECES RIVER BASINS, TEXAS: TEXAS WATER COMMISSION BULLETIN 6409, 1964.

BASE-FLOW STUDIES, GUADALUPE RIVER, COMAL COUNTY, TEXAS-QUANTITY, MARCH 1962: TEXAS WATER COMMISSION BULLETIN 6503, 1965.

CHEMICAL ANALYSES OF WATER FROM OBSERVATION WELLS IN THE EDWARDS AND ASSOCIATED LIMESTONES, SAN ANTONIO AREA, TEXAS, 1964: EDWARDS UNDERGROUND WATER DISTRICT BULLETIN 7, 1965.

GROUND-WATER DISCHARGE FROM THE EDWARDS AND ASSOCIATED LIMESTONES, SAN ANTONIO AREA, TEXAS, 1964: EDWARDS UNDERGROUND WATER DISTRICT BULLETIN 8, 1965.

GROUND-WATER RECHARGE TO THE EDWARDS AND ASSOCIATED LIMESTONES, SAN ANTONIO AREA, TEXAS, 1964: EDWARDS UNDERGROUND WATER DISTRICT BULLETIN 9, 1965.

CHEMICAL ANALYSES FROM OBSERVATION WELLS IN THE EDWARDS AND ASSOCIATED LIMESTONES, SAN ANTONIO AREA, TEXAS, 1965: EDWARDS UNDERGROUND WATER DISTRICT BULLETIN 10, 1966.

GROUND-WATER DISCHARGE FROM THE EDWARDS AND ASSOCIATED LIMESTONES, SAN ANTONIO AREA, TEXAS, 1965: EDWARDS UNDERGROUND WATER DISTRICT BULLETIN 11, 1966.

RECORDS OF PRECIPITATION, AQUIFER HEAD, AND GROUNDWATER RECHARGE TO THE EDWARDS AND ASSOCIATED LIMESTONES, SAN ANTONIO AREA, TEXAS, 1965: EDWARDS UNDERGROUND WATER DISTRICT BULLETIN 12, 1966.

GROUND-WATER RESOURCES OF THE SAN ANTONIO AREA, TEXAS, A PROGRESS REPORT ON STUDIES, 1960-64: TEXAS WATER DEVELOPMENT BOARD REPORT 34, 1966.
THE EDWARDS UNDERGROUND WATER DISTRICT AND EDWARDS UNDERGROUND RESERVOIR: EDWARDS UNDERGROUND WATER DISTRICT, 1966 ?

CHEMICAL ANALYSES OF WATER FROM OBSERVATION WELLS IN THE EDWARDS AND ASSOCIATED LIMESTONES, SAN ANTONIO AREA, TEXAS, 1966: EDWARDS UNDERGROUND WATER DISTRICT BULLETIN 13, 1967.

GROUND-WATER DISCHARGE FROM THE EDWARDS AND ASSOCIATED LIMESTONES, SAN ANTONIO AREA, TEXAS, 1966: EDWARDS UNDERGROUND WATER DISTRICT BULLETIN 14, 1967.

RECORDS OF PRECIPITATION, AQUIFER HEAD, AND GROUNDWATER RECHARGE TO THE EDWARDS AND ASSOCIATED LIMESTONES, SAN ANTONIO AREA, TEXAS, 1966: EDWARDS UNDERGROUND WATER DISTRICT BULLETIN 15, 1967.

CHEMICAL ANALYSES OF WATER FROM OBSERVATION WELLS IN THE EDWARDS AND ASSOCIATED LIMESTONES, SAN ANTONIO AREA, TEXAS, 1967: EDWARDS UNDERGROUND WATER DISTRICT BULLETIN 16, 1968.

GROUND-WATER DISCHARGE FROM THE EDWARDS AND ASSOCIATED LIMESTONES, SAN ANTONIO AREA, TEXAS, 1967: EDWARDS UNDERGROUND WATER DISTRICT BULLETIN 17, 1968

RECORDS OF PRECIPITATION, AQUIFER HEAD, AND GROUNDWATER RECHARGE TO THE EDWARDS AND ASSOCIATED LIMESTONES, SAN ANTONIO AREA, TEXAS, 1967: EDWARDS UNDERGROUND WATER DISTRICT BULLETIN 18, 1968.

RECORDS OF WELLS AND SPRINGS, SAN ANTONIO AREA, TEXAS: EDWARDS UNDERGROUND WATER DISTRICT, 1969.

GROUND-WATER DISCHARGE FROM THE EDWARDS AND ASSOCIATED LIMESTONES, SAN ANTONIO AREA, TEXAS, 1968: EDWARDS UNDERGROUND WATER DISTRICT BULLETIN 20, 1969

RECORDS OF PRECIPITATION, AQUIFER HEAD, AND GROUNDWATER RECHARGE TO THE EDWARDS AND ASSOCIATED LIMESTONES, SAN ANTONIO AREA, TEXAS, 1968: EDWARDS UNDERGROUND WATER DISTRICT BULLETIN 21, 1969.

GEOLOGY AND WATER QUALITY AT SELECTED LOCATIONS IN THE SAN ANTONIO AREA, TEXAS, PROGRESS REPORT, 1969: USGS OPEN-FILE REPORT 70-272, 1970.

GEOLOGY AND WATER QUALITY AT SELECTED LOCATIONS IN THE SAN ANTONIO AREA, TEXAS, PROGRESS REPORT, 1969: EDWARDS UNDERGROUND WATER DISTRICT, 1970.

GROUND-WATER DISCHARGE FROM THE EDWARDS AND ASSOCIATED LIMESTONES, SAN ANTONIO AREA, TEXAS, 1969: EDWARDS UNDERGROUND WATER DISTRICT BULLETIN 23, 1970

RECORDS OF PRECIPITATION, WATER LEVELS, AND GROUNDWATER RECHARGE TO THE EDWARDS AND ASSOCIATED LIMESTONES, SAN ANTONIO AREA, TEXAS, 1969: EDWARDS UNDERGROUND WATER DISTRICT BULLETIN 24, 1970.

GROUND-WATER DISCHARGE FROM THE EDWARDS AND ASSOCIATED LIMESTONES, SAN ANTONIO AREA, TEXAS, 1970: EDWARDS UNDERGROUND WATER DISTRICT BULLETIN 26, 1971.

RECORDS OF PRECIPITATION, WATER LEVELS, AND GROUNDWATER RECHARGE TO THE EDWARDS AND ASSOCIATED LIMESTONES, SAN ANTONIO AREA, TEXAS, 1970: EDWARDS UNDERGROUND WATER DISTRICT BULLETIN 27, 1971. 
GROUND-WATER DISCHARGE FROM THE EDWARDS AND ASSOCIATED LIMESTONES, SAN ANTONIO AREA, TEXAS, 1971: EDWARDS UNDERGROUND WATER DISTRICT BULLETIN 29, 1972.

RECORDS OF PRECIPITATION, WATER LEVELS, AND GROUNDWATER RECHARGE TO THE EDWARDS AND ASSOCIATED LIMESTONES, SAN ANTONIO AREA, TEXAS, 1971: EDWARDS UNDERGROUND WATER DISTRICT BULLETIN 30, 1972.

CHEMICAL AND BACTERIOLOGICAL QUALITY OF WATER AT SELECTED SITES IN THE SAN ANTONIO AREA, TEXAS, AUGUST 1968-APRIL 1972: EDWARDS UNDERGROUND WATER DISTRICT, 1972.

GROUND-WATER DISCHARGE FROM THE EDWARDS AND ASSOCIATED LIMESTONES, SAN ANTONIO AREA, TEXAS, 1972: EDWARDS UNDERGROUND WATER DISTRICT BULLETIN 31, 1973

REGIONAL SPECIFIC YIELD OF THE EDWARDS AND ASSOCIATED LIMESTONES IN THE SAN ANTONIO, TEXAS, AREA: EDWARDS UNDERGROUND WATER DISTRICT, 1973.

GROUND-WATER DISCHARGE FROM THE EDWARDS AND ASSOCIATED LIMESTONES, SAN ANTONIO AREA, TEXAS, 1973: EDWARDS UNDERGROUND WATER DISTRICT BULLETIN 32, 1974

RECORDS OF PRECIPITATION, WATER LEVELS, AND GROUNDWATER RECHARGE TO THE EDWARDS AND ASSOCIATED LIMESTONES, SAN ANTONIO AREA, TEXAS, 1972-73: EDWARDS UNDERGROUND WATER DISTRICT BULLETIN 33, 1974.

RELATION OF PRECIPITATION TO ANNUAL GROUND-WATER RECHARGE IN THE EDWARDS AQUIFER, SAN ANTONIO AREA, TEXAS: USGS OPEN-FILE REPORT 75-298, 1975.

THE EDWARDS UNDERGROUND RESERVOIR AND THE EDWARDS UNDERGROUND WATER DISTRICT: SOUTH TEXAS GEOLOGICAL SOCIETY BULLETIN V. 15, NO. 7, 1975.

RECORDS OF PRECIPITATION, WATER LEVELS, AND GROUNDWATER RECHARGE TO THE EDWARDS AND ASSOCIATED LIMESTONES, SAN ANTONIO AREA, TEXAS, 1972-73: SOUTH TEXAS GEOLOGICAL SOCIETY BULLETIN V. 15, NO. 7, 1975.

GROUND-WATER DISCHARGE FROM THE EDWARDS AND ASSOCIATED LIMESTONES, SAN ANTONIO AREA, TEXAS, 1974: EDWARDS UNDERGROUND WATER DISTRICT BULLETIN 34, 1975

MAJOR AND HISTORICAL SPRINGS OF TEXAS: TEXAS WATER DEVELOPMENT BOARD REPORT 189, 1975.

GEOCHEMICAL AND ISOTOPIC ANALYSES OF WATERS ASSOCIATED WITH THE EDWARDS LIMESTONE AQUIFER, CENTRAL TEXAS: EDWARDS UNDERGROUND WATER DISTRICT, 1976.

GROUND-WATER DISCHARGE FROM THE EDWARDS AND ASSOCIATED LIMESTONES, SAN ANTONIO AREA, TEXAS, 1975: EDWARDS UNDERGROUND WATER DISTRICT BULLETIN 35, 1976.

STATISTICAL ANALYSIS OF WATER-LEVEL, SPRINGFLOW, AND STREAMFLOW DATA FOR THE EDWARDS AQUIFER IN SOUTHCENTRAL TEXAS: USGS OPEN-FILE REPORT 76-393, 1976.

STATISTICAL ANALYSIS OF WATER-LEVEL, SPRINGFLOW, AND STREAMFLOW DATA FOR THE EDWARDS AQUIFER IN SOUTHCENTRAL TEXAS: EDWARDS UNDERGROUND WATER DISTRICT, 1976.

CHEMICAL AND BACTERIOLOGICAL QUALITY OF WATER AT SELECTED SITES IN THE SAN ANTONIO AREA, TEXAS, AUGUST 1968-JANUARY 1975: USGS OPEN-FILE REPORT 76-574, 1976.
CHEMICAL AND BACTERIOLOGICAL QUALITY OF WATER AT SELECTED SITES IN THE SAN ANTONIO AREA, TEXAS, AUGUST 1968-JANUARY 1975: EDWARDS UNDERGROUND WATER DISTRICT, 1976

PROGRESS REPORT ON GEOLOGY OF THE EDWARDS AQUIFER, SAN ANTONIO AREA, TEXAS, AND PRELIMINARY INTERPRETATION OF BOREHOLE GEOPHYSICAL AND LABORATORY DATA ON CARBONATE ROCKS: USGS OPEN-FILE REPORT 76-627, 1976.

SUMMARY APPRAISALS OF THE NATION'S GROUND-WATER RESOURCES-TEXAS-GULF REGION: USGS PROFESSIONAL PAPER 813-F, 1976.

GROUND-WATER DISCHARGE FROM THE EDWARDS AND ASSOCIATED LIMESTONES, SAN ANTONIO AREA, TEXAS, 1976: EDWARDS UNDERGROUND WATER DISTRICT, 1977.

METHOD OF ESTIMATING NATURAL RECHARGE TO THE EDWARDS AQUIFER IN THE SAN ANTONIO AREA, TEXAS: USGS WATERRESOURCES INVESTIGATIONS REPORT 78-10, 1978.

REGIONAL DISTRIBUTION OF FRACTURES IN THE SOUTHERN EDWARDS PLATEAU AND THEIR RELATIONSHIP TO TECTONICS AND CAVES: UNIVERSITY OF TEXAS, BUREAU OF ECONOMIC GEOLOGY GEOLOGICAL CIRCULAR 78-2, 1978.

CHEMICAL AND BACTERIOLOGICAL QUALITY OF WATER AT SELECTED SITES IN THE SAN ANTONIO AREA, TEXAS, FEBRUARY 1975-SEPTEMBER 1977: EDWARDS UNDERGROUND WATER DISTRICT, 1978.

RECORDS OF GROUND-WATER RECHARGE AND DISCHARGE FOR THE EDWARDS AQUIFER IN THE SAN ANTONIO AREA, TEXAS, 1934-77: EDWARDS UNDERGROUND WATER DISTRICT BULLETIN 37, 1979.

GEOHYDROLOGY OF COMAL, SAN MARCOS, AND HUECO SPRINGS: TEXAS DEPARTMENT OF WATER RESOURCES REPORT 234, 1979

GROUND-WATER RESOURCES AND MODEL APPLICATIONS FOR THE EDWARDS (BALCONES FAULT SYSTEM) AQUIFER IN THE SAN ANTONIO REGION: TEXAS DEPARTMENT OF WATER RESOURCES REPORT 239, 1979.

HYDROCHEMICAL DATA FOR THE EDWARDS AQUIFER IN THE SAN ANTONIO AREA, TEXAS: TEXAS DEPARTMENT OF WATER RESOURCES LIMITED PRINTING REPORT LP-131, 1980.

RECORDS OF GROUND-WATER RECHARGE, DISCHARGE, WATER LEVELS, AND CHEMICAL QUALITY OF WATER FOR THE EDWARDS AQUIFER IN THE SAN ANTONIO AREA, TEXAS, 1934-78: EDWARDS UNDERGROUND WATER DISTRICT BULLETIN 38, 1980.

WATER-LEVEL, RECHARGE, DISCHARGE, SPECIFIC CAPACITY, WELL-YIELD, AND AQUIFER-TEST DATA FOR THE EDWARDS AQUIFER IN THE SAN ANTONIO AREA, TEXAS: TEXAS DEPARTMENT OF WATER RESOURCES LIMITED PRINTING REPORT LP-133, 1980.

HYDROLOGIC DATA FOR URBAN STUDIES IN THE AUSTIN, TEXAS METROPOLITAN AREA, 1978: USGS OPEN-FILE REPORT 80-728, 1980.

HYDROLOGIC DATA FOR URBAN STUDIES IN THE AUSTIN, TEXAS METROPOLITAN AREA, 1979: USGS OPEN-FILE REPORT 81-628, 1981.

SPRINGS OF TEXAS, VOLUME 1: (BY GUNNAR BRUNE), BRANCHSMITH, INC., FORT WORTH, TEXAS, 1981. 
RECORDS OF GROUND-WATER RECHARGE, DISCHARGE, WATER LEVELS, AND CHEMICAL QUALITY OF WATER FOR THE EDWARDS AQUIFER IN THE SAN ANTONIO AREA, TEXAS, 1934-79: EDWARDS UNDERGROUND WATER DISTRICT BULLETIN 39, 1981.

APPLICATION AND ANALYSIS OF BOREHOLE DATA FOR THE EDWARDS AQUIFER IN THE SAN ANTONIO AREA, TEXAS: TEXAS DEPARTMENT OF WATER RESOURCES LIMITED PRINTING REPORT LP-139, 1981.

TEST-HOLE DATA FOR THE EDWARDS AQUIFER IN THE SAN ANTONIO AREA, TEXAS: TEXAS DEPARTMENT OF WATER RESOURCES LIMITED PRINTING REPORT LP-171, 1982.

RECORDS OF GROUND-WATER RECHARGE, DISCHARGE, WATER LEVELS, AND CHEMICAL QUALITY OF WATER FOR THE EDWARDS AQUIFER IN THE SAN ANTONIO AREA, TEXAS, 1934-80: EDWARDS UNDERGROUND WATER DISTRICT BULLETIN 40, 1982.

HYDROLOGIC DATA FOR URBAN STUDIES IN THE AUSTIN, TEXAS METROPOLITAN AREA, 1981: USGS OPEN-FILE REPORT 83-44, 1983.

GROUND-WATER AVAILABILITY OF THE LOWER CRETACEOUS FORMATIONS IN THE HILL COUNTRY OF SOUTH-CENTRAL TEXAS: TEXAS DEPARTMENT OF WATER RESOURCES REPORT 273,1983

RECORDS OF GROUND-WATER RECHARGE, DISCHARGE, WATER LEVELS, AND CHEMICAL QUALITY OF WATER FOR THE EDWARDS AQUIFER IN THE SAN ANTONIO AREA, TEXAS, 1934-81: EDWARDS UNDERGROUND WATER DISTRICT BULLETIN 41, 1984.

CARBONATE GEOLOGY AND HYDROLOGY OF THE EDWARDS AQUIFER IN THE SAN ANTONIO AREA, TEXAS: USGS OPEN-FILE REPORT 83-537, 1984.

HYDROLOGIC DATA FOR URBAN STUDIES IN THE AUSTIN, TEXAS, METROPOLITAN AREA, 1982: USGS OPEN-FILE REPORT 84-061, 1984.

IDENTIFICATION AND TABULATION OF GEOLOGICAL CONTACTS IN THE EDWARDS AQUIFER, SAN ANTONIO AREA, TEXAS: USGS OPEN-FILE REPORT 84-075, 1984.

EFFECTS OF STORM-WATER RUNOFF ON WATER QUALITY OF THE EDWARDS AQUIFER NEAR AUSTIN, TEXAS: USGS WATERRESOURCES INVESTIGATIONS REPORT 84-4124, 1984.

PROPOSED 10-YEAR PLAN FOR CONTINUATION OF HYDROLOGIC STUDIES OF THE EDWARDS AQUIFER, SAN ANTONIO AREA, TEXAS: USGS OPEN-FILE REPORT 84-817, 1984.

HYDROGEOLOGY OF THE EDWARDS AQUIFER, AUSTIN AREA, CENTRAL TEXAS: UNIVERSITY OF TEXAS, BUREAU OF ECONOMIC GEOLOGY REPORT OF INVESTIGATIONS NO. 141, 1984

HYDROGEOLOGY OF THE EDWARDS AQUIFER-BARTON SPRINGS SEGMENT, TRAVIS AND HAYS COUNTIES, TEXAS: AUSTIN GEOLOGICAL SOCIETY GUIDEBOOK 6, 1984.

RECORDS OF GROUND-WATER RECHARGE, DISCHARGE, WATER LEVELS, AND CHEMICAL QUALITY OF WATER FOR THE EDWARDS AQUIFER IN THE SAN ANTONIO AREA, TEXAS, 1934-82: EDWARDS UNDERGROUND WATER DISTRICT BULLETIN 42, 1985.
IDENTIFICATION AND TABULATION OF GEOLOGICAL CONTACTS IN THE EDWARDS AQUIFER, SAN ANTONIO AREA, TEXAS: TEXAS DEPARTMENT OF WATER RESOURCES LIMITED PRINTING REPORT LP-199, 1985.

HYDROLOGIC DATA FOR URBAN STUDIES IN THE AUSTIN, TEXAS, METROPOLITAN AREA, 1983: USGS OPEN-FILE REPORT 85-172, 1985.

SIMULATION OF THE FLOW SYSTEM OF BARTON SPRINGS AND ASSOCIATED EDWARDS AQUIFER IN THE AUSTIN AREA, TEXAS: USGS WATER-RESOURCES INVESTIGATIONS REPORT 85-4299, 1985.

STATISTICAL SUMMARY OF WATER-QUALITY DATA COLLECTED FROM SELECTED WELLS AND SPRINGS IN THE EDWARDS AQUIFER NEAR SAN ANTONIO, TEXAS: USGS OPEN-FILE REPORT 85-182, 1985.

WATER USE, PROJECTED WATER REQUIREMENTS, AND RELATED DATA AND INFORMATION FOR THE METROPOLITAN STATISTICAL AREAS IN TEXAS: TEXAS DEPARTMENT OF WATER RESOURCES LIMITED PRINTING REPORT LP-201, 1985.

TEXAS GROUND-WATER RESOURCES, in NATIONAL WATER SUMMARY 1984: USGS WATER-SUPPLY PAPER 2275, 1985.

COMPILATION OF HYDROLOGIC DATA FOR THE EDWARDS AQUIFER, SAN ANTONIO AREA, TEXAS, 1983-84, WITH 1934-84 SUMMARY: EDWARDS UNDERGROUND WATER DISTRICT BULLETIN 43-44, 1986

HYDROGEOLOGIC SECTIONS OF THE EDWARDS AQUIFER AND ITS CONFINING UNITS IN THE SAN ANTONIO AREA, TEXAS: USGS WATER-RESOURCES INVESTIGATIONS REPORT 85-4259, 1986.

GEOHYDROLOGY OF THE EDWARDS AQUIFER IN THE AUSTIN AREA, TEXAS: TEXAS WATER DEVELOPMENT BOARD REPORT 293, 1986.

HYDROLOGY AND WATER QUALITY OF THE EDWARDS AQUIFER ASSOCIATED WITH BARTON SPRINGS IN THE AUSTIN AREA, TEXAS: USGS WATER-RESOURCES INVESTIGATIONS REPORT 86-4036, 1986.

RECHARGE ZONE OF THE EDWARDS AQUIFER HYDROLOGICALLY ASSOCIATED WITH BARTON SPRINGS IN THE AUSTIN AREA, TEXAS: USGS WATER-RESOURCES INVESTIGATIONS REPORT 86-4062, 1986.

CARBONATE GEOLOGY AND HYDROLOGY OF THE EDWARDS AQUIFER IN THE SAN ANTONIO AREA, TEXAS: TEXAS WATER DEVELOPMENT BOARD REPORT 296, 1986.

THE EDWARDS AQUIFER: EXTREMELY PRODUCTIVE, BUT....A SOLE-SOURCE WATER SUPPLY FOR SAN ANTONIO AND SURROUNDING COUNTIES IN SOUTH-CENTRAL TEXAS: EDWARDS UNDERGROUND WATER DISTRICT, 1986.

POTENTIAL FOR UPDIP MOVEMENT OF SALINEWATER IN THE EDWARDS AQUIFER, SAN ANTONIO, TEXAS: USGS WATERRESOURCES INVESTIGATIONS REPORT 86-4032, 1986.

HYDROCHEMISTRY OF THE COMAL, HUECO, AND SAN MARCOS SPRINGS, EDWARDS AQUIFER, TEXAS: in BALCONES ESCARPMENT, PUBLISHED FOR GEOLOGICAL SOCIETY OF AMERICA ANNUAL MEETING, SAN ANTONIO, TEXAS, NOVEMBER, 1986.

SIMULATION OF FLOW IN THE EDWARDS AQUIFER, SAN ANTONIO REGION, TEXAS, AND REFINEMENT OF STORAGE AND FLOW CONCEPTS: USGS OPEN-FILE REPORT 86-532, 1987. 
HYDROLOGIC DATA FOR URBAN STUDIES IN THE AUSTIN METROPOLITAN AREA, TEXAS, 1985: USGS OPEN-FILE REPORT 87-224, 1987.

RELATION OF WATER CHEMISTRY OF THE EDWARDS AQUIFER TO HYDROGEOLOGY AND LAND USE, SAN ANTONIO AREA, TEXAS: USGS WATER-RESOURCES INVESTIGATIONS REPORT 87-4116, 1987.

HYDROGEOLOGIC DATA FROM A STUDY OF THE FRESHWATER ZONE/SALINEWATER ZONE INTERFACE IN THE EDWARDS AQUIFER, SAN ANTONIO REGION, TEXAS: USGS OPEN-FILE REPORT 87-389, 1987.

COMPILATION OF HYDROLOGIC DATA FOR THE EDWARDS AQUIFER, SAN ANTONIO AREA, TEXAS, 1985, WITH 1934-85 SUMMARY: EDWARDS UNDERGROUND WATER DISTRICT BULLETIN 45, 1987.

GROUND-WATER CONDITIONS OF THE TRINITY GROUP AQUIFER IN WESTERN HAYS COUNTY: TEXAS WATER DEVELOPMENT BOARD LIMITED PRINTING REPORT LP-205, 1987.

SUGGESTED DESIGN AND CONSTRUCTION OF EDWARDS AQUIFER WELLS: EDWARDS UNDERGROUND WATER DISTRICT, 1987?

COMPILATION OF HYDROLOGIC DATA FOR THE EDWARDS AQUIFER, SAN ANTONIO AREA, TEXAS, 1986, WITH 1934-86 SUMMARY: EDWARDS UNDERGROUND WATER DISTRICT BULLETIN 46, 1988

SIMULATION OF FLOW IN THE EDWARDS AQUIFER, SAN ANTONIO REGION, TEXAS, AND REFINEMENT OF STORAGE AND FLOW CONCEPTS: USGS WATER-SUPPLY PAPER 2336-A, 1988.

HYDROLOGIC DATA FOR URBAN STUDIES IN THE AUSTIN METROPOLITAN AREA, TEXAS, 1986: USGS OPEN-FILE REPORT 87-768, 1988.

COMPILATION OF HYDROLOGIC DATA FOR THE EDWARDS AQUIFER, SAN ANTONIO AREA, TEXAS, 1987, WITH 1934-87 SUMMARY: EDWARDS UNDERGROUND WATER DISTRICT BULLETIN 47, 1988.

COMPILATION OF HYDROLOGIC DATA FOR THE EDWARDS AQUIFER, SAN ANTONIO AREA, TEXAS, 1988, WITH 1934-88 SUMMARY: EDWARDS UNDERGROUND WATER DISTRICT BULLETIN 48, 1989.

POTENTIOMETRIC SURFACE OF THE EDWARDS-TRINITY AQUIFER SYSTEM AND CONTIGUOUS HYDRAULICALLY CONNECTED UNITS, WEST-CENTRAL TEXAS, WINTER 1974-75: USGS WATERRESOURCES INVESTIGATIONS REPORT 89-4208, 1990.

HYDROGEOLOGY OF THE NORTHERN SEGMENT OF THE EDWARDS AQUIFER, AUSTIN REGION: UNIVERSITY OF TEXAS, BUREAU OF ECONOMIC GEOLOGY REPORT OF INVESTIGATIONS NO. 192, 1990.

GROUND-WATER EVALUATION IN AND ADJACENT TO DRIPPING SPRINGS, TEXAS: TEXAS WATER DEVELOPMENT BOARD REPORT 322, 1990.

EDWARDS AQUIFER, A TEXAS TREASURE-A TEACHERS GUIDE, SECONDARY, GRADES 7-12: EDWARDS UNDERGROUND WATER DISTRICT, 1991.

COMPILATION OF HYDROLOGIC DATA FOR THE EDWARDS AQUIFER, SAN ANTONIO AREA, TEXAS, 1990, WITH 1934-90 SUMMARY: EDWARDS UNDERGROUND WATER DISTRICT BULLETIN 50, 1991.
MODELING INFILTRATION, SUBSURFACE MOISTURE, AND BASE FLOW IN BARTON CREEK, AUSTIN, TEXAS: TEXAS STATE SECTION OF THE AMERICAN WATER RESOURCES ASSOCIATION, TRIGG TWICHELL SYMPOSIUM, FALL MEETING, NOVEMBER 8, 1991, AUSTIN, TEXAS, 1991.

INSIDE THE EDWARDS AQUIFER-A THREE-PART TECHNICAL FILM, HIGH-SCHOOL LEVEL TEACHER'S GUIDE: EDWARDS UNDERGROUND WATER DISTRICT, 1992.

WITHDRAWALS FROM THE EDWARDS-TRINITY AQUIFER SYSTEM AND CONTIGUOUS HYDRAULICALLY CONNECTED UNITS, WEST-CENTRAL TEXAS, DECEMBER 1974 THROUGH MARCH 1977: USGS WATER-RESOURCES INVESTIGATIONS REPORT 91-4021, 1991.

CONFIGURATION OF THE BASE OF THE EDWARDS-TRINITY AQUIFER SYSTEM AND HYDROGEOLOGY OF THE UNDERLYING PRECRETACEOUS ROCKS, WEST-CENTRAL TEXAS: USGS WATERRESOURCES INVESTIGATIONS REPORT 91-4071, 1992.

EVALUATION OF THE GROUND-WATER RESOURCES OF THE PALEOZOIC AND CRETACEOUS AQUIFERS IN THE HILL COUNTRY OF CENTRAL TEXAS: TEXAS WATER DEVELOPMENT BOARD REPORT 339, 1992

INVESTIGATION OF THE FRESH/SALINE-WATER INTERFACE IN THE EDWARDS AQUIFER IN NEW BRAUNFELS AND SAN MARCOS, TEXAS: EDWARDS UNDERGROUND WATER DISTRICT REPORT 92-02, 1992.

MODEL REFINEMENT AND APPLICATIONS FOR THE EDWARDS (BALCONES FAULT ZONE) AQUIFER IN THE SAN ANTONIO REGION, TEXAS: TEXAS WATER DEVELOPMENT BOARD REPORT 340,1992

WATER QUALITY IN THE EDWARDS AQUIFER AND STREAMS RECHARGING THE AQUIFER IN THE SAN ANTONIO REGION, TEXAS: USGS HYDROLOGIC INVESTIGATIONS ATLAS HA-723, 1992

COMPILATION OF HYDROLOGIC DATA FOR THE EDWARDS AQUIFER, SAN ANTONIO AREA, TEXAS, 1991, WITH 1934-91 SUMMARY: EDWARDS UNDERGROUND WATER DISTRICT BULLETIN $51,1992$.

WATER-RESOURCES DATA, TEXAS, WATER YEAR 1991, VOLUME 4 GROUND-WATER DATA: USGS WATER-DATA REPORT TX-91-4, 1992.

HISTORICAL POTENTIOMETRIC SURFACE OF THE EDWARDS-TRINITY AQUIFER SYSTEM AND CONTIGUOUS HYDRAULICALLY CONNECTED UNITS, WEST-CENTRAL TEXAS: USGS WATERRESOURCES INVESTIGATIONS REPORT 92-4055, 1993.

HISTORICAL SATURATED THICKNESS OF THE EDWARDS-TRINITY AQUIFER SYSTEM AND SELECTED CONTIGUOUS HYDRAULICALLY CONNECTED UNITS, WEST-CENTRAL TEXAS: USGS WATER-RESOURCES INVESTIGATIONS REPORT 92-4125, 1993.

DEFINING THE EDWARDS AQUIFER FRESHWATER/SALINE-WATER INTERFACE WITH GEOPHYSICAL LOGS AND MEASURED DATA (SAN ANTONIO TO KYLE, TEXAS): EDWARDS UNDERGROUND WATER DISTRICT REPORT 93-06, 1993.

EDWARDS AQUIFER HYDROGEOLOGIC STATUS REPORT FOR 1992 EDWARDS UNDERGROUND WATER DISTRICT REPORT 93-05, 1993. 
WATER-RESOURCES DATA, TEXAS, WATER YEAR 1992, VOLUME 4, GROUND-WATER DATA: USGS WATER-DATA REPORT TX-92-4, 1993.

SIMULATIONS OF FLOW IN THE EDWARDS-TRINITY AQUIFER SYSTEM AND CONTIGUOUS HYDRAULICALLY CONNECTED UNITS, WEST-CENTRAL TEXAS: USGS WATER-RESOURCES INVESTIGATIONS REPORT 93-4039, 1994.

DISSOLVED-SOLIDS CONCENTRATIONS AND HYDROCHEMICAL FACIES IN WATER OF THE EDWARDS-TRINITY AQUIFER SYSTEM, WEST-CENTRAL TEXAS: USGS WATER-RESOURCES INVESTIGATIONS REPORT 93-4126, 1994.

NATIONAL WATER-QUALITY ASSESSMENT PROGRAM-SOUTHCENTRAL TEXAS: USGS FACT SHEET FS-94-048, 1994.

GEOLOGIC HISTORY AND HYDROGEOLOGIC SETTING OF THE EDWARDS-TRINITY AQUIFER SYSTEM, WEST-CENTRAL TEXAS: USGS WATER-RESOURCES INVESTIGATIONS REPORT 94-4039, 1994.

1994 REVIEW AND UPDATE OF THE POSITION OF THE EDWARDS AQUIFER FRESHWATER/SALINE-WATER INTERFACE FROM UVALDE TO KYLE, TEXAS: EDWARDS UNDERGROUND WATER DISTRICT REPORT 94-05, 1994.

WATER-RESOURCES DATA, TEXAS, WATER YEAR 1993, VOLUME 4, GROUND-WATER DATA: USGS WATER-DATA REPORT TX-93-4, 1994.

GEOLOGY AND HYDROLOGY OF THE EDWARDS AQUIFER IN THE SAN ANTONIO AREA, TEXAS: USGS WATER-RESOURCES INVESTIGATIONS REPORT 95-4186, 1995.

GEOLOGIC FRAMEWORK AND HYDROGEOLOGIC CHARACTERISTICS OF THE EDWARDS AQUIFER OUTCROP, HAYS COUNTY, TEXAS: USGS WATER-RESOURCES INVESTIGATIONS REPORT 95-4265, 1995.

REGIONAL DISTRIBUTION OF PERMEABILITY IN THE EDWARDS AQUIFER: EDWARDS UNDERGROUND WATER DISTRICT REPORT 95-02, 1995.

AQUIFERS OF TEXAS: TEXAS WATER DEVELOPMENT BOARD REPORT 345, 1995.

WATER-RESOURCES DATA, TEXAS, WATER YEAR 1994, VOLUME 4, GROUND-WATER DATA: USGS WATER-DATA REPORT TX-94-4, 1995.

HYDROGEOLOGIC FACTORS THAT AFFECT THE FLOWPATH OF WATER IN SELECTED ZONES OF THE EDWARDS AQUIFER, SAN ANTONIO REGION, TEXAS: USGS WATER-RESOURCES INVESTIGATIONS REPORT 96-4046, 1996.

GEOLOGIC FRAMEWORK AND HYDROGEOLOGIC CHARACTERISTICS OF THE EDWARDS AQUIFER OUTCROP (BARTON SPRINGS SEGMENT), NORTHEASTERN HAYS AND SOUTHWESTERN TRAVIS COUNTY, TEXAS: USGS WATER-RESOURCES INVESTIGATIONS REPORT 96-4306, 1996.

RECHARGE TO AND DISCHARGE FROM THE EDWARDS AQUIFER IN THE SAN ANTONIO AREA, TEXAS, 1995: USGS OPEN-FILE REPORT 96-181, 1996.

EDWARDS AQUIFER GROUND-WATER RESOURCES: GEOLOGIC CONTROLS ON POROSITY DEVELOPMENT IN PLATFORM CARBONATES, SOUTH TEXAS: UNIVERSITY OF TEXAS, BUREAU OF ECONOMIC GEOLOGY REPORT OF INVESTIGATIONS NO. 238, 1996.
WATER-RESOURCES DATA, TEXAS, WATER YEAR 1995, VOLUME 4, GROUND-WATER DATA: USGS WATER-DATA REPORT TX-95-4, 1996.

WATER-QUALITY ASSESSMENT OF SOUTH-CENTRAL TEXASOCCURRENCE AND DISTRIBUTION OF VOLATILE ORGANIC COMPOUNDS IN SURFACE WATER AND GROUND WATER, 1983-94, AND IMPLICATIONS FOR FUTURE MONITORING: USGS WATER-RESOURCES INVESTIGATIONS REPORT 97-4028, 1997.

HYDROGEOLOGIC FRAMEWORK AND GEOCHEMISTRY OF THE EDWARDS AQUIFER SALINE-WATER ZONE, SOUTH-CENTRAL TEXAS: USGS WATER-RESOURCES INVESTIGATIONS REPORT 97-4133, 1997.

WATER-QUALITY SUMMARY OF THE SAN MARCOS SPRINGS RIVERINE SYSTEM, SAN MARCOS, TEXAS, JULY-AUGUST 1994: USGS FACT SHEET FS-059-97, 1997.

WATER-RESOURCES DATA, TEXAS, WATER YEAR 1996, VOLUME 4 GROUND-WATER DATA: USGS WATER-DATA REPORT TX-96-4, 1997.

MONITORING OF SELECTED WATER-QUALITY CONSTITUENTS NEAR THE FRESHWATER/SALINE-WATER INTERFACE OF THE EDWARDS AQUIFER, JULY 1996-DECEMBER 1997: USGS FACT SHEET FS-103-98, 1998.

WATER-RESOURCES DATA, TEXAS, WATER YEAR 1997, VOLUME 4, GROUND-WATER DATA: USGS WATER-DATA REPORT TX-97-4, 1998.

WATER-RESOURCES DATA, TEXAS, WATER YEAR 1998, VOLUME 4, GROUND-WATER DATA: USGS WATER-DATA REPORT TX-98-4, 1999.

GROUNDWATER AVAILABILITY OF THE TRINITY AQUIFER, HILL COUNTRY AREA, TEXAS: NUMERICAL SIMULATIONS THROUGH 2050: TEXAS WATER DEVELOPMENT BOARD REPORT 353, 2000.

WATER QUALITY IN SOUTH-CENTRAL TEXAS-TEXAS, 1996-98: USGS CIRCULAR 1212, 2000

WATER-RESOURCES DATA, TEXAS, WATER YEAR 1999, VOLUME 6 , GROUND-WATER DATA: USGS WATER-DATA REPORT TX-99-6, 2000.

WATER-RESOURCES DATA, TEXAS, WATER YEAR 2000, VOLUME 6 , GROUND-WATER DATA: USGS WATER-DATA REPORT TX-00-6, 2001.

\section{HEMPHILL COUNTY}

THE GEOLOGY AND WATER RESOURCES OF THE EASTERN PORTION OF THE PANHANDLE OF TEXAS: USGS WATER-SUPPLY PAPER 154, 1906.

GEOLOGY AND GROUND-WATER RESOURCES OF THE SOUTHERN HIGH PLAINS: USGS OPEN-FILE REPORT (UNNUMBERED), 1935.

GROUND WATER IN THE HIGH PLAINS OF TEXAS: TEXAS BOARD OF WATER ENGINEERS DUPLICATED REPORT (UNNUMBERED), 1938.

GROUND WATER IN THE HIGH PLAINS OF TEXAS: TEXAS BOARD OF WATER ENGINEERS MISCELLANEOUS PUBLICATION 119, 1940. 
ROGRESS REPORT ON GROUND WATER IN THE HIGH PLAINS OF TEXAS: TEXAS BOARD OF WATER ENGINEERS MISCELLANEOUS PUBLICATION (UNNUMBERED), 1942.

PROGRESS REPORT ON GROUND WATER IN THE HIGH PLAINS OF TEXAS: TEXAS BOARD OF WATER ENGINEERS MISCELLANEOUS PUBLICATION 120, 1943.

PROGRESS REPORT ON GROUND WATER IN THE HIGH PLAINS OF TEXAS: TEXAS BOARD OF WATER ENGINEERS MISCELLANEOUS PUBLICATION 121, 1944.

GROUND WATER IN HIGH PLAINS OF TEXAS, PROGRESS REPORT NO. 5: TEXAS BOARD OF WATER ENGINEERS MISCELLANEOUS PUBLICATION 122, 1945.

GROUND WATER IN THE HIGH PLAINS OF TEXAS: USGS WATERSUPPLY PAPER 889-F, 1946.

GROUND WATER IN HIGH PLAINS OF TEXAS, PROGRESS REPORT NO. 6: TEXAS BOARD OF WATER ENGINEERS MISCELLANEOUS PUBLICATION 123, 1947.

COST OF PUMPING WATER FOR IRRIGATION, TEXAS HIGH PLAINS, FIELD INVESTIGATIONS-1947 IRRIGATION SEASON: TEXAS BOARD OF WATER ENGINEERS MISCELLANEOUS PUBLICATION 124, 1951.

PUBLIC WATER SUPPLIES IN WESTERN TEXAS: USGS WATERSUPPLY PAPER 1106, 1951 [1952].

DEVELOPMENT OF WELLS FOR IRRIGATION AND FLUCTUATION OF WATER LEVELS IN THE HIGH PLAINS OF TEXAS TO JANUARY 1951: TEXAS BOARD OF WATER ENGINEERS BULLETIN 5104, 1951.

WATER-LEVEL MAPS AND WATER LEVELS IN OBSERVATION WELLS IN THE NORTH HIGH PLAINS, TEXAS: TEXAS BOARD OF WATER ENGINEERS BULLETIN 5707, 1957.

RECORDS OF WATER-LEVEL MEASUREMENTS IN COLLINGSWORTH, HEMPHILL, ROBERTS, AND WHEELER COUNTIES, TEXAS, 1937 THROUGH JULY 1958: TEXAS BOARD OF WATER ENGINEERS BULLETIN 5806, 1958.

WATER-LEVEL MEASUREMENTS AND MAPS, NORTHERN HIGH PLAINS, TEXAS, 1958 AND 1959: TEXAS BOARD OF WATER ENGINEERS BULLETIN 5909, 1959.

WATER LEVELS IN OBSERVATION WELLS, NORTHERN HIGH PLAINS, TEXAS, 1958-1960: TEXAS BOARD OF WATER ENGINEERS BULLETIN 6012, 1960.

RECONNAISSANCE INVESTIGATION OF THE GROUND-WATER RESOURCES OF THE CANADIAN RIVER BASIN, TEXAS: TEXAS BOARD OF WATER ENGINEERS BULLETIN 6016, 1960.

ANNUAL WATER-LEVEL MEASUREMENTS IN OBSERVATION WELLS, NORTHERN HIGH PLAINS, TEXAS, 1960 AND 1961: TEXAS BOARD OF WATER ENGINEERS BULLETIN 6103, 1961.

GEOLOGY AND GROUND-WATER RESOURCES OF THE NORTHERN HIGH PLAINS OF TEXAS, PROGRESS REPORT NO. 1: TEXAS BOARD OF WATER ENGINEERS BULLETIN 6109, 1961.

ANNUAL WATER-LEVEL MEASUREMENTS IN OBSERVATION WELLS, NORTHERN HIGH PLAINS, TEXAS, 1961 AND 1962: TEXAS WATER COMMISSION BULLETIN 6213, 1962.

RECONNAISSANCE INVESTIGATION OF THE GROUND-WATER RESOURCES OF THE RED RIVER, SULPHUR RIVER, AND CYPRESS
CREEK BASINS, TEXAS: TEXAS WATER COMMISSION BULLETIN 6306, 1963.

WATER-LEVEL DATA FROM OBSERVATION WELLS IN THE SOUTHERN HIGH PLAINS OF TEXAS: TEXAS WATER DEVELOPMENT BOARD REPORT 21, 1966.

WATER-LEVEL DATA FROM OBSERVATION WELLS IN THE SOUTHERN HIGH PLAINS OF TEXAS, 1965-70: TEXAS WATER DEVELOPMENT BOARD REPORT 121, 1970.

WATER-LEVEL DATA FROM OBSERVATION WELLS IN THE NORTHERN PANHANDLE OF TEXAS: TEXAS WATER DEVELOPMENT BOARD REPORT 137, 1971

PRELIMINARY DATA DESCRIBING THE DISTRIBUTION OF FLUORIDE AND SILICA IN THE OGALLALA AQUIFER ON THE HIGH PLAINS OF TEXAS: USGS OPEN-FILE REPORT 80-349, 1980.

WATER-LEVEL DATA FROM OBSERVATION WELLS IN THE NORTHERN PANHANDLE OF TEXAS, 1972-78: TEXAS DEPARTMENT OF WATER RESOURCES REPORT 248, 1980.

WATER TABLE IN THE HIGH PLAINS AQUIFER IN 1978 IN PARTS OF COLORADO, KANSAS, NEBRASKA, NEW MEXICO, OKLAHOMA, SOUTH DAKOTA, TEXAS, AND WYOMING: USGS HYDROLOGIC INVESTIGATIONS ATLAS HA-642, 1980.

EVALUATING THE GROUND-WATER RESOURCES OF THE HIGH PLAINS OF TEXAS: RESULTS OF TEST HOLE DRILLING: TEXAS DEPARTMENT OF WATER RESOURCES LIMITED PRINTING REPORT LP-129, 1980.

EVALUATING THE GROUND-WATER RESOURCES OF THE HIGH PLAINS OF TEXAS: RESULTS OF SURFACE ELECTRICAL RESISTIVITY: TEXAS DEPARTMENT OF WATER RESOURCES LIMITED PRINTING REPORT LP-130, 1980.

SPRINGS OF TEXAS, VOLUME 1: (BY GUNNAR BRUNE), BRANCHSMITH, INC., FORT WORTH, TEXAS, 1981.

BEDROCK GEOLOGY, ALTITUDE OF BASE, AND 1980 SATURATED THICKNESS OF THE HIGH PLAINS AQUIFER IN PARTS OF COLORADO, KANSAS, NEBRASKA, NEW MEXICO, OKLAHOMA, SOUTH DAKOTA, TEXAS, AND WYOMING: USGS HYDROLOGIC INVESTIGATIONS ATLAS HA-648, 1981

WATER-LEVEL AND SATURATED-THICKNESS CHANGES, PREDEVELOPMENT TO 1980, IN THE HIGH PLAINS AQUIFER IN PARTS OF COLORADO, KANSAS, NEBRASKA, NEW MEXICO, OKLAHOMA, SOUTH DAKOTA, TEXAS, AND WYOMING: USGS HYDROLOGIC INVESTIGATIONS ATLAS HA-652, 1981.

ANALYTICAL STUDY OF THE OGALLALA AQUIFER IN HEMPHILL COUNTY, TEXAS-PROJECTIONS OF SATURATED THICKNESS, VOLUME OF WATER IN STORAGE, PUMPAGE RATES, PUMPING LIFTS, AND WELL YIELDS: TEXAS DEPARTMENT OF WATER RESOURCES REPORT 267, 1982

DISSOLVED SOLIDS AND SODIUM IN WATER FROM THE HIGH PLAINS AQUIFER IN PARTS OF COLORADO, KANSAS, NEBRASKA, NEW MEXICO, OKLAHOMA, SOUTH DAKOTA, TEXAS, AND WYOMING: USGS HYDROLOGIC INVESTIGATIONS ATLAS HA-658, 1982

GEOHYDROLOGY OF THE HIGH PLAINS AQUIFER IN PARTS OF COLORADO, KANSAS, NEBRASKA, NEW MEXICO, OKLAHOMA, SOUTH DAKOTA, TEXAS, AND WYOMING: USGS PROFESSIONAL PAPER 1400-B, 1984. 
EVALUATING THE GROUND-WATER RESOURCES OF THE HIGH PLAINS OF TEXAS, VOLUME 1: TEXAS DEPARTMENT OF WATER RESOURCES REPORT 288, V. 1, 1984.

EVALUATING THE GROUND-WATER RESOURCES OF THE HIGH PLAINS OF TEXAS, VOLUME 2, RECORDS OF WELLS, AND MAPS SHOWING WELL LOCATIONS, BASE OF AQUIFER, WATER LEVELS, AND SATURATED THICKNESS (ARMSTRONG, CARSON, DALLAS, DONLEY, GRAY, HANSFORD, HARTLEY, HEMPHILL, HUTCHINSON, LIPSCOMB, MOORE, OCHILTREE, POTTER, ROBERTS, SHERMAN, AND WHEELER COUNTIES): TEXAS DEPARTMENT OF WATER RESOURCES REPORT 288, V. 2, 1984.

TEXAS GROUND-WATER RESOURCES, in NATIONAL WATER SUMMARY 1984: USGS WATER-SUPPLY PAPER 2275, 1985.

DIGITAL SIMULATION OF GROUND-WATER FLOW IN THE HIGH PLAINS AQUIFER IN PARTS OF COLORADO, KANSAS, NEBRASKA, NEW MEXICO, OKLAHOMA, SOUTH DAKOTA, TEXAS, AND WYOMING: USGS PROFESSIONAL PAPER 1400-D, 1986.

SUMMARY OF THE HIGH PLAINS REGIONAL AQUIFER-SYSTEM ANALYSIS IN PARTS OF COLORADO, KANSAS, NEBRASKA, NEW MEXICO, OKLAHOMA, SOUTH DAKOTA, TEXAS, AND WYOMING: USGS PROFESSIONAL PAPER 1400-A, 1988.

WATER-LEVEL CHANGES IN THE HIGH PLAINS AQUIFER OF TEXAS, 1980-1990: TEXAS WATER DEVELOPMENT BOARD HYDROLOGIC ATLAS NO. 1, 1991.

PUBLIC-SUPPLY GROUND-WATER USE IN THE NORTHERN HIGH PLAINS OF TEXAS: TEXAS WATER DEVELOPMENT BOARD REPORT 336, 1992.

THE HIGH PLAINS AQUIFER SYSTEM OF TEXAS, 1980 TO 1990. OVER VIEW AND PROJECTIONS: TEXAS WATER DEVELOPMENT BOARD REPORT 341, 1993.

WATER-QUALITY EVALUATION OF THE OGALLALA AQUIFER, TEXAS: TEXAS WATER DEVELOPMENT BOARD REPORT 342 , 1993.

WATER-LEVEL CHANGES IN THE HIGH PLAINS AQUIFER-PREDEVELOPMENT TO 1992: USGS WATER-RESOURCES INVESTIGATIONS REPORT 94-4027, 1994.

WATER-LEVEL CHANGES IN THE HIGH PLAINS AQUIFER, 1980 TO 1994: USGS FACT SHEET FS-215-95, 1995.

AQUIFERS OF TEXAS: TEXAS WATER DEVELOPMENT BOARD REPORT 345, 1995.

WATER-LEVEL CHANGES IN THE HIGH PLAINS AQUIFER, 1980 TO 1995: USGS FACT SHEET FS-068-97, 1997.

WATER-LEVEL CHANGES IN THE HIGH PLAINS AQUIFER-PREDEVELOPMENT TO 1995: USGS WATER-RESOURCES INVESTIGATIONS REPORT 97-4081, 1997.

PLAYAS AND RECHARGE OF THE OGALLALA AQUIFER ON THE SOUTHERN HIGH PLAINS OF TEXAS-AN EXAMINATION USING NUMERICAL TECHNIQUES: UNIVERSITY OF TEXAS, BUREAU OF ECONOMIC GEOLOGY REPORT OF INVESTIGATIONS NO. 242, 1997.

UPDATED WATER-QUALITY EVALUATION OF THE OGALLALA AQUIFER INCLUDING SELECTED METALLIC AND NON-METALLIC INORGANIC CONSTITUENTS: TEXAS WATER DEVELOPMENT BOARD HYDROLOGIC ATLAS NO. 10, 1998.

\section{HENDERSON COUNTY}

GEOLOGY AND UNDERGROUND WATERS OF THE SOUTHEASTERN PART OF THE TEXAS COASTAL PLAIN: USGS WATER-SUPPLY PAPER 335, 1914.

HENDERSON COUNTY: USGS OPEN-FILE REPORT, 1936.

RECORDS OF WELLS, DRILLERS' LOGS, AND WATER ANALYSES, AND MAP SHOWING LOCATION OF WELLS IN HENDERSON COUNTY, TEXAS: TEXAS BOARD OF WATER ENGINEERS MISCELLANEOUS PUBLICATION 115, 1936.

POSSIBILITIES OF IRRIGATION FROM WELLS IN THE CARRIZO SAND IN SOUTHERN HENDERSON AND NORTHERN ANDERSON COUNTIES: USGS OPEN-FILE REPORT (UNNUMBERED), 1948.

PUBLIC WATER SUPPLIES IN EASTERN TEXAS: USGS WATERSUPPLY PAPER 1047, 1948

RECONNAISSANCE INVESTIGATION OF THE GROUND-WATER RESOURCES OF THE NECHES RIVER BASIN, TEXAS: TEXAS WATER COMMISSION BULLETIN 6308, 1963.

RECONNAISSANCE INVESTIGATION OF THE GROUND-WATER RESOURCES OF THE TRINITY RIVER BASIN, TEXAS: TEXAS WATER COMMISSION BULLETIN 6309, 1963.

GROUND-WATER CONDITIONS IN ANDERSON, CHEROKEE, FREESTONE AND HENDERSON COUNTIES, TEXAS: TEXAS WATER DEVELOPMENT BOARD REPORT 150, 1972.

PROJECTED EFFECTS OF THE PROPOSED TENNESSEE COLONY RESERVOIR ON GROUND-WATER CONDITIONS IN THE CARRIZOWILCOX AQUIFER AND TRINITY RIVER ALLUVIUM, TRINIDADOAKWOOD AREA, TEXAS: USGS OPEN-FILE REPORT 74-297, 1974.

GEOHYDROLOGIC SIGNIFICANCE OF LITHOFACIES OF THE CARRIZO SAND OF ARKANSAS, LOUISIANA, AND TEXAS AND THE MERIDIAN SAND OF MISSISSIPPI: USGS PROFESSIONAL PAPER 569-D, 1975.

SUMMARY APPRAISALS OF THE NATION'S GROUND-WATER RESOURCES-TEXAS-GULF REGION: USGS PROFESSIONAL PAPER 813-F, 1976.

PROJECTED EFFECTS OF THE PROPOSED TENNESSEE COLONY RESERVOIR ON GROUND-WATER CONDITIONS IN THE ALLUVIUM OF THE TRINITY RIVER AND CEDAR CREEK, TEXAS-PRELIMINARY RESULTS FOR THE TRINIDAD AREA: USGS OPEN-FILE REPORT 79-1270, 1979.

WATER-QUALITY DATA FOR AQUIFERS, STREAMS, AND LAKES IN THE VICINITY OF KEECHI, MOUNT SYLVAN, OAKWOOD, AND PALESTINE SALT DOMES, NORTHEAST TEXAS SALT-DOME BASIN: USGS OPEN-FILE REPORT 80-2037, 1980

GEOHYDROLOGY OF THE KEECHI, MOUNT SYLVAN, OAKWOOD, AND PALESTINE SALT DOMES IN THE NORTHEAST TEXAS SALTDOME BASIN: USGS OPEN-FILE REPORT 80-2044, 1980.

GEOLOGY AND GEOHYDROLOGY OF THE EAST TEXAS BASIN-A REPORT ON THE PROGRESS OF NUCLEAR WASTE ISOLATION FEASIBILITY STUDIES (1979): UNIVERSITY OF TEXAS, BUREAU OF ECONOMIC GEOLOGY GEOLOGICAL CIRCULAR 80-12, 1980.

GEOLOGY AND GEOHYDROLOGY OF THE EAST TEXAS BASIN-A REPORT ON THE PROGRESS OF NUCLEAR WASTE ISOLATION FEASIBILITY STUDIES (1980): UNIVERSITY OF TEXAS, BUREAU OF ECONOMIC GEOLOGY GEOLOGICAL CIRCULAR 81-7, 1981. 
TEXAS GROUND-WATER RESOURCES, in NATIONAL WATER SUMMARY 1984: USGS WATER-SUPPLY PAPER 2275, 1985.

APPROXIMATE POTENTIOMETRIC SURFACES FOR THE AQUIFERS OF THE TEXAS COASTAL UPLANDS SYSTEM, 1980: USGS HYDROLOGIC INVESTIGATIONS ATLAS HA-704, 1987.

GEOHYDROLOGIC FRAMEWORK OF THE GULF COASTAL PLAIN: USGS HYDROLOGIC INVESTIGATIONS ATLAS HA-695, 1988.

EVALUATION OF WATER RESOURCES IN PART OF NORTH-CENTRAL TEXAS: TEXAS WATER DEVELOPMENT BOARD REPORT 318,1990 .

NATIONAL WATER-QUALITY ASSESSMENT PROGRAM-THE TRINITY RIVER BASIN: USGS OPEN-FILE REPORT 91-158, 1991.

PROPERTIES AND CHEMICAL CONSTITUENTS IN GROUND WATER FROM THE LOWER CLAIBORNE-UPPER WILCOX AQUIFER, GULF COAST REGIONAL AQUIFER SYSTEMS, SOUTH-CENTRAL UNITED STATES: USGS WATER-RESOURCES INVESTIGATIONS REPORT 92-4102, 1993.

PROPERTIES AND CHEMICAL CONSTITUENTS IN GROUND WATER FROM THE MIDDLE CLAIBORNE AQUIFER, GULF COAST REGIONAL AQUIFER SYSTEMS, SOUTH-CENTRAL UNITED STATES: USGS WATER-RESOURCES INVESTIGATIONS REPORT 92-4104, 1993.

PROPERTIES AND CHEMICAL CONSTITUENTS IN GROUND WATER FROM THE MIDDLE WILCOX AQUIFER, GULF COAST AQUIFER SYSTEMS, SOUTH-CENTRAL UNITED STATES: USGS WATERRESOURCES INVESTIGATIONS REPORT 93-4070, 1993.

NATIONAL WATER-QUALITY ASSESSMENT PROGRAM-PESTICIDES IN THE TRINITY RIVER BASIN STUDY UNIT, TEXAS, 1968-91: USGS FACT SHEET FS-088-95, 1995.

WATER-QUALITY ASSESSMENT OF THE TRINITY RIVER BASIN, TEXAS-DATA COLLECTION, 1992-95: USGS FACT SHEET FS-095-95, 1995.

WATER-QUALITY ASSESSMENT OF THE TRINITY RIVER BASIN, TEXAS-PESTICIDES IN A SUBURBAN WATERSHED, ARLINGTON, 1993-94: USGS FACT SHEET FS-159-95, 1995.

AQUIFERS OF TEXAS: TEXAS WATER DEVELOPMENT BOARD REPORT 345, 1995.

WATER QUALITY IN THE QUEEN CITY AQUIFER, EAST TEXAS: TEXAS WATER DEVELOPMENT BOARD HYDROLOGIC ATLAS NO. 6, 1996.

\section{HIDALGO COUNTY}

UNDERGROUND WATERS OF THE COASTAL PLAIN OF TEXAS: USGS WATER-SUPPLY AND IRRIGATION PAPER 190, 1907.

WATER TABLE SURVEY IN THE LOWER RIO GRANDE VALLEY, PART 5-HIDALGO COUNTY W.I.D. NO. 2 (WPA PROG. 1759): TEXAS BOARD OF WATER ENGINEERS MISCELLANEOUS PUBLICATION 170, 1937.

WATER TABLE SURVEY IN THE LOWER RIO GRANDE VALLEY, PART 3-DONNA IRRIGATION DISTRICT, HIDALGO COUNTY NO. 1 (WPA PROG. 1759): TEXAS BOARD OF WATER ENGINEERS MISCELLANEOUS PUBLICATION 172, 1937.
RECORDS OF WELLS, DRILLERS' LOGS, WATER ANALYSES, AND MAP SHOWING LOCATION OF WELLS IN HIDALGO COUNTY, TEXAS: TEXAS BOARD OF WATER ENGINEERS MISCELLANEOUS PUBLICATION 116, 1938.

RECORDS OF WELLS, DRILLERS' LOGS, WATER ANALYSES, AND MAP SHOWING LOCATION OF WELLS IN HIDALGO COUNTY, TEXAS: TEXAS BOARD OF WATER ENGINEERS MISCELLANEOUS PUBLICATION 117, 1941.

WATER SUPPLY, MISSION, TEXAS, NATIONAL DEFENSE AREA: USGS OPEN-FILE REPORT (UNNUMBERED), 1941.

GROUND-WATER RESOURCES OF HIDALGO COUNTY, TEXAS: USGS OPEN-FILE REPORT (UNNUMBERED), 1941.

GROUND WATER IN THE LOWER RIO GRANDE VALLEY: USGS OPEN-FILE REPORT (UNNUMBERED), 1945.

GROUND WATER IN THE LINN DISTRICT, NORTH-CENTRAL HIDALGO COUNTY, TEXAS: TEXAS BOARD OF WATER ENGINEERS MISCELLANEOUS PUBLICATION 117A, 1947.

LINN DISTRICT IN THE NORTH-CENTRAL PART OF HIDALGO COUNTY, TEXAS: USGS OPEN-FILE REPORT (UNNUMBERED), 1947.

WELL IRRIGATION IN THE LINN-FAYSVILLE DISTRICT IN NORTHCENTRAL HIDALGO COUNTY, TEXAS: USGS OPEN-FILE REPORT (UNNUMBERED), 1948.

MEMORANDUM TO THE TEXAS BOARD OF WATER ENGINEERS REGARDING THE EFFECT OF SEISMOGRAPH EXPLOSIONS ON WATER WELLS AND THE CONTAMINATION OF WATER SANDS BY DRAINAGE WELLS IN HIDALGO COUNTY, TEXAS: USGS OPEN-FILE REPORT (UNNUMBERED), 1948.

LA JOYA RESERVOIR SITE: USGS OPEN-FILE REPORT (UNNUMBERED), 1949.

OCCURRENCE AND DEVELOPMENT OF GROUND WATER IN THE LINN-FAYSVILLE AREA, HIDALGO COUNTY, TEXAS: TEXAS BOARD OF WATER ENGINEERS MISCELLANEOUS PUBLICATION 118,1949

PUBLIC WATER SUPPLIES IN SOUTHERN TEXAS: USGS WATERSUPPLY PAPER 1070, 1950.

AVAILABILITY OF GROUND WATER IN THE GULF COAST REGION OF TEXAS: USGS OPEN-FILE REPORT (UNNUMBERED), 1956

WATER LEVELS IN OBSERVATION WELLS IN CAMERON, HIDALGO, AND STARR COUNTIES, TEXAS, 1950-1959: TEXAS BOARD OF WATER ENGINEERS BULLETIN 6008, 1960.

GROUND-WATER RESOURCES OF THE LOWER RIO GRANDE VALLEY AREA, TEXAS: TEXAS BOARD OF WATER ENGINEERS BULLETIN 6014, V. 1, 1961.

GROUND-WATER RESOURCES OF THE LOWER RIO GRANDE VALLEY AREA, TEXAS: TEXAS BOARD OF WATER ENGINEERS BULLETIN 6014, V. 2, 1961.

SUMMARY OF THE GROUND-WATER AQUIFERS IN THE RIO GRANDE BASIN: TEXAS WATER COMMISSION CIRCULAR 63-05, 1963.

RECONNAISSANCE INVESTIGATION OF THE GROUND-WATER RESOURCES OF THE GULF COAST REGION, TEXAS: TEXAS WATER COMMISSION BULLETIN 6305, 1963. 
WATER-SUPPLY LIMITATIONS ON IRRIGATION FROM THE RIO GRANDE IN STARR, HIDALGO, CAMERON, AND WILLACY COUNTIES, TEXAS: TEXAS WATER COMMISSION BULLETIN 6413, 1964.

GROUND-WATER RESOURCES OF THE LOWER RIO GRANDE VALLEY AREA, TEXAS: USGS WATER-SUPPLY PAPER 1653, 1964.

APPENDICES TO BULLETIN 6413, WATER-SUPPLY LIMITATIONS ON IRRIGATION FROM THE RIO GRANDE IN STARR, HIDALGO, CAM ERON, AND WILLACY COUNTIES, TEXAS: TEXAS WATER COMMISSION BULLETIN 6413A, 1965.

RECONNAISSANCE INVESTIGATION OF THE GROUND-WATER RESOURCES OF THE RIO GRANDE BASIN, TEXAS: TEXAS WATER COMMISSION BULLETIN 6502, 1965.

RECONNAISSANCE INVESTIGATION OF GROUND WATER IN THE RIO GRANDE DRAINAGE BASIN-WITH SPECIAL EMPHASIS ON SALINE GROUND-WATER RESOURCES: USGS HYDROLOGIC INVESTIGATIONS ATLAS HA-510, 1974.

SUMMARY APPRAISALS OF THE NATION'S GROUND-WATER RESOURCES-TEXAS-GULF REGION: USGS PROFESSIONAL PAPER 813-F, 1976.

USE OF HYDROGEOLOGIC MAPPING TECHNIQUES IN IDENTIFYING POTENTIAL GEOPRESSURED-GEOTHERMAL RESERVOIRS IN THE LOWER RIO GRANDE EMBAYMENT, TEXAS: USGS REPRINT FROM THE THIRD GEOPRESSURED-GEOTHERMAL ENERGY CONFERENCE, UNIV. SOUTHWESTERN LOUISIANA, LAFAYETTE, LOUISIANA, NOVEMBER 16-18, 1977.

STRATIGRAPHIC AND HYDROGEOLOGIC FRAMEWORK OF PART OF THE COASTAL PLAIN OF TEXAS: TEXAS DEPARTMENT OF WATER RESOURCES REPORT 236, 1979.

SPRINGS OF TEXAS, VOLUME 1: (BY GUNNAR BRUNE), BRANCHSMITH, INC., FORT WORTH, TEXAS, 1981.

LAND-SURFACE SUBSIDENCE IN THE TEXAS COASTAL REGION: TEXAS DEPARTMENT OF WATER RESOURCES REPORT 272, 1982

WATER USE, PROJECTED WATER REQUIREMENTS, AND RELATED DATA AND INFORMATION FOR THE METROPOLITAN STATISTICAL AREAS IN TEXAS: TEXAS DEPARTMENT OF WATER RESOURCES LIMITED PRINTING REPORT LP-201, 1985.

TEXAS GROUND-WATER RESOURCES, in NATIONAL WATER SUMMARY 1984: USGS WATER-SUPPLY PAPER 2275, 1985.

HYDROGEOLOGY AND PREDEVELOPMENT FLOW IN THE TEXAS GULF COAST AQUIFER SYSTEMS: USGS WATER-RESOURCES INVESTIGATIONS REPORT 87-4248, 1988.

GEOHYDROLOGIC FRAMEWORK OF THE GULF COASTAL PLAIN: USGS HYDROLOGIC INVESTIGATIONS ATLAS HA-695, 1988.

EVALUATION OF GROUND-WATER RESOURCES IN THE LOWER RIO GRANDE VALLEY, TEXAS: TEXAS DEPARTMENT OF WATER RESOURCES REPORT 316, 1990.

GROUND-WATER FLOW IN THE GULF COAST AQUIFER SYSTEMS, SOUTH-CENTRAL UNITED STATES-A PRELIMINARY ANALYSIS: USGS WATER-RESOURCES INVESTIGATIONS REPORT 89-4071, 1990

HYDROLOGY OF THE TEXAS GULF COAST AQUIFER SYSTEMS: USGS OPEN-FILE REPORT 91-64, 1991.

PROPERTIES AND CHEMICAL CONSTITUENTS IN GROUND WATER FROM THE MISSISSIPPI RIVER VALLEY ALLUVIAL AQUIFER AND PERMEABLE ZONE A (HOLOCENE-UPPER PLEISTOCENE DEPOS-
ITS), SOUTH-CENTRAL UNITED STATES: USGS WATERRESOURCES INVESTIGATIONS REPORT 91-4149, 1992.

PROPERTIES AND CHEMICAL CONSTITUENTS IN GROUND WATER FROM THE UPPER CLAIBORNE AQUIFER, GULF COAST REGIONAL AQUIFER SYSTEMS, SOUTH-CENTRAL UNITED STATES: USGS WATER-RESOURCES INVESTIGATIONS REPORT 91-4150, 1993.

PROPERTIES AND CHEMICAL CONSTITUENTS IN GROUND WATER FROM PERMEABLE ZONE C (LOWER PLIOCENE-UPPER MIOCENE DEPOSITS), COASTAL LOWLANDS AQUIFER SYSTEM, SOUTHCENTRAL UNITED STATES: USGS WATER-RESOURCES INVESTIGATIONS REPORT 91-4151, 1993.

PROPERTIES AND CHEMICAL CONSTITUENTS IN GROUND WATER FROM PERMEABLE ZONE B (LOWER PLEISTOCENE-UPPER PLIOCENE DEPOSITS), COASTAL LOWLANDS AQUIFER SYSTEM, SOUTH-CENTRAL UNITED STATES: USGS WATER-RESOURCES INVESTIGATIONS REPORT 91-4152, 1993.

PROPERTIES AND CHEMICAL CONSTITUENTS IN GROUND WATER FROM PERMEABLE ZONE E (LOWER MIOCENE-UPPER OLIGOCENE DEPOSITS), COASTAL LOWLANDS AQUIFER SYSTEM, SOUTH-CENTRAL UNITED STATES: USGS WATER-RESOURCES INVESTIGATIONS REPORT 92-4103, 1993.

PROPERTIES AND CHEMICAL CONSTITUENTS IN GROUND WATER FROM PERMEABLE ZONE D (MIDDLE MIOCENE DEPOSITS), COASTAL LOWLANDS AQUIFER SYSTEM, SOUTH-CENTRAL UNITED STATES: USGS WATER-RESOURCES INVESTIGATIONS REPORT 92-4105, 1993.

AQUIFERS OF TEXAS: TEXAS WATER DEVELOPMENT BOARD REPORT 345, 1995.

WATER-QUALITY ASSESSMENT OF THE TRINITY RIVER BASIN, TEXAS-GROUND-WATER QUALITY OF THE TRINITY, CARRIZOWILCOX, AND GULF COAST AQUIFERS, FEBRUARY-AUGUST 1994: USGS WATER-RESOURCES INVESTIGATIONS REPORT 99-4233, 2000.

\section{HILL COUNTY}

GEOGRAPHY AND GEOLOGY OF THE BLACK AND GRAND PRAIRIES, TEXAS, WITH DETAILED DESCRIPTIONS OF THE CRETACEOUS FORMATIONS AND SPECIAL REFERENCE TO ARTESIAN WATERS: USGS 21ST ANNUAL REPORT, PART 7, 1901.

PUBLIC WATER SUPPLIES IN EASTERN TEXAS: USGS WATERSUPPLY PAPER 1047, 1948.

RECONNAISSANCE INVESTIGATION OF THE GROUND-WATER RESOURCES OF THE TRINITY RIVER BASIN, TEXAS: TEXAS WATER COMMISSION BULLETIN 6309, 1963.

RECONNAISSANCE INVESTIGATION OF THE GROUND-WATER RESOURCES OF THE BRAZOS RIVER BASIN, TEXAS: TEXAS WATER COMMISSION BULLETIN 6310, 1963.

GROUND-WATER AVAILABILITY AT WHITNEY, HILL COUNTY, TEXAS: TEXAS WATER COMMISSION LIMITED DISTRIBUTION REPORT LD-263-MR, 1963.

GROUND WATER IN THE FLOOD-PLAIN ALLUVIUM OF THE BRAZOS RIVER, WHITNEY DAM TO VICINITY OF RICHMOND, TEXAS: TEXAS WATER DEVELOPMENT BOARD REPORT 41, 1967. 
COMPILATION OF RESULTS OF AQUIFER TESTS IN TEXAS: TEXAS WATER DEVELOPMENT BOARD REPORT 98, 1969.

GROUND-WATER RESOURCES OF PART OF CENTRAL TEXAS WITH EMPHASIS ON THE ANTLERS AND TRAVIS PEAK FORMATIONS: TEXAS WATER DEVELOPMENT BOARD REPORT 195, V. 1, 1975.

GROUND-WATER RESOURCES OF PART OF CENTRAL TEXAS WITH EMPHASIS ON THE ANTLERS AND TRAVIS PEAK FORMATIONS: TEXAS WATER DEVELOPMENT BOARD REPORT 195, V. 2, 1976.

SUMMARY APPRAISALS OF THE NATION'S GROUND-WATER RESOURCES-TEXAS-GULF REGION: USGS PROFESSIONAL PAPER 813-F, 1976.

TEXAS GROUND-WATER RESOURCES, in NATIONAL WATER SUMMARY 1984: USGS WATER-SUPPLY PAPER 2275, 1985.

A HYDROGEOLOGIC ASSESSMENT OF THE OZAN FORMATION, CENTRAL TEXAS: BAYLOR GEOLOGICAL STUDIES (THESIS ABSTRACTS), BAYLOR UNIVERSITY, WACO, TEXAS, 1989.

A HYDROGEOLOGIC ASSESSMENT OF THE AUSTIN CHALK OUTCROP BELT, CENTRAL TEXAS: BAYLOR GEOLOGICAL STUDIES (THESIS ABSTRACTS), BAYLOR UNIVERSITY, WACO, TEXAS, 1989.

EVALUATION OF WATER RESOURCES IN PART OF CENTRAL TEXAS: TEXAS WATER DEVELOPMENT BOARD REPORT 319, 1990.

NATIONAL WATER-QUALITY ASSESSMENT PROGRAM-THE TRINITY RIVER BASIN: USGS OPEN-FILE REPORT 91-158, 1991.

NATIONAL WATER-QUALITY ASSESSMENT PROGRAM-PESTICIDES IN THE TRINITY RIVER BASIN STUDY UNIT, TEXAS, 1968-91: USGS FACT SHEET FS-088-95, 1995.

WATER-QUALITY ASSESSMENT OF THE TRINITY RIVER BASIN, TEXAS-DATA COLLECTION, 1992-95: USGS FACT SHEET FS-095-95, 1995.

WATER-QUALITY ASSESSMENT OF THE TRINITY RIVER BASIN, TEXAS-PESTICIDES IN A SUBURBAN WATERSHED, ARLINGTON, 1993-94: USGS FACT SHEET FS-159-95, 1995.

AQUIFERS OF TEXAS: TEXAS WATER DEVELOPMENT BOARD REPORT 345, 1995.

WATER QUALITY IN THE WOODBINE AQUIFER, NORTH-CENTRAL TEXAS: TEXAS WATER DEVELOPMENT BOARD HYDROLOGIC ATLAS NO. 4, 1996.

\section{HOCKLEY COUNTY}

GEOLOGY AND GROUND-WATER RESOURCES OF THE SOUTHERN HIGH PLAINS: USGS MANUSCRIPT REPORT (UNNUMBERED), 1935.

GROUND WATER IN THE SOUTHERN HIGH PLAINS: USGS OPENFILE REPORT (UNNUMBERED), 1937.

GROUND WATER IN THE HIGH PLAINS OF TEXAS: TEXAS BOARD OF WATER ENGINEERS OPEN-FILE REPORT (UNNUMBERED), 1938.

RECORDS OF WELLS, DRILLERS' LOGS, WATER ANALYSES, AND MAP SHOWING LOCATION OF WELLS IN HOCKLEY COUNTY, TEXAS: TEXAS BOARD OF WATER ENGINEERS MISCELLANEOUS PUBLICATION 126, 1940.
GROUND WATER IN THE HIGH PLAINS OF TEXAS: TEXAS BOARD OF WATER ENGINEERS MISCELLANEOUS PUBLICATION 119, 1940.

PROGRESS REPORT ON GROUND WATER IN THE HIGH PLAINS OF TEXAS: TEXAS BOARD OF WATER ENGINEERS MISCELLANEOUS PUBLICATION (UNNUMBERED), 1942.

PROGRESS REPORT ON GROUND WATER IN THE HIGH PLAINS OF TEXAS: TEXAS BOARD OF WATER ENGINEERS MISCELLANEOUS PUBLICATION 120, 1943.

PROGRESS REPORT ON GROUND WATER IN THE HIGH PLAINS OF TEXAS: TEXAS BOARD OF WATER ENGINEERS MISCELLANEOUS PUBLICATION 121, 1944.

GROUND WATER IN HIGH PLAINS OF TEXAS, PROGRESS REPORT NO. 5: TEXAS BOARD OF WATER ENGINEERS MISCELLANEOUS PUBLICATION 122, 1945.

GROUND WATER IN THE HIGH PLAINS OF TEXAS: USGS WATERSUPPLY PAPER 889-F, 1946.

GROUND WATER IN HIGH PLAINS OF TEXAS, PROGRESS REPORT NO. 6: TEXAS BOARD OF WATER ENGINEERS MISCELLANEOUS PUBLICATION 123, 1947.

GEOLOGY AND GROUND WATER IN THE IRRIGATED REGION OF THE SOUTHERN HIGH PLAINS IN TEXAS, PROGRESS REPORT NO. 7: TEXAS BOARD OF WATER ENGINEERS MISCELLANEOUS PUBLICATION 125, 1949.

COST OF PUMPING WATER FOR IRRIGATION, TEXAS HIGH PLAINS, FIELD INVESTIGATIONS-1947 IRRIGATION SEASON: TEXAS BOARD OF WATER ENGINEERS MISCELLANEOUS PUBLICATION 124, 1951.

DEVELOPMENT OF WELLS FOR IRRIGATION AND FLUCTUATION OF WATER LEVELS IN THE HIGH PLAINS OF TEXAS TO JANUARY 1951: TEXAS BOARD OF WATER ENGINEERS BULLETIN 5104, 1951.

PUBLIC WATER SUPPLIES IN WESTERN TEXAS: USGS WATERSUPPLY PAPER 1106, 1951 [1952].

LOGS OF WELLS AND TEST HOLES: REPORT BY CITY OF LUBBOCK, TEXAS, 1953.

SUMMARY OF GROUND-WATER DEVELOPMENT IN THE SOUTHERN HIGH PLAINS, TEXAS: TEXAS BOARD OF WATER ENGINEERS BULLETIN 5402, 1954.

RECORDS OF WATER-LEVEL MEASUREMENTS IN COCHRAN, CROSBY, GAINES, HOCKLEY, LYNN, AND TERRY COUNTIES, TEXAS: TEXAS BOARD OF WATER ENGINEERS BULLETIN 5407 , 1954.

GROUND-WATER DEVELOPMENT IN THE SOUTHERN HIGH PLAINS OF TEXAS, 1953: TEXAS BOARD OF WATER ENGINEERS BULLETIN 5410, 1954.

WATER-LEVEL DECLINE MAPS OF 16 COUNTIES IN THE SOUTHERN HIGH PLAINS, TEXAS, JANUARY 1954 TO JANUARY 1955: (BAILEY, BRISCOE, CASTRO, COCHRAN, CROSBY, DEAF SMITH, FLOYD, GAINES, HALE, HOCKLEY, LAMB, LUBBOCK, PARMER, RANDALL, SWISHER, AND TERRY): USGS OPEN-FILE REPORT, 1955.

WATER-LEVEL DECLINE MAPS OF 17 COUNTIES IN THE SOUTHERN HIGH PLAINS, TEXAS, JANUARY 1955 TO JANUARY 1956: TEXAS BOARD OF WATER ENGINEERS BULLETIN 5607, 1956. 
WATER-LEVEL DECLINE MAPS, 1956 TO 1957, AND WATER LEVELS IN OBSERVATION WELLS IN 20 COUNTIES IN THE SOUTHERN HIGH PLAINS, TEXAS: TEXAS BOARD OF WATER ENGINEERS BULLETIN 5705, 1957.

WATER-LEVEL MEASUREMENTS AND MAPS, SOUTHERN HIGH PLAINS, TEXAS, 1958 AND 1959: TEXAS BOARD OF WATER ENGINEERS BULLETIN 5908, 1959.

WATER LEVELS IN OBSERVATION WELLS, SOUTHERN HIGH PLAINS, TEXAS, 1959 AND 1960: TEXAS BOARD OF WATER ENGINEERS BULLETIN 6011, 1960.

WATER LEVELS IN OBSERVATION WELLS, SOUTHERN HIGH PLAINS, TEXAS, 1960 AND 1961: TEXAS BOARD OF WATER ENGINEERS BULLETIN 6101, 1961.

SHALLOW FORMATIONS AND AQUIFERS OF THE WEST TEXAS AREA: WEST TEXAS GEOLOGICAL SOCIETY PUBLICATION 61-45 AND PERMIAN BASIN GEOPHYSICAL SOCIETY, MIDLAND, TEXAS, 1961.

A SUMMARY OF THE OCCURRENCE AND DEVELOPMENT OF GROUND WATER IN THE SOUTHERN HIGH PLAINS OF TEXAS: TEXAS BOARD OF WATER ENGINEERS BULLETIN 6107, 1961.

WATER-LEVEL MEASUREMENTS THROUGH 1962 IN SELECTED OBSERVATION WELLS, SOUTHERN HIGH PLAINS, TEXAS: TEXAS WATER COMMISSION BULLETIN 6207, 1962.

RECONNAISSANCE INVESTIGATION OF THE GROUND-WATER RESOURCES OF THE BRAZOS RIVER BASIN, TEXAS: TEXAS WATER COMMISSION BULLETIN 6310, 1963.

A SUMMARY OF THE OCCURRENCE AND DEVELOPMENT OF GROUND WATER IN THE SOUTHERN HIGH PLAINS OF TEXAS, WITH A SECTION ON ARTIFICIAL RECHARGE STUDIES: USGS WATER-SUPPLY PAPER 1693, 1964.

WATER-LEVEL DATA FROM OBSERVATION WELLS IN THE SOUTHERN HIGH PLAINS OF TEXAS: TEXAS WATER DEVELOPMENT BOARD REPORT 21, 1966

RECONNAISSANCE INVESTIGATION OF THE GROUND-WATER RESOURCES OF THE COLORADO RIVER BASIN, TEXAS: TEXAS WATER DEVELOPMENT BOARD REPORT 51, 1967.

GROUND WATER IN THE OGALLALA FORMATION IN THE SOUTHERN HIGH PLAINS OF TEXAS AND NEW MEXICO: USGS HYDROLOGIC INVESTIGATIONS ATLAS HA-330, 1969.

COMPILATION OF RESULTS OF AQUIFER TESTS IN TEXAS: TEXAS WATER DEVELOPMENT BOARD REPORT 98, 1969.

WATER-LEVEL DATA FROM OBSERVATION WELLS IN THE SOUTHERN HIGH PLAINS OF TEXAS, 1965-70: TEXAS WATER DEVELOPMENT BOARD REPORT 121, 1970.

MAJOR AND HISTORICAL SPRINGS OF TEXAS: TEXAS WATER DEVELOPMENT BOARD REPORT 189, 1975.

SUMMARY APPRAISALS OF THE NATION'S GROUND-WATER RESOURCES-TEXAS-GULF REGION: USGS PROFESSIONAL PAPER 813-F, 1976.

ANALYTICAL STUDY OF THE OGALLALA AQUIFER IN HOCKLEY COUNTY, TEXAS-PROJECTIONS OF SATURATED THICKNESS, VOLUME OF WATER IN STORAGE, PUMPING RATES, PUMPING LIFTS, AND WELL YIELDS: TEXAS DEPARTMENT OF WATER RESOURCES REPORT 214, 1977.
WATER-LEVEL DATA FROM OBSERVATION WELLS IN THE SOUTHERN HIGH PLAINS OF TEXAS, 1971-77: TEXAS DEPARTMENT OF WATER RESOURCES REPORT 228, 1979.

PRELIMINARY DATA DESCRIBING THE DISTRIBUTION OF FLUORIDE AND SILICA IN THE OGALLALA AQUIFER ON THE HIGH PLAINS OF TEXAS: USGS OPEN-FILE REPORT 80-349, 1980

EVALUATING THE GROUND-WATER RESOURCES OF THE HIGH PLAINS OF TEXAS: RESULTS OF TEST HOLE DRILLING: TEXAS DEPARTMENT OF WATER RESOURCES LIMITED PRINTING REPORT LP-129, 1980.

EVALUATING THE GROUND-WATER RESOURCES OF THE HIGH PLAINS OF TEXAS: NEUTRON-PROBE MEASUREMENTS OF DEEP SOIL MOISTURE AS AN INDICATION OF AQUIFER RECHARGE RATES: TEXAS DEPARTMENT OF WATER RESOURCES LIMITED PRINTING REPORT LP-142, 1981.

SPRINGS OF TEXAS, VOLUME 1: (BY GUNNAR BRUNE), BRANCHSMITH, INC., FORT WORTH, TEXAS, 1981.

BEDROCK GEOLOGY, ALTITUDE OF BASE, AND 1980 SATURATED THICKNESS OF THE HIGH PLAINS AQUIFER IN PARTS OF COLORADO, KANSAS, NEBRASKA, NEW MEXICO, OKLAHOMA, SOUTH DAKOTA, TEXAS, AND WYOMING: USGS HYDROLOGIC INVESTIGATIONS ATLAS HA-648, 1981.

WATER LEVEL AND SATURATED THICKNESS CHANGES, PREDEVELOPMENT TO 1980, IN THE HIGH PLAINS AQUIFER IN PARTS OF COLORADO, KANSAS, NEBRASKA, NEW MEXICO, OKLAHOMA, SOUTH DAKOTA, TEXAS, AND WYOMING: USGS HYDROLOGIC INVESTIGATIONS ATLAS HA-652, 1981

DISSOLVED SOLIDS AND SODIUM IN WATER FROM THE HIGH PLAINS AQUIFER IN PARTS OF COLORADO, KANSAS, NEBRASKA, NEW MEXICO, OKLAHOMA, SOUTH DAKOTA, TEXAS, AND WYOMING: USGS HYDROLOGIC INVESTIGATIONS ATLAS HA-658, 1982.

EVALUATING THE GROUND-WATER RESOURCES OF THE HIGH PLAINS OF TEXAS, VOLUME 1: TEXAS DEPARTMENT OF WATER RESOURCES REPORT 288, V. 1, 1984.

EVALUATING THE GROUND-WATER RESOURCES OF THE HIGH PLAINS OF TEXAS, VOLUME 4, RECORDS OF WELLS, AND MAPS SHOWING WELL LOCATIONS, BASE OF AQUIFER, WATER LEVELS, AND SATURATED THICKNESS (ANDREWS, BORDEN, COCHRAN, DAWSON, ECTOR, GAINES, GARZA, GLASSCOCK, HOWARD, HOCKLEY, LUBBOCK, LYNN, MARTIN, MIDLAND, TERRY, AND YOAKUM COUNTIES: TEXAS DEPARTMENT OF WATER RESOURCES REPORT 288 V. 4, 1984.

GEOHYDROLOGY OF THE HIGH PLAINS AQUIFER IN PARTS OF COLORADO, KANSAS, NEBRASKA, NEW MEXICO, OKLAHOMA, SOUTH DAKOTA, TEXAS, AND WYOMING: USGS PROFESSIONAL PAPER 1400-B, 1984.

TEXAS GROUND-WATER RESOURCES, in NATIONAL WATER SUMMARY 1984: USGS WATER-SUPPLY PAPER 2275, 1985.

DIGITAL SIMULATION OF GROUND-WATER FLOW IN THE HIGH PLAINS AQUIFER IN PARTS OF COLORADO, KANSAS, NEBRASKA, NEW MEXICO, OKLAHOMA, SOUTH DAKOTA, TEXAS, AND WYOMING: USGS PROFESSIONAL PAPER 1400-D, 1986.

HYDROLOGIC ATLAS FOR HOCKLEY COUNTY, TEXAS: HIGH PLAINS UNDERGROUND WATER CONSERVATION DISTRICT NO. 1, LUBBOCK, TEXAS, 1987. 
SUMMARY OF THE HIGH PLAINS REGIONAL AQUIFER-SYSTEM ANALYSIS IN PARTS OF COLORADO, KANSAS, NEBRASKA, NEW MEXICO, OKLAHOMA, SOUTH DAKOTA, TEXAS, AND WYOMING: USGS PROFESSIONAL PAPER 1400-A, 1988.

HYDROGEOLOGY AND HYDROCHEMISTRY OF CRETACEOUS AQUIFERS, TEXAS PANHANDLE AND EASTERN NEW MEXICO: UNIVERSITY OF TEXAS, BUREAU OF ECONOMIC GEOLOGY GEOLOGICAL CIRCULAR 88-3, 1988.

HYDROGEOLOGY OF LOWER CRETACEOUS STRATA UNDER THE SOUTHERN HIGH PLAINS OF TEXAS AND NEW MEXICO: TEXAS WATER DEVELOPMENT BOARD REPORT 314, 1989.

PUBLIC SUPPLY GROUND-WATER USE IN THE SOUTHERN HIGH PLAINS OF TEXAS: TEXAS WATER DEVELOPMENT BOARD REPORT 328, 1990

ORIGIN OF SOLUTES IN SALINE LAKES AND SPRINGS ON THE SOUTHERN HIGH PLAINS OF TEXAS AND NEW MEXICO, in GEOLOGIC FRAMEWORK AND REGIONAL HYDROLOGY: UPPER CENOZOIC BLACKWATER DRAW AND OGALLALA FORMATIONS, GREAT PLAINS: UNIVERSITY OF TEXAS, BUREAU OF ECONOMIC GEOLOGY SYMPOSIUM, LUBBOCK, TEXAS, OCTOBER 1-4, 1987, 1990.

WATER-LEVEL CHANGES IN THE HIGH PLAINS AQUIFER OF TEXAS, 1980-1990: TEXAS WATER DEVELOPMENT BOARD HYDROLOGIC ATLAS NO. 1, 1991.

RADON 222 IN THE GROUND WATER SURROUNDING THE ANTON LAKE BASIN, HOCKLEY COUNTY, SOUTHERN HIGH PLAINS OF TEXAS: TEXAS STATE SECTION OF THE AMERICAN WATER RESOURCES ASSOCIATION, TRIGG TWICHELL SYMPOSIUM, FALL MEETING, NOVEMBER 8, 1991, AUSTIN, TEXAS, 1991.

WATER-RESOURCES DATA, TEXAS, WATER YEAR 1991, VOLUME 4, GROUND-WATER DATA: USGS WATER-DATA REPORT TX-91-4, 1992.

THE HIGH PLAINS AQUIFER SYSTEM OF TEXAS, 1980-1990. OVERVIEW AND PROJECTIONS: TEXAS WATER DEVELOPMENT BOARD REPORT 341, 1993.

WATER-QUALITY EVALUATION OF THE OGALLALA AQUIFER, TEXAS: TEXAS WATER DEVELOPMENT BOARD REPORT 342, 1993.

WATER-RESOURCES DATA, TEXAS, WATER YEAR 1992, VOLUME 4, GROUND-WATER DATA: USGS WATER-DATA REPORT TX-92-4, 1993.

WATER-LEVEL CHANGES IN THE HIGH PLAINS AQUIFER-PREDEVELOPMENT TO 1992: USGS WATER-RESOURCES INVESTIGATIONS REPORT 94-4027, 1994.

WATER-RESOURCES DATA, TEXAS, WATER YEAR 1993, VOLUME 4 GROUND-WATER DATA: USGS WATER-DATA REPORT TX-93-4, 1994.

WATER-LEVEL CHANGES IN THE HIGH PLAINS AQUIFER, 1980 TO 1994: USGS FACT SHEET FS-215-95, 1995.

AQUIFERS OF TEXAS: TEXAS WATER DEVELOPMENT BOARD REPORT 345, 1995.

HYDROLOGIC ATLAS FOR HOCKLEY COUNTY, TEXAS: HIGH PLAINS UNDERGROUND WATER CONSERVATION DISTRICT NO. 1, LUBBOCK, TEXAS, 1996.

WATER-LEVEL CHANGES IN THE HIGH PLAINS AQUIFER, 1980 TO 1995: USGS FACT SHEET FS-068-97, 1997.
WATER-LEVEL CHANGES IN THE HIGH PLAINS AQUIFER-PREDEVELOPMENT TO 1995: USGS WATER-RESOURCES INVESTIGATIONS REPORT 97-4081, 1997.

UPDATED WATER-QUALITY EVALUATION OF THE OGALLALA AQUIFER INCLUDING SELECTED METALLIC AND NON-METALLIC INORGANIC CONSTITUENTS: TEXAS WATER DEVELOPMENT BOARD HYDROLOGIC ATLAS NO. 10, 1998.

\section{HOOD COUNTY}

GEOGRAPHY AND GEOLOGY OF THE BLACK AND GRAND PRAIRIES, TEXAS, WITH DETAILED DESCRIPTIONS OF THE CRETACEOUS FORMATIONS AND SPECIAL REFERENCE TO ARTESIAN WATERS: USGS 21ST ANNUAL REPORT, PART 7, 1901.

GROUND-WATER RESOURCES IN SELECTED AREAS IN ERATH, HOOD, AND HAMILTON COUNTIES, TEXAS: USGS OPEN-FILE REPORT (UNNUMBERED), 1942.

PUBLIC WATER SUPPLIES IN CENTRAL AND NORTH-CENTRAL TEXAS: USGS WATER-SUPPLY PAPER 1069, 1949.

RECONNAISSANCE INVESTIGATION OF THE GROUND-WATER RESOURCES OF THE BRAZOS RIVER BASIN, TEXAS: TEXAS WATER COMMISSION BULLETIN 6310, 1963.

MAJOR AND HISTORICAL SPRINGS OF TEXAS: TEXAS WATER DEVELOPMENT BOARD REPORT 189, 1975.

GROUND-WATER RESOURCES OF PART OF CENTRAL TEXAS WITH EMPHASIS ON THE ANTLERS AND TRAVIS PEAK FORMATIONS: TEXAS WATER DEVELOPMENT BOARD REPORT 195, V. 1, 1975.

GROUND-WATER RESOURCES OF PART OF CENTRAL TEXAS WITH EMPHASIS ON THE ANTLERS AND TRAVIS PEAK FORMATIONS: TEXAS WATER DEVELOPMENT BOARD REPORT 195, V. 2, 1976.

WATER-LEVEL AND WATER-QUALITY DATA FROM OBSERVATION WELLS IN NORTHEAST TEXAS: TEXAS WATER DEVELOPMENT BOARD REPORT 198, 1976.

SUMMARY APPRAISALS OF THE NATION'S GROUND-WATER RESOURCES-TEXAS-GULF REGION: USGS PROFESSIONAL PAPER 813-F, 1976.

SPRINGS OF TEXAS, VOLUME 1: (BY GUNNAR BRUNE), BRANCHSMITH, INC., FORT WORTH, TEXAS, 1981.

OCCURRENCE, AVAILABILITY, AND CHEMICAL QUALITY OF GROUND WATER IN THE CRETACEOUS AQUIFERS OF NORTHCENTRAL TEXAS: TEXAS DEPARTMENT OF WATER RESOURCES REPORT 269, V. 1, 1982.

OCCURRENCE, AVAILABILITY, AND CHEMICAL QUALITY OF GROUND WATER IN THE CRETACEOUS AQUIFERS OF NORTHCENTRAL TEXAS: TEXAS DEPARTMENT OF WATER RESOURCES REPORT 269, V. 2, 1982.

TEXAS GROUND-WATER RESOURCES, in NATIONAL WATER SUMMARY 1984: USGS WATER-SUPPLY PAPER 2275, 1985.

EVALUATION OF WATER RESOURCES IN PART OF NORTH-CENTRAL TEXAS: TEXAS WATER DEVELOPMENT BOARD REPORT 318, 1990.

GROUND-WATER QUALITY MONITORING OF THE TRINITY AQUIFER IN THE VICINITY OF ERATH COUNTY: TEXAS WATER DEVELOPMENT BOARD REPORT 331, 1991. 
HYDROGEOLOGIC ASSESSMENT OF SHALLOW GROUNDWATER FLOW SYSTEMS OF THE WALNUT FORMATION, CENTRAL TEXAS: (MASTER'S THESIS), BAYLOR GEOLOGICAL STUDIES (THESIS ABSTRACTS), BULLETIN 56, BAYLOR UNIVERSITY, WACO, TEXAS, 1995.

AQUIFERS OF TEXAS: TEXAS WATER DEVELOPMENT BOARD REPORT 345, 1995.

UPDATED EVALUATION OF WATER RESOURCES IN PART OF NORTH-CENTRAL TEXAS, 1990-1999: TEXAS WATER DEVELOPMENT BOARD REPORT 349, 1999.

WATER-RESOURCES DATA, TEXAS, WATER YEAR 2000, VOLUME 6, GROUND-WATER DATA: USGS WATER-DATA REPORT TX-00-6, 2001.

\section{HOPKINS COUNTY}

NATURAL MINERAL WATERS OF THE UNITED STATES: USGS 14TH ANNUAL REPORT, 1894.

GEOLOGY AND UNDERGROUND WATERS OF NORTHEASTERN TEXAS: USGS WATER-SUPPLY PAPER 276, 1911.

RECORDS OF WELLS, SPRINGS, DRILLERS' LOGS, WATER ANALYSES, AND MAP SHOWING LOCATION OF WELLS AND SPRINGS IN HOPKINS COUNTY, TEXAS: TEXAS BOARD OF WATER ENGINEERS MISCELLANEOUS PUBLICATION 127, 1943.

RECONNAISSANCE INVESTIGATION OF THE GROUND-WATER RESOURCES OF THE RED RIVER, SULPHUR RIVER, AND CYPRESS CREEK BASINS, TEXAS: TEXAS WATER COMMISSION BULLETIN 6306, 1963.

RECONNAISSANCE INVESTIGATION OF THE GROUND-WATER RESOURCES OF THE SABINE RIVER BASIN, TEXAS: TEXAS WATER COMMISSION BULLETIN 6307, 1963.

MAJOR AND HISTORICAL SPRINGS OF TEXAS: TEXAS WATER DEVELOPMENT BOARD REPORT 189, 1975.

SUMMARY APPRAISALS OF THE NATION'S GROUND-WATER RESOURCES-TEXAS-GULF REGION: USGS PROFESSIONAL PAPER 813-F, 1976.

WATER-QUALITY DATA FOR AQUIFERS, STREAMS, AND LAKES IN THE VICINITY OF KEECHI, MOUNT SYLVAN, OAKWOOD, AND PALESTINE SALT DOMES, NORTHEAST TEXAS SALT-DOME BASIN: USGS OPEN-FILE REPORT 80-2037, 1980

GEOHYDROLOGY OF THE KEECHI, MOUNT SYLVAN, OAKWOOD, AND PALESTINE SALT DOMES IN THE NORTHEAST TEXAS SALTDOME BASIN: USGS OPEN-FILE REPORT 80-2044, 1980.

SPRINGS OF TEXAS, VOLUME 1: (BY GUNNAR BRUNE), BRANCHSMITH, INC., FORT WORTH, TEXAS, 1981.

GEOLOGY AND GEOHYDROLOGY OF THE EAST TEXAS BASIN-A REPORT ON THE PROGRESS OF NUCLEAR WASTE ISOLATION FEASIBILITY STUDIES (1979): UNIVERSITY OF TEXAS, BUREAU OF ECONOMIC GEOLOGY GEOLOGICAL CIRCULAR 80-12, 1980.

GEOLOGY AND GEOHYDROLOGY OF THE EAST TEXAS BASIN-A REPORT ON THE PROGRESS OF NUCLEAR WASTE ISOLATION FEASIBILITY STUDIES (1980): UNIVERSITY OF TEXAS, BUREAU OF ECONOMIC GEOLOGY GEOLOGICAL CIRCULAR 81-7, 1981.
APPROXIMATE POTENTIOMETRIC SURFACES FOR THE AQUIFERS OF THE TEXAS COASTAL UPLANDS SYSTEM, 1980: USGS HYDROLOGIC INVESTIGATIONS ATLAS HA-704, 1987.

GEOHYDROLOGIC FRAMEWORK OF THE GULF COASTAL PLAIN: USGS HYDROLOGIC INVESTIGATIONS ATLAS HA-695, 1988.

GROUND-WATER RESOURCES OF THE NACATOCH AQUIFER: TEXAS WATER DEVELOPMENT BOARD REPORT 305, 1988.

PROPERTIES AND CHEMICAL CONSTITUENTS IN GROUND WATER FROM THE LOWER CLAIBORNE-UPPER WILCOX AQUIFER, GULF COAST REGIONAL AQUIFER SYSTEMS, SOUTH-CENTRAL UNITED STATES: USGS WATER-RESOURCES INVESTIGATIONS REPORT 92-4102, 1993

PROPERTIES AND CHEMICAL CONSTITUENTS IN GROUND WATER FROM THE MIDDLE WILCOX AQUIFER, GULF COAST REGIONAL AQUIFER SYSTEMS, SOUTH-CENTRAL UNITED STATES: USGS WATER-RESOURCES INVESTIGATIONS REPORT 93-4070, 1993.

AQUIFERS OF TEXAS: TEXAS WATER DEVELOPMENT BOARD REPORT 345, 1995.

\section{HOUSTON COUNTY}

UNDERGROUND WATERS OF THE COASTAL PLAIN OF TEXAS: USGS WATER-SUPPLY PAPER 190, 1907.

GEOLOGY AND UNDERGROUND WATERS OF THE SOUTHEASTERN PART OF THE TEXAS COASTAL PLAIN: USGS WATER-SUPPLY PAPER 335, 1914.

RECONNAISSANCE INVESTIGATION OF THE GROUND-WATER RESOURCES OF THE NECHES RIVER BASIN, TEXAS: TEXAS WATER COMMISSION BULLETIN 6308, 1963,

RECONNAISSANCE INVESTIGATION OF THE GROUND-WATER RESOURCES OF THE TRINITY RIVER BASIN, TEXAS: TEXAS WATER COMMISSION BULLETIN 6309, 1963.

GROUND-WATER RESOURCES OF HOUSTON COUNTY, TEXAS: TEXAS WATER DEVELOPMENT BOARD REPORT 18, 1966.

HYDROLOGIC SIGNIFICANCE OF THE LITHOFACIES OF THE SPARTA SAND IN ARKANSAS, LOUISIANA, MISSISSIPPI, AND TEXAS: USGS PROFESSIONAL PAPER 569-A, 1968.

GEOHYDROLOGIC SIGNIFICANCE OF LITHOFACIES OF THE COCKFIELD FORMATION OF LOUISIANA AND MISSISSIPPI AND OF THE YEGUA FORMATION OF TEXAS: USGS PROFESSIONAL PAPER 569-B, 1970.

HYDROLOGIC SIGNIFICANCE OF LITHOFACIES OF THE CANE RIVER FORMATION OR EQUIVALENTS OF ARKANSAS, LOUISIANA, MISSISSIPPI, AND TEXAS: USGS PROFESSIONAL PAPER 569-C, 1972.

GEOHYDROLOGIC SIGNIFICANCE OF LITHOFACIES OF THE CARRIZO SAND OF ARKANSAS, LOUISIANA, AND TEXAS AND THE MERIDIAN SAND OF MISSISSIPPI: USGS PROFESSIONAL PAPER 569-D, 1975.

MAJOR AND HISTORICAL SPRINGS OF TEXAS: TEXAS WATER DEVELOPMENT BOARD REPORT 189, 1975.

SUMMARY APPRAISALS OF THE NATION'S GROUND-WATER RESOURCES-TEXAS-GULF REGION: USGS PROFESSIONAL PAPER 813-F, 1976. 
WATER-QUALITY DATA FOR AQUIFERS, STREAMS, AND LAKES IN THE VICINITY OF KEECHI, MOUNT SYLVAN, OAKWOOD, AND PALESTINE SALT DOMES, NORTHEAST TEXAS SALT-DOME BASIN: USGS OPEN-FILE REPORT 80-2037, 1980

GEOHYDROLOGY OF THE KEECHI, MOUNT SYLVAN, OAKWOOD, AND PALESTINE SALT DOMES IN THE NORTHEAST TEXAS SALTDOME BASIN: USGS OPEN-FILE REPORT 80-2044, 1980.

GEOLOGY AND GEOHYDROLOGY OF THE EAST TEXAS BASIN-A REPORT ON THE PROGRESS OF NUCLEAR WASTE ISOLATION FEASIBILITY STUDIES (1979): UNIVERSITY OF TEXAS, BUREAU OF ECONOMIC GEOLOGY GEOLOGICAL CIRCULAR 80-12, 1980.

GEOLOGY AND GEOHYDROLOGY OF THE EAST TEXAS BASIN-A REPORT ON THE PROGRESS OF NUCLEAR WASTE ISOLATION FEASIBILITY STUDIES (1980): UNIVERSITY OF TEXAS, BUREAU OF ECONOMIC GEOLOGY GEOLOGICAL CIRCULAR 81-7, 1981.

TEXAS GROUND-WATER RESOURCES, in NATIONAL WATER SUMMARY 1984: USGS WATER-SUPPLY PAPER 2275, 1985.

APPROXIMATE POTENTIOMETRIC SURFACES FOR THE AQUIFERS OF THE TEXAS COASTAL UPLANDS SYSTEM, 1980: USGS HYDROLOGIC INVESTIGATIONS ATLAS HA-704, 1987.

GEOHYDROLOGIC FRAMEWORK OF THE GULF COASTAL PLAIN: USGS HYDROLOGIC INVESTIGATIONS ATLAS HA-695, 1988

NATIONAL WATER-QUALITY ASSESSMENT PROGRAM-THE TRINITY RIVER BASIN: USGS OPEN-FILE REPORT 91-158, 1991.

PROPERTIES AND CHEMICAL CONSTITUENTS IN GROUND WATER FROM THE UPPER CLAIBORNE AQUIFER, GULF COAST REGIONAL AQUIFER SYSTEMS, SOUTH-CENTRAL UNITED STATES: USGS WATER-RESOURCES INVESTIGATIONS REPORT 91-4150, 1993.

PROPERTIES AND CHEMICAL CONSTITUENTS IN GROUND WATER FROM THE LOWER CLAIBORNE-UPPER WILCOX AQUIFER, GULF COAST REGIONAL AQUIFER SYSTEMS, SOUTH-CENTRAL UNITED STATES: USGS WATER-RESOURCES INVESTIGATIONS REPORT 92-4102, 1993

PROPERTIES AND CHEMICAL CONSTITUENTS IN GROUND WATER FROM THE MIDDLE CLAIBORNE AQUIFER, GULF COAST REGIONAL AQUIFER SYSTEMS, SOUTH-CENTRAL UNITED STATES: USGS WATER-RESOURCES INVESTIGATIONS REPORT 92-4104, 1993.

PROPERTIES AND CHEMICAL CONSTITUENTS IN GROUND WATER FROM THE MIDDLE WILCOX AQUIFER, GULF COAST REGIONAL AQUIFER SYSTEMS, SOUTH-CENTRAL UNITED STATES: USGS WATER-RESOURCES INVESTIGATIONS REPORT 93-4070, 1993.

NATIONAL WATER-QUALITY ASSESSMENT PROGRAM-PESTICIDES IN THE TRINITY RIVER BASIN STUDY UNIT, TEXAS, 1968-91: USGS FACT SHEET FS-088-95, 1995.

WATER-QUALITY ASSESSMENT OF THE TRINITY RIVER BASIN, TEXAS-DATA COLLECTION, 1992-95: USGS FACT SHEET FS-095-95, 1995.

WATER-QUALITY ASSESSMENT OF THE TRINITY RIVER BASIN, TEXAS-PESTICIDES IN A SUBURBAN WATERSHED, ARLINGTON, 1993-94: USGS FACT SHEET FS-159-95, 1995.

AQUIFERS OF TEXAS: TEXAS WATER DEVELOPMENT BOARD REPORT 345, 1995.
WATER QUALITY IN THE SPARTA AQUIFER, EAST TEXAS: TEXAS WATER DEVELOPMENT BOARD HYDROLOGIC ATLAS NO. 5, 1996.

WATER QUALITY IN THE QUEEN CITY AQUIFER, EAST TEXAS: TEXAS WATER DEVELOPMENT BOARD HYDROLOGIC ATLAS NO. 6, 1996.

\section{HOWARD COUNTY}

GROUND-WATER SUPPLY, CITY OF BIG SPRING, HOWARD COUNTY, TEXAS: USGS OPEN-FILE REPORT (UNNUMBERED), 1936.

MEMORANDUM; GROUND WATER IN HOWARD COUNTY, TEXAS: USGS OPEN-FILE REPORT (UNNUMBERED), 1937.

RECORDS OF WELLS, DRILLERS' LOGS, WATER-LEVEL MEASUREMENTS, WATER ANALYSES, AND MAP SHOWING LOCATION OF WELLS IN HOWARD COUNTY, TEXAS: TEXAS BOARD OF WATER ENGINEERS MISCELLANEOUS PUBLICATION 140, 1937.

WATER SUPPLY OF BIG SPRING, TEXAS: USGS OPEN-FILE REPORT (UNNUMBERED), 1942

GROUND-WATER SUPPLY OF BIG SPRING, TEXAS, PROGRESS REPORT: USGS OPEN-FILE REPORT (UNNUMBERED), 1943.

ADDITIONAL GROUND-WATER SUPPLIES FOR BIG SPRING, TEXAS: USGS OPEN-FILE REPORT (UNNUMBERED), 1943.

MEMORANDUM ON DRILLING PROGRAM AT BIG SPRING: USGS OPEN-FILE REPORT (UNNUMBERED), 1944.

WATER SUPPLY, CITY OF BIG SPRING, TEXAS: USGS OPEN-FILE REPORT (UNNUMBERED), 1944

GEOLOGY AND GROUND-WATER RESOURCES OF THE BIG SPRING AREA, TEXAS: USGS WATER-SUPPLY PAPER 913, 1944.

PROPOSED VETERANS HOSPITAL AT BIG SPRING, TEXAS: USGS OPEN-FILE REPORT (UNNUMBERED), 1945.

RESULTS OF TEST DRILLING BY CITY OF BIG SPRING IN 1944: USGS OPEN-FILE REPORT (UNNUMBERED), 1945.

PROGRESS REPORT ON WATER SUPPLY AT BIG SPRING, TEXAS: USGS OPEN-FILE REPORT (UNNUMBERED), 1945.

MEMORANDUM REGARDING RESISTIVITY PROBES AT LUBBOCK AND BIG SPRING, TEXAS: USGS OPEN-FILE REPORT (UNNUMBERED), 1946.

PROGRESS REPORT ON THE O'BARR WELL FIELD, BIG SPRING, TEXAS: USGS OPEN-FILE REPORT (UNNUMBERED), 1947.

SPEECH MADE AT GOVERNOR'S CONFERENCE-BIG SPRING, TEXAS: USGS OPEN-FILE REPORT (UNNUMBERED), 1948.

PUBLIC WATER SUPPLIES IN WESTERN TEXAS: USGS WATERSUPPLY PAPER 1106, 1951.

A SUMMARY OF THE OCCURRENCE AND DEVELOPMENT OF GROUND WATER IN THE SOUTHERN HIGH PLAINS OF TEXAS: TEXAS BOARD OF WATER ENGINEERS BULLETIN 6107, 1961.

BACTERIAL POLLUTION OF THE GROUND WATER IN THE BIG SPRING AREA, HOWARD COUNTY, TEXAS: TEXAS WATER COMMISSION LIMITED DISTRIBUTION REPORT LD-163-MR, 1963. 
INVESTIGATION OF GROUND-WATER CONTAMINATION IN THE VEALMOOR OIL FIELD, HOWARD AND BORDEN COUNTIES, TEXAS: TEXAS WATER COMMISSION LIMITED DISTRIBUTION REPORT LD-265, 1965.

RECONNAISSANCE INVESTIGATION OF THE GROUND-WATER RESOURCES OF THE COLORADO RIVER BASIN, TEXAS: TEXAS WATER DEVELOPMENT BOARD REPORT 51, 1967.

WATER-LEVEL DATA FROM OBSERVATION WELLS IN THE SOUTHERN HIGH PLAINS OF TEXAS, 1965-70: TEXAS WATER DEVELOPMENT BOARD REPORT 121, 1970.

WOODY PHREATOPHYTES ALONG THE COLORADO RIVER FROM SOUTHEAST RUNNELS COUNTY TO THE HEADWATERS IN BORDEN COUNTY, TEXAS: TEXAS WATER DEVELOPMENT BOARD REPORT 182, 1974.

MAJOR AND HISTORICAL SPRINGS OF TEXAS: TEXAS WATER DEVELOPMENT BOARD REPORT 189, 1975.

SUMMARY APPRAISALS OF THE NATION'S GROUND-WATER RESOURCES-TEXAS-GULF REGION: USGS PROFESSIONAL PAPER 813-F, 1976.

ANALYTICAL STUDY OF THE OGALLALA AQUIFER IN DAWSON AND BORDEN COUNTIES, TEXAS-PROJECTIONS OF SATURATED THICKNESS, VOLUME OF WATER IN STORAGE, PUMPAGE RATES, PUMPING LIFTS, AND WELL YIELDS: TEXAS DEPARTMENT OF WATER RESOURCES REPORT 225, 1978.

WATER-LEVEL DATA FROM OBSERVATION WELLS IN THE SOUTHERN HIGH PLAINS OF TEXAS, 1971-77: TEXAS DEPARTMENT OF WATER RESOURCES REPORT 228, 1979.

OCCURRENCE, AVAILABILITY, AND CHEMICAL QUALITY OF GROUND WATER IN THE EDWARDS PLATEAU REGION OF TEXAS: TEXAS DEPARTMENT OF WATER RESOURCES REPORT 235, 1979.

PRELIMINARY DATA DESCRIBING THE DISTRIBUTION OF FLUORIDE AND SILICA IN THE OGALLALA AQUIFER ON THE HIGH PLAINS OF TEXAS: USGS OPEN-FILE REPORT 80-349, 1980.

SOURCE AREAS OF SALINITY AND TRENDS OF SALT LOADS IN STREAMFLOW IN THE UPPER COLORADO RIVER, TEXAS: USGS OPEN-FILE REPORT 80-224, 1980.

EVALUATING THE GROUND-WATER RESOURCES OF THE HIGH PLAINS OF TEXAS: RESULTS OF TEST-HOLE DRILLING: TEXAS DEPARTMENT OF WATER RESOURCES LIMITED PRINTING REPORT LP-129, 1980.

SPRINGS OF TEXAS, VOLUME 1: (BY GUNNAR BRUNE), BRANCHSMITH, INC., FORT WORTH, TEXAS, 1981.

BEDROCK GEOLOGY, ALTITUDE OF BASE, AND 1980 SATURATED THICKNESS OF THE HIGH PLAINS AQUIFER IN PARTS OF COLORADO, KANSAS, NEBRASKA, NEW MEXICO, OKLAHOMA, SOUTH DAKOTA, TEXAS, AND WYOMING: USGS HYDROLOGIC INVESTIGATIONS ATLAS HA-648, 1981.

WATER LEVEL AND SATURATED THICKNESS CHANGES, PREDEVELOPMENT TO 1980, IN THE HIGH PLAINS AQUIFER IN PARTS OF COLORADO, KANSAS, NEBRASKA, NEW MEXICO, OKLAHOMA, SOUTH DAKOTA, TEXAS, AND WYOMING: USGS HYDROLOGIC INVESTIGATIONS ATLAS HA-652, 1981.

DISSOLVED SOLIDS AND SODIUM IN WATER FROM THE HIGH PLAINS AQUIFER IN PARTS OF COLORADO, KANSAS, NEBRASKA, NEW MEXICO, OKLAHOMA, SOUTH DAKOTA,
TEXAS, AND WYOMING: USGS HYDROLOGIC INVESTIGATIONS ATLAS HA-658, 1982.

EVALUATING THE GROUND-WATER RESOURCES OF THE HIGH PLAINS OF TEXAS, VOLUME 1: TEXAS DEPARTMENT OF WATER RESOURCES REPORT 288, V. 1, 1984.

EVALUATING THE GROUND-WATER RESOURCES OF THE HIGH PLAINS OF TEXAS, VOLUME 4, RECORDS OF WELLS AND MAPS SHOWING WELL LOCATIONS, BASE OF AQUIFER, WATER LEVELS, AND SATURATED THICKNESS (ANDREWS, BORDEN, COCHRAN, DAWSON, ECTOR, GAINES, GARZA, GLASSCOCK, HOWARD, HOCKLEY, LUBBOCK, LYNN, MARTIN, MIDLAND, TERRY, AND YOAKUM COUNTIES: TEXAS DEPARTMENT OF WATER RESOURCES REPORT 288 V. 4, 1984.

GEOHYDROLOGY OF THE HIGH PLAINS AQUIFER IN PARTS OF COLORADO, KANSAS, NEBRASKA, NEW MEXICO, OKLAHOMA, SOUTH DAKOTA, TEXAS, AND WYOMING: USGS PROFESSIONAL PAPER 1400-B, 1984.

TEXAS GROUND-WATER RESOURCES, in NATIONAL WATER SUMMARY 1984: USGS WATER-SUPPLY PAPER 2275, 1985.

DIGITAL SIMULATION OF GROUND-WATER FLOW IN THE HIGH PLAINS AQUIFER IN PARTS OF COLORADO, KANSAS, NEBRASKA, NEW MEXICO, OKLAHOMA, SOUTH DAKOTA, TEXAS, AND WYOMING: USGS PROFESSIONAL PAPER 1400-D, 1986.

SUMMARY OF THE HIGH PLAINS REGIONAL AQUIFER-SYSTEM ANALYSIS IN PARTS OF COLORADO, KANSAS, NEBRASKA, NEW MEXICO, OKLAHOMA, SOUTH DAKOTA, TEXAS, AND WYOMING: USGS PROFESSIONAL PAPER 1400-A, 1988.

HYDROGEOLOGY AND HYDROCHEMISTRY OF CRETACEOUS AQUIFERS, TEXAS PANHANDLE AND EASTERN NEW MEXICO: UNIVERSITY OF TEXAS, BUREAU OF ECONOMIC GEOLOGY GEOLOGICAL CIRCULAR 88-3, 1988.

HYDROGEOLOGY OF LOWER CRETACEOUS STRATA UNDER THE SOUTHERN HIGH PLAINS OF TEXAS AND NEW MEXICO: TEXAS WATER DEVELOPMENT BOARD REPORT 314, 1989.

POTENTIOMETRIC SURFACE OF THE EDWARDS-TRINITY AQUIFER SYSTEM AND CONTIGUOUS HYDRAULICALLY CONNECTED UNITS, WEST-CENTRAL TEXAS, WINTER 1974-75: USGS WATERRESOURCES INVESTIGATIONS REPORT 89-4208, 1990.

PUBLIC SUPPLY GROUND-WATER USE IN THE SOUTHERN HIGH PLAINS OF TEXAS: TEXAS WATER DEVELOPMENT BOARD REPORT 328, 1990.

WITHDRAWALS FROM THE EDWARDS-TRINITY AQUIFER SYSTEM AND CONTIGUOUS HYDRAULICALLY CONNECTED UNITS, WEST-CENTRAL TEXAS, DECEMBER 1974 THROUGH MARCH 1977: USGS WATER-RESOURCES INVESTIGATIONS REPORT 91-4021, 1991.

EVALUATION OF GROUND-WATER RESOURCES IN THE SOUTHERN HIGH PLAINS OF TEXAS: TEXAS WATER DEVELOPMENT BOARD REPORT 330, 1991.

WATER-LEVEL CHANGES IN THE HIGH PLAINS AQUIFER OF TEXAS, 1980-1990: TEXAS WATER DEVELOPMENT BOARD HYDROLOGIC ATLAS NO. 1, 1991.

CONFIGURATION OF THE BASE OF THE EDWARDS-TRINITY AQUIFER SYSTEM AND HYDROGEOLOGY OF THE UNDERLYING PRECRETACEOUS ROCKS, WEST-CENTRAL TEXAS: USGS WATERRESOURCES INVESTIGATIONS REPORT 91-4071, 1992. 
HISTORICAL POTENTIOMETRIC SURFACE OF THE EDWARDS-TRINITY AQUIFER SYSTEM AND CONTIGUOUS HYDRAULICALLY CONNECTED UNITS, WEST-CENTRAL TEXAS: USGS WATERRESOURCES INVESTIGATIONS REPORT 92-4055, 1993.

HISTORICAL SATURATED THICKNESS OF THE EDWARDS-TRINITY AQUIFER SYSTEM AND SELECTED CONTIGUOUS HYDRAULICALLY CONNECTED UNITS, WEST-CENTRAL TEXAS: USGS WATER-RESOURCES INVESTIGATIONS REPORT 92-4125, 1993.

THE HIGH PLAINS AQUIFER SYSTEM OF TEXAS, 1980-1990. OVERVIEW AND PROJECTIONS: TEXAS WATER DEVELOPMENT BOARD REPORT 341, 1993.

WATER-QUALITY EVALUATION OF THE OGALLALA AQUIFER, TEXAS: TEXAS WATER DEVELOPMENT BOARD REPORT 342, 1993.

SIMULATIONS OF FLOW IN THE EDWARDS-TRINITY AQUIFER SYSTEM AND CONTIGUOUS HYDRAULICALLY CONNECTED UNITS, WEST-CENTRAL TEXAS: USGS WATER-RESOURCES INVESTIGATIONS REPORT 93-4039, 1994.

DISSOLVED-SOLIDS CONCENTRATIONS AND HYDROCHEMICAL FACIES IN WATER OF THE EDWARDS-TRINITY AQUIFER SYSTEM, WEST-CENTRAL TEXAS: USGS WATER-RESOURCES INVESTIGATIONS REPORT 93-4126, 1994.

CHARACTERISTICS OF STREAMS AND AQUIFERS AND PROCESSES AFFECTING THE SALINITY OF WATER IN THE UPPER COLORADO RIVER BASIN, TEXAS: USGS WATER-RESOURCES INVESTIGATIONS REPORT 94-4036, 1994.

GEOLOGIC HISTORY AND HYDROGEOLOGIC SETTING OF THE EDWARDS-TRINITY AQUIFER SYSTEM, WEST-CENTRAL TEXAS: USGS WATER-RESOURCES INVESTIGATIONS REPORT 94-4039, 1994.

WATER QUALITY IN THE EDWARDS-TRINITY (PLATEAU) AQUIFER, EDWARDS PLATEAU AND TRANS-PECOS, TEXAS: TEXAS WATER DEVELOPMENT BOARD HYDROLOGIC ATLAS NO. 3, 1995.

WATER-LEVEL CHANGES IN THE HIGH PLAINS AQUIFER, 1980 TO 1994: USGS FACT SHEET FS-215-95, 1995.

WATER-LEVEL CHANGES IN THE HIGH PLAINS AQUIFER, 1980 TO 1995: USGS FACT SHEET FS-068-97, 1997.

UPDATED WATER-QUALITY EVALUATION OF THE OGALLALA AQUIFER INCLUDING SELECTED METALLIC AND NON-METALLIC INORGANIC CONSTITUENTS: TEXAS WATER DEVELOPMENT BOARD HYDROLOGIC INVESTIGATIONS ATLAS HA-10, 1998.

AN OVERVIEW OF THE EDWARDS-TRINITY AQUIFER SYSTEM, CENTRAL-WEST TEXAS, CHAPTER 8, in AQUIFERS OF WEST TEXAS: TEXAS WATER DEVELOPMENT BOARD REPORT 356, 2001.

\section{HUDSPETH COUNTY}

THERMAL SPRINGS IN THE UNITED STATES: USGS WATER-SUPPLY PAPER 679-B, 1937.

GROUND-WATER RESOURCES OF THE EL PASO AREA, TEXAS: USGS WATER-SUPPLY PAPER 919, 1945.

WELL IRRIGATION PROJECT OPENS ON DESERT NEAR SALT FLATS: USGS OPEN-FILE REPORT (UNNUMBERED), 1948.
GROUND-WATER RESOURCES OF THE EL PASO AREA, TEXAS, PROGRESS REPORT NO. 6: TEXAS BOARD OF WATER ENGINEERS MISCELLANEOUS PUBLICATION 79, 1949.

PROPOSED 6-YEAR PROGRAM OF GROUND-WATER INVESTIGATIONS IN THE TEXAS PORTION OF THE RIO GRANDE BASIN ABOVE FORT QUITMAN, INCLUDING THE CLOSED SALT FLAT BASIN IN HUDSPETH AND CULBERSON COUNTIES, TEXAS: USGS OPEN-FILE REPORT (UNNUMBERED), 1949.

DEVELOPMENT OF GROUND WATER FOR IRRIGATION IN THE DELL CITY AREA, HUDSPETH COUNTY, TEXAS: TEXAS BOARD OF WATER ENGINEERS BULLETIN 5004, 1950.

PUBLIC WATER SUPPLIES IN WESTERN TEXAS: USGS WATERSUPPLY PAPER 1106, 1951.

RECORDS OF WATER-LEVEL MEASUREMENTS IN CULBERSON, HUDSPETH, AND JEFF DAVIS COUNTIES, TEXAS: TEXAS BOARD OF WATER ENGINEERS BULLETIN 5415, 1954.

GROUND-WATER RESOURCES OF THE EL PASO AREA, TEXAS, PROGRESS REPORT NO. 7: TEXAS BOARD OF WATER ENGINEERS BULLETIN 5603, 1956.

WATER-LEVEL MEASUREMENTS IN CULBERSON, HUDSPETH, AND JEFF DAVIS COUNTIES, TEXAS: TEXAS BOARD OF WATER ENGINEERS BULLETIN 6005, 1960.

DEVELOPMENT OF GROUND WATER IN THE EL PASO DISTRICT, TEXAS, 1955-60, PROGRESS REPORT NO. 8: TEXAS WATER COMMISSION BULLETIN 6204, 1962.

SUMMARY OF THE GROUND-WATER AQUIFERS IN THE RIO GRANDE BASIN: TEXAS WATER COMMISSION CIRCULAR 63-05, 1963.

WATER LEVELS AND CHEMICAL ANALYSES FROM OBSERVATION WELLS IN THE DELL CITY AREA, HUDSPETH AND CULBERSON COUNTIES, TEXAS, 1948 THROUGH JANUARY 1964: TEXAS WATER COMMISSION CIRCULAR C64-01, 1964.

THERMAL SPRINGS OF THE UNITED STATES AND OTHER COUNTRIES OF THE WORLD—A SUMMARY: USGS PROFESSIONAL PAPER 492, 1965.

RECONNAISSANCE INVESTIGATION OF THE GROUND-WATER RESOURCES OF THE RIO GRANDE BASIN, TEXAS: TEXAS WATER COMMISSION BULLETIN 6502, 1965.

COMPILATION OF RESULTS OF AQUIFER TESTS IN TEXAS: TEXAS WATER DEVELOPMENT BOARD REPORT 98, 1969.

RECORDS OF WATER LEVELS AND CHEMICAL ANALYSES FROM SELECTED WELLS IN PARTS OF THE TRANS-PECOS REGION, TEXAS, 1965-68: TEXAS WATER DEVELOPMENT BOARD REPORT $114,1970$.

RECONNAISSANCE INVESTIGATION OF GROUND WATER IN THE RIO GRANDE DRAINAGE BASIN-WITH SPECIAL EMPHASIS ON SALINE GROUND-WATER RESOURCES: USGS HYDROLOGIC INVESTIGATIONS ATLAS HA-510, 1974.

EXPLORATION FOR FRESH GROUND WATER IN THE EAGLE MOUNTAINS AREA, HUDSPETH COUNTY AREA, TEXAS: in GEOLOGY OF THE EAGLE MOUNTAINS AND VICINITY: SOCIETY OF ECONOMIC PALEONTOLOGISTS AND MINERALOGISTS-PERMIAN BASIN SECTION, 1975.

MAJOR AND HISTORICAL SPRINGS OF TEXAS: TEXAS WATER DEVELOPMENT BOARD REPORT 189, 1975. 
TEST DRILLING FOR GROUND WATER IN HUDSPETH, CULBERSON, AND PRESIDIO COUNTIES IN WESTERNMOST TEXAS: USGS OPEN-FILE REPORT 76-338, 1976.

HYDROLOGIC INTERPRETATION OF GEOPHYSICAL DATA FROM THE SOUTHEASTERN HUECO BOLSON, EL PASO AND HUDSPETH COUNTIES, TEXAS: USGS OPEN-FILE REPORT 76-650, 1976.

AVAILABILITY OF FRESH AND SLIGHTLY SALINE GROUND WATER IN THE BASINS OF WESTERNMOST TEXAS: USGS OPEN-FILE REPORT 78-663, 1978.

GROUND-WATER DEVELOPMENT IN THE EL PASO REGION, TEXAS WITH EMPHASIS ON THE LOWER EL PASO VALLEY: TEXAS DEPARTMENT OF WATER RESOURCES REPORT 246, 1980.

AVAILABILITY OF FRESH AND SLIGHTLY SALINE GROUND WATER IN THE BASINS OF WESTERNMOST TEXAS: TEXAS DEPARTMENT OF WATER RESOURCES REPORT 256, 1980.

GROUND-WATER DATA FOR THE SALT BASIN, EAGLE FLAT, RED LIGHT DRAW, GREEN RIVER VALLEY, AND PRESIDIO BOLSON IN WESTERN TEXAS: TEXAS DEPARTMENT OF WATER RESOURCES REPORT 259, 1980

PLANNING REPORT FOR THE SOUTHWEST ALLUVIAL BASINS (EAST) REGIONAL AQUIFER SYSTEM ANALYSIS IN PARTS OF COLORADO, NEW MEXICO, AND TEXAS: USGS OPEN-FILE REPORT 80-564, 1980.

HYDROGEOLOGY OF THE NORTHERN SALT BASIN OF WEST TEXAS AND NEW MEXICO: UNIVERSITY OF TEXAS AT AUSTIN MASTER'S THESIS, 1982.

MAPS SHOWING GROUND-WATER UNITS AND WITHDRAWAL, BASIN AND RANGE PROVINCE, TEXAS: USGS WATERRESOURCES INVESTIGATIONS REPORT 83-4121-A, 1984.

MAPS SHOWING GROUND-WATER LEVELS, SPRINGS, AND DEPTH TO GROUND WATER, BASIN AND RANGE PROVINCE, TEXAS: USGS WATER-RESOURCES INVESTIGATIONS REPORT 83-4121-B, 1984.

MAPS SHOWING DISTRIBUTION OF DISSOLVED SOLIDS AND DOMINANT CHEMICAL TYPE IN GROUND WATER, BASIN AND RANGE PROVINCE, TEXAS: USGS WATER-RESOURCES INVESTIGATIONS REPORT 83-4121-C, 1984

TECTONIC CONTROLS ON THE HYDROGEOLOGY OF THE SALT BASIN, TRANS-PECOS TEXAS: in STRUCTURE AND TECTONICS OF TRANS-PECOS TEXAS: WEST TEXAS GEOLOGICAL SOCIETY FIELD TRIP CONFERENCE, 85-81, 1985.

TEXAS GROUND-WATER RESOURCES, in NATIONAL WATER SUMMARY 1984: USGS WATER-SUPPLY PAPER 2275, 1985.

SOUTHWEST ALLUVIAL-BASIN REGIONAL AQUIFER-SYSTEM STUDY IN PARTS OF COLORADO, NEW MEXICO, AND TEXAS, in REGIONAL AQUIFER-SYSTEM ANALYSIS PROGRAM OF THE U.S. GEOLOGICAL SURVEY-SUMMARY OF PROJECTS, 1978-84: USGS CIRCULAR 1002, 1986.

GEOHYDROLOGY OF THE SOUTHWEST ALLUVIAL BASINS, REGIONAL AQUIFER-SYSTEM ANALYSIS IN PARTS OF COLORADO, NEW MEXICO, AND TEXAS: USGS WATER-RESOURCES INVESTIGATIONS REPORT 84-4224, 1986.

HYDROGEOLOGY OF A GYPSUM PLAYA, NORTHERN SALT BASIN, TEXAS: UNIVERSITY OF TEXAS, BUREAU OF ECONOMIC GEOLOGY REPORT OF INVESTIGATIONS NO. 158, 1986.
RECORDS OF WELLS, WATER LEVELS, PUMPAGE, AND CHEMICAL ANALYSES FROM SELECTED WELLS IN PARTS OF THE TRANSPECOS REGION, TEXAS, 1968-1980: TEXAS WATER DEVELOPMENT BOARD REPORT 301, 1987.

PUBLIC SUPPLY GROUND-WATER USE IN WESTERN TEXAS: TEXAS WATER DEVELOPMENT BOARD REPORT 311, 1989.

INTEGRATION OF GROUND-WATER AND VADOSE-ZONE GEOCHEMISTRY TO INVESTIGATE HYDROCHEMICAL EVOLUTION-A CASE STUDY IN ARID LANDS OF THE NORTHERN CHIHUAHUAN DESERT, TRANS-PECOS TEXAS: UNIVERSITY OF TEXAS, BUREAU OF ECONOMIC GEOLOGY GEOLOGICAL CIRCULAR 90-5, 1990.

GEOLOGIC AND GEOHYDROLOGIC STUDIES NEAR FORT HANCOCK, TEXAS: RECENT INVESTIGATIONS OF THE PROPOSED SITE OF THE TEXAS LOW-LEVEL RADIOACTIVE WASTE REPOSITORY: WEST TEXAS GEOLOGICAL SOCIETY BULLETIN, V. 30, NO. 4, DECEMBER 1990

SATURATED-ZONE HYDROLOGY OF SOUTH-CENTRAL HUDSPETH COUNTY, TEXAS: in HYDROGEOLOGY OF TRANS-PECOS TEXAS: UNIVERSITY OF TEXAS, BUREAU OF ECONOMIC GEOLOGY GUIDEBOOK 25, 1990

UNSATURATED FLOW STUDIES AT THE PROPOSED TEXAS LOWLEVEL RADIOACTIVE WASTE RESPOSITORY: WEST TEXAS GEOLOGICAL SOCIETY BULLETIN, V. 30, NO. 8, APRIL 1991.

SATURATED-ZONE HYDROLOGY AND HYDROCHEMISTRY OF THE NORTHERN CHIHUAHUAN DESERT, TRANS-PECOS TEXAS: WEST TEXAS GEOLOGICAL SOCIETY BULLETIN, V. 30, NO. 9, MAY 1991.

GEOHYDROLOGY AND SIMULATION OF GROUND-WATER FLOW IN THE MESILLA BASIN, DONA ANA COUNTY, NEW MEXICO AND EL PASO COUNTY, TEXAS, WITH A SECTION ON WATER QUALITY AND GEOCHEMISTRY: USGS PROFESSIONAL PAPER 1407-C, 1992.

HYDROGEOLOGIC INVESTIGATIONS OF DEEP GROUND-WATER FLOW IN THE CHIHUAHUAN DESERT, TEXAS: UNIVERSITY OF TEXAS, BUREAU OF ECONOMIC GEOLOGY REPORT OF INVESTIGATIONS NO. 205, 1992.

GROUND-WATER HYDROLOGY AND HYDROCHEMISTRY OF EAGLE FLAT AND SURROUNDING AREA: UNIVERSITY OF TEXAS, BUREAU OF ECONOMIC GEOLOGY CONTRACT REPORT, PREPARED FOR TEXAS LOW-LEVEL RADIOACTIVE WASTE DISPOSAL AUTHORITY, 1994.

GROUND-WATER RESOURCES OF THE BONE SPRING-VICTORIO PEAK AQUIFER IN THE DELL VALLEY AREA, TEXAS: TEXAS WATER DEVELOPMENT BOARD REPORT 344, 1995.

AQUIFERS OF TEXAS: TEXAS WATER DEVELOPMENT BOARD REPORT 345, 1995.

DELINEATION OF THE GROUND-WATER FLOW SYSTEMS OF THE EAGLE FLAT AND RED LIGHT BASINS OF TRANS-PECOS TEXAS: THE UNIVERSITY OF TEXAS AT AUSTIN, DOCTORAL DISSERTATION, 1997.

EVALUATION OF POTENTIAL IMPACT OF THE APPLICATION OF BIOSOLIDS ON SURFACE-WATER AND GROUND-WATER RESOURCES IN THE VICINITY OF THE PINION RANCH, HUDSPETH COUNTY, TEXAS: LBG-GUYTON ASSOCIATES, CONTRACT REPORT PREPARED FOR THE ENVIRONMENTAL PROTECTION AND IMPROVEMENT COMPANY, INC., DENVILLE, NJ, 1997. 
AQUIFERS OF WEST TEXAS: TEXAS WATER DEVELOPMENT BOARD REPORT 356, 2001

EVALUATION OF GROUND-WATER RECHARGE IN BASINS OF TRANS-PECOS TEXAS, CHAPTER 3, in AQUIFERS OF WEST TEXAS: TEXAS WATER DEVELOPMENT BOARD REPORT 356, 2001.

REGIONAL GROUND-WATER FLOW SYSTEMS IN TRANS-PECOS TEXAS, CHAPTER 4, in AQUIFERS OF WEST TEXAS: TEXAS WATER DEVELOPMENT BOARD REPORT 356, 2001

THE HUECO BOLSON: AN AQUIFER AT THE CROSSROADS, CHAPTER 6, in AQUIFERS OF WEST TEXAS: TEXAS WATER DEVELOPMENT BOARD REPORT 356, 2001.

BONE SPRING-VICTORIO PEAK AQUIFER OF THE DELL VALLEY REGION OF TEXAS, CHAPTER 10, in AQUIFERS OF WEST TEXAS: TEXAS WATER DEVELOPMENT BOARD REPORT 356, 2001.

THE GEOLOGY AND HYDROGEOLOGY OF THE CAPITAN AQUIFER: A BRIEF OVERVIEW, CHAPTER 11, in AQUIFERS OF WEST TEXAS: TEXAS WATER DEVELOPMENT BOARD REPORT 356, 2001.

THE AQUIFERS OF RED LIGHT DRAW, GREEN RIVER VALLEY, AND EAGLE FLAT, CHAPTER 16, in AQUIFERS OF WEST TEXAS: TEXAS WATER DEVELOPMENT BOARD REPORT 356, 2001.

HYDROGEOLOGY OF THE SALT BASIN, CHAPTER 17, in AQUIFERS OF WEST TEXAS: TEXAS WATER DEVELOPMENT BOARD REPORT 356, 2001.

THE DIABLO PLATEAU AQUIFER, CHAPTER 18, in AQUIFERS OF WEST TEXAS: TEXAS WATER DEVELOPMENT BOARD REPORT $356,2001$.

\section{HUNT COUNTY}

GEOGRAPHY AND GEOLOGY OF THE BLACK AND GRAND PRAIRIES, TEXAS, WITH DETAILED DESCRIPTIONS OF THE CRETACEOUS FORMATIONS AND SPECIAL REFERENCE TO ARTESIAN WATERS: USGS 21ST ANNUAL REPORT, PART 7, 1901.

DEVELOPMENT OF GROUND WATER FOR PUBLIC SUPPLY AT COMMERCE, TEXAS: USGS OPEN-FILE REPORT (UNNUMBERED), 1944.

GROUND WATER IN THE GREENVILLE AREA, HUNT COUNTY, TEXAS: TEXAS BOARD OF WATER ENGINEERS MISCELLANEOUS PUBLICATION M96, 1945.

WATER-LEVEL MAPS AND WATER LEVELS IN OBSERVATION WELLS IN THE NORTH HIGH PLAINS, TEXAS: TEXAS BOARD OF WATER ENGINEERS BULLETIN 5707, 1957.

PUBLIC WATER SUPPLIES IN EASTERN TEXAS: USGS WATERSUPPLY PAPER 1047, 1948.

RECONNAISSANCE INVESTIGATION OF THE GROUND-WATER RESOURCES OF THE RED RIVER, SULPHUR RIVER, AND CYPRESS CREEK BASINS, TEXAS: TEXAS WATER COMMISSION BULLETIN 6306, 1963.

RECONNAISSANCE INVESTIGATION OF THE GROUND-WATER RESOURCES OF THE SABINE RIVER BASIN, TEXAS: TEXAS WATER COMMISSION BULLETIN 6307, 1963.

RECONNAISSANCE INVESTIGATION OF THE GROUND-WATER RESOURCES OF THE TRINITY RIVER BASIN, TEXAS: TEXAS WATER COMMISSION BULLETIN 6309, 1963.
COMPILATION OF RESULTS OF AQUIFER TESTS IN TEXAS: TEXAS WATER DEVELOPMENT BOARD REPORT 98, 1969.

WATER-LEVEL AND WATER-QUALITY DATA FROM OBSERVATION WELLS IN NORTHEAST TEXAS: TEXAS WATER DEVELOPMENT BOARD REPORT 198, 1976.

SUMMARY APPRAISALS OF THE NATION'S GROUND-WATER RESOURCES-TEXAS GULF REGION: USGS PROFESSIONAL PAPER 813-F, 1976.

SPRINGS OF TEXAS, VOLUME 1: (BY GUNNAR BRUNE), BRANCHSMITH, INC., FORT WORTH, TEXAS, 1981.

OCCURRENCE, AVAILABILITY, AND CHEMICAL QUALITY OF GROUND WATER IN THE CRETACEOUS AQUIFERS OF NORTHCENTRAL TEXAS: TEXAS DEPARTMENT OF WATER RESOURCES REPORT 269, V. 1, 1982.

OCCURRENCE, AVAILABILITY, AND CHEMICAL QUALITY OF GROUND WATER IN THE CRETACEOUS AQUIFERS OF NORTHCENTRAL TEXAS: TEXAS DEPARTMENT OF WATER RESOURCES REPORT 269, V. 2, 1982

TEXAS GROUND-WATER RESOURCES, in NATIONAL WATER SUMMARY 1984: USGS WATER-SUPPLY PAPER 2275, 1985.

GEOHYDROLOGIC FRAMEWORK OF THE GULF COASTAL PLAIN: USGS HYDROLOGIC INVESTIGATIONS ATLAS HA-695, 1988.

GROUND-WATER RESOURCES OF THE NACATOCH AQUIFER: TEXAS WATER DEVELOPMENT BOARD REPORT 305, 1988.

EVALUATION OF WATER RESOURCES IN PART OF NORTH-CENTRAL TEXAS: TEXAS WATER DEVELOPMENT BOARD REPORT 318,1990

NATIONAL WATER-QUALITY ASSESSMENT PROGRAM-THE TRINITY RIVER BASIN: USGS OPEN-FILE REPORT 91-158, 1991.

SIMULATION OF GROUND-WATER FLOW IN THE ANTLERS AQUIFER IN SOUTHEASTERN OKLAHOMA AND NORTHEASTERN TEXAS: USGS WATER-RESOURCES INVESTIGATIONS REPORT 88-4208, 1992.

NATIONAL WATER-QUALITY ASSESSMENT PROGRAM-PESTICIDES IN THE TRINITY RIVER BASIN STUDY UNIT, TEXAS, 1968-91: USGS FACT SHEET FS-088-95, 1995.

WATER-QUALITY ASSESSMENT OF THE TRINITY RIVER BASIN, TEXAS-DATA COLLECTION, 1992-95: USGS FACT SHEET FS-095-95, 1995.

WATER-QUALITY ASSESSMENT OF THE TRINITY RIVER BASIN, TEXAS-PESTICIDES IN A SUBURBAN WATERSHED, ARLINGTON, 1993-94: USGS FACT SHEET FS-159-95, 1995.

AQUIFERS OF TEXAS: TEXAS WATER DEVELOPMENT BOARD REPORT 345, 1995.

STRATIGRAPHIC NOMENCLATURE AND GEOLOGIC SECTIONS OF THE GULF COASTAL PLAIN OF TEXAS: USGS OPEN-FILE REPORT 94-461, 1995.

WATER QUALITY IN THE WOODBINE AQUIFER, NORTH-CENTRAL TEXAS: TEXAS WATER DEVELOPMENT BOARD HYDROLOGIC ATLAS NO. 4, 1996

UPDATED EVALUATION OF WATER RESOURCES IN PART OF NORTH-CENTRAL TEXAS, 1990-1999: TEXAS WATER DEVELOPMENT BOARD REPORT 349, 1999. 


\section{HUTCHINSON COUNTY}

THE GEOLOGY AND WATER RESOURCES OF THE EASTERN PORTION OF THE PANHANDLE OF TEXAS: USGS WATER-SUPPLY PAPER 154, 1906.

GEOLOGY AND GROUND-WATER RESOURCES OF THE SOUTHERN HIGH PLAINS: USGS OPEN-FILE REPORT (UNNUMBERED), 1935.

GROUND WATER IN THE HIGH PLAINS OF TEXAS: TEXAS BOARD OF WATER ENGINEERS MISCELLANEOUS PUBLICATION (UNNUMBERED), 1938.

GROUND WATER IN THE HIGH PLAINS OF TEXAS: TEXAS BOARD OF WATER ENGINEERS MISCELLANEOUS PUBLICATION 119, 1940.

ROGRESS REPORT ON GROUND WATER IN THE HIGH PLAINS OF TEXAS: TEXAS BOARD OF WATER ENGINEERS DUPLICATED REPORT (UNNUMBERED), 1942.

PROGRESS REPORT ON GROUND WATER IN THE HIGH PLAINS OF TEXAS: TEXAS BOARD OF WATER ENGINEERS MISCELLANEOUS PUBLICATION 120, 1943.

PROGRESS REPORT ON GROUND WATER IN THE HIGH PLAINS OF TEXAS: TEXAS BOARD OF WATER ENGINEERS MISCELLANEOUS PUBLICATION 121, 1944.

GROUND-WATER SUPPLY OF HERRING WELL FIELD OF DEFENSE PLANT CORPORATION NEAR STINNETT, HUTCHINSON COUNTY, TEXAS: USGS OPEN-FILE REPORT (UNNUMBERED), 1944.

GROUND WATER IN THE HIGH PLAINS OF TEXAS, PROGRESS REPORT NO. 5: TEXAS BOARD OF WATER ENGINEERS MISCELLANEOUS PUBLICATION 122, 1945.

GROUND WATER IN THE HIGH PLAINS OF TEXAS: USGS WATERSUPPLY PAPER 889-F, 1946.

GROUND WATER IN HIGH PLAINS OF TEXAS, PROGRESS REPORT NO. 6: TEXAS BOARD OF WATER ENGINEERS MISCELLANEOUS PUBLICATION 123, 1947.

COST OF PUMPING WATER FOR IRRIGATION, TEXAS HIGH PLAINS, FIELD INVESTIGATIONS-1947 IRRIGATION SEASON: TEXAS BOARD OF WATER ENGINEERS MISCELLANEOUS PUBLICATION $124,1951$.

PUBLIC WATER SUPPLIES IN WESTERN TEXAS: USGS WATERSUPPLY PAPER 1106, 1951 [1952].

DEVELOPMENT OF WELLS FOR IRRIGATION AND FLUCTUATION OF WATER LEVELS IN THE HIGH PLAINS OF TEXAS TO JANUARY 1951: TEXAS BOARD OF WATER ENGINEERS BULLETIN 5104, 1951

RECORDS OF WATER-LEVEL MEASUREMENTS IN DALLAM, HANSFORD, HARTLEY, HUTCHINSON, MOORE, OCHILTREE, AND SHERMAN COUNTIES, TEXAS: TEXAS BOARD OF WATER ENGINEERS BULLETIN 5404, 1954.

WATER-LEVEL MAPS AND WATER LEVELS IN OBSERVATION WELLS IN THE NORTH HIGH PLAINS, TEXAS: TEXAS BOARD OF WATER ENGINEERS BULLETIN 5707, 1957.

WATER-LEVEL MEASUREMENTS AND MAPS, NORTHERN HIGH PLAINS, TEXAS, 1958 AND 1959: TEXAS BOARD OF WATER ENGINEERS BULLETIN 5909, 1959.
WATER LEVELS IN OBSERVATION WELLS, NORTHERN HIGH PLAINS, TEXAS, 1958-1960: TEXAS BOARD OF WATER ENGINEERS BULLETIN 6012, 1960.

RECONNAISSANCE INVESTIGATION OF THE GROUND-WATER RESOURCES OF THE CANADIAN RIVER BASIN, TEXAS: TEXAS BOARD OF WATER ENGINEERS BULLETIN 6016, 1960.

ANNUAL WATER-LEVEL MEASUREMENTS IN OBSERVATION WELLS, NORTHERN HIGH PLAINS, TEXAS, 1960 AND 1961: TEXAS BOARD OF WATER ENGINEERS BULLETIN 6103, 1961.

GEOLOGY AND GROUND-WATER RESOURCES OF THE NORTHERN HIGH PLAINS OF TEXAS, PROGRESS REPORT NO. 1: TEXAS BOARD OF WATER ENGINEERS BULLETIN 6109, 1961.

ANNUAL WATER-LEVEL MEASUREMENTS IN OBSERVATION WELLS, NORTHERN HIGH PLAINS, TEXAS, 1961 AND 1962: TEXAS WATER COMMISSION BULLETIN 6213, 1962.

RECONNAISSANCE INVESTIGATION OF THE GROUND-WATER RESOURCES OF THE RED RIVER, SULPHUR RIVER, AND CYPRESS CREEK BASINS, TEXAS: TEXAS WATER COMMISSION BULLETIN 6306, 1963.

WATER-LEVEL DATA FROM OBSERVATION WELLS IN THE NORTHERN PANHANDLE OF TEXAS: TEXAS WATER DEVELOPMENT BOARD REPORT 137, 1971.

GROUND-WATER RESOURCES OF THE PALO DURO CREEK BASIN, TEXAS AND OKLAHOMA: USGS OPEN-FILE REPORT 79-209, 1979.

PRELIMINARY DATA DESCRIBING THE DISTRIBUTION OF FLUORIDE AND SILICA IN THE OGALLALA AQUIFER ON THE HIGH PLAINS OF TEXAS: USGS OPEN-FILE REPORT 80-349, 1980.

WATER-LEVEL DATA FROM OBSERVATION WELLS IN THE NORTHERN PANHANDLE OF TEXAS, 1972-78: TEXAS DEPARTMENT OF WATER RESOURCES REPORT 248, 1980.

WATER TABLE IN THE HIGH PLAINS AQUIFER IN 1978 IN PARTS OF COLORADO, KANSAS, NEBRASKA, NEW MEXICO, OKLAHOMA, SOUTH DAKOTA, TEXAS, AND WYOMING: USGS HYDROLOGIC INVESTIGATIONS ATLAS HA-642, 1980.

EVALUATING THE GROUND-WATER RESOURCES OF THE HIGH PLAINS OF TEXAS: RESULTS OF TEST HOLE DRILLING: TEXAS DEPARTMENT OF WATER RESOURCES LIMITED PRINTING REPORT LP-129, 1980.

EVALUATING THE GROUND-WATER RESOURCES OF THE HIGH PLAINS OF TEXAS: RESULTS OF SURFACE ELECTRICAL RESISTIVITY: TEXAS DEPARTMENT OF WATER RESOURCES LIMITED PRINTING REPORT LP-130, 1980.

SPRINGS OF TEXAS, VOLUME 1: (BY GUNNAR BRUNE), BRANCHSMITH, INC., FORT WORTH, TEXAS, 1981.

BEDROCK GEOLOGY, ALTITUDE OF BASE, AND 1980 SATURATED THICKNESS OF THE HIGH PLAINS AQUIFER IN PARTS OF COLORADO, KANSAS, NEBRASKA, NEW MEXICO, OKLAHOMA, SOUTH DAKOTA, TEXAS, AND WYOMING: USGS HYDROLOGIC INVESTIGATIONS ATLAS HA-648, 1981.

WATER-LEVEL AND SATURATED-THICKNESS CHANGES, PREDEVELOPMENT TO 1980, IN THE HIGH PLAINS AQUIFER IN PARTS OF COLORADO, KANSAS, NEBRASKA, NEW MEXICO, OKLAHOMA, SOUTH DAKOTA, TEXAS, AND WYOMING: USGS HYDROLOGIC INVESTIGATIONS ATLAS HA-652, 1981.

ANALYTICAL STUDY OF THE OGALLALA AQUIFER IN HEMPHILL COUNTY, TEXAS—PROJECTIONS OF SATURATED THICKNESS, 
VOLUME OF WATER IN STORAGE, PUMPAGE RATES, PUMPING LIFTS, AND WELL YIELDS: TEXAS DEPARTMENT OF WATER RESOURCES REPORT 267, 1982.

DISSOLVED SOLIDS AND SODIUM IN WATER FROM THE HIGH PLAINS AQUIFER IN PARTS OF COLORADO, KANSAS, NEBRASKA, NEW MEXICO, OKLAHOMA, SOUTH DAKOTA, TEXAS, AND WYOMING: USGS HYDROLOGIC INVESTIGATIONS ATLAS HA-658, 1982.

GEOHYDROLOGY OF THE HIGH PLAINS AQUIFER IN PARTS OF COLORADO, KANSAS, NEBRASKA, NEW MEXICO, OKLAHOMA, SOUTH DAKOTA, TEXAS, AND WYOMING: USGS PROFESSIONAL PAPER 1400-B, 1984

EVALUATING THE GROUND-WATER RESOURCES OF THE HIGH PLAINS OF TEXAS, VOLUME 1: TEXAS DEPARTMENT OF WATER RESOURCES REPORT 288, V. 1, 1984.

EVALUATING THE GROUND-WATER RESOURCES OF THE HIGH PLAINS OF TEXAS, VOLUME 2, RECORDS OF WELLS, AND MAPS SHOWING WELL LOCATIONS, BASE OF AQUIFER, WATER LEVELS, AND SATURATED THICKNESS (ARMSTRONG, CARSON, DALLAS, DONLEY, GRAY, HANSFORD, HARTLEY, HEMPHILL, HUTCHINSON, LIPSCOMB, MOORE, OCHILTREE, POTTER, ROBERTS, SHERMAN, AND WHEELER COUNTIES): TEXAS DEPARTMENT OF WATER RESOURCES REPORT 288, V. 2, 1984.

TEXAS GROUND-WATER RESOURCES, in NATIONAL WATER SUMMARY 1984: USGS WATER-SUPPLY PAPER 2275, 1985.

DIGITAL SIMULATION OF GROUND-WATER FLOW IN THE HIGH PLAINS AQUIFER IN PARTS OF COLORADO, KANSAS, NEBRASKA, NEW MEXICO, OKLAHOMA, SOUTH DAKOTA, TEXAS, AND WYOMING: USGS PROFESSIONAL PAPER 1400-D, 1986.

SUMMARY OF THE HIGH PLAINS REGIONAL AQUIFER-SYSTEM ANALYSIS IN PARTS OF COLORADO, KANSAS, NEBRASKA, NEW MEXICO, OKLAHOMA, SOUTH DAKOTA, TEXAS, AND WYOMING: USGS PROFESSIONAL PAPER 1400-A, 1988.

WATER-LEVEL CHANGES IN THE HIGH PLAINS AQUIFER OF TEXAS, 1980-1990: TEXAS WATER DEVELOPMENT BOARD HYDROLOGIC ATLAS NO. 1, 1991.

PUBLIC-SUPPLY GROUND-WATER USE IN THE NORTHERN HIGH PLAINS OF TEXAS: TEXAS WATER DEVELOPMENT BOARD REPORT 336, 1992

THE HIGH PLAINS AQUIFER SYSTEM OF TEXAS, 1980 TO 1990. OVERVIEW AND PROJECTIONS: TEXAS WATER DEVELOPMENT BOARD REPORT 341, 1993.

WATER-QUALITY EVALUATION OF THE OGALLALA AQUIFER, TEXAS: TEXAS WATER DEVELOPMENT BOARD REPORT 342, 1993.

WATER-LEVEL CHANGES IN THE HIGH PLAINS AQUIFER-PREDEVELOPMENT TO 1992: USGS WATER-RESOURCES INVESTIGATIONS REPORT 94-4027, 1994.

WATER-LEVEL CHANGES IN THE HIGH PLAINS AQUIFER, 1980 TO 1994: USGS FACT SHEET FS-215-95, 1995.

AQUIFERS OF TEXAS: TEXAS WATER DEVELOPMENT BOARD REPORT 345, 1995.

WATER-LEVEL CHANGES IN THE HIGH PLAINS AQUIFER, 1980 TO 1995: USGS FACT SHEET FS-068-97, 1997.
WATER-LEVEL CHANGES IN THE HIGH PLAINS AQUIFER-PREDEVELOPMENT TO 1995: USGS WATER-RESOURCES INVESTIGATIONS REPORT 97-4081, 1997.

PLAYAS AND RECHARGE OF THE OGALLALA AQUIFER ON THE SOUTHERN HIGH PLAINS OF TEXAS-AN EXAMINATION USING NUMERICAL TECHNIQUES: UNIVERSITY OF TEXAS, BUREAU OF ECONOMIC GEOLOGY REPORT OF INVESTIGATIONS NO. 242, 1997.

UPDATED WATER-QUALITY EVALUATION OF THE OGALLALA AQUIFER INCLUDING SELECTED METALLIC AND NON-METALLIC INORGANIC CONSTITUENTS: TEXAS WATER DEVELOPMENT BOARD HYDROLOGIC ATLAS NO. 10, 1998.

\section{IRION COUNTY}

RECORDS OF WELLS AND SPRINGS, DRILLERS' LOGS, WATER ANALYSES, AND MAP SHOWING LOCATIONS OF WELLS AND SPRINGS IN IRION COUNTY, TEXAS: TEXAS BOARD OF WATER ENGINEERS MISCELLANEOUS PUBLICATION 142, 1941.

PUBLIC WATER SUPPLIES IN WESTERN TEXAS: USGS WATERSUPPLY PAPER 1106, 1951.

RECONNAISSANCE INVESTIGATION OF THE GROUND-WATER RESOURCES OF THE COLORADO RIVER BASIN, TEXAS: TEXAS WATER DEVELOPMENT BOARD REPORT 51, 1967.

WATER WELL AND GROUND-WATER CHEMICAL ANALYSIS DATA, IRION COUNTY, TEXAS: TEXAS WATER DEVELOPMENT BOARD REPORT 146, 1972.

MAJOR AND HISTORICAL SPRINGS OF TEXAS: TEXAS WATER DEVELOPMENT BOARD REPORT 189, 1975.

SUMMARY APPRAISALS OF THE NATION'S GROUND-WATER RESOURCES-TEXAS-GULF REGION: USGS PROFESSIONAL PAPER 813-F, 1976.

OCCURRENCE, AVAILABILITY, AND CHEMICAL QUALITY OF GROUND WATER IN THE EDWARDS PLATEAU REGION OF TEXAS: TEXAS DEPARTMENT OF WATER RESOURCES REPORT 235,1979

TEXAS GROUND-WATER RESOURCES, in NATIONAL WATER SUMMARY 1984: USGS WATER-SUPPLY PAPER 2275, 1985.

PUBLIC SUPPLY GROUND-WATER USE IN WESTERN TEXAS: TEXAS WATER DEVELOPMENT BOARD REPORT 311, 1989.

POTENTIOMETRIC SURFACE OF THE EDWARDS-TRINITY AQUIFER SYSTEM AND CONTIGUOUS HYDRAULICALLY CONNECTED UNITS, WEST-CENTRAL TEXAS, WINTER 1974-75: USGS WATERRESOURCES INVESTIGATIONS REPORT 89-4208, 1990.

WITHDRAWALS FROM THE EDWARDS-TRINITY AQUIFER SYSTEM AND CONTIGUOUS HYDRAULICALLY CONNECTED UNITS, WEST-CENTRAL TEXAS, DECEMBER 1974 THROUGH MARCH 1977: USGS WATER-RESOURCES INVESTIGATIONS REPORT 91-4021, 1991.

CONFIGURATION OF THE BASE OF THE EDWARDS-TRINITY AQUIFER SYSTEM AND HYDROGEOLOGY OF THE UNDERLYING PRECRETACEOUS ROCKS, WEST-CENTRAL TEXAS: USGS WATERRESOURCES INVESTIGATIONS REPORT 91-4071, 1992.

HISTORICAL POTENTIOMETRIC SURFACE OF THE EDWARDS-TRINITY AQUIFER SYSTEM AND CONTIGUOUS HYDRAULICALLY 
CONNECTED UNITS, WEST-CENTRAL TEXAS: USGS WATERRESOURCES INVESTIGATIONS REPORT 92-4055, 1993.

HISTORICAL SATURATED THICKNESS OF THE EDWARDS-TRINITY AQUIFER SYSTEM AND SELECTED CONTIGUOUS HYDRAULICALLY CONNECTED UNITS, WEST-CENTRAL TEXAS: USGS WATER-RESOURCES INVESTIGATIONS REPORT 92-4125, 1993.

SIMULATIONS OF FLOW IN THE EDWARDS-TRINITY AQUIFER SYSTEM AND CONTIGUOUS HYDRAULICALLY CONNECTED UNITS, WEST-CENTRAL TEXAS: USGS WATER-RESOURCES INVESTIGATIONS REPORT 93-4039, 1994.

DISSOLVED-SOLIDS CONCENTRATIONS AND HYDROCHEMICAL FACIES IN WATER OF THE EDWARDS-TRINITY AQUIFER SYSTEM, WEST-CENTRAL TEXAS: USGS WATER-RESOURCES INVESTIGATIONS REPORT 93-4126, 1994.

GEOLOGIC HISTORY AND HYDROGEOLOGIC SETTING OF THE EDWARDS-TRINITY AQUIFER SYSTEM, WEST-CENTRAL TEXAS: USGS WATER-RESOURCES INVESTIGATIONS REPORT 94-4039, 1994.

AQUIFERS OF TEXAS: TEXAS WATER DEVELOPMENT BOARD REPORT 345, 1995.

WATER QUALITY IN THE EDWARDS-TRINITY (PLATEAU) AQUIFER, EDWARDS PLATEAU AND TRANS PECOS, TEXAS: TEXAS WATER DEVELOPMENT BOARD HYDROLOGIC ATLAS NO. 3, 1995.

AN OVERVIEW OF THE EDWARDS-TRINITY AQUIFER SYSTEM, CENTRAL-WEST TEXAS, CHAPTER 8, in AQUIFERS OF WEST TEXAS: TEXAS WATER DEVELOPMENT BOARD REPORT 356, 2001.

\section{JACK COUNTY}

GEOLOGY AND UNDERGROUND WATERS OF THE WICHITA REGION, NORTH-CENTRAL TEXAS: USGS WATER-SUPPLY PAPER $317,1913$.

GROUND WATER IN THE VICINITY OF JACKSBORO, JACK COUNTY, TEXAS: USGS OPEN-FILE REPORT (UNNUMBERED), 1947

RECONNAISSANCE INVESTIGATION OF THE GROUND-WATER RESOURCES OF THE TRINITY RIVER BASIN, TEXAS: TEXAS WATER COMMISSION BULLETIN 6309, 1963.

RECONNAISSANCE INVESTIGATION OF THE GROUND-WATER RESOURCES OF THE BRAZOS RIVER BASIN, TEXAS: TEXAS WATER COMMISSION BULLETIN 6310, 1963.

SUMMARY APPRAISALS OF THE NATION'S GROUND-WATER RESOURCES-TEXAS-GULF REGION: USGS PROFESSIONAL PAPER 813-F, 1976.

GROUND-WATER CONDITIONS IN THE VICINITY OF JACKSBORO, JACK COUNTY, TEXAS: TEXAS DEPARTMENT OF WATER RESOURCES LIMITED PRINTING REPORT LP-4, 1977.

TEXAS GROUND-WATER RESOURCES, in NATIONAL WATER SUMMARY 1984: USGS WATER-SUPPLY PAPER 2275, 1985.

OCCURRENCE AND QUALITY OF GROUND WATER IN JACK COUNTY, TEXAS: TEXAS WATER DEVELOPMENT BOARD REPORT 308, 1988.

EVALUATION OF WATER RESOURCES IN PART OF NORTH-CENTRAL TEXAS: TEXAS WATER DEVELOPMENT BOARD REPORT $318,1990$.
NATIONAL WATER-QUALITY ASSESSMENT PROGRAM-THE TRINITY RIVER BASIN: USGS OPEN-FILE REPORT 91-158, 1991.

EVALUATION OF WATER RESOURCES IN PARTS OF THE ROLLING PRAIRIES REGION OF NORTH-CENTRAL TEXAS: TEXAS WATER DEVELOPMENT BOARD REPORT 337, 1992.

NATIONAL WATER-QUALITY ASSESSMENT PROGRAM-PESTICIDES IN THE TRINITY RIVER BASIN STUDY UNIT, TEXAS, 1968-91: USGS FACT SHEET FS-088-95, 1995.

WATER-QUALITY ASSESSMENT OF THE TRINITY RIVER BASIN, TEXAS-DATA COLLECTION, 1992-95: USGS FACT SHEET FS-095-95, 1995.

WATER-QUALITY ASSESSMENT OF THE TRINITY RIVER BASIN, TEXAS-PESTICIDES IN A SUBURBAN WATERSHED, ARLINGTON, 1993-94: USGS FACT SHEET FS-159-95, 1995.

AQUIFERS OF TEXAS: TEXAS WATER DEVELOPMENT BOARD REPORT 345, 1995.

\section{JACKSON COUNTY}

UNDERGROUND WATERS OF THE COASTAL PLAIN OF TEXAS: USGS WATER-SUPPLY PAPER 190, 1907.

GROUND WATER IN JACKSON COUNTY, TEXAS: USGS OPEN-FILE REPORT (UNNUMBERED), 1934.

RECORDS OF WELLS, DRILLERS' LOGS, AND WATER ANALYSES, AND MAP SHOWING LOCATION OF WELLS IN JACKSON COUNTY, TEXAS: USGS OPEN-FILE REPORT (UNNUMBERED), 1935.

RECORDS OF WELLS, DRILLERS' LOGS, WATER ANALYSES, AND MAP SHOWING LOCATION OF WELLS IN JACKSON COUNTY, TEXAS: TEXAS BOARD OF WATER ENGINEERS MISCELLANEOUS PUBLICATION 144, 1943

PUBLIC WATER SUPPLIES IN EASTERN TEXAS: USGS WATERSUPPLY PAPER 1047, 1948

MEMORANDUM REGARDING AVAILABILITY OF GROUND WATER IN THE AREA NORTH OF THE GALVESTON, HARRISBURG, AND SAN ANTONIO RAILROAD IN JACKSON AND WHARTON COUNTIES: USGS OPEN-FILE REPORT (UNNUMBERED), 1950.

AVAILABILITY OF GROUND WATER IN THE GULF COAST REGION OF TEXAS: USGS OPEN-FILE REPORT (UNNUMBERED), 1956.

RECORDS OF WATER-LEVEL MEASUREMENTS IN JACKSON, MATAGORDA, AND WHARTON COUNTIES, TEXAS, 1934 TO APRIL 1958: TEXAS BOARD OF WATER ENGINEERS BULLETIN 5804, 1958.

RECONNAISSANCE INVESTIGATION OF THE GROUND-WATER RESOURCES OF THE GULF COAST REGION, TEXAS: TEXAS WATER COMMISSION BULLETIN 6305, 1963.

INVESTIGATION OF GROUND-WATER QUALITY IN THE AREA OF THE MAURITZ; MAURITZ, EAST; MAURITZ, WEST; LITTLE KENTUCKY; AND HARMON, SOUTH OIL FIELDS, JACKSON COUNTY, TEXAS: TEXAS WATER DEVELOPMENT BOARD OPENFILE/INTEROFFICE MEMORANDUM, 1965.

GROUND-WATER RESOURCES OF JACKSON COUNTY, TEXAS: TEXAS WATER DEVELOPMENT BOARD REPORT 1, 1965. 
HYDROLOGIC EFFECTS OF THE EARTHQUAKE OF MARCH 27, 1964, OUTSIDE ALASKA: USGS PROFESSIONAL PAPER 544-C, 1968.

GEOHYDROLOGIC SIGNIFICANCE OF LITHOFACIES OF THE COCKFIELD FORMATION OF LOUISIANA AND MISSISSIPPI AND OF THE YEGUA FORMATION OF TEXAS: USGS PROFESSIONAL PAPER 569-B, 1970.

EFFECTS OF GROUND-WATER DEVELOPMENT ON THE PROPOSED PALMETTO BEND DAM AND RESERVOIR IN SOUTHEAST TEXAS: USGS WATER-RESOURCES INVESTIGATIONS REPORT 18-73, 1973.

SUMMARY APPRAISALS OF THE NATION'S GROUND-WATER RESOURCES-TEXAS-GULF REGION: USGS PROFESSIONAL PAPER 813-F, 1976.

STRATIGRAPHIC AND HYDROGEOLOGIC FRAMEWORK OF PART OF THE COASTAL PLAIN OF TEXAS: USGS OPEN-FILE REPORT 77-712, 1978.

STRATIGRAPHIC AND HYDROGEOLOGIC FRAMEWORK OF PART OF THE COASTAL PLAIN OF TEXAS: TEXAS DEPARTMENT OF WATER RESOURCES REPORT 236, 1979.

LAND-SURFACE SUBSIDENCE IN THE TEXAS COASTAL REGION: USGS OPEN-FILE REPORT 80-969, 1980.

SPRINGS OF TEXAS, VOLUME 1: (BY GUNNAR BRUNE), BRANCHSMITH, INC., FORT WORTH, TEXAS, 1981.

LAND-SURFACE SUBSIDENCE IN THE TEXAS COASTAL REGION: TEXAS DEPARTMENT OF WATER RESOURCES REPORT 272, 1982.

REGIONAL HYDRODYNAMICS AND HYDROCHEMISTRY OF THE URANIUM-BEARING OAKVILLE AQUIFER (MIOCENE) OF SOUTH TEXAS: UNIVERSITY OF TEXAS, BUREAU OF ECONOMIC GEOLOGY REPORT OF INVESTIGATIONS NO. 124, 1982.

TEXAS GROUND-WATER RESOURCES, in NATIONAL WATER SUMMARY 1984: USGS WATER-SUPPLY PAPER 2275, 1985.

DIGITAL MODELS FOR SIMULATION OF GROUND-WATER HYDROLOGY OF THE CHICOT AND EVANGELINE AQUIFERS ALONG THE GULF COAST OF TEXAS: TEXAS DEPARTMENT OF WATER RESOURCES REPORT 289, 1985.

GEOHYDROLOGIC FRAMEWORK OF THE GULF COASTAL PLAIN: USGS HYDROLOGIC INVESTIGATIONS ATLAS HA-695, 1988.

HYDROGEOLOGY AND PREDEVELOPMENT FLOW IN THE TEXAS GULF COAST AQUIFER SYSTEMS: USGS WATER-RESOURCES INVESTIGATIONS REPORT 87-4248, 1988.

GROUND-WATER FLOW IN THE GULF COAST AQUIFER SYSTEMS SOUTH-CENTRAL UNITED STATES: USGS WATER-RESOURCES INVESTIGATIONS REPORT 89-4071, 1990.

SALT-DOME LOCATIONS IN THE GULF COASTAL PLAIN, SOUTHCENTRAL UNITED STATES: USGS WATER-RESOURCES INVESTIGATIONS REPORT 90-4060, 1990.

HYDROLOGY OF THE TEXAS GULF COAST AQUIFER SYSTEMS: USGS OPEN-FILE REPORT 91-64, 1991.

PROPERTIES AND CHEMICAL CONSTITUENTS IN GROUND WATER FROM THE MISSISSIPPI RIVER VALLEY ALLUVIAL AQUIFER AND PERMEABLE ZONE A (HOLOCENE-UPPER PLEISTOCENE DEPOSITS), SOUTH-CENTRAL UNITED STATES: USGS WATERRESOURCES INVESTIGATIONS REPORT 91-4149, 1992.
PROPERTIES AND CHEMICAL CONSTITUENTS IN GROUND WATER FROM THE UPPER CLAIBORNE AQUIFER, GULF COAST REGIONAL AQUIFER SYSTEMS, SOUTH-CENTRAL UNITED STATES: USGS WATER-RESOURCES INVESTIGATIONS REPORT 91-4150, 1993.

PROPERTIES AND CHEMICAL CONSTITUENTS IN GROUND WATER FROM PERMEABLE ZONE C (LOWER PLIOCENE-UPPER MIOCENE DEPOSITS), COASTAL LOWLANDS AQUIFER SYSTEM, SOUTHCENTRAL UNITED STATES: USGS WATER-RESOURCES INVESTIGATIONS REPORT 91-4151, 1993.

PROPERTIES AND CHEMICAL CONSTITUENTS IN GROUND WATER FROM PERMEABLE ZONE B (LOWER PLEISTOCENE-UPPER PLIOCENE DEPOSITS), COASTAL LOWLANDS AQUIFER SYSTEM, SOUTH-CENTRAL UNITED STATES: USGS WATER-RESOURCES INVESTIGATIONS REPORT 91-4152, 1993.

PROPERTIES AND CHEMICAL CONSTITUENTS IN GROUND WATER FROM PERMEABLE ZONE E (LOWER MIOCENE-UPPER OLIGOCENE DEPOSITS), COASTAL LOWLANDS AQUIFER SYSTEM, SOUTH-CENTRAL UNITED STATES: USGS WATER-RESOURCES INVESTIGATIONS REPORT 92-4103, 1993.

PROPERTIES AND CHEMICAL CONSTITUENTS IN GROUND WATER FROM PERMEABLE ZONE D (MIDDLE MIOCENE DEPOSITS), COASTAL LOWLANDS AQUIFER SYSTEM, SOUTH-CENTRAL UNITED STATES: USGS WATER-RESOURCES INVESTIGATIONS REPORT 92-4105, 1993.

PROPERTIES AND CHEMICAL CONSTITUENTS IN GROUND WATER FROM THE MIDDLE WILCOX AQUIFER, GULF COAST REGIONAL AQUIFER SYSTEMS, SOUTH-CENTRAL UNITED STATES: USGS WATER-RESOURCES INVESTIGATIONS REPORT 93-4070, 1993.

AQUIFERS OF TEXAS: TEXAS WATER DEVELOPMENT BOARD REPORT 345, 1995.

\section{JASPER COUNTY}

UNDERGROUND WATERS OF THE COASTAL PLAIN OF TEXAS: USGS WATER-SUPPLY PAPER 190, 1907.

GEOLOGY AND UNDERGROUND WATERS OF THE SOUTHEASTERN PART OF THE TEXAS COASTAL PLAIN: USGS WATER-SUPPLY PAPER 335, 1914.

MEMORANDUM ON THE WATER RESOURCES IN THE VICINITY OF JASPER, JASPER COUNTY, TEXAS: USGS OPEN-FILE REPORT (UNNUMBERED), 1941

GROUND-WATER RESOURCES IN THE VICINITY OF JASPER, JASPER COUNTY, TEXAS: USGS OPEN-FILE REPORT (UNNUMBERED), 1941.

MEMORANDUM TO MR. DEBUSK REGARDING GROUND WATER IN JASPER COUNTY: USGS OPEN-FILE REPORT (UNNUMBERED), 1941.

RECORDS OF WELLS, DRILLERS' LOGS, WATER ANALYSES, AND MAP SHOWING LOCATIONS OF WELLS IN JASPER AND NEWTON COUNTIES, TEXAS: TEXAS BOARD OF WATER ENGINEERS MISCELLANEOUS PUBLICATION 145, 1942.

GROUND WATER IN THE BEAUMONT AREA, TEXAS, WITH SPECIAL REFERENCE TO SOUTHEASTERN HARDIN COUNTY AND SOUTHWESTERN JASPER COUNTY: USGS OPEN-FILE REPORT (UNNUMBERED), 1945. 
PUBLIC WATER SUPPLIES IN EASTERN TEXAS: USGS WATERSUPPLY PAPER 1047, 1948.

MEMORANDUM REGARDING AVAILABILITY OF GROUND WATER IN THE AREA NEAR BESSMAY IN JASPER AND NEWTON COUNTIES: USGS OPEN-FILE REPORT (UNNUMBERED), 1950.

AVAILABILITY OF GROUND WATER IN THE GULF COAST REGION OF TEXAS: USGS OPEN-FILE REPORT (UNNUMBERED), 1956.

RECONNAISSANCE INVESTIGATION OF THE GROUND-WATER RESOURCES OF THE GULF COAST REGION, TEXAS: TEXAS WATER COMMISSION BULLETIN 6305, 1963.

RECONNAISSANCE INVESTIGATION OF THE GROUND-WATER RESOURCES OF THE SABINE RIVER BASIN, TEXAS: TEXAS WATER COMMISSION BULLETIN 6307, 1963.

RECONNAISSANCE INVESTIGATION OF THE GROUND-WATER RESOURCES OF THE NECHES RIVER BASIN, TEXAS: TEXAS WATER COMMISSION BULLETIN 6308, 1963.

GROUND-WATER RESOURCES OF JASPER AND NEWTON COUNTIES, TEXAS: TEXAS WATER DEVELOPMENT BOARD REPORT 59, 1967.

GROUND-WATER DATA FOR ORANGE COUNTY AND VICINITY, TEXAS AND LOUISIANA, 1968: USGS OPEN-FILE REPORT 68-50, 1968.

GROUND-WATER DATA FOR ORANGE COUNTY AND VICINITY, TEXAS AND LOUISIANA, 1969: USGS OPEN-FILE REPORT 69-204, 1969.

COMPILATION OF RESULTS OF AQUIFER TESTS IN TEXAS: TEXAS WATER DEVELOPMENT BOARD REPORT 98, 1969.

GEOHYDROLOGIC SIGNIFICANCE OF LITHOFACIES OF THE COCKFIELD FORMATION OF LOUISIANA AND MISSISSIPPI AND OF THE YEGUA FORMATION OF TEXAS: USGS PROFESSIONAL PAPER 569-B, 1970.

GROUND-WATER DATA FOR ORANGE COUNTY AND VICINITY, TEXAS AND LOUISIANA, 1970: USGS OPEN-FILE REPORT 70-123, 1970.

DEVELOPMENT OF GROUND-WATER RESOURCES IN THE ORANGE COUNTY AREA, TEXAS AND LOUISIANA, 1963-71: USGS OPENFILE REPORT 72-243, 1972.

DEVELOPMENT OF GROUND-WATER RESOURCES IN THE ORANGE COUNTY AREA, TEXAS AND LOUISIANA, 1963-71: TEXAS WATER DEVELOPMENT BOARD REPORT 156, 1972.

GEOHYDROLOGIC SIGNIFICANCE OF LITHOFACIES OF THE CARRIZO SAND OF ARKANSAS, LOUISIANA, AND TEXAS AND THE MERIDIAN SAND OF MISSISSIPPI: USGS PROFESSIONAL PAPER 569-D, 1975.

GROUND-WATER DATA FOR ORANGE COUNTY AND VICINITY, TEXAS AND LOUISIANA, 1971-74: USGS OPEN-FILE REPORT 75-129 1975.

GROUND-WATER DATA FOR ORANGE COUNTY AND VICINITY, TEXAS AND LOUISIANA, 1971-74: TEXAS WATER DEVELOPMENT BOARD REPORT 197, 1975.

SUMMARY APPRAISALS OF THE NATION'S GROUND-WATER RESOURCES-TEXAS-GULF REGION: USGS PROFESSIONAL PAPER 813-F, 1976.
STRATIGRAPHIC AND HYDROGEOLOGIC FRAMEWORK OF PART OF THE COASTAL PLAIN OF TEXAS: USGS OPEN-FILE REPORT $77-712,1978$.

STRATIGRAPHIC AND HYDROGEOLOGIC FRAMEWORK OF PART OF THE COASTAL PLAIN OF TEXAS: TEXAS DEPARTMENT OF WATER RESOURCES REPORT 236, 1979.

LAND-SURFACE SUBSIDENCE IN THE TEXAS COASTAL REGION: USGS OPEN-FILE REPORT 80-969, 1980.

SPRINGS OF TEXAS, VOLUME 1: (BY GUNNAR BRUNE), BRANCHSMITH, INC., FORT WORTH, TEXAS, 1981.

DEVELOPMENT OF GROUND-WATER RESOURCES IN ORANGE COUNTY, TEXAS, AND ADJACENT AREAS IN TEXAS AND LOUISIANA, 1971-80: USGS OPEN-FILE REPORT 82-330, 1982.

LAND-SURFACE SUBSIDENCE IN THE TEXAS COASTAL REGION: TEXAS DEPARTMENT OF WATER RESOURCES REPORT 272, 1982

DEVELOPMENT OF GROUND-WATER RESOURCES IN ORANGE COUNTY, TEXAS, AND ADJACENT AREAS IN TEXAS AND LOUISIANA, 1971-80: TEXAS DEPARTMENT OF WATER RESOURCES REPORT 283, 1983.

TEXAS GROUND-WATER RESOURCES, in NATIONAL WATER SUMMARY 1984: USGS WATER-SUPPLY PAPER 2275, 1985.

DIGITAL MODELS FOR SIMULATION OF GROUND-WATER HYDROLOGY OF THE CHICOT AND EVANGELINE AQUIFERS ALONG THE GULF COAST OF TEXAS: TEXAS DEPARTMENT OF WATER RESOURCES REPORT 289, 1985.

HYDROLOGY OF THE JASPER AQUIFER IN THE SOUTHEAST TEXAS COASTAL PLAIN: TEXAS WATER DEVELOPMENT BOARD REPORT 295, 1986

DEVELOPMENT OF GROUND-WATER RESOURCES IN THE ORANGE COUNTY AREA, TEXAS AND LOUISIANA, 1980-SPRING OF 1985: USGS WATER-RESOURCES INVESTIGATIONS REPORT 87-4158, 1987.

GEOHYDROLOGIC FRAMEWORK OF THE GULF COASTAL PLAIN: USGS HYDROLOGIC INVESTIGATIONS ATLAS HA-695, 1988.

HYDROGEOLOGY AND PREDEVELOPMENT FLOW IN THE TEXAS GULF COAST AQUIFER SYSTEMS: USGS WATER-RESOURCES INVESTIGATIONS REPORT 87-4248, 1988.

GROUND-WATER FLOW IN THE GULF COAST AQUIFER SYSTEMS, SOUTH-CENTRAL UNITED STATES-A PRELIMINARY ANALYSIS USGS WATER-RESOURCES INVESTIGATIONS REPORT 89-4071, 1990.

SALT-DOME LOCATIONS IN THE GULF COASTAL PLAIN, SOUTHCENTRAL UNITED STATES: USGS WATER-RESOURCES INVESTIGATIONS REPORT 90-4060, 1990.

HYDROLOGY OF THE TEXAS GULF COAST AQUIFER SYSTEMS: USGS OPEN-FILE REPORT 91-64, 1991.

PROPERTIES AND CHEMICAL CONSTITUENTS IN GROUND WATER FROM THE MISSISSIPPI RIVER VALLEY ALLUVIAL AQUIFER AND PERMEABLE ZONE A (HOLOCENE-UPPER PLEISTOCENE DEPOSITS), SOUTH-CENTRAL UNITED STATES: USGS WATERRESOURCES INVESTIGATIONS REPORT 91-4149, 1992.

PROPERTIES AND CHEMICAL CONSTITUENTS IN GROUND WATER FROM THE UPPER CLAIBORNE AQUIFER, GULF COAST REGIONAL AQUIFER SYSTEMS, SOUTH-CENTRAL UNITED 
STATES: USGS WATER-RESOURCES INVESTIGATIONS REPORT 91-4150, 1993.

PROPERTIES AND CHEMICAL CONSTITUENTS IN GROUND WATER FROM PERMEABLE ZONE C (LOWER PLIOCENE-UPPER MIOCENE DEPOSITS), COASTAL LOWLANDS AQUIFER SYSTEM, SOUTHCENTRAL UNITED STATES: USGS WATER-RESOURCES INVESTIGATIONS REPORT 91-4151, 1993.

PROPERTIES AND CHEMICAL CONSTITUENTS IN GROUND WATER FROM PERMEABLE ZONE B (LOWER PLEISTOCENE-UPPER PLIOCENE DEPOSITS), COASTAL LOWLANDS AQUIFER SYSTEM, SOUTH-CENTRAL UNITED STATES: USGS WATER-RESOURCES INVESTIGATIONS REPORT 91-4152, 1993.

PROPERTIES AND CHEMICAL CONSTITUENTS IN GROUND WATER FROM PERMEABLE ZONE E (LOWER MIOCENE-UPPER OLIGOCENE DEPOSITS), COASTAL LOWLANDS AQUIFER SYSTEM, SOUTH-CENTRAL UNITED STATES: USGS WATER-RESOURCES INVESTIGATIONS REPORT 92-4103, 1993.

PROPERTIES AND CHEMICAL CONSTITUENTS IN GROUND WATER FROM THE MIDDLE CLAIBORNE AQUIFER, GULF COAST REGIONAL AQUIFER SYSTEMS, SOUTH-CENTRAL UNITED STATES: USGS WATER-RESOURCES INVESTIGATIONS REPORT 92-4104, 1993.

PROPERTIES AND CHEMICAL CONSTITUENTS IN GROUND WATER FROM THE MIDDLE WILCOX AQUIFER, GULF COAST REGIONAL AQUIFER SYSTEMS, SOUTH-CENTRAL UNITED STATES: USGS WATER-RESOURCES INVESTIGATIONS REPORT 93-4070, 1993.

WATER-RESOURCES DATA, TEXAS, WATER YEAR 1992, VOLUME 4, GROUND-WATER DATA: USGS WATER-DATA REPORT TX-92-4, 1993.

WATER-RESOURCES DATA, TEXAS, WATER YEAR 1993, VOLUME 4, GROUND-WATER DATA: USGS WATER-DATA REPORT TX-93-4, 1994.

AQUIFERS OF TEXAS: TEXAS WATER DEVELOPMENT BOARD REPORT 345, 1995.

WATER-RESOURCES DATA, TEXAS, WATER YEAR 1994, VOLUME 4 GROUND-WATER DATA: USGS WATER-DATA REPORT TX-94-4, 1995.

WATER-RESOURCES DATA, TEXAS, WATER YEAR 1995, VOLUME 4, GROUND-WATER DATA: USGS WATER-DATA REPORT TX-95-4, 1996.

WATER-RESOURCES DATA, TEXAS, WATER YEAR 1996, VOLUME 4, GROUND-WATER DATA: USGS WATER-DATA REPORT TX-96-4, 1997.

WATER-RESOURCES DATA, TEXAS, WATER YEAR 1997, VOLUME 4, GROUND-WATER DATA: USGS WATER-DATA REPORT TX-97-4, 1998.

GROUND-WATER DATA IN ORANGE COUNTY AND ADJACENT COUNTIES, TEXAS, 1985-90: USGS OPEN-FILE REPORT 99-603, 1999.

WATER-RESOURCES DATA, TEXAS, WATER YEAR 1998, VOLUME 4, GROUND-WATER DATA: USGS WATER-DATA REPORT TX-98-4, 1999.

WATER-RESOURCES DATA, TEXAS, WATER YEAR 1999, VOLUME 6, GROUND-WATER DATA: USGS WATER-DATA REPORT TX-99-6, 2000 .
WATER-RESOURCES DATA, TEXAS, WATER YEAR 2000, VOLUME 6, GROUND-WATER DATA: USGS WATER-DATA REPORT TX-00-6, 2001.

\section{JEFF DAVIS COUNTY}

GROUND-WATER RESOURCES OF THE BALMORHEA AREA IN WESTERN TEXAS: USGS OPEN-FILE REPORT (UNNUMBERED), 1938.

GROUND-WATER RESOURCES OF THE BALMORHEA AREA, WESTERN TEXAS: USGS WATER-SUPPLY PAPER 849-C, 1941.

PUBLIC WATER SUPPLIES IN WESTERN TEXAS: USGS WATERSUPPLY PAPER 1106, 1951.

SUMMARY OF THE DEVELOPMENT OF GROUND WATER FOR IRRIGATION IN THE LOBO FLATS AREA, CULBERSON AND JEFF DAVIS COUNTIES, TEXAS: TEXAS BOARD OF WATER ENGINEERS BULLETIN 5102, 1951

RECORDS OF WATER-LEVEL MEASUREMENTS IN CULBERSON, HUDSPETH, AND JEFF DAVIS COUNTIES, TEXAS: TEXAS BOARD OF WATER ENGINEERS BULLETIN 5415, 1954.

GROUND-WATER GEOLOGY OF THE ALPINE AREA, BREWSTER, JEFF DAVIS, AND PRESIDIO COUNTIES, TEXAS: TEXAS BOARD OF WATER ENGINEERS BULLETIN 5712, 1957.

WATER-LEVEL MEASUREMENTS IN CULBERSON, HUDSPETH, AND JEFF DAVIS COUNTIES, TEXAS: TEXAS BOARD OF WATER ENGINEERS BULLETIN 6005, 1960.

SHALLOW FORMATIONS AND AQUIFERS OF THE WEST TEXAS AREA: WEST TEXAS GEOLOGICAL SOCIETY PUBLICATION 61-45 AND PERMIAN BASIN GEOPHYSICAL SOCIETY, MIDLAND, TEXAS, 1961

RECONNAISSANCE INVESTIGATION OF THE GROUND-WATER RESOURCES OF THE RIO GRANDE BASIN, TEXAS: TEXAS WATER COMMISSION BULLETIN 6502, 1965

WATER-LEVEL DATA FROM OBSERVATION WELLS IN CULBERSON, JEFF DAVIS, PRESIDIO, AND BREWSTER COUNTIES, TEXAS: TEXAS WATER DEVELOPMENT BOARD REPORT 16, 1966.

RECORDS OF WATER LEVELS AND CHEMICAL ANALYSES FROM SELECTED WELLS IN PART OF THE TRANS-PECOS REGION OF TEXAS, 1965-68: TEXAS WATER DEVELOPMENT BOARD REPORT 114,1970

RECONNAISSANCE INVESTIGATION OF GROUND WATER IN THE RIO GRANDE DRAINAGE BASIN-WITH SPECIAL EMPHASIS ON SALINE GROUND-WATER RESOURCES: USGS HYDROLOGIC INVESTIGATIONS ATLAS HA-510, 1974.

QUALITY AND AVAILABILITY OF WATER IN WESTERNMOST TEXAS: USGS OPEN-FILE REPORT 75-133, 1975.

EXPLORATION FOR FRESH GROUND WATER IN THE EAGLE MOUNTAINS AREA, HUDSPETH COUNTY AREA, TEXAS: in GEOLOGY OF THE EAGLE MOUNTAINS AND VICINITY: SOCIETY OF ECONOMIC PALEONTOLOGISTS AND MINERALOGISTS-PERMIAN BASIN SECTION, 1975.

MAJOR AND HISTORICAL SPRINGS OF TEXAS: TEXAS WATER DEVELOPMENT BOARD REPORT 189, 1975. 
GROUND-WATER DATA FOR THE SALT BASIN, EAGLE FLAT, RED LIGHT DRAW, GREEN RIVER VALLEY, AND PRESIDIO BOLSON IN WESTERNMOST TEXAS: USGS OPEN-FILE REPORT 77-575, 1978.

AVAILABILITY OF FRESH AND SLIGHTLY SALINE GROUND WATER IN THE BASINS OF WESTERNMOST TEXAS: USGS OPEN-FILE REPORT 78-663, 1978.

OCCURRENCE AND QUALITY OF GROUND WATER IN THE EDWARDS-TRINITY (PLATEAU) AQUIFER IN THE TRANS-PECOS REGION OF TEXAS: TEXAS DEPARTMENT OF WATER RESOURCES REPORT 255, 1980.

AVAILABILITY OF FRESH AND SLIGHTLY SALINE GROUND WATER IN THE BASINS OF WESTERNMOST TEXAS: TEXAS DEPARTMENT OF WATER RESOURCES REPORT 256, 1980.

GROUND-WATER DATA FOR THE SALT BASIN, EAGLE FLAT, RED LIGHT DRAW, GREEN RIVER VALLEY, AND PRESIDIO BOLSON IN WESTERNMOST TEXAS: TEXAS DEPARTMENT OF WATER RESOURCES REPORT 259, 1980.

SPRINGS OF TEXAS, VOLUME 1: (BY GUNNAR BRUNE), BRANCHSMITH, INC., FORT WORTH, TEXAS, 1981.

MAPS SHOWING GROUND-WATER UNITS AND WITHDRAWAL, BASIN AND RANGE PROVINCE, TEXAS: USGS WATERRESOURCES INVESTIGATIONS REPORT 83-4121-A, 1984.

MAPS SHOWING GROUND-WATER LEVELS, SPRINGS, AND DEPTH TO GROUND WATER, BASIN AND RANGE PROVINCE, TEXAS: USGS WATER-RESOURCES INVESTIGATIONS REPORT 83-4121-B, 1984

MAPS SHOWING DISTRIBUTION OF DISSOLVED SOLIDS AND DOMINANT CHEMICAL TYPE IN GROUND WATER, BASIN AND RANGE PROVINCE, TEXAS: USGS WATER-RESOURCES INVESTIGATIONS REPORT 83-4121-C, 1984

TEXAS GROUND-WATER RESOURCES, in NATIONAL WATER SUMMARY 1984: USGS WATER-SUPPLY PAPER 2275, 1985.

RECORDS OF WELLS, WATER LEVELS, PUMPAGE, AND CHEMICAL ANALYSES FROM SELECTED WELLS IN PARTS OF THE TRANSPECOS REGION, TEXAS, 1968-80: TEXAS WATER DEVELOPMENT BOARD REPORT 301, 1987.

PUBLIC SUPPLY GROUND-WATER USE IN WESTERN TEXAS: TEXAS WATER DEVELOPMENT BOARD REPORT 311, 1989.

POTENTIOMETRIC SURFACE OF THE EDWARDS-TRINITY AQUIFER SYSTEM AND CONTIGUOUS HYDRAULICALLY CONNECTED UNITS, WEST-CENTRAL TEXAS, WINTER 1974-75: USGS WATERRESOURCES INVESTIGATIONS REPORT 89-4208, 1990.

WITHDRAWALS FROM THE EDWARDS-TRINITY AQUIFER SYSTEM AND CONTIGUOUS HYDRAULICALLY CONNECTED UNITS, WEST-CENTRAL TEXAS, DECEMBER 1974 THROUGH MARCH 1977: USGS WATER-RESOURCES INVESTIGATIONS REPORT 91-4021, 1991.

CONFIGURATION OF THE BASE OF THE EDWARDS-TRINITY AQUIFER SYSTEM AND HYDROGEOLOGY OF THE UNDERLYING PRECRETACEOUS ROCKS, WEST-CENTRAL TEXAS: USGS WATERRESOURCES INVESTIGATIONS REPORT 91-4071, 1992.

THE HYDROGEOLOGY OF THE DAVIS MOUNTAINS, TRANS-PECOS TEXAS: THE UNIVERSITY OF TEXAS AT AUSTIN, MASTER'S THESIS, 1992

HISTORICAL POTENTIOMETRIC SURFACE OF THE EDWARDS-TRINITY AQUIFER SYSTEM AND CONTIGUOUS HYDRAULICALLY
CONNECTED UNITS, WEST-CENTRAL TEXAS: USGS WATERRESOURCES INVESTIGATIONS REPORT 92-4055, 1993.

HISTORICAL SATURATED THICKNESS OF THE EDWARDS-TRINITY AQUIFER SYSTEM AND SELECTED CONTIGUOUS HYDRAULICALLY CONNECTED UNITS, WEST-CENTRAL TEXAS: USGS WATER-RESOURCES INVESTIGATIONS REPORT 92-4125, 1993.

SIMULATIONS OF FLOW IN THE EDWARDS-TRINITY AQUIFER SYSTEM AND CONTIGUOUS HYDRAULICALLY CONNECTED UNITS, WEST-CENTRAL TEXAS: USGS WATER-RESOURCES INVESTIGATIONS REPORT 93-4039, 1994.

DISSOLVED-SOLIDS CONCENTRATIONS AND HYDROCHEMICAL FACIES IN WATER OF THE EDWARDS-TRINITY AQUIFER SYSTEM, WEST-CENTRAL TEXAS: USGS WATER-RESOURCES INVESTIGATIONS REPORT 93-4126, 1994.

GEOLOGIC HISTORY AND HYDROGEOLOGIC SETTING OF THE EDWARDS-TRINITY AQUIFER SYSTEM, WEST-CENTRAL TEXAS: USGS WATER-RESOURCES INVESTIGATIONS REPORT 94-4039, 1994.

GROUND-WATER HYDROLOGY AND HYDROCHEMISTRY OF EAGLE FLAT AND SURROUNDING AREA: UNIVERSITY OF TEXAS, BUREAU OF ECONOMIC GEOLOGY CONTRACT REPORT, PREPARED FOR TEXAS LOW-LEVEL RADIOACTIVE WASTE DISPOSAL AUTHORITY, 1994.

AQUIFERS OF TEXAS: TEXAS WATER DEVELOPMENT BOARD REPORT 345, 1995.

WATER QUALITY IN THE EDWARDS-TRINITY (PLATEAU) AQUIFER, EDWARDS PLATEAU AND TRANS-PECOS, TEXAS: TEXAS WATER DEVELOPMENT BOARD HYDROLOGIC ATLAS NO. 3, 1995.

WATER-RESOURCES DATA, TEXAS, WATER YEAR 1995, VOLUME 4, GROUND-WATER DATA: USGS WATER-DATA REPORT TX-95-4, 1996.

WATER QUALITY IN THE CAPITAN REEF AQUIFER: TEXAS WATER DEVELOPMENT BOARD HYDROLOGIC ATLAS NO. 8, 1997.

CHLOROFLUOROCARBON AND TRITIUM AGE DETERMINATION OF GROUND-WATER RECHARGE IN THE RYAN FLAT SUBBASIN, TRANS-PECOS TEXAS: USGS WATER-RESOURCES INVESTIGATIONS REPORT 96-4245, 1997.

DELINEATION OF THE GROUND-WATER FLOW SYSTEMS OF THE EAGLE FLAT AND RED LIGHT BASINS OF TRANS-PECOS TEXAS: THE UNIVERSITY OF TEXAS AT AUSTIN, DOCTORAL DISSERTATION, 1997.

WATER QUALITY IN THE RUSTLER AQUIFER: TEXAS WATER DEVELOPMENT BOARD HYDROLOGIC ATLAS NO. 9, 1998.

IGNEOUS AQUIFER SYSTEM OF BREWSTER, JEFF DAVIS, AND PRESIDIO COUNTIES, TEXAS: LBG-GUYTON ASSOCIATES, WATER PROSPECTING AND RESOURCE CONSULTING, LLC., AND SUL ROSS UNIVERSITY, 2001.

AQUIFERS OF WEST TEXAS: TEXAS WATER DEVELOPMENT BOARD REPORT 356, 2001

EVALUATION OF GROUND-WATER RECHARGE IN BASINS OF TRANS-PECOS TEXAS, CHAPTER 3, in AQUIFERS OF WEST TEXAS: TEXAS WATER DEVELOPMENT BOARD REPORT 356, 2001

REGIONAL GROUND-WATER FLOW SYSTEMS IN TRANS-PECOS TEXAS, CHAPTER 4, in AQUIFERS OF WEST TEXAS: TEXAS WATER DEVELOPMENT BOARD REPORT 356, 2001 
AN OVERVIEW OF THE EDWARDS-TRINITY AQUIFER SYSTEM, CENTRAL-WEST TEXAS, CHAPTER 8, in AQUIFERS OF WEST TEXAS: TEXAS WATER DEVELOPMENT BOARD REPORT 356, 2001.

THE GEOLOGY AND HYDROGEOLOGY OF THE CAPITAN AQUIFER: A BRIEF OVERVIEW, CHAPTER 11, in AQUIFERS OF WEST TEXAS: TEXAS WATER DEVELOPMENT BOARD REPORT 356, 2001.

IGNEOUS AQUIFERS OF FAR WEST TEXAS, CHAPTER 13, in AQUIFERS OF WEST TEXAS: TEXAS WATER DEVELOPMENT BOARD REPORT 356, 2001

HYDROGEOLOGY OF THE RUSTLER AQUIFER, TRANS-PECOS TEXAS, CHAPTER 15, in AQUIFERS OF WEST TEXAS: TEXAS WATER DEVELOPMENT BOARD REPORT 356, 2001.

THE AQUIFERS OF RED LIGHT DRAW, GREEN RIVER VALLEY, AND EAGLE FLAT, CHAPTER 16, in AQUIFERS OF WEST TEXAS: TEXAS WATER DEVELOPMENT BOARD REPORT 356, 2001.

HYDROGEOLOGY OF THE SALT BASIN, CHAPTER 17, in AQUIFERS OF WEST TEXAS: TEXAS WATER DEVELOPMENT BOARD REPORT 356, 2001.

\section{JEFFERSON COUNTY}

UNDERGROUND WATERS OF THE COASTAL PLAIN OF TEXAS: USGS WATER-SUPPLY PAPER 190, 1907.

GEOLOGY AND UNDERGROUND WATERS OF THE SOUTHEASTERN PART OF THE TEXAS COASTAL PLAIN: USGS WATER-SUPPLY PAPER 335, 1914.

PORT ARTHUR, TEXAS: USGS OPEN-FILE REPORT (UNNUMBERED), 1941

GROUND WATER IN THE VICINITY OF SABINE PASS, TEXAS: USGS OPEN-FILE REPORT (UNNUMBERED), 1941.

BEAUMONT WATER SUPPLY: USGS OPEN-FILE REPORT (UNNUMBERED), 1941.

WATER-WELL DATA, JEFFERSON COUNTY, TEXAS: TEXAS BOARD OF WATER ENGINEERS MISCELLANEOUS PUBLICATION 146, 1942.

EMERGENCY WATER SUPPLY FOR SUBMARINE BASE NEAR SABINE PASS, TEXAS: TEXAS BOARD OF WATER ENGINEERS MISCELLANEOUS PUBLICATION (UNNUMBERED), 1942.

GROUND-WATER RESOURCES OF JEFFERSON COUNTY, TEXAS: USGS OPEN-FILE REPORT (UNNUMBERED), 1943.

GROUND WATER IN THE BEAUMONT AREA, TEXAS, WITH SPECIAL REFERENCE TO SOUTHEASTERN HARDIN COUNTY AND SOUTHWESTERN JASPER COUNTY: USGS OPEN-FILE REPORT (UNNUMBERED), 1945.

GROUND WATER IN BEAUMONT, NEDERLAND, PORT NECHES, AND PORT ARTHUR AREAS, TEXAS: USGS OPEN-FILE REPORT (UNNUMBERED), 1945.

PUBLIC WATER SUPPLIES IN EASTERN TEXAS: USGS WATERSUPPLY PAPER 1047, 1948.

AVAILABILITY OF GROUND WATER IN THE GULF COAST REGION OF TEXAS: USGS OPEN-FILE REPORT (UNNUMBERED), 1956.
RECONNAISSANCE INVESTIGATION OF THE GROUND-WATER RESOURCES OF THE GULF COAST REGION, TEXAS: TEXAS WATER COMMISSION BULLETIN 6305, 1963.

RECONNAISSANCE INVESTIGATION OF THE GROUND-WATER RESOURCES OF THE NECHES RIVER BASIN, TEXAS: TEXAS WATER COMMISSION BULLETIN 6308, 1963.

GROUND-WATER DATA FOR ORANGE COUNTY AND VICINITY, TEXAS AND LOUISIANA, 1968: USGS OPEN-FILE REPORT 68-50, 1968.

GROUND-WATER DATA FOR ORANGE COUNTY AND VICINITY, TEXAS AND LOUISIANA, 1969: USGS OPEN-FILE REPORT 69-204, 1969.

COMPILATION OF RESULTS OF AQUIFER TESTS IN TEXAS: TEXAS WATER DEVELOPMENT BOARD REPORT 98, 1969.

GROUND-WATER DATA FOR ORANGE COUNTY AND VICINITY, TEXAS AND LOUISIANA, 1970: USGS OPEN-FILE REPORT 70-123, 1970.

GROUND-WATER RESOURCES OF CHAMBERS AND JEFFERSON COUNTIES, TEXAS: TEXAS WATER DEVELOPMENT BOARD REPORT 133, 1971

DEVELOPMENT OF GROUND-WATER RESOURCES IN THE ORANGE COUNTY AREA, TEXAS AND LOUISIANA, 1963-71: USGS OPENFILE REPORT 72-243, 1972.

DEVELOPMENT OF GROUND-WATER RESOURCES IN THE ORANGE COUNTY AREA, TEXAS AND LOUISIANA, 1963-71: TEXAS WATER DEVELOPMENT BOARD REPORT 156, 1972.

GROUND-WATER DATA FOR ORANGE COUNTY AND VICINITY, TEXAS AND LOUISIANA, 1971-74: USGS OPEN-FILE REPORT $75-129,1975$

GROUND-WATER DATA FOR ORANGE COUNTY AND VICINITY, TEXAS AND LOUISIANA, 1971-74: TEXAS WATER DEVELOPMENT BOARD REPORT 197, 1975.

SUMMARY APPRAISALS OF THE NATION'S GROUND-WATER RESOURCES-TEXAS-GULF REGION: USGS PROFESSIONAL PAPER 813-F, 1976.

STRATIGRAPHIC AND HYDROGEOLOGIC FRAMEWORK OF PART OF THE COASTAL PLAIN OF TEXAS: USGS OPEN-FILE REPORT $77-712,1978$

STRATIGRAPHIC AND HYDROGEOLOGIC FRAMEWORK OF PART OF THE COASTAL PLAIN OF TEXAS: TEXAS DEPARTMENT OF WATER RESOURCES REPORT 236, 1979.

LAND-SURFACE SUBSIDENCE IN THE TEXAS COASTAL REGION: USGS OPEN-FILE REPORT 80-969, 1980.

SPRINGS OF TEXAS, VOLUME 1: (BY GUNNAR BRUNE), BRANCHSMITH, INC., FORT WORTH, TEXAS, 1981.

DEVELOPMENT OF GROUND-WATER RESOURCES IN ORANGE COUNTY, TEXAS, AND ADJACENT AREAS IN TEXAS AND LOUISIANA, 1971-80: USGS OPEN-FILE REPORT 82-330, 1982.

LAND-SURFACE SUBSIDENCE IN THE TEXAS COASTAL REGION: TEXAS DEPARTMENT OF WATER RESOURCES REPORT 272, 1982.

DEVELOPMENT OF GROUND-WATER RESOURCES IN ORANGE COUNTY, TEXAS, AND ADJACENT AREAS IN TEXAS AND LOUISIANA, 1971-80: TEXAS DEPARTMENT OF WATER RESOURCES REPORT 283, 1983. 
TEXAS GROUND-WATER RESOURCES, in NATIONAL WATER SUMMARY 1984: USGS WATER-SUPPLY PAPER 2275, 1985.

DIGITAL MODELS FOR SIMULATION OF GROUND-WATER HYDROLOGY OF THE CHICOT AND EVANGELINE AQUIFERS ALONG THE GULF COAST OF TEXAS: TEXAS DEPARTMENT OF WATER RESOURCES REPORT 289, 1985.

WATER USE, PROJECTED WATER REQUIREMENTS, AND RELATED DATA AND INFORMATION FOR THE METROPOLITAN STATISTICAL AREAS IN TEXAS: TEXAS DEPARTMENT OF WATER RESOURCES LIMITED PRINTING REPORT LP-201, 1985.

HYDROLOGY OF THE JASPER AQUIFER IN THE SOUTHEAST TEXAS COASTAL PLAIN: TEXAS WATER DEVELOPMENT BOARD REPORT 295, 1986.

DEVELOPMENT OF GROUND-WATER RESOURCES IN THE ORANGE COUNTY AREA, TEXAS AND LOUISIANA, 1980-SPRING OF 1985: USGS WATER-RESOURCES INVESTIGATIONS REPORT 87-4158, 1987.

GEOHYDROLOGIC FRAMEWORK OF THE GULF COASTAL PLAIN: USGS HYDROLOGIC INVESTIGATIONS ATLAS HA-695, 1988.

HYDROGEOLOGY AND PREDEVELOPMENT FLOW IN THE TEXAS GULF COAST AQUIFER SYSTEMS: USGS WATER-RESOURCES INVESTIGATIONS REPORT 87-4248, 1988.

EVALUATION OF WATER RESOURCES OF ORANGE AND EASTERN JEFFERSON COUNTIES, TEXAS: TEXAS WATER DEVELOPMENT BOARD REPORT 320, 1990.

GROUND-WATER FLOW IN THE GULF COAST AQUIFER SYSTEMS, SOUTH-CENTRAL UNITED STATES-A PRELIMINARY ANALYSIS: USGS WATER-RESOURCES INVESTIGATIONS REPORT 89-4071, 1990.

SALT-DOME LOCATIONS IN THE GULF COASTAL PLAIN, SOUTHCENTRAL UNITED STATES: USGS WATER-RESOURCES INVESTIGATIONS REPORT 90-4060, 1990.

HYDROLOGY OF THE TEXAS GULF COAST AQUIFER SYSTEMS: USGS OPEN-FILE REPORT 91-64, 1991.

HYDROGEOLOGIC ASSESSMENT OF POTENTIAL CONTAMINANT PATHWAYS AT A HAZARDOUS WASTE DISPOSAL SITE LOCATED ON THE BEAUMONT FORMATION, SOUTHEAST TEXAS: (MASTER'S THESIS), BAYLOR GEOLOGICAL STUDIES (THESIS ABSTRACTS), BULLETIN 53, BAYLOR UNIVERSITY, WACO, TEXAS, 1992.

PROPERTIES AND CHEMICAL CONSTITUENTS IN GROUND WATER FROM THE MISSISSIPPI RIVER VALLEY ALLUVIAL AQUIFER AND PERMEABLE ZONE A (HOLOCENE-UPPER PLEISTOCENE DEPOSITS), SOUTH-CENTRAL UNITED STATES: USGS WATERRESOURCES INVESTIGATIONS REPORT 91-4149, 1992.

PROPERTIES AND CHEMICAL CONSTITUENTS IN GROUND WATER FROM THE UPPER CLAIBORNE AQUIFER, GULF COAST REGIONAL AQUIFER SYSTEMS, SOUTH-CENTRAL UNITED STATES: USGS WATER-RESOURCES INVESTIGATIONS REPORT 91-4150, 1993.

PROPERTIES AND CHEMICAL CONSTITUENTS IN GROUND WATER FROM PERMEABLE ZONE C (LOWER PLIOCENE-UPPER MIOCENE DEPOSITS), COASTAL LOWLANDS AQUIFER SYSTEM, SOUTHCENTRAL UNITED STATES: USGS WATER-RESOURCES INVESTIGATIONS REPORT 91-4151, 1993.
PROPERTIES AND CHEMICAL CONSTITUENTS IN GROUND WATER FROM PERMEABLE ZONE B (LOWER PLEISTOCENE-UPPER PLIOCENE DEPOSITS), COASTAL LOWLANDS AQUIFER SYSTEM, SOUTH-CENTRAL UNITED STATES: USGS WATER-RESOURCES INVESTIGATIONS REPORT 91-4152, 1993.

PROPERTIES AND CHEMICAL CONSTITUENTS IN GROUND WATER FROM PERMEABLE ZONE E (LOWER MIOCENE-UPPER OLIGOCENE DEPOSITS), COASTAL LOWLANDS AQUIFER SYSTEM, SOUTH-CENTRAL UNITED STATES: USGS WATER-RESOURCES INVESTIGATIONS REPORT 92-4103, 1993.

PROPERTIES AND CHEMICAL CONSTITUENTS IN GROUND WATER FROM PERMEABLE ZONE D (MIDDLE MIOCENE DEPOSITS), COASTAL LOWLANDS AQUIFER SYSTEM, SOUTH-CENTRAL UNITED STATES: USGS WATER-RESOURCES INVESTIGATIONS REPORT 92-4105, 1993.

WATER-RESOURCES DATA, TEXAS, WATER YEAR 1992, VOLUME 4, GROUND-WATER DATA: USGS WATER-DATA REPORT TX-92-4, 1993.

WATER-RESOURCES DATA, TEXAS, WATER YEAR 1993, VOLUME 4, GROUND-WATER DATA: USGS WATER-DATA REPORT TX-93-4, 1994.

STRATIGRAPHIC NOMENCLATURE AND GEOLOGIC SECTIONS OF THE GULF COASTAL PLAIN OF TEXAS: USGS OPEN-FILE REPORT 94-461, 1995.

AQUIFERS OF TEXAS: TEXAS WATER DEVELOPMENT BOARD REPORT 345, 1995

WATER-RESOURCES DATA, TEXAS, WATER YEAR 1994, VOLUME 4, GROUND-WATER DATA: USGS WATER-DATA REPORT TX-94-4, 1995.

WATER-RESOURCES DATA, TEXAS, WATER YEAR 1995, VOLUME 4, GROUND-WATER DATA: USGS WATER-DATA REPORT TX-95-4, 1996.

WATER-RESOURCES DATA, TEXAS, WATER YEAR 1996, VOLUME 4 GROUND-WATER DATA: USGS WATER-DATA REPORT TX-96-4, 1997.

WATER-RESOURCES DATA, TEXAS, WATER YEAR 1997, VOLUME 4, GROUND-WATER DATA: USGS WATER-DATA REPORT TX-97-4, 1998.

GROUND-WATER DATA IN ORANGE COUNTY AND ADJACENT COUNTIES, TEXAS, 1985-90: USGS OPEN-FILE REPORT 99-603, 1999.

WATER-RESOURCES DATA, TEXAS, WATER YEAR 2000, VOLUME 6 GROUND-WATER DATA: USGS WATER-DATA REPORT TX-00-6, 2001.

\section{JIM HOGG COUNTY}

RECORDS OF WELLS, DRILLERS' LOGS, AND WATER ANALYSES AND MAP SHOWING LOCATION OF WELLS IN JIM HOGG COUNTY, TEXAS: USGS OPEN-FILE REPORT (UNNUMBERED), 1935.

RECORDS OF WELLS, DRILLERS' LOGS, AND WATER ANALYSES, AND MAP SHOWING LOCATION OF WELLS IN NORTHERN PART OF JIM HOGG COUNTY, TEXAS: TEXAS BOARD OF WATER ENGINEERS MISCELLANEOUS PUBLICATION 147, 1940. 
PUBLIC WATER SUPPLIES IN SOUTHERN TEXAS: USGS WATERSUPPLY PAPER 1070, 1950.

RECONNAISSANCE INVESTIGATION OF THE GROUND-WATER RESOURCES OF THE GULF COAST REGION, TEXAS: TEXAS WATER COMMISSION BULLETIN 6305, 1963.

RECONNAISSANCE INVESTIGATION OF THE GROUND-WATER RESOURCES OF THE RIO GRANDE BASIN, TEXAS: TEXAS WATER COMMISSION BULLETIN 6502, 1965.

RECONNAISSANCE INVESTIGATION OF GROUND WATER IN THE RIO GRANDE DRAINAGE BASIN—WITH SPECIAL EMPHASIS ON SALINE GROUND-WATER RESOURCES: USGS HYDROLOGIC INVESTIGATIONS ATLAS HA-510, 1974.

SUMMARY APPRAISALS OF THE NATION'S GROUND-WATER RESOURCES-TEXAS-GULF REGION: USGS PROFESSIONAL PAPER 813-F, 1976.

STRATIGRAPHIC AND HYDROGEOLOGIC FRAMEWORK OF PART OF THE COASTAL PLAIN OF TEXAS: TEXAS DEPARTMENT OF WATER RESOURCES REPORT 236, 1979.

SPRINGS OF TEXAS, VOLUME 1: (BY GUNNAR BRUNE), BRANCHSMITH, INC., FORT WORTH, TEXAS, 1981.

LAND-SURFACE SUBSIDENCE IN THE TEXAS COASTAL REGION: TEXAS DEPARTMENT OF WATER RESOURCES REPORT 272, 1982.

STRUCTURE, TEMPERATURE, PRESSURE, AND SALINITY OF CENOZOIC AQUIFERS OF SOUTH TEXAS: USGS HYDROLOGIC INVESTIGATIONS ATLAS HA-654, 1983.

TEXAS GROUND-WATER RESOURCES, in NATIONAL WATER SUMMARY 1984: USGS WATER-SUPPLY PAPER 2275, 1985.

DIGITAL MODELS FOR SIMULATION OF GROUND-WATER HYDROLOGY OF THE CHICOT AND EVANGELINE AQUIFERS ALONG THE GULF COAST OF TEXAS: TEXAS DEPARTMENT OF WATER RESOURCES REPORT 289, 1985.

HYDROGEOLOGY AND PREDEVELOPMENT FLOW IN THE TEXAS GULF COAST AQUIFER SYSTEMS: USGS WATER-RESOURCES INVESTIGATIONS REPORT 87-4248, 1988.

GEOHYDROLOGIC FRAMEWORK OF THE GULF COASTAL PLAIN: USGS HYDROLOGIC INVESTIGATIONS ATLAS HA-695, 1988.

GROUND-WATER FLOW IN THE GULF COAST AQUIFER SYSTEMS, SOUTH-CENTRAL UNITED STATES-A PRELIMINARY ANALYSIS: USGS WATER-RESOURCES INVESTIGATIONS REPORT 89-4071, 1990.

HYDROLOGY OF THE TEXAS GULF COAST AQUIFER SYSTEMS: USGS OPEN-FILE REPORT 91-64, 1991.

PROPERTIES AND CHEMICAL CONSTITUENTS IN GROUND WATER FROM THE MISSISSIPPI RIVER VALLEY ALLUVIAL AQUIFER AND PERMEABLE ZONE A (HOLOCENE-UPPER PLEISTOCENE DEPOSITS), SOUTH-CENTRAL UNITED STATES: USGS WATERRESOURCES INVESTIGATIONS REPORT 91-4149, 1992.

PROPERTIES AND CHEMICAL CONSTITUENTS IN GROUND WATER FROM THE UPPER CLAIBORNE AQUIFER, GULF COAST REGIONAL AQUIFER SYSTEMS, SOUTH-CENTRAL UNITED STATES: USGS WATER-RESOURCES INVESTIGATIONS REPORT 91-4150, 1993.

PROPERTIES AND CHEMICAL CONSTITUENTS IN GROUND WATER FROM PERMEABLE ZONE C (LOWER PLIOCENE-UPPER MIOCENE DEPOSITS), COASTAL LOWLANDS AQUIFER SYSTEM, SOUTH-
CENTRAL UNITED STATES: USGS WATER-RESOURCES INVESTIGATIONS REPORT 91-4151, 1993.

PROPERTIES AND CHEMICAL CONSTITUENTS IN GROUND WATER FROM PERMEABLE ZONE B (LOWER PLEISTOCENE-UPPER PLIOCENE DEPOSITS), COASTAL LOWLANDS AQUIFER SYSTEM, SOUTH-CENTRAL UNITED STATES: USGS WATER-RESOURCES INVESTIGATIONS REPORT 91-4152, 1993.

PROPERTIES AND CHEMICAL CONSTITUENTS IN GROUND WATER FROM PERMEABLE ZONE E (LOWER MIOCENE-UPPER OLIGOCENE DEPOSITS), COASTAL LOWLANDS AQUIFER SYSTEM, SOUTH-CENTRAL UNITED STATES: USGS WATER-RESOURCES INVESTIGATIONS REPORT 92-4103, 1993.

PROPERTIES AND CHEMICAL CONSTITUENTS IN GROUND WATER FROM THE MIDDLE CLAIBORNE AQUIFER, GULF COAST REGIONAL AQUIFER SYSTEMS, SOUTH-CENTRAL UNITED STATES: USGS WATER-RESOURCES INVESTIGATIONS REPORT 92-4104, 1993.

PROPERTIES AND CHEMICAL CONSTITUENTS IN GROUND WATER FROM PERMEABLE ZONE D (MIDDLE MIOCENE DEPOSITS), COASTAL LOWLANDS AQUIFER SYSTEM, SOUTH-CENTRAL UNITED STATES: USGS WATER-RESOURCES INVESTIGATIONS REPORT 92-4105, 1993.

AQUIFERS OF TEXAS: TEXAS WATER DEVELOPMENT BOARD REPORT 345, 1995.

GROUND WATER ATLAS OF THE UNITED STATES-SEGMENT 4OKLAHOMA AND TEXAS: USGS HYDROLOGIC INVESTIGATIONS ATLAS 730-E, 1996.

\section{JIM WELLS COUNTY}

UNDERGROUND WATERS OF COASTAL PLAIN OF TEXAS: USGS WATER-SUPPLY AND IRRIGATION PAPER 190, 1907.

RECORDS OF WELLS, DRILLERS' LOGS, AND WATER ANALYSES, AND MAP SHOWING LOCATION OF WELLS IN JIM WELLS COUNTY, TEXAS: USGS OPEN-FILE REPORT (UNNUMBERED), 1934.

MEMORANDUM CONCERNING QUALITY OF WATER TO WHICH WELL CASING IS EXPOSED IN JIM WELLS, BROOKS, AND KENEDY COUNTIES: USGS OPEN-FILE REPORT (UNNUMBERED), 1935.

UNDERGROUND WATER IN THE VICINITY OF ALICE, TEXAS: USGS OPEN-FILE REPORT (UNNUMBERED), 1937.

MEMORANDUM ON THE WASTE WATER FROM WEST PREMONT OIL FIELD, JIM WELLS COUNTY, TEXAS: USGS OPEN-FILE REPORT (UNNUMBERED), 1940.

RECORDS OF WELLS, DRILLERS' LOGS, AND WATER ANALYSES, AND MAP SHOWING LOCATION OF WELLS IN JIM WELLS COUNTY, TEXAS: TEXAS BOARD OF WATER ENGINEERS MISCELLANEOUS PUBLICATION 148, 1940.

MEMORANDUM ON THE PUBLIC WATER SUPPLY OF PREMONT, JIM WELLS COUNTY, TEXAS: USGS OPEN-FILE REPORT (UNNUMBERED), 1940.

MEMORANDUM ON THE PUBLIC WATER SUPPLY OF ALICE, JIM WELLS COUNTY, TEXAS: USGS OPEN-FILE REPORT (UNNUMBERED), 1940. 
MEMORANDUM ON THE GROUND-WATER SUPPLIES IN THE VICINITY OF THE LA GLORIA REFINERY, SOUTHERN JIM WELLS COUNTY, TEXAS: USGS OPEN-FILE REPORT (UNNUMBERED), 1943.

GROUND-WATER CONDITIONS IN PREMONT-LA GLORIA-FALFURRIAS DISTRICT, TEXAS: TEXAS BOARD OF WATER ENGINEERS MISCELLANEOUS PUBLICATION 212, 1944.

THE OCCURRENCE AND DEVELOPMENT OF GROUND WATER IN JIM WELLS COUNTY, TEXAS: USGS OPEN-FILE REPORT (UNNUMBERED, 1949

SUPPLEMENTARY REPORT ON SURFACE-WATER AND GROUNDWATER SURVEYS, NUECES RIVER BASIN, TEXAS: USGS OPENFILE REPORT (UNNUMBERED), 1950.

PUBLIC WATER SUPPLIES IN SOUTHERN TEXAS: USGS WATERSUPPLY PAPER 1070, 1950.

AVAILABILITY OF GROUND WATER IN THE GULF COAST REGION OF TEXAS: USGS OPEN-FILE REPORT (UNNUMBERED), 1956.

AVAILABILITY OF GROUND WATER FROM THE GOLIAD SAND IN THE ALICE AREA, TEXAS: TEXAS WATER COMMISSION BULLETIN 6301, 1963.

RECONNAISSANCE INVESTIGATION OF THE GROUND-WATER RESOURCES OF THE GULF COAST REGION, TEXAS: TEXAS WATER COMMISSION BULLETIN 6305, 1963.

RECONNAISSANCE INVESTIGATION OF THE GROUND-WATER RESOURCES OF THE GUADALUPE, SAN ANTONIO, AND NUECES RIVER BASINS, TEXAS: TEXAS WATER COMMISSION, BULLETIN 6409, 1964.

COMPILATION OF RESULTS OF AQUIFER TESTS IN TEXAS: TEXAS WATER DEVELOPMENT BOARD REPORT 98, 1969.

GEOHYDROLOGIC SIGNIFICANCE OF LITHOFACIES OF THE COCKFIELD FORMATION OF LOUISIANA AND MISSISSIPPI AND OF THE YEGUA FORMATION OF TEXAS: USGS PROFESSIONAL PAPER 569-B, 1970.

GROUND-WATER RESOURCES OF KLEBERG, KENEDY, AND SOUTHERN JIM WELLS COUNTIES, TEXAS: TEXAS WATER DEVELOPMENT BOARD REPORT 173, 1973.

GEOHYDROLOGIC SIGNIFICANCE OF LITHOFACIES OF THE CARRIZO SAND OF ARKANSAS, LOUISIANA, AND TEXAS AND THE MERIDIAN SAND OF MISSISSIPPI: USGS PROFESSIONAL PAPER 569-D, 1975.

SUMMARY APPRAISALS OF THE NATION'S GROUND-WATER RESOURCES-TEXAS GULF REGION: USGS PROFESSIONAL PAPER 813-F, 1976.

STRATIGRAPHIC AND HYDROGEOLOGIC FRAMEWORK OF PART OF THE COASTAL PLAIN OF TEXAS: USGS OPEN-FILE REPORT 77-712, 1978.

STRATIGRAPHIC AND HYDROGEOLOGIC FRAMEWORK OF PART OF THE COASTAL PLAIN OF TEXAS: TEXAS DEPARTMENT OF WATER RESOURCES REPORT 236, 1979.

LAND-SURFACE SUBSIDENCE IN THE TEXAS COASTAL REGION: USGS OPEN-FILE REPORT 80-969, 1980.

SPRINGS OF TEXAS, VOLUME 1: (BY GUNNAR BRUNE), BRANCHSMITH, INC., FORT WORTH, TEXAS, 1981.
LAND-SURFACE SUBSIDENCE IN THE TEXAS COASTAL REGION: TEXAS DEPARTMENT OF WATER RESOURCES REPORT 272, 1982.

REGIONAL HYDRODYNAMICS AND HYDROCHEMISTRY OF THE URANIUM-BEARING OAKVILLE AQUIFER (MIOCENE) OF SOUTH TEXAS: UNIVERSITY OF TEXAS, BUREAU OF ECONOMIC GEOLOGY REPORT OF INVESTIGATIONS NO. 124, 1982.

WATER LEVELS AND SALINITIES OF WATER WITHIN THE EVANGELINE AQUIFER IN AN AREA SOUTHWEST OF CORPUS CHRISTI, TEXAS: USGS OPEN-FILE REPORT 82-174, 1983.

TEXAS GROUND-WATER RESOURCES, in NATIONAL WATER SUMMARY 1984: USGS WATER-SUPPLY PAPER 2275, 1985.

SIMULATED EFFECTS OF PROJECTED PUMPING ON THE AVAILABILITY OF FRESHWATER IN THE EVANGELINE AQUIFER IN AN AREA SOUTHWEST OF CORPUS CHRISTI, TEXAS: USGS WATERRESOURCES INVESTIGATIONS REPORT 85-4182, 1985.

DIGITAL MODELS FOR SIMULATION OF GROUND-WATER HYDROLOGY OF THE CHICOT AND EVANGELINE AQUIFERS ALONG THE GULF COAST OF TEXAS: TEXAS DEPARTMENT OF WATER RESOURCES REPORT 289, 1985.

HYDROGEOLOGY AND PREDEVELOPMENT FLOW IN THE TEXAS GULF COAST AQUIFER SYSTEMS: USGS WATER-RESOURCES INVESTIGATIONS REPORT 87-4248, 1988.

GEOHYDROLOGIC FRAMEWORK OF THE GULF COASTAL PLAIN: USGS HYDROLOGIC INVESTIGATIONS ATLAS HA-695, 1988.

GROUND-WATER FLOW IN THE GULF COAST AQUIFER SYSTEMS, SOUTH-CENTRAL UNITED STATES-A PRELIMINARY ANALYSIS: USGS WATER-RESOURCES INVESTIGATIONS REPORT 89-4071, 1990.

HYDROLOGY OF THE TEXAS GULF COAST AQUIFER SYSTEMS: USGS OPEN-FILE REPORT 91-64, 1991.

PROPERTIES AND CHEMICAL CONSTITUENTS IN GROUND WATER FROM THE MISSISSIPPI RIVER VALLEY ALLUVIAL AQUIFER AND PERMEABLE ZONE A (HOLOCENE-UPPER PLEISTOCENE DEPOSITS), SOUTH-CENTRAL UNITED STATES: USGS WATERRESOURCES INVESTIGATIONS REPORT 91-4149, 1992.

PROPERTIES AND CHEMICAL CONSTITUENTS IN GROUND WATER FROM THE UPPER CLAIBORNE AQUIFER, GULF COAST REGIONAL AQUIFER SYSTEMS, SOUTH-CENTRAL UNITED STATES: USGS WATER-RESOURCES INVESTIGATIONS REPORT 91-4150, 1993.

PROPERTIES AND CHEMICAL CONSTITUENTS IN GROUND WATER FROM PERMEABLE ZONE C (LOWER PLIOCENE-UPPER MIOCENE DEPOSITS), COASTAL LOWLANDS AQUIFER SYSTEM, SOUTHCENTRAL UNITED STATES: USGS WATER-RESOURCES INVESTIGATIONS REPORT 91-4151, 1993.

PROPERTIES AND CHEMICAL CONSTITUENTS IN GROUND WATER FROM PERMEABLE ZONE B (LOWER PLEISTOCENE-UPPER PLIOCENE DEPOSITS), COASTAL LOWLANDS AQUIFER SYSTEM, SOUTH-CENTRAL UNITED STATES: USGS WATER-RESOURCES INVESTIGATIONS REPORT 91-4152, 1993.

PROPERTIES AND CHEMICAL CONSTITUENTS IN GROUND WATER FROM PERMEABLE ZONE E (LOWER MIOCENE-UPPER OLIGOCENE DEPOSITS), COASTAL LOWLANDS AQUIFER SYSTEM, SOUTH-CENTRAL UNITED STATES: USGS WATER-RESOURCES INVESTIGATIONS REPORT 92-4103, 1993. 
PROPERTIES AND CHEMICAL CONSTITUENTS IN GROUND WATER FROM PERMEABLE ZONE D (MIDDLE MIOCENE DEPOSITS), COASTAL LOWLANDS AQUIFER SYSTEM, SOUTH-CENTRAL UNITED STATES: USGS WATER-RESOURCES INVESTIGATIONS REPORT 92-4105, 1993.

AQUIFERS OF TEXAS: TEXAS WATER DEVELOPMENT BOARD REPORT 345, 1995.

STRATIGRAPHIC NOMENCLATURE AND GEOLOGIC SECTIONS OF THE GULF COASTAL PLAIN OF TEXAS: USGS OPEN-FILE REPORT 94-461, 1995.

\section{JOHNSON COUNTY}

GEOGRAPHY AND GEOLOGY OF THE BLACK AND GRAND PRAIRIES, TEXAS, WITH DETAILED DESCRIPTIONS OF THE CRETACEOUS FORMATIONS AND SPECIAL REFERENCE TO ARTESIAN WATERS: USGS 21ST ANNUAL REPORT, PART 7, 1901.

GROUND WATER IN THE VICINITY OF GODLEY, TEXAS: USGS OPEN-FILE REPORT (UNNUMBERED), 1942.

RESULTS OF PUMPING TESTS ON WELL (EASTMAN NO. 1) AT PROPOSED ARMY CAMP NEAR GODLEY, TEXAS: USGS OPEN-FILE REPORT (UNNUMBERED), 1942.

PUBLIC WATER SUPPLIES IN JOHNSON COUNTY, TEXAS: USGS OPEN-FILE REPORT (UNNUMBERED), 1943.

PUBLIC WATER SUPPLIES IN CENTRAL AND NORTH-CENTRAL TEXAS: USGS WATER-SUPPLY PAPER 1069, 1949.

RECONNAISSANCE INVESTIGATION OF THE GROUND-WATER RESOURCES OF THE TRINITY RIVER BASIN, TEXAS: TEXAS WATER COMMISSION BULLETIN 6309, 1963.

RECONNAISSANCE INVESTIGATION OF THE GROUND-WATER RESOURCES OF THE BRAZOS RIVER BASIN, TEXAS: TEXAS WATER COMMISSION BULLETIN 6310, 1963.

GROUND-WATER RESOURCES OF JOHNSON COUNTY, TEXAS: TEXAS WATER DEVELOPMENT BOARD REPORT 94, 1969.

COMPILATION OF RESULTS OF AQUIFER TESTS IN TEXAS: TEXAS WATER DEVELOPMENT BOARD REPORT 98, 1969.

MAJOR AND HISTORICAL SPRINGS OF TEXAS: TEXAS WATER DEVELOPMENT BOARD REPORT 189, 1975.

GROUND-WATER RESOURCES OF PART OF CENTRAL TEXAS WITH EMPHASIS ON THE ANTLERS AND TRAVIS PEAK FORMATIONS: TEXAS WATER DEVELOPMENT BOARD REPORT 195, V. 1, 1975.

GROUND-WATER RESOURCES OF PART OF CENTRAL TEXAS WITH EMPHASIS ON THE ANTLERS AND TRAVIS PEAK FORMATIONS: TEXAS WATER DEVELOPMENT BOARD REPORT 195, V. 2, 1976.

SUMMARY APPRAISALS OF THE NATION'S GROUND-WATER RESOURCES-TEXAS-GULF REGION: USGS PROFESSIONAL PAPER 813-F, 1976.

WATER-LEVEL AND WATER-QUALITY DATA FROM OBSERVATION WELLS IN NORTHEAST TEXAS: TEXAS WATER DEVELOPMENT BOARD REPORT 198, 1976.

OCCURRENCE, AVAILABILITY, AND CHEMICAL QUALITY OF GROUND WATER IN THE CRETACEOUS AQUIFERS OF NORTH-
CENTRAL TEXAS: TEXAS DEPARTMENT OF WATER RESOURCES REPORT 269, V. 1, 1982.

OCCURRENCE, AVAILABILITY, AND CHEMICAL QUALITY OF GROUND WATER IN THE CRETACEOUS AQUIFERS OF NORTHCENTRAL TEXAS: TEXAS DEPARTMENT OF WATER RESOURCES REPORT 269, V. 2, 1982.

TEXAS GROUND-WATER RESOURCES, in NATIONAL WATER SUMMARY 1984: USGS WATER-SUPPLY PAPER 2275, 1985.

WATER USE, PROJECTED WATER REQUIREMENTS, AND RELATED DATA AND INFORMATION FOR THE METROPOLITAN STATISTICAL AREAS IN TEXAS: TEXAS DEPARTMENT OF WATER RESOURCES LIMITED PRINTING REPORT LP-201, 1985.

EVALUATION OF WATER RESOURCES IN PART OF NORTH-CENTRAL TEXAS: TEXAS WATER DEVELOPMENT BOARD REPORT 318,1990

NATIONAL WATER-QUALITY ASSESSMENT PROGRAM-THE TRINITY RIVER BASIN: USGS OPEN-FILE REPORT 91-158, 1991.

NATIONAL WATER-QUALITY ASSESSMENT PROGRAM-PESTICIDES IN THE TRINITY RIVER BASIN STUDY UNIT, TEXAS, 1968-91: USGS FACT SHEET FS-088-95, 1995.

WATER-QUALITY ASSESSMENT OF THE TRINITY RIVER BASIN, TEXAS-DATA COLLECTION, 1992-95: USGS FACT SHEET FS-095-95, 1995.

WATER-QUALITY ASSESSMENT OF THE TRINITY RIVER BASIN, TEXAS-PESTICIDES IN A SUBURBAN WATERSHED, ARLINGTON, 1993-94: USGS FACT SHEET FS-159-95, 1995.

HYDROGEOLOGIC ASSESSMENT OF SHALLOW GROUNDWATER FLOW SYSTEMS OF THE WALNUT FORMATION, CENTRAL TEXAS: (MASTER'S THESIS), BAYLOR GEOLOGICAL STUDIES (THESIS ABSTRACTS), BULLETIN 56, BAYLOR UNIVERSITY, WACO, TEXAS, 1995.

AQUIFERS OF TEXAS: TEXAS WATER DEVELOPMENT BOARD REPORT 345, 1995.

WATER QUALITY IN THE WOODBINE AQUIFER, NORTH-CENTRAL TEXAS: TEXAS WATER DEVELOPMENT BOARD HYDROLOGIC ATLAS NO. 4, 1996.

UPDATED EVALUATION OF WATER RESOURCES IN PART OF NORTH-CENTRAL TEXAS, 1990-1999: TEXAS WATER DEVELOPMENT BOARD REPORT 349, 1999.

\section{JONES COUNTY}

PRELIMINARY REPORT OF GROUND-WATER RESOURCES NEAR STAMFORD IN JONES AND HASKELL COUNTIES, TEXAS: USGS OPEN-FILE REPORT (UNNUMBERED), 1944.

PUBLIC WATER SUPPLIES IN CENTRAL AND NORTH-CENTRAL TEXAS: USGS WATER-SUPPLY PAPER 1069, 1949.

GROUND-WATER RESOURCES OF JONES COUNTY, TEXAS: TEXAS BOARD OF WATER ENGINEERS BULLETIN 5418, 1954.

RECONNAISSANCE REPORT ON ALLEGED CONTAMINATION OF CALIFORNIA CREEK NEAR AVOCA, JONES COUNTY, TEXAS: TEXAS BOARD OF WATER ENGINEERS CONTAMINATION REPORT NO. 5, 1958. 
RECONNAISSANCE OF ALLEGED SALT-CONTAMINATION OF SOILS NEAR STAMFORD, JONES COUNTY, TEXAS: TEXAS BOARD OF WATER ENGINEERS CONTAMINATION REPORT NO. 6, 1960.

RECONNAISSANCE INVESTIGATION OF THE GROUND-WATER RESOURCES OF THE BRAZOS RIVER BASIN, TEXAS: TEXAS WATER COMMISSION BULLETIN 6310, 1963.

OCCURRENCE, QUALITY, AND AVAILABILITY OF GROUND WATER IN JONES COUNTY, TEXAS: TEXAS DEPARTMENT OF WATER RESOURCES REPORT 215, 1978.

EVALUATION OF WATER RESOURCES IN PARTS OF THE ROLLING PRAIRIES REGION OF NORTH-CENTRAL TEXAS: TEXAS WATER DEVELOPMENT BOARD REPORT 337, 1992.

AQUIFERS OF TEXAS: TEXAS WATER DEVELOPMENT BOARD REPORT 345, 1995.

\section{KARNES COUNTY}

UNDERGROUND WATERS OF THE COASTAL PLAIN OF TEXAS: USGS WATER-SUPPLY AND IRRIGATION PAPER 190, 1907.

RECORDS OF WELLS, DRILLERS' LOGS, WATER ANALYSES, AND MAP SHOWING LOCATION OF WELLS IN KARNES COUNTY, TEXAS: TEXAS BOARD OF WATER ENGINEERS MISCELLANEOUS PUBLICATION 151, 1937.

PUBLIC WATER SUPPLIES IN SOUTHERN TEXAS: USGS WATERSUPPLY PAPER 1070, 1950.

SUPPLEMENTARY REPORT ON SURFACE-WATER AND GROUNDWATER SURVEYS, NUECES RIVER BASIN, TEXAS: USGS OPENFILE REPORT (UNNUMBERED), 1950

CROSS SECTION SHOWING SAND AND CLAY ZONES, McMULLEN ATASCOSA, AND KARNES COUNTIES, TEXAS: USGS OPEN-FILE REPORT (UNNUMBERED), 1952.

GROUND-WATER GEOLOGY OF KARNES COUNTY, TEXAS: TEXAS BOARD OF WATER ENGINEERS BULLETIN 6007, 1960.

RECONNAISSANCE INVESTIGATION OF THE GROUND-WATER RESOURCES OF THE GUADALUPE, SAN ANTONIO, AND NUECES RIVER BASINS, TEXAS: TEXAS WATER COMMISSION BULLETIN 6409, 1964.

HYDROLOGIC SIGNIFICANCE OF THE LITHOFACIES OF THE SPARTA SAND IN ARKANSAS, LOUISIANA, MISSISSIPPI, AND TEXAS: USGS PROFESSIONAL PAPER 569-A, 1968.

COMPILATION OF RESULTS OF AQUIFER TESTS IN TEXAS: TEXAS WATER DEVELOPMENT BOARD REPORT 98, 1969.

GEOHYDROLOGIC SIGNIFICANCE OF LITHOFACIES OF THE COCKFIELD FORMATION OF LOUISIANA AND MISSISSIPPI AND OF THE YEGUA FORMATION OF TEXAS: USGS PROFESSIONAL PAPER 569-B, 1970.

DEPOSITIONAL ENVIRONMENT AS INDICATED BY CHLORINITY OF INTERSTITIAL WATER IN CORES FROM KARNES COUNTY, TEXAS: USGS OPEN-FILE REPORT 73-0175, 1972

HYDROLOGIC SIGNIFICANCE OF LITHOFACIES OF THE CANE RIVER FORMATION OR EQUIVALENTS OF ARKANSAS, LOUISIANA, MISSISSIPPI, AND TEXAS: USGS PROFESSIONAL PAPER 569-C, 1972
GEOHYDROLOGIC SIGNIFICANCE OF LITHOFACIES OF THE CARRIZO SAND OF ARKANSAS, LOUISIANA, AND TEXAS AND THE MERIDIAN SAND OF MISSISSIPPI: USGS PROFESSIONAL PAPER 569-D, 1975.

SUMMARY APPRAISALS OF THE NATION'S GROUND-WATER RESOURCES-TEXAS-GULF REGION: USGS PROFESSIONAL PAPER 813-F, 1976.

GROUND-WATER RESOURCES OF THE CARRIZO AQUIFER IN THE WINTER GARDEN AREA OF TEXAS, VOLUME 1: TEXAS WATER DEVELOPMENT BOARD REPORT 210, V. 1, 1976.

GROUND-WATER RESOURCES OF THE CARRIZO AQUIFER IN THE WINTER GARDEN AREA OF TEXAS, VOLUME 2: TEXAS WATER DEVELOPMENT BOARD REPORT 210, V. 2, 1977.

STRATIGRAPHIC AND HYDROGEOLOGIC FRAMEWORK OF PART OF THE COASTAL PLAIN OF TEXAS: USGS OPEN-FILE REPORT 77-712, 1978.

STRATIGRAPHIC AND HYDROGEOLOGIC FRAMEWORK OF PART OF THE COASTAL PLAIN OF TEXAS: TEXAS DEPARTMENT OF WATER RESOURCES REPORT 236, 1979.

REGIONAL HYDRODYNAMICS AND HYDROCHEMISTRY OF THE URANIUM-BEARING OAKVILLE AQUIFER (MIOCENE) OF SOUTH TEXAS: UNIVERSITY OF TEXAS, BUREAU OF ECONOMIC GEOLOGY REPORT OF INVESTIGATIONS NO. 124, 1982.

TEXAS GROUND-WATER RESOURCES, in NATIONAL WATER SUMMARY 1984: USGS WATER-SUPPLY PAPER 2275, 1985.

APPROXIMATE POTENTIOMETRIC SURFACES FOR THE AQUIFERS OF THE TEXAS COASTAL UPLANDS SYSTEM, 1980: USGS HYDROLOGIC INVESTIGATIONS ATLAS HA-704, 1987.

HYDROGEOLOGY AND PREDEVELOPMENT FLOW IN THE TEXAS GULF COAST AQUIFER SYSTEMS: USGS WATER-RESOURCES INVESTIGATIONS REPORT 87-4248, 1988.

DEPOSITIONAL AND GROUND-WATER FLOW SYSTEMS OF THE CARRIZO-UPPER WILCOX, SOUTH TEXAS: UNIVERSITY OF TEXAS, BUREAU OF ECONOMIC GEOLOGY REPORT OF INVESTIGATIONS NO. 175, 1988.

GEOHYDROLOGIC FRAMEWORK OF THE GULF COASTAL PLAIN: USGS HYDROLOGIC INVESTIGATIONS ATLAS HA-695, 1988

GROUND-WATER FLOW IN THE GULF COAST AQUIFER SYSTEMS, SOUTH-CENTRAL UNITED STATES-A PRELIMINARY ANALYSIS USGS WATER-RESOURCES INVESTIGATIONS REPORT 89-4071, 1990.

GROUND-WATER QUALITY MONITORING RESULTS IN THE WINTER GARDEN AREA, 1990: TEXAS WATER DEVELOPMENT BOARD REPORT 335, 1992.

PROPERTIES AND CHEMICAL CONSTITUENTS IN GROUND WATER FROM THE UPPER CLAIBORNE AQUIFER, GULF COAST REGIONAL AQUIFER SYSTEMS, SOUTH-CENTRAL UNITED STATES: USGS WATER-RESOURCES INVESTIGATIONS REPORT 91-4150, 1993.

PROPERTIES AND CHEMICAL CONSTITUENTS IN GROUND WATER FROM PERMEABLE ZONE C (LOWER PLIOCENE-UPPER MIOCENE DEPOSITS), COASTAL LOWLANDS AQUIFER SYSTEM, SOUTHCENTRAL UNITED STATES: USGS WATER-RESOURCES INVESTIGATIONS REPORT 91-4151, 1993.

PROPERTIES AND CHEMICAL CONSTITUENTS IN GROUND WATER FROM THE LOWER CLAIBORNE-UPPER WILCOX AQUIFER, GULF 
COAST REGIONAL AQUIFER SYSTEMS, SOUTH-CENTRAL UNITED STATES: USGS WATER-RESOURCES INVESTIGATIONS REPORT 92-4102, 1993

PROPERTIES AND CHEMICAL CONSTITUENTS IN GROUND WATER FROM PERMEABLE ZONE E (LOWER MIOCENE-UPPER OLIGOCENE DEPOSITS), COASTAL LOWLANDS AQUIFER SYSTEM, SOUTH-CENTRAL UNITED STATES: USGS WATER-RESOURCES INVESTIGATIONS REPORT 92-4103, 1993.

PROPERTIES AND CHEMICAL CONSTITUENTS IN GROUND WATER FROM THE MIDDLE CLAIBORNE AQUIFER, GULF COAST REGIONAL AQUIFER SYSTEMS, SOUTH-CENTRAL UNITED STATES: USGS WATER-RESOURCES INVESTIGATIONS REPORT 92-4104, 1993.

PROPERTIES AND CHEMICAL CONSTITUENTS IN GROUND WATER FROM PERMEABLE ZONE D (MIDDLE MIOCENE DEPOSITS), COASTAL LOWLANDS AQUIFER SYSTEM, SOUTH-CENTRAL UNITED STATES: USGS WATER-RESOURCES INVESTIGATIONS REPORT 92-4105, 1993.

PROPERTIES AND CHEMICAL CONSTITUENTS IN GROUND WATER FROM THE MIDDLE WILCOX AQUIFER, GULF COAST REGIONAL AQUIFER SYSTEMS, SOUTH-CENTRAL UNITED STATES: USGS WATER-RESOURCES INVESTIGATIONS REPORT 93-4070, 1993.

AQUIFERS OF TEXAS: TEXAS WATER DEVELOPMENT BOARD REPORT 345, 1995.

STRATIGRAPHIC NOMENCLATURE AND GEOLOGIC SECTIONS OF THE GULF COASTAL PLAIN OF TEXAS: USGS OPEN-FILE REPORT 94-461, 1995.

HYDROGEOLOGIC FRAMEWORK AND GEOCHEMISTRY OF THE EDWARDS AQUIFER SALINE-WATER ZONE, SOUTH-CENTRAL TEXAS: USGS WATER-RESOURCES INVESTIGATIONS REPORT 97-4133, 1997.

WATER QUALITY IN SOUTH-CENTRAL TEXAS-TEXAS, 1996-98: USGS CIRCULAR 1212, 2000

\section{KAUFMAN COUNTY}

GEOGRAPHY AND GEOLOGY OF THE BLACK AND GRAND PRAIRIES, TEXAS, WITH DETAILED DESCRIPTIONS OF THE CRETACEOUS FORMATIONS AND SPECIAL REFERENCE TO ARTESIAN WATERS: USGS 21ST ANNUAL REPORT, PART 7, 1901

GEOLOGY AND UNDERGROUND WATERS OF THE SOUTHEASTERN PART OF THE TEXAS COASTAL PLAIN: USGS WATER-SUPPLY PAPER 335, 1914.

PUBLIC WATER SUPPLIES IN EASTERN TEXAS: USGS WATERSUPPLY PAPER 1047, 1948.

RECONNAISSANCE INVESTIGATION OF THE GROUND-WATER RESOURCES OF THE SABINE RIVER BASIN, TEXAS: TEXAS WATER COMMISSION BULLETIN 6307, 1963.

RECONNAISSANCE INVESTIGATION OF THE GROUND-WATER RESOURCES OF THE TRINITY RIVER BASIN, TEXAS: TEXAS WATER COMMISSION BULLETIN 6309, 1963.

WATER-LEVEL AND WATER-QUALITY DATA FROM OBSERVATION WELLS IN NORTHEAST TEXAS: TEXAS WATER DEVELOPMENT BOARD REPORT 198, 1976
SUMMARY APPRAISALS OF THE NATION'S GROUND-WATER RESOURCES-TEXAS-GULF REGION: USGS PROFESSIONAL PAPER 813-F, 1976.

SPRINGS OF TEXAS, VOLUME 1: (BY GUNNAR BRUNE), BRANCHSMITH, INC., FORT WORTH, TEXAS, 1981.

GEOLOGY AND GEOHYDROLOGY OF THE EAST TEXAS BASIN-A REPORT ON THE PROGRESS OF NUCLEAR WASTE ISOLATION FEASIBILITY STUDIES (1979): UNIVERSITY OF TEXAS, BUREAU OF ECONOMIC GEOLOGY GEOLOGICAL CIRCULAR 80-12, 1980.

GEOLOGY AND GEOHYDROLOGY OF THE EAST TEXAS BASIN-A REPORT ON THE PROGRESS OF NUCLEAR WASTE ISOLATION FEASIBILITY STUDIES (1980): UNIVERSITY OF TEXAS, BUREAU OF ECONOMIC GEOLOGY GEOLOGICAL CIRCULAR 81-7, 1981.

OCCURRENCE, AVAILABILITY, AND CHEMICAL QUALITY OF GROUND WATER IN THE CRETACEOUS AQUIFERS OF NORTHCENTRAL TEXAS: TEXAS DEPARTMENT OF WATER RESOURCES REPORT 269, V. 1, 1982.

OCCURRENCE, AVAILABILITY, AND CHEMICAL QUALITY OF GROUND WATER IN THE CRETACEOUS AQUIFERS OF NORTHCENTRAL TEXAS: TEXAS DEPARTMENT OF WATER RESOURCES REPORT 269, V. 2, 1982

WATER USE, PROJECTED WATER REQUIREMENTS, AND RELATED DATA AND INFORMATION FOR THE METROPOLITAN STATISTICAL AREAS IN TEXAS: TEXAS DEPARTMENT OF WATER RESOURCES LIMITED PRINTING REPORT LP-201, 1985.

TEXAS GROUND-WATER RESOURCES, in NATIONAL WATER SUMMARY 1984: USGS WATER-SUPPLY PAPER 2275, 1985.

APPROXIMATE POTENTIOMETRIC SURFACES FOR THE AQUIFERS OF THE COASTAL UPLANDS SYSTEM, 1980: USGS HYDROLOGIC INVESTIGATIONS ATLAS HA-704, 1987.

GROUND-WATER RESOURCES OF THE NACATOCH AQUIFER: TEXAS WATER DEVELOPMENT BOARD REPORT 305, 1988.

EVALUATION OF WATER RESOURCES IN PART OF NORTH-CENTRAL TEXAS: TEXAS WATER DEVELOPMENT BOARD REPORT 318,1990

NATIONAL WATER-QUALITY ASSESSMENT PROGRAM-THE TRINITY RIVER BASIN: USGS OPEN-FILE REPORT 91-158, 1991.

NATIONAL WATER-QUALITY ASSESSMENT PROGRAM-PESTICIDES IN THE TRINITY RIVER BASIN STUDY UNIT, TEXAS, 1968-91: USGS FACT SHEET FS-088-95, 1995.

WATER-QUALITY ASSESSMENT OF THE TRINITY RIVER BASIN, TEXAS-DATA COLLECTION, 1992-95: USGS FACT SHEET FS-095-95, 1995.

WATER-QUALITY ASSESSMENT OF THE TRINITY RIVER BASIN, TEXAS-PESTICIDES IN A SUBURBAN WATERSHED, ARLINGTON, 1993-94: USGS FACT SHEET FS-159-95, 1995.

AQUIFERS OF TEXAS: TEXAS WATER DEVELOPMENT BOARD REPORT 345, 1995

WATER QUALITY IN THE WOODBINE AQUIFER, NORTH-CENTRAL TEXAS: TEXAS WATER DEVELOPMENT BOARD HYDROLOGIC ATLAS NO. 4, 1996

UPDATED EVALUATION OF WATER RESOURCES IN PART OF NORTH-CENTRAL TEXAS, 1990-1999: TEXAS WATER DEVELOPMENT BOARD REPORT 349, 1999. 


\section{KENDAL COUNTY}

RECORDS OF WELLS, DRILLERS' LOGS, WATER ANALYSES, AND MAP SHOWING LOCATIONS OF WELLS IN KENDALL COUNTY, TEXAS: TEXAS BOARD OF WATER ENGINEERS MISCELLANEOUS PUBLICATION 152, 1940.

MEMORANDUM ON BOERNE GROUND-WATER INVESTIGATION: USGS OPEN-FILE REPORT (UNNUMBERED), 1940.

GROUND-WATER CONDITIONS IN VICINITY OF RESERVOIR SITE ON CIBOLO CREEK AT BOERNE, TEXAS: USGS OPEN-FILE REPORT (UNNUMBERED), 1940.

PUBLIC WATER SUPPLIES IN SOUTHERN TEXAS: USGS WATERSUPPLY PAPER 1070, 1950.

GROUND-WATER RESOURCES IN THE VICINITY OF KENMORE FARMS, KENDALL COUNTY, TEXAS: TEXAS BOARD OF WATER ENGINEERS BULLETIN 5204, 1952.

GROUND-WATER RESOURCES OF THE SAN ANTONIO AREA, TEXAS, A PROGRESS REPORT OF CURRENT STUDIES: TEXAS BOARD OF WATER ENGINEERS BULLETIN 5412, 1954.

RECONNAISSANCE INVESTIGATION OF THE GROUND-WATER RESOURCES OF THE GUADALUPE, SAN ANTONIO, AND NUECES RIVER BASINS, TEXAS: TEXAS WATER COMMISSION BULLETIN 6409, 1964.

RECORDS OF PRECIPITATION, AQUIFER HEAD, AND GROUNDWATER RECHARGE TO THE EDWARDS AND ASSOCIATED LIMESTONES, SAN ANTONIO AREA, TEXAS, 1965: EDWARDS UNDERGROUND WATER DISTRICT BULLETIN 12, 1966.

RECONNAISSANCE INVESTIGATION OF THE GROUND-WATER RESOURCES OF THE COLORADO RIVER BASIN, TEXAS: TEXAS WATER DEVELOPMENT BOARD REPORT 51, 1967.

RECORDS OF PRECIPITATION, AQUIFER HEAD, AND GROUNDWATER RECHARGE TO THE EDWARDS AND ASSOCIATED LIMESTONES, SAN ANTONIO AREA, TEXAS, 1966: EDWARDS UNDERGROUND WATER DISTRICT BULLETIN 15, 1967.

GROUND-WATER RESOURCES OF KENDALL COUNTY, TEXAS: TEXAS WATER DEVELOPMENT BOARD REPORT 60, 1967.

RECORDS OF PRECIPITATION, AQUIFER HEAD, AND GROUNDWATER RECHARGE TO THE EDWARDS AND ASSOCIATED LIMESTONES, SAN ANTONIO AREA, TEXAS, 1967: EDWARDS UNDERGROUND WATER DISTRICT BULLETIN 18, 1968.

RECORDS OF PRECIPITATION, AQUIFER HEAD, AND GROUNDWATER RECHARGE TO THE EDWARDS AND ASSOCIATED LIMESTONES, SAN ANTONIO AREA, TEXAS, 1968: EDWARDS UNDERGROUND WATER DISTRICT BULLETIN 21, 1969.

COMPILATION OF RESULTS OF AQUIFER TESTS IN TEXAS: TEXAS WATER DEVELOPMENT BOARD REPORT 98, 1969.

RECORDS OF PRECIPITATION, WATER LEVELS, AND GROUNDWATER RECHARGE TO THE EDWARDS AND ASSOCIATED LIMESTONES, SAN ANTONIO AREA, TEXAS, 1969: EDWARDS UNDERGROUND WATER DISTRICT BULLETIN 24, 1970.

RECORDS OF PRECIPITATION, WATER LEVELS, AND GROUNDWATER RECHARGE TO THE EDWARDS AND ASSOCIATED LIMESTONES, SAN ANTONIO AREA, TEXAS, 1970: EDWARDS UNDERGROUND WATER DISTRICT BULLETIN 27, 1971.
RECORDS OF PRECIPITATION, WATER LEVELS, AND GROUNDWATER RECHARGE TO THE EDWARDS AND ASSOCIATED LIMESTONES, SAN ANTONIO AREA, TEXAS, 1971: EDWARDS UNDERGROUND WATER DISTRICT BULLETIN 30, 1972.

RECORDS OF PRECIPITATION, WATER LEVELS, AND GROUNDWATER RECHARGE TO THE EDWARDS AND ASSOCIATED LIMESTONES, SAN ANTONIO AREA, TEXAS, 1972-73: EDWARDS UNDERGROUND WATER DISTRICT BULLETIN 33, 1974.

RELATION OF PRECIPITATION TO ANNUAL GROUND-WATER RECHARGE IN THE EDWARDS AQUIFER, SAN ANTONIO AREA, TEXAS: USGS OPEN-FILE REPORT 75-298, 1975.

MAJOR AND HISTORICAL SPRINGS OF TEXAS: TEXAS WATER DEVELOPMENT BOARD REPORT 189, 1975.

SUMMARY APPRAISALS OF THE NATION'S GROUND-WATER RESOURCES-TEXAS-GULF REGION: USGS PROFESSIONAL PAPER 813-F, 1976.

METHOD OF ESTIMATING NATURAL RECHARGE TO THE EDWARDS AQUIFER IN THE SAN ANTONIO AREA, TEXAS: USGS WATERRESOURCES INVESTIGATIONS REPORT 78-10, 1978.

REGIONAL DISTRIBUTION OF FRACTURES IN THE SOUTHERN EDWARDS PLATEAU AND THEIR RELATIONSHIP TO TECTONICS AND CAVES: UNIVERSITY OF TEXAS, BUREAU OF ECONOMIC GEOLOGY GEOLOGICAL CIRCULAR 78-2, 1978.

RECORDS OF GROUND-WATER RECHARGE AND DISCHARGE FOR THE EDWARDS AQUIFER IN THE SAN ANTONIO AREA, TEXAS, 1934-77: EDWARDS UNDERGROUND WATER DISTRICT BULLETIN 37, 1979.

RECORDS OF GROUND-WATER RECHARGE, DISCHARGE, WATER LEVELS, AND CHEMICAL QUALITY OF WATER FOR THE EDWARDS AQUIFER IN THE SAN ANTONIO AREA, TEXAS, 1934-78: EDWARDS UNDERGROUND WATER DISTRICT BULLETIN 38, 1980.

RECORDS OF GROUND-WATER RECHARGE, DISCHARGE, WATER LEVELS, AND CHEMICAL QUALITY OF WATER FOR THE EDWARDS AQUIFER IN THE SAN ANTONIO AREA, TEXAS, 1934-79: EDWARDS UNDERGROUND WATER DISTRICT BULLETIN 39, 1981.

RECORDS OF GROUND-WATER RECHARGE, DISCHARGE, WATER LEVELS, AND CHEMICAL QUALITY OF WATER FOR THE EDWARDS AQUIFER IN THE SAN ANTONIO AREA, TEXAS, 1934-80: EDWARDS UNDERGROUND WATER DISTRICT BULLETIN 40, 1982.

GROUND-WATER AVAILABILITY OF THE LOWER CRETACEOUS FORMATIONS IN THE HILL COUNTRY OF SOUTH-CENTRAL TEXAS: TEXAS DEPARTMENT OF WATER RESOURCES REPORT 273,1983

RECORDS OF GROUND-WATER RECHARGE, DISCHARGE, WATER LEVELS, AND CHEMICAL QUALITY OF WATER FOR THE EDWARDS AQUIFER IN THE SAN ANTONIO AREA, TEXAS, 1934-81: EDWARDS UNDERGROUND WATER DISTRICT BULLETIN 41, 1984.

CARBONATE GEOLOGY AND HYDROLOGY OF THE EDWARDS AQUIFER IN THE SAN ANTONIO AREA, TEXAS: USGS OPEN-FILE REPORT 83-537, 1984.

RECORDS OF GROUND-WATER RECHARGE, DISCHARGE, WATER LEVELS, AND CHEMICAL QUALITY OF WATER FOR THE EDWARDS AQUIFER IN THE SAN ANTONIO AREA, TEXAS, 
1934-82: EDWARDS UNDERGROUND WATER DISTRICT BULLETIN 42, 1985.

TEXAS GROUND-WATER RESOURCES, in NATIONAL WATER SUMMARY 1984: USGS WATER-SUPPLY PAPER 2275, 1985.

COMPILATION OF HYDROLOGIC DATA FOR THE EDWARDS AQUIFER, SAN ANTONIO AREA, TEXAS, 1983-84, WITH 1934-84 SUMMARY: EDWARDS UNDERGROUND WATER DISTRICT BULLETIN 43-44, 1986.

CARBONATE GEOLOGY AND HYDROLOGY OF THE EDWARDS AQUIFER IN THE SAN ANTONIO AREA, TEXAS: TEXAS WATER DEVELOPMENT BOARD REPORT 296, 1986.

COMPILATION OF HYDROLOGIC DATA FOR THE EDWARDS AQUIFER, SAN ANTONIO AREA, TEXAS, 1985, WITH 1934-85 SUMMARY: EDWARDS UNDERGROUND WATER DISTRICT BULLETIN 45, 1987.

COMPILATION OF HYDROLOGIC DATA FOR THE EDWARDS AQUIFER, SAN ANTONIO AREA, TEXAS, 1986, WITH 1934-86 SUMMARY: EDWARDS UNDERGROUND WATER DISTRICT BULLETIN 46, 1988

COMPILATION OF HYDROLOGIC DATA FOR THE EDWARDS AQUIFER, SAN ANTONIO AREA, TEXAS, 1987, WITH 1934-87 SUMMARY: EDWARDS UNDERGROUND WATER DISTRICT BULLETIN 47, 1988.

COMPILATION OF HYDROLOGIC DATA FOR THE EDWARDS AQUIFER, SAN ANTONIO AREA, TEXAS, 1988, WITH 1934-88 SUMMARY: EDWARDS UNDERGROUND WATER DISTRICT BULLETIN 48, 1989.

POTENTIOMETRIC SURFACE OF THE EDWARDS-TRINITY AQUIFER SYSTEM AND CONTIGUOUS HYDRAULICALLY CONNECTED UNITS, WEST-CENTRAL TEXAS, WINTER 1974-75: USGS WATERRESOURCES INVESTIGATIONS REPORT 89-4208, 1990.

COMPILATION OF HYDROLOGIC DATA FOR THE EDWARDS AQUIFER, SAN ANTONIO AREA, TEXAS, 1989, WITH 1934-89 SUMMARY: EDWARDS UNDERGROUND WATER DISTRICT BULLETIN 49, 1990.

WITHDRAWALS FROM THE EDWARDS-TRINITY AQUIFER SYSTEM AND CONTIGUOUS HYDRAULICALLY CONNECTED UNITS, WEST-CENTRAL TEXAS, DECEMBER 1974 THROUGH MARCH 1977: USGS WATER-RESOURCES INVESTIGATIONS REPORT 91-4021, 1991.

EDWARDS AQUIFER, A TEXAS TREASURE-A TEACHERS GUIDE, SECONDARY, GRADES 7-12: EDWARDS UNDERGROUND WATER DISTRICT, 1991.

COMPILATION OF HYDROLOGIC DATA FOR THE EDWARDS AQUIFER, SAN ANTONIO AREA, TEXAS, 1990, WITH 1934-90 SUMMARY: EDWARDS UNDERGROUND WATER DISTRICT BULLETIN 50, 1991.

INSIDE THE EDWARDS AQUIFER-A THREE-PART TECHNICAL FILM, HIGH-SCHOOL LEVEL TEACHER'S GUIDE: EDWARDS UNDERGROUND WATER DISTRICT, 1992.

CONFIGURATION OF THE BASE OF THE EDWARDS-TRINITY AQUIFER SYSTEM AND HYDROGEOLOGY OF THE UNDERLYING PRECRETACEOUS ROCKS, WEST-CENTRAL TEXAS: USGS WATERRESOURCES INVESTIGATIONS REPORT 91-4071, 1992.

EVALUATION OF THE GROUND-WATER RESOURCES OF THE PALEOZOIC AND CRETACEOUS AQUIFERS IN THE HILL COUNTRY OF
CENTRAL TEXAS: TEXAS WATER DEVELOPMENT BOARD REPORT 339, 1992

COMPILATION OF HYDROLOGIC DATA FOR THE EDWARDS AQUIFER, SAN ANTONIO AREA, TEXAS, 1991, WITH 1934-91 SUMMARY: EDWARDS UNDERGROUND WATER DISTRICT BULLETIN $51,1992$.

HISTORICAL POTENTIOMETRIC SURFACE OF THE EDWARDS-TRINITY AQUIFER SYSTEM AND CONTIGUOUS HYDRAULICALLY CONNECTED UNITS, WEST-CENTRAL TEXAS: USGS WATERRESOURCES INVESTIGATIONS REPORT 92-4055, 1993.

HISTORICAL SATURATED THICKNESS OF THE EDWARDS-TRINITY AQUIFER SYSTEM AND SELECTED CONTIGUOUS HYDRAULICALLY CONNECTED UNITS, WEST-CENTRAL TEXAS: USGS WATER-RESOURCES INVESTIGATIONS REPORT 92-4125, 1993.

EDWARDS AQUIFER HYDROGEOLOGIC STATUS REPORT FOR 1992 EDWARDS UNDERGROUND WATER DISTRICT REPORT 93-05, 1993.

SIMULATIONS OF FLOW IN THE EDWARDS-TRINITY AQUIFER SYSTEM AND CONTIGUOUS HYDRAULICALLY CONNECTED UNITS, WEST-CENTRAL TEXAS: USGS WATER-RESOURCES INVESTIGATIONS REPORT 93-4039, 1994.

DISSOLVED-SOLIDS CONCENTRATIONS AND HYDROCHEMICAL FACIES IN WATER OF THE EDWARDS-TRINITY AQUIFER SYSTEM, WEST-CENTRAL TEXAS: USGS WATER-RESOURCES INVESTIGATIONS REPORT 93-4126, 1994.

NATIONAL WATER-QUALITY ASSESSMENT PROGRAM-SOUTHCENTRAL TEXAS: USGS FACT SHEET FS-94-048, 1994.

GEOLOGIC HISTORY AND HYDROGEOLOGIC SETTING OF THE EDWARDS-TRINITY AQUIFER SYSTEM, WEST-CENTRAL TEXAS: USGS WATER-RESOURCES INVESTIGATIONS REPORT 94-4039, 1994.

AQUIFERS OF TEXAS: TEXAS WATER DEVELOPMENT BOARD REPORT 345, 1995.

WATER QUALITY IN THE EDWARDS-TRINITY (PLATEAU) AQUIFER, EDWARDS PLATEAU AND TRANS-PECOS, TEXAS: TEXAS WATER DEVELOPMENT BOARD HYDROLOGIC ATLAS NO. 3, 1995.

HYDROGEOLOGIC FRAMEWORK OF THE EDWARDS-TRINITY AQUIFER SYSTEM, WEST-CENTRAL TEXAS: USGS PROFESSIONAL PAPER 1421-B, 1996.

WATER-RESOURCES DATA, TEXAS, WATER YEAR 1997, VOLUME 4 , GROUND-WATER DATA: USGS WATER-DATA REPORT TX-97-4, 1998.

WATER-RESOURCES DATA, TEXAS, WATER YEAR 1998, VOLUME 4 GROUND-WATER DATA: USGS WATER-DATA REPORT TX-98-4, 1999.

WATER QUALITY IN SOUTH-CENTRAL TEXAS-TEXAS, 1996-98: USGS CIRCULAR 1212, 2000.

GROUNDWATER AVAILABILITY OF THE TRINITY AQUIFER, HILL COUNTRY AREA, TEXAS: NUMERICAL SIMULATIONS THROUGH 2050: TEXAS WATER DEVELOPMENT BOARD REPORT 353, 2000.

AN OVERVIEW OF THE EDWARDS-TRINITY AQUIFER SYSTEM, CENTRAL-WEST TEXAS, CHAPTER 8, in AQUIFERS OF WEST TEXAS: TEXAS WATER DEVELOPMENT BOARD REPORT 356, 2001 
WATER-RESOURCES DATA, TEXAS, WATER YEAR 2000, VOLUME 6, GROUND-WATER DATA: USGS WATER-DATA REPORT TX-00-6, 2001

\section{KENEDY COUNTY}

UNDERGROUND WATERS OF COASTAL PLAIN OF TEXAS: USGS WATER-SUPPLY AND IRRIGATION PAPER 190, 1907.

WELL RECORDS, DRILLERS' LOGS, AND WATER ANALYSES IN KENEDY COUNTY, TEXAS: USGS OPEN-FILE REPORT (UNNUMBERED), 1934.

MEMORANDUM CONCERNING QUALITY OF WATER TO WHICH WELL CASING IS EXPOSED IN JIM WELLS, BROOKS, AND KENEDY COUNTIES, TEXAS: USGS OPEN-FILE REPORT (UNNUMBERED), 1935.

RECORDS OF WELLS, DRILLERS' LOGS, WATER ANALYSES, AND MAP SHOWING LOCATION OF WELLS IN KENEDY COUNTY, TEXAS: TEXAS BOARD OF WATER ENGINEERS MISCELLANEOUS PUBLICATION 153, 1940.

AVAILABILITY OF GROUND WATER IN THE GULF COAST REGION OF TEXAS: USGS OPEN-FILE REPORT (UNNUMBERED), 1956.

RECONNAISSANCE INVESTIGATION OF THE GROUND-WATER RESOURCES OF THE GULF COAST REGION, TEXAS: TEXAS WATER COMMISSION BULLETIN 6305, 1963.

RELATION OF PONDED FLOODWATER FROM HURRICANE BEULAH TO GROUND WATER IN KLEBERG, KENEDY, AND WILLACY COUNTIES, TEXAS: TEXAS WATER DEVELOPMENT BOARD REPORT 138, 1971.

GROUND-WATER RESOURCES OF KLEBERG, KENEDY, AND SOUTHERN JIM WELLS COUNTIES, TEXAS: TEXAS WATER DEVELOPMENT BOARD REPORT 173, 1973.

SUMMARY APPRAISALS OF THE NATION'S GROUND-WATER RESOURCES-TEXAS-GULF REGION: USGS PROFESSIONAL PAPER 813-F, 1976.

STRATIGRAPHIC AND HYDROGEOLOGIC FRAMEWORK OF PART OF THE COASTAL PLAIN OF TEXAS: USGS OPEN-FILE REPORT 77-712, 1978.

STRATIGRAPHIC AND HYDROGEOLOGIC FRAMEWORK OF PART OF THE COASTAL PLAIN OF TEXAS: TEXAS DEPARTMENT OF WATER RESOURCES REPORT 236, 1979.

LAND-SURFACE SUBSIDENCE IN THE TEXAS COASTAL REGION: USGS OPEN-FILE REPORT 80-969, 1980.

SPRINGS OF TEXAS, VOLUME 1: (BY GUNNAR BRUNE), BRANCHSMITH, INC., FORT WORTH, TEXAS, 1981.

LAND-SURFACE SUBSIDENCE IN THE TEXAS COASTAL REGION: TEXAS DEPARTMENT OF WATER RESOURCES REPORT 272, 1982.

STRUCTURE, TEMPERATURE, PRESSURE, AND SALINITY OF CENOZOIC AQUIFERS OF SOUTH TEXAS: USGS HYDROLOGIC INVESTIGATIONS ATLAS HA-654, 1983.

WATER LEVELS AND SALINITIES OF WATER WITHIN THE EVANGELINE AQUIFER IN AN AREA SOUTHWEST OF CORPUS CHRISTI, TEXAS: USGS OPEN-FILE REPORT 82-174, 1983.
TEXAS GROUND-WATER RESOURCES, in NATIONAL WATER SUMMARY 1984: USGS WATER-SUPPLY PAPER 2275, 1985.

SIMULATED EFFECTS OF PROJECTED PUMPING ON THE AVAILABILITY OF FRESHWATER IN THE EVANGELINE AQUIFER IN AN AREA SOUTHWEST OF CORPUS CHRISTI, TEXAS: USGS WATERRESOURCES INVESTIGATIONS REPORT 85-4182, 1985.

DIGITAL MODELS FOR SIMULATION OF GROUND-WATER HYDROLOGY OF THE CHICOT AND EVANGELINE AQUIFERS ALONG THE GULF COAST OF TEXAS: TEXAS DEPARTMENT OF WATER RESOURCES REPORT 289, 1985.

GEOHYDROLOGIC FRAMEWORK OF THE GULF COASTAL PLAIN: USGS HYDROLOGIC INVESTIGATIONS ATLAS HA-695, 1988.

HYDROGEOLOGY AND PREDEVELOPMENT FLOW IN THE TEXAS GULF COAST AQUIFER SYSTEMS: USGS WATER-RESOURCES INVESTIGATIONS REPORT 87-4248, 1988.

GROUND-WATER FLOW IN THE GULF COAST AQUIFER SYSTEMS, SOUTH-CENTRAL UNITED STATES-A PRELIMINARY ANALYSIS: USGS WATER-RESOURCES INVESTIGATIONS REPORT 89-4071, 1990.

HYDROLOGY OF THE TEXAS GULF COAST AQUIFER SYSTEMS: USGS OPEN-FILE REPORT 91-64, 1991.

PROPERTIES AND CHEMICAL CONSTITUENTS IN GROUND WATER FROM THE MISSISSIPPI RIVER VALLEY ALLUVIAL AQUIFER AND PERMEABLE ZONE A (HOLOCENE-UPPER PLEISTOCENE DEPOSITS), SOUTH-CENTRAL UNITED STATES: USGS WATERRESOURCES INVESTIGATIONS REPORT 91-4149, 1992.

PROPERTIES AND CHEMICAL CONSTITUENTS IN GROUND WATER FROM THE UPPER CLAIBORNE AQUIFER, GULF COAST REGIONAL AQUIFER SYSTEMS, SOUTH-CENTRAL UNITED STATES: USGS WATER-RESOURCES INVESTIGATIONS REPORT 91-4150, 1993.

PROPERTIES AND CHEMICAL CONSTITUENTS IN GROUND WATER FROM PERMEABLE ZONE C (LOWER PLIOCENE-UPPER MIOCENE DEPOSITS), COASTAL LOWLANDS AQUIFER SYSTEM, SOUTHCENTRAL UNITED STATES: USGS WATER-RESOURCES INVESTIGATIONS REPORT 91-4151, 1993.

PROPERTIES AND CHEMICAL CONSTITUENTS IN GROUND WATER FROM PERMEABLE ZONE B (LOWER PLEISTOCENE-UPPER PLIOCENE DEPOSITS), COASTAL LOWLANDS AQUIFER SYSTEM, SOUTH-CENTRAL UNITED STATES: USGS WATER-RESOURCES INVESTIGATIONS REPORT 91-4152, 1993.

PROPERTIES AND CHEMICAL CONSTITUENTS IN GROUND WATER FROM PERMEABLE ZONE E (LOWER MIOCENE-UPPER OLIGOCENE DEPOSITS), COASTAL LOWLANDS AQUIFER SYSTEM, SOUTH-CENTRAL UNITED STATES: USGS WATER-RESOURCES INVESTIGATIONS REPORT 92-4103, 1993.

PROPERTIES AND CHEMICAL CONSTITUENTS IN GROUND WATER FROM PERMEABLE ZONE D (MIDDLE MIOCENE DEPOSITS), COASTAL LOWLANDS AQUIFER SYSTEM, SOUTH-CENTRAL UNITED STATES: USGS WATER-RESOURCES INVESTIGATIONS REPORT 92-4105, 1993.

AQUIFERS OF TEXAS: TEXAS WATER DEVELOPMENT BOARD REPORT 345, 1995. 


\section{KENT COUNTY}

PUBLIC WATER SUPPLIES IN WESTERN TEXAS: USGS WATERSUPPLY PAPER 1106, 1951.

GROUND-WATER GEOLOGY IN THE VICINITY OF DOVE AND CROTON CREEKS, STONEWALL, KENT, DICKENS, AND KING COUNTIES, TEXAS, WITH SPECIAL REFERENCE TO SALT-WATER SEEPAGE: TEXAS BOARD OF WATER ENGINEERS BULLETIN 5801, 1958.

RECONNAISSANCE INVESTIGATION OF THE GROUND-WATER RESOURCES OF THE BRAZOS RIVER BASIN, TEXAS: TEXAS WATER COMMISSION BULLETIN 6310, 1963.

PRELIMINARY REPORT ON THE INVESTIGATION OF SALT SPRINGS AND SEEPS IN A PORTION OF THE PERMIAN BASIN IN TEXAS: USGS OPEN-FILE REPORT 65-153, 1965.

SOURCES OF SALINE WATER IN THE UPPER BRAZOS RIVER BASIN, TEXAS: USGS OPEN-FILE REPORT 68-108, 1968.

GROUND WATER IN DICKENS AND KENT COUNTIES, TEXAS: TEXAS WATER DEVELOPMENT BOARD REPORT 158, 1972.

RECOGNITION OF NATURAL BRINE BY ELECTRICAL SOUNDINGS NEAR THE SALT FORK OF THE BRAZOS RIVER, KENT AND STONEWALL COUNTIES, TEXAS: USGS PROFESSIONAL PAPER 809-A, 1973.

LOCATION AND CHARACTERISTICS OF THE INTERFACE BETWEEN BRINE AND FRESHWATER FROM GEOPHYSICAL LOGS OF BOREHOLES IN THE UPPER BRAZOS RIVER BASIN, TEXAS: USGS PROFESSIONAL PAPER 809-B, 1973.

SUMMARY APPRAISALS OF THE NATION'S GROUND-WATER RESOURCES-TEXAS-GULF REGION: USGS PROFESSIONAL PAPER 813-F, 1976.

SPRINGS OF TEXAS, VOLUME 1: (BY GUNNAR BRUNE), BRANCHSMITH, INC., FORT WORTH, TEXAS, 1981.

PROJECTED EFFECTS OF PROPOSED SALINITY-CONTROL PROJECTS ON SHALLOW GROUND WATER-PRELIMINARY RESULTS FOR THE UPPER BRAZOS RIVER BASIN, TEXAS: USGS OPEN-FILE REPORT 82-908, 1982.

TEXAS GROUND-WATER RESOURCES, in NATIONAL WATER SUMMARY 1984: USGS WATER-SUPPLY PAPER 2275, 1985.

PUBLIC SUPPLY GROUND-WATER USE IN THE SOUTHERN HIGH PLAINS OF TEXAS: TEXAS WATER DEVELOPMENT BOARD REPORT 328, 1990.

WATER-LEVEL CHANGES IN THE HIGH PLAINS AQUIFER OF TEXAS, 1980-1990: TEXAS WATER DEVELOPMENT BOARD HYDROLOGIC ATLAS NO. 1, 1991.

EVALUATION OF WATER RESOURCES IN PARTS OF THE ROLLING PRAIRIES REGION OF NORTH-CENTRAL TEXAS: TEXAS WATER DEVELOPMENT BOARD REPORT 337, 1992.

AQUIFERS OF TEXAS: TEXAS WATER DEVELOPMENT BOARD REPORT 345, 1995.

UPDATED WATER-QUALITY EVALUATION OF THE OGALLALA AQUIFER INCLUDING SELECTED METALLIC AND NON-METALLIC INORGANIC CONSTITUENTS: TEXAS WATER DEVELOPMENT BOARD HYDROLOGIC ATLAS NO. 10, 1998.

\section{KERR COUNTY}

GEOLOGY OF THE EDWARDS PLATEAU AND RIO GRANDE PLAIN ADJACENT TO AUSTIN AND SAN ANTONIO, TEXAS, WITH REFERENCE TO THE OCCURRENCE OF UNDERGROUND WATERS: USGS 18TH ANNUAL REPORT, PART 2, 1898.

GROUND WATER NEAR HICO, GATESVILLE, BRADY, KERRVILLE, AND PLAINVIEW, TEXAS: USGS OPEN-FILE REPORT (UNNUMBERED), 1944.

PUBLIC WATER SUPPLIES IN CENTRAL AND NORTH-CENTRAL TEXAS: TEXAS BOARD OF WATER ENGINEERS MISCELLANEOUS PUBLICATION 213, 1947.

PUBLIC WATER SUPPLIES IN CENTRAL AND NORTH-CENTRAL TEXAS: USGS WATER-SUPPLY PAPER 1069, 1949.

GROUND-WATER RESOURCES OF THE SAN ANTONIO AREA, TEXAS, A PROGRESS REPORT OF CURRENT STUDIES: TEXAS BOARD OF WATER ENGINEERS BULLETIN 5412, 1954.

MEMORANDUM REPORT OF KERRVILLE RECHARGE AND PUMPING TESTS: USGS OPEN-FILE REPORT, 1955.

RECONNAISSANCE INVESTIGATION OF THE GROUND-WATER RESOURCES OF THE GUADALUPE, SAN ANTONIO, AND NUECES RIVER BASINS, TEXAS: TEXAS WATER COMMISSION BULLETIN 6409, 1964.

RECONNAISSANCE INVESTIGATION OF THE GROUND-WATER RESOURCES OF THE COLORADO RIVER BASIN, TEXAS: TEXAS WATER DEVELOPMENT BOARD REPORT 51, 1967.

COMPILATION OF RESULTS OF AQUIFER TESTS IN TEXAS: TEXAS WATER DEVELOPMENT BOARD REPORT 98, 1969.

GROUND-WATER RESOURCES OF KERR COUNTY, TEXAS: TEXAS WATER DEVELOPMENT BOARD REPORT 102, 1969.

RELATION OF PRECIPITATION TO ANNUAL GROUND-WATER RECHARGE IN THE EDWARDS AQUIFER, SAN ANTONIO AREA, TEXAS: USGS OPEN-FILE REPORT 75-298, 1975.

MAJOR AND HISTORICAL SPRINGS OF TEXAS: TEXAS WATER DEVELOPMENT BOARD REPORT 189, 1975.

SUMMARY APPRAISALS OF THE NATION'S GROUND-WATER RESOURCES-TEXAS-GULF REGION: USGS PROFESSIONAL PAPER 813-F, 1976.

METHOD OF ESTIMATING NATURAL RECHARGE TO THE EDWARDS AQUIFER IN THE SAN ANTONIO AREA, TEXAS: USGS WATERRESOURCES INVESTIGATIONS REPORT 78-10, 1978.

REGIONAL DISTRIBUTION OF FRACTURES IN THE SOUTHERN EDWARDS PLATEAU AND THEIR RELATIONSHIP TO TECTONICS AND CAVES: UNIVERSITY OF TEXAS, BUREAU OF ECONOMIC GEOLOGY GEOLOGICAL CIRCULAR 78-2, 1978.

RECORDS OF GROUND-WATER RECHARGE AND DISCHARGE FOR THE EDWARDS AQUIFER IN THE SAN ANTONIO AREA, TEXAS, 1934-77: EDWARDS UNDERGROUND WATER DISTRICT BULLETIN 37, 1979.

OCCURRENCE, AVAILABILITY, AND CHEMICAL QUALITY OF GROUND WATER IN THE EDWARDS PLATEAU REGION OF TEXAS: TEXAS DEPARTMENT OF WATER RESOURCES REPORT $235,1979$. 
RECORDS OF GROUND-WATER RECHARGE, DISCHARGE, WATER LEVELS, AND CHEMICAL QUALITY OF WATER FOR THE EDWARDS AQUIFER IN THE SAN ANTONIO AREA, TEXAS, 1934-78: EDWARDS UNDERGROUND WATER DISTRICT BULLETIN 38, 1980.

RECORDS OF GROUND-WATER RECHARGE, DISCHARGE, WATER LEVELS, AND CHEMICAL QUALITY OF WATER FOR THE EDWARDS AQUIFER IN THE SAN ANTONIO AREA, TEXAS, 1934-79: EDWARDS UNDERGROUND WATER DISTRICT BULLETIN 39, 1981.

RECORDS OF GROUND-WATER RECHARGE, DISCHARGE, WATER LEVELS, AND CHEMICAL QUALITY OF WATER FOR THE EDWARDS AQUIFER IN THE SAN ANTONIO AREA, TEXAS, 1934-80: EDWARDS UNDERGROUND WATER DISTRICT BULLETIN 40, 1982.

GROUND-WATER AVAILABILITY OF THE LOWER CRETACEOUS FORMATIONS IN THE HILL COUNTRY OF SOUTH-CENTRAL TEXAS: TEXAS DEPARTMENT OF WATER RESOURCES REPORT 273, 1983.

RECORDS OF GROUND-WATER RECHARGE, DISCHARGE, WATER LEVELS, AND CHEMICAL QUALITY OF WATER FOR THE EDWARDS AQUIFER IN THE SAN ANTONIO AREA, TEXAS, 1934-81: EDWARDS UNDERGROUND WATER DISTRICT BULLETIN 41, 1984.

CARBONATE GEOLOGY AND HYDROLOGY OF THE EDWARDS AQUIFER IN THE SAN ANTONIO AREA, TEXAS: USGS OPEN-FILE REPORT 83-537, 1984.

RECORDS OF GROUND-WATER RECHARGE, DISCHARGE, WATER LEVELS, AND CHEMICAL QUALITY OF WATER FOR THE EDWARDS AQUIFER IN THE SAN ANTONIO AREA, TEXAS, 1934-82: EDWARDS UNDERGROUND WATER DISTRICT BULLETIN 42, 1985.

TEXAS GROUND-WATER RESOURCES, in NATIONAL WATER SUMMARY 1984: USGS WATER-SUPPLY PAPER 2275, 1985.

COMPILATION OF HYDROLOGIC DATA FOR THE EDWARDS AQUIFER, SAN ANTONIO AREA, TEXAS, 1983-84, WITH 1934-84 SUMMARY: EDWARDS UNDERGROUND WATER DISTRICT BULLETIN 43-44, 1986.

CARBONATE GEOLOGY AND HYDROLOGY OF THE EDWARDS AQUIFER IN THE SAN ANTONIO AREA, TEXAS: TEXAS WATER DEVELOPMENT BOARD REPORT 296, 1986.

COMPILATION OF HYDROLOGIC DATA FOR THE EDWARDS AQUIFER, SAN ANTONIO AREA, TEXAS, 1985, WITH 1934-85 SUMMARY: EDWARDS UNDERGROUND WATER DISTRICT BULLETIN 45, 1987.

COMPILATION OF HYDROLOGIC DATA FOR THE EDWARDS AQUIFER, SAN ANTONIO AREA, TEXAS, 1986, WITH 1934-86 SUMMARY: EDWARDS UNDERGROUND WATER DISTRICT BULLETIN 46, 1988.

COMPILATION OF HYDROLOGIC DATA FOR THE EDWARDS AQUIFER, SAN ANTONIO AREA, TEXAS, 1987, WITH 1934-87 SUMMARY: EDWARDS UNDERGROUND WATER DISTRICT BULLETIN 47, 1988.

COMPILATION OF HYDROLOGIC DATA FOR THE EDWARDS AQUIFER, SAN ANTONIO AREA, TEXAS, 1988, WITH 1934-88 SUMMARY: EDWARDS UNDERGROUND WATER DISTRICT BULLETIN 48, 1989 .
POTENTIOMETRIC SURFACE OF THE EDWARDS-TRINITY AQUIFER SYSTEM AND CONTIGUOUS HYDRAULICALLY CONNECTED UNITS, WEST-CENTRAL TEXAS, WINTER 1974-75: USGS WATERRESOURCES INVESTIGATIONS REPORT 89-4208, 1990.

COMPILATION OF HYDROLOGIC DATA FOR THE EDWARDS AQUIFER, SAN ANTONIO AREA, TEXAS, 1989, WITH 1934-89 SUMMARY: EDWARDS UNDERGROUND WATER DISTRICT BULLETIN 49, 1990.

WITHDRAWALS FROM THE EDWARDS-TRINITY AQUIFER SYSTEM AND CONTIGUOUS HYDRAULICALLY CONNECTED UNITS, WEST-CENTRAL TEXAS, DECEMBER 1974 THROUGH MARCH 1977: USGS WATER-RESOURCES INVESTIGATIONS REPORT 91-4021, 1991.

EDWARDS AQUIFER, A TEXAS TREASURE-A TEACHERS GUIDE, SECONDARY, GRADES 7-12: EDWARDS UNDERGROUND WATER DISTRICT, 1991.

COMPILATION OF HYDROLOGIC DATA FOR THE EDWARDS AQUIFER, SAN ANTONIO AREA, TEXAS, 1990, WITH 1934-90 SUMMARY: EDWARDS UNDERGROUND WATER DISTRICT BULLETIN 50, 1991.

INSIDE THE EDWARDS AQUIFER-A THREE-PART TECHNICAL FILM, HIGH-SCHOOL LEVEL TEACHER'S GUIDE: EDWARDS UNDERGROUND WATER DISTRICT, 1992.

CONFIGURATION OF THE BASE OF THE EDWARDS-TRINITY AQUIFER SYSTEM AND HYDROGEOLOGY OF THE UNDERLYING PRECRETACEOUS ROCKS, WEST-CENTRAL TEXAS: USGS WATERRESOURCES INVESTIGATIONS REPORT 91-4071, 1992.

EVALUATION OF THE GROUND-WATER RESOURCES OF THE PALEOZOIC AND CRETACEOUS AQUIFERS IN THE HILL COUNTRY OF CENTRAL TEXAS: TEXAS WATER DEVELOPMENT BOARD REPORT 339, 1992.

COMPILATION OF HYDROLOGIC DATA FOR THE EDWARDS AQUIFER, SAN ANTONIO AREA, TEXAS, 1991, WITH 1934-91 SUMMARY: EDWARDS UNDERGROUND WATER DISTRICT BULLETIN 51, 1992.

HISTORICAL POTENTIOMETRIC SURFACE OF THE EDWARDS-TRINITY AQUIFER SYSTEM AND CONTIGUOUS HYDRAULICALLY CONNECTED UNITS, WEST-CENTRAL TEXAS: USGS WATERRESOURCES INVESTIGATIONS REPORT 92-4055, 1993.

HISTORICAL SATURATED THICKNESS OF THE EDWARDS-TRINITY AQUIFER SYSTEM AND SELECTED CONTIGUOUS HYDRAULICALLY CONNECTED UNITS, WEST-CENTRAL TEXAS: USGS WATER-RESOURCES INVESTIGATIONS REPORT 92-4125, 1993.

EDWARDS AQUIFER HYDROGEOLOGIC STATUS REPORT FOR 1992: EDWARDS UNDERGROUND WATER DISTRICT REPORT 93-05, 1993.

SIMULATIONS OF FLOW IN THE EDWARDS-TRINITY AQUIFER SYSTEM AND CONTIGUOUS HYDRAULICALLY CONNECTED UNITS, WEST-CENTRAL TEXAS: USGS WATER-RESOURCES INVESTIGATIONS REPORT 93-4039, 1994.

DISSOLVED-SOLIDS CONCENTRATIONS AND HYDROCHEMICAL FACIES IN WATER OF THE EDWARDS-TRINITY AQUIFER SYSTEM, WEST-CENTRAL TEXAS: USGS WATER-RESOURCES INVESTIGATIONS REPORT 93-4126, 1994.

NATIONAL WATER-QUALITY ASSESSMENT PROGRAM-SOUTHCENTRAL TEXAS: USGS FACT SHEET FS-94-048, 1994. 
GEOLOGIC HISTORY AND HYDROGEOLOGIC SETTING OF THE EDWARDS-TRINITY AQUIFER SYSTEM, WEST-CENTRAL TEXAS: USGS WATER-RESOURCES INVESTIGATIONS REPORT 94-4039, 1994.

AQUIFERS OF TEXAS: TEXAS WATER DEVELOPMENT BOARD REPORT 345, 1995.

WATER QUALITY IN THE EDWARDS-TRINITY (PLATEAU) AQUIFER, EDWARDS PLATEAU AND TRANS-PECOS, TEXAS: TEXAS WATER DEVELOPMENT BOARD HYDROLOGIC ATLAS NO. 3, 1995.

WATER-RESOURCES DATA, TEXAS, WATER YEAR 1997, VOLUME 4 , GROUND-WATER DATA: USGS WATER-DATA REPORT TX-97-4, 1998.

WATER-RESOURCES DATA, TEXAS, WATER YEAR 1998, VOLUME 4, GROUND-WATER DATA: USGS WATER-DATA REPORT TX-98-4, 1999.

WATER QUALITY IN SOUTH-CENTRAL TEXAS-TEXAS, 1996-98: USGS CIRCULAR 1212, 2000.

GROUNDWATER AVAILABILITY OF THE TRINITY AQUIFER, HILL COUNTRY AREA, TEXAS: NUMERICAL SIMULATIONS THROUGH 2050: TEXAS WATER DEVELOPMENT BOARD REPORT 353, 2000.

AN OVERVIEW OF THE EDWARDS-TRINITY AQUIFER SYSTEM, CENTRAL-WEST TEXAS, CHAPTER 8, in AQUIFERS OF WEST TEXAS: TEXAS WATER DEVELOPMENT BOARD REPORT 356, 2001.

WATER-RESOURCES DATA, TEXAS, WATER YEAR 2000, VOLUME 6, GROUND-WATER DATA: USGS WATER-DATA REPORT TX-00-6, 2001.

\section{KIMBLE COUNTY}

PUBLIC WATER SUPPLIES IN CENTRAL AND NORTH-CENTRAL TEXAS: TEXAS BOARD OF WATER ENGINEERS MISCELLANEOUS PUBLICATION 213, 1947.

PUBLIC WATER SUPPLIES IN CENTRAL AND NORTH-CENTRAL TEXAS: USGS WATER-SUPPLY PAPER 1069, 1949.

RECONNAISSANCE INVESTIGATION OF THE GROUND-WATER RESOURCES OF THE COLORADO RIVER BASIN, TEXAS: TEXAS WATER DEVELOPMENT BOARD REPORT 51, 1967.

GROUND-WATER RESOURCES OF KIMBLE COUNTY, TEXAS: TEXAS WATER DEVELOPMENT BOARD REPORT 95, 1969.

MAJOR AND HISTORICAL SPRINGS OF TEXAS: TEXAS WATER DEVELOPMENT BOARD REPORT 189, 1975.

SUMMARY APPRAISALS OF THE NATION'S GROUND-WATER RESOURCES-TEXAS-GULF REGION: USGS PROFESSIONAL PAPER 813-F, 1976.

OCCURRENCE, AVAILABILITY, AND CHEMICAL QUALITY OF GROUND WATER IN THE EDWARDS PLATEAU REGION OF TEXAS: TEXAS DEPARTMENT OF WATER RESOURCES REPORT $235,1979$.

TEXAS GROUND-WATER RESOURCES, in NATIONAL WATER SUMMARY 1984: USGS WATER-SUPPLY PAPER 2275, 1985.

POTENTIOMETRIC SURFACE OF THE EDWARDS-TRINITY AQUIFER SYSTEM AND CONTIGUOUS HYDRAULICALLY CONNECTED
UNITS, WEST-CENTRAL TEXAS, WINTER 1974-75: USGS WATERRESOURCES INVESTIGATIONS REPORT 89-4208, 1990.

WITHDRAWALS FROM THE EDWARDS-TRINITY AQUIFER SYSTEM AND CONTIGUOUS HYDRAULICALLY CONNECTED UNITS, WEST-CENTRAL TEXAS, DECEMBER 1974 THROUGH MARCH 1977: USGS WATER-RESOURCES INVESTIGATIONS REPORT 91-4021, 1991.

CONFIGURATION OF THE BASE OF THE EDWARDS-TRINITY AQUIFER SYSTEM AND HYDROGEOLOGY OF THE UNDERLYING PRECRETACEOUS ROCKS, WEST-CENTRAL TEXAS: USGS WATERRESOURCES INVESTIGATIONS REPORT 91-4071, 1992.

HISTORICAL POTENTIOMETRIC SURFACE OF THE EDWARDS-TRINITY AQUIFER SYSTEM AND CONTIGUOUS HYDRAULICALLY CONNECTED UNITS, WEST-CENTRAL TEXAS: USGS WATERRESOURCES INVESTIGATIONS REPORT 92-4055, 1993.

HISTORICAL SATURATED THICKNESS OF THE EDWARDS-TRINITY AQUIFER SYSTEM AND SELECTED CONTIGUOUS HYDRAULICALLY CONNECTED UNITS, WEST-CENTRAL TEXAS: USGS WATER-RESOURCES INVESTIGATIONS REPORT 92-4125, 1993.

SIMULATIONS OF FLOW IN THE EDWARDS-TRINITY AQUIFER SYSTEM AND CONTIGUOUS HYDRAULICALLY CONNECTED UNITS, WEST-CENTRAL TEXAS: USGS WATER-RESOURCES INVESTIGATIONS REPORT 93-4039, 1994.

DISSOLVED-SOLIDS CONCENTRATIONS AND HYDROCHEMICAL FACIES IN WATER OF THE EDWARDS-TRINITY AQUIFER SYSTEM, WEST-CENTRAL TEXAS: USGS WATER-RESOURCES INVESTIGATIONS REPORT 93-4126, 1994.

GEOLOGIC HISTORY AND HYDROGEOLOGIC SETTING OF THE EDWARDS-TRINITY AQUIFER SYSTEM, WEST-CENTRAL TEXAS USGS WATER-RESOURCES INVESTIGATIONS REPORT 94-4039, 1994.

AQUIFERS OF TEXAS: TEXAS WATER DEVELOPMENT BOARD REPORT 345, 1995.

WATER QUALITY IN THE EDWARDS-TRINITY (PLATEAU) AQUIFER, EDWARDS PLATEAU AND TRANS-PECOS, TEXAS: TEXAS WATER DEVELOPMENT BOARD HYDROLOGIC ATLAS NO. 3, 1995.

THE PALEOZOIC AND RELATED AQUIFERS OF CENTRAL TEXAS: TEXAS WATER DEVELOPMENT BOARD REPORT 346, 1996.

HYDROGEOLOGIC FRAMEWORK OF THE EDWARDS-TRINITY AQUIFER SYSTEM, WEST-CENTRAL TEXAS: USGS PROFESSIONAL PAPER 1421-B, 1996.

AN OVERVIEW OF THE EDWARDS-TRINITY AQUIFER SYSTEM, CENTRAL-WEST TEXAS, CHAPTER 8, in AQUIFERS OF WEST TEXAS: TEXAS WATER DEVELOPMENT BOARD REPORT 356, 2001.

\section{KING COUNTY}

RECORDS OF WATER-LEVEL MEASUREMENTS IN CHILDRESS, COTTLE, HARDEMAN, AND KING COUNTIES, TEXAS, 1940 TO JANUARY 1956: TEXAS BOARD OF WATER ENGINEERS BULLETIN 5613, 1956.

GROUND-WATER GEOLOGY IN THE VICINITY OF DOVE AND CROTON CREEKS, STONEWALL, KENT, DICKENS, AND KING COUNTIES, TEXAS, WITH SPECIAL REFERENCE TO SALT-WATER 
SEEPAGE: TEXAS BOARD OF WATER ENGINEERS BULLETIN 5801, 1958.

RECONNAISSANCE INVESTIGATION OF THE GROUND-WATER RESOURCES OF THE RED RIVER, SULPHUR RIVER, AND CYPRESS CREEK BASINS, TEXAS: TEXAS WATER COMMISSION BULLETIN 6306, 1963.

RECONNAISSANCE INVESTIGATION OF THE GROUND-WATER RESOURCES OF THE BRAZOS RIVER BASIN, TEXAS: TEXAS WATER COMMISSION BULLETIN 6310, 1963.

PRELIMINARY REPORT ON THE INVESTIGATION OF SALT SPRINGS AND SEEPS IN A PORTION OF THE PERMIAN BASIN IN TEXAS: USGS OPEN-FILE REPORT 65-153, 1965.

SOURCES OF SALINE WATER IN THE UPPER BRAZOS RIVER BASIN, TEXAS: USGS OPEN-FILE REPORT 68-108, 1968.

THEORETICAL EFFECTS OF GROUND-WATER PUMPING ON THE DISCHARGE OF BRINE SPRINGS IN THE UPPER BRAZOS RIVER BASIN, TEXAS: USGS ADMINISTRATIVE REPORT, 1972.

SUMMARY APPRAISALS OF THE NATION'S GROUND-WATER RESOURCES-TEXAS-GULF REGION: USGS PROFESSIONAL PAPER 813-F, 1976.

SPRINGS OF TEXAS, VOLUME 1: (BY GUNNAR BRUNE), BRANCHSMITH, INC., FORT WORTH, TEXAS, 1981.

PROJECTED EFFECTS OF PROPOSED SALINITY-CONTROL PROJECTS ON SHALLOW GROUND WATER-PRELIMINARY RESULTS FOR THE UPPER BRAZOS RIVER BASIN, TEXAS: USGS OPEN-FILE REPORT 82-908, 1982.

TEXAS GROUND-WATER RESOURCES, in NATIONAL WATER SUMMARY 1984: USGS WATER-SUPPLY PAPER 2275, 1985.

EVALUATION OF WATER RESOURCES IN PARTS OF THE ROLLING PRAIRIES REGION OF NORTH-CENTRAL TEXAS: TEXAS WATER DEVELOPMENT BOARD REPORT 337, 1992.

AQUIFERS OF TEXAS: TEXAS WATER DEVELOPMENT BOARD REPORT 345, 1995.

\section{KINNEY COUNTY}

REPORT OF PROGRESS OF THE DIVISION OF HYDROGRAPHY FOR 1895: USGS BULLETIN 140, 1896.

GEOLOGY OF THE EDWARDS PLATEAU AND RIO GRANDE PLAIN ADJACENT TO AUSTIN AND SAN ANTONIO, TEXAS, WITH REFERENCE TO THE OCCURRENCE OF UNDERGROUND WATERS: USGS 18TH ANNUAL REPORT, PART 2, 1898.

REPORT OF PROGRESS OF STREAM MEASUREMENTS FOR THE CALENDAR YEAR 1904: USGS WATER-SUPPLY AND IRRIGATION PAPER 132, 1905.

UNDERGROUND WATERS OF THE COASTAL PLAIN OF TEXAS: USGS WATER-SUPPLY PAPER 190, 1907.

LARGE SPRINGS IN THE UNITED STATES: USGS WATER-SUPPLY PAPER 557, 1927.

RECORDS OF WELLS, DRILLERS' LOGS, WATER ANALYSES, AND MAP SHOWING LOCATION OF WELLS IN KINNEY COUNTY, TEXAS: TEXAS BOARD OF WATER ENGINEERS MISCELLANEOUS PUBLICATION 154, 1940.
RELATION OF SHALLOW GROUND WATER TO LAS MORAS SPRING AT BRACKETTVILLE, TEXAS: USGS OPEN-FILE REPORT (UNNUMBERED), 1942.

WATER SUPPLY IN THE VICINITY OF BRACKETTVILLE, TEXAS USGS OPEN-FILE REPORT (UNNUMBERED), 1942.

GROUND WATER AT PROPOSED AIR BASE ON LAS MORAS CREEK NEAR CROSSING OF SOUTHERN PACIFIC RR., KINNEY COUNTY, TEXAS: USGS OPEN-FILE REPORT (UNNUMBERED), 1943.

SUPPLEMENTARY REPORT ON SURFACE-WATER AND GROUNDWATER SURVEYS, NUECES RIVER BASIN, TEXAS: USGS OPENFILE REPORT, (UNNUMBERED) 1950.

PUBLIC WATER SUPPLIES IN SOUTHERN TEXAS: USGS WATERSUPPLY PAPER 1070, 1950

GROUND-WATER RESOURCES OF THE SAN ANTONIO AREA, TEXAS, A PROGRESS REPORT OF CURRENT STUDIES: TEXAS BOARD OF WATER ENGINEERS BULLETIN 5412, 1954.

GROUND-WATER RESOURCES OF THE SAN ANTONIO AREA, TEXAS, VOLUME 1, A PROGRESS REPORT ON CURRENT STUDIES: TEXAS BOARD OF WATER ENGINEERS BULLETIN 5608, V. 1, 1956

GROUND-WATER RESOURCES OF THE SAN ANTONIO AREA, TEXAS, VOLUME 2, PART 1, RECORDS OF WELLS AND SPRINGS: TEXAS BOARD OF WATER ENGINEERS BULLETIN 5608, V. 2, PART 1, 1956.

GROUND-WATER RESOURCES OF THE SAN ANTONIO AREA, TEXAS, VOLUME 2, PART 2, RECORDS OF DRILLERS' LOGS: TEXAS BOARD OF WATER ENGINEERS BULLETIN 5608, V. 2, PART 2, 1956.

GROUND-WATER RESOURCES OF THE SAN ANTONIO AREA, TEXAS, VOLUME 2, PART 3, WATER LEVELS IN WELLS, CHEMICAL ANALYSES OF WATER, RECORDS OF STREAMFLOW AND RESERVOIR CONTENTS, DISCHARGE MEASUREMENTS, AND PRECIPITATION IN THE SAN ANTONIO AREA, TEXAS: TEXAS BOARD OF WATER ENGINEERS BULLETIN 5608, V. 2, PART 3, 1956.

RECORDS OF WATER-LEVEL MEASUREMENTS IN KINNEY, UVALDE, AND VAL VERDE COUNTIES, TEXAS, 1929 TO MARCH 1956: TEXAS BOARD OF WATER ENGINEERS BULLETIN 5611, 1956.

RECHARGE, DISCHARGE, AND CHANGES IN GROUND-WATER STORAGE IN THE EDWARDS AND ASSOCIATED LIMESTONES, SAN ANTONIO AREA, TEXAS, A PROGRESS REPORT ON STUDIES 1955-59: TEXAS WATER COMMISSION BULLETIN 6201, 1962.

GEOLOGY AND GROUND-WATER RESOURCES OF KINNEY COUNTY, TEXAS: TEXAS WATER COMMISSION BULLETIN 6201, 1962.

CHEMICAL ANALYSES OF WATER FROM OBSERVATION WELLS IN THE EDWARDS AND ASSOCIATED LIMESTONES, SAN ANTONIO AREA, TEXAS: EDWARDS UNDERGROUND WATER DISTRICT BULLETIN 1, 1962

GROUND-WATER DISCHARGE FROM THE EDWARDS AND ASSOCIATED LIMESTONES, 1955-62, SAN ANTONIO AREA, TEXAS: EDWARDS UNDERGROUND WATER DISTRICT BULLETIN 2, 1963.

RECORDS OF PRECIPITATION, AQUIFER HEAD, AND GROUNDWATER DISCHARGE TO THE EDWARDS AND ASSOCIATED LIMESTONES, 1960-62, SAN ANTONIO AREA, TEXAS: EDWARDS UNDERGROUND WATER DISTRICT BULLETIN 3, 1963.

CHEMICAL ANALYSES OF WATER FROM OBSERVATION WELLS IN THE EDWARDS AND ASSOCIATED LIMESTONES, SAN ANTONIO 
AREA, TEXAS, 1963: EDWARDS UNDERGROUND WATER DISTRICT BULLETIN 4, 1964.

GROUND-WATER DISCHARGE FROM THE EDWARDS AND ASSOCIATED LIMESTONES, SAN ANTONIO AREA, TEXAS, 1963: EDWARDS UNDERGROUND WATER DISTRICT BULLETIN 5, 1964.

RECORDS OF PRECIPITATION, AQUIFER HEAD, AND GROUNDWATER RECHARGE TO THE EDWARDS AND ASSOCIATED LIMESTONES, SAN ANTONIO AREA, TEXAS, 1963: EDWARDS UNDERGROUND WATER DISTRICT BULLETIN 6, 1964.

CHEMICAL ANALYSES OF WATER FROM OBSERVATION WELLS IN THE EDWARDS AND ASSOCIATED LIMESTONES, SAN ANTONIO AREA, TEXAS, 1964: EDWARDS UNDERGROUND WATER DISTRICT BULLETIN 7, 1965.

GROUND-WATER DISCHARGE FROM THE EDWARDS AND ASSOCIATED LIMESTONES, SAN ANTONIO AREA, TEXAS, 1964: EDWARDS UNDERGROUND WATER DISTRICT BULLETIN 8, 1965.

GROUND-WATER RECHARGE TO THE EDWARDS AND ASSOCIATED LIMESTONES, SAN ANTONIO AREA, TEXAS, 1964: EDWARDS UNDERGROUND WATER DISTRICT BULLETIN 9, 1965.

CHEMICAL ANALYSES FROM OBSERVATION WELLS IN THE EDWARDS AND ASSOCIATED LIMESTONES, SAN ANTONIO AREA, TEXAS, 1965: EDWARDS UNDERGROUND WATER DISTRICT BULLETIN 10, 1966.

GROUND-WATER DISCHARGE FROM THE EDWARDS AND ASSOCIATED LIMESTONES, SAN ANTONIO AREA, TEXAS, 1965: EDWARDS UNDERGROUND WATER DISTRICT BULLETIN 11, 1966.

RECORDS OF PRECIPITATION, AQUIFER HEAD, AND GROUNDWATER RECHARGE TO THE EDWARDS AND ASSOCIATED LIMESTONES, SAN ANTONIO AREA, TEXAS, 1965: EDWARDS UNDERGROUND WATER DISTRICT BULLETIN 12, 1966.

GROUND-WATER RESOURCES OF THE SAN ANTONIO AREA, TEXAS, A PROGRESS REPORT ON STUDIES, 1960-64: TEXAS WATER DEVELOPMENT BOARD REPORT 34, 1966.

CHEMICAL ANALYSES OF WATER FROM OBSERVATION WELLS IN THE EDWARDS AND ASSOCIATED LIMESTONES, SAN ANTONIO AREA, TEXAS, 1966: EDWARDS UNDERGROUND WATER DISTRICT BULLETIN 13, 1967.

GROUND-WATER DISCHARGE FROM THE EDWARDS AND ASSOCIATED LIMESTONES, SAN ANTONIO AREA, TEXAS, 1966: EDWARDS UNDERGROUND WATER DISTRICT BULLETIN 14, 1967.

RECORDS OF PRECIPITATION, AQUIFER HEAD, AND GROUNDWATER RECHARGE TO THE EDWARDS AND ASSOCIATED LIMESTONES, SAN ANTONIO AREA, TEXAS, 1966: EDWARDS UNDERGROUND WATER DISTRICT BULLETIN 15, 1967.

CHEMICAL ANALYSES OF WATER FROM OBSERVATION WELLS IN THE EDWARDS AND ASSOCIATED LIMESTONES, SAN ANTONIO AREA, TEXAS, 1967: EDWARDS UNDERGROUND WATER DISTRICT BULLETIN 16, 1968.

GROUND-WATER DISCHARGE FROM THE EDWARDS AND ASSOCIATED LIMESTONES, SAN ANTONIO AREA, TEXAS, 1967: EDWARDS UNDERGROUND WATER DISTRICT BULLETIN 17, 1968.

RECORDS OF PRECIPITATION, AQUIFER HEAD, AND GROUNDWATER RECHARGE TO THE EDWARDS AND ASSOCIATED LIMESTONES, SAN ANTONIO AREA, TEXAS, 1967: EDWARDS UNDERGROUND WATER DISTRICT BULLETIN 18, 1968.
RECORDS OF WELLS AND SPRINGS, SAN ANTONIO AREA, TEXAS: EDWARDS UNDERGROUND WATER DISTRICT, 1969.

GROUND-WATER DISCHARGE FROM THE EDWARDS AND ASSOCIATED LIMESTONES, SAN ANTONIO AREA, TEXAS, 1968: EDWARDS UNDERGROUND WATER DISTRICT BULLETIN 20, 1969.

RECORDS OF PRECIPITATION, AQUIFER HEAD, AND GROUNDWATER RECHARGE TO THE EDWARDS AND ASSOCIATED LIMESTONES, SAN ANTONIO AREA, TEXAS, 1968: EDWARDS UNDERGROUND WATER DISTRICT BULLETIN 21, 1969.

GEOLOGY AND WATER QUALITY AT SELECTED LOCATIONS IN THE SAN ANTONIO AREA, TEXAS, PROGRESS REPORT, 1969: EDWARDS UNDERGROUND WATER DISTRICT, 1970.

GROUND-WATER DISCHARGE FROM THE EDWARDS AND ASSOCIATED LIMESTONES, SAN ANTONIO AREA, TEXAS, 1969: EDWARDS UNDERGROUND WATER DISTRICT BULLETIN 23, 1970.

RECORDS OF PRECIPITATION, WATER LEVELS, AND GROUNDWATER RECHARGE TO THE EDWARDS AND ASSOCIATED LIMESTONES, SAN ANTONIO AREA, TEXAS, 1969: EDWARDS UNDERGROUND WATER DISTRICT BULLETIN 24, 1970.

GROUND-WATER DISCHARGE FROM THE EDWARDS AND ASSOCIATED LIMESTONES, SAN ANTONIO AREA, TEXAS, 1970: EDWARDS UNDERGROUND WATER DISTRICT BULLETIN 26, 1971.

RECORDS OF PRECIPITATION, WATER LEVELS, AND GROUNDWATER RECHARGE TO THE EDWARDS AND ASSOCIATED LIMESTONES, SAN ANTONIO AREA, TEXAS, 1970: EDWARDS UNDERGROUND WATER DISTRICT BULLETIN 27, 1971.

GROUND-WATER DISCHARGE FROM THE EDWARDS AND ASSOCIATED LIMESTONES, SAN ANTONIO AREA, TEXAS, 1971: EDWARDS UNDERGROUND WATER DISTRICT BULLETIN 29, 1972.

RECORDS OF PRECIPITATION, WATER LEVELS, AND GROUNDWATER RECHARGE TO THE EDWARDS AND ASSOCIATED LIMESTONES, SAN ANTONIO AREA, TEXAS, 1971: EDWARDS UNDERGROUND WATER DISTRICT BULLETIN 30, 1972.

GROUND-WATER DISCHARGE FROM THE EDWARDS AND ASSOCIATED LIMESTONES, SAN ANTONIO AREA, TEXAS, 1972: EDWARDS UNDERGROUND WATER DISTRICT BULLETIN 31, 1973.

REGIONAL SPECIFIC YIELD OF THE EDWARDS AND ASSOCIATED LIMESTONES IN THE SAN ANTONIO, TEXAS, AREA: EDWARDS UNDERGROUND WATER DISTRICT, 1973.

GROUND-WATER DISCHARGE FROM THE EDWARDS AND ASSOCIATED LIMESTONES, SAN ANTONIO AREA, TEXAS, 1973: EDWARDS UNDERGROUND WATER DISTRICT BULLETIN 32, 1974.

RECORDS OF PRECIPITATION, WATER LEVELS, AND GROUNDWATER RECHARGE TO THE EDWARDS AND ASSOCIATED LIMESTONES, SAN ANTONIO AREA, TEXAS, 1972-73: EDWARDS UNDERGROUND WATER DISTRICT BULLETIN 33, 1974.

RECONNAISSANCE INVESTIGATION OF GROUND WATER IN THE RIO GRANDE DRAINAGE BASIN-WITH SPECIAL EMPHASIS ON SALINE GROUND-WATER RESOURCES: USGS HYDROLOGIC INVESTIGATIONS ATLAS HA-510, 1974.

RELATION OF PRECIPITATION TO ANNUAL GROUND-WATER RECHARGE IN THE EDWARDS AQUIFER, SAN ANTONIO AREA, TEXAS: USGS OPEN-FILE REPORT 75-298, 1975.

THE EDWARDS UNDERGROUND RESERVOIR AND THE EDWARDS UNDERGROUND WATER DISTRICT: SOUTH TEXAS GEOLOGICAL SOCIETY BULLETIN V. 15, NO. 7, 1975. 
RECORDS OF PRECIPITATION, WATER LEVELS, AND GROUNDWATER RECHARGE TO THE EDWARDS AND ASSOCIATED LIMESTONES, SAN ANTONIO AREA, TEXAS, 1972-73: SOUTH TEXAS GEOLOGICAL SOCIETY BULLETIN V. 15, NO. 7, 1975.

GROUND-WATER DISCHARGE FROM THE EDWARDS AND ASSOCIATED LIMESTONES, SAN ANTONIO AREA, TEXAS, 1974: EDWARDS UNDERGROUND WATER DISTRICT BULLETIN 34, 1975.

MAJOR AND HISTORICAL SPRINGS OF TEXAS: TEXAS WATER DEVELOPMENT BOARD REPORT 189, 1975.

GEOCHEMICAL AND ISOTOPIC ANALYSES OF WATERS ASSOCIATED WITH THE EDWARDS LIMESTONE AQUIFER, CENTRAL TEXAS: EDWARDS UNDERGROUND WATER DISTRICT, 1976

GROUND-WATER DISCHARGE FROM THE EDWARDS AND ASSOCIATED LIMESTONES, SAN ANTONIO AREA, TEXAS, 1975: EDWARDS UNDERGROUND WATER DISTRICT BULLETIN 35, 1976

STATISTICAL ANALYSIS OF WATER-LEVEL, SPRINGFLOW, AND STREAMFLOW DATA FOR THE EDWARDS AQUIFER IN SOUTHCENTRAL TEXAS: EDWARDS UNDERGROUND WATER DISTRICT, 1976.

CHEMICAL AND BACTERIOLOGICAL QUALITY OF WATER AT SELECTED SITES IN THE SAN ANTONIO AREA, TEXAS, AUGUST 1968-JANUARY 1975: USGS OPEN-FILE REPORT 76-574, 1976.

CHEMICAL AND BACTERIOLOGICAL QUALITY OF WATER AT SELECTED SITES IN THE SAN ANTONIO AREA, TEXAS, AUGUST 1968-JANUARY 1975: EDWARDS UNDERGROUND WATER DISTRICT, 1976

GROUND-WATER DISCHARGE FROM THE EDWARDS AND ASSOCIATED LIMESTONES, SAN ANTONIO AREA, TEXAS, 1976: EDWARDS UNDERGROUND WATER DISTRICT, 1977.

METHOD OF ESTIMATING NATURAL RECHARGE TO THE EDWARDS AQUIFER IN THE SAN ANTONIO AREA, TEXAS: USGS WATERRESOURCES INVESTIGATIONS REPORT 78-10, 1978.

REGIONAL DISTRIBUTION OF FRACTURES IN THE SOUTHERN EDWARDS PLATEAU AND THEIR RELATIONSHIP TO TECTONICS AND CAVES: UNIVERSITY OF TEXAS, BUREAU OF ECONOMIC GEOLOGY GEOLOGICAL CIRCULAR 78-2, 1978 .

RECORDS OF GROUND-WATER RECHARGE AND DISCHARGE FOR THE EDWARDS AQUIFER IN THE SAN ANTONIO AREA, TEXAS, 1934-77: EDWARDS UNDERGROUND WATER DISTRICT BULLETIN 37, 1979.

OCCURRENCE, AVAILABILITY, AND CHEMICAL QUALITY OF GROUND WATER IN THE EDWARDS PLATEAU REGION OF TEXAS: TEXAS DEPARTMENT OF WATER RESOURCES REPORT $235,1979$.

GROUND-WATER RESOURCES AND MODEL APPLICATIONS FOR THE EDWARDS (BALCONES FAULT SYSTEM) AQUIFER IN THE SAN ANTONIO REGION: TEXAS DEPARTMENT OF WATER RESOURCES REPORT 239, 1979.

HYDROCHEMICAL DATA FOR THE EDWARDS AQUIFER IN THE SAN ANTONIO AREA, TEXAS: TEXAS DEPARTMENT OF WATER RESOURCES LIMITED PRINTING REPORT LP-131, 1980.

RECORDS OF GROUND-WATER RECHARGE, DISCHARGE, WATER LEVELS, AND CHEMICAL QUALITY OF WATER FOR THE EDWARDS AQUIFER IN THE SAN ANTONIO AREA, TEXAS, 1934-78: EDWARDS UNDERGROUND WATER DISTRICT BULLETIN 38, 1980.
WATER-LEVEL, RECHARGE, DISCHARGE, SPECIFIC CAPACITY, WELL-YIELD, AND AQUIFER-TEST DATA FOR THE EDWARDS AQUIFER IN THE SAN ANTONIO AREA, TEXAS: TEXAS DEPARTMENT OF WATER RESOURCES LIMITED PRINTING REPORT LP-133, 1980.

SPRINGS OF TEXAS, VOLUME 1: (BY GUNNAR BRUNE), BRANCHSMITH, INC., FORT WORTH, TEXAS, 1981.

APPLICATION AND ANALYSIS OF BOREHOLE DATA FOR THE EDWARDS AQUIFER IN THE SAN ANTONIO AREA, TEXAS: TEXAS DEPARTMENT OF WATER RESOURCES LIMITED PRINTING REPORT LP-139, 1981.

RECORDS OF GROUND-WATER RECHARGE, DISCHARGE, WATER LEVELS, AND CHEMICAL QUALITY OF WATER FOR THE EDWARDS AQUIFER IN THE SAN ANTONIO AREA, TEXAS, 1934-79: EDWARDS UNDERGROUND WATER DISTRICT BULLETIN 39, 1981

TEST-HOLE DATA FOR THE EDWARDS AQUIFER IN THE SAN ANTONIO AREA, TEXAS: TEXAS DEPARTMENT OF WATER RESOURCES LIMITED PRINTING REPORT LP-171, 1982.

RECORDS OF GROUND-WATER RECHARGE, DISCHARGE, WATER LEVELS, AND CHEMICAL QUALITY OF WATER FOR THE EDWARDS AQUIFER IN THE SAN ANTONIO AREA, TEXAS, 1934-80: EDWARDS UNDERGROUND WATER DISTRICT BULLETIN 40, 1982.

GROUND-WATER AVAILABILITY OF THE LOWER CRETACEOUS FORMATIONS IN THE HILL COUNTRY OF SOUTH-CENTRAL TEXAS: TEXAS DEPARTMENT OF WATER RESOURCES REPORT 273,1983

STREAMFLOW LOSSES ALONG THE BALCONES FAULT ZONE, NUECES RIVER BASIN, TEXAS: USGS WATER-RESOURCES INVESTIGATIONS REPORT 83-4368, 1983.

RECORDS OF GROUND-WATER RECHARGE, DISCHARGE, WATER LEVELS, AND CHEMICAL QUALITY OF WATER FOR THE EDWARDS AQUIFER IN THE SAN ANTONIO AREA, TEXAS, 1934-81: EDWARDS UNDERGROUND WATER DISTRICT BULLETIN 41, 1984.

CARBONATE GEOLOGY AND HYDROLOGY OF THE EDWARDS AQUIFER IN THE SAN ANTONIO AREA, TEXAS: USGS OPEN-FILE REPORT 83-537, 1984.

IDENTIFICATION AND TABULATION OF GEOLOGICAL CONTACTS IN THE EDWARDS AQUIFER, SAN ANTONIO AREA, TEXAS: USGS OPEN-FILE REPORT 84-075, 1984.

PROPOSED 10-YEAR PLAN FOR CONTINUATION OF HYDROLOGIC STUDIES OF THE EDWARDS AQUIFER, SAN ANTONIO AREA, TEXAS: USGS OPEN-FILE REPORT 84-817, 1984.

RECORDS OF GROUND-WATER RECHARGE, DISCHARGE, WATER LEVELS, AND CHEMICAL QUALITY OF WATER FOR THE EDWARDS AQUIFER IN THE SAN ANTONIO AREA, TEXAS, 1934-82: EDWARDS UNDERGROUND WATER DISTRICT BULLETIN 42, 1985

TEXAS GROUND-WATER RESOURCES, in NATIONAL WATER SUMMARY 1984: USGS WATER-SUPPLY PAPER 2275, 1985.

IDENTIFICATION AND TABULATION OF GEOLOGICAL CONTACTS IN THE EDWARDS AQUIFER, SAN ANTONIO AREA, TEXAS: TEXAS DEPARTMENT OF WATER RESOURCES LIMITED PRINTING REPORT LP-199, 1985 
STATISTICAL SUMMARY OF WATER-QUALITY DATA COLLECTED FROM SELECTED WELLS AND SPRINGS IN THE EDWARDS AQUIFER NEAR SAN ANTONIO, TEXAS: USGS OPEN-FILE REPORT 85-182, 1985.

COMPILATION OF HYDROLOGIC DATA FOR THE EDWARDS AQUIFER, SAN ANTONIO AREA, TEXAS, 1983-84, WITH 1934-84 SUMMARY: EDWARDS UNDERGROUND WATER DISTRICT BULLETIN 43-44, 1986.

CARBONATE GEOLOGY AND HYDROLOGY OF THE EDWARDS AQUIFER IN THE SAN ANTONIO AREA, TEXAS: TEXAS WATER DEVELOPMENT BOARD REPORT 296, 1986.

POTENTIAL FOR UPDIP MOVEMENT OF SALINEWATER IN THE EDWARDS AQUIFER, SAN ANTONIO, TEXAS: USGS WATERRESOURCES INVESTIGATIONS REPORT 86-4032, 1986.

THE EDWARDS AQUIFER; EXTREMELY PRODUCTIVE, BUT....A SOLE-SOURCE WATER SUPPLY FOR SAN ANTONIO AND SURROUNDING COUNTIES IN SOUTH-CENTRAL TEXAS: EDWARDS UNDERGROUND WATER DISTRICT, 1986.

SIMULATION OF FLOW IN THE EDWARDS AQUIFER, SAN ANTONIO REGION, TEXAS, AND REFINEMENT OF STORAGE AND FLOW CONCEPTS: USGS OPEN-FILE REPORT 86-532, 1987.

HYDROGEOLOGIC DATA FROM A STUDY OF THE FRESHWATER ZONE/SALINEWATER ZONE INTERFACE IN THE EDWARDS AQUIFER, SAN ANTONIO REGION, TEXAS: USGS OPEN-FILE REPORT 87-389, 1987.

COMPILATION OF HYDROLOGIC DATA FOR THE EDWARDS AQUIFER, SAN ANTONIO AREA, TEXAS, 1985, WITH 1934-85 SUMMARY: EDWARDS UNDERGROUND WATER DISTRICT BULLETIN 45, 1987.

SUGGESTED DESIGN AND CONSTRUCTION OF EDWARDS AQUIFER WELLS: EDWARDS UNDERGROUND WATER DISTRICT, 1987 ?

COMPILATION OF HYDROLOGIC DATA FOR THE EDWARDS AQUIFER, SAN ANTONIO AREA, TEXAS, 1986, WITH 1934-86 SUMMARY: EDWARDS UNDERGROUND WATER DISTRICT BULLETIN 46, 1988.

SIMULATION OF FLOW IN THE EDWARDS AQUIFER, SAN ANTONIO REGION, TEXAS, AND REFINEMENT OF STORAGE AND FLOW CONCEPTS: USGS WATER-SUPPLY PAPER 2336-A, 1988.

COMPILATION OF HYDROLOGIC DATA FOR THE EDWARDS AQUIFER, SAN ANTONIO AREA, TEXAS, 1987, WITH 1934-87 SUMMARY: EDWARDS UNDERGROUND WATER DISTRICT BULLETIN 47, 1988.

COMPILATION OF HYDROLOGIC DATA FOR THE EDWARDS AQUIFER, SAN ANTONIO AREA, TEXAS, 1988, WITH 1934-88 SUMMARY: EDWARDS UNDERGROUND WATER DISTRICT BULLETIN 48, 1989.

POTENTIOMETRIC SURFACE OF THE EDWARDS-TRINITY AQUIFER SYSTEM AND CONTIGUOUS HYDRAULICALLY CONNECTED UNITS, WEST-CENTRAL TEXAS, WINTER 1974-75: USGS WATERRESOURCES INVESTIGATIONS REPORT 89-4208, 1990.

COMPILATION OF HYDROLOGIC DATA FOR THE EDWARDS AQUIFER, SAN ANTONIO AREA, TEXAS, 1989, WITH 1934-89 SUMMARY: EDWARDS UNDERGROUND WATER DISTRICT BULLETIN 49, 1990.

WITHDRAWALS FROM THE EDWARDS-TRINITY AQUIFER SYSTEM AND CONTIGUOUS HYDRAULICALLY CONNECTED UNITS,
WEST-CENTRAL TEXAS, DECEMBER 1974 THROUGH MARCH 1977: USGS WATER-RESOURCES INVESTIGATIONS REPORT 91-4021, 1991.

EDWARDS AQUIFER, A TEXAS TREASURE-A TEACHERS GUIDE, SECONDARY, GRADES 7-12: EDWARDS UNDERGROUND WATER DISTRICT, 1991

COMPILATION OF HYDROLOGIC DATA FOR THE EDWARDS AQUIFER, SAN ANTONIO AREA, TEXAS, 1990, WITH 1934-90 SUMMARY: EDWARDS UNDERGROUND WATER DISTRICT BULLETIN $50,1991$.

INSIDE THE EDWARDS AQUIFER-A THREE-PART TECHNICAL FILM, HIGH-SCHOOL LEVEL TEACHER'S GUIDE: EDWARDS UNDERGROUND WATER DISTRICT, 1992.

CONFIGURATION OF THE BASE OF THE EDWARDS-TRINITY AQUIFER SYSTEM AND HYDROGEOLOGY OF THE UNDERLYING PRECRETACEOUS ROCKS, WEST-CENTRAL TEXAS: USGS WATERRESOURCES INVESTIGATIONS REPORT 91-4071, 1992.

GROUND-WATER QUALITY MONITORING RESULTS IN THE WINTER GARDEN AREA, 1990: TEXAS WATER DEVELOPMENT BOARD REPORT 335, 1992.

MODEL REFINEMENT AND APPLICATION FOR THE EDWARDS AQUIFER IN THE SAN ANTONIO AREA, TEXAS: TEXAS WATER DEVELOPMENT BOARD REPORT 340, 1992.

WATER QUALITY IN THE EDWARDS AQUIFER AND STREAMS RECHARGING THE AQUIFER IN THE SAN ANTONIO REGION, TEXAS: USGS HYDROLOGIC INVESTIGATIONS ATLAS HA-723, 1992.

COMPILATION OF HYDROLOGIC DATA FOR THE EDWARDS AQUIFER, SAN ANTONIO AREA, TEXAS, 1991, WITH 1934-91 SUMMARY: EDWARDS UNDERGROUND WATER DISTRICT BULLETIN $51,1992$.

HISTORICAL POTENTIOMETRIC SURFACE OF THE EDWARDS-TRINITY AQUIFER SYSTEM AND CONTIGUOUS HYDRAULICALLY CONNECTED UNITS, WEST-CENTRAL TEXAS: USGS WATERRESOURCES INVESTIGATIONS REPORT 92-4055, 1993.

HISTORICAL SATURATED THICKNESS OF THE EDWARDS-TRINITY AQUIFER SYSTEM AND SELECTED CONTIGUOUS HYDRAULICALLY CONNECTED UNITS, WEST-CENTRAL TEXAS: USGS WATER-RESOURCES INVESTIGATIONS REPORT 92-4125, 1993.

RECONNAISSANCE INVESTIGATION OF THE GEOLOGY AND HYDROGEOLOGY OF LACKLAND AIR FORCE BASE, SAN ANTONIO, TEXAS: USGS WATER-RESOURCES INVESTIGATIONS REPORT 93-4037, 1993.

EDWARDS AQUIFER HYDROGEOLOGIC STATUS REPORT FOR 1992 EDWARDS UNDERGROUND WATER DISTRICT REPORT 93-05, 1993.

SIMULATIONS OF FLOW IN THE EDWARDS-TRINITY AQUIFER SYSTEM AND CONTIGUOUS HYDRAULICALLY CONNECTED UNITS, WEST-CENTRAL TEXAS: USGS WATER-RESOURCES INVESTIGATIONS REPORT 93-4039, 1994

DISSOLVED-SOLIDS CONCENTRATIONS AND HYDROCHEMICAL FACIES IN WATER OF THE EDWARDS-TRINITY AQUIFER SYSTEM, WEST-CENTRAL TEXAS: USGS WATER-RESOURCES INVESTIGATIONS REPORT 93-4126, 1994.

NATIONAL WATER-QUALITY ASSESSMENT PROGRAM-SOUTHCENTRAL TEXAS: USGS FACT SHEET FS-94-048, 1994. 
GEOLOGIC HISTORY AND HYDROGEOLOGIC SETTING OF THE EDWARDS-TRINITY AQUIFER SYSTEM, WEST-CENTRAL TEXAS: USGS WATER-RESOURCES INVESTIGATIONS REPORT 94-4039, 1994.

WATER QUALITY IN THE EDWARDS-TRINITY (PLATEAU) AQUIFER, EDWARDS PLATEAU AND TRANS-PECOS, TEXAS: TEXAS WATER DEVELOPMENT BOARD HYDROLOGIC ATLAS NO. 3, 1995.

REGIONAL DISTRIBUTION OF PERMEABILITY IN THE EDWARDS AQUIFER: EDWARDS UNDERGROUND WATER DISTRICT REPORT 95-02, 1995.

GEOLOGY AND HYDROLOGY OF THE EDWARDS AQUIFER IN THE SAN ANTONIO AREA, TEXAS: USGS WATER-RESOURCES INVESTIGATIONS REPORT 95-4186, 1995.

HYDROGEOLOGIC FACTORS THAT AFFECT THE FLOWPATH OF WATER IN SELECTED ZONES OF THE EDWARDS AQUIFER, SAN ANTONIO REGION, TEXAS: USGS WATER-RESOURCES INVESTIGATIONS REPORT 96-4046, 1996.

RECHARGE TO AND DISCHARGE FROM THE EDWARDS AQUIFER IN THE SAN ANTONIO AREA, TEXAS, 1995: USGS OPEN-FILE REPORT 96-181, 1996.

EDWARDS AQUIFER GROUND-WATER RESOURCES: GEOLOGIC CONTROLS ON POROSITY DEVELOPMENT IN PLATFORM CARBONATES, SOUTH TEXAS: UNIVERSITY OF TEXAS, BUREAU OF ECONOMIC GEOLOGY REPORT OF INVESTIGATIONS NO. 238, 1996.

HYDROGEOLOGIC FRAMEWORK AND GEOCHEMISTRY OF THE EDWARDS AQUIFER SALINE-WATER ZONE, SOUTH-CENTRAL TEXAS: USGS WATER-RESOURCES INVESTIGATIONS REPORT 97-4133, 1997.

WATER-RESOURCES DATA, TEXAS, WATER YEAR 1997, VOLUME 4, GROUND-WATER DATA: USGS WATER-DATA REPORT TX-97-4, 1998.

WATER-RESOURCES DATA, TEXAS, WATER YEAR 1998, VOLUME 4, GROUND-WATER DATA: USGS WATER-DATA REPORT TX-98-4, 1999.

WATER QUALITY IN SOUTH-CENTRAL TEXAS-TEXAS, 1996-98: USGS CIRCULAR 1212, 2000.

AN OVERVIEW OF THE EDWARDS-TRINITY AQUIFER SYSTEM, CENTRAL-WEST TEXAS, CHAPTER 8, in AQUIFERS OF WEST TEXAS: TEXAS WATER DEVELOPMENT BOARD REPORT 356, 2001.

\section{KLEBERG COUNTY}

UNDERGROUND WATERS OF COASTAL PLAIN OF TEXAS: USGS WATER-SUPPLY AND IRRIGATION PAPER 190, 1907.

WATER RESOURCES OF KLEBERG COUNTY, TEXAS: USGS OPENFILE REPORT (UNNUMBERED), 1935?

GROUND-WATER RESOURCES OF KLEBERG COUNTY, TEXAS: USGS WATER-SUPPLY PAPER 773-D, 1936.

METHODS OF LOCATING SALT-WATER LEAKS IN WATER WELLS USGS WATER-SUPPLY PAPER 796-A, 1937.

EXPLORATION OF SALTY WELLS ON THE KING RANCH, TEXAS: USGS OPEN-FILE REPORT (UNNUMBERED), 1942.
NAVAL AIR TRAINING STATION NEAR KINGSVILLE, KLEBERG COUNTY, TEXAS - DECLINE OF WATER LEVELS IN WELLS: USGS OPEN-FILE REPORT (UNNUMBERED), 1943.

RECENT OBSERVATIONS OF GROUND-WATER CONDITIONS IN THE VICINITY OF KINGSVILLE, TEXAS: USGS OPEN-FILE REPORT (UNNUMBERED), 1943.

GROUND-WATER CONDITIONS IN THE PREMONT-LA GLORIA-FALFURRIAS DISTRICT, TEXAS: USGS OPEN-FILE REPORT (UNNUMBERED), 1944.

PUBLIC WATER SUPPLIES IN SOUTHERN TEXAS: TEXAS BOARD OF WATER ENGINEERS MISCELLANEOUS PUBLICATION 215, 1946.

PUBLIC WATER SUPPLIES IN SOUTHERN TEXAS: USGS WATERSUPPLY PAPER 1070, 1950

AVAILABILITY OF GROUND WATER IN THE GULF COAST REGION OF TEXAS: USGS OPEN-FILE REPORT, 1956

AVAILABILITY OF GROUND WATER FROM THE GOLIAD SAND IN THE ALICE AREA, TEXAS: TEXAS WATER COMMISSION BULLETIN 6301, 1963.

RECONNAISSANCE INVESTIGATION OF THE GROUND-WATER RESOURCES OF THE GULF COAST REGION, TEXAS: TEXAS WATER COMMISSION BULLETIN 6305, 1963.

COMPILATION OF RESULTS OF AQUIFER TESTS IN TEXAS: TEXAS WATER DEVELOPMENT BOARD REPORT 98, 1969.

RELATION OF PONDED FLOODWATER FROM HURRICANE BEULAH TO GROUND WATER IN KLEBERG, KENEDY, AND WILLACY COUNTIES, TEXAS: TEXAS WATER DEVELOPMENT BOARD REPORT 138, 1971.

GROUND-WATER RESOURCES OF KLEBERG, KENEDY, AND SOUTHERN JIM WELLS COUNTIES, TEXAS: TEXAS WATER DEVELOPMENT BOARD REPORT 173, 1973.

SUMMARY APPRAISALS OF THE NATION'S GROUND-WATER RESOURCES-TEXAS-GULF REGION: USGS PROFESSIONAL PAPER 813-F, 1976.

STRATIGRAPHIC AND HYDROGEOLOGIC FRAMEWORK OF PART OF THE COASTAL PLAIN OF TEXAS: USGS OPEN-FILE REPORT $77-712,1978$.

STRATIGRAPHIC AND HYDROGEOLOGIC FRAMEWORK OF PART OF THE COASTAL PLAIN OF TEXAS: TEXAS DEPARTMENT OF WATER RESOURCES REPORT 236, 1979.

LAND-SURFACE SUBSIDENCE IN THE TEXAS COASTAL REGION: USGS OPEN-FILE REPORT 80-969, 1980.

SPRINGS OF TEXAS, VOLUME 1: (BY GUNNAR BRUNE), BRANCHSMITH, INC., FORT WORTH, TEXAS, 1981.

LAND-SURFACE SUBSIDENCE IN THE TEXAS COASTAL REGION: TEXAS DEPARTMENT OF WATER RESOURCES REPORT 272, 1982

REGIONAL HYDRODYNAMICS AND HYDROCHEMISTRY OF THE URANIUM-BEARING OAKVILLE AQUIFER (MIOCENE) OF SOUTH TEXAS: UNIVERSITY OF TEXAS, BUREAU OF ECONOMIC GEOLOGY REPORT OF INVESTIGATIONS NO. 124, 1982.

STRUCTURE, TEMPERATURE, PRESSURE, AND SALINITY OF CENOZOIC AQUIFERS OF SOUTH TEXAS: USGS HYDROLOGIC INVESTIGATIONS ATLAS HA-654, 1983. 
WATER LEVELS AND SALINITIES OF WATER WITHIN THE EVANGELINE AQUIFER IN AN AREA SOUTHWEST OF CORPUS CHRISTI, TEXAS: USGS OPEN-FILE REPORT 82-174, 1983.

SIMULATED EFFECTS OF PROJECTED PUMPING ON THE AVAILABILITY OF FRESHWATER IN THE EVANGELINE AQUIFER IN AN AREA SOUTHWEST OF CORPUS CHRISTI, TEXAS: USGS WATERRESOURCES INVESTIGATIONS REPORT 85-4182, 1985.

TEXAS GROUND-WATER RESOURCES, in NATIONAL WATER SUMMARY 1984: USGS WATER-SUPPLY PAPER 2275, 1985.

DIGITAL MODELS FOR SIMULATION OF GROUND-WATER HYDROLOGY OF THE CHICOT AND EVANGELINE AQUIFERS ALONG THE GULF COAST OF TEXAS: TEXAS DEPARTMENT OF WATER RESOURCES REPORT 289, 1985.

GEOHYDROLOGIC FRAMEWORK OF THE GULF COASTAL PLAIN: USGS HYDROLOGIC INVESTIGATIONS ATLAS HA-695, 1988.

HYDROGEOLOGY AND PREDEVELOPMENT FLOW IN THE TEXAS GULF COAST AQUIFER SYSTEMS: USGS WATER-RESOURCES INVESTIGATIONS REPORT 87-4248, 1988.

GROUND-WATER FLOW IN THE GULF COAST AQUIFER SYSTEMS, SOUTH-CENTRAL UNITED STATES-A PRELIMINARY ANALYSIS: USGS WATER-RESOURCES INVESTIGATIONS REPORT 89-4071, 1990.

HYDROLOGY OF THE TEXAS GULF COAST AQUIFER SYSTEMS: USGS OPEN-FILE REPORT 91-64, 1991.

PROPERTIES AND CHEMICAL CONSTITUENTS IN GROUND WATER FROM THE MISSISSIPPI RIVER VALLEY ALLUVIAL AQUIFER AND PERMEABLE ZONE A (HOLOCENE-UPPER PLEISTOCENE DEPOSITS), SOUTH-CENTRAL UNITED STATES: USGS WATERRESOURCES INVESTIGATIONS REPORT 91-4149, 1992.

PROPERTIES AND CHEMICAL CONSTITUENTS IN GROUND WATER FROM THE UPPER CLAIBORNE AQUIFER, GULF COAST REGIONAL AQUIFER SYSTEMS, SOUTH-CENTRAL UNITED STATES: USGS WATER-RESOURCES INVESTIGATIONS REPORT 91-4150, 1993.

PROPERTIES AND CHEMICAL CONSTITUENTS IN GROUND WATER FROM PERMEABLE ZONE C (LOWER PLIOCENE-UPPER MIOCENE DEPOSITS), COASTAL LOWLANDS AQUIFER SYSTEM, SOUTHCENTRAL UNITED STATES: USGS WATER-RESOURCES INVESTIGATIONS REPORT 91-4151, 1993.

PROPERTIES AND CHEMICAL CONSTITUENTS IN GROUND WATER FROM PERMEABLE ZONE B (LOWER PLEISTOCENE-UPPER PLIOCENE DEPOSITS), COASTAL LOWLANDS AQUIFER SYSTEM, SOUTH-CENTRAL UNITED STATES: USGS WATER-RESOURCES INVESTIGATIONS REPORT 91-4152, 1993.

PROPERTIES AND CHEMICAL CONSTITUENTS IN GROUND WATER FROM PERMEABLE ZONE E (LOWER MIOCENE-UPPER OLIGOCENE DEPOSITS), COASTAL LOWLANDS AQUIFER SYSTEM, SOUTH-CENTRAL UNITED STATES: USGS WATER-RESOURCES INVESTIGATIONS REPORT 92-4103, 1993.

PROPERTIES AND CHEMICAL CONSTITUENTS IN GROUND WATER FROM PERMEABLE ZONE D (MIDDLE MIOCENE DEPOSITS), COASTAL LOWLANDS AQUIFER SYSTEM, SOUTH-CENTRAL UNITED STATES: USGS WATER-RESOURCES INVESTIGATIONS REPORT 92-4105, 1993.

AQUIFERS OF TEXAS: TEXAS WATER DEVELOPMENT BOARD REPORT 345, 1995.
STRATIGRAPHIC NOMENCLATURE AND GEOLOGIC SECTIONS OF THE GULF COASTAL PLAIN OF TEXAS: USGS OPEN-FILE REPORT 94-461, 1995.

\section{KNOX COUNTY}

GEOLOGY AND UNDERGROUND WATERS OF THE WICHITA REGION, NORTH-CENTRAL TEXAS: USGS WATER-SUPPLY PAPER 317,1913

RECORDS OF WELLS, DRILLERS' LOGS, AND WATER ANALYSES, AND MAP SHOWING LOCATION OF WELLS IN KNOX COUNTY, TEXAS: TEXAS BOARD OF WATER ENGINEERS MISCELLANEOUS PUBLICATION 155, 1937.

GROUND WATER IN THE VICINITY OF BENJAMIN, TEXAS: USGS OPEN-FILE REPORT (UNNUMBERED), 1945.

PUBLIC WATER SUPPLIES IN CENTRAL AND NORTH-CENTRAL TEXAS: USGS WATER-SUPPLY PAPER 1069, 1949.

RECORDS OF WATER-LEVEL MEASUREMENTS IN HASKELL AND KNOX COUNTIES, TEXAS: TEXAS BOARD OF WATER ENGINEERS BULLETIN 5503, 1955.

INVESTIGATION OF CONTAMINATION COMPLAINT IN SOUTH-CENTRAL KNOX COUNTY, TEXAS (CONTAMINATION REPORT NO. 7): TEXAS BOARD OF WATER ENGINEERS MISCELLANEOUS PUBLICATION 156, 1960

WATER LEVELS IN OBSERVATION WELLS IN HASKELL AND KNOX COUNTIES, TEXAS, 1956-1960: TEXAS BOARD OF WATER ENGINEERS BULLETIN 6009, 1960.

GROUND-WATER RESOURCES OF HASKELL AND KNOX COUNTIES, TEXAS: TEXAS WATER COMMISSION BULLETIN 6209, 1962.

RECONNAISSANCE INVESTIGATION OF THE GROUND-WATER RESOURCES OF THE RED RIVER, SULPHUR RIVER, AND CYPRESS CREEK BASINS, TEXAS: TEXAS WATER COMMISSION BULLETIN 6306, 1963.

RECONNAISSANCE INVESTIGATION OF THE GROUND-WATER RESOURCES OF THE BRAZOS RIVER BASIN, TEXAS: TEXAS WATER COMMISSION BULLETIN 6310, 1963.

INVESTIGATION OF GROUND-WATER CONTAMINATION, RHINELAND AREA, KNOX COUNTY, TEXAS: TEXAS WATER COMMISSION BULLETIN 6521, 1965.

COMPILATION OF RESULTS OF AQUIFER TESTS IN TEXAS: TEXAS WATER DEVELOPMENT BOARD REPORT 98, 1969.

SUMMARY APPRAISALS OF THE NATION'S GROUND-WATER RESOURCES-TEXAS-GULF REGION: USGS PROFESSIONAL PAPER 813-F, 1976.

THE SEYMOUR AQUIFER: GROUND-WATER QUALITY AND AVAILABILITY IN HASKELL AND KNOX COUNTIES, TEXAS: TEXAS DEPARTMENT OF WATER RESOURCES REPORT 226, V. 1, 1978.

THE SEYMOUR AQUIFER: GROUND-WATER QUALITY AND AVAILABILITY IN HASKELL AND KNOX COUNTIES, TEXAS: TEXAS DEPARTMENT OF WATER RESOURCES REPORT 226, V. 2, 1978.

SPRINGS OF TEXAS, VOLUME 1: (BY GUNNAR BRUNE), BRANCHSMITH, INC., FORT WORTH, TEXAS, 1981. 
PROJECTED EFFECTS OF PROPOSED CHLORIDE-CONTROL PROJECTS ON SHALLOW GROUND-WATER-PRELIMINARY RESULTS FOR THE WICHITA RIVER BASIN, TEXAS: USGS WATERRESOURCES INVESTIGATIONS REPORT 83-4026, 1983.

TEXAS GROUND-WATER RESOURCES, in NATIONAL WATER SUMMARY 1984: USGS WATER-SUPPLY PAPER 2275, 1985.

JOINT GROUND-WATER QUALITY PROJECT WITH THE TEXAS DEPARTMENT OF AGRICULTURE IN PARTS OF HASKELL, KNOX, AND STONEWALL COUNTIES: TEXAS WATER DEVELOPMENT BOARD REPORT 333, 1991.

EVALUATION OF WATER RESOURCES IN PARTS OF THE ROLLING PRAIRIES REGION OF NORTH-CENTRAL TEXAS: TEXAS WATER DEVELOPMENT BOARD REPORT 337, 1992.

WATER-RESOURCES DATA, TEXAS, WATER YEAR 1992, VOLUME 4 , GROUND-WATER DATA: USGS WATER-DATA REPORT TX-92-4, 1993.

AQUIFERS OF TEXAS: TEXAS WATER DEVELOPMENT BOARD REPORT 345, 1995.

WATER-RESOURCES DATA, TEXAS, WATER YEAR 1995, VOLUME 4 GROUND-WATER DATA: USGS WATER-DATA REPORT TX-95-4, 1996.

\section{LAMAR COUNTY}

GEOGRAPHY AND GEOLOGY OF THE BLACK AND GRAND PRAIRIES, TEXAS, WITH DETAILED DESCRIPTIONS OF THE CRETACEOUS FORMATIONS AND SPECIAL REFERENCE TO ARTESIAN WATERS: USGS 21ST ANNUAL REPORT, PART 7, 1901.

GEOLOGY AND UNDERGROUND WATERS OF NORTHEASTERN TEXAS: USGS WATER-SUPPLY PAPER 276, 1911.

MEMORANDUM ON GROUND WATER AT HOWLAND IN LAMAR COUNTY, TEXAS: USGS OPEN-FILE REPORT (UNNUMBERED), 1943.

PUBLIC WATER SUPPLIES IN EASTERN TEXAS, VOLUME 2, HARRISON COUNTY THROUGH WOOD COUNTY: TEXAS BOARD OF WATER ENGINEERS MISCELLANEOUS PUBLICATION 214, V. 2, 1945

PUBLIC WATER SUPPLIES IN EASTERN TEXAS: USGS WATERSUPPLY PAPER 1047, 1948.

RECONNAISSANCE INVESTIGATION OF THE GROUND-WATER RESOURCES OF THE RED RIVER, SULFUR RIVER, AND CYPRESS CREEK BASINS, TEXAS: TEXAS WATER COMMISSION BULLETIN 6306, 1963.

WATER-LEVEL AND WATER-QUALITY DATA FROM OBSERVATION WELLS IN NORTHEAST TEXAS: TEXAS WATER DEVELOPMENT BOARD REPORT 198, 1976.

SPRINGS OF TEXAS, VOLUME 1: (BY GUNNAR BRUNE), BRANCHSMITH, INC., FORT WORTH, TEXAS, 1981.

OCCURRENCE, AVAILABILITY, AND CHEMICAL QUALITY OF GROUND WATER IN THE CRETACEOUS AQUIFERS OF NORTHCENTRAL TEXAS: TEXAS DEPARTMENT OF WATER RESOURCES REPORT 269, V. 1, 1982.

OCCURRENCE, AVAILABILITY, AND CHEMICAL QUALITY OF GROUND WATER IN THE CRETACEOUS AQUIFERS OF NORTH-
CENTRAL TEXAS: TEXAS DEPARTMENT OF WATER RESOURCES REPORT 269, V. 2, 1982.

TEXAS GROUND-WATER RESOURCES, in NATIONAL WATER SUMMARY 1984: USGS WATER-SUPPLY PAPER 2275, 1985.

GROUND-WATER RESOURCES OF THE NACATOCH AQUIFER: TEXAS WATER DEVELOPMENT BOARD REPORT 305, 1988.

OCCURRENCE, AVAILABILITY, AND CHEMICAL QUALITY OF GROUND WATER IN THE BLOSSOM SAND AQUIFER: TEXAS WATER DEVELOPMENT BOARD REPORT 307, 1988.

EVALUATION OF WATER RESOURCES IN PART OF NORTH-CENTRAL TEXAS: TEXAS WATER DEVELOPMENT BOARD REPORT 318,1990

SIMULATION OF GROUND-WATER FLOW IN THE ANTLERS AQUIFER IN SOUTHEASTERN OKLAHOMA AND NORTHEASTERN TEXAS: USGS WATER-RESOURCES INVESTIGATIONS REPORT 88-4208, 1992.

AQUIFERS OF TEXAS: TEXAS WATER DEVELOPMENT BOARD REPORT 345, 1995

WATER QUALITY IN THE WOODBINE AQUIFER, NORTH-CENTRAL TEXAS: TEXAS WATER DEVELOPMENT BOARD HYDROLOGIC ATLAS NO. 4, 1996.

UPDATED EVALUATION OF WATER RESOURCES IN PART OF NORTH-CENTRAL TEXAS, 1990-1999: TEXAS WATER DEVELOPMENT BOARD REPORT 349, 1999.

\section{LAMB COUNTY}

GEOLOGY AND GROUND-WATER RESOURCES OF THE SOUTHERN HIGH PLAINS: USGS OPEN-FILE REPORT (UNNUMBERED), 1935.

PRELIMINARY REPORT ON THE UNDERGROUND WATER SUPPLY OF THE PLAINVIEW, TEXAS PROJECT: USGS OPEN-FILE REPORT (UNNUMBERED), 1936.

GROUND WATER IN THE SOUTHERN HIGH PLAINS: USGS OPENFILE REPORT (UNNUMBERED), 1937.

RECORDS OF WELLS, DRILLERS' LOGS, AND WATER ANALYSES, AND MAP SHOWING LOCATION OF WELLS IN LAMB COUNTY, TEXAS: TEXAS BOARD OF WATER ENGINEERS MISCELLANEOUS PUBLICATION 157, 1938.

GROUND WATER IN THE HIGH PLAINS IN TEXAS (1940): TEXAS BOARD OF WATER ENGINEERS MISCELLANEOUS PUBLICATION M119, 1940

GROUND WATER IN THE HIGH PLAINS IN TEXAS, PROGRESS REPORT (1943): TEXAS BOARD OF WATER ENGINEERS MISCELLANEOUS PUBLICATION M120, 1943.

GROUND WATER IN THE HIGH PLAINS IN TEXAS, PROGRESS REPORT (1944): TEXAS BOARD OF WATER ENGINEERS MISCELLANEOUS PUBLICATION M121, 1944.

GROUND WATER IN THE HIGH PLAINS IN TEXAS, PROGRESS REPORT NO. 5: TEXAS BOARD OF WATER ENGINEERS MISCELLANEOUS PUBLICATION M122, 1945.

GROUND WATER IN THE HIGH PLAINS IN TEXAS, PROGRESS REPORT NO. 6: TEXAS BOARD OF WATER ENGINEERS MISCELLANEOUS PUBLICATION M123, 1947. 
GEOLOGY AND GROUND WATER IN THE IRRIGATED REGION OF THE SOUTHERN HIGH PLAINS IN TEXAS, PROGRESS REPORT NO. 7: TEXAS BOARD OF WATER ENGINEERS MISCELLANEOUS PUBLICATION M125, 1949.

COST OF PUMPING WATER FOR IRRIGATION, TEXAS HIGH PLAINS, FIELD INVESTIGATION-1947 IRRIGATION SEASON: TEXAS BOARD OF WATER ENGINEERS MISCELLANEOUS PUBLICATION M124, 1951.

DEVELOPMENT OF WELLS FOR IRRIGATION AND FLUCTUATION OF WATER LEVELS IN THE HIGH PLAINS OF TEXAS TO JANUARY 1951: TEXAS BOARD OF WATER ENGINEERS BULLETIN 5104, 1951.

PUBLIC WATER SUPPLIES IN WESTERN TEXAS: USGS WATERSUPPLY PAPER 1106, 1951 [1952].

MEMORANDUM REGARDING PUMPING TEST SOUTHWESTERN PUBLIC SERVICE CO., LAMB COUNTY: USGS OPEN-FILE REPORT (UNNUMBERED), 1952.

RECORDS OF WATER-LEVEL MEASUREMENTS IN LAMB COUNTY, TEXAS, 1914-1953: TEXAS BOARD OF WATER ENGINEERS BULLETIN 5306, 1953.

WATER-LEVEL DECLINE MAPS OF 6 COUNTIES IN THE SOUTHERN HIGH PLAINS, TEXAS, JANUARY 1953 TO JANUARY 1954: (DEAF SMITH, FLOYD, HALE, LAMB, LUBBOCK, AND SWISHER): USGS OPEN-FILE REPORT (UNNUMBERED), 1954.

SUMMARY OF GROUND-WATER DEVELOPMENT IN THE SOUTHERN HIGH PLAINS, TEXAS: TEXAS BOARD OF WATER ENGINEERS BULLETIN 5402, 1954.

GROUND-WATER DEVELOPMENT IN THE SOUTHERN HIGH PLAINS OF TEXAS, 1953: TEXAS BOARD OF WATER ENGINEERS BULLETIN 5410, 1954.

WATER-LEVEL DECLINE MAPS OF 16 COUNTIES IN THE SOUTHERN HIGH PLAINS, TEXAS, JANUARY 1954 TO JANUARY 1955: (BAILEY, BRISCOE, CASTRO, COCHRAN, CROSBY, DEAF SMITH, FLOYD, GAINES, HALE, HOCKLEY, LAMB, LUBBOCK, PARMER, RANDALL, SWISHER, AND TERRY): USGS OPEN-FILE REPORT (UNNUMBERED), 1955.

WATER-LEVEL DECLINE MAPS OF 17 COUNTIES IN THE SOUTHERN HIGH PLAINS, TEXAS, JANUARY 1955 TO JANUARY 1956: TEXAS BOARD OF WATER ENGINEERS BULLETIN 5607, 1956.

GEOLOGY AND GROUND-WATER RESOURCES OF LAMB COUNTY, TEXAS: TEXAS BOARD OF WATER ENGINEERS BULLETIN 5704, 1957.

WATER-LEVEL DECLINE MAPS, 1956 TO 1957, AND WATER LEVELS IN OBSERVATION WELLS IN 20 COUNTIES IN THE SOUTHERN HIGH PLAINS, TEXAS: TEXAS BOARD OF WATER ENGINEERS BULLETIN 5705, 1957.

PRELIMINARY ANALYSIS OF PUMPING TEST DATA, CITY OF LUBBOCK WELL 114-A, LAMB COUNTY, TEXAS: USGS OPEN-FILE REPORT, 1958.

WATER-LEVEL MEASUREMENTS AND MAPS, SOUTHERN HIGH PLAINS, TEXAS, 1958 AND 1959: TEXAS BOARD OF WATER ENGINEERS BULLETIN 5908, 1959.

WATER LEVELS IN OBSERVATION WELLS, SOUTHERN HIGH PLAINS, TEXAS, 1959 AND 1960: TEXAS BOARD OF WATER ENGINEERS BULLETIN 6011, 1960.
WATER LEVELS IN OBSERVATION WELLS, SOUTHERN HIGH PLAINS, TEXAS, 1960 AND 1961: TEXAS BOARD OF WATER ENGINEERS BULLETIN 6101, 1961.

A SUMMARY OF THE OCCURRENCE AND DEVELOPMENT OF GROUND WATER IN THE SOUTHERN HIGH PLAINS OF TEXAS: TEXAS BOARD OF WATER ENGINEERS BULLETIN 6107, 1961.

WATER-LEVEL MEASUREMENTS THROUGH 1962 IN SELECTED OBSERVATION WELLS, SOUTHERN HIGH PLAINS, TEXAS: TEXAS WATER COMMISSION BULLETIN 6207, 1962.

RECONNAISSANCE INVESTIGATION OF THE GROUND-WATER RESOURCES OF THE BRAZOS RIVER BASIN, TEXAS: TEXAS WATER COMMISSION BULLETIN 6310, 1963.

A SUMMARY OF THE OCCURRENCE AND DEVELOPMENT OF GROUND WATER IN THE SOUTHERN HIGH PLAINS OF TEXAS: USGS WATER-SUPPLY PAPER 1693, 1964.

PUBLIC WATER SUPPLIES OF THE 100 LARGEST CITIES IN THE UNITED STATES: USGS WATER-SUPPLY PAPER 1812, 1964.

WATER-LEVEL DATA FROM OBSERVATION WELLS IN THE SOUTHERN HIGH PLAINS OF TEXAS: TEXAS WATER DEVELOPMENT BOARD REPORT 21, 1966.

COMPILATION OF RESULTS OF AQUIFER TESTS IN TEXAS: TEXAS WATER DEVELOPMENT BOARD REPORT 98, 1969.

GROUND WATER IN THE OGALLALA FORMATION IN THE SOUTHERN HIGH PLAINS OF TEXAS AND NEW MEXICO: USGS HYDROLOGIC INVESTIGATIONS ATLAS HA-330, 1969.

WATER-LEVEL DATA FROM OBSERVATION WELLS IN THE SOUTHERN HIGH PLAINS OF TEXAS, 1956-70: TEXAS WATER DEVELOPMENT BOARD REPORT 121, 1970.

AN EVALUATION OF THE USE OF DRILLERS' LOGS IN LITHOLOGIC STUDIES OF THE OGALLALA FORMATION OF THE SOUTHERN HIGH PLAINS OF TEXAS: USGS OPEN-FILE REPORT 72-451, 1972.

SUMMARY APPRAISALS OF THE NATION'S GROUND-WATER RESOURCES-TEXAS-GULF REGION: USGS PROFESSIONAL PAPER 813-F, 1976.

ANALYTICAL STUDY OF THE OGALLALA AQUIFER IN LAMB COUNTY, TEXAS—PROJECTIONS OF SATURATED THICKNESS, VOLUME OF WATER IN STORAGE, PUMPAGE RATES, PUMPING LIFTS, AND WELL YIELDS: TEXAS WATER DEVELOPMENT BOARD REPORT 204, 1976.

WATER-LEVEL DATA FROM OBSERVATION WELLS IN THE SOUTHERN HIGH PLAINS OF TEXAS, 1971-77: TEXAS DEPARTMENT OF WATER RESOURCES REPORT 228, 1979.

PRELIMINARY DATA DESCRIBING THE DISTRIBUTION OF FLUORIDE AND SILICA IN THE OGALLALA AQUIFER ON THE HIGH PLAINS OF TEXAS: USGS OPEN-FILE REPORT 80-349, 1980.

EVALUATING THE GROUND-WATER RESOURCES OF THE HIGH PLAINS OF TEXAS: RESULTS OF TEST-HOLE DRILLING: TEXAS DEPARTMENT OF WATER RESOURCES LIMITED PRINTING REPORT LP-129, 1980.

EVALUATING THE GROUND-WATER RESOURCES OF THE HIGH PLAINS OF TEXAS: RESULTS OF SURFACE ELECTRICAL SURVEYS: TEXAS DEPARTMENT OF WATER RESOURCES LIMITED PRINTING REPORT LP-130, 1980.

EVALUATING THE GROUND-WATER RESOURCES OF THE HIGH PLAINS OF TEXAS: NEUTRON-PROBE MEASUREMENTS OF DEEP 
SOIL MOISTURE AS AN INDICATION OF AQUIFER RECHARGE RATES: TEXAS DEPARTMENT OF WATER RESOURCES LIMITED PRINTING REPORT LP-142, 1981.

SPRINGS OF TEXAS: VOLUME 1, (BY GUNNAR BRUNE), BRANCHSMITH, INC., FORT WORTH, TEXAS, 1981.

BEDROCK GEOLOGY, ALTITUDE OF BASE, AND 1980 SATURATED THICKNESS OF THE HIGH PLAINS AQUIFER IN PARTS OF COLORADO, KANSAS, NEBRASKA, NEW MEXICO, OKLAHOMA, SOUTH DAKOTA, TEXAS, AND WYOMING: USGS HYDROLOGIC INVESTIGATIONS ATLAS HA-648, 1981.

WATER LEVEL AND SATURATED THICKNESS CHANGES, PREDEVELOPMENT TO 1980, IN THE HIGH PLAINS AQUIFER IN PARTS OF COLORADO, KANSAS, NEBRASKA, NEW MEXICO, OKLAHOMA, SOUTH DAKOTA, TEXAS, AND WYOMING: USGS HYDROLOGIC INVESTIGATIONS ATLAS HA-652, 1981.

DISSOLVED SOLIDS AND SODIUM IN WATER FROM THE HIGH PLAINS AQUIFER IN PARTS OF COLORADO, KANSAS, NEBRASKA, NEW MEXICO, OKLAHOMA, SOUTH DAKOTA, TEXAS, AND WYOMING: USGS HYDROLOGIC INVESTIGATIONS ATLAS HA-658, 1982.

EVALUATING THE GROUND-WATER RESOURCES OF THE HIGH PLAINS OF TEXAS, VOLUME 1: TEXAS DEPARTMENT OF WATER RESOURCES REPORT 288, V. 1, 1984.

EVALUATING THE GROUND-WATER RESOURCES OF THE HIGH PLAINS OF TEXAS, VOLUME 3, RECORDS OF WELLS, AND MAPS SHOWING WELL LOCATIONS, BASE OF AQUIFER, WATER LEVELS, AND SATURATED THICKNESS: TEXAS DEPARTMENT OF WATER RESOURCES REPORT 288, V. 3, 1984.

GEOHYDROLOGY OF THE HIGH PLAINS AQUIFER IN PARTS OF COLORADO, KANSAS, NEBRASKA, NEW MEXICO, OKLAHOMA, SOUTH DAKOTA, TEXAS, AND WYOMING: USGS PROFESSIONAL PAPER 1400-B, 1984.

TEXAS GROUND-WATER RESOURCES, in NATIONAL WATER SUMMARY 1984: USGS WATER-SUPPLY PAPER 2275, 1985.

DIGITAL SIMULATION OF GROUND-WATER FLOW IN THE HIGH PLAINS AQUIFER IN PARTS OF COLORADO, KANSAS, NEBRASKA, NEW MEXICO, OKLAHOMA, SOUTH DAKOTA, TEXAS, AND WYOMING: USGS PROFESSIONAL PAPER 1400-D, 1986.

HYDROLOGIC ATLAS FOR LAMB COUNTY, TEXAS: HIGH PLAINS UNDERGROUND WATER CONSERVATION DISTRICT NO. 1, LUBBOCK, TEXAS, 1987.

SUMMARY OF THE HIGH PLAINS REGIONAL AQUIFER-SYSTEM ANALYSIS IN PARTS OF COLORADO, KANSAS, NEBRASKA, NEW MEXICO, OKLAHOMA, SOUTH DAKOTA, TEXAS, AND WYOMING: USGS PROFESSIONAL PAPER 1400-A, 1988.

HYDROGEOLOGY AND HYDROCHEMISTRY OF CRETACEOUS AQUIFERS, TEXAS PANHANDLE AND EASTERN NEW MEXICO: UNIVERSITY OF TEXAS, BUREAU OF ECONOMIC GEOLOGY GEOLOGICAL CIRCULAR 88-3, 1988.

HYDROGEOLOGY OF LOWER CRETACEOUS STRATA UNDER THE SOUTHERN HIGH PLAINS OF TEXAS AND NEW MEXICO: TEXAS WATER DEVELOPMENT BOARD REPORT 314, 1989.

PUBLIC-SUPPLY GROUND-WATER USE IN THE SOUTHERN HIGH PLAINS OF TEXAS: TEXAS WATER DEVELOPMENT BOARD REPORT 328, 1990
ORIGIN OF SOLUTES IN SALINE LAKES AND SPRINGS ON THE SOUTHERN HIGH PLAINS OF TEXAS AND NEW MEXICO, in GEOLOGIC FRAMEWORK AND REGIONAL HYDROLOGY: UPPER CENOZOIC BLACKWATER DRAW AND OGALLALA FORMATIONS, GREAT PLAINS: UNIVERSITY OF TEXAS, BUREAU OF ECONOMIC GEOLOGY SYMPOSIUM, LUBBOCK, TEXAS, OCTOBER 1-4, 1987, 1990.

WATER-LEVEL CHANGES IN THE HIGH PLAINS AQUIFER OF TEXAS, 1980-1990: TEXAS WATER DEVELOPMENT BOARD HYDROLOGIC ATLAS NO. 1, 1991.

THE HIGH PLAINS AQUIFER SYSTEM OF TEXAS, 1980 TO 1990. OVERVIEW AND PROJECTIONS: TEXAS WATER DEVELOPMENT BOARD REPORT 341, 1993

WATER-QUALITY EVALUATION OF THE OGALLALA AQUIFER, TEXAS: TEXAS WATER DEVELOPMENT BOARD REPORT 342 , 1993.

WATER-LEVEL CHANGES IN THE HIGH PLAINS AQUIFER, 1980 TO 1994: USGS FACT SHEET FS-215-95, 1995.

AQUIFERS OF TEXAS: TEXAS WATER DEVELOPMENT BOARD REPORT 345, 1995.

HYDROLOGIC ATLAS FOR LAMB COUNTY, TEXAS: HIGH PLAINS UNDERGROUND WATER CONSERVATION DISTRICT NO. 1, LUBBOCK, TEXAS, 1996.

WATER-LEVEL CHANGES IN THE HIGH PLAINS AQUIFER, 1980 TO 1995: USGS FACT SHEET FS-068-97, 1997.

WATER-LEVEL CHANGES IN THE HIGH PLAINS AQUIFER-PREDEVELOPMENT TO 1995: USGS WATER-RESOURCES INVESTIGATIONS REPORT 97-4081, 1997.

UPDATED WATER-QUALITY EVALUATION OF THE OGALLALA AQUIFER INCLUDING SELECTED METALLIC AND NON-METALLIC INORGANIC CONSTITUENTS: TEXAS WATER DEVELOPMENT BOARD HYDROLOGIC ATLAS NO. 10, 1998.

WATER-RESOURCES DATA, TEXAS, WATER YEAR 2000, VOLUME 6, GROUND-WATER DATA: USGS WATER-DATA REPORT TX-00-6, 2001.

\section{LAMPASAS COUNTY}

GEOGRAPHY AND GEOLOGY OF THE BLACK AND GRAND PRAIRIES OF TEXAS, WITH DETAILED DESCRIPTIONS OF THE CRETACEOUS FORMATIONS AND SPECIAL REFERENCE TO ARTESIAN WATERS: USGS 21ST ANNUAL REPORT, PART 7, 1901.

GROUND-WATER SUPPLIES NEAR LAMPASAS, TEXAS: USGS OPENFILE REPORT (UNNUMBERED), 1942.

PUBLIC WATER SUPPLIES IN CENTRAL AND NORTH-CENTRAL TEXAS: TEXAS BOARD OF WATER ENGINEERS MISCELLANEOUS PUBLICATION 213, 1947.

PUBLIC WATER SUPPLIES IN CENTRAL AND NORTH-CENTRAL TEXAS: USGS WATER-SUPPLY PAPER 1069, 1949.

GROUND-WATER CONDITIONS IN THE VICINITY OF BURNET, TEXAS: TEXAS WATER COMMISSION MEMORANDUM REPORT MR 62-01, 1962. 
RECONNAISSANCE INVESTIGATION OF THE GROUND-WATER RESOURCES OF THE BRAZOS RIVER BASIN, TEXAS: TEXAS WATER COMMISSION BULLETIN 6310, 1963.

RECONNAISSANCE INVESTIGATION OF THE GROUND-WATER RESOURCES OF THE COLORADO RIVER BASIN, TEXAS: TEXAS WATER DEVELOPMENT BOARD REPORT 51, 1967.

MAJOR AND HISTORICAL SPRINGS OF TEXAS: TEXAS WATER DEVELOPMENT BOARD REPORT 189, 1975.

GROUND-WATER RESOURCES OF PART OF CENTRAL TEXAS WITH EMPHASIS ON THE ANTLERS AND TRAVIS PEAK FORMATIONS, VOLUME 1: TEXAS WATER DEVELOPMENT BOARD REPORT 195, V. 1, 1975.

GROUND-WATER RESOURCES OF PART OF CENTRAL TEXAS WITH EMPHASIS ON THE ANTLERS AND TRAVIS PEAK FORMATIONS, VOLUME 2, RECORDS OF WELLS; DRILLERS' LOGS; WATER LEVELS IN WELLS; CHEMICAL ANALYSES OF GROUND WATER; CHEMICAL ANALYSES OF OIL-FIELD BRINES; AND WELL LOCATION MAPS: TEXAS WATER DEVELOPMENT BOARD REPORT 195, V. 2, 1976

SUMMARY APPRAISALS OF THE NATION'S GROUND-WATER RESOURCES-TEXAS-GULF REGION: USGS PROFESSIONAL PAPER 813-F, 1976.

SPRINGS OF TEXAS, VOLUME 1: (BY GUNNAR BRUNE), BRANCHSMITH, INC., FORT WORTH, TEXAS, 1981.

TEXAS GROUND-WATER RESOURCES, in NATIONAL WATER SUMMARY 1984: USGS WATER-SUPPLY PAPER 2275, 1985.

EVALUATION OF WATER RESOURCES IN PART OF CENTRAL TEXAS: TEXAS WATER DEVELOPMENT BOARD REPORT 319, 1990.

EVALUATION OF WATER RESOURCES IN BELL, BURNET, TRAVIS, WILLIAMSON, AND PARTS OF ADJACENT COUNTIES, TEXAS: TEXAS WATER DEVELOPMENT BOARD REPORT 326, 1991.

AQUIFERS OF TEXAS: TEXAS WATER DEVELOPMENT BOARD REPORT 345, 1995.

THE PALEOZOIC AND RELATED AQUIFERS OF CENTRAL TEXAS: TEXAS WATER DEVELOPMENT BOARD REPORT 346, 1996.

\section{LA SALLE COUNTY}

ARTESIAN WELLS OF THE COASTAL PRAIRIE REGION AND TERTIARY BELT OF TEXAS: GEOLOGICAL SURVEY OF TEXAS, CHAPTER 2, 1893.

UNDERGROUND WATERS OF THE COASTAL PLAIN OF TEXAS: USGS WATER-SUPPLY PAPER 190, 1907.

GROUND WATER IN LA SALLE AND McMULLEN COUNTIES, TEXAS: USGS WATER-SUPPLY PAPER 375-G, 1916.

GROUND WATER IN THE WINTER GARDEN AND ADJACENT DISTRICTS IN SOUTHWESTERN TEXAS: USGS OPEN-FILE REPORT (UNNUMBERED), 1931.

SUPPLEMENTAL MEMORANDUM ON ADDITIONAL DEEP WELLS TO THE CARRIZO SAND IN LA SALLE COUNTY, TEXAS: USGS OPENFILE REPORT (UNNUMBERED), 1942.
WATER-WELL DATA IN THE COTULLA-ENCINAL-GARDENDALE AREA, LA SALLE COUNTY, TEXAS: USGS OPEN-FILE REPORT (UNNUMBERED), 1942

MEMORANDUM REGARDING GROUND WATER ON SAN IGNACIO RANCH, ETC.: USGS OPEN-FILE REPORT (UNNUMBERED), 1943.

RESULTS OF A PRELIMINARY INVESTIGATION TO DETERMINE THE AMOUNT OF SEEPAGE LOSSES FROM THE NUECES AND FRIO RIVERS IN THE AREA BETWEEN COTULLA AND THREE RIVERS, TEXAS: USGS OPEN-FILE REPORT (UNNUMBERED), 1949.

PUBLIC WATER SUPPLIES IN SOUTHERN TEXAS: USGS WATERSUPPLY PAPER 1070, 1950.

SUPPLEMENTARY REPORT ON SURFACE-WATER AND GROUNDWATER SURVEYS, NUECES RIVER BASIN, TEXAS: USGS OPENFILE REPORT (UNNUMBERED), 1950.

DEVELOPMENT OF GROUND WATER FROM THE CARRIZO SAND AND WILCOX GROUP IN DIMMIT, ZAVALA, MAVERICK, FRIO, ATASCOSA, MEDINA, BEXAR, LIVE OAK, McMULLEN, LA SALLE, AND WEBB COUNTIES, TEXAS: USGS OPEN-FILE REPORT 57-77, 1957.

RECONNAISSANCE INVESTIGATION OF THE GROUND-WATER RESOURCES OF THE GUADALUPE, SAN ANTONIO, AND NUECES RIVER BASINS, TEXAS: TEXAS WATER COMMISSION BULLETIN 6409, 1964.

GROUND-WATER RESOURCES OF LA SALLE AND McMULLEN COUNTIES, TEXAS: TEXAS WATER COMMISSION BULLETIN 6520 , 1965.

WATER-LEVEL DATA FROM OBSERVATION WELLS IN THE NORTHWESTERN GULF COASTAL PLAIN OF TEXAS: TEXAS WATER DEVELOPMENT BOARD REPORT 70, 1968.

HYDROLOGIC SIGNIFICANCE OF THE LITHOFACIES OF THE SPARTA SAND IN ARKANSAS, LOUISIANA, MISSISSIPPI, AND TEXAS: USGS PROFESSIONAL PAPER 569-A, 1968.

COMPILATION OF RESULTS OF AQUIFER TESTS IN TEXAS: TEXAS WATER DEVELOPMENT BOARD REPORT 98, 1969.

GEOHYDROLOGIC SIGNIFICANCE OF LITHOFACIES OF THE COCKFIELD FORMATION OF LOUISIANA AND MISSISSIPPI AND OF THE YEGUA FORMATION OF TEXAS: USGS PROFESSIONAL PAPER 569-B, 1970.

HYDROLOGIC SIGNIFICANCE OF LITHOFACIES OF THE CANE RIVER FORMATION OR EQUIVALENTS OF ARKANSAS, LOUISIANA, MISSISSIPPI, AND TEXAS: USGS PROFESSIONAL PAPER 569-C, 1972.

HYDROLOGIC SIGNIFICANCE OF LITHOFACIES OF THE CARRIZO SAND OF ARKANSAS, LOUISIANA, AND TEXAS AND THE MERIDIAN SAND OF MISSISSIPPI: USGS PROFESSIONAL PAPER 569-D, 1975.

SUMMARY APPRAISALS OF THE NATION'S GROUND-WATER RESOURCES-TEXAS-GULF REGION: USGS PROFESSIONAL PAPER 813-F, 1976.

GROUND-WATER RESOURCES OF THE CARRIZO AQUIFER IN THE WINTER GARDEN AREA OF TEXAS, VOLUME 1: TEXAS WATER DEVELOPMENT BOARD REPORT 210, V. 1, 1976.

GROUND-WATER RESOURCES OF THE CARRIZO AQUIFER IN THE WINTER GARDEN AREA OF TEXAS, VOLUME 2: TEXAS WATER DEVELOPMENT BOARD REPORT 210, V. 2, 1977. 
VARIATIONS IN SPECIFIC YIELD IN THE OUTCROP OF THE CARRIZO SAND IN SOUTH TEXAS AS ESTIMATED BY SEISMIC REFRACTION: TEXAS DEPARTMENT OF WATER RESOURCES REPORT 229, 1979.

SPRINGS OF TEXAS, VOLUME 1: (BY GUNNAR BRUNE), BRANCHSMITH, INC., FORT WORTH, TEXAS, 1981.

TEXAS GROUND-WATER RESOURCES, in NATIONAL WATER SUMMARY 1984: USGS WATER-SUPPLY PAPER 2275, 1985.

APPROXIMATE POTENTIOMETRIC SURFACES FOR THE AQUIFERS OF THE COASTAL UPLANDS SYSTEM, 1980: USGS HYDROLOGIC INVESTIGATIONS ATLAS HA-704, 1987.

GEOHYDROLOGIC FRAMEWORK OF THE GULF COASTAL PLAIN: USGS HYDROLOGIC INVESTIGATIONS ATLAS HA-695, 1988.

DEPOSITIONAL AND GROUND-WATER FLOW SYSTEMS OF THE CARRIZO-UPPER WILCOX, SOUTH TEXAS: UNIVERSITY OF TEXAS, BUREAU OF ECONOMIC GEOLOGY REPORT OF INVESTIGATIONS NO. 175, 1988.

EVALUATION OF THE GROUND-WATER RESOURCES IN THE WESTERN PORTION OF THE WINTER GARDEN AREA, TEXAS: TEXAS WATER DEVELOPMENT BOARD REPORT 334, 1991.

GROUND-WATER QUALITY MONITORING RESULTS IN THE WINTER GARDEN AREA, 1990: TEXAS WATER DEVELOPMENT BOARD REPORT 335, 1992.

PROPERTIES AND CHEMICAL CONSTITUENTS IN GROUND WATER FROM THE MIDDLE WILCOX AQUIFER, GULF COAST REGIONAL AQUIFER SYSTEMS, SOUTH-CENTRAL UNITED STATES: USGS WATER-RESOURCES INVESTIGATIONS REPORT 93-4070, 1993.

PROPERTIES AND CHEMICAL CONSTITUENTS IN GROUND WATER FROM THE UPPER CLAIBORNE AQUIFER, GULF COAST REGIONAL AQUIFER SYSTEMS, SOUTH-CENTRAL UNITED STATES: USGS WATER-RESOURCES INVESTIGATIONS REPORT 91-4150, 1993.

PROPERTIES AND CHEMICAL CONSTITUENTS IN GROUND WATER FROM THE LOWER CLAIBORNE-UPPER WILCOX AQUIFER, GULF COAST REGIONAL AQUIFER SYSTEMS, SOUTH-CENTRAL UNITED STATES: USGS WATER-RESOURCES INVESTIGATIONS REPORT 92-4102, 1993.

PROPERTIES AND CHEMICAL CONSTITUENTS IN GROUND WATER FROM THE MIDDLE CLAIBORNE AQUIFER, GULF COAST REGIONAL AQUIFER SYSTEMS, SOUTH-CENTRAL UNITED STATES: USGS WATER-RESOURCES INVESTIGATIONS REPORT 92-4104, 1993.

AQUIFERS OF TEXAS: TEXAS WATER DEVELOPMENT BOARD REPORT 345, 1995.

STRATIGRAPHIC NOMENCLATURE AND GEOLOGIC SECTIONS OF THE GULF COASTAL PLAIN OF TEXAS: USGS OPEN-FILE REPORT 94-461, 1995.

WATER QUALITY IN THE SPARTA AQUIFER, EAST TEXAS: TEXAS WATER DEVELOPMENT BOARD HYDROLOGIC ATLAS NO. 5 , 1996.

WATER QUALITY IN THE QUEEN CITY AQUIFER, EAST TEXAS: TEXAS WATER DEVELOPMENT BOARD HYDROLOGIC ATLAS, NO. 6, 1996.

HYDROGEOLOGIC FRAMEWORK AND GEOCHEMISTRY OF THE EDWARDS AQUIFER SALINE-WATER ZONE, SOUTH-CENTRAL
TEXAS: USGS WATER-RESOURCES INVESTIGATIONS REPORT 97-4133, 1997.

\section{LAVACA COUNTY}

GEOGRAPHY AND GEOLOGY OF THE BLACK AND GRAND PRAIRIES OF TEXAS, WITH DETAILED DESCRIPTIONS OF THE CRETACEOUS FORMATIONS AND SPECIAL REFERENCE TO ARTESIAN WATERS: USGS 21ST ANNUAL REPORT, PART 7, 1901.

UNDERGROUND WATERS OF THE COASTAL PLAIN OF TEXAS: USGS WATER-SUPPLY PAPER 190, 1907.

RECORDS OF WELLS, DRILLERS' LOGS, AND WATER ANALYSES, AND MAP SHOWING LOCATION OF WELLS IN LAVACA COUNTY, TEXAS: TEXAS BOARD OF WATER ENGINEERS MISCELLANEOUS PUBLICATION 158, 1936.

PUBLIC WATER SUPPLIES IN EASTERN TEXAS, V. 2, HARRISON COUNTY THROUGH WOOD COUNTY: TEXAS BOARD OF WATER ENGINEERS MISCELLANEOUS PUBLICATION 214, V. 2, 1945.

PUBLIC WATER SUPPLIES IN EASTERN TEXAS: USGS WATERSUPPLY PAPER 1047, 1948.

AVAILABILITY OF GROUND WATER IN THE GULF COAST REGION OF TEXAS: USGS OPEN-FILE REPORT (UNNUMBERED), 1956.

RECONNAISSANCE INVESTIGATION OF THE GROUND-WATER RESOURCES OF THE GULF COAST REGION, TEXAS: TEXAS WATER COMMISSION BULLETIN 6305, 1963.

HYDROLOGIC SIGNIFICANCE OF THE LITHOFACIES OF THE SPARTA SAND IN ARKANSAS, LOUISIANA, MISSISSIPPI, AND TEXAS: USGS PROFESSIONAL PAPER 569-A, 1968.

HYDROLOGIC SIGNIFICANCE OF LITHOFACIES OF THE CANE RIVER FORMATION OR EQUIVALENTS OF ARKANSAS, LOUISIANA, MISSISSIPPI, AND TEXAS: USGS PROFESSIONAL PAPER 569-C, 1972.

SUMMARY APPRAISALS OF THE NATION'S GROUND-WATER RESOURCES-TEXAS-GULF REGION: USGS PROFESSIONAL PAPER 813-F, 1976.

STRATIGRAPHIC AND HYDROGEOLOGIC FRAMEWORK OF PART OF THE COASTAL PLAIN OF TEXAS: USGS OPEN-FILE REPORT 77-712, 1978.

GROUND-WATER RESOURCES OF COLORADO, LAVACA, AND WHARTON COUNTIES, TEXAS: USGS OPEN-FILE REPORT 79-212, 1979.

STRATIGRAPHIC AND HYDROGEOLOGIC FRAMEWORK OF PART OF THE COASTAL PLAIN OF TEXAS: TEXAS DEPARTMENT OF WATER RESOURCES REPORT 236, 1979.

SPRINGS OF TEXAS, VOLUME 1: (BY GUNNAR BRUNE), BRANCHSMITH, INC., FORT WORTH, TEXAS, 1981.

GROUND-WATER RESOURCES OF COLORADO, LAVACA, AND WHARTON COUNTIES, TEXAS: TEXAS DEPARTMENT OF WATER RESOURCES REPORT 270, 1982.

REGIONAL HYDRODYNAMICS AND HYDROCHEMISTRY OF THE URANIUM-BEARING OAKVILLE AQUIFER (MIOCENE) OF SOUTH TEXAS: UNIVERSITY OF TEXAS, BUREAU OF ECONOMIC GEOLOGY REPORT OF INVESTIGATIONS NO. 124, 1982. 
TEXAS GROUND-WATER RESOURCES, in NATIONAL WATER SUMMARY 1984: USGS WATER-SUPPLY PAPER 2275, 1985.

DIGITAL MODELS FOR SIMULATION OF GROUND-WATER HYDROLOGY OF THE CHICOT AND EVANGELINE AQUIFERS ALONG THE GULF COAST OF TEXAS: TEXAS DEPARTMENT OF WATER RESOURCES REPORT 289, 1985.

GEOHYDROLOGIC FRAMEWORK OF THE GULF COASTAL PLAIN: USGS HYDROLOGIC INVESTIGATIONS ATLAS HA-695, 1988.

HYDROGEOLOGY AND PREDEVELOPMENT FLOW IN THE TEXAS GULF COAST AQUIFER SYSTEMS: USGS WATER-RESOURCES INVESTIGATIONS REPORT 87-4248, 1988.

GROUND-WATER FLOW IN THE GULF COAST AQUIFER SYSTEMS, SOUTH-CENTRAL UNITED STATES-A PRELIMINARY ANALYSIS: USGS WATER-RESOURCES INVESTIGATIONS REPORT 89-4071, 1990.

HYDROLOGY OF THE TEXAS GULF COAST AQUIFER SYSTEMS: USGS OPEN-FILE REPORT 91-64, 1991.

PROPERTIES AND CHEMICAL CONSTITUENTS IN GROUND WATER FROM THE UPPER CLAIBORNE AQUIFER, GULF COAST REGIONAL AQUIFER SYSTEMS, SOUTH-CENTRAL UNITED STATES: USGS WATER-RESOURCES INVESTIGATIONS REPORT 91-4150, 1993.

PROPERTIES AND CHEMICAL CONSTITUENTS IN GROUND WATER FROM PERMEABLE ZONE C (LOWER PLIOCENE-UPPER MIOCENE DEPOSITS), COASTAL LOWLANDS AQUIFER SYSTEM, SOUTHCENTRAL UNITED STATES: USGS WATER-RESOURCES INVESTIGATIONS REPORT 91-4151, 1993.

PROPERTIES AND CHEMICAL CONSTITUENTS IN GROUND WATER FROM PERMEABLE ZONE B (LOWER PLEISTOCENE-UPPER PLIOCENE DEPOSITS), COASTAL LOWLANDS AQUIFER SYSTEM, SOUTH-CENTRAL UNITED STATES: USGS WATER-RESOURCES INVESTIGATIONS REPORT 91-5152, 1993.

PROPERTIES AND CHEMICAL CONSTITUENTS IN GROUND WATER FROM THE LOWER CLAIBORNE-UPPER WILCOX AQUIFER, GULF COAST REGIONAL AQUIFER SYSTEMS, SOUTH-CENTRAL UNITED STATES: USGS WATER-RESOURCES INVESTIGATIONS REPORT 92-4102, 1993.

PROPERTIES AND CHEMICAL CONSTITUENTS IN GROUND WATER FROM PERMEABLE ZONE E (LOWER MIOCENE-UPPER OLIGOCENE DEPOSITS), COASTAL LOWLANDS AQUIFER SYSTEM, SOUTH-CENTRAL UNITED STATES: USGS WATER-RESOURCES INVESTIGATIONS REPORT 92-4103, 1993.

PROPERTIES AND CHEMICAL CONSTITUENTS IN GROUND WATER FROM THE MIDDLE CLAIBORNE AQUIFER, GULF COAST REGIONAL AQUIFER SYSTEMS, SOUTH-CENTRAL UNITED STATES: USGS WATER-RESOURCES INVESTIGATIONS REPORT 92-4104, 1993.

PROPERTIES AND CHEMICAL CONSTITUENTS IN GROUND WATER FROM PERMEABLE ZONE D (MIDDLE MIOCENE DEPOSITS), COASTAL LOWLANDS AQUIFER SYSTEM, SOUTH-CENTRAL UNITED STATES: USGS WATER-RESOURCES INVESTIGATIONS REPORT 92-4105, 1993.

PROPERTIES AND CHEMICAL CONSTITUENTS IN GROUND WATER FROM THE MIDDLE WILCOX AQUIFER, GULF COAST AQUIFER SYSTEMS, SOUTH-CENTRAL UNITED STATES: USGS WATERRESOURCES INVESTIGATIONS REPORT 93-4070, 1993.
AQUIFERS OF TEXAS: TEXAS WATER DEVELOPMENT BOARD REPORT 345, 1995.

HYDROGEOLOGIC FRAMEWORK AND GEOCHEMISTRY OF THE EDWARDS AQUIFER SALINE-WATER ZONE, SOUTH-CENTRAL TEXAS: USGS WATER-RESOURCES INVESTIGATIONS REPORT 97-4133, 1997.

\section{LEE COUNTY}

ARTESIAN WELLS OF THE COASTAL PRAIRIE REGION AND TERTIARY BELT OF TEXAS: GEOLOGICAL SURVEY OF TEXAS, CHAPTER 2, 1893.

UNDERGROUND WATERS OF THE COASTAL PLAIN OF TEXAS: USGS WATER-SUPPLY PAPER 190, 1907.

RECORDS OF WELLS, DRILLERS' LOGS, AND WATER ANALYSES, AND MAP SHOWING LOCATION OF WELLS IN LEE COUNTY, TEXAS: TEXAS BOARD OF WATER ENGINEERS MISCELLANEOUS PUBLICATION 159, 1937.

GROUND WATER, LEE COUNTY: USGS OPEN-FILE REPORT (UNNUMBERED), 1937?

PUBLIC WATER SUPPLIES IN EASTERN TEXAS, V. 2, HARRISON COUNTY THROUGH WOOD COUNTY: TEXAS BOARD OF WATER ENGINEERS MISCELLANEOUS PUBLICATION 214, V. 2, 1945.

PUBLIC WATER SUPPLIES IN EASTERN TEXAS: USGS WATERSUPPLY PAPER 1047, 1948.

RECONNAISSANCE INVESTIGATION OF THE GROUND-WATER RESOURCES OF THE BRAZOS RIVER BASIN: TEXAS WATER COMMISSION BULLETIN 6310, 1963.

GROUND-WATER RESOURCES OF LEE COUNTY, TEXAS: TEXAS WATER DEVELOPMENT BOARD REPORT 20, 1966.

HYDROLOGIC SIGNIFICANCE OF THE LITHOFACIES OF THE SPARTA SAND IN ARKANSAS, LOUISIANA, MISSISSIPPI, AND TEXAS: USGS PROFESSIONAL PAPER 569-A, 1968.

COMPILATION OF RESULTS OF AQUIFER TESTS IN TEXAS: TEXAS WATER DEVELOPMENT BOARD REPORT 98, 1969.

GEOHYDROLOGIC SIGNIFICANCE OF LITHOFACIES OF THE COCKFIELD FORMATION OF LOUISIANA AND MISSISSIPPI AND OF THE YEGUA FORMATION OF TEXAS: USGS PROFESSIONAL PAPER 569-B, 1970.

HYDROLOGIC SIGNIFICANCE OF LITHOFACIES OF THE CANE RIVER FORMATION OR EQUIVALENTS OF ARKANSAS, LOUISIANA, MISSISSIPPI, AND TEXAS: USGS PROFESSIONAL PAPER 569-C, 1972.

HYDROLOGIC SIGNIFICANCE OF LITHOFACIES OF THE CARRIZO SAND OF ARKANSAS, LOUISIANA, AND TEXAS AND THE MERIDIAN SAND OF MISSISSIPPI: USGS PROFESSIONAL PAPER 569-D, 1975.

SUMMARY APPRAISALS OF THE NATION'S GROUND-WATER RESOURCES-TEXAS-GULF REGION: USGS PROFESSIONAL PAPER 813-F, 1976.

SPRINGS OF TEXAS, VOLUME 1: (BY GUNNAR BRUNE), BRANCHSMITH, INC., FORT WORTH, TEXAS, 1981. 
TEXAS GROUND-WATER RESOURCES, in NATIONAL WATER SUMMARY 1984: USGS WATER-SUPPLY PAPER 2275, 1985.

APPROXIMATE POTENTIOMETRIC SURFACES FOR THE AQUIFERS OF THE COASTAL UPLANDS SYSTEM, 1980: USGS HYDROLOGIC INVESTIGATIONS ATLAS HA-704, 1987.

GEOHYDROLOGIC FRAMEWORK OF THE GULF COASTAL PLAIN: USGS HYDROLOGIC INVESTIGATIONS ATLAS HA-695, 1988.

HYDROGEOLOGY AND PREDEVELOPMENT FLOW IN THE TEXAS GULF COAST AQUIFER SYSTEMS: USGS WATER-RESOURCES INVESTIGATIONS REPORT 87-4248, 1988.

A DIGITAL MODEL OF THE CARRIZO-WILCOX AQUIFER WITHIN THE COLORADO RIVER BASIN OF TEXAS: TEXAS WATER DEVELOPMENT BOARD LIMITED PRINTING REPORT LP-208, 1989.

GROUND-WATER FLOW IN THE GULF COAST AQUIFER SYSTEMS, SOUTH-CENTRAL UNITED STATES-A PRELIMINARY ANALYSIS USGS WATER-RESOURCES INVESTIGATIONS REPORT 89-4071, 1990.

HYDROLOGY OF THE TEXAS GULF COAST AQUIFER SYSTEMS: USGS OPEN-FILE REPORT 91-64, 1991.

GROUND-WATER RESOURCES OF THE CARRIZO-WILCOX AQUIFER IN THE CENTRAL TEXAS REGION: TEXAS WATER DEVELOPMENT BOARD REPORT 332, 1991.

PROPERTIES AND CHEMICAL CONSTITUENTS IN GROUND WATER FROM THE UPPER CLAIBORNE AQUIFER, GULF COAST REGIONAL AQUIFER SYSTEMS, SOUTH-CENTRAL UNITED STATES: USGS WATER-RESOURCES INVESTIGATIONS REPORT 91-4150, 1993.

PROPERTIES AND CHEMICAL CONSTITUENTS IN GROUND WATER FROM THE LOWER CLAIBORNE-UPPER WILCOX AQUIFER, GULF COAST REGIONAL AQUIFER SYSTEMS, SOUTH-CENTRAL UNITED STATES: USGS WATER-RESOURCES INVESTIGATIONS REPORT 92-4102, 1993

PROPERTIES AND CHEMICAL CONSTITUENTS IN GROUND WATER FROM THE MIDDLE CLAIBORNE AQUIFER, GULF COAST REGIONAL AQUIFER SYSTEMS, SOUTH-CENTRAL UNITED STATES: USGS WATER-RESOURCES INVESTIGATIONS REPORT 92-4104, 1993

PROPERTIES AND CHEMICAL CONSTITUENTS IN GROUND WATER FROM THE MIDDLE WILCOX AQUIFER, GULF COAST REGIONAL AQUIFER SYSTEMS, SOUTH-CENTRAL UNITED STATES: USGS WATER-RESOURCES INVESTIGATIONS REPORT 93-4070, 1993.

STRATIGRAPHIC NOMENCLATURE AND GEOLOGIC SECTIONS OF THE GULF COASTAL PLAIN OF TEXAS: USGS OPEN-FILE REPORT 94-461, 1995.

AQUIFERS OF TEXAS: TEXAS WATER DEVELOPMENT BOARD REPORT 345, 1995.

WATER QUALITY IN THE SPARTA AQUIFER, EAST TEXAS: TEXAS WATER DEVELOPMENT BOARD HYDROLOGIC ATLAS NO. 5 , 1996.

WATER QUALITY IN THE QUEEN CITY AQUIFER, EAST TEXAS: TEXAS WATER DEVELOPMENT BOARD HYDROLOGIC ATLAS NO. 6, 1996

GROUND-WATER AVAILABILITY IN THE CARRIZO-WILCOX AQUIFER IN CENTRAL TEXAS-NUMERICAL SIMULATIONS OF 2000 THROUGH 2050 WITHDRAWAL PROJECTIONS: UNIVERSITY OF
TEXAS, BUREAU OF ECONOMIC GEOLOGY REPORT OF INVESTIGATIONS NO. 256, 1999.

CHANGES IN GROUNDWATER CONDITIONS IN THE EDWARDS AND TRINITY AQUIFERS, 1987-1997, FOR PORTIONS OF BASTROP, BELL, BURNET, LEE, MILAM, TRAVIS, AND WILLIAMSON COUNTIES, TEXAS: TEXAS WATER DEVELOPMENT BOARD REPORT 350, 1999.

\section{LEON COUNTY}

UNDERGROUND WATERS OF THE COASTAL PLAIN OF TEXAS: USGS WATER-SUPPLY PAPER 190, 1907.

GEOLOGY AND UNDERGROUND WATERS OF THE SOUTHEASTERN PART OF THE TEXAS COASTAL PLAIN: USGS WATER-SUPPLY PAPER 335, 1914

RECORDS OF WELLS, DRILLERS' LOGS, AND WATER ANALYSES, AND MAP SHOWING LOCATION OF WELLS IN LEON COUNTY, TEXAS: TEXAS BOARD OF WATER ENGINEERS MISCELLANEOUS PUBLICATION 160, 1937.

GROUND-WATER RESOURCES IN THE VICINITY OF NORMANGEE, LEON COUNTY, TEXAS: USGS OPEN-FILE REPORT (UNNUMBERED), 1939.

PUBLIC WATER SUPPLIES IN EASTERN TEXAS, V. 2, HARRISON COUNTY THROUGH WOOD COUNTY: TEXAS BOARD OF WATER ENGINEERS MISCELLANEOUS PUBLICATION 214, V. 2, 1945

PUBLIC WATER SUPPLIES IN EASTERN TEXAS: USGS WATERSUPPLY PAPER 1047, 1948

RECONNAISSANCE INVESTIGATION OF THE GROUND-WATER RESOURCES OF THE TRINITY RIVER BASIN: TEXAS WATER COMMISSION BULLETIN 6309, 1963.

RECONNAISSANCE INVESTIGATION OF THE GROUND-WATER RESOURCES OF THE BRAZOS RIVER BASIN: TEXAS WATER COMMISSION BULLETIN 6310, 1963.

AVAILABILITY AND QUALITY OF GROUND WATER IN LEON COUNTY, TEXAS: TEXAS WATER COMMISSION BULLETIN 6513, 1965.

HYDROLOGIC SIGNIFICANCE OF THE LITHOFACIES OF THE SPARTA SAND IN ARKANSAS, LOUISIANA, MISSISSIPPI, AND TEXAS: USGS PROFESSIONAL PAPER 569-A, 1968.

COMPILATION OF RESULTS OF AQUIFER TESTS IN TEXAS: TEXAS WATER DEVELOPMENT BOARD REPORT 98, 1969.

HYDROLOGIC SIGNIFICANCE OF LITHOFACIES OF THE CANE RIVER FORMATION OR EQUIVALENTS OF ARKANSAS, LOUISIANA, MISSISSIPPI, AND TEXAS: USGS PROFESSIONAL PAPER 569-C, 1972.

HYDROLOGIC SIGNIFICANCE OF LITHOFACIES OF THE CARRIZO SAND OF ARKANSAS, LOUISIANA, AND TEXAS AND THE MERIDIAN SAND OF MISSISSIPPI: USGS PROFESSIONAL PAPER 569-D, 1975.

SUMMARY APPRAISALS OF THE NATION'S GROUND-WATER RESOURCES-TEXAS-GULF REGION: USGS PROFESSIONAL PAPER 813-F, 1976.

WATER-QUALITY DATA FOR AQUIFERS, STREAMS, AND LAKES IN THE VICINITY OF KEECHI, MOUNT SYLVAN, OAKWOOD, AND 
PALESTINE SALT DOMES, NORTHEAST TEXAS SALT-DOME BASIN: USGS OPEN-FILE REPORT 80-2037, 1980

GEOHYDROLOGY OF THE KEECHI, MOUNT SYLVAN, OAKWOOD, AND PALESTINE SALT DOMES IN THE NORTHEAST TEXAS SALTDOME BASIN: USGS OPEN-FILE REPORT 80-2044, 1980.

GEOLOGY AND GEOHYDROLOGY OF THE EAST TEXAS BASIN-A REPORT ON THE PROGRESS OF NUCLEAR WASTE ISOLATION FEASIBILITY STUDIES (1979): UNIVERSITY OF TEXAS, BUREAU OF ECONOMIC GEOLOGY GEOLOGICAL CIRCULAR 80-12, 1980.

GEOLOGY AND GEOHYDROLOGY OF THE EAST TEXAS BASIN-A REPORT ON THE PROGRESS OF NUCLEAR WASTE ISOLATION FEASIBILITY STUDIES (1980): UNIVERSITY OF TEXAS, BUREAU OF ECONOMIC GEOLOGY GEOLOGICAL CIRCULAR 81-7, 1981.

THREE-DIMENSIONAL GROUND-WATER MODELING IN DEPOSITIONAL SYSTEMS, WILCOX GROUP, OAKWOOD SALT DOME AREA, EAST TEXAS: UNIVERSITY OF TEXAS, BUREAU OF ECONOMIC GEOLOGY REPORT OF INVESTIGATIONS NO. 133, 1983.

TEXAS GROUND-WATER RESOURCES, in NATIONAL WATER SUMMARY 1984: USGS WATER-SUPPLY PAPER 2275, 1985.

APPROXIMATE POTENTIOMETRIC SURFACES FOR THE AQUIFERS OF THE COASTAL UPLANDS SYSTEM, 1980: USGS HYDROLOGIC INVESTIGATIONS ATLAS HA-704, 1987.

GEOHYDROLOGIC FRAMEWORK OF THE GULF COASTAL PLAIN: USGS HYDROLOGIC INVESTIGATIONS ATLAS HA-695, 1988.

HYDROGEOLOGY AND PREDEVELOPMENT FLOW IN THE TEXAS GULF COAST AQUIFER SYSTEMS: USGS WATER-RESOURCES INVESTIGATIONS REPORT 87-4248, 1988.

A DIGITAL MODEL OF THE CARRIZO-WILCOX AQUIFER WITHIN THE COLORADO RIVER BASIN OF TEXAS: TEXAS WATER DEVELOPMENT BOARD LIMITED PRINTING REPORT LP-208, 1989.

GROUND-WATER FLOW IN THE GULF COAST AQUIFER SYSTEMS, SOUTH-CENTRAL UNITED STATES-A PRELIMINARY ANALYSIS: USGS WATER-RESOURCES INVESTIGATIONS REPORT 89-4071, 1990.

NATIONAL WATER-QUALITY ASSESSMENT PROGRAM-THE TRINITY RIVER BASIN: USGS OPEN-FILE REPORT 91-158, 1991.

HYDROLOGY OF THE TEXAS GULF COAST AQUIFER SYSTEMS: USGS OPEN-FILE REPORT 91-64, 1991.

GROUND-WATER RESOURCES OF THE CARRIZO-WILCOX AQUIFER IN THE CENTRAL TEXAS REGION: TEXAS WATER DEVELOPMENT BOARD REPORT 332, 1991.

PROPERTIES AND CHEMICAL CONSTITUENTS IN GROUND WATER FROM THE LOWER CLAIBORNE-UPPER WILCOX AQUIFER, GULF COAST REGIONAL AQUIFER SYSTEMS, SOUTH-CENTRAL UNITED STATES: USGS WATER-RESOURCES INVESTIGATIONS REPORT 92-4102, 1993.

PROPERTIES AND CHEMICAL CONSTITUENTS IN GROUND WATER FROM THE MIDDLE CLAIBORNE AQUIFER, GULF COAST REGIONAL AQUIFER SYSTEMS, SOUTH-CENTRAL UNITED STATES: USGS WATER-RESOURCES INVESTIGATIONS REPORT 92-4104, 1993.

PROPERTIES AND CHEMICAL CONSTITUENTS IN GROUND WATER FROM THE MIDDLE WILCOX AQUIFER, GULF COAST AQUIFER SYSTEMS, SOUTH-CENTRAL UNITED STATES: USGS WATERRESOURCES INVESTIGATIONS REPORT 93-4070, 1993.
NATIONAL WATER-QUALITY ASSESSMENT PROGRAM-PESTICIDES IN THE TRINITY RIVER BASIN STUDY UNIT, TEXAS, 1968-91: USGS FACT SHEET FS-088-95, 1995.

WATER-QUALITY ASSESSMENT OF THE TRINITY RIVER BASIN, TEXAS-DATA COLLECTION, 1992-95: USGS FACT SHEET FS-095-95, 1995.

WATER-QUALITY ASSESSMENT OF THE TRINITY RIVER BASIN, TEXAS-PESTICIDES IN A SUBURBAN WATERSHED, ARLINGTON, 1993-94: USGS FACT SHEET FS-159-95, 1995.

STRATIGRAPHIC NOMENCLATURE AND GEOLOGIC SECTIONS OF THE GULF COASTAL PLAIN OF TEXAS: USGS OPEN-FILE REPORT 94-461, 1995.

AQUIFERS OF TEXAS: TEXAS WATER DEVELOPMENT BOARD REPORT 345, 1995.

WATER QUALITY IN THE SPARTA AQUIFER, EAST TEXAS: TEXAS WATER DEVELOPMENT BOARD HYDROLOGIC ATLAS NO. 5, 1996.

WATER QUALITY IN THE QUEEN CITY AQUIFER, EAST TEXAS: TEXAS WATER DEVELOPMENT BOARD HYDROLOGIC ATLAS NO. 6, 1996

\section{LIBERTY COUNTY}

ARTESIAN WELLS OF THE COASTAL PRAIRIE REGION AND TERTIARY BELT OF TEXAS: GEOLOGICAL SURVEY OF TEXAS, CHAPTER 2, 1893.

UNDERGROUND WATERS OF COASTAL PLAIN OF TEXAS: USGS WATER SUPPLY AND IRRIGATION PAPER 190, 1907.

GEOLOGY AND UNDERGROUND WATERS OF THE SOUTHEASTERN PART OF THE TEXAS COASTAL PLAIN: USGS WATER-SUPPLY PAPER 335, 1914.

GROUND-WATER RESOURCES OF LIBERTY COUNTY, TEXAS: TEXAS BOARD OF WATER ENGINEERS MISCELLANEOUS PUBLICATION 161, 1945

PUBLIC WATER SUPPLIES IN EASTERN TEXAS, V. 2, HARRISON COUNTY THROUGH WOOD COUNTY: TEXAS BOARD OF WATER ENGINEERS MISCELLANEOUS PUBLICATION 214, V. 2, 1945.

PUBLIC WATER SUPPLIES IN EASTERN TEXAS: USGS WATERSUPPLY PAPER 1047, 1948.

GROUND-WATER RESOURCES OF LIBERTY COUNTY, TEXAS: USGS WATER-SUPPLY PAPER 1079-A, 1950.

WATER SUPPLY OF THE HOUSTON GULF COAST REGION: TEXAS BOARD OF WATER ENGINEERS BULLETIN 5101, 1951.

AVAILABILITY OF GROUND WATER IN THE GULF COAST REGION OF TEXAS: USGS OPEN-FILE REPORT (UNNUMBERED), 1956.

RECORDS OF WATER-LEVEL MEASUREMENTS IN CHAMBERS, LIBERTY, AND MONTGOMERY COUNTIES, TEXAS, 1931 THROUGH APRIL 1958: TEXAS BOARD OF WATER ENGINEERS BULLETIN $5901,1959$.

RECONNAISSANCE INVESTIGATION OF THE GROUND-WATER RESOURCES OF THE GULF COAST REGION, TEXAS: TEXAS WATER COMMISSION BULLETIN 6305, 1963. 
ANALOG MODEL STUDY OF GROUND WATER IN THE HOUSTON DISTRICT, TEXAS: TEXAS WATER COMMISSION BULLETIN 6508, 1965.

DEVELOPMENT OF GROUND WATER IN THE HOUSTON DISTRICT, TEXAS, 1961-65: TEXAS WATER DEVELOPMENT BOARD REPORT 63, 1967

GROUND-WATER RESOURCES OF LIBERTY COUNTY, TEXAS: TEXAS WATER DEVELOPMENT BOARD REPORT 72, 1968.

LAND-SURFACE SUBSIDENCE IN THE HOUSTON-GALVESTON REGION, TEXAS: USGS OPEN-FILE REPORT 69-61, 1969.

COMPILATION OF RESULTS OF AQUIFER TESTS IN TEXAS: TEXAS WATER DEVELOPMENT BOARD REPORT 98, 1969.

DEVELOPMENT OF GROUND WATER IN THE HOUSTON DISTRICT, TEXAS, 1966-69: TEXAS WATER DEVELOPMENT BOARD REPORT $152,1972$.

GEOLOGIC AND HYDROLOGIC SUMMARY OF SALT DOMES IN GULF COAST REGION OF TEXAS, LOUISIANA, AND ALABAMA: USGS OPEN-FILE REPORT 73-07, 1973.

LAND-SURFACE SUBSIDENCE IN THE HOUSTON-GALVESTON REGION, TEXAS: USGS OPEN-FILE REPORT 74-123, 1974.

RECORDS OF WELLS, DRILLERS' LOGS, WATER-LEVEL MEASUREMENTS, AND CHEMICAL ANALYSES OF GROUND WATER IN CHAMBERS, LIBERTY, AND MONTGOMERY COUNTIES, TEXAS, 1966-74: TEXAS WATER DEVELOPMENT BOARD REPORT 202, 1976.

SUMMARY APPRAISALS OF THE NATION'S GROUND-WATER RESOURCES-TEXAS GULF REGION: USGS PROFESSIONAL PAPER 813-F, 1976.

APPROXIMATE AREAS OF RECHARGE TO THE CHICOT AND EVANGELINE AQUIFER SYSTEMS IN THE HOUSTON-GALVESTON AREA, TEXAS: USGS OPEN-FILE REPORT 77-754, 1977.

HYDROGEOLOGY OF GULF COAST AQUIFERS, HOUSTONGALVESTON AREA, TEXAS: UNIVERSITY OF TEXAS, BUREAU OF ECONOMIC GEOLOGY GEOLOGICAL CIRCULAR 77-4, 1977.

STRATIGRAPHIC AND HYDROGEOLOGIC FRAMEWORK OF PART OF THE COASTAL PLAIN OF TEXAS: USGS OPEN-FILE REPORT 77-712, 1978.

STRATIGRAPHIC AND HYDROGEOLOGIC FRAMEWORK OF PART OF THE COASTAL PLAIN OF TEXAS: TEXAS DEPARTMENT OF WATER RESOURCES REPORT 236, 1979.

APPROXIMATE ALTITUDE OF WATER LEVELS IN WELLS IN THE CHICOT AND EVANGELINE AQUIFERS IN THE HOUSTON AREA, TEXAS, SPRING 1977 AND SPRING 1978: USGS OPEN-FILE REPORT 79-334, 1979.

APPROXIMATE WATER-LEVEL CHANGES IN WELLS IN THE CHICOT AND EVANGELINE AQUIFERS IN THE HOUSTON-GALVESTON REGION, TEXAS, 1977-80 AND 1979-80: USGS OPEN-FILE REPORT 80-337, 1980

APPROXIMATE ALTITUDE OF WATER LEVELS IN WELLS IN THE CHICOT AND EVANGELINE AQUIFERS IN THE HOUSTON AREA, TEXAS, SPRING 1979 AND SPRING 1980: USGS OPEN-FILE REPORT 80-579, 1980.

APPROXIMATE LAND-SURFACE SUBSIDENCE IN THE HOUSTONGALVESTON REGION, TEXAS, 1906-78, 1943-78, AND 1973-78: USGS OPEN-FILE REPORT 80-338, 1980.
LAND-SURFACE SUBSIDENCE IN THE TEXAS COASTAL REGION: USGS OPEN-FILE REPORT 80-969, 1980.

DEVELOPMENT OF GROUND WATER IN THE HOUSTONGALVESTON DISTRICT, TEXAS, 1970-74: TEXAS DEPARTMENT OF WATER RESOURCES REPORT 241, 1980.

APPROXIMATE WATER-LEVEL CHANGES IN WELLS IN THE CHICOT AND EVANGELINE AQUIFERS, 1977-81 AND 1980-81, AND MEASURED COMPACTION, 1973-81, IN THE HOUSTON-GALVESTON REGION, TEXAS: USGS OPEN-FILE REPORT 81-341, 1981.

SPRINGS OF TEXAS, VOLUME 1: (BY GUNNAR BRUNE), BRANCHSMITH, INC., FORT WORTH, TEXAS, 1981.

APPROXIMATE ALTITUDE OF WATER LEVELS IN THE CHICOT AND EVANGELINE AQUIFERS IN THE HOUSTON AREA, TEXAS, SPRING 1981: USGS OPEN-FILE REPORT 81-676, 1981.

APPROXIMATE WATER-LEVEL CHANGES IN WELLS IN THE CHICOT AND EVANGELINE AQUIFERS, 1977-82 AND 1981-82, AND MEASURED COMPACTION, 1973-82, IN THE HOUSTON-GALVESTON REGION, TEXAS: USGS OPEN-FILE REPORT 82-328, 1982.

GROUND-WATER WITHDRAWALS AND CHANGES IN WATER LEVELS IN THE HOUSTON DISTRICT, 1975-79: USGS OPEN-FILE REPORT 82-431, 1982.

APPROXIMATE ALTITUDE OF WATER LEVELS IN WELLS IN THE CHICOT AND EVANGELINE AQUIFERS IN THE HOUSTON AREA, TEXAS, SPRING 1982: USGS OPEN-FILE REPORT 82-559, 1982.

LAND-SURFACE SUBSIDENCE IN THE TEXAS COASTAL REGION: TEXAS DEPARTMENT OF WATER RESOURCES REPORT 272, 1982.

APPROXIMATE WATER-LEVEL CHANGES IN WELLS IN THE CHICOT AND EVANGELINE AQUIFERS, 1977-83 AND 1982-83, AND MEASURED COMPACTION, 1973-83, IN THE HOUSTON-GALVESTON REGION, TEXAS: USGS OPEN-FILE REPORT 83-150, 1983.

RECORDS OF WELLS, DRILLERS' LOGS, WATER-LEVEL MEASUREMENTS, AND CHEMICAL ANALYSES OF GROUND WATER IN CHAMBERS, LIBERTY, AND MONTGOMERY COUNTIES, TEXAS, 1975-79: TEXAS DEPARTMENT OF WATER RESOURCES REPORT 280,1983 .

APPROXIMATE ALTITUDE OF WATER LEVELS IN WELLS IN THE CHICOT AND EVANGELINE AQUIFERS IN THE HOUSTON AREA, TEXAS, SPRING 1983: USGS OPEN-FILE REPORT 83-529, 1983.

APPROXIMATE WATER-LEVEL CHANGES IN WELLS IN THE CHICOT AND EVANGELINE AQUIFERS, 1977-84 AND 1983-84, AND MEASURED COMPACTION, 1973-84, IN THE HOUSTON-GALVESTON REGION, TEXAS: USGS OPEN-FILE REPORT 84-140, 1984.

APPROXIMATE ALTITUDE OF WATER LEVELS IN WELLS IN THE CHICOT AND EVANGELINE AQUIFERS IN THE HOUSTON AREA, TEXAS, SPRING, 1984: USGS OPEN-FILE REPORT 84-436, 1984.

TEXAS GROUND-WATER RESOURCES, in NATIONAL WATER SUMMARY 1984: USGS WATER-SUPPLY PAPER 2275, 1985.

DIGITAL MODELS FOR SIMULATION OF GROUND-WATER HYDROLOGY OF THE CHICOT AND EVANGELINE AQUIFERS ALONG THE GULF COAST OF TEXAS: TEXAS DEPARTMENT OF WATER RESOURCES REPORT 289, 1985.

WATER USE, PROJECTED WATER REQUIREMENTS, AND RELATED DATA AND INFORMATION FOR THE METROPOLITAN STATISTICAL AREAS IN TEXAS: TEXAS DEPARTMENT OF WATER RESOURCES LIMITED PRINTING REPORT LP-201, 1985. 
APPROXIMATE WATER-LEVEL CHANGES IN WELLS IN THE CHICOT AND EVANGELINE AQUIFERS, 1977-85 AND 1984-85, AND MEASURED COMPACTION, 1973-85, IN THE HOUSTON-GALVESTON REGION, TEXAS: USGS OPEN-FILE REPORT 85-158, 1985.

APPROXIMATE CHANGES IN WATER LEVELS IN THE CHICOT AND EVANGELINE AQUIFERS, 1977-86 AND 1985-86, AND MEASURED COMPACTION, 1973-86, IN THE HOUSTON-GALVESTON REGION, TEXAS: USGS OPEN-FILE REPORT 86-135, 1986.

APPROXIMATE ALTITUDE OF WATER LEVELS IN WELLS IN THE CHICOT AND EVANGELINE AQUIFERS IN THE HOUSTON AREA, TEXAS, SPRING 1986: USGS OPEN-FILE REPORT 86-306, 1986.

HYDROLOGY OF THE JASPER AQUIFER IN THE SOUTHEAST TEXAS COASTAL PLAIN: TEXAS WATER DEVELOPMENT BOARD REPORT 295, 1986.

RECORDS OF WELLS, DRILLERS' LOGS, WATER-LEVEL MEASUREMENTS, AND CHEMICAL ANALYSES OF GROUND WATER IN CHAMBERS, LIBERTY, AND MONTGOMERY COUNTIES, TEXAS, 1980-84: USGS OPEN-FILE REPORT 86-57, 1986.

RECORDS OF WELLS, DRILLERS' LOGS, WATER-LEVEL MEASUREMENTS, AND CHEMICAL ANALYSES OF GROUND WATER IN CHAMBERS, LIBERTY, AND MONTGOMERY COUNTIES, TEXAS, 1980-84: TEXAS WATER DEVELOPMENT BOARD REPORT 304, 1987.

APPROXIMATE WATER-LEVEL CHANGES IN WELLS COMPLETED IN THE CHICOT AND EVANGELINE AQUIFERS, 1977-87 AND 1986-87, AND MEASURED COMPACTION, 1973-87, IN THE HOUSTONGALVESTON REGION, TEXAS: USGS OPEN-FILE REPORT 87-108, 1987.

APPROXIMATE ALTITUDE OF WATER-LEVELS IN WELLS IN THE CHICOT AND EVANGELINE AQUIFERS IN THE HOUSTON AREA, TEXAS, SPRING 1987: USGS OPEN-FILE REPORT 87-233, 1987.

HYDROGEOLOGY AND PREDEVELOPMENT FLOW IN THE TEXAS GULF COAST AQUIFER SYSTEMS: USGS WATER-RESOURCES INVESTIGATIONS REPORT 87-4248, 1988.

GEOHYDROLOGIC FRAMEWORK OF THE GULF COASTAL PLAIN: USGS HYDROLOGIC INVESTIGATIONS ATLAS HA-695, 1988.

APPROXIMATE WATER-LEVEL CHANGES IN WELLS COMPLETED IN THE CHICOT AND EVANGELINE AQUIFERS, 1977-88 AND 1987-88, AND MEASURED COMPACTION, 1973-88, IN THE HOUSTONGALVESTON REGION, TEXAS: USGS OPEN-FILE REPORT 88-168, 1988.

APPROXIMATE ALTITUDE OF WATER LEVELS IN WELLS IN THE CHICOT AND EVANGELINE AQUIFERS IN THE HOUSTON AREA, TEXAS, SPRING 1988: USGS OPEN-FILE REPORT 88-334, 1988.

HYDROGEOLOGY OF BARBERS HILL SALT DOME, TEXAS COASTAL PLAIN: UNIVERSITY OF TEXAS, BUREAU OF ECONOMIC GEOLOGY REPORT OF INVESTIGATIONS NO. 176, 1988.

APPROXIMATE ALTITUDE OF WATER LEVELS IN WELLS IN THE CHICOT AND EVANGELINE AQUIFERS IN THE HOUSTON AREA, TEXAS, SPRING 1989: USGS OPEN-FILE REPORT 89-237, 1989.

APPROXIMATE WATER-LEVEL CHANGE IN WELLS COMPLETED IN THE CHICOT AND EVANGELINE AQUIFERS, 1977-89 AND 1988-89, AND MEASURED COMPACTION, 1973-89, IN THE HOUSTONGALVESTON REGION, TEXAS: USGS OPEN-FILE REPORT 89-057, 1989.
APPROXIMATE WATER-LEVEL CHANGES IN WELLS COMPLETED IN THE CHICOT AND EVANGELINE AQUIFERS, 1977-90 AND 1989-90, AND MEASURED COMPACTION, 1973-DECEMBER 1989, IN THE HOUSTON-GALVESTON REGION, TEXAS: USGS OPEN-FILE REPORT 90-132, 1990.

GROUND-WATER FLOW IN THE GULF COAST AQUIFER SYSTEMS, SOUTH-CENTRAL UNITED STATES-A PRELIMINARY ANALYSIS USGS WATER-RESOURCES INVESTIGATIONS REPORT 89-4071, 1990.

SALT-DOME LOCATIONS IN THE GULF COASTAL PLAIN, SOUTHCENTRAL UNITED STATES: USGS WATER-RESOURCES INVESTIGATIONS REPORT 90-4060, 1990.

NATIONAL WATER-QUALITY ASSESSMENT PROGRAM-THE TRINITY RIVER BASIN: USGS OPEN-FILE REPORT 91-158, 1991.

HYDROLOGY OF THE TEXAS GULF COAST AQUIFER SYSTEMS: USGS OPEN-FILE REPORT 91-64, 1991.

RECORDS OF WELLS, DRILLERS' LOGS, WATER-WELL MEASUREMENTS, AND CHEMICAL ANALYSES OF GROUND WATER IN CHAMBERS, LIBERTY, AND MONTGOMERY COUNTIES, TEXAS, 1985-89: USGS OPEN-FILE REPORT 90-594, 1991.

APPROXIMATE WATER-LEVEL CHANGES IN WELLS COMPLETED IN THE CHICOT AND EVANGELINE AQUIFERS, 1977-91 AND 1990-91, AND MEASURED COMPACTION, 1973-90, IN THE HOUSTONGALVESTON REGION, TEXAS: USGS OPEN-FILE REPORT 91-094, 1991.

APPROXIMATE ALTITUDE OF WATER LEVELS IN WELLS IN THE CHICOT AND EVANGELINE AQUIFERS IN THE HOUSTON AREA, TEXAS, JANUARY-FEBRUARY 1990: USGS OPEN-FILE REPORT 91-240, 1991

APPROXIMATE CHANGE IN WATER LEVELS IN WELLS COMPLETED IN THE CHICOT AND EVANGELINE AQUIFERS, 1977-92 AND 1991-92, AND MEASURED COMPACTION, 1973-91, IN THE HOUSTON-GALVESTON REGION, TEXAS: USGS OPEN-FILE REPORT 92-066, 1992.

PROPERTIES AND CHEMICAL CONSTITUENTS IN GROUND WATER FROM THE MISSISSIPPI RIVER VALLEY ALLUVIAL AQUIFER AND PERMEABLE ZONE A (HOLOCENE-UPPER PLEISTOCENE DEPOSITS), SOUTH-CENTRAL UNITED STATES: USGS WATERRESOURCES INVESTIGATIONS REPORT 91-4149, 1992.

WATER-RESOURCES DATA, TEXAS, WATER YEAR 1991, VOLUME 4 GROUND-WATER DATA: USGS WATER-DATA REPORT TX-91-4, 1992.

PROPERTIES AND CHEMICAL CONSTITUENTS IN GROUND WATER FROM THE UPPER CLAIBORNE AQUIFER, GULF COAST REGIONAL AQUIFER SYSTEMS, SOUTH-CENTRAL UNITED STATES: USGS WATER-RESOURCES INVESTIGATIONS REPORT 91-4150, 1993.

PROPERTIES AND CHEMICAL CONSTITUENTS IN GROUND WATER FROM PERMEABLE ZONE C (LOWER PLIOCENE-UPPER MIOCENE DEPOSITS), COASTAL LOWLANDS AQUIFER SYSTEM, SOUTHCENTRAL UNITED STATES: USGS WATER-RESOURCES INVESTIGATIONS REPORT 91-4151, 1993.

PROPERTIES AND CHEMICAL CONSTITUENTS IN GROUND WATER FROM PERMEABLE ZONE B (LOWER PLEISTOCENE-UPPER PLIOCENE DEPOSITS), COASTAL LOWLANDS AQUIFER SYSTEM, SOUTH-CENTRAL UNITED STATES: USGS WATER-RESOURCES INVESTIGATIONS REPORT 91-4152, 1993. 
PROPERTIES AND CHEMICAL CONSTITUENTS IN GROUND WATER FROM PERMEABLE ZONE E (LOWER MIOCENE-UPPER OLIGOCENE DEPOSITS), COASTAL LOWLANDS AQUIFER SYSTEM, SOUTH-CENTRAL UNITED STATES: USGS WATER-RESOURCES INVESTIGATIONS REPORT 92-4103, 1993.

PROPERTIES AND CHEMICAL CONSTITUENTS IN GROUND WATER FROM PERMEABLE ZONE D (MIDDLE MIOCENE DEPOSITS), COASTAL LOWLANDS AQUIFER SYSTEM, SOUTH-CENTRAL UNITED STATES: USGS WATER-RESOURCES INVESTIGATIONS REPORT 92-4105, 1993.

GROUND-WATER WITHDRAWALS, WATER LEVELS, AND GROUNDWATER QUALITY IN THE HOUSTON DISTRICT, TEXAS, WITH EMPHASIS ON 1985-89: USGS WATER-RESOURCES INVESTIGATIONS REPORT 92-4180, 1993.

PROPERTIES AND CHEMICAL CONSTITUENTS IN GROUND WATER FROM THE MIDDLE WILCOX AQUIFER, GULF COAST REGIONAL AQUIFER SYSTEMS, SOUTH-CENTRAL UNITED STATES: USGS WATER-RESOURCES INVESTIGATIONS REPORT 93-4070, 1993.

APPROXIMATE ALTITUDE OF WATER LEVELS IN WELLS COMPLETED IN THE CHICOT AND EVANGELINE AQUIFERS IN THE HOUSTON AREA, TEXAS, JANUARY-FEBRUARY 1991: USGS OPEN-FILE REPORT 93-075, 1993.

APPROXIMATE CHANGE IN WATER LEVELS IN WELLS COMPLETED IN THE CHICOT AND EVANGELINE AQUIFERS, 1977-93 AND 1992-93, AND MEASURED COMPACTION, 1973-92, IN THE HOUSTON-GALVESTON REGION, TEXAS: USGS OPEN-FILE REPORT 93-086, 1993.

WATER-RESOURCES DATA, TEXAS, WATER YEAR 1992, VOLUME 4, GROUND-WATER DATA: USGS WATER-DATA REPORT TX-92-4, 1993.

APPROXIMATE CHANGE IN WATER LEVELS IN WELLS COMPLETED IN THE CHICOT AND EVANGELINE AQUIFERS, 1977-94 AND 1993-94, AND MEASURED COMPACTION, 1973-93, IN THE HOUSTON-GALVESTON REGION, TEXAS: USGS OPEN-FILE REPORT 94-346, 1994.

WATER-RESOURCES DATA, TEXAS, WATER YEAR 1993, VOLUME 4 , GROUND-WATER DATA: USGS WATER-DATA REPORT TX-93-4, 1994.

WATER-LEVEL ALTITUDES 1995, WATER-LEVEL CHANGES 1977-95 AND 1994-95, AND COMPACTION 1973-94 IN THE CHICOT AND EVANGELINE AQUIFERS, HOUSTON-GALVESTON REGION, TEXAS: USGS OPEN-FILE REPORT 95-182, 1995.

NATIONAL WATER-QUALITY ASSESSMENT PROGRAM-PESTICIDES IN THE TRINITY RIVER BASIN STUDY UNIT, TEXAS, 1968-91: USGS FACT SHEET FS-088-95, 1995.

WATER-QUALITY ASSESSMENT OF THE TRINITY RIVER BASIN, TEXAS-DATA COLLECTION, 1992-95: USGS FACT SHEET FS-095-95, 1995.

WATER-QUALITY ASSESSMENT OF THE TRINITY RIVER BASIN, TEXAS-PESTICIDES IN A SUBURBAN WATERSHED, ARLINGTON, 1993-94: USGS FACT SHEET FS-159-95, 1995.

AQUIFERS OF TEXAS: TEXAS WATER DEVELOPMENT BOARD REPORT 345, 1995.

WATER-RESOURCES DATA, TEXAS, WATER YEAR 1994, VOLUME 4, GROUND-WATER DATA: USGS WATER-DATA REPORT TX-94-4, 1995.
WATER-LEVEL ALTITUDES 1996, WATER-LEVEL CHANGES 1977-96 AND 1995-96, AND COMPACTION 1973-95 IN THE CHICOT AND EVANGELINE AQUIFERS, HOUSTON-GALVESTON REGION, TEXAS: USGS OPEN-FILE REPORT 96-163, 1996.

WATER-RESOURCES DATA, TEXAS, WATER YEAR 1995, VOLUME 4, GROUND-WATER DATA: USGS WATER-DATA REPORT TX-95-4, 1996.

WATER-LEVEL ALTITUDES 1997, WATER-LEVEL CHANGES 1977-97 AND 1996-97, AND COMPACTION 1973-96 IN THE CHICOT AND EVANGELINE AQUIFERS, HOUSTON-GALVESTON REGION, TEXAS: USGS OPEN-FILE REPORT 97-181, 1997.

WATER-LEVEL ALTITUDES IN WELLS COMPLETED IN THE CHICOT AND EVANGELINE AQUIFERS, HOUSTON-GALVESTON REGION, TEXAS, JANUARY-FEBRUARY 1992, 1993, AND 1994: USGS OPENFILE REPORT 97-786, 1997.

WATER-RESOURCES DATA, TEXAS, WATER YEAR 1996, VOLUME 4, GROUND-WATER DATA: USGS WATER-DATA REPORT TX-96-4, 1997.

WATER-LEVEL ALTITUDES 1998, WATER-LEVEL CHANGES 1977-98 AND 1997-98, AND COMPACTION IN THE CHICOT AND EVANGELINE AQUIFERS, HOUSTON-GALVESTON REGION, TEXAS: USGS OPEN-FILE REPORT 98-096, 1998.

WATER-RESOURCES DATA, TEXAS, WATER YEAR 1997, VOLUME 4, GROUND-WATER DATA: USGS WATER-DATA REPORT TX-97-4, 1998.

WATER-LEVEL ALTITUDES 1999, WATER-LEVEL CHANGES 1977-99 AND 1998-99, AND COMPACTION 1973-98 IN THE CHICOT AND EVANGELINE AQUIFERS, HOUSTON-GALVESTON REGION, TEXAS: USGS OPEN-FILE REPORT 99-178, 1999.

WATER-RESOURCES DATA, TEXAS, WATER YEAR 1998, VOLUME 4, GROUND-WATER DATA: USGS WATER-DATA REPORT TX-98-4, 1999.

WATER-LEVEL ALTITUDES 2000, WATER-LEVEL CHANGES 1977-2000 AND 1999-2000, AND COMPACTION 1973-99 IN THE CHICOT AND EVANGELINE AQUIFERS, HOUSTON-GALVESTON REGION, TEXAS: USGS OPEN-FILE REPORT 00-094, 2000.

WATER-QUALITY ASSESSMENT OF THE TRINITY RIVER BASIN, TEXAS-GROUND-WATER QUALITY OF THE TRINITY, CARRIZOWILCOX, AND GULF COAST AQUIFERS, FEBRUARY-AUGUST 1994: USGS WATER-RESOURCES INVESTIGATIONS REPORT 99-4233, 2000.

WATER-RESOURCES DATA, TEXAS, WATER YEAR 1999, VOLUME 6, GROUND-WATER DATA: USGS WATER-DATA REPORT TX-99-6, 2000.

WATER-RESOURCES DATA, TEXAS, WATER YEAR 2000, VOLUME 6, GROUND-WATER DATA: USGS WATER-DATA REPORT TX-00-6, 2001.

\section{LIMESTONE COUNTY}

UNDERGROUND WATERS OF COASTAL PLAIN OF TEXAS: USGS WATER SUPPLY AND IRRIGATION PAPER 190, 1907.

GEOLOGY AND UNDERGROUND WATERS OF THE SOUTHEASTERN PART OF THE TEXAS COASTAL PLAIN: USGS WATER-SUPPLY PAPER 335, 1914. 
MEMORANDUM REGARDING REPORTED SHORTAGE OF WATER AT GROESBECK, TEXAS: USGS OPEN-FILE REPORT (UNNUMBERED), 1943.

MEMORANDUM ON GROUND-WATER SUPPLIES IN THE VICINITY OF THORNTON, TEXAS: USGS OPEN-FILE REPORT (UNNUMBERED), 1943.

PUBLIC WATER SUPPLIES IN EASTERN TEXAS, V. 2, HARRISON COUNTY THROUGH WOOD COUNTY: TEXAS BOARD OF WATER ENGINEERS MISCELLANEOUS PUBLICATION 214, V. 2, 1945.

PUBLIC WATER SUPPLIES IN EASTERN TEXAS: USGS WATERSUPPLY PAPER 1047, 1948.

RECONNAISSANCE SURVEY OF SALT-WATER DISPOSAL IN THE MEXIA, NEGRO CREEK, AND CEDAR CREEK OIL FIELDS, LIMESTONE COUNTY, TEXAS: TEXAS WATER COMMISSION MEMORANDUM REPORT 62-02, 1962.

RECONNAISSANCE INVESTIGATION OF THE GROUND-WATER RESOURCES OF THE TRINITY RIVER BASIN: TEXAS WATER COMMISSION BULLETIN 6309, 1963.

RECONNAISSANCE INVESTIGATION OF THE GROUND-WATER RESOURCES OF THE BRAZOS RIVER BASIN: TEXAS WATER COMMISSION BULLETIN 6310, 1963.

MAJOR AND HISTORICAL SPRINGS OF TEXAS: TEXAS WATER DEVELOPMENT BOARD REPORT 189, 1975.

GROUND-WATER RESOURCES OF PART OF CENTRAL TEXAS WITH EMPHASIS ON THE ANTLERS AND TRAVIS PEAK FORMATIONS: TEXAS WATER DEVELOPMENT BOARD REPORT 195, V. 1, 1975.

GROUND-WATER RESOURCES OF PART OF CENTRAL TEXAS WITH EMPHASIS ON THE ANTLERS AND TRAVIS PEAK FORMATIONS: TEXAS WATER DEVELOPMENT BOARD REPORT 195, V. 2, 1976.

SUMMARY APPRAISALS OF THE NATION'S GROUND-WATER RESOURCES-TEXAS-GULF REGION: USGS PROFESSIONAL PAPER 813-F, 1976.

WATER-QUALITY DATA FOR AQUIFERS, STREAMS, AND LAKES IN THE VICINITY OF KEECHI, MOUNT SYLVAN, OAKWOOD, AND PALESTINE SALT DOMES, NORTHEAST TEXAS SALT-DOME BASIN: USGS OPEN-FILE REPORT 80-2037, 1980

GEOHYDROLOGY OF THE KEECHI, MOUNT SYLVAN, OAKWOOD, AND PALESTINE SALT DOMES IN THE NORTHEAST TEXAS SALTDOME BASIN: USGS OPEN-FILE REPORT 80-2044, 1980.

GEOLOGY AND GEOHYDROLOGY OF THE EAST TEXAS BASIN-A REPORT ON THE PROGRESS OF NUCLEAR WASTE ISOLATION FEASIBILITY STUDIES (1979): UNIVERSITY OF TEXAS, BUREAU OF ECONOMIC GEOLOGY GEOLOGICAL CIRCULAR 80-12, 1980.

GEOLOGY AND GEOHYDROLOGY OF THE EAST TEXAS BASIN-A REPORT ON THE PROGRESS OF NUCLEAR WASTE ISOLATION FEASIBILITY STUDIES (1980): UNIVERSITY OF TEXAS, BUREAU OF ECONOMIC GEOLOGY GEOLOGICAL CIRCULAR 81-7, 1981.

GROUND-WATER RESOURCES OF LIMESTONE COUNTY, TEXAS: USGS OPEN-FILE REPORT 84-713, 1984.

TEXAS GROUND-WATER RESOURCES, in NATIONAL WATER SUMMARY 1984: USGS WATER-SUPPLY PAPER 2275, 1985.

GROUND-WATER RESOURCES OF LIMESTONE COUNTY, TEXAS: TEXAS WATER DEVELOPMENT BOARD REPORT 299, 1987.
APPROXIMATE POTENTIOMETRIC SURFACES FOR THE AQUIFERS OF THE COASTAL UPLANDS SYSTEM, 1980: USGS HYDROLOGIC INVESTIGATIONS ATLAS HA-704, 1987.

GEOHYDROLOGIC FRAMEWORK OF THE GULF COASTAL PLAIN: USGS HYDROLOGIC INVESTIGATIONS ATLAS HA-695, 1988.

HYDROGEOLOGY AND PREDEVELOPMENT FLOW IN THE TEXAS GULF COAST AQUIFER SYSTEMS: USGS WATER-RESOURCES INVESTIGATIONS REPORT 87-4248, 1988.

GROUND-WATER FLOW IN THE GULF COAST AQUIFER SYSTEMS, SOUTH-CENTRAL UNITED STATES-A PRELIMINARY ANALYSIS USGS WATER-RESOURCES INVESTIGATIONS REPORT 89-4071, 1990.

NATIONAL WATER-QUALITY ASSESSMENT PROGRAM-THE TRINITY RIVER BASIN: USGS OPEN-FILE REPORT 91-158, 1991.

GROUND-WATER RESOURCES OF THE CARRIZO-WILCOX AQUIFER IN THE CENTRAL TEXAS REGION: TEXAS WATER DEVELOPMENT BOARD REPORT 332, 1991.

PROPERTIES AND CHEMICAL CONSTITUENTS IN GROUND WATER FROM THE MIDDLE WILCOX AQUIFER, GULF COAST REGIONAL AQUIFER SYSTEMS, SOUTH-CENTRAL UNITED STATES: USGS WATER-RESOURCES INVESTIGATIONS REPORT 93-4070, 1993.

NATIONAL WATER-QUALITY ASSESSMENT PROGRAM-PESTICIDES IN THE TRINITY RIVER BASIN STUDY UNIT, TEXAS, 1968-91: USGS FACT SHEET FS-088-95, 1995.

WATER-QUALITY ASSESSMENT OF THE TRINITY RIVER BASIN, TEXAS-DATA COLLECTION, 1992-95: USGS FACT SHEET FS-095-95, 1995.

WATER-QUALITY ASSESSMENT OF THE TRINITY RIVER BASIN, TEXAS-PESTICIDES IN A SUBURBAN WATERSHED, ARLINGTON, 1993-94: USGS FACT SHEET FS-159-95, 1995.

AQUIFERS OF TEXAS: TEXAS WATER DEVELOPMENT BOARD REPORT 345, 1995.

\section{LIPSCOMB COUNTY}

THE GEOLOGY AND WATER RESOURCES OF THE EASTERN PORTION OF THE PANHANDLE OF TEXAS: USGS WATER-SUPPLY PAPER 154, 1906.

GEOLOGY AND GROUND-WATER RESOURCES OF THE SOUTHERN HIGH PLAINS: USGS OPEN-FILE REPORT (UNNUMBERED), 1935.

GROUND WATER IN THE HIGH PLAINS OF TEXAS: USGS WATERSUPPLY PAPER 889-F, 1946.

GROUND WATER IN HIGH PLAINS OF TEXAS, PROGRESS REPORT NO. 6: TEXAS BOARD OF WATER ENGINEERS MISCELLANEOUS PUBLICATION 123, 1947.

PUBLIC WATER SUPPLIES IN WESTERN TEXAS: TEXAS BOARD OF WATER ENGINEERS MISCELLANEOUS PUBLICATION 216, 1949.

COST OF PUMPING WATER FOR IRRIGATION, TEXAS HIGH PLAINS, FIELD INVESTIGATIONS-1947 IRRIGATION SEASON: TEXAS BOARD OF WATER ENGINEERS MISCELLANEOUS PUBLICATION 124,1951

PUBLIC WATER SUPPLIES IN WESTERN TEXAS: USGS WATERSUPPLY PAPER 1106, 1951 [1952]. 
DEVELOPMENT OF WELLS FOR IRRIGATION AND FLUCTUATION OF WATER LEVELS IN THE HIGH PLAINS OF TEXAS TO JANUARY 1951: TEXAS BOARD OF WATER ENGINEERS BULLETIN 5104, 1951.

WATER-LEVEL MEASUREMENTS AND MAPS, NORTHERN HIGH PLAINS, TEXAS, 1958 AND 1959: TEXAS BOARD OF WATER ENGINEERS BULLETIN 5909, 1959.

WATER LEVELS IN OBSERVATION WELLS, NORTHERN HIGH PLAINS, TEXAS, 1958-1960: TEXAS BOARD OF WATER ENGINEERS BULLETIN 6012, 1960.

RECONNAISSANCE INVESTIGATION OF THE GROUND-WATER RESOURCES OF THE CANADIAN RIVER BASIN, TEXAS: TEXAS BOARD OF WATER ENGINEERS BULLETIN 6016, 1960.

ANNUAL WATER-LEVEL MEASUREMENTS IN OBSERVATION WELLS, NORTHERN HIGH PLAINS, TEXAS, 1960 AND 1961: TEXAS BOARD OF WATER ENGINEERS BULLETIN 6103, 1961.

GEOLOGY AND GROUND-WATER RESOURCES OF THE NORTHERN HIGH PLAINS OF TEXAS, PROGRESS REPORT NO. 1: TEXAS BOARD OF WATER ENGINEERS BULLETIN 6109, 1961.

ANNUAL WATER-LEVEL MEASUREMENTS IN OBSERVATION WELLS, NORTHERN HIGH PLAINS, TEXAS, 1961 AND 1962: TEXAS WATER COMMISSION BULLETIN 6213, 1962.

WATER-LEVEL DATA FROM OBSERVATION WELLS IN THE NORTHERN PANHANDLE OF TEXAS: TEXAS WATER DEVELOPMENT BOARD REPORT 137, 1971.

PRELIMINARY DATA DESCRIBING THE DISTRIBUTION OF FLUORIDE AND SILICA IN THE OGALLALA AQUIFER ON THE HIGH PLAINS OF TEXAS: USGS OPEN-FILE REPORT 80-349, 1980.

WATER-LEVEL DATA FROM OBSERVATION WELLS IN THE NORTHERN PANHANDLE OF TEXAS, 1972-78: TEXAS DEPARTMENT OF WATER RESOURCES REPORT 248, 1980.

WATER TABLE IN THE HIGH PLAINS AQUIFER IN 1978 IN PARTS OF COLORADO, KANSAS, NEBRASKA, NEW MEXICO, OKLAHOMA, SOUTH DAKOTA, TEXAS, AND WYOMING: USGS HYDROLOGIC INVESTIGATIONS ATLAS HA-642, 1980.

EVALUATING THE GROUND-WATER RESOURCES OF THE HIGH PLAINS OF TEXAS: RESULTS OF TEST HOLE DRILLING: TEXAS DEPARTMENT OF WATER RESOURCES LIMITED PRINTING REPORT LP-129, 1980.

EVALUATING THE GROUND-WATER RESOURCES OF THE HIGH PLAINS OF TEXAS: RESULTS OF SURFACE ELECTRICAL RESISTIVITY: TEXAS DEPARTMENT OF WATER RESOURCES LIMITED PRINTING REPORT LP-130, 1980.

EVALUATING THE GROUND-WATER RESOURCES OF THE HIGH PLAINS OF TEXAS: NEUTRON-PROBE MEASUREMENTS OF DEEP SOIL MOISTURE AS AN INDICATION OF AQUIFER RECHARGE: TEXAS DEPARTMENT OF WATER RESOURCES LIMITED PRINTING REPORT LP-142, 1981.

SPRINGS OF TEXAS, VOLUME 1: (BY GUNNAR BRUNE), BRANCHSMITH, INC., FORT WORTH, TEXAS, 1981.

BEDROCK GEOLOGY, ALTITUDE OF BASE, AND 1980 SATURATED THICKNESS OF THE HIGH PLAINS AQUIFER IN PARTS OF COLORADO, KANSAS, NEBRASKA, NEW MEXICO, OKLAHOMA, SOUTH DAKOTA, TEXAS, AND WYOMING: USGS HYDROLOGIC INVESTIGATIONS ATLAS HA-648, 1981.
WATER-LEVEL AND SATURATED-THICKNESS CHANGES, PREDEVELOPMENT TO 1980, IN THE HIGH PLAINS AQUIFER IN PARTS OF COLORADO, KANSAS, NEBRASKA, NEW MEXICO, OKLAHOMA, SOUTH DAKOTA, TEXAS, AND WYOMING: USGS HYDROLOGIC INVESTIGATIONS ATLAS HA-652, 1981.

ANALYTICAL STUDY OF THE OGALLALA AQUIFER IN LIPSCOMB COUNTY, TEXAS-PROJECTIONS OF SATURATED THICKNESS, VOLUME OF WATER IN STORAGE, PUMPAGE RATES, PUMPING LIFTS, AND WELL YIELDS: TEXAS DEPARTMENT OF WATER RESOURCES REPORT 262, 1981.

DISSOLVED SOLIDS AND SODIUM IN WATER FROM THE HIGH PLAINS AQUIFER IN PARTS OF COLORADO, KANSAS, NEBRASKA, NEW MEXICO, OKLAHOMA, SOUTH DAKOTA, TEXAS, AND WYOMING: USGS HYDROLOGIC INVESTIGATIONS ATLAS HA-658, 1982.

GEOHYDROLOGY OF THE HIGH PLAINS AQUIFER IN PARTS OF COLORADO, KANSAS, NEBRASKA, NEW MEXICO, OKLAHOMA, SOUTH DAKOTA, TEXAS, AND WYOMING: USGS PROFESSIONAL PAPER 1400-B, 1984.

EVALUATING THE GROUND-WATER RESOURCES OF THE HIGH PLAINS OF TEXAS, VOLUME 1: TEXAS DEPARTMENT OF WATER RESOURCES REPORT 288, V. 1, 1984.

EVALUATING THE GROUND-WATER RESOURCES OF THE HIGH PLAINS OF TEXAS, VOLUME 2, RECORDS OF WELLS, AND MAPS SHOWING WELL LOCATIONS, BASE OF AQUIFER, WATER LEVELS, AND SATURATED THICKNESS (ARMSTRONG, CARSON, DALLAS, DONLEY, GRAY, HANSFORD, HARTLEY, HEMPHILL, HUTCHINSON, LIPSCOMB, MOORE, OCHILTREE, POTTER, ROBERTS, SHERMAN, AND WHEELER COUNTIES): TEXAS DEPARTMENT OF WATER RESOURCES REPORT 288, V. 2, 1984.

TEXAS GROUND-WATER RESOURCES, in NATIONAL WATER SUMMARY 1984: USGS WATER-SUPPLY PAPER 2275, 1985.

DIGITAL SIMULATION OF GROUND-WATER FLOW IN THE HIGH PLAINS AQUIFER IN PARTS OF COLORADO, KANSAS, NEBRASKA, NEW MEXICO, OKLAHOMA, SOUTH DAKOTA, TEXAS, AND WYOMING: USGS PROFESSIONAL PAPER 1400-D, 1986.

SUMMARY OF THE HIGH PLAINS REGIONAL AQUIFER-SYSTEM ANALYSIS IN PARTS OF COLORADO, KANSAS, NEBRASKA, NEW MEXICO, OKLAHOMA, SOUTH DAKOTA, TEXAS, AND WYOMING: USGS PROFESSIONAL PAPER 1400-A, 1988.

WATER-LEVEL CHANGES IN THE HIGH PLAINS AQUIFER OF TEXAS, 1980-1990: TEXAS WATER DEVELOPMENT BOARD HYDROLOGIC ATLAS NO. 1, 1991.

PUBLIC-SUPPLY GROUND-WATER USE IN THE NORTHERN HIGH PLAINS OF TEXAS: TEXAS WATER DEVELOPMENT BOARD REPORT 336, 1992.

THE HIGH PLAINS AQUIFER SYSTEM OF TEXAS, 1980 TO 1990. OVERVIEW AND PROJECTIONS: TEXAS WATER DEVELOPMENT BOARD REPORT 341, 1993.

WATER-QUALITY EVALUATION OF THE OGALLALA AQUIFER, TEXAS: TEXAS WATER DEVELOPMENT BOARD REPORT 342 , 1993.

WATER-LEVEL CHANGES IN THE HIGH PLAINS AQUIFER-PREDEVELOPMENT TO 1992: USGS WATER-RESOURCES INVESTIGATIONS REPORT 94-4027, 1994. 
WATER-LEVEL CHANGES IN THE HIGH PLAINS AQUIFER, 1980 TO 1994: USGS FACT SHEET FS-215-95, 1995.

AQUIFERS OF TEXAS: TEXAS WATER DEVELOPMENT BOARD REPORT 345, 1995.

WATER-LEVEL CHANGES IN THE HIGH PLAINS AQUIFER, 1980 TO 1995: USGS FACT SHEET FS-068-97, 1997.

WATER-LEVEL CHANGES IN THE HIGH PLAINS AQUIFER-PREDEVELOPMENT TO 1995: USGS WATER-RESOURCES INVESTIGATIONS REPORT 97-4081, 1997.

UPDATED WATER-QUALITY EVALUATION OF THE OGALLALA AQUIFER INCLUDING SELECTED METALLIC AND NON-METALLIC INORGANIC CONSTITUENTS: TEXAS WATER DEVELOPMENT BOARD HYDROLOGIC ATLAS NO. 10, 1998.

\section{UVE OAK COUNTY}

UNDERGROUND WATERS OF THE COASTAL PLAIN OF TEXAS: USGS WATER-SUPPLY PAPER 190, 1907.

LIVE OAK COUNTY: USGS OPEN-FILE REPORT (UNNUMBERED), 1928.

RECORDS OF WELLS IN LIVE OAK COUNTY, TEXAS: USGS OPENFILE REPORT (UNNUMBERED), 1935.

RECORDS OF WELLS, DRILLERS' LOGS, WATER ANALYSES, AND MAP SHOWING LOCATION OF WELLS IN LIVE OAK COUNTY, TEXAS: TEXAS BOARD OF WATER ENGINEERS MISCELLANEOUS PUBLICATION 162, 1940.

PUBLIC WATER SUPPLIES IN SOUTHERN TEXAS: TEXAS BOARD OF WATER ENGINEERS MISCELLANEOUS PUBLICATION 215, 1946.

MEMORANDUM ON TRIP TO LIVE OAK, SAN PATRICIO, AND NUECES COUNTIES, JULY 15-18, 1948: USGS OPEN-FILE REPORT (UNNUMBERED), 1948

RESULTS OF A PRELIMINARY INVESTIGATION TO DETERMINE THE AMOUNT OF SEEPAGE LOSSES FROM THE NUECES AND FRIO RIVERS IN THE AREA BETWEEN COTULLA AND THREE RIVERS, TEXAS: USGS OPEN-FILE REPORT (UNNUMBERED), 1949.

CONTAMINATION OF FRIO RIVER BY SALT WATER FROM CALLIHAM OIL FIELD: USGS OPEN-FILE REPORT (UNNUMBERED), 1949.

PUBLIC WATER SUPPLIES IN SOUTHERN TEXAS: USGS WATERSUPPLY PAPER 1070, 1950.

SUPPLEMENTARY REPORT ON SURFACE-WATER AND GROUNDWATER SURVEYS, NUECES RIVER BASIN, TEXAS: USGS OPENFILE REPORT (UNNUMBERED), 1950

CROSS SECTION SHOWING SAND AND CLAY ZONES, ATASCOSA AND LIVE OAK COUNTIES, TEXAS: USGS OPEN-FILE REPORT, 1952.

AVAILABILITY OF GROUND WATER IN THE GULF COAST REGION OF TEXAS: USGS OPEN-FILE REPORT (UNNUMBERED), 1956.

DEVELOPMENT OF GROUND WATER FROM THE CARRIZO SAND AND WILCOX GROUP IN DIMMIT, ZAVALA, MAVERICK, FRIO, ATASCOSA, MEDINA, BEXAR, LIVE OAK, McMULLEN, LA SALLE, AND WEBB COUNTIES, TEXAS: USGS OPEN-FILE REPORT 57-77, 1957.
GROUND-WATER GEOLOGY OF LIVE OAK COUNTY, TEXAS: TEXAS BOARD OF WATER ENGINEERS BULLETIN 6105, 1961.

AVAILABILITY OF GROUND WATER FROM THE GOLIAD SAND IN THE ALICE AREA, TEXAS: TEXAS WATER COMMISSION BULLETIN 6301, 1963.

RECONNAISSANCE INVESTIGATION OF THE GROUND-WATER RESOURCES OF THE GUADALUPE, SAN ANTONIO, AND NUECES RIVER BASINS, TEXAS: TEXAS WATER COMMISSION BULLETIN 6409, 1964.

HYDROLOGIC SIGNIFICANCE OF THE LITHOFACIES OF THE SPARTA SAND IN ARKANSAS, LOUISIANA, MISSISSIPPI, AND TEXAS: USGS PROFESSIONAL PAPER 569-A, 1968.

COMPILATION OF RESULTS OF AQUIFER TESTS IN TEXAS: TEXAS WATER DEVELOPMENT BOARD REPORT 98, 1969.

GEOHYDROLOGIC SIGNIFICANCE OF LITHOFACIES OF THE COCKFIELD FORMATION OF LOUISIANA AND MISSISSIPPI AND OF THE YEGUA FORMATION OF TEXAS: USGS PROFESSIONAL PAPER 569-B, 1970.

HYDROLOGIC SIGNIFICANCE OF LITHOFACIES OF THE CANE RIVER FORMATION OR EQUIVALENTS OF ARKANSAS, LOUISIANA, MISSISSIPPI, AND TEXAS: USGS PROFESSIONAL PAPER 569-C, 1972.

HYDROLOGIC SIGNIFICANCE OF LITHOFACIES OF THE CARRIZO SAND OF ARKANSAS, LOUISIANA, AND TEXAS AND THE MERIDIAN SAND OF MISSISSIPPI: USGS PROFESSIONAL PAPER 569-D, 1975.

SUMMARY APPRAISALS OF THE NATION'S GROUND-WATER RESOURCES-TEXAS-GULF REGION: USGS PROFESSIONAL PAPER 813-F, 1976

GROUND-WATER RESOURCES OF THE CARRIZO AQUIFER IN THE WINTER GARDEN AREA OF TEXAS, VOLUME 1: TEXAS WATER DEVELOPMENT BOARD REPORT 210, V. 1, 1976.

GROUND-WATER RESOURCES OF THE CARRIZO AQUIFER IN THE WINTER GARDEN AREA OF TEXAS, VOLUME 2: TEXAS WATER DEVELOPMENT BOARD REPORT 210, V. 2, 1977.

STRATIGRAPHIC AND HYDROGEOLOGIC FRAMEWORK OF PART OF THE COASTAL PLAIN OF TEXAS: USGS OPEN-FILE REPORT $77-712,1978$.

STRATIGRAPHIC AND HYDROGEOLOGIC FRAMEWORK OF PART OF THE COASTAL PLAIN OF TEXAS: TEXAS DEPARTMENT OF WATER RESOURCES REPORT 236, 1979.

SPRINGS OF TEXAS, VOLUME 1: (BY GUNNAR BRUNE), BRANCHSMITH, INC., FORT WORTH, TEXAS, 1981.

REGIONAL HYDRODYNAMICS AND HYDROCHEMISTRY OF THE URANIUM-BEARING OAKVILLE AQUIFER (MIOCENE) OF SOUTH TEXAS: UNIVERSITY OF TEXAS, BUREAU OF ECONOMIC GEOLOGY REPORT OF INVESTIGATIONS NO. 124, 1982.

TEXAS GROUND-WATER RESOURCES, in NATIONAL WATER SUMMARY 1984: USGS WATER-SUPPLY PAPER 2275, 1985.

SIMULATED EFFECTS OF PROJECTED PUMPING ON THE AVAILABILITY OF FRESHWATER IN THE EVANGELINE AQUIFER IN AN AREA SOUTHWEST OF CORPUS CHRISTI, TEXAS: USGS WATERRESOURCES INVESTIGATIONS REPORT 85-4182, 1985. 
APPROXIMATE POTENTIOMETRIC SURFACES FOR THE AQUIFERS OF THE TEXAS COASTAL UPLANDS SYSTEM, 1980: USGS HYDROLOGIC INVESTIGATIONS ATLAS HA-704, 1987.

GEOHYDROLOGIC FRAMEWORK OF THE GULF COASTAL PLAIN: USGS HYDROLOGIC INVESTIGATIONS ATLAS HA-695, 1988.

DEPOSITIONAL AND GROUND-WATER FLOW SYSTEMS OF THE CARRIZO-UPPER WILCOX, SOUTH TEXAS: UNIVERSITY OF TEXAS, BUREAU OF ECONOMIC GEOLOGY REPORT OF INVESTIGATIONS NO. 175, 1988.

HYDROGEOLOGY AND PREDEVELOPMENT FLOW IN THE TEXAS GULF COAST AQUIFER SYSTEMS: USGS WATER-RESOURCES INVESTIGATIONS REPORT 87-4248, 1988.

GROUND-WATER FLOW IN THE GULF COAST AQUIFER SYSTEMS, SOUTH-CENTRAL UNITED STATES-A PRELIMINARY ANALYSIS: USGS WATER-RESOURCES INVESTIGATIONS REPORT 89-4071, 1990.

HYDROLOGY OF THE TEXAS GULF COAST AQUIFER SYSTEMS: USGS OPEN-FILE REPORT 91-64, 1991.

PROPERTIES AND CHEMICAL CONSTITUENTS IN GROUND WATER FROM THE UPPER CLAIBORNE AQUIFER, GULF COAST REGIONAL AQUIFER SYSTEMS, SOUTH-CENTRAL UNITED STATES: USGS WATER-RESOURCES INVESTIGATIONS REPORT 91-4150, 1993.

PROPERTIES AND CHEMICAL CONSTITUENTS IN GROUND WATER FROM PERMEABLE ZONE C (LOWER PLIOCENE-UPPER MIOCENE DEPOSITS), COASTAL LOWLANDS AQUIFER SYSTEM, SOUTHCENTRAL UNITED STATES: USGS WATER-RESOURCES INVESTIGATIONS REPORT 91-4151, 1993.

PROPERTIES AND CHEMICAL CONSTITUENTS IN GROUND WATER FROM PERMEABLE ZONE B (LOWER PLEISTOCENE-UPPER PLIOCENE DEPOSITS), COASTAL LOWLANDS AQUIFER SYSTEM, SOUTH-CENTRAL UNITED STATES: USGS WATER-RESOURCES INVESTIGATIONS REPORT 91-4152, 1993.

PROPERTIES AND CHEMICAL CONSTITUENTS IN GROUND WATER FROM THE LOWER CLAIBORNE-UPPER WILCOX AQUIFER, GULF COAST REGIONAL AQUIFER SYSTEMS, SOUTH-CENTRAL UNITED STATES: USGS WATER-RESOURCES INVESTIGATIONS REPORT 92-4102, 1993

PROPERTIES AND CHEMICAL CONSTITUENTS IN GROUND WATER FROM PERMEABLE ZONE E (LOWER MIOCENE-UPPER OLIGOCENE DEPOSITS), COASTAL LOWLANDS AQUIFER SYSTEM, SOUTH-CENTRAL UNITED STATES: USGS WATER-RESOURCES INVESTIGATIONS REPORT 92-4103, 1993.

PROPERTIES AND CHEMICAL CONSTITUENTS IN GROUND WATER FROM THE MIDDLE CLAIBORNE AQUIFER, GULF COAST REGIONAL AQUIFER SYSTEMS, SOUTH-CENTRAL UNITED STATES: USGS WATER-RESOURCES INVESTIGATIONS REPORT 92-4104, 1993.

PROPERTIES AND CHEMICAL CONSTITUENTS IN GROUND WATER FROM PERMEABLE ZONE D (MIDDLE MIOCENE DEPOSITS), COASTAL LOWLANDS AQUIFER SYSTEM, SOUTH-CENTRAL UNITED STATES: USGS WATER-RESOURCES INVESTIGATIONS REPORT 92-4105, 1993.

PROPERTIES AND CHEMICAL CONSTITUENTS IN GROUND WATER FROM THE MIDDLE WILCOX AQUIFER, GULF COAST REGIONAL AQUIFER SYSTEMS, SOUTH-CENTRAL UNITED STATES: USGS WATER-RESOURCES INVESTIGATIONS REPORT 93-4070, 1993.
AQUIFERS OF TEXAS: TEXAS WATER DEVELOPMENT BOARD REPORT 345, 1995.

HYDROGEOLOGIC FRAMEWORK AND GEOCHEMISTRY OF THE EDWARDS AQUIFER SALINE-WATER ZONE, SOUTH-CENTRAL TEXAS: USGS WATER-RESOURCES INVESTIGATIONS REPORT 97-4133, 1997.

\section{LLANO COUNTY}

GEOLOGIC ATLAS OF THE UNITED STATES-LLANO-BURNET FOLIO, TEXAS: USGS GEOLOGIC FOLIO, 1912.

PUBLIC WATER SUPPLIES IN CENTRAL AND NORTH-CENTRAL TEXAS: TEXAS BOARD OF WATER ENGINEERS MISCELLANEOUS PUBLICATION 213, 1947.

PUBLIC WATER SUPPLIES IN CENTRAL AND NORTH-CENTRAL TEXAS: USGS WATER-SUPPLY PAPER 1069, 1949.

BASE-FLOW STUDIES-LLANO RIVER, TEXAS: TEXAS WATER COMMISSION BULLETIN 6505, 1965.

RECONNAISSANCE INVESTIGATION OF THE GROUND-WATER RESOURCES OF THE COLORADO RIVER BASIN, TEXAS: TEXAS WATER DEVELOPMENT BOARD REPORT 51, 1967.

MAJOR AND HISTORICAL SPRINGS OF TEXAS: TEXAS WATER DEVELOPMENT BOARD REPORT 189, 1975.

TEXAS GROUND-WATER RESOURCES, in NATIONAL WATER SUMMARY 1984: USGS WATER-SUPPLY PAPER 2275, 1985.

POTENTIOMETRIC SURFACE OF THE EDWARDS-TRINITY AQUIFER SYSTEM AND CONTIGUOUS HYDRAULICALLY CONNECTED UNITS, WEST-CENTRAL TEXAS, WINTER 1974-75: USGS WATERRESOURCES INVESTIGATIONS REPORT 89-4208, 1990.

WITHDRAWALS FROM THE EDWARDS-TRINITY AQUIFER SYSTEM AND CONTIGUOUS HYDRAULICALLY CONNECTED UNITS, WEST-CENTRAL TEXAS, DECEMBER 1974 THROUGH MARCH 1977: USGS WATER-RESOURCES INVESTIGATIONS REPORT 91-4021, 1991.

CONFIGURATION OF THE BASE OF THE EDWARDS-TRINITY AQUIFER SYSTEM AND HYDROGEOLOGY OF THE UNDERLYING PRECRETACEOUS ROCKS, WEST-CENTRAL TEXAS: USGS WATERRESOURCES INVESTIGATIONS REPORT 91-4071, 1992.

HISTORICAL POTENTIOMETRIC SURFACE OF THE EDWARDS-TRINITY AQUIFER SYSTEM AND CONTIGUOUS HYDRAULICALLY CONNECTED UNITS, WEST-CENTRAL TEXAS: USGS WATERRESOURCES INVESTIGATIONS REPORT 92-4055, 1993.

HISTORICAL POTENTIOMETRIC SURFACE OF THE EDWARDS-TRINITY AQUIFER SYSTEM AND CONTIGUOUS HYDRAULICALLY CONNECTED UNITS, WEST-CENTRAL TEXAS: USGS WATERRESOURCES INVESTIGATIONS REPORT 92-4055, 1993.

SIMULATIONS OF FLOW IN THE EDWARDS-TRINITY AQUIFER SYSTEM AND CONTIGUOUS HYDRAULICALLY CONNECTED UNITS, WEST-CENTRAL TEXAS: USGS WATER-RESOURCES INVESTIGATIONS REPORT 93-4039, 1994.

DISSOLVED-SOLIDS CONCENTRATIONS AND HYDROCHEMICAL FACIES IN WATER OF THE EDWARDS-TRINITY AQUIFER SYSTEM, WEST-CENTRAL TEXAS: USGS WATER-RESOURCES INVESTIGATIONS REPORT 93-4126, 1994. 
GEOLOGIC HISTORY AND HYDROGEOLOGIC SETTING OF THE EDWARDS-TRINITY AQUIFER SYSTEM, WEST-CENTRAL TEXAS: USGS WATER-RESOURCES INVESTIGATIONS REPORT 94-4039, 1994.

AQUIFERS OF TEXAS: TEXAS WATER DEVELOPMENT BOARD REPORT 345, 1995.

THE PALEOZOIC AND RELATED AQUIFERS OF CENTRAL TEXAS: TEXAS WATER DEVELOPMENT BOARD REPORT 346, 1996.

\section{LOVING COUNTY}

WATER RESOURCES OF THE PECOS RIVER BASIN, VOLUME 1, PECOS RIVER JOINT INVESTIGATION_PART 3, REPORT B, GEOLOGY AND GROUND WATER: TEXAS BOARD OF WATER ENGINEERS MISCELLANEOUS PUBLICATION 209A, V. 1, 1941.

WATER RESOURCES OF THE PECOS RIVER BASIN, VOLUME 2, RECORDS OF WELLS AND SPRINGS AND ANALYSES OF WATER IN LOVING, WARD, REEVES, AND NORTHERN PECOS COUNTIES: TEXAS BOARD OF WATER ENGINEERS MISCELLANEOUS PUBLICATION 209A, V. 2, 1941.

WATER RESOURCES OF THE PECOS RIVER BASIN, VOLUME 3, RECORDS OF AUGER HOLES INCLUDING LOGS, RECORDS OF FLUCTUATIONS OF WATER LEVELS, WATER ANALYSES, AND MAPS SHOWING LOCATIONS OF WELLS: TEXAS BOARD OF WATER ENGINEERS MISCELLANEOUS PUBLICATION 209A, V. 3, 1941.

GEOLOGIC FORMATIONS OF LOVING COUNTY AND THEIR WATERBEARING PROPERTIES: USGS OPEN-FILE REPORT (UNNUMBERED), 1943.

PUBLIC WATER SUPPLIES IN WESTERN TEXAS: TEXAS BOARD OF WATER ENGINEERS MISCELLANEOUS PUBLICATION 216, 1949.

PUBLIC WATER SUPPLIES IN WESTERN TEXAS: USGS WATERSUPPLY PAPER 1106, 1951 [1952].

RECORDS OF WATER-LEVEL MEASUREMENTS IN LOVING AND WARD COUNTIES, TEXAS: TEXAS BOARD OF WATER ENGINEERS BULLETIN 5408, 1954

SHALLOW FORMATIONS AND AQUIFERS OF THE WEST TEXAS AREA: WEST TEXAS GEOLOGICAL SOCIETY PUBLICATION 61-45 AND PERMIAN BASIN GEOPHYSICAL SOCIETY, MIDLAND, TEXAS, 1961

RECONNAISSANCE INVESTIGATION OF THE GROUND-WATER RESOURCES OF THE RIO GRANDE BASIN, TEXAS: TEXAS WATER COMMISSION BULLETIN 6502, 1965.

RECONNAISSANCE INVESTIGATION OF GROUND WATER IN THE RIO GRANDE DRAINAGE BASIN—WITH SPECIAL EMPHASIS ON SALINE GROUND-WATER RESOURCES: USGS HYDROLOGIC INVESTIGATIONS ATLAS HA-510, 1974.

SUMMARY APPRAISALS OF THE NATION'S GROUND-WATER RESOURCES-RIO GRANDE REGION: USGS PROFESSIONAL PAPER 813-D, 1975.

SPRINGS OF TEXAS, VOLUME 1: (BY GUNNAR BRUNE), BRANCHSMITH, INC., FORT WORTH, TEXAS, 1981.

TEXAS GROUND-WATER RESOURCES, in NATIONAL WATER SUMMARY 1984: USGS WATER-SUPPLY PAPER 2275, 1985.
RECORDS OF WELLS, WATER LEVELS, PUMPAGE, AND CHEMICAL ANALYSES FROM SELECTED WELLS IN PARTS OF THE TRANSPECOS REGION, TEXAS, 1968-1980: TEXAS WATER DEVELOPMENT BOARD REPORT 301, 1987.

PUBLIC SUPPLY GROUND-WATER USE IN WESTERN TEXAS: TEXAS WATER DEVELOPMENT BOARD REPORT 311, 1989.

EVALUATION OF GROUND-WATER RESOURCES IN PARTS OF LOVING, PECOS, REEVES, WARD, AND WINKLER COUNTIES, TEXAS: TEXAS WATER DEVELOPMENT BOARD REPORT 317, 1990.

WATER QUALITY IN THE EDWARDS-TRINITY (PLATEAU) AQUIFER, EDWARDS PLATEAU AND TRANS-PECOS, TEXAS: TEXAS WATER DEVELOPMENT BOARD HYDROLOGIC ATLAS NO. 3, 1995.

AQUIFERS OF TEXAS: TEXAS WATER DEVELOPMENT BOARD REPORT 345, 1995

WATER QUALITY IN THE RUSTLER AQUIFER: TEXAS WATER DEVELOPMENT BOARD HYDROLOGIC ATLAS NO. 9, 1998.

CHANGES IN GROUNDWATER CONDITIONS IN PARTS OF TRANSPECOS TEXAS, 1988-1998: TEXAS WATER DEVELOPMENT BOARD REPORT 348, 1999.

AQUIFERS OF WEST TEXAS: TEXAS WATER DEVELOPMENT BOARD REPORT 356, 2001.

REGIONAL GROUND-WATER FLOW SYSTEMS IN TRANS-PECOS TEXAS, CHAPTER 4, in AQUIFERS OF WEST TEXAS: TEXAS WATER DEVELOPMENT BOARD REPORT 356, 2001

CENOZOIC PECOS ALLUVIUM AQUIFER, CHAPTER 9, in AQUIFERS OF WEST TEXAS: TEXAS WATER DEVELOPMENT BOARD REPORT 356, 2001.

THE GEOLOGY AND HYDROGEOLOGY OF THE CAPITAN AQUIFER A BRIEF OVERVIEW, CHAPTER 11, in AQUIFERS OF WEST TEXAS TEXAS WATER DEVELOPMENT BOARD REPORT 356, 2001

THE DOCKUM AQUIFER IN WEST TEXAS, CHAPTER 12, in AQUIFERS OF WEST TEXAS: TEXAS WATER DEVELOPMENT BOARD REPORT 356, 2001.

HYDROGEOLOGY OF THE RUSTLER AQUIFER, TRANS-PECOS TEXAS, CHAPTER 15, in AQUIFERS OF WEST TEXAS: TEXAS WATER DEVELOPMENT BOARD REPORT 356, 2001.

\section{LUBBOCK COUNTY}

GEOLOGY AND GROUND-WATER RESOURCES OF THE SOUTHERN HIGH PLAINS: USGS OPEN-FILE REPORT (UNNUMBERED), 1935.

PRELIMINARY REPORT ON THE UNDERGROUND WATER SUPPLY OF THE PLAINVIEW, TEXAS PROJECT: USGS OPEN-FILE REPORT (UNNUMBERED), 1936

GROUND WATER IN THE SOUTHERN HIGH PLAINS: USGS OPENFILE REPORT (UNNUMBERED), 1937.

RECORDS OF WELLS, DRILLERS' LOGS, AND WATER ANALYSES, AND MAP SHOWING LOCATION OF WELLS IN LUBBOCK COUNTY, TEXAS: TEXAS BOARD OF WATER ENGINEERS MISCELLANEOUS PUBLICATION 175, 1937.

GROUND WATER IN THE HIGH PLAINS IN TEXAS (1940): TEXAS BOARD OF WATER ENGINEERS MISCELLANEOUS PUBLICATION M119, 1940 
GROUND WATER IN THE HIGH PLAINS IN TEXAS, PROGRESS REPORT (1943): TEXAS BOARD OF WATER ENGINEERS MISCELLANEOUS PUBLICATION M120, 1943.

WATER WELLS IN VICINITY OF LUBBOCK, TEXAS: USGS OPEN-FILE REPORT (UNNUMBERED), 1944.

GROUND WATER IN THE HIGH PLAINS IN TEXAS, PROGRESS REPORT (1944): TEXAS BOARD OF WATER ENGINEERS MISCELLANEOUS PUBLICATION M121, 1944.

RECORDS OF WELLS AND SPRINGS, DRILLERS' LOGS, WATER ANALYSES, AND MAP SHOWING LOCATIONS OF WELLS AND SPRINGS IN LUBBOCK COUNTY, TEXAS: TEXAS BOARD OF WATER ENGINEERS MISCELLANEOUS PUBLICATION 176, 1945.

WATER RESOURCES OF THE LUBBOCK DISTRICT, TEXAS: TEXAS BOARD OF WATER ENGINEERS MISCELLANEOUS PUBLICATION $177,1945$.

MEMORANDUM CONCERNING THE FEASIBILITY OF DEVELOPING A GROUND-WATER SUPPLY OF 4,000 GALLONS A MINUTE TO SUPPLY AN INDUSTRIAL PLANT IN THE IMMEDIATE VICINITY OF LUBBOCK, TEXAS: USGS OPEN-FILE REPORT (UNNUMBERED), 1945.

GROUND WATER IN THE HIGH PLAINS IN TEXAS, PROGRESS REPORT NO. 5: TEXAS BOARD OF WATER ENGINEERS MISCELLANEOUS PUBLICATION M122, 1945.

MEMORANDUM REGARDING RESISTIVITY PROBES AT LUBBOCK AND BIG SPRING, TEXAS: USGS OPEN-FILE REPORT (UNNUMBERED), 1946.

GROUND WATER IN THE HIGH PLAINS IN TEXAS, PROGRESS REPORT NO. 6: TEXAS BOARD OF WATER ENGINEERS MISCELLANEOUS PUBLICATION M123, 1947.

MEMORANDUM TO THE TEXAS STATE BOARD OF WATER ENGINEERS REGARDING THE PROPOSED DEVELOPMENT OF WATERSUPPLY WELLS FOR THE CITY OF LUBBOCK, IN AN AREA NORTHWEST OF THE CITY ALONG YELLOWHOUSE DRAW: USGS OPEN-FILE REPORT (UNNUMBERED), 1948.

PUBLIC WATER SUPPLIES IN WESTERN TEXAS: TEXAS BOARD OF WATER ENGINEERS MISCELLANEOUS PUBLICATION 216, 1949.

GROUND WATER IN THE VICINITY OF AMARILLO AND LUBBOCK, TEXAS: USGS OPEN-FILE REPORT (UNNUMBERED), 1949.

GEOLOGY AND GROUND WATER IN THE IRRIGATED REGION OF THE SOUTHERN HIGH PLAINS IN TEXAS, PROGRESS REPORT NO. 7: TEXAS BOARD OF WATER ENGINEERS MISCELLANEOUS PUBLICATION M125, 1949.

COST OF PUMPING WATER FOR IRRIGATION, TEXAS HIGH PLAINS, FIELD INVESTIGATION-1947 IRRIGATION SEASON: TEXAS BOARD OF WATER ENGINEERS MISCELLANEOUS PUBLICATION M124, 1951.

DEVELOPMENT OF WELLS FOR IRRIGATION AND FLUCTUATION OF WATER LEVELS IN THE HIGH PLAINS OF TEXAS TO JANUARY 1951: TEXAS BOARD OF WATER ENGINEERS BULLETIN 5104, 1951.

PUBLIC WATER SUPPLIES IN WESTERN TEXAS: USGS WATERSUPPLY PAPER 1106, 1951 [1952].

RECORDS OF WATER-LEVEL MEASUREMENTS IN LUBBOCK COUNTY, TEXAS, 1936-1953: TEXAS BOARD OF WATER ENGINEERS BULLETIN 5303, 1953.
LOGS OF WELLS AND TEST HOLES: CITY OF LUBBOCK, TEXAS, 1953

WATER-LEVEL DECLINE MAPS OF 6 COUNTIES IN THE SOUTHERN HIGH PLAINS, TEXAS, JANUARY 1953 TO JANUARY 1954: (DEAF SMITH, FLOYD, HALE, LAMB, LUBBOCK, AND SWISHER): USGS OPEN-FILE REPORT (UNNUMBERED), 1954.

SUMMARY OF GROUND-WATER DEVELOPMENT IN THE SOUTHERN HIGH PLAINS, TEXAS: TEXAS BOARD OF WATER ENGINEERS BULLETIN 5402, 1954.

GROUND-WATER DEVELOPMENT IN THE SOUTHERN HIGH PLAINS OF TEXAS, 1953: TEXAS BOARD OF WATER ENGINEERS BULLETIN 5410, 1954

WATER-LEVEL DECLINE MAPS OF 16 COUNTIES IN THE SOUTHERN HIGH PLAINS, TEXAS, JANUARY 1954 TO JANUARY 1955: (BAILEY, BRISCOE, CASTRO, COCHRAN, CROSBY, DEAF SMITH, FLOYD, GAINES, HALE, HOCKLEY, LAMB, LUBBOCK, PARMER, RANDALL, SWISHER, AND TERRY): USGS OPEN-FILE REPORT (UNNUMBERED), 1955.

WATER-LEVEL DECLINE MAPS OF 17 COUNTIES IN THE SOUTHERN HIGH PLAINS, TEXAS, JANUARY 1955 TO JANUARY 1956: TEXAS BOARD OF WATER ENGINEERS BULLETIN 5607, 1956.

WATER-LEVEL DECLINE MAPS, 1956 TO 1957, AND WATER LEVELS IN OBSERVATION WELLS IN 20 COUNTIES IN THE SOUTHERN HIGH PLAINS, TEXAS: TEXAS BOARD OF WATER ENGINEERS BULLETIN 5705, 1957.

PRELIMINARY ANALYSIS OF PUMPING TEST DATA, CITY OF LUBBOCK WELL 114-A, LAMB COUNTY, TEXAS: USGS OPEN-FILE REPORT (UNNUMBERED), 1958.

WATER-LEVEL MEASUREMENTS AND MAPS, SOUTHERN HIGH PLAINS, TEXAS, 1958 AND 1959: TEXAS BOARD OF WATER ENGINEERS BULLETIN 5908, 1959.

WATER LEVELS IN OBSERVATION WELLS, SOUTHERN HIGH PLAINS, TEXAS, 1959 AND 1960: TEXAS BOARD OF WATER ENGINEERS BULLETIN 6011, 1960.

WATER LEVELS IN OBSERVATION WELLS, SOUTHERN HIGH PLAINS, TEXAS, 1960 AND 1961: TEXAS BOARD OF WATER ENGINEERS BULLETIN 6101, 1961.

A SUMMARY OF THE OCCURRENCE AND DEVELOPMENT OF GROUND WATER IN THE SOUTHERN HIGH PLAINS OF TEXAS: TEXAS BOARD OF WATER ENGINEERS BULLETIN 6107, 1961.

SHALLOW FORMATIONS AND AQUIFERS OF THE WEST TEXAS AREA: WEST TEXAS GEOLOGICAL SOCIETY PUBLICATION 61-45 AND PERMIAN BASIN GEOPHYSICAL SOCIETY, MIDLAND, TEXAS, 1961

WATER-LEVEL MEASUREMENTS THROUGH 1962 IN SELECTED OBSERVATION WELLS, SOUTHERN HIGH PLAINS, TEXAS: TEXAS WATER COMMISSION BULLETIN 6207, 1962.

RECONNAISSANCE INVESTIGATION OF THE GROUND-WATER RESOURCES OF THE BRAZOS RIVER BASIN, TEXAS: TEXAS WATER COMMISSION BULLETIN 6310, 1963.

A SUMMARY OF THE OCCURRENCE AND DEVELOPMENT OF GROUND WATER IN THE SOUTHERN HIGH PLAINS OF TEXAS: USGS WATER-SUPPLY PAPER 1693, 1964.

PUBLIC WATER SUPPLIES OF THE 100 LARGEST CITIES IN THE UNITED STATES: USGS WATER-SUPPLY PAPER 1812, 1964. 
WATER-LEVEL DATA FROM OBSERVATION WELLS IN THE SOUTHERN HIGH PLAINS OF TEXAS: TEXAS WATER DEVELOPMENT BOARD REPORT 21, 1966.

COMPILATION OF RESULTS OF AQUIFER TESTS IN TEXAS: TEXAS WATER DEVELOPMENT BOARD REPORT 98, 1969.

GROUND WATER IN THE OGALLALA FORMATION IN THE SOUTHERN HIGH PLAINS OF TEXAS AND NEW MEXICO: USGS HYDROLOGIC INVESTIGATIONS ATLAS HA-330, 1969.

WATER-LEVEL DATA FROM OBSERVATION WELLS IN THE SOUTHERN HIGH PLAINS OF TEXAS, 1956-70: TEXAS WATER DEVELOPMENT BOARD REPORT 121, 1970.

AN EVALUATION OF THE USE OF DRILLERS' LOGS IN LITHOLOGIC STUDIES OF THE OGALLALA FORMATION OF THE SOUTHERN HIGH PLAINS OF TEXAS: USGS OPEN-FILE REPORT 72-451, 1972.

MAJOR AND HISTORICAL SPRINGS OF TEXAS: TEXAS WATER DEVELOPMENT BOARD REPORT 189, 1975.

SUMMARY APPRAISALS OF THE NATION'S GROUND-WATER RESOURCES-TEXAS-GULF REGION: USGS PROFESSIONAL PAPER 813-F, 1976.

ANALYTICAL STUDY OF THE OGALLALA AQUIFER IN LAMB COUNTY, TEXAS-PROJECTIONS OF SATURATED THICKNESS, VOLUME OF WATER IN STORAGE, PUMPAGE RATES, PUMPING LIFTS, AND WELL YIELDS: TEXAS WATER DEVELOPMENT BOARD REPORT 204, 1976.

ARTIFICIAL GROUND-WATER RECHARGE AS A WATER-MANAGEMENT TECHNIQUE ON THE SOUTHERN HIGH PLAINS OF TEXAS AND NEW MEXICO: USGS OPEN-FILE REPORT 76-730, 1976.

FIELD DETERMINATION OF VERTICAL PERMEABILITY TO AIR IN THE UNSATURATED ZONE: USGS OPEN-FILE REPORT 77-346, 1977.

ANALYTICAL STUDY OF THE OGALLALA AQUIFER IN LUBBOCK COUNTY, TEXAS—PROJECTIONS OF SATURATED THICKNESS, VOLUME OF WATER IN STORAGE, PUMPAGE RATES, PUMPING LIFTS, AND WELL YIELDS: TEXAS DEPARTMENT OF WATER RESOURCES REPORT 216, 1978.

WATER-LEVEL DATA FROM OBSERVATION WELLS IN THE SOUTHERN HIGH PLAINS OF TEXAS, 1971-77: TEXAS DEPARTMENT OF WATER RESOURCES REPORT 228, 1979.

PRELIMINARY DATA DESCRIBING THE DISTRIBUTION OF FLUORIDE AND SILICA IN THE OGALLALA AQUIFER ON THE HIGH PLAINS OF TEXAS: USGS OPEN-FILE REPORT 80-349, 1980.

EVALUATING THE GROUND-WATER RESOURCES OF THE HIGH PLAINS OF TEXAS: RESULTS OF TEST-HOLE DRILLING: TEXAS DEPARTMENT OF WATER RESOURCES LIMITED PRINTING REPORT LP-129, 1980.

EVALUATING THE GROUND-WATER RESOURCES OF THE HIGH PLAINS OF TEXAS: RESULTS OF SURFACE ELECTRICAL SURVEYS: TEXAS DEPARTMENT OF WATER RESOURCES LIMITED PRINTING REPORT LP-130, 1980.

EVALUATING THE GROUND-WATER RESOURCES OF THE HIGH PLAINS OF TEXAS: NEUTRON-PROBE MEASUREMENTS OF DEEP SOIL MOISTURE AS AN INDICATION OF AQUIFER RECHARGE RATES: TEXAS DEPARTMENT OF WATER RESOURCES LIMITED PRINTING REPORT LP-142, 1981.

SPRINGS OF TEXAS, VOLUME 1: (BY GUNNAR BRUNE), BRANCHSMITH, INC., FORT WORTH, TEXAS, 1981.
BEDROCK GEOLOGY, ALTITUDE OF BASE, AND 1980 SATURATED THICKNESS OF THE HIGH PLAINS AQUIFER IN PARTS OF COLORADO, KANSAS, NEBRASKA, NEW MEXICO, OKLAHOMA, SOUTH DAKOTA, TEXAS, AND WYOMING: USGS HYDROLOGIC INVESTIGATIONS ATLAS HA-648, 1981.

WATER LEVEL AND SATURATED THICKNESS CHANGES, PREDEVELOPMENT TO 1980, IN THE HIGH PLAINS AQUIFER IN PARTS OF COLORADO, KANSAS, NEBRASKA, NEW MEXICO, OKLAHOMA, SOUTH DAKOTA, TEXAS, AND WYOMING: USGS HYDROLOGIC INVESTIGATIONS ATLAS HA-652, 1981.

INVESTIGATION OF THE FEASIBILITY OF SECONDARY RECOVERY OF GROUND WATER FROM THE OGALLALA AQUIFER. A REPORT TO THE 68TH TEXAS LEGISLATURE: TEXAS DEPARTMENT OF WATER RESOURCES LIMITED PRINTING REPORT LP-185, 1982.

DISSOLVED SOLIDS AND SODIUM IN WATER FROM THE HIGH PLAINS AQUIFER IN PARTS OF COLORADO, KANSAS, NEBRASKA, NEW MEXICO, OKLAHOMA, SOUTH DAKOTA, TEXAS, AND WYOMING: USGS HYDROLOGIC INVESTIGATIONS ATLAS HA-658, 1982.

INVESTIGATION OF SECONDARY RECOVERY OF GROUND WATER FROM THE OGALLALA FORMATION, HIGH PLAINS OF TEXASSUMMARY OF STUDY: HIGH PLAINS UNDERGROUND WATER CONSERVATION DISTRICT NO. 1, LUBBOCK, TEXAS, 1982.

EVALUATING THE GROUND-WATER RESOURCES OF THE HIGH PLAINS OF TEXAS, VOLUME 1: TEXAS DEPARTMENT OF WATER RESOURCES REPORT 288, V. 1, 1984.

'EVALUATING THE GROUND-WATER RESOURCES OF THE HIGH PLAINS OF TEXAS, VOLUME 4, RECORDS OF WELLS, AND MAPS SHOWING WELL LOCATIONS, BASE OF AQUIFER, WATER LEVELS, AND SATURATED THICKNESS (ANDREWS, BORDEN, COCHRAN, DAWSON, ECTOR, GAINES, GARZA, GLASSCOCK, HOWARD, HOCKLEY, LUBBOCK, LYNN, MARTIN, MIDLAND, TERRY, AND YOAKUM COUNTIES: TEXAS DEPARTMENT OF WATER RESOURCES REPORT 288 V. 4, 1984.

GEOHYDROLOGY OF THE HIGH PLAINS AQUIFER IN PARTS OF COLORADO, KANSAS, NEBRASKA, NEW MEXICO, OKLAHOMA, SOUTH DAKOTA, TEXAS, AND WYOMING: USGS PROFESSIONAL PAPER 1400-B, 1984.

TEXAS GROUND-WATER RESOURCES, in NATIONAL WATER SUMMARY 1984: USGS WATER-SUPPLY PAPER 2275, 1985.

WATER USE, PROJECTED WATER REQUIREMENTS, AND RELATED DATA AND INFORMATION FOR THE METROPOLITAN STATISTICAL AREAS IN TEXAS: TEXAS DEPARTMENT OF WATER RESOURCES LIMITED PRINTING REPORT LP-201, 1985.

INVESTIGATION OF THE FEASIBILITY OF SECONDARY RECOVERY OF GROUND WATER FROM THE OGALLALA AQUIFER. A REPORT TO THE 69TH TEXAS LEGISLATURE: TEXAS WATER DEVELOPMENT BOARD LIMITED PRINTING REPORT LP-202, 1985.

DIGITAL SIMULATION OF GROUND-WATER FLOW IN THE HIGH PLAINS AQUIFER IN PARTS OF COLORADO, KANSAS, NEBRASKA, NEW MEXICO, OKLAHOMA, SOUTH DAKOTA, TEXAS, AND WYOMING: USGS PROFESSIONAL PAPER 1400-D, 1986.

LUBBOCK COUNTY, TEXAS, OBSERVATION WELL WATER DATA AND WATER QUALITY DATA FROM SELECTED WELLS (HISTORICAL AND CURRENT): HIGH PLAINS UNDERGROUND WATER CONSERVATION DISTRICT NO. 1, LUBBOCK, TEXAS, 1988. 
SUMMARY OF THE HIGH PLAINS REGIONAL AQUIFER-SYSTEM ANALYSIS IN PARTS OF COLORADO, KANSAS, NEBRASKA, NEW MEXICO, OKLAHOMA, SOUTH DAKOTA, TEXAS, AND WYOMING: USGS PROFESSIONAL PAPER 1400-A, 1988.

HYDROGEOLOGY AND HYDROCHEMISTRY OF CRETACEOUS AQUIFERS, TEXAS PANHANDLE AND EASTERN NEW MEXICO: UNIVERSITY OF TEXAS, BUREAU OF ECONOMIC GEOLOGY GEOLOGICAL CIRCULAR 88-3, 1988.

HYDROGEOLOGY OF LOWER CRETACEOUS STRATA UNDER THE SOUTHERN HIGH PLAINS OF TEXAS AND NEW MEXICO: TEXAS WATER DEVELOPMENT BOARD REPORT 314, 1989.

PUBLIC-SUPPLY GROUND-WATER USE IN THE SOUTHERN HIGH PLAINS OF TEXAS: TEXAS WATER DEVELOPMENT BOARD REPORT 328, 1990.

WATER-LEVEL CHANGES IN THE HIGH PLAINS AQUIFER OF TEXAS, 1980-1990: TEXAS WATER DEVELOPMENT BOARD HYDROLOGIC ATLAS NO. 1, 1991.

THE HIGH PLAINS AQUIFER SYSTEM OF TEXAS, 1980 TO 1990. OVERVIEW AND PROJECTIONS: TEXAS WATER DEVELOPMENT BOARD REPORT 341, 1993.

WATER-QUALITY EVALUATION OF THE OGALLALA AQUIFER, TEXAS: TEXAS WATER DEVELOPMENT BOARD REPORT 342, 1993.

WATER-LEVEL CHANGES IN THE HIGH PLAINS AQUIFER, 1980 TO 1994: USGS FACT SHEET FS-215-95, 1995.

AQUIFERS OF TEXAS: TEXAS WATER DEVELOPMENT BOARD REPORT 345, 1995.

WATER-LEVEL CHANGES IN THE HIGH PLAINS AQUIFER, 1980 TO 1995: USGS FACT SHEET FS-068-97, 1997.

WATER-LEVEL CHANGES IN THE HIGH PLAINS AQUIFER-PREDEVELOPMENT TO 1995: USGS WATER-RESOURCES INVESTIGATIONS REPORT 97-4081, 1997.

UPDATED WATER-QUALITY EVALUATION OF THE OGALLALA AQUIFER INCLUDING SELECTED METALLIC AND NON-METALLIC INORGANIC CONSTITUENTS: TEXAS WATER DEVELOPMENT BOARD HYDROLOGIC ATLAS NO. 10, 1998.

\section{LYNN COUNTY}

GEOLOGY AND GROUND-WATER RESOURCES OF THE SOUTHERN HIGH PLAINS: USGS OPEN-FILE REPORT (UNNUMBERED), 1935.

PRELIMINARY REPORT ON THE UNDERGROUND WATER SUPPLY OF THE PLAINVIEW, TEXAS PROJECT: USGS OPEN-FILE REPORT (UNNUMBERED), 1936.

GROUND WATER IN THE SOUTHERN HIGH PLAINS: USGS OPENFILE REPORT (UNNUMBERED), 1937.

GROUND WATER IN THE HIGH PLAINS IN TEXAS (1940): TEXAS BOARD OF WATER ENGINEERS MISCELLANEOUS PUBLICATION M119, 1940.

GROUND WATER IN THE HIGH PLAINS IN TEXAS, PROGRESS REPORT (1943): TEXAS BOARD OF WATER ENGINEERS MISCELLANEOUS PUBLICATION M120, 1943.
GROUND WATER IN THE HIGH PLAINS IN TEXAS, PROGRESS REPORT (1944): TEXAS BOARD OF WATER ENGINEERS MISCELLANEOUS PUBLICATION M121, 1944.

GROUND WATER IN THE HIGH PLAINS IN TEXAS, PROGRESS REPORT NO. 5: TEXAS BOARD OF WATER ENGINEERS MISCELLANEOUS PUBLICATION M122, 1945.

GROUND WATER IN THE HIGH PLAINS IN TEXAS, PROGRESS REPORT NO. 6: TEXAS BOARD OF WATER ENGINEERS MISCELLANEOUS PUBLICATION M123, 1947.

GEOLOGY AND GROUND WATER IN THE IRRIGATED REGION OF THE SOUTHERN HIGH PLAINS IN TEXAS, PROGRESS REPORT NO. 7: TEXAS BOARD OF WATER ENGINEERS MISCELLANEOUS PUBLICATION M125, 1949.

PUBLIC WATER SUPPLIES IN WESTERN TEXAS: TEXAS BOARD OF WATER ENGINEERS MISCELLANEOUS PUBLICATION 216, 1949.

COST OF PUMPING WATER FOR IRRIGATION, TEXAS HIGH PLAINS, FIELD INVESTIGATION-1947 IRRIGATION SEASON: TEXAS BOARD OF WATER ENGINEERS MISCELLANEOUS PUBLICATION M124, 1951.

DEVELOPMENT OF WELLS FOR IRRIGATION AND FLUCTUATION OF WATER LEVELS IN THE HIGH PLAINS OF TEXAS TO JANUARY 1951: TEXAS BOARD OF WATER ENGINEERS BULLETIN 5104, 1951.

PUBLIC WATER SUPPLIES IN WESTERN TEXAS: USGS WATERSUPPLY PAPER 1106, 1951 [1952].

GROUND-WATER RESOURCES OF LYNN COUNTY, TEXAS: TEXAS BOARD OF WATER ENGINEERS BULLETIN 5207, 1952.

SUMMARY OF GROUND-WATER DEVELOPMENT IN THE SOUTHERN HIGH PLAINS, TEXAS: TEXAS BOARD OF WATER ENGINEERS BULLETIN 5402, 1954.

RECORDS OF WATER-LEVEL MEASUREMENTS IN COCHRAN, CROSBY, GAINES, HOCKLEY, LYNN, AND TERRY COUNTIES, TEXAS: TEXAS BOARD OF WATER ENGINEERS BULLETIN 5407, 1954.

GROUND-WATER DEVELOPMENT IN THE SOUTHERN HIGH PLAINS OF TEXAS, 1953: TEXAS BOARD OF WATER ENGINEERS BULLETIN 5410, 1954

MEMORANDUM ON VERTICAL CURRENT METER AND CONDUCTANCE TESTS ON FLOWING WELL IN LYNN COUNTY, TEXAS: USGS OPEN-FILE REPORT, 1957.

WATER-LEVEL MEASUREMENTS AND MAPS, SOUTHERN HIGH PLAINS, TEXAS, 1958 AND 1959: TEXAS BOARD OF WATER ENGINEERS BULLETIN 5908, 1959.

WATER LEVELS IN OBSERVATION WELLS, SOUTHERN HIGH PLAINS, TEXAS, 1959 AND 1960: TEXAS BOARD OF WATER ENGINEERS BULLETIN 6011, 1960.

WATER LEVELS IN OBSERVATION WELLS, SOUTHERN HIGH PLAINS, TEXAS, 1960 AND 1961: TEXAS BOARD OF WATER ENGINEERS BULLETIN 6101, 1961.

A SUMMARY OF THE OCCURRENCE AND DEVELOPMENT OF GROUND WATER IN THE SOUTHERN HIGH PLAINS OF TEXAS: TEXAS BOARD OF WATER ENGINEERS BULLETIN 6107, 1961.

WATER-LEVEL MEASUREMENTS THROUGH 1962 IN SELECTED OBSERVATION WELLS, SOUTHERN HIGH PLAINS, TEXAS: TEXAS WATER COMMISSION BULLETIN 6207, 1962. 
RECONNAISSANCE INVESTIGATION OF THE GROUND-WATER RESOURCES OF THE BRAZOS RIVER BASIN, TEXAS: TEXAS WATER COMMISSION BULLETIN 6310, 1963.

A SUMMARY OF THE OCCURRENCE AND DEVELOPMENT OF GROUND WATER IN THE SOUTHERN HIGH PLAINS OF TEXAS: USGS WATER-SUPPLY PAPER 1693, 1964.

WATER-LEVEL DATA FROM OBSERVATION WELLS IN THE SOUTHERN HIGH PLAINS OF TEXAS: TEXAS WATER DEVELOPMENT BOARD REPORT 21, 1966.

RECONNAISSANCE INVESTIGATION OF THE GROUND-WATER RESOURCES OF THE COLORADO RIVER BASIN, TEXAS: TEXAS WATER DEVELOPMENT BOARD REPORT 51, 1967.

COMPILATION OF RESULTS OF AQUIFER TESTS IN TEXAS: TEXAS WATER DEVELOPMENT BOARD REPORT 98, 1969.

GROUND WATER IN THE OGALLALA FORMATION IN THE SOUTHERN HIGH PLAINS OF TEXAS AND NEW MEXICO: USGS HYDROLOGIC INVESTIGATIONS ATLAS HA-330, 1969.

WATER-LEVEL DATA FROM OBSERVATION WELLS IN THE SOUTHERN HIGH PLAINS OF TEXAS, 1956-70: TEXAS WATER DEVELOPMENT BOARD REPORT 121, 1970.

AN EVALUATION OF THE USE OF DRILLERS' LOGS IN LITHOLOGIC STUDIES OF THE OGALLALA FORMATION OF THE SOUTHERN HIGH PLAINS OF TEXAS: USGS OPEN-FILE REPORT 72-451, 1972.

SUMMARY APPRAISALS OF THE NATION'S GROUND-WATER RESOURCES-TEXAS-GULF REGION: USGS PROFESSIONAL PAPER 813-F, 1976.

ANALYTICAL STUDY OF THE OGALLALA AQUIFER IN LYNN AND GARZA COUNTIES, TEXAS-PROJECTIONS OF SATURATED THICKNESS, VOLUME OF WATER IN STORAGE, PUMPAGE RATES, PUMPING LIFTS, AND WELL YIELDS: TEXAS WATER DEVELOPMENT BOARD REPORT 223, 1978.

WATER-LEVEL DATA FROM OBSERVATION WELLS IN THE SOUTHERN HIGH PLAINS OF TEXAS, 1971-77: TEXAS DEPARTMENT OF WATER RESOURCES REPORT 228, 1979.

PRELIMINARY DATA DESCRIBING THE DISTRIBUTION OF FLUORIDE AND SILICA IN THE OGALLALA AQUIFER ON THE HIGH PLAINS OF TEXAS: USGS OPEN-FILE REPORT 80-349, 1980.

EVALUATING THE GROUND-WATER RESOURCES OF THE HIGH PLAINS OF TEXAS: RESULTS OF TEST-HOLE DRILLING: TEXAS DEPARTMENT OF WATER RESOURCES LIMITED PRINTING REPORT LP-129, 1980.

EVALUATING THE GROUND-WATER RESOURCES OF THE HIGH PLAINS OF TEXAS: NEUTRON-PROBE MEASUREMENTS OF DEEP SOIL MOISTURE AS AN INDICATION OF AQUIFER RECHARGE RATES: TEXAS DEPARTMENT OF WATER RESOURCES LIMITED PRINTING REPORT LP-142, 1981.

SPRINGS OF TEXAS, VOLUME 1: (BY GUNNAR BRUNE), BRANCHSMITH, INC., FORT WORTH, TEXAS, 1981.

BEDROCK GEOLOGY, ALTITUDE OF BASE, AND 1980 SATURATED THICKNESS OF THE HIGH PLAINS AQUIFER IN PARTS OF COLORADO, KANSAS, NEBRASKA, NEW MEXICO, OKLAHOMA, SOUTH DAKOTA, TEXAS, AND WYOMING: USGS HYDROLOGIC INVESTIGATIONS ATLAS HA-648, 1981.

WATER LEVEL AND SATURATED THICKNESS CHANGES, PREDEVELOPMENT TO 1980, IN THE HIGH PLAINS AQUIFER IN PARTS OF COLORADO, KANSAS, NEBRASKA, NEW MEXICO, OKLA-
HOMA, SOUTH DAKOTA, TEXAS, AND WYOMING: USGS HYDROLOGIC INVESTIGATIONS ATLAS HA-652, 1981.

INVESTIGATION OF THE FEASIBILITY OF SECONDARY RECOVERY OF GROUND WATER FROM THE OGALLALA AQUIFER. A REPORT TO THE 68TH TEXAS LEGISLATURE: TEXAS DEPARTMENT OF WATER RESOURCES LIMITED PRINTING REPORT LP-185, 1982.

DISSOLVED SOLIDS AND SODIUM IN WATER FROM THE HIGH PLAINS AQUIFER IN PARTS OF COLORADO, KANSAS, NEBRASKA, NEW MEXICO, OKLAHOMA, SOUTH DAKOTA, TEXAS, AND WYOMING: USGS HYDROLOGIC INVESTIGATIONS ATLAS HA-658, 1982.

EVALUATING THE GROUND-WATER RESOURCES OF THE HIGH PLAINS OF TEXAS, VOLUME 1: TEXAS DEPARTMENT OF WATER RESOURCES REPORT 288, V. 1, 1984.

EVALUATING THE GROUND-WATER RESOURCES OF THE HIGH PLAINS OF TEXAS, VOLUME 4, RECORDS OF WELLS, AND MAPS SHOWING WELL LOCATIONS, BASE OF AQUIFER, WATER LEVELS, AND SATURATED THICKNESS (ANDREWS, BORDEN, COCHRAN, DAWSON, ECTOR, GAINES, GARZA, GLASSCOCK, HOWARD, HOCKLEY, LUBBOCK, LYNN, MARTIN, MIDLAND, TERRY, AND YOAKUM COUNTIES: TEXAS DEPARTMENT OF WATER RESOURCES REPORT 288 V. 4, 1984.

GEOHYDROLOGY OF THE HIGH PLAINS AQUIFER IN PARTS OF COLORADO, KANSAS, NEBRASKA, NEW MEXICO, OKLAHOMA, SOUTH DAKOTA, TEXAS, AND WYOMING: USGS PROFESSIONAL PAPER 1400-B, 1984.

TEXAS GROUND-WATER RESOURCES, in NATIONAL WATER SUMMARY 1984: USGS WATER-SUPPLY PAPER 2275, 1985.

INVESTIGATION OF THE FEASIBILITY OF SECONDARY RECOVERY OF GROUND WATER FROM THE OGALLALA AQUIFER. A REPORT TO THE 69TH TEXAS LEGISLATURE: TEXAS WATER DEVELOPMENT BOARD LIMITED PRINTING REPORT LP-202, 1985.

DIGITAL SIMULATION OF GROUND-WATER FLOW IN THE HIGH PLAINS AQUIFER IN PARTS OF COLORADO, KANSAS, NEBRASKA, NEW MEXICO, OKLAHOMA, SOUTH DAKOTA, TEXAS, AND WYOMING: USGS PROFESSIONAL PAPER 1400-D, 1986.

HYDROLOGIC ATLAS FOR LYNN COUNTY, TEXAS: HIGH PLAINS UNDERGROUND WATER CONSERVATION DISTRICT NO. 1, 1987.

SUMMARY OF THE HIGH PLAINS REGIONAL AQUIFER-SYSTEM ANALYSIS IN PARTS OF COLORADO, KANSAS, NEBRASKA, NEW MEXICO, OKLAHOMA, SOUTH DAKOTA, TEXAS, AND WYOMING: USGS PROFESSIONAL PAPER 1400-A, 1988.

HYDROGEOLOGY AND HYDROCHEMISTRY OF CRETACEOUS AQUIFERS, TEXAS PANHANDLE AND EASTERN NEW MEXICO: UNIVERSITY OF TEXAS, BUREAU OF ECONOMIC GEOLOGY GEOLOGICAL CIRCULAR 88-3, 1988.

HYDROGEOLOGY OF LOWER CRETACEOUS STRATA UNDER THE SOUTHERN HIGH PLAINS OF TEXAS AND NEW MEXICO: TEXAS WATER DEVELOPMENT BOARD REPORT 314, 1989.

PUBLIC-SUPPLY GROUND-WATER USE IN THE SOUTHERN HIGH PLAINS OF TEXAS: TEXAS WATER DEVELOPMENT BOARD REPORT 328, 1990.

ORIGIN OF SOLUTES IN SALINE LAKES AND SPRINGS ON THE SOUTHERN HIGH PLAINS OF TEXAS AND NEW MEXICO, in GEOLOGIC FRAMEWORK AND REGIONAL HYDROLOGY: UPPER CENOZOIC BLACKWATER DRAW AND OGALLALA FORMATIONS, 
GREAT PLAINS: UNIVERSITY OF TEXAS, BUREAU OF ECONOMIC GEOLOGY SYMPOSIUM, LUBBOCK, TEXAS, OCTOBER 1-4, 1987, 1990.

EVALUATION OF GROUND-WATER RESOURCES IN THE SOUTHERN HIGH PLAINS OF TEXAS: TEXAS WATER DEVELOPMENT BOARD REPORT 330, 1991

WATER-LEVEL CHANGES IN THE HIGH PLAINS AQUIFER OF TEXAS, 1980-1990: TEXAS WATER DEVELOPMENT BOARD HYDROLOGIC ATLAS NO. 1, 1991.

THE HIGH PLAINS AQUIFER SYSTEM OF TEXAS, 1980 TO 1990. OVERVIEW AND PROJECTIONS: TEXAS WATER DEVELOPMENT BOARD REPORT 341, 1993.

WATER-QUALITY EVALUATION OF THE OGALLALA AQUIFER, TEXAS: TEXAS WATER DEVELOPMENT BOARD REPORT 342, 1993.

WATER-LEVEL CHANGES IN THE HIGH PLAINS AQUIFER, 1980 TO 1994: USGS FACT SHEET FS-215-95, 1995.

AQUIFERS OF TEXAS: TEXAS WATER DEVELOPMENT BOARD REPORT 345, 1995.

WATER-LEVEL CHANGES IN THE HIGH PLAINS AQUIFER, 1980 TO 1995: USGS FACT SHEET FS-068-97, 1997.

WATER-LEVEL CHANGES IN THE HIGH PLAINS AQUIFER-PREDEVELOPMENT TO 1995: USGS WATER-RESOURCES INVESTIGATIONS REPORT 97-4081, 1997.

UPDATED WATER-QUALITY EVALUATION OF THE OGALLALA AQUIFER INCLUDING SELECTED METALLIC AND NON-METALLIC INORGANIC CONSTITUENTS: TEXAS WATER DEVELOPMENT BOARD HYDROLOGIC ATLAS NO. 10, 1998.

\section{MADISON COUNTY}

UNDERGROUND WATERS OF COASTAL PLAIN OF TEXAS: USGS WATER SUPPLY AND IRRIGATION PAPER 190, 1907.

GEOLOGY AND UNDERGROUND WATERS OF THE SOUTHEASTERN PART OF THE TEXAS COASTAL PLAIN: USGS WATER-SUPPLY PAPER 335, 1914.

PUBLIC WATER SUPPLIES IN EASTERN TEXAS, V. 2, HARRISON COUNTY THROUGH WOOD COUNTY: TEXAS BOARD OF WATER ENGINEERS MISCELLANEOUS PUBLICATION 214, V. 2, 1945.

PUBLIC WATER SUPPLIES IN EASTERN TEXAS: USGS WATERSUPPLY PAPER 1047, 1948.

HYDROLOGIC SIGNIFICANCE OF THE LITHOFACIES OF THE SPARTA SAND IN ARKANSAS, LOUISIANA, MISSISSIPPI, AND TEXAS: USGS PROFESSIONAL PAPER 569-A, 1968.

GEOHYDROLOGIC SIGNIFICANCE OF LITHOFACIES OF THE COCKFIELD FORMATION OF LOUISIANA AND MISSISSIPPI AND OF THE YEGUA FORMATION OF TEXAS: USGS PROFESSIONAL PAPER 569-B, 1970.

HYDROLOGIC SIGNIFICANCE OF LITHOFACIES OF THE CANE RIVER FORMATION OR EQUIVALENTS OF ARKANSAS, LOUISIANA, MISSISSIPPI, AND TEXAS: USGS PROFESSIONAL PAPER 569-C, 1972
HYDROLOGIC SIGNIFICANCE OF LITHOFACIES OF THE CARRIZO SAND OF ARKANSAS, LOUISIANA, AND TEXAS AND THE MERIDIAN SAND OF MISSISSIPPI: USGS PROFESSIONAL PAPER 569-D, 1975.

SUMMARY APPRAISALS OF THE NATION'S GROUND-WATER RESOURCES-TEXAS-GULF REGION: USGS PROFESSIONAL PAPER 813-F, 1976.

TEXAS GROUND-WATER RESOURCES, in NATIONAL WATER SUMMARY 1984: USGS WATER-SUPPLY PAPER 2275, 1985.

APPROXIMATE POTENTIOMETRIC SURFACES FOR THE AQUIFERS OF THE TEXAS COASTAL UPLANDS SYSTEM, 1980: USGS HYDROLOGIC INVESTIGATIONS ATLAS HA-704, 1987.

GEOHYDROLOGIC FRAMEWORK OF THE GULF COASTAL PLAIN: USGS HYDROLOGIC INVESTIGATIONS ATLAS HA-695, 1988.

HYDROGEOLOGY AND PREDEVELOPMENT FLOW IN THE TEXAS GULF COAST AQUIFER SYSTEMS: USGS WATER-RESOURCES INVESTIGATIONS REPORT 87-4248, 1988.

GROUND-WATER FLOW IN THE GULF COAST AQUIFER SYSTEMS, SOUTH-CENTRAL UNITED STATES-A PRELIMINARY ANALYSIS USGS WATER-RESOURCES INVESTIGATIONS REPORT 89-4071, 1990.

NATIONAL WATER-QUALITY ASSESSMENT PROGRAM-THE TRINITY RIVER BASIN: USGS OPEN-FILE REPORT 91-158, 1991.

GROUND-WATER RESOURCES OF THE CARRIZO-WILCOX AQUIFER IN THE CENTRAL TEXAS REGION: TEXAS WATER DEVELOPMENT BOARD REPORT 332, 1991.

HYDROLOGY OF THE TEXAS GULF COAST AQUIFER SYSTEMS: USGS OPEN-FILE REPORT 91-64, 1991.

PROPERTIES AND CHEMICAL CONSTITUENTS IN GROUND WATER FROM THE UPPER CLAIBORNE AQUIFER, GULF COAST REGIONAL AQUIFER SYSTEMS, SOUTH-CENTRAL UNITED STATES: USGS WATER-RESOURCES INVESTIGATIONS REPORT 91-4150, 1993.

PROPERTIES AND CHEMICAL CONSTITUENTS IN GROUND WATER FROM THE LOWER CLAIBORNE-UPPER WILCOX AQUIFER, GULF COAST REGIONAL AQUIFER SYSTEMS, SOUTH-CENTRAL UNITED STATES: USGS WATER-RESOURCES INVESTIGATIONS REPORT 92-4102, 1993.

PROPERTIES AND CHEMICAL CONSTITUENTS IN GROUND WATER FROM THE MIDDLE CLAIBORNE AQUIFER, GULF COAST REGIONAL AQUIFER SYSTEMS, SOUTH-CENTRAL UNITED STATES: USGS WATER-RESOURCES INVESTIGATIONS REPORT 92-4104, 1993.

PROPERTIES AND CHEMICAL CONSTITUENTS IN GROUND WATER FROM THE MIDDLE WILCOX AQUIFER, GULF COAST AQUIFER SYSTEMS, SOUTH-CENTRAL UNITED STATES: USGS WATERRESOURCES INVESTIGATIONS REPORT 93-4070, 1993.

STRATIGRAPHIC NOMENCLATURE AND GEOLOGIC SECTIONS OF THE GULF COASTAL PLAIN OF TEXAS: USGS OPEN-FILE REPORT 94-461, 1995.

NATIONAL WATER-QUALITY ASSESSMENT PROGRAM-PESTICIDES IN THE TRINITY RIVER BASIN STUDY UNIT, TEXAS, 1968-91: USGS FACT SHEET FS-088-95, 1995.

WATER-QUALITY ASSESSMENT OF THE TRINITY RIVER BASIN, TEXAS-DATA COLLECTION, 1992-95: USGS FACT SHEET FS-095-95, 1995. 
WATER-QUALITY ASSESSMENT OF THE TRINITY RIVER BASIN, TEXAS-PESTICIDES IN A SUBURBAN WATERSHED, ARLINGTON, 1993-94: USGS FACT SHEET FS-159-95, 1995.

AQUIFERS OF TEXAS: TEXAS WATER DEVELOPMENT BOARD REPORT 345, 1995.

WATER QUALITY IN THE SPARTA AQUIFER, EAST TEXAS: TEXAS WATER DEVELOPMENT BOARD HYDROLOGIC ATLAS NO. 5, 1996.

WATER QUALITY IN THE QUEEN CITY AQUIFER, EAST TEXAS: TEXAS WATER DEVELOPMENT BOARD HYDROLOGIC ATLAS NO. 6, 1996.

\section{MARION COUNTY}

ARTESIAN WELLS OF THE COASTAL PRAIRIE REGION AND TERTIARY BELT OF TEXAS: GEOLOGICAL SURVEY OF TEXAS, CHAPTER 2, 1893.

UNDERGROUND WATERS OF COASTAL PLAIN OF TEXAS: USGS WATER SUPPLY AND IRRIGATION PAPER 190, 1907.

GEOLOGY AND UNDERGROUND WATERS OF THE SOUTHEASTERN PART OF THE TEXAS COASTAL PLAIN: USGS WATER-SUPPLY PAPER 335, 1914.

RECORDS OF WELLS, DRILLERS' LOGS, WATER ANALYSES, AND MAP SHOWING LOCATIONS OF WELLS IN MARION COUNTY, TEXAS: TEXAS BOARD OF WATER ENGINEERS MISCELLANEOUS PUBLICATION 179, 1943.

WATER RESOURCES OF MARION COUNTY, TEXAS: TEXAS BOARD OF WATER ENGINEERS MISCELLANEOUS PUBLICATION 180, 1943.

PUBLIC WATER SUPPLIES IN EASTERN TEXAS, V. 2, HARRISON COUNTY THROUGH WOOD COUNTY: TEXAS BOARD OF WATER ENGINEERS MISCELLANEOUS PUBLICATION 214, V. 2, 1945.

PUBLIC WATER SUPPLIES IN EASTERN TEXAS: USGS WATERSUPPLY PAPER 1047, 1948.

GEOHYDROLOGY OF THE PRINCIPAL WATER-BEARING FORMATIONS OF THE MISSISSIPPI EMBAYMENT (GEOLOGIC PHASE) TEXAS SECTION: USGS OPEN-FILE REPORT (UNNUMBERED), 1960.

RECONNAISSANCE INVESTIGATION OF THE GROUND-WATER RESOURCES OF THE RED RIVER, SULFUR RIVER, AND CYPRESS CREEK BASINS, TEXAS: TEXAS WATER COMMISSION BULLETIN 6306, 1963.

GENERAL GEOLOGY OF THE MISSISSIPPI EMBAYMENT: USGS PROFESSIONAL PAPER 448-B, 1964.

CRETACEOUS AQUIFERS OF THE MISSISSIPPI EMBAYMENT, WITH DISCUSSIONS OF QUALITY OF THE WATER: USGS PROFESSIONAL PAPER 448-C, 1965

TERTIARY AQUIFERS OF THE MISSISSIPPI EMBAYMENT, WITH DISCUSSIONS OF QUALITY OF THE WATER: USGS PROFESSIONAL PAPER 448-D, 1968.

QUATERNARY AQUIFERS IN THE MISSISSIPPI EMBAYMENT, WITH A DISCUSSION OF QUALITY OF THE WATER: USGS PROFESSIONAL PAPER 448-E, 1968.
COMPILATION OF RESULTS OF AQUIFER TESTS IN TEXAS: TEXAS WATER DEVELOPMENT BOARD REPORT 98, 1969.

GROUND-WATER RESOURCES OF CASS AND MARION COUNTIES, TEXAS: TEXAS WATER DEVELOPMENT BOARD REPORT 135, 1971.

SUMMARY APPRAISALS OF THE NATION'S GROUND-WATER RESOURCES-TEXAS-GULF REGION: USGS PROFESSIONAL PAPER 813-F, 1976.

SPRINGS OF TEXAS, VOLUME 1: (BY GUNNAR BRUNE), BRANCHSMITH, INC., FORT WORTH, TEXAS, 1981.

REGIONAL AQUIFER CHARACTERIZATION FOR DEEP-BASIN LIGNITE MINING, SABINE UPLIFT AREA, NORTHEAST TEXAS: UNIVERSITY OF TEXAS, BUREAU OF ECONOMIC GEOLOGY GEOLOGICAL CIRCULAR 83-3, 1983.

TEXAS GROUND-WATER RESOURCES, in NATIONAL WATER SUMMARY 1984: USGS WATER-SUPPLY PAPER 2275, 1985.

APPROXIMATE POTENTIOMETRIC SURFACES FOR THE AQUIFERS OF THE TEXAS COASTAL UPLANDS SYSTEM, 1980: USGS HYDROLOGIC INVESTIGATIONS ATLAS HA-704, 1987.

GEOHYDROLOGIC FRAMEWORK OF THE GULF COASTAL PLAIN: USGS HYDROLOGIC INVESTIGATIONS ATLAS HA-695, 1988.

HYDROGEOLOGY AND PREDEVELOPMENT FLOW IN THE TEXAS GULF COAST AQUIFER SYSTEMS: USGS WATER-RESOURCES INVESTIGATIONS REPORT 87-4248, 1988.

GROUND-WATER FLOW IN THE GULF COAST AQUIFER SYSTEMS, SOUTH-CENTRAL UNITED STATES-A PRELIMINARY ANALYSIS USGS WATER-RESOURCES INVESTIGATIONS REPORT 89-4071, 1990.

PROPERTIES AND CHEMICAL CONSTITUENTS IN GROUND WATER FROM THE LOWER CLAIBORNE-UPPER WILCOX AQUIFER, GULF COAST REGIONAL AQUIFER SYSTEMS, SOUTH-CENTRAL UNITED STATES: USGS WATER-RESOURCES INVESTIGATIONS REPORT 92-4102, 1993.

PROPERTIES AND CHEMICAL CONSTITUENTS IN GROUND WATER FROM THE MIDDLE CLAIBORNE AQUIFER, GULF COAST REGIONAL AQUIFER SYSTEMS, SOUTH-CENTRAL UNITED STATES: USGS WATER-RESOURCES INVESTIGATIONS REPORT 92-4104, 1993.

PROPERTIES AND CHEMICAL CONSTITUENTS IN GROUND WATER FROM THE MIDDLE WILCOX AQUIFER, GULF COAST AQUIFER SYSTEMS, SOUTH-CENTRAL UNITED STATES: USGS WATERRESOURCES INVESTIGATIONS REPORT 93-4070, 1993.

WATER-RESOURCES DATA, TEXAS, WATER YEAR 1992, VOLUME 4 GROUND-WATER DATA: USGS WATER-DATA REPORT TX-92-4, 1993.

AQUIFERS OF TEXAS: TEXAS WATER DEVELOPMENT BOARD REPORT 345, 1995.

WATER QUALITY IN THE QUEEN CITY AQUIFER, EAST TEXAS: TEXAS WATER DEVELOPMENT BOARD HYDROLOGIC ATLAS NO. 6, 1996 


\section{MARTIN COUNTY}

GEOLOGY AND GROUND-WATER RESOURCES OF THE SOUTHERN HIGH PLAINS: USGS OPEN-FILE REPORT (UNNUMBERED), 1935.

RECORDS OF WELLS, DRILLERS' LOGS, AND WATER ANALYSES, AND MAP SHOWING LOCATION OF WELLS IN MARTIN COUNTY, TEXAS: TEXAS BOARD OF WATER ENGINEERS MISCELLANEOUS PUBLICATION 181, 1936.

GEOLOGY AND GROUND-WATER RESOURCES OF MARTIN COUNTY, TEXAS: USGS OPEN-FILE REPORT (UNNUMBERED), 1936.

GROUND WATER IN THE SOUTHERN HIGH PLAINS: USGS OPENFILE REPORT (UNNUMBERED, 1937.

GROUND WATER IN THE HIGH PLAINS OF TEXAS: TEXAS BOARD OF WATER ENGINEERS MISCELLANEOUS PUBLICATION (UNNUMBERED), 1938.

GROUND WATER IN THE HIGH PLAINS OF TEXAS: TEXAS BOARD OF WATER ENGINEERS MISCELLANEOUS PUBLICATION 119, 1940.

PROGRESS REPORT ON GROUND WATER IN THE HIGH PLAINS OF TEXAS: TEXAS BOARD OF WATER ENGINEERS MISCELLANEOUS PUBLICATION (UNNUMBERED), 1942.

PROGRESS REPORT ON GROUND WATER IN THE HIGH PLAINS OF TEXAS: TEXAS BOARD OF WATER ENGINEERS MISCELLANEOUS PUBLICATION 120, 1943.

PROGRESS REPORT ON GROUND WATER IN THE HIGH PLAINS OF TEXAS: TEXAS BOARD OF WATER ENGINEERS MISCELLANEOUS PUBLICATION 121, 1944.

GROUND WATER IN THE HIGH PLAINS OF TEXAS, PROGRESS REPORT NO. 5: TEXAS BOARD OF WATER ENGINEERS MISCELLANEOUS PUBLICATION 122, 1945.

GROUND WATER IN THE HIGH PLAINS OF TEXAS: USGS WATERSUPPLY PAPER 889-F, 1946.

GROUND WATER IN HIGH PLAINS OF TEXAS, PROGRESS REPORT NO. 6: TEXAS BOARD OF WATER ENGINEERS MISCELLANEOUS PUBLICATION 123, 1947.

GEOLOGY AND GROUND WATER IN THE IRRIGATED REGION OF THE SOUTHERN HIGH PLAINS IN TEXAS, PROGRESS REPORT NO. 7: TEXAS BOARD OF WATER ENGINEERS MISCELLANEOUS PUBLICATION 125, 1949.

PUBLIC WATER SUPPLIES IN WESTERN TEXAS: TEXAS BOARD OF WATER ENGINEERS MISCELLANEOUS PUBLICATION 216, 1949.

COST OF PUMPING WATER FOR IRRIGATION, TEXAS HIGH PLAINS, FIELD INVESTIGATIONS-1947 IRRIGATION SEASON: TEXAS BOARD OF WATER ENGINEERS MISCELLANEOUS PUBLICATION 124, 1951.

DEVELOPMENT OF WELLS FOR IRRIGATION AND FLUCTUATION OF WATER LEVELS IN THE HIGH PLAINS OF TEXAS TO JANUARY 1951: TEXAS BOARD OF WATER ENGINEERS BULLETIN 5104, 1951.

PUBLIC WATER SUPPLIES IN WESTERN TEXAS: USGS WATERSUPPLY PAPER 1106, 1951 [1952].

SUMMARY OF GROUND-WATER DEVELOPMENT IN THE SOUTHERN HIGH PLAINS, TEXAS: TEXAS BOARD OF WATER ENGINEERS BULLETIN 5402, 1954.
RECORDS OF WATER-LEVEL MEASUREMENTS IN MARTIN COUNTY, TEXAS, 1936-1953: TEXAS BOARD OF WATER ENGINEERS BULLETIN 5405, 1954.

GROUND-WATER DEVELOPMENT IN THE SOUTHERN HIGH PLAINS OF TEXAS, 1953: TEXAS BOARD OF WATER ENGINEERS BULLETIN 5410, 1954.

WATER-LEVEL DECLINE MAPS OF 17 COUNTIES IN THE SOUTHERN HIGH PLAINS, TEXAS, JANUARY 1955 TO JANUARY 1956: TEXAS BOARD OF WATER ENGINEERS BULLETIN 5607, 1956.

WATER-LEVEL DECLINE MAPS, 1956 TO 1957, AND WATER LEVELS IN OBSERVATION WELLS IN 20 COUNTIES IN THE SOUTHERN HIGH PLAINS, TEXAS: TEXAS BOARD OF WATER ENGINEERS BULLETIN 5705, 1957.

A SUMMARY OF THE OCCURRENCE AND DEVELOPMENT OF GROUND WATER IN THE SOUTHERN HIGH PLAINS OF TEXAS: TEXAS BOARD OF WATER ENGINEERS BULLETIN 6107, 1961.

SHALLOW FORMATIONS AND AQUIFERS OF THE WEST TEXAS AREA: WEST TEXAS GEOLOGICAL SOCIETY PUBLICATION 61-45 AND PERMIAN BASIN GEOPHYSICAL SOCIETY, MIDLAND, TEXAS, 1961.

A SUMMARY OF THE OCCURRENCE AND DEVELOPMENT OF GROUND WATER IN THE SOUTHERN HIGH PLAINS OF TEXAS, WITH A SECTION ON ARTIFICIAL RECHARGE STUDIES: USGS WATER-SUPPLY PAPER 1693, 1964.

WATER-LEVEL DATA FROM OBSERVATION WELLS IN THE SOUTHERN HIGH PLAINS OF TEXAS: TEXAS WATER DEVELOPMENT BOARD REPORT 21, 1966.

RECONNAISSANCE INVESTIGATION OF THE GROUND-WATER RESOURCES OF THE COLORADO RIVER BASIN, TEXAS: TEXAS WATER COMMISSION REPORT 51, 1967.

GROUND WATER IN THE OGALLALA FORMATION IN THE SOUTHERN HIGH PLAINS OF TEXAS AND NEW MEXICO: USGS HYDROLOGIC INVESTIGATIONS ATLAS HA-330, 1969.

WATER-LEVEL DATA FROM OBSERVATION WELLS IN THE SOUTHERN HIGH PLAINS OF TEXAS, 1965-70: TEXAS WATER DEVELOPMENT BOARD REPORT 121, 1970

AN EVALUATION OF THE USE OF DRILLERS' LOGS IN LITHOLOGIC STUDIES OF THE OGALLALA FORMATION OF THE SOUTHERN HIGH PLAINS OF TEXAS: USGS OPEN-FILE REPORT 72-451, 1972.

MAJOR AND HISTORICAL SPRINGS OF TEXAS: TEXAS WATER DEVELOPMENT BOARD REPORT 189, 1975.

SUMMARY APPRAISALS OF THE NATION'S GROUND-WATER RESOURCES-TEXAS-GULF REGION: USGS PROFESSIONAL PAPER 813-F, 1976.

ARTIFICIAL GROUND-WATER RECHARGE AS A WATER-MANAGEMENT TECHNIQUE ON THE SOUTHERN HIGH PLAINS OF TEXAS AND NEW MEXICO: USGS OPEN-FILE REPORT 76-730, 1976.

WATER-LEVEL DATA FROM OBSERVATION WELLS IN THE SOUTHERN HIGH PLAINS OF TEXAS, 1971-77: TEXAS DEPARTMENT OF WATER RESOURCES REPORT 228, 1979.

PRELIMINARY DATA DESCRIBING THE DISTRIBUTION OF FLUORIDE AND SILICA IN THE OGALLALA AQUIFER ON THE HIGH PLAINS OF TEXAS: USGS OPEN-FILE REPORT 80-349, 1980.

EVALUATING THE GROUND-WATER RESOURCES OF THE HIGH PLAINS OF TEXAS: RESULTS OF TEST HOLE DRILLING: TEXAS 
DEPARTMENT OF WATER RESOURCES LIMITED PRINTING REPORT LP-129, 1980.

PRELIMINARY DATA FROM A SERIES OF ARTIFICIAL RECHARGE EXPERIMENTS AT STANTON, TEXAS: USGS OPEN-FILE REPORT 81-149, 1981.

SPRINGS OF TEXAS, VOLUME 1: (BY GUNNAR BRUNE), BRANCHSMITH, INC., FORT WORTH, TEXAS, 1981.

BEDROCK GEOLOGY, ALTITUDE OF BASE, AND 1980 SATURATED THICKNESS OF THE HIGH PLAINS AQUIFER IN PARTS OF COLORADO, KANSAS, NEBRASKA, NEW MEXICO, OKLAHOMA, SOUTH DAKOTA, TEXAS, AND WYOMING: USGS HYDROLOGIC INVESTIGATIONS ATLAS HA-648, 1981.

WATER LEVEL AND SATURATED THICKNESS CHANGES, PREDEVELOPMENT TO 1980, IN THE HIGH PLAINS AQUIFER IN PARTS OF COLORADO, KANSAS, NEBRASKA, NEW MEXICO, OKLAHOMA, SOUTH DAKOTA, TEXAS, AND WYOMING: USGS HYDROLOGIC INVESTIGATIONS ATLAS HA-652, 1981.

DISSOLVED SOLIDS AND SODIUM IN WATER FROM THE HIGH PLAINS AQUIFER IN PARTS OF COLORADO, KANSAS, NEBRASKA, NEW MEXICO, OKLAHOMA, SOUTH DAKOTA, TEXAS, AND WYOMING: USGS HYDROLOGIC INVESTIGATIONS ATLAS HA-658, 1982.

EVALUATING THE GROUND-WATER RESOURCES OF THE HIGH PLAINS OF TEXAS, VOLUME 1: TEXAS DEPARTMENT OF WATER RESOURCES REPORT 288, V. 1, 1984.

EVALUATING THE GROUND-WATER RESOURCES OF THE HIGH PLAINS OF TEXAS, VOLUME 4, RECORDS OF WELLS, AND MAPS SHOWING WELL LOCATIONS, BASE OF AQUIFER, WATER LEVELS, AND SATURATED THICKNESS (ANDREWS, BORDEN, COCHRAN, DAWSON, ECTOR, GAINES, GARZA, GLASSCOCK, HOWARD, HOCKLEY, LUBBOCK, LYNN, MARTIN, MIDLAND, TERRY, AND YOAKUM COUNTIES: TEXAS DEPARTMENT OF WATER RESOURCES REPORT 288 V. 4, 1984.

GEOHYDROLOGY OF THE HIGH PLAINS AQUIFER IN PARTS OF COLORADO, KANSAS, NEBRASKA, NEW MEXICO, OKLAHOMA, SOUTH DAKOTA, TEXAS, AND WYOMING: USGS PROFESSIONAL PAPER 1400-B, 1984.

TEXAS GROUND-WATER RESOURCES, in NATIONAL WATER SUMMARY 1984: USGS WATER-SUPPLY PAPER 2275, 1985.

DIGITAL SIMULATION OF GROUND-WATER FLOW IN THE HIGH PLAINS AQUIFER IN PARTS OF COLORADO, KANSAS, NEBRASKA, NEW MEXICO, OKLAHOMA, SOUTH DAKOTA, TEXAS, AND WYOMING: USGS PROFESSIONAL PAPER 1400-D, 1986.

SUMMARY OF THE HIGH PLAINS REGIONAL AQUIFER-SYSTEM ANALYSIS IN PARTS OF COLORADO, KANSAS, NEBRASKA, NEW MEXICO, OKLAHOMA, SOUTH DAKOTA, TEXAS, AND WYOMING: USGS PROFESSIONAL PAPER 1400-A, 1988.

HYDROGEOLOGY AND HYDROCHEMISTRY OF CRETACEOUS AQUIFERS, TEXAS PANHANDLE AND EASTERN NEW MEXICO: UNIVERSITY OF TEXAS, BUREAU OF ECONOMIC GEOLOGY GEOLOGICAL CIRCULAR 88-3, 1988.

HYDROGEOLOGY OF LOWER CRETACEOUS STRATA UNDER THE SOUTHERN HIGH PLAINS OF TEXAS AND NEW MEXICO: TEXAS WATER DEVELOPMENT BOARD REPORT 314, 1989.
PUBLIC SUPPLY GROUND-WATER USE IN THE SOUTHERN HIGH PLAINS OF TEXAS: TEXAS WATER DEVELOPMENT BOARD REPORT 328, 1990.

POTENTIOMETRIC SURFACE OF THE EDWARDS-TRINITY AQUIFER SYSTEM AND CONTIGUOUS HYDRAULICALLY CONNECTED UNITS, WEST-CENTRAL TEXAS, WINTER 1974-75: USGS WATERRESOURCES INVESTIGATIONS REPORT 89-4208, 1990.

WITHDRAWALS FROM THE EDWARDS-TRINITY AQUIFER SYSTEM AND CONTIGUOUS HYDRAULICALLY CONNECTED UNITS, WEST-CENTRAL TEXAS, DECEMBER 1974 THROUGH MARCH 1977: USGS WATER-RESOURCES INVESTIGATIONS REPORT 91-4021, 1991.

WATER-LEVEL CHANGES IN THE HIGH PLAINS AQUIFER OF TEXAS, 1980-1990: TEXAS WATER DEVELOPMENT BOARD HYDROLOGIC ATLAS NO. 1, 1991.

EVALUATION OF GROUND-WATER RESOURCES IN THE SOUTHERN HIGH PLAINS OF TEXAS: TEXAS WATER DEVELOPMENT BOARD REPORT 330, 1991.

CONFIGURATION OF THE BASE OF THE EDWARDS-TRINITY AQUIFER SYSTEM AND HYDROGEOLOGY OF THE UNDERLYING PRECRETACEOUS ROCKS, WEST-CENTRAL TEXAS: USGS WATERRESOURCES INVESTIGATIONS REPORT 91-4071, 1992.

HISTORICAL POTENTIOMETRIC SURFACE OF THE EDWARDS-TRINITY AQUIFER SYSTEM AND CONTIGUOUS HYDRAULICALLY CONNECTED UNITS, WEST-CENTRAL TEXAS: USGS WATERRESOURCES INVESTIGATIONS REPORT 92-4055, 1993.

HISTORICAL SATURATED THICKNESS OF THE EDWARDS-TRINITY AQUIFER SYSTEM AND SELECTED CONTIGUOUS HYDRAULICALLY CONNECTED UNITS, WEST-CENTRAL TEXAS: USGS WATER-RESOURCES INVESTIGATIONS REPORT 92-4125, 1993.

THE HIGH PLAINS AQUIFER SYSTEM OF TEXAS, 1980 TO 1990. OVERVIEW AND PROJECTIONS: TEXAS WATER DEVELOPMENT BOARD REPORT 341, 1993.

WATER-QUALITY EVALUATION OF THE OGALLALA AQUIFER, TEXAS: TEXAS WATER DEVELOPMENT BOARD REPORT 342, 1993.

SIMULATIONS OF FLOW IN THE EDWARDS-TRINITY AQUIFER SYSTEM AND CONTIGUOUS HYDRAULICALLY CONNECTED UNITS, WEST-CENTRAL TEXAS: USGS WATER-RESOURCES INVESTIGATIONS REPORT 93-4039, 1994.

DISSOLVED-SOLIDS CONCENTRATIONS AND HYDROCHEMICAL FACIES IN WATER OF THE EDWARDS-TRINITY AQUIFER SYSTEM, WEST-CENTRAL TEXAS: USGS WATER-RESOURCES INVESTIGATIONS REPORT 93-4126, 1994

WATER-LEVEL CHANGES IN THE HIGH PLAINS AQUIFER-PREDEVELOPMENT TO 1992: USGS WATER-RESOURCES INVESTIGATIONS REPORT 94-4027, 1994.

GEOLOGIC HISTORY AND HYDROGEOLOGIC SETTING OF THE EDWARDS-TRINITY AQUIFER SYSTEM, WEST-CENTRAL TEXAS: USGS WATER-RESOURCES INVESTIGATIONS REPORT 94-4039, 1994.

WATER QUALITY IN THE EDWARDS-TRINITY (PLATEAU) AQUIFER, EDWARDS PLATEAU AND TRANS-PECOS, TEXAS: TEXAS WATER DEVELOPMENT BOARD HYDROLOGIC ATLAS NO. 3, 1995.

WATER-LEVEL CHANGES IN THE HIGH PLAINS AQUIFER, 1980 TO 1994: USGS FACT SHEET FS-215-95, 1995. 
AQUIFERS OF TEXAS: TEXAS WATER DEVELOPMENT BOARD REPORT 345, 1995.

WATER-LEVEL CHANGES IN THE HIGH PLAINS AQUIFER, 1980 TO 1995: USGS FACT SHEET FS-068-97, 1997.

WATER-LEVEL CHANGES IN THE HIGH PLAINS AQUIFER-PREDEVELOPMENT TO 1995: USGS WATER-RESOURCES INVESTIGATIONS REPORT 97-4081, 1997.

UPDATED WATER-QUALITY EVALUATION OF THE OGALLALA AQUIFER INCLUDING SELECTED METALLIC AND NON-METALLIC INORGANIC CONSTITUENTS: TEXAS WATER DEVELOPMENT BOARD HYDROLOGIC ATLAS NO. 10, 1998.

AN OVERVIEW OF THE EDWARDS-TRINITY AQUIFER SYSTEM, CENTRAL-WEST TEXAS, CHAPTER 8, in AQUIFERS OF WEST TEXAS: TEXAS WATER DEVELOPMENT BOARD REPORT 356, 2001.

\section{MASON COUNTY}

RECORDS OF WELLS AND SPRINGS, DRILLERS' LOGS, WATER ANALYSES, AND MAP SHOWING LOCATION OF WELLS AND SPRINGS IN MASON COUNTY, TEXAS: TEXAS BOARD OF WATER ENGINEERS MISCELLANEOUS PUBLICATION 182, 1940.

GROUND-WATER CONDITIONS IN THE VICINITY OF MASON, MASON COUNTY, TEXAS: USGS OPEN-FILE REPORT (UNNUMBERED), 1947.

RECONNAISSANCE INVESTIGATION OF THE GROUND-WATER RESOURCES OF THE COLORADO RIVER BASIN, TEXAS: TEXAS WATER DEVELOPMENT BOARD REPORT 51, 1967.

COMPILATION OF RESULTS OF AQUIFER TESTS IN TEXAS: TEXAS WATER DEVELOPMENT BOARD REPORT 98, 1969.

MAJOR AND HISTORICAL SPRINGS OF TEXAS: TEXAS WATER DEVELOPMENT BOARD REPORT 189, 1975.

SUMMARY APPRAISALS OF THE NATION'S GROUND-WATER RESOURCES-TEXAS-GULF REGION: USGS PROFESSIONAL PAPER 813-F, 1976.

OCCURRENCE, AVAILABILITY, AND CHEMICAL QUALITY OF GROUND WATER IN THE EDWARDS PLATEAU REGION OF TEXAS: TEXAS DEPARTMENT OF WATER RESOURCES REPORT $235,1979$.

TEXAS GROUND-WATER RESOURCES, in NATIONAL WATER SUMMARY 1984: USGS WATER-SUPPLY PAPER 2275, 1985.

HYDROGEOLOGY OF THE HICKORY SANDSTONE AQUIFER, UPPER CAMBRIAN RILEY FORMATION, MASON AND MCCULLOCH COUNTIES, TEXAS: UNIVERSITY OF TEXAS AT AUSTIN MASTER'S THESIS, 1988 .

POTENTIOMETRIC SURFACE OF THE EDWARDS-TRINITY AQUIFER SYSTEM AND CONTIGUOUS HYDRAULICALLY CONNECTED UNITS, WEST-CENTRAL TEXAS, WINTER 1974-75: USGS WATERRESOURCES INVESTIGATIONS REPORT 89-4208, 1990.

WITHDRAWALS FROM THE EDWARDS-TRINITY AQUIFER SYSTEM AND CONTIGUOUS HYDRAULICALLY CONNECTED UNITS, WEST-CENTRAL TEXAS, DECEMBER 1974 THROUGH MARCH 1977: USGS WATER-RESOURCES INVESTIGATIONS REPORT 91-4021, 1991.
CONFIGURATION OF THE BASE OF THE EDWARDS-TRINITY AQUIFER SYSTEM AND HYDROGEOLOGY OF THE UNDERLYING PRECRETACEOUS ROCKS, WEST-CENTRAL TEXAS: USGS WATERRESOURCES INVESTIGATIONS REPORT 91-4071, 1992.

HISTORICAL POTENTIOMETRIC SURFACE OF THE EDWARDS-TRINITY AQUIFER SYSTEM AND CONTIGUOUS HYDRAULICALLY CONNECTED UNITS, WEST-CENTRAL TEXAS: USGS WATERRESOURCES INVESTIGATIONS REPORT 92-4055, 1993.

HISTORICAL SATURATED THICKNESS OF THE EDWARDS-TRINITY AQUIFER SYSTEM AND SELECTED CONTIGUOUS HYDRAULICALLY CONNECTED UNITS, WEST-CENTRAL TEXAS: USGS WATER-RESOURCES INVESTIGATIONS REPORT 92-4125, 1993.

SIMULATIONS OF FLOW IN THE EDWARDS-TRINITY AQUIFER SYSTEM AND CONTIGUOUS HYDRAULICALLY CONNECTED UNITS, WEST-CENTRAL TEXAS: USGS WATER-RESOURCES INVESTIGATIONS REPORT 93-4039, 1994.

DISSOLVED-SOLIDS CONCENTRATIONS AND HYDROCHEMICAL FACIES IN WATER OF THE EDWARDS-TRINITY AQUIFER SYSTEM, WEST-CENTRAL TEXAS: USGS WATER-RESOURCES INVESTIGATIONS REPORT 93-4126, 1994.

GEOLOGIC HISTORY AND HYDROGEOLOGIC SETTING OF THE EDWARDS-TRINITY AQUIFER SYSTEM, WEST-CENTRAL TEXAS: USGS WATER-RESOURCES INVESTIGATIONS REPORT 94-4039, 1994.

WATER QUALITY IN THE EDWARDS-TRINITY (PLATEAU) AQUIFER, EDWARDS PLATEAU AND TRANS-PECOS, TEXAS: TEXAS WATER DEVELOPMENT BOARD HYDROLOGIC ATLAS NO. 3, 1995.

AQUIFERS OF TEXAS: TEXAS WATER DEVELOPMENT BOARD REPORT 345, 1995.

THE PALEOZOIC AND RELATED AQUIFERS OF CENTRAL TEXAS: TEXAS WATER DEVELOPMENT BOARD REPORT 346, 1996.

HYDROGEOLOGIC FRAMEWORK OF THE EDWARDS-TRINITY AQUIFER SYSTEM, WEST-CENTRAL TEXAS: USGS PROFESSIONAL PAPER 1421-B, 1996.

AN OVERVIEW OF THE EDWARDS-TRINITY AQUIFER SYSTEM, CENTRAL-WEST TEXAS, CHAPTER 8, in AQUIFERS OF WEST TEXAS: TEXAS WATER DEVELOPMENT BOARD REPORT 356, 2001.

\section{MATAGORDA COUNTY}

UNDERGROUND WATERS OF THE COASTAL PLAIN OF TEXAS: USGS WATER-SUPPLY PAPER 190, 1907.

RECORDS OF WELLS, DRILLERS' LOGS, AND WATER ANALYSES, AND MAP SHOWING LOCATION OF WELLS IN MATAGORDA COUNTY, TEXAS: USGS OPEN-FILE REPORT (UNNUMBERED), 1935.

MEMORANDUM ON GROUND-WATER SUPPLY OF MATAGORDA PENINSULA FLYING FIELD: USGS OPEN-FILE REPORT (UNNUMBERED), 1943.

RECORDS OF WELLS, DRILLERS' LOGS, WATER ANALYSES, AND MAP SHOWING LOCATIONS OF WELLS IN MATAGORDA COUNTY, TEXAS: TEXAS BOARD OF WATER ENGINEERS MISCELLANEOUS PUBLICATION 183, 1944. 
PUBLIC WATER SUPPLIES IN EASTERN TEXAS, V. 2, HARRISON COUNTY THROUGH WOOD COUNTY: TEXAS BOARD OF WATER ENGINEERS MISCELLANEOUS PUBLICATION 214, V. 2, 1945.

PUBLIC WATER SUPPLIES IN EASTERN TEXAS: USGS WATERSUPPLY PAPER 1047, 1948.

GROUND-WATER RESOURCES OF MATAGORDA COUNTY, TEXAS: TEXAS BOARD OF WATER ENGINEERS MISCELLANEOUS PUBLICATION 184, 1949.

AVAILABILITY OF GROUND WATER IN THE GULF COAST REGION OF TEXAS: USGS OPEN-FILE REPORT (UNNUMBERED), 1956.

RECORDS OF WATER-LEVEL MEASUREMENTS IN JACKSON, MATAGORDA, AND WHARTON COUNTIES, TEXAS, 1934 TO APRIL 1958: TEXAS BOARD OF WATER ENGINEERS BULLETIN 5804, 1958.

RECONNAISSANCE INVESTIGATION OF THE GROUND-WATER RESOURCES OF THE GULF COAST REGION, TEXAS: TEXAS WATER COMMISSION BULLETIN 6305, 1963.

GROUND-WATER RESOURCES OF JACKSON COUNTY, TEXAS: TEXAS WATER DEVELOPMENT BOARD REPORT 1, 1965.

GROUND-WATER RESOURCES OF MATAGORDA COUNTY, TEXAS: TEXAS WATER DEVELOPMENT BOARD REPORT 91, 1969.

GEOLOGIC AND HYDROLOGIC SUMMARY OF SALT DOMES IN GULF COAST REGION OF TEXAS, LOUISIANA, AND ALABAMA: USGS OPEN-FILE REPORT 73-07, 1973.UP

SUMMARY APPRAISALS OF THE NATION'S GROUND-WATER RESOURCES-TEXAS-GULF REGION: USGS PROFESSIONAL PAPER 813-F, 1976.

STRATIGRAPHIC AND HYDROGEOLOGIC FRAMEWORK OF PART OF THE COASTAL PLAIN OF TEXAS: USGS OPEN-FILE REPORT $77-712,1978$

STRATIGRAPHIC AND HYDROGEOLOGIC FRAMEWORK OF PART OF THE COASTAL PLAIN OF TEXAS: TEXAS DEPARTMENT OF WATER RESOURCES REPORT 236, 1979.

LAND-SURFACE SUBSIDENCE IN THE TEXAS COASTAL REGION: USGS OPEN-FILE REPORT 80-969, 1980.

SPRINGS OF TEXAS, VOLUME 1: (BY GUNNAR BRUNE), BRANCHSMITH, INC., FORT WORTH, TEXAS, 1981.

LAND-SURFACE SUBSIDENCE IN THE TEXAS COASTAL REGION: TEXAS DEPARTMENT OF WATER RESOURCES REPORT 272, 1982.

TEXAS GROUND-WATER RESOURCES, in NATIONAL WATER SUMMARY 1984: USGS WATER-SUPPLY PAPER 2275, 1985.

DIGITAL MODELS FOR SIMULATION OF GROUND-WATER HYDROLOGY OF THE CHICOT AND EVANGELINE AQUIFERS ALONG THE GULF COAST OF TEXAS: TEXAS DEPARTMENT OF WATER RESOURCES REPORT 289, 1985.

GEOHYDROLOGIC FRAMEWORK OF THE GULF COASTAL PLAIN: USGS HYDROLOGIC INVESTIGATIONS ATLAS HA-695, 1988

HYDROGEOLOGY AND PREDEVELOPMENT FLOW IN THE TEXAS GULF COAST AQUIFER SYSTEMS: USGS WATER-RESOURCES INVESTIGATIONS REPORT 87-4248, 1988.

FLOW PATTERN IN REGIONAL AQUIFERS AND FLOW RELATIONS BETWEEN THE LOWER COLORADO RIVER VALLEY AND REGIONAL AQUIFERS IN SIX COUNTIES OF SOUTHEASTERN
TEXAS: USGS WATER-RESOURCES INVESTIGATIONS REPORT 88-4154, 1989.

GROUND-WATER FLOW IN THE GULF COAST AQUIFER SYSTEMS, SOUTH-CENTRAL UNITED STATES: USGS WATER-RESOURCES INVESTIGATIONS REPORT 89-4071, 1990.

SALT-DOME LOCATIONS IN THE GULF COASTAL PLAIN, SOUTHCENTRAL UNITED STATES: USGS WATER-RESOURCES INVESTIGATIONS REPORT 90-4060, 1990.

HYDROLOGY OF THE TEXAS GULF COAST AQUIFER SYSTEMS: USGS OPEN-FILE REPORT 91-64, 1991.

PROPERTIES AND CHEMICAL CONSTITUENTS IN GROUND WATER FROM THE MISSISSIPPI RIVER VALLEY ALLUVIAL AQUIFER AND PERMEABLE ZONE A (HOLOCENE-UPPER PLEISTOCENE DEPOSITS), SOUTH-CENTRAL UNITED STATES: USGS WATERRESOURCES INVESTIGATIONS REPORT 91-4149, 1992.

PROPERTIES AND CHEMICAL CONSTITUENTS IN GROUND WATER FROM THE UPPER CLAIBORNE AQUIFER, GULF COAST REGIONAL AQUIFER SYSTEMS, SOUTH-CENTRAL UNITED STATES: USGS WATER-RESOURCES INVESTIGATIONS REPORT 91-4150, 1993.

PROPERTIES AND CHEMICAL CONSTITUENTS IN GROUND WATER FROM PERMEABLE ZONE C (LOWER PLIOCENE-UPPER MIOCENE DEPOSITS), COASTAL LOWLANDS AQUIFER SYSTEM, SOUTHCENTRAL UNITED STATES: USGS WATER-RESOURCES INVESTIGATIONS REPORT 91-4151, 1993.

PROPERTIES AND CHEMICAL CONSTITUENTS IN GROUND WATER FROM PERMEABLE ZONE B (LOWER PLEISTOCENE-UPPER PLIOCENE DEPOSITS), COASTAL LOWLANDS AQUIFER SYSTEM, SOUTH-CENTRAL UNITED STATES: USGS WATER-RESOURCES INVESTIGATIONS REPORT 91-4152, 1993.

PROPERTIES AND CHEMICAL CONSTITUENTS IN GROUND WATER FROM PERMEABLE ZONE E (LOWER MIOCENE-UPPER OLIGOCENE DEPOSITS), COASTAL LOWLANDS AQUIFER SYSTEM, SOUTH-CENTRAL UNITED STATES: USGS WATER-RESOURCES INVESTIGATIONS REPORT 92-4103, 1993.

PROPERTIES AND CHEMICAL CONSTITUENTS IN GROUND WATER FROM PERMEABLE ZONE D (MIDDLE MIOCENE DEPOSITS), COASTAL LOWLANDS AQUIFER SYSTEM, SOUTH-CENTRAL UNITED STATES: USGS WATER-RESOURCES INVESTIGATIONS REPORT 92-4105, 1993

AQUIFERS OF TEXAS: TEXAS WATER DEVELOPMENT BOARD REPORT 345, 1995.

\section{MAVERICK COUNTY}

GEOLOGY OF THE EDWARDS PLATEAU AND RIO GRANDE PLAIN ADJACENT TO AUSTIN AND SAN ANTONIO, TEXAS, WITH REFERENCE TO THE OCCURRENCE OF UNDERGROUND WATERS: USGS 18TH ANNUAL REPORT, PART 2, 1898.

UNDERGROUND WATERS OF COASTAL PLAIN OF TEXAS: USGS WATER-SUPPLY AND IRRIGATION PAPER 190, 1907.

GROUND WATER IN THE WINTER GARDEN AND ADJACENT DISTRICTS IN SOUTHWESTERN TEXAS: USGS OPEN-FILE REPORT (UNNUMBERED), 1931 
RECORDS OF WELLS AND WATER-LEVEL FLUCTUATIONS IN OBSERVATION WELLS IN DIMMIT, ZAVALA, AND EASTERN MAVERICK COUNTIES, TEXAS: USGS OPEN-FILE REPORT (UNNUMBERED), 1934.

WELLS IN WINTER GARDEN DISTRICT IN DIMMIT AND ZAVALA COUNTIES AND EASTERN MAVERICK COUNTY, TEXAS (RECORDS OF WELLS, DRILLERS' LOGS, WATER ANALYSES, AND MAPS SHOWING LOCATION OF WELLS): TEXAS BOARD OF WATER ENGINEERS MISCELLANEOUS PUBLICATION 302, 1940.

PUBLIC WATER SUPPLIES IN SOUTHERN TEXAS: TEXAS BOARD OF WATER ENGINEERS MISCELLANEOUS PUBLICATION 215, 1946.

WATER SUPPLY IN THE CARRIZO SAND IN DIMMIT COUNTY, TEXAS: USGS OPEN-FILE REPORT (UNNUMBERED), 1948.

SUPPLEMENTARY REPORT ON SURFACE-WATER AND GROUNDWATER SURVEYS, NUECES RIVER BASIN, TEXAS: USGS OPENFILE REPORT (UNNUMBERED), 1950.

PUBLIC WATER SUPPLIES IN SOUTHERN TEXAS: USGS WATERSUPPLY PAPER 1070, 1950.

WINTER GARDEN DISTRICT DIMMIT AND ZAVALA COUNTIES AND EASTERN MAVERICK COUNTY, TEXAS (RECORDS OF WELLS, DRILLERS' LOGS, WATER ANALYSES, AND MAP SHOWING LOCATIONS OF WELLS): TEXAS BOARD OF WATER ENGINEERS BULLETIN 5203, 1952.

RECORDS OF WATER-LEVEL MEASUREMENTS IN DIMMIT, MAVERICK, AND ZAVALA COUNTIES, TEXAS, 1920, 1928 TO SEPTEMBER 1956: TEXAS BOARD OF WATER ENGINEERS BULLETIN 5617, 1956.

DEVELOPMENT OF GROUND WATER FROM THE CARRIZO SAND AND WILCOX GROUP IN DIMMIT, ZAVALA, MAVERICK, FRIO, ATASCOSA, MEDINA, BEXAR, LIVE OAK, McMULLEN, LA SALLE, AND WEBB COUNTIES, TEXAS: USGS OPEN-FILE REPORT 57-77, 1957.

GEOLOGY AND GROUND-WATER RESOURCES OF DIMMIT COUNTY, TEXAS: TEXAS BOARD OF WATER ENGINEERS BULLETIN 6003, 1960.

RECONNAISSANCE INVESTIGATION OF THE GROUND-WATER RESOURCES OF THE GUADALUPE, SAN ANTONIO, AND NUECES RIVER BASINS, TEXAS: TEXAS WATER COMMISSION BULLETIN 6409, 1964.

CARRIZO SAND APPRAISAL STUDY, MAVERICK AND WEBB COUNTIES, TEXAS: USGS OPEN-FILE REPORT, 1965.

RECONNAISSANCE INVESTIGATIONS OF THE GROUND-WATER RESOURCES OF THE RIO GRANDE BASIN, TEXAS: TEXAS WATER COMMISSION BULLETIN 6502, 1965.

WATER-LEVEL DATA FROM OBSERVATION WELLS IN THE NORTHWESTERN GULF COASTAL PLAIN OF TEXAS: TEXAS WATER DEVELOPMENT BOARD REPORT 70, 1968.

COMPILATION OF RESULTS OF AQUIFER TESTS IN TEXAS: TEXAS WATER DEVELOPMENT BOARD REPORT 98, 1969.

RECONNAISSANCE INVESTIGATION OF GROUND WATER IN THE RIO GRANDE DRAINAGE BASIN-WITH SPECIAL EMPHASIS ON SALINE GROUND-WATER RESOURCES: USGS HYDROLOGIC INVESTIGATIONS ATLAS HA-510, 1974.

MAJOR AND HISTORICAL SPRINGS OF TEXAS: TEXAS WATER DEVELOPMENT BOARD REPORT 189, 1975.
GROUND-WATER RESOURCES OF THE CARRIZO AQUIFER IN THE WINTER GARDEN AREA OF TEXAS, VOLUME 1: TEXAS WATER DEVELOPMENT BOARD REPORT 210, V. 1, 1976.

GROUND-WATER RESOURCES OF THE CARRIZO AQUIFER IN THE WINTER GARDEN AREA OF TEXAS, VOLUME 2: TEXAS WATER DEVELOPMENT BOARD REPORT 210, V. 2, 1977.

VARIATIONS IN SPECIFIC YIELD IN THE OUTCROP OF THE CARRIZO SAND IN SOUTH TEXAS AS ESTIMATED BY SEISMIC REFRACTION: TEXAS DEPARTMENT OF WATER RESOURCES REPORT 229, 1979.

SPRINGS OF TEXAS, VOLUME 1: (BY GUNNAR BRUNE), BRANCHSMITH, INC., FORT WORTH, TEXAS, 1981.

STRUCTURE, TEMPERATURE, PRESSURE, AND SALINITY OF CENOZOIC AQUIFERS OF SOUTH TEXAS: USGS HYDROLOGIC INVESTIGATIONS ATLAS HA-654, 1983.

TEXAS GROUND-WATER RESOURCES, in NATIONAL WATER SUMMARY 1984: USGS WATER-SUPPLY PAPER 2275, 1985.

APPROXIMATE POTENTIOMETRIC SURFACES FOR THE AQUIFERS OF THE TEXAS COASTAL UPLANDS SYSTEM, 1980: USGS HYDROLOGIC INVESTIGATIONS ATLAS HA-704, 1987.

GEOHYDROLOGIC FRAMEWORK OF THE GULF COASTAL PLAIN: USGS HYDROLOGIC INVESTIGATIONS ATLAS HA-695, 1988.

DEPOSITIONAL AND GROUND-WATER FLOW SYSTEMS OF THE CARRIZO-UPPER WILCOX, SOUTH TEXAS: UNIVERSITY OF TEXAS, BUREAU OF ECONOMIC GEOLOGY REPORT OF INVESTIGATIONS NO. 175, 1988.

HYDROGEOLOGY AND PREDEVELOPMENT FLOW IN THE TEXAS GULF COAST AQUIFER SYSTEMS: USGS WATER-RESOURCES INVESTIGATIONS REPORT 87-4248, 1988.

GROUND-WATER FLOW IN THE GULF COAST AQUIFER SYSTEMS, SOUTH-CENTRAL UNITED STATES-A PRELIMINARY ANALYSIS: USGS WATER-RESOURCES INVESTIGATIONS REPORT 89-4071, 1990.

HYDROLOGY OF THE TEXAS GULF COAST AQUIFER SYSTEMS USGS OPEN-FILE REPORT 91-64, 1991.

EVALUATION OF THE GROUND-WATER RESOURCES IN THE WESTERN PORTION OF THE WINTER GARDEN AREA, TEXAS: TEXAS WATER DEVELOPMENT BOARD REPORT 334, 1991.

GROUND-WATER QUALITY MONITORING RESULTS IN THE WINTER GARDEN AREA, 1990: TEXAS WATER DEVELOPMENT BOARD REPORT 335, 1992.

PROPERTIES AND CHEMICAL CONSTITUENTS IN GROUND WATER FROM THE LOWER CLAIBORNE-UPPER WILCOX AQUIFER, GULF COAST REGIONAL AQUIFER SYSTEMS, SOUTH-CENTRAL UNITED STATES: USGS WATER-RESOURCES INVESTIGATIONS REPORT 92-4102, 1993.

PROPERTIES AND CHEMICAL CONSTITUENTS IN GROUND-WATER FROM THE MIDDLE CLAIBORNE AQUIFER, GULF COAST REGIONAL AQUIFER SYSTEMS, SOUTH-CENTRAL UNITED STATES: USGS WATER-RESOURCES INVESTIGATIONS REPORT 92-4104, 1993.

PROPERTIES AND CHEMICAL CONSTITUENTS IN GROUND WATER FROM THE MIDDLE WILCOX AQUIFER, GULF COAST REGIONAL AQUIFER SYSTEMS, SOUTH-CENTRAL UNITED STATES: USGS WATER-RESOURCES INVESTIGATIONS REPORT 93-4070, 1993. 
AQUIFERS OF TEXAS: TEXAS WATER DEVELOPMENT BOARD REPORT 345, 1995.

STRATIGRAPHIC NOMENCLATURE AND GEOLOGIC SECTIONS OF THE GULF COASTAL PLAIN OF TEXAS: USGS OPEN-FILE REPORT, 1995.

HYDROGEOLOGIC FRAMEWORK AND GEOCHEMISTRY OF THE EDWARDS AQUIFER SALINE-WATER ZONE, SOUTH-CENTRAL TEXAS: USGS WATER-RESOURCES INVESTIGATIONS REPORT 97-4133, 1997.

WATER QUALITY IN SOUTH-CENTRAL TEXAS—TEXAS, 1996-98: USGS CIRCULAR 1212, 2000.

\section{McCULLOCH COUNTY}

WATER RESOURCES IN THE VICINITY OF MELVIN, MCCULLOCH COUNTY, AND MENARD, MENARD COUNTY, TEXAS: USGS OPENFILE REPORT (UNNUMBERED), 1942.

GROUND WATER NEAR HICO, GATESVILLE, BRADY, KERRVILLE, AND PLAINVIEW, TEXAS: USGS OPEN-FILE REPORT (UNNUMBERED), 1942.

CITY OF BRADY, PUBLIC SUPPLY, WELLS 1 AND 2: USGS OPEN-FILE REPORT (UNNUMBERED), 1943.

GROUND WATER AT BRADY, McCULLOCH COUNTY, TEXAS: USGS OPEN-FILE REPORT (UNNUMBERED), 1943.

PUBLIC WATER SUPPLIES IN CENTRAL AND NORTH-CENTRAL TEXAS: USGS WATER-SUPPLY PAPER 1069, 1949.

MEMORANDUM FOR PUMPING TEST, McCULLOCH COUNTY, CITY OF BRADY, TEXAS, FEB. 25, 1958 TO MARCH 1, 1958: USGS OPENFILE REPORT (UNNUMBERED), 1958.

GROUND-WATER GEOLOGY OF THE HICKORY SANDSTONE MEMBER OF THE RILEY FORMATION, MCCULLOCH COUNTY, TEXAS: TEXAS BOARD OF WATER ENGINEERS BULLETIN 6017, 1961.

RECONNAISSANCE INVESTIGATION OF THE GROUND-WATER RESOURCES OF THE COLORADO RIVER BASIN, TEXAS: TEXAS WATER DEVELOPMENT BOARD REPORT 51, 1967.

COMPILATION OF RESULTS OF AQUIFER TESTS IN TEXAS: TEXAS WATER DEVELOPMENT BOARD REPORT 98, 1969.

MAJOR AND HISTORICAL SPRINGS OF TEXAS: TEXAS WATER DEVELOPMENT BOARD REPORT 189, 1975.

SUMMARY APPRAISALS OF THE NATION'S GROUND-WATER RESOURCES-TEXAS-GULF REGION: USGS PROFESSIONAL PAPER 813-F, 1976.

OCCURRENCE, AVAILABILITY, AND CHEMICAL QUALITY OF GROUND WATER IN THE EDWARDS PLATEAU REGION OF TEXAS: TEXAS DEPARTMENT OF WATER RESOURCES REPORT 235, 1979.

TEXAS GROUND-WATER RESOURCES, in NATIONAL WATER SUMMARY 1984: USGS WATER-SUPPLY PAPER 2275, 1985.

HYDROGEOLOGY OF THE HICKORY SANDSTONE AQUIFER, UPPER CAMBRIAN RILEY FORMATION, MASON AND MCCULLOCH COUNTIES, TEXAS: UNIVERSITY OF TEXAS AT AUSTIN MASTER'S THESIS, 1988
POTENTIOMETRIC SURFACE OF THE EDWARDS-TRINITY AQUIFER SYSTEM AND CONTIGUOUS HYDRAULICALLY CONNECTED UNITS, WEST-CENTRAL TEXAS, WINTER 1974-75: USGS WATERRESOURCES INVESTIGATIONS REPORT 89-4208, 1990.

WITHDRAWALS FROM THE EDWARDS-TRINITY AQUIFER SYSTEM AND CONTIGUOUS HYDRAULICALLY CONNECTED UNITS, WEST-CENTRAL TEXAS, DECEMBER 1974 THROUGH MARCH 1977: USGS WATER-RESOURCES INVESTIGATIONS REPORT 91-4021, 1991.

CONFIGURATION OF THE BASE OF THE EDWARDS-TRINITY AQUIFER SYSTEM AND HYDROGEOLOGY OF THE UNDERLYING PRECRETACEOUS ROCKS, WEST-CENTRAL TEXAS: USGS WATERRESOURCES INVESTIGATIONS REPORT 91-4071, 1992.

HISTORICAL POTENTIOMETRIC SURFACE OF THE EDWARDS-TRINITY AQUIFER SYSTEM AND CONTIGUOUS HYDRAULICALLY CONNECTED UNITS, WEST-CENTRAL TEXAS: USGS WATERRESOURCES INVESTIGATIONS REPORT 92-4055, 1993.

HISTORICAL SATURATED THICKNESS OF THE EDWARDS-TRINITY AQUIFER SYSTEM AND SELECTED CONTIGUOUS HYDRAULICALLY CONNECTED UNITS, WEST-CENTRAL TEXAS: USGS WATER-RESOURCES INVESTIGATIONS REPORT 92-4125, 1993.

SIMULATIONS OF FLOW IN THE EDWARDS-TRINITY AQUIFER SYSTEM AND CONTIGUOUS HYDRAULICALLY CONNECTED UNITS, WEST-CENTRAL TEXAS: USGS WATER-RESOURCES INVESTIGATIONS REPORT 93-4039, 1994.

DISSOLVED-SOLIDS CONCENTRATIONS AND HYDROCHEMICAL FACIES IN WATER OF THE EDWARDS-TRINITY AQUIFER SYSTEM, WEST-CENTRAL TEXAS: USGS WATER-RESOURCES INVESTIGATIONS REPORT 93-4126, 1994.

GEOLOGIC HISTORY AND HYDROGEOLOGIC SETTING OF THE EDWARDS-TRINITY AQUIFER SYSTEM, WEST-CENTRAL TEXAS: USGS WATER-RESOURCES INVESTIGATIONS REPORT 94-4039, 1994.

WATER QUALITY IN THE EDWARDS-TRINITY (PLATEAU) AQUIFER, EDWARDS PLATEAU AND TRANS-PECOS, TEXAS: TEXAS WATER DEVELOPMENT BOARD HYDROLOGIC ATLAS NO. 3, 1995.

AQUIFERS OF TEXAS: TEXAS WATER DEVELOPMENT BOARD REPORT 345, 1995.

THE PALEOZOIC AND RELATED AQUIFERS OF CENTRAL TEXAS: TEXAS WATER DEVELOPMENT BOARD REPORT 346, 1996.

HYDROGEOLOGIC FRAMEWORK OF THE EDWARDS-TRINITY AQUIFER SYSTEM, WEST-CENTRAL TEXAS: USGS PROFESSIONAL PAPER 1421-B, 1996.

AN OVERVIEW OF THE EDWARDS-TRINITY AQUIFER SYSTEM, CENTRAL-WEST TEXAS, CHAPTER 8, in AQUIFERS OF WEST TEXAS: TEXAS WATER DEVELOPMENT BOARD REPORT 356, 2001.

\section{McLENNAN COUNTY}

GEOGRAPHY AND GEOLOGY OF THE BLACK AND GRAND PRAIRIES OF TEXAS, WITH DETAILED DESCRIPTIONS OF THE CRETACEOUS FORMATIONS AND SPECIAL REFERENCE TO ARTESIAN WATERS: USGS 21ST ANNUAL REPORT, PART 7, 1901.

WACO, TEXAS: USGS OPEN-FILE REPORT (UNNUMBERED), 1941. 
GROUND WATER IN THE VICINITY OF McGREGOR, McLENNAN COUNTY, TEXAS: USGS OPEN-FILE REPORT (UNNUMBERED), 1942.

MEMORANDUM ON PUMP SETTINGS IN WELLS AT WACO FLYING FIELD, WACO, TEXAS: USGS OPEN-FILE REPORT (UNNUMBERED), 1943.

MEMORANDUM ON PUMP SETTINGS IN WELLS AT BLACKLAND FLYING FIELD, WACO, TEXAS: USGS OPEN-FILE REPORT (UNNUMBERED), 1943.

RESULTS OF TESTS ON WELLS AT WACO, TEXAS: TEXAS BOARD OF WATER ENGINEERS MISCELLANEOUS PUBLICATION 288, 1945.

MEMORANDUM REGARDING THE WATER SUPPLY AT GENERAL TIRE AND RUBBER CO. PLANT AT WACO, TEXAS: USGS OPENFILE REPORT (UNNUMBERED), 1945.

PUBLIC WATER SUPPLIES IN EASTERN TEXAS, V. 2, HARRISON COUNTY THROUGH WOOD COUNTY: TEXAS BOARD OF WATER ENGINEERS MISCELLANEOUS PUBLICATION 214, V. 2, 1945.

PUBLIC WATER SUPPLIES IN EASTERN TEXAS: USGS WATERSUPPLY PAPER 1047, 1948.

RECORDS OF WATER-LEVEL MEASUREMENTS IN BELL, MCLENNAN, AND SOMERVELL COUNTIES, TEXAS, 1930 THROUGH 1957: TEXAS BOARD OF WATER ENGINEERS BULLETIN 5902, 1959.

THE LOWER CRETACEOUS TRINITY AQUIFERS, MC LENNON COUNTY, TEXAS: BAYLOR GEOLOGICAL STUDIES BULLETIN NO. 1, BAYLOR UNIVERSITY, 1961.

RECONNAISSANCE INVESTIGATION OF THE GROUND-WATER RESOURCES OF THE BRAZOS RIVER BASIN: TEXAS WATER COMMISSION BULLETIN 6310, 1963.

GROUND WATER IN THE FLOOD-PLAIN ALLUVIUM OF THE BRAZOS RIVER, WHITNEY DAM TO VICINITY OF RICHMOND, TEXAS: TEXAS WATER DEVELOPMENT BOARD REPORT 41, 1967.

COMPILATION OF RESULTS OF AQUIFER TESTS IN TEXAS: TEXAS WATER DEVELOPMENT BOARD REPORT 98, 1969.

MAJOR AND HISTORICAL SPRINGS OF TEXAS: TEXAS WATER DEVELOPMENT BOARD REPORT 189, 1975.

GROUND-WATER RESOURCES OF PART OF CENTRAL TEXAS WITH EMPHASIS ON THE ANTLERS AND TRAVIS PEAK FORMATIONS: TEXAS WATER DEVELOPMENT BOARD REPORT 195, V. 1, 1975.

GROUND-WATER RESOURCES OF PART OF CENTRAL TEXAS WITH EMPHASIS ON THE ANTLERS AND TRAVIS PEAK FORMATIONS: TEXAS WATER DEVELOPMENT BOARD REPORT 195, V. 2, 1976.

SUMMARY APPRAISALS OF THE NATION'S GROUND-WATER RESOURCES-TEXAS-GULF REGION: USGS PROFESSIONAL PAPER 813-F, 1976.

URBAN GEOLOGY OF GREATER WACO. PART III: WATER. SUBSURFACE WATERS OF WACO: BAYLOR GEOLOGICAL STUDIES BULLETIN NO. 11, BAYLOR UNIVERSITY, 1976.

TEXAS GROUND-WATER RESOURCES, in NATIONAL WATER SUMMARY 1984: USGS WATER-SUPPLY PAPER 2275, 1985.

WATER USE, PROJECTED WATER REQUIREMENTS, AND RELATED DATA AND INFORMATION FOR THE METROPOLITAN STATISTICAL AREAS IN TEXAS: TEXAS DEPARTMENT OF WATER RESOURCES LIMITED PRINTING REPORT LP-201, 1985.
HYDROGEOLOGY OF THE EDWARDS AQUIFER, NORTHERN BALCONES AND WASHITA PRAIRIE SEGMENTS: AUSTIN GEOLOGICAL SOCIETY GUIDEBOOK 11, 1987.

A HYDROGEOLOGIC ASSESSMENT OF THE OZAN FORMATION, CENTRAL TEXAS: (MASTER'S THESIS), BAYLOR GEOLOGICAL STUDIES (THESIS ABSTRACTS), BULLETIN 48, BAYLOR UNIVERSITY, WACO, TEXAS, 1989.

A HYDROGEOLOGIC ASSESSMENT OF THE AUSTIN CHALK OUTCROP BELT, CENTRAL TEXAS: (MASTER'S THESIS), BAYLOR GEOLOGICAL STUDIES (THESIS ABSTRACTS), BULLETIN 48, BAYLOR UNIVERSITY, WACO, TEXAS, 1989.

AQUIFER-STREAM INTERACTIONS IN NON-KARSTIC LIMESTONES: WASHITA PRAIRIE, CENTRAL TEXAS: (MASTER'S THESIS), BAYLOR GEOLOGICAL STUDIES (THESIS ABSTRACTS), BULLETIN 48, BAYLOR UNIVERSITY, WACO, TEXAS, 1989.

EVALUATION OF WATER RESOURCES IN PART OF CENTRAL TEXAS: TEXAS WATER DEVELOPMENT BOARD REPORT 319 , 1990.

SURFACE-GROUNDWATER STUDY, WASHITA PRAIRIE, CENTRAL TEXAS: (MASTER'S THESIS), BAYLOR GEOLOGICAL STUDIES (THESIS ABSTRACTS), BULLETIN 53, 1992.

AQUIFERS OF TEXAS: TEXAS WATER DEVELOPMENT BOARD REPORT 345, 1995.

WATER QUALITY IN THE WOODBINE AQUIFER, NORTH-CENTRAL TEXAS: TEXAS WATER DEVELOPMENT BOARD HYDROLOGIC ATLAS NO. 4, 1996.

\section{McMULLEN COUNTY}

UNDERGROUND WATERS OF THE COASTAL PLAIN OF TEXAS: USGS WATER-SUPPLY PAPER 190, 1907.

GROUND WATER IN LA SALLE AND MCMULLEN COUNTIES, TEXAS USGS WATER-SUPPLY PAPER 375-G, 1916.

McMULLEN COUNTY: USGS OPEN-FILE REPORT (UNNUMBERED), 1928.

GROUND WATER IN THE WINTER GARDEN AND ADJACENT DISTRICTS IN SOUTHWESTERN TEXAS: USGS OPEN-FILE REPORT (UNNUMBERED), 1931.

PUBLIC WATER SUPPLIES IN SOUTHERN TEXAS: TEXAS BOARD OF WATER ENGINEERS MISCELLANEOUS PUBLICATION 215, 1946.

RESULTS OF A PRELIMINARY INVESTIGATION TO DETERMINE THE AMOUNT OF SEEPAGE LOSSES FROM THE NUECES AND FRIO RIVERS IN THE AREA BETWEEN COTULLA AND THREE RIVERS, TEXAS: USGS OPEN-FILE REPORT (UNNUMBERED), 1949.

CONTAMINATION OF FRIO RIVER BY SALT WATER FROM CALLIHAM OIL FIELD: USGS OPEN-FILE REPORT (UNNUMBERED), 1949

PUBLIC WATER SUPPLIES IN SOUTHERN TEXAS: USGS WATERSUPPLY PAPER 1070, 1950.

SUPPLEMENTARY REPORT ON SURFACE-WATER AND GROUNDWATER SURVEYS, NUECES RIVER BASIN, TEXAS: USGS OPENFILE REPORT (UNNUMBERED), 1950. 
CROSS SECTION SHOWING SAND AND CLAY ZONES, McMULLEN, ATASCOSA, AND KARNES COUNTIES, TEXAS: USGS OPEN-FILE REPORT (UNNUMBERED), 1952.

DEVELOPMENT OF GROUND WATER FROM THE CARRIZO SAND AND WILCOX GROUP IN DIMMIT, ZAVALA, MAVERICK, FRIO, ATASCOSA, MEDINA, BEXAR, LIVE OAK, McMULLEN, LA SALLE, AND WEBB COUNTIES, TEXAS: USGS OPEN-FILE REPORT 57-77, 1957.

RECONNAISSANCE INVESTIGATION OF THE GROUND-WATER RESOURCES OF THE GUADALUPE, SAN ANTONIO, AND NUECES RIVER BASINS, TEXAS: TEXAS WATER COMMISSION BULLETIN 6409, 1964.

GROUND-WATER RESOURCES OF LA SALLE AND McMULLEN COUNTIES, TEXAS: TEXAS WATER COMMISSION BULLETIN 6520, 1965.

WATER-LEVEL DATA FROM OBSERVATION WELLS IN THE NORTHWESTERN GULF COASTAL PLAIN OF TEXAS: TEXAS WATER DEVELOPMENT BOARD REPORT 70, 1968

HYDROLOGIC SIGNIFICANCE OF THE LITHOFACIES OF THE SPARTA SAND IN ARKANSAS, LOUISIANA, MISSISSIPPI, AND TEXAS: USGS PROFESSIONAL PAPER 569-A, 1968.

GEOHYDROLOGIC SIGNIFICANCE OF LITHOFACIES OF THE COCKFIELD FORMATION OF LOUISIANA AND MISSISSIPPI AND OF THE YEGUA FORMATION OF TEXAS: USGS PROFESSIONAL PAPER 569-B, 1970

HYDROLOGIC SIGNIFICANCE OF LITHOFACIES OF THE CANE RIVER FORMATION OR EQUIVALENTS OF ARKANSAS, LOUISIANA, MISSISSIPPI, AND TEXAS: USGS PROFESSIONAL PAPER 569-C, 1972.

HYDROLOGIC SIGNIFICANCE OF LITHOFACIES OF THE CARRIZO SAND OF ARKANSAS, LOUISIANA, AND TEXAS AND THE MERIDIAN SAND OF MISSISSIPPI: USGS PROFESSIONAL PAPER 569-D, 1975.

SUMMARY APPRAISALS OF THE NATION'S GROUND-WATER RESOURCES-TEXAS-GULF REGION: USGS PROFESSIONAL PAPER 813-F, 1976.

GROUND-WATER RESOURCES OF THE CARRIZO AQUIFER IN THE WINTER GARDEN AREA OF TEXAS, VOLUME 1: TEXAS WATER DEVELOPMENT BOARD REPORT 210, V. 1, 1976.

GROUND-WATER RESOURCES OF THE CARRIZO AQUIFER IN THE WINTER GARDEN AREA OF TEXAS, VOLUME 2: TEXAS WATER DEVELOPMENT BOARD REPORT 210, V. 2, 1977.

VARIATIONS IN SPECIFIC YIELD IN THE OUTCROP OF THE CARRIZO SAND IN SOUTH TEXAS AS ESTIMATED BY SEISMIC REFRACTION: TEXAS DEPARTMENT OF WATER RESOURCES REPORT 229 1979.

STRATIGRAPHIC AND HYDROGEOLOGIC FRAMEWORK OF PART OF THE COASTAL PLAIN OF TEXAS: TEXAS DEPARTMENT OF WATER RESOURCES REPORT 236, 1979.

SPRINGS OF TEXAS, VOLUME 1: (BY GUNNAR BRUNE), BRANCHSMITH, INC., FORT WORTH, TEXAS, 1981.

REGIONAL HYDRODYNAMICS AND HYDROCHEMISTRY OF THE URANIUM-BEARING OAKVILLE AQUIFER (MIOCENE) OF SOUTH TEXAS: UNIVERSITY OF TEXAS, BUREAU OF ECONOMIC GEOLOGY REPORT OF INVESTIGATIONS NO. 124, 1982.
TEXAS GROUND-WATER RESOURCES, in NATIONAL WATER SUMMARY 1984: USGS WATER-SUPPLY PAPER 2275, 1985.

APPROXIMATE POTENTIOMETRIC SURFACES FOR THE AQUIFERS OF THE COASTAL UPLANDS SYSTEM, 1980: USGS HYDROLOGIC INVESTIGATIONS ATLAS HA-704, 1987.

GEOHYDROLOGIC FRAMEWORK OF THE GULF COASTAL PLAIN: USGS HYDROLOGIC INVESTIGATIONS ATLAS HA-695, 1988.

DEPOSITIONAL AND GROUND-WATER FLOW SYSTEMS OF THE CARRIZO-UPPER WILCOX, SOUTH TEXAS: UNIVERSITY OF TEXAS, BUREAU OF ECONOMIC GEOLOGY REPORT OF INVESTIGATIONS NO. 175, 1988.

EVALUATION OF THE GROUND-WATER RESOURCES IN THE WESTERN PORTION OF THE WINTER GARDEN AREA, TEXAS: TEXAS WATER DEVELOPMENT BOARD REPORT 334, 1991.

GROUND-WATER QUALITY MONITORING RESULTS IN THE WINTER GARDEN AREA, 1990: TEXAS WATER DEVELOPMENT BOARD REPORT 335, 1992.

PROPERTIES AND CHEMICAL CONSTITUENTS IN GROUND WATER FROM THE MIDDLE WILCOX AQUIFER, GULF COAST REGIONAL AQUIFER SYSTEMS, SOUTH-CENTRAL UNITED STATES: USGS WATER-RESOURCES INVESTIGATIONS REPORT 93-4070, 1993.

PROPERTIES AND CHEMICAL CONSTITUENTS IN GROUND WATER FROM THE UPPER CLAIBORNE AQUIFER, GULF COAST REGIONAL AQUIFER SYSTEMS, SOUTH-CENTRAL UNITED STATES: USGS WATER-RESOURCES INVESTIGATIONS REPORT 91-4150, 1993.

PROPERTIES AND CHEMICAL CONSTITUENTS IN GROUND WATER FROM THE LOWER CLAIBORNE-UPPER WILCOX AQUIFER, GULF COAST REGIONAL AQUIFER SYSTEMS, SOUTH-CENTRAL UNITED STATES: USGS WATER-RESOURCES INVESTIGATIONS REPORT 92-4102, 1993.

PROPERTIES AND CHEMICAL CONSTITUENTS IN GROUND WATER FROM THE MIDDLE CLAIBORNE AQUIFER, GULF COAST REGIONAL AQUIFER SYSTEMS, SOUTH-CENTRAL UNITED STATES: USGS WATER-RESOURCES INVESTIGATIONS REPORT 92-4104, 1993.

PROPERTIES AND CHEMICAL CONSTITUENTS IN GROUND WATER FROM PERMEABLE ZONE D (MIDDLE MIOCENE DEPOSITS), COASTAL LOWLANDS AQUIFER SYSTEM, SOUTH-CENTRAL UNITED STATES: USGS WATER-RESOURCES INVESTIGATIONS REPORT 92-4105, 1993.

AQUIFERS OF TEXAS: TEXAS WATER DEVELOPMENT BOARD REPORT 345, 1995.

WATER QUALITY IN THE SPARTA AQUIFER, EAST TEXAS: TEXAS WATER DEVELOPMENT BOARD HYDROLOGIC ATLAS NO. 5, 1996.

WATER QUALITY IN THE QUEEN CITY AQUIFER, EAST TEXAS: TEXAS WATER DEVELOPMENT BOARD HYDROLOGIC ATLAS, NO. 6, 1996.

HYDROGEOLOGIC FRAMEWORK AND GEOCHEMISTRY OF THE EDWARDS AQUIFER SALINE-WATER ZONE, SOUTH-CENTRAL TEXAS: USGS WATER-RESOURCES INVESTIGATIONS REPORT 97-4133, 1997. 


\section{MEDINA COUNTY}

UNDERGROUND WATERS OF THE COASTAL PLAIN OF TEXAS: USGS WATER-SUPPLY PAPER 190, 1907.

GROUND WATER IN THE WINTER GARDEN AND ADJACENT DISTRICTS IN SOUTHWESTERN TEXAS: USGS OPEN-FILE REPORT (UNNUMBERED), 1931.

GEOLOGY AND GROUND-WATER RESOURCES OF UVALDE AND MEDINA COUNTIES, TEXAS: USGS WATER-SUPPLY PAPER 678, 1936.

WATER RESOURCES OF THE EDWARDS LIMESTONE IN THE SAN ANTONIO AREA, TEXAS: USGS WATER-SUPPLY PAPER 773-B, 1936.

SOME GROUND-WATER PROBLEMS OF UVALDE, MEDINA, AND BEXAR COUNTIES: USGS OPEN-FILE REPORT (UNNUMBERED), 1938.

GROUND WATER IN THE VICINITY OF HONDO, MEDINA COUNTY, TEXAS: USGS OPEN-FILE REPORT (UNNUMBERED), 1942.

PUBLIC WATER SUPPLIES IN SOUTHERN TEXAS: TEXAS BOARD OF WATER ENGINEERS MISCELLANEOUS PUBLICATION 215, 1946.

MISCELLANEOUS FIELD NOTES ON SAN ANTONIO AREA, TEXAS: USGS OPEN-FILE REPORT (UNNUMBERED), 1950.

PUBLIC WATER SUPPLIES IN SOUTHERN TEXAS: USGS WATERSUPPLY PAPER 1070, 1950.

RECHARGE TO THE CARRIZO SAND IN ATASCOSA COUNTY AND ADJACENT AREAS: USGS OPEN-FILE REPORT (UNNUMBERED), 1951.

GROUND-WATER CONDITIONS IN THE LACOSTE-MACDONA AREA, TEXAS: USGS OPEN-FILE REPORT (UNNUMBERED), 1951.

PROGRESS REPORT ON THE GEOLOGY AND WATER RESOURCES OF MEDINA COUNTY, TEXAS: USGS OPEN-FILE REPORT (UNNUMBERED), 1951.

GROUND WATER IN THE TRINITY GROUP IN THE SAN ANTONIO AREA, TEXAS: USGS OPEN-FILE REPORT (UNNUMBERED), 1953.

MISCELLANEOUS FIELD NOTES ON THE GEOLOGY OF THE SAN ANTONIO AREA, TEXAS 1950-53: USGS OPEN-FILE REPORT (UNNUMBERED), 1953.

GROUND WATER IN MEDINA COUNTY: USGS OPEN-FILE REPORT (UNNUMBERED), 1954.

GROUND-WATER RESOURCES OF THE SAN ANTONIO AREA, TEXAS, A PROGRESS REPORT OF CURRENT STUDIES: TEXAS BOARD OF WATER ENGINEERS BULLETIN 5412, 1954.

MEMORANDUM ON IRRIGATION BY GROUND WATER FROM THE EDWARDS AND ASSOCIATED LIMESTONES IN THE SAN ANTONIO-HONDO-UVALDE AREA: USGS OPEN-FILE REPORT 56-93, 1956.

GEOLOGY AND GROUND-WATER RESOURCES OF MEDINA COUNTY, TEXAS: TEXAS BOARD OF WATER ENGINEERS BULLETIN 5601, 1956.

GROUND-WATER RESOURCES OF THE SAN ANTONIO AREA, TEXAS, VOLUME 1, A PROGRESS REPORT ON CURRENT STUDIES: TEXAS BOARD OF WATER ENGINEERS BULLETIN 5608, V. 1, 1956.
GROUND-WATER RESOURCES OF THE SAN ANTONIO AREA, TEXAS, VOLUME 2, PART 1, RECORDS OF WELLS AND SPRINGS: TEXAS BOARD OF WATER ENGINEERS BULLETIN 5608, V. 2, PART 1, 1956.

GROUND-WATER RESOURCES OF THE SAN ANTONIO AREA, TEXAS, VOLUME 2, PART 2, RECORDS OF DRILLERS' LOGS: TEXAS BOARD OF WATER ENGINEERS BULLETIN 5608, V. 2, PART 2, 1956

GROUND-WATER RESOURCES OF THE SAN ANTONIO AREA, TEXAS, VOLUME 2, PART 3, WATER LEVELS IN WELLS, CHEMICAL ANALYSES OF WATER, RECORDS OF STREAMFLOW AND RESERVOIR CONTENTS, DISCHARGE MEASUREMENTS, AND PRECIPITATION IN THE SAN ANTONIO AREA, TEXAS: TEXAS BOARD OF WATER ENGINEERS BULLETIN 5608, V. 2, PART 3, 1956.

RECORDS OF WATER-LEVEL MEASUREMENTS IN MEDINA COUNTY, TEXAS, 1930 TO MARCH 1956: TEXAS BOARD OF WATER ENGINEERS BULLETIN 5609, 1956.

DEVELOPMENT OF GROUND WATER FROM THE CARRIZO SAND AND WILCOX GROUP IN DIMMIT, ZAVALA, MAVERICK, FRIO, ATASCOSA, MEDINA, BEXAR, LIVE OAK, McMULLEN, LA SALLE, AND WEBB COUNTIES, TEXAS: USGS OPEN-FILE REPORT 57-77, 1957.

GROUND-WATER GEOLOGY OF MEDINA COUNTY, TEXAS: SOUTH TEXAS GEOLOGICAL SOCIETY BULLETIN V. 2, NO. 3, FEBRUARY 7, 1962.

RECHARGE, DISCHARGE, AND CHANGES IN GROUND-WATER STORAGE IN THE EDWARDS AND ASSOCIATED LIMESTONES, SAN ANTONIO AREA, TEXAS, A PROGRESS REPORT ON STUDIES 1955-59: TEXAS WATER COMMISSION BULLETIN 6201, 1962.

CHEMICAL ANALYSES OF WATER FROM OBSERVATION WELLS IN THE EDWARDS AND ASSOCIATED LIMESTONES, SAN ANTONIO AREA, TEXAS: EDWARDS UNDERGROUND WATER DISTRICT BULLETIN 1, 1962.

GROUND-WATER DISCHARGE FROM THE EDWARDS AND ASSOCIATED LIMESTONES, 1955-62, SAN ANTONIO AREA, TEXAS: EDWARDS UNDERGROUND WATER DISTRICT BULLETIN 2, 1963.

RECORDS OF PRECIPITATION, AQUIFER HEAD, AND GROUNDWATER DISCHARGE TO THE EDWARDS AND ASSOCIATED LIMESTONES, 1960-62, SAN ANTONIO AREA, TEXAS: EDWARDS UNDERGROUND WATER DISTRICT BULLETIN 3, 1963.

CHEMICAL ANALYSES OF WATER FROM OBSERVATION WELLS IN THE EDWARDS AND ASSOCIATED LIMESTONES, SAN ANTONIO AREA, TEXAS, 1963: EDWARDS UNDERGROUND WATER DISTRICT BULLETIN 4, 1964.

GROUND-WATER DISCHARGE FROM THE EDWARDS AND ASSOCIATED LIMESTONES, SAN ANTONIO AREA, TEXAS, 1963: EDWARDS UNDERGROUND WATER DISTRICT BULLETIN 5, 1964.

RECORDS OF PRECIPITATION, AQUIFER HEAD, AND GROUNDWATER RECHARGE TO THE EDWARDS AND ASSOCIATED LIMESTONES, SAN ANTONIO AREA, TEXAS, 1963: EDWARDS UNDERGROUND WATER DISTRICT BULLETIN 6, 1964.

RECONNAISSANCE INVESTIGATION OF THE GROUND-WATER RESOURCES OF THE GUADALUPE, SAN ANTONIO, AND NUECES RIVER BASINS, TEXAS: TEXAS WATER COMMISSION BULLETIN 6409, 1964.

CHEMICAL ANALYSES OF WATER FROM OBSERVATION WELLS IN THE EDWARDS AND ASSOCIATED LIMESTONES, SAN ANTONIO AREA, TEXAS, 1964: EDWARDS UNDERGROUND WATER DISTRICT BULLETIN 7, 1965. 
GROUND-WATER DISCHARGE FROM THE EDWARDS AND ASSOCIATED LIMESTONES, SAN ANTONIO AREA, TEXAS, 1964: EDWARDS UNDERGROUND WATER DISTRICT BULLETIN 8, 1965.

GROUND-WATER RECHARGE TO THE EDWARDS AND ASSOCIATED LIMESTONES, SAN ANTONIO AREA, TEXAS, 1964: EDWARDS UNDERGROUND WATER DISTRICT BULLETIN 9, 1965.

CHEMICAL ANALYSES FROM OBSERVATION WELLS IN THE EDWARDS AND ASSOCIATED LIMESTONES, SAN ANTONIO AREA, TEXAS, 1965: EDWARDS UNDERGROUND WATER DISTRICT BULLETIN 10, 1966.

GROUND-WATER DISCHARGE FROM THE EDWARDS AND ASSOCIATED LIMESTONES, SAN ANTONIO AREA, TEXAS, 1965: EDWARDS UNDERGROUND WATER DISTRICT BULLETIN 11, 1966.

RECORDS OF PRECIPITATION, AQUIFER HEAD, AND GROUNDWATER RECHARGE TO THE EDWARDS AND ASSOCIATED LIMESTONES, SAN ANTONIO AREA, TEXAS, 1965: EDWARDS UNDERGROUND WATER DISTRICT BULLETIN 12, 1966.

GROUND-WATER RESOURCES OF THE SAN ANTONIO AREA, TEXAS, A PROGRESS REPORT ON STUDIES, 1960-64: TEXAS WATER DEVELOPMENT BOARD REPORT 34, 1966.

CHEMICAL ANALYSES OF WATER FROM OBSERVATION WELLS IN THE EDWARDS AND ASSOCIATED LIMESTONES, SAN ANTONIO AREA, TEXAS, 1966: EDWARDS UNDERGROUND WATER DISTRICT BULLETIN 13, 1967.

GROUND-WATER DISCHARGE FROM THE EDWARDS AND ASSOCIATED LIMESTONES, SAN ANTONIO AREA, TEXAS, 1966: EDWARDS UNDERGROUND WATER DISTRICT BULLETIN 14, 1967.

RECORDS OF PRECIPITATION, AQUIFER HEAD, AND GROUNDWATER RECHARGE TO THE EDWARDS AND ASSOCIATED LIMESTONES, SAN ANTONIO AREA, TEXAS, 1966: EDWARDS UNDERGROUND WATER DISTRICT BULLETIN 15, 1967.

CHEMICAL ANALYSES OF WATER FROM OBSERVATION WELLS IN THE EDWARDS AND ASSOCIATED LIMESTONES, SAN ANTONIO AREA, TEXAS, 1967: EDWARDS UNDERGROUND WATER DISTRICT BULLETIN 16, 1968.

HYDROLOGIC EFFECTS OF THE EARTHQUAKE OF MARCH 27, 1964, OUTSIDE ALASKA: USGS PROFESSIONAL PAPER 544-C, 1968.

GROUND-WATER DISCHARGE FROM THE EDWARDS AND ASSOCIATED LIMESTONES, SAN ANTONIO AREA, TEXAS, 1967: EDWARDS UNDERGROUND WATER DISTRICT BULLETIN 17, 1968.

RECORDS OF PRECIPITATION, AQUIFER HEAD, AND GROUNDWATER RECHARGE TO THE EDWARDS AND ASSOCIATED LIMESTONES, SAN ANTONIO AREA, TEXAS, 1967: EDWARDS UNDERGROUND WATER DISTRICT BULLETIN 18, 1968.

RECORDS OF WELLS AND SPRINGS, SAN ANTONIO AREA, TEXAS: EDWARDS UNDERGROUND WATER DISTRICT, 1969.

GROUND-WATER DISCHARGE FROM THE EDWARDS AND ASSOCIATED LIMESTONES, SAN ANTONIO AREA, TEXAS, 1968: EDWARDS UNDERGROUND WATER DISTRICT BULLETIN 20, 1969.

RECORDS OF PRECIPITATION, AQUIFER HEAD, AND GROUNDWATER RECHARGE TO THE EDWARDS AND ASSOCIATED LIMESTONES, SAN ANTONIO AREA, TEXAS, 1968: EDWARDS UNDERGROUND WATER DISTRICT BULLETIN 21, 1969.

COMPILATION OF RESULTS OF AQUIFER TESTS IN TEXAS: TEXAS WATER DEVELOPMENT BOARD REPORT 98, 1969.
QUANTITY AND QUALITY OF LOW FLOW IN THE HONDO CREEK BASIN, TEXAS, MARCH 27-28, 1968: EDWARDS UNDERGROUND WATER DISTRICT, 1969.

GEOLOGY AND WATER QUALITY AT SELECTED LOCATIONS IN THE SAN ANTONIO AREA, TEXAS, PROGRESS REPORT, 1969: EDWARDS UNDERGROUND WATER DISTRICT, 1970.

GROUND-WATER DISCHARGE FROM THE EDWARDS AND ASSOCIATED LIMESTONES, SAN ANTONIO AREA, TEXAS, 1969: EDWARDS UNDERGROUND WATER DISTRICT BULLETIN 23, 1970.

RECORDS OF PRECIPITATION, WATER LEVELS, AND GROUNDWATER RECHARGE TO THE EDWARDS AND ASSOCIATED LIMESTONES, SAN ANTONIO AREA, TEXAS, 1969: EDWARDS UNDERGROUND WATER DISTRICT BULLETIN 24, 1970.

GROUND-WATER DISCHARGE FROM THE EDWARDS AND ASSOCIATED LIMESTONES, SAN ANTONIO AREA, TEXAS, 1970: EDWARDS UNDERGROUND WATER DISTRICT BULLETIN 26, 1971.

RECORDS OF PRECIPITATION, WATER LEVELS, AND GROUNDWATER RECHARGE TO THE EDWARDS AND ASSOCIATED LIMESTONES, SAN ANTONIO AREA, TEXAS, 1970: EDWARDS UNDERGROUND WATER DISTRICT BULLETIN 27, 1971.

GROUND-WATER DISCHARGE FROM THE EDWARDS AND ASSOCIATED LIMESTONES, SAN ANTONIO AREA, TEXAS, 1971: EDWARDS UNDERGROUND WATER DISTRICT BULLETIN 29, 1972.

RECORDS OF PRECIPITATION, WATER LEVELS, AND GROUNDWATER RECHARGE TO THE EDWARDS AND ASSOCIATED LIMESTONES, SAN ANTONIO AREA, TEXAS, 1971: EDWARDS UNDERGROUND WATER DISTRICT BULLETIN 30, 1972.

CHEMICAL AND BACTERIOLOGICAL QUALITY OF WATER AT SELECTED SITES IN THE SAN ANTONIO AREA, TEXAS, AUGUST 1968-APRIL 1972: EDWARDS UNDERGROUND WATER DISTRICT, 1972.

MAPS SHOWING OUTCROPS OF THE EDWARDS AND ASSOCIATED LIMESTONES IN THE PRINCIPAL RECHARGE AREA OF THE EDWARDS AQUIFER IN BEXAR COUNTY, TEXAS: USGS OPENFILE REPORT 72-310, 1972.

GROUND-WATER DISCHARGE FROM THE EDWARDS AND ASSOCIATED LIMESTONES, SAN ANTONIO AREA, TEXAS, 1972: EDWARDS UNDERGROUND WATER DISTRICT BULLETIN 31, 1973.

REGIONAL SPECIFIC YIELD OF THE EDWARDS AND ASSOCIATED LIMESTONES IN THE SAN ANTONIO, TEXAS, AREA: EDWARDS UNDERGROUND WATER DISTRICT, 1973.

GROUND-WATER DISCHARGE FROM THE EDWARDS AND ASSOCIATED LIMESTONES, SAN ANTONIO AREA, TEXAS, 1973: EDWARDS UNDERGROUND WATER DISTRICT BULLETIN 32, 1974.

RECORDS OF PRECIPITATION, WATER LEVELS, AND GROUNDWATER RECHARGE TO THE EDWARDS AND ASSOCIATED LIMESTONES, SAN ANTONIO AREA, TEXAS, 1972-73: EDWARDS UNDERGROUND WATER DISTRICT BULLETIN 33, 1974.

RELATION OF PRECIPITATION TO ANNUAL GROUND-WATER RECHARGE IN THE EDWARDS AQUIFER, SAN ANTONIO AREA, TEXAS: USGS OPEN-FILE REPORT 75-298, 1975.

THE EDWARDS UNDERGROUND RESERVOIR AND THE EDWARDS UNDERGROUND WATER DISTRICT: SOUTH TEXAS GEOLOGICAL SOCIETY BULLETIN V. 15, NO. 7, 1975.

RECORDS OF PRECIPITATION, WATER LEVELS, AND GROUNDWATER RECHARGE TO THE EDWARDS AND ASSOCIATED LIME- 
STONES, SAN ANTONIO AREA, TEXAS, 1972-73: SOUTH TEXAS GEOLOGICAL SOCIETY BULLETIN V. 15, NO. 7, 1975.

GROUND-WATER DISCHARGE FROM THE EDWARDS AND ASSOCIATED LIMESTONES, SAN ANTONIO AREA, TEXAS, 1974: EDWARDS UNDERGROUND WATER DISTRICT BULLETIN 34, 1975.

MAJOR AND HISTORICAL SPRINGS OF TEXAS: TEXAS WATER DEVELOPMENT BOARD REPORT 189, 1975.

GEOHYDROLOGIC SIGNIFICANCE OF LITHOFACIES OF THE CARRIZO SAND OF ARKANSAS, LOUISIANA, AND TEXAS AND THE MERIDIAN SAND OF MISSISSIPPI: USGS PROFESSIONAL PAPER 569-D, 1975.

GEOCHEMICAL AND ISOTOPIC ANALYSES OF WATERS ASSOCIATED WITH THE EDWARDS LIMESTONE AQUIFER, CENTRAL TEXAS: EDWARDS UNDERGROUND WATER DISTRICT, 1976.

GROUND-WATER DISCHARGE FROM THE EDWARDS AND ASSOCIATED LIMESTONES, SAN ANTONIO AREA, TEXAS, 1975: EDWARDS UNDERGROUND WATER DISTRICT BULLETIN 35, 1976

STATISTICAL ANALYSIS OF WATER-LEVEL, SPRINGFLOW, AND STREAMFLOW DATA FOR THE EDWARDS AQUIFER IN SOUTHCENTRAL TEXAS: USGS OPEN-FILE REPORT 76-393, 1976.

STATISTICAL ANALYSIS OF WATER-LEVEL, SPRINGFLOW, AND STREAMFLOW DATA FOR THE EDWARDS AQUIFER IN SOUTHCENTRAL TEXAS: EDWARDS UNDERGROUND WATER DISTRICT, 1976.

CHEMICAL AND BACTERIOLOGICAL QUALITY OF WATER AT SELECTED SITES IN THE SAN ANTONIO AREA, TEXAS, AUGUST 1968-JANUARY 1975: USGS OPEN-FILE REPORT 76-574, 1976

CHEMICAL AND BACTERIOLOGICAL QUALITY OF WATER AT SELECTED SITES IN THE SAN ANTONIO AREA, TEXAS, AUGUST 1968-JANUARY 1975: EDWARDS UNDERGROUND WATER DISTRICT, 1976

PROGRESS REPORT ON GEOLOGY OF THE EDWARDS AQUIFER, SAN ANTONIO AREA, TEXAS, AND PRELIMINARY INTERPRETATION OF BOREHOLE GEOPHYSICAL AND LABORATORY DATA ON CARBONATE ROCKS: USGS OPEN-FILE REPORT 76-627, 1976.

GROUND-WATER RESOURCES OF THE CARRIZO AQUIFER IN THE WINTER GARDEN AREA OF TEXAS, VOLUME 1: TEXAS WATER DEVELOPMENT BOARD REPORT 210, V. 1, 1976.

GROUND-WATER RESOURCES OF THE CARRIZO AQUIFER IN THE WINTER GARDEN AREA OF TEXAS, VOLUME 2: TEXAS WATER DEVELOPMENT BOARD REPORT 210, V. 2, 1977.

GROUND-WATER DISCHARGE FROM THE EDWARDS AND ASSOCIATED LIMESTONES, SAN ANTONIO AREA, TEXAS, 1976: EDWARDS UNDERGROUND WATER DISTRICT, 1977.

METHOD OF ESTIMATING NATURAL RECHARGE TO THE EDWARDS AQUIFER IN THE SAN ANTONIO AREA, TEXAS: USGS WATERRESOURCES INVESTIGATIONS REPORT 78-10, 1978.

MEDINA COUNTY SEEPAGE INVESTIGATION. FOUR SQUARE MILE AREA SOUTH OF HONDO, TEXAS: U.S. SOIL CONSERVATION SERVICE, 1978.

REGIONAL DISTRIBUTION OF FRACTURES IN THE SOUTHERN EDWARDS PLATEAU AND THEIR RELATIONSHIP TO TECTONICS AND CAVES: UNIVERSITY OF TEXAS, BUREAU OF ECONOMIC GEOLOGY GEOLOGICAL CIRCULAR 78-2, 1978.
CHEMICAL AND BACTERIOLOGICAL QUALITY OF WATER AT SELECTED SITES IN THE SAN ANTONIO AREA, TEXAS, FEBRUARY 1975-SEPTEMBER 1977: EDWARDS UNDERGROUND WATER DISTRICT, 1978.

RECORDS OF GROUND-WATER RECHARGE AND DISCHARGE FOR THE EDWARDS AQUIFER IN THE SAN ANTONIO AREA, TEXAS, 1934-77: EDWARDS UNDERGROUND WATER DISTRICT BULLETIN 37, 1979.

VARIATIONS IN SPECIFIC YIELD IN THE OUTCROP OF THE CARRIZO SAND IN SOUTH TEXAS AS ESTIMATED BY SEISMIC REFRACTION: TEXAS DEPARTMENT OF WATER RESOURCES REPORT 229 , 1979.

GROUND-WATER RESOURCES AND MODEL APPLICATIONS FOR THE EDWARDS (BALCONES FAULT ZONE) AQUIFER IN THE SAN ANTONIO REGION: TEXAS DEPARTMENT OF WATER RESOURCES REPORT 239, 1979.

HYDROCHEMICAL DATA FOR THE EDWARDS AQUIFER IN THE SAN ANTONIO AREA, TEXAS: TEXAS DEPARTMENT OF WATER RESOURCES LIMITED PRINTING REPORT LP-131, 1980.

RECORDS OF GROUND-WATER RECHARGE, DISCHARGE, WATER LEVELS, AND CHEMICAL QUALITY OF WATER FOR THE EDWARDS AQUIFER IN THE SAN ANTONIO AREA, TEXAS, 1934-78: EDWARDS UNDERGROUND WATER DISTRICT BULLETIN 38, 1980

WATER-LEVEL, RECHARGE, DISCHARGE, SPECIFIC CAPACITY, WELL-YIELD, AND AQUIFER-TEST DATA FOR THE EDWARDS AQUIFER IN THE SAN ANTONIO AREA, TEXAS: TEXAS DEPARTMENT OF WATER RESOURCES LIMITED PRINTING REPORT LP-133, 1980

APPLICATION AND ANALYSIS OF BOREHOLE DATA FOR THE EDWARDS AQUIFER IN THE SAN ANTONIO AREA, TEXAS: TEXAS DEPARTMENT OF WATER RESOURCES LIMITED PRINTING REPORT LP-139, 1981.

RECORDS OF GROUND-WATER RECHARGE, DISCHARGE, WATER LEVELS, AND CHEMICAL QUALITY OF WATER FOR THE EDWARDS AQUIFER IN THE SAN ANTONIO AREA, TEXAS, 1934-79: EDWARDS UNDERGROUND WATER DISTRICT BULLETIN 39, 1981

TEST-HOLE DATA FOR THE EDWARDS AQUIFER IN THE SAN ANTONIO AREA, TEXAS: TEXAS DEPARTMENT OF WATER RESOURCES LIMITED PRINTING REPORT LP-171, 1982.

RECORDS OF GROUND-WATER RECHARGE, DISCHARGE, WATER LEVELS, AND CHEMICAL QUALITY OF WATER FOR THE EDWARDS AQUIFER IN THE SAN ANTONIO AREA, TEXAS, 1934-80: EDWARDS UNDERGROUND WATER DISTRICT BULLETIN 40, 1982

GROUND-WATER AVAILABILITY OF THE LOWER CRETACEOUS FORMATIONS IN THE HILL COUNTRY OF SOUTH-CENTRAL TEXAS: TEXAS DEPARTMENT OF WATER RESOURCES REPORT 273,1983

RECORDS OF GROUND-WATER RECHARGE, DISCHARGE, WATER LEVELS, AND CHEMICAL QUALITY OF WATER FOR THE EDWARDS AQUIFER IN THE SAN ANTONIO AREA, TEXAS, 1934-81: EDWARDS UNDERGROUND WATER DISTRICT BULLETIN 41, 1984.

CARBONATE GEOLOGY AND HYDROLOGY OF THE EDWARDS AQUIFER IN THE SAN ANTONIO AREA, TEXAS: USGS OPEN-FILE REPORT 83-537, 1984. 
IDENTIFICATION AND TABULATION OF GEOLOGICAL CONTACTS IN THE EDWARDS AQUIFER, SAN ANTONIO AREA, TEXAS: USGS OPEN-FILE REPORT 84-075, 1984.

PROPOSED 10-YEAR PLAN FOR CONTINUATION OF HYDROLOGIC STUDIES OF THE EDWARDS AQUIFER, SAN ANTONIO AREA, TEXAS: USGS OPEN-FILE REPORT 84-817, 1984.

RECORDS OF GROUND-WATER RECHARGE, DISCHARGE, WATER LEVELS, AND CHEMICAL QUALITY OF WATER FOR THE EDWARDS AQUIFER IN THE SAN ANTONIO AREA, TEXAS, 1934-82: EDWARDS UNDERGROUND WATER DISTRICT BULLETIN 42, 1985.

TEXAS GROUND-WATER RESOURCES, in NATIONAL WATER SUMMARY 1984: USGS WATER-SUPPLY PAPER 2275, 1985.

STATISTICAL SUMMARY OF WATER-QUALITY DATA COLLECTED FROM SELECTED WELLS AND SPRINGS IN THE EDWARDS AQUIFER NEAR SAN ANTONIO, TEXAS: USGS OPEN-FILE REPORT 85-182, 1985.

IDENTIFICATION AND TABULATION OF GEOLOGICAL CONTACTS IN THE EDWARDS AQUIFER, SAN ANTONIO AREA, TEXAS: TEXAS DEPARTMENT OF WATER RESOURCES LIMITED PRINTING REPORT LP-199, 1985.

COMPILATION OF HYDROLOGIC DATA FOR THE EDWARDS AQUIFER, SAN ANTONIO AREA, TEXAS, 1983-84, WITH 1934-84 SUMMARY: EDWARDS UNDERGROUND WATER DISTRICT BULLETIN 43-44, 1986.

HYDROGEOLOGIC SECTIONS OF THE EDWARDS AQUIFER AND ITS CONFINING UNITS IN THE SAN ANTONIO AREA, TEXAS: USGS WATER-RESOURCES INVESTIGATIONS REPORT 85-4259, 1986.

POTENTIAL FOR UPDIP MOVEMENT OF SALINEWATER IN THE EDWARDS AQUIFER, SAN ANTONIO, TEXAS: USGS WATERRESOURCES INVESTIGATIONS REPORT 86-4032, 1986.

CARBONATE GEOLOGY AND HYDROLOGY OF THE EDWARDS AQUIFER IN THE SAN ANTONIO AREA, TEXAS: TEXAS WATER DEVELOPMENT BOARD REPORT 296, 1986.

THE EDWARDS AQUIFER; EXTREMELY PRODUCTIVE, BUT....A SOLE-SOURCE WATER SUPPLY FOR SAN ANTONIO AND SURROUNDING COUNTIES IN SOUTH-CENTRAL TEXAS: EDWARDS UNDERGROUND WATER DISTRICT, 1986.

SIMULATION OF FLOW IN THE EDWARDS AQUIFER, SAN ANTONIO REGION, TEXAS, AND REFINEMENT OF STORAGE AND FLOW CONCEPTS: USGS OPEN-FILE REPORT 86-532, 1987.

RELATION OF WATER CHEMISTRY OF THE EDWARDS AQUIFER TO HYDROGEOLOGY AND LAND USE, SAN ANTONIO AREA, TEXAS: USGS WATER-RESOURCES INVESTIGATIONS REPORT 87-4116, 1987.

HYDROGEOLOGIC DATA FROM A STUDY OF THE FRESHWATER ZONE/SALINEWATER ZONE INTERFACE IN THE EDWARDS AQUIFER, SAN ANTONIO REGION, TEXAS: USGS OPEN-FILE REPORT 87-389, 1987.

COMPILATION OF HYDROLOGIC DATA FOR THE EDWARDS AQUIFER, SAN ANTONIO AREA, TEXAS, 1985, WITH 1934-85 SUMMARY: EDWARDS UNDERGROUND WATER DISTRICT BULLETIN $45,1987$.

APPROXIMATE POTENTIOMETRIC SURFACES FOR THE AQUIFERS OF THE TEXAS COASTAL UPLANDS SYSTEM, 1980: USGS HYDROLOGIC INVESTIGATIONS ATLAS HA-704, 1987.
SUGGESTED DESIGN AND CONSTRUCTION OF EDWARDS AQUIFER WELLS: EDWARDS UNDERGROUND WATER DISTRICT, 1987?

COMPILATION OF HYDROLOGIC DATA FOR THE EDWARDS AQUIFER, SAN ANTONIO AREA, TEXAS, 1986, WITH 1934-86 SUMMARY: EDWARDS UNDERGROUND WATER DISTRICT BULLETIN 46, 1988.

SIMULATION OF FLOW IN THE EDWARDS AQUIFER, SAN ANTONIO REGION, TEXAS, AND REFINEMENT OF STORAGE AND FLOW CONCEPTS: USGS WATER-SUPPLY PAPER 2336-A, 1988.

DEPOSITIONAL AND GROUND-WATER FLOW SYSTEMS OF THE CARRIZO-UPPER WILCOX, SOUTH TEXAS: UNIVERSITY OF TEXAS, BUREAU OF ECONOMIC GEOLOGY REPORT OF INVESTIGATIONS NO. 175, 1988.

COMPILATION OF HYDROLOGIC DATA FOR THE EDWARDS AQUIFER, SAN ANTONIO AREA, TEXAS, 1987, WITH 1934-87 SUMMARY: EDWARDS UNDERGROUND WATER DISTRICT BULLETIN 47, 1988.

COMPILATION OF HYDROLOGIC DATA FOR THE EDWARDS AQUIFER, SAN ANTONIO AREA, TEXAS, 1988, WITH 1934-88 SUMMARY: EDWARDS UNDERGROUND WATER DISTRICT BULLETIN 48, 1989.

POTENTIOMETRIC SURFACE OF THE EDWARDS-TRINITY AQUIFER SYSTEM AND CONTIGUOUS HYDRAULICALLY CONNECTED UNITS, WEST-CENTRAL TEXAS, WINTER 1974-75: USGS WATERRESOURCES INVESTIGATIONS REPORT 89-4208, 1990.

COMPILATION OF HYDROLOGIC DATA FOR THE EDWARDS AQUIFER, SAN ANTONIO AREA, TEXAS, 1989, WITH 1934-89 SUMMARY: EDWARDS UNDERGROUND WATER DISTRICT BULLETIN 49, 1990.

WITHDRAWALS FROM THE EDWARDS-TRINITY AQUIFER SYSTEM AND CONTIGUOUS HYDRAULICALLY CONNECTED UNITS, WEST-CENTRAL TEXAS, DECEMBER 1974 THROUGH MARCH 1977: USGS WATER-RESOURCES INVESTIGATIONS REPORT 91-4021, 1991.

EDWARDS AQUIFER, A TEXAS TREASURE-A TEACHERS GUIDE, SECONDARY, GRADES 7-12: EDWARDS UNDERGROUND WATER DISTRICT, 1991.

COMPILATION OF HYDROLOGIC DATA FOR THE EDWARDS AQUIFER, SAN ANTONIO AREA, TEXAS, 1990, WITH 1934-90 SUMMARY: EDWARDS UNDERGROUND WATER DISTRICT BULLETIN 50, 1991.

INSIDE THE EDWARDS AQUIFER-A THREE-PART TECHNICAL FILM, HIGH-SCHOOL LEVEL TEACHER'S GUIDE: EDWARDS UNDERGROUND WATER DISTRICT, 1992.

CONFIGURATION OF THE BASE OF THE EDWARDS-TRINITY AQUIFER SYSTEM AND HYDROGEOLOGY OF THE UNDERLYING PRECRETACEOUS ROCKS, WEST-CENTRAL TEXAS: USGS WATERRESOURCES INVESTIGATIONS REPORT 91-4071, 1992.

GROUND-WATER QUALITY MONITORING RESULTS IN THE WINTER GARDEN AREA, 1990: TEXAS WATER DEVELOPMENT BOARD REPORT 335, 1992.

EVALUATION OF THE GROUND-WATER RESOURCES OF THE PALEOZOIC AND CRETACEOUS AQUIFERS IN THE HILL COUNTRY OF CENTRAL TEXAS: TEXAS WATER DEVELOPMENT BOARD REPORT 339, 1992. 
MODEL REFINEMENT AND APPLICATION FOR THE EDWARDS (BALCONES FAULT ZONE) AQUIFER IN THE SAN ANTONIO AREA, TEXAS: TEXAS WATER DEVELOPMENT BOARD REPORT 340, 1992.

USING GEOPHYSICAL LOGS IN THE EDWARDS AQUIFER TO ESTIMATE WATER QUALITY ALONG THE FRESHWATER/SALINEWATER INTERFACE (UVALDE TO SAN ANTONIO, TEXAS): EDWARDS UNDERGROUND WATER DISTRICT REPORT 92-03, 1992.

WATER QUALITY IN THE EDWARDS AQUIFER AND STREAMS RECHARGING THE AQUIFER IN THE SAN ANTONIO REGION, TEXAS: USGS HYDROLOGIC INVESTIGATIONS ATLAS HA-723, 1992.

COMPILATION OF HYDROLOGIC DATA FOR THE EDWARDS AQUIFER, SAN ANTONIO AREA, TEXAS, 1991, WITH 1934-91 SUMMARY: EDWARDS UNDERGROUND WATER DISTRICT BULLETIN 51, 1992.

WATER-RESOURCES DATA, TEXAS, WATER YEAR 1991, VOLUME 4, GROUND-WATER DATA: USGS WATER-DATA REPORT TX-91-4, 1992.

HISTORICAL POTENTIOMETRIC SURFACE OF THE EDWARDS-TRINITY AQUIFER SYSTEM AND CONTIGUOUS HYDRAULICALLY CONNECTED UNITS, WEST-CENTRAL TEXAS: USGS WATERRESOURCES INVESTIGATIONS REPORT 92-4055, 1993.

HISTORICAL SATURATED THICKNESS OF THE EDWARDS-TRINITY AQUIFER SYSTEM AND SELECTED CONTIGUOUS HYDRAULICALLY CONNECTED UNITS, WEST-CENTRAL TEXAS: USGS WATER-RESOURCES INVESTIGATIONS REPORT 92-4125, 1993.

PROPERTIES AND CHEMICAL CONSTITUENTS IN GROUND WATER FROM THE MIDDLE WILCOX AQUIFER, GULF COAST REGIONAL AQUIFER SYSTEMS, SOUTH-CENTRAL UNITED STATES: USGS WATER-RESOURCES INVESTIGATIONS REPORT 93-4070, 1993.

EDWARDS AQUIFER HYDROGEOLOGIC STATUS REPORT FOR 1992: EDWARDS UNDERGROUND WATER DISTRICT REPORT 93-05, 1993.

DEFINING THE EDWARDS AQUIFER FRESHWATER/SALINE-WATER INTERFACE WITH GEOPHYSICAL LOGS AND MEASURED DATA (SAN ANTONIO TO KYLE, TEXAS): EDWARDS UNDERGROUND WATER DISTRICT REPORT 93-06, 1993.

SOUTH MEDINA COUNTY OBSERVATION WELL PROJECT: EDWARDS UNDERGROUND WATER DISTRICT REPORT 93-11, 1993.

WATER-RESOURCES DATA, TEXAS, WATER YEAR 1992, VOLUME 4, GROUND-WATER DATA: USGS WATER-DATA REPORT TX-92-4, 1993.

SIMULATIONS OF FLOW IN THE EDWARDS-TRINITY AQUIFER SYSTEM AND CONTIGUOUS HYDRAULICALLY CONNECTED UNITS, WEST-CENTRAL TEXAS: USGS WATER-RESOURCES INVESTIGATIONS REPORT 93-4039, 1994.

DISSOLVED-SOLIDS CONCENTRATIONS AND HYDROCHEMICAL FACIES IN WATER OF THE EDWARDS-TRINITY AQUIFER SYSTEM, WEST-CENTRAL TEXAS: USGS WATER-RESOURCES INVESTIGATIONS REPORT 93-4126, 1994.

NATIONAL WATER-QUALITY ASSESSMENT PROGRAM-SOUTHCENTRAL TEXAS: USGS FACT SHEET FS-94-048, 1994.
GEOLOGIC HISTORY AND HYDROGEOLOGIC SETTING OF THE EDWARDS-TRINITY AQUIFER SYSTEM, WEST-CENTRAL TEXAS USGS WATER-RESOURCES INVESTIGATIONS REPORT 94-4039, 1994.

1994 REVIEW AND UPDATE OF THE POSITION OF THE EDWARDS AQUIFER FRESHWATER/SALINE-WATER INTERFACE FROM UVALDE TO KYLE, TEXAS: EDWARDS UNDERGROUND WATER DISTRICT REPORT 94-05, 1994.

WATER-RESOURCES DATA, TEXAS, WATER YEAR 1993, VOLUME 4 , GROUND-WATER DATA: USGS WATER-DATA REPORT TX-93-4, 1994.

REGIONAL DISTRIBUTION OF PERMEABILITY IN THE EDWARDS AQUIFER: EDWARDS UNDERGROUND WATER DISTRICT REPORT 95-02, 1995.

GEOLOGY AND HYDROLOGY OF THE EDWARDS AQUIFER IN THE SAN ANTONIO AREA, TEXAS: USGS WATER-RESOURCES INVESTIGATIONS REPORT 95-4186, 1995.

GEOLOGIC FRAMEWORK AND HYDROGEOLOGIC CHARACTERISTICS OF THE EDWARDS AQUIFER RECHARGE ZONE, BEXAR COUNTY, TEXAS: USGS WATER-RESOURCES INVESTIGATIONS REPORT 95-4030, 1995 [1996].

HYDROGEOLOGIC FACTORS THAT AFFECT THE FLOWPATH OF WATER IN SELECTED ZONES OF THE EDWARDS AQUIFER, SAN ANTONIO REGION, TEXAS: USGS WATER-RESOURCES INVESTIGATIONS REPORT 96-4046, 1996.

RECHARGE TO AND DISCHARGE FROM THE EDWARDS AQUIFER IN THE SAN ANTONIO AREA, TEXAS, 1995: USGS OPEN-FILE REPORT 96-181, 1996.

EDWARDS AQUIFER GROUND-WATER RESOURCES: GEOLOGIC CONTROLS ON POROSITY DEVELOPMENT IN PLATFORM CARBONATES, SOUTH TEXAS: UNIVERSITY OF TEXAS, BUREAU OF ECONOMIC GEOLOGY REPORT OF INVESTIGATIONS NO. 238, 1996.

WATER-QUALITY ASSESSMENT OF SOUTH-CENTRAL TEXASOCCURRENCE AND DISTRIBUTION OF VOLATILE ORGANIC COMPOUNDS IN SURFACE WATER AND GROUND WATER, 1983-94, AND IMPLICATIONS FOR FUTURE MONITORING: USGS WATER-RESOURCES INVESTIGATIONS REPORT 97-4028, 1997.

HYDROGEOLOGIC FRAMEWORK AND GEOCHEMISTRY OF THE EDWARDS AQUIFER SALINE-WATER ZONE, SOUTH-CENTRAL TEXAS: USGS WATER-RESOURCES INVESTIGATIONS REPORT 97-4133, 1997.

GEOLOGIC FRAMEWORK AND HYDROGEOLOGIC CHARACTERISTICS OF THE OUTCROPS OF THE EDWARDS AND TRINITY AQUIFERS, MEDINA LAKE AREA, TEXAS: USGS WATER-RESOURCES INVESTIGATIONS REPORT 97-4290, 1998.

WATER-RESOURCES DATA, TEXAS, WATER YEAR 1997, VOLUME 4, GROUND-WATER DATA: USGS WATER-DATA REPORT TX-97-4, 1998.

GEOLOGIC FRAMEWORK AND HYDROGEOLOGIC PROPERTIES OF THE SECO CREEK WATERSHED, TEXAS: USGS FACT SHEET FS-104-98, 1999.

WATER-RESOURCES DATA, TEXAS, WATER YEAR 1998, VOLUME 4, GROUND-WATER DATA: USGS WATER-DATA REPORT TX-98-4, 1999. 
GROUNDWATER AVAILABILITY OF THE TRINITY AQUIFER, HILL COUNTRY AREA, TEXAS: NUMERICAL SIMULATIONS THROUGH 2050: TEXAS WATER DEVELOPMENT BOARD REPORT 353, 2000.

GEOLOGIC FRAMEWORK AND HYDROGEOLOGIC CHARACTERISTICS OF THE EDWARDS AQUIFER OUTCROP, MEDINA COUNTY, TEXAS: USGS WATER-RESOURCES INVESTIGATIONS REPORT 00-4195, 2000.

WATER QUALITY IN SOUTH-CENTRAL TEXAS-TEXAS, 1996-98: USGS CIRCULAR 1212, 2000.

WATER-RESOURCES DATA, TEXAS, WATER YEAR 1999, VOLUME 6, GROUND-WATER DATA: USGS WATER-DATA REPORT TX-99-6, 2000.

WATER-RESOURCES DATA, TEXAS, WATER YEAR 2000, VOLUME 6, GROUND-WATER DATA: USGS WATER-DATA REPORT TX-00-6, 2001.

\section{MENARD COUNTY}

WATER RESOURCES IN THE VICINITY OF MELVIN, MCCULLOCH COUNTY, AND MENARD, MENARD COUNTY, TEXAS: USGS OPENFILE REPORT (UNNUMBERED), 1942.

PUBLIC WATER SUPPLIES IN CENTRAL AND NORTH-CENTRAL TEXAS: TEXAS BOARD OF WATER ENGINEERS MISCELLANEOUS PUBLICATION 213, 1947.

PUBLIC WATER SUPPLIES IN CENTRAL AND NORTH-CENTRAL TEXAS: USGS WATER-SUPPLY PAPER 1069, 1949.

GROUND-WATER CONDITIONS IN MENARD COUNTY, TEXAS: TEXAS WATER DEVELOPMENT BOARD BULLETIN 6519, 1965.

RECONNAISSANCE INVESTIGATION OF THE GROUND-WATER RESOURCES OF THE COLORADO RIVER BASIN, TEXAS: TEXAS WATER DEVELOPMENT BOARD REPORT 51, 1967.

MAJOR AND HISTORICAL SPRINGS OF TEXAS: TEXAS WATER DEVELOPMENT BOARD REPORT 189, 1975.

SUMMARY APPRAISALS OF THE NATION'S GROUND-WATER RESOURCES-TEXAS-GULF REGION: USGS PROFESSIONAL PAPER 813-F, 1976.

OCCURRENCE, AVAILABILITY, AND CHEMICAL QUALITY OF GROUND WATER IN THE EDWARDS PLATEAU REGION OF TEXAS: TEXAS DEPARTMENT OF WATER RESOURCES REPORT $235,1979$.

TEXAS GROUND-WATER RESOURCES, in NATIONAL WATER SUMMARY 1984: USGS WATER-SUPPLY PAPER 2275, 1985.

POTENTIOMETRIC SURFACE OF THE EDWARDS-TRINITY AQUIFER SYSTEM AND CONTIGUOUS HYDRAULICALLY CONNECTED UNITS, WEST-CENTRAL TEXAS, WINTER 1974-75: USGS WATERRESOURCES INVESTIGATIONS REPORT 89-4208, 1990.

WITHDRAWALS FROM THE EDWARDS-TRINITY AQUIFER SYSTEM AND CONTIGUOUS HYDRAULICALLY CONNECTED UNITS, WEST-CENTRAL TEXAS, DECEMBER 1974 THROUGH MARCH 1977: USGS WATER-RESOURCES INVESTIGATIONS REPORT 91-4021, 1991.

CONFIGURATION OF THE BASE OF THE EDWARDS-TRINITY AQUIFER SYSTEM AND HYDROGEOLOGY OF THE UNDERLYING PRE-
CRETACEOUS ROCKS, WEST-CENTRAL TEXAS: USGS WATERRESOURCES INVESTIGATIONS REPORT 91-4071, 1992.

HISTORICAL POTENTIOMETRIC SURFACE OF THE EDWARDS-TRINITY AQUIFER SYSTEM AND CONTIGUOUS HYDRAULICALLY CONNECTED UNITS, WEST-CENTRAL TEXAS: USGS WATERRESOURCES INVESTIGATIONS REPORT 92-4055, 1993.

HISTORICAL SATURATED THICKNESS OF THE EDWARDS-TRINITY AQUIFER SYSTEM AND SELECTED CONTIGUOUS HYDRAULICALLY CONNECTED UNITS, WEST-CENTRAL TEXAS: USGS WATER-RESOURCES INVESTIGATIONS REPORT 92-4125, 1993.

SIMULATIONS OF FLOW IN THE EDWARDS-TRINITY AQUIFER SYSTEM AND CONTIGUOUS HYDRAULICALLY CONNECTED UNITS, WEST-CENTRAL TEXAS: USGS WATER-RESOURCES INVESTIGATIONS REPORT 93-4039, 1994.

DISSOLVED-SOLIDS CONCENTRATIONS AND HYDROCHEMICAL FACIES IN WATER OF THE EDWARDS-TRINITY AQUIFER SYSTEM, WEST-CENTRAL TEXAS: USGS WATER-RESOURCES INVESTIGATIONS REPORT 93-4126, 1994.

GEOLOGIC HISTORY AND HYDROGEOLOGIC SETTING OF THE EDWARDS-TRINITY AQUIFER SYSTEM, WEST-CENTRAL TEXAS: USGS WATER-RESOURCES INVESTIGATIONS REPORT 94-4039, 1994.

AQUIFERS OF TEXAS: TEXAS WATER DEVELOPMENT BOARD REPORT 345, 1995.

WATER QUALITY IN THE EDWARDS-TRINITY (PLATEAU) AQUIFER, EDWARDS PLATEAU AND TRANS-PECOS, TEXAS: TEXAS WATER DEVELOPMENT BOARD HYDROLOGIC ATLAS NO. 3, 1995.

THE PALEOZOIC AND RELATED AQUIFERS OF CENTRAL TEXAS: TEXAS WATER DEVELOPMENT BOARD REPORT 346, 1996.

HYDROGEOLOGIC FRAMEWORK OF THE EDWARDS-TRINITY AQUIFER SYSTEM, WEST-CENTRAL TEXAS: USGS PROFESSIONAL PAPER 1421-B, 1996.

AN OVERVIEW OF THE EDWARDS-TRINITY AQUIFER SYSTEM, CENTRAL-WEST TEXAS, CHAPTER 8, in AQUIFERS OF WEST TEXAS: TEXAS WATER DEVELOPMENT BOARD REPORT 356, 2001.

\section{MIDLAND COUNTY}

RECORDS OF WELLS, DRILLERS' LOGS, AND WATER ANALYSES, AND MAP SHOWING LOCATION OF WELLS IN MIDLAND COUNTY, TEXAS: TEXAS BOARD OF WATER ENGINEERS MISCELLANEOUS PUBLICATION 187, 1938

GROUND WATER IN THE VICINITY OF THE ARMY FLYING SCHOOL (BOMBADIER), MIDLAND, TEXAS: USGS OPEN-FILE REPORT (UNNUMBERED), 1943.

MEMORANDUM, MIDLAND CITY WATER SUPPLY: USGS OPEN-FILE REPORT (UNNUMBERED), 1944.

PUBLIC WATER SUPPLIES IN WESTERN TEXAS: TEXAS BOARD OF WATER ENGINEERS MISCELLANEOUS PUBLICATION 216, 1949.

PUBLIC WATER SUPPLIES IN WESTERN TEXAS: USGS WATERSUPPLY PAPER 1106, 1951.

RECORDS OF WATER-LEVEL MEASUREMENTS IN CRANE AND MIDLAND COUNTIES, TEXAS, 1937 THROUGH 1957: TEXAS BOARD OF WATER ENGINEERS BULLETIN 5906, 1959. 
SHALLOW FORMATIONS AND AQUIFERS OF THE WEST TEXAS AREA: WEST TEXAS GEOLOGICAL SOCIETY PUBLICATION 61-45 AND PERMIAN BASIN GEOPHYSICAL SOCIETY, MIDLAND, TEXAS, 1961.

A SUMMARY OF THE OCCURRENCE AND DEVELOPMENT OF GROUND WATER IN THE SOUTHERN HIGH PLAINS OF TEXAS: TEXAS BOARD OF WATER ENGINEERS BULLETIN 6107, 1961.

RECONNAISSANCE INVESTIGATION OF THE GROUND-WATER RESOURCES OF THE COLORADO RIVER BASIN, TEXAS: TEXAS WATER DEVELOPMENT BOARD REPORT 51, 1967.

SUMMARY APPRAISALS OF THE NATION'S GROUND-WATER RESOURCES-TEXAS-GULF REGION: USGS PROFESSIONAL PAPER 813-F, 1976.

OCCURRENCE, AVAILABILITY, AND CHEMICAL QUALITY OF GROUND WATER IN THE EDWARDS PLATEAU REGION OF TEXAS: TEXAS DEPARTMENT OF WATER RESOURCES REPORT 235,1979

PRELIMINARY DATA DESCRIBING THE DISTRIBUTION OF FLUORIDE AND SILICA IN THE OGALLALA AQUIFER ON THE HIGH PLAINS OF TEXAS: USGS OPEN-FILE REPORT 80-349, 1980.

EVALUATING THE GROUND-WATER RESOURCES OF THE HIGH PLAINS OF TEXAS: RESULTS OF TEST HOLE DRILLING: TEXAS DEPARTMENT OF WATER RESOURCES LIMITED PRINTING REPORT LP-129, 1980.

SPRINGS OF TEXAS, VOLUME 1: (BY GUNNAR BRUNE), BRANCHSMITH, INC., FORT WORTH, TEXAS, 1981.

BEDROCK GEOLOGY, ALTITUDE OF BASE, AND 1980 SATURATED THICKNESS OF THE HIGH PLAINS AQUIFER IN PARTS OF COLORADO, KANSAS, NEBRASKA, NEW MEXICO, OKLAHOMA, SOUTH DAKOTA, TEXAS, AND WYOMING: USGS HYDROLOGIC INVESTIGATIONS ATLAS HA-648, 1981.

WATER LEVEL AND SATURATED THICKNESS CHANGES, PREDEVELOPMENT TO 1980, IN THE HIGH PLAINS AQUIFER IN PARTS OF COLORADO, KANSAS, NEBRASKA, NEW MEXICO, OKLAHOMA, SOUTH DAKOTA, TEXAS, AND WYOMING: USGS HYDROLOGIC INVESTIGATIONS ATLAS HA-652, 1981.

DISSOLVED SOLIDS AND SODIUM IN WATER FROM THE HIGH PLAINS AQUIFER IN PARTS OF COLORADO, KANSAS, NEBRASKA, NEW MEXICO, OKLAHOMA, SOUTH DAKOTA, TEXAS, AND WYOMING: USGS HYDROLOGIC INVESTIGATIONS ATLAS HA-658, 1982.

EVALUATING THE GROUND-WATER RESOURCES OF THE HIGH PLAINS OF TEXAS, VOLUME 1: TEXAS DEPARTMENT OF WATER RESOURCES REPORT 288, V. 1, 1984.

EVALUATING THE GROUND-WATER RESOURCES OF THE HIGH PLAINS OF TEXAS, VOLUME 4, RECORDS OF WELLS, AND MAPS SHOWING WELL LOCATIONS, BASE OF AQUIFER, WATER LEVELS, AND SATURATED THICKNESS (ANDREWS, BORDEN, COCHRAN, DAWSON, ECTOR, GAINES, GARZA, GLASSCOCK, HOWARD, HOCKLEY, LUBBOCK, LYNN, MARTIN, MIDLAND, TERRY, AND YOAKUM COUNTIES: TEXAS DEPARTMENT OF WATER RESOURCES REPORT 288 V. 4, 1984.

GEOHYDROLOGY OF THE HIGH PLAINS AQUIFER IN PARTS OF COLORADO, KANSAS, NEBRASKA, NEW MEXICO, OKLAHOMA, SOUTH DAKOTA, TEXAS, AND WYOMING: USGS PROFESSIONAL PAPER 1400-B, 1984.
TEXAS GROUND-WATER RESOURCES, in NATIONAL WATER SUMMARY 1984: USGS WATER-SUPPLY PAPER 2275, 1985.

WATER USE, PROJECTED WATER REQUIREMENTS, AND RELATED DATA AND INFORMATION FOR THE METROPOLITAN STATISTICAL AREAS IN TEXAS: TEXAS DEPARTMENT OF WATER RESOURCES LIMITED PRINTING REPORT LP-201, 1985.

DIGITAL SIMULATION OF GROUND-WATER FLOW IN THE HIGH PLAINS AQUIFER IN PARTS OF COLORADO, KANSAS, NEBRASKA, NEW MEXICO, OKLAHOMA, SOUTH DAKOTA, TEXAS, AND WYOMING: USGS PROFESSIONAL PAPER 1400-D, 1986.

SUMMARY OF THE HIGH PLAINS REGIONAL AQUIFER-SYSTEM ANALYSIS IN PARTS OF COLORADO, KANSAS, NEBRASKA, NEW MEXICO, OKLAHOMA, SOUTH DAKOTA, TEXAS, AND WYOMING: USGS PROFESSIONAL PAPER 1400-A, 1988.

HYDROGEOLOGY AND HYDROCHEMISTRY OF CRETACEOUS AQUIFERS, TEXAS PANHANDLE AND EASTERN NEW MEXICO: UNIVERSITY OF TEXAS, BUREAU OF ECONOMIC GEOLOGY GEOLOGICAL CIRCULAR 88-3, 1988.

PUBLIC SUPPLY GROUND-WATER USE IN WESTERN TEXAS: TEXAS WATER DEVELOPMENT BOARD REPORT 311, 1989.

EVALUATION OF GROUND-WATER RESOURCES IN PARTS OF MIDLAND, REAGAN, AND UPTON COUNTIES, TEXAS: TEXAS WATER DEVELOPMENT BOARD REPORT 312, 1989.

POTENTIOMETRIC SURFACE OF THE EDWARDS-TRINITY AQUIFER SYSTEM AND CONTIGUOUS HYDRAULICALLY CONNECTED UNITS, WEST-CENTRAL TEXAS, WINTER 1974-75: USGS WATERRESOURCES INVESTIGATIONS REPORT 89-4208, 1990.

WITHDRAWALS FROM THE EDWARDS-TRINITY AQUIFER SYSTEM AND CONTIGUOUS HYDRAULICALLY CONNECTED UNITS, WEST-CENTRAL TEXAS, DECEMBER 1974 THROUGH MARCH 1977: USGS WATER-RESOURCES INVESTIGATIONS REPORT 91-4021, 1991.

EVALUATION OF GROUND-WATER RESOURCES IN THE SOUTHERN HIGH PLAINS OF TEXAS: TEXAS DEPARTMENT OF WATER RESOURCES REPORT 330, 1991

WATER-LEVEL CHANGES IN THE HIGH PLAINS AQUIFER OF TEXAS, 1980-1990: TEXAS WATER DEVELOPMENT BOARD HYDROLOGIC ATLAS NO. 1, 1991.

CONFIGURATION OF THE BASE OF THE EDWARDS-TRINITY AQUIFER SYSTEM AND HYDROGEOLOGY OF THE UNDERLYING PRECRETACEOUS ROCKS, WEST-CENTRAL TEXAS: USGS WATERRESOURCES INVESTIGATIONS REPORT 91-4071, 1992.

THE HIGH PLAINS AQUIFER SYSTEM OF TEXAS, 1980 TO 1990. OVERVIEW AND PROJECTIONS: TEXAS WATER DEVELOPMENT BOARD REPORT 341, 1993.

HISTORICAL POTENTIOMETRIC SURFACE OF THE EDWARDS-TRINITY AQUIFER SYSTEM AND CONTIGUOUS HYDRAULICALLY CONNECTED UNITS, WEST-CENTRAL TEXAS: USGS WATERRESOURCES INVESTIGATIONS REPORT 92-4055, 1993.

HISTORICAL SATURATED THICKNESS OF THE EDWARDS-TRINITY AQUIFER SYSTEM AND SELECTED CONTIGUOUS HYDRAULICALLY CONNECTED UNITS, WEST-CENTRAL TEXAS: USGS WATER-RESOURCES INVESTIGATIONS REPORT 92-4125, 1993. 
WATER-QUALITY EVALUATION OF THE OGALLALA AQUIFER, TEXAS: TEXAS WATER DEVELOPMENT BOARD REPORT 342, 1993.

SIMULATIONS OF FLOW IN THE EDWARDS-TRINITY AQUIFER SYSTEM AND CONTIGUOUS HYDRAULICALLY CONNECTED UNITS, WEST-CENTRAL TEXAS: USGS WATER-RESOURCES INVESTIGATIONS REPORT 93-4039, 1994.

DISSOLVED-SOLIDS CONCENTRATIONS AND HYDROCHEMICAL FACIES IN WATER OF THE EDWARDS-TRINITY AQUIFER SYSTEM, WEST-CENTRAL TEXAS: USGS WATER-RESOURCES INVESTIGATIONS REPORT 93-4126, 1994.

GEOLOGIC HISTORY AND HYDROGEOLOGIC SETTING OF THE EDWARDS-TRINITY AQUIFER SYSTEM, WEST-CENTRAL TEXAS: USGS WATER-RESOURCES INVESTIGATIONS REPORT 94-4039, 1994.

WATER-LEVEL CHANGES IN THE HIGH PLAINS AQUIFER, 1980 TO 1994: USGS FACT SHEET FS-215-95, 1995.

AQUIFERS OF TEXAS: TEXAS WATER DEVELOPMENT BOARD REPORT 345, 1995.

WATER QUALITY IN THE EDWARDS-TRINITY (PLATEAU) AQUIFER, EDWARDS PLATEAU AND TRANS-PECOS, TEXAS: TEXAS WATER DEVELOPMENT BOARD HYDROLOGIC ATLAS NO. 3, 1995.

WATER-LEVEL CHANGES IN THE HIGH PLAINS AQUIFER, 1980 TO 1995: USGS FACT SHEET FS-068-97, 1997.

UPDATED WATER-QUALITY EVALUATION OF THE OGALLALA AQUIFER INCLUDING SELECTED METALLIC AND NON-METALLIC INORGANIC CONSTITUENTS: TEXAS WATER DEVELOPMENT BOARD HYDROLOGIC ATLAS NO. 10, 1998.

AN OVERVIEW OF THE EDWARDS-TRINITY AQUIFER SYSTEM, CENTRAL-WEST TEXAS, CHAPTER 8, in AQUIFERS OF WEST TEXAS: TEXAS WATER DEVELOPMENT BOARD REPORT 356, 2001.

\section{MILAM COUNTY}

GEOGRAPHY AND GEOLOGY OF THE BLACK AND GRAND PRAIRIES OF TEXAS, WITH DETAILED DESCRIPTIONS OF THE CRETACEOUS FORMATIONS AND SPECIAL REFERENCE TO ARTESIAN WATERS: USGS 21ST ANNUAL REPORT, PART 7, 1901.

UNDERGROUND WATERS OF COASTAL PLAIN OF TEXAS: USGS WATER SUPPLY AND IRRIGATION PAPER 190, 1907.

GEOLOGY AND UNDERGROUND WATERS OF THE SOUTHEASTERN PART OF THE TEXAS COASTAL PLAIN: USGS WATER-SUPPLY PAPER 335, 1914.

RECORDS OF WELLS, DRILLERS' LOGS, AND WATER ANALYSES, AND MAP SHOWING LOCATION OF WELLS IN MILAM COUNTY, TEXAS: TEXAS BOARD OF WATER ENGINEERS MISCELLANEOUS PUBLICATION 188, 1937.

PUBLIC WATER SUPPLIES IN EASTERN TEXAS, V. 2, HARRISON COUNTY THROUGH WOOD COUNTY: TEXAS BOARD OF WATER ENGINEERS MISCELLANEOUS PUBLICATION 214, V. 2, 1945.

PUBLIC WATER SUPPLIES IN EASTERN TEXAS: USGS WATERSUPPLY PAPER 1047, 1948.
RECONNAISSANCE INVESTIGATION OF THE GROUND-WATER RESOURCES OF THE BRAZOS RIVER BASIN: TEXAS WATER COMMISSION BULLETIN 6310, 1963.

GROUND WATER IN THE FLOOD-PLAIN ALLUVIUM OF THE BRAZOS RIVER, WHITNEY DAM TO VICINITY OF RICHMOND, TEXAS: TEXAS WATER DEVELOPMENT BOARD REPORT 41, 1967.

HYDROLOGIC SIGNIFICANCE OF LITHOFACIES OF THE CANE RIVER FORMATION OR EQUIVALENTS OF ARKANSAS, LOUISIANA, MISSISSIPPI, AND TEXAS: USGS PROFESSIONAL PAPER 569-C, 1972.

MAJOR AND HISTORICAL SPRINGS OF TEXAS: TEXAS WATER DEVELOPMENT BOARD REPORT 189, 1975.

GEOHYDROLOGIC SIGNIFICANCE OF LITHOFACIES OF THE CARRIZO SAND OF ARKANSAS, LOUISIANA, AND TEXAS AND THE MERIDIAN SAND OF MISSISSIPPI: USGS PROFESSIONAL PAPER 569-D, 1975.

GROUND-WATER RESOURCES OF PART OF CENTRAL TEXAS WITH EMPHASIS ON THE ANTLERS AND TRAVIS PEAK FORMATIONS: TEXAS WATER DEVELOPMENT BOARD REPORT 195, V. 1, 1975.

GROUND-WATER RESOURCES OF PART OF CENTRAL TEXAS WITH EMPHASIS ON THE ANTLERS AND TRAVIS PEAK FORMATIONS: TEXAS WATER DEVELOPMENT BOARD REPORT 195, V. 2, 1976.

SUMMARY APPRAISALS OF THE NATION'S GROUND-WATER RESOURCES-TEXAS-GULF REGION: USGS PROFESSIONAL PAPER 813-F, 1976.

SPRINGS OF TEXAS, VOLUME 1: (BY GUNNAR BRUNE), BRANCHSMITH, INC., FORT WORTH, TEXAS, 1981.

TEXAS GROUND-WATER RESOURCES, in NATIONAL WATER SUMMARY 1984: USGS WATER-SUPPLY PAPER 2275, 1985.

APPROXIMATE POTENTIOMETRIC SURFACES FOR THE AQUIFERS OF THE COASTAL UPLANDS SYSTEM, 1980: USGS HYDROLOGIC INVESTIGATIONS ATLAS HA-704, 1987.

GEOHYDROLOGIC FRAMEWORK OF THE GULF COASTAL PLAIN: USGS HYDROLOGIC INVESTIGATIONS ATLAS HA-695, 1988.

HYDROGEOLOGY AND PREDEVELOPMENT FLOW IN THE TEXAS GULF COAST AQUIFER SYSTEMS: USGS WATER-RESOURCES INVESTIGATIONS REPORT 87-4248, 1988.

EVALUATION OF WATER RESOURCES IN PART OF CENTRAL TEXAS: TEXAS WATER DEVELOPMENT BOARD REPORT 319 , 1990.

GROUND-WATER FLOW IN THE GULF COAST AQUIFER SYSTEMS, SOUTH-CENTRAL UNITED STATES-A PRELIMINARY ANALYSIS: USGS WATER-RESOURCES INVESTIGATIONS REPORT 89-4071, 1990.

HYDROLOGY OF THE TEXAS GULF COAST AQUIFER SYSTEMS: USGS OPEN-FILE REPORT 91-64, 1991.

GROUND-WATER RESOURCES OF THE CARRIZO-WILCOX AQUIFER IN THE CENTRAL TEXAS REGION: TEXAS WATER DEVELOPMENT BOARD REPORT 332, 1991.

PROPERTIES AND CHEMICAL CONSTITUENTS IN GROUND WATER FROM THE LOWER CLAIBORNE-UPPER WILCOX AQUIFER, GULF COAST REGIONAL AQUIFER SYSTEMS, SOUTH-CENTRAL UNITED STATES: USGS WATER-RESOURCES INVESTIGATIONS REPORT 92-4102, 1993. 
PROPERTIES AND CHEMICAL CONSTITUENTS IN GROUND WATER FROM THE MIDDLE CLAIBORNE AQUIFER, GULF COAST REGIONAL AQUIFER SYSTEMS, SOUTH-CENTRAL UNITED STATES: USGS WATER-RESOURCES INVESTIGATIONS REPORT 92-4104, 1993.

PROPERTIES AND CHEMICAL CONSTITUENTS IN GROUND WATER FROM THE MIDDLE WILCOX AQUIFER, GULF COAST AQUIFER SYSTEMS, SOUTH-CENTRAL UNITED STATES: USGS WATERRESOURCES INVESTIGATIONS REPORT 93-4070, 1993.

AQUIFERS OF TEXAS: TEXAS WATER DEVELOPMENT BOARD REPORT 345, 1995.

STRATIGRAPHIC NOMENCLATURE AND GEOLOGIC SECTIONS OF THE GULF COASTAL PLAIN OF TEXAS: USGS OPEN-FILE REPORT 94-461, 1995.

WATER QUALITY IN THE QUEEN CITY AQUIFER, EAST TEXAS: TEXAS WATER DEVELOPMENT BOARD HYDROLOGIC ATLAS NO. 6, 1996.

GROUND-WATER AVAILABILITY IN THE CARRIZO-WILCOX AQUIFER IN CENTRAL TEXAS-NUMERICAL SIMULATIONS OF 2000 THROUGH 2050 WITHDRAWAL PROJECTIONS: UNIVERSITY OF TEXAS, BUREAU OF ECONOMIC GEOLOGY REPORT OF INVESTIGATIONS NO. 256, 1999.

CHANGES IN GROUNDWATER CONDITIONS IN THE EDWARDS AND TRINITY AQUIFERS, 1987-1997, FOR PORTIONS OF BASTROP, BELL, BURNET, LEE, MILAM, TRAVIS, AND WILLIAMSON COUNTIES, TEXAS: TEXAS WATER DEVELOPMENT BOARD REPORT $350,1999$.

\section{MILLS COUNTY}

GEOGRAPHY AND GEOLOGY OF THE BLACK AND GRAND PRAIRIES OF TEXAS, WITH DETAILED DESCRIPTIONS OF THE CRETACEOUS FORMATIONS AND SPECIAL REFERENCE TO ARTESIAN WATERS: USGS 21ST ANNUAL REPORT, PART 7, 1901.

PUBLIC WATER SUPPLIES IN CENTRAL AND NORTH-CENTRAL TEXAS: TEXAS BOARD OF WATER ENGINEERS MISCELLANEOUS PUBLICATION 213, 1947.

PUBLIC WATER SUPPLIES IN CENTRAL AND NORTH-CENTRAL TEXAS: USGS WATER-SUPPLY PAPER 1069, 1949.

RECONNAISSANCE INVESTIGATION OF THE GROUND-WATER RESOURCES OF THE BRAZOS RIVER BASIN, TEXAS: TEXAS WATER COMMISSION BULLETIN 6310, 1963.

RECONNAISSANCE INVESTIGATION OF THE GROUND-WATER RESOURCES OF THE COLORADO RIVER BASIN, TEXAS: TEXAS WATER DEVELOPMENT BOARD REPORT 51, 1967.

GROUND-WATER RESOURCES OF PART OF CENTRAL TEXAS WITH EMPHASIS ON THE ANTLERS AND TRAVIS PEAK FORMATIONS, VOLUME 1: TEXAS WATER DEVELOPMENT BOARD REPORT 195, V. 1, 1975.

GROUND-WATER RESOURCES OF PART OF CENTRAL TEXAS WITH EMPHASIS ON THE ANTLERS AND TRAVIS PEAK FORMATIONS, VOLUME 2, RECORDS OF WELLS; DRILLERS' LOGS; WATER LEVELS IN WELLS; CHEMICAL ANALYSES OF GROUND WATER; CHEMICAL ANALYSES OF OIL-FIELD BRINES; AND WELL LOCATION MAPS: TEXAS WATER DEVELOPMENT BOARD REPORT 195, V. 2, 1976.
SUMMARY APPRAISALS OF THE NATION'S GROUND-WATER RESOURCES-TEXAS-GULF REGION: USGS PROFESSIONAL PAPER 813-F, 1976.

TEXAS GROUND-WATER RESOURCES, in NATIONAL WATER SUMMARY 1984: USGS WATER-SUPPLY PAPER 2275, 1985.

EVALUATION OF WATER RESOURCES IN PART OF CENTRAL TEXAS: TEXAS WATER DEVELOPMENT BOARD REPORT 319, 1990.

AQUIFERS OF TEXAS: TEXAS WATER DEVELOPMENT BOARD REPORT 345, 1995.

THE PALEOZOIC AND RELATED AQUIFERS OF CENTRAL TEXAS: TEXAS WATER DEVELOPMENT BOARD REPORT 346, 1996.

\section{MITCHELL COUNTY}

GEOGRAPHY AND GEOLOGY OF THE BLACK AND GRAND PRAIRIES OF TEXAS, WITH DETAILED DESCRIPTIONS OF THE CRETACEOUS FORMATIONS AND SPECIAL REFERENCE TO ARTESIAN WATERS: USGS 21ST ANNUAL REPORT, PART 7, 1901.

GROUND-WATER RESOURCES OF COLORADO CITY AND VICINITY, TEXAS: USGS OPEN-FILE REPORT (UNNUMBERED), 1946.

PUBLIC WATER SUPPLIES IN WESTERN TEXAS: TEXAS BOARD OF WATER ENGINEERS MISCELLANEOUS PUBLICATION 216, 1949.

PUBLIC WATER SUPPLIES IN WESTERN TEXAS: USGS WATERSUPPLY PAPER 1106, 1951.

MEMORANDUM ON GROUND-WATER IRRIGATION IN MITCHELL COUNTY, TEXAS: TEXAS BOARD OF WATER ENGINEERS MISCELLANEOUS PUBLICATION 189, 1953.

RECORDS OF WATER-LEVEL MEASUREMENTS IN MITCHELL, NOLAN, STERLING, AND TOM GREEN COUNTIES, TEXAS, 1938 THROUGH 1957: TEXAS BOARD OF WATER ENGINEERS BULLETIN 5907, 1959.

A STUDY OF SALT WATER POLLUTION OF THE COLORADO RIVER, SCURRY AND MITCHELL COUNTIES, TEXAS: PREPARED FOR THE COLORADO RIVER MUNICIPAL WATER DISTRICT, BIG SPRING, TEXAS, BY ED L. REED, CONSULTING GROUND-WATER HYDROLOGIST, MIDLAND, TEXAS, 1961.

GROUND-WATER RESOURCES OF MITCHELL AND WESTERN NOLAN COUNTIES, TEXAS: TEXAS WATER DEVELOPMENT BOARD REPORT 50, 1967.

RECONNAISSANCE INVESTIGATION OF THE GROUND-WATER RESOURCES OF THE COLORADO RIVER BASIN, TEXAS: TEXAS WATER DEVELOPMENT BOARD REPORT 51, 1967.

WOODY PHREATOPHYTES ALONG THE COLORADO RIVER FROM SOUTHEAST RUNNELS COUNTY TO THE HEADWATERS IN BORDEN COUNTY, TEXAS: TEXAS WATER DEVELOPMENT BOARD REPORT 182, 1974

SUMMARY APPRAISALS OF THE NATION'S GROUND-WATER RESOURCES-TEXAS-GULF REGION: USGS PROFESSIONAL PAPER 813-F, 1976.

SOURCE AREAS OF SALINITY AND TRENDS OF SALT LOADS IN STREAMFLOW IN THE UPPER COLORADO RIVER, TEXAS: USGS OPEN-FILE REPORT 80-224, 1980. 
AN INVESTIGATION OF SOURCES OF SALT POLLUTION IN THE UPPER COLORADO RIVER BASIN, TEXAS: U.S. ARMY CORPS OF ENGINEERS REPORT, 1980.

TEXAS GROUND-WATER RESOURCES, in NATIONAL WATER SUMMARY 1984: USGS WATER-SUPPLY PAPER 2275, 1985.

PUBLIC SUPPLY GROUND-WATER USE IN THE SOUTHERN HIGH PLAINS OF TEXAS: TEXAS WATER DEVELOPMENT BOARD REPORT 328, 1990.

WATER-LEVEL CHANGES IN THE HIGH PLAINS AQUIFER OF TEXAS, 1980-1990: TEXAS WATER DEVELOPMENT BOARD HYDROLOGIC ATLAS NO. 1, 1991.

CHARACTERISTICS OF STREAMS AND AQUIFERS AND PROCESSES AFFECTING THE SALINITY OF WATER IN THE UPPER COLORADO RIVER BASIN, TEXAS: USGS WATER-RESOURCES INVESTIGATIONS REPORT 94-4036, 1994.

AQUIFERS OF TEXAS: TEXAS WATER DEVELOPMENT BOARD REPORT 345, 1995.

WATER QUALITY IN THE EDWARDS-TRINITY (PLATEAU) AQUIFER, EDWARDS PLATEAU AND TRANS-PECOS, TEXAS: TEXAS WATER DEVELOPMENT BOARD HYDROLOGIC ATLAS NO. 3, 1995.

UPDATED WATER-QUALITY EVALUATION OF THE OGALLALA AQUIFER INCLUDING SELECTED METALLIC AND NON-METALLIC INORGANIC CONSTITUENTS: TEXAS WATER DEVELOPMENT BOARD HYDROLOGIC ATLAS HA-10, 1998.

\section{MONTAGUE COUNTY}

GEOGRAPHY AND GEOLOGY OF THE BLACK AND GRAND PRAIRIES, TEXAS, WITH DETAILED DESCRIPTIONS OF THE CRETACEOUS FORMATIONS AND SPECIAL REFERENCE TO ARTESIAN WATERS: USGS 21ST ANNUAL REPORT, PART 7, 1901.

GROUND-WATER RESOURCES IN THE VICINITY OF NACONA, MONTAGUE COUNTY, TEXAS: TEXAS BOARD OF WATER ENGINEERS MISCELLANEOUS PUBLICATION 190, 1944.

PUBLIC WATER SUPPLIES IN CENTRAL AND NORTH-CENTRAL TEXAS: TEXAS BOARD OF WATER ENGINEERS MISCELLANEOUS PUBLICATION 213, 1947.

GEOLOGY AND UNDERGROUND WATERS OF THE WICHITA REGION, NORTH-CENTRAL TEXAS: USGS WATER-SUPPLY PAPER 1069, 1949.

PUBLIC WATER SUPPLIES IN CENTRAL AND NORTH-CENTRAL TEXAS: USGS WATER-SUPPLY PAPER 1069, 1949.

MEMORANDUM ON MEASUREMENTS OF NACONA CITY WELLS, MONTAGUE COUNTY, TEXAS: USGS OPEN-FILE REPORT (UNNUMBERED), 1956.

RECONNAISSANCE INVESTIGATION OF THE GROUND-WATER RESOURCES OF THE RED RIVER, SULPHUR RIVER, AND CYPRESS CREEK BASINS, TEXAS: TEXAS WATER COMMISSION BULLETIN 6306, 1963.

RECONNAISSANCE INVESTIGATION OF THE GROUND-WATER RESOURCES OF THE TRINITY RIVER BASIN, TEXAS: TEXAS WATER COMMISSION BULLETIN 6309, 1963.
OCCURRENCE AND QUALITY OF GROUND WATER IN MONTAGUE COUNTY, TEXAS: TEXAS WATER DEVELOPMENT BOARD REPORT 58, 1967.

COMPILATION OF RESULTS OF AQUIFER TESTS IN TEXAS: TEXAS WATER DEVELOPMENT BOARD REPORT 98, 1969.

MAJOR AND HISTORICAL SPRINGS OF TEXAS: TEXAS WATER DEVELOPMENT BOARD REPORT 189, 1975.

SUMMARY APPRAISALS OF THE NATION'S GROUND-WATER RESOURCES-TEXAS-GULF REGION: USGS PROFESSIONAL PAPER 813-F, 1976.

WATER-LEVEL AND WATER-QUALITY DATA FROM OBSERVATION WELLS IN NORTHEAST TEXAS: TEXAS WATER DEVELOPMENT BOARD REPORT 198, 1976.

SPRINGS OF TEXAS, VOLUME 1: (BY GUNNAR BRUNE), BRANCHSMITH, INC., FORT WORTH, TEXAS, 1981.

OCCURRENCE, AVAILABILITY, AND CHEMICAL QUALITY OF GROUND WATER IN THE CRETACEOUS AQUIFERS OF NORTHCENTRAL TEXAS: TEXAS DEPARTMENT OF WATER RESOURCES REPORT 269, V. 1, 1982.

OCCURRENCE, AVAILABILITY, AND CHEMICAL QUALITY OF GROUND WATER IN THE CRETACEOUS AQUIFERS OF NORTHCENTRAL TEXAS: TEXAS DEPARTMENT OF WATER RESOURCES REPORT 269, V. 2, 1982.

TEXAS GROUND-WATER RESOURCES, in NATIONAL WATER SUMMARY 1984: USGS WATER-SUPPLY PAPER 2275, 1985.

EVALUATION OF WATER RESOURCES IN PART OF NORTH-CENTRAL TEXAS: TEXAS WATER DEVELOPMENT BOARD REPORT 318,1990 .

NATIONAL WATER-QUALITY ASSESSMENT PROGRAM-THE TRINITY RIVER BASIN: USGS OPEN-FILE REPORT 91-158, 1991.

SIMULATION OF GROUND-WATER FLOW IN THE ANTLERS AQUIFER IN SOUTHEASTERN OKLAHOMA AND NORTHEASTERN TEXAS: USGS WATER-RESOURCES INVESTIGATIONS REPORT 88-4208, 1992.

EVALUATION OF WATER RESOURCES IN PARTS OF THE ROLLING PRAIRIES REGION OF NORTH-CENTRAL TEXAS: TEXAS WATER DEVELOPMENT BOARD REPORT 337, 1992.

NATIONAL WATER-QUALITY ASSESSMENT PROGRAM-PESTICIDES IN THE TRINITY RIVER BASIN STUDY UNIT, TEXAS, 1968-91: USGS FACT SHEET FS-088-95, 1995.

WATER-QUALITY ASSESSMENT OF THE TRINITY RIVER BASIN, TEXAS-DATA COLLECTION, 1992-95: USGS FACT SHEET FS-095-95, 1995.

WATER-QUALITY ASSESSMENT OF THE TRINITY RIVER BASIN, TEXAS-PESTICIDES IN A SUBURBAN WATERSHED, ARLINGTON, 1993-94: USGS FACT SHEET FS-159-95, 1995.

AQUIFERS OF TEXAS: TEXAS WATER DEVELOPMENT BOARD REPORT 345, 1995.

UPDATED EVALUATION OF WATER RESOURCES IN PART OF NORTH-CENTRAL TEXAS, 1990-1999: TEXAS WATER DEVELOPMENT BOARD REPORT 349, 1999.

WATER-QUALITY ASSESSMENT OF THE TRINITY RIVER BASIN, TEXAS-GROUND-WATER QUALITY OF THE TRINITY, CARRIZOWILCOX, AND GULF COAST AQUIFERS, FEBRUARY-AUGUST 
1994: USGS WATER-RESOURCES INVESTIGATIONS REPORT 99-4233, 2000.

\section{MONTGOMERY COUNTY}

UNDERGROUND WATERS OF COASTAL PLAIN OF TEXAS: USGS WATER SUPPLY AND IRRIGATION PAPER 190, 1907.

GEOLOGY AND UNDERGROUND WATERS OF THE SOUTHEASTERN PART OF THE TEXAS COASTAL PLAIN: USGS WATER-SUPPLY PAPER 335, 1914.

RECORDS OF WELLS, DRILLERS' LOGS, WATER ANALYSES, AND MAP SHOWING LOCATION OF WELLS IN MONTGOMERY COUNTY, TEXAS: TEXAS BOARD OF WATER ENGINEERS MISCELLANEOUS PUBLICATION 191, 1939.

NOTES ON RECHARGE TEST WELLS-HOUSTON DISTRICT, 1-29-41 AND 1-31-41: USGS OPEN-FILE REPORT (UNNUMBERED), 1941.

GROUND WATER IN THE VICINITY OF CONROE, MONTGOMERY COUNTY, TEXAS: USGS OPEN-FILE REPORT (UNNUMBERED), 1941.

GROUND WATER AND THE RELATION OF GEOLOGY TO ITS OCCURRENCE IN THE HOUSTON DISTRICT, TEXAS: USGS OPEN-FILE REPORT (UNNUMBERED), 1942.

RECORDS OF WELLS, DRILLERS' LOGS, WATER ANALYSES, AND MAP SHOWING LOCATION OF WELLS IN MONTGOMERY COUNTY, TEXAS: TEXAS BOARD OF WATER ENGINEERS MISCELLANEOUS PUBLICATION 192, 1943.

GROUND WATER AND RELATION OF GEOLOGY TO ITS OCCURRENCE IN HOUSTON DISTRICT, TEXAS: AMERICAN ASSOCIATION OF PETROLEUM GEOLOGISTS, V. 27, NO. 8, P. 1081-1101, 1943.

GROUND-WATER RESOURCES OF THE HOUSTON DISTRICT, TEXAS: USGS WATER-SUPPLY PAPER 889-C, 1944.

PUBLIC WATER SUPPLIES IN EASTERN TEXAS, V. 2, HARRISON COUNTY THROUGH WOOD COUNTY: TEXAS BOARD OF WATER ENGINEERS MISCELLANEOUS PUBLICATION 214, V. 2, 1945.

GROUND-WATER RESOURCES OF THE HOUSTON DISTRICT, TEXAS, PROGRESS REPORT FOR 1946, WITH SECTION ON RESULTS OF PUMPING TESTS AT NEW SOUTHWEST PUMPING PLANT: TEXAS BOARD OF WATER ENGINEERS MISCELLANEOUS PUBLICATION $138,1946$.

PUBLIC WATER SUPPLIES IN EASTERN TEXAS: USGS WATERSUPPLY PAPER 1047, 1948.

GEOLOGY AND GROUND-WATER RESOURCES OF THE HOUSTON DISTRICT: TEXAS BOARD OF WATER ENGINEERS BULLETIN 5001, 1950.

WATER SUPPLY OF THE HOUSTON GULF COAST REGION: TEXAS BOARD OF WATER ENGINEERS BULLETIN 5101, 1951.

AVAILABILITY OF GROUND WATER IN THE GULF COAST REGION OF TEXAS: USGS OPEN-FILE REPORT (UNNUMBERED), 1956.

RECORDS OF WATER-LEVEL MEASUREMENTS IN CHAMBERS, LIBERTY, AND MONTGOMERY COUNTIES, TEXAS, 1931 THROUGH APRIL 1958: TEXAS BOARD OF WATER ENGINEERS BULLETIN 5901, 1959.
RECONNAISSANCE INVESTIGATION OF THE GROUND-WATER RESOURCES OF THE GULF COAST REGION, TEXAS: TEXAS WATER COMMISSION BULLETIN 6305, 1963.

ANALOG MODEL STUDY OF GROUND WATER IN THE HOUSTON DISTRICT, TEXAS: TEXAS WATER COMMISSION BULLETIN 6508, 1965.

DEVELOPMENT OF GROUND WATER IN THE HOUSTON DISTRICT, TEXAS, 1961-65: TEXAS WATER DEVELOPMENT BOARD REPORT 63, 1967.

HYDROLOGIC SIGNIFICANCE OF THE LITHOFACIES OF THE SPARTA SAND IN ARKANSAS, LOUISIANA, MISSISSIPPI, AND TEXAS: USGS PROFESSIONAL PAPER 569-A, 1968.

COMPILATION OF RESULTS OF AQUIFER TESTS IN TEXAS: TEXAS WATER DEVELOPMENT BOARD REPORT 98, 1969.

GEOHYDROLOGIC SIGNIFICANCE OF LITHOFACIES OF THE COCKFIELD FORMATION OF LOUISIANA AND MISSISSIPPI AND OF THE YEGUA FORMATION OF TEXAS: USGS PROFESSIONAL PAPER 569-B, 1970.

GROUND-WATER RESOURCES OF MONTGOMERY COUNTY, TEXAS: TEXAS WATER DEVELOPMENT BOARD REPORT 136, 1971.

DEVELOPMENT OF GROUND WATER IN THE HOUSTON DISTRICT, TEXAS, 1966-69: TEXAS WATER DEVELOPMENT BOARD REPORT $152,1972$.

LAND-SURFACE SUBSIDENCE IN THE HOUSTON-GALVESTON REGION, TEXAS: USGS OPEN-FILE REPORT 74-123, 1974.

HYDROLOGIC SIGNIFICANCE OF LITHOFACIES OF THE CANE RIVER FORMATION OR EQUIVALENTS OF ARKANSAS, LOUISIANA, MISSISSIPPI, AND TEXAS: USGS PROFESSIONAL PAPER 569-C, 1972.

GEOHYDROLOGIC SIGNIFICANCE OF LITHOFACIES OF THE CARRIZO SAND OF ARKANSAS, LOUISIANA, AND TEXAS AND THE MERIDIAN SAND OF MISSISSIPPI: USGS PROFESSIONAL PAPER 569-D, 1975.

LAND-SURFACE SUBSIDENCE IN THE HOUSTON-GALVESTON REGION, TEXAS: TEXAS: TEXAS WATER DEVELOPMENT BOARD REPORT 188, 1975.

RECORDS OF WELLS, DRILLERS' LOGS, WATER-LEVEL MEASUREMENTS, AND CHEMICAL ANALYSES OF GROUND WATER IN CHAMBERS, LIBERTY, AND MONTGOMERY COUNTIES, TEXAS, 1966-74: TEXAS WATER DEVELOPMENT BOARD REPORT 202, 1976.

SUMMARY APPRAISALS OF THE NATION'S GROUND-WATER RESOURCES-TEXAS GULF REGION: USGS PROFESSIONAL PAPER 813-F, 1976.

APPROXIMATE AREAS OF RECHARGE TO THE CHICOT AND EVANGELINE AQUIFER SYSTEMS IN THE HOUSTON-GALVESTON AREA, TEXAS: USGS OPEN-FILE REPORT 77-754, 1977.

STRATIGRAPHIC AND HYDROGEOLOGIC FRAMEWORK OF PART OF THE COASTAL PLAIN OF TEXAS: USGS OPEN-FILE REPORT 77-712, 1978.

STRATIGRAPHIC AND HYDROGEOLOGIC FRAMEWORK OF PART OF THE COASTAL PLAIN OF TEXAS: TEXAS DEPARTMENT OF WATER RESOURCES REPORT 236, 1979.

APPROXIMATE ALTITUDE OF WATER LEVELS IN WELLS IN THE CHICOT AND EVANGELINE AQUIFERS IN THE HOUSTON AREA, 
TEXAS, SPRING 1977 AND SPRING 1978: USGS OPEN-FILE REPORT 79-334, 1979.

APPROXIMATE WATER-LEVEL CHANGES IN WELLS IN THE CHICOT AND EVANGELINE AQUIFERS, 1977-79, AND MEASURED COMPACTION 1973-79, IN HARRIS AND GALVESTON COUNTIES, TEXAS: USGS OPEN-FILE REPORT 79-693, 1979.

APPROXIMATE WATER-LEVEL CHANGES IN WELLS IN THE CHICOT AND EVANGELINE AQUIFERS IN THE HOUSTON-GALVESTON REGION, TEXAS, 1977-80 AND 1979-80: USGS OPEN-FILE REPORT 80-337, 1980.

APPROXIMATE ALTITUDE OF WATER LEVELS IN WELLS IN THE CHICOT AND EVANGELINE AQUIFERS IN THE HOUSTON AREA, TEXAS, SPRING 1979 AND SPRING 1980: USGS OPEN-FILE REPORT 80-579, 1980.

APPROXIMATE LAND-SURFACE SUBSIDENCE IN THE HOUSTONGALVESTON REGION, TEXAS, 1906-78, 1943-78, AND 1973-78: USGS OPEN-FILE REPORT 80-338, 1980.

DEVELOPMENT OF GROUND WATER IN THE HOUSTONGALVESTON DISTRICT, TEXAS, 1970-74: TEXAS DEPARTMENT OF WATER RESOURCES REPORT 241, 1980.

APPROXIMATE WATER-LEVEL CHANGES IN WELLS IN THE CHICOT AND EVANGELINE AQUIFERS, 1977-81 AND 1980-81, AND MEASURED COMPACTION, 1973-81, IN THE HOUSTON-GALVESTON REGION, TEXAS: USGS OPEN-FILE REPORT 81-341, 1981.

SPRINGS OF TEXAS, VOLUME 1: (BY GUNNAR BRUNE), BRANCHSMITH, INC., FORT WORTH, TEXAS, 1981.

APPROXIMATE ALTITUDE OF WATER LEVELS IN THE CHICOT AND EVANGELINE AQUIFERS IN THE HOUSTON AREA, TEXAS, SPRING 1981: USGS OPEN-FILE REPORT 81-676, 1981.

APPROXIMATE WATER-LEVEL CHANGES IN WELLS IN THE CHICOT AND EVANGELINE AQUIFERS, 1977-82 AND 1981-82, AND MEASURED COMPACTION, 1973-82, IN THE HOUSTON-GALVESTON REGION, TEXAS: USGS OPEN-FILE REPORT 82-328, 1982.

APPROXIMATE ALTITUDE OF WATER LEVELS IN WELLS IN THE CHICOT AND EVANGELINE AQUIFERS IN THE HOUSTON AREA, TEXAS, SPRING 1982: USGS OPEN-FILE REPORT 82-559, 1982.

LAND-SURFACE SUBSIDENCE IN THE TEXAS COASTAL REGION: TEXAS DEPARTMENT OF WATER RESOURCES REPORT 272, 1982.

APPROXIMATE WATER-LEVEL CHANGES IN WELLS IN THE CHICOT AND EVANGELINE AQUIFERS, 1977-83 AND 1982-83, AND MEASURED COMPACTION, 1973-83, IN THE HOUSTON-GALVESTON REGION, TEXAS: USGS OPEN-FILE REPORT 83-150, 1983.

RECORDS OF WELLS, DRILLERS' LOGS, WATER-LEVEL MEASUREMENTS, AND CHEMICAL ANALYSES OF GROUND WATER IN CHAMBERS, LIBERTY, AND MONTGOMERY COUNTIES, TEXAS, 1975-79: TEXAS DEPARTMENT OF WATER RESOURCES REPORT $280,1983$.

APPROXIMATE ALTITUDE OF WATER LEVELS IN WELLS IN THE CHICOT AND EVANGELINE AQUIFERS IN THE HOUSTON AREA, TEXAS, SPRING 1983: USGS OPEN-FILE REPORT 83-529, 1983.

APPROXIMATE WATER-LEVEL CHANGES IN WELLS IN THE CHICOT AND EVANGELINE AQUIFERS, 1977-84 AND 1983-84, AND MEASURED COMPACTION, 1973-84, IN THE HOUSTON-GALVESTON REGION, TEXAS: USGS OPEN-FILE REPORT 84-140, 1984.
APPROXIMATE ALTITUDE OF WATER LEVELS IN WELLS IN THE CHICOT AND EVANGELINE AQUIFERS IN THE HOUSTON AREA, TEXAS, SPRING, 1984: USGS OPEN-FILE REPORT 84-436, 1984.

TEXAS GROUND-WATER RESOURCES, in NATIONAL WATER SUMMARY 1984: USGS WATER-SUPPLY PAPER 2275, 1985.

DIGITAL MODELS FOR SIMULATION OF GROUND-WATER HYDROLOGY OF THE CHICOT AND EVANGELINE AQUIFERS ALONG THE GULF COAST OF TEXAS: TEXAS DEPARTMENT OF WATER RESOURCES REPORT 289, 1985.

WATER USE, PROJECTED WATER REQUIREMENTS, AND RELATED DATA AND INFORMATION FOR THE METROPOLITAN STATISTICAL AREAS IN TEXAS: TEXAS DEPARTMENT OF WATER RESOURCES LIMITED PRINTING REPORT LP-201, 1985.

APPROXIMATE WATER-LEVEL CHANGES IN WELLS IN THE CHICOT AND EVANGELINE AQUIFERS, 1977-85 AND 1984-85, AND MEASURED COMPACTION, 1973-85, IN THE HOUSTON-GALVESTON REGION, TEXAS: USGS OPEN-FILE REPORT 85-158, 1985.

APPROXIMATE CHANGES IN WATER LEVELS IN THE CHICOT AND EVANGELINE AQUIFERS, 1977-86 AND 1985-86, AND MEASURED COMPACTION, 1973-86, IN THE HOUSTON-GALVESTON REGION, TEXAS: USGS OPEN-FILE REPORT 86-135, 1986.

APPROXIMATE ALTITUDE OF WATER LEVELS IN WELLS IN THE CHICOT AND EVANGELINE AQUIFERS IN THE HOUSTON AREA, TEXAS, SPRING 1986: USGS OPEN-FILE REPORT 86-306, 1986.

HYDROLOGY OF THE JASPER AQUIFER IN THE SOUTHEAST TEXAS COASTAL PLAIN: TEXAS WATER DEVELOPMENT BOARD REPORT 295, 1986.

RECORDS OF WELLS, DRILLERS' LOGS, WATER-LEVEL MEASUREMENTS, AND CHEMICAL ANALYSES OF GROUND WATER IN CHAMBERS, LIBERTY, AND MONTGOMERY COUNTIES, TEXAS, 1980-84: USGS OPEN-FILE REPORT 86-57, 1986.

RECORDS OF WELLS, DRILLERS' LOGS, WATER-LEVEL MEASUREMENTS, AND CHEMICAL ANALYSES OF CHAMBERS, LIBERTY, AND MONTGOMERY COUNTIES, TEXAS, 1980-84: TEXAS WATER DEVELOPMENT BOARD REPORT 304, 1987.

APPROXIMATE WATER-LEVEL CHANGES IN WELLS COMPLETED IN THE CHICOT AND EVANGELINE AQUIFERS, 1977-87 AND 1986-87, AND MEASURED COMPACTION, 1973-87, IN THE HOUSTONGALVESTON REGION, TEXAS: USGS OPEN-FILE REPORT 87-108, 1987.

APPROXIMATE ALTITUDE OF WATER-LEVELS IN WELLS IN THE CHICOT AND EVANGELINE AQUIFERS IN THE HOUSTON AREA, TEXAS, SPRING 1987: USGS OPEN-FILE REPORT 87-233, 1987.

GEOHYDROLOGIC FRAMEWORK OF THE GULF COASTAL PLAIN: USGS HYDROLOGIC INVESTIGATIONS ATLAS HA-695, 1988.

HYDROGEOLOGY AND PREDEVELOPMENT FLOW IN THE TEXAS GULF COAST AQUIFER SYSTEMS: USGS WATER-RESOURCES INVESTIGATIONS REPORT 87-4248, 1988.

APPROXIMATE WATER-LEVEL CHANGES IN WELLS COMPLETED IN THE CHICOT AND EVANGELINE AQUIFERS, 1977-88 AND 1987-88, AND MEASURED COMPACTION, 1973-88, IN THE HOUSTONGALVESTON REGION, TEXAS: USGS OPEN-FILE REPORT 88-168, 1988.

APPROXIMATE ALTITUDE OF WATER LEVELS IN WELLS IN THE CHICOT AND EVANGELINE AQUIFERS IN THE HOUSTON AREA, TEXAS, SPRING 1988: USGS OPEN-FILE REPORT 88-334, 1988. 
APPROXIMATE ALTITUDE OF WATER LEVELS IN WELLS IN THE CHICOT AND EVANGELINE AQUIFERS IN THE HOUSTON AREA, TEXAS, SPRING 1989: USGS OPEN-FILE REPORT 89-237, 1989

APPROXIMATE WATER-LEVEL CHANGE IN WELLS COMPLETED IN THE CHICOT AND EVANGELINE AQUIFERS, 1977-89 AND 1988-89, AND MEASURED COMPACTION, 1973-89, IN THE HOUSTONGALVESTON REGION, TEXAS: USGS OPEN-FILE REPORT 89-057, 1989.

APPROXIMATE WATER-LEVEL CHANGES IN WELLS COMPLETED IN THE CHICOT AND EVANGELINE AQUIFERS, 1977-90 AND 1989-90, AND MEASURED COMPACTION, 1973-DECEMBER 1989, IN THE HOUSTON-GALVESTON REGION, TEXAS: USGS OPEN-FILE REPORT 90-132, 1990.

GROUND-WATER FLOW IN THE GULF COAST AQUIFER SYSTEMS, SOUTH-CENTRAL UNITED STATES-A PRELIMINARY ANALYSIS: USGS WATER-RESOURCES INVESTIGATIONS REPORT 89-4071, 1990.

RECORDS OF WELLS, DRILLERS' LOGS, WATER-WELL MEASUREMENTS, AND CHEMICAL ANALYSES OF GROUND WATER IN CHAMBERS, LIBERTY, AND MONTGOMERY COUNTIES, TEXAS, 1985-89: USGS OPEN-FILE REPORT 90-594, 1991.

HYDROLOGY OF THE TEXAS GULF COAST AQUIFER SYSTEMS: USGS OPEN-FILE REPORT 91-64, 1991.

APPROXIMATE WATER-LEVEL CHANGES IN WELLS COMPLETED IN THE CHICOT AND EVANGELINE AQUIFERS, 1977-91 AND 1990-91, AND MEASURED COMPACTION, 1973-90, IN THE HOUSTONGALVESTON REGION, TEXAS: USGS OPEN-FILE REPORT 91-094, 1991.

APPROXIMATE ALTITUDE OF WATER LEVELS IN WELLS IN THE CHICOT AND EVANGELINE AQUIFERS IN THE HOUSTON AREA, TEXAS, JANUARY-FEBRUARY 1990: USGS OPEN-FILE REPORT 91-240, 1991.

APPROXIMATE CHANGE IN WATER LEVELS IN WELLS COMPLETED IN THE CHICOT AND EVANGELINE AQUIFERS, 1977-92 AND 1991-92, AND MEASURED COMPACTION, 1973-91, IN THE HOUSTON-GALVESTON REGION, TEXAS: USGS OPEN-FILE REPORT 92-066, 1992.

PROPERTIES AND CHEMICAL CONSTITUENTS IN GROUND WATER FROM THE MISSISSIPPI RIVER VALLEY ALLUVIAL AQUIFER AND PERMEABLE ZONE A (HOLOCENE-UPPER PLEISTOCENE DEPOSITS), SOUTH-CENTRAL UNITED STATES: USGS WATERRESOURCES INVESTIGATIONS REPORT 91-4149, 1992.

WATER-RESOURCES DATA, TEXAS, WATER YEAR 1991, VOLUME 4, GROUND-WATER DATA: USGS WATER-DATA REPORT TX-91-4, 1992.

PROPERTIES AND CHEMICAL CONSTITUENTS IN GROUND WATER FROM THE UPPER CLAIBORNE AQUIFER, GULF COAST REGIONAL AQUIFER SYSTEMS, SOUTH-CENTRAL UNITED STATES: USGS WATER-RESOURCES INVESTIGATIONS REPORT 91-4150, 1993.

PROPERTIES AND CHEMICAL CONSTITUENTS IN GROUND WATER FROM PERMEABLE ZONE C (LOWER PLIOCENE-UPPER MIOCENE DEPOSITS), COASTAL LOWLANDS AQUIFER SYSTEM, SOUTHCENTRAL UNITED STATES: USGS WATER-RESOURCES INVESTIGATIONS REPORT 91-4151, 1993.

PROPERTIES AND CHEMICAL CONSTITUENTS IN GROUND WATER FROM PERMEABLE ZONE B (LOWER PLEISTOCENE-UPPER PLIOCENE DEPOSITS), COASTAL LOWLANDS AQUIFER SYSTEM,
SOUTH-CENTRAL UNITED STATES: USGS WATER-RESOURCES INVESTIGATIONS REPORT 91-4152, 1993.

PROPERTIES AND CHEMICAL CONSTITUENTS IN GROUND WATER FROM PERMEABLE ZONE E (LOWER MIOCENE-UPPER OLIGOCENE DEPOSITS), COASTAL LOWLANDS AQUIFER SYSTEM, SOUTH-CENTRAL UNITED STATES: USGS WATER-RESOURCES INVESTIGATIONS REPORT 92-4103, 1993.

PROPERTIES AND CHEMICAL CONSTITUENTS IN GROUND WATER FROM THE MIDDLE CLAIBORNE AQUIFER, GULF COAST REGIONAL AQUIFER SYSTEMS, SOUTH-CENTRAL UNITED STATES: USGS WATER-RESOURCES INVESTIGATIONS REPORT 92-4104, 1993.

PROPERTIES AND CHEMICAL CONSTITUENTS IN GROUND WATER FROM PERMEABLE ZONE D (MIDDLE MIOCENE DEPOSITS), COASTAL LOWLANDS AQUIFER SYSTEM, SOUTH-CENTRAL UNITED STATES: USGS WATER-RESOURCES INVESTIGATIONS REPORT 92-4105, 1993.

GROUND-WATER WITHDRAWALS, WATER LEVELS, AND GROUNDWATER QUALITY IN THE HOUSTON DISTRICT, TEXAS, WITH EMPHASIS ON 1985-89: USGS WATER-RESOURCES INVESTIGATIONS REPORT 92-4180, 1993.

PROPERTIES AND CHEMICAL CONSTITUENTS IN GROUND WATER FROM THE MIDDLE WILCOX AQUIFER, GULF COAST AQUIFER SYSTEMS, SOUTH-CENTRAL UNITED STATES: USGS WATERRESOURCES INVESTIGATIONS REPORT 93-4070, 1993.

APPROXIMATE ALTITUDE OF WATER LEVELS IN WELLS COMPLETED IN THE CHICOT AND EVANGELINE AQUIFERS IN THE HOUSTON AREA, TEXAS, JANUARY-FEBRUARY 1991: USGS OPEN-FILE REPORT 93-075, 1993.

APPROXIMATE CHANGE IN WATER LEVELS IN WELLS COMPLETED IN THE CHICOT AND EVANGELINE AQUIFERS, 1977-93 AND 1992-93, AND MEASURED COMPACTION, 1973-92, IN THE HOUSTON-GALVESTON REGION, TEXAS: USGS OPEN-FILE REPORT 93-086, 1993.

WATER-RESOURCES DATA, TEXAS, WATER YEAR 1992, VOLUME 4, GROUND-WATER DATA: USGS WATER-DATA REPORT TX-92-4, 1993.

APPROXIMATE CHANGE IN WATER LEVELS IN WELLS COMPLETED IN THE CHICOT AND EVANGELINE AQUIFERS, 1977-94 AND 1993-94, AND MEASURED COMPACTION, 1973-93, IN THE HOUSTON-GALVESTON REGION, TEXAS: USGS OPEN-FILE REPORT 94-346, 1994.

WATER-LEVEL ALTITUDES 1995, WATER-LEVEL CHANGES 1977-95 AND 1994-95, AND COMPACTION 1973-94 IN THE CHICOT AND EVANGELINE AQUIFERS, HOUSTON-GALVESTON REGION, TEXAS: USGS OPEN-FILE REPORT 95-182, 1995.

AQUIFERS OF TEXAS: TEXAS WATER DEVELOPMENT BOARD REPORT 345, 1995.

WATER-RESOURCES DATA, TEXAS, WATER YEAR 1994, VOLUME 4, GROUND-WATER DATA: USGS WATER-DATA REPORT TX-94-4, 1995.

WATER-LEVEL ALTITUDES 1996, WATER-LEVEL CHANGES 1977-96 AND 1995-96, AND COMPACTION 1973-95 IN THE CHICOT AND EVANGELINE AQUIFERS, HOUSTON-GALVESTON REGION, TEXAS: USGS OPEN-FILE REPORT 96-163, 1996.

ESTIMATED DEPTH TO THE WATER TABLE AND ESTIMATED RATE OF RECHARGE IN OUTCROPS OF THE CHICOT AND EVANGELINE 
AQUIFERS NEAR HOUSTON, TEXAS: USGS WATER-RESOURCES INVESTIGATIONS REPORT 96-4018, 1996.

WATER-RESOURCES DATA, TEXAS, WATER YEAR 1995, VOLUME 4, GROUND-WATER DATA: USGS WATER-DATA REPORT TX-95-4, 1996.

WATER-LEVEL ALTITUDES 1997, WATER-LEVEL CHANGES 1977-97 AND 1996-97, AND COMPACTION 1973-96 IN THE CHICOT AND EVANGELINE AQUIFERS, HOUSTON-GALVESTON REGION, TEXAS: USGS OPEN-FILE REPORT 97-181, 1997.

WATER-LEVEL ALTITUDES IN WELLS COMPLETED IN THE CHICOT AND EVANGELINE AQUIFERS, HOUSTON-GALVESTON REGION, TEXAS, JANUARY-FEBRUARY 1992, 1993, AND 1994: USGS OPENFILE REPORT 97-786, 1997.

ESTIMATED RATE OF RECHARGE IN OUTCROPS OF THE CHICOT AND EVANGELINE AQUIFERS NEAR HOUSTON, TEXAS: USGS FACT SHEET FS-179-97, 1997.

WATER-RESOURCES DATA, TEXAS, WATER YEAR 1996, VOLUME 4, GROUND-WATER DATA: USGS WATER-DATA REPORT TX-96-4, 1997.

WATER-LEVEL ALTITUDES 1998, WATER-LEVEL CHANGES 1977-98 AND 1997-98, AND COMPACTION IN THE CHICOT AND EVANGELINE AQUIFERS, HOUSTON-GALVESTON REGION, TEXAS: USGS OPEN-FILE REPORT 98-096, 1998.

WATER-RESOURCES DATA, TEXAS, WATER YEAR 1997, VOLUME 4, GROUND-WATER DATA: USGS WATER-DATA REPORT TX-97-4, 1998.

WATER-LEVEL ALTITUDES 1999, WATER-LEVEL CHANGES 1977-99 AND 1998-99, AND COMPACTION 1973-98 IN THE CHICOT AND EVANGELINE AQUIFERS, HOUSTON-GALVESTON REGION, TEXAS: USGS OPEN-FILE REPORT 99-178, 1999.

WATER-RESOURCES DATA, TEXAS, WATER YEAR 1998, VOLUME 4, GROUND-WATER DATA: USGS WATER-DATA REPORT TX-98-4, 1999.

WATER-LEVEL ALTITUDES 2000 AND WATER-LEVEL CHANGES 1990-2000 AND 1999-2000 IN THE CHICOT AND EVANGELINE AQUIFERS, FORT BEND COUNTY AND ADJACENT AREAS, TEXAS: USGS OPEN-FILE REPORT 00-093, 2000.

WATER-LEVEL ALTITUDES 2000, WATER-LEVEL CHANGES 1977-2000 AND 1999-2000, AND COMPACTION 1973-99 IN THE CHICOT AND EVANGELINE AQUIFERS, HOUSTON-GALVESTON REGION, TEXAS: USGS OPEN-FILE REPORT 00-094, 2000.

WATER-RESOURCES DATA, TEXAS, WATER YEAR 1999, VOLUME 6 , GROUND-WATER DATA: USGS WATER-DATA REPORT TX-99-6, 2000.

WATER-LEVEL ALTITUDES IN WELLS COMPLETED IN THE JASPER AQUIFER, GREATER HOUSTON AREA, TEXAS, SPRING 2000: USGS OPEN-FILE REPORT 01-147, 2001.

WATER-RESOURCES DATA, TEXAS, WATER YEAR 2000, VOLUME 6, GROUND-WATER DATA: USGS WATER-DATA REPORT TX-00-6, 2001.

\section{MOORE COUNTY}

THE GEOLOGY AND WATER RESOURCES OF THE WESTERN PORTION OF THE PANHANDLE OF TEXAS: USGS WATER-SUPPLY PAPER 191, 1907.

GROUND WATER IN THE VICINITIES OF SUNRAY AND ETTER, MOORE COUNTY, TEXAS: USGS OPEN-FILE REPORT (UNNUMBERED), 1942.

GROUND-WATER RESOURCES IN THE VICINITIES OF SUNRAY, ETTER, AND DUMAS, MOORE COUNTY, TEXAS, SUPPLEMENTARY MEMORANDUM: USGS OPEN-FILE REPORT (UNNUMBERED), 1942.

EXELL HELIUM PLANT: USGS OPEN-FILE REPORT (UNNUMBERED), 1943.

PUBLIC WATER SUPPLIES IN WESTERN TEXAS: TEXAS BOARD OF WATER ENGINEERS MISCELLANEOUS PUBLICATION 216, 1949.

PUBLIC WATER SUPPLIES IN WESTERN TEXAS: USGS WATERSUPPLY PAPER 1106, 1951 [1952].

RECORDS OF WATER-LEVEL MEASUREMENTS IN DALLAM, HANSFORD, HARTLEY, HUTCHINSON, MOORE, OCHILTREE, AND SHERMAN COUNTIES, TEXAS: TEXAS BOARD OF WATER ENGINEERS BULLETIN 5404, 1954.

PUMPING COSTS, SELECTED PUMPING PLANTS IN MOORE AND HANSFORD COUNTIES, TEXAS: TEXAS BOARD OF WATER ENGINEERS MISCELLANEOUS PUBLICATION M193, 1955.

WATER-LEVEL MAPS AND WATER LEVELS IN OBSERVATION WELLS IN THE NORTH HIGH PLAINS, TEXAS: TEXAS BOARD OF WATER ENGINEERS BULLETIN 5707, 1957.

WATER-LEVEL MEASUREMENTS AND MAPS, NORTHERN HIGH PLAINS, TEXAS, 1958 AND 1959: TEXAS BOARD OF WATER ENGINEERS BULLETIN 5909, 1959.

WATER LEVELS IN OBSERVATION WELLS, NORTHERN HIGH PLAINS, TEXAS, 1958-1960: TEXAS BOARD OF WATER ENGINEERS BULLETIN 6012, 1960.

RECONNAISSANCE INVESTIGATION OF THE GROUND-WATER RESOURCES OF THE CANADIAN RIVER BASIN, TEXAS: TEXAS BOARD OF WATER ENGINEERS BULLETIN 6016, 1960.

ANNUAL WATER-LEVEL MEASUREMENTS IN OBSERVATION WELLS, NORTHERN HIGH PLAINS, TEXAS, 1960 AND 1961: TEXAS BOARD OF WATER ENGINEERS BULLETIN 6103, 1961.

GEOLOGY AND GROUND-WATER RESOURCES OF THE NORTHERN HIGH PLAINS OF TEXAS, PROGRESS REPORT NO. 1: TEXAS BOARD OF WATER ENGINEERS BULLETIN 6109, 1961.

ANNUAL WATER-LEVEL MEASUREMENTS IN OBSERVATION WELLS, NORTHERN HIGH PLAINS, TEXAS, 1961 AND 1962: TEXAS WATER COMMISSION BULLETIN 6213, 1962.

WATER-LEVEL DATA FROM OBSERVATION WELLS IN THE NORTHERN PANHANDLE OF TEXAS: TEXAS DEPARTMENT OF WATER RESOURCES REPORT 137, 1971.

GROUND-WATER RESOURCES OF THE PALO DURO CREEK BASIN, TEXAS AND OKLAHOMA: USGS OPEN-FILE REPORT 79-209, 1979.

PRELIMINARY DATA DESCRIBING THE DISTRIBUTION OF FLUORIDE AND SILICA IN THE OGALLALA AQUIFER ON THE HIGH PLAINS OF TEXAS: USGS OPEN-FILE REPORT 80-349, 1980. 
WATER-LEVEL DATA FROM OBSERVATION WELLS IN THE NORTHERN PANHANDLE OF TEXAS, 1972-78: TEXAS DEPARTMENT OF WATER RESOURCES REPORT 248, 1980.

WATER TABLE IN THE HIGH PLAINS AQUIFER IN 1978 IN PARTS OF COLORADO, KANSAS, NEBRASKA, NEW MEXICO, OKLAHOMA, SOUTH DAKOTA, TEXAS, AND WYOMING: USGS HYDROLOGIC INVESTIGATIONS ATLAS HA-642, 1980.

EVALUATING THE GROUND-WATER RESOURCES OF THE HIGH PLAINS OF TEXAS: RESULTS OF TEST HOLE DRILLING: TEXAS DEPARTMENT OF WATER RESOURCES LIMITED PRINTING REPORT LP-129, 1980.

EVALUATING THE GROUND-WATER RESOURCES OF THE HIGH PLAINS OF TEXAS: RESULTS OF SURFACE ELECTRICAL RESISTIVITY SURVEYS: TEXAS DEPARTMENT OF WATER RESOURCES LIMITED PRINTING REPORT LP-130, 1980.

ANALYTICAL STUDY OF THE OGALLALA AQUIFER IN MOORE COUNTY, TEXAS-PROJECTIONS OF SATURATED THICKNESS, VOLUME OF WATER IN STORAGE, PUMPAGE RATES, PUMPING LIFTS, AND WELL YIELDS: TEXAS DEPARTMENT OF WATER RESOURCES REPORT 252, 1980.

EVALUATING THE GROUND-WATER RESOURCES OF THE HIGH PLAINS OF TEXAS: NEUTRON-PROBE MEASUREMENTS OF DEEP SOIL MOISTURE AS AN INDICATION OF AQUIFER RECHARGE RATES: TEXAS DEPARTMENT OF WATER RESOURCES LIMITED PRINTING REPORT LP-142, 1981.

SPRINGS OF TEXAS, VOLUME 1: (BY GUNNAR BRUNE), BRANCHSMITH, INC., FORT WORTH, TEXAS, 1981.

BEDROCK GEOLOGY, ALTITUDE OF BASE, AND 1980 SATURATED THICKNESS OF THE HIGH PLAINS AQUIFER IN PARTS OF COLORADO, KANSAS, NEBRASKA, NEW MEXICO, OKLAHOMA, SOUTH DAKOTA, TEXAS, AND WYOMING: USGS HYDROLOGIC INVESTIGATIONS ATLAS HA-648, 1981.

WATER-LEVEL AND SATURATED-THICKNESS CHANGES, PREDEVELOPMENT TO 1980, IN THE HIGH PLAINS AQUIFER IN PARTS OF COLORADO, KANSAS, NEBRASKA, NEW MEXICO, OKLAHOMA, SOUTH DAKOTA, TEXAS, AND WYOMING: USGS HYDROLOGIC INVESTIGATIONS ATLAS HA-652, 1981.

DISSOLVED SOLIDS AND SODIUM IN WATER FROM THE HIGH PLAINS AQUIFER IN PARTS OF COLORADO, KANSAS, NEBRASKA, NEW MEXICO, OKLAHOMA, SOUTH DAKOTA, TEXAS, AND WYOMING: USGS HYDROLOGIC INVESTIGATIONS ATLAS HA-658, 1982.

GEOHYDROLOGY OF THE HIGH PLAINS AQUIFER IN PARTS OF COLORADO, KANSAS, NEBRASKA, NEW MEXICO, OKLAHOMA, SOUTH DAKOTA, TEXAS, AND WYOMING: USGS PROFESSIONAL PAPER 1400-B, 1984.

EVALUATING THE GROUND-WATER RESOURCES OF THE HIGH PLAINS OF TEXAS, VOLUME 1: TEXAS DEPARTMENT OF WATER RESOURCES REPORT 288, V. 1, 1984.

EVALUATING THE GROUND-WATER RESOURCES OF THE HIGH PLAINS OF TEXAS, VOLUME 2, RECORDS OF WELLS, AND MAPS SHOWING WELL LOCATIONS, BASE OF AQUIFER, WATER LEVELS, AND SATURATED THICKNESS (ARMSTRONG, CARSON, DALLAS, DONLEY, GRAY, HANSFORD, HARTLEY, HEMPHILL, HUTCHINSON, LIPSCOMB, MOORE, OCHILTREE, POTTER, ROBERTS, SHERMAN, AND WHEELER COUNTIES): TEXAS DEPARTMENT OF WATER RESOURCES REPORT 288, V. 2, 1984.
TEXAS GROUND-WATER RESOURCES, in NATIONAL WATER SUMMARY 1984: USGS WATER-SUPPLY PAPER 2275, 1985.

DIGITAL SIMULATION OF GROUND-WATER FLOW IN THE HIGH PLAINS AQUIFER IN PARTS OF COLORADO, KANSAS, NEBRASKA, NEW MEXICO, OKLAHOMA, SOUTH DAKOTA, TEXAS, AND WYOMING: USGS PROFESSIONAL PAPER 1400-D, 1986.

SUMMARY OF THE HIGH PLAINS REGIONAL AQUIFER-SYSTEM ANALYSIS IN PARTS OF COLORADO, KANSAS, NEBRASKA, NEW MEXICO, OKLAHOMA, SOUTH DAKOTA, TEXAS, AND WYOMING: USGS PROFESSIONAL PAPER 1400-A, 1988.

WATER-LEVEL CHANGES IN THE HIGH PLAINS AQUIFER OF TEXAS, 1980-1990: TEXAS WATER DEVELOPMENT BOARD HYDROLOGIC ATLAS NO. 1, 1991.

PUBLIC-SUPPLY GROUND-WATER USE IN THE NORTHERN HIGH PLAINS OF TEXAS: TEXAS WATER DEVELOPMENT BOARD REPORT 336, 1992

THE HIGH PLAINS AQUIFER SYSTEM OF TEXAS, 1980-1990. OVERVIEW AND PROJECTIONS: TEXAS WATER DEVELOPMENT BOARD REPORT 341, 1993

WATER-QUALITY EVALUATION OF THE OGALLALA AQUIFER, TEXAS: TEXAS WATER DEVELOPMENT BOARD REPORT 342, 1993.

WATER-LEVEL CHANGES IN THE HIGH PLAINS AQUIFER-PREDEVELOPMENT TO 1992: USGS WATER-RESOURCES INVESTIGATIONS REPORT 94-4027, 1994.

WATER-LEVEL CHANGES IN THE HIGH PLAINS AQUIFER, 1980 TO 1994: USGS FACT SHEET FS-215-95, 1995.

AQUIFERS OF TEXAS: TEXAS WATER DEVELOPMENT BOARD REPORT 345, 1995.

WATER-LEVEL CHANGES IN THE HIGH PLAINS AQUIFER, 1980 TO 1995: USGS FACT SHEET FS-068-97, 1997.

WATER-LEVEL CHANGES IN THE HIGH PLAINS AQUIFER-PREDEVELOPMENT TO 1995: USGS WATER-RESOURCES INVESTIGATIONS REPORT 97-4081, 1997.

UPDATED WATER-QUALITY EVALUATION OF THE OGALLALA AQUIFER INCLUDING SELECTED METALLIC AND NON-METALLIC INORGANIC CONSTITUENTS: TEXAS WATER DEVELOPMENT BOARD HYDROLOGIC ATLAS NO. 10, 1998.

\section{MORRIS COUNTY}

WATER SUPPLY IN THE VICINITY OF HUGHES SPRINGS, CASS COUNTY, TEXAS AND DAINGERFIELD, MORRIS COUNTY, TEXAS: USGS OPEN-FILE REPORT (UNNUMBERED), 1941.

RECORDS OF WELLS AND SPRINGS, DRILLERS' LOGS, WATER ANALYSES, AND MAP SHOWING LOCATIONS OF WELLS AND SPRINGS IN MORRIS COUNTY, TEXAS: TEXAS BOARD OF WATER ENGINEERS MISCELLANEOUS PUBLICATION 194, 1942.

PUBLIC WATER SUPPLIES IN EASTERN TEXAS, V. 2, HARRISON COUNTY THROUGH WOOD COUNTY: TEXAS BOARD OF WATER ENGINEERS MISCELLANEOUS PUBLICATION 214, V. 2, 1945.

PUBLIC WATER SUPPLIES IN EASTERN TEXAS: USGS WATERSUPPLY PAPER 1047, 1948 
RECONNAISSANCE INVESTIGATION OF THE GROUND-WATER RESOURCES OF THE RED RIVER, SULPHUR RIVER, AND CYPRESS CREEK BASINS, TEXAS: TEXAS WATER COMMISSION BULLETIN 6306, 1963.

GROUND-WATER RESOURCES OF CAMP, FRANKLIN, MORRIS, AND TITUS COUNTIES, TEXAS: TEXAS WATER COMMISSION BULLETIN 6517, 1965

COMPILATION OF RESULTS OF AQUIFER TESTS IN TEXAS: TEXAS WATER DEVELOPMENT BOARD REPORT 98, 1969.

SUMMARY APPRAISALS OF THE NATION'S GROUND-WATER RESOURCES-TEXAS-GULF REGION: USGS PROFESSIONAL PAPER 813-F, 1976.

WATER-QUALITY DATA FOR AQUIFERS, STREAMS, AND LAKES IN THE VICINITY OF KEECHI, MOUNT SYLVAN, OAKWOOD, AND PALESTINE SALT DOMES, NORTHEAST TEXAS SALT-DOME BASIN: USGS OPEN-FILE REPORT 80-2037, 1980

GEOHYDROLOGY OF THE KEECHI, MOUNT SYLVAN, OAKWOOD, AND PALESTINE SALT DOMES IN THE NORTHEAST TEXAS SALTDOME BASIN: USGS OPEN-FILE REPORT 80-2044, 1980.

GEOLOGY AND GEOHYDROLOGY OF THE EAST TEXAS BASIN-A REPORT ON THE PROGRESS OF NUCLEAR WASTE ISOLATION FEASIBILITY STUDIES (1979): UNIVERSITY OF TEXAS, BUREAU OF ECONOMIC GEOLOGY GEOLOGICAL CIRCULAR 80-12, 1980.

GEOLOGY AND GEOHYDROLOGY OF THE EAST TEXAS BASIN-A REPORT ON THE PROGRESS OF NUCLEAR WASTE ISOLATION FEASIBILITY STUDIES (1980): UNIVERSITY OF TEXAS, BUREAU OF ECONOMIC GEOLOGY GEOLOGICAL CIRCULAR 81-7, 1981.

SPRINGS OF TEXAS, VOLUME 1: (BY GUNNAR BRUNE), BRANCHSMITH, INC., FORT WORTH, TEXAS, 1981.

TEXAS GROUND-WATER RESOURCES, in NATIONAL WATER SUMMARY 1984: USGS WATER-SUPPLY PAPER 2275, 1985.

APPROXIMATE POTENTIOMETRIC SURFACES FOR THE AQUIFERS OF THE TEXAS COASTAL UPLANDS SYSTEM, 1980: USGS HYDROLOGIC INVESTIGATIONS ATLAS HA-704, 1987.

GEOHYDROLOGIC FRAMEWORK OF THE GULF COASTAL PLAIN: USGS HYDROLOGIC INVESTIGATIONS ATLAS HA-695, 1988.

HYDROGEOLOGY AND PREDEVELOPMENT FLOW IN THE TEXAS GULF COAST AQUIFER SYSTEMS: USGS WATER-RESOURCES INVESTIGATIONS REPORT 87-4248, 1988.

GROUND-WATER FLOW IN THE GULF COAST AQUIFER SYSTEMS, SOUTH-CENTRAL UNITED STATES-A PRELIMINARY ANALYSIS: USGS WATER-RESOURCES INVESTIGATIONS REPORT 89-4071, 1990.

PROPERTIES AND CHEMICAL CONSTITUENTS IN GROUND WATER FROM THE LOWER CLAIBORNE-UPPER WILCOX AQUIFER, GULF COAST REGIONAL AQUIFER SYSTEMS, SOUTH-CENTRAL UNITED STATES: USGS WATER-RESOURCES INVESTIGATIONS REPORT 92-4102, 1993.

PROPERTIES AND CHEMICAL CONSTITUENTS IN GROUND WATER FROM THE MIDDLE CLAIBORNE AQUIFER, GULF COAST REGIONAL AQUIFER SYSTEMS, SOUTH-CENTRAL UNITED STATES: USGS WATER-RESOURCES INVESTIGATIONS REPORT 92-4104, 1993.

PROPERTIES AND CHEMICAL CONSTITUENTS IN GROUND WATER FROM THE MIDDLE WILCOX AQUIFER, GULF COAST AQUIFER
SYSTEMS, SOUTH-CENTRAL UNITED STATES: USGS WATERRESOURCES INVESTIGATIONS REPORT 93-4070, 1993.

AQUIFERS OF TEXAS: TEXAS WATER DEVELOPMENT BOARD REPORT 345, 1995.

WATER QUALITY IN THE QUEEN CITY AQUIFER, EAST TEXAS: TEXAS WATER DEVELOPMENT BOARD HYDROLOGIC ATLAS NO. 6, 1996.

\section{MOTLEY COUNTY}

GEOLOGY AND GROUND-WATER RESOURCES OF THE SOUTHERN HIGH PLAINS: USGS OPEN-FILE REPORT (UNNUMBERED), 1935.

GROUND WATER IN THE SOUTHERN HIGH PLAINS: USGS OPENFILE REPORT (UNNUMBERED), 1937.

GROUND WATER IN THE HIGH PLAINS IN TEXAS (1940): TEXAS BOARD OF WATER ENGINEERS MISCELLANEOUS PUBLICATION M119, 1940.

GROUND WATER IN THE HIGH PLAINS IN TEXAS, PROGRESS REPORT NO. 5: TEXAS BOARD OF WATER ENGINEERS MISCELLANEOUS PUBLICATION M122, 1945.

GROUND WATER IN THE HIGH PLAINS OF TEXAS: USGS WATERSUPPLY PAPER 889-F, 1946.

GROUND WATER IN THE HIGH PLAINS IN TEXAS, PROGRESS REPORT NO. 6: TEXAS BOARD OF WATER ENGINEERS MISCELLANEOUS PUBLICATION M123, 1947.

GEOLOGY AND GROUND WATER IN THE IRRIGATED REGION OF THE SOUTHERN HIGH PLAINS IN TEXAS, PROGRESS REPORT NO. 7: TEXAS BOARD OF WATER ENGINEERS MISCELLANEOUS PUBLICATION 125, 1949.

PUBLIC WATER SUPPLIES IN WESTERN TEXAS: TEXAS BOARD OF WATER ENGINEERS MISCELLANEOUS PUBLICATION 216, 1949.

COST OF PUMPING WATER FOR IRRIGATION, TEXAS HIGH PLAINS, FIELD INVESTIGATION-1947 IRRIGATION SEASON: TEXAS BOARD OF WATER ENGINEERS MISCELLANEOUS PUBLICATION M124, 1951.

DEVELOPMENT OF WELLS FOR IRRIGATION AND FLUCTUATION OF WATER LEVELS IN THE HIGH PLAINS OF TEXAS TO JANUARY 1951: TEXAS BOARD OF WATER ENGINEERS BULLETIN 5104, 1951.

PUBLIC WATER SUPPLIES IN WESTERN TEXAS: USGS WATERSUPPLY PAPER 1106, 1951 [1952].

RECONNAISSANCE INVESTIGATION OF THE GROUND-WATER RESOURCES OF THE RED RIVER, SULPHUR RIVER, AND CYPRESS CREEK BASINS, TEXAS: TEXAS WATER COMMISSION BULLETIN 6306, 1963.

A SUMMARY OF THE OCCURRENCE AND DEVELOPMENT OF GROUND WATER IN THE SOUTHERN HIGH PLAINS OF TEXAS: USGS WATER-SUPPLY PAPER 1693, 1964.

COMPILATION OF RESULTS OF AQUIFER TESTS IN TEXAS: TEXAS WATER DEVELOPMENT BOARD REPORT 98, 1969.

GROUND WATER IN THE OGALLALA FORMATION IN THE SOUTHERN HIGH PLAINS OF TEXAS AND NEW MEXICO: USGS HYDROLOGIC INVESTIGATIONS ATLAS HA-330, 1969. 
GROUND-WATER RESOURCES OF MOTLEY AND NORTHEASTERN FLOYD COUNTIES, TEXAS: TEXAS WATER DEVELOPMENT BOARD REPORT 165, 1973.

MAJOR AND HISTORICAL SPRINGS OF TEXAS: TEXAS WATER DEVELOPMENT BOARD REPORT 189, 1975.

PRELIMINARY DATA DESCRIBING THE DISTRIBUTION OF FLUORIDE AND SILICA IN THE OGALLALA AQUIFER ON THE HIGH PLAINS OF TEXAS: USGS OPEN-FILE REPORT 80-349, 1980.

EVALUATING THE GROUND-WATER RESOURCES OF THE HIGH PLAINS OF TEXAS: RESULTS OF SURFACE ELECTRICAL RESISTIVITY SURVEYS: TEXAS DEPARTMENT OF WATER RESOURCES LIMITED PRINTING REPORT 130, 1980.

SPRINGS OF TEXAS, VOLUME 1: (BY GUNNAR BRUNE), BRANCHSMITH, INC., FORT WORTH, TEXAS, 1981.

BEDROCK GEOLOGY, ALTITUDE OF BASE, AND 1980 SATURATED THICKNESS OF THE HIGH PLAINS AQUIFER IN PARTS OF COLORADO, KANSAS, NEBRASKA, NEW MEXICO, OKLAHOMA, SOUTH DAKOTA, TEXAS, AND WYOMING: USGS HYDROLOGIC INVESTIGATIONS ATLAS HA-648, 1981.

WATER LEVEL AND SATURATED THICKNESS CHANGES, PREDEVELOPMENT TO 1980, IN THE HIGH PLAINS AQUIFER IN PARTS OF COLORADO, KANSAS, NEBRASKA, NEW MEXICO, OKLAHOMA, SOUTH DAKOTA, TEXAS, AND WYOMING: USGS HYDROLOGIC INVESTIGATIONS ATLAS HA-652, 1981.

DISSOLVED SOLIDS AND SODIUM IN WATER FROM THE HIGH PLAINS AQUIFER IN PARTS OF COLORADO, KANSAS, NEBRASKA, NEW MEXICO, OKLAHOMA, SOUTH DAKOTA, TEXAS, AND WYOMING: USGS HYDROLOGIC INVESTIGATIONS ATLAS HA-658, 1982.

EVALUATING THE GROUND-WATER RESOURCES OF THE HIGH PLAINS OF TEXAS, VOLUME 1: TEXAS DEPARTMENT OF WATER RESOURCES REPORT 288, V. 1, 1984.

EVALUATING THE GROUND-WATER RESOURCES OF THE HIGH PLAINS OF TEXAS, VOLUME 3, RECORDS OF WELLS, AND MAPS SHOWING WELL LOCATIONS, BASE OF AQUIFER, WATER LEVELS, AND SATURATED THICKNESS: TEXAS DEPARTMENT OF WATER RESOURCES REPORT 288, V. 3, 1984.

GEOHYDROLOGY OF THE HIGH PLAINS AQUIFER IN PARTS OF COLORADO, KANSAS, NEBRASKA, NEW MEXICO, OKLAHOMA, SOUTH DAKOTA, TEXAS, AND WYOMING: USGS PROFESSIONAL PAPER 1400-B, 1984.

TEXAS GROUND-WATER RESOURCES, in NATIONAL WATER SUMMARY 1984: USGS WATER-SUPPLY PAPER 2275, 1985.

DIGITAL SIMULATION OF GROUND-WATER FLOW IN THE HIGH PLAINS AQUIFER IN PARTS OF COLORADO, KANSAS, NEBRASKA, NEW MEXICO, OKLAHOMA, SOUTH DAKOTA, TEXAS, AND WYOMING: USGS PROFESSIONAL PAPER 1400-D, 1986.

SUMMARY OF THE HIGH PLAINS REGIONAL AQUIFER-SYSTEM ANALYSIS IN PARTS OF COLORADO, KANSAS, NEBRASKA, NEW MEXICO, OKLAHOMA, SOUTH DAKOTA, TEXAS, AND WYOMING: USGS PROFESSIONAL PAPER 1400-A, 1988.

PUBLIC-SUPPLY GROUND-WATER USE IN THE SOUTHERN HIGH PLAINS OF TEXAS: TEXAS WATER DEVELOPMENT BOARD REPORT 328, 1990.
WATER-LEVEL CHANGES IN THE HIGH PLAINS AQUIFER OF TEXAS, 1980-1990: TEXAS WATER DEVELOPMENT BOARD HYDROLOGIC ATLAS NO. 1, 1991.

EVALUATION OF WATER RESOURCES IN PARTS OF THE ROLLING PRAIRIES REGION OF NORTH-CENTRAL TEXAS: TEXAS WATER DEVELOPMENT BOARD REPORT 337, 1992.

THE HIGH PLAINS AQUIFER SYSTEM OF TEXAS, 1980 TO 1990. OVERVIEW AND PROJECTIONS: TEXAS WATER DEVELOPMENT BOARD REPORT 341, 1993.

WATER-QUALITY EVALUATION OF THE OGALLALA AQUIFER, TEXAS: TEXAS WATER DEVELOPMENT BOARD REPORT 342, 1993.

WATER-LEVEL CHANGES IN THE HIGH PLAINS AQUIFER, 1980 TO 1994: USGS FACT SHEET FS-215-95, 1995.

AQUIFERS OF TEXAS: TEXAS WATER DEVELOPMENT BOARD REPORT 345, 1995.

WATER-LEVEL CHANGES IN THE HIGH PLAINS AQUIFER, 1980 TO 1995: USGS FACT SHEET FS-068-97, 1997.

WATER-LEVEL CHANGES IN THE HIGH PLAINS AQUIFER-PREDEVELOPMENT TO 1995: USGS WATER-RESOURCES INVESTIGATIONS REPORT 97-4081, 1997.

UPDATED WATER-QUALITY EVALUATION OF THE OGALLALA AQUIFER INCLUDING SELECTED METALLIC AND NON-METALLIC INORGANIC CONSTITUENTS: TEXAS WATER DEVELOPMENT BOARD HYDROLOGIC ATLAS NO. 10, 1998.

\section{NACOGDOCHES COUNTY}

UNDERGROUND WATERS OF THE COASTAL PLAIN OF TEXAS: USGS WATER-SUPPLY PAPER 190, 1907.

GEOLOGY AND UNDERGROUND WATERS OF THE SOUTHEASTERN PART OF THE TEXAS COASTAL PLAIN: USGS WATER-SUPPLY PAPER 335, 1914.

RECORDS OF WELLS, DRILLERS' LOGS, AND WATER ANALYSES, AND MAP SHOWING LOCATION OF WELLS IN NACOGDOCHES COUNTY, TEXAS: TEXAS BOARD OF WATER ENGINEERS MISCELLANEOUS PUBLICATION 195, 1937.

GEOLOGY AND GROUND-WATER RESOURCES IN THE LUFKIN AREA, TEXAS: TEXAS BOARD OF WATER ENGINEERS OPEN-FILE REPORT (UNNUMBERED), 1938.

INVESTIGATION OF SPARTA AND WILCOX SANDS NORTH OF LUFKIN: USGS OPEN-FILE REPORT (UNNUMBERED), 1941

SPARTA FORMATION IN NACOGDOCHES COUNTY: USGS OPENFILE REPORT (UNNUMBERED), 1941.

GEOLOGY AND GROUND-WATER RESOURCES IN THE LUFKIN AREA, TEXAS: USGS WATER-SUPPLY PAPER 849-A, 1941.

MEMORANDUM OF CONFERENCE OF JULY 7, 1942 ON GROUNDWATER INVESTIGATION OF SPARTA SAND NORTH OF SOUTHLAND PAPER MILL: USGS OPEN-FILE REPORT (UNNUMBERED), 1942.

DECLINE IN WATER LEVELS IN CITY WELLS AT NACOGDOCHES, TEXAS, AS A RESULT OF PUMPING FROM WELLS OF SOUTH- 
LAND PAPER MILL NEAR LUFKIN: USGS OPEN-FILE REPORT (UNNUMBERED), 1942

WATER SUPPLY IN THE SANDFLAT AREA AND ADJACENT TERRITORY IN RUSK, NACOGDOCHES, AND SHELBY COUNTIES, TEXAS: USGS OPEN-FILE REPORT (UNNUMBERED), 1942.

DRILLING AND PUMPING OF SPARTA TEST WELLS IN NACOGDOCHES COUNTY: USGS OPEN-FILE REPORT (UNNUMBERED), 1943.

PUBLIC WATER SUPPLIES IN EASTERN TEXAS, V. 2, HARRISON COUNTY THROUGH WOOD COUNTY: TEXAS BOARD OF WATER ENGINEERS MISCELLANEOUS PUBLICATION 214, V. 2, 1945.

DECLINE OF WATER LEVELS IN WELLS AT NACOGDOCHES CAUSED FROM PUMPING BY SOUTHLAND PAPER MILLS: USGS OPEN-FILE REPORT (UNNUMBERED), 1948.

PUBLIC WATER SUPPLIES IN EASTERN TEXAS: USGS WATERSUPPLY PAPER 1047, 1948.

RECONNAISSANCE INVESTIGATION OF THE GROUND-WATER RESOURCES OF THE NECHES RIVER BASIN, TEXAS: TEXAS WATER COMMISSION BULLETIN 6308, 1963.

HYDROLOGIC SIGNIFICANCE OF THE LITHOFACIES OF THE SPARTA SAND IN ARKANSAS, LOUISIANA, MISSISSIPPI, AND TEXAS: USGS PROFESSIONAL PAPER 569-A, 1968.

COMPILATION OF RESULTS OF AQUIFER TESTS IN TEXAS: TEXAS WATER DEVELOPMENT BOARD REPORT 98, 1969.

GROUND-WATER CONDITIONS IN ANGELINA AND NACOGDOCHES COUNTIES, TEXAS: TEXAS WATER DEVELOPMENT BOARD REPORT 110, 1970

GEOHYDROLOGIC SIGNIFICANCE OF LITHOFACIES OF THE COCKFIELD FORMATION OF LOUISIANA AND MISSISSIPPI AND OF THE YEGUA FORMATION OF TEXAS: USGS PROFESSIONAL PAPER 569-B, 1970.

HYDROLOGIC SIGNIFICANCE OF LITHOFACIES OF THE CANE RIVER FORMATION OR EQUIVALENTS OF ARKANSAS, LOUISIANA, MISSISSIPPI, AND TEXAS: USGS PROFESSIONAL PAPER 569-C, 1972

HYDROLOGIC SIGNIFICANCE OF LITHOFACIES OF THE CARRIZO SAND OF ARKANSAS, LOUISIANA, AND TEXAS AND THE MERIDIAN SAND OF MISSISSIPPI: USGS PROFESSIONAL PAPER 569-D, 1975.

MAJOR AND HISTORICAL SPRINGS OF TEXAS: TEXAS WATER DEVELOPMENT BOARD REPORT 189, 1975.

SUMMARY APPRAISALS OF THE NATION'S GROUND-WATER RESOURCES-TEXAS-GULF REGION: USGS PROFESSIONAL PAPER 813-F, 1976.

WATER-QUALITY DATA FOR AQUIFERS, STREAMS, AND LAKES IN THE VICINITY OF KEECHI, MOUNT SYLVAN, OAKWOOD, AND PALESTINE SALT DOMES, NORTHEAST TEXAS SALT-DOME BASIN: USGS OPEN-FILE REPORT 80-2037, 1980

GEOHYDROLOGY OF THE KEECHI, MOUNT SYLVAN, OAKWOOD, AND PALESTINE SALT DOMES IN THE NORTHEAST TEXAS SALTDOME BASIN: USGS OPEN-FILE REPORT 80-2044, 1980.

GEOLOGY AND GEOHYDROLOGY OF THE EAST TEXAS BASIN-A REPORT ON THE PROGRESS OF NUCLEAR WASTE ISOLATION FEASIBILITY STUDIES (1979): UNIVERSITY OF TEXAS, BUREAU OF ECONOMIC GEOLOGY GEOLOGICAL CIRCULAR 80-12, 1980
GEOLOGY AND GEOHYDROLOGY OF THE EAST TEXAS BASIN-A REPORT ON THE PROGRESS OF NUCLEAR WASTE ISOLATION FEASIBILITY STUDIES (1980): UNIVERSITY OF TEXAS, BUREAU OF ECONOMIC GEOLOGY GEOLOGICAL CIRCULAR 81-7, 1981.

SPRINGS OF TEXAS, VOLUME 1: (BY GUNNAR BRUNE), BRANCHSMITH, INC., FORT WORTH, TEXAS, 1981.

REGIONAL AQUIFER CHARACTERIZATION FOR DEEP-BASIN LIGNITE MINING, SABINE UPLIFT AREA, NORTHEAST TEXAS: UNIVERSITY OF TEXAS, BUREAU OF ECONOMIC GEOLOGY GEOLOGICAL CIRCULAR 83-3, 1983.

TEXAS GROUND-WATER RESOURCES, in NATIONAL WATER SUMMARY 1984: USGS WATER-SUPPLY PAPER 2275, 1985.

APPROXIMATE POTENTIOMETRIC SURFACES FOR THE AQUIFERS OF THE COASTAL UPLANDS SYSTEM, 1980: USGS HYDROLOGIC INVESTIGATIONS ATLAS HA-704, 1987.

GEOHYDROLOGIC FRAMEWORK OF THE GULF COASTAL PLAIN: USGS HYDROLOGIC INVESTIGATIONS ATLAS HA-695, 1988.

HYDROGEOLOGY AND PREDEVELOPMENT FLOW IN THE TEXAS GULF COAST AQUIFER SYSTEMS: USGS WATER-RESOURCES INVESTIGATIONS REPORT 87-4248, 1988.

GROUND-WATER FLOW IN THE GULF COAST AQUIFER SYSTEMS, SOUTH-CENTRAL UNITED STATES—A PRELIMINARY ANALYSIS USGS WATER-RESOURCES INVESTIGATIONS REPORT 89-4071, 1990.

EVALUATION OF GROUND-WATER RESOURCES IN THE VICINITY OF THE CITIES OF HENDERSON, JACKSONVILLE, KILGORE, LUFKIN, NACOGDOCHES, RUSK, AND TYLER IN EAST TEXAS: TEXAS WATER DEVELOPMENT BOARD REPORT 327, 1991.

HYDROLOGY OF THE TEXAS GULF COAST AQUIFER SYSTEMS: USGS OPEN-FILE REPORT 91-64, 1991.

PROPERTIES AND CHEMICAL CONSTITUENTS IN GROUND WATER FROM THE LOWER CLAIBORNE-UPPER WILCOX AQUIFER, GULF COAST REGIONAL AQUIFER SYSTEMS, SOUTH-CENTRAL UNITED STATES: USGS WATER-RESOURCES INVESTIGATIONS REPORT 92-4102, 1992.

PROPERTIES AND CHEMICAL CONSTITUENTS IN GROUND WATER FROM THE UPPER CLAIBORNE AQUIFER, GULF COAST REGIONAL AQUIFER SYSTEMS, SOUTH-CENTRAL UNITED STATES: USGS WATER-RESOURCES INVESTIGATIONS REPORT 91-4150, 1993.

PROPERTIES AND CHEMICAL CONSTITUENTS IN GROUND WATER FROM THE MIDDLE CLAIBORNE AQUIFER, GULF COAST REGIONAL AQUIFER SYSTEMS, SOUTH-CENTRAL UNITED STATES: USGS WATER-RESOURCES INVESTIGATIONS REPORT 92-4104, 1993.

PROPERTIES AND CHEMICAL CONSTITUENTS IN GROUND WATER FROM THE MIDDLE WILCOX AQUIFER, GULF COAST REGIONAL AQUIFER SYSTEMS, SOUTH-CENTRAL UNITED STATES: USGS WATER-RESOURCES INVESTIGATIONS REPORT 93-4070, 1993.

STRATIGRAPHIC NOMENCLATURE AND GEOLOGIC SECTIONS OF THE GULF COASTAL PLAIN OF TEXAS: USGS OPEN-FILE REPORT 94-461, 1995.

AQUIFERS OF TEXAS: TEXAS WATER DEVELOPMENT BOARD REPORT 345, 1995. 
WATER QUALITY IN THE SPARTA AQUIFER, EAST TEXAS: TEXAS WATER DEVELOPMENT BOARD HYDROLOGIC ATLAS NO. 5, 1996.

WATER QUALITY IN THE QUEEN CITY AQUIFER, EAST TEXAS: TEXAS WATER DEVELOPMENT BOARD HYDROLOGIC ATLAS NO. 6, 1996

\section{NAVARRO COUNTY}

GEOGRAPHY AND GEOLOGY OF THE BLACK AND GRAND PRAIRIES, TEXAS, WITH DETAILED DESCRIPTIONS OF THE CRETACEOUS FORMATIONS AND SPECIAL REFERENCE TO ARTESIAN WATERS: USGS 21ST ANNUAL REPORT, PART 7, 1901.

GEOLOGY AND UNDERGROUND WATERS OF THE SOUTHEASTERN PART OF THE TEXAS COASTAL PLAIN: USGS WATER-SUPPLY PAPER 335, 1914

PUBLIC WATER SUPPLIES IN EASTERN TEXAS, V. 2, HARRISON COUNTY THROUGH WOOD COUNTY: TEXAS BOARD OF WATER ENGINEERS MISCELLANEOUS PUBLICATION 214, V. 2, 1945.

PUBLIC WATER SUPPLIES IN EASTERN TEXAS: USGS WATERSUPPLY PAPER 1047, 1948.

BRINE PRODUCTION AND DISPOSAL ON THE LOWER WATERSHED OF CHAMBERS AND RICHLAND CREEKS, NAVARRO COUNTY, TEXAS: TEXAS BOARD OF WATER ENGINEERS BULLETIN 6002, 1960

RECONNAISSANCE INVESTIGATION OF THE GROUND-WATER RESOURCES OF THE TRINITY RIVER BASIN: TEXAS WATER COMMISSION BULLETIN 6309, 1963.

GROUND-WATER RESOURCES OF NAVARRO COUNTY, TEXAS: TEXAS WATER DEVELOPMENT BOARD REPORT 160, 1972.

PROJECTED EFFECTS OF THE PROPOSED TENNESSEE COLONY RES ERVOIR ON GROUND-WATER CONDITIONS IN THE CARRIZOWILCOX AQUIFER AND TRINITY RIVER ALLUVIUM, TRINIDADOAKWOOD AREA, TEXAS: USGS OPEN-FILE REPORT 74-297, 1974.

GROUND-WATER RESOURCES OF PART OF CENTRAL TEXAS WITH EMPHASIS ON THE ANTLERS AND TRAVIS PEAK FORMATIONS: TEXAS WATER DEVELOPMENT BOARD REPORT 195, V. 1, 1975.

GROUND-WATER RESOURCES OF PART OF CENTRAL TEXAS WITH EMPHASIS ON THE ANTLERS AND TRAVIS PEAK FORMATIONS: TEXAS WATER DEVELOPMENT BOARD REPORT 195, V. 2, 1976.

WATER-LEVEL AND WATER-QUALITY DATA FROM OBSERVATION WELLS IN NORTHEAST TEXAS: TEXAS WATER DEVELOPMENT BOARD REPORT 198, 1976.

SUMMARY APPRAISALS OF THE NATION'S GROUND-WATER RESOURCES-TEXAS-GULF REGION: USGS PROFESSIONAL PAPER 813-F, 1976.

PROJECTED EFFECTS OF THE PROPOSED TENNESSEE COLONY RESERVOIR ON GROUND-WATER CONDITIONS IN THE ALLUVIUM OF THE TRINITY RIVER AND CEDAR CREEK, TEXAS-PRELIMINARY RESULTS FOR THE TRINIDAD AREA: USGS OPEN-FILE REPORT 79-1270, 1979.

ALTITUDE OF THE WATER TABLE IN THE ALLUVIAL AND WILCOX AQUIFERS IN THE VICINITY OF RICHLAND AND TEHUACANA CREEKS AND THE TRINITY RIVER, TEXAS, DECEMBER 1979: USGS OPEN-FILE REPORT 80-1007, 1980.
WATER-QUALITY DATA FOR AQUIFERS, STREAMS, AND LAKES IN THE VICINITY OF KEECHI, MOUNT SYLVAN, OAKWOOD, AND PALESTINE SALT DOMES, NORTHEAST TEXAS SALT-DOME BASIN: USGS OPEN-FILE REPORT 80-2037, 1980

GEOHYDROLOGY OF THE KEECHI, MOUNT SYLVAN, OAKWOOD, AND PALESTINE SALT DOMES IN THE NORTHEAST TEXAS SALTDOME BASIN: USGS OPEN-FILE REPORT 80-2044, 1980.

GEOLOGY AND GEOHYDROLOGY OF THE EAST TEXAS BASIN-A REPORT ON THE PROGRESS OF NUCLEAR WASTE ISOLATION FEASIBILITY STUDIES (1979): UNIVERSITY OF TEXAS, BUREAU OF ECONOMIC GEOLOGY GEOLOGICAL CIRCULAR 80-12, 1980.

GEOLOGY AND GEOHYDROLOGY OF THE EAST TEXAS BASIN-A REPORT ON THE PROGRESS OF NUCLEAR WASTE ISOLATION FEASIBILITY STUDIES (1980): UNIVERSITY OF TEXAS, BUREAU OF ECONOMIC GEOLOGY GEOLOGICAL CIRCULAR 81-7, 1981.

OCCURRENCE, AVAILABILITY, AND CHEMICAL QUALITY OF GROUND WATER IN THE CRETACEOUS AQUIFERS OF NORTHCENTRAL TEXAS: TEXAS DEPARTMENT OF WATER RESOURCES REPORT 269, V. 1, 1982

OCCURRENCE, AVAILABILITY, AND CHEMICAL QUALITY OF GROUND WATER IN THE CRETACEOUS AQUIFERS OF NORTHCENTRAL TEXAS: TEXAS DEPARTMENT OF WATER RESOURCES REPORT 269, V. 2, 1982.

TEXAS GROUND-WATER RESOURCES, in NATIONAL WATER SUMMARY 1984: USGS WATER-SUPPLY PAPER 2275, 1985.

APPROXIMATE POTENTIOMETRIC SURFACES FOR THE AQUIFERS OF THE COASTAL UPLANDS SYSTEM, 1980: USGS HYDROLOGIC INVESTIGATIONS ATLAS HA-704, 1987.

GROUND-WATER RESOURCES OF THE NACATOCH AQUIFER: TEXAS WATER DEVELOPMENT BOARD REPORT 305, 1988.

GEOHYDROLOGIC FRAMEWORK OF THE GULF COASTAL PLAIN: USGS HYDROLOGIC INVESTIGATIONS ATLAS HA-695, 1988

HYDROGEOLOGY AND PREDEVELOPMENT FLOW IN THE TEXAS GULF COAST AQUIFER SYSTEMS: USGS WATER-RESOURCES INVESTIGATIONS REPORT 87-4248, 1988.

GROUND-WATER FLOW IN THE GULF COAST AQUIFER SYSTEMS, SOUTH-CENTRAL UNITED STATES-A PRELIMINARY ANALYSIS USGS WATER-RESOURCES INVESTIGATIONS REPORT 89-4071, 1990.

EVALUATION OF WATER RESOURCES IN PART OF NORTH-CENTRAL TEXAS: TEXAS WATER DEVELOPMENT BOARD REPORT 318,1990 .

NATIONAL WATER-QUALITY ASSESSMENT PROGRAM-THE TRINITY RIVER BASIN: USGS OPEN-FILE REPORT 91-158, 1991.

GROUND-WATER RESOURCES OF THE CARRIZO-WILCOX AQUIFER IN THE CENTRAL TEXAS REGION: TEXAS WATER DEVELOPMENT BOARD REPORT 332, 1991.

NATIONAL WATER-QUALITY ASSESSMENT PROGRAM-PESTICIDES IN THE TRINITY RIVER BASIN STUDY UNIT, TEXAS, 1968-91: USGS FACT SHEET FS-088-95, 1995.

WATER-QUALITY ASSESSMENT OF THE TRINITY RIVER BASIN, TEXAS-DATA COLLECTION, 1992-95: USGS FACT SHEET FS-095-95, 1995. 
WATER-QUALITY ASSESSMENT OF THE TRINITY RIVER BASIN, TEXAS-PESTICIDES IN A SUBURBAN WATERSHED, ARLINGTON, 1993-94: USGS FACT SHEET FS-159-95, 1995.

AQUIFERS OF TEXAS: TEXAS WATER DEVELOPMENT BOARD REPORT 345, 1995

WATER QUALITY IN THE WOODBINE AQUIFER, NORTH-CENTRAL TEXAS: TEXAS WATER DEVELOPMENT BOARD HYDROLOGIC ATLAS NO. 4, 1996.

UPDATED EVALUATION OF WATER RESOURCES IN PART OF NORTH-CENTRAL TEXAS, 1990-1999: TEXAS WATER DEVELOPMENT BOARD REPORT 349, 1999.

WATER-QUALITY ASSESSMENT OF THE TRINITY RIVER BASIN, TEXAS-GROUND-WATER QUALITY OF THE TRINITY, CARRIZOWILCOX, AND GULF COAST AQUIFERS, FEBRUARY-AUGUST 1994: USGS WATER-RESOURCES INVESTIGATIONS REPORT 99-4233, 2000.

\section{NEWTON COUNTY}

UNDERGROUND WATERS OF THE COASTAL PLAIN OF TEXAS: USGS WATER-SUPPLY PAPER 190, 1907.

GEOLOGY AND UNDERGROUND WATERS OF THE SOUTHEASTERN PART OF THE TEXAS COASTAL PLAIN: USGS WATER-SUPPLY PAPER 335, 1914.

MEMORANDUM ON THE WATER RESOURCES IN THE VICINITY OF JASPER, JASPER COUNTY, TEXAS: USGS OPEN-FILE REPORT (UNNUMBERED), 1941

GROUND-WATER RESOURCES IN THE VICINITY OF JASPER, JASPER COUNTY, TEXAS: USGS OPEN-FILE REPORT (UNNUMBERED), 1941.

MEMORANDUM TO MR. DEBUSK REGARDING GROUND WATER IN JASPER COUNTY: USGS OPEN-FILE REPORT (UNNUMBERED), 1941.

RECORDS OF WELLS, DRILLERS' LOGS, WATER ANALYSES, AND MAP SHOWING LOCATIONS OF WELLS IN JASPER AND NEWTON COUNTIES, TEXAS: TEXAS BOARD OF WATER ENGINEERS MISCELLANEOUS PUBLICATION 145, 1942.

GROUND WATER IN THE BEAUMONT AREA, TEXAS, WITH SPECIAL REFERENCE TO SOUTHEASTERN HARDIN COUNTY AND SOUTHWESTERN JASPER COUNTY: USGS OPEN-FILE REPORT (UNNUMBERED), 1945.

PUBLIC WATER SUPPLIES IN EASTERN TEXAS: USGS WATERSUPPLY PAPER 1047, 1948.

MEMORANDUM REGARDING AVAILABILITY OF GROUND WATER IN THE AREA NEAR BESSMAY IN JASPER AND NEWTON COUNTIES: USGS OPEN-FILE REPORT (UNNUMBERED), 1950.

AVAILABILITY OF GROUND WATER IN THE GULF COAST REGION OF TEXAS: USGS OPEN-FILE REPORT (UNNUMBERED), 1956.

RECONNAISSANCE INVESTIGATION OF THE GROUND-WATER RESOURCES OF THE GULF COAST REGION, TEXAS: TEXAS WATER COMMISSION BULLETIN 6305, 1963.

RECONNAISSANCE INVESTIGATION OF THE GROUND-WATER RESOURCES OF THE SABINE RIVER BASIN, TEXAS: TEXAS WATER COMMISSION BULLETIN 6307, 1963.
GROUND-WATER RESOURCES OF JASPER AND NEWTON COUNTIES, TEXAS: TEXAS WATER DEVELOPMENT BOARD REPORT 59, 1967.

GROUND-WATER DATA FOR ORANGE COUNTY AND VICINITY, TEXAS AND LOUISIANA, 1968: USGS OPEN-FILE REPORT 68-50, 1968.

GROUND-WATER DATA FOR ORANGE COUNTY AND VICINITY, TEXAS AND LOUISIANA, 1969: USGS OPEN-FILE REPORT 69-204, 1969.

COMPILATION OF RESULTS OF AQUIFER TESTS IN TEXAS: TEXAS WATER DEVELOPMENT BOARD REPORT 98, 1969.

GEOHYDROLOGIC SIGNIFICANCE OF LITHOFACIES OF THE COCKFIELD FORMATION OF LOUISIANA AND MISSISSIPPI AND OF THE YEGUA FORMATION OF TEXAS: USGS PROFESSIONAL PAPER 569-B, 1970.

GROUND-WATER DATA FOR ORANGE COUNTY AND VICINITY, TEXAS AND LOUISIANA, 1970: USGS OPEN-FILE REPORT 70-123, 1970.

GROUND-WATER POLLUTION IN THE VICINITY OF TOLEDO BEND RESERVOIR, TEXAS, PROGRESS REPORT, 1972: USGS OPEN-FILE REPORT 72-010, 1972

DEVELOPMENT OF GROUND-WATER RESOURCES IN THE ORANGE COUNTY AREA, TEXAS AND LOUISIANA, 1963-71: USGS OPENFILE REPORT 72-243, 1972.

DEVELOPMENT OF GROUND-WATER RESOURCES IN THE ORANGE COUNTY AREA, TEXAS AND LOUISIANA, 1963-71: TEXAS WATER DEVELOPMENT BOARD REPORT 156, 1972.

GROUND-WATER POLLUTION IN THE VICINITY OF TOLEDO BEND RESERVOIR, TEXAS: USGS OPEN-FILE REPORT 74-296, 1974.

GROUND-WATER DATA FOR ORANGE COUNTY AND VICINITY, TEXAS AND LOUISIANA, 1971-74: USGS OPEN-FILE REPORT 75-129, 1975.

GROUND-WATER DATA FOR ORANGE COUNTY AND VICINITY, TEXAS AND LOUISIANA, 1971-74: TEXAS WATER DEVELOPMENT BOARD REPORT 197, 1975.

SUMMARY APPRAISALS OF THE NATION'S GROUND-WATER RESOURCES-TEXAS-GULF REGION: USGS PROFESSIONAL PAPER 813-F, 1976.

STRATIGRAPHIC AND HYDROGEOLOGIC FRAMEWORK OF PART OF THE COASTAL PLAIN OF TEXAS: USGS OPEN-FILE REPORT $77-712,1978$

STRATIGRAPHIC AND HYDROGEOLOGIC FRAMEWORK OF PART OF THE COASTAL PLAIN OF TEXAS: TEXAS DEPARTMENT OF WATER RESOURCES REPORT 236, 1979.

LAND-SURFACE SUBSIDENCE IN THE TEXAS COASTAL REGION: USGS OPEN-FILE REPORT 80-969, 1980.

SPRINGS OF TEXAS, VOLUME 1: (BY GUNNAR BRUNE), BRANCHSMITH, INC., FORT WORTH, TEXAS, 1981.

DEVELOPMENT OF GROUND-WATER RESOURCES IN ORANGE COUNTY, TEXAS, AND ADJACENT AREAS IN TEXAS AND LOUISIANA, 1971-80: USGS OPEN-FILE REPORT 82-330, 1982.

LAND-SURFACE SUBSIDENCE IN THE TEXAS COASTAL REGION: TEXAS DEPARTMENT OF WATER RESOURCES REPORT 272, 1982 
DEVELOPMENT OF GROUND-WATER RESOURCES IN ORANGE COUNTY, TEXAS, AND ADJACENT AREAS IN TEXAS AND LOUISIANA, 1971-80: TEXAS DEPARTMENT OF WATER RESOURCES REPORT 283, 1983.

TEXAS GROUND-WATER RESOURCES, in NATIONAL WATER SUMMARY 1984: USGS WATER-SUPPLY PAPER 2275, 1985.

DIGITAL MODELS FOR SIMULATION OF GROUND-WATER HYDROLOGY OF THE CHICOT AND EVANGELINE AQUIFERS ALONG THE GULF COAST OF TEXAS: TEXAS DEPARTMENT OF WATER RESOURCES REPORT 289, 1985.

HYDROLOGY OF THE JASPER AQUIFER IN THE SOUTHEAST TEXAS COASTAL PLAIN: TEXAS WATER DEVELOPMENT BOARD REPORT 295, 1986.

DEVELOPMENT OF GROUND-WATER RESOURCES IN THE ORANGE COUNTY AREA, TEXAS AND LOUISIANA, 1980-SPRING OF 1985 USGS WATER-RESOURCES INVESTIGATIONS REPORT 87-4158, 1987.

GEOHYDROLOGIC FRAMEWORK OF THE GULF COASTAL PLAIN: USGS HYDROLOGIC INVESTIGATIONS ATLAS HA-695, 1988.

HYDROGEOLOGY AND PREDEVELOPMENT FLOW IN THE TEXAS GULF COAST AQUIFER SYSTEMS: USGS WATER-RESOURCES INVESTIGATIONS REPORT 87-4248, 1988.

GROUND-WATER FLOW IN THE GULF COAST AQUIFER SYSTEMS, SOUTH-CENTRAL UNITED STATES-A PRELIMINARY ANALYSIS: USGS WATER-RESOURCES INVESTIGATIONS REPORT 89-4071, 1990.

SALT-DOME LOCATIONS IN THE GULF COASTAL PLAIN, SOUTHCENTRAL UNITED STATES: USGS WATER-RESOURCES INVESTIGATIONS REPORT 90-4060, 1990.

HYDROLOGY OF THE TEXAS GULF COAST AQUIFER SYSTEMS: USGS OPEN-FILE REPORT 91-64, 1991.

PROPERTIES AND CHEMICAL CONSTITUENTS IN GROUND WATER FROM THE MISSISSIPPI RIVER VALLEY ALLUVIAL AQUIFER AND PERMEABLE ZONE A (HOLOCENE-UPPER PLEISTOCENE DEPOSITS), SOUTH-CENTRAL UNITED STATES: USGS WATERRESOURCES INVESTIGATIONS REPORT 91-4149, 1992.

PROPERTIES AND CHEMICAL CONSTITUENTS IN GROUND WATER FROM THE UPPER CLAIBORNE AQUIFER, GULF COAST REGIONAL AQUIFER SYSTEMS, SOUTH-CENTRAL UNITED STATES: USGS WATER-RESOURCES INVESTIGATIONS REPORT 91-4150, 1993.

PROPERTIES AND CHEMICAL CONSTITUENTS IN GROUND WATER FROM PERMEABLE ZONE C (LOWER PLIOCENE-UPPER MIOCENE DEPOSITS), COASTAL LOWLANDS AQUIFER SYSTEM, SOUTHCENTRAL UNITED STATES: USGS WATER-RESOURCES INVESTIGATIONS REPORT 91-4151, 1993.

PROPERTIES AND CHEMICAL CONSTITUENTS IN GROUND WATER FROM PERMEABLE ZONE B (LOWER PLEISTOCENE-UPPER PLIOCENE DEPOSITS), COASTAL LOWLANDS AQUIFER SYSTEM, SOUTH-CENTRAL UNITED STATES: USGS WATER-RESOURCES INVESTIGATIONS REPORT 91-4152, 1993.

PROPERTIES AND CHEMICAL CONSTITUENTS IN GROUND WATER FROM PERMEABLE ZONE E (LOWER MIOCENE-UPPER OLIGOCENE DEPOSITS), COASTAL LOWLANDS AQUIFER SYSTEM, SOUTH-CENTRAL UNITED STATES: USGS WATER-RESOURCES INVESTIGATIONS REPORT 92-4103, 1993.
PROPERTIES AND CHEMICAL CONSTITUENTS IN GROUND WATER FROM THE MIDDLE CLAIBORNE AQUIFER, GULF COAST REGIONAL AQUIFER SYSTEMS, SOUTH-CENTRAL UNITED STATES: USGS WATER-RESOURCES INVESTIGATIONS REPORT 92-4104, 1993.

PROPERTIES AND CHEMICAL CONSTITUENTS IN GROUND WATER FROM PERMEABLE ZONE D (MIDDLE MIOCENE DEPOSITS), COASTAL LOWLANDS AQUIFER SYSTEM, SOUTH-CENTRAL UNITED STATES: USGS WATER-RESOURCES INVESTIGATIONS REPORT 92-4105, 1993.

PROPERTIES AND CHEMICAL CONSTITUENTS IN GROUND WATER FROM THE MIDDLE WILCOX AQUIFER, GULF COAST AQUIFER SYSTEMS, SOUTH-CENTRAL UNITED STATES: USGS WATERRESOURCES INVESTIGATIONS REPORT 93-4070, 1993.

WATER-RESOURCES DATA, TEXAS, WATER YEAR 1992, VOLUME 4, GROUND-WATER DATA: USGS WATER-DATA REPORT TX-92-4, 1993.

WATER-RESOURCES DATA, TEXAS, WATER YEAR 1993, VOLUME 4, GROUND-WATER DATA: USGS WATER-DATA REPORT TX-93-4, 1994.

AQUIFERS OF TEXAS: TEXAS WATER DEVELOPMENT BOARD REPORT 345, 1995.

WATER-RESOURCES DATA, TEXAS, WATER YEAR 1994, VOLUME 4, GROUND-WATER DATA: USGS WATER-DATA REPORT TX-94-4, 1995.

WATER-RESOURCES DATA, TEXAS, WATER YEAR 1995, VOLUME 4, GROUND-WATER DATA: USGS WATER-DATA REPORT TX-95-4, 1996.

WATER-RESOURCES DATA, TEXAS, WATER YEAR 1996, VOLUME 4, GROUND-WATER DATA: USGS WATER-DATA REPORT TX-96-4, 1997.

WATER-RESOURCES DATA, TEXAS, WATER YEAR 1997, VOLUME 4, GROUND-WATER DATA: USGS WATER-DATA REPORT TX-97-4, 1998.

GROUND-WATER DATA IN ORANGE COUNTY AND ADJACENT COUNTIES, TEXAS, 1985-90: USGS OPEN-FILE REPORT 99-603, 1999.

WATER-RESOURCES DATA, TEXAS, WATER YEAR 1998, VOLUME 4, GROUND-WATER DATA: USGS WATER-DATA REPORT TX-98-4, 1999.

WATER-RESOURCES DATA, TEXAS, WATER YEAR 1999, VOLUME 6, GROUND-WATER DATA: USGS WATER-DATA REPORT TX-99-6, 2000 .

WATER-RESOURCES DATA, TEXAS, WATER YEAR 2000, VOLUME 6, GROUND-WATER DATA: USGS WATER-DATA REPORT TX-00-6, 2001.

\section{NOLAN COUNTY}

GROUND WATER IN NORTHWESTERN NOLAN COUNTY, TEXAS, RECORDS OF WELLS, DRILLERS' LOGS, WATER ANALYSES, AND MAP SHOWING LOCATIONS OF WELLS: TEXAS BOARD OF WATER ENGINEERS MISCELLANEOUS PUBLICATION 196, 1947.

PUBLIC WATER SUPPLIES IN WESTERN TEXAS: TEXAS BOARD OF WATER ENGINEERS MISCELLANEOUS PUBLICATION 216, 1949. 
PUBLIC WATER SUPPLIES IN WESTERN TEXAS: USGS WATERSUPPLY PAPER 1106, 1951.

RECORDS OF WATER-LEVEL MEASUREMENTS IN MITCHELL, NOLAN, STERLING, AND TOM GREEN COUNTIES, TEXAS, 1938 THROUGH 1957: TEXAS BOARD OF WATER ENGINEERS BULLETIN 5907, 1959.

RECONNAISSANCE INVESTIGATION OF THE GROUND-WATER RESOURCES OF THE BRAZOS RIVER BASIN, TEXAS: TEXAS WATER COMMISSION BULLETIN 6310, 1963.

GROUND-WATER RESOURCES OF MITCHELL AND WESTERN NOLAN COUNTIES, TEXAS: TEXAS WATER DEVELOPMENT BOARD REPORT 50, 1967.

RECONNAISSANCE INVESTIGATION OF THE GROUND-WATER RESOURCES OF THE COLORADO RIVER BASIN, TEXAS: TEXAS WATER DEVELOPMENT BOARD REPORT 51, 1967.

SUMMARY APPRAISALS OF THE NATION'S GROUND-WATER RESOURCES-TEXAS-GULF REGION: USGS PROFESSIONAL PAPER 813-F, 1976.

SOURCE AREAS OF SALINITY AND TRENDS OF SALT LOADS IN STREAMFLOW IN THE UPPER COLORADO RIVER, TEXAS: USGS OPEN-FILE REPORT 80-224, 1980.

TEXAS GROUND-WATER RESOURCES, in NATIONAL WATER SUMMARY 1984: USGS WATER-SUPPLY PAPER 2275, 1985.

PUBLIC SUPPLY GROUND-WATER USE IN THE SOUTHERN HIGH PLAINS OF TEXAS: TEXAS WATER DEVELOPMENT BOARD REPORT 328, 1990.

EVALUATION OF WATER RESOURCES IN PARTS OF THE ROLLING PLAINS OF NORTH-CENTRAL TEXAS: TEXAS WATER DEVELOPMENT BOARD REPORT 337, 1992.

WATER QUALITY IN THE EDWARDS-TRINITY (PLATEAU) AQUIFER, EDWARDS PLATEAU AND TRANS-PECOS, TEXAS: TEXAS WATER DEVELOPMENT BOARD HYDROLOGIC ATLAS NO. 3, 1995.

AQUIFERS OF TEXAS: TEXAS WATER DEVELOPMENT BOARD REPORT 345, 1995.

AN OVERVIEW OF THE EDWARDS-TRINITY AQUIFER SYSTEM, CENTRAL-WEST TEXAS, CHAPTER 8, in AQUIFERS OF WEST TEXAS: TEXAS WATER DEVELOPMENT BOARD REPORT 356, 2001.

\section{NUECES COUNTY}

ARTESIAN WELLS OF THE COASTAL PRAIRIE REGION AND TERTIARY BELT OF TEXAS: GEOLOGICAL SURVEY OF TEXAS, CHAPTER 2, 1893.

UNDERGROUND WATERS OF THE COASTAL PLAIN OF TEXAS: USGS WATER-SUPPLY PAPER 190, 1907.

GROUND WATER IN SAN PATRICIO COUNTY, TEXAS, AND GROUND WATER IN NUECES COUNTY, TEXAS: USGS OPEN-FILE REPORT (UNNUMBERED), 1933.

SYNOPSIS OF WELL DATA IN NUECES COUNTY, TEXAS: USGS OPEN-FILE REPORT (UNNUMBERED), 1934?

GROUND WATER IN NUECES COUNTY, TEXAS: USGS OPEN-FILE REPORT (UNNUMBERED), 1934.
RECORDS OF WELLS, DRILLERS' LOGS, WATER ANALYSES, AND MAP SHOWING LOCATIONS OF WELLS IN NUECES COUNTY, TEXAS: TEXAS BOARD OF WATER ENGINEERS MISCELLANEOUS PUBLICATION 197, 1934.

GROUND WATER IN THE CORPUS CHRISTI AREA, TEXAS: USGS OPEN-FILE REPORT (UNNUMBERED), 1940.

EMERGENCY WATER SUPPLY FOR NAVAL RESERVE AIR BASE NEAR CORPUS CHRISTI, TEXAS: USGS OPEN-FILE REPORT (UNNUMBERED), 1942.

MEMORANDUM; BISHOP CELENESE PLANT: USGS OPEN-FILE REPORT (UNNUMBERED), 1943.

RESULTS OF THE PUMPING TEST OF WELLS TO THE 900-FOOT SANDS AT THE CELENESE PLANT NEAR BISHOP, TEXAS: USGS OPEN-FILE REPORT (UNNUMBERED), 1944.

RESULTS OF THE PUMPING TEST OF WELLS TO THE 700-FOOT SANDS AT THE CELENESE PLANT NEAR BISHOP, TEXAS: USGS OPEN-FILE REPORT (UNNUMBERED), 1944.

GROUND WATER AT SITE OF PROPOSED CELANESE PLANT NEAR BISHOP, NUECES COUNTY, TEXAS: USGS OPEN-FILE REPORT (UNNUMBERED), 1944.

MEMORANDUM REGARDING THE WATER SUPPLY FOR THE CELANESE PLANT AT BISHOP, NUECES COUNTY, TEXAS: USGS OPEN-FILE REPORT (UNNUMBERED), 1944.

NOTES ON A FIELD STUDY OF THE GROUND-WATER RESOURCES IN THE AGUA DULCE GAS FIELD, SEPT. 5-7, 1944: USGS OPEN-FILE REPORT (UNNUMBERED), 1944.

MEMORANDUM REGARDING WATER SUPPLY FOR PROPOSED GASOLINE PLANT OF THE SOUTHERN MINERALS CORP. IN THE STRATTON FIELD, SOUTHWEST NUECES COUNTY, TEXAS: USGS OPEN-FILE REPORT (UNNUMBERED), 1944.

PUBLIC WATER SUPPLIES IN SOUTHERN TEXAS: TEXAS BOARD OF WATER ENGINEERS MISCELLANEOUS PUBLICATION 215, 1946.

SUPPLEMENTARY REPORT ON SURFACE-WATER AND GROUNDWATER SURVEYS, NUECES RIVER BASIN, TEXAS: USGS OPENFILE REPORT (UNNUMBERED), 1950.

PUBLIC WATER SUPPLIES IN SOUTHERN TEXAS: USGS WATERSUPPLY PAPER 1070, 1950.

AVAILABILITY OF GROUND WATER IN THE GULF COAST REGION OF TEXAS: USGS OPEN-FILE REPORT (UNNUMBERED), 1956.

AVAILABILITY OF GROUND WATER FROM THE GOLIAD SAND IN THE ALICE AREA, TEXAS: TEXAS WATER COMMISSION BULLETIN 6301, 1963.

RECONNAISSANCE INVESTIGATION OF THE GROUND-WATER RESOURCES OF THE GULF COAST REGION, TEXAS: TEXAS WATER COMMISSION BULLETIN 6305, 1963.

GROUND-WATER RESOURCES OF NUECES AND SAN PATRICIO COUNTIES, TEXAS: TEXAS WATER DEVELOPMENT BOARD REPORT 73, 1968.

COMPILATION OF RESULTS OF AQUIFER TESTS IN TEXAS: TEXAS WATER DEVELOPMENT BOARD REPORT 98, 1969.

SUMMARY APPRAISALS OF THE NATION'S GROUND-WATER RESOURCES-TEXAS-GULF REGION: USGS PROFESSIONAL PAPER 813-F, 1976. 
HYDROLOGY OF THE CORPUS CHRISTI AREA, TEXAS: UNIVERSITY OF TEXAS, BUREAU OF ECONOMIC GEOLOGY RESEARCH NOTE 12, 1978.

LAND AND WATER RESOURCES OF THE CORPUS CHRISTI AREA, TEXAS: UNIVERSITY OF TEXAS, BUREAU OF ECONOMIC GEOLOGY REPORT OF INVESTIGATIONS NO. 95, 1978.

STRATIGRAPHIC AND HYDROGEOLOGIC FRAMEWORK OF PART OF THE COASTAL PLAIN OF TEXAS: USGS OPEN-FILE REPORT 77-712, 1978.

STRATIGRAPHIC AND HYDROGEOLOGIC FRAMEWORK OF PART OF THE COASTAL PLAIN OF TEXAS: TEXAS DEPARTMENT OF WATER RESOURCES REPORT 236, 1979.

LAND-SURFACE SUBSIDENCE IN THE TEXAS COASTAL REGION: USGS OPEN-FILE REPORT 80-969, 1980.

SPRINGS OF TEXAS, VOLUME 1: (BY GUNNAR BRUNE), BRANCHSMITH, INC., FORT WORTH, TEXAS, 1981.

LAND-SURFACE SUBSIDENCE IN THE TEXAS COASTAL REGION: TEXAS DEPARTMENT OF WATER RESOURCES REPORT 272, 1982.

REGIONAL HYDRODYNAMICS AND HYDROCHEMISTRY OF THE URANIUM-BEARING OAKVILLE AQUIFER (MIOCENE) OF SOUTH TEXAS: UNIVERSITY OF TEXAS, BUREAU OF ECONOMIC GEOLOGY REPORT OF INVESTIGATIONS NO. 124, 1982.

WATER LEVELS AND SALINITIES OF WATER WITHIN THE EVANGELINE AQUIFER IN AN AREA SOUTHWEST OF CORPUS CHRISTI, TEXAS: USGS OPEN-FILE REPORT 82-174, 1983.

TEXAS GROUND-WATER RESOURCES, in NATIONAL WATER SUMMARY 1984: USGS WATER-SUPPLY PAPER 2275, 1985.

SIMULATED EFFECTS OF PROJECTED PUMPING ON THE AVAILABILITY OF FRESHWATER IN THE EVANGELINE AQUIFER IN AN AREA SOUTHWEST OF CORPUS CHRISTI, TEXAS: USGS WATERRESOURCES INVESTIGATIONS REPORT 85-4182, 1985.

DIGITAL MODELS FOR SIMULATION OF GROUND-WATER HYDROLOGY OF THE CHICOT AND EVANGELINE AQUIFERS ALONG THE GULF COAST OF TEXAS: TEXAS DEPARTMENT OF WATER RESOURCES REPORT 289, 1985.

WATER USE, PROJECTED WATER REQUIREMENTS, AND RELATED DATA AND INFORMATION FOR THE METROPOLITAN STATISTICAL AREAS IN TEXAS: TEXAS DEPARTMENT OF WATER RESOURCES LIMITED PRINTING REPORT LP-201, 1985.

GEOHYDROLOGIC FRAMEWORK OF THE GULF COASTAL PLAIN: USGS HYDROLOGIC INVESTIGATIONS ATLAS HA-695, 1988.

HYDROGEOLOGY AND PREDEVELOPMENT FLOW IN THE TEXAS GULF COAST AQUIFER SYSTEMS: USGS WATER-RESOURCES INVESTIGATIONS REPORT 87-4248, 1988.

GROUND-WATER FLOW IN THE GULF COAST AQUIFER SYSTEMS, SOUTH-CENTRAL UNITED STATES-A PRELIMINARY ANALYSIS USGS WATER-RESOURCES INVESTIGATIONS REPORT 89-4071, 1990.

HYDROLOGY OF THE TEXAS GULF COAST AQUIFER SYSTEMS: USGS OPEN-FILE REPORT 91-64, 1991.

PROPERTIES AND CHEMICAL CONSTITUENTS IN GROUND WATER FROM THE MISSISSIPPI RIVER VALLEY ALLUVIAL AQUIFER AND PERMEABLE ZONE A (HOLOCENE-UPPER PLEISTOCENE DEPOSITS), SOUTH-CENTRAL UNITED STATES: USGS WATERRESOURCES INVESTIGATIONS REPORT 91-4149, 1992.
PROPERTIES AND CHEMICAL CONSTITUENTS IN GROUND WATER FROM THE UPPER CLAIBORNE AQUIFER, GULF COAST REGIONAL AQUIFER SYSTEMS, SOUTH-CENTRAL UNITED STATES: USGS WATER-RESOURCES INVESTIGATIONS REPORT 91-4150, 1993.

PROPERTIES AND CHEMICAL CONSTITUENTS IN GROUND WATER FROM PERMEABLE ZONE C (LOWER PLIOCENE-UPPER MIOCENE DEPOSITS), COASTAL LOWLANDS AQUIFER SYSTEM, SOUTHCENTRAL UNITED STATES: USGS WATER-RESOURCES INVESTIGATIONS REPORT 91-4151, 1993.

PROPERTIES AND CHEMICAL CONSTITUENTS IN GROUND WATER FROM PERMEABLE ZONE B (LOWER PLEISTOCENE-UPPER PLIOCENE DEPOSITS), COASTAL LOWLANDS AQUIFER SYSTEM, SOUTH-CENTRAL UNITED STATES: USGS WATER-RESOURCES INVESTIGATIONS REPORT 91-4152, 1993.

PROPERTIES AND CHEMICAL CONSTITUENTS IN GROUND WATER FROM PERMEABLE ZONE E (LOWER MIOCENE-UPPER OLIGOCENE DEPOSITS), COASTAL LOWLANDS AQUIFER SYSTEM, SOUTH-CENTRAL UNITED STATES: USGS WATER-RESOURCES INVESTIGATIONS REPORT 92-4103, 1993.

PROPERTIES AND CHEMICAL CONSTITUENTS IN GROUND WATER FROM PERMEABLE ZONE D (MIDDLE MIOCENE DEPOSITS), COASTAL LOWLANDS AQUIFER SYSTEM, SOUTH-CENTRAL UNITED STATES: USGS WATER-RESOURCES INVESTIGATIONS REPORT 92-4105, 1993.

AQUIFERS OF TEXAS: TEXAS WATER DEVELOPMENT BOARD REPORT 345, 1995.

\section{OCHILTREE COUNTY}

THE GEOLOGY AND WATER RESOURCES OF THE EASTERN PORTION OF THE PANHANDLE OF TEXAS: USGS WATER-SUPPLY PAPER 154, 1906

GEOLOGY AND GROUND-WATER RESOURCES OF THE SOUTHERN HIGH PLAINS: USGS OPEN-FILE REPORT (UNNUMBERED), 1935.

RECORDS OF WELLS, DRILLERS' LOGS, WATER ANALYSES, AND MAP SHOWING LOCATIONS OF WELLS IN OCHILTREE COUNTY, TEXAS: TEXAS BOARD OF WATER ENGINEERS MISCELLANEOUS PUBLICATION 198, 1939.

GROUND WATER IN THE HIGH PLAINS OF TEXAS: USGS WATERSUPPLY PAPER 889-F, 1946.

GROUND WATER IN HIGH PLAINS OF TEXAS, PROGRESS REPORT NO. 6: TEXAS BOARD OF WATER ENGINEERS MISCELLANEOUS PUBLICATION 123, 1947.

PUBLIC WATER SUPPLIES IN WESTERN TEXAS: TEXAS BOARD OF WATER ENGINEERS MISCELLANEOUS PUBLICATION 216, 1949.

COST OF PUMPING WATER FOR IRRIGATION, TEXAS HIGH PLAINS, FIELD INVESTIGATIONS-1947 IRRIGATION SEASON: TEXAS BOARD OF WATER ENGINEERS MISCELLANEOUS PUBLICATION 124,1951

PUBLIC WATER SUPPLIES IN WESTERN TEXAS: USGS WATERSUPPLY PAPER 1106, 1951 [1952].

DEVELOPMENT OF WELLS FOR IRRIGATION AND FLUCTUATION OF WATER LEVELS IN THE HIGH PLAINS OF TEXAS TO JANUARY 
1951: TEXAS BOARD OF WATER ENGINEERS BULLETIN 5104, 1951.

RECORDS OF WATER-LEVEL MEASUREMENTS IN DALLAM, HANSFORD, HARTLEY, HUTCHINSON, MOORE, OCHILTREE, AND SHERMAN COUNTIES, TEXAS: TEXAS BOARD OF WATER ENGINEERS BULLETIN 5404, 1954.

WATER-LEVEL MAPS AND WATER LEVELS IN OBSERVATION WELLS IN THE NORTH HIGH PLAINS, TEXAS: TEXAS BOARD OF WATER ENGINEERS BULLETIN 5707, 1957.

WATER-LEVEL MEASUREMENTS AND MAPS, NORTHERN HIGH PLAINS, TEXAS, 1958 AND 1959: TEXAS BOARD OF WATER ENGINEERS BULLETIN 5909, 1959.

WATER LEVELS IN OBSERVATION WELLS, NORTHERN HIGH PLAINS, TEXAS, 1958-1960: TEXAS BOARD OF WATER ENGINEERS BULLETIN 6012, 1960.

RECONNAISSANCE INVESTIGATION OF THE GROUND-WATER RESOURCES OF THE CANADIAN RIVER BASIN, TEXAS: TEXAS BOARD OF WATER ENGINEERS BULLETIN 6016, 1960.

ANNUAL WATER-LEVEL MEASUREMENTS IN OBSERVATION WELLS, NORTHERN HIGH PLAINS, TEXAS, 1960 AND 1961: TEXAS BOARD OF WATER ENGINEERS BULLETIN 6103, 1961.

GEOLOGY AND GROUND-WATER RESOURCES OF THE NORTHERN HIGH PLAINS OF TEXAS, PROGRESS REPORT NO. 1: TEXAS BOARD OF WATER ENGINEERS BULLETIN 6109, 1961.

ANNUAL WATER-LEVEL MEASUREMENTS IN OBSERVATION WELLS, NORTHERN HIGH PLAINS, TEXAS, 1961 AND 1962: TEXAS WATER COMMISSION BULLETIN 6213, 1962.

WATER-LEVEL DATA FROM OBSERVATION WELLS IN THE NORTHERN PANHANDLE OF TEXAS: TEXAS WATER DEVELOPMENT BOARD REPORT 137, 1971.

GROUND-WATER RESOURCES OF THE PALO DURO CREEK BASIN, TEXAS AND OKLAHOMA: USGS OPEN-FILE REPORT 79-209, 1979.

PRELIMINARY DATA DESCRIBING THE DISTRIBUTION OF FLUORIDE AND SILICA IN THE OGALLALA AQUIFER ON THE HIGH PLAINS OF TEXAS: USGS OPEN-FILE REPORT 80-349, 1980.

WATER-LEVEL DATA FROM OBSERVATION WELLS IN THE NORTHERN PANHANDLE OF TEXAS, 1972-78: TEXAS DEPARTMENT OF WATER RESOURCES REPORT 248, 1980.

ANALYTICAL STUDY OF THE OGALLALA AQUIFER IN OCHILTREE COUNTY, TEXAS-PROJECTIONS OF SATURATED THICKNESS, VOLUME OF WATER IN STORAGE, PUMPAGE RATES, PUMPING LIFTS, AND WELL YIELDS: TEXAS DEPARTMENT OF WATER RESOURCES REPORT 258, 1980.

WATER TABLE IN THE HIGH PLAINS AQUIFER IN 1978 IN PARTS OF COLORADO, KANSAS, NEBRASKA, NEW MEXICO, OKLAHOMA, SOUTH DAKOTA, TEXAS, AND WYOMING: USGS HYDROLOGIC INVESTIGATIONS ATLAS HA-642, 1980.

EVALUATING THE GROUND-WATER RESOURCES OF THE HIGH PLAINS OF TEXAS: RESULTS OF TEST HOLE DRILLING: TEXAS DEPARTMENT OF WATER RESOURCES LIMITED PRINTING REPORT LP-129, 1980.

EVALUATING THE GROUND-WATER RESOURCES OF THE HIGH PLAINS OF TEXAS: RESULTS OF SURFACE ELECTRICAL RESISTIVITY: TEXAS DEPARTMENT OF WATER RESOURCES LIMITED PRINTING REPORT LP-130, 1980.
EVALUATING THE GROUND-WATER RESOURCES OF THE HIGH PLAINS OF TEXAS: NEUTRON-PROBE MEASUREMENTS OF DEEP SOIL MOISTURE AS AN INDICATION OF AQUIFER RECHARGE: TEXAS DEPARTMENT OF WATER RESOURCES LIMITED PRINTING REPORT LP-142, 1981.

SPRINGS OF TEXAS, VOLUME 1: (BY GUNNAR BRUNE), BRANCHSMITH, INC., FORT WORTH, TEXAS, 1981.

BEDROCK GEOLOGY, ALTITUDE OF BASE, AND 1980 SATURATED THICKNESS OF THE HIGH PLAINS AQUIFER IN PARTS OF COLORADO, KANSAS, NEBRASKA, NEW MEXICO, OKLAHOMA, SOUTH DAKOTA, TEXAS, AND WYOMING: USGS HYDROLOGIC INVESTIGATIONS ATLAS HA-648, 1981.

WATER-LEVEL AND SATURATED-THICKNESS CHANGES, PREDEVELOPMENT TO 1980, IN THE HIGH PLAINS AQUIFER IN PARTS OF COLORADO, KANSAS, NEBRASKA, NEW MEXICO, OKLAHOMA, SOUTH DAKOTA, TEXAS, AND WYOMING: USGS HYDROLOGIC INVESTIGATIONS ATLAS HA-652, 1981.

ANALYTICAL STUDY OF THE OGALLALA AQUIFER IN LIPSCOMB COUNTY, TEXAS-PROJECTIONS OF SATURATED THICKNESS, VOLUME OF WATER IN STORAGE, PUMPAGE RATES, PUMPING LIFTS, AND WELL YIELDS: TEXAS DEPARTMENT OF WATER RESOURCES REPORT 262, 1981.

DISSOLVED SOLIDS AND SODIUM IN WATER FROM THE HIGH PLAINS AQUIFER IN PARTS OF COLORADO, KANSAS, NEBRASKA, NEW MEXICO, OKLAHOMA, SOUTH DAKOTA, TEXAS, AND WYOMING: USGS HYDROLOGIC INVESTIGATIONS ATLAS HA-658, 1982.

GEOHYDROLOGY OF THE HIGH PLAINS AQUIFER IN PARTS OF COLORADO, KANSAS, NEBRASKA, NEW MEXICO, OKLAHOMA, SOUTH DAKOTA, TEXAS, AND WYOMING: USGS PROFESSIONAL PAPER 1400-B, 1984.

EVALUATING THE GROUND-WATER RESOURCES OF THE HIGH PLAINS OF TEXAS, VOLUME 1: TEXAS DEPARTMENT OF WATER RESOURCES REPORT 288, V. 1, 1984.

EVALUATING THE GROUND-WATER RESOURCES OF THE HIGH PLAINS OF TEXAS, VOLUME 2, RECORDS OF WELLS, AND MAPS SHOWING WELL LOCATIONS, BASE OF AQUIFER, WATER LEVELS, AND SATURATED THICKNESS (ARMSTRONG, CARSON, DALLAS, DONLEY, GRAY, HANSFORD, HARTLEY, HEMPHILL, HUTCHINSON, LIPSCOMB, MOORE, OCHILTREE, POTTER, ROBERTS, SHERMAN, AND WHEELER COUNTIES): TEXAS DEPARTMENT OF WATER RESOURCES REPORT 288, V. 2, 1984.

TEXAS GROUND-WATER RESOURCES, in NATIONAL WATER SUMMARY 1984: USGS WATER-SUPPLY PAPER 2275, 1985.

DIGITAL SIMULATION OF GROUND-WATER FLOW IN THE HIGH PLAINS AQUIFER IN PARTS OF COLORADO, KANSAS, NEBRASKA, NEW MEXICO, OKLAHOMA, SOUTH DAKOTA, TEXAS, AND WYOMING: USGS PROFESSIONAL PAPER 1400-D, 1986.

SUMMARY OF THE HIGH PLAINS REGIONAL AQUIFER-SYSTEM ANALYSIS IN PARTS OF COLORADO, KANSAS, NEBRASKA, NEW MEXICO, OKLAHOMA, SOUTH DAKOTA, TEXAS, AND WYOMING: USGS PROFESSIONAL PAPER 1400-A, 1988.

WATER-LEVEL CHANGES IN THE HIGH PLAINS AQUIFER OF TEXAS, 1980-1990: TEXAS WATER DEVELOPMENT BOARD HYDROLOGIC ATLAS NO. 1, 1991. 
PUBLIC-SUPPLY GROUND-WATER USE IN THE NORTHERN HIGH PLAINS OF TEXAS: TEXAS WATER DEVELOPMENT BOARD REPORT 336, 1992.

WATER-RESOURCES DATA, TEXAS, WATER YEAR 1991, VOLUME 4, GROUND-WATER DATA: USGS WATER-DATA REPORT TX-91-4, 1992.

THE HIGH PLAINS AQUIFER SYSTEM OF TEXAS, 1980 TO 1990. OVERVIEW AND PROJECTIONS: TEXAS WATER DEVELOPMENT BOARD REPORT 341, 1993.

WATER-QUALITY EVALUATION OF THE OGALLALA AQUIFER, TEXAS: TEXAS WATER DEVELOPMENT BOARD REPORT 342, 1993.

WATER-RESOURCES DATA, TEXAS, WATER YEAR 1992, VOLUME 4, GROUND-WATER DATA: USGS WATER-DATA REPORT TX-92-4, 1993.

WATER-LEVEL CHANGES IN THE HIGH PLAINS AQUIFER-PREDEVELOPMENT TO 1992: USGS WATER-RESOURCES INVESTIGATIONS REPORT 94-4027, 1994.

WATER-RESOURCES DATA, TEXAS, WATER YEAR 1993, VOLUME 4, GROUND-WATER DATA: USGS WATER-DATA REPORT TX-93-4, 1994.

WATER-LEVEL CHANGES IN THE HIGH PLAINS AQUIFER, 1980 TO 1994: USGS FACT SHEET FS-215-95, 1995.

AQUIFERS OF TEXAS: TEXAS WATER DEVELOPMENT BOARD REPORT 345, 1995.

WATER-LEVEL CHANGES IN THE HIGH PLAINS AQUIFER, 1980 TO 1995: USGS FACT SHEET FS-068-97, 1997.

WATER-LEVEL CHANGES IN THE HIGH PLAINS AQUIFER-PREDEVELOPMENT TO 1995: USGS WATER-RESOURCES INVESTIGATIONS REPORT 97-4081, 1997.

UPDATED WATER-QUALITY EVALUATION OF THE OGALLALA AQUIFER INCLUDING SELECTED METALLIC AND NON-METALLIC INORGANIC CONSTITUENTS: TEXAS WATER DEVELOPMENT BOARD HYDROLOGIC ATLAS NO. 10, 1998.

\section{OLDHAM COUNTY}

THE GEOLOGY AND WATER RESOURCES OF THE WESTERN PORTION OF THE PANHANDLE OF TEXAS: USGS WATER-SUPPLY PAPER 191, 1907.

GEOLOGY AND GROUND-WATER RESOURCES OF THE SOUTHERN HIGH PLAINS: USGS OPEN-FILE REPORT (UNNUMBERED), 1935.

GROUND WATER IN THE SOUTHERN HIGH PLAINS: USGS OPENFILE REPORT (UNNUMBERED), 1937.

RECORDS OF WELLS AND SPRINGS, DRILLERS' LOGS, WATER ANALYSES, AND MAP SHOWING LOCATION OF WELLS AND SPRINGS IN OLDHAM COUNTY, TEXAS: TEXAS BOARD OF WATER ENGINEERS MISCELLANEOUS PUBLICATION 199, 1938.

GROUND WATER IN THE HIGH PLAINS OF TEXAS: TEXAS BOARD OF WATER ENGINEERS MISCELLANEOUS PUBLICATION 119, 1940.

PROGRESS REPORT ON GROUND WATER IN THE HIGH PLAINS OF TEXAS: TEXAS BOARD OF WATER ENGINEERS MISCELLANEOUS PUBLICATION (UNNUMBERED), 1942.
PROGRESS REPORT ON GROUND WATER IN THE HIGH PLAINS OF TEXAS: TEXAS BOARD OF WATER ENGINEERS MISCELLANEOUS PUBLICATION 120, 1943.

PROGRESS REPORT ON GROUND WATER IN THE HIGH PLAINS OF TEXAS: TEXAS BOARD OF WATER ENGINEERS MISCELLANEOUS PUBLICATION 121, 1944

PROGRESS REPORT ON GROUND WATER IN THE HIGH PLAINS OF TEXAS, PROGRESS REPORT NO. 5: TEXAS BOARD OF WATER ENGINEERS MISCELLANEOUS PUBLICATION 122, 1945.

GROUND-WATER RESOURCES OF THE AREA SOUTHWEST OF AMARILLO, TEXAS: TEXAS BOARD OF WATER ENGINEERS MISCELLANEOUS PUBLICATION 1, 1946.

GROUND WATER IN THE HIGH PLAINS OF TEXAS: USGS WATERSUPPLY PAPER 889-F, 1946.

GROUND WATER IN HIGH PLAINS IN TEXAS, PROGRESS REPORT NO. 6: TEXAS BOARD OF WATER ENGINEERS MISCELLANEOUS PUBLICATION 123, 1947.

GEOLOGY AND GROUND WATER IN THE IRRIGATED REGION OF THE SOUTHERN HIGH PLAINS IN TEXAS, PROGRESS REPORT NO 7: TEXAS BOARD OF WATER ENGINEERS MISCELLANEOUS PUB LICATION 125, 1949

PUBLIC WATER SUPPLIES IN WESTERN TEXAS: TEXAS BOARD OF WATER ENGINEERS MISCELLANEOUS PUBLICATION 216, 1949.

COST OF PUMPING WATER FOR IRRIGATION, TEXAS HIGH PLAINS, FIELD INVESTIGATIONS-1947 IRRIGATION SEASON: TEXAS BOARD OF WATER ENGINEERS MISCELLANEOUS PUBLICATION $124,1951$.

PUBLIC WATER SUPPLIES IN WESTERN TEXAS: USGS WATERSUPPLY PAPER 1106, 1951 [1952].

DEVELOPMENT OF WELLS FOR IRRIGATION AND FLUCTUATION OF WATER LEVELS IN THE HIGH PLAINS OF TEXAS TO JANUARY 1951: TEXAS BOARD OF WATER ENGINEERS BULLETIN 5104, 1951.

RECORDS OF WATER-LEVEL MEASUREMENTS IN DEAF SMITH COUNTY, TEXAS, 1914-1953: TEXAS BOARD OF WATER ENGINEERS BULLETIN 5305, 1953.

SUMMARY OF GROUND-WATER DEVELOPMENT IN THE SOUTHERN HIGH PLAINS, TEXAS: TEXAS BOARD OF WATER ENGINEERS BULLETIN 5402, 1954

GROUND-WATER DEVELOPMENT IN THE SOUTHERN HIGH PLAINS OF TEXAS, 1953: TEXAS BOARD OF WATER ENGINEERS BULLETIN 5410, 1954.

WATER-LEVEL DECLINE MAPS OF 17 COUNTIES IN THE SOUTHERN HIGH PLAINS, TEXAS, JANUARY 1955 TO JANUARY 1956: TEXAS BOARD OF WATER ENGINEERS BULLETIN 5607, 1956.

WATER-LEVEL DECLINE MAPS, 1956 TO 1957, AND WATER LEVELS IN OBSERVATION WELLS IN 20 COUNTIES IN THE SOUTHERN HIGH PLAINS, TEXAS: TEXAS BOARD OF WATER ENGINEERS BULLETIN 5705, 1957.

WATER-LEVEL MEASUREMENTS AND MAPS, SOUTHERN HIGH PLAINS, TEXAS, 1958 AND 1959: TEXAS BOARD OF WATER ENGINEERS BULLETIN 5908, 1959.

WATER LEVELS IN OBSERVATION WELLS, SOUTHERN HIGH PLAINS, TEXAS, 1959 AND 1960, TEXAS BOARD OF WATER ENGINEERS BULLETIN 6011, 1960. 
RECONNAISSANCE INVESTIGATION OF THE GROUND-WATER RESOURCES OF THE CANADIAN RIVER BASIN, TEXAS: TEXAS BOARD OF WATER ENGINEERS BULLETIN 6016, 1960

WATER LEVELS IN OBSERVATION WELLS, SOUTHERN HIGH PLAINS, TEXAS, 1960 AND 1961: TEXAS BOARD OF WATER ENGINEERS BULLETIN 6101, 1961.

A SUMMARY OF THE OCCURRENCE AND DEVELOPMENT OF GROUND WATER IN THE SOUTHERN HIGH PLAINS OF TEXAS: TEXAS BOARD OF WATER ENGINEERS BULLETIN 6107, 1961.

WATER-LEVEL MEASUREMENTS THROUGH 1962 IN SELECTED OBSERVATION WELLS, SOUTHERN HIGH PLAINS, TEXAS: TEXAS WATER COMMISSION BULLETIN 6207, 1962.

RECONNAISSANCE INVESTIGATION OF THE GROUND-WATER RESOURCES OF THE RED RIVER, SULPHUR RIVER, AND CYPRESS CREEK BASINS, TEXAS: TEXAS WATER COMMISSION BULLETIN 6306, 1963.

A SUMMARY OF THE OCCURRENCE AND DEVELOPMENT OF GROUND WATER IN THE SOUTHERN HIGH PLAINS OF TEXAS: USGS WATER-SUPPLY PAPER 1693, 1964.

WATER-LEVEL DATA FROM OBSERVATION WELLS IN THE SOUTHERN HIGH PLAINS OF TEXAS: TEXAS WATER DEVELOPMENT BOARD REPORT 21, 1966.

COMPILATION OR RESULTS OF AQUIFER TESTS IN TEXAS: TEXAS WATER DEVELOPMENT BOARD REPORT 98, 1969.

GROUND WATER IN THE OGALLALA FORMATION IN THE SOUTHERN HIGH PLAINS OF TEXAS AND NEW MEXICO: USGS HYDROLOGIC INVESTIGATIONS ATLAS HA-330, 1969.

WATER-LEVEL DATA FROM OBSERVATION WELLS IN THE SOUTHERN HIGH PLAINS OF TEXAS, 1965-70: TEXAS WATER DEVELOPMENT BOARD REPORT 121, 1970.

MAJOR AND HISTORICAL SPRINGS OF TEXAS: TEXAS WATER DEVELOPMENT BOARD REPORT 189, 1975.

ANALYTICAL STUDY OF THE OGALLALA AQUIFER IN DEAF SMITH COUNTY, TEXAS-PROJECTIONS OF SATURATED THICKNESS, VOLUME OF WATER IN STORAGE, PUMPAGE RATES, PUMPING LIFTS, AND WELL YIELDS: TEXAS WATER DEVELOPMENT BOARD REPORT 213, 1977.

WATER-LEVEL DATA FROM OBSERVATION WELLS IN THE SOUTHERN HIGH PLAINS OF TEXAS, 1971-77: TEXAS DEPARTMENT OF WATER RESOURCES REPORT 228, 1979.

PRELIMINARY DATA DESCRIBING THE DISTRIBUTION OF FLUORIDE AND SILICA IN THE OGALLALA AQUIFER ON THE HIGH PLAINS OF TEXAS: USGS OPEN-FILE REPORT 80-349, 1980.

EVALUATING THE GROUND-WATER RESOURCES OF THE HIGH PLAINS OF TEXAS: RESULTS OF SURFACE ELECTRICAL RESISTIVITY SURVEYS: TEXAS DEPARTMENT OF WATER RESOURCES LIMITED PRINTING REPORT LP-130, 1980.

EVALUATING THE GROUND-WATER RESOURCES OF THE HIGH PLAINS OF TEXAS: NEUTRON-PROBE MEASUREMENTS OF DEEP SOIL MOISTURE AS AN INDICATION OF AQUIFER RECHARGE RATES: TEXAS DEPARTMENT OF WATER RESOURCES LIMITED PRINTING REPORT LP-142, 1981.

SPRINGS OF TEXAS, VOLUME 1: (BY GUNNAR BRUNE), BRANCHSMITH, INC., FORT WORTH, TEXAS, 1981.
BEDROCK GEOLOGY, ALTITUDE OF BASE, AND 1980 SATURATED THICKNESS OF THE HIGH PLAINS AQUIFER IN PARTS OF COLORADO, KANSAS, NEBRASKA, NEW MEXICO, OKLAHOMA, SOUTH DAKOTA, TEXAS, AND WYOMING: USGS HYDROLOGIC INVESTIGATIONS ATLAS HA-648, 1981.

WATER LEVEL AND SATURATED THICKNESS CHANGES, PREDEVELOPMENT TO 1980, IN THE HIGH PLAINS AQUIFER IN PARTS OF COLORADO, KANSAS, NEBRASKA, NEW MEXICO, OKLAHOMA, SOUTH DAKOTA, TEXAS, AND WYOMING: USGS HYDROLOGIC INVESTIGATIONS ATLAS HA-652, 1981.

DISSOLVED SOLIDS AND SODIUM IN WATER FROM THE HIGH PLAINS AQUIFER IN PARTS OF COLORADO, KANSAS, NEBRASKA, NEW MEXICO, OKLAHOMA, SOUTH DAKOTA, TEXAS, AND WYOMING: USGS HYDROLOGIC INVESTIGATIONS ATLAS HA-658, 1982.

ANALYTICAL STUDY OF THE OGALLALA AQUIFER IN POTTER AND OLDHAM COUNTIES, TEXAS-PROJECTIONS OF SATURATED THICKNESS, VOLUME OF WATER IN STORAGE, PUNPING LIFTS, AND WELL YIELDS: TEXAS DEPARTMENT OF WATER RESOURCES REPORT 265, 1982.

EVALUATING THE GROUND-WATER RESOURCES OF THE HIGH PLAINS OF TEXAS, VOLUME 1: TEXAS DEPARTMENT OF WATER RESOURCES REPORT 288, V. 1, 1984.

EVALUATING THE GROUND-WATER RESOURCES OF THE HIGH PLAINS OF TEXAS, VOLUME 3, RECORDS OF WELLS, AND MAPS SHOWING WELL LOCATIONS, BASE OF AQUIFER, WATER LEVELS, AND SATURATED THICKNESS (BAILEY, BRISCOE, CASTRO, CROSBY, DEAF SMITH, DICKENS, FLOYD, HALE, LAMB, MOTLEY, OLDHAM, PARMER, RANDALL, AND SWISHER COUNTIES): TEXAS DEPARTMENT OF WATER RESOURCES REPORT 288, V. 3 , 1984.

GROUND-WATER CONDITIONS OF THE TRIASSIC AQUIFER IN DEAF SMITH AND SWISHER COUNTIES: TEXAS DEPARTMENT OF WATER RESOURCES LIMITED PRINTING REPORT LP-196, 1984.

GEOHYDROLOGY OF THE HIGH PLAINS AQUIFER IN PARTS OF COLORADO, KANSAS, NEBRASKA, NEW MEXICO, OKLAHOMA, SOUTH DAKOTA, TEXAS, AND WYOMING: USGS PROFESSIONAL PAPER 1400-B, 1984.

TEXAS GROUND-WATER RESOURCES, in NATIONAL WATER SUMMARY 1984: USGS WATER-SUPPLY PAPER 2275, 1985.

DIGITAL SIMULATION OF GROUND-WATER FLOW IN THE HIGH PLAINS AQUIFER IN PARTS OF COLORADO, KANSAS, NEBRASKA, NEW MEXICO, OKLAHOMA, SOUTH DAKOTA, TEXAS, AND WYOMING: USGS PROFESSIONAL PAPER 1400-D, 1986.

SUMMARY OF THE HIGH PLAINS REGIONAL AQUIFER-SYSTEM ANALYSIS IN PARTS OF COLORADO, KANSAS, NEBRASKA, NEW MEXICO, OKLAHOMA, SOUTH DAKOTA, TEXAS, AND WYOMING: USGS PROFESSIONAL PAPER 1400-A, 1988.

WATER-LEVEL CHANGES IN THE HIGH PLAINS AQUIFER OF TEXAS, 1980-1990: TEXAS WATER DEVELOPMENT BOARD HYDROLOGIC ATLAS NO. 1, 1991.

PUBLIC SUPPLY GROUND-WATER USE IN THE NORTHERN HIGH PLAINS OF TEXAS: TEXAS WATER DEVELOPMENT BOARD REPORT 336, 1992.

THE HIGH PLAINS AQUIFER SYSTEM OF TEXAS, 1980 TO 1990. OVERVIEW AND PROJECTIONS: TEXAS WATER DEVELOPMENT BOARD REPORT 341, 1993. 
WATER-QUALITY EVALUATION OF THE OGALLALA AQUIFER, TEXAS: TEXAS WATER DEVELOPMENT BOARD REPORT 342, 1993.

WATER-LEVEL CHANGES IN THE HIGH PLAINS AQUIFER-PREDEVELOPMENT TO 1992: USGS WATER-RESOURCES INVESTIGATIONS REPORT 94-4027, 1994.

WATER-LEVEL CHANGES IN THE HIGH PLAINS AQUIFER, 1980 TO 1994: USGS FACT SHEET FS-215-95, 1995.

AQUIFERS OF TEXAS: TEXAS WATER DEVELOPMENT BOARD REPORT 345, 1995.

WATER-LEVEL CHANGES IN THE HIGH PLAINS AQUIFER, 1980 TO 1995: USGS FACT SHEET FS-068-97, 1997.

WATER-LEVEL CHANGES IN THE HIGH PLAINS AQUIFER-PREDEVELOPMENT TO 1995: USGS WATER-RESOURCES INVESTIGATIONS REPORT 97-4081, 1997.

UPDATED WATER-QUALITY EVALUATION OF THE OGALLALA AQUIFER INCLUDING SELECTED METALLIC AND NON-METALLIC INORGANIC CONSTITUENTS: TEXAS WATER DEVELOPMENT BOARD HYDROLOGIC ATLAS NO. 10, 1998.

\section{ORANGE COUNTY}

UNDERGROUND WATERS OF THE COASTAL PLAIN OF TEXAS: USGS WATER-SUPPLY PAPER 190, 1907.

GEOLOGY AND UNDERGROUND WATERS OF THE SOUTHEASTERN PART OF THE TEXAS COASTAL PLAIN: USGS WATER-SUPPLY PAPER 335, 1914

ORANGE WATER SUPPLY; GROUND WATER: USGS OPEN-FILE REPORT (UNNUMBERED), 1941.

MEMORANDUM REGARDING PUBLIC WATER SUPPLY AT ORANGE, TEXAS: USGS OPEN-FILE REPORT (UNNUMBERED), 1941.

WATER-WELL DATA IN ORANGE COUNTY, TEXAS: TEXAS BOARD OF WATER ENGINEERS MISCELLANEOUS PUBLICATION 200, 1942.

GROUND-WATER RESOURCES OF ORANGE COUNTY, TEXAS: USGS OPEN-FILE REPORT (UNNUMBERED), 1942.

ORANGE, TEXAS: USGS OPEN-FILE REPORT (UNNUMBERED), 1942.

GROUND WATER AVAILABLE FOR PROPOSED DUPONT PLANT NEAR ORANGE, TEXAS: USGS OPEN-FILE REPORT (UNNUMBERED), 1944.

PUBLIC WATER SUPPLIES IN EASTERN TEXAS, V. 2, HARRISON COUNTY THROUGH WOOD COUNTY: TEXAS BOARD OF WATER ENGINEERS MISCELLANEOUS PUBLICATION 214, V. 2, 1945.

PUBLIC WATER SUPPLIES IN EASTERN TEXAS: USGS WATERSUPPLY PAPER 1047, 1948.

AVAILABILITY OF GROUND WATER IN THE GULF COAST REGION OF TEXAS: USGS OPEN-FILE REPORT (UNNUMBERED), 1956

RECONNAISSANCE INVESTIGATION OF THE GROUND-WATER RESOURCES OF THE GULF COAST REGION, TEXAS: TEXAS WATER COMMISSION BULLETIN 6305, 1963.
RECONNAISSANCE INVESTIGATION OF THE GROUND-WATER RESOURCES OF THE NECHES RIVER BASIN, TEXAS: TEXAS WATER COMMISSION BULLETIN 6308, 1963.

GEOLOGY AND GROUND-WATER RESOURCES OF ORANGE COUNTY, TEXAS: TEXAS WATER COMMISSION BULLETIN 6516, 1965.

LOW-FLOW STUDIES, SABINE AND OLD RIVERS NEAR ORANGE, TEXAS, QUANTITY AND QUALITY, APRIL 12, OCTOBER 31-NOVEMBER 4, 1966: TEXAS WATER DEVELOPMENT BOARD REPORT 66, 1967.

GROUND-WATER DATA FOR ORANGE COUNTY AND VICINITY, TEXAS AND LOUISIANA, 1968: USGS OPEN-FILE REPORT 68-50, 1968.

QUANTITY AND QUALITY OF LOW FLOW IN SABINE AND OLD RIVERS NEAR ORANGE, TEXAS, SEPTEMBER 12-15, 1967.

GROUND-WATER DATA FOR ORANGE COUNTY AND VICINITY, TEXAS AND LOUISIANA, 1969: USGS OPEN-FILE REPORT 69-204, 1969.

COMPILATION OF RESULTS OF AQUIFER TESTS IN TEXAS: TEXAS WATER DEVELOPMENT BOARD REPORT 98, 1969.

GROUND-WATER DATA FOR ORANGE COUNTY AND VICINITY, TEXAS AND LOUISIANA, 1970: USGS OPEN-FILE REPORT 70-123, 1970.

GROUND-WATER RESOURCES OF CHAMBERS AND JEFFERSON COUNTIES, TEXAS: TEXAS WATER DEVELOPMENT BOARD REPORT 133, 1971

DEVELOPMENT OF GROUND-WATER RESOURCES IN THE ORANGE COUNTY AREA, TEXAS AND LOUISIANA, 1963-71: USGS OPENFILE REPORT 72-243, 1972.

DEVELOPMENT OF GROUND-WATER RESOURCES IN THE ORANGE COUNTY AREA, TEXAS AND LOUISIANA, 1963-71: TEXAS WATER DEVELOPMENT BOARD REPORT 156, 1972.

GROUND-WATER DATA FOR ORANGE COUNTY AND VICINITY, TEXAS AND LOUISIANA, 1971-74: USGS OPEN-FILE REPORT 75-129, 1975

GROUND-WATER DATA FOR ORANGE COUNTY AND VICINITY, TEXAS AND LOUISIANA, 1971-1974: TEXAS WATER DEVELOPMENT BOARD REPORT 197, 1975.

GROUND-WATER DATA FOR ORANGE COUNTY AND VICINITY, TEXAS AND LOUISIANA, 1971-74: TEXAS WATER DEVELOPMENT BOARD REPORT 197, 1975.

SUMMARY APPRAISALS OF THE NATION'S GROUND-WATER RESOURCES-TEXAS-GULF REGION: USGS PROFESSIONAL PAPER 813-F, 1976.

STRATIGRAPHIC AND HYDROGEOLOGIC FRAMEWORK OF PART OF THE COASTAL PLAIN OF TEXAS: USGS OPEN-FILE REPORT $77-712,1978$

STRATIGRAPHIC AND HYDROGEOLOGIC FRAMEWORK OF PART OF THE COASTAL PLAIN OF TEXAS: TEXAS DEPARTMENT OF WATER RESOURCES REPORT 236, 1979.

LAND-SURFACE SUBSIDENCE IN THE TEXAS COASTAL REGION: USGS OPEN-FILE REPORT 80-969, 1980.

SPRINGS OF TEXAS, VOLUME 1: (BY GUNNAR BRUNE), BRANCHSMITH, INC., FORT WORTH, TEXAS, 1981. 
DEVELOPMENT OF GROUND-WATER RESOURCES IN ORANGE COUNTY, TEXAS, AND ADJACENT AREAS IN TEXAS AND LOUISIANA, 1971-80: USGS OPEN-FILE REPORT 82-330, 1982.

LAND-SURFACE SUBSIDENCE IN THE TEXAS COASTAL REGION: TEXAS DEPARTMENT OF WATER RESOURCES REPORT 272, 1982.

DEVELOPMENT OF GROUND-WATER RESOURCES IN ORANGE COUNTY, TEXAS, AND ADJACENT AREAS IN TEXAS AND LOUISIANA, 1971-80: TEXAS DEPARTMENT OF WATER RESOURCES REPORT 283, 1983

TEXAS GROUND-WATER RESOURCES, in NATIONAL WATER SUMMARY 1984: USGS WATER-SUPPLY PAPER 2275, 1985.

DIGITAL MODELS FOR SIMULATION OF GROUND-WATER HYDROLOGY OF THE CHICOT AND EVANGELINE AQUIFERS ALONG THE GULF COAST OF TEXAS: TEXAS DEPARTMENT OF WATER RESOURCES REPORT 289, 1985.

WATER USE, PROJECTED WATER REQUIREMENTS, AND RELATED DATA AND INFORMATION FOR THE METROPOLITAN STATISTICAL AREAS IN TEXAS: TEXAS DEPARTMENT OF WATER RESOURCES LIMITED PRINTING REPORT LP-201, 1985.

HYDROLOGY OF THE JASPER AQUIFER IN THE SOUTHEAST TEXAS COASTAL PLAIN: TEXAS WATER DEVELOPMENT BOARD REPORT 295, 1986

DEVELOPMENT OF GROUND-WATER RESOURCES IN THE ORANGE COUNTY AREA, TEXAS AND LOUISIANA, 1980-SPRING OF 1985: USGS WATER-RESOURCES INVESTIGATIONS REPORT 87-4158, 1987.

GEOHYDROLOGIC FRAMEWORK OF THE GULF COASTAL PLAIN: USGS HYDROLOGIC INVESTIGATIONS ATLAS HA-695, 1988.

HYDROGEOLOGY AND PREDEVELOPMENT FLOW IN THE TEXAS GULF COAST AQUIFER SYSTEMS: USGS WATER-RESOURCES INVESTIGATIONS REPORT 87-4248, 1988.

EVALUATION OF WATER RESOURCES OF ORANGE AND EASTERN JEFFERSON COUNTIES, TEXAS: TEXAS WATER DEVELOPMENT BOARD REPORT 320, 1990.

GROUND-WATER FLOW IN THE GULF COAST AQUIFER SYSTEMS, SOUTH-CENTRAL UNITED STATES-A PRELIMINARY ANALYSIS: USGS WATER-RESOURCES INVESTIGATIONS REPORT 89-4071, 1990.

SALT-DOME LOCATIONS IN THE GULF COASTAL PLAIN, SOUTHCENTRAL UNITED STATES: USGS WATER-RESOURCES INVESTIGATIONS REPORT 90-4060, 1990.

HYDROLOGY OF THE TEXAS GULF COAST AQUIFER SYSTEMS: USGS OPEN-FILE REPORT 91-64, 1991.

PROPERTIES AND CHEMICAL CONSTITUENTS IN GROUND WATER FROM THE MISSISSIPPI RIVER VALLEY ALLUVIAL AQUIFER AND PERMEABLE ZONE A (HOLOCENE-UPPER PLEISTOCENE DEPOSITS), SOUTH-CENTRAL UNITED STATES: USGS WATERRESOURCES INVESTIGATIONS REPORT 91-4149, 1992.

WATER-RESOURCES DATA, TEXAS, WATER YEAR 1991, VOLUME 4, GROUND-WATER DATA: USGS WATER-DATA REPORT TX-91-4, 1992.

PROPERTIES AND CHEMICAL CONSTITUENTS IN GROUND WATER FROM THE UPPER CLAIBORNE AQUIFER, GULF COAST REGIONAL AQUIFER SYSTEMS, SOUTH-CENTRAL UNITED STATES: USGS WATER-RESOURCES INVESTIGATIONS REPORT 91-4150, 1993.
PROPERTIES AND CHEMICAL CONSTITUENTS IN GROUND WATER FROM PERMEABLE ZONE C (LOWER PLIOCENE-UPPER MIOCENE DEPOSITS), COASTAL LOWLANDS AQUIFER SYSTEM, SOUTHCENTRAL UNITED STATES: USGS WATER-RESOURCES INVESTIGATIONS REPORT 91-4151, 1993.

PROPERTIES AND CHEMICAL CONSTITUENTS IN GROUND WATER FROM PERMEABLE ZONE B (LOWER PLEISTOCENE-UPPER PLIOCENE DEPOSITS), COASTAL LOWLANDS AQUIFER SYSTEM, SOUTH-CENTRAL UNITED STATES: USGS WATER-RESOURCES INVESTIGATIONS REPORT 91-4152, 1993.

PROPERTIES AND CHEMICAL CONSTITUENTS IN GROUND WATER FROM PERMEABLE ZONE E (LOWER MIOCENE-UPPER OLIGOCENE DEPOSITS), COASTAL LOWLANDS AQUIFER SYSTEM, SOUTH-CENTRAL UNITED STATES: USGS WATER-RESOURCES INVESTIGATIONS REPORT 92-4103, 1993.

PROPERTIES AND CHEMICAL CONSTITUENTS IN GROUND WATER FROM PERMEABLE ZONE D (MIDDLE MIOCENE DEPOSITS), COASTAL LOWLANDS AQUIFER SYSTEM, SOUTH-CENTRAL UNITED STATES: USGS WATER-RESOURCES INVESTIGATIONS REPORT 92-4105, 1993.

WATER-RESOURCES DATA, TEXAS, WATER YEAR 1992, VOLUME 4, GROUND-WATER DATA: USGS WATER-DATA REPORT TX-92-4, 1993.

WATER-RESOURCES DATA, TEXAS, WATER YEAR 1993, VOLUME 4 , GROUND-WATER DATA: USGS WATER-DATA REPORT TX-93-4, 1994.

STRATIGRAPHIC NOMENCLATURE AND GEOLOGIC SECTIONS OF THE GULF COASTAL PLAIN OF TEXAS: USGS OPEN-FILE REPORT 94-461, 1995.

AQUIFERS OF TEXAS: TEXAS WATER DEVELOPMENT BOARD REPORT 345, 1995.

WATER-RESOURCES DATA, TEXAS, WATER YEAR 1994, VOLUME 4, GROUND-WATER DATA: USGS WATER-DATA REPORT TX-94-4, 1995.

WATER-RESOURCES DATA, TEXAS, WATER YEAR 1995, VOLUME 4, GROUND-WATER DATA: USGS WATER-DATA REPORT TX-95-4, 1996.

WATER-RESOURCES DATA, TEXAS, WATER YEAR 1996, VOLUME 4, GROUND-WATER DATA: USGS WATER-DATA REPORT TX-96-4, 1997.

WATER-RESOURCES DATA, TEXAS, WATER YEAR 1997, VOLUME 4, GROUND-WATER DATA: USGS WATER-DATA REPORT TX-97-4, 1998.

GROUND-WATER DATA IN ORANGE COUNTY AND ADJACENT COUNTIES, TEXAS, 1985-90: USGS OPEN-FILE REPORT 99-603, 1999.

WATER-RESOURCES DATA, TEXAS, WATER YEAR 1998, VOLUME 4, GROUND-WATER DATA: USGS WATER-DATA REPORT TX-98-4, 1999.

WATER-RESOURCES DATA, TEXAS, WATER YEAR 1999, VOLUME 6, GROUND-WATER DATA: USGS WATER-DATA REPORT TX-99-6, 2000.

WATER-RESOURCES DATA, TEXAS, WATER YEAR 2000, VOLUME 6 , GROUND-WATER DATA: USGS WATER-DATA REPORT TX-00-6, 2001. 


\section{PALO PINTO COUNTY}

MINERAL WATER SUPPLY OF THE MINERAL WELLS AREA, TEXAS: USGS CIRCULAR 6, 1934.

PUBLIC WATER SUPPLIES IN CENTRAL AND NORTH-CENTRAL TEXAS: TEXAS BOARD OF WATER ENGINEERS MISCELLANEOUS PUBLICATION 213, 1947.

PUBLIC WATER SUPPLIES IN CENTRAL AND NORTH-CENTRAL TEXAS: USGS WATER-SUPPLY PAPER 1069, 1949.

RECONNAISSANCE INVESTIGATION OF THE GROUND-WATER RESOURCES OF THE BRAZOS RIVER BASIN: TEXAS WATER COMMISSION BULLETIN 6310, 1963.

TEXAS GROUND-WATER RESOURCES, in NATIONAL WATER SUMMARY 1984: USGS WATER-SUPPLY PAPER 2275, 1985.

OCCURRENCE AND QUALITY OF GROUND WATER IN JACK COUNTY, TEXAS: TEXAS WATER DEVELOPMENT BOARD REPORT 308, 1988.

EVALUATION OF WATER RESOURCES IN PART OF NORTH-CENTRAL TEXAS: TEXAS WATER DEVELOPMENT BOARD REPORT $318,1990$.

EVALUATION OF WATER RESOURCES IN PARTS OF THE ROLLING PRAIRIES REGION OF NORTH-CENTRAL TEXAS: TEXAS WATER DEVELOPMENT BOARD REPORT 337, 1992.

AQUIFERS OF TEXAS: TEXAS WATER DEVELOPMENT BOARD REPORT 345, 1995.

\section{PANOLACOUNTY}

UNDERGROUND WATERS OF THE COASTAL PLAIN OF TEXAS: USGS WATER-SUPPLY PAPER 190, 1907.

GEOLOGY AND UNDERGROUND WATERS OF THE SOUTHEASTERN PART OF THE TEXAS COASTAL PLAIN: USGS WATER-SUPPLY PAPER 335, 1914.

RECORDS OF WELLS, DRILLERS' LOGS, AND WATER ANALYSES, AND MAP SHOWING LOCATION OF WELLS IN PANOLA COUNTY, TEXAS: TEXAS BOARD OF WATER ENGINEERS MISCELLANEOUS PUBLICATION 202, 1938.

PUBLIC WATER SUPPLIES IN EASTERN TEXAS, V. 2, HARRISON COUNTY THROUGH WOOD COUNTY: TEXAS BOARD OF WATER ENGINEERS MISCELLANEOUS PUBLICATION 214, V. 2, 1945.

PUBLIC WATER SUPPLIES IN EASTERN TEXAS: USGS WATERSUPPLY PAPER 1047, 1948.

RECONNAISSANCE INVESTIGATION OF THE GROUND-WATER RESOURCES OF THE SABINE RIVER BASIN, TEXAS: TEXAS WATER COMMISSION BULLETIN 6307, 1963.

COMPILATION OF RESULTS OF AQUIFER TESTS IN TEXAS: TEXAS WATER DEVELOPMENT BOARD REPORT 98, 1969.

GROUND-WATER POLLUTION IN THE VICINITY OF TOLEDO BEND RESERVOIR, TEXAS, PROGRESS REPORT, 1972: USGS OPEN-FILE REPORT 72-010, 1972.

GROUND-WATER POLLUTION IN THE VICINITY OF TOLEDO BEND RESERVOIR, TEXAS: USGS OPEN-FILE REPORT 74-296, 1974.
SUMMARY APPRAISALS OF THE NATION'S GROUND-WATER RESOURCES-TEXAS-GULF REGION: USGS PROFESSIONAL PAPER 813-F, 1976.

SPRINGS OF TEXAS, VOLUME 1: (BY GUNNAR BRUNE), BRANCHSMITH, INC., FORT WORTH, TEXAS, 1981.

REGIONAL AQUIFER CHARACTERIZATION FOR DEEP-BASIN LIGNITE MINING, SABINE UPLIFT AREA, NORTHEAST TEXAS: UNIVERSITY OF TEXAS, BUREAU OF ECONOMIC GEOLOGY GEOLOGICAL CIRCULAR 83-3, 1983.

TEXAS GROUND-WATER RESOURCES, in NATIONAL WATER SUMMARY 1984: USGS WATER-SUPPLY PAPER 2275, 1985.

APPROXIMATE POTENTIOMETRIC SURFACES FOR THE AQUIFERS OF THE COASTAL UPLANDS SYSTEM, 1980: USGS HYDROLOGIC INVESTIGATIONS ATLAS HA-704, 1987.

HYDROGEOLOGY AND PREDEVELOPMENT FLOW IN THE TEXAS GULF COAST AQUIFER SYSTEMS: USGS WATER-RESOURCES INVESTIGATIONS REPORT 87-4248, 1988.

GEOHYDROLOGIC FRAMEWORK OF THE GULF COASTAL PLAIN: USGS HYDROLOGIC INVESTIGATIONS ATLAS HA-695, 1988.

GROUND-WATER FLOW IN THE GULF COAST AQUIFER SYSTEMS, SOUTH-CENTRAL UNITED STATES-A PRELIMINARY ANALYSIS USGS WATER-RESOURCES INVESTIGATIONS REPORT 89-4071, 1990.

HYDROLOGY OF THE TEXAS GULF COAST AQUIFER SYSTEMS: USGS OPEN-FILE REPORT 91-64, 1991.

PROPERTIES AND CHEMICAL CONSTITUENTS IN GROUND WATER FROM THE MIDDLE WILCOX AQUIFER, GULF COAST REGIONAL AQUIFER SYSTEMS, SOUTH-CENTRAL UNITED STATES: USGS WATER-RESOURCES INVESTIGATIONS REPORT 93-4070, 1993.

AQUIFERS OF TEXAS: TEXAS WATER DEVELOPMENT BOARD REPORT 345, 1995.

\section{PARKER COUNTY}

GEOGRAPHY AND GEOLOGY OF THE BLACK AND GRAND PRAIRIES, TEXAS, WITH DETAILED DESCRIPTIONS OF THE CRETACEOUS FORMATIONS AND SPECIAL REFERENCE TO ARTESIAN WATERS: USGS 21ST ANNUAL REPORT, PART 7, 1901.

WATER SUPPLY OF WEATHERFORD-GROUND WATER: USGS OPEN-FILE REPORT (UNNUMBERED), 1941.

PUBLIC WATER SUPPLIES IN CENTRAL AND NORTH-CENTRAL TEXAS: TEXAS BOARD OF WATER ENGINEERS MISCELLANEOUS PUBLICATION 213, 1947.

PUBLIC WATER SUPPLIES IN CENTRAL AND NORTH-CENTRAL TEXAS: USGS WATER-SUPPLY PAPER 1069, 1949.

GROUND-WATER RESOURCES OF PARKER COUNTY, TEXAS: TEXAS BOARD OF WATER ENGINEERS BULLETIN 5103, 1951.

RECONNAISSANCE INVESTIGATION OF THE GROUND-WATER RESOURCES OF THE TRINITY RIVER BASIN, TEXAS: TEXAS WATER COMMISSION BULLETIN 6309, 1963.

RECONNAISSANCE INVESTIGATION OF THE GROUND-WATER RESOURCES OF THE BRAZOS RIVER BASIN, TEXAS: TEXAS WATER COMMISSION BULLETIN 6310, 1963. 
COMPILATION OF RESULTS OF AQUIFER TESTS IN TEXAS: TEXAS WATER DEVELOPMENT BOARD REPORT 98, 1969.

MAJOR AND HISTORICAL SPRINGS OF TEXAS: TEXAS WATER DEVELOPMENT BOARD REPORT 189, 1975.

GROUND-WATER RESOURCES OF PART OF CENTRAL TEXAS WITH EMPHASIS ON THE ANTLERS AND TRAVIS PEAK FORMATIONS: TEXAS WATER DEVELOPMENT BOARD REPORT 195, V. 1, 1975.

GROUND-WATER RESOURCES OF PART OF CENTRAL TEXAS WITH EMPHASIS ON THE ANTLERS AND TRAVIS PEAK FORMATIONS: TEXAS WATER DEVELOPMENT BOARD REPORT 195, V. 2, 1976.

SUMMARY APPRAISALS OF THE NATION'S GROUND-WATER RESOURCES-TEXAS-GULF REGION: USGS PROFESSIONAL PAPER 813-F, 1976.

WATER-LEVEL AND WATER-QUALITY DATA FROM OBSERVATION WELLS IN NORTHEAST TEXAS: TEXAS WATER DEVELOPMENT BOARD REPORT 198, 1976.

OCCURRENCE, AVAILABILITY, AND CHEMICAL QUALITY OF GROUND WATER IN THE CRETACEOUS AQUIFERS OF NORTHCENTRAL TEXAS: TEXAS DEPARTMENT OF WATER RESOURCES REPORT 269, V. 1, 1982.

OCCURRENCE, AVAILABILITY, AND CHEMICAL QUALITY OF GROUND WATER IN THE CRETACEOUS AQUIFERS OF NORTHCENTRAL TEXAS: TEXAS DEPARTMENT OF WATER RESOURCES REPORT 269, V. 2, 1982.

TEXAS GROUND-WATER RESOURCES, in NATIONAL WATER SUMMARY 1984: USGS WATER-SUPPLY PAPER 2275, 1985.

WATER USE, PROJECTED WATER REQUIREMENTS, AND RELATED DATA AND INFORMATION FOR THE METROPOLITAN STATISTICAL AREAS IN TEXAS: TEXAS DEPARTMENT OF WATER RESOURCES LIMITED PRINTING REPORT LP-201, 1985.

OCCURRENCE AND QUALITY OF GROUND WATER IN JACK COUNTY, TEXAS: TEXAS WATER DEVELOPMENT BOARD REPORT 308, 1988.

EVALUATION OF WATER RESOURCES IN PART OF NORTH-CENTRAL TEXAS: TEXAS WATER DEVELOPMENT BOARD REPORT 318, 1990.

NATIONAL WATER-QUALITY ASSESSMENT PROGRAM-THE TRINITY RIVER BASIN: USGS OPEN-FILE REPORT 91-158, 1991.

EVALUATION OF WATER RESOURCES IN PARTS OF THE ROLLING PRAIRIES REGION OF NORTH-CENTRAL TEXAS: TEXAS WATER DEVELOPMENT BOARD REPORT 337, 1992.

NATIONAL WATER-QUALITY ASSESSMENT PROGRAM-PESTICIDES IN THE TRINITY RIVER BASIN STUDY UNIT, TEXAS, 1968-91: USGS FACT SHEET FS-088-95, 1995.

WATER-QUALITY ASSESSMENT OF THE TRINITY RIVER BASIN, TEXAS-DATA COLLECTION, 1992-95: USGS FACT SHEET FS-095-95, 1995.

WATER-QUALITY ASSESSMENT OF THE TRINITY RIVER BASIN, TEXAS-PESTICIDES IN A SUBURBAN WATERSHED, ARLINGTON, 1993-94: USGS FACT SHEET FS-159-95, 1995.

HYDROGEOLOGIC ASSESSMENT OF SHALLOW GROUNDWATER FLOW SYSTEMS OF THE WALNUT FORMATION, CENTRAL TEXAS: (MASTER'S THESIS), BAYLOR GEOLOGICAL STUDIES (THESIS ABSTRACTS), BULLETIN 56, BAYLOR UNIVERSITY, WACO, TEXAS, 1995.
AQUIFERS OF TEXAS: TEXAS WATER DEVELOPMENT BOARD REPORT 345, 1995.

UPDATED EVALUATION OF WATER RESOURCES IN PART OF NORTH-CENTRAL TEXAS, 1990-1999: TEXAS WATER DEVELOPMENT BOARD REPORT 349, 1999.

WATER-QUALITY ASSESSMENT OF THE TRINITY RIVER BASIN, TEXAS-GROUND-WATER QUALITY OF THE TRINITY, CARRIZOWILCOX, AND GULF COAST AQUIFERS, FEBRUARY-AUGUST 1994: USGS WATER-RESOURCES INVESTIGATIONS REPORT 99-4233, 2000.

\section{PARMER COUNTY}

GEOLOGY AND GROUND-WATER RESOURCES OF THE SOUTHERN HIGH PLAINS: USGS OPEN-FILE REPORT (UNNUMBERED), 1935.

GROUND WATER IN THE SOUTHERN HIGH PLAINS: USGS OPENFILE REPORT (UNNUMBERED), 1937.

RECORDS OF WELLS, DRILLERS' LOGS, AND WATER ANALYSES, AND MAP SHOWING LOCATION OF WELLS IN PARMER COUNTY, TEXAS: TEXAS BOARD OF WATER ENGINEERS MISCELLANEOUS PUBLICATION 203, 1938.

GROUND WATER IN THE HIGH PLAINS IN TEXAS (1940): TEXAS BOARD OF WATER ENGINEERS MISCELLANEOUS PUBLICATION M119, 1940.

GROUND WATER IN THE HIGH PLAINS IN TEXAS, PROGRESS REPORT (1943): TEXAS BOARD OF WATER ENGINEERS MISCELLANEOUS PUBLICATION M120, 1943.

GROUND WATER IN THE HIGH PLAINS IN TEXAS, PROGRESS REPORT (1944): TEXAS BOARD OF WATER ENGINEERS MISCELLANEOUS PUBLICATION M121, 1944.

GROUND WATER IN THE HIGH PLAINS IN TEXAS, PROGRESS REPORT NO. 5: TEXAS BOARD OF WATER ENGINEERS MISCELLANEOUS PUBLICATION M122, 1945.

GROUND WATER IN THE HIGH PLAINS IN TEXAS, PROGRESS REPORT NO. 6: TEXAS BOARD OF WATER ENGINEERS MISCELLANEOUS PUBLICATION M123, 1947.

GEOLOGY AND GROUND WATER IN THE IRRIGATED REGION OF THE SOUTHERN HIGH PLAINS IN TEXAS, PROGRESS REPORT NO. 7: TEXAS BOARD OF WATER ENGINEERS MISCELLANEOUS PUBLICATION M125, 1949.

PUBLIC WATER SUPPLIES IN WESTERN TEXAS: TEXAS BOARD OF WATER ENGINEERS MISCELLANEOUS PUBLICATION 216, 1949.

COST OF PUMPING WATER FOR IRRIGATION, TEXAS HIGH PLAINS, FIELD INVESTIGATION—1947 IRRIGATION SEASON: TEXAS BOARD OF WATER ENGINEERS MISCELLANEOUS PUBLICATION M124, 1951.

DEVELOPMENT OF WELLS FOR IRRIGATION AND FLUCTUATION OF WATER LEVELS IN THE HIGH PLAINS OF TEXAS TO JANUARY 1951: TEXAS BOARD OF WATER ENGINEERS BULLETIN 5104, 1951.

PUBLIC WATER SUPPLIES IN WESTERN TEXAS: USGS WATERSUPPLY PAPER 1106, 1951 [1952]. 
SUMMARY OF GROUND-WATER DEVELOPMENT IN THE SOUTHERN HIGH PLAINS, TEXAS: TEXAS BOARD OF WATER ENGINEERS BULLETIN 5402, 1954.

RECORDS OF WATER-LEVEL MEASUREMENTS IN BAILEY, BRISCOE, CASTRO, PARMER, POTTER, AND RANDALL COUNTIES, TEXAS: TEXAS BOARD OF WATER ENGINEERS BULLETIN 5406, 1954.

GROUND-WATER DEVELOPMENT IN THE SOUTHERN HIGH PLAINS OF TEXAS, 1953: TEXAS BOARD OF WATER ENGINEERS BULLETIN 5410, 1954.

WATER-LEVEL DECLINE MAPS OF 16 COUNTIES IN THE SOUTHERN HIGH PLAINS, TEXAS, JANUARY 1954 TO JANUARY 1955: (BAILEY, BRISCOE, CASTRO, COCHRAN, CROSBY, DEAF SMITH, FLOYD, GAINES, HALE, HOCKLEY, LAMB, LUBBOCK, PARMER, RANDALL, SWISHER, AND TERRY): USGS OPEN-FILE REPORT (UNNUMBERED), 1955.

WATER-LEVEL DECLINE MAPS OF 17 COUNTIES IN THE SOUTHERN HIGH PLAINS, TEXAS, JANUARY 1955 TO JANUARY 1956: TEXAS BOARD OF WATER ENGINEERS BULLETIN 5607, 1956.

WATER-LEVEL DECLINE MAPS, 1956 TO 1957, AND WATER LEVELS IN OBSERVATION WELLS IN 20 COUNTIES IN THE SOUTHERN HIGH PLAINS, TEXAS: TEXAS BOARD OF WATER ENGINEERS BULLETIN 5705, 1957.

WATER-LEVEL MEASUREMENTS AND MAPS, SOUTHERN HIGH PLAINS, TEXAS, 1958 AND 1959: TEXAS BOARD OF WATER ENGINEERS BULLETIN 5908, 1959.

WATER LEVELS IN OBSERVATION WELLS, SOUTHERN HIGH PLAINS, TEXAS, 1959 AND 1960: TEXAS BOARD OF WATER ENGINEERS BULLETIN 6011, 1960.

WATER LEVELS IN OBSERVATION WELLS, SOUTHERN HIGH PLAINS, TEXAS, 1960 AND 1961: TEXAS BOARD OF WATER ENGINEERS BULLETIN 6101, 1961.

A SUMMARY OF THE OCCURRENCE AND DEVELOPMENT OF GROUND WATER IN THE SOUTHERN HIGH PLAINS OF TEXAS TEXAS BOARD OF WATER ENGINEERS BULLETIN 6107, 1961.

WATER-LEVEL MEASUREMENTS THROUGH 1962 IN SELECTED OBSERVATION WELLS, SOUTHERN HIGH PLAINS, TEXAS: TEXAS WATER COMMISSION BULLETIN 6207, 1962.

RECONNAISSANCE INVESTIGATION OF THE GROUND-WATER RESOURCES OF THE RED RIVER, SULPHUR RIVER, AND CYPRESS CREEK BASINS, TEXAS: TEXAS WATER COMMISSION BULLETIN 6306, 1963.

RECONNAISSANCE INVESTIGATION OF THE GROUND-WATER RESOURCES OF THE BRAZOS RIVER BASIN, TEXAS: TEXAS WATER COMMISSION BULLETIN 6310, 1963

A SUMMARY OF THE OCCURRENCE AND DEVELOPMENT OF GROUND WATER IN THE SOUTHERN HIGH PLAINS OF TEXAS: USGS WATER-SUPPLY PAPER 1693, 1964.

WATER-LEVEL DATA FROM OBSERVATION WELLS IN THE SOUTHERN HIGH PLAINS OF TEXAS: TEXAS WATER DEVELOPMENT BOARD REPORT 21, 1966.

COMPILATION OF RESULTS OF AQUIFER TESTS IN TEXAS: TEXAS WATER DEVELOPMENT BOARD REPORT 98, 1969.

GROUND WATER IN THE OGALLALA FORMATION IN THE SOUTHERN HIGH PLAINS OF TEXAS AND NEW MEXICO: USGS HYDROLOGIC INVESTIGATIONS ATLAS HA-330, 1969.
WATER-LEVEL DATA FROM OBSERVATION WELLS IN THE SOUTHERN HIGH PLAINS OF TEXAS, 1956-70: TEXAS WATER DEVELOPMENT BOARD REPORT 121, 1970.

AN EVALUATION OF THE USE OF DRILLERS' LOGS IN LITHOLOGIC STUDIES OF THE OGALLALA FORMATION OF THE SOUTHERN HIGH PLAINS OF TEXAS: USGS OPEN-FILE REPORT 72-451, 1972.

SUMMARY APPRAISALS OF THE NATION'S GROUND-WATER RESOURCES-TEXAS-GULF REGION: USGS PROFESSIONAL PAPER 813-F, 1976.

ANALYTICAL STUDY OF THE OGALLALA AQUIFER IN PARMER COUNTY, TEXAS-PROJECTIONS OF SATURATED THICKNESS, VOLUME OF WATER IN STORAGE, PUMPAGE RATES, PUMPING LIFTS, AND WELL YIELDS: TEXAS WATER DEVELOPMENT BOARD REPORT 205, 1976.

WATER-LEVEL DATA FROM OBSERVATION WELLS IN THE SOUTHERN HIGH PLAINS OF TEXAS, 1971-77: TEXAS DEPARTMENT OF WATER RESOURCES REPORT 228, 1979.

PRELIMINARY DATA DESCRIBING THE DISTRIBUTION OF FLUORIDE AND SILICA IN THE OGALLALA AQUIFER ON THE HIGH PLAINS OF TEXAS: USGS OPEN-FILE REPORT 80-349, 1980.

EVALUATING THE GROUND-WATER RESOURCES OF THE HIGH PLAINS OF TEXAS: RESULTS OF TEST-HOLE DRILLING: TEXAS DEPARTMENT OF WATER RESOURCES LIMITED PRINTING REPORT LP-129, 1980.

EVALUATING THE GROUND-WATER RESOURCES OF THE HIGH PLAINS OF TEXAS: RESULTS OF SURFACE ELECTRICAL SURVEYS: TEXAS DEPARTMENT OF WATER RESOURCES LIMITED PRINTING REPORT LP-130, 1980.

SPRINGS OF TEXAS, VOLUME 1: (BY GUNNAR BRUNE), BRANCHSMITH, INC., FORT WORTH, TEXAS, 1981.

BEDROCK GEOLOGY, ALTITUDE OF BASE, AND 1980 SATURATED THICKNESS OF THE HIGH PLAINS AQUIFER IN PARTS OF COLORADO, KANSAS, NEBRASKA, NEW MEXICO, OKLAHOMA, SOUTH DAKOTA, TEXAS, AND WYOMING: USGS HYDROLOGIC INVESTIGATIONS ATLAS HA-648, 1981

WATER LEVEL AND SATURATED THICKNESS CHANGES, PREDEVELOPMENT TO 1980, IN THE HIGH PLAINS AQUIFER IN PARTS OF COLORADO, KANSAS, NEBRASKA, NEW MEXICO, OKLAHOMA, SOUTH DAKOTA, TEXAS, AND WYOMING: USGS HYDROLOGIC INVESTIGATIONS ATLAS HA-652, 1981.

DISSOLVED SOLIDS AND SODIUM IN WATER FROM THE HIGH PLAINS AQUIFER IN PARTS OF COLORADO, KANSAS, NEBRASKA, NEW MEXICO, OKLAHOMA, SOUTH DAKOTA, TEXAS, AND WYOMING: USGS HYDROLOGIC INVESTIGATIONS ATLAS HA-658, 1982.

EVALUATING THE GROUND-WATER RESOURCES OF THE HIGH PLAINS OF TEXAS, VOLUME 1: TEXAS DEPARTMENT OF WATER RESOURCES REPORT 288, V. 1, 1984.

EVALUATING THE GROUND-WATER RESOURCES OF THE HIGH PLAINS OF TEXAS, VOLUME 3, RECORDS OF WELLS, AND MAPS SHOWING WELL LOCATIONS, BASE OF AQUIFER, WATER LEVELS, AND SATURATED THICKNESS: TEXAS DEPARTMENT OF WATER RESOURCES REPORT 288, V. 3, 1984.

GEOHYDROLOGY OF THE HIGH PLAINS AQUIFER IN PARTS OF COLORADO, KANSAS, NEBRASKA, NEW MEXICO, OKLAHOMA, SOUTH DAKOTA, TEXAS, AND WYOMING: USGS PROFESSIONAL PAPER 1400-B, 1984. 
TEXAS GROUND-WATER RESOURCES, in NATIONAL WATER SUMMARY 1984: USGS WATER-SUPPLY PAPER 2275, 1985.

DIGITAL SIMULATION OF GROUND-WATER FLOW IN THE HIGH PLAINS AQUIFER IN PARTS OF COLORADO, KANSAS, NEBRASKA, NEW MEXICO, OKLAHOMA, SOUTH DAKOTA, TEXAS, AND WYOMING: USGS PROFESSIONAL PAPER 1400-D, 1986.

IRRIGATION DATA FROM CASTRO AND PARMER COUNTIES, TEXAS, 1983-84: USGS OPEN-FILE REPORT 85-699, 1986.

COMPARISON OF IRRIGATION PUMPAGE AND CHANGE IN WATER STORAGE OF THE HIGH PLAINS AQUIFER IN CASTRO AND PARMER COUNTIES, TEXAS, 1975-83: USGS WATER-RESOURCES INVESTIGATIONS REPORT 87-4032, 1987.

SUMMARY OF THE HIGH PLAINS REGIONAL AQUIFER-SYSTEM ANALYSIS IN PARTS OF COLORADO, KANSAS, NEBRASKA, NEW MEXICO, OKLAHOMA, SOUTH DAKOTA, TEXAS, AND WYOMING: USGS PROFESSIONAL PAPER 1400-A, 1988.

HYDROGEOLOGY OF LOWER CRETACEOUS STRATA UNDER THE SOUTHERN HIGH PLAINS OF TEXAS AND NEW MEXICO: TEXAS WATER DEVELOPMENT BOARD REPORT 314, 1989.

PUBLIC-SUPPLY GROUND-WATER USE IN THE SOUTHERN HIGH PLAINS OF TEXAS: TEXAS WATER DEVELOPMENT BOARD REPORT 328, 1990.

WATER-LEVEL CHANGES IN THE HIGH PLAINS AQUIFER OF TEXAS, 1980-1990: TEXAS WATER DEVELOPMENT BOARD HYDROLOGIC ATLAS NO. 1, 1991.

THE HIGH PLAINS AQUIFER SYSTEM OF TEXAS, 1980 TO 1990. OVERVIEW AND PROJECTIONS: TEXAS WATER DEVELOPMENT BOARD REPORT 341, 1993.

WATER-QUALITY EVALUATION OF THE OGALLALA AQUIFER, TEXAS: TEXAS WATER DEVELOPMENT BOARD REPORT 342, 1993.

WATER QUALITY IN THE EDWARDS-TRINITY (PLATEAU) AQUIFER, EDWARDS PLATEAU AND TRANS-PECOS, TEXAS: TEXAS WATER DEVELOPMENT BOARD HYDROLOGIC ATLAS NO. 3, 1995.

WATER-LEVEL CHANGES IN THE HIGH PLAINS AQUIFER, 1980 TO 1994: USGS FACT SHEET FS-215-95, 1995.

AQUIFERS OF TEXAS: TEXAS WATER DEVELOPMENT BOARD REPORT 345, 1995.

HYDROLOGIC ATLAS FOR PARMER COUNTY, TEXAS: HIGH PLAINS UNDERGROUND WATER CONSERVATION DISTRICT NO. 1, LUBBOCK, TEXAS, 1996.

WATER-LEVEL CHANGES IN THE HIGH PLAINS AQUIFER, 1980 TO 1995: USGS FACT SHEET FS-068-97, 1997.

WATER-LEVEL CHANGES IN THE HIGH PLAINS AQUIFER-PREDEVELOPMENT TO 1995: USGS WATER-RESOURCES INVESTIGATIONS REPORT 97-4081, 1997.

UPDATED WATER-QUALITY EVALUATION OF THE OGALLALA AQUIFER INCLUDING SELECTED METALLIC AND NON-METALLIC INORGANIC CONSTITUENTS: TEXAS WATER DEVELOPMENT BOARD HYDROLOGIC ATLAS NO. 10, 1998.

WATER-RESOURCES DATA, TEXAS, WATER YEAR 2000, VOLUME 6, GROUND-WATER DATA: USGS WATER-DATA REPORT TX-00-6, 2001.

\section{PECOS COUNTY}

REPORT OF PROGRESS OF STREAM MEASUREMENTS FOR THE CALENDAR YEAR 1904: USGS WATER-SUPPLY AND IRRIGATION PAPER 132, 1905.

LARGE SPRINGS IN THE UNITED STATES: USGS WATER-SUPPLY PAPER 557, 1927.

GROUND-WATER RESOURCES OF THE BALMORHEA AREA IN WESTERN TEXAS: TEXAS BOARD OF WATER ENGINEERS MISCELLANEOUS PUBLICATION 11, 1938.

WATER RESOURCES OF THE PECOS RIVER BASIN, VOLUME 1, PECOS RIVER JOINT INVESTIGATION-PART 3, REPORT B, GEOLOGY AND GROUND WATER: TEXAS BOARD OF WATER ENGINEERS MISCELLANEOUS PUBLICATION 209A, V. 1, 1941.

WATER RESOURCES OF THE PECOS RIVER BASIN, VOLUME 2, RECORDS OF WELLS AND SPRINGS AND ANALYSES OF WATER IN LOVING, WARD, REEVES, AND NORTHERN PECOS COUNTIES: TEXAS BOARD OF WATER ENGINEERS MISCELLANEOUS PUBLICATION 209A, V. 2, 1941.

WATER RESOURCES OF THE PECOS RIVER BASIN, VOLUME 3 , RECORDS OF AUGER HOLES INCLUDING LOGS, RECORDS OF FLUCTUATIONS OF WATER LEVELS, WATER ANALYSES, AND MAPS SHOWING LOCATIONS OF WELLS: TEXAS BOARD OF WATER ENGINEERS MISCELLANEOUS PUBLICATION 209A, V. 3, 1941.

GEOLOGY AND GROUND-WATER RESOURCES OF THE BALMORHEA AREA WESTERN TEXAS: USGS WATER-SUPPLY PAPER 849-C, 1941,

AVAILABLE SUPPLIES OF GROUND WATER OF LOW MINERAL CONTENT IN VICINITY OF FORT STOCKTON, TEXAS: USGS OPEN-FILE REPORT (UNNUMBERED), 1942.

RECORDS OF WELLS AND SPRINGS IN NORTHERN PECOS COUNTY, TEXAS: TEXAS BOARD OF WATER ENGINEERS MISCELLANEOUS PUBLICATION 208, 1947.

SUGGESTED ITEMS OF FIELD WORK NEEDED TO COMPLETE GROUND-WATER INVESTIGATIONS IN PECOS COUNTY, TEXAS: USGS OPEN-FILE REPORT, 1948.

PUBLIC WATER SUPPLIES IN WESTERN TEXAS: TEXAS BOARD OF WATER ENGINEERS MISCELLANEOUS PUBLICATION 216, 1949.

PUBLIC WATER SUPPLIES IN WESTERN TEXAS: USGS WATERSUPPLY PAPER 1106, 1951.

THE FORT STOCKTON PROJECT: USGS OPEN-FILE REPORT (UNNUMBERED), 1951.

GEOLOGY AND GROUND-WATER RESOURCES OF THE FORT STOCKTON AREA, TEXAS: USGS OPEN-FILE REPORT (UNNUMBERED), 1951.

RECONNAISSANCE OF GROUND-WATER DEVELOPMENT IN THE FORT STOCKTON AREA, PECOS COUNTY, TEXAS: USGS MISCELLANEOUS PUBLICATION 209, 1956.

GEOLOGY AND GROUND-WATER RESOURCES OF PECOS COUNTY, TEXAS, V. 1. INCLUDES RECORDS OF WELLS: TEXAS BOARD OF WATER ENGINEERS BULLETIN 6106, V. 1, 1961.

GEOLOGY AND GROUND-WATER RESOURCES OF PECOS COUNTY, TEXAS, VOLUME 2, DRILLERS' LOGS, WATER LEVELS IN WELLS, 
AND CHEMICAL ANALYSES OF WATER: TEXAS BOARD OF WATER ENGINEERS BULLETIN 6106, V. 2, 1961.

RECONNAISSANCE INVESTIGATION OF THE GROUND-WATER RESOURCES OF THE RIO GRANDE BASIN, TEXAS: TEXAS WATER COMMISSION BULLETIN 6502, 1965.

WATER-LEVEL DATA FROM OBSERVATION WELLS IN PECOS AND REEVES COUNTIES, TEXAS: TEXAS WATER COMMISSION BULLETIN 6507, 1965.

COMPILATION OF RESULTS OF AQUIFER TESTS IN TEXAS: TEXAS WATER DEVELOPMENT BOARD REPORT 98, 1969.

RECONNAISSANCE INVESTIGATION OF GROUND WATER IN THE RIO GRANDE DRAINAGE BASIN-WITH SPECIAL EMPHASIS ON SALINE GROUND-WATER RESOURCES: USGS HYDROLOGIC INVESTIGATIONS ATLAS HA-510, 1974.

SUMMARY APPRAISALS OF THE NATION'S GROUND-WATER RESOURCES-RIO GRANDE REGION: USGS PROFESSIONAL PAPER 813-D, 1975.

MAJOR AND HISTORICAL SPRINGS OF TEXAS: TEXAS WATER DEVELOPMENT BOARD REPORT 189, 1975.

OCCURRENCE AND QUALITY OF GROUND WATER IN THE EDWARDS-TRINITY (PLATEAU) AQUIFER IN THE TRANS PECOS REGION OF TEXAS: TEXAS DEPARTMENT OF WATER RESOURCES REPORT 255, 1980.

SPRINGS OF TEXAS, VOLUME 1: (BY GUNNAR BRUNE), BRANCHSMITH, INC., FORT WORTH, TEXAS, 1981.

MAPS SHOWING GROUND-WATER UNITS AND WITHDRAWAL, BASIN AND RANGE PROVINCE, TEXAS: USGS WATERRESOURCES INVESTIGATIONS REPORT 83-4121-A, 1984.

MAPS SHOWING GROUND-WATER LEVELS, SPRINGS, AND DEPTH TO GROUND WATER, BASIN AND RANGE PROVINCE, TEXAS: USGS WATER-RESOURCES INVESTIGATIONS REPORT 83-4121-B, 1984.

MAPS SHOWING DISTRIBUTION OF DISSOLVED SOLIDS AND DOMINANT CHEMICAL TYPE IN GROUND WATER, BASIN AND RANGE PROVINCE, TEXAS: USGS WATER-RESOURCES INVESTIGATIONS REPORT 83-4121-C, 1984

TEXAS GROUND-WATER RESOURCES, in NATIONAL WATER SUMMARY 1984: USGS WATER-SUPPLY PAPER 2275, 1985.

RECORDS OF WELLS, WATER LEVELS, PUMPAGE, AND CHEMICAL ANALYSES FROM SELECTED WELLS IN PARTS OF THE TRANSPECOS REGION, TEXAS, 1968-1980: TEXAS WATER DEVELOPMENT BOARD REPORT 301, 1987.

PUBLIC SUPPLY GROUND-WATER USE IN WESTERN TEXAS: TEXAS WATER DEVELOPMENT BOARD REPORT 311, 1989.

POTENTIOMETRIC SURFACE OF THE EDWARDS-TRINITY AQUIFER SYSTEM AND CONTIGUOUS HYDRAULICALLY CONNECTED UNITS, WEST-CENTRAL TEXAS, WINTER 1974-75: USGS WATERRESOURCES INVESTIGATIONS REPORT 89-4208, 1990.

WITHDRAWALS FROM THE EDWARDS-TRINITY AQUIFER SYSTEM AND CONTIGUOUS HYDRAULICALLY CONNECTED UNITS, WEST-CENTRAL TEXAS, DECEMBER 1974 THROUGH MARCH 1977: USGS WATER-RESOURCES INVESTIGATIONS REPORT 91-4021, 1991.
EVALUATION OF GROUND-WATER RESOURCES IN PARTS OF LOVING, PECOS, REEVES, WARD, AND WINKLER COUNTIES, TEXAS: TEXAS WATER DEVELOPMENT BOARD REPORT 317, 1990.

CONFIGURATION OF THE BASE OF THE EDWARDS-TRINITY AQUIFER SYSTEM AND HYDROGEOLOGY OF THE UNDERLYING PRECRETACEOUS ROCKS, WEST-CENTRAL TEXAS: USGS WATERRESOURCES INVESTIGATIONS REPORT 91-4071, 1992.

HISTORICAL POTENTIOMETRIC SURFACE OF THE EDWARDS-TRINITY AQUIFER SYSTEM AND CONTIGUOUS HYDRAULICALLY CONNECTED UNITS, WEST-CENTRAL TEXAS: USGS WATERRESOURCES INVESTIGATIONS REPORT 92-4055, 1993.

HISTORICAL SATURATED THICKNESS OF THE EDWARDS-TRINITY AQUIFER SYSTEM AND SELECTED CONTIGUOUS HYDRAULICALLY CONNECTED UNITS, WEST-CENTRAL TEXAS: USGS WATER-RESOURCES INVESTIGATIONS REPORT 92-4125, 1993.

GROUND-WATER CONDITIONS IN PECOS COUNTY, TEXAS, 1987: USGS WATER-RESOURCES INVESTIGATIONS REPORT 92-4190, 1993.

SIMULATIONS OF FLOW IN THE EDWARDS-TRINITY AQUIFER SYSTEM AND CONTIGUOUS HYDRAULICALLY CONNECTED UNITS, WEST-CENTRAL TEXAS: USGS WATER-RESOURCES INVESTIGATIONS REPORT 93-4039, 1994.

DISSOLVED-SOLIDS CONCENTRATIONS AND HYDROCHEMICAL FACIES IN WATER OF THE EDWARDS-TRINITY AQUIFER SYSTEM, WEST-CENTRAL TEXAS: USGS WATER-RESOURCES INVESTIGATIONS REPORT 93-4126, 1994.

GEOLOGIC HISTORY AND HYDROGEOLOGIC SETTING OF THE EDWARDS-TRINITY AQUIFER SYSTEM, WEST-CENTRAL TEXAS: USGS WATER-RESOURCES INVESTIGATIONS REPORT 94-4039, 1994.

WATER QUALITY IN THE EDWARDS-TRINITY (PLATEAU) AQUIFER, EDWARDS PLATEAU AND TRANS-PECOS, TEXAS: TEXAS WATER DEVELOPMENT BOARD HYDROLOGIC ATLAS NO. 3, 1995.

AQUIFERS OF TEXAS: TEXAS WATER DEVELOPMENT BOARD REPORT 345, 1995.

HYDROGEOLOGIC FRAMEWORK OF THE EDWARDS-TRINITY AQUIFER SYSTEM, WEST-CENTRAL TEXAS: USGS PROFESSIONAL PAPER 1421-B, 1996.

WATER QUALITY IN THE CAPITAN REEF AQUIFER: TEXAS WATER DEVELOPMENT BOARD HYDROLOGIC ATLAS NO. 8, 1997.

WATER QUALITY IN THE RUSTLER AQUIFER: TEXAS WATER DEVELOPMENT BOARD HYDROLOGIC ATLAS NO. 9, 1998.

CHANGES IN GROUNDWATER CONDITIONS IN PARTS OF TRANS PECOS TEXAS, 1988-1998: TEXAS WATER DEVELOPMENT BOARD REPORT 348, 1999.

AQUIFERS OF WEST TEXAS: TEXAS WATER DEVELOPMENT BOARD REPORT 356, 2001

REGIONAL GROUND-WATER FLOW SYSTEMS IN TRANS-PECOS TEXAS, CHAPTER 4, in AQUIFERS OF WEST TEXAS: TEXAS WATER DEVELOPMENT BOARD REPORT 356, 2001

AN OVERVIEW OF THE EDWARDS-TRINITY AQUIFER SYSTEM, CENTRAL-WEST TEXAS, CHAPTER 8, in AQUIFERS OF WEST TEXAS: TEXAS WATER DEVELOPMENT BOARD REPORT 356, 2001. 
CENOZOIC PECOS ALLUVIUM AQUIFER, CHAPTER 9, in AQUIFERS OF WEST TEXAS: TEXAS WATER DEVELOPMENT BOARD REPORT 356, 2001.

THE GEOLOGY AND HYDROGEOLOGY OF THE CAPITAN AQUIFER: A BRIEF OVERVIEW, CHAPTER 11, in AQUIFERS OF WEST TEXAS: TEXAS WATER DEVELOPMENT BOARD REPORT 356, 2001.

THE DOCKUM AQUIFER IN WEST TEXAS, CHAPTER 12, in AQUIFERS OF WEST TEXAS: TEXAS WATER DEVELOPMENT BOARD REPORT 356, 2001.

HYDROGEOLOGY OF THE RUSTLER AQUIFER, TRANS-PECOS TEXAS, CHAPTER 15, in AQUIFERS OF WEST TEXAS: TEXAS WATER DEVELOPMENT BOARD REPORT 356, 2001.

\section{POLK COUNTY}

ARTESIAN WELLS OF THE COASTAL PRAIRIE REGION AND TERTIARY BELT OF TEXAS: GEOLOGICAL SURVEY OF TEXAS, CHAPTER 2, 1893.

UNDERGROUND WATERS OF THE COASTAL PLAIN OF TEXAS: USGS WATER-SUPPLY PAPER 190, 1907.

GEOLOGY AND UNDERGROUND WATERS OF THE SOUTHEASTERN PART OF THE TEXAS COASTAL PLAIN: USGS WATER-SUPPLY PAPER 335, 1914

PUBLIC WATER SUPPLIES IN EASTERN TEXAS, V. 2, HARRISON COUNTY THROUGH WOOD COUNTY: TEXAS BOARD OF WATER ENGINEERS MISCELLANEOUS PUBLICATION 214, V. 2, 1945.

PUBLIC WATER SUPPLIES IN EASTERN TEXAS: USGS WATERSUPPLY PAPER 1047, 1948.

AVAILABILITY OF GROUND WATER IN THE GULF COAST REGION OF TEXAS: USGS OPEN-FILE REPORT (UNNUMBERED), 1956.

RECONNAISSANCE INVESTIGATION OF THE GROUND-WATER RESOURCES OF THE NECHES RIVER BASIN, TEXAS: TEXAS WATER COMMISSION BULLETIN 6308, 1963.

RECONNAISSANCE INVESTIGATION OF THE GROUND-WATER RESOURCES OF THE TRINITY RIVER BASIN, TEXAS: TEXAS WATER COMMISSION BULLETIN 6309, 1963.

GROUND-WATER RESOURCES OF POLK COUNTY, TEXAS: TEXAS WATER DEVELOPMENT BOARD REPORT 82, 1968.

HYDROLOGIC SIGNIFICANCE OF THE LITHOFACIES OF THE SPARTA SAND IN ARKANSAS, LOUISIANA, MISSISSIPPI, AND TEXAS: USGS PROFESSIONAL PAPER 569-A, 1968.

COMPILATION OF RESULTS OF AQUIFER TESTS IN TEXAS: TEXAS WATER DEVELOPMENT BOARD REPORT 98, 1969.

GEOHYDROLOGIC SIGNIFICANCE OF LITHOFACIES OF THE COCKFIELD FORMATION OF LOUISIANA AND MISSISSIPPI AND OF THE YEGUA FORMATION OF TEXAS: USGS PROFESSIONAL PAPER 569-B, 1970.

HYDROLOGIC SIGNIFICANCE OF LITHOFACIES OF THE CANE RIVER FORMATION OR EQUIVALENTS OF ARKANSAS, LOUISIANA, MISSISSIPPI, AND TEXAS: USGS PROFESSIONAL PAPER 569-C, 1972.

HYDROLOGIC SIGNIFICANCE OF LITHOFACIES OF THE CARRIZO SAND OF ARKANSAS, LOUISIANA, AND TEXAS AND THE MERID-
IAN SAND OF MISSISSIPPI: USGS PROFESSIONAL PAPER 569-D, 1975.

SUMMARY APPRAISALS OF THE NATION'S GROUND-WATER RESOURCES-TEXAS-GULF REGION: USGS PROFESSIONAL PAPER 813-F, 1976.

APPROXIMATE AREAS OF RECHARGE TO THE CHICOT AND EVANGELINE AQUIFER SYSTEMS IN THE HOUSTON-GALVESTON AREA, TEXAS: USGS OPEN-FILE REPORT 77-754, 1977.

STRATIGRAPHIC AND HYDROGEOLOGIC FRAMEWORK OF PART OF THE COASTAL PLAIN OF TEXAS: USGS OPEN-FILE REPORT $77-712,1978$.

STRATIGRAPHIC AND HYDROGEOLOGIC FRAMEWORK OF PART OF THE COASTAL PLAIN OF TEXAS: TEXAS DEPARTMENT OF WATER RESOURCES REPORT 236, 1979.

SPRINGS OF TEXAS, VOLUME 1: (BY GUNNAR BRUNE), BRANCHSMITH, INC., FORT WORTH, TEXAS, 1981.

TEXAS GROUND-WATER RESOURCES, in NATIONAL WATER SUMMARY 1984: USGS WATER-SUPPLY PAPER 2275, 1985.

HYDROLOGY OF THE JASPER AQUIFER IN THE SOUTHEAST TEXAS COASTAL PLAIN: TEXAS WATER DEVELOPMENT BOARD REPORT 295, 1986.

HYDROGEOLOGY AND PREDEVELOPMENT FLOW IN THE TEXAS GULF COAST AQUIFER SYSTEMS: USGS WATER-RESOURCES INVESTIGATIONS REPORT 87-4248, 1988.

GEOHYDROLOGIC FRAMEWORK OF THE GULF COASTAL PLAIN: USGS HYDROLOGIC INVESTIGATIONS ATLAS HA-695, 1988.

GROUND-WATER FLOW IN THE GULF COAST AQUIFER SYSTEMS, SOUTH-CENTRAL UNITED STATES-A PRELIMINARY ANALYSIS: USGS WATER-RESOURCES INVESTIGATIONS REPORT 89-4071, 1990.

NATIONAL WATER-QUALITY ASSESSMENT PROGRAM-THE TRINITY RIVER BASIN: USGS OPEN-FILE REPORT 91-158, 1991.

HYDROLOGY OF THE TEXAS GULF COAST AQUIFER SYSTEMS: USGS OPEN-FILE REPORT 91-64, 1991.

PROPERTIES AND CHEMICAL CONSTITUENTS IN GROUND WATER FROM THE UPPER CLAIBORNE AQUIFER, GULF COAST REGIONAL AQUIFER SYSTEMS, SOUTH-CENTRAL UNITED STATES: USGS WATER-RESOURCES INVESTIGATIONS REPORT 91-4150, 1993.

PROPERTIES AND CHEMICAL CONSTITUENTS IN GROUND WATER FROM PERMEABLE ZONE C (LOWER PLIOCENE-UPPER MIOCENE DEPOSITS), COASTAL LOWLANDS AQUIFER SYSTEM, SOUTHCENTRAL UNITED STATES: USGS WATER-RESOURCES INVESTIGATIONS REPORT 91-4151, 1993.

PROPERTIES AND CHEMICAL CONSTITUENTS IN GROUND WATER FROM PERMEABLE ZONE B (LOWER PLEISTOCENE-UPPER PLIOCENE DEPOSITS), COASTAL LOWLANDS AQUIFER SYSTEM, SOUTH-CENTRAL UNITED STATES: USGS WATER-RESOURCES INVESTIGATIONS REPORT 91-4152, 1993.

PROPERTIES AND CHEMICAL CONSTITUENTS IN GROUND WATER FROM PERMEABLE ZONE E (LOWER MIOCENE-UPPER OLIGOCENE DEPOSITS), COASTAL LOWLANDS AQUIFER SYSTEM, SOUTH-CENTRAL UNITED STATES: USGS WATER-RESOURCES INVESTIGATIONS REPORT 92-4103, 1993. 
PROPERTIES AND CHEMICAL CONSTITUENTS IN GROUND WATER FROM THE MIDDLE CLAIBORNE AQUIFER, GULF COAST REGIONAL AQUIFER SYSTEMS, SOUTH-CENTRAL UNITED STATES: USGS WATER-RESOURCES INVESTIGATIONS REPORT 92-4104, 1993.

PROPERTIES AND CHEMICAL CONSTITUENTS IN GROUND WATER FROM PERMEABLE ZONE D (MIDDLE MIOCENE DEPOSITS), COASTAL LOWLANDS AQUIFER SYSTEM, SOUTH-CENTRAL UNITED STATES: USGS WATER-RESOURCES INVESTIGATIONS REPORT 92-4105, 1993.

PROPERTIES AND CHEMICAL CONSTITUENTS IN GROUND WATER FROM THE MIDDLE WILCOX AQUIFER, GULF COAST AQUIFER SYSTEMS, SOUTH-CENTRAL UNITED STATES: USGS WATERRESOURCES INVESTIGATIONS REPORT 93-4070, 1993.

NATIONAL WATER-QUALITY ASSESSMENT PROGRAM-PESTICIDES IN THE TRINITY RIVER BASIN STUDY UNIT, TEXAS, 1968-91: USGS FACT SHEET FS-088-95, 1995.

WATER-QUALITY ASSESSMENT OF THE TRINITY RIVER BASIN, TEXAS-DATA COLLECTION, 1992-95: USGS FACT SHEET FS-095-95, 1995.

WATER-QUALITY ASSESSMENT OF THE TRINITY RIVER BASIN, TEXAS—PESTICIDES IN A SUBURBAN WATERSHED, ARLINGTON, 1993-94: USGS FACT SHEET FS-159-95, 1995.

AQUIFERS OF TEXAS: TEXAS WATER DEVELOPMENT BOARD REPORT 345, 1995.

STRATIGRAPHIC NOMENCLATURE AND GEOLOGIC SECTIONS OF THE GULF COASTAL PLAIN OF TEXAS: USGS OPEN-FILE REPORT 94-461, 1995.

WATER-QUALITY ASSESSMENT OF THE TRINITY RIVER BASIN, TEXAS-GROUND-WATER QUALITY OF THE TRINITY, CARRIZOWILCOX, AND GULF COAST AQUIFERS, FEBRUARY-AUGUST 1994: USGS WATER-RESOURCES INVESTIGATIONS REPORT 99-4233, 2000.

\section{POTTER COUNTY}

THE GEOLOGY AND WATER RESOURCES OF THE WESTERN PORTION OF THE PANHANDLE OF TEXAS: USGS WATER-SUPPLY PAPER 191, 1907.

GEOLOGY AND WATER RESOURCES IN THE VICINITY OF AMARILLO, TEXAS: USGS OPEN-FILE REPORT (UNNUMBERED), 1927.

GEOLOGY AND GROUND-WATER RESOURCES OF THE SOUTHERN HIGH PLAINS: USGS OPEN-FILE REPORT (UNNUMBERED), 1935.

RECORDS OF WELLS, SPRINGS, AND REPRESENTATIVE EARTHERN TANKS, DRILLERS' LOGS, WATER ANALYSES, AND MAP SHOWING LOCATION OF WELLS AND TANKS IN POTTER COUNTY, TEXAS: TEXAS BOARD OF WATER ENGINEERS MISCELLANEOUS PUBLICATION 211, 1938.

GROUND WATER IN VICINITY OF SITE OF U.S. VETERANS HOSPITAL, AMARILLO, TEXAS: USGS OPEN-FILE REPORT (UNNUMBERED), 1939.

SOURCE OF WATER (PANTEX ORDNANCE PLANT): USGS OPEN-FILE REPORT (UNNUMBERED), 1942.
PROGRESS REPORT ON GROUND WATER IN THE HIGH PLAINS OF TEXAS: TEXAS BOARD OF WATER ENGINEERS MISCELLANEOUS PUBLICATION (UNNUMBERED), 1942.

GROUND-WATER RESOURCES IN THE VICINITY OF AMARILLO, TEXAS: USGS OPEN-FILE REPORT (UNNUMBERED), 1942.

PROGRESS REPORT ON GROUND WATER IN THE HIGH PLAINS OF TEXAS: TEXAS BOARD OF WATER ENGINEERS MISCELLANEOUS PUBLICATION 120, 1943.

GROUND-WATER RESOURCES OF THE AREA SOUTHWEST OF AMARILLO, TEXAS: TEXAS BOARD OF WATER ENGINEERS MISCELLANEOUS PUBLICATION 1, 1946.

AN INVESTIGATION OF UNDERGROUND WATER IN SOUTHWESTERN POTTER COUNTY AND NORTHWESTERN RANDALL COUNTY, TEXAS; SUMMARY AND CONCLUSIONS: USGS OPENFILE REPORT (UNNUMBERED), 1948.

PUBLIC WATER SUPPLIES IN WESTERN TEXAS: TEXAS BOARD OF WATER ENGINEERS MISCELLANEOUS PUBLICATION 216, 1949.

GROUND WATER IN THE VICINITY OF AMARILLO AND LUBBOCK, TEXAS: USGS OPEN-FILE REPORT (UNNUMBERED), 1949.

GEOLOGY AND GROUND WATER IN THE IRRIGATED REGION OF THE SOUTHERN HIGH PLAINS IN TEXAS, PROGRESS REPORT NO. 7: TEXAS BOARD OF WATER ENGINEERS MISCELLANEOUS PUBLICATION 125, 1949.

COST OF PUMPING WATER FOR IRRIGATION, TEXAS HIGH PLAINS, FIELD INVESTIGATIONS-1947 IRRIGATION SEASON: TEXAS BOARD OF WATER ENGINEERS MISCELLANEOUS PUBLICATION $124,1951$.

PUBLIC WATER SUPPLIES IN WESTERN TEXAS: USGS WATERSUPPLY PAPER 1106, 1951 [1952].

DEVELOPMENT OF WELLS FOR IRRIGATION AND FLUCTUATION OF WATER LEVELS IN THE HIGH PLAINS OF TEXAS TO JANUARY 1951: TEXAS BOARD OF WATER ENGINEERS BULLETIN 5104, 1951.

SUMMARY OF REPORTS ON GROUND-WATER RESOURCES NEAR AMARILLO, TEXAS: USGS OPEN-FILE REPORT, 1952.

SUMMARY OF GROUND-WATER DEVELOPMENT IN THE SOUTHERN HIGH PLAINS, TEXAS: TEXAS BOARD OF WATER ENGINEERS BULLETIN 5402, 1954.

RECORDS OF WATER-LEVEL MEASUREMENTS IN BAILEY, CASTRO, PARMER, POTTER, AND RANDALL COUNTIES, TEXAS: TEXAS BOARD OF WATER ENGINEERS BULLETIN 5406, 1954.

ARTIFICIAL-RECHARGE EXPERIMENTS AT MCDONALD WELL FIELD, AMARILLO, TEXAS: TEXAS BOARD OF WATER ENGINEERS BULLETIN 5701, 1957.

RECONNAISSANCE INVESTIGATION OF THE GROUND-WATER RESOURCES OF THE CANADIAN RIVER BASIN, TEXAS: TEXAS BOARD OF WATER ENGINEERS BULLETIN 6016, 1960.

ANNUAL WATER-LEVEL MEASUREMENTS IN OBSERVATION WELLS, NORTHERN HIGH PLAINS, TEXAS, 1960 AND 1961: TEXAS BOARD OF WATER ENGINEERS BULLETIN 6103, 1961.

GEOLOGY AND GROUND-WATER RESOURCES OF THE NORTHERN HIGH PLAINS OF TEXAS, PROGRESS REPORT NO. 1: TEXAS BOARD OF WATER ENGINEERS BULLETIN 6109, 1961. 
RECONNAISSANCE INVESTIGATION OF THE GROUND-WATER RESOURCES OF THE RED RIVER, SULPHUR RIVER, AND CYPRESS CREEK BASINS, TEXAS: TEXAS WATER COMMISSION BULLETIN 6306, 1963.

A SUMMARY OF THE OCCURRENCE AND DEVELOPMENT OF GROUND WATER IN THE SOUTHERN HIGH PLAINS OF TEXAS, WITH A SECTION ON ARTIFICIAL RECHARGE STUDIES: USGS WATER-SUPPLY PAPER 1693, 1964.

WATER-LEVEL DATA FROM OBSERVATION WELLS IN THE SOUTHERN HIGH PLAINS OF TEXAS: TEXAS WATER DEVELOPMENT BOARD REPORT 21, 1966.

WATER-LEVEL DATA FROM OBSERVATION WELLS IN THE SOUTHERN HIGH PLAINS OF TEXAS, 1965-70: TEXAS WATER DEVELOPMENT BOARD REPORT 121, 1970;

HYDROGEOLOGY OF A PLAYA NEAR AMARILLO, TEXAS: THE TEXAS AGRICULTURAL EXPERIMENT STATION, TEXAS A\&M UNIVERSITY, 1971.

MAJOR AND HISTORICAL SPRINGS OF TEXAS: TEXAS DEPARTMENT OF WATER RESOURCES REPORT 189, 1975.

WATER-LEVEL DATA FROM OBSERVATION WELLS IN THE SOUTHERN HIGH PLAINS OF TEXAS 1971-77: TEXAS DEPARTMENT OF WATER RESOURCES REPORT 228, 1979.

PRELIMINARY DATA DESCRIBING THE DISTRIBUTION OF FLUORIDE AND SILICA IN THE OGALLALA AQUIFER ON THE HIGH PLAINS OF TEXAS: USGS OPEN-FILE REPORT 80-349, 1980.

WATER TABLE IN THE HIGH PLAINS AQUIFER IN 1978 IN PARTS OF COLORADO, KANSAS, NEBRASKA, NEW MEXICO, OKLAHOMA, SOUTH DAKOTA, TEXAS, AND WYOMING: USGS HYDROLOGIC INVESTIGATIONS ATLAS HA-642, 1980.

EVALUATING THE GROUND-WATER RESOURCES OF THE HIGH PLAINS OF TEXAS: RESULTS OF TEST HOLE DRILLING: TEXAS DEPARTMENT OF WATER RESOURCES LIMITED PRINTING REPORT LP-129, 1980.

EVALUATING THE GROUND-WATER RESOURCES OF THE HIGH PLAINS OF TEXAS: RESULTS OF SURFACE ELECTRICAL RESISTIVITY SURVEYS: TEXAS DEPARTMENT OF WATER RESOURCES LIMITED PRINTING REPORT LP-130, 1980.

EVALUATING THE GROUND-WATER RESOURCES OF THE HIGH PLAINS OF TEXAS: NEUTRON-PROBE MEASUREMENTS OF DEEP SOIL MOISTURE AS AN INDICATION OF AQUIFER RECHARGE RATES: TEXAS DEPARTMENT OF WATER RESOURCES LIMITED PRINTING REPORT LP-142, 1981.

SPRINGS OF TEXAS, VOLUME 1: (BY GUNNAR BRUNE), BRANCHSMITH, INC., FORT WORTH, TEXAS, 1981.

BEDROCK GEOLOGY, ALTITUDE OF BASE, AND 1980 SATURATED THICKNESS OF THE HIGH PLAINS AQUIFER IN PARTS OF COLORADO, KANSAS, NEBRASKA, NEW MEXICO, OKLAHOMA, SOUTH DAKOTA, TEXAS, AND WYOMING: USGS HYDROLOGIC INVESTIGATIONS ATLAS HA-648, 1981.

WATER-LEVEL AND SATURATED-THICKNESS CHANGES, PREDEVELOPMENT TO 1980, IN THE HIGH PLAINS AQUIFER IN PARTS OF COLORADO, KANSAS, NEBRASKA, NEW MEXICO, OKLAHOMA, SOUTH DAKOTA, TEXAS, AND WYOMING: USGS HYDROLOGIC INVESTIGATIONS ATLAS HA-652, 1981.

DISSOLVED SOLIDS AND SODIUM IN WATER FROM THE HIGH PLAINS AQUIFER IN PARTS OF COLORADO, KANSAS,
NEBRASKA, NEW MEXICO, OKLAHOMA, SOUTH DAKOTA, TEXAS, AND WYOMING: USGS HYDROLOGIC INVESTIGATIONS ATLAS HA-658, 1982.

ANALYTICAL STUDY OF THE OGALLALA AQUIFER IN POTTER AND OLDHAM COUNTIES, TEXAS-PROJECTIONS OF SATURATED THICKNESS, VOLUME OF WATER IN STORAGE, PUMPING RATES, PUMPING LIFTS, AND WELL YIELDS: TEXAS DEPARTMENT OF WATER RESOURCES REPORT 265, 1982.

GEOHYDROLOGY OF THE HIGH PLAINS AQUIFER IN PARTS OF COLORADO, KANSAS, NEBRASKA, NEW MEXICO, OKLAHOMA, SOUTH DAKOTA, TEXAS, AND WYOMING: USGS PROFESSIONAL PAPER 1400-B, 1984.

EVALUATING THE GROUND-WATER RESOURCES OF THE HIGH PLAINS OF TEXAS, VOLUME 1: TEXAS DEPARTMENT OF WATER RESOURCES REPORT 288, V. 1, 1984.

EVALUATING THE GROUND-WATER RESOURCES OF THE HIGH PLAINS OF TEXAS, VOLUME 2, RECORDS OF WELLS, AND MAPS SHOWING WELL LOCATIONS, BASE OF AQUIFER, WATER LEVELS, AND SATURATED THICKNESS (ARMSTRONG, CARSON, DALLAS, DONLEY, GRAY, HANSFORD, HARTLEY, HEMPHILL, HUTCHINSON, LIPSCOMB, MOORE, OCHILTREE, POTTER, ROBERTS, SHERMAN, AND WHEELER COUNTIES): TEXAS DEPARTMENT OF WATER RESOURCES REPORT 288, V. 2, 1984.

TEXAS GROUND-WATER RESOURCES, in NATIONAL WATER SUMMARY 1984: USGS WATER-SUPPLY PAPER 2275, 1985.

WATER USE, PROJECTED WATER REQUIREMENTS, AND RELATED DATA AND INFORMATION FOR THE METROPOLITAN STATISTICAL AREAS IN TEXAS: TEXAS DEPARTMENT OF WATER RESOURCES LIMITED PRINTING REPORT LP-201, 1985.

DIGITAL SIMULATION OF GROUND-WATER FLOW IN THE HIGH PLAINS AQUIFER IN PARTS OF COLORADO, KANSAS, NEBRASKA, NEW MEXICO, OKLAHOMA, SOUTH DAKOTA, TEXAS, AND WYOMING: USGS PROFESSIONAL PAPER 1400-D, 1986.

SUMMARY OF THE HIGH PLAINS REGIONAL AQUIFER-SYSTEM ANALYSIS IN PARTS OF COLORADO, KANSAS, NEBRASKA, NEW MEXICO, OKLAHOMA, SOUTH DAKOTA, TEXAS, AND WYOMING: USGS PROFESSIONAL PAPER 1400-A, 1988.

WATER-LEVEL CHANGES IN THE HIGH PLAINS AQUIFER OF TEXAS, 1980-1990: TEXAS WATER DEVELOPMENT BOARD HYDROLOGIC ATLAS NO. 1, 1991.

PUBLIC-SUPPLY GROUND-WATER USE IN THE NORTHERN HIGH PLAINS OF TEXAS: TEXAS WATER DEVELOPMENT BOARD REPORT 336, 1992.

THE HIGH PLAINS AQUIFER SYSTEM OF TEXAS, 1980-1990. OVERVIEW AND PROJECTIONS: TEXAS WATER DEVELOPMENT BOARD REPORT 341, 1993.

WATER-QUALITY EVALUATION OF THE OGALLALA AQUIFER, TEXAS: TEXAS WATER DEVELOPMENT BOARD REPORT 342, 1993.

WATER-LEVEL CHANGES IN THE HIGH PLAINS AQUIFER-PREDEVELOPMENT TO 1992: USGS WATER-RESOURCES INVESTIGATIONS REPORT 94-4027, 1994.

WATER-LEVEL CHANGES IN THE HIGH PLAINS AQUIFER, 1980 TO 1994: USGS FACT SHEET FS-215-95, 1995. 
AQUIFERS OF TEXAS: TEXAS WATER DEVELOPMENT BOARD REPORT 345, 1995.

HYDROLOGIC ATLAS FOR CASTRO COUNTY, TEXAS: HIGH PLAINS UNDERGROUND WATER CONSERVATION DISTRICT NO. 1, LUBBOCK, TEXAS, 1987.

WATER-LEVEL CHANGES IN THE HIGH PLAINS AQUIFER, 1980 TO 1995: USGS FACT SHEET FS-068-97, 1997.

WATER-LEVEL CHANGES IN THE HIGH PLAINS AQUIFER-PREDEVELOPMENT TO 1995: USGS WATER-RESOURCES INVESTIGATIONS REPORT 97-4081, 1997.

PLAYAS AND RECHARGE OF THE OGALLALA AQUIFER ON THE SOUTHERN HIGH PLAINS OF TEXAS-AN EXAMINATION USING NUMERICAL TECHNIQUES: UNIVERSITY OF TEXAS, BUREAU OF ECONOMIC GEOLOGY REPORT OF INVESTIGATIONS NO. 242, 1997.

SPATIAL VARIABILITY IN UNSATURATED FLOW BENEATH PLAYA AND ADJACENT INTERPLAYA SETTINGS AND IMPLICATIONS FOR CONTAMINANT TRANSPORT, SOUTHERN HIGH PLAINS, TEXAS: UNIVERSITY OF TEXAS, BUREAU OF ECONOMIC GEOLOGY REPORT OF INVESTIGATIONS NO. 243, 1997.

UPDATED WATER-QUALITY EVALUATION OF THE OGALLALA AQUIFER INCLUDING SELECTED METALLIC AND NON-METALLIC INORGANIC CONSTITUENTS: TEXAS WATER DEVELOPMENT BOARD HYDROLOGIC ATLAS NO. 10, 1998.

\section{PRESIDIO COUNTY}

THERMAL SPRINGS IN THE UNITED STATES: USGS WATER-SUPPLY PAPER 679-B, 1937.

MARFA WATER SUPPLY: USGS OPEN-FILE REPORT (UNNUMBERED), 1941.

MEMORANDUM REGARDING WATER SUPPLY OF FORT RUSSELL NEAR MARFA, TEXAS: USGS OPEN-FILE REPORT (UNNUMBERED), 1941.

ARMY AIRPORT 10 MILES EAST OF MARFA: USGS OPEN-FILE REPORT (UNNUMBERED), 1942.

MARFA AIRFIELD, SUPPLEMENTARY WELL DATA: USGS OPEN-FILE REPORT (UNNUMBERED), 1943.

GROUND WATER IN THE VICINITY OF MARFA ARMY FLYING FIELD: USGS OPEN-FILE REPORT (UNNUMBERED), 1943.

MARFA ARMY AIR BASE, SUPPLEMENTARY DATA ON WELL 3: USGS OPEN-FILE REPORT (UNNUMBERED), 1943.

PUBLIC WATER SUPPLIES IN WESTERN TEXAS: TEXAS BOARD OF WATER ENGINEERS MISCELLANEOUS PUBLICATION 216, 1949.

PUBLIC WATER SUPPLIES IN WESTERN TEXAS: USGS WATERSUPPLY PAPER 1106, 1951.

MEMORANDUM ON THE GROUND-WATER RESOURCES OF THE VIEJA PEAK AREA, PRESIDIO COUNTY, TEXAS: USGS OPEN-FILE REPORT (UNNUMBERED), 1955.

GROUND-WATER GEOLOGY OF THE ALPINE AREA, BREWSTER, JEFF DAVIS, AND PRESIDIO COUNTIES, TEXAS: TEXAS BOARD OF WATER ENGINEERS BULLETIN 5712, 1957.
GROUND-WATER RECONNAISSANCE OF THE MARFA AREA, PRESIDIO COUNTY, TEXAS: TEXAS BOARD OF WATER ENGINEERS BULLETIN 6110, 1961

THERMAL SPRINGS OF THE UNITED STATES AND OTHER COUNTRIES OF THE WORLD-A SUMMARY: USGS PROFESSIONAL PAPER 492, 1965.

RECONNAISSANCE INVESTIGATION OF THE GROUND-WATER RESOURCES OF THE RIO GRANDE BASIN, TEXAS: TEXAS WATER COMMISSION BULLETIN 6502, 1965.

WATER-LEVEL DATA FROM OBSERVATION WELLS IN CULBERSON, JEFF DAVIS, PRESIDIO, AND BREWSTER COUNTIES, TEXAS TEXAS WATER DEVELOPMENT BOARD REPORT 16, 1966.

RECORDS OF WATER LEVELS AND CHEMICAL ANALYSES FROM SELECTED WELLS IN PART OF THE TRANS-PECOS REGION OF TEXAS, 1965-68: TEXAS WATER DEVELOPMENT BOARD REPORT 114,1970

RECONNAISSANCE INVESTIGATION OF GROUND WATER IN THE RIO GRANDE DRAINAGE BASIN-WITH SPECIAL EMPHASIS ON SALINE GROUND-WATER RESOURCES: USGS HYDROLOGIC INVESTIGATIONS ATLAS HA-510, 1974.

MAJOR AND HISTORICAL SPRINGS OF TEXAS: TEXAS WATER DEVELOPMENT BOARD REPORT 189, 1975.

TEST DRILLING FOR GROUND WATER IN HUDSPETH, CULBERSON, AND PRESIDIO COUNTIES IN WESTERNMOST TEXAS: USGS OPEN-FILE REPORT 76-338, 1976.

GROUND-WATER DATA FOR THE SALT BASIN, EAGLE FLAT, RED LIGHT DRAW, GREEN RIVER VALLEY, AND PRESIDIO BOLSON IN WESTERNMOST TEXAS: USGS OPEN-FILE REPORT 77-575, 1978

AVAILABILITY OF FRESH AND SLIGHTLY SALINE GROUND WATER IN THE BASINS OF WESTERNMOST TEXAS: USGS OPEN-FILE REPORT 78-663, 1978 .

OCCURRENCE AND QUALITY OF GROUND WATER IN THE EDWARDS-TRINITY (PLATEAU) AQUIFER IN THE TRANS-PECOS REGION OF TEXAS: TEXAS DEPARTMENT OF WATER RESOURCES REPORT 255, 1980.

AVAILABILITY OF FRESH AND SLIGHTLY SALINE GROUND WATER IN THE BASINS OF WESTERNMOST TEXAS: TEXAS DEPARTMENT OF WATER RESOURCES REPORT 256, 1980.

GROUND-WATER DATA FOR THE SALT BASIN, EAGLE FLAT, RED LIGHT DRAW, GREEN RIVER VALLEY, AND PRESIDIO BOLSON IN WESTERNMOST TEXAS: TEXAS DEPARTMENT OF WATER RESOURCES REPORT 259, 1980.

SPRINGS OF TEXAS, VOLUME 1: (BY GUNNAR BRUNE), BRANCHSMITH, INC., FORT WORTH, TEXAS, 1981.

MAPS SHOWING GROUND-WATER UNITS AND WITHDRAWAL, BASIN AND RANGE PROVINCE, TEXAS: USGS WATERRESOURCES INVESTIGATIONS REPORT 83-4121-A, 1984.

MAPS SHOWING GROUND-WATER LEVELS, SPRINGS, AND DEPTH TO GROUND WATER, BASIN AND RANGE PROVINCE, TEXAS: USGS WATER-RESOURCES INVESTIGATIONS REPORT 83-4121-B 1984.

MAPS SHOWING DISTRIBUTION OF DISSOLVED SOLIDS AND DOMINANT CHEMICAL TYPE IN GROUND WATER, BASIN AND RANGE PROVINCE, TEXAS: USGS WATER-RESOURCES INVESTIGATIONS REPORT 83-4121-C, 1984. 
TEXAS GROUND-WATER RESOURCES, in NATIONAL WATER SUMMARY 1984: USGS WATER-SUPPLY PAPER 2275, 1985.

RECORDS OF WELLS, WATER LEVELS, PUMPAGE, AND CHEMICAL ANALYSES FROM SELECTED WELLS IN PARTS OF THE TRANSPECOS REGION, TEXAS, 1968-1980: TEXAS WATER DEVELOPMENT BOARD REPORT 301, 1987.

PUBLIC SUPPLY GROUND-WATER USE IN WESTERN TEXAS: TEXAS WATER DEVELOPMENT BOARD REPORT 311, 1989.

AQUIFERS OF TEXAS: TEXAS WATER DEVELOPMENT BOARD REPORT 345, 1995.

WATER-RESOURCES DATA, TEXAS, WATER YEAR 1995, VOLUME 4, GROUND-WATER DATA: USGS WATER-DATA REPORT TX-95-4, 1996.

CHLOROFLUOROCARBON AND TRITIUM AGE DETERMINATION OF GROUND-WATER RECHARGE IN THE RYAN FLAT SUBBASIN, TRANS-PECOS TEXAS: USGS WATER-RESOURCES INVESTIGATIONS REPORT 96-4245, 1997.

DELINEATION OF THE GROUND-WATER FLOW SYSTEMS OF THE EAGLE FLAT AND RED LIGHT BASINS OF TRANS-PECOS TEXAS: THE UNIVERSITY OF TEXAS AT AUSTIN, DOCTORAL DISSERTATION, 1997.

CHANGES IN GROUNDWATER CONDITIONS IN PARTS OF TRANSPECOS TEXAS, 1988-1998: TEXAS WATER DEVELOPMENT BOARD REPORT 348, 1999.

IGNEOUS AQUIFER SYSTEM OF BREWSTER, JEFF DAVIS, AND PRESIDIO COUNTIES, TEXAS: LBG-GUYTON ASSOCIATES, WATER PROSPECTING AND RESOURCE CONSULTING, LLC., AND SUL ROSS UNIVERSITY, 2001.

AQUIFERS OF WEST TEXAS: TEXAS WATER DEVELOPMENT BOARD REPORT 356, 2001.

EVALUATION OF GROUND-WATER RECHARGE IN BASINS OF TRANS-PECOS TEXAS, CHAPTER 4, in AQUIFERS OF WEST TEXAS: TEXAS WATER DEVELOPMENT BOARD REPORT 356, 2001.

REGIONAL GROUND-WATER FLOW SYSTEMS IN TRANS-PECOS TEXAS, CHAPTER 4, in AQUIFERS OF WEST TEXAS: TEXAS WATER DEVELOPMENT BOARD REPORT 356, 2001

HYDROGEOLOGY OF THE SALT BASIN, CHAPTER 17, in AQUIFERS OF WEST TEXAS: TEXAS WATER DEVELOPMENT BOARD REPORT 356, 2001.

IGNEOUS AQUIFERS OF FAR WEST TEXAS, CHAPTER 13, in AQUIFERS OF WEST TEXAS: TEXAS WATER DEVELOPMENT BOARD REPORT 356, 2001.

\section{RAINS COUNTY}

UNDERGROUND WATERS OF THE COASTAL PLAIN OF TEXAS: USGS WATER-SUPPLY PAPER 190, 1907.

RECORDS OF WELLS, SPRINGS, DRILLERS' LOGS, WATER ANALYSES, AND MAP SHOWING LOCATIONS OF WELLS AND SPRINGS IN RAINS COUNTY, TEXAS: TEXAS BOARD OF WATER ENGINEERS MISCELLANEOUS PUBLICATION 223, 1943.

PUBLIC WATER SUPPLIES IN EASTERN TEXAS, V. 2, HARRISON COUNTY THROUGH WOOD COUNTY: TEXAS BOARD OF WATER ENGINEERS MISCELLANEOUS PUBLICATION 214, V. 2, 1945.
PUBLIC WATER SUPPLIES IN EASTERN TEXAS: USGS WATERSUPPLY PAPER 1047, 1948.

RECONNAISSANCE INVESTIGATION OF THE GROUND-WATER RESOURCES OF THE SABINE RIVER BASIN, TEXAS: TEXAS WATER COMMISSION BULLETIN 6307, 1963.

GROUND-WATER RESOURCES OF RAINS AND VAN ZANDT COUNTIES, TEXAS: TEXAS WATER DEVELOPMENT BOARD REPORT $169,1973$.

SUMMARY APPRAISALS OF THE NATION'S GROUND-WATER RESOURCES-TEXAS-GULF REGION: USGS PROFESSIONAL PAPER 813-F, 1976.

WATER-QUALITY DATA FOR AQUIFERS, STREAMS, AND LAKES IN THE VICINITY OF KEECHI, MOUNT SYLVAN, OAKWOOD, AND PALESTINE SALT DOMES, NORTHEAST TEXAS SALT-DOME BASIN: USGS OPEN-FILE REPORT 80-2037, 1980

GEOHYDROLOGY OF THE KEECHI, MOUNT SYLVAN, OAKWOOD, AND PALESTINE SALT DOMES IN THE NORTHEAST TEXAS SALTDOME BASIN: USGS OPEN-FILE REPORT 80-2044, 1980.

GEOLOGY AND GEOHYDROLOGY OF THE EAST TEXAS BASIN-A REPORT ON THE PROGRESS OF NUCLEAR WASTE ISOLATION FEASIBILITY STUDIES (1979): UNIVERSITY OF TEXAS, BUREAU OF ECONOMIC GEOLOGY GEOLOGICAL CIRCULAR 80-12, 1980.

GEOLOGY AND GEOHYDROLOGY OF THE EAST TEXAS BASIN-A REPORT ON THE PROGRESS OF NUCLEAR WASTE ISOLATION FEASIBILITY STUDIES (1980): UNIVERSITY OF TEXAS, BUREAU OF ECONOMIC GEOLOGY GEOLOGICAL CIRCULAR 81-7, 1981.

SPRINGS OF TEXAS, VOLUME 1: (BY GUNNAR BRUNE), BRANCHSMITH, INC., FORT WORTH, TEXAS, 1981.

TEXAS GROUND-WATER RESOURCES, in NATIONAL WATER SUMMARY 1984: USGS WATER-SUPPLY PAPER 2275, 1985.

APPROXIMATE POTENTIOMETRIC SURFACES FOR THE AQUIFERS OF THE COASTAL UPLANDS SYSTEM, 1980: USGS HYDROLOGIC INVESTIGATIONS ATLAS HA-704, 1987.

HYDROGEOLOGY AND PREDEVELOPMENT FLOW IN THE TEXAS GULF COAST AQUIFER SYSTEMS: USGS WATER-RESOURCES INVESTIGATIONS REPORT 87-4248, 1988.

GEOHYDROLOGIC FRAMEWORK OF THE GULF COASTAL PLAIN: USGS HYDROLOGIC INVESTIGATIONS ATLAS HA-695, 1988.

GROUND-WATER FLOW IN THE GULF COAST AQUIFER SYSTEMS, SOUTH-CENTRAL UNITED STATES-A PRELIMINARY ANALYSIS USGS WATER-RESOURCES INVESTIGATIONS REPORT 89-4071, 1990.

HYDROLOGY OF THE TEXAS GULF COAST AQUIFER SYSTEMS: USGS OPEN-FILE REPORT 91-64, 1991

PROPERTIES AND CHEMICAL CONSTITUENTS IN GROUND WATER FROM THE MIDDLE WILCOX AQUIFER, GULF COAST AQUIFER SYSTEMS, SOUTH-CENTRAL UNITED STATES: USGS WATERRESOURCES INVESTIGATIONS REPORT 93-4070, 1993.

AQUIFERS OF TEXAS: TEXAS WATER DEVELOPMENT BOARD REPORT 345, 1995. 


\section{RANDALL COUNTY}

THE GEOLOGY AND WATER RESOURCES OF THE WESTERN PORTION OF THE PANHANDLE OF TEXAS: USGS WATER-SUPPLY PAPER 191, 1907.

GEOLOGY AND WATER RESOURCES IN THE VICINITY OF AMARILLO, TEXAS: USGS OPEN-FILE REPORT (UNNUMBERED), 1927.

GEOLOGY AND GROUND-WATER RESOURCES OF THE SOUTHERN HIGH PLAINS: USGS OPEN-FILE REPORT (UNNUMBERED), 1935.

RECORDS OF WELLS AND SPRINGS, DRILLERS' LOGS, AND WATER ANALYSES, AND MAP SHOWING LOCATION OF WELLS AND SPRINGS IN RANDALL COUNTY, TEXAS: TEXAS BOARD OF WATER ENGINEERS MISCELLANEOUS PUBLICATION 224, 1938.

GROUND WATER IN THE HIGH PLAINS OF TEXAS: TEXAS BOARD OF WATER ENGINEERS MISCELLANEOUS PUBLICATION (UNNUMBERED), 1938.

GROUND WATER IN VICINITY OF SITE OF U.S. VETERANS HOSPITAL, AMARILLO, TEXAS: USGS OPEN-FILE REPORT (UNNUMBERED), 1939.

GROUND WATER IN THE HIGH PLAINS OF TEXAS: TEXAS BOARD OF WATER ENGINEERS MISCELLANEOUS PUBLICATION 119, 1940.

SOURCE OF WATER (PANTEX ORDNANCE PLANT): USGS OPEN-FILE REPORT (UNNUMBERED), 1942.

PROGRESS REPORT ON GROUND WATER IN THE HIGH PLAINS OF TEXAS: TEXAS BOARD OF WATER ENGINEERS MISCELLANEOUS PUBLICATION (UNNUMBERED), 1942.

GROUND-WATER RESOURCES IN THE VICINITY OF AMARILLO, TEXAS: USGS OPEN-FILE REPORT (UNNUMBERED), 1942.

PROGRESS REPORT ON GROUND WATER IN THE HIGH PLAINS OF TEXAS: TEXAS BOARD OF WATER ENGINEERS MISCELLANEOUS PUBLICATION 120, 1943.

PROGRESS REPORT ON GROUND WATER IN THE HIGH PLAINS OF TEXAS: TEXAS BOARD OF WATER ENGINEERS MISCELLANEOUS PUBLICATION 121, 1944.

GROUND WATER IN HIGH PLAINS OF TEXAS, PROGRESS REPORT NO. 5: TEXAS BOARD OF WATER ENGINEERS MISCELLANEOUS PUBLICATION 122, 1945.

GROUND WATER IN THE HIGH PLAINS OF TEXAS: USGS WATERSUPPLY PAPER 889-F, 1946.

GROUND-WATER RESOURCES OF THE AREA SOUTHWEST OF AMARILLO, TEXAS: TEXAS BOARD OF WATER ENGINEERS MISCELLANEOUS PUBLICATION 1, 1946.

GROUND WATER IN HIGH PLAINS OF TEXAS, PROGRESS REPORT NO. 6: TEXAS BOARD OF WATER ENGINEERS MISCELLANEOUS PUBLICATION 123, 1947

AN INVESTIGATION OF UNDERGROUND WATER IN SOUTHWESTERN POTTER COUNTY AND NORTHWESTERN RANDALL COUNTY, TEXAS; SUMMARY AND CONCLUSIONS: USGS OPENFILE REPORT (UNNUMBERED), 1948.

PUBLIC WATER SUPPLIES IN WESTERN TEXAS: TEXAS BOARD OF WATER ENGINEERS MISCELLANEOUS PUBLICATION 216, 1949.

GROUND WATER IN THE VICINITY OF AMARILLO AND LUBBOCK, TEXAS: USGS OPEN-FILE REPORT (UNNUMBERED), 1949.
GEOLOGY AND GROUND WATER IN THE IRRIGATED REGION OF THE SOUTHERN HIGH PLAINS IN TEXAS, PROGRESS REPORT NO. 7: TEXAS BOARD OF WATER ENGINEERS MISCELLANEOUS PUBLICATION 125, 1949.

COST OF PUMPING WATER FOR IRRIGATION, TEXAS HIGH PLAINS, FIELD INVESTIGATIONS-1947 IRRIGATION SEASON: TEXAS BOARD OF WATER ENGINEERS MISCELLANEOUS PUBLICATION 124, 1951.

PUBLIC WATER SUPPLIES IN WESTERN TEXAS: USGS WATERSUPPLY PAPER 1106, 1951 [1952].

DEVELOPMENT OF WELLS FOR IRRIGATION AND FLUCTUATION OF WATER LEVELS IN THE HIGH PLAINS OF TEXAS TO JANUARY 1951: TEXAS BOARD OF WATER ENGINEERS BULLETIN 5104, 1951.

SUMMARY OF REPORTS ON GROUND-WATER RESOURCES NEAR AMARILLO, TEXAS: USGS OPEN-FILE REPORT (UNNUMBERED), 1952.

SUMMARY OF GROUND-WATER DEVELOPMENT IN THE SOUTHERN HIGH PLAINS, TEXAS: TEXAS BOARD OF WATER ENGINEERS BULLETIN 5402, 1954.

RECORDS OF WATER-LEVEL MEASUREMENTS IN BAILEY, CASTRO, PARMER, POTTER, AND RANDALL COUNTIES, TEXAS: TEXAS BOARD OF WATER ENGINEERS BULLETIN 5406, 1954.

GROUND-WATER DEVELOPMENT IN THE SOUTHERN HIGH PLAINS OF TEXAS, 1953: TEXAS BOARD OF WATER ENGINEERS BULLETIN 5410, 1954

WATER-LEVEL DECLINE MAPS OF 16 COUNTIES IN THE SOUTHERN HIGH PLAINS, TEXAS, JANUARY 1954 TO JANUARY 1955: (BAILEY, BRISCOE, CASTRO, COCHRAN, CROSBY, DEAF SMITH, FLOYD, GAINES, HALE, HOCKLEY, LAMB, LUBBOCK, PARMER, RANDALL, SWISHER, AND TERRY): USGS OPEN-FILE REPORT (UNNUMBERED), 1955.

WATER-LEVEL DECLINE MAPS OF 17 COUNTIES IN THE SOUTHERN HIGH PLAINS, TEXAS, JANUARY 1955 TO JANUARY 1956: TEXAS BOARD OF WATER ENGINEERS BULLETIN 5607, 1956.

ARTIFICIAL-RECHARGE EXPERIMENTS AT McDONALD WELL FIELD, AMARILLO, TEXAS: TEXAS BOARD OF WATER ENGINEERS BULLETIN 5701, 1957.

WATER-LEVEL DECLINE MAPS, 1956 TO 1957, AND WATER LEVELS IN OBSERVATION WELLS IN 20 COUNTIES IN THE SOUTHERN HIGH PLAINS, TEXAS: TEXAS BOARD OF WATER ENGINEERS BULLETIN 5705, 1957.

WATER-LEVEL MEASUREMENTS AND MAPS, SOUTHERN HIGH PLAINS, TEXAS, 1958 AND 1959: TEXAS BOARD OF WATER ENGINEERS BULLETIN 5908, 1959.

WATER LEVELS IN OBSERVATION WELLS, SOUTHERN HIGH PLAINS, TEXAS, 1959 AND 1960: TEXAS BOARD OF WATER ENGINEERS BULLETIN 6011, 1960.

RECONNAISSANCE INVESTIGATION OF THE GROUND-WATER RESOURCES OF THE CANADIAN RIVER BASIN, TEXAS: TEXAS BOARD OF WATER ENGINEERS BULLETIN 6016, 1960.

REVIEW OF THE PROPOSED SUNDAY CANYON RESERVOIR PROJECT, PALO DURO STATE PARK, TEXAS: TEXAS BOARD OF WATER ENGINEERS OPEN-FILE REPORT, 1961. 
WATER LEVELS IN OBSERVATION WELLS, SOUTHERN HIGH PLAINS, TEXAS, 1960 AND 1961: TEXAS BOARD OF WATER ENGINEERS BULLETIN 6101, 1961.

A SUMMARY OF THE OCCURRENCE AND DEVELOPMENT OF GROUND WATER IN THE SOUTHERN HIGH PLAINS OF TEXAS: TEXAS BOARD OF WATER ENGINEERS BULLETIN 6107, 1961.

WATER-LEVEL MEASUREMENTS THROUGH 1962 IN SELECTED OBSERVATION WELLS, SOUTHERN HIGH PLAINS, TEXAS: TEXAS WATER COMMISSION BULLETIN 6207, 1962.

RECONNAISSANCE INVESTIGATION OF THE GROUND-WATER RESOURCES OF THE RED RIVER, SULPHUR RIVER, AND CYPRESS CREEK BASINS, TEXAS: TEXAS WATER COMMISSION BULLETIN 6306, 1963.

A SUMMARY OF THE OCCURRENCE AND DEVELOPMENT OF GROUND WATER IN THE SOUTHERN HIGH PLAINS OF TEXAS, WITH A SECTION ON ARTIFICIAL RECHARGE STUDIES: USGS WATER-SUPPLY PAPER 1693, 1964.

WATER-LEVEL DATA FROM OBSERVATION WELLS IN THE SOUTHERN HIGH PLAINS OF TEXAS: TEXAS WATER DEVELOPMENT BOARD REPORT 21, 1966.

COMPILATION OF RESULTS OF AQUIFER TESTS IN TEXAS: TEXAS WATER DEVELOPMENT BOARD REPORT 98, 1969.

WATER-LEVEL DATA FROM OBSERVATION WELLS IN THE SOUTHERN HIGH PLAINS OF TEXAS, 1965-70: TEXAS WATER DEVELOPMENT BOARD REPORT 121, 1970;

AN EVALUATION OF THE USE OF DRILLERS' LOGS IN LITHOLOGIC STUDIES OF THE OGALLALA FORMATION OF THE SOUTHERN HIGH PLAINS OF TEXAS: USGS OPEN-FILE REPORT 72-451, 1972.

WATER-LEVEL DATA FROM OBSERVATION WELLS IN THE SOUTHERN HIGH PLAINS OF TEXAS 1971-77: TEXAS DEPARTMENT OF WATER RESOURCES REPORT 228, 1979.

PRELIMINARY DATA DESCRIBING THE DISTRIBUTION OF FLUORIDE AND SILICA IN THE OGALLALA AQUIFER ON THE HIGH PLAINS OF TEXAS: USGS OPEN-FILE REPORT 80-349, 1980.

ANALYTICAL STUDY OF THE OGALLALA AQUIFER IN RANDALL COUNTY, TEXAS—PROJECTIONS OF SATURATED THICKNESS, VOLUME OF WATER IN STORAGE, PUMPAGE RATES, PUMPING LIFTS, AND WELL YIELDS: TEXAS DEPARTMENT OF WATER RESOURCES REPORT 250, 1980.

WATER TABLE IN THE HIGH PLAINS AQUIFER IN 1978 IN PARTS OF COLORADO, KANSAS, NEBRASKA, NEW MEXICO, OKLAHOMA, SOUTH DAKOTA, TEXAS, AND WYOMING: USGS HYDROLOGIC INVESTIGATIONS ATLAS HA-642, 1980.

EVALUATING THE GROUND-WATER RESOURCES OF THE HIGH PLAINS OF TEXAS: RESULTS OF TEST HOLE DRILLING: TEXAS DEPARTMENT OF WATER RESOURCES LIMITED PRINTING REPORT LP-129, 1980.

EVALUATING THE GROUND-WATER RESOURCES OF THE HIGH PLAINS OF TEXAS: RESULTS OF SURFACE ELECTRICAL RESISTIVITY SURVEYS: TEXAS DEPARTMENT OF WATER RESOURCES LIMITED PRINTING REPORT LP-130, 1980.

EVALUATING THE GROUND-WATER RESOURCES OF THE HIGH PLAINS OF TEXAS: NEUTRON-PROBE MEASUREMENTS OF DEEP SOIL MOISTURE AS AN INDICATION OF AQUIFER RECHARGE RATES: TEXAS DEPARTMENT OF WATER RESOURCES LIMITED PRINTING REPORT LP-142, 1981.
SPRINGS OF TEXAS, VOLUME 1: (BY GUNNAR BRUNE), BRANCHSMITH, INC., FORT WORTH, TEXAS, 1981.

BEDROCK GEOLOGY, ALTITUDE OF BASE, AND 1980 SATURATED THICKNESS OF THE HIGH PLAINS AQUIFER IN PARTS OF COLORADO, KANSAS, NEBRASKA, NEW MEXICO, OKLAHOMA, SOUTH DAKOTA, TEXAS, AND WYOMING: USGS HYDROLOGIC INVESTIGATIONS ATLAS HA-648, 1981.

WATER-LEVEL AND SATURATED-THICKNESS CHANGES, PREDEVELOPMENT TO 1980, IN THE HIGH PLAINS AQUIFER IN PARTS OF COLORADO, KANSAS, NEBRASKA, NEW MEXICO, OKLAHOMA, SOUTH DAKOTA, TEXAS, AND WYOMING: USGS HYDROLOGIC INVESTIGATIONS ATLAS HA-652, 1981.

DISSOLVED SOLIDS AND SODIUM IN WATER FROM THE HIGH PLAINS AQUIFER IN PARTS OF COLORADO, KANSAS, NEBRASKA, NEW MEXICO, OKLAHOMA, SOUTH DAKOTA, TEXAS, AND WYOMING: USGS HYDROLOGIC INVESTIGATIONS ATLAS HA-658, 1982

ANALYTICAL STUDY OF THE OGALLALA AQUIFER IN POTTER AND OLDHAM COUNTIES, TEXAS-PROJECTIONS OF SATURATED THICKNESS, VOLUME OF WATER IN STORAGE, PUMPING RATES, PUMPING LIFTS, AND WELL YIELDS: TEXAS DEPARTMENT OF WATER RESOURCES REPORT 265, 1982.

GEOHYDROLOGY OF THE HIGH PLAINS AQUIFER IN PARTS OF COLORADO, KANSAS, NEBRASKA, NEW MEXICO, OKLAHOMA, SOUTH DAKOTA, TEXAS, AND WYOMING: USGS PROFESSIONAL PAPER 1400-B, 1984.

EVALUATING THE GROUND-WATER RESOURCES OF THE HIGH PLAINS OF TEXAS, VOLUME 1: TEXAS DEPARTMENT OF WATER RESOURCES REPORT 288, V. 1, 1984.

EVALUATING THE GROUND-WATER RESOURCES OF THE HIGH PLAINS OF TEXAS, VOLUME 3, RECORDS OF WELLS, AND MAPS SHOWING WELL LOCATIONS, BASE OF AQUIFER, WATER LEVELS, AND SATURATED THICKNESS (BAILEY, BRISCOE, CASTRO, CROSBY, DEAF SMITH, DICKENS, FLOYD, HALE, LAMB, MOTLEY, OLDHAM, PARMER, RANDALL, AND SWISHER COUNTIES): TEXAS DEPARTMENT OF WATER RESOURCES REPORT 288, V. 3 , 1984.

TEXAS GROUND-WATER RESOURCES, in NATIONAL WATER SUMMARY 1984: USGS WATER-SUPPLY PAPER 2275, 1985.

WATER USE, PROJECTED WATER REQUIREMENTS, AND RELATED DATA AND INFORMATION FOR THE METROPOLITAN STATISTICAL AREAS IN TEXAS: TEXAS DEPARTMENT OF WATER RESOURCES LIMITED PRINTING REPORT LP-201, 1985.

DIGITAL SIMULATION OF GROUND-WATER FLOW IN THE HIGH PLAINS AQUIFER IN PARTS OF COLORADO, KANSAS, NEBRASKA, NEW MEXICO, OKLAHOMA, SOUTH DAKOTA, TEXAS, AND WYOMING: USGS PROFESSIONAL PAPER 1400-D, 1986.

SUMMARY OF THE HIGH PLAINS REGIONAL AQUIFER-SYSTEM ANALYSIS IN PARTS OF COLORADO, KANSAS, NEBRASKA, NEW MEXICO, OKLAHOMA, SOUTH DAKOTA, TEXAS, AND WYOMING: USGS PROFESSIONAL PAPER 1400-A, 1988.

WATER-LEVEL CHANGES IN THE HIGH PLAINS AQUIFER OF TEXAS, 1980-1990: TEXAS WATER DEVELOPMENT BOARD HYDROLOGIC ATLAS NO. 1, 1991.

PUBLIC-SUPPLY GROUND-WATER USE IN THE NORTHERN HIGH PLAINS OF TEXAS: TEXAS WATER DEVELOPMENT BOARD REPORT 336, 1992 
EVALUATION OF WATER RESOURCES IN PARTS OF THE ROLLING PRAIRIES REGION OF NORTH-CENTRAL TEXAS: TEXAS WATER DEVELOPMENT BOARD REPORT 337, 1992.

THE HIGH PLAINS AQUIFER SYSTEM OF TEXAS, 1980-1990. OVERVIEW AND PROJECTIONS: TEXAS WATER DEVELOPMENT BOARD REPORT 341, 1993.

WATER-QUALITY EVALUATION OF THE OGALLALA AQUIFER, TEXAS: TEXAS WATER DEVELOPMENT BOARD REPORT 342, 1993.

WATER-LEVEL CHANGES IN THE HIGH PLAINS AQUIFER-PREDEVELOPMENT TO 1992: USGS WATER-RESOURCES INVESTIGATIONS REPORT 94-4027, 1994.

WATER-LEVEL CHANGES IN THE HIGH PLAINS AQUIFER, 1980 TO 1994: USGS FACT SHEET FS-215-95, 1995.

AQUIFERS OF TEXAS: TEXAS WATER DEVELOPMENT BOARD REPORT 345, 1995.

HYDROLOGIC ATLAS FOR RANDALL COUNTY, TEXAS: HIGH PLAINS UNDERGROUND WATER CONSERVATION DISTRICT NO. 1, LUBBOCK, TEXAS, 1996.

WATER-RESOURCES DATA, TEXAS, WATER YEAR 1995, VOLUME 4, GROUND-WATER DATA: USGS WATER-DATA REPORT TX-95-4, 1996.

WATER-LEVEL CHANGES IN THE HIGH PLAINS AQUIFER, 1980 TO 1995: USGS FACT SHEET FS-068-97, 1997.

WATER-LEVEL CHANGES IN THE HIGH PLAINS AQUIFER-PREDEVELOPMENT TO 1995: USGS WATER-RESOURCES INVESTIGATIONS REPORT 97-4081, 1997.

PLAYAS AND RECHARGE OF THE OGALLALA AQUIFER ON THE SOUTHERN HIGH PLAINS OF TEXAS-AN EXAMINATION USING NUMERICAL TECHNIQUES: UNIVERSITY OF TEXAS, BUREAU OF ECONOMIC GEOLOGY REPORT OF INVESTIGATIONS NO. 242, 1997.

SPATIAL VARIABILITY IN UNSATURATED FLOW BENEATH PLAYA AND ADJACENT INTERPLAYA SETTINGS AND IMPLICATIONS FOR CONTAMINANT TRANSPORT, SOUTHERN HIGH PLAINS, TEXAS: UNIVERSITY OF TEXAS, BUREAU OF ECONOMIC GEOLOGY REPORT OF INVESTIGATIONS NO. 243, 1997.

UPDATED WATER-QUALITY EVALUATION OF THE OGALLALA AQUIFER INCLUDING SELECTED METALLIC AND NON-METALLIC INORGANIC CONSTITUENTS: TEXAS WATER DEVELOPMENT BOARD HYDROLOGIC ATLAS NO. 10, 1998.

\section{REAGAN COUNTY}

PUBLIC WATER SUPPLIES IN WESTERN TEXAS: TEXAS BOARD OF WATER ENGINEERS MISCELLANEOUS PUBLICATION 216, 1949.

PUBLIC WATER SUPPLIES IN WESTERN TEXAS: USGS WATERSUPPLY PAPER 1106, 1951.

RECORDS OF WATER-LEVEL MEASUREMENTS IN CROCKETT, GLASSCOCK, REAGAN, UPTON, AND TERRELL COUNTIES, TEXAS, 1937 THROUGH 1957: TEXAS BOARD OF WATER ENGINEERS BULLETIN 5903, 1959.
RECONNAISSANCE INVESTIGATION OF THE GROUND-WATER RESOURCES OF THE RIO GRANDE BASIN, TEXAS: TEXAS WATER COMMISSION BULLETIN 6502, 1965.

RECONNAISSANCE INVESTIGATION OF THE GROUND-WATER RESOURCES OF THE COLORADO RIVER BASIN, TEXAS: TEXAS WATER DEVELOPMENT BOARD REPORT 51, 1967.

WATER WELL AND GROUND-WATER CHEMICAL ANALYSIS DATA, REAGAN COUNTY, TEXAS: TEXAS WATER DEVELOPMENT BOARD REPORT 145, 1972

MAJOR AND HISTORICAL SPRINGS OF TEXAS: TEXAS WATER DEVELOPMENT BOARD REPORT 189, 1975.

SUMMARY APPRAISALS OF THE NATION'S GROUND-WATER RESOURCES-TEXAS-GULF REGION: USGS PROFESSIONAL PAPER 813-F, 1976.

OCCURRENCE, AVAILABILITY, AND CHEMICAL QUALITY OF GROUND WATER IN THE EDWARDS PLATEAU REGION OF TEXAS: TEXAS DEPARTMENT OF WATER RESOURCES REPORT $235,1979$.

TEXAS GROUND-WATER RESOURCES, in NATIONAL WATER SUMMARY 1984: USGS WATER-SUPPLY PAPER 2275, 1985.

PUBLIC SUPPLY GROUND-WATER USE IN WESTERN TEXAS: TEXAS WATER DEVELOPMENT BOARD REPORT 311, 1989.

EVALUATION OF GROUND-WATER RESOURCES IN PARTS OF MIDLAND, REAGAN, AND UPTON COUNTIES, TEXAS: TEXAS WATER DEVELOPMENT BOARD REPORT 312, 1989.

POTENTIOMETRIC SURFACE OF THE EDWARDS-TRINITY AQUIFER SYSTEM AND CONTIGUOUS HYDRAULICALLY CONNECTED UNITS, WEST-CENTRAL TEXAS, WINTER 1974-75: USGS WATERRESOURCES INVESTIGATIONS REPORT 89-4208, 1990.

WITHDRAWALS FROM THE EDWARDS-TRINITY AQUIFER SYSTEM AND CONTIGUOUS HYDRAULICALLY CONNECTED UNITS, WEST-CENTRAL TEXAS, DECEMBER 1974 THROUGH MARCH 1977: USGS WATER-RESOURCES INVESTIGATIONS REPORT 91-4021, 1991.

CONFIGURATION OF THE BASE OF THE EDWARDS-TRINITY AQUIFER SYSTEM AND HYDROGEOLOGY OF THE UNDERLYING PRECRETACEOUS ROCKS, WEST-CENTRAL TEXAS: USGS WATERRESOURCES INVESTIGATIONS REPORT 91-4071, 1992.

HISTORICAL POTENTIOMETRIC SURFACE OF THE EDWARDS-TRINITY AQUIFER SYSTEM AND CONTIGUOUS HYDRAULICALLY CONNECTED UNITS, WEST-CENTRAL TEXAS: USGS WATERRESOURCES INVESTIGATIONS REPORT 92-4055, 1993.

HISTORICAL SATURATED THICKNESS OF THE EDWARDS-TRINITY AQUIFER SYSTEM AND SELECTED CONTIGUOUS HYDRAULICALLY CONNECTED UNITS, WEST-CENTRAL TEXAS: USGS WATER-RESOURCES INVESTIGATIONS REPORT 92-4125, 1993.

SIMULATIONS OF FLOW IN THE EDWARDS-TRINITY AQUIFER SYSTEM AND CONTIGUOUS HYDRAULICALLY CONNECTED UNITS, WEST-CENTRAL TEXAS: USGS WATER-RESOURCES INVESTIGATIONS REPORT 93-4039, 1994.

DISSOLVED-SOLIDS CONCENTRATIONS AND HYDROCHEMICAL FACIES IN WATER OF THE EDWARDS-TRINITY AQUIFER SYSTEM, WEST-CENTRAL TEXAS: USGS WATER-RESOURCES INVESTIGATIONS REPORT 93-4126, 1994.

GEOLOGIC HISTORY AND HYDROGEOLOGIC SETTING OF THE EDWARDS-TRINITY AQUIFER SYSTEM, WEST-CENTRAL TEXAS: 
USGS WATER-RESOURCES INVESTIGATIONS REPORT 94-4039, 1994.

AQUIFERS OF TEXAS: TEXAS WATER DEVELOPMENT BOARD REPORT 345, 1995.

WATER QUALITY IN THE EDWARDS-TRINITY (PLATEAU) AQUIFER, EDWARDS PLATEAU AND TRANS PECOS, TEXAS: TEXAS WATER DEVELOPMENT BOARD HYDROLOGIC ATLAS NO. 3, 1995.

AN OVERVIEW OF THE EDWARDS-TRINITY AQUIFER SYSTEM, CENTRAL-WEST TEXAS, CHAPTER 8, in AQUIFERS OF WEST TEXAS: TEXAS WATER DEVELOPMENT BOARD REPORT 356, 2001.

\section{REAL COUNTY}

SUPPLEMENTARY REPORT ON SURFACE-WATER AND GROUNDWATER SURVEYS, NUECES RIVER BASIN, TEXAS: USGS OPENFILE REPORT (UNNUMBERED), 1950.

GROUND AND SURFACE WATERS IN WILLIAMS RANCH AREA, SOUTHEAST REAL COUNTY, TEXAS: USGS OPEN-FILE REPORT (UNNUMBERED), 1951.

GROUND-WATER RESOURCES OF THE SAN ANTONIO AREA, TEXAS, A PROGRESS REPORT OF CURRENT STUDIES: TEXAS BOARD OF WATER ENGINEERS BULLETIN 5412, 1954.

GROUND-WATER GEOLOGY OF REAL COUNTY, TEXAS: TEXAS BOARD OF WATER ENGINEERS BULLETIN 5803, 1958.

CHEMICAL AND BACTERIOLOGICAL QUALITY OF WATER AT SELECTED SITES IN THE SAN ANTONIO AREA, TEXAS, AUGUST 1968-APRIL 1972: EDWARDS UNDERGROUND WATER DISTRICT, 1972.

RELATION OF PRECIPITATION TO ANNUAL GROUND-WATER RECHARGE IN THE EDWARDS AQUIFER, SAN ANTONIO AREA, TEXAS: USGS OPEN-FILE REPORT 75-298, 1975.

MAJOR AND HISTORICAL SPRINGS OF TEXAS: TEXAS WATER DEVELOPMENT BOARD REPORT 189, 1975.

SUMMARY APPRAISALS OF THE NATION'S GROUND-WATER RESOURCES-TEXAS-GULF REGION: USGS PROFESSIONAL PAPER 813-F, 1976.

METHOD OF ESTIMATING NATURAL RECHARGE TO THE EDWARDS AQUIFER IN THE SAN ANTONIO AREA, TEXAS: USGS WATERRESOURCES INVESTIGATIONS REPORT 78-10, 1978.

REGIONAL DISTRIBUTION OF FRACTURES IN THE SOUTHERN EDWARDS PLATEAU AND THEIR RELATIONSHIP TO TECTONICS AND CAVES: UNIVERSITY OF TEXAS, BUREAU OF ECONOMIC GEOLOGY GEOLOGICAL CIRCULAR 78-2, 1978.

RECORDS OF GROUND-WATER RECHARGE AND DISCHARGE FOR THE EDWARDS AQUIFER IN THE SAN ANTONIO AREA, TEXAS, 1934-77: EDWARDS UNDERGROUND WATER DISTRICT BULLETIN 37, 1979.

OCCURRENCE, AVAILABILITY, AND CHEMICAL QUALITY OF GROUND WATER IN THE EDWARDS PLATEAU REGION OF TEXAS: TEXAS DEPARTMENT OF WATER RESOURCES REPORT $235,1979$.

RECORDS OF GROUND-WATER RECHARGE, DISCHARGE, WATER LEVELS, AND CHEMICAL QUALITY OF WATER FOR THE EDWARDS AQUIFER IN THE SAN ANTONIO AREA, TEXAS,
1934-78: EDWARDS UNDERGROUND WATER DISTRICT BULLETIN 38, 1980.

RECORDS OF GROUND-WATER RECHARGE, DISCHARGE, WATER LEVELS, AND CHEMICAL QUALITY OF WATER FOR THE EDWARDS AQUIFER IN THE SAN ANTONIO AREA, TEXAS, 1934-79: EDWARDS UNDERGROUND WATER DISTRICT BULLETIN 39, 1981.

RECORDS OF GROUND-WATER RECHARGE, DISCHARGE, WATER LEVELS, AND CHEMICAL QUALITY OF WATER FOR THE EDWARDS AQUIFER IN THE SAN ANTONIO AREA, TEXAS, 1934-80: EDWARDS UNDERGROUND WATER DISTRICT BULLETIN 40, 1982.

GROUND-WATER AVAILABILITY OF THE LOWER CRETACEOUS FORMATIONS IN THE HILL COUNTRY OF SOUTH-CENTRAL TEXAS: TEXAS DEPARTMENT OF WATER RESOURCES REPORT $273,1983$.

RECORDS OF GROUND-WATER RECHARGE, DISCHARGE, WATER LEVELS, AND CHEMICAL QUALITY OF WATER FOR THE EDWARDS AQUIFER IN THE SAN ANTONIO AREA, TEXAS, 1934-81: EDWARDS UNDERGROUND WATER DISTRICT BULLETIN 41, 1984.

CARBONATE GEOLOGY AND HYDROLOGY OF THE EDWARDS AQUIFER IN THE SAN ANTONIO AREA, TEXAS: USGS OPEN-FILE REPORT 83-537, 1984.

TEXAS GROUND-WATER RESOURCES, in NATIONAL WATER SUMMARY 1984: USGS WATER-SUPPLY PAPER 2275, 1985.

RECORDS OF GROUND-WATER RECHARGE, DISCHARGE, WATER LEVELS, AND CHEMICAL QUALITY OF WATER FOR THE EDWARDS AQUIFER IN THE SAN ANTONIO AREA, TEXAS, 1934-82: EDWARDS UNDERGROUND WATER DISTRICT BULLETIN 42, 1985.

COMPILATION OF HYDROLOGIC DATA FOR THE EDWARDS AQUIFER, SAN ANTONIO AREA, TEXAS, 1983-84, WITH 1934-84 SUMMARY: EDWARDS UNDERGROUND WATER DISTRICT BULLETIN 43-44, 1986.

CARBONATE GEOLOGY AND HYDROLOGY OF THE EDWARDS AQUIFER IN THE SAN ANTONIO AREA, TEXAS: TEXAS WATER DEVELOPMENT BOARD REPORT 296, 1986.

COMPILATION OF HYDROLOGIC DATA FOR THE EDWARDS AQUIFER, SAN ANTONIO AREA, TEXAS, 1985, WITH 1934-85 SUMMARY: EDWARDS UNDERGROUND WATER DISTRICT BULLETIN 45, 1987.

COMPILATION OF HYDROLOGIC DATA FOR THE EDWARDS AQUIFER, SAN ANTONIO AREA, TEXAS, 1986, WITH 1934-86 SUMMARY: EDWARDS UNDERGROUND WATER DISTRICT BULLETIN 46, 1988.

COMPILATION OF HYDROLOGIC DATA FOR THE EDWARDS AQUIFER, SAN ANTONIO AREA, TEXAS, 1987, WITH 1934-87 SUMMARY: EDWARDS UNDERGROUND WATER DISTRICT BULLETIN 47, 1988.

COMPILATION OF HYDROLOGIC DATA FOR THE EDWARDS AQUIFER, SAN ANTONIO AREA, TEXAS, 1988, WITH 1934-88 SUMMARY: EDWARDS UNDERGROUND WATER DISTRICT BULLETIN 48, 1989.

POTENTIOMETRIC SURFACE OF THE EDWARDS-TRINITY AQUIFER SYSTEM AND CONTIGUOUS HYDRAULICALLY CONNECTED 
UNITS, WEST-CENTRAL TEXAS, WINTER 1974-75: USGS WATERRESOURCES INVESTIGATIONS REPORT 89-4208, 1990.

COMPILATION OF HYDROLOGIC DATA FOR THE EDWARDS AQUIFER, SAN ANTONIO AREA, TEXAS, 1989, WITH 1934-89 SUMMARY: EDWARDS UNDERGROUND WATER DISTRICT BULLETIN 49, 1990

WITHDRAWALS FROM THE EDWARDS-TRINITY AQUIFER SYSTEM AND CONTIGUOUS HYDRAULICALLY CONNECTED UNITS, WEST-CENTRAL TEXAS, DECEMBER 1974 THROUGH MARCH 1977: USGS WATER-RESOURCES INVESTIGATIONS REPORT 91-4021, 1991.

COMPILATION OF HYDROLOGIC DATA FOR THE EDWARDS AQUIFER, SAN ANTONIO AREA, TEXAS, 1990, WITH 1934-90 SUMMARY: EDWARDS UNDERGROUND WATER DISTRICT BULLETIN 50, 1991

CONFIGURATION OF THE BASE OF THE EDWARDS-TRINITY AQUIFER SYSTEM AND HYDROGEOLOGY OF THE UNDERLYING PRECRETACEOUS ROCKS, WEST-CENTRAL TEXAS: USGS WATERRESOURCES INVESTIGATIONS REPORT 91-4071, 1992.

COMPILATION OF HYDROLOGIC DATA FOR THE EDWARDS AQUIFER, SAN ANTONIO AREA, TEXAS, 1991, WITH 1934-91 SUMMARY: EDWARDS UNDERGROUND WATER DISTRICT BULLETIN 51,1992

HISTORICAL POTENTIOMETRIC SURFACE OF THE EDWARDS-TRINITY AQUIFER SYSTEM AND CONTIGUOUS HYDRAULICALLY CONNECTED UNITS, WEST-CENTRAL TEXAS: USGS WATERRESOURCES INVESTIGATIONS REPORT 92-4055, 1993.

HISTORICAL SATURATED THICKNESS OF THE EDWARDS-TRINITY AQUIFER SYSTEM AND SELECTED CONTIGUOUS HYDRAULICALLY CONNECTED UNITS, WEST-CENTRAL TEXAS: USGS WATER-RESOURCES INVESTIGATIONS REPORT 92-4125, 1993.

EDWARDS AQUIFER HYDROGEOLOGIC STATUS REPORT FOR 1992: EDWARDS UNDERGROUND WATER DISTRICT REPORT 93-05, 1993.

SIMULATIONS OF FLOW IN THE EDWARDS-TRINITY AQUIFER SYSTEM AND CONTIGUOUS HYDRAULICALLY CONNECTED UNITS, WEST-CENTRAL TEXAS: USGS WATER-RESOURCES INVESTIGATIONS REPORT 93-4039, 1994.

DISSOLVED-SOLIDS CONCENTRATIONS AND HYDROCHEMICAL FACIES IN WATER OF THE EDWARDS-TRINITY AQUIFER SYSTEM, WEST-CENTRAL TEXAS: USGS WATER-RESOURCES INVESTIGATIONS REPORT 93-4126, 1994.

NATIONAL WATER-QUALITY ASSESSMENT PROGRAM-SOUTHCENTRAL TEXAS: USGS FACT SHEET FS-94-048, 1994.

GEOLOGIC HISTORY AND HYDROGEOLOGIC SETTING OF THE EDWARDS-TRINITY AQUIFER SYSTEM, WEST-CENTRAL TEXAS: USGS WATER-RESOURCES INVESTIGATIONS REPORT 94-4039, 1994.

AQUIFERS OF TEXAS: TEXAS WATER DEVELOPMENT BOARD REPORT 345, 1995.

WATER QUALITY IN THE EDWARDS-TRINITY (PLATEAU) AQUIFER, EDWARDS PLATEAU AND TRANS-PECOS, TEXAS: TEXAS WATER DEVELOPMENT BOARD HYDROLOGIC ATLAS NO. 3, 1995.

THE PALEOZOIC AND RELATED AQUIFERS OF CENTRAL TEXAS: TEXAS WATER DEVELOPMENT BOARD REPORT 346, 1996.
HYDROGEOLOGIC FRAMEWORK OF THE EDWARDS-TRINITY AQUIFER SYSTEM, WEST-CENTRAL TEXAS: USGS PROFESSIONAL PAPER 1421-B, 1996.

AN OVERVIEW OF THE EDWARDS-TRINITY AQUIFER SYSTEM, CENTRAL-WEST TEXAS, CHAPTER 8, in AQUIFERS OF WEST TEXAS: TEXAS WATER DEVELOPMENT BOARD REPORT 356, 2001

\section{RED RIVER COUNTY}

GEOGRAPHY AND GEOLOGY OF THE BLACK AND GRAND PRAIRIES OF TEXAS, WITH DETAILED DESCRIPTIONS OF THE CRETACEOUS FORMATIONS AND SPECIAL REFERENCE TO ARTESIAN WATERS: USGS 21ST ANNUAL REPORT, PART 7, 1901.

GEOLOGY AND UNDERGROUND WATERS OF NORTHEASTERN TEXAS: USGS WATER-SUPPLY PAPER 276, 1911.

PUBLIC WATER SUPPLIES IN EASTERN TEXAS, V. 2, HARRISON COUNTY THROUGH WOOD COUNTY: TEXAS BOARD OF WATER ENGINEERS MISCELLANEOUS PUBLICATION 214, V. 2, 1945.

PUBLIC WATER SUPPLIES IN EASTERN TEXAS: USGS WATERSUPPLY PAPER 1047, 1948

MEMORANDUM REGARDING THE AVAILABILITY OF GROUND WATER IN AN AREA 50 MILES NORTHWEST OF TEXARKANA ON THE TEXAS SIDE OF RED RIVER: USGS OPEN-FILE REPORT (UNNUMBERED), 1950.

RECONNAISSANCE INVESTIGATION OF THE GROUND-WATER RESOURCES OF THE RED RIVER, SULFUR RIVER, AND CYPRESS CREEK BASINS, TEXAS: TEXAS WATER COMMISSION BULLETIN 6306, 1963.

COMPILATION OF RESULTS OF AQUIFER TESTS IN TEXAS: TEXAS WATER DEVELOPMENT BOARD REPORT 98, 1969.

WATER-LEVEL AND WATER-QUALITY DATA FROM OBSERVATION WELLS IN NORTHEAST TEXAS: TEXAS WATER DEVELOPMENT BOARD REPORT 198, 1976.

SPRINGS OF TEXAS, VOLUME 1: (BY GUNNAR BRUNE), BRANCHSMITH, INC., FORT WORTH, TEXAS, 1981.

OCCURRENCE, AVAILABILITY, AND CHEMICAL QUALITY OF GROUND WATER IN THE CRETACEOUS AQUIFERS OF NORTHCENTRAL TEXAS: TEXAS DEPARTMENT OF WATER RESOURCES REPORT 269, V. 1, 1982

OCCURRENCE, AVAILABILITY, AND CHEMICAL QUALITY OF GROUND WATER IN THE CRETACEOUS AQUIFERS OF NORTHCENTRAL TEXAS: TEXAS DEPARTMENT OF WATER RESOURCES REPORT 269, V. 2, 1982.

TEXAS GROUND-WATER RESOURCES, in NATIONAL WATER SUMMARY 1984: USGS WATER-SUPPLY PAPER 2275, 1985.

GEOHYDROLOGIC FRAMEWORK OF THE GULF COASTAL PLAIN: USGS HYDROLOGIC INVESTIGATIONS ATLAS HA-695, 1988

GROUND-WATER RESOURCES OF THE NACATOCH AQUIFER: TEXAS WATER DEVELOPMENT BOARD REPORT 305, 1988.

OCCURRENCE, AVAILABILITY, AND CHEMICAL QUALITY OF GROUND WATER IN THE BLOSSOM SAND AQUIFER: TEXAS WATER DEVELOPMENT BOARD REPORT 307, 1988. 
EVALUATION OF WATER RESOURCES IN PART OF NORTH-CENTRAL TEXAS: TEXAS WATER DEVELOPMENT BOARD REPORT $318,1990$.

SIMULATION OF GROUND-WATER FLOW IN THE ANTLERS AQUIFER IN SOUTHEASTERN OKLAHOMA AND NORTHEASTERN TEXAS: USGS WATER-RESOURCES INVESTIGATIONS REPORT 88-4208, 1992.

AQUIFERS OF TEXAS: TEXAS WATER DEVELOPMENT BOARD REPORT 345, 1995.

WATER QUALITY IN THE WOODBINE AQUIFER, NORTH-CENTRAL TEXAS: TEXAS WATER DEVELOPMENT BOARD HYDROLOGIC ATLAS NO. 4, 1996.

UPDATED EVALUATION OF WATER RESOURCES IN PART OF NORTH-CENTRAL TEXAS, 1990-1999: TEXAS WATER DEVELOPMENT BOARD REPORT 349, 1999.

\section{REEVES COUNTY}

LARGE SPRINGS IN THE UNITED STATES: USGS WATER-SUPPLY PAPER 557, 1927.

THE NEW CITY WELL AT PECOS, TEXAS: USGS OPEN-FILE REPORT (UNNUMBERED), 1933.

THE GEOLOGY AND ITS EFFECT ON THE RECHARGE, MOVEMENT, AND DISCHARGE OF THE GROUND WATER: USGS OPEN-FILE REPORT (UNNUMBERED), 1934.

GEOLOGY AND GROUND-WATER RESOURCES OF THE PERMIAN ROCKS IN THE TOYAH BASIN IN WESTERN TEXAS: USGS OPENFILE REPORT (UNNUMBERED), 1934

GEOLOGY AND GROUND-WATER RESOURCES OF THE TRIASSIC ROCKS IN THE TOYAH BASIN IN WESTERN TEXAS: USGS OPENFILE REPORT (UNNUMBERED), 1934.

GEOLOGY AND GROUND-WATER RESOURCES OF THE CRETACEOUS ROCKS IN THE TOYAH BASIN IN WESTERN TEXAS: USGS OPEN-FILE REPORT (UNNUMBERED), 1934.

GEOLOGY AND GROUND-WATER RESOURCES OF THE QUATERNARY ROCKS IN THE TOYAH BASIN IN WESTERN TEXAS: USGS OPEN-FILE REPORT (UNNUMBERED), 1934.

GROUND-WATER RESOURCES OF THE BALMORHEA AREA IN WESTERN TEXAS: TEXAS BOARD OF WATER ENGINEERS MISCELLANEOUS PUBLICATION 11, 1938.

GEOLOGY AND GROUND-WATER RESOURCES OF THE BALMORHEA AREA IN WESTERN TEXAS: USGS WATER-SUPPLY PAPER 849-C, 1941.

PARTIAL RECORDS OF WELLS IN SOUTHEASTERN PART OF REEVES COUNTY, TEXAS: USGS OPEN-FILE REPORT (UNNUMBERED), 1941.

RESULTS OF PLUGGING A LEAKY ARTESIAN WELL AT PECOS JUNIOR HIGH SCHOOL, PECOS, TEXAS: USGS OPEN-FILE REPORT (UNNUMBERED), 1941.

WATER RESOURCES OF THE PECOS RIVER BASIN, VOLUME 1, PECOS RIVER JOINT INVESTIGATION_PART 3, REPORT B, GEOLOGY AND GROUND WATER: TEXAS BOARD OF WATER ENGINEERS MISCELLANEOUS PUBLICATION 209A, V. 1, 1941.
WATER RESOURCES OF THE PECOS RIVER BASIN, VOLUME 2, RECORDS OF WELLS AND SPRINGS AND ANALYSES OF WATER IN LOVING, WARD, REEVES, AND NORTHERN PECOS COUNTIES: TEXAS BOARD OF WATER ENGINEERS MISCELLANEOUS PUBLICATION 209A, V. 2, 1941.

WATER RESOURCES OF THE PECOS RIVER BASIN, VOLUME 3, RECORDS OF AUGER HOLES INCLUDING LOGS, RECORDS OF FLUCTUATIONS OF WATER LEVELS, WATER ANALYSES, AND MAPS SHOWING LOCATIONS OF WELLS: TEXAS BOARD OF WATER ENGINEERS MISCELLANEOUS PUBLICATION 209A, V. 3, 1941.

MEMORANDUM REGARDING THE SITES FOR ADDITIONAL WELLS FOR THE MUNICIPAL SUPPLY AT PECOS, TEXAS: USGS OPENFILE REPORT (UNNUMBERED), 1942.

MEMORANDUM REGARDING WATER SUPPLIES AT PECOS, TEXAS, FOR A PROPOSED BASIC TRAINING SCHOOL OF THE U.S. ARMY AIR CORPS: USGS OPEN-FILE REPORT (UNNUMBERED), 1942.

GROUND WATER AVAILABLE FOR EMERGENCY LANDING FIELDS NEAR FLYING SCHOOL AT PECOS, TEXAS: USGS OPEN-FILE REPORT (UNNUMBERED), 1942.

MEMORANDUM REGARDING THE AVAILABILITY OF GROUND WATER TO SUPPLY AN ALIEN CONCENTRATION CAMP NEAR PECOS, TEXAS: USGS OPEN-FILE REPORT (UNNUMBERED), 1942.

MEMORANDUM REGARDING THE AVAILABILITY OF GROUND WATER FOR IRRIGATION, SPRINKLING, AND DRINKING PURPOSES ON AND NEAR 5 PROPOSED SITES FOR EMERGENCY LANDING FIELDS FOR THE ARMY BASIC-TRAINING FLYING SCHOOL NEAR PECOS, TEXAS: USGS OPEN-FILE REPORT (UNNUMBERED), 1942

GROUND-WATER RESOURCES OF THE TOYAH AREA, REEVES COUNTY, TEXAS: USGS OPEN-FILE REPORT (UNNUMBERED), 1943.

MEMORANDUM; GROUND WATER AT PECOS, TEXAS: USGS OPENFILE REPORT (UNNUMBERED), 1944.

PRELIMINARY REPORT ON GEOLOGY AND GROUND-WATER RESOURCES OF REEVES COUNTY, TEXAS: TEXAS BOARD OF WATER ENGINEERS MISCELLANEOUS PUBLICATION 226, 1947.

PUBLIC WATER SUPPLIES IN WESTERN TEXAS: TEXAS BOARD OF WATER ENGINEERS MISCELLANEOUS PUBLICATION 216, 1949.

PHENOMENAL INCREASE IN IRRIGATION WITH GROUND WATER NEAR PECOS, TEXAS: TEXAS BOARD OF WATER ENGINEERS MISCELLANEOUS PUBLICATION (PRESS RELEASE) (UNNUMBERED), 1950.

RELATIONSHIP OF THE BARSTOW AREA TO THE RESERVOIR IN REEVES COUNTY, TEXAS: USGS OPEN-FILE REPORT (UNNUMBERED), 1951.

MEMORANDUM CONCERNING THE RELATIONSHIP OF PUMPING FROM WELLS IN THE ALLUVIAL RESERVOIR IN REEVES COUNTY, TEXAS, TO WELLS IN THE BARSTOW AREA IN SOUTHWESTERN WARD COUNTY, TEXAS: USGS OPEN-FILE REPORT (UNNUMBERED), 1951.

DEVELOPMENT OF GROUND WATER FOR IRRIGATION IN THE PECOS AREA, REEVES AND WARD COUNTIES, TEXAS: USGS OPEN-FILE REPORT (UNNUMBERED), 1951.

PUBLIC WATER SUPPLIES IN WESTERN TEXAS: USGS WATERSUPPLY PAPER 1106, 1951. 
GEOLOGY AND GROUND-WATER RESOURCES OF THE FORT STOCKTON AREA, TEXAS: USGS OPEN-FILE REPORT (UNNUMBERED), 1951.

SUMMARY OF GROUND-WATER DEVELOPMENT IN THE PECOS AREA, REEVES AND WARD COUNTIES, TEXAS, 1947-51: TEXAS BOARD OF WATER ENGINEERS BULLETIN 5202, 1952.

RECORDS OF WATER-LEVEL MEASUREMENTS IN REEVES COUNTY, TEXAS: TEXAS BOARD OF WATER ENGINEERS BULLETIN 5414, 1954.

SHALLOW FORMATIONS AND AQUIFERS OF THE WEST TEXAS AREA: WEST TEXAS GEOLOGICAL SOCIETY PUBLICATION 61-45 AND PERMIAN BASIN GEOPHYSICAL SOCIETY, MIDLAND, TEXAS, 1961.

GEOLOGY AND GROUND-WATER RESOURCES OF REEVES COUNTY, TEXAS, VOLUME 1, INCLUDES RECORDS OF WELLS: TEXAS WATER COMMISSION BULLETIN 6214, V. 1, 1962.

GEOLOGY AND GROUND-WATER RESOURCES OF REEVES COUNTY, TEXAS, VOLUME 2, DRILLERS' LOGS, WATER LEVELS IN WELLS, AND CHEMICAL ANALYSES OF WATER: TEXAS WATER COMMISSION BULLETIN 6214, V. 2, 1962.

RECONNAISSANCE INVESTIGATION OF THE GROUND-WATER RESOURCES OF THE RIO GRANDE BASIN, TEXAS: TEXAS WATER COMMISSION BULLETIN 6502, 1965.

WATER-LEVEL DATA FROM OBSERVATION WELLS IN PECOS AND REEVES COUNTIES, TEXAS: TEXAS WATER COMMISSION BULLETIN 6507, 1965.

COMPILATION OF RESULTS OF AQUIFER TESTS IN TEXAS: TEXAS WATER DEVELOPMENT BOARD REPORT 98, 1969.

RECONNAISSANCE INVESTIGATION OF GROUND WATER IN THE RIO GRANDE DRAINAGE BASIN-WITH SPECIAL EMPHASIS ON SALINE GROUND-WATER RESOURCES: USGS HYDROLOGIC INVESTIGATIONS ATLAS HA-510, 1974.

SUMMARY APPRAISALS OF THE NATION'S GROUND-WATER RESOURCES-RIO GRANDE REGION: USGS PROFESSIONAL PAPER 813-D, 1975.

MAJOR AND HISTORICAL SPRINGS OF TEXAS: TEXAS WATER DEVELOPMENT BOARD REPORT 189, 1975.

OCCURRENCE AND QUALITY OF GROUND WATER IN THE EDWARDS-TRINITY (PLATEAU) AQUIFER IN THE TRANS PECOS REGION OF TEXAS: TEXAS DEPARTMENT OF WATER RESOURCES REPORT 255, 1980.

SPRINGS OF TEXAS, VOLUME 1: (BY GUNNAR BRUNE), BRANCHSMITH, INC., FORT WORTH, TEXAS, 1981.

MAPS SHOWING GROUND-WATER UNITS AND WITHDRAWAL, BASIN AND RANGE PROVINCE, TEXAS: USGS WATERRESOURCES INVESTIGATIONS REPORT 83-4121-A, 1984.

MAPS SHOWING GROUND-WATER LEVELS, SPRINGS, AND DEPTH TO GROUND WATER, BASIN AND RANGE PROVINCE, TEXAS: USGS WATER-RESOURCES INVESTIGATIONS REPORT 83-4121-B, 1984.

MAPS SHOWING DISTRIBUTION OF DISSOLVED SOLIDS AND DOMINANT CHEMICAL TYPE IN GROUND WATER, BASIN AND RANGE PROVINCE, TEXAS: USGS WATER-RESOURCES INVESTIGATIONS REPORT 83-4121-C, 1984
TEXAS GROUND-WATER RESOURCES, in NATIONAL WATER SUMMARY 1984: USGS WATER-SUPPLY PAPER 2275, 1985.

RECORDS OF WELLS, WATER LEVELS, PUMPAGE, AND CHEMICAL ANALYSES FROM SELECTED WELLS IN PARTS OF THE TRANSPECOS REGION, TEXAS, 1968-1980: TEXAS WATER DEVELOPMENT BOARD REPORT 301, 1987.

PUBLIC SUPPLY GROUND-WATER USE IN WESTERN TEXAS: TEXAS WATER DEVELOPMENT BOARD REPORT 311, 1989.

POTENTIOMETRIC SURFACE OF THE EDWARDS-TRINITY AQUIFER SYSTEM AND CONTIGUOUS HYDRAULICALLY CONNECTED UNITS, WEST-CENTRAL TEXAS, WINTER 1974-75: USGS WATERRESOURCES INVESTIGATIONS REPORT 89-4208, 1990.

EVALUATION OF GROUND-WATER RESOURCES IN PARTS OF LOVING, PECOS, REEVES, WARD, AND WINKLER COUNTIES, TEXAS: TEXAS WATER DEVELOPMENT BOARD REPORT 317, 1990.

WITHDRAWALS FROM THE EDWARDS-TRINITY AQUIFER SYSTEM AND CONTIGUOUS HYDRAULICALLY CONNECTED UNITS, WEST-CENTRAL TEXAS, DECEMBER 1974 THROUGH MARCH 1977: USGS WATER-RESOURCES INVESTIGATIONS REPORT 91-4021, 1991.

CONFIGURATION OF THE BASE OF THE EDWARDS-TRINITY AQUIFER SYSTEM AND HYDROGEOLOGY OF THE UNDERLYING PRECRETACEOUS ROCKS, WEST-CENTRAL TEXAS: USGS WATERRESOURCES INVESTIGATIONS REPORT 91-4071, 1992.

HISTORICAL POTENTIOMETRIC SURFACE OF THE EDWARDS-TRINITY AQUIFER SYSTEM AND CONTIGUOUS HYDRAULICALLY CONNECTED UNITS, WEST-CENTRAL TEXAS: USGS WATERRESOURCES INVESTIGATIONS REPORT 92-4055, 1993.

HISTORICAL SATURATED THICKNESS OF THE EDWARDS-TRINITY AQUIFER SYSTEM AND SELECTED CONTIGUOUS HYDRAULICALLY CONNECTED UNITS, WEST-CENTRAL TEXAS: USGS WATER-RESOURCES INVESTIGATIONS REPORT 92-4125, 1993.

SIMULATIONS OF FLOW IN THE EDWARDS-TRINITY AQUIFER SYSTEM AND CONTIGUOUS HYDRAULICALLY CONNECTED UNITS, WEST-CENTRAL TEXAS: USGS WATER-RESOURCES INVESTIGATIONS REPORT 93-4039, 1994.

DISSOLVED-SOLIDS CONCENTRATIONS AND HYDROCHEMICAL FACIES IN WATER OF THE EDWARDS-TRINITY AQUIFER SYSTEM, WEST-CENTRAL TEXAS: USGS WATER-RESOURCES INVESTIGATIONS REPORT 93-4126, 1994.

GEOLOGIC HISTORY AND HYDROGEOLOGIC SETTING OF THE EDWARDS-TRINITY AQUIFER SYSTEM, WEST-CENTRAL TEXAS: USGS WATER-RESOURCES INVESTIGATIONS REPORT 94-4039, 1994.

WATER QUALITY IN THE EDWARDS-TRINITY (PLATEAU) AQUIFER, EDWARDS PLATEAU AND TRANS-PECOS, TEXAS: TEXAS WATER DEVELOPMENT BOARD HYDROLOGIC ATLAS NO. 3, 1995.

AQUIFERS OF TEXAS: TEXAS WATER DEVELOPMENT BOARD REPORT 345, 1995.

HYDROGEOLOGIC FRAMEWORK OF THE EDWARDS-TRINITY AQUIFER SYSTEM, WEST-CENTRAL TEXAS: USGS PROFESSIONAL PAPER 1421-B, 1996.

WATER QUALITY IN THE CAPITAN REEF AQUIFER: TEXAS WATER DEVELOPMENT BOARD HYDROLOGIC ATLAS NO. 8, 1997.

WATER QUALITY IN THE RUSTLER AQUIFER: TEXAS WATER DEVELOPMENT BOARD HYDROLOGIC ATLAS NO. 9, 1998 
CHANGES IN GROUNDWATER CONDITIONS IN PARTS OF TRANSPECOS TEXAS, 1988-1998: TEXAS WATER DEVELOPMENT BOARD REPORT 348, 1999.

AQUIFERS OF WEST TEXAS: TEXAS WATER DEVELOPMENT BOARD REPORT 356, 2001

REGIONAL GROUND-WATER FLOW SYSTEMS IN TRANS-PECOS TEXAS, CHAPTER 4, in AQUIFERS OF WEST TEXAS: TEXAS WATER DEVELOPMENT BOARD REPORT 356, 2001

AN OVERVIEW OF THE EDWARDS-TRINITY AQUIFER SYSTEM, CENTRAL-WEST TEXAS, CHAPTER 8, in AQUIFERS OF WEST TEXAS: TEXAS WATER DEVELOPMENT BOARD REPORT 356, 2001.

CENOZOIC PECOS ALLUVIUM AQUIFER, CHAPTER 9, in AQUIFERS OF WEST TEXAS: TEXAS WATER DEVELOPMENT BOARD REPORT 356, 2001

THE GEOLOGY AND HYDROGEOLOGY OF THE CAPITAN AQUIFER: A BRIEF OVERVIEW, CHAPTER 11, in AQUIFERS OF WEST TEXAS: TEXAS WATER DEVELOPMENT BOARD REPORT 356, 2001.

THE DOCKUM AQUIFER IN WEST TEXAS, CHAPTER 12, in AQUIFERS OF WEST TEXAS: TEXAS WATER DEVELOPMENT BOARD REPORT 356, 2001

IGNEOUS AQUIFERS OF FAR WEST TEXAS, CHAPTER 13, in AQUIFERS OF WEST TEXAS: TEXAS WATER DEVELOPMENT BOARD REPORT 356, 2001

HYDROGEOLOGY OF THE RUSTLER AQUIFER, TRANS-PECOS TEXAS, CHAPTER 15, in AQUIFERS OF WEST TEXAS: TEXAS WATER DEVELOPMENT BOARD REPORT 356, 2001.

\section{REFUGIO COUNTY}

ARTESIAN WELLS OF THE COASTAL PRAIRIE REGION AND TERTIARY BELT OF TEXAS: GEOLOGICAL SURVEY OF TEXAS, CHAPTER 2, 1893

UNDERGROUND WATERS OF THE COASTAL PLAIN OF TEXAS: USGS WATER-SUPPLY PAPER 190, 1907.

RECORDS OF WELLS, DRILLERS' LOGS, AND WATER ANALYSES AND MAPS SHOWING LOCATION OF WELLS IN REFUGIO COUNTY, TEXAS: TEXAS BOARD OF WATER ENGINEERS MISCELLANEOUS PUBLICATION 227, 1936.

RECORDS OF WELLS, DRILLERS' LOGS, AND WATER ANALYSES AND MAPS SHOWING LOCATION OF WELLS IN REFUGIO AND PART OF GOLIAD COUNTY, TEXAS: TEXAS BOARD OF WATER ENGINEERS MISCELLANEOUS PUBLICATION 228, 1938.

PUBLIC WATER SUPPLIES IN SOUTHERN TEXAS: USGS WATERSUPPLY PAPER 1070, 1950

AVAILABILITY OF GROUND WATER IN THE GULF COAST REGION OF TEXAS: USGS OPEN-FILE REPORT (UNNUMBERED), 1956.

RECONNAISSANCE INVESTIGATION OF THE GROUND-WATER RESOURCES OF THE GULF COAST REGION, TEXAS: TEXAS WATER COMMISSION BULLETIN 6305, 1963.

GROUND-WATER RESOURCES OF REFUGIO COUNTY, TEXAS: TEXAS WATER COMMISSION BULLETIN 6312, 1963.

COMPILATION OF RESULTS OF AQUIFER TESTS IN TEXAS: TEXAS WATER DEVELOPMENT BOARD REPORT 98, 1969.
SUMMARY APPRAISALS OF THE NATION'S GROUND-WATER RESOURCES-TEXAS-GULF REGION: USGS PROFESSIONAL PAPER 813-F, 1976.

HYDROLOGY OF THE CORPUS CHRISTI AREA, TEXAS: UNIVERSITY OF TEXAS, BUREAU OF ECONOMIC GEOLOGY RESEARCH NOTE $12,1978$.

LAND AND WATER RESOURCES OF THE CORPUS CHRISTI AREA, TEXAS: UNIVERSITY OF TEXAS, BUREAU OF ECONOMIC GEOLOGY REPORT OF INVESTIGATIONS NO. 95, 1978.

STRATIGRAPHIC AND HYDROGEOLOGIC FRAMEWORK OF PART OF THE COASTAL PLAIN OF TEXAS: USGS OPEN-FILE REPORT $77-712,1978$.

STRATIGRAPHIC AND HYDROGEOLOGIC FRAMEWORK OF PART OF THE COASTAL PLAIN OF TEXAS: TEXAS DEPARTMENT OF WATER RESOURCES REPORT 236, 1979.

LAND-SURFACE SUBSIDENCE IN THE TEXAS COASTAL REGION: USGS OPEN-FILE REPORT 80-969, 1980.

SPRINGS OF TEXAS, VOLUME 1: (BY GUNNAR BRUNE), BRANCHSMITH, INC., FORT WORTH, TEXAS, 1981.

LAND-SURFACE SUBSIDENCE IN THE TEXAS COASTAL REGION: TEXAS DEPARTMENT OF WATER RESOURCES REPORT 272, 1982.

REGIONAL HYDRODYNAMICS AND HYDROCHEMISTRY OF THE URANIUM-BEARING OAKVILLE AQUIFER (MIOCENE) OF SOUTH TEXAS: UNIVERSITY OF TEXAS, BUREAU OF ECONOMIC GEOLOGY REPORT OF INVESTIGATIONS NO. 124, 1982.

TEXAS GROUND-WATER RESOURCES, in NATIONAL WATER SUMMARY 1984: USGS WATER-SUPPLY PAPER 2275, 1985

DIGITAL MODELS FOR SIMULATION OF GROUND-WATER HYDROLOGY OF THE CHICOT AND EVANGELINE AQUIFERS ALONG THE GULF COAST OF TEXAS: TEXAS DEPARTMENT OF WATER RESOURCES REPORT 289, 1985.

GEOHYDROLOGIC FRAMEWORK OF THE GULF COASTAL PLAIN: USGS HYDROLOGIC INVESTIGATIONS ATLAS HA-695, 1988

HYDROGEOLOGY AND PREDEVELOPMENT FLOW IN THE TEXAS GULF COAST AQUIFER SYSTEMS: USGS WATER-RESOURCES INVESTIGATIONS REPORT 87-4248, 1988.

GROUND-WATER FLOW IN THE GULF COAST AQUIFER SYSTEMS, SOUTH-CENTRAL UNITED STATES-A PRELIMINARY ANALYSIS USGS WATER-RESOURCES INVESTIGATIONS REPORT 89-4071, 1990.

HYDROLOGY OF THE TEXAS GULF COAST AQUIFER SYSTEMS: USGS OPEN-FILE REPORT 91-64, 1991.

PROPERTIES AND CHEMICAL CONSTITUENTS IN GROUND WATER FROM THE MISSISSIPPI RIVER VALLEY ALLUVIAL AQUIFER AND PERMEABLE ZONE A (HOLOCENE-UPPER PLEISTOCENE DEPOSITS), SOUTH-CENTRAL UNITED STATES: USGS WATERRESOURCES INVESTIGATIONS REPORT 91-4149, 1992.

PROPERTIES AND CHEMICAL CONSTITUENTS IN GROUND WATER FROM THE UPPER CLAIBORNE AQUIFER, GULF COAST REGIONAL AQUIFER SYSTEMS, SOUTH-CENTRAL UNITED STATES: USGS WATER-RESOURCES INVESTIGATIONS REPORT 91-4150, 1993.

PROPERTIES AND CHEMICAL CONSTITUENTS IN GROUND WATER FROM PERMEABLE ZONE C (LOWER PLIOCENE-UPPER MIOCENE DEPOSITS), COASTAL LOWLANDS AQUIFER SYSTEM, SOUTH- 
CENTRAL UNITED STATES: USGS WATER-RESOURCES INVESTIGATIONS REPORT 91-4151, 1993.

PROPERTIES AND CHEMICAL CONSTITUENTS IN GROUND WATER FROM PERMEABLE ZONE B (LOWER PLEISTOCENE-UPPER PLIOCENE DEPOSITS), COASTAL LOWLANDS AQUIFER SYSTEM, SOUTH-CENTRAL UNITED STATES: USGS WATER-RESOURCES INVESTIGATIONS REPORT 91-4152, 1993.

PROPERTIES AND CHEMICAL CONSTITUENTS IN GROUND WATER FROM PERMEABLE ZONE E (LOWER MIOCENE-UPPER OLIGOCENE DEPOSITS), COASTAL LOWLANDS AQUIFER SYSTEM, SOUTH-CENTRAL UNITED STATES: USGS WATER-RESOURCES INVESTIGATIONS REPORT 92-4103, 1993.

PROPERTIES AND CHEMICAL CONSTITUENTS IN GROUND WATER FROM PERMEABLE ZONE D (MIDDLE MIOCENE DEPOSITS), COASTAL LOWLANDS AQUIFER SYSTEM, SOUTH-CENTRAL UNITED STATES: USGS WATER-RESOURCES INVESTIGATIONS REPORT 92-4105, 1993.

AQUIFERS OF TEXAS: TEXAS WATER DEVELOPMENT BOARD REPORT 345, 1995.

STRATIGRAPHIC NOMENCLATURE AND GEOLOGIC SECTIONS OF THE GULF COASTAL PLAIN OF TEXAS: USGS OPEN-FILE REPORT 94-461, 1995.

\section{ROBERTS COUNTY}

THE GEOLOGY AND WATER RESOURCES OF THE EASTERN PORTION OF THE PANHANDLE OF TEXAS: USGS WATER-SUPPLY PAPER 154, 1906.

RECORDS OF WELLS AND SPRINGS, DRILLERS' LOGS, WATER ANALYSES, AND MAP SHOWING LOCATION OF WELLS IN ROBERTS COUNTY, TEXAS: TEXAS BOARD OF WATER ENGINEERS MISCELLANEOUS PUBLICATION 231, 1940.

PUBLIC WATER SUPPLIES IN WESTERN TEXAS: TEXAS BOARD OF WATER ENGINEERS MISCELLANEOUS PUBLICATION 216, 1949.

PUBLIC WATER SUPPLIES IN WESTERN TEXAS: USGS WATERSUPPLY PAPER 1106, 1951 [1952].

DEVELOPMENT OF WELLS FOR IRRIGATION AND FLUCTUATION OF WATER LEVELS IN THE HIGH PLAINS OF TEXAS TO JANUARY 1951: TEXAS BOARD OF WATER ENGINEERS BULLETIN 5104, 1951.

WATER-LEVEL MAPS AND WATER LEVELS IN OBSERVATION WELLS IN THE NORTH HIGH PLAINS, TEXAS: TEXAS BOARD OF WATER ENGINEERS BULLETIN 5707, 1957.

RECORDS OF WATER-LEVEL MEASUREMENTS IN COLLINGSWORTH, HEMPHILL, ROBERTS, AND WHEELER COUNTIES, TEXAS, 1937 THROUGH JULY 1958: TEXAS BOARD OF WATER ENGINEERS BULLETIN 5806, 1958.

WATER-LEVEL MEASUREMENTS AND MAPS, NORTHERN HIGH PLAINS, TEXAS, 1958 AND 1959: TEXAS BOARD OF WATER ENGINEERS BULLETIN 5909, 1959.

WATER LEVELS IN OBSERVATION WELLS, NORTHERN HIGH PLAINS, TEXAS, 1958-1960: TEXAS BOARD OF WATER ENGINEERS BULLETIN 6012, 1960.
RECONNAISSANCE INVESTIGATION OF THE GROUND-WATER RESOURCES OF THE CANADIAN RIVER BASIN, TEXAS: TEXAS BOARD OF WATER ENGINEERS BULLETIN 6016, 1960.

WATER LEVELS IN OBSERVATION WELLS, SOUTHERN HIGH PLAINS, TEXAS, 1960 AND 1961: TEXAS BOARD OF WATER ENGINEERS BULLETIN 6101, 1961.

ANNUAL WATER-LEVEL MEASUREMENTS IN OBSERVATION WELLS, NORTHERN HIGH PLAINS, TEXAS, 1960 AND 1961: TEXAS BOARD OF WATER ENGINEERS BULLETIN 6103, 1961.

A SUMMARY OF THE OCCURRENCE AND DEVELOPMENT OF GROUND WATER IN THE SOUTHERN HIGH PLAINS OF TEXAS: TEXAS BOARD OF WATER ENGINEERS BULLETIN 6107, 1961.

GEOLOGY AND GROUND-WATER RESOURCES OF THE NORTHERN HIGH PLAINS OF TEXAS, PROGRESS REPORT NO. 1: TEXAS BOARD OF WATER ENGINEERS BULLETIN 6109, 1961.

WATER-LEVEL MEASUREMENTS THROUGH 1962 IN SELECTED OBSERVATION WELLS, SOUTHERN HIGH PLAINS, TEXAS: TEXAS WATER COMMISSION BULLETIN 6207, 1962.

ANNUAL WATER-LEVEL MEASUREMENTS IN OBSERVATION WELLS, NORTHERN HIGH PLAINS, TEXAS, 1961 AND 1962: TEXAS WATER COMMISSION BULLETIN 6213, 1962.

RECONNAISSANCE INVESTIGATION OF THE GROUND-WATER RESOURCES OF THE RED RIVER, SULPHUR RIVER, AND CYPRESS CREEK BASINS, TEXAS: TEXAS WATER COMMISSION BULLETIN 6306, 1963.

WATER-LEVEL DATA FROM OBSERVATION WELLS IN THE SOUTHERN HIGH PLAINS OF TEXAS: TEXAS WATER DEVELOPMENT BOARD REPORT 21, 1966.

WATER-LEVEL DATA FROM OBSERVATION WELLS IN THE SOUTHERN HIGH PLAINS OF TEXAS, 1965-70: TEXAS WATER DEVELOPMENT BOARD REPORT 121, 1970.

WATER-LEVEL DATA FROM OBSERVATION WELLS IN THE NORTHERN PANHANDLE OF TEXAS: TEXAS WATER DEVELOPMENT BOARD REPORT 137, 1971

PRELIMINARY DATA DESCRIBING THE DISTRIBUTION OF FLUORIDE AND SILICA IN THE OGALLALA AQUIFER ON THE HIGH PLAINS OF TEXAS: USGS OPEN-FILE REPORT 80-349, 1980.

WATER-LEVEL DATA FROM OBSERVATION WELLS IN THE NORTHERN PANHANDLE OF TEXAS, 1972-78: TEXAS DEPARTMENT OF WATER RESOURCES REPORT 248, 1980.

WATER TABLE IN THE HIGH PLAINS AQUIFER IN 1978 IN PARTS OF COLORADO, KANSAS, NEBRASKA, NEW MEXICO, OKLAHOMA, SOUTH DAKOTA, TEXAS, AND WYOMING: USGS HYDROLOGIC INVESTIGATIONS ATLAS HA-642, 1980.

EVALUATING THE GROUND-WATER RESOURCES OF THE HIGH PLAINS OF TEXAS: RESULTS OF TEST HOLE DRILLING: TEXAS DEPARTMENT OF WATER RESOURCES LIMITED PRINTING REPORT LP-129, 1980.

EVALUATING THE GROUND-WATER RESOURCES OF THE HIGH PLAINS OF TEXAS: RESULTS OF SURFACE ELECTRICAL RESISTIVITY: TEXAS DEPARTMENT OF WATER RESOURCES LIMITED PRINTING REPORT LP-130, 1980.

SPRINGS OF TEXAS, VOLUME 1: (BY GUNNAR BRUNE), BRANCHSMITH, INC., FORT WORTH, TEXAS, 1981. 
BEDROCK GEOLOGY, ALTITUDE OF BASE, AND 1980 SATURATED THICKNESS OF THE HIGH PLAINS AQUIFER IN PARTS OF COLORADO, KANSAS, NEBRASKA, NEW MEXICO, OKLAHOMA, SOUTH DAKOTA, TEXAS, AND WYOMING: USGS HYDROLOGIC INVESTIGATIONS ATLAS HA-648, 1981.

WATER-LEVEL AND SATURATED-THICKNESS CHANGES, PREDEVELOPMENT TO 1980, IN THE HIGH PLAINS AQUIFER IN PARTS OF COLORADO, KANSAS, NEBRASKA, NEW MEXICO, OKLAHOMA, SOUTH DAKOTA, TEXAS, AND WYOMING: USGS HYDROLOGIC INVESTIGATIONS ATLAS HA-652, 1981.

ANALYTICAL STUDY OF THE OGALLALA AQUIFER IN HEMPHILL COUNTY, TEXAS—PROJECTIONS OF SATURATED THICKNESS, VOLUME OF WATER IN STORAGE, PUMPAGE RATES, PUMPING LIFTS, AND WELL YIELDS: TEXAS DEPARTMENT OF WATER RESOURCES REPORT 267, 1982.

DISSOLVED SOLIDS AND SODIUM IN WATER FROM THE HIGH PLAINS AQUIFER IN PARTS OF COLORADO, KANSAS, NEBRASKA, NEW MEXICO, OKLAHOMA, SOUTH DAKOTA, TEXAS, AND WYOMING: USGS HYDROLOGIC INVESTIGATIONS ATLAS HA-658, 1982.

GEOHYDROLOGY OF THE HIGH PLAINS AQUIFER IN PARTS OF COLORADO, KANSAS, NEBRASKA, NEW MEXICO, OKLAHOMA, SOUTH DAKOTA, TEXAS, AND WYOMING: USGS PROFESSIONAL PAPER 1400-B, 1984.

EVALUATING THE GROUND-WATER RESOURCES OF THE HIGH PLAINS OF TEXAS, VOLUME 1: TEXAS DEPARTMENT OF WATER RESOURCES REPORT 288, V. 1, 1984.

EVALUATING THE GROUND-WATER RESOURCES OF THE HIGH PLAINS OF TEXAS, VOLUME 2, RECORDS OF WELLS, AND MAPS SHOWING WELL LOCATIONS, BASE OF AQUIFER, WATER LEVELS, AND SATURATED THICKNESS (ARMSTRONG, CARSON, DALLAS, DONLEY, GRAY, HANSFORD, HARTLEY, HEMPHILL, HUTCHINSON, LIPSCOMB, MOORE, OCHILTREE, POTTER, ROBERTS, SHERMAN, AND WHEELER COUNTIES): TEXAS DEPARTMENT OF WATER RESOURCES REPORT 288, V. 2, 1984.

TEXAS GROUND-WATER RESOURCES, in NATIONAL WATER SUMMARY 1984: USGS WATER-SUPPLY PAPER 2275, 1985.

DIGITAL SIMULATION OF GROUND-WATER FLOW IN THE HIGH PLAINS AQUIFER IN PARTS OF COLORADO, KANSAS, NEBRASKA, NEW MEXICO, OKLAHOMA, SOUTH DAKOTA, TEXAS, AND WYOMING: USGS PROFESSIONAL PAPER 1400-D, 1986.

SUMMARY OF THE HIGH PLAINS REGIONAL AQUIFER-SYSTEM ANALYSIS IN PARTS OF COLORADO, KANSAS, NEBRASKA, NEW MEXICO, OKLAHOMA, SOUTH DAKOTA, TEXAS, AND WYOMING: USGS PROFESSIONAL PAPER 1400-A, 1988.

WATER-LEVEL CHANGES IN THE HIGH PLAINS AQUIFER OF TEXAS, 1980-1990: TEXAS WATER DEVELOPMENT BOARD HYDROLOGIC ATLAS NO. 1, 1991.

PUBLIC-SUPPLY GROUND-WATER USE IN THE NORTHERN HIGH PLAINS OF TEXAS: TEXAS WATER DEVELOPMENT BOARD REPORT 336, 1992.

THE HIGH PLAINS AQUIFER SYSTEM OF TEXAS, 1980 TO 1990. OVERVIEW AND PROJECTIONS: TEXAS WATER DEVELOPMENT BOARD REPORT 341, 1993.

WATER-QUALITY EVALUATION OF THE OGALLALA AQUIFER, TEXAS: TEXAS WATER DEVELOPMENT BOARD REPORT 342, 1993.
WATER-LEVEL CHANGES IN THE HIGH PLAINS AQUIFER-PREDEVELOPMENT TO 1992: USGS WATER-RESOURCES INVESTIGATIONS REPORT 94-4027, 1994.

WATER-LEVEL CHANGES IN THE HIGH PLAINS AQUIFER, 1980 TO 1994: USGS FACT SHEET FS-215-95, 1995.

AQUIFERS OF TEXAS: TEXAS WATER DEVELOPMENT BOARD REPORT 345, 1995.

WATER-LEVEL CHANGES IN THE HIGH PLAINS AQUIFER, 1980 TO 1995: USGS FACT SHEET FS-068-97, 1997.

WATER-LEVEL CHANGES IN THE HIGH PLAINS AQUIFER-PREDEVELOPMENT TO 1995: USGS WATER-RESOURCES INVESTIGATIONS REPORT 97-4081, 1997.

PLAYAS AND RECHARGE OF THE OGALLALA AQUIFER ON THE SOUTHERN HIGH PLAINS OF TEXAS-AN EXAMINATION USING NUMERICAL TECHNIQUES: UNIVERSITY OF TEXAS, BUREAU OF ECONOMIC GEOLOGY REPORT OF INVESTIGATIONS NO. 242, 1997.

UPDATED WATER-QUALITY EVALUATION OF THE OGALLALA AQUIFER INCLUDING SELECTED METALLIC AND NON-METALLIC INORGANIC CONSTITUENTS: TEXAS WATER DEVELOPMENT BOARD HYDROLOGIC ATLAS NO. 10, 1998.

WATER-RESOURCES DATA, TEXAS, WATER YEAR 2000, VOLUME 6, GROUND-WATER DATA: USGS WATER-DATA REPORT TX-00-6, 2001.

\section{ROBERTSON COUNTY}

ARTESIAN WELLS OF THE COASTAL PRAIRIE REGION AND TERTIARY BELT OF TEXAS: GEOLOGICAL SURVEY OF TEXAS, CHAPTER 2, 1893.

UNDERGROUND WATERS OF THE COASTAL PLAIN OF TEXAS: USGS WATER-SUPPLY PAPER 190, 1907.

GEOLOGY AND UNDERGROUND WATERS OF THE SOUTHEASTERN PART OF THE TEXAS COASTAL PLAIN: USGS WATER-SUPPLY PAPER 335, 1914.

RECORDS OF WELLS AND SPRINGS, DRILLERS' LOGS, WATER ANALYSES, AND MAP SHOWING LOCATIONS OF WELLS AND SPRINGS IN ROBERTSON COUNTY, TEXAS: TEXAS BOARD OF WATER ENGINEERS MISCELLANEOUS PUBLICATION 232, 1937.

PUBLIC WATER SUPPLIES IN EASTERN TEXAS, V. 2, HARRISON COUNTY THROUGH WOOD COUNTY: TEXAS BOARD OF WATER ENGINEERS MISCELLANEOUS PUBLICATION 214, V. 2, 1945.

PUBLIC WATER SUPPLIES IN EASTERN TEXAS: USGS WATERSUPPLY PAPER 1047, 1948.

RECONNAISSANCE INVESTIGATION OF THE GROUND-WATER RESOURCES OF THE BRAZOS RIVER BASIN: TEXAS WATER COMMISSION BULLETIN 6310, 1963.

GROUND WATER IN THE FLOOD-PLAIN ALLUVIUM OF THE BRAZOS RIVER, WHITNEY DAM TO VICINITY OF RICHMOND, TEXAS: TEXAS WATER DEVELOPMENT BOARD REPORT 41, 1967.

HYDROLOGIC SIGNIFICANCE OF THE LITHOFACIES OF THE SPARTA SAND IN ARKANSAS, LOUISIANA, MISSISSIPPI, AND TEXAS: USGS PROFESSIONAL PAPER 569-A, 1968. 
HYDROLOGIC SIGNIFICANCE OF LITHOFACIES OF THE CANE RIVER FORMATION OR EQUIVALENTS OF ARKANSAS, LOUISIANA, MISSISSIPPI, AND TEXAS: USGS PROFESSIONAL PAPER 569-C, 1972.

HYDROLOGIC SIGNIFICANCE OF LITHOFACIES OF THE CARRIZO SAND OF ARKANSAS, LOUISIANA, AND TEXAS AND THE MERIDIAN SAND OF MISSISSIPPI: USGS PROFESSIONAL PAPER 569-D, 1975.

SUMMARY APPRAISALS OF THE NATION'S GROUND-WATER RESOURCES-TEXAS-GULF REGION: USGS PROFESSIONAL PAPER 813-F, 1976.

TEXAS GROUND-WATER RESOURCES, in NATIONAL WATER SUMMARY 1984: USGS WATER-SUPPLY PAPER 2275, 1985.

APPROXIMATE POTENTIOMETRIC SURFACES FOR THE AQUIFERS OF THE COASTAL UPLANDS SYSTEM, 1980: USGS HYDROLOGIC INVESTIGATIONS ATLAS HA-704, 1987.

GEOHYDROLOGIC FRAMEWORK OF THE GULF COASTAL PLAIN: USGS HYDROLOGIC INVESTIGATIONS ATLAS HA-695, 1988.

HYDROGEOLOGY AND PREDEVELOPMENT FLOW IN THE TEXAS GULF COAST AQUIFER SYSTEMS: USGS WATER-RESOURCES INVESTIGATIONS REPORT 87-4248, 1988.

A DIGITAL MODEL OF THE CARRIZO-WILCOX AQUIFER WITHIN THE COLORADO RIVER BASIN OF TEXAS: TEXAS WATER DEVELOPMENT BOARD LIMITED PRINTING REPORT LP-208, 1989.

GROUND-WATER FLOW IN THE GULF COAST AQUIFER SYSTEMS, SOUTH-CENTRAL UNITED STATES-A PRELIMINARY ANALYSIS: USGS WATER-RESOURCES INVESTIGATIONS REPORT 89-4071, 1990.

HYDROLOGY OF THE TEXAS GULF COAST AQUIFER SYSTEMS: USGS OPEN-FILE REPORT 91-64, 1991.

GROUND-WATER RESOURCES OF THE CARRIZO-WILCOX AQUIFER IN THE CENTRAL TEXAS REGION: TEXAS WATER DEVELOPMENT BOARD REPORT 332, 1991.

PROPERTIES AND CHEMICAL CONSTITUENTS IN GROUND WATER FROM THE LOWER CLAIBORNE-UPPER WILCOX AQUIFER, GULF COAST REGIONAL AQUIFER SYSTEMS, SOUTH-CENTRAL UNITED STATES: USGS WATER-RESOURCES INVESTIGATIONS REPORT 92-4102, 1993.

PROPERTIES AND CHEMICAL CONSTITUENTS IN GROUND WATER FROM THE MIDDLE CLAIBORNE AQUIFER, GULF COAST REGIONAL AQUIFER SYSTEMS, SOUTH-CENTRAL UNITED STATES: USGS WATER-RESOURCES INVESTIGATIONS REPORT 92-4104, 1993.

PROPERTIES AND CHEMICAL CONSTITUENTS IN GROUND WATER FROM THE MIDDLE WILCOX AQUIFER, GULF COAST AQUIFER SYSTEMS, SOUTH-CENTRAL UNITED STATES: USGS WATERRESOURCES INVESTIGATIONS REPORT 93-4070, 1993.

AQUIFERS OF TEXAS: TEXAS WATER DEVELOPMENT BOARD REPORT 345, 1995

WATER QUALITY IN THE SPARTA AQUIFER, EAST TEXAS: TEXAS WATER DEVELOPMENT BOARD HYDROLOGIC ATLAS NO. 5, 1996.

WATER QUALITY IN THE QUEEN CITY AQUIFER, EAST TEXAS: TEXAS WATER DEVELOPMENT BOARD HYDROLOGIC ATLAS NO. 6, 1996

\section{ROCKWALL COUNTY}

GEOLOGY AND UNDERGROUND WATERS OF THE SOUTHEASTERN PART OF THE TEXAS COASTAL PLAIN: USGS WATER-SUPPLY PAPER 335, 1914

PUBLIC WATER SUPPLIES IN EASTERN TEXAS, V. 2, HARRISON COUNTY THROUGH WOOD COUNTY: TEXAS BOARD OF WATER ENGINEERS MISCELLANEOUS PUBLICATION 214, V. 2, 1945.

PUBLIC WATER SUPPLIES IN EASTERN TEXAS: USGS WATERSUPPLY PAPER 1047, 1948.

RECONNAISSANCE INVESTIGATION OF THE GROUND-WATER RESOURCES OF THE SABINE RIVER BASIN, TEXAS: TEXAS WATER COMMISSION BULLETIN 6307, 1963.

RECONNAISSANCE INVESTIGATION OF THE GROUND-WATER RESOURCES OF THE TRINITY RIVER BASIN, TEXAS: TEXAS WATER COMMISSION BULLETIN 6309, 1963.

WATER-LEVEL AND WATER-QUALITY DATA FROM OBSERVATION WELLS IN NORTHEAST TEXAS: TEXAS WATER DEVELOPMENT BOARD REPORT 198, 1976.

SUMMARY APPRAISALS OF THE NATION'S GROUND-WATER RESOURCES-TEXAS-GULF REGION: USGS PROFESSIONAL PAPER 813-F, 1976.

SPRINGS OF TEXAS, VOLUME 1: (BY GUNNAR BRUNE), BRANCHSMITH, INC., FORT WORTH, TEXAS, 1981

OCCURRENCE, AVAILABILITY, AND CHEMICAL QUALITY OF GROUND WATER IN THE CRETACEOUS AQUIFERS OF NORTHCENTRAL TEXAS: TEXAS DEPARTMENT OF WATER RESOURCES REPORT 269, V. 1, 1982.

OCCURRENCE, AVAILABILITY, AND CHEMICAL QUALITY OF GROUND WATER IN THE CRETACEOUS AQUIFERS OF NORTHCENTRAL TEXAS: TEXAS DEPARTMENT OF WATER RESOURCES REPORT 269, V. 2, 1982.

TEXAS GROUND-WATER RESOURCES, in NATIONAL WATER SUMMARY 1984: USGS WATER-SUPPLY PAPER 2275, 1985.

APPROXIMATE POTENTIOMETRIC SURFACES FOR THE AQUIFERS OF THE COASTAL UPLANDS SYSTEM, 1980: USGS HYDROLOGIC INVESTIGATIONS ATLAS HA-704, 1987.

GROUND-WATER RESOURCES OF THE NACATOCH AQUIFER: TEXAS WATER DEVELOPMENT BOARD REPORT 305, 1988.

EVALUATION OF WATER RESOURCES IN PART OF NORTH-CENTRAL TEXAS: TEXAS WATER DEVELOPMENT BOARD REPORT 318,1990

NATIONAL WATER-QUALITY ASSESSMENT PROGRAM-THE TRINITY RIVER BASIN: USGS OPEN-FILE REPORT 91-158, 1991.

NATIONAL WATER-QUALITY ASSESSMENT PROGRAM-PESTICIDES IN THE TRINITY RIVER BASIN STUDY UNIT, TEXAS, 1968-91: USGS FACT SHEET FS-088-95, 1995.

AQUIFERS OF TEXAS: TEXAS WATER DEVELOPMENT BOARD REPORT 345, 1995.

WATER QUALITY IN THE WOODBINE AQUIFER, NORTH-CENTRAL TEXAS: TEXAS WATER DEVELOPMENT BOARD HYDROLOGIC ATLAS NO. 4, 1996. 
UPDATED EVALUATION OF WATER RESOURCES IN PART OF NORTH-CENTRAL TEXAS, 1990-1999: TEXAS WATER DEVELOPMENT BOARD REPORT 349, 1999.

\section{RUNNELS COUNTY}

PUBLIC WATER SUPPLIES IN CENTRAL AND NORTH-CENTRAL TEXAS: TEXAS BOARD OF WATER ENGINEERS MISCELLANEOUS PUBLICATION 213, 1947.

PUBLIC WATER SUPPLIES IN CENTRAL AND NORTH-CENTRAL TEXAS: USGS WATER-SUPPLY PAPER 1069, 1949.

RECONNAISSANCE OF WATER-WELL POLLUTION AND THE OCCURRENCE OF SHALLOW GROUND WATER, RUNNELS COUNTY, TEXAS: TEXAS BOARD OF WATER ENGINEERS MISCELLANEOUS PUBLICATION 236, 1959.

RECONNAISSANCE INVESTIGATION OF THE GROUND-WATER RESOURCES OF THE COLORADO RIVER BASIN, TEXAS: TEXAS WATER DEVELOPMENT BOARD REPORT 51, 1967.

AN INVESTIGATION OF THE NITRATE PROBLEM IN RUNNELS COUNTY, TEXAS: U.S. ENVIRONMENTAL PROTECTION AGENCY ENVIRONMENTAL PROTECTION TECHNOLOGY SERIES EPAR2-73-267, 1973.

WOODY PHREATOPHYTES ALONG THE COLORADO RIVER FROM SOUTHEAST RUNNELS COUNTY TO THE HEADWATERS IN BORDEN COUNTY, TEXAS: TEXAS WATER DEVELOPMENT BOARD REPORT 182, 1974.

SUMMARY APPRAISALS OF THE NATION'S GROUND-WATER RESOURCES-TEXAS-GULF REGION: USGS PROFESSIONAL PAPER 813-F, 1976.

TEXAS GROUND-WATER RESOURCES, in NATIONAL WATER SUMMARY 1984: USGS WATER-SUPPLY PAPER 2275, 1985.

CHARACTERISTICS OF STREAMS AND AQUIFERS AND PROCESSES AFFECTING THE SALINITY OF WATER IN THE UPPER COLORADO RIVER BASIN, TEXAS: USGS WATER-RESOURCES INVESTIGATIONS REPORT 94-4036, 1994.

WATER-QUALITY ASSESSMENT OF THE TRINITY RIVER BASIN, TEXAS-DATA COLLECTION, 1992-95: USGS FACT SHEET FS-095-95, 1995.

WATER-QUALITY ASSESSMENT OF THE TRINITY RIVER BASIN, TEXAS-PESTICIDES IN A SUBURBAN WATERSHED, ARLINGTON, 1993-94: USGS FACT SHEET FS-159-95, 1995.

AQUIFERS OF TEXAS: TEXAS WATER DEVELOPMENT BOARD REPORT 345, 1995.

\section{RUSK COUNTY}

UNDERGROUND WATERS OF THE COASTAL PLAIN OF TEXAS: USGS WATER-SUPPLY PAPER 190, 1907.

GEOLOGY AND UNDERGROUND WATERS OF THE SOUTHEASTERN PART OF THE TEXAS COASTAL PLAIN: USGS WATER-SUPPLY PAPER 335, 1914.

GEOLOGY AND GROUND-WATER RESOURCES OF RUSK COUNTY, TEXAS: USGS OPEN-FILE REPORT (UNNUMBERED), 1937.
RECORDS OF WELLS, DRILLERS' LOGS, AND WATER ANALYSES, AND MAP SHOWING LOCATION OF WELLS IN RUSK COUNTY, TEXAS: TEXAS BOARD OF WATER ENGINEERS MISCELLANEOUS PUBLICATION 237, 1937.

WATER SUPPLY IN THE SAND FLAT AREA AND ADJACENT TERRITORY IN RUSK, NACOGDOCHES, AND SHELBY COUNTIES, TEXAS: TEXAS BOARD OF WATER ENGINEERS MISCELLANEOUS PUBLICATION 236A, 1942.

RECORDS OF WELLS, DRILLERS' LOGS, WATER ANALYSES, AND MAP SHOWING LOCATIONS OF WELLS IN RUSK COUNTY (NORTHWESTERN PART), TEXAS: TEXAS BOARD OF WATER ENGINEERS MISCELLANEOUS PUBLICATION 238, 1943.

PUBLIC WATER SUPPLIES IN EASTERN TEXAS, V. 2, HARRISON COUNTY THROUGH WOOD COUNTY: TEXAS BOARD OF WATER ENGINEERS MISCELLANEOUS PUBLICATION 214, V. 2, 1945

PUBLIC WATER SUPPLIES IN EASTERN TEXAS: USGS WATERSUPPLY PAPER 1047, 1948.

HENDERSON OIL FIELD AREA, RUSK COUNTY, TEXAS: TEXAS WATER COMMISSION LIMITED DISTRIBUTION REPORT LD-262-MR, 1962,

RECONNAISSANCE INVESTIGATION OF THE GROUND-WATER RESOURCES OF THE SABINE RIVER BASIN, TEXAS: TEXAS WATER COMMISSION BULLETIN 6307, 1963.

RECONNAISSANCE INVESTIGATION OF THE GROUND-WATER RESOURCES OF THE NECHES RIVER BASIN, TEXAS: TEXAS WATER COMMISSION BULLETIN 6308, 1963.

COMPILATION OF RESULTS OF AQUIFER TESTS IN TEXAS: TEXAS WATER DEVELOPMENT BOARD REPORT 98, 1969.

SALT-WATER DISPOSAL AND POTENTIAL FOR POLLUTION IN THE EAST TEXAS OIL FIELD: USGS OPEN-FILE REPORT (UNNUMBERED) (MEMORANDUM), 1971

HYDROLOGIC SIGNIFICANCE OF LITHOFACIES OF THE CARRIZO SAND OF ARKANSAS, LOUISIANA, AND TEXAS AND THE MERIDIAN SAND OF MISSISSIPPI: USGS PROFESSIONAL PAPER 569-D, 1975.

SUMMARY APPRAISALS OF THE NATION'S GROUND-WATER RESOURCES-TEXAS-GULF REGION: USGS PROFESSIONAL PAPER 813-F, 1976.

WATER-QUALITY DATA FOR AQUIFERS, STREAMS, AND LAKES IN THE VICINITY OF KEECHI, MOUNT SYLVAN, OAKWOOD, AND PALESTINE SALT DOMES, NORTHEAST TEXAS SALT-DOME BASIN: USGS OPEN-FILE REPORT 80-2037, 1980

GEOHYDROLOGY OF THE KEECHI, MOUNT SYLVAN, OAKWOOD, AND PALESTINE SALT DOMES IN THE NORTHEAST TEXAS SALTDOME BASIN: USGS OPEN-FILE REPORT 80-2044, 1980.

GEOLOGY AND GEOHYDROLOGY OF THE EAST TEXAS BASIN-A REPORT ON THE PROGRESS OF NUCLEAR WASTE ISOLATION FEASIBILITY STUDIES (1979): UNIVERSITY OF TEXAS, BUREAU OF ECONOMIC GEOLOGY GEOLOGICAL CIRCULAR 80-12, 1980.

GEOLOGY AND GEOHYDROLOGY OF THE EAST TEXAS BASIN-A REPORT ON THE PROGRESS OF NUCLEAR WASTE ISOLATION FEASIBILITY STUDIES (1980): UNIVERSITY OF TEXAS, BUREAU OF ECONOMIC GEOLOGY GEOLOGICAL CIRCULAR 81-7, 1981.

SPRINGS OF TEXAS, VOLUME 1: (BY GUNNAR BRUNE), BRANCHSMITH, INC., FORT WORTH, TEXAS, 1981. 
REGIONAL AQUIFER CHARACTERIZATION FOR DEEP-BASIN LIGNITE MINING, SABINE UPLIFT AREA, NORTHEAST TEXAS: UNIVERSITY OF TEXAS, BUREAU OF ECONOMIC GEOLOGY GEOLOGICAL CIRCULAR 83-3, 1983.

GROUND-WATER RESOURCES OF RUSK COUNTY, TEXAS: USGS OPEN-FILE REPORT 83-757, 1984.

TEXAS GROUND-WATER RESOURCES, in NATIONAL WATER SUMMARY 1984: USGS WATER-SUPPLY PAPER 2275, 1985.

APPROXIMATE POTENTIOMETRIC SURFACES FOR THE AQUIFERS OF THE TEXAS COASTAL UPLANDS SYSTEM, 1980: USGS HYDROLOGIC INVESTIGATIONS ATLAS HA-704, 1987.

GROUND-WATER RESOURCES OF RUSK COUNTY, TEXAS: TEXAS WATER DEVELOPMENT BOARD REPORT 297, 1987.

HYDROGEOLOGY AND PREDEVELOPMENT FLOW IN THE TEXAS GULF COAST AQUIFER SYSTEMS: USGS WATER-RESOURCES INVESTIGATIONS REPORT 87-4248, 1988.

GEOHYDROLOGIC FRAMEWORK OF THE GULF COASTAL PLAIN: USGS HYDROLOGIC INVESTIGATIONS ATLAS HA-695, 1988

GROUND-WATER FLOW IN THE GULF COAST AQUIFER SYSTEMS, SOUTH-CENTRAL UNITED STATES-A PRELIMINARY ANALYSIS USGS WATER-RESOURCES INVESTIGATIONS REPORT 89-4071, 1990.

HYDROLOGY OF THE TEXAS GULF COAST AQUIFER SYSTEMS: USGS OPEN-FILE REPORT 91-64, 1991.

EVALUATION OF GROUND-WATER RESOURCES IN THE VICINITY OF THE CITIES OF HENDERSON, JACKSONVILLE, KILGORE, LUFKIN, NACOGDOCHES, RUSK, AND TYLER IN EAST TEXAS: TEXAS WATER DEVELOPMENT BOARD REPORT 327, 1991.

PROPERTIES AND CHEMICAL CONSTITUENTS IN GROUND WATER FROM THE LOWER CLAIBORNE-UPPER WILCOX AQUIFER, GULF COAST REGIONAL AQUIFER SYSTEMS, SOUTH-CENTRAL UNITED STATES: USGS WATER-RESOURCES INVESTIGATIONS REPORT 92-4102, 1993.

PROPERTIES AND CHEMICAL CONSTITUENTS IN GROUND WATER FROM THE MIDDLE CLAIBORNE AQUIFER, GULF COAST REGIONAL AQUIFER SYSTEMS, SOUTH-CENTRAL UNITED STATES: USGS WATER-RESOURCES INVESTIGATIONS REPORT 92-4104, 1993.

PROPERTIES AND CHEMICAL CONSTITUENTS IN GROUND WATER FROM THE MIDDLE WILCOX AQUIFER, GULF COAST REGIONAL AQUIFER SYSTEMS, SOUTH-CENTRAL UNITED STATES: USGS WATER-RESOURCES INVESTIGATIONS REPORT 93-4070, 1993.

AQUIFERS OF TEXAS: TEXAS WATER DEVELOPMENT BOARD REPORT 345, 1995.

STRATIGRAPHIC NOMENCLATURE AND GEOLOGIC SECTIONS OF THE GULF COASTAL PLAIN OF TEXAS: USGS OPEN-FILE REPORT 94-461, 1995.

WATER QUALITY IN THE QUEEN CITY AQUIFER, EAST TEXAS: TEXAS WATER DEVELOPMENT BOARD HYDROLOGIC ATLAS NO. 6, 1996

\section{SABINE COUNTY}

UNDERGROUND WATERS OF THE COASTAL PLAIN OF TEXAS: USGS WATER-SUPPLY PAPER 190, 1907.

GEOLOGY AND UNDERGROUND WATERS OF THE SOUTHEASTERN PART OF THE TEXAS COASTAL PLAIN: USGS WATER-SUPPLY PAPER 335, 1914.

RECORDS OF WELLS AND SPRINGS, DRILLERS' LOGS, WATER ANALYSES, AND MAP SHOWING LOCATIONS OF WELLS AND SPRINGS IN SABINE AND SAN AUGUSTINE COUNTIES, TEXAS: TEXAS BOARD OF WATER ENGINEERS MISCELLANEOUS PUBLICATION 239, 1943.

PUBLIC WATER SUPPLIES IN EASTERN TEXAS, V. 2, HARRISON COUNTY THROUGH WOOD COUNTY: TEXAS BOARD OF WATER ENGINEERS MISCELLANEOUS PUBLICATION 214, V. 2, 1945.

PUBLIC WATER SUPPLIES IN EASTERN TEXAS: USGS WATERSUPPLY PAPER 1047, 1948.

RECONNAISSANCE INVESTIGATION OF THE GROUND-WATER RESOURCES OF THE SABINE RIVER BASIN, TEXAS: TEXAS WATER COMMISSION BULLETIN 6307, 1963.

RECONNAISSANCE INVESTIGATION OF THE GROUND-WATER RESOURCES OF THE NECHES RIVER BASIN, TEXAS: TEXAS WATER COMMISSION BULLETIN 6308, 1963.

GROUND-WATER RESOURCES OF SABINE AND SAN AUGUSTINE COUNTIES, TEXAS: TEXAS WATER DEVELOPMENT BOARD REPORT 37, 1967.

HYDROLOGIC SIGNIFICANCE OF THE LITHOFACIES OF THE SPARTA SAND IN ARKANSAS, LOUISIANA, MISSISSIPPI, AND TEXAS: USGS PROFESSIONAL PAPER 569-A, 1968.

COMPILATION OF RESULTS OF AQUIFER TESTS IN TEXAS: TEXAS WATER DEVELOPMENT BOARD REPORT 98, 1969.

GEOHYDROLOGIC SIGNIFICANCE OF LITHOFACIES OF THE COCKFIELD FORMATION OF LOUISIANA AND MISSISSIPPI AND OF THE YEGUA FORMATION OF TEXAS: USGS PROFESSIONAL PAPER 569-B, 1970.

GROUND-WATER POLLUTION IN THE VICINITY OF TOLEDO BEND RESERVOIR, TEXAS, PROGRESS REPORT, 1972: USGS OPEN-FILE REPORT 72-010, 1972.

HYDROLOGIC SIGNIFICANCE OF LITHOFACIES OF THE CANE RIVER FORMATION OR EQUIVALENTS OF ARKANSAS, LOUISIANA, MISSISSIPPI, AND TEXAS: USGS PROFESSIONAL PAPER 569-C, 1972.

GROUND-WATER POLLUTION IN THE VICINITY OF TOLEDO BEND RESERVOIR, TEXAS: USGS OPEN-FILE REPORT 74-296, 1974.

HYDROLOGIC SIGNIFICANCE OF LITHOFACIES OF THE CARRIZO SAND OF ARKANSAS, LOUISIANA, AND TEXAS AND THE MERIDIAN SAND OF MISSISSIPPI: USGS PROFESSIONAL PAPER 569-D, 1975.

SUMMARY APPRAISALS OF THE NATION'S GROUND-WATER RESOURCES-TEXAS-GULF REGION: USGS PROFESSIONAL PAPER 813-F, 1976.

SPRINGS OF TEXAS, VOLUME 1: (BY GUNNAR BRUNE), BRANCHSMITH, INC., FORT WORTH, TEXAS, 1981. 
REGIONAL AQUIFER CHARACTERIZATION FOR DEEP-BASIN LIGNITE MINING, SABINE UPLIFT AREA, NORTHEAST TEXAS: UNIVERSITY OF TEXAS, BUREAU OF ECONOMIC GEOLOGY GEOLOGICAL CIRCULAR 83-3, 1983.

TEXAS GROUND-WATER RESOURCES, in NATIONAL WATER SUMMARY 1984: USGS WATER-SUPPLY PAPER 2275, 1985.

APPROXIMATE POTENTIOMETRIC SURFACES FOR THE AQUIFERS OF THE COASTAL UPLANDS SYSTEM, 1980: USGS HYDROLOGIC INVESTIGATIONS ATLAS HA-704, 1987.

GEOHYDROLOGIC FRAMEWORK OF THE GULF COASTAL PLAIN: USGS HYDROLOGIC INVESTIGATIONS ATLAS HA-695, 1988.

HYDROGEOLOGY AND PREDEVELOPMENT FLOW IN THE TEXAS GULF COAST AQUIFER SYSTEMS: USGS WATER-RESOURCES INVESTIGATIONS REPORT 87-4248, 1988.

GROUND-WATER FLOW IN THE GULF COAST AQUIFER SYSTEMS, SOUTH-CENTRAL UNITED STATES-A PRELIMINARY ANALYSIS: USGS WATER-RESOURCES INVESTIGATIONS REPORT 89-4071, 1990.

HYDROLOGY OF THE TEXAS GULF COAST AQUIFER SYSTEMS: USGS OPEN-FILE REPORT 91-64, 1991.

PROPERTIES AND CHEMICAL CONSTITUENTS IN GROUND WATER FROM THE UPPER CLAIBORNE AQUIFER, GULF COAST REGIONAL AQUIFER SYSTEMS, SOUTH-CENTRAL UNITED STATES: USGS WATER-RESOURCES INVESTIGATIONS REPORT 91-4150, 1993.

PROPERTIES AND CHEMICAL CONSTITUENTS IN GROUND WATER FROM THE LOWER CLAIBORNE-UPPER WILCOX AQUIFER, GULF COAST REGIONAL AQUIFER SYSTEMS, SOUTH-CENTRAL UNITED STATES: USGS WATER-RESOURCES INVESTIGATIONS REPORT 92-4102, 1993.

PROPERTIES AND CHEMICAL CONSTITUENTS IN GROUND WATER FROM PERMEABLE ZONE E (LOWER MIOCENE-UPPER OLIGOCENE DEPOSITS), COASTAL LOWLANDS AQUIFER SYSTEM, SOUTH-CENTRAL UNITED STATES: USGS WATER-RESOURCES INVESTIGATIONS REPORT 92-4103, 1993.

PROPERTIES AND CHEMICAL CONSTITUENTS IN GROUND WATER FROM THE MIDDLE CLAIBORNE AQUIFER, GULF COAST REGIONAL AQUIFER SYSTEMS, SOUTH-CENTRAL UNITED STATES: USGS WATER-RESOURCES INVESTIGATIONS REPORT 92-4104, 1993.

PROPERTIES AND CHEMICAL CONSTITUENTS IN GROUND WATER FROM THE MIDDLE WILCOX AQUIFER, GULF COAST REGIONAL AQUIFER SYSTEMS, SOUTH-CENTRAL UNITED STATES: USGS WATER-RESOURCES INVESTIGATIONS REPORT 93-4070, 1993.

STRATIGRAPHIC NOMENCLATURE AND GEOLOGIC SECTIONS OF THE GULF COASTAL PLAIN OF TEXAS: USGS OPEN-FILE REPORT 94-461, 1995.

AQUIFERS OF TEXAS: TEXAS WATER DEVELOPMENT BOARD REPORT 345, 1995

WATER QUALITY IN THE SPARTA AQUIFER, EAST TEXAS: TEXAS WATER DEVELOPMENT BOARD HYDROLOGIC ATLAS NO. 5, 1996.

WATER QUALITY IN THE QUEEN CITY AQUIFER, EAST TEXAS: TEXAS WATER DEVELOPMENT BOARD HYDROLOGIC ATLAS NO. 6, 1996

\section{SAN AUGUSTINE COUNTY}

UNDERGROUND WATERS OF THE COASTAL PLAIN OF TEXAS: USGS WATER-SUPPLY PAPER 190, 1907.

GEOLOGY AND UNDERGROUND WATERS OF THE SOUTHEASTERN PART OF THE TEXAS COASTAL PLAIN: USGS WATER-SUPPLY PAPER 335, 1914.

RECORDS OF WELLS AND SPRINGS, DRILLERS' LOGS, WATER ANALYSES, AND MAP SHOWING LOCATIONS OF WELLS AND SPRINGS IN SABINE AND SAN AUGUSTINE COUNTIES, TEXAS: TEXAS BOARD OF WATER ENGINEERS MISCELLANEOUS PUBLICATION 239, 1943.

MEMORANDUM ON THE WATER SUPPLY FOR THE CITY OF SAN AUGUSTINE, TEXAS: USGS OPEN-FILE REPORT (UNNUMBERED), 1945.

PUBLIC WATER SUPPLIES IN EASTERN TEXAS, V. 2, HARRISON COUNTY THROUGH WOOD COUNTY: TEXAS BOARD OF WATER ENGINEERS MISCELLANEOUS PUBLICATION 214, V. 2, 1945.

PUBLIC WATER SUPPLIES IN EASTERN TEXAS: USGS WATERSUPPLY PAPER 1047, 1948.

RECONNAISSANCE INVESTIGATION OF THE GROUND-WATER RESOURCES OF THE SABINE RIVER BASIN, TEXAS: TEXAS WATER COMMISSION BULLETIN 6307, 1963.

RECONNAISSANCE INVESTIGATION OF THE GROUND-WATER RESOURCES OF THE NECHES RIVER BASIN, TEXAS: TEXAS WATER COMMISSION BULLETIN 6308, 1963.

GROUND-WATER RESOURCES OF SABINE AND SAN AUGUSTINE COUNTIES, TEXAS: TEXAS WATER DEVELOPMENT BOARD REPORT 37, 1967.

HYDROLOGIC SIGNIFICANCE OF THE LITHOFACIES OF THE SPARTA SAND IN ARKANSAS, LOUISIANA, MISSISSIPPI, AND TEXAS: USGS PROFESSIONAL PAPER 569-A, 1968.

COMPILATION OF RESULTS OF AQUIFER TESTS IN TEXAS: TEXAS WATER DEVELOPMENT BOARD REPORT 98, 1969.

GEOHYDROLOGIC SIGNIFICANCE OF LITHOFACIES OF THE COCKFIELD FORMATION OF LOUISIANA AND MISSISSIPPI AND OF THE YEGUA FORMATION OF TEXAS: USGS PROFESSIONAL PAPER 569-B, 1970.

HYDROLOGIC SIGNIFICANCE OF LITHOFACIES OF THE CANE RIVER FORMATION OR EQUIVALENTS OF ARKANSAS, LOUISIANA, MISSISSIPPI, AND TEXAS: USGS PROFESSIONAL PAPER 569-C, 1972.

HYDROLOGIC SIGNIFICANCE OF LITHOFACIES OF THE CARRIZO SAND OF ARKANSAS, LOUISIANA, AND TEXAS AND THE MERIDIAN SAND OF MISSISSIPPI: USGS PROFESSIONAL PAPER 569-D, 1975.

SUMMARY APPRAISALS OF THE NATION'S GROUND-WATER RESOURCES-TEXAS-GULF REGION: USGS PROFESSIONAL PAPER 813-F, 1976.

SPRINGS OF TEXAS, VOLUME 1: (BY GUNNAR BRUNE), BRANCHSMITH, INC., FORT WORTH, TEXAS, 1981.

REGIONAL AQUIFER CHARACTERIZATION FOR DEEP-BASIN LIGNITE MINING, SABINE UPLIFT AREA, NORTHEAST TEXAS: UNIVERSITY OF TEXAS, BUREAU OF ECONOMIC GEOLOGY GEOLOGICAL CIRCULAR 83-3, 1983. 
TEXAS GROUND-WATER RESOURCES, in NATIONAL WATER SUMMARY 1984: USGS WATER-SUPPLY PAPER 2275, 1985.

APPROXIMATE POTENTIOMETRIC SURFACES FOR THE AQUIFERS OF THE COASTAL UPLANDS SYSTEM, 1980: USGS HYDROLOGIC INVESTIGATIONS ATLAS HA-704, 1987.

GEOHYDROLOGIC FRAMEWORK OF THE GULF COASTAL PLAIN: USGS HYDROLOGIC INVESTIGATIONS ATLAS HA-695, 1988.

HYDROGEOLOGY AND PREDEVELOPMENT FLOW IN THE TEXAS GULF COAST AQUIFER SYSTEMS: USGS WATER-RESOURCES INVESTIGATIONS REPORT 87-4248, 1988.

GROUND-WATER FLOW IN THE GULF COAST AQUIFER SYSTEMS, SOUTH-CENTRAL UNITED STATES-A PRELIMINARY ANALYSIS: USGS WATER-RESOURCES INVESTIGATIONS REPORT 89-4071, 1990.

HYDROLOGY OF THE TEXAS GULF COAST AQUIFER SYSTEMS: USGS OPEN-FILE REPORT 91-64, 1991.

PROPERTIES AND CHEMICAL CONSTITUENTS IN GROUND WATER FROM THE UPPER CLAIBORNE AQUIFER, GULF COAST REGIONAL AQUIFER SYSTEMS, SOUTH-CENTRAL UNITED STATES: USGS WATER-RESOURCES INVESTIGATIONS REPORT 91-4150, 1993.

PROPERTIES AND CHEMICAL CONSTITUENTS IN GROUND WATER FROM THE LOWER CLAIBORNE-UPPER WILCOX AQUIFER, GULF COAST REGIONAL AQUIFER SYSTEMS, SOUTH-CENTRAL UNITED STATES: USGS WATER-RESOURCES INVESTIGATIONS REPORT 92-4102, 1993.

PROPERTIES AND CHEMICAL CONSTITUENTS IN GROUND WATER FROM PERMEABLE ZONE E (LOWER MIOCENE-UPPER OLIGOCENE DEPOSITS), COASTAL LOWLANDS AQUIFER SYSTEM, SOUTH-CENTRAL UNITED STATES: USGS WATER-RESOURCES INVESTIGATIONS REPORT 92-4103, 1993.

PROPERTIES AND CHEMICAL CONSTITUENTS IN GROUND WATER FROM THE MIDDLE CLAIBORNE AQUIFER, GULF COAST REGIONAL AQUIFER SYSTEMS, SOUTH-CENTRAL UNITED STATES: USGS WATER-RESOURCES INVESTIGATIONS REPORT 92-4104, 1993.

PROPERTIES AND CHEMICAL CONSTITUENTS IN GROUND WATER FROM THE MIDDLE WILCOX AQUIFER, GULF COAST REGIONAL AQUIFER SYSTEMS, SOUTH-CENTRAL UNITED STATES: USGS WATER-RESOURCES INVESTIGATIONS REPORT 93-4070, 1993

STRATIGRAPHIC NOMENCLATURE AND GEOLOGIC SECTIONS OF THE GULF COASTAL PLAIN OF TEXAS: USGS OPEN-FILE REPORT 94-461, 1995.

AQUIFERS OF TEXAS: TEXAS WATER DEVELOPMENT BOARD REPORT 345, 1995.

WATER QUALITY IN THE SPARTA AQUIFER, EAST TEXAS: TEXAS WATER DEVELOPMENT BOARD HYDROLOGIC ATLAS NO. 5, 1996.

WATER QUALITY IN THE QUEEN CITY AQUIFER, EAST TEXAS: TEXAS WATER DEVELOPMENT BOARD HYDROLOGIC ATLAS NO. 6, 1996.

\section{SAN JACINTO COUNTY}

UNDERGROUND WATERS OF THE COASTAL PLAIN OF TEXAS: USGS WATER-SUPPLY PAPER 190, 1907.

GEOLOGY AND UNDERGROUND WATERS OF THE SOUTHEASTERN PART OF THE TEXAS COASTAL PLAIN: USGS WATER-SUPPLY PAPER 335, 1914.

PUBLIC WATER SUPPLIES IN EASTERN TEXAS, V. 2, HARRISON COUNTY THROUGH WOOD COUNTY: TEXAS BOARD OF WATER ENGINEERS MISCELLANEOUS PUBLICATION 214, V. 2, 1945.

GROUND-WATER RESOURCES OF SAN JACINTO COUNTY, TEXAS: TEXAS BOARD OF WATER ENGINEERS MISCELLANEOUS PUBLICATION 241, 1947.

PUBLIC WATER SUPPLIES IN EASTERN TEXAS: USGS WATERSUPPLY PAPER 1047, 1948.

WATER SUPPLY OF THE GULF COAST REGION: TEXAS BOARD OF WATER ENGINEERS BULLETIN 5101, 1951.

AVAILABILITY OF GROUND WATER IN THE GULF COAST REGION OF TEXAS: USGS OPEN-FILE REPORT (UNNUMBERED), 1956.

RECONNAISSANCE INVESTIGATION OF THE GROUND-WATER RESOURCES OF THE TRINITY RIVER BASIN, TEXAS: TEXAS WATER COMMISSION BULLETIN 6309, 1963.

RECONNAISSANCE INVESTIGATION OF THE GROUND-WATER RESOURCES OF THE GUADALUPE, SAN ANTONIO, AND NUECES RIVER BASINS, TEXAS: TEXAS WATER COMMISSION BULLETIN 6409, 1964.

GROUND-WATER RESOURCES OF SAN JACINTO COUNTY, TEXAS: TEXAS WATER DEVELOPMENT BOARD REPORT 80, 1968.

HYDROLOGIC SIGNIFICANCE OF THE LITHOFACIES OF THE SPARTA SAND IN ARKANSAS, LOUISIANA, MISSISSIPPI, AND TEXAS: USGS PROFESSIONAL PAPER 569-A, 1968.

COMPILATION OF RESULTS OF AQUIFER TESTS IN TEXAS: TEXAS WATER DEVELOPMENT BOARD REPORT 98, 1969.

GEOHYDROLOGIC SIGNIFICANCE OF LITHOFACIES OF THE COCKFIELD FORMATION OF LOUISIANA AND MISSISSIPPI AND OF THE YEGUA FORMATION OF TEXAS: USGS PROFESSIONAL PAPER 569-B, 1970.

HYDROLOGIC SIGNIFICANCE OF LITHOFACIES OF THE CANE RIVER FORMATION OR EQUIVALENTS OF ARKANSAS, LOUISIANA, MISSISSIPPI, AND TEXAS: USGS PROFESSIONAL PAPER 569-C, 1972.

HYDROLOGIC SIGNIFICANCE OF LITHOFACIES OF THE CARRIZO SAND OF ARKANSAS, LOUISIANA, AND TEXAS AND THE MERIDIAN SAND OF MISSISSIPPI: USGS PROFESSIONAL PAPER 569-D, 1975.

MAJOR AND HISTORICAL SPRINGS OF TEXAS: TEXAS WATER DEVELOPMENT BOARD REPORT 189, 1975.

SUMMARY APPRAISALS OF THE NATION'S GROUND-WATER RESOURCES-TEXAS-GULF REGION: USGS PROFESSIONAL PAPER 813-F, 1976.

APPROXIMATE AREAS OF RECHARGE TO THE CHICOT AND EVANGELINE AQUIFER SYSTEMS IN THE HOUSTON-GALVESTON AREA, TEXAS: USGS OPEN-FILE REPORT 77-754, 1977. 
STRATIGRAPHIC AND HYDROGEOLOGIC FRAMEWORK OF PART OF THE COASTAL PLAIN OF TEXAS: USGS OPEN-FILE REPORT 77-712, 1978.

STRATIGRAPHIC AND HYDROGEOLOGIC FRAMEWORK OF PART OF THE COASTAL PLAIN OF TEXAS: TEXAS DEPARTMENT OF WATER RESOURCES REPORT 236, 1979.

SPRINGS OF TEXAS, VOLUME 1: (BY GUNNAR BRUNE), BRANCHSMITH, INC., FORT WORTH, TEXAS, 1981.

TEXAS GROUND-WATER RESOURCES, in NATIONAL WATER SUMMARY 1984: USGS WATER-SUPPLY PAPER 2275, 1985.

HYDROLOGY OF THE JASPER AQUIFER IN THE SOUTHEAST TEXAS COASTAL PLAIN: TEXAS WATER DEVELOPMENT BOARD REPORT 295, 1986.

HYDROGEOLOGY AND PREDEVELOPMENT FLOW IN THE TEXAS GULF COAST AQUIFER SYSTEMS: USGS WATER-RESOURCES INVESTIGATIONS REPORT 87-4248, 1988.

GEOHYDROLOGIC FRAMEWORK OF THE GULF COASTAL PLAIN: USGS HYDROLOGIC INVESTIGATIONS ATLAS HA-695, 1988.

GROUND-WATER FLOW IN THE GULF COAST AQUIFER SYSTEMS, SOUTH-CENTRAL UNITED STATES-A PRELIMINARY ANALYSIS: USGS WATER-RESOURCES INVESTIGATIONS REPORT 89-4071, 1990.

NATIONAL WATER-QUALITY ASSESSMENT PROGRAM-THE TRINITY RIVER BASIN: USGS OPEN-FILE REPORT 91-158, 1991.

HYDROLOGY OF THE TEXAS GULF COAST AQUIFER SYSTEMS: USGS OPEN-FILE REPORT 91-64, 1991.

PROPERTIES AND CHEMICAL CONSTITUENTS IN GROUND WATER FROM THE UPPER CLAIBORNE AQUIFER, GULF COAST REGIONAL AQUIFER SYSTEMS, SOUTH-CENTRAL UNITED STATES: USGS WATER-RESOURCES INVESTIGATIONS REPORT 91-4150, 1993.

PROPERTIES AND CHEMICAL CONSTITUENTS IN GROUND WATER FROM PERMEABLE ZONE C (LOWER PLIOCENE-UPPER MIOCENE DEPOSITS), COASTAL LOWLANDS AQUIFER SYSTEM, SOUTHCENTRAL UNITED STATES: USGS WATER-RESOURCES INVESTIGATIONS REPORT 91-4151, 1993.

PROPERTIES AND CHEMICAL CONSTITUENTS IN GROUND WATER FROM PERMEABLE ZONE B (LOWER PLEISTOCENE-UPPER PLIOCENE DEPOSITS), COASTAL LOWLANDS AQUIFER SYSTEM, SOUTH-CENTRAL UNITED STATES: USGS WATER-RESOURCES INVESTIGATIONS REPORT 91-4152, 1993.

PROPERTIES AND CHEMICAL CONSTITUENTS IN GROUND WATER FROM PERMEABLE ZONE E (LOWER MIOCENE-UPPER OLIGOCENE DEPOSITS), COASTAL LOWLANDS AQUIFER SYSTEM, SOUTH-CENTRAL UNITED STATES: USGS WATER-RESOURCES INVESTIGATIONS REPORT 92-4103, 1993.

PROPERTIES AND CHEMICAL CONSTITUENTS IN GROUND WATER FROM THE MIDDLE CLAIBORNE AQUIFER, GULF COAST REGIONAL AQUIFER SYSTEMS, SOUTH-CENTRAL UNITED STATES: USGS WATER-RESOURCES INVESTIGATIONS REPORT 92-4104, 1993.

PROPERTIES AND CHEMICAL CONSTITUENTS IN GROUND WATER FROM PERMEABLE ZONE D (MIDDLE MIOCENE DEPOSITS), COASTAL LOWLANDS AQUIFER SYSTEM, SOUTH-CENTRAL UNITED STATES: USGS WATER-RESOURCES INVESTIGATIONS REPORT 92-4105, 1993.
PROPERTIES AND CHEMICAL CONSTITUENTS IN GROUND WATER FROM THE MIDDLE WILCOX AQUIFER, GULF COAST AQUIFER SYSTEMS, SOUTH-CENTRAL UNITED STATES: USGS WATERRESOURCES INVESTIGATIONS REPORT 93-4070, 1993.

NATIONAL WATER-QUALITY ASSESSMENT PROGRAM-PESTICIDES IN THE TRINITY RIVER BASIN STUDY UNIT, TEXAS, 1968-91: USGS FACT SHEET FS-088-95, 1995.

WATER-QUALITY ASSESSMENT OF THE TRINITY RIVER BASIN, TEXAS-DATA COLLECTION, 1992-95: USGS FACT SHEET FS-095-95, 1995.

WATER-QUALITY ASSESSMENT OF THE TRINITY RIVER BASIN, TEXAS-PESTICIDES IN A SUBURBAN WATERSHED, ARLINGTON, 1993-94: USGS FACT SHEET FS-159-95, 1995.

AQUIFERS OF TEXAS: TEXAS WATER DEVELOPMENT BOARD REPORT 345, 1995.

WATER-QUALITY ASSESSMENT OF THE TRINITY RIVER BASIN, TEXAS-GROUND-WATER QUALITY OF THE TRINITY, CARRIZOWILCOX, AND GULF COAST AQUIFERS, FEBRUARY-AUGUST 1994: USGS WATER-RESOURCES INVESTIGATIONS REPORT 99-4233, 2000.

\section{SAN PATRICIO COUNTY}

UNDERGROUND WATERS OF THE COASTAL PLAIN OF TEXAS: USGS WATER-SUPPLY PAPER 190, 1907.

GROUND WATER IN SAN PATRICIO COUNTY, TEXAS, AND GROUND WATER IN NUECES COUNTY, TEXAS: USGS OPEN-FILE REPORT (UNNUMBERED), 1933.

GROUND WATER IN NUECES COUNTY, TEXAS: USGS OPEN-FILE REPORT (UNNUMBERED), 1934.

RECORDS OF WELLS, DRILLERS' LOGS, WATER ANALYSES, AND MAP SHOWING LOCATIONS OF WELLS IN SAN PATRICIO COUNTY, TEXAS: TEXAS BOARD OF WATER ENGINEERS MISCELLANEOUS PUBLICATION 242, 1939.

REPORT ON PUMPING TEST CONDUCTED AUGUST 1939 BY HUMBLE OIL \& REFINING COMPANY ON WATER WELLS IN THE LIVE OAK RIDGE AREA NEAR INGLESIDE, TEXAS: USGS OPEN-FILE REPORT (UNNUMBERED), 1939.

GROUND-WATER SUPPLY OF LIVE OAK RIDGE, SOUTHWEST OF ARANSAS PASS, TEXAS: USGS OPEN-FILE REPORT (UNNUMBERED), 1939.

GROUND-WATER RESOURCES OF LIVE OAK RIDGE IN SAN PATRICIO AND ARANSAS COUNTIES: USGS OPEN-FILE REPORT (UNNUMBERED), 1941.

PUBLIC WATER SUPPLIES IN SOUTHERN TEXAS: TEXAS BOARD OF WATER ENGINEERS MISCELLANEOUS PUBLICATION 215, 1946.

SUPPLEMENTARY REPORT ON SURFACE-WATER AND GROUNDWATER SURVEYS, NUECES RIVER BASIN, TEXAS: USGS OPENFILE REPORT (UNNUMBERED), 1950.

PUBLIC WATER SUPPLIES IN SOUTHERN TEXAS: USGS WATERSUPPLY PAPER 1070, 1950.

AVAILABILITY OF GROUND WATER IN THE GULF COAST REGION OF TEXAS: USGS OPEN-FILE REPORT (UNNUMBERED), 1956. 
RECORDS OF WATER LEVELS IN ARANSAS AND SAN PATRICIO COUNTIES, TEXAS, 1938 THROUGH DECEMBER 1956: TEXAS BOARD OF WATER ENGINEERS BULLETIN 5703, 1957.

RECONNAISSANCE INVESTIGATION OF THE GROUND-WATER RESOURCES OF THE GULF COAST REGION, TEXAS: TEXAS WATER COMMISSION BULLETIN 6305, 1963.

GROUND-WATER RESOURCES OF NUECES AND SAN PATRICIO COUNTIES, TEXAS: TEXAS WATER DEVELOPMENT BOARD REPORT 73, 1968.

COMPILATION OF RESULTS OF AQUIFER TESTS IN TEXAS: TEXAS WATER DEVELOPMENT BOARD REPORT 98, 1969.

WATER-LOSS STUDIES OF LAKE CORPUS CHRISTI, NUECES RIVER BASIN, TEXAS, 1949-65: TEXAS WATER DEVELOPMENT BOARD REPORT 104, 1970.

SUMMARY APPRAISALS OF THE NATION'S GROUND-WATER RESOURCES-TEXAS-GULF REGION: USGS PROFESSIONAL PAPER 813-F, 1976.

HYDROLOGY OF THE CORPUS CHRISTI AREA, TEXAS: UNIVERSITY OF TEXAS, BUREAU OF ECONOMIC GEOLOGY RESEARCH NOTE $12,1978$.

LAND AND WATER RESOURCES OF THE CORPUS CHRISTI AREA, TEXAS: UNIVERSITY OF TEXAS, BUREAU OF ECONOMIC GEOLOGY REPORT OF INVESTIGATIONS NO. 95, 1978.

STRATIGRAPHIC AND HYDROGEOLOGIC FRAMEWORK OF PART OF THE COASTAL PLAIN OF TEXAS: USGS OPEN-FILE REPORT $77-712,1978$.

STRATIGRAPHIC AND HYDROGEOLOGIC FRAMEWORK OF PART OF THE COASTAL PLAIN OF TEXAS: TEXAS DEPARTMENT OF WATER RESOURCES REPORT 236, 1979.

LAND-SURFACE SUBSIDENCE IN THE TEXAS COASTAL REGION: USGS OPEN-FILE REPORT 80-969, 1980.

SPRINGS OF TEXAS, VOLUME 1: (BY GUNNAR BRUNE), BRANCHSMITH, INC., FORT WORTH, TEXAS, 1981.

LAND-SURFACE SUBSIDENCE IN THE TEXAS COASTAL REGION: TEXAS DEPARTMENT OF WATER RESOURCES REPORT 272, 1982.

REGIONAL HYDRODYNAMICS AND HYDROCHEMISTRY OF THE URANIUM-BEARING OAKVILLE AQUIFER (MIOCENE) OF SOUTH TEXAS: UNIVERSITY OF TEXAS, BUREAU OF ECONOMIC GEOLOGY REPORT OF INVESTIGATIONS NO. 124, 1982.

SIMULATED EFFECTS OF PROJECTED PUMPING ON THE AVAILABILITY OF FRESHWATER IN THE EVANGELINE AQUIFER IN AN AREA SOUTHWEST OF CORPUS CHRISTI, TEXAS: USGS WATERRESOURCES INVESTIGATIONS REPORT 85-4182, 1985.

TEXAS GROUND-WATER RESOURCES, in NATIONAL WATER SUMMARY 1984: USGS WATER-SUPPLY PAPER 2275, 1985.

DIGITAL MODELS FOR SIMULATION OF GROUND-WATER HYDROLOGY OF THE CHICOT AND EVANGELINE AQUIFERS ALONG THE GULF COAST OF TEXAS: TEXAS DEPARTMENT OF WATER RESOURCES REPORT 289, 1985.

WATER USE, PROJECTED WATER REQUIREMENTS, AND RELATED DATA AND INFORMATION FOR THE METROPOLITAN STATISTICAL AREAS IN TEXAS: TEXAS DEPARTMENT OF WATER RESOURCES LIMITED PRINTING REPORT LP-201, 1985.
GEOHYDROLOGIC FRAMEWORK OF THE GULF COASTAL PLAIN: USGS HYDROLOGIC INVESTIGATIONS ATLAS HA-695, 1988.

HYDROGEOLOGY AND PREDEVELOPMENT FLOW IN THE TEXAS GULF COAST AQUIFER SYSTEMS: USGS WATER-RESOURCES INVESTIGATIONS REPORT 87-4248, 1988.

GROUND-WATER FLOW IN THE GULF COAST AQUIFER SYSTEMS, SOUTH-CENTRAL UNITED STATES-A PRELIMINARY ANALYSIS USGS WATER-RESOURCES INVESTIGATIONS REPORT 89-4071, 1990.

HYDROLOGY OF THE TEXAS GULF COAST AQUIFER SYSTEMS: USGS OPEN-FILE REPORT 91-64, 1991.

PROPERTIES AND CHEMICAL CONSTITUENTS IN GROUND WATER FROM THE MISSISSIPPI RIVER VALLEY ALLUVIAL AQUIFER AND PERMEABLE ZONE A (HOLOCENE-UPPER PLEISTOCENE DEPOSITS), SOUTH-CENTRAL UNITED STATES: USGS WATERRESOURCES INVESTIGATIONS REPORT 91-4149, 1992.

PROPERTIES AND CHEMICAL CONSTITUENTS IN GROUND WATER FROM THE UPPER CLAIBORNE AQUIFER, GULF COAST REGIONAL AQUIFER SYSTEMS, SOUTH-CENTRAL UNITED STATES: USGS WATER-RESOURCES INVESTIGATIONS REPORT 91-4150, 1993.

PROPERTIES AND CHEMICAL CONSTITUENTS IN GROUND WATER FROM PERMEABLE ZONE C (LOWER PLIOCENE-UPPER MIOCENE DEPOSITS), COASTAL LOWLANDS AQUIFER SYSTEM, SOUTHCENTRAL UNITED STATES: USGS WATER-RESOURCES INVESTIGATIONS REPORT 91-4151, 1993.

PROPERTIES AND CHEMICAL CONSTITUENTS IN GROUND WATER FROM PERMEABLE ZONE B (LOWER PLEISTOCENE-UPPER PLIOCENE DEPOSITS), COASTAL LOWLANDS AQUIFER SYSTEM, SOUTH-CENTRAL UNITED STATES: USGS WATER-RESOURCES INVESTIGATIONS REPORT 91-4152, 1993.

PROPERTIES AND CHEMICAL CONSTITUENTS IN GROUND WATER FROM PERMEABLE ZONE E (LOWER MIOCENE-UPPER OLIGOCENE DEPOSITS), COASTAL LOWLANDS AQUIFER SYSTEM, SOUTH-CENTRAL UNITED STATES: USGS WATER-RESOURCES INVESTIGATIONS REPORT 92-4103, 1993.

PROPERTIES AND CHEMICAL CONSTITUENTS IN GROUND WATER FROM PERMEABLE ZONE D (MIDDLE MIOCENE DEPOSITS), COASTAL LOWLANDS AQUIFER SYSTEM, SOUTH-CENTRAL UNITED STATES: USGS WATER-RESOURCES INVESTIGATIONS REPORT 92-4105, 1993.

AQUIFERS OF TEXAS: TEXAS WATER DEVELOPMENT BOARD REPORT 345, 1995.

\section{SAN SABA COUNTY}

RECORDS OF WELLS AND SPRINGS, DRILLERS' LOGS, WATER ANALYSES, AND MAP SHOWING LOCATIONS OF WELLS AND SPRINGS IN SAN SABA COUNTY, TEXAS: TEXAS BOARD OF WATER ENGINEERS MISCELLANEOUS PUBLICATION 243, 1939.

WATER SUPPLY FOR THE CITY OF SAN SABA, TEXAS: TEXAS BOARD OF WATER ENGINEERS MISCELLANEOUS PUBLICATION 244,1944

PUBLIC WATER SUPPLIES IN CENTRAL AND NORTH-CENTRAL TEXAS: TEXAS BOARD OF WATER ENGINEERS MISCELLANEOUS PUBLICATION 213, 1947. 
MEMORANDUM REGARDING LETTER OF FEBRUARY 9, 1947 FROM J.C. WILLINGHAM OF RICHLAND SPRINGS, TEXAS: USGS OPENFILE REPORT (UNNUMBERED), 1948

PUBLIC WATER SUPPLIES IN CENTRAL AND NORTH-CENTRAL TEXAS: USGS WATER-SUPPLY PAPER 1069, 1949.

RECONNAISSANCE INVESTIGATION OF THE GROUND-WATER RESOURCES OF THE COLORADO RIVER BASIN, TEXAS: TEXAS WATER DEVELOPMENT BOARD REPORT 51, 1967.

MAJOR AND HISTORICAL SPRINGS OF TEXAS: TEXAS WATER DEVELOPMENT BOARD REPORT 189, 1975.

SUMMARY APPRAISALS OF THE NATION'S GROUND-WATER RESOURCES-TEXAS-GULF REGION: USGS PROFESSIONAL PAPER 813-F, 1976.

OCCURRENCE, AVAILABILITY, AND CHEMICAL QUALITY OF GROUND WATER IN THE EDWARDS PLATEAU REGION OF TEXAS: TEXAS DEPARTMENT OF WATER RESOURCES REPORT 235, 1979.

TEXAS GROUND-WATER RESOURCES, in NATIONAL WATER SUMMARY 1984: USGS WATER-SUPPLY PAPER 2275, 1985.

POTENTIOMETRIC SURFACE OF THE EDWARDS-TRINITY AQUIFER SYSTEM AND CONTIGUOUS HYDRAULICALLY CONNECTED UNITS, WEST-CENTRAL TEXAS, WINTER 1974-75: USGS WATERRESOURCES INVESTIGATIONS REPORT 89-4208, 1990.

WITHDRAWALS FROM THE EDWARDS-TRINITY AQUIFER SYSTEM AND CONTIGUOUS HYDRAULICALLY CONNECTED UNITS, WEST-CENTRAL TEXAS, DECEMBER 1974 THROUGH MARCH 1977: USGS WATER-RESOURCES INVESTIGATIONS REPORT 91-4021, 1991.

CONFIGURATION OF THE BASE OF THE EDWARDS-TRINITY AQUIFER SYSTEM AND HYDROGEOLOGY OF THE UNDERLYING PRECRETACEOUS ROCKS, WEST-CENTRAL TEXAS: USGS WATERRESOURCES INVESTIGATIONS REPORT 91-4071, 1992.

HISTORICAL POTENTIOMETRIC SURFACE OF THE EDWARDS-TRINITY AQUIFER SYSTEM AND CONTIGUOUS HYDRAULICALLY CONNECTED UNITS, WEST-CENTRAL TEXAS: USGS WATERRESOURCES INVESTIGATIONS REPORT 92-4055, 1993.

HISTORICAL SATURATED THICKNESS OF THE EDWARDS-TRINITY AQUIFER SYSTEM AND SELECTED CONTIGUOUS HYDRAULICALLY CONNECTED UNITS, WEST-CENTRAL TEXAS: USGS WATER-RESOURCES INVESTIGATIONS REPORT 92-4125, 1993.

SIMULATIONS OF FLOW IN THE EDWARDS-TRINITY AQUIFER SYSTEM AND CONTIGUOUS HYDRAULICALLY CONNECTED UNITS, WEST-CENTRAL TEXAS: USGS WATER-RESOURCES INVESTIGATIONS REPORT 93-4039, 1994.

GEOLOGIC HISTORY AND HYDROGEOLOGIC SETTING OF THE EDWARDS-TRINITY AQUIFER SYSTEM, WEST-CENTRAL TEXAS: USGS WATER-RESOURCES INVESTIGATIONS REPORT 94-4039, 1994.

AQUIFERS OF TEXAS: TEXAS WATER DEVELOPMENT BOARD REPORT 345, 1995.

THE PALEOZOIC AND RELATED AQUIFERS OF CENTRAL TEXAS: TEXAS WATER DEVELOPMENT BOARD REPORT 346, 1996.

\section{SCHLEICHER COUNTY}

WATER SUPPLY OF ELDORADO, TEXAS: USGS OPEN-FILE REPORT (UNNUMBERED), 1940

PUBLIC WATER SUPPLIES IN WESTERN TEXAS: TEXAS BOARD OF WATER ENGINEERS MISCELLANEOUS PUBLICATION 216, 1949.

PUBLIC WATER SUPPLIES IN WESTERN TEXAS: USGS WATERSUPPLY PAPER 1106, 1951.

RECONNAISSANCE INVESTIGATION OF THE GROUND-WATER RESOURCES OF THE RIO GRANDE BASIN, TEXAS: TEXAS WATER COMMISSION BULLETIN 6502, 1965.

RECONNAISSANCE INVESTIGATION OF THE GROUND-WATER RESOURCES OF THE COLORADO RIVER BASIN, TEXAS: TEXAS WATER DEVELOPMENT BOARD REPORT 51, 1967.

WATER WELL AND GROUND WATER CHEMICAL ANALYSIS DATA SCHLEICHER COUNTY, TEXAS: TEXAS WATER DEVELOPMENT BOARD REPORT 132, 1971.

RECONNAISSANCE INVESTIGATION OF GROUND WATER IN THE RIO GRANDE DRAINAGE BASIN-WITH SPECIAL EMPHASIS ON SALINE GROUND-WATER RESOURCES: USGS HYDROLOGIC INVESTIGATIONS ATLAS HA-510, 1974.

MAJOR AND HISTORICAL SPRINGS OF TEXAS: TEXAS WATER DEVELOPMENT BOARD REPORT 189, 1975.

SUMMARY APPRAISALS OF THE NATION'S GROUND-WATER RESOURCES-TEXAS-GULF REGION: USGS PROFESSIONAL PAPER 813-F, 1976

OCCURRENCE, AVAILABILITY, AND CHEMICAL QUALITY OF GROUND WATER IN THE EDWARDS PLATEAU REGION OF TEXAS: TEXAS DEPARTMENT OF WATER RESOURCES REPORT 235,1979

TEXAS GROUND-WATER RESOURCES, in NATIONAL WATER SUMMARY 1984: USGS WATER-SUPPLY PAPER 2275, 1985.

POTENTIOMETRIC SURFACE OF THE EDWARDS-TRINITY AQUIFER SYSTEM AND CONTIGUOUS HYDRAULICALLY CONNECTED UNITS, WEST-CENTRAL TEXAS, WINTER 1974-75: USGS WATERRESOURCES INVESTIGATIONS REPORT 89-4208, 1990.

WITHDRAWALS FROM THE EDWARDS-TRINITY AQUIFER SYSTEM AND CONTIGUOUS HYDRAULICALLY CONNECTED UNITS, WEST-CENTRAL TEXAS, DECEMBER 1974 THROUGH MARCH 1977: USGS WATER-RESOURCES INVESTIGATIONS REPORT 91-4021, 1991.

CONFIGURATION OF THE BASE OF THE EDWARDS-TRINITY AQUIFER SYSTEM AND HYDROGEOLOGY OF THE UNDERLYING PRECRETACEOUS ROCKS, WEST-CENTRAL TEXAS: USGS WATERRESOURCES INVESTIGATIONS REPORT 91-4071, 1992.

HISTORICAL POTENTIOMETRIC SURFACE OF THE EDWARDS-TRINITY AQUIFER SYSTEM AND CONTIGUOUS HYDRAULICALLY CONNECTED UNITS, WEST-CENTRAL TEXAS: USGS WATERRESOURCES INVESTIGATIONS REPORT 92-4055, 1993.

HISTORICAL SATURATED THICKNESS OF THE EDWARDS-TRINITY AQUIFER SYSTEM AND SELECTED CONTIGUOUS HYDRAULICALLY CONNECTED UNITS, WEST-CENTRAL TEXAS: USGS WATER-RESOURCES INVESTIGATIONS REPORT 92-4125, 1993.

SIMULATIONS OF FLOW IN THE EDWARDS-TRINITY AQUIFER SYSTEM AND CONTIGUOUS HYDRAULICALLY CONNECTED 
UNITS, WEST-CENTRAL TEXAS: USGS WATER-RESOURCES INVESTIGATIONS REPORT 93-4039, 1994.

DISSOLVED-SOLIDS CONCENTRATIONS AND HYDROCHEMICAL FACIES IN WATER OF THE EDWARDS-TRINITY AQUIFER SYSTEM, WEST-CENTRAL TEXAS: USGS WATER-RESOURCES INVESTIGATIONS REPORT 93-4126, 1994.

GEOLOGIC HISTORY AND HYDROGEOLOGIC SETTING OF THE EDWARDS-TRINITY AQUIFER SYSTEM, WEST-CENTRAL TEXAS: USGS WATER-RESOURCES INVESTIGATIONS REPORT 94-4039, 1994.

AQUIFERS OF TEXAS: TEXAS WATER DEVELOPMENT BOARD REPORT 345, 1995.

WATER QUALITY IN THE EDWARDS-TRINITY (PLATEAU) AQUIFER, EDWARDS PLATEAU AND TRANS-PECOS, TEXAS: TEXAS WATER DEVELOPMENT BOARD HYDROLOGIC ATLAS NO. 3, 1995.

HYDROGEOLOGIC FRAMEWORK OF THE EDWARDS-TRINITY AQUIFER SYSTEM, WEST-CENTRAL TEXAS: USGS PROFESSIONAL PAPER 1421-B, 1996.

\section{SCURRY COUNTY}

GROUND WATER IN PARTS OF SCURRY COUNTY, RECORDS OF WELLS, DRILLERS' LOGS, WATER ANALYSES, AND MAP SHOWING LOCATIONS OF WELLS IN SCURRY COUNTY, TEXAS: TEXAS BOARD OF WATER ENGINEERS MISCELLANEOUS PUBLICATION 245,1946

PUBLIC WATER SUPPLIES IN WESTERN TEXAS: TEXAS BOARD OF WATER ENGINEERS MISCELLANEOUS PUBLICATION 216, 1949.

PUBLIC WATER SUPPLIES IN WESTERN TEXAS: USGS WATERSUPPLY PAPER 1106, 1951.

RECORDS OF WATER-LEVEL MEASUREMENTS IN MITCHELL, NOLAN, STERLING, AND TOM GREEN COUNTIES, TEXAS, 1938 THROUGH 1957: TEXAS BOARD OF WATER ENGINEERS BULLETIN 5907, 1959.

A STUDY OF SALT WATER POLLUTION OF THE COLORADO RIVER, SCURRY AND MITCHELL COUNTIES, TEXAS: PREPARED FOR THE COLORADO RIVER MUNICIPAL WATER DISTRICT, BIG SPRING, TEXAS, BY ED L. REED, CONSULTING GROUND-WATER HYDROLOGIST, MIDLAND, TEXAS, 1961.

RECONNAISSANCE INVESTIGATION OF THE GROUND-WATER RESOURCES OF THE BRAZOS RIVER BASIN, TEXAS: TEXAS WATER COMMISSION BULLETIN 6310, 1963.

INVESTIGATION OF ALLEGED GROUND-WATER CONTAMINATION-TRI-RUE OIL FIELDS, SCURRY COUNTY, TEXAS: TEXAS WATER COMMISSION LIMITED-DISTRIBUTION REPORT LD-0464-MR, 1964.

RECONNAISSANCE INVESTIGATION OF THE GROUND-WATER RESOURCES OF THE COLORADO RIVER BASIN, TEXAS: TEXAS WATER DEVELOPMENT BOARD REPORT 51, 1967.

COMPILATION OF RESULTS OF AQUIFER TESTS IN TEXAS: TEXAS WATER DEVELOPMENT BOARD REPORT 98, 1969.

WOODY PHREATOPHYTES ALONG THE COLORADO RIVER FROM SOUTHEAST RUNNELS COUNTY TO THE HEADWATERS IN BORDEN COUNTY, TEXAS: TEXAS WATER DEVELOPMENT BOARD REPORT 182, 1974.
MAJOR AND HISTORICAL SPRINGS OF TEXAS: TEXAS WATER DEVELOPMENT BOARD REPORT 189, 1975.

SUMMARY APPRAISALS OF THE NATION'S GROUND-WATER RESOURCES-TEXAS-GULF REGION: USGS PROFESSIONAL PAPER 813-F, 1976.

PRELIMINARY DATA DESCRIBING THE DISTRIBUTION OF FLUORIDE AND SILICA IN THE OGALLALA AQUIFER ON THE HIGH PLAINS OF TEXAS: USGS OPEN-FILE REPORT 80-349, 1980.

SOURCE AREAS OF SALINITY AND TRENDS OF SALT LOADS IN STREAMFLOW IN THE UPPER COLORADO RIVER, TEXAS: USGS OPEN-FILE REPORT 80-224, 1980.

AN INVESTIGATION OF SOURCES OF SALT POLLUTION IN THE UPPER COLORADO RIVER BASIN, TEXAS: U.S. ARMY CORPS OF ENGINEERS REPORT, 1980.

SPRINGS OF TEXAS, VOLUME 1: (BY GUNNAR BRUNE), BRANCHSMITH, INC., FORT WORTH, TEXAS, 1981.

TEXAS GROUND-WATER RESOURCES, in NATIONAL WATER SUMMARY 1984: USGS WATER-SUPPLY PAPER 2275, 1985.

PUBLIC SUPPLY GROUND-WATER USE IN THE SOUTHERN HIGH PLAINS OF TEXAS: TEXAS WATER DEVELOPMENT BOARD REPORT 328, 1990

WATER-LEVEL CHANGES IN THE HIGH PLAINS AQUIFER OF TEXAS, 1980-1990: TEXAS WATER DEVELOPMENT BOARD HYDROLOGIC ATLAS NO. 1, 1991.

EVALUATION OF WATER RESOURCES IN PARTS OF THE ROLLING PRAIRIES REGION OF NORTH-CENTRAL TEXAS: TEXAS WATER DEVELOPMENT BOARD REPORT 337, 1992.

CHARACTERISTICS OF STREAMS AND AQUIFERS AND PROCESSES AFFECTING THE SALINITY OF WATER IN THE UPPER COLORADO RIVER BASIN, TEXAS: USGS WATER-RESOURCES INVESTIGATIONS REPORT 94-4036, 1994.

AQUIFERS OF TEXAS: TEXAS WATER DEVELOPMENT BOARD REPORT 345, 1995.

UPDATED WATER-QUALITY EVALUATION OF THE OGALLALA AQUIFER INCLUDING SELECTED METALLIC AND NON-METALLIC INORGANIC CONSTITUENTS: TEXAS WATER DEVELOPMENT BOARD HYDROLOGIC ATLAS HA-10, 1998.

\section{SHACKELFORD COUNTY}

SALT-WATER PROBLEM AT ALBANY: USGS OPEN-FILE REPORT (UNNUMBERED), 1940.

PUBLIC WATER SUPPLIES IN CENTRAL AND NORTH-CENTRAL TEXAS: TEXAS BOARD OF WATER ENGINEERS MISCELLANEOUS PUBLICATION 213, 1947.

PUBLIC WATER SUPPLIES IN CENTRAL AND NORTH-CENTRAL TEXAS: USGS WATER-SUPPLY PAPER 1069, 1949.

RECONNAISSANCE INVESTIGATION OF THE GROUND-WATER RESOURCES OF THE BRAZOS RIVER BASIN, TEXAS: TEXAS WATER COMMISSION BULLETIN 6310, 1963.

OCCURRENCE AND QUALITY OF GROUND WATER IN SHACKELFORD COUNTY, TEXAS: TEXAS WATER DEVELOPMENT BOARD REPORT 100, 1969. 
TEXAS GROUND-WATER RESOURCES, in NATIONAL WATER SUMMARY 1984: USGS WATER-SUPPLY PAPER 2275, 1985.

EVALUATION OF WATER RESOURCES IN PARTS OF THE ROLLING PRAIRIES REGION OF NORTH-CENTRAL TEXAS: TEXAS WATER DEVELOPMENT BOARD REPORT 337, 1992.

\section{SHELBY COUNTY}

UNDERGROUND WATERS OF THE COASTAL PLAIN OF TEXAS: USGS WATER-SUPPLY PAPER 190, 1907.

GEOLOGY AND UNDERGROUND WATERS OF THE SOUTHEASTERN PART OF THE TEXAS COASTAL PLAIN: USGS WATER-SUPPLY PAPER 335, 1914.

RECORDS OF WELLS AND SPRINGS, DRILLERS' LOGS, AND WATER ANALYSES, AND MAP SHOWING LOCATION OF WELLS AND SPRINGS IN SHELBY COUNTY, TEXAS: TEXAS BOARD OF WATER ENGINEERS MISCELLANEOUS PUBLICATION 247, 1938.

WATER SUPPLY IN THE SANDFLAT AREA AND ADJACENT TERRITORY IN RUSK, NACOGDOCHES, AND SHELBY COUNTIES, TEXAS: TEXAS BOARD OF WATER ENGINEERS MISCELLANEOUS PUBLICATION 236A, 1942.

PUBLIC WATER SUPPLIES IN EASTERN TEXAS, V. 2, HARRISON COUNTY THROUGH WOOD COUNTY: TEXAS BOARD OF WATER ENGINEERS MISCELLANEOUS PUBLICATION 214, V. 2, 1945.

PUBLIC WATER SUPPLIES IN EASTERN TEXAS: USGS WATERSUPPLY PAPER 1047, 1948

GROUND-WATER INVESTIGATION OF SHELBY COUNTY, TEXAS: TEXAS BOARD OF WATER ENGINEERS MISCELLANEOUS PUBLICATION 248, 1960

RECONNAISSANCE INVESTIGATION OF THE GROUND-WATER RESOURCES OF THE SABINE RIVER BASIN, TEXAS: TEXAS WATER COMMISSION BULLETIN 6307, 1963.

RECONNAISSANCE INVESTIGATION OF THE GROUND-WATER RESOURCES OF THE NECHES RIVER BASIN, TEXAS: TEXAS WATER COMMISSION BULLETIN 6308, 1963.

COMPILATION OF RESULTS OF AQUIFER TESTS IN TEXAS: TEXAS WATER DEVELOPMENT BOARD REPORT 98, 1969.

GROUND-WATER POLLUTION IN THE VICINITY OF TOLEDO BEND RESERVOIR, TEXAS, PROGRESS REPORT, 1972: USGS OPEN-FILE REPORT 72-010, 1972.

GROUND-WATER POLLUTION IN THE VICINITY OF TOLEDO BEND RESERVOIR, TEXAS: USGS OPEN-FILE REPORT 74-296, 1974.

HYDROLOGIC SIGNIFICANCE OF LITHOFACIES OF THE CARRIZO SAND OF ARKANSAS, LOUISIANA, AND TEXAS AND THE MERIDIAN SAND OF MISSISSIPPI: USGS PROFESSIONAL PAPER 569-D, 1975.

SUMMARY APPRAISALS OF THE NATION'S GROUND-WATER RESOURCES-TEXAS-GULF REGION: USGS PROFESSIONAL PAPER 813-F, 1976.

SPRINGS OF TEXAS, VOLUME 1: (BY GUNNAR BRUNE), BRANCHSMITH, INC., FORT WORTH, TEXAS, 1981.

REGIONAL AQUIFER CHARACTERIZATION FOR DEEP-BASIN LIGNITE MINING, SABINE UPLIFT AREA, NORTHEAST TEXAS: UNI-
VERSITY OF TEXAS, BUREAU OF ECONOMIC GEOLOGY GEOLOGICAL CIRCULAR 83-3, 1983.

TEXAS GROUND-WATER RESOURCES, in NATIONAL WATER SUMMARY 1984: USGS WATER-SUPPLY PAPER 2275, 1985.

APPROXIMATE POTENTIOMETRIC SURFACES FOR THE AQUIFERS OF THE TEXAS COASTAL UPLANDS SYSTEM, 1980: USGS HYDROLOGIC INVESTIGATIONS ATLAS HA-704, 1987.

GEOHYDROLOGIC FRAMEWORK OF THE GULF COASTAL PLAIN: USGS HYDROLOGIC INVESTIGATIONS ATLAS HA-695, 1988.

HYDROGEOLOGY AND PREDEVELOPMENT FLOW IN THE TEXAS GULF COAST AQUIFER SYSTEMS: USGS WATER-RESOURCES INVESTIGATIONS REPORT 87-4248, 1988.

GROUND-WATER FLOW IN THE GULF COAST AQUIFER SYSTEMS, SOUTH-CENTRAL UNITED STATES-A PRELIMINARY ANALYSIS: USGS WATER-RESOURCES INVESTIGATIONS REPORT 89-4071, 1990.

HYDROLOGY OF THE TEXAS GULF COAST AQUIFER SYSTEMS: USGS OPEN-FILE REPORT 91-64, 1991.

PROPERTIES AND CHEMICAL CONSTITUENTS IN GROUND WATER FROM THE MIDDLE WILCOX AQUIFER, GULF COAST REGIONAL AQUIFER SYSTEMS, SOUTH-CENTRAL UNITED STATES: USGS WATER-RESOURCES INVESTIGATIONS REPORT 93-4070, 1993.

AQUIFERS OF TEXAS: TEXAS WATER DEVELOPMENT BOARD REPORT 345, 1995.

WATER QUALITY IN THE SPARTA AQUIFER, EAST TEXAS: TEXAS WATER DEVELOPMENT BOARD HYDROLOGIC ATLAS NO. 5, 1996.

WATER QUALITY IN THE QUEEN CITY AQUIFER, EAST TEXAS: TEXAS WATER DEVELOPMENT BOARD HYDROLOGIC ATLAS NO. 6, 1996.

\section{SHERMAN COUNTY}

THE GEOLOGY AND WATER RESOURCES OF THE WESTERN PORTION OF THE PANHANDLE OF TEXAS: USGS WATER-SUPPLY PAPER 191, 1907.

GEOLOGY AND GROUND-WATER RESOURCES OF THE SOUTHERN HIGH PLAINS: USGS OPEN-FILE REPORT (UNNUMBERED), 1935.

PUBLIC WATER SUPPLIES IN WESTERN TEXAS: TEXAS BOARD OF WATER ENGINEERS MISCELLANEOUS PUBLICATION 216, 1949.

PUBLIC WATER SUPPLIES IN WESTERN TEXAS: USGS WATERSUPPLY PAPER 1106, 1951 [1952].

RECORDS OF WATER-LEVEL MEASUREMENTS IN DALLAM, HANSFORD, HARTLEY, HUTCHINSON, MOORE, OCHILTREE, AND SHERMAN COUNTIES, TEXAS: TEXAS BOARD OF WATER ENGINEERS BULLETIN 5404, 1954.

WATER-LEVEL MAPS AND WATER LEVELS IN OBSERVATION WELLS IN THE NORTH HIGH PLAINS, TEXAS: TEXAS BOARD OF WATER ENGINEERS BULLETIN 5707, 1957.

WATER-LEVEL MEASUREMENTS AND MAPS, NORTHERN HIGH PLAINS, TEXAS, 1958 AND 1959: TEXAS BOARD OF WATER ENGINEERS BULLETIN 5909, 1959. 
WATER LEVELS IN OBSERVATION WELLS, NORTHERN HIGH PLAINS, TEXAS, 1958-1960: TEXAS BOARD OF WATER ENGINEERS BULLETIN 6012, 1960.

RECONNAISSANCE INVESTIGATION OF THE GROUND-WATER RESOURCES OF THE CANADIAN RIVER BASIN, TEXAS: TEXAS BOARD OF WATER ENGINEERS BULLETIN 6016, 1960.

ANNUAL WATER-LEVEL MEASUREMENTS IN OBSERVATION WELLS, NORTHERN HIGH PLAINS, TEXAS, 1960 AND 1961: TEXAS BOARD OF WATER ENGINEERS BULLETIN 6103, 1961.

GEOLOGY AND GROUND-WATER RESOURCES OF THE NORTHERN HIGH PLAINS OF TEXAS, PROGRESS REPORT NO. 1: TEXAS BOARD OF WATER ENGINEERS BULLETIN 6109, 1961.

ANNUAL WATER-LEVEL MEASUREMENTS IN OBSERVATION WELLS, NORTHERN HIGH PLAINS, TEXAS, 1961 AND 1962: TEXAS WATER COMMISSION BULLETIN 6213, 1962.

WATER-LEVEL DATA FROM OBSERVATION WELLS IN THE NORTHERN PANHANDLE OF TEXAS: TEXAS DEPARTMENT OF WATER RESOURCES REPORT 137, 1971.

GROUND-WATER RESOURCES OF THE PALO DURO CREEK BASIN, TEXAS AND OKLAHOMA: USGS OPEN-FILE REPORT 79-209, 1979.

PRELIMINARY DATA DESCRIBING THE DISTRIBUTION OF FLUORIDE AND SILICA IN THE OGALLALA AQUIFER ON THE HIGH PLAINS OF TEXAS: USGS OPEN-FILE REPORT 80-349, 1980.

WATER-LEVEL DATA FROM OBSERVATION WELLS IN THE NORTHERN PANHANDLE OF TEXAS, 1972-78: TEXAS DEPARTMENT OF WATER RESOURCES REPORT 248, 1980.

WATER TABLE IN THE HIGH PLAINS AQUIFER IN 1978 IN PARTS OF COLORADO, KANSAS, NEBRASKA, NEW MEXICO, OKLAHOMA, SOUTH DAKOTA, TEXAS, AND WYOMING: USGS HYDROLOGIC INVESTIGATIONS ATLAS HA-642, 1980.

EVALUATING THE GROUND-WATER RESOURCES OF THE HIGH PLAINS OF TEXAS: RESULTS OF TEST HOLE DRILLING: TEXAS DEPARTMENT OF WATER RESOURCES LIMITED PRINTING REPORT LP-129, 1980.

EVALUATING THE GROUND-WATER RESOURCES OF THE HIGH PLAINS OF TEXAS: RESULTS OF SURFACE ELECTRICAL RESISTIVITY SURVEYS: TEXAS DEPARTMENT OF WATER RESOURCES LIMITED PRINTING REPORT LP-130, 1980.

ANALYTICAL STUDY OF THE OGALLALA AQUIFER IN SHERMAN COUNTY, TEXAS; PROJECTIONS OF SATURATED THICKNESS, VOLUME OF WATER IN STORAGE, PUMPAGE RATES, PUMPING LIFTS, AND WELL YIELDS: TEXAS DEPARTMENT OF WATER RESOURCES REPORT 253, 1980.

EVALUATING THE GROUND-WATER RESOURCES OF THE HIGH PLAINS OF TEXAS: NEUTRON-PROBE MEASUREMENTS OF DEEP SOIL MOISTURE AS AN INDICATION OF AQUIFER RECHARGE RATES: TEXAS DEPARTMENT OF WATER RESOURCES LIMITED PRINTING REPORT LP-142, 1981.

SPRINGS OF TEXAS, VOLUME 1: (BY GUNNAR BRUNE), BRANCHSMITH, INC., FORT WORTH, TEXAS, 1981.

BEDROCK GEOLOGY, ALTITUDE OF BASE, AND 1980 SATURATED THICKNESS OF THE HIGH PLAINS AQUIFER IN PARTS OF COLORADO, KANSAS, NEBRASKA, NEW MEXICO, OKLAHOMA, SOUTH DAKOTA, TEXAS, AND WYOMING: USGS HYDROLOGIC INVESTIGATIONS ATLAS HA-648, 1981.
WATER-LEVEL AND SATURATED-THICKNESS CHANGES, PREDEVELOPMENT TO 1980, IN THE HIGH PLAINS AQUIFER IN PARTS OF COLORADO, KANSAS, NEBRASKA, NEW MEXICO, OKLAHOMA, SOUTH DAKOTA, TEXAS, AND WYOMING: USGS HYDROLOGIC INVESTIGATIONS ATLAS HA-652, 1981.

DISSOLVED SOLIDS AND SODIUM IN WATER FROM THE HIGH PLAINS AQUIFER IN PARTS OF COLORADO, KANSAS, NEBRASKA, NEW MEXICO, OKLAHOMA, SOUTH DAKOTA, TEXAS, AND WYOMING: USGS HYDROLOGIC INVESTIGATIONS ATLAS HA-658, 1982.

GEOHYDROLOGY OF THE HIGH PLAINS AQUIFER IN PARTS OF COLORADO, KANSAS, NEBRASKA, NEW MEXICO, OKLAHOMA, SOUTH DAKOTA, TEXAS, AND WYOMING: USGS PROFESSIONAL PAPER 1400-B, 1984.

EVALUATING THE GROUND-WATER RESOURCES OF THE HIGH PLAINS OF TEXAS, VOLUME 1: TEXAS DEPARTMENT OF WATER RESOURCES REPORT 288, V. 1, 1984.

EVALUATING THE GROUND-WATER RESOURCES OF THE HIGH PLAINS OF TEXAS, VOLUME 2, RECORDS OF WELLS, AND MAPS SHOWING WELL LOCATIONS, BASE OF AQUIFER, WATER LEVELS, AND SATURATED THICKNESS (ARMSTRONG, CARSON, DALLAS, DONLEY, GRAY, HANSFORD, HARTLEY, HEMPHILL, HUTCHINSON, LIPSCOMB, MOORE, OCHILTREE, POTTER, ROBERTS, SHERMAN, AND WHEELER COUNTIES): TEXAS DEPARTMENT OF WATER RESOURCES REPORT 288, V. 2, 1984.

TEXAS GROUND-WATER RESOURCES, in NATIONAL WATER SUMMARY 1984: USGS WATER-SUPPLY PAPER 2275, 1985.

DIGITAL SIMULATION OF GROUND-WATER FLOW IN THE HIGH PLAINS AQUIFER IN PARTS OF COLORADO, KANSAS, NEBRASKA, NEW MEXICO, OKLAHOMA, SOUTH DAKOTA, TEXAS, AND WYOMING: USGS PROFESSIONAL PAPER 1400-D, 1986.

SUMMARY OF THE HIGH PLAINS REGIONAL AQUIFER-SYSTEM ANALYSIS IN PARTS OF COLORADO, KANSAS, NEBRASKA, NEW MEXICO, OKLAHOMA, SOUTH DAKOTA, TEXAS, AND WYOMING: USGS PROFESSIONAL PAPER 1400-A, 1988.

WATER-LEVEL CHANGES IN THE HIGH PLAINS AQUIFER OF TEXAS, 1980-1990: TEXAS WATER DEVELOPMENT BOARD HYDROLOGIC ATLAS NO. 1, 1991.

PUBLIC-SUPPLY GROUND-WATER USE IN THE NORTHERN HIGH PLAINS OF TEXAS: TEXAS WATER DEVELOPMENT BOARD REPORT 336, 1992.

THE HIGH PLAINS AQUIFER SYSTEM OF TEXAS, 1980-1990. OVERVIEW AND PROJECTIONS: TEXAS WATER DEVELOPMENT BOARD REPORT 341, 1993.

WATER-QUALITY EVALUATION OF THE OGALLALA AQUIFER, TEXAS: TEXAS WATER DEVELOPMENT BOARD REPORT 342 , 1993.

WATER-LEVEL CHANGES IN THE HIGH PLAINS AQUIFER-PREDEVELOPMENT TO 1992: USGS WATER-RESOURCES INVESTIGATIONS REPORT 94-4027, 1994.

WATER-LEVEL CHANGES IN THE HIGH PLAINS AQUIFER, 1980 TO 1994: USGS FACT SHEET FS-215-95, 1995.

AQUIFERS OF TEXAS: TEXAS WATER DEVELOPMENT BOARD REPORT 345, 1995. 
WATER-LEVEL CHANGES IN THE HIGH PLAINS AQUIFER, 1980 TO 1995: USGS FACT SHEET FS-068-97, 1997.

WATER-LEVEL CHANGES IN THE HIGH PLAINS AQUIFER-PREDEVELOPMENT TO 1995: USGS WATER-RESOURCES INVESTIGATIONS REPORT 97-4081, 1997.

UPDATED WATER-QUALITY EVALUATION OF THE OGALLALA AQUIFER INCLUDING SELECTED METALLIC AND NON-METALLIC INORGANIC CONSTITUENTS: TEXAS WATER DEVELOPMENT BOARD HYDROLOGIC ATLAS NO. 10, 1998.

\section{SMITH COUNTY}

UNDERGROUND WATERS OF THE COASTAL PLAIN OF TEXAS: USGS WATER-SUPPLY PAPER 335, 1907.

GEOLOGY AND UNDERGROUND WATERS OF THE SOUTHEASTERN PART OF THE TEXAS COASTAL PLAIN: USGS WATER-SUPPLY PAPER 335, 1914.

RECORDS OF WELLS, DRILLERS' LOGS, WATER ANALYSES, AND MAP SHOWING LOCATION OF WELLS IN SMITH COUNTY, TEXAS: TEXAS BOARD OF WATER ENGINEERS MISCELLANEOUS PUBLICATION 267, 1937.

RESULTS OF PUMPING TEST OF MUNICIPAL WELLS AT TYLER, TEXAS: TEXAS BOARD OF WATER ENGINEERS MISCELLANEOUS PUBLICATION 280, 1944.

PUBLIC WATER SUPPLIES IN EASTERN TEXAS, V. 2, HARRISON COUNTY THROUGH WOOD COUNTY: TEXAS BOARD OF WATER ENGINEERS MISCELLANEOUS PUBLICATION 214, V. 2, 1945.

PUBLIC WATER SUPPLIES IN EASTERN TEXAS: USGS WATERSUPPLY PAPER 1047, 1948.

AVAILABILITY AND QUALITY OF GROUND WATER IN SMITH COUNTY, TEXAS: TEXAS WATER COMMISSION BULLETIN 6302, 1963.

RECONNAISSANCE INVESTIGATION OF THE GROUND-WATER RESOURCES OF THE SABINE RIVER BASIN, TEXAS: TEXAS WATER COMMISSION BULLETIN 6307, 1963.

RECONNAISSANCE INVESTIGATION OF THE GROUND-WATER RESOURCES OF THE NECHES RIVER BASIN, TEXAS: TEXAS WATER COMMISSION BULLETIN 6308, 1963.

COMPILATION OF RESULTS OF AQUIFER TESTS IN TEXAS: TEXAS WATER DEVELOPMENT BOARD REPORT 98, 1969.

SALT-WATER DISPOSAL AND POTENTIAL FOR POLLUTION IN THE EAST TEXAS OIL FIELD: USGS OPEN-FILE REPORT (UNNUMBERED) (MEMORANDUM), 1971

GEOLOGIC AND HYDROLOGIC SUMMARY OF SALT DOMES IN GULF COAST REGION OF TEXAS, LOUISIANA, AND ALABAMA: USGS OPEN-FILE REPORT 73-07, 1973.

MAJOR AND HISTORICAL SPRINGS OF TEXAS: TEXAS WATER DEVELOPMENT BOARD REPORT 189, 1975.

SUMMARY APPRAISALS OF THE NATION'S GROUND-WATER RESOURCES-TEXAS-GULF REGION: USGS PROFESSIONAL PAPER 813-F, 1976.

WATER-QUALITY DATA FOR AQUIFERS, STREAMS, AND LAKES IN THE VICINITY OF KEECHI, MOUNT SYLVAN, OAKWOOD, AND
PALESTINE SALT DOMES, NORTHEAST TEXAS SALT-DOME BASIN: USGS OPEN-FILE REPORT 80-2037, 1980

GEOHYDROLOGY OF THE KEECHI, MOUNT SYLVAN, OAKWOOD, AND PALESTINE SALT DOMES IN THE NORTHEAST TEXAS SALTDOME BASIN: USGS OPEN-FILE REPORT 80-2044, 1980.

GEOLOGY AND GEOHYDROLOGY OF THE EAST TEXAS BASIN-A REPORT ON THE PROGRESS OF NUCLEAR WASTE ISOLATION FEASIBILITY STUDIES (1979): UNIVERSITY OF TEXAS, BUREAU OF ECONOMIC GEOLOGY GEOLOGICAL CIRCULAR 80-12, 1980.

GEOLOGY AND GEOHYDROLOGY OF THE EAST TEXAS BASIN-A REPORT ON THE PROGRESS OF NUCLEAR WASTE ISOLATION FEASIBILITY STUDIES (1980): UNIVERSITY OF TEXAS, BUREAU OF ECONOMIC GEOLOGY GEOLOGICAL CIRCULAR 81-7, 1981.

SPRINGS OF TEXAS, VOLUME 1: (BY GUNNAR BRUNE), BRANCHSMITH, INC., FORT WORTH, TEXAS, 1981.

REGIONAL AQUIFER CHARACTERIZATION FOR DEEP-BASIN LIGNITE MINING, SABINE UPLIFT AREA, NORTHEAST TEXAS: UNIVERSITY OF TEXAS, BUREAU OF ECONOMIC GEOLOGY GEOLOGICAL CIRCULAR 83-3, 1983.

TEXAS GROUND-WATER RESOURCES, in NATIONAL WATER SUMMARY 1984: USGS WATER-SUPPLY PAPER 2275, 1985.

WATER USE, PROJECTED WATER REQUIREMENTS, AND RELATED DATA AND INFORMATION FOR THE METROPOLITAN STATISTICAL AREAS IN TEXAS: TEXAS DEPARTMENT OF WATER RESOURCES LIMITED PRINTING REPORT LP-201, 1985.

APPROXIMATE POTENTIOMETRIC SURFACES FOR THE AQUIFERS OF THE TEXAS COASTAL UPLANDS SYSTEM, 1980: USGS HYDROLOGIC INVESTIGATIONS ATLAS HA-704, 1987.

GEOHYDROLOGIC FRAMEWORK OF THE GULF COASTAL PLAIN: USGS HYDROLOGIC INVESTIGATIONS ATLAS HA-695, 1988.

EVALUATION OF GROUND-WATER RESOURCES IN THE VICINITY OF THE CITIES OF HENDERSON, JACKSONVILLE, KILGORE, LUFKIN, NACOGDOCHES, RUSK, AND TYLER IN EAST TEXAS: TEXAS WATER DEVELOPMENT BOARD REPORT 327, 1991

PROPERTIES AND CHEMICAL CONSTITUENTS IN GROUND WATER FROM THE LOWER CLAIBORNE-UPPER WILCOX AQUIFER, GULF COAST REGIONAL AQUIFER SYSTEMS, SOUTH-CENTRAL UNITED STATES: USGS WATER-RESOURCES INVESTIGATIONS REPORT 92-4102, 1993.

PROPERTIES AND CHEMICAL CONSTITUENTS IN GROUND WATER FROM THE MIDDLE CLAIBORNE AQUIFER, GULF COAST REGIONAL AQUIFER SYSTEMS, SOUTH-CENTRAL UNITED STATES: USGS WATER-RESOURCES INVESTIGATIONS REPORT 92-4104, 1993.

PROPERTIES AND CHEMICAL CONSTITUENTS IN GROUND WATER FROM THE MIDDLE WILCOX AQUIFER, GULF COAST AQUIFER SYSTEMS, SOUTH-CENTRAL UNITED STATES: USGS WATERRESOURCES INVESTIGATIONS REPORT 93-4070, 1993.

AQUIFERS OF TEXAS: TEXAS WATER DEVELOPMENT BOARD REPORT 345, 1995.

WATER QUALITY IN THE QUEEN CITY AQUIFER, EAST TEXAS: TEXAS WATER DEVELOPMENT BOARD HYDROLOGIC ATLAS NO. 6, 1996 


\section{SOMERVELL COUNTY}

GEOGRAPHY AND GEOLOGY OF THE BLACK AND GRAND PRAIRIES, TEXAS, WITH DETAILED DESCRIPTIONS OF THE CRETACEOUS FORMATIONS AND SPECIAL REFERENCE TO ARTESIAN WATERS: USGS 21ST ANNUAL REPORT, PART 7, 1901.

ARTESIAN WATER IN SOMERVELL COUNTY, TEXAS: USGS WATERSUPPLY PAPER 660, 1934

PUBLIC WATER SUPPLIES IN CENTRAL AND NORTH-CENTRAL TEXAS: TEXAS BOARD OF WATER ENGINEERS MISCELLANEOUS PUBLICATION 213, 1947.

PUBLIC WATER SUPPLIES IN CENTRAL AND NORTH-CENTRAL TEXAS: USGS WATER-SUPPLY PAPER 1069, 1949.

RECORDS OF WATER-LEVEL MEASUREMENTS IN BELL, McLENNAN, AND SOMERVELL COUNTIES, TEXAS: TEXAS WATER COMMISSION BULLETIN 5902, 1959.

RECONNAISSANCE INVESTIGATION OF THE GROUND-WATER RESOURCES OF THE BRAZOS RIVER BASIN, TEXAS: TEXAS WATER COMMISSION BULLETIN 6310, 1963.

COMPILATION OF RESULTS OF AQUIFER TESTS IN TEXAS: TEXAS WATER DEVELOPMENT BOARD REPORT 98, 1969.

GROUND-WATER RESOURCES OF PART OF CENTRAL TEXAS WITH EMPHASIS ON THE ANTLERS AND TRAVIS PEAK FORMATIONS: TEXAS WATER DEVELOPMENT BOARD REPORT 195, V. 1, 1975.

GROUND-WATER RESOURCES OF PART OF CENTRAL TEXAS WITH EMPHASIS ON THE ANTLERS AND TRAVIS PEAK FORMATIONS: TEXAS WATER DEVELOPMENT BOARD REPORT 195, V. 2, 1976.

WATER-LEVEL AND WATER-QUALITY DATA FROM OBSERVATION WELLS IN NORTHEAST TEXAS: TEXAS WATER DEVELOPMENT BOARD REPORT 198, 1976.

SUMMARY APPRAISALS OF THE NATION'S GROUND-WATER RESOURCES-TEXAS-GULF REGION: USGS PROFESSIONAL PAPER 813-F, 1976.

OCCURRENCE, AVAILABILITY, AND CHEMICAL QUALITY OF GROUND WATER IN THE CRETACEOUS AQUIFERS OF NORTHCENTRAL TEXAS: TEXAS DEPARTMENT OF WATER RESOURCES REPORT 269, V. 1, 1982.

OCCURRENCE, AVAILABILITY, AND CHEMICAL QUALITY OF GROUND WATER IN THE CRETACEOUS AQUIFERS OF NORTHCENTRAL TEXAS: TEXAS DEPARTMENT OF WATER RESOURCES REPORT 269, V. 2, 1982.

TEXAS GROUND-WATER RESOURCES, in NATIONAL WATER SUMMARY 1984: USGS WATER-SUPPLY PAPER 2275, 1985.

EVALUATION OF WATER RESOURCES IN PART OF CENTRAL TEXAS: TEXAS WATER DEVELOPMENT BOARD REPORT 319, 1990.

GROUND-WATER QUALITY MONITORING OF THE TRINITY AQUIFER IN THE VICINITY OF ERATH COUNTY: TEXAS WATER DEVELOPMENT BOARD REPORT 331, 1991.

HYDROGEOLOGIC ASSESSMENT OF SHALLOW GROUNDWATER FLOW SYSTEMS OF THE WALNUT FORMATION, CENTRAL TEXAS: (MASTER'S THESIS), BAYLOR GEOLOGICAL STUDIES (THESIS ABSTRACTS), BULLETIN 56, BAYLOR UNIVERSITY, WACO, TEXAS, 1995.
AQUIFERS OF TEXAS: TEXAS WATER DEVELOPMENT BOARD REPORT 345, 1995.

\section{STARR COUNTY}

UNDERGROUND WATERS OF THE COASTAL PLAIN OF TEXAS: USGS WATER-SUPPLY PAPER 190, 1907.

PUBLIC WATER SUPPLIES IN SOUTHERN TEXAS: TEXAS BOARD OF WATER ENGINEERS MISCELLANEOUS PUBLICATION 215, 1946.

PUBLIC WATER SUPPLIES IN SOUTHERN TEXAS: USGS WATERSUPPLY PAPER 1070, 1950.

GROUND-WATER RESOURCES OF STARR COUNTY: TEXAS BOARD OF WATER ENGINEERS BULLETIN 5209, 1952.

AVAILABILITY OF GROUND WATER IN THE GULF COAST REGION OF TEXAS: USGS OPEN-FILE REPORT (UNNUMBERED), 1956.

WATER LEVELS IN OBSERVATION WELLS IN CAMERON, HIDALGO, AND STARR COUNTIES, TEXAS, 1950-1959: TEXAS BOARD OF WATER ENGINEERS BULLETIN 6008, 1960.

GROUND-WATER RESOURCES OF THE LOWER RIO GRANDE VALLEY AREA, TEXAS, VOLUME 1: TEXAS BOARD OF WATER ENGINEERS BULLETIN 6014, V. 1, 1961.

GROUND-WATER RESOURCES OF THE LOWER RIO GRANDE VALLEY AREA, TEXAS, VOLUME 2: TEXAS BOARD OF WATER ENGINEERS BULLETIN 6014, V. 2, 1961.

RECONNAISSANCE INVESTIGATION OF THE GROUND-WATER RESOURCES OF THE GULF COAST REGION, TEXAS: TEXAS WATER COMMISSION BULLETIN 6305, 1963.

WATER-SUPPLY LIMITATIONS ON IRRIGATION FROM THE RIO GRANDE IN STARR, HIDALGO, CAMERON, AND WILLACY COUNTIES, TEXAS: TEXAS WATER COMMISSION BULLETIN 6413, 1964

APPENDICES TO B6413, WATER-SUPPLY LIMITATIONS ON IRRIGATION FROM THE RIO GRANDE IN STARR, HIDALGO, CAMERON, AND WILLACY COUNTIES, TEXAS: TEXAS WATER COMMISSION BULLETIN 6413A, 1965.

RECONNAISSANCE INVESTIGATION OF THE GROUND-WATER RESOURCES OF THE RIO GRANDE BASIN, TEXAS: TEXAS WATER COMMISSION BULLETIN 6502, 1965.

RECONNAISSANCE INVESTIGATION OF GROUND WATER IN THE RIO GRANDE DRAINAGE BASIN-WITH SPECIAL EMPHASIS ON SALINE GROUND-WATER RESOURCES: USGS HYDROLOGIC INVESTIGATIONS ATLAS HA-510, 1974.

SUMMARY APPRAISALS OF THE NATION'S GROUND-WATER RESOURCES-TEXAS-GULF REGION: USGS PROFESSIONAL PAPER 813-F, 1976.

STRATIGRAPHIC AND HYDROGEOLOGIC FRAMEWORK OF PART OF THE COASTAL PLAIN OF TEXAS: TEXAS DEPARTMENT OF WATER RESOURCES REPORT 236, 1979.

SPRINGS OF TEXAS, VOLUME 1: (BY GUNNAR BRUNE), BRANCHSMITH, INC., FORT WORTH, TEXAS, 1981.

LAND-SURFACE SUBSIDENCE IN THE TEXAS COASTAL REGION: TEXAS DEPARTMENT OF WATER RESOURCES REPORT 272, 1982. 
STRUCTURE, TEMPERATURE, PRESSURE, AND SALINITY OF CENOZOIC AQUIFERS OF SOUTH TEXAS: USGS HYDROLOGIC INVESTIGATIONS ATLAS HA-654, 1983.

TEXAS GROUND-WATER RESOURCES, in NATIONAL WATER SUMMARY 1984: USGS WATER-SUPPLY PAPER 2275, 1985.

DIGITAL MODELS FOR SIMULATION OF GROUND-WATER HYDROLOGY OF THE CHICOT AND EVANGELINE AQUIFERS ALONG THE GULF COAST OF TEXAS: TEXAS DEPARTMENT OF WATER RESOURCES REPORT 289, 1985.

HYDROGEOLOGY AND PREDEVELOPMENT FLOW IN THE TEXAS GULF COAST AQUIFER SYSTEMS: USGS WATER-RESOURCES INVESTIGATIONS REPORT 87-4248, 1988.

GEOHYDROLOGIC FRAMEWORK OF THE GULF COASTAL PLAIN: USGS HYDROLOGIC INVESTIGATIONS ATLAS HA-695, 1988.

EVALUATION OF GROUND-WATER RESOURCES IN THE LOWER RIO GRANDE VALLEY, TEXAS: TEXAS WATER DEVELOPMENT BOARD REPORT 316, 1990.

GROUND-WATER FLOW IN THE GULF COAST AQUIFER SYSTEMS, SOUTH-CENTRAL UNITED STATES-A PRELIMINARY ANALYSIS: USGS WATER-RESOURCES INVESTIGATIONS REPORT 89-4071, 1990.

HYDROLOGY OF THE TEXAS GULF COAST AQUIFER SYSTEMS: USGS OPEN-FILE REPORT 91-64, 1991.

PROPERTIES AND CHEMICAL CONSTITUENTS IN GROUND WATER FROM THE MISSISSIPPI RIVER VALLEY ALLUVIAL AQUIFER AND PERMEABLE ZONE A (HOLOCENE-UPPER PLEISTOCENE DEPOSITS), SOUTH-CENTRAL UNITED STATES: USGS WATERRESOURCES INVESTIGATIONS REPORT 91-4149, 1992.

PROPERTIES AND CHEMICAL CONSTITUENTS IN GROUND WATER FROM THE UPPER CLAIBORNE AQUIFER, GULF COAST REGIONAL AQUIFER SYSTEMS, SOUTH-CENTRAL UNITED STATES: USGS WATER-RESOURCES INVESTIGATIONS REPORT 91-4150, 1993.

PROPERTIES AND CHEMICAL CONSTITUENTS IN GROUND WATER FROM PERMEABLE ZONE C (LOWER PLIOCENE-UPPER MIOCENE DEPOSITS), COASTAL LOWLANDS AQUIFER SYSTEM, SOUTHCENTRAL UNITED STATES: USGS WATER-RESOURCES INVESTIGATIONS REPORT 91-4151, 1993.

PROPERTIES AND CHEMICAL CONSTITUENTS IN GROUND WATER FROM PERMEABLE ZONE B (LOWER PLEISTOCENE-UPPER PLIOCENE DEPOSITS), COASTAL LOWLANDS AQUIFER SYSTEM, SOUTH-CENTRAL UNITED STATES: USGS WATER-RESOURCES INVESTIGATIONS REPORT 91-4152, 1993.

PROPERTIES AND CHEMICAL CONSTITUENTS IN GROUND WATER FROM PERMEABLE ZONE E (LOWER MIOCENE-UPPER OLIGOCENE DEPOSITS), COASTAL LOWLANDS AQUIFER SYSTEM, SOUTH-CENTRAL UNITED STATES: USGS WATER-RESOURCES INVESTIGATIONS REPORT 92-4103, 1993.

PROPERTIES AND CHEMICAL CONSTITUENTS IN GROUND WATER FROM THE MIDDLE CLAIBORNE AQUIFER, GULF COAST REGIONAL AQUIFER SYSTEMS, SOUTH-CENTRAL UNITED STATES: USGS WATER-RESOURCES INVESTIGATIONS REPORT 92-4104, 1993.

PROPERTIES AND CHEMICAL CONSTITUENTS IN GROUND WATER FROM PERMEABLE ZONE D (MIDDLE MIOCENE DEPOSITS), COASTAL LOWLANDS AQUIFER SYSTEM, SOUTH-CENTRAL
UNITED STATES: USGS WATER-RESOURCES INVESTIGATIONS REPORT 92-4105, 1993.

AQUIFERS OF TEXAS: TEXAS WATER DEVELOPMENT BOARD REPORT 345, 1995.

\section{STEPHENS COUNTY}

RECORDS OF WELLS AND DRILLERS' LOGS; WATER ANALYSES FROM WELLS, STREAMS, AND TANKS; AND MAP SHOWING LOCATION OF WELLS, STREAMS, AND TANKS IN STEPHENS COUNTY, TEXAS: TEXAS BOARD OF WATER ENGINEERS MISCELLANEOUS PUBLICATION 270, 1937.

REPORT OF UNDERGROUND WATER SURVEY, STEPHENS COUNTY, TEXAS: USGS OPEN-FILE REPORT (UNNUMBERED), 1937.

PUBLIC WATER SUPPLIES IN CENTRAL AND NORTH-CENTRAL TEXAS: USGS WATER-SUPPLY PAPER 1069, 1949.

RECONNAISSANCE INVESTIGATION OF THE GROUND-WATER RESOURCES OF THE BRAZOS RIVER BASIN, TEXAS: TEXAS WATER COMMISSION BULLETIN 6310, 1963.

TEXAS GROUND-WATER RESOURCES, in NATIONAL WATER SUMMARY 1984: USGS WATER-SUPPLY PAPER 2275, 1985.

EVALUATION OF WATER RESOURCES IN PARTS OF THE ROLLING PRAIRIES REGION OF NORTH-CENTRAL TEXAS: TEXAS WATER DEVELOPMENT BOARD REPORT 337, 1992.

\section{STERLNG COUNTY}

RECORDS OF WELLS AND SPRINGS, DRILLERS' LOGS, WATER ANALYSES, AND MAP SHOWING LOCATIONS OF WELLS AND SPRINGS IN STERLING COUNTY, TEXAS: TEXAS BOARD OF WATER ENGINEERS MISCELLANEOUS PUBLICATION 271, 1942.

RECORDS OF WATER-LEVEL MEASUREMENTS IN MITCHELL, NOLAN, STERLING, AND TOM GREEN COUNTIES, TEXAS, 1938 THROUGH 1957: TEXAS BOARD OF WATER ENGINEERS BULLETIN 5907, 1959.

WATER WELL AND GROUND-WATER CHEMICAL ANALYSIS DATA, STERLING COUNTY, TEXAS: TEXAS WATER DEVELOPMENT BOARD REPORT 148, 1972.

SUMMARY APPRAISALS OF THE NATION'S GROUND-WATER RESOURCES-TEXAS-GULF REGION: USGS PROFESSIONAL PAPER 813-F, 1976.

OCCURRENCE, AVAILABILITY, AND CHEMICAL QUALITY OF GROUND WATER IN THE EDWARDS PLATEAU REGION OF TEXAS: TEXAS DEPARTMENT OF WATER RESOURCES REPORT 235,1979

SOURCE AREAS OF SALINITY AND TRENDS OF SALT LOADS IN STREAMFLOW IN THE UPPER COLORADO RIVER, TEXAS: USGS OPEN-FILE REPORT 80-224, 1980.

TEXAS GROUND-WATER RESOURCES, in NATIONAL WATER SUMMARY 1984: USGS WATER-SUPPLY PAPER 2275, 1985.

HYDROGEOLOGY AND HYDROCHEMISTRY OF CRETACEOUS AQUIFERS, TEXAS PANHANDLE AND EASTERN NEW MEXICO: UNI- 
VERSITY OF TEXAS, BUREAU OF ECONOMIC GEOLOGY GEOLOGICAL CIRCULAR 88-3, 1988.

PUBLIC SUPPLY GROUND-WATER USE IN WESTERN TEXAS: TEXAS WATER DEVELOPMENT BOARD REPORT 311, 1989.

POTENTIOMETRIC SURFACE OF THE EDWARDS-TRINITY AQUIFER SYSTEM AND CONTIGUOUS HYDRAULICALLY CONNECTED UNITS, WEST-CENTRAL TEXAS, WINTER 1974-75: USGS WATERRESOURCES INVESTIGATIONS REPORT 89-4208, 1990.

WITHDRAWALS FROM THE EDWARDS-TRINITY AQUIFER SYSTEM AND CONTIGUOUS HYDRAULICALLY CONNECTED UNITS, WEST-CENTRAL TEXAS, DECEMBER 1974 THROUGH MARCH 1977: USGS WATER-RESOURCES INVESTIGATIONS REPORT 91-4021, 1991.

CONFIGURATION OF THE BASE OF THE EDWARDS-TRINITY AQUIFER SYSTEM AND HYDROGEOLOGY OF THE UNDERLYING PRECRETACEOUS ROCKS, WEST-CENTRAL TEXAS: USGS WATERRESOURCES INVESTIGATIONS REPORT 91-4071, 1992.

HISTORICAL POTENTIOMETRIC SURFACE OF THE EDWARDS-TRINITY AQUIFER SYSTEM AND CONTIGUOUS HYDRAULICALLY CONNECTED UNITS, WEST-CENTRAL TEXAS: USGS WATERRESOURCES INVESTIGATIONS REPORT 92-4055, 1993.

HISTORICAL SATURATED THICKNESS OF THE EDWARDS-TRINITY AQUIFER SYSTEM AND SELECTED CONTIGUOUS HYDRAULICALLY CONNECTED UNITS, WEST-CENTRAL TEXAS: USGS WATER-RESOURCES INVESTIGATIONS REPORT 92-4125, 1993.

SIMULATIONS OF FLOW IN THE EDWARDS-TRINITY AQUIFER SYSTEM AND CONTIGUOUS HYDRAULICALLY CONNECTED UNITS, WEST-CENTRAL TEXAS: USGS WATER-RESOURCES INVESTIGATIONS REPORT 93-4039, 1994.

DISSOLVED-SOLIDS CONCENTRATIONS AND HYDROCHEMICAL FACIES IN WATER OF THE EDWARDS-TRINITY AQUIFER SYSTEM, WEST-CENTRAL TEXAS: USGS WATER-RESOURCES INVESTIGATIONS REPORT 93-4126, 1994.

CHARACTERISTICS OF STREAMS AND AQUIFERS AND PROCESSES AFFECTING THE SALINITY OF WATER IN THE UPPER COLORADO RIVER BASIN, TEXAS: USGS WATER-RESOURCES INVESTIGATIONS REPORT 94-4036, 1994.

GEOLOGIC HISTORY AND HYDROGEOLOGIC SETTING OF THE EDWARDS-TRINITY AQUIFER SYSTEM, WEST-CENTRAL TEXAS: USGS WATER-RESOURCES INVESTIGATIONS REPORT 94-4039, 1994.

AQUIFERS OF TEXAS: TEXAS WATER DEVELOPMENT BOARD REPORT 345, 1995.

WATER QUALITY IN THE EDWARDS-TRINITY (PLATEAU) AQUIFER, EDWARDS PLATEAU AND TRANS-PECOS, TEXAS: TEXAS WATER DEVELOPMENT BOARD HYDROLOGIC ATLAS NO. 3, 1995.

HYDROGEOLOGIC FRAMEWORK OF THE EDWARDS-TRINITY AQUIFER SYSTEM, WEST-CENTRAL TEXAS: USGS PROFESSIONAL PAPER 1421-B, 1996.

AN OVERVIEW OF THE EDWARDS-TRINITY AQUIFER SYSTEM, CENTRAL-WEST TEXAS, CHAPTER 8, in AQUIFERS OF WEST TEXAS: TEXAS WATER DEVELOPMENT BOARD REPORT 356, 2001.

\section{STONEWALL COUNTY}

PUBLIC WATER SUPPLIES IN WESTERN TEXAS: TEXAS BOARD OF WATER ENGINEERS MISCELLANEOUS PUBLICATION 216, 1949.

PUBLIC WATER SUPPLIES IN WESTERN TEXAS: USGS WATERSUPPLY PAPER 1106, 1951.

GROUND-WATER GEOLOGY IN THE VICINITY OF DOVE AND CROTON CREEKS, STONEWALL, KENT, DICKENS, AND KING COUNTIES, WITH SPECIAL REFERENCE TO SEEPAGE: TEXAS BOARD OF WATER ENGINEERS BULLETIN 5801, 1958.

INVESTIGATION OF GROUND-WATER CONTAMINATION IN THE JULIANA AND WEST JUD OIL FIELDS, HASKELL AND STONEWALL COUNTIES, TEXAS: TEXAS WATER COMMISSION LIMITED DISTRIBUTION REPORT LD-0364-MR, 1964.

PRELIMINARY REPORT ON THE INVESTIGATION OF SALT SPRINGS AND SEEPS IN A PORTION OF THE PERMIAN BASIN IN TEXAS: USGS OPEN-FILE REPORT 65-153, 1965.

SOURCES OF SALINE WATER IN THE UPPER BRAZOS RIVER BASIN, TEXAS: USGS OPEN-FILE REPORT 68-108, 1968.

THEORETICAL EFFECTS OF GROUND-WATER PUMPING ON THE DISCHARGE OF BRINE SPRINGS IN THE UPPER BRAZOS RIVER BASIN, TEXAS: USGS OPEN-FILE REPORT, 1972.

RECOGNITION OF NATURAL BRINE BY ELECTRICAL SOUNDINGS NEAR THE SALT FORK OF THE BRAZOS RIVER, KENT AND STONEWALL COUNTIES, TEXAS: USGS PROFESSIONAL PAPER 809-A, 1973.

LOCATION AND CHARACTERISTICS OF THE INTERFACE BETWEEN BRINE AND FRESHWATER FROM GEOPHYSICAL LOGS OF BOREHOLES IN THE UPPER BRAZOS RIVER BASIN, TEXAS: USGS PROFESSIONAL PAPER 809-B, 1973.

SPRINGS OF TEXAS, VOLUME 1: (BY GUNNAR BRUNE), BRANCHSMITH, INC., FORT WORTH, TEXAS, 1981.

PROJECTED EFFECTS OF PROPOSED SALINITY-CONTROL PROJECTS ON SHALLOW GROUND WATER-PRELIMINARY RESULTS FOR THE UPPER BRAZOS RIVER BASIN, TEXAS: USGS OPEN-FILE REPORT 82-908, 1982.

TEXAS GROUND-WATER RESOURCES, in NATIONAL WATER SUMMARY 1984: USGS WATER-SUPPLY PAPER 2275, 1985.

JOINT GROUND-WATER QUALITY PROJECT WITH THE TEXAS DEPARTMENT OF AGRICULTURE IN PARTS OF HASKELL, KNOX, AND STONEWALL COUNTIES: TEXAS WATER DEVELOPMENT BOARD REPORT 333, 1991.

EVALUATION OF WATER RESOURCES IN PARTS OF THE ROLLING PRAIRIES REGION OF NORTH-CENTRAL TEXAS: TEXAS WATER DEVELOPMENT BOARD REPORT 337, 1992.

AQUIFERS OF TEXAS: TEXAS WATER DEVELOPMENT BOARD REPORT 345, 1995.

\section{SUTTON COUNTY}

WATER SUPPLY OF CITY OF SONORA, TEXAS: USGS OPEN-FILE REPORT (UNNUMBERED), 1940. 
PUBLIC WATER SUPPLIES IN WESTERN TEXAS: TEXAS BOARD OF WATER ENGINEERS MISCELLANEOUS PUBLICATION 216, 1949.

PUBLIC WATER SUPPLIES IN WESTERN TEXAS: USGS WATERSUPPLY PAPER 1106, 1951.

RECONNAISSANCE INVESTIGATION OF THE GROUND-WATER RESOURCES OF THE RIO GRANDE BASIN, TEXAS: TEXAS WATER COMMISSION BULLETIN 6502, 1965.

RECONNAISSANCE INVESTIGATION OF THE GROUND-WATER RESOURCES OF THE COLORADO RIVER BASIN, TEXAS: TEXAS WATER DEVELOPMENT BOARD REPORT 51, 1967.

WATER WELL AND GROUND WATER CHEMICAL ANALYSIS DATA, SUTTON COUNTY, TEXAS: TEXAS WATER DEVELOPMENT BOARD REPORT 147, 1972.

RECONNAISSANCE INVESTIGATION OF GROUND WATER IN THE RIO GRANDE DRAINAGE BASIN-WITH SPECIAL EMPHASIS ON SALINE GROUND-WATER RESOURCES: USGS HYDROLOGIC INVESTIGATIONS ATLAS HA-510, 1974.

MAJOR AND HISTORICAL SPRINGS OF TEXAS: TEXAS WATER DEVELOPMENT BOARD REPORT 189, 1975.

SUMMARY APPRAISALS OF THE NATION'S GROUND-WATER RESOURCES-TEXAS-GULF REGION: USGS PROFESSIONAL PAPER 813-F, 1976.

OCCURRENCE, AVAILABILITY, AND CHEMICAL QUALITY OF GROUND WATER IN THE EDWARDS PLATEAU REGION OF TEXAS: TEXAS DEPARTMENT OF WATER RESOURCES REPORT $235,1979$.

SPRINGS OF TEXAS, VOLUME 1: (BY GUNNAR BRUNE), BRANCHSMITH, INC., FORT WORTH, TEXAS, 1981.

TEXAS GROUND-WATER RESOURCES, in NATIONAL WATER SUMMARY 1984: USGS WATER-SUPPLY PAPER 2275, 1985.

POTENTIOMETRIC SURFACE OF THE EDWARDS-TRINITY AQUIFER SYSTEM AND CONTIGUOUS HYDRAULICALLY CONNECTED UNITS, WEST-CENTRAL TEXAS, WINTER 1974-75: USGS WATERRESOURCES INVESTIGATIONS REPORT 89-4208, 1990.

WITHDRAWALS FROM THE EDWARDS-TRINITY AQUIFER SYSTEM AND CONTIGUOUS HYDRAULICALLY CONNECTED UNITS, WEST-CENTRAL TEXAS, DECEMBER 1974 THROUGH MARCH 1977: USGS WATER-RESOURCES INVESTIGATIONS REPORT 91-4021, 1991.

CONFIGURATION OF THE BASE OF THE EDWARDS-TRINITY AQUIFER SYSTEM AND HYDROGEOLOGY OF THE UNDERLYING PRECRETACEOUS ROCKS, WEST-CENTRAL TEXAS: USGS WATERRESOURCES INVESTIGATIONS REPORT 91-4071, 1992.

HISTORICAL POTENTIOMETRIC SURFACE OF THE EDWARDS-TRINITY AQUIFER SYSTEM AND CONTIGUOUS HYDRAULICALLY CONNECTED UNITS, WEST-CENTRAL TEXAS: USGS WATERRESOURCES INVESTIGATIONS REPORT 92-4055, 1993.

HISTORICAL SATURATED THICKNESS OF THE EDWARDS-TRINITY AQUIFER SYSTEM AND SELECTED CONTIGUOUS HYDRAULICALLY CONNECTED UNITS, WEST-CENTRAL TEXAS: USGS WATER-RESOURCES INVESTIGATIONS REPORT 92-4125, 1993.

SIMULATIONS OF FLOW IN THE EDWARDS-TRINITY AQUIFER SYSTEM AND CONTIGUOUS HYDRAULICALLY CONNECTED UNITS, WEST-CENTRAL TEXAS: USGS WATER-RESOURCES INVESTIGATIONS REPORT 93-4039, 1994.
DISSOLVED-SOLIDS CONCENTRATIONS AND HYDROCHEMICAL FACIES IN WATER OF THE EDWARDS-TRINITY AQUIFER SYSTEM, WEST-CENTRAL TEXAS: USGS WATER-RESOURCES INVESTIGATIONS REPORT 93-4126, 1994.

GEOLOGIC HISTORY AND HYDROGEOLOGIC SETTING OF THE EDWARDS-TRINITY AQUIFER SYSTEM, WEST-CENTRAL TEXAS USGS WATER-RESOURCES INVESTIGATIONS REPORT 94-4039, 1994.

AQUIFERS OF TEXAS: TEXAS WATER DEVELOPMENT BOARD REPORT 345, 1995.

WATER QUALITY IN THE EDWARDS-TRINITY (PLATEAU) AQUIFER, EDWARDS PLATEAU AND TRANS-PECOS, TEXAS: TEXAS WATER DEVELOPMENT BOARD HYDROLOGIC ATLAS NO. 3, 1995.

HYDROGEOLOGIC FRAMEWORK OF THE EDWARDS-TRINITY AQUIFER SYSTEM, WEST-CENTRAL TEXAS: USGS PROFESSIONAL PAPER 1421-B, 1996.

\section{SWISHER COUNTY}

GEOLOGY AND GROUND-WATER RESOURCES OF THE SOUTHERN HIGH PLAINS: USGS OPEN-FILE REPORT (UNNUMBERED), 1935.

RECORDS OF WELLS, DRILLERS' LOGS, AND WATER ANALYSES, AND MAP SHOWING LOCATION OF WELLS IN SWISHER COUNTY, TEXAS: TEXAS BOARD OF WATER ENGINEERS MISCELLANEOUS PUBLICATION 274, 1938

GROUND WATER IN THE HIGH PLAINS OF TEXAS: TEXAS BOARD OF WATER ENGINEERS OPEN-FILE REPORT, 1938.

GROUND WATER IN THE HIGH PLAINS OF TEXAS: TEXAS BOARD OF WATER ENGINEERS OPEN-FILE REPORT, 1940.

PROGRESS REPORT ON GROUND WATER IN THE HIGH PLAINS OF TEXAS: TEXAS BOARD OF WATER ENGINEERS OPEN-FILE REPORT, 1942

PROGRESS REPORT ON GROUND WATER IN THE HIGH PLAINS OF TEXAS: TEXAS BOARD OF WATER ENGINEERS OPEN-FILE REPORT, 1943

PROGRESS REPORT ON GROUND WATER IN THE HIGH PLAINS OF TEXAS: TEXAS BOARD OF WATER ENGINEERS OPEN-FILE REPORT, 1944.

GROUND WATER IN HIGH PLAINS OF TEXAS, PROGRESS REPORT NO. 5: TEXAS BOARD OF WATER ENGINEERS OPEN-FILE REPORT, 1945.

GROUND WATER IN THE HIGH PLAINS OF TEXAS: USGS WATERSUPPLY PAPER 889-F, 1946.

RECORDS OF WELLS, DRILLERS' LOGS, WATER ANALYSES, AND MAP SHOWING LOCATIONS OF WELLS IN SWISHER COUNTY, TEXAS: TEXAS BOARD OF WATER ENGINEERS MISCELLANEOUS PUBLICATION 275, 1946

GROUND WATER IN HIGH PLAINS OF TEXAS, PROGRESS REPORT NO. 6: TEXAS BOARD OF WATER ENGINEERS MISCELLANEOUS PUBLICATION 123, 1947

GEOLOGY AND GROUND WATER IN THE IRRIGATED REGION OF THE SOUTHERN HIGH PLAINS IN TEXAS, PROGRESS REPORT NO. 7: TEXAS BOARD OF WATER ENGINEERS MISCELLANEOUS PUBLICATION 125, 1949. 
PUBLIC WATER SUPPLIES IN WESTERN TEXAS: TEXAS BOARD OF WATER ENGINEERS MISCELLANEOUS PUBLICATION 216, 1949.

COST OF PUMPING WATER FOR IRRIGATION, TEXAS HIGH PLAINS. FIELD INVESTIGATIONS-1947 IRRIGATION SEASON: TEXAS BOARD OF WATER ENGINEERS MISCELLANEOUS PUBLICATION $124,1951$.

PUBLIC WATER SUPPLIES IN WESTERN TEXAS: USGS WATERSUPPLY PAPER 1106, 1951 [1952].

DEVELOPMENT OF WELLS FOR IRRIGATION AND FLUCTUATION OF WATER LEVELS IN THE HIGH PLAINS OF TEXAS TO JANUARY 1951: TEXAS BOARD OF WATER ENGINEERS BULLETIN 5104, 1951.

RECORDS OF WATER-LEVEL MEASUREMENTS IN SWISHER COUNTY, TEXAS, 1914-1953: TEXAS BOARD OF WATER ENGINEERS BULLETIN 5307, 1953.

SUMMARY OF GROUND-WATER DEVELOPMENT IN THE SOUTHERN HIGH PLAINS, TEXAS: TEXAS BOARD OF WATER ENGINEERS BULLETIN 5402, 1954

GROUND-WATER DEVELOPMENT IN THE SOUTHERN HIGH PLAINS OF TEXAS, 1953: TEXAS BOARD OF WATER ENGINEERS BULLETIN 5410, 1954.

WATER-LEVEL DECLINE MAPS OF 6 COUNTIES IN THE SOUTHERN HIGH PLAINS, TEXAS, JANUARY 1953 TO JANUARY 1954: USGS OPEN-FILE REPORT, 1954.

WATER-LEVEL DECLINE MAPS OF 16 COUNTIES IN THE SOUTHERN HIGH PLAINS, TEXAS, JANUARY 1954 TO JANUARY 1955: (BAILEY, BRISCOE, CASTRO, COCHRAN, CROSBY, DEAF SMITH, FLOYD, GAINES, HALE, HOCKLEY, LAMB, LUBBOCK, PARMER, RANDALL, SWISHER, AND TERRY): USGS OPEN-FILE REPORT, 1955.

WATER-LEVEL DECLINE MAPS OF 17 COUNTIES IN THE SOUTHERN HIGH PLAINS, TEXAS, JANUARY 1955 TO JANUARY 1956: TEXAS BOARD OF WATER ENGINEERS BULLETIN 5607, 1956.

WATER-LEVEL DECLINE MAPS, 1956 TO 1957, AND WATER LEVELS IN OBSERVATION WELLS IN 20 COUNTIES IN THE SOUTHERN HIGH PLAINS, TEXAS: TEXAS BOARD OF WATER ENGINEERS BULLETIN 5705, 1957.

WATER-LEVEL MEASUREMENTS AND MAPS, SOUTHERN HIGH PLAINS, TEXAS, 1958 AND 1959: TEXAS BOARD OF WATER ENGINEERS BULLETIN 5908, 1959.

WATER LEVELS IN OBSERVATION WELLS, SOUTHERN HIGH PLAINS, TEXAS, 1959 AND 1960: TEXAS BOARD OF WATER ENGINEERS BULLETIN 6011, 1960.

WATER LEVELS IN OBSERVATION WELLS, SOUTHERN HIGH PLAINS, TEXAS, 1960 AND 1961: TEXAS BOARD OF WATER ENGINEERS BULLETIN 6101, 1961.

A SUMMARY OF THE OCCURRENCE AND DEVELOPMENT OF GROUND WATER IN THE SOUTHERN HIGH PLAINS OF TEXAS: TEXAS BOARD OF WATER ENGINEERS BULLETIN 6107, 1961.

WATER-LEVEL MEASUREMENTS THROUGH 1962 IN SELECTED OBSERVATION WELLS, SOUTHERN HIGH PLAINS, TEXAS: TEXAS WATER COMMISSION BULLETIN 6207, 1962.

RECONNAISSANCE INVESTIGATION OF THE GROUND-WATER RESOURCES OF THE RED RIVER, SULPHUR RIVER, AND CYPRESS CREEK BASINS, TEXAS: TEXAS WATER COMMISSION BULLETIN 6306, 1963.
RECONNAISSANCE INVESTIGATION OF THE GROUND-WATER RESOURCES OF THE BRAZOS RIVER BASIN, TEXAS: TEXAS WATER COMMISSION BULLETIN 6310, 1963.

A SUMMARY OF THE OCCURRENCE AND DEVELOPMENT OF GROUND WATER IN THE SOUTHERN HIGH PLAINS OF TEXAS, WITH A SECTION ON ARTIFICIAL RECHARGE STUDIES: USGS WATER-SUPPLY PAPER 1693, 1964.

WATER-LEVEL DATA FROM OBSERVATION WELLS IN THE SOUTHERN HIGH PLAINS OF TEXAS: TEXAS WATER DEVELOPMENT BOARD REPORT 21, 1966.

COMPILATION OF RESULTS OF AQUIFER TESTS IN TEXAS: TEXAS WATER DEVELOPMENT BOARD REPORT 98, 1969.

WATER-LEVEL DATA FROM OBSERVATION WELLS IN THE SOUTHERN HIGH PLAINS OF TEXAS, 1965-70: TEXAS WATER DEVELOPMENT BOARD REPORT 121, 1970

AN EVALUATION OF THE USE OF DRILLERS' LOGS IN LITHOLOGIC STUDIES OF THE OGALLALA FORMATION OF THE SOUTHERN HIGH PLAINS OF TEXAS: USGS OPEN-FILE REPORT 72-451, 1972.

SUMMARY APPRAISALS OF THE NATION'S GROUND-WATER RESOURCES-TEXAS-GULF REGION: USGS PROFESSIONAL PAPER 813-F, 1976.

WATER-LEVEL DATA FROM OBSERVATION WELLS IN THE SOUTHERN HIGH PLAINS OF TEXAS 1971-77: TEXAS DEPARTMENT OF WATER RESOURCES REPORT 228, 1979.

PRELIMINARY DATA DESCRIBING THE DISTRIBUTION OF FLUORIDE AND SILICA IN THE OGALLALA AQUIFER ON THE HIGH PLAINS OF TEXAS: USGS OPEN-FILE REPORT 80-349, 1980.

ANALYTICAL STUDY OF THE OGALLALA AQUIFER IN SWISHER COUNTY, TEXAS-PROJECTIONS OF SATURATED THICKNESS, VOLUME OF WATER IN STORAGE, PUMPAGE RATES, PUMPING LIFTS, AND WELL YIELDS: TEXAS DEPARTMENT OF WATER RESOURCES REPORT 249, 1980.

WATER TABLE IN THE HIGH PLAINS AQUIFER IN 1978 IN PARTS OF COLORADO, KANSAS, NEBRASKA, NEW MEXICO, OKLAHOMA, SOUTH DAKOTA, TEXAS, AND WYOMING: USGS HYDROLOGIC INVESTIGATIONS ATLAS HA-642, 1980.

EVALUATING THE GROUND-WATER RESOURCES OF THE HIGH PLAINS OF TEXAS: RESULTS OF TEST HOLE DRILLING: TEXAS DEPARTMENT OF WATER RESOURCES LIMITED PRINTING REPORT LP-129, 1980.

EVALUATING THE GROUND-WATER RESOURCES OF THE HIGH PLAINS OF TEXAS: RESULTS OF SURFACE ELECTRICAL RESISTIVITY SURVEYS: TEXAS DEPARTMENT OF WATER RESOURCES LIMITED PRINTING REPORT LP-130, 1980.

SPRINGS OF TEXAS, VOLUME 1: (BY GUNNAR BRUNE), BRANCHSMITH, INC., FORT WORTH, TEXAS, 1981.

BEDROCK GEOLOGY, ALTITUDE OF BASE, AND 1980 SATURATED THICKNESS OF THE HIGH PLAINS AQUIFER IN PARTS OF COLORADO, KANSAS, NEBRASKA, NEW MEXICO, OKLAHOMA, SOUTH DAKOTA, TEXAS, AND WYOMING: USGS HYDROLOGIC INVESTIGATIONS ATLAS HA-648, 1981.

WATER-LEVEL AND SATURATED-THICKNESS CHANGES, PREDEVELOPMENT TO 1980, IN THE HIGH PLAINS AQUIFER IN PARTS OF COLORADO, KANSAS, NEBRASKA, NEW MEXICO, OKLAHOMA, SOUTH DAKOTA, TEXAS, AND WYOMING: USGS HYDROLOGIC INVESTIGATIONS ATLAS HA-652, 1981 
DISSOLVED SOLIDS AND SODIUM IN WATER FROM THE HIGH PLAINS AQUIFER IN PARTS OF COLORADO, KANSAS, NEBRASKA, NEW MEXICO, OKLAHOMA, SOUTH DAKOTA, TEXAS, AND WYOMING: USGS HYDROLOGIC INVESTIGATIONS ATLAS HA-658, 1982.

GEOHYDROLOGY OF THE HIGH PLAINS AQUIFER IN PARTS OF COLORADO, KANSAS, NEBRASKA, NEW MEXICO, OKLAHOMA, SOUTH DAKOTA, TEXAS, AND WYOMING: USGS PROFESSIONAL PAPER 1400-B, 1984.

GROUND-WATER CONDITIONS OF THE TRIASSIC AQUIFER IN DEAF SMITH AND SWISHER COUNTIES: TEXAS DEPARTMENT OF WATER RESOURCES LIMITED PRINTING REPORT LP-196, 1984.

EVALUATING THE GROUND-WATER RESOURCES OF THE HIGH PLAINS OF TEXAS, VOLUME 1: TEXAS DEPARTMENT OF WATER RESOURCES REPORT 288, V. 1, 1984.

EVALUATING THE GROUND-WATER RESOURCES OF THE HIGH PLAINS OF TEXAS, VOLUME 3, RECORDS OF WELLS, AND MAPS SHOWING WELL LOCATIONS, BASE OF AQUIFER, WATER LEVELS, AND SATURATED THICKNESS (BAILEY, BRISCOE, CASTRO, CROSBY, DEAF SMITH, DICKENS, FLOYD, HALE, LAMB, MOTLEY, OLDHAM, PARMER, RANDALL, AND SWISHER COUNTIES): TEXAS DEPARTMENT OF WATER RESOURCES REPORT 288, V. 3, 1984.

TEXAS GROUND-WATER RESOURCES, in NATIONAL WATER SUMMARY 1984: USGS WATER-SUPPLY PAPER 2275, 1985.

DIGITAL SIMULATION OF GROUND-WATER FLOW IN THE HIGH PLAINS AQUIFER IN PARTS OF COLORADO, KANSAS, NEBRASKA, NEW MEXICO, OKLAHOMA, SOUTH DAKOTA, TEXAS, AND WYOMING: USGS PROFESSIONAL PAPER 1400-D, 1986.

SUMMARY OF THE HIGH PLAINS REGIONAL AQUIFER-SYSTEM ANALYSIS IN PARTS OF COLORADO, KANSAS, NEBRASKA, NEW MEXICO, OKLAHOMA, SOUTH DAKOTA, TEXAS, AND WYOMING: USGS PROFESSIONAL PAPER 1400-A, 1988.

EVALUATION OF GROUND-WATER RESOURCES IN BRISCOE, HALE, AND SWISHER COUNTIES, TEXAS: TEXAS WATER DEVELOPMENT BOARD REPORT 313, 1989.

PUBLIC SUPPLY GROUND-WATER USE IN THE SOUTHERN HIGH PLAINS OF TEXAS: TEXAS WATER DEVELOPMENT BOARD REPORT 328, 1990.

WATER-LEVEL CHANGES IN THE HIGH PLAINS AQUIFER OF TEXAS, 1980-1990: TEXAS WATER DEVELOPMENT BOARD HYDROLOGIC ATLAS NO. 1, 1991.

EVALUATION OF WATER RESOURCES IN PARTS OF THE ROLLING PRAIRIES REGION OF NORTH-CENTRAL TEXAS: TEXAS WATER DEVELOPMENT BOARD REPORT 337, 1992.

WATER-RESOURCES DATA, TEXAS, WATER YEAR 1991, VOLUME 4, GROUND-WATER DATA: USGS WATER-DATA REPORT TX-91-4, 1992.

THE HIGH PLAINS AQUIFER SYSTEM OF TEXAS, 1980-1990. OVERVIEW AND PROJECTIONS: TEXAS WATER DEVELOPMENT BOARD REPORT 341, 1993.

WATER-QUALITY EVALUATION OF THE OGALLALA AQUIFER, TEXAS: TEXAS WATER DEVELOPMENT BOARD REPORT 342, 1993.
WATER-RESOURCES DATA, TEXAS, WATER YEAR 1992, VOLUME 4, GROUND-WATER DATA: USGS WATER-DATA REPORT TX-92-4, 1993.

WATER-LEVEL CHANGES IN THE HIGH PLAINS AQUIFER-PREDEVELOPMENT TO 1992: USGS WATER-RESOURCES INVESTIGATIONS REPORT 94-4027, 1994.

WATER-RESOURCES DATA, TEXAS, WATER YEAR 1993, VOLUME 4, GROUND-WATER DATA: USGS WATER-DATA REPORT TX-93-4, 1994.

WATER-LEVEL CHANGES IN THE HIGH PLAINS AQUIFER, 1980 TO 1994: USGS FACT SHEET FS-215-95, 1995.

AQUIFERS OF TEXAS: TEXAS WATER DEVELOPMENT BOARD REPORT 345, 1995.

WATER-RESOURCES DATA, TEXAS, WATER YEAR 1994, VOLUME 4, GROUND-WATER DATA: USGS WATER-DATA REPORT TX-94-4, 1995.

WATER-RESOURCES DATA, TEXAS, WATER YEAR 1995, VOLUME 4, GROUND-WATER DATA: USGS WATER-DATA REPORT TX-95-4, 1996.

WATER-LEVEL CHANGES IN THE HIGH PLAINS AQUIFER, 1980 TO 1995: USGS FACT SHEET FS-068-97, 1997.

WATER-LEVEL CHANGES IN THE HIGH PLAINS AQUIFER-PREDEVELOPMENT TO 1995: USGS WATER-RESOURCES INVESTIGATIONS REPORT 97-4081, 1997.

WATER-RESOURCES DATA, TEXAS, WATER YEAR 1996, VOLUME 4, GROUND-WATER DATA: USGS WATER-DATA REPORT TX-96-4, 1997.

WATER-RESOURCES DATA, TEXAS, WATER YEAR 1997, VOLUME 4, GROUND-WATER DATA: USGS WATER-DATA REPORT TX-97-4, 1998.

WATER-RESOURCES DATA, TEXAS, WATER YEAR 1998, VOLUME 4, GROUND-WATER DATA: USGS WATER-DATA REPORT TX-98-4, 1999.

WATER-RESOURCES DATA, TEXAS, WATER YEAR 1999, VOLUME 6, GROUND-WATER DATA: USGS WATER-DATA REPORT TX-99-6, 2000 .

WATER-RESOURCES DATA, TEXAS, WATER YEAR 2000, VOLUME 6, GROUND-WATER DATA: USGS WATER-DATA REPORT TX-00-6, 2001.

\section{TARRANT COUNTY}

GEOGRAPHY AND GEOLOGY OF THE BLACK AND GRAND PRAIRIES, TEXAS, WITH DETAILED DESCRIPTIONS OF THE CRETACEOUS FORMATIONS AND SPECIAL REFERENCE TO ARTESIAN WATERS: USGS 21ST ANNUAL REPORT, PART 7, 1901.

ARLINGTON WATER SUPPLY: USGS OPEN-FILE REPORT (UNNUMBERED), 1941.

GROUND-WATER RESOURCES OF FORT WORTH AND VICINITY, TEXAS: TEXAS BOARD OF WATER ENGINEERS MISCELLANEOUS PUBLICATION 87, 1942. 
A FEW FACTS REGARDING GROUND-WATER SUPPLY OF FORT WORTH AND VICINITY, TEXAS: USGS OPEN-FILE REPORT (UNNUMBERED), 1944.

PUBLIC WATER SUPPLIES IN CENTRAL AND NORTH-CENTRAL TEXAS: TEXAS BOARD OF WATER ENGINEERS MISCELLANEOUS PUBLICATION 213, 1947.

MEMORANDUM REGARDING TESTS RUN ON WELLS AT GENERATING PLANT OF TEXAS ELECTRIC SERVICE CO. AT HANDLEY, TEXAS: USGS OPEN-FILE REPORT (UNNUMBERED), 1948

PUBLIC WATER SUPPLIES IN CENTRAL AND NORTH-CENTRAL TEXAS: USGS WATER-SUPPLY PAPER 1069, 1949.

GEOLOGY AND GROUND-WATER RESOURCES OF TARRANT COUNTY, TEXAS: TEXAS BOARD OF WATER ENGINEERS BULLETIN 5709, 1957.

RECONNAISSANCE INVESTIGATION OF THE GROUND-WATER RESOURCES OF THE TRINITY RIVER BASIN, TEXAS: TEXAS WATER COMMISSION BULLETIN 6309, 1963.

COMPILATION OF RESULTS OF AQUIFER TESTS IN TEXAS: TEXAS WATER DEVELOPMENT BOARD REPORT 98, 1969.

MAJOR AND HISTORICAL SPRINGS OF TEXAS: TEXAS WATER DEVELOPMENT BOARD REPORT 189, 1975.

GROUND-WATER RESOURCES OF PART OF CENTRAL TEXAS WITH EMPHASIS ON THE ANTLERS AND TRAVIS PEAK FORMATIONS: TEXAS WATER DEVELOPMENT BOARD REPORT 195, V. 1, 1975.

GROUND-WATER RESOURCES OF PART OF CENTRAL TEXAS WITH EMPHASIS ON THE ANTLERS AND TRAVIS PEAK FORMATIONS: TEXAS WATER DEVELOPMENT BOARD REPORT 195, V. 2, 1976.

SUMMARY APPRAISALS OF THE NATION'S GROUND-WATER RESOURCES-TEXAS-GULF REGION: USGS PROFESSIONAL PAPER 813-F, 1976.

WATER-LEVEL AND WATER-QUALITY DATA FROM OBSERVATION WELLS IN NORTHEAST TEXAS: TEXAS WATER DEVELOPMENT BOARD REPORT 198, 1976.

SPRINGS OF TEXAS, VOLUME 1: (BY GUNNAR BRUNE), BRANCHSMITH, INC., FORT WORTH, TEXAS, 1981.

OCCURRENCE, AVAILABILITY, AND CHEMICAL QUALITY OF GROUND WATER IN THE CRETACEOUS AQUIFERS OF NORTHCENTRAL TEXAS: TEXAS DEPARTMENT OF WATER RESOURCES REPORT 269, V. 1, 1982.

OCCURRENCE, AVAILABILITY, AND CHEMICAL QUALITY OF GROUND WATER IN THE CRETACEOUS AQUIFERS OF NORTHCENTRAL TEXAS: TEXAS DEPARTMENT OF WATER RESOURCES REPORT 269, V. 2, 1982.

TEXAS GROUND-WATER RESOURCES, in NATIONAL WATER SUMMARY 1984: USGS WATER-SUPPLY PAPER 2275, 1985.

WATER USE, PROJECTED WATER REQUIREMENTS, AND RELATED DATA AND INFORMATION FOR THE METROPOLITAN STATISTICAL AREAS IN TEXAS: TEXAS DEPARTMENT OF WATER RESOURCES LIMITED PRINTING REPORT LP-201, 1985.

EVALUATION OF WATER RESOURCES IN PART OF NORTH-CENTRAL TEXAS: TEXAS WATER DEVELOPMENT BOARD REPORT $318,1990$.

NATIONAL WATER-QUALITY ASSESSMENT PROGRAM-THE TRINITY RIVER BASIN: USGS OPEN-FILE REPORT 91-158, 1991.
PHASE II REPORT, GROUND-WATER SAMPLING \& SUBSURFACE SOIL DELINEATION, U.S. AIR FORCE PLANT 4, CARSWELL AIR FORCE BASE, FORT WORTH, TEXAS: GEO-MARINE, INC., PLANO, TEXAS, 1993

NATIONAL WATER-QUALITY ASSESSMENT PROGRAM-PESTICIDES IN THE TRINITY RIVER BASIN STUDY UNIT, TEXAS, 1968-91: USGS FACT SHEET FS-088-95, 1995.

WATER-QUALITY ASSESSMENT OF THE TRINITY RIVER BASIN, TEXAS-DATA COLLECTION, 1992-95: USGS FACT SHEET FS-095-95, 1995.

WATER-QUALITY ASSESSMENT OF THE TRINITY RIVER BASIN, TEXAS-PESTICIDES IN A SUBURBAN WATERSHED, ARLINGTON, 1993-94: USGS FACT SHEET FS-159-95, 1995.

AQUIFERS OF TEXAS: TEXAS WATER DEVELOPMENT BOARD REPORT 345, 1995.

WATER QUALITY IN THE WOODBINE AQUIFER, NORTH-CENTRAL TEXAS: TEXAS WATER DEVELOPMENT BOARD HYDROLOGIC ATLAS NO. 4, 1996.

NATIONAL WATER-QUALITY ASSESSMENT OF THE TRINITY RIVER BASIN, TEXAS - WELL AND WATER-QUALITY DATA FROM THE OUTCROP OF THE WOODBINE AQUIFER IN URBAN TARRANT COUNTY, 1993: USGS OPEN-FILE REPORT 96-413, 1996.

LOCATIONS AND MONITORING WELL COMPLETION LOGS OF WELLS SURVEYED BY U.S. GEOLOGICAL SURVEY AT AIR FORCE PLANT 4 AND NAVAL AIR STATION, JOINT RESERVE BASE, CARSWELL FIELD, FORT WORTH AREA, TEXAS: USGS OPEN-FILE REPORT 96-650, 1996.

GEOHYDROLOGIC UNITS AND WATER-LEVEL CONDITIONS IN THE TERRACE ALLUVIAL AQUIFER AND PALUXY AQUIFER, MAY 1993 AND FEBRUARY 1994, NEAR AIR FORCE PLANT 4, FORT WORTH AREA, TEXAS: USGS WATER-RESOURCES INVESTIGATIONS REPORT 96-4032, 1996.

HYDROGEOLOGY AND SIMULATION OF GROUND-WATER FLOW IN THE PALUXY AQUIFER IN THE VICINITY OF LANDFILLS 1 AND 3 , U.S. AIR FORCE PLANT 4, FORT WORTH, TEXAS: USGS WATERRESOURCES INVESTIGATIONS REPORT 98-4023, 1998.

UPDATED EVALUATION OF WATER RESOURCES IN PART OF NORTH-CENTRAL TEXAS, 1990-1999: TEXAS WATER DEVELOPMENT BOARD REPORT 349, 1999.

\section{TAYLOR COUNTY}

RECORDS OF WELLS AND SPRINGS, DRILLERS' LOGS, AND WATER ANALYSES, AND MAP SHOWING LOCATION OF WELLS AND SPRINGS IN TAYLOR COUNTY, TEXAS: TEXAS BOARD OF WATER ENGINEERS MISCELLANEOUS PUBLICATION 276, 1940.

ABILENE WATER SUPPLY: USGS OPEN-FILE REPORT (UNNUMBERED), 1941.

PUBLIC WATER SUPPLIES IN CENTRAL AND NORTH-CENTRAL TEXAS: TEXAS BOARD OF WATER ENGINEERS MISCELLANEOUS PUBLICATION 213, 1947.

EFFECT ON GROUND-WATER SUPPLY OF BUFFALO GAP, TEXAS, PRODUCED BY CUTTING OFF UNDERFLOW AT ABILENE RESERVOIR: USGS OPEN-FILE REPORT (UNNUMBERED), 1948. 
PUBLIC WATER SUPPLIES IN CENTRAL AND NORTH-CENTRAL TEXAS: USGS WATER-SUPPLY PAPER 1069, 1949.

NEW WATER SUPPLY OF ABILENE AND OTHER CITIES IN WESTCENTRAL TEXAS JEOPARDIZED BY SALT-WATER CONTAMINATION: USGS OPEN-FILE REPORT, 1963.

RECONNAISSANCE INVESTIGATION OF THE GROUND-WATER RESOURCES OF THE BRAZOS RIVER BASIN, TEXAS: TEXAS WATER COMMISSION BULLETIN 6310, 1963.

RECONNAISSANCE INVESTIGATION OF THE GROUND-WATER RESOURCES OF THE COLORADO RIVER BASIN, TEXAS: TEXAS WATER DEVELOPMENT BOARD REPORT 51, 1967.

SUMMARY APPRAISALS OF THE NATION'S GROUND-WATER RESOURCES-TEXAS-GULF REGION: USGS PROFESSIONAL PAPER 813-F, 1976.

OCCURRENCE, QUANTITY, AND QUALITY OF GROUND WATER IN TAYLOR COUNTY, TEXAS: TEXAS DEPARTMENT OF WATER RESOURCES REPORT 224, 1978.

TEXAS GROUND-WATER RESOURCES, in NATIONAL WATER SUMMARY 1984: USGS WATER-SUPPLY PAPER 2275, 1985.

WATER USE, PROJECTED WATER REQUIREMENTS, AND RELATED DATA AND INFORMATION FOR THE METROPOLITAN STATISTICAL AREAS IN TEXAS: TEXAS DEPARTMENT OF WATER RESOURCES LIMITED PRINTING REPORT LP-201, 1985.

EVALUATION OF WATER RESOURCES IN PARTS OF THE ROLLING PRAIRIES REGION OF NORTH-CENTRAL TEXAS: TEXAS WATER DEVELOPMENT BOARD REPORT 337, 1992.

WATER QUALITY IN THE EDWARDS-TRINITY (PLATEAU) AQUIFER, EDWARDS PLATEAU AND TRANS-PECOS, TEXAS: TEXAS WATER DEVELOPMENT BOARD HYDROLOGIC ATLAS NO. 3, 1995.

AQUIFERS OF TEXAS: TEXAS WATER DEVELOPMENT BOARD REPORT 345, 1995.

AN OVERVIEW OF THE EDWARDS-TRINITY AQUIFER SYSTEM, CENTRAL-WEST TEXAS, CHAPTER 8, in AQUIFERS OF WEST TEXAS: TEXAS WATER DEVELOPMENT BOARD REPORT 356, 2001.

\section{TERRELL COUNTY}

GROUND WATER IN THE VICINITY OF SANDERSON, TEXAS: USGS OPEN-FILE REPORT (UNNUMBERED), 1940.

PUBLIC WATER SUPPLIES IN WESTERN TEXAS: TEXAS BOARD OF WATER ENGINEERS MISCELLANEOUS PUBLICATION 216, 1949.

PUBLIC WATER SUPPLIES IN WESTERN TEXAS: USGS WATERSUPPLY PAPER 1106, 1951.

RECORDS OF TEST HOLES ALONG THE RIO GRANDE IN TERRELL AND VAL VERDE COUNTIES: USGS OPEN-FILE REPORT (UNNUMBERED), 1954.

RECORDS OF WATER-LEVEL MEASUREMENTS IN CROCKETT, GLASSCOCK, REAGAN, UPTON, AND TERRELL COUNTIES, 1937 THROUGH 1957: TEXAS BOARD OF WATER ENGINEERS BULLETIN 5903, 1959.

RECONNAISSANCE INVESTIGATION OF THE GROUND-WATER RESOURCES OF THE RIO GRANDE BASIN, TEXAS: TEXAS WATER COMMISSION BULLETIN 6502, 1965.
MAJOR AND HISTORICAL SPRINGS OF TEXAS: TEXAS WATER DEVELOPMENT BOARD REPORT 189, 1975.

RECONNAISSANCE INVESTIGATION OF GROUND WATER IN THE RIO GRANDE DRAINAGE BASIN-WITH SPECIAL EMPHASIS ON SALINE GROUND-WATER RESOURCES: USGS HYDROLOGIC INVESTIGATIONS ATLAS HA-510, 1974.

SUMMARY APPRAISALS OF THE NATION'S GROUND-WATER RESOURCES-TEXAS-GULF REGION: USGS PROFESSIONAL PAPER 813-F, 1976.

OCCURRENCE, AVAILABILITY, AND CHEMICAL QUALITY OF GROUND WATER IN THE EDWARDS PLATEAU REGION OF TEXAS: TEXAS DEPARTMENT OF WATER RESOURCES REPORT 235,1979 .

OCCURRENCE AND QUALITY OF GROUND WATER IN THE EDWARDS-TRINITY (PLATEAU) AQUIFER IN THE TRANS-PECOS REGION OF TEXAS: TEXAS DEPARTMENT OF WATER RESOURCES REPORT 255, 1980.

SPRINGS OF TEXAS, VOLUME 1: (BY GUNNAR BRUNE), BRANCHSMITH, INC., FORT WORTH, TEXAS, 1981.

MAPS SHOWING GROUND-WATER UNITS AND WITHDRAWAL, BASIN AND RANGE PROVINCE, TEXAS: USGS WATERRESOURCES INVESTIGATIONS REPORT 83-4121-A, 1984.

MAPS SHOWING GROUND-WATER LEVELS, SPRINGS, AND DEPTH TO GROUND WATER, BASIN AND RANGE PROVINCE, TEXAS: USGS WATER-RESOURCES INVESTIGATIONS REPORT 83-4121-B, 1984.

MAPS SHOWING DISTRIBUTION OF DISSOLVED SOLIDS AND DOMINANT CHEMICAL TYPE IN GROUND WATER, BASIN AND RANGE PROVINCE, TEXAS: USGS WATER-RESOURCES INVESTIGATIONS REPORT 83-4121-C, 1984.

TEXAS GROUND-WATER RESOURCES, in NATIONAL WATER SUMMARY 1984: USGS WATER-SUPPLY PAPER 2275, 1985.

RECORDS OF WELLS, WATER LEVELS, PUMPAGE, AND CHEMICAL ANALYSES FROM SELECTED WELLS IN PARTS OF THE TRANSPECOS REGION, TEXAS, 1968-1980: TEXAS WATER DEVELOPMENT BOARD REPORT 301, 1987

POTENTIOMETRIC SURFACE OF THE EDWARDS-TRINITY AQUIFER SYSTEM AND CONTIGUOUS HYDRAULICALLY CONNECTED UNITS, WEST-CENTRAL TEXAS, WINTER 1974-75: USGS WATERRESOURCES INVESTIGATIONS REPORT 89-4208, 1990.

WITHDRAWALS FROM THE EDWARDS-TRINITY AQUIFER SYSTEM AND CONTIGUOUS HYDRAULICALLY CONNECTED UNITS, WEST-CENTRAL TEXAS, DECEMBER 1974 THROUGH MARCH 1977: USGS WATER-RESOURCES INVESTIGATIONS REPORT 91-4021, 1991.

CONFIGURATION OF THE BASE OF THE EDWARDS-TRINITY AQUIFER SYSTEM AND HYDROGEOLOGY OF THE UNDERLYING PRECRETACEOUS ROCKS, WEST-CENTRAL TEXAS: USGS WATERRESOURCES INVESTIGATIONS REPORT 91-4071, 1992.

HISTORICAL POTENTIOMETRIC SURFACE OF THE EDWARDS-TRINITY AQUIFER SYSTEM AND CONTIGUOUS HYDRAULICALLY CONNECTED UNITS, WEST-CENTRAL TEXAS: USGS WATERRESOURCES INVESTIGATIONS REPORT 92-4055, 1993.

HISTORICAL SATURATED THICKNESS OF THE EDWARDS-TRINITY AQUIFER SYSTEM AND SELECTED CONTIGUOUS HYDRAULI- 
CALLY CONNECTED UNITS, WEST-CENTRAL TEXAS: USGS WATER-RESOURCES INVESTIGATIONS REPORT 92-4125, 1993.

SIMULATIONS OF FLOW IN THE EDWARDS-TRINITY AQUIFER SYSTEM AND CONTIGUOUS HYDRAULICALLY CONNECTED UNITS, WEST-CENTRAL TEXAS: USGS WATER-RESOURCES INVESTIGATIONS REPORT 93-4039, 1994.

DISSOLVED-SOLIDS CONCENTRATIONS AND HYDROCHEMICAL FACIES IN WATER OF THE EDWARDS-TRINITY AQUIFER SYSTEM, WEST-CENTRAL TEXAS: USGS WATER-RESOURCES INVESTIGATIONS REPORT 93-4126, 1994.

GEOLOGIC HISTORY AND HYDROGEOLOGIC SETTING OF THE EDWARDS-TRINITY AQUIFER SYSTEM, WEST-CENTRAL TEXAS: USGS WATER-RESOURCES INVESTIGATIONS REPORT 94-4039, 1994.

AQUIFERS OF TEXAS: TEXAS WATER DEVELOPMENT BOARD REPORT 345, 1995.

WATER QUALITY IN THE EDWARDS-TRINITY (PLATEAU) AQUIFER, EDWARDS PLATEAU AND TRANS-PECOS, TEXAS: TEXAS WATER DEVELOPMENT BOARD HYDROLOGIC ATLAS NO. 3, 1995.

HYDROGEOLOGIC FRAMEWORK OF THE EDWARDS-TRINITY AQUIFER SYSTEM, WEST-CENTRAL TEXAS: USGS PROFESSIONAL PAPER 1421-B, 1996.

AN OVERVIEW OF THE EDWARDS-TRINITY AQUIFER SYSTEM, CEN TRAL-WEST TEXAS, CHAPTER 8, in AQUIFERS OF WEST TEXAS: TEXAS WATER DEVELOPMENT BOARD REPORT 356, 2001.

WATER-RESOURCES DATA, TEXAS, WATER YEAR 2000, VOLUME 6, GROUND-WATER DATA: USGS WATER-DATA REPORT TX-00-6, 2001.

\section{TERRY COUNTY}

GROUND WATER IN THE HIGH PLAINS IN TEXAS (1940): TEXAS BOARD OF WATER ENGINEERS MISCELLANEOUS PUBLICATION M119, 1940

RECORDS OF WELLS AND SPRINGS, DRILLERS' LOGS, WATER ANALYSES, AND MAP SHOWING LOCATIONS OF WELLS AND SPRINGS IN TERRY COUNTY, TEXAS: TEXAS BOARD OF WATER ENGINEERS MISCELLANEOUS PUBLICATION 277, 1944.

GROUND WATER IN THE HIGH PLAINS IN TEXAS, PROGRESS REPORT (1944): TEXAS BOARD OF WATER ENGINEERS MISCELLANEOUS PUBLICATION M121, 1944.

GROUND WATER IN THE HIGH PLAINS IN TEXAS, PROGRESS REPORT NO. 5: TEXAS BOARD OF WATER ENGINEERS MISCELLANEOUS PUBLICATION M122, 1945.

GROUND WATER IN THE HIGH PLAINS OF TEXAS: USGS WATERSUPPLY PAPER 889-F, 1946.

GROUND WATER IN THE HIGH PLAINS IN TEXAS, PROGRESS REPORT NO. 6: TEXAS BOARD OF WATER ENGINEERS MISCELLANEOUS PUBLICATION M123, 1947.

GEOLOGY AND GROUND WATER IN THE IRRIGATED REGION OF THE SOUTHERN HIGH PLAINS IN TEXAS, PROGRESS REPORT NO. 7: TEXAS BOARD OF WATER ENGINEERS MISCELLANEOUS PUBLICATION M125, 1949.
PUBLIC WATER SUPPLIES IN WESTERN TEXAS: TEXAS BOARD OF WATER ENGINEERS MISCELLANEOUS PUBLICATION 216, 1949.

COST OF PUMPING WATER FOR IRRIGATION, TEXAS HIGH PLAINS, FIELD INVESTIGATION_1947 IRRIGATION SEASON: TEXAS BOARD OF WATER ENGINEERS MISCELLANEOUS PUBLICATION M124, 1951.

DEVELOPMENT OF WELLS FOR IRRIGATION AND FLUCTUATION OF WATER LEVELS IN THE HIGH PLAINS OF TEXAS TO JANUARY 1951: TEXAS BOARD OF WATER ENGINEERS BULLETIN 5104, 1951.

PUBLIC WATER SUPPLIES IN WESTERN TEXAS: USGS WATERSUPPLY PAPER 1106, 1951 [1952].

GROUND-WATER RESOURCES OF LYNN COUNTY, TEXAS: TEXAS BOARD OF WATER ENGINEERS BULLETIN 5207, 1952.

SUMMARY OF GROUND-WATER DEVELOPMENT IN THE SOUTHERN HIGH PLAINS, TEXAS: TEXAS BOARD OF WATER ENGINEERS BULLETIN 5402, 1954

RECORDS OF WATER-LEVEL MEASUREMENTS IN COCHRAN, CROSBY, GAINES, HOCKLEY, LYNN, AND TERRY COUNTIES, TEXAS: TEXAS BOARD OF WATER ENGINEERS BULLETIN 5407, 1954.

GROUND-WATER DEVELOPMENT IN THE SOUTHERN HIGH PLAINS OF TEXAS, 1953: TEXAS BOARD OF WATER ENGINEERS BULLETIN 5410, 1954.

WATER-LEVEL DECLINE MAPS OF 16 COUNTIES IN THE SOUTHERN HIGH PLAINS, TEXAS, JANUARY 1954 TO JANUARY 1955: (BAILEY, BRISCOE, CASTRO, COCHRAN, CROSBY, DEAF SMITH, FLOYD, GAINES, HALE, HOCKLEY, LAMB, LUBBOCK, PARMER, RANDALL, SWISHER, AND TERRY): USGS OPEN-FILE REPORT, 1955.

WATER-LEVEL DECLINE MAPS OF 17 COUNTIES IN THE SOUTHERN HIGH PLAINS, TEXAS, JANUARY 1955 TO JANUARY 1956: TEXAS BOARD OF WATER ENGINEERS BULLETIN 5607, 1956.

WATER-LEVEL DECLINE MAPS, 1956 TO 1957, AND WATER LEVELS IN OBSERVATION WELLS IN 20 COUNTIES IN THE SOUTHERN HIGH PLAINS, TEXAS: TEXAS BOARD OF WATER ENGINEERS BULLETIN 5705, 1957.

WATER-LEVEL MEASUREMENTS AND MAPS, SOUTHERN HIGH PLAINS, TEXAS, 1958 AND 1959: TEXAS BOARD OF WATER ENGINEERS BULLETIN 5908, 1959.

WATER LEVELS IN OBSERVATION WELLS, SOUTHERN HIGH PLAINS, TEXAS, 1959 AND 1960: TEXAS BOARD OF WATER ENGINEERS BULLETIN 6011, 1960.

SHALLOW FORMATIONS AND AQUIFERS OF THE WEST TEXAS AREA: WEST TEXAS GEOLOGICAL SOCIETY PUBLICATION 61-45 AND PERMIAN BASIN GEOPHYSICAL SOCIETY, MIDLAND, TEXAS, 1961.

WATER LEVELS IN OBSERVATION WELLS, SOUTHERN HIGH PLAINS, TEXAS, 1960 AND 1961: TEXAS BOARD OF WATER ENGINEERS BULLETIN 6101, 1961.

A SUMMARY OF THE OCCURRENCE AND DEVELOPMENT OF GROUND WATER IN THE SOUTHERN HIGH PLAINS OF TEXAS: TEXAS BOARD OF WATER ENGINEERS BULLETIN 6107, 1961.

WATER-LEVEL MEASUREMENTS THROUGH 1962 IN SELECTED OBSERVATION WELLS, SOUTHERN HIGH PLAINS, TEXAS: TEXAS WATER COMMISSION BULLETIN 6207, 1962. 
RECONNAISSANCE INVESTIGATION OF THE GROUND-WATER RESOURCES OF THE BRAZOS RIVER BASIN, TEXAS: TEXAS WATER COMMISSION BULLETIN 6310, 1963.

A SUMMARY OF THE OCCURRENCE AND DEVELOPMENT OF GROUND WATER IN THE SOUTHERN HIGH PLAINS OF TEXAS: USGS WATER-SUPPLY PAPER 1693, 1964.

INVESTIGATION OF GROUND-WATER CONTAMINATION BY COTTON SEED DELINTING WASTE, TERRY COUNTY, TEXAS: TEXAS WATER COMMISSION LIMITED-DISTRIBUTION REPORT LD-864, 1964.

WATER-LEVEL DATA FROM OBSERVATION WELLS IN THE SOUTHERN HIGH PLAINS OF TEXAS: TEXAS WATER DEVELOPMENT BOARD REPORT 21, 1966.

RECONNAISSANCE INVESTIGATION OF THE GROUND-WATER RESOURCES OF THE COLORADO RIVER BASIN, TEXAS: TEXAS WATER DEVELOPMENT BOARD REPORT 51, 1967.

COMPILATION OF RESULTS OF AQUIFER TESTS IN TEXAS: TEXAS WATER DEVELOPMENT BOARD REPORT 98, 1969.

GROUND WATER IN THE OGALLALA FORMATION IN THE SOUTHERN HIGH PLAINS OF TEXAS AND NEW MEXICO: USGS HYDROLOGIC INVESTIGATIONS ATLAS HA-330, 1969.

WATER-LEVEL DATA FROM OBSERVATION WELLS IN THE SOUTHERN HIGH PLAINS OF TEXAS, 1956-70: TEXAS WATER DEVELOPMENT BOARD REPORT 121, 1970.

SUMMARY APPRAISALS OF THE NATION'S GROUND-WATER RESOURCES-TEXAS-GULF REGION: USGS PROFESSIONAL PAPER 813-F, 1976.

ANALYTICAL STUDY OF THE OGALLALA AQUIFER IN TERRY COUNTY, TEXAS-PROJECTIONS OF SATURATED THICKNESS, VOLUME OF WATER IN STORAGE, PUMPAGE RATES, PUMPING LIFTS, AND WELL YIELDS: TEXAS WATER DEVELOPMENT BOARD REPORT 222, 1978.

WATER-LEVEL DATA FROM OBSERVATION WELLS IN THE SOUTHERN HIGH PLAINS OF TEXAS, 1971-77: TEXAS DEPARTMENT OF WATER RESOURCES REPORT 228, 1979.

PRELIMINARY DATA DESCRIBING THE DISTRIBUTION OF FLUORIDE AND SILICA IN THE OGALLALA AQUIFER ON THE HIGH PLAINS OF TEXAS: USGS OPEN-FILE REPORT 80-349, 1980.

EVALUATING THE GROUND-WATER RESOURCES OF THE HIGH PLAINS OF TEXAS: RESULTS OF TEST-HOLE DRILLING: TEXAS DEPARTMENT OF WATER RESOURCES LIMITED PRINTING REPORT LP-129, 1980.

EVALUATING THE GROUND-WATER RESOURCES OF THE HIGH PLAINS OF TEXAS: NEUTRON-PROBE MEASUREMENTS OF DEEP SOIL MOISTURE AS AN INDICATION OF AQUIFER RECHARGE RATES: TEXAS DEPARTMENT OF WATER RESOURCES LIMITED PRINTING REPORT LP-142, 1981.

SPRINGS OF TEXAS, VOLUME 1: (BY GUNNAR BRUNE), BRANCHSMITH, INC., FORT WORTH, TEXAS, 1981.

BEDROCK GEOLOGY, ALTITUDE OF BASE, AND 1980 SATURATED THICKNESS OF THE HIGH PLAINS AQUIFER IN PARTS OF COLORADO, KANSAS, NEBRASKA, NEW MEXICO, OKLAHOMA, SOUTH DAKOTA, TEXAS, AND WYOMING: USGS HYDROLOGIC INVESTIGATIONS ATLAS HA-648, 1981.

WATER LEVEL AND SATURATED THICKNESS CHANGES, PREDEVELOPMENT TO 1980, IN THE HIGH PLAINS AQUIFER IN PARTS
OF COLORADO, KANSAS, NEBRASKA, NEW MEXICO, OKLAHOMA, SOUTH DAKOTA, TEXAS, AND WYOMING: USGS HYDROLOGIC INVESTIGATIONS ATLAS HA-652, 1981.

INVESTIGATION OF THE FEASIBILITY OF SECONDARY RECOVERY OF GROUND WATER FROM THE OGALLALA AQUIFER. A REPORT TO THE 68TH TEXAS LEGISLATURE: TEXAS DEPARTMENT OF WATER RESOURCES LIMITED PRINTING REPORT LP-185, 1982.

DISSOLVED SOLIDS AND SODIUM IN WATER FROM THE HIGH PLAINS AQUIFER IN PARTS OF COLORADO, KANSAS, NEBRASKA, NEW MEXICO, OKLAHOMA, SOUTH DAKOTA, TEXAS, AND WYOMING: USGS HYDROLOGIC INVESTIGATIONS ATLAS HA-658, 1982.

INVESTIGATION OF SECONDARY RECOVERY OF GROUND WATER FROM THE OGALLALA FORMATION, HIGH PLAINS OF TEXASSUMMARY OF STUDY: HIGH PLAINS UNDERGROUND WATER CONSERVATION DISTRICT NO. 1, LUBBOCK, TEXAS, 1982.

EVALUATING THE GROUND-WATER RESOURCES OF THE HIGH PLAINS OF TEXAS, VOLUME 1: TEXAS DEPARTMENT OF WATER RESOURCES REPORT 288, V. 1, 1984.

EVALUATING THE GROUND-WATER RESOURCES OF THE HIGH PLAINS OF TEXAS, VOLUME 4, RECORDS OF WELLS, AND MAPS SHOWING WELL LOCATIONS, BASE OF AQUIFER, WATER LEVELS, AND SATURATED THICKNESS (ANDREWS, BORDEN, COCHRAN, DAWSON, ECTOR, GAINES, GARZA, GLASSCOCK, HOWARD, HOCKLEY, LUBBOCK, LYNN, MARTIN, MIDLAND, TERRY, AND YOAKUM COUNTIES: TEXAS DEPARTMENT OF WATER RESOURCES REPORT 288 V. 4, 1984.

GEOHYDROLOGY OF THE HIGH PLAINS AQUIFER IN PARTS OF COLORADO, KANSAS, NEBRASKA, NEW MEXICO, OKLAHOMA, SOUTH DAKOTA, TEXAS, AND WYOMING: USGS PROFESSIONAL PAPER 1400-B, 1984.

TEXAS GROUND-WATER RESOURCES, in NATIONAL WATER SUMMARY 1984: USGS WATER-SUPPLY PAPER 2275, 1985.

INVESTIGATION OF THE FEASIBILITY OF SECONDARY RECOVERY OF GROUND WATER FROM THE OGALLALA AQUIFER. A REPORT TO THE 69TH TEXAS LEGISLATURE: TEXAS WATER DEVELOPMENT BOARD LIMITED PRINTING REPORT LP-202, 1985.

DIGITAL SIMULATION OF GROUND-WATER FLOW IN THE HIGH PLAINS AQUIFER IN PARTS OF COLORADO, KANSAS, NEBRASKA, NEW MEXICO, OKLAHOMA, SOUTH DAKOTA, TEXAS, AND WYOMING: USGS PROFESSIONAL PAPER 1400-D, 1986.

SUMMARY OF THE HIGH PLAINS REGIONAL AQUIFER-SYSTEM ANALYSIS IN PARTS OF COLORADO, KANSAS, NEBRASKA, NEW MEXICO, OKLAHOMA, SOUTH DAKOTA, TEXAS, AND WYOMING: USGS PROFESSIONAL PAPER 1400-A, 1988.

HYDROGEOLOGY AND HYDROCHEMISTRY OF CRETACEOUS AQUIFERS, TEXAS PANHANDLE AND EASTERN NEW MEXICO: UNIVERSITY OF TEXAS, BUREAU OF ECONOMIC GEOLOGY GEOLOGICAL CIRCULAR 88-3, 1988.

HYDROGEOLOGY OF LOWER CRETACEOUS STRATA UNDER THE SOUTHERN HIGH PLAINS OF TEXAS AND NEW MEXICO: TEXAS WATER DEVELOPMENT BOARD REPORT 314, 1989.

PUBLIC-SUPPLY GROUND-WATER USE IN THE SOUTHERN HIGH PLAINS OF TEXAS: TEXAS WATER DEVELOPMENT BOARD REPORT 328, 1990. 
ORIGIN OF SOLUTES IN SALINE LAKES AND SPRINGS ON THE SOUTHERN HIGH PLAINS OF TEXAS AND NEW MEXICO, in GEOLOGIC FRAMEWORK AND REGIONAL HYDROLOGY: UPPER CENOZOIC BLACKWATER DRAW AND OGALLALA FORMATIONS, GREAT PLAINS: UNIVERSITY OF TEXAS, BUREAU OF ECONOMIC GEOLOGY SYMPOSIUM, LUBBOCK, TEXAS, OCTOBER 1-4, 1987, 1990.

EVALUATION OF GROUND-WATER RESOURCES IN THE SOUTHERN HIGH PLAINS OF TEXAS: TEXAS WATER DEVELOPMENT BOARD REPORT 330, 1991.

WATER-LEVEL CHANGES IN THE HIGH PLAINS AQUIFER OF TEXAS, 1980-1990: TEXAS WATER DEVELOPMENT BOARD HYDROLOGIC ATLAS NO. 1, 1991.

THE HIGH PLAINS AQUIFER SYSTEM OF TEXAS, 1980 TO 1990. OVERVIEW AND PROJECTIONS: TEXAS WATER DEVELOPMENT BOARD REPORT 341, 1993.

WATER-QUALITY EVALUATION OF THE OGALLALA AQUIFER, TEXAS: TEXAS WATER DEVELOPMENT BOARD REPORT 342, 1993.

WATER-LEVEL CHANGES IN THE HIGH PLAINS AQUIFER, 1980 TO 1994: USGS FACT SHEET FS-215-95, 1995.

AQUIFERS OF TEXAS: TEXAS WATER DEVELOPMENT BOARD REPORT 345, 1995.

WATER-LEVEL CHANGES IN THE HIGH PLAINS AQUIFER, 1980 TO 1995: USGS FACT SHEET FS-068-97, 1997.

WATER-LEVEL CHANGES IN THE HIGH PLAINS AQUIFER-PREDEVELOPMENT TO 1995: USGS WATER-RESOURCES INVESTIGATIONS REPORT 97-4081, 1997.

UPDATED WATER-QUALITY EVALUATION OF THE OGALLALA AQUIFER INCLUDING SELECTED METALLIC AND NON-METALLIC INORGANIC CONSTITUENTS: TEXAS WATER DEVELOPMENT BOARD HYDROLOGIC ATLAS NO. 10, 1998.

\section{THROCKMORTON COUNTY}

GEOLOGY AND UNDERGROUND WATERS OF THE WICHITA REGION, NORTH-CENTRAL TEXAS: USGS WATER-SUPPLY PAPER 317,1913 ,

PUBLIC WATER SUPPLIES IN CENTRAL AND NORTH-CENTRAL TEXAS: TEXAS BOARD OF WATER ENGINEERS MISCELLANEOUS PUBLICATION 213, 1947.

PUBLIC WATER SUPPLIES IN CENTRAL AND NORTH-CENTRAL TEXAS: USGS WATER-SUPPLY PAPER 1069, 1949.

RECONNAISSANCE INVESTIGATION OF THE GROUND-WATER RESOURCES OF THE BRAZOS RIVER BASIN, TEXAS: TEXAS WATER COMMISSION BULLETIN 6310, 1963.

OCCURRENCE AND QUALITY OF GROUND WATER IN THROCKMORTON COUNTY, TEXAS: TEXAS WATER DEVELOPMENT BOARD REPORT 113, 1970.

TEXAS GROUND-WATER RESOURCES, in NATIONAL WATER SUMMARY 1984: USGS WATER-SUPPLY PAPER 2275, 1985.

EVALUATION OF WATER RESOURCES IN PARTS OF THE ROLLING PRAIRIES REGION OF NORTH-CENTRAL TEXAS: TEXAS WATER DEVELOPMENT BOARD REPORT 337, 1992.
AQUIFERS OF TEXAS: TEXAS WATER DEVELOPMENT BOARD REPORT 345, 1995.

\section{TITUS COUNTY}

RECORDS OF WELLS, SPRINGS, DRILLERS' LOGS, WATER ANALYSES, AND MAP SHOWING LOCATIONS OF WELLS AND SPRINGS IN CAMP, FRANKLIN, AND TITUS COUNTIES, TEXAS: TEXAS BOARD OF WATER ENGINEERS MISCELLANEOUS PUBLICATION $30,1943$.

PUBLIC WATER SUPPLIES IN EASTERN TEXAS, V. 2, HARRISON COUNTY THROUGH WOOD COUNTY: TEXAS BOARD OF WATER ENGINEERS MISCELLANEOUS PUBLICATION 214, V. 2, 1945.

PUBLIC WATER SUPPLIES IN EASTERN TEXAS: USGS WATERSUPPLY PAPER 1047, 1948

RECONNAISSANCE INVESTIGATION OF THE GROUND-WATER RESOURCES OF THE RED RIVER, SULPHUR RIVER, AND CYPRESS CREEK BASINS, TEXAS: TEXAS WATER COMMISSION BULLETIN 6306, 1963.

GROUND-WATER RESOURCES OF CAMP, FRANKLIN, MORRIS, AND TITUS COUNTIES, TEXAS: TEXAS WATER COMMISSION BULLETIN $6517,1965$.

COMPILATION OF RESULTS OF AQUIFER TESTS IN TEXAS: TEXAS WATER DEVELOPMENT BOARD REPORT 98, 1969.

SUMMARY APPRAISALS OF THE NATION'S GROUND-WATER RESOURCES-TEXAS-GULF REGION: USGS PROFESSIONAL PAPER 813-F, 1976.

WATER-QUALITY DATA FOR AQUIFERS, STREAMS, AND LAKES IN THE VICINITY OF KEECHI, MOUNT SYLVAN, OAKWOOD, AND PALESTINE SALT DOMES, NORTHEAST TEXAS SALT-DOME BASIN: USGS OPEN-FILE REPORT 80-2037, 1980

GEOHYDROLOGY OF THE KEECHI, MOUNT SYLVAN, OAKWOOD, AND PALESTINE SALT DOMES IN THE NORTHEAST TEXAS SALTDOME BASIN: USGS OPEN-FILE REPORT 80-2044, 1980.

GEOLOGY AND GEOHYDROLOGY OF THE EAST TEXAS BASIN-A REPORT ON THE PROGRESS OF NUCLEAR WASTE ISOLATION FEASIBILITY STUDIES (1979): UNIVERSITY OF TEXAS, BUREAU OF ECONOMIC GEOLOGY GEOLOGICAL CIRCULAR 80-12, 1980.

GEOLOGY AND GEOHYDROLOGY OF THE EAST TEXAS BASIN-A REPORT ON THE PROGRESS OF NUCLEAR WASTE ISOLATION FEASIBILITY STUDIES (1980): UNIVERSITY OF TEXAS, BUREAU OF ECONOMIC GEOLOGY GEOLOGICAL CIRCULAR 81-7, 1981.

SPRINGS OF TEXAS, VOLUME 1: (BY GUNNAR BRUNE), BRANCHSMITH, INC., FORT WORTH, TEXAS, 1981.

TEXAS GROUND-WATER RESOURCES, in NATIONAL WATER SUMMARY 1984: USGS WATER-SUPPLY PAPER 2275, 1985.

APPROXIMATE POTENTIOMETRIC SURFACES FOR THE AQUIFERS OF THE TEXAS COASTAL UPLANDS SYSTEM, 1980: USGS HYDROLOGIC INVESTIGATIONS ATLAS HA-704, 1987.

GROUND-WATER RESOURCES OF THE NACATOCH AQUIFER: TEXAS WATER DEVELOPMENT BOARD REPORT 305, 1988.

GEOHYDROLOGIC FRAMEWORK OF THE GULF COASTAL PLAIN: USGS HYDROLOGIC INVESTIGATIONS ATLAS HA-695, 1988. 
HYDROGEOLOGY AND PREDEVELOPMENT FLOW IN THE TEXAS GULF COAST AQUIFER SYSTEMS: USGS WATER-RESOURCES INVESTIGATIONS REPORT 87-4248, 1988.

GROUND-WATER FLOW IN THE GULF COAST AQUIFER SYSTEMS, SOUTH-CENTRAL UNITED STATES-A PRELIMINARY ANALYSIS: USGS WATER-RESOURCES INVESTIGATIONS REPORT 89-4071, 1990.

HYDROLOGY OF THE TEXAS GULF COAST AQUIFER SYSTEMS: USGS OPEN-FILE REPORT 91-64, 1991.

PROPERTIES AND CHEMICAL CONSTITUENTS IN GROUND WATER FROM THE LOWER CLAIBORNE-UPPER WILCOX AQUIFER, GULF COAST REGIONAL AQUIFER SYSTEMS, SOUTH-CENTRAL UNITED STATES: USGS WATER-RESOURCES INVESTIGATIONS REPORT 92-4102, 1993.

PROPERTIES AND CHEMICAL CONSTITUENTS IN GROUND WATER FROM THE MIDDLE WILCOX AQUIFER, GULF COAST AQUIFER SYSTEMS, SOUTH-CENTRAL UNITED STATES: USGS WATERRESOURCES INVESTIGATIONS REPORT 93-4070, 1993.

AQUIFERS OF TEXAS: TEXAS WATER DEVELOPMENT BOARD REPORT 345, 1995

WATER QUALITY IN THE QUEEN CITY AQUIFER, EAST TEXAS: TEXAS WATER DEVELOPMENT BOARD HYDROLOGIC ATLAS NO. 6, 1996.

\section{TOM GREEN COUNTY}

REPORT OF PROGRESS OF STREAM MEASUREMENTS FOR THE CALENDAR YEAR 1904: USGS WATER-SUPPLY AND IRRIGATION PAPER 132, 1905.

RECORDS OF WELLS AND SPRINGS, DRILLERS' LOGS, WATER ANALYSES, AND MAP SHOWING LOCATIONS OF WELLS AND SPRINGS IN TOM GREEN COUNTY, TEXAS: TEXAS BOARD OF WATER ENGINEERS MISCELLANEOUS PUBLICATION 279, 1941.

WATER SUPPLY OF SAN ANGELO: USGS OPEN-FILE REPORT (UNNUMBERED), 1941.

GROUND-WATER RESOURCES OF GOODFELLOW AUXILIARY FIELD NO. 4, U.S. AIR CORPS, SAN ANGELO, TEXAS: USGS OPEN-FILE REPORT (UNNUMBERED), 1943.

PUBLIC WATER SUPPLIES IN WESTERN TEXAS: TEXAS BOARD OF WATER ENGINEERS MISCELLANEOUS PUBLICATION 216, 1949.

PERSONAL CORRESPONDENCE FROM HEAD-OF-THE-RIVER RANCH, CHRISTOVAL, TEXAS: USGS OPEN-FILE REPORT, 1949.

INVESTIGATIONS OF SPRINGS ON THE HEADWATERS OF THE CONCHO RIVER: USGS OPEN-FILE REPORT (UNNUMBERED), 1950.

PUBLIC WATER SUPPLIES IN WESTERN TEXAS: USGS WATERSUPPLY PAPER 1106, 1951.

GROUND-WATER RESOURCES OF TOM GREEN COUNTY, TEXAS: TEXAS BOARD OF WATER ENGINEERS BULLETIN 5411, 1954.

RECORDS OF WATER-LEVEL MEASUREMENTS IN MITCHELL, NOLAN, STERLING, AND TOM GREEN COUNTIES, TEXAS, 1938 THROUGH 1957, TEXAS BOARD OF WATER ENGINEERS BULLETIN 5907, 1959.
RECONNAISSANCE INVESTIGATION OF THE GROUND-WATER RESOURCES OF THE COLORADO RIVER BASIN, TEXAS: TEXAS WATER DEVELOPMENT BOARD REPORT 51, 1967.

MAJOR AND HISTORICAL SPRINGS OF TEXAS: TEXAS WATER DEVELOPMENT BOARD REPORT 189, 1975.

SUMMARY APPRAISALS OF THE NATION'S GROUND-WATER RESOURCES-TEXAS-GULF REGION: USGS PROFESSIONAL PAPER 813-F, 1976.

OCCURRENCE, AVAILABILITY, AND CHEMICAL QUALITY OF GROUND WATER IN THE EDWARDS PLATEAU REGION OF TEXAS: TEXAS DEPARTMENT OF WATER RESOURCES REPORT $235,1979$.

TEXAS GROUND-WATER RESOURCES, in NATIONAL WATER SUMMARY 1984: USGS WATER-SUPPLY PAPER 2275, 1985.

WATER USE, PROJECTED WATER REQUIREMENTS, AND RELATED DATA AND INFORMATION FOR THE METROPOLITAN STATISTICAL AREAS IN TEXAS: TEXAS DEPARTMENT OF WATER RESOURCES LIMITED PRINTING REPORT LP-201, 1985.

SHALLOW GROUND-WATER CONDITIONS, TOM GREEN COUNTY, TEXAS: USGS WATER-RESOURCES INVESTIGATIONS REPORT 86-4177, 1986.

PUBLIC SUPPLY GROUND-WATER USE IN WESTERN TEXAS: TEXAS WATER DEVELOPMENT BOARD REPORT 311, 1989.

POTENTIOMETRIC SURFACE OF THE EDWARDS-TRINITY AQUIFER SYSTEM AND CONTIGUOUS HYDRAULICALLY CONNECTED UNITS, WEST-CENTRAL TEXAS, WINTER 1974-75: USGS WATERRESOURCES INVESTIGATIONS REPORT 89-4208, 1990.

WITHDRAWALS FROM THE EDWARDS-TRINITY AQUIFER SYSTEM AND CONTIGUOUS HYDRAULICALLY CONNECTED UNITS, WEST-CENTRAL TEXAS, DECEMBER 1974 THROUGH MARCH 1977: USGS WATER-RESOURCES INVESTIGATIONS REPORT 91-4021, 1991.

CONFIGURATION OF THE BASE OF THE EDWARDS-TRINITY AQUIFER SYSTEM AND HYDROGEOLOGY OF THE UNDERLYING PRECRETACEOUS ROCKS, WEST-CENTRAL TEXAS: USGS WATERRESOURCES INVESTIGATIONS REPORT 91-4071, 1992.

HISTORICAL POTENTIOMETRIC SURFACE OF THE EDWARDS-TRINITY AQUIFER SYSTEM AND CONTIGUOUS HYDRAULICALLY CONNECTED UNITS, WEST-CENTRAL TEXAS: USGS WATERRESOURCES INVESTIGATIONS REPORT 92-4055, 1993.

HISTORICAL SATURATED THICKNESS OF THE EDWARDS-TRINITY AQUIFER SYSTEM AND SELECTED CONTIGUOUS HYDRAULICALLY CONNECTED UNITS, WEST-CENTRAL TEXAS: USGS WATER-RESOURCES INVESTIGATIONS REPORT 92-4125, 1993.

SIMULATIONS OF FLOW IN THE EDWARDS-TRINITY AQUIFER SYSTEM AND CONTIGUOUS HYDRAULICALLY CONNECTED UNITS, WEST-CENTRAL TEXAS: USGS WATER-RESOURCES INVESTIGATIONS REPORT 93-4039, 1994.

DISSOLVED-SOLIDS CONCENTRATIONS AND HYDROCHEMICAL FACIES IN WATER OF THE EDWARDS-TRINITY AQUIFER SYSTEM, WEST-CENTRAL TEXAS: USGS WATER-RESOURCES INVESTIGATIONS REPORT 93-4126, 1994.

CHARACTERISTICS OF STREAMS AND AQUIFERS AND PROCESSES AFFECTING THE SALINITY OF WATER IN THE UPPER COLORADO RIVER BASIN, TEXAS: USGS WATER-RESOURCES INVESTIGATIONS REPORT 94-4036, 1994. 
GEOLOGIC HISTORY AND HYDROGEOLOGIC SETTING OF THE EDWARDS-TRINITY AQUIFER SYSTEM, WEST-CENTRAL TEXAS: USGS WATER-RESOURCES INVESTIGATIONS REPORT 94-4039, 1994.

AQUIFERS OF TEXAS: TEXAS WATER DEVELOPMENT BOARD REPORT 345, 1995

WATER QUALITY IN THE EDWARDS-TRINITY (PLATEAU) AQUIFER, EDWARDS PLATEAU AND TRANS-PECOS, TEXAS: TEXAS WATER DEVELOPMENT BOARD HYDROLOGIC ATLAS NO. 3, 1995.

HYDROGEOLOGIC FRAMEWORK OF THE EDWARDS-TRINITY AQUIFER SYSTEM, WEST-CENTRAL TEXAS: USGS PROFESSIONAL PAPER 1421-B, 1996.

AN OVERVIEW OF THE EDWARDS-TRINITY AQUIFER SYSTEM, CENTRAL-WEST TEXAS, CHAPTER 8, in AQUIFERS OF WEST TEXAS: TEXAS WATER DEVELOPMENT BOARD REPORT 356, 2001

\section{TRAVIS COUNTY}

REPORT OF PROGRESS OF THE DIVISION OF HYDROGRAPHY FOR 1895: USGS BULLETIN 140, 1896.

GEOLOGY OF THE EDWARDS PLATEAU AND RIO GRANDE PLAIN ADJACENT TO AUSTIN AND SAN ANTONIO, TEXAS, WITH REFERENCE TO THE OCCURRENCE OF UNDERGROUND WATERS: USGS 18TH ANNUAL REPORT, PART 2, 1898.

GEOGRAPHY AND GEOLOGY OF THE BLACK AND GRAND PRAIRIES, TEXAS, WITH DETAILED DESCRIPTIONS OF THE CRETACEOUS FORMATIONS AND SPECIAL REFERENCE TO ARTESIAN WATERS: USGS 21ST ANNUAL REPORT, PART 7, 1901.

REPORT OF PROGRESS OF STREAM MEASUREMENTS FOR THE CALENDAR YEAR 1904: USGS WATER-SUPPLY AND IRRIGATION PAPER 132, 1905

MEMORANDUM ON EXPLORATIONS OF WELL OWNED BY B.R. PAYTON, TRAVIS COUNTY, TEXAS: USGS OPEN-FILE REPORT (UNNUMBERED), 1940.

RECORDS OF WELLS AND SPRINGS, DRILLERS' LOGS, WATER ANALYSES, AND MAP SHOWING LOCATIONS OF WELLS AND SPRINGS IN TRAVIS COUNTY, TEXAS: TEXAS BOARD OF WATER ENGINEERS MISCELLANEOUS PUBLICATION 282, 1941.

WATER RESOURCES OF AUSTIN, TEXAS: USGS OPEN-FILE REPORT, 1941.

GROUND-WATER SUPPLIES FOR INTERNATIONAL MINERALS AND CHEMICAL COMPANY (MAGNESIUM PLANT): USGS OPEN-FILE REPORT, 1942.

MEMORANDUM ON THE CHEMICAL CHARACTER OF WATERS IN THE VICINITY OF THE MAGNESIUM PLANT NEAR AUSTIN, TEXAS: USGS OPEN-FILE REPORT (UNNUMBERED), 1943.

MAGNESIUM PLANT WASTE WATER: USGS OPEN-FILE REPORT (UNNUMBERED), 1943.

MAGNESIUM PLANT, OFFICE MEMORANDUM: USGS OPEN-FILE REPORT (UNNUMBERED), 1943.

PUBLIC WATER SUPPLIES IN CENTRAL AND NORTH-CENTRAL TEXAS: TEXAS BOARD OF WATER ENGINEERS MISCELLANEOUS PUBLICATION 213, 1947.
CONTAMINATION AND RECOVERY IN QUALITY OF GROUND WATER NEAR AUSTIN, TEXAS: USGS OPEN-FILE REPORT (UNNUMBERED), 1948?

MEMORANDUM ON THE RESULTS OF AN INSOLUBLE RESIDUE TEST RUN ON SAMPLE CUTTINGS FROM WELL DRILLED ON THE PROPERTY OF EGBERT SMITH: USGS OPEN-FILE REPORT (UNNUMBERED), 1948.

AREAL GEOLOGY OF THE JOLLYVILLE PLATEAU AND THE REGIONAL GROUND WATER: UNIVERSITY OF TEXAS AT AUSTIN MASTERS THESIS, 1948.

MEMORANDUM ON THE GROUND-WATER RESOURCES AT THE STATE HOG AND DAIRY FARM: USGS OPEN-FILE REPORT (UNNUMBERED), 1948.

MEMORANDUM ON PHILLIPS WELL NEAR OAK HILL: USGS OPENFILE REPORT (UNNUMBERED), 1949.

NOTES ON FEDERAL WATER WELL AT FISH AND WILD LIFE STATION, AUSTIN: USGS OPEN-FILE REPORT (UNNUMBERED), 1949.

PUBLIC WATER SUPPLIES IN CENTRAL AND NORTH-CENTRAL TEXAS: USGS WATER-SUPPLY PAPER 1069, 1949.

MEMORANDUM REGARDING AVAILABILITY OF GROUND WATER IN AN AREA ADJACENT TO THE COLORADO RIVER SOUTHEAST OF AUSTIN, TEXAS: USGS OPEN-FILE REPORT (UNNUMBERED), 1950.

POSSIBILITIES FOR OBTAINING A SUPPLY OF GROUND WATER ON THE ROOT TRACT IN BLUFFINGTON NEAR AUSTIN: USGS OPENFILE REPORT (UNNUMBERED), 1951.

MEMORANDUM ON THE SHORT TEST ON WELL 886, TRAVIS COUNTY, EDWARDS LIMESTONE WELL: USGS OPEN-FILE REPORT (UNNUMBERED), 1952.

RECORDS OF WATER-LEVEL MEASUREMENTS IN HAYS, TRAVIS, AND WILLIAMSON COUNTIES, TEXAS, 1937 TO MAY 1956: TEXAS BOARD OF WATER ENGINEERS BULLETIN 5612, 1956.

RECORDS OF WELLS IN TRAVIS COUNTY, TEXAS: TEXAS BOARD OF WATER ENGINEERS BULLETIN 5708, 1957.

RECHARGE TO THE EDWARDS RESERVOIR BETWEEN KYLE AND AUSTIN: WILLIAM F. GUYTON AND ASSOCIATES, AUSTIN, TEXAS, 1958

RECONNAISSANCE INVESTIGATION OF THE GROUND-WATER RESOURCES OF THE COLORADO RIVER BASIN, TEXAS: TEXAS WATER DEVELOPMENT BOARD REPORT 51, 1967.

COMPILATION OF RESULTS OF AQUIFER TESTS IN TEXAS: TEXAS WATER DEVELOPMENT BOARD REPORT 98, 1969.

HYDROGEOLOGY, GEOCHEMISTRY, AND PUBLIC HEALTH ASPECTS OF ENVIRONMENTAL IMPAIRMENT AT AN ABANDONED LANDFILL NEAR AUSTIN, TEXAS: UNIVERSITY OF TEXAS AT AUSTIN, MASTER'S THESIS, 1972.

QUANTITY OF LOW FLOW IN BARTON CREEK, TEXAS, JULY 6-8 AND OCTOBER 1-3, 1970: USGS OPEN-FILE REPORT (UNNUMBERED), 1974.

MAJOR AND HISTORICAL SPRINGS OF TEXAS: TEXAS WATER DEVELOPMENT BOARD REPORT 189, 1975.

GROUND-WATER RESOURCES OF PART OF CENTRAL TEXAS WITH EMPHASIS ON THE ANTLERS AND TRAVIS PEAK FORMATIONS: TEXAS WATER DEVELOPMENT BOARD REPORT 195, V. 1, 1975. 
GROUND-WATER RESOURCES OF PART OF CENTRAL TEXAS WITH EMPHASIS ON THE ANTLERS AND TRAVIS PEAK FORMATIONS: TEXAS WATER DEVELOPMENT BOARD REPORT 195, V. 2, 1976.

SUMMARY APPRAISALS OF THE NATION'S GROUND-WATER RESOURCES-TEXAS-GULF REGION: USGS PROFESSIONAL PAPER 813-F, 1976.

REGIONAL DISTRIBUTION OF FRACTURES IN THE SOUTHERN EDWARDS PLATEAU AND THEIR RELATIONSHIP TO TECTONICS AND CAVES: UNIVERSITY OF TEXAS, BUREAU OF ECONOMIC GEOLOGY GEOLOGICAL CIRCULAR 78-2, 1978.

HYDROLOGIC DATA FOR URBAN STUDIES IN THE AUSTIN, TEXAS METROPOLITAN AREA, 1978: USGS OPEN-FILE REPORT 80-728, 1980.

HYDROLOGIC DATA FOR URBAN STUDIES IN THE AUSTIN, TEXAS METROPOLITAN AREA, 1979: USGS OPEN-FILE REPORT 81-628, 1981.

SPRINGS OF TEXAS, VOLUME 1: (BY GUNNAR BRUNE), BRANCHSMITH, INC., FORT WORTH, TEXAS, 1981.

OCCURRENCE, AVAILABILITY, AND QUALITY OF GROUND WATER IN TRAVIS COUNTY, TEXAS: TEXAS DEPARTMENT OF WATER RESOURCES REPORT 276, 1983.

HYDROLOGIC DATA FOR URBAN STUDIES IN THE AUSTIN, TEXAS, METROPOLITAN AREA, 1981: USGS OPEN-FILE REPORT 83-44, 1983.

HYDROLOGIC DATA FOR URBAN STUDIES IN THE AUSTIN, TEXAS, METROPOLITAN AREA, 1982: USGS OPEN-FILE REPORT 84-061, 1984.

EFFECTS OF STORM-WATER RUNOFF ON WATER QUALITY OF THE EDWARDS AQUIFER NEAR AUSTIN, TEXAS: USGS WATERRESOURCES INVESTIGATIONS REPORT 84-4124, 1984.

HYDROGEOLOGY OF THE EDWARDS AQUIFER, AUSTIN AREA, CENTRAL TEXAS: UNIVERSITY OF TEXAS, BUREAU OF ECONOMIC GEOLOGY REPORT OF INVESTIGATIONS NO. 141, 1984

HYDROGEOLOGY OF THE EDWARDS AQUIFER-BARTON SPRINGS SEGMENT, TRAVIS AND HAYS COUNTIES, TEXAS: AUSTIN GEOLOGICAL SOCIETY GUIDEBOOK 6, 1984.

EDWARDS AQUIFER-NORTHERN SEGMENT, TRAVIS, WILLIAMSON, AND BELL COUNTIES, TEXAS: AUSTIN GEOLOGICAL SOCIETY GUIDEBOOK 8, 1985.

HYDROLOGIC DATA FOR URBAN STUDIES IN THE AUSTIN, TEXAS, METROPOLITAN AREA, 1983: USGS OPEN-FILE REPORT 85-172, 1985.

TEXAS GROUND-WATER RESOURCES, in NATIONAL WATER SUMMARY 1984: USGS WATER-SUPPLY PAPER 2275, 1985.

SIMULATION OF THE FLOW SYSTEM OF BARTON SPRINGS AND ASSOCIATED EDWARDS AQUIFER IN THE AUSTIN AREA, TEXAS: USGS WATER-RESOURCES INVESTIGATIONS REPORT 85-4299, 1985.

WATER USE, PROJECTED WATER REQUIREMENTS, AND RELATED DATA AND INFORMATION FOR THE METROPOLITAN STATISTICAL AREAS IN TEXAS: TEXAS DEPARTMENT OF WATER RESOURCES LIMITED PRINTING REPORT LP-201, 1985.

GEOHYDROLOGY OF THE EDWARDS AQUIFER IN THE AUSTIN AREA, TEXAS: TEXAS WATER DEVELOPMENT BOARD REPORT 293, 1986.
HYDROLOGY AND WATER QUALITY OF THE EDWARDS AQUIFER ASSOCIATED WITH BARTON SPRINGS IN THE AUSTIN AREA, TEXAS: USGS WATER-RESOURCES INVESTIGATIONS REPORT 86-4036, 1986.

RECHARGE ZONE OF THE EDWARDS AQUIFER HYDROLOGICALLY ASSOCIATED WITH BARTON SPRINGS IN THE AUSTIN AREA, TEXAS: USGS WATER-RESOURCES INVESTIGATIONS REPORT 86-4062, 1986.

HYDROLOGIC DATA FOR URBAN STUDIES IN THE AUSTIN METROPOLITAN AREA, TEXAS, 1985: USGS OPEN-FILE REPORT 87-224, 1987.

HYDROGEOLOGY OF THE EDWARDS AQUIFER, NORTHERN BALCONES AND WASHITA PRAIRIE SEGMENTS: AUSTIN GEOLOGICAL SOCIETY GUIDEBOOK 11, 1987.

HYDROLOGIC DATA FOR URBAN STUDIES IN THE AUSTIN METROPOLITAN AREA, TEXAS, 1986: USGS OPEN-FILE REPORT 87-768, 1988.

GEOHYDROLOGIC FRAMEWORK OF THE GULF COASTAL PLAIN: USGS HYDROLOGIC INVESTIGATIONS ATLAS HA-695, 1988.

FLOW PATTERN IN REGIONAL AQUIFERS AND FLOW RELATIONS BETWEEN THE LOWER COLORADO RIVER VALLEY AND REGIONAL AQUIFERS IN SIX COUNTIES OF SOUTHEASTERN TEXAS: USGS WATER-RESOURCES INVESTIGATIONS REPORT 88-4154, 1989.

POTENTIOMETRIC SURFACE OF THE EDWARDS-TRINITY AQUIFER SYSTEM AND CONTIGUOUS HYDRAULICALLY CONNECTED UNITS, WEST-CENTRAL TEXAS, WINTER 1974-75: USGS WATERRESOURCES INVESTIGATIONS REPORT 89-4208, 1990.

HYDROGEOLOGY OF THE NORTHERN SEGMENT OF THE EDWARDS AQUIFER, AUSTIN REGION: UNIVERSITY OF TEXAS, BUREAU OF ECONOMIC GEOLOGY REPORT OF INVESTIGATIONS NO. 192, 1990.

TEST WELL DRILLING INVESTIGATION TO DELINEATE THE DOWNDIP LIMITS OF USABLE-QUALITY GROUND WATER IN THE EDWARDS AQUIFER IN THE AUSTIN REGION, TEXAS: TEXAS WATER DEVELOPMENT BOARD REPORT 325, 1990.

WITHDRAWALS FROM THE EDWARDS-TRINITY AQUIFER SYSTEM AND CONTIGUOUS HYDRAULICALLY CONNECTED UNITS, WEST-CENTRAL TEXAS, DECEMBER 1974 THROUGH MARCH 1977: USGS WATER-RESOURCES INVESTIGATIONS REPORT 91-4021, 1991.

EVALUATION OF WATER RESOURCES IN BELL, BURNET, TRAVIS, WILLIAMSON, AND PARTS OF ADJACENT COUNTIES, TEXAS: TEXAS WATER DEVELOPMENT BOARD REPORT 326, 1991.

MODELING INFILTRATION, SUBSURFACE MOISTURE, AND BASE FLOW IN BARTON CREEK, AUSTIN, TEXAS: TEXAS STATE SECTION OF THE AMERICAN WATER RESOURCES ASSOCIATION, TRIGG TWICHELL SYMPOSIUM, FALL MEETING, NOVEMBER 8, 1991, AUSTIN, TEXAS, 1991

THE INTERACTION OF FLOW MECHANICS AND AQUEOUS CHEMISTRY IN A TEXAS HILL COUNTRY GROTTO: TEXAS STATE SECTION OF THE AMERICAN WATER RESOURCES ASSOCIATION, TRIGG TWICHELL SYMPOSIUM, FALL MEETING, NOVEMBER 8, 1991, AUSTIN, TEXAS, 1991.

WATER-QUALITY ISSUES FOR BARTON CREEK AND BARTON SPRINGS: AUSTIN GEOLOGICAL SOCIETY, FALL 1991 FIELD TRIP, DECEMBER 7, 1991, 1992. 
CONFIGURATION OF THE BASE OF THE EDWARDS-TRINITY AQUIFER SYSTEM AND HYDROGEOLOGY OF THE UNDERLYING PRECRETACEOUS ROCKS, WEST-CENTRAL TEXAS: USGS WATERRESOURCES INVESTIGATIONS REPORT 91-4071, 1992.

EVALUATION OF THE GROUND-WATER RESOURCES OF THE PALEOZOIC AND CRETACEOUS AQUIFERS ON THE HILL COUNTRY OF CENTRAL TEXAS: TEXAS WATER DEVELOPMENT BOARD REPORT 339, 1992.

WATER-RESOURCES DATA, TEXAS, WATER YEAR 1991, VOLUME 4, GROUND-WATER DATA: USGS WATER-DATA REPORT TX-91-4, 1992.

HISTORICAL POTENTIOMETRIC SURFACE OF THE EDWARDS-TRINITY AQUIFER SYSTEM AND CONTIGUOUS HYDRAULICALLY CONNECTED UNITS, WEST-CENTRAL TEXAS: USGS WATERRESOURCES INVESTIGATIONS REPORT 92-4055, 1993.

HISTORICAL SATURATED THICKNESS OF THE EDWARDS-TRINITY AQUIFER SYSTEM AND SELECTED CONTIGUOUS HYDRAULICALLY CONNECTED UNITS, WEST-CENTRAL TEXAS: USGS WATER-RESOURCES INVESTIGATIONS REPORT 92-4125, 1993.

WATER-RESOURCES DATA, TEXAS, WATER YEAR 1992, VOLUME 4, GROUND-WATER DATA: USGS WATER-DATA REPORT TX-92-4, 1993.

SIMULATIONS OF FLOW IN THE EDWARDS-TRINITY AQUIFER SYSTEM AND CONTIGUOUS HYDRAULICALLY CONNECTED UNITS, WEST-CENTRAL TEXAS: USGS WATER-RESOURCES INVESTIGATIONS REPORT 93-4039, 1994.

DISSOLVED-SOLIDS CONCENTRATIONS AND HYDROCHEMICAL FACIES IN WATER OF THE EDWARDS-TRINITY AQUIFER SYSTEM, WEST-CENTRAL TEXAS: USGS WATER-RESOURCES INVESTIGATIONS REPORT 93-4126, 1994.

GEOLOGIC HISTORY AND HYDROGEOLOGIC SETTING OF THE EDWARDS-TRINITY AQUIFER SYSTEM, WEST-CENTRAL TEXAS: USGS WATER-RESOURCES INVESTIGATIONS REPORT 94-4039, 1994.

1994 REVIEW AND UPDATE OF THE POSITION OF THE EDWARDS AQUIFER FRESHWATER/SALINE-WATER INTERFACE FROM UVALDE TO KYLE, TEXAS: EDWARDS UNDERGROUND WATER DISTRICT REPORT 94-05, 1994.

WATER-RESOURCES DATA, TEXAS, WATER YEAR 1993, VOLUME 4, GROUND-WATER DATA: USGS WATER-DATA REPORT TX-93-4, 1994.

AQUIFERS OF TEXAS: TEXAS WATER DEVELOPMENT BOARD REPORT 345, 1995.

WATER-RESOURCES DATA, TEXAS, WATER YEAR 1994, VOLUME 4, GROUND-WATER DATA: USGS WATER-DATA REPORT TX-94-4, 1995.

GEOLOGIC FRAMEWORK AND HYDROGEOLOGIC CHARACTERISTICS OF THE EDWARDS AQUIFER OUTCROP (BARTON SPRINGS SEGMENT), NORTHEASTERN HAYS AND SOUTHWESTERN TRAVIS COUNTY, TEXAS: USGS WATER-RESOURCES INVESTIGATIONS REPORT 96-4306, 1996.

WATER-RESOURCES DATA, TEXAS, WATER YEAR 1995, VOLUME 4, GROUND-WATER DATA: USGS WATER-DATA REPORT TX-95-4, 1996.

HYDROGEOLOGIC FRAMEWORK AND GEOCHEMISTRY OF THE EDWARDS AQUIFER SALINE-WATER ZONE, SOUTH-CENTRAL
TEXAS: USGS WATER-RESOURCES INVESTIGATIONS REPORT 97-4133, 1997.

WATER-RESOURCES DATA, TEXAS, WATER YEAR 1996, VOLUME 4 GROUND-WATER DATA: USGS WATER-DATA REPORT TX-96-4, 1997.

PRELIMINARY REPORT FOR GROUND-WATER TRACING STUDIES WITHIN THE BARTON CREEK AND WILLIAMSON CREEK WATERSHEDS, BARTON SPRINGS/EDWARDS AQUIFER: BARTON SPRINGS/EDWARDS AQUIFER CONSERVATION DISTRICT AND CITY OF AUSTIN WATERSHED PROTECTION DEPARTMENT WORKING DRAFT DOCUMENT, 1998.

WATER-RESOURCES DATA, TEXAS, WATER YEAR 1997, VOLUME 4 GROUND-WATER DATA: USGS WATER-DATA REPORT TX-97-4, 1998.

CHANGES IN GROUNDWATER CONDITIONS IN THE EDWARDS AND TRINITY AQUIFERS, 1987-1997, FOR PORTIONS OF BASTROP, BELL, BURNET, LEE, MILAM, TRAVIS, AND WILLIAMSON COUNTIES, TEXAS: TEXAS WATER DEVELOPMENT BOARD REPORT 350,1999

WATER-RESOURCES DATA, TEXAS, WATER YEAR 1998, VOLUME 4, GROUND-WATER DATA: USGS WATER-DATA REPORT TX-98-4, 1999.

GROUNDWATER AVAILABILITY OF THE TRINITY AQUIFER, HILL COUNTRY AREA, TEXAS: NUMERICAL SIMULATIONS THROUGH 2050: TEXAS WATER DEVELOPMENT BOARD REPORT 353, 2000.

WATER-RESOURCES DATA, TEXAS, WATER YEAR 1999, VOLUME 6 , GROUND-WATER DATA: USGS WATER-DATA REPORT TX-99-6, 2000.

WATER-RESOURCES DATA, TEXAS, WATER YEAR 2000, VOLUME 6 , GROUND-WATER DATA: USGS WATER-DATA REPORT TX-00-6, 2001.

\section{TRINITY COUNTY}

UNDERGROUND WATERS OF THE COASTAL PLAIN OF TEXAS: USGS WATER-SUPPLY PAPER 190, 1907.

GEOLOGY AND UNDERGROUND WATERS OF THE SOUTHEASTERN PART OF THE TEXAS COASTAL PLAIN: USGS WATER-SUPPLY PAPER 335, 1914

PUBLIC WATER SUPPLIES IN EASTERN TEXAS, V. 2, HARRISON COUNTY THROUGH WOOD COUNTY: TEXAS BOARD OF WATER ENGINEERS MISCELLANEOUS PUBLICATION 214, V. 2, 1945.

PUBLIC WATER SUPPLIES IN EASTERN TEXAS: USGS WATERSUPPLY PAPER 1047, 1948.

RECONNAISSANCE INVESTIGATION OF THE GROUND-WATER RESOURCES OF THE NECHES RIVER BASIN, TEXAS: TEXAS WATER COMMISSION BULLETIN 6308, 1963.

RECONNAISSANCE INVESTIGATION OF THE GROUND-WATER RESOURCES OF THE TRINITY RIVER BASIN, TEXAS: TEXAS WATER COMMISSION BULLETIN 6309, 1963.

HYDROLOGIC SIGNIFICANCE OF THE LITHOFACIES OF THE SPARTA SAND IN ARKANSAS, LOUISIANA, MISSISSIPPI, AND TEXAS: USGS PROFESSIONAL PAPER 569-A, 1968. 
GEOHYDROLOGIC SIGNIFICANCE OF LITHOFACIES OF THE COCKFIELD FORMATION OF LOUISIANA AND MISSISSIPPI AND OF THE YEGUA FORMATION OF TEXAS: USGS PROFESSIONAL PAPER 569-B, 1970.

HYDROLOGIC SIGNIFICANCE OF LITHOFACIES OF THE CANE RIVER FORMATION OR EQUIVALENTS OF ARKANSAS, LOUISIANA, MISSISSIPPI, AND TEXAS: USGS PROFESSIONAL PAPER 569-C, 1972.

HYDROLOGIC SIGNIFICANCE OF LITHOFACIES OF THE CARRIZO SAND OF ARKANSAS, LOUISIANA, AND TEXAS AND THE MERIDIAN SAND OF MISSISSIPPI: USGS PROFESSIONAL PAPER 569-D, 1975.

SUMMARY APPRAISALS OF THE NATION'S GROUND-WATER RESOURCES-TEXAS-GULF REGION: USGS PROFESSIONAL PAPER 813-F, 1976.

STRATIGRAPHIC AND HYDROGEOLOGIC FRAMEWORK OF PART OF THE COASTAL PLAIN OF TEXAS: USGS OPEN-FILE REPORT 77-712, 1978.

STRATIGRAPHIC AND HYDROGEOLOGIC FRAMEWORK OF PART OF THE COASTAL PLAIN OF TEXAS: TEXAS DEPARTMENT OF WATER RESOURCES REPORT 236, 1979.

TEXAS GROUND-WATER RESOURCES, in NATIONAL WATER SUMMARY 1984: USGS WATER-SUPPLY PAPER 2275, 1985.

HYDROLOGY OF THE JASPER AQUIFER IN THE SOUTHEAST TEXAS COASTAL PLAIN: TEXAS WATER DEVELOPMENT BOARD REPORT 295, 1986.

APPROXIMATE POTENTIOMETRIC SURFACES FOR THE AQUIFERS OF THE TEXAS COASTAL UPLANDS SYSTEM, 1980: USGS HYDROLOGIC INVESTIGATIONS ATLAS HA-704, 1987.

GEOHYDROLOGIC FRAMEWORK OF THE GULF COASTAL PLAIN: USGS HYDROLOGIC INVESTIGATIONS ATLAS HA-695, 1988.

HYDROGEOLOGY AND PREDEVELOPMENT FLOW IN THE TEXAS GULF COAST AQUIFER SYSTEMS: USGS WATER-RESOURCES INVESTIGATIONS REPORT 87-4248, 1988.

GEOHYDROLOGIC FRAMEWORK OF THE GULF COASTAL PLAIN: USGS HYDROLOGIC INVESTIGATIONS ATLAS HA-695, 1988.

GROUND-WATER FLOW IN THE GULF COAST AQUIFER SYSTEMS, SOUTH-CENTRAL UNITED STATES-A PRELIMINARY ANALYSIS: USGS WATER-RESOURCES INVESTIGATIONS REPORT 89-4071, 1990.

NATIONAL WATER-QUALITY ASSESSMENT PROGRAM-THE TRINITY RIVER BASIN: USGS OPEN-FILE REPORT 91-158, 1991.

HYDROLOGY OF THE TEXAS GULF COAST AQUIFER SYSTEMS: USGS OPEN-FILE REPORT 91-64, 1991.

PROPERTIES AND CHEMICAL CONSTITUENTS IN GROUND WATER FROM THE UPPER CLAIBORNE AQUIFER, GULF COAST REGIONAL AQUIFER SYSTEMS, SOUTH-CENTRAL UNITED STATES: USGS WATER-RESOURCES INVESTIGATIONS REPORT 91-4150, 1993.

PROPERTIES AND CHEMICAL CONSTITUENTS IN GROUND WATER FROM PERMEABLE ZONE E (LOWER MIOCENE-UPPER OLIGOCENE DEPOSITS), COASTAL LOWLANDS AQUIFER SYSTEM, SOUTH-CENTRAL UNITED STATES: USGS WATER-RESOURCES INVESTIGATIONS REPORT 92-4103, 1993.
PROPERTIES AND CHEMICAL CONSTITUENTS IN GROUND WATER FROM THE MIDDLE CLAIBORNE AQUIFER, GULF COAST REGIONAL AQUIFER SYSTEMS, SOUTH-CENTRAL UNITED STATES: USGS WATER-RESOURCES INVESTIGATIONS REPORT 92-4104, 1993.

PROPERTIES AND CHEMICAL CONSTITUENTS IN GROUND WATER FROM THE MIDDLE WILCOX AQUIFER, GULF COAST AQUIFER SYSTEMS, SOUTH-CENTRAL UNITED STATES: USGS WATERRESOURCES INVESTIGATIONS REPORT 93-4070, 1993.

NATIONAL WATER-QUALITY ASSESSMENT PROGRAM-PESTICIDES IN THE TRINITY RIVER BASIN STUDY UNIT, TEXAS, 1968-91: USGS FACT SHEET FS-088-95, 1995.

WATER-QUALITY ASSESSMENT OF THE TRINITY RIVER BASIN, TEXAS-DATA COLLECTION, 1992-95: USGS FACT SHEET FS-095-95, 1995.

WATER-QUALITY ASSESSMENT OF THE TRINITY RIVER BASIN, TEXAS-PESTICIDES IN A SUBURBAN WATERSHED, ARLINGTON, 1993-94: USGS FACT SHEET FS-159-95, 1995.

AQUIFERS OF TEXAS: TEXAS WATER DEVELOPMENT BOARD REPORT 345, 1995.

STRATIGRAPHIC NOMENCLATURE AND GEOLOGIC SECTIONS OF THE GULF COASTAL PLAIN OF TEXAS: USGS OPEN-FILE REPORT 94-461, 1995.

WATER QUALITY IN THE SPARTA AQUIFER, EAST TEXAS: TEXAS WATER DEVELOPMENT BOARD HYDROLOGIC ATLAS NO. 5, 1996.

WATER QUALITY IN THE QUEEN CITY AQUIFER, EAST TEXAS: TEXAS WATER DEVELOPMENT BOARD HYDROLOGIC ATLAS NO. 6, 1996.

\section{TYLER COUNTY}

UNDERGROUND WATERS OF THE COASTAL PLAIN OF TEXAS: USGS WATER-SUPPLY PAPER 190, 1907.

GEOLOGY AND UNDERGROUND WATERS OF THE SOUTHEASTERN PART OF THE TEXAS COASTAL PLAIN: USGS WATER-SUPPLY PAPER 335, 1914.

PUBLIC WATER SUPPLIES IN EASTERN TEXAS, V. 2, HARRISON COUNTY THROUGH WOOD COUNTY: TEXAS BOARD OF WATER ENGINEERS MISCELLANEOUS PUBLICATION 214, V. 2, 1945.

PUBLIC WATER SUPPLIES IN EASTERN TEXAS: USGS WATERSUPPLY PAPER 1047, 1948.

AVAILABILITY OF GROUND WATER IN THE GULF COAST REGION OF TEXAS: USGS OPEN-FILE REPORT (UNNUMBERED), 1956.

RECONNAISSANCE INVESTIGATION OF THE GROUND-WATER RESOURCES OF THE NECHES RIVER BASIN, TEXAS: TEXAS WATER COMMISSION BULLETIN 6308, 1963.

GROUND-WATER RESOURCES OF TYLER COUNTY, TEXAS: TEXAS WATER DEVELOPMENT BOARD REPORT 74, 1968.

HYDROLOGIC SIGNIFICANCE OF THE LITHOFACIES OF THE SPARTA SAND IN ARKANSAS, LOUISIANA, MISSISSIPPI, AND TEXAS: USGS PROFESSIONAL PAPER 569-A, 1968. 
COMPILATION OF RESULTS OF AQUIFER TESTS IN TEXAS: TEXAS WATER DEVELOPMENT BOARD REPORT 98, 1969.

GEOHYDROLOGIC SIGNIFICANCE OF LITHOFACIES OF THE COCKFIELD FORMATION OF LOUISIANA AND MISSISSIPPI AND OF THE YEGUA FORMATION OF TEXAS: USGS PROFESSIONAL PAPER 569-B, 1970.

HYDROLOGIC SIGNIFICANCE OF LITHOFACIES OF THE CANE RIVER FORMATION OR EQUIVALENTS OF ARKANSAS, LOUISIANA, MISSISSIPPI, AND TEXAS: USGS PROFESSIONAL PAPER 569-C, 1972.

HYDROLOGIC SIGNIFICANCE OF LITHOFACIES OF THE CARRIZO SAND OF ARKANSAS, LOUISIANA, AND TEXAS AND THE MERIDIAN SAND OF MISSISSIPPI: USGS PROFESSIONAL PAPER 569-D, 1975.

SUMMARY APPRAISALS OF THE NATION'S GROUND-WATER RESOURCES-TEXAS-GULF REGION: USGS PROFESSIONAL PAPER 813-F, 1976.

STRATIGRAPHIC AND HYDROGEOLOGIC FRAMEWORK OF PART OF THE COASTAL PLAIN OF TEXAS: USGS OPEN-FILE REPORT 77-712, 1978.

STRATIGRAPHIC AND HYDROGEOLOGIC FRAMEWORK OF PART OF THE COASTAL PLAIN OF TEXAS: TEXAS DEPARTMENT OF WATER RESOURCES REPORT 236, 1979.

SPRINGS OF TEXAS, VOLUME 1: (BY GUNNAR BRUNE), BRANCHSMITH, INC., FORT WORTH, TEXAS, 1981.

TEXAS GROUND-WATER RESOURCES, in NATIONAL WATER SUMMARY 1984: USGS WATER-SUPPLY PAPER 2275, 1985.

HYDROLOGY OF THE JASPER AQUIFER IN THE SOUTHEAST TEXAS COASTAL PLAIN: TEXAS WATER DEVELOPMENT BOARD REPORT 295, 1986.

HYDROGEOLOGY AND PREDEVELOPMENT FLOW IN THE TEXAS GULF COAST AQUIFER SYSTEMS: USGS WATER-RESOURCES INVESTIGATIONS REPORT 87-4248, 1988.

GEOHYDROLOGIC FRAMEWORK OF THE GULF COASTAL PLAIN: USGS HYDROLOGIC INVESTIGATIONS ATLAS HA-695, 1988.

GROUND-WATER FLOW IN THE GULF COAST AQUIFER SYSTEMS, SOUTH-CENTRAL UNITED STATES-A PRELIMINARY ANALYSIS: USGS WATER-RESOURCES INVESTIGATIONS REPORT 89-4071, 1990.

HYDROLOGY OF THE TEXAS GULF COAST AQUIFER SYSTEMS: USGS OPEN-FILE REPORT 91-64, 1991.

PROPERTIES AND CHEMICAL CONSTITUENTS IN GROUND WATER FROM THE UPPER CLAIBORNE AQUIFER, GULF COAST REGIONAL AQUIFER SYSTEMS, SOUTH-CENTRAL UNITED STATES: USGS WATER-RESOURCES INVESTIGATIONS REPORT 91-4150, 1993.

PROPERTIES AND CHEMICAL CONSTITUENTS IN GROUND WATER FROM PERMEABLE ZONE C (LOWER PLIOCENE-UPPER MIOCENE DEPOSITS), COASTAL LOWLANDS AQUIFER SYSTEM, SOUTHCENTRAL UNITED STATES: USGS WATER-RESOURCES INVESTIGATIONS REPORT 91-4151, 1993.

PROPERTIES AND CHEMICAL CONSTITUENTS IN GROUND WATER FROM PERMEABLE ZONE B (LOWER PLEISTOCENE-UPPER PLIOCENE DEPOSITS), COASTAL LOWLANDS AQUIFER SYSTEM, SOUTH-CENTRAL UNITED STATES: USGS WATER-RESOURCES INVESTIGATIONS REPORT 91-4152, 1993.
PROPERTIES AND CHEMICAL CONSTITUENTS IN GROUND WATER FROM PERMEABLE ZONE E (LOWER MIOCENE-UPPER OLIGOCENE DEPOSITS), COASTAL LOWLANDS AQUIFER SYSTEM, SOUTH-CENTRAL UNITED STATES: USGS WATER-RESOURCES INVESTIGATIONS REPORT 92-4103, 1993.

PROPERTIES AND CHEMICAL CONSTITUENTS IN GROUND WATER FROM THE MIDDLE CLAIBORNE AQUIFER, GULF COAST REGIONAL AQUIFER SYSTEMS, SOUTH-CENTRAL UNITED STATES: USGS WATER-RESOURCES INVESTIGATIONS REPORT 92-4104, 1993.

PROPERTIES AND CHEMICAL CONSTITUENTS IN GROUND WATER FROM PERMEABLE ZONE D (MIDDLE MIOCENE DEPOSITS), COASTAL LOWLANDS AQUIFER SYSTEM, SOUTH-CENTRAL UNITED STATES: USGS WATER-RESOURCES INVESTIGATIONS REPORT 92-4105, 1993.

PROPERTIES AND CHEMICAL CONSTITUENTS IN GROUND WATER FROM THE MIDDLE WILCOX AQUIFER, GULF COAST AQUIFER SYSTEMS, SOUTH-CENTRAL UNITED STATES: USGS WATERRESOURCES INVESTIGATIONS REPORT 93-4070, 1993.

AQUIFERS OF TEXAS: TEXAS WATER DEVELOPMENT BOARD REPORT 345, 1995.

\section{UPSHUR COUNTY}

UNDERGROUND WATERS OF THE COASTAL PLAIN OF TEXAS: USGS WATER-SUPPLY PAPER 335, 1907.

GEOLOGY AND UNDERGROUND WATERS OF THE SOUTHEASTERN PART OF THE TEXAS COASTAL PLAIN: USGS WATER-SUPPLY PAPER 335, 1914.

RECORDS OF WELLS, DRILLERS' LOGS, WATER ANALYSES, AND MAP SHOWING LOCATIONS OF WELLS IN UPSHUR COUNTY, TEXAS: TEXAS BOARD OF WATER ENGINEERS MISCELLANEOUS PUBLICATION 283, 1942.

GROUND WATER IN THE GLADEWATER-BIG SANDY DISTRICT, TEXAS: USGS OPEN-FILE REPORT (UNNUMBERED), 1942.

WATER RESOURCES OF UPSHUR COUNTY, TEXAS: USGS OPEN-FILE REPORT (UNNUMBERED), 1943.

PUBLIC WATER SUPPLIES IN EASTERN TEXAS, V. 2, HARRISON COUNTY THROUGH WOOD COUNTY: TEXAS BOARD OF WATER ENGINEERS MISCELLANEOUS PUBLICATION 214, V. 2, 1945.

PUBLIC WATER SUPPLIES IN EASTERN TEXAS: USGS WATERSUPPLY PAPER 1047, 1948.

RECONNAISSANCE INVESTIGATION OF THE GROUND-WATER RESOURCES OF THE RED RIVER, SULPHUR RIVER, AND CYPRESS CREEK BASINS, TEXAS: TEXAS WATER COMMISSION BULLETIN 6306, 1963.

RECONNAISSANCE INVESTIGATION OF THE GROUND-WATER RESOURCES OF THE SABINE RIVER BASIN, TEXAS: TEXAS WATER COMMISSION BULLETIN 6307, 1963.

BASE-FLOW STUDIES, LITTLE CYPRESS CREEK, UPSHUR, GREGG, AND HARRISON COUNTIES, TEXAS, QUANTITY AND QUALITY, JANUARY AND JUNE 1964: TEXAS WATER DEVELOPMENT BOARD REPORT 25, 1966.

COMPILATION OF RESULTS OF AQUIFER TESTS IN TEXAS: TEXAS WATER DEVELOPMENT BOARD REPORT 98, 1969. 
GROUND-WATER RESOURCES OF GREGG AND UPSHUR COUNTIES, TEXAS: TEXAS WATER DEVELOPMENT BOARD REPORT 101, 1969.

SALT-WATER DISPOSAL AND POTENTIAL FOR POLLUTION IN THE EAST TEXAS OIL FIELD: USGS OPEN-FILE REPORT (UNNUMBERED) (MEMORANDUM), 1971

SUMMARY APPRAISALS OF THE NATION'S GROUND-WATER RESOURCES-TEXAS-GULF REGION: USGS PROFESSIONAL PAPER 813-F, 1976.

WATER-QUALITY DATA FOR AQUIFERS, STREAMS, AND LAKES IN THE VICINITY OF KEECHI, MOUNT SYLVAN, OAKWOOD, AND PALESTINE SALT DOMES, NORTHEAST TEXAS SALT-DOME BASIN: USGS OPEN-FILE REPORT 80-2037, 1980

GEOHYDROLOGY OF THE KEECHI, MOUNT SYLVAN, OAKWOOD, AND PALESTINE SALT DOMES IN THE NORTHEAST TEXAS SALTDOME BASIN: USGS OPEN-FILE REPORT 80-2044, 1980.

GEOLOGY AND GEOHYDROLOGY OF THE EAST TEXAS BASIN-A REPORT ON THE PROGRESS OF NUCLEAR WASTE ISOLATION FEASIBILITY STUDIES (1979): UNIVERSITY OF TEXAS, BUREAU OF ECONOMIC GEOLOGY GEOLOGICAL CIRCULAR 80-12, 1980.

GEOLOGY AND GEOHYDROLOGY OF THE EAST TEXAS BASIN-A REPORT ON THE PROGRESS OF NUCLEAR WASTE ISOLATION FEASIBILITY STUDIES (1980): UNIVERSITY OF TEXAS, BUREAU OF ECONOMIC GEOLOGY GEOLOGICAL CIRCULAR 81-7, 1981.

SPRINGS OF TEXAS, VOLUME 1: (BY GUNNAR BRUNE), BRANCHSMITH, INC., FORT WORTH, TEXAS, 1981.

REGIONAL AQUIFER CHARACTERIZATION FOR DEEP-BASIN LIGNITE MINING, SABINE UPLIFT AREA, NORTHEAST TEXAS: UNIVERSITY OF TEXAS, BUREAU OF ECONOMIC GEOLOGY GEOLOGICAL CIRCULAR 83-3, 1983.

TEXAS GROUND-WATER RESOURCES, in NATIONAL WATER SUMMARY 1984: USGS WATER-SUPPLY PAPER 2275, 1985.

GEOHYDROLOGIC FRAMEWORK OF THE GULF COASTAL PLAIN: USGS HYDROLOGIC INVESTIGATIONS ATLAS HA-695, 1988

HYDROGEOLOGY AND PREDEVELOPMENT FLOW IN THE TEXAS GULF COAST AQUIFER SYSTEMS: USGS WATER-RESOURCES INVESTIGATIONS REPORT 87-4248, 1988.

GROUND-WATER FLOW IN THE GULF COAST AQUIFER SYSTEMS, SOUTH-CENTRAL UNITED STATES-A PRELIMINARY ANALYSIS: USGS WATER-RESOURCES INVESTIGATIONS REPORT 89-4071, 1990.

PROPERTIES AND CHEMICAL CONSTITUENTS IN GROUND WATER FROM THE LOWER CLAIBORNE-UPPER WILCOX AQUIFER, GULF COAST REGIONAL AQUIFER SYSTEMS, SOUTH-CENTRAL UNITED STATES: USGS WATER-RESOURCES INVESTIGATIONS REPORT 92-4102, 1993.

PROPERTIES AND CHEMICAL CONSTITUENTS IN GROUND WATER FROM THE MIDDLE CLAIBORNE AQUIFER, GULF COAST REGIONAL AQUIFER SYSTEMS, SOUTH-CENTRAL UNITED STATES: USGS WATER-RESOURCES INVESTIGATIONS REPORT 92-4104, 1993.

PROPERTIES AND CHEMICAL CONSTITUENTS IN GROUND WATER FROM THE MIDDLE WILCOX AQUIFER, GULF COAST AQUIFER SYSTEMS, SOUTH-CENTRAL UNITED STATES: USGS WATERRESOURCES INVESTIGATIONS REPORT 93-4070, 1993.
AQUIFERS OF TEXAS: TEXAS WATER DEVELOPMENT BOARD REPORT 345, 1995

WATER QUALITY IN THE QUEEN CITY AQUIFER, EAST TEXAS: TEXAS WATER DEVELOPMENT BOARD HYDROLOGIC ATLAS NO. 6, 1996.

\section{UPTON COUNTY}

PUBLIC WATER SUPPLIES IN WESTERN TEXAS: TEXAS BOARD OF WATER ENGINEERS MISCELLANEOUS PUBLICATION 216, 1949.

PUBLIC WATER SUPPLIES IN WESTERN TEXAS: USGS WATERSUPPLY PAPER 1106, 1951

SHALLOW FORMATIONS AND AQUIFERS OF THE WEST TEXAS AREA: WEST TEXAS GEOLOGICAL SOCIETY PUBLICATION 61-45 AND PERMIAN BASIN GEOPHYSICAL SOCIETY, MIDLAND, TEXAS, 1961.

RECONNAISSANCE INVESTIGATION OF THE GROUND-WATER RESOURCES OF THE RIO GRANDE BASIN, TEXAS: TEXAS WATER COMMISSION BULLETIN 6502, 1965.

RECONNAISSANCE INVESTIGATION OF THE GROUND-WATER RESOURCES OF THE COLORADO RIVER BASIN, TEXAS: TEXAS WATER DEVELOPMENT BOARD REPORT 51, 1967.

GROUND-WATER RESOURCES OF UPTON COUNTY, TEXAS: TEXAS WATER DEVELOPMENT BOARD REPORT 78, 1968

RECONNAISSANCE INVESTIGATION OF GROUND WATER IN THE RIO GRANDE DRAINAGE BASIN-WITH SPECIAL EMPHASIS ON SALINE GROUND-WATER RESOURCES: USGS HYDROLOGIC INVESTIGATIONS ATLAS HA-510, 1974.

SUMMARY APPRAISALS OF THE NATION'S GROUND-WATER RESOURCES-TEXAS-GULF REGION: USGS PROFESSIONAL PAPER 813-F, 1976.

OCCURRENCE, AVAILABILITY, AND CHEMICAL QUALITY OF GROUND WATER IN THE EDWARDS PLATEAU REGION OF TEXAS: TEXAS DEPARTMENT OF WATER RESOURCES REPORT 235,1979

SPRINGS OF TEXAS, VOLUME 1: (BY GUNNAR BRUNE), BRANCHSMITH, INC., FORT WORTH, TEXAS, 1981.

TEXAS GROUND-WATER RESOURCES, in NATIONAL WATER SUMMARY 1984: USGS WATER-SUPPLY PAPER 2275, 1985.

HYDROGEOLOGY AND PREDEVELOPMENT FLOW IN THE TEXAS GULF COAST AQUIFER SYSTEMS: USGS WATER-RESOURCES INVESTIGATIONS REPORT 87-4248, 1988.

GROUND-WATER FLOW IN THE GULF COAST AQUIFER SYSTEMS, SOUTH-CENTRAL UNITED STATES-A PRELIMINARY ANALYSIS: USGS WATER-RESOURCES INVESTIGATIONS REPORT 89-4071, 1990.

PUBLIC SUPPLY GROUND-WATER USE IN WESTERN TEXAS: TEXAS WATER DEVELOPMENT BOARD REPORT 311, 1989.

EVALUATION OF GROUND-WATER RESOURCES IN PARTS OF MIDLAND, REAGAN, AND UPTON COUNTIES, TEXAS: TEXAS WATER DEVELOPMENT BOARD REPORT 312, 1989.

POTENTIOMETRIC SURFACE OF THE EDWARDS-TRINITY AQUIFER SYSTEM AND CONTIGUOUS HYDRAULICALLY CONNECTED 
UNITS, WEST-CENTRAL TEXAS, WINTER 1974-75: USGS WATERRESOURCES INVESTIGATIONS REPORT 89-4208, 1990.

WITHDRAWALS FROM THE EDWARDS-TRINITY AQUIFER SYSTEM AND CONTIGUOUS HYDRAULICALLY CONNECTED UNITS, WEST-CENTRAL TEXAS, DECEMBER 1974 THROUGH MARCH 1977: USGS WATER-RESOURCES INVESTIGATIONS REPORT 91-4021, 1991.

CONFIGURATION OF THE BASE OF THE EDWARDS-TRINITY AQUIFER SYSTEM AND HYDROGEOLOGY OF THE UNDERLYING PRECRETACEOUS ROCKS, WEST-CENTRAL TEXAS: USGS WATERRESOURCES INVESTIGATIONS REPORT 91-4071, 1992.

HISTORICAL POTENTIOMETRIC SURFACE OF THE EDWARDS-TRINITY AQUIFER SYSTEM AND CONTIGUOUS HYDRAULICALLY CONNECTED UNITS, WEST-CENTRAL TEXAS: USGS WATERRESOURCES INVESTIGATIONS REPORT 92-4055, 1993.

HISTORICAL SATURATED THICKNESS OF THE EDWARDS-TRINITY AQUIFER SYSTEM AND SELECTED CONTIGUOUS HYDRAULICALLY CONNECTED UNITS, WEST-CENTRAL TEXAS: USGS WATER-RESOURCES INVESTIGATIONS REPORT 92-4125, 1993.

SIMULATIONS OF FLOW IN THE EDWARDS-TRINITY AQUIFER SYSTEM AND CONTIGUOUS HYDRAULICALLY CONNECTED UNITS, WEST-CENTRAL TEXAS: USGS WATER-RESOURCES INVESTIGATIONS REPORT 93-4039, 1994.

DISSOLVED-SOLIDS CONCENTRATIONS AND HYDROCHEMICAL FACIES IN WATER OF THE EDWARDS-TRINITY AQUIFER SYSTEM, WEST-CENTRAL TEXAS: USGS WATER-RESOURCES INVESTIGATIONS REPORT 93-4126, 1994.

GEOLOGIC HISTORY AND HYDROGEOLOGIC SETTING OF THE EDWARDS-TRINITY AQUIFER SYSTEM, WEST-CENTRAL TEXAS: USGS WATER-RESOURCES INVESTIGATIONS REPORT 94-4039, 1994.

AQUIFERS OF TEXAS: TEXAS WATER DEVELOPMENT BOARD REPORT 345, 1995.

WATER QUALITY IN THE EDWARDS-TRINITY (PLATEAU) AQUIFER, EDWARDS PLATEAU AND TRANS PECOS, TEXAS: TEXAS WATER DEVELOPMENT BOARD HYDROLOGIC ATLAS NO. 3, 1995.

CENOZOIC PECOS ALLUVIUM AQUIFER, CHAPTER 9, in AQUIFERS OF WEST TEXAS: TEXAS WATER DEVELOPMENT BOARD REPORT 356, 2001.

\section{UVALDE COUNTY}

REPORT OF PROGRESS OF THE DIVISION OF HYDROGRAPHY FOR 1895: USGS BULLETIN 140, 1896.

GEOLOGY OF THE EDWARDS PLATEAU AND RIO GRANDE PLAIN ADJACENT TO AUSTIN AND SAN ANTONIO, TEXAS, WITH REFERENCE TO THE OCCURRENCE OF UNDERGROUND WATERS: USGS 18TH ANNUAL REPORT, PART 2, 1898.

THE WATER POWERS OF TEXAS: USGS WATER-SUPPLY AND IRRIGATION PAPER 105, 1904.

UNDERGROUND WATERS OF THE COASTAL PLAIN OF TEXAS: USGS WATER-SUPPLY PAPER 190, 1907.

GROUND WATER IN THE WINTER GARDEN AND ADJACENT DISTRICTS IN SOUTHWESTERN TEXAS: USGS OPEN-FILE REPORT (UNNUMBERED), 1931.
GEOLOGY AND GROUND-WATER RESOURCES OF UVALDE AND MEDINA COUNTIES, TEXAS: USGS WATER-SUPPLY PAPER 678, 1936.

WATER RESOURCES OF THE EDWARDS LIMESTONE IN THE SAN ANTONIO AREA, TEXAS: USGS WATER-SUPPLY PAPER 773-B, 1936.

SOME GROUND-WATER PROBLEMS OF UVALDE, MEDINA, AND BEXAR COUNTIES: USGS OPEN-FILE REPORT (UNNUMBERED), 1938.

PUBLIC WATER SUPPLIES IN SOUTHERN TEXAS: TEXAS BOARD OF WATER ENGINEERS MISCELLANEOUS PUBLICATION 215, 1946.

RELATIONSHIP OF GROUND WATER TO THE DISCHARGE OF THE LEONA RIVER IN UVALDE AND ZAVALA COUNTIES, TEXAS: TEXAS BOARD OF WATER ENGINEERS MISCELLANEOUS PUBLICATION 284, 1947

MEMORANDUM ON ACIDIZING WATER WELLS IN UVALDE COUNTY, TEXAS: USGS OPEN-FILE REPORT (UNNUMBERED), 1948.

MISCELLANEOUS FIELD NOTES ON SAN ANTONIO AREA, TEXAS: USGS OPEN-FILE REPORT (UNNUMBERED), 1950.

SUPPLEMENTARY REPORT ON SURFACE-WATER AND GROUNDWATER SURVEYS, NUECES RIVER BASIN, TEXAS: USGS OPENFILE REPORT (UNNUMBERED), 1950.

PUBLIC WATER SUPPLIES IN SOUTHERN TEXAS: USGS WATERSUPPLY PAPER 1070, 1950.

RECHARGE TO THE CARRIZO SAND IN ATASCOSA COUNTY AND ADJACENT AREAS: USGS OPEN-FILE REPORT (UNNUMBERED), 1951.

MEMORANDUM CONCERNING WATER SUPPLY AT F.A. LUNDELL FARM, UVALDE COUNTY, TEXAS: USGS OPEN-FILE REPORT (UNNUMBERED), 1951.

GROUND-WATER CONDITIONS IN THE LACOSTE-MACDONA AREA, TEXAS: USGS OPEN-FILE REPORT (UNNUMBERED), 1951.

MISCELLANEOUS FIELD NOTES ON THE GEOLOGY OF THE SAN ANTONIO AREA, TEXAS 1950-53: USGS OPEN-FILE REPORT (UNNUMBERED), 1953

PROGRESS REPORT ON A PUMPAGE INVENTORY OF IRRIGATION WELLS PRODUCING FROM THE EDWARDS LIMESTONE IN UVALDE COUNTY, TEXAS: USGS OPEN-FILE REPORT (UNNUMBERED), 1954

GROUND-WATER RESOURCES OF THE SAN ANTONIO AREA, TEXAS, A PROGRESS REPORT OF CURRENT STUDIES: TEXAS BOARD OF WATER ENGINEERS BULLETIN 5412, 1954.

MEMORANDUM ON IRRIGATION BY GROUND WATER FROM THE EDWARDS AND ASSOCIATED LIMESTONES IN THE SAN ANTO NIO-HONDO-UVALDE AREA: USGS OPEN-FILE REPORT 56-93, 1956.

GROUND-WATER RESOURCES OF THE SAN ANTONIO AREA, TEXAS VOLUME 1, A PROGRESS REPORT ON CURRENT STUDIES: TEXAS BOARD OF WATER ENGINEERS BULLETIN 5608, V. 1, 1956.

GROUND-WATER RESOURCES OF THE SAN ANTONIO AREA, TEXAS, VOLUME 2, PART 1, RECORDS OF WELLS AND SPRINGS: TEXAS BOARD OF WATER ENGINEERS BULLETIN 5608, V. 2, PART 1, 1956. 
GROUND-WATER RESOURCES OF THE SAN ANTONIO AREA, TEXAS, VOLUME 2, PART 2, RECORDS OF DRILLERS' LOGS: TEXAS BOARD OF WATER ENGINEERS BULLETIN 5608, V. 2, PART 2, 1956

GROUND-WATER RESOURCES OF THE SAN ANTONIO AREA, TEXAS, VOLUME 2, PART 3, WATER LEVELS IN WELLS, CHEMICAL ANALYSES OF WATER, RECORDS OF STREAMFLOW AND RESERVOIR CONTENTS, DISCHARGE MEASUREMENTS, AND PRECIPITATION IN THE SAN ANTONIO AREA, TEXAS: TEXAS BOARD OF WATER ENGINEERS BULLETIN 5608, V. 2, PART 3, 1956.

RECORDS OF WATER-LEVEL MEASUREMENTS IN KINNEY, UVALDE, AND VAL VERDE COUNTIES, TEXAS, 1929 TO MARCH 1956: TEXAS BOARD OF WATER ENGINEERS BULLETIN 5611, 1956.

OCCURRENCE OF GROUND WATER IN THE EDWARDS LIMESTONE IN UVALDE COUNTY, TEXAS: USGS OPEN-FILE REPORT, 1957.

RECHARGE, DISCHARGE, AND CHANGES IN GROUND-WATER STORAGE IN THE EDWARDS AND ASSOCIATED LIMESTONES, SAN ANTONIO AREA, TEXAS, A PROGRESS REPORT ON STUDIES 1955-59: TEXAS WATER COMMISSION BULLETIN 6201, 1962.

GEOLOGY AND GROUND-WATER RESOURCES OF UVALDE COUNTY, TEXAS: SOUTH TEXAS GEOLOGICAL SOCIETY BULLETIN V. 2, NO. 4, FEBRUARY 15, 1962.

GEOLOGY AND GROUND-WATER RESOURCES OF UVALDE COUNTY, TEXAS: TEXAS WATER COMMISSION BULLETIN 6212, 1962.

CHEMICAL ANALYSES OF WATER FROM OBSERVATION WELLS IN THE EDWARDS AND ASSOCIATED LIMESTONES, SAN ANTONIO AREA, TEXAS: EDWARDS UNDERGROUND WATER DISTRICT BULLETIN 1, 1962.

GROUND-WATER DISCHARGE FROM THE EDWARDS AND ASSOCIATED LIMESTONES, 1955-62, SAN ANTONIO AREA, TEXAS: EDWARDS UNDERGROUND WATER DISTRICT BULLETIN 2, 1963.

RECORDS OF PRECIPITATION, AQUIFER HEAD, AND GROUNDWATER DISCHARGE TO THE EDWARDS AND ASSOCIATED LIMESTONES, 1960-62, SAN ANTONIO AREA, TEXAS: EDWARDS UNDERGROUND WATER DISTRICT BULLETIN 3, 1963.

CHEMICAL ANALYSES OF WATER FROM OBSERVATION WELLS IN THE EDWARDS AND ASSOCIATED LIMESTONES, SAN ANTONIO AREA, TEXAS, 1963: EDWARDS UNDERGROUND WATER DISTRICT BULLETIN 4, 1964.

GROUND-WATER DISCHARGE FROM THE EDWARDS AND ASSOCIATED LIMESTONES, SAN ANTONIO AREA, TEXAS, 1963: EDWARDS UNDERGROUND WATER DISTRICT BULLETIN 5, 1964.

RECORDS OF PRECIPITATION, AQUIFER HEAD, AND GROUNDWATER RECHARGE TO THE EDWARDS AND ASSOCIATED LIMESTONES, SAN ANTONIO AREA, TEXAS, 1963: EDWARDS UNDERGROUND WATER DISTRICT BULLETIN 6, 1964.

RECONNAISSANCE INVESTIGATION OF THE GROUND-WATER RESOURCES OF THE GUADALUPE, SAN ANTONIO, AND NUECES RIVER BASINS, TEXAS: TEXAS WATER COMMISSION BULLETIN 6409, 1964.

CHEMICAL ANALYSES OF WATER FROM OBSERVATION WELLS IN THE EDWARDS AND ASSOCIATED LIMESTONES, SAN ANTONIO AREA, TEXAS, 1964: EDWARDS UNDERGROUND WATER DISTRICT BULLETIN 7, 1965
GROUND-WATER DISCHARGE FROM THE EDWARDS AND ASSOCIATED LIMESTONES, SAN ANTONIO AREA, TEXAS, 1964: EDWARDS UNDERGROUND WATER DISTRICT BULLETIN 8, 1965

GROUND-WATER RECHARGE TO THE EDWARDS AND ASSOCIATED LIMESTONES, SAN ANTONIO AREA, TEXAS, 1964: EDWARDS UNDERGROUND WATER DISTRICT BULLETIN 9, 1965.

CHEMICAL ANALYSES FROM OBSERVATION WELLS IN THE EDWARDS AND ASSOCIATED LIMESTONES, SAN ANTONIO AREA, TEXAS, 1965: EDWARDS UNDERGROUND WATER DISTRICT BULLETIN 10, 1966.

GROUND-WATER DISCHARGE FROM THE EDWARDS AND ASSOCIATED LIMESTONES, SAN ANTONIO AREA, TEXAS, 1965: EDWARDS UNDERGROUND WATER DISTRICT BULLETIN 11, 1966.

RECORDS OF PRECIPITATION, AQUIFER HEAD, AND GROUNDWATER RECHARGE TO THE EDWARDS AND ASSOCIATED LIMESTONES, SAN ANTONIO AREA, TEXAS, 1965: EDWARDS UNDERGROUND WATER DISTRICT BULLETIN 12, 1966.

GROUND-WATER RESOURCES OF THE SAN ANTONIO AREA, TEXAS, A PROGRESS REPORT ON STUDIES, 1960-64: TEXAS WATER DEVELOPMENT BOARD REPORT 34, 1966

CHEMICAL ANALYSES OF WATER FROM OBSERVATION WELLS IN THE EDWARDS AND ASSOCIATED LIMESTONES, SAN ANTONIO AREA, TEXAS, 1966: EDWARDS UNDERGROUND WATER DISTRICT BULLETIN 13, 1967.

GROUND-WATER DISCHARGE FROM THE EDWARDS AND ASSOCIATED LIMESTONES, SAN ANTONIO AREA, TEXAS, 1966: EDWARDS UNDERGROUND WATER DISTRICT BULLETIN 14, 1967.

RECORDS OF PRECIPITATION, AQUIFER HEAD, AND GROUNDWATER RECHARGE TO THE EDWARDS AND ASSOCIATED LIMESTONES, SAN ANTONIO AREA, TEXAS, 1966: EDWARDS UNDERGROUND WATER DISTRICT BULLETIN 15, 1967.

CHEMICAL ANALYSES OF WATER FROM OBSERVATION WELLS IN THE EDWARDS AND ASSOCIATED LIMESTONES, SAN ANTONIO AREA, TEXAS, 1967: EDWARDS UNDERGROUND WATER DISTRICT BULLETIN 16, 1968.

HYDROLOGIC EFFECTS OF THE EARTHQUAKE OF MARCH 27, 1964, OUTSIDE ALASKA: USGS PROFESSIONAL PAPER 544-C, 1968.

GROUND-WATER DISCHARGE FROM THE EDWARDS AND ASSOCIATED LIMESTONES, SAN ANTONIO AREA, TEXAS, 1967: EDWARDS UNDERGROUND WATER DISTRICT BULLETIN 17, 1968.

RECORDS OF PRECIPITATION, AQUIFER HEAD, AND GROUNDWATER RECHARGE TO THE EDWARDS AND ASSOCIATED LIMESTONES, SAN ANTONIO AREA, TEXAS, 1967: EDWARDS UNDERGROUND WATER DISTRICT BULLETIN 18, 1968.

RECORDS OF WELLS AND SPRINGS, SAN ANTONIO AREA, TEXAS: EDWARDS UNDERGROUND WATER DISTRICT, 1969.

GROUND-WATER DISCHARGE FROM THE EDWARDS AND ASSOCIATED LIMESTONES, SAN ANTONIO AREA, TEXAS, 1968: EDWARDS UNDERGROUND WATER DISTRICT BULLETIN 20, 1969.

RECORDS OF PRECIPITATION, AQUIFER HEAD, AND GROUNDWATER RECHARGE TO THE EDWARDS AND ASSOCIATED LIMESTONES, SAN ANTONIO AREA, TEXAS, 1968: EDWARDS UNDERGROUND WATER DISTRICT BULLETIN 21, 1969.

GEOLOGY AND WATER QUALITY AT SELECTED LOCATIONS IN THE SAN ANTONIO AREA, TEXAS, PROGRESS REPORT, 1969: EDWARDS UNDERGROUND WATER DISTRICT, 1970. 
GROUND-WATER DISCHARGE FROM THE EDWARDS AND ASSOCIATED LIMESTONES, SAN ANTONIO AREA, TEXAS, 1969:

EDWARDS UNDERGROUND WATER DISTRICT BULLETIN 23, 1970.

RECORDS OF PRECIPITATION, WATER LEVELS, AND GROUNDWATER RECHARGE TO THE EDWARDS AND ASSOCIATED LIMESTONES, SAN ANTONIO AREA, TEXAS, 1969: EDWARDS UNDERGROUND WATER DISTRICT BULLETIN 24, 1970.

GROUND-WATER DISCHARGE FROM THE EDWARDS AND ASSOCIATED LIMESTONES, SAN ANTONIO AREA, TEXAS, 1970: EDWARDS UNDERGROUND WATER DISTRICT BULLETIN 26, 1971.

RECORDS OF PRECIPITATION, WATER LEVELS, AND GROUNDWATER RECHARGE TO THE EDWARDS AND ASSOCIATED LIMESTONES, SAN ANTONIO AREA, TEXAS, 1970: EDWARDS UNDERGROUND WATER DISTRICT BULLETIN 27, 1971.

GROUND-WATER DISCHARGE FROM THE EDWARDS AND ASSOCIATED LIMESTONES, SAN ANTONIO AREA, TEXAS, 1971:

EDWARDS UNDERGROUND WATER DISTRICT BULLETIN 29, 1972.

RECORDS OF PRECIPITATION, WATER LEVELS, AND GROUNDWATER RECHARGE TO THE EDWARDS AND ASSOCIATED LIMESTONES, SAN ANTONIO AREA, TEXAS, 1971: EDWARDS UNDERGROUND WATER DISTRICT BULLETIN 30, 1972.

CHEMICAL AND BACTERIOLOGICAL QUALITY OF WATER AT SELECTED SITES IN THE SAN ANTONIO AREA, TEXAS, AUGUST 1968-APRIL 1972: EDWARDS UNDERGROUND WATER DISTRICT, 1972.

MAPS SHOWING OUTCROPS OF THE EDWARDS AND ASSOCIATED LIMESTONES IN THE PRINCIPAL RECHARGE AREA OF THE EDWARDS AQUIFER IN BEXAR COUNTY, TEXAS: USGS OPENFILE REPORT 72-310, 1972.

GROUND-WATER DISCHARGE FROM THE EDWARDS AND ASSOCIATED LIMESTONES, SAN ANTONIO AREA, TEXAS, 1972: EDWARDS UNDERGROUND WATER DISTRICT BULLETIN 31, 1973.

REGIONAL SPECIFIC YIELD OF THE EDWARDS AND ASSOCIATED LIMESTONES IN THE SAN ANTONIO, TEXAS, AREA: EDWARDS UNDERGROUND WATER DISTRICT, 1973.

GROUND-WATER DISCHARGE FROM THE EDWARDS AND ASSOCIATED LIMESTONES, SAN ANTONIO AREA, TEXAS, 1973: EDWARDS UNDERGROUND WATER DISTRICT BULLETIN 32, 1974

RECORDS OF PRECIPITATION, WATER LEVELS, AND GROUNDWATER RECHARGE TO THE EDWARDS AND ASSOCIATED LIMESTONES, SAN ANTONIO AREA, TEXAS, 1972-73: EDWARDS UNDERGROUND WATER DISTRICT BULLETIN 33, 1974.

RELATION OF PRECIPITATION TO ANNUAL GROUND-WATER RECHARGE IN THE EDWARDS AQUIFER, SAN ANTONIO AREA, TEXAS: USGS OPEN-FILE REPORT 75-298, 1975.

THE EDWARDS UNDERGROUND RESERVOIR AND THE EDWARDS UNDERGROUND WATER DISTRICT: SOUTH TEXAS GEOLOGICAL SOCIETY BULLETIN V. 15, NO. 7, 1975.

RECORDS OF PRECIPITATION, WATER LEVELS, AND GROUNDWATER RECHARGE TO THE EDWARDS AND ASSOCIATED LIMESTONES, SAN ANTONIO AREA, TEXAS, 1972-73: SOUTH TEXAS GEOLOGICAL SOCIETY BULLETIN V. 15, NO. 7, 1975.

GROUND-WATER DISCHARGE FROM THE EDWARDS AND ASSOCIATED LIMESTONES, SAN ANTONIO AREA, TEXAS, 1974: EDWARDS UNDERGROUND WATER DISTRICT BULLETIN 34, 1975.
MAJOR AND HISTORICAL SPRINGS OF TEXAS: TEXAS WATER DEVELOPMENT BOARD REPORT 189, 1975.

GEOHYDROLOGIC SIGNIFICANCE OF LITHOFACIES OF THE CARRIZO SAND OF ARKANSAS, LOUISIANA, AND TEXAS AND THE MERIDIAN SAND OF MISSISSIPPI: USGS PROFESSIONAL PAPER 569-D, 1975.

GEOCHEMICAL AND ISOTOPIC ANALYSES OF WATERS ASSOCIATED WITH THE EDWARDS LIMESTONE AQUIFER, CENTRAL TEXAS: EDWARDS UNDERGROUND WATER DISTRICT, 1976.

GROUND-WATER DISCHARGE FROM THE EDWARDS AND ASSOCIATED LIMESTONES, SAN ANTONIO AREA, TEXAS, 1975: EDWARDS UNDERGROUND WATER DISTRICT BULLETIN 35, 1976.

STATISTICAL ANALYSIS OF WATER-LEVEL, SPRINGFLOW, AND STREAMFLOW DATA FOR THE EDWARDS AQUIFER IN SOUTHCENTRAL TEXAS: USGS OPEN-FILE REPORT 76-393, 1976.

STATISTICAL ANALYSIS OF WATER-LEVEL, SPRINGFLOW, AND STREAMFLOW DATA FOR THE EDWARDS AQUIFER IN SOUTHCENTRAL TEXAS: EDWARDS UNDERGROUND WATER DISTRICT, 1976.

CHEMICAL AND BACTERIOLOGICAL QUALITY OF WATER AT SELECTED SITES IN THE SAN ANTONIO AREA, TEXAS, AUGUST 1968-JANUARY 1975: USGS OPEN-FILE REPORT 76-574, 1976.

CHEMICAL AND BACTERIOLOGICAL QUALITY OF WATER AT SELECTED SITES IN THE SAN ANTONIO AREA, TEXAS, AUGUST 1968-JANUARY 1975: EDWARDS UNDERGROUND WATER DISTRICT, 1976

PROGRESS REPORT ON GEOLOGY OF THE EDWARDS AQUIFER, SAN ANTONIO AREA, TEXAS, AND PRELIMINARY INTERPRETATION OF BOREHOLE GEOPHYSICAL AND LABORATORY DATA ON CARBONATE ROCKS: USGS OPEN-FILE REPORT 76-627, 1976.

GROUND-WATER RESOURCES OF THE CARRIZO AQUIFER IN THE WINTER GARDEN AREA OF TEXAS, VOLUME 1: TEXAS WATER DEVELOPMENT BOARD REPORT 210, V. 1, 1976.

GROUND-WATER RESOURCES OF THE CARRIZO AQUIFER IN THE WINTER GARDEN AREA OF TEXAS, VOLUME 2: TEXAS WATER DEVELOPMENT BOARD REPORT 210, V. 2, 1977.

GROUND-WATER DISCHARGE FROM THE EDWARDS AND ASSOCIATED LIMESTONES, SAN ANTONIO AREA, TEXAS, 1976: EDWARDS UNDERGROUND WATER DISTRICT, 1977.

METHOD OF ESTIMATING NATURAL RECHARGE TO THE EDWARDS AQUIFER IN THE SAN ANTONIO AREA, TEXAS: USGS WATERRESOURCES INVESTIGATIONS REPORT 78-10, 1978.

REGIONAL DISTRIBUTION OF FRACTURES IN THE SOUTHERN EDWARDS PLATEAU AND THEIR RELATIONSHIP TO TECTONICS AND CAVES: UNIVERSITY OF TEXAS, BUREAU OF ECONOMIC GEOLOGY GEOLOGICAL CIRCULAR 78-2, 1978.

CHEMICAL AND BACTERIOLOGICAL QUALITY OF WATER AT SELECTED SITES IN THE SAN ANTONIO AREA, TEXAS, FEBRUARY 1975-SEPTEMBER 1977: EDWARDS UNDERGROUND WATER DISTRICT, 1978.

RECORDS OF GROUND-WATER RECHARGE AND DISCHARGE FOR THE EDWARDS AQUIFER IN THE SAN ANTONIO AREA, TEXAS, 1934-77: EDWARDS UNDERGROUND WATER DISTRICT BULLETIN 37, 1979.

VARIATIONS IN SPECIFIC YIELD IN THE OUTCROP OF THE CARRIZO SAND IN SOUTH TEXAS AS ESTIMATED BY SEISMIC REFRAC- 
TION: TEXAS DEPARTMENT OF WATER RESOURCES REPORT 229, 1979.

OCCURRENCE, AVAILABILITY, AND CHEMICAL QUALITY OF GROUND WATER IN THE EDWARDS PLATEAU REGION OF TEXAS: TEXAS DEPARTMENT OF WATER RESOURCES REPORT $235,1979$.

GROUND-WATER RESOURCES AND MODEL APPLICATIONS FOR THE EDWARDS (BALCONES FAULT ZONE) AQUIFER IN THE SAN ANTONIO REGION: TEXAS DEPARTMENT OF WATER RESOURCES REPORT 239, 1979.

HYDROCHEMICAL DATA FOR THE EDWARDS AQUIFER IN THE SAN ANTONIO AREA, TEXAS: TEXAS DEPARTMENT OF WATER RESOURCES LIMITED PRINTING REPORT LP-131, 1980.

RECORDS OF GROUND-WATER RECHARGE, DISCHARGE, WATER LEVELS, AND CHEMICAL QUALITY OF WATER FOR THE EDWARDS AQUIFER IN THE SAN ANTONIO AREA, TEXAS, 1934-78: EDWARDS UNDERGROUND WATER DISTRICT BULLETIN 38, 1980.

WATER-LEVEL, RECHARGE, DISCHARGE, SPECIFIC CAPACITY, WELL-YIELD, AND AQUIFER-TEST DATA FOR THE EDWARDS AQUIFER IN THE SAN ANTONIO AREA, TEXAS: TEXAS DEPARTMENT OF WATER RESOURCES LIMITED PRINTING REPORT LP-133, 1980.

SPRINGS OF TEXAS, VOLUME 1: (BY GUNNAR BRUNE), BRANCHSMITH, INC., FORT WORTH, TEXAS, 1981.

APPLICATION AND ANALYSIS OF BOREHOLE DATA FOR THE EDWARDS AQUIFER IN THE SAN ANTONIO AREA, TEXAS: TEXAS DEPARTMENT OF WATER RESOURCES LIMITED PRINTING REPORT LP-139, 1981.

RECORDS OF GROUND-WATER RECHARGE, DISCHARGE, WATER LEVELS, AND CHEMICAL QUALITY OF WATER FOR THE EDWARDS AQUIFER IN THE SAN ANTONIO AREA, TEXAS, 1934-79: EDWARDS UNDERGROUND WATER DISTRICT BULLETIN 39, 1981.

TEST-HOLE DATA FOR THE EDWARDS AQUIFER IN THE SAN ANTONIO AREA, TEXAS: TEXAS DEPARTMENT OF WATER RESOURCES LIMITED PRINTING REPORT LP-171, 1982.

RECORDS OF GROUND-WATER RECHARGE, DISCHARGE, WATER LEVELS, AND CHEMICAL QUALITY OF WATER FOR THE EDWARDS AQUIFER IN THE SAN ANTONIO AREA, TEXAS, 1934-80: EDWARDS UNDERGROUND WATER DISTRICT BULLETIN 40, 1982.

GROUND-WATER AVAILABILITY OF THE LOWER CRETACEOUS FORMATIONS IN THE HILL COUNTRY OF SOUTH-CENTRAL TEXAS: TEXAS DEPARTMENT OF WATER RESOURCES REPORT $273,1983$.

RECORDS OF GROUND-WATER RECHARGE, DISCHARGE, WATER LEVELS, AND CHEMICAL QUALITY OF WATER FOR THE EDWARDS AQUIFER IN THE SAN ANTONIO AREA, TEXAS, 1934-81: EDWARDS UNDERGROUND WATER DISTRICT BULLETIN 41, 1984.

CARBONATE GEOLOGY AND HYDROLOGY OF THE EDWARDS AQUIFER IN THE SAN ANTONIO AREA, TEXAS: USGS OPEN-FILE REPORT 83-537, 1984.

IDENTIFICATION AND TABULATION OF GEOLOGICAL CONTACTS IN THE EDWARDS AQUIFER, SAN ANTONIO AREA, TEXAS: USGS OPEN-FILE REPORT 84-075, 1984.
PROPOSED 10-YEAR PLAN FOR CONTINUATION OF HYDROLOGIC STUDIES OF THE EDWARDS AQUIFER, SAN ANTONIO AREA, TEXAS: USGS OPEN-FILE REPORT 84-817, 1984.

TEXAS GROUND-WATER RESOURCES, in NATIONAL WATER SUMMARY 1984: USGS WATER-SUPPLY PAPER 2275, 1985.

STATISTICAL SUMMARY OF WATER-QUALITY DATA COLLECTED FROM SELECTED WELLS AND SPRINGS IN THE EDWARDS AQUIFER NEAR SAN ANTONIO, TEXAS: USGS OPEN-FILE REPORT 85-182, 1985.

RECORDS OF GROUND-WATER RECHARGE, DISCHARGE, WATER LEVELS, AND CHEMICAL QUALITY OF WATER FOR THE EDWARDS AQUIFER IN THE SAN ANTONIO AREA, TEXAS, 1934-82: EDWARDS UNDERGROUND WATER DISTRICT BULLETIN 42, 1985.

IDENTIFICATION AND TABULATION OF GEOLOGICAL CONTACTS IN THE EDWARDS AQUIFER, SAN ANTONIO AREA, TEXAS: TEXAS DEPARTMENT OF WATER RESOURCES LIMITED PRINTING REPORT LP-199, 1985.

COMPILATION OF HYDROLOGIC DATA FOR THE EDWARDS AQUIFER, SAN ANTONIO AREA, TEXAS, 1983-84, WITH 1934-84 SUMMARY: EDWARDS UNDERGROUND WATER DISTRICT BULLETIN 43-44, 1986.

HYDROGEOLOGIC SECTIONS OF THE EDWARDS AQUIFER AND ITS CONFINING UNITS IN THE SAN ANTONIO AREA, TEXAS: USGS WATER-RESOURCES INVESTIGATIONS REPORT 85-4259, 1986.

POTENTIAL FOR UPDIP MOVEMENT OF SALINEWATER IN THE EDWARDS AQUIFER, SAN ANTONIO, TEXAS: USGS WATERRESOURCES INVESTIGATIONS REPORT 86-4032, 1986.

CARBONATE GEOLOGY AND HYDROLOGY OF THE EDWARDS AQUIFER IN THE SAN ANTONIO AREA, TEXAS: TEXAS WATER DEVELOPMENT BOARD REPORT 296, 1986.

THE EDWARDS AQUIFER; EXTREMELY PRODUCTIVE, BUT....A SOLE-SOURCE WATER SUPPLY FOR SAN ANTONIO AND SURROUNDING COUNTIES IN SOUTH-CENTRAL TEXAS: EDWARDS UNDERGROUND WATER DISTRICT, 1986.

SIMULATION OF FLOW IN THE EDWARDS AQUIFER, SAN ANTONIO REGION, TEXAS, AND REFINEMENT OF STORAGE AND FLOW CONCEPTS: USGS OPEN-FILE REPORT 86-532, 1987.

RELATION OF WATER CHEMISTRY OF THE EDWARDS AQUIFER TO HYDROGEOLOGY AND LAND USE, SAN ANTONIO AREA, TEXAS: USGS WATER-RESOURCES INVESTIGATIONS REPORT 87-4116, 1987.

HYDROGEOLOGIC DATA FROM A STUDY OF THE FRESHWATER ZONE/SALINEWATER ZONE INTERFACE IN THE EDWARDS AQUIFER, SAN ANTONIO REGION, TEXAS: USGS OPEN-FILE REPORT 87-389, 1987.

COMPILATION OF HYDROLOGIC DATA FOR THE EDWARDS AQUIFER, SAN ANTONIO AREA, TEXAS, 1985, WITH 1934-85 SUMMARY: EDWARDS UNDERGROUND WATER DISTRICT BULLETIN 45, 1987.

APPROXIMATE POTENTIOMETRIC SURFACES FOR THE AQUIFERS OF THE TEXAS COASTAL UPLANDS SYSTEM, 1980: USGS HYDROLOGIC INVESTIGATIONS ATLAS HA-704, 1987.

SUGGESTED DESIGN AND CONSTRUCTION OF EDWARDS AQUIFER WELLS: EDWARDS UNDERGROUND WATER DISTRICT, 1987? 
COMPILATION OF HYDROLOGIC DATA FOR THE EDWARDS AQUIFER, SAN ANTONIO AREA, TEXAS, 1986, WITH 1934-86 SUMMARY: EDWARDS UNDERGROUND WATER DISTRICT BULLETIN 46, 1988.

GEOHYDROLOGIC FRAMEWORK OF THE GULF COASTAL PLAIN: USGS HYDROLOGIC INVESTIGATIONS ATLAS HA-695, 1988.

SIMULATION OF FLOW IN THE EDWARDS AQUIFER, SAN ANTONIO REGION, TEXAS, AND REFINEMENT OF STORAGE AND FLOW CONCEPTS: USGS WATER-SUPPLY PAPER 2336-A, 1988.

COMPILATION OF HYDROLOGIC DATA FOR THE EDWARDS AQUIFER, SAN ANTONIO AREA, TEXAS, 1987, WITH 1934-87 SUMMARY: EDWARDS UNDERGROUND WATER DISTRICT BULLETIN 47, 1988.

COMPILATION OF HYDROLOGIC DATA FOR THE EDWARDS AQUIFER, SAN ANTONIO AREA, TEXAS, 1988, WITH 1934-88 SUMMARY: EDWARDS UNDERGROUND WATER DISTRICT BULLETIN 48, 1989.

POTENTIOMETRIC SURFACE OF THE EDWARDS-TRINITY AQUIFER SYSTEM AND CONTIGUOUS HYDRAULICALLY CONNECTED UNITS, WEST-CENTRAL TEXAS, WINTER 1974-75: USGS WATERRESOURCES INVESTIGATIONS REPORT 89-4208, 1990.

COMPILATION OF HYDROLOGIC DATA FOR THE EDWARDS AQUIFER, SAN ANTONIO AREA, TEXAS, 1989, WITH 1934-89 SUMMARY: EDWARDS UNDERGROUND WATER DISTRICT BULLETIN 49, 1990.

WITHDRAWALS FROM THE EDWARDS-TRINITY AQUIFER SYSTEM AND CONTIGUOUS HYDRAULICALLY CONNECTED UNITS, WEST-CENTRAL TEXAS, DECEMBER 1974 THROUGH MARCH 1977: USGS WATER-RESOURCES INVESTIGATIONS REPORT 91-4021, 1991.

EDWARDS AQUIFER, A TEXAS TREASURE-A TEACHERS GUIDE, SECONDARY, GRADES 7-12: EDWARDS UNDERGROUND WATER DISTRICT, 1991.

COMPILATION OF HYDROLOGIC DATA FOR THE EDWARDS AQUIFER, SAN ANTONIO AREA, TEXAS, 1990, WITH 1934-90 SUMMARY: EDWARDS UNDERGROUND WATER DISTRICT BULLETIN 50, 1991.

INSIDE THE EDWARDS AQUIFER-A THREE-PART TECHNICAL FILM, HIGH-SCHOOL LEVEL TEACHER'S GUIDE: EDWARDS UNDERGROUND WATER DISTRICT, 1992.

CONFIGURATION OF THE BASE OF THE EDWARDS-TRINITY AQUIFER SYSTEM AND HYDROGEOLOGY OF THE UNDERLYING PRECRETACEOUS ROCKS, WEST-CENTRAL TEXAS: USGS WATERRESOURCES INVESTIGATIONS REPORT 91-4071, 1992.

GROUND-WATER QUALITY MONITORING RESULTS IN THE WINTER GARDEN AREA, 1990: TEXAS WATER DEVELOPMENT BOARD REPORT 335, 1992.

EVALUATION OF THE GROUND-WATER RESOURCES OF THE PALEOZOIC AND CRETACEOUS AQUIFERS IN THE HILL COUNTRY OF CENTRAL TEXAS: TEXAS WATER DEVELOPMENT BOARD REPORT 339, 1992.

MODEL REFINEMENT AND APPLICATION FOR THE EDWARDS (BALCONES FAULT ZONE) AQUIFER IN THE SAN ANTONIO AREA, TEXAS: TEXAS WATER DEVELOPMENT BOARD REPORT 340, 1992.
USING GEOPHYSICAL LOGS IN THE EDWARDS AQUIFER TO ESTIMATE WATER QUALITY ALONG THE FRESHWATER/SALINEWATER INTERFACE (UVALDE TO SAN ANTONIO, TEXAS): EDWARDS UNDERGROUND WATER DISTRICT REPORT 92-03, 1992.

WATER QUALITY IN THE EDWARDS AQUIFER AND STREAMS RECHARGING THE AQUIFER IN THE SAN ANTONIO REGION, TEXAS: USGS HYDROLOGIC INVESTIGATIONS ATLAS HA-723, 1992.

COMPILATION OF HYDROLOGIC DATA FOR THE EDWARDS AQUIFER, SAN ANTONIO AREA, TEXAS, 1991, WITH 1934-91 SUMMARY: EDWARDS UNDERGROUND WATER DISTRICT BULLETIN $51,1992$.

WATER-RESOURCES DATA, TEXAS, WATER YEAR 1991, VOLUME 4 GROUND-WATER DATA: USGS WATER-DATA REPORT TX-91-4, 1992.

HISTORICAL POTENTIOMETRIC SURFACE OF THE EDWARDS-TRINITY AQUIFER SYSTEM AND CONTIGUOUS HYDRAULICALLY CONNECTED UNITS, WEST-CENTRAL TEXAS: USGS WATERRESOURCES INVESTIGATIONS REPORT 92-4055, 1993.

PROPERTIES AND CHEMICAL CONSTITUENTS IN GROUND WATER FROM THE LOWER CLAIBORNE-UPPER WILCOX AQUIFER, GULF COAST REGIONAL AQUIFER SYSTEMS, SOUTH-CENTRAL UNITED STATES: USGS WATER-RESOURCES INVESTIGATIONS REPORT 92-4102, 1993

HISTORICAL SATURATED THICKNESS OF THE EDWARDS-TRINITY AQUIFER SYSTEM AND SELECTED CONTIGUOUS HYDRAULICALLY CONNECTED UNITS, WEST-CENTRAL TEXAS: USGS WATER-RESOURCES INVESTIGATIONS REPORT 92-4125, 1993.

PROPERTIES AND CHEMICAL CONSTITUENTS IN GROUND WATER FROM THE MIDDLE WILCOX AQUIFER, GULF COAST AQUIFER SYSTEMS, SOUTH-CENTRAL UNITED STATES: USGS WATERRESOURCES INVESTIGATIONS REPORT 93-4070, 1993.

DEFINING THE EDWARDS AQUIFER FRESHWATER/SALINE-WATER INTERFACE WITH GEOPHYSICAL LOGS AND MEASURED DATA (SAN ANTONIO TO KYLE, TEXAS): EDWARDS UNDERGROUND WATER DISTRICT REPORT 93-06, 1993.

EDWARDS AQUIFER HYDROGEOLOGIC STATUS REPORT FOR 1992: EDWARDS UNDERGROUND WATER DISTRICT REPORT 93-05, 1993.

WATER-RESOURCES DATA, TEXAS, WATER YEAR 1992, VOLUME 4 GROUND-WATER DATA: USGS WATER-DATA REPORT TX-92-4, 1993.

SIMULATIONS OF FLOW IN THE EDWARDS-TRINITY AQUIFER SYSTEM AND CONTIGUOUS HYDRAULICALLY CONNECTED UNITS, WEST-CENTRAL TEXAS: USGS WATER-RESOURCES INVESTIGATIONS REPORT 93-4039, 1994.

DISSOLVED-SOLIDS CONCENTRATIONS AND HYDROCHEMICAL FACIES IN WATER OF THE EDWARDS-TRINITY AQUIFER SYSTEM, WEST-CENTRAL TEXAS: USGS WATER-RESOURCES INVESTIGATIONS REPORT 93-4126, 1994.

NATIONAL WATER-QUALITY ASSESSMENT PROGRAM-SOUTHCENTRAL TEXAS: USGS FACT SHEET FS-94-048, 1994.

GEOLOGIC HISTORY AND HYDROGEOLOGIC SETTING OF THE EDWARDS-TRINITY AQUIFER SYSTEM, WEST-CENTRAL TEXAS: USGS WATER-RESOURCES INVESTIGATIONS REPORT 94-4039, 1994. 
1994 REVIEW AND UPDATE OF THE POSITION OF THE EDWARDS AQUIFER FRESHWATER/SALINE-WATER INTERFACE FROM UVALDE TO KYLE, TEXAS: EDWARDS UNDERGROUND WATER DISTRICT REPORT 94-05, 1994.

WATER-RESOURCES DATA, TEXAS, WATER YEAR 1993, VOLUME 4, GROUND-WATER DATA: USGS WATER-DATA REPORT TX-93-4, 1994.

REGIONAL DISTRIBUTION OF PERMEABILITY IN THE EDWARDS AQUIFER: EDWARDS UNDERGROUND WATER DISTRICT REPORT 95-02, 1995.

GEOLOGY AND HYDROLOGY OF THE EDWARDS AQUIFER IN THE SAN ANTONIO AREA, TEXAS: USGS WATER-RESOURCES INVESTIGATIONS REPORT 95-4186, 1995.

WATER QUALITY IN THE EDWARDS-TRINITY (PLATEAU) AQUIFER, EDWARDS PLATEAU AND TRANS-PECOS, TEXAS: TEXAS WATER DEVELOPMENT BOARD HYDROLOGIC ATLAS NO. 3, 1995.

HYDROGEOLOGIC FACTORS THAT AFFECT THE FLOWPATH OF WATER IN SELECTED ZONES OF THE EDWARDS AQUIFER, SAN ANTONIO REGION, TEXAS: USGS WATER-RESOURCES INVESTIGATIONS REPORT 96-4046, 1996.

RECHARGE TO AND DISCHARGE FROM THE EDWARDS AQUIFER IN THE SAN ANTONIO AREA, TEXAS, 1995: USGS OPEN-FILE REPORT 96-181, 1996.

EDWARDS AQUIFER GROUND-WATER RESOURCES: GEOLOGIC CONTROLS ON POROSITY DEVELOPMENT IN PLATFORM CARBONATES, SOUTH TEXAS: UNIVERSITY OF TEXAS, BUREAU OF ECONOMIC GEOLOGY REPORT OF INVESTIGATIONS NO. 238, 1996.

WATER-QUALITY ASSESSMENT OF SOUTH-CENTRAL TEXASOCCURRENCE AND DISTRIBUTION OF VOLATILE ORGANIC COMPOUNDS IN SURFACE WATER AND GROUND WATER, 1983-94, AND IMPLICATIONS FOR FUTURE MONITORING: USGS WATER-RESOURCES INVESTIGATIONS REPORT 97-4028, 1997.

GEOLOGIC FRAMEWORK OF THE EDWARDS AQUIFER AND UPPER CONFINING UNIT, AND HYDROGEOLOGIC CHARACTERISTICS OF THE EDWARDS AQUIFER, SOUTH-CENTRAL UVALDE COUNTY, TEXAS: USGS WATER-RESOURCES INVESTIGATIONS REPORT 97-4094, 1997.

HYDROGEOLOGIC FRAMEWORK AND GEOCHEMISTRY OF THE EDWARDS AQUIFER SALINE-WATER ZONE, SOUTH-CENTRAL TEXAS: USGS WATER-RESOURCES INVESTIGATIONS REPORT 97-4133, 1997.

WATER-RESOURCES DATA, TEXAS, WATER YEAR 1997, VOLUME 4, GROUND-WATER DATA: USGS WATER-DATA REPORT TX-97-4, 1998.

GEOLOGIC FRAMEWORK AND HYDROGEOLOGIC PROPERTIES OF THE SECO CREEK WATERSHED, TEXAS: USGS FACT SHEET FS-104-98, 1999.

WATER-RESOURCES DATA, TEXAS, WATER YEAR 1998, VOLUME 4, GROUND-WATER DATA: USGS WATER-DATA REPORT TX-98-4, 1999.

GROUNDWATER AVAILABILITY OF THE TRINITY AQUIFER, HILL COUNTRY AREA, TEXAS: NUMERICAL SIMULATIONS THROUGH 2050: TEXAS WATER DEVELOPMENT BOARD REPORT 353, 2000.

WATER QUALITY IN SOUTH-CENTRAL TEXAS-TEXAS, 1996-98: USGS CIRCULAR 1212, 2000.
WATER-RESOURCES DATA, TEXAS, WATER YEAR 1999, VOLUME 6, GROUND-WATER DATA: USGS WATER-DATA REPORT TX-99-6, 2000 .

AN OVERVIEW OF THE EDWARDS-TRINITY AQUIFER SYSTEM, CENTRAL-WEST TEXAS, CHAPTER 8, in AQUIFERS OF WEST TEXAS: TEXAS WATER DEVELOPMENT BOARD REPORT 356, 2001.

WATER-RESOURCES DATA, TEXAS, WATER YEAR 2000, VOLUME 6, GROUND-WATER DATA: USGS WATER-DATA REPORT TX-00-6, 2001.

\section{VAL VERDE COUNTY}

REPORT OF PROGRESS OF THE DIVISION OF HYDROGRAPHY FOR 1895: USGS BULLETIN 140, 1896.

GEOLOGY OF THE EDWARDS PLATEAU AND RIO GRANDE PLAIN ADJACENT TO AUSTIN AND SAN ANTONIO, TEXAS, WITH REFERENCE TO THE OCCURRENCE OF UNDERGROUND WATERS: USGS 18TH ANNUAL REPORT, PART 2, 1898.

REPORT OF PROGRESS OF STREAM MEASUREMENTS FOR THE CALENDAR YEAR 1904: USGS WATER-SUPPLY AND IRRIGATION PAPER 132, 1905.

VAL VERDE COUNTY, TEXAS (RECORDS OF WELLS): TEXAS BOARD OF WATER ENGINEERS MISCELLANEOUS PUBLICATION 285, 1940.

GROUND WATER AT THE BOMBADIER SCHOOL NEAR DEL RIO, TEXAS: USGS OPEN-FILE REPORT (UNNUMBERED), 1942.

MEMORANDUM REGARDING OCCURRENCE OF GROUND WATER IN THE AREA 6-1/2 MILES EAST OF DEL RIO, TEXAS: USGS OPENFILE REPORT (UNNUMBERED), 1942.

MEMORANDUM ON WATER SUPPLY FROM SAN FELIPE SPRINGS, NEAR DEL RIO, TEXAS: USGS OPEN-FILE REPORT (UNNUMBERED), 1942.

REPORT ON GROUND WATER AT DEL RIO BOMBADIER SCHOOL: USGS OPEN-FILE REPORT (UNNUMBERED), 1942.

PUBLIC WATER SUPPLIES IN WESTERN TEXAS: TEXAS BOARD OF WATER ENGINEERS MISCELLANEOUS PUBLICATION 216, 1949.

PUBLIC WATER SUPPLIES IN WESTERN TEXAS: USGS WATERSUPPLY PAPER 1106, 1951.

RECORDS OF TEST HOLES ALONG THE RIO GRANDE IN TERRELL AND VAL VERDE COUNTIES: USGS OPEN-FILE REPORT (UNNUMBERED), 1954.

RECORDS OF WATER-LEVEL MEASUREMENTS IN KINNEY, UVALDE, AND VAL VERDE COUNTIES, TEXAS, 1929 TO MARCH 1956: TEXAS BOARD OF WATER ENGINEERS BULLETIN 5611, 1956.

RECONNAISSANCE INVESTIGATION OF THE GROUND-WATER RESOURCES OF THE RIO GRANDE BASIN, TEXAS: TEXAS WATER COMMISSION BULLETIN 6502, 1965.

HYDROLOGIC EFFECTS OF THE EARTHQUAKE OF MARCH 27, 1964, OUTSIDE ALASKA: USGS PROFESSIONAL PAPER 544-C, 1968.

GROUND-WATER RESOURCES OF VAL VERDE COUNTY, TEXAS: TEXAS WATER DEVELOPMENT BOARD REPORT 172, 1973. 
RECONNAISSANCE INVESTIGATION OF GROUND WATER IN THE RIO GRANDE DRAINAGE BASIN-WITH SPECIAL EMPHASIS ON SALINE GROUND-WATER RESOURCES: USGS HYDROLOGIC INVESTIGATIONS ATLAS HA-510, 1974.

MAJOR AND HISTORICAL SPRINGS OF TEXAS: TEXAS WATER DEVELOPMENT BOARD REPORT 189, 1975.

SUMMARY APPRAISALS OF THE NATION'S GROUND-WATER RESOURCES-TEXAS-GULF REGION: USGS PROFESSIONAL PAPER 813-F, 1976.

OCCURRENCE, AVAILABILITY, AND CHEMICAL QUALITY OF GROUND WATER IN THE EDWARDS PLATEAU REGION OF TEXAS: TEXAS DEPARTMENT OF WATER RESOURCES REPORT $235,1979$.

OCCURRENCE AND QUALITY OF GROUND WATER IN THE EDWARDS-TRINITY (PLATEAU) AQUIFER IN THE TRANS-PECOS REGION OF TEXAS: TEXAS DEPARTMENT OF WATER RESOURCES REPORT 255, 1980.

SPRINGS OF TEXAS, VOLUME 1: (BY GUNNAR BRUNE), BRANCHSMITH, INC., FORT WORTH, TEXAS, 1981.

TEXAS GROUND-WATER RESOURCES, in NATIONAL WATER SUMMARY 1984: USGS WATER-SUPPLY PAPER 2275, 1985.

RECORDS OF WELLS, WATER LEVELS, PUMPAGE, AND CHEMICAL ANALYSES FROM SELECTED WELLS IN PARTS OF THE TRANSPECOS REGION, TEXAS, 1968-1980: TEXAS WATER DEVELOPMENT BOARD REPORT 301, 1987.

POTENTIOMETRIC SURFACE OF THE EDWARDS-TRINITY AQUIFER SYSTEM AND CONTIGUOUS HYDRAULICALLY CONNECTED UNITS, WEST-CENTRAL TEXAS, WINTER 1974-75: USGS WATERRESOURCES INVESTIGATIONS REPORT 89-4208, 1990.

WITHDRAWALS FROM THE EDWARDS-TRINITY AQUIFER SYSTEM AND CONTIGUOUS HYDRAULICALLY CONNECTED UNITS, WEST-CENTRAL TEXAS, DECEMBER 1974 THROUGH MARCH 1977: USGS WATER-RESOURCES INVESTIGATIONS REPORT 91-4021, 1991.

CONFIGURATION OF THE BASE OF THE EDWARDS-TRINITY AQUIFER SYSTEM AND HYDROGEOLOGY OF THE UNDERLYING PRECRETACEOUS ROCKS, WEST-CENTRAL TEXAS: USGS WATERRESOURCES INVESTIGATIONS REPORT 91-4071, 1992.

HISTORICAL POTENTIOMETRIC SURFACE OF THE EDWARDS-TRINITY AQUIFER SYSTEM AND CONTIGUOUS HYDRAULICALLY CONNECTED UNITS, WEST-CENTRAL TEXAS: USGS WATERRESOURCES INVESTIGATIONS REPORT 92-4055, 1993.

HISTORICAL SATURATED THICKNESS OF THE EDWARDS-TRINITY AQUIFER SYSTEM AND SELECTED CONTIGUOUS HYDRAULICALLY CONNECTED UNITS, WEST-CENTRAL TEXAS: USGS WATER-RESOURCES INVESTIGATIONS REPORT 92-4125, 1993.

SIMULATIONS OF FLOW IN THE EDWARDS-TRINITY AQUIFER SYSTEM AND CONTIGUOUS HYDRAULICALLY CONNECTED UNITS, WEST-CENTRAL TEXAS: USGS WATER-RESOURCES INVESTIGATIONS REPORT 93-4039, 1994.

DISSOLVED-SOLIDS CONCENTRATIONS AND HYDROCHEMICAL FACIES IN WATER OF THE EDWARDS-TRINITY AQUIFER SYSTEM, WEST-CENTRAL TEXAS: USGS WATER-RESOURCES INVESTIGATIONS REPORT 93-4126, 1994.

GEOLOGIC HISTORY AND HYDROGEOLOGIC SETTING OF THE EDWARDS-TRINITY AQUIFER SYSTEM, WEST-CENTRAL TEXAS:
USGS WATER-RESOURCES INVESTIGATIONS REPORT 94-4039, 1994.

AQUIFERS OF TEXAS: TEXAS WATER DEVELOPMENT BOARD REPORT 345, 1995.

WATER QUALITY IN THE EDWARDS-TRINITY (PLATEAU) AQUIFER, EDWARDS PLATEAU AND TRANS-PECOS, TEXAS: TEXAS WATER DEVELOPMENT BOARD HYDROLOGIC ATLAS NO. 3, 1995.

HYDROGEOLOGIC FRAMEWORK OF THE EDWARDS-TRINITY AQUIFER SYSTEM, WEST-CENTRAL TEXAS: USGS PROFESSIONAL PAPER 1421-B, 1996.

AN OVERVIEW OF THE EDWARDS-TRINITY AQUIFER SYSTEM, CENTRAL-WEST TEXAS, CHAPTER 8, in AQUIFERS OF WEST TEXAS: TEXAS WATER DEVELOPMENT BOARD REPORT 356, 2001.

\section{VAN ZANDT COUNTY}

UNDERGROUND WATERS OF THE COASTAL PLAIN OF TEXAS: USGS WATER-SUPPLY PAPER 335, 1907.

GEOLOGY AND UNDERGROUND WATERS OF THE SOUTHEASTERN PART OF THE TEXAS COASTAL PLAIN: USGS WATER-SUPPLY PAPER 335, 1914.

PUBLIC WATER SUPPLIES IN EASTERN TEXAS, V. 2, HARRISON COUNTY THROUGH WOOD COUNTY: TEXAS BOARD OF WATER ENGINEERS MISCELLANEOUS PUBLICATION 214, V. 2, 1945.

PUBLIC WATER SUPPLIES IN EASTERN TEXAS: USGS WATERSUPPLY PAPER 1047, 1948.

RECONNAISSANCE INVESTIGATION OF THE GROUND-WATER RESOURCES OF THE SABINE RIVER BASIN, TEXAS: TEXAS WATER COMMISSION BULLETIN 6307, 1963.

RECONNAISSANCE INVESTIGATION OF THE GROUND-WATER RESOURCES OF THE NECHES RIVER BASIN, TEXAS: TEXAS WATER COMMISSION BULLETIN 6308, 1963.

RECONNAISSANCE INVESTIGATION OF THE GROUND-WATER RESOURCES OF THE TRINITY RIVER BASIN, TEXAS: TEXAS WATER COMMISSION BULLETIN 6309, 1963.

GROUND-WATER CONDITIONS IN ANDERSON, CHEROKEE, FREESTONE AND HENDERSON COUNTIES, TEXAS: TEXAS WATER DEVELOPMENT BOARD REPORT 150, 1972.

GROUND-WATER RESOURCES OF RAINS AND VAN ZANDT COUNTIES, TEXAS: TEXAS WATER DEVELOPMENT BOARD REPORT $169,1973$.

MAJOR AND HISTORICAL SPRINGS OF TEXAS: TEXAS WATER DEVELOPMENT BOARD REPORT 189, 1975.

SUMMARY APPRAISALS OF THE NATION'S GROUND-WATER RESOURCES-TEXAS-GULF REGION: USGS PROFESSIONAL PAPER 813-F, 1976.

WATER-QUALITY DATA FOR AQUIFERS, STREAMS, AND LAKES IN THE VICINITY OF KEECHI, MOUNT SYLVAN, OAKWOOD, AND PALESTINE SALT DOMES, NORTHEAST TEXAS SALT-DOME BASIN: USGS OPEN-FILE REPORT 80-2037, 1980

GEOHYDROLOGY OF THE KEECHI, MOUNT SYLVAN, OAKWOOD, AND PALESTINE SALT DOMES IN THE NORTHEAST TEXAS SALTDOME BASIN: USGS OPEN-FILE REPORT 80-2044, 1980. 
GEOLOGY AND GEOHYDROLOGY OF THE EAST TEXAS BASIN-A REPORT ON THE PROGRESS OF NUCLEAR WASTE ISOLATION FEASIBILITY STUDIES (1979): UNIVERSITY OF TEXAS, BUREAU OF ECONOMIC GEOLOGY GEOLOGICAL CIRCULAR 80-12, 1980.

GEOLOGY AND GEOHYDROLOGY OF THE EAST TEXAS BASIN-A REPORT ON THE PROGRESS OF NUCLEAR WASTE ISOLATION FEASIBILITY STUDIES (1980): UNIVERSITY OF TEXAS, BUREAU OF ECONOMIC GEOLOGY GEOLOGICAL CIRCULAR 81-7, 1981.

SPRINGS OF TEXAS, VOLUME 1: (BY GUNNAR BRUNE), BRANCHSMITH, INC., FORT WORTH, TEXAS, 1981.

TEXAS GROUND-WATER RESOURCES, in NATIONAL WATER SUMMARY 1984: USGS WATER-SUPPLY PAPER 2275, 1985.

APPROXIMATE POTENTIOMETRIC SURFACES FOR THE AQUIFERS OF THE TEXAS COASTAL UPLANDS SYSTEM, 1980: USGS HYDROLOGIC INVESTIGATIONS ATLAS HA-704, 1987.

GEOHYDROLOGIC FRAMEWORK OF THE GULF COASTAL PLAIN: USGS HYDROLOGIC INVESTIGATIONS ATLAS HA-695, 1988.

HYDROGEOLOGY AND PREDEVELOPMENT FLOW IN THE TEXAS GULF COAST AQUIFER SYSTEMS: USGS WATER-RESOURCES INVESTIGATIONS REPORT 87-4248, 1988.

GROUND-WATER FLOW IN THE GULF COAST AQUIFER SYSTEMS, SOUTH-CENTRAL UNITED STATES-A PRELIMINARY ANALYSIS: USGS WATER-RESOURCES INVESTIGATIONS REPORT 89-4071, 1990.

NATIONAL WATER-QUALITY ASSESSMENT PROGRAM-THE TRINITY RIVER BASIN: USGS OPEN-FILE REPORT 91-158, 1991.

HYDROLOGY OF THE TEXAS GULF COAST AQUIFER SYSTEMS: USGS OPEN-FILE REPORT 91-64, 1991.

PROPERTIES AND CHEMICAL CONSTITUENTS IN GROUND WATER FROM THE LOWER CLAIBORNE-UPPER WILCOX AQUIFER, GULF COAST REGIONAL AQUIFER SYSTEMS, SOUTH-CENTRAL UNITED STATES: USGS WATER-RESOURCES INVESTIGATIONS REPORT 92-4102, 1993.

PROPERTIES AND CHEMICAL CONSTITUENTS IN GROUND WATER FROM THE MIDDLE CLAIBORNE AQUIFER, GULF COAST REGIONAL AQUIFER SYSTEMS, SOUTH-CENTRAL UNITED STATES: USGS WATER-RESOURCES INVESTIGATIONS REPORT 92-4104, 1993.

PROPERTIES AND CHEMICAL CONSTITUENTS IN GROUND WATER FROM THE MIDDLE WILCOX AQUIFER, GULF COAST AQUIFER SYSTEMS, SOUTH-CENTRAL UNITED STATES: USGS WATERRESOURCES INVESTIGATIONS REPORT 93-4070, 1993.

NATIONAL WATER-QUALITY ASSESSMENT PROGRAM-PESTICIDES IN THE TRINITY RIVER BASIN STUDY UNIT, TEXAS, 1968-91: USGS FACT SHEET FS-088-95, 1995.

WATER-QUALITY ASSESSMENT OF THE TRINITY RIVER BASIN, TEXAS-DATA COLLECTION, 1992-95: USGS FACT SHEET FS-095-95, 1995.

WATER-QUALITY ASSESSMENT OF THE TRINITY RIVER BASIN, TEXAS-PESTICIDES IN A SUBURBAN WATERSHED, ARLINGTON, 1993-94: USGS FACT SHEET FS-159-95, 1995.

STRATIGRAPHIC NOMENCLATURE AND GEOLOGIC SECTIONS OF THE GULF COASTAL PLAIN OF TEXAS: USGS OPEN-FILE REPORT 94-461, 1995.
AQUIFERS OF TEXAS: TEXAS WATER DEVELOPMENT BOARD REPORT 345, 1995.

WATER QUALITY IN THE QUEEN CITY AQUIFER, EAST TEXAS: TEXAS WATER DEVELOPMENT BOARD HYDROLOGIC ATLAS NO. 6, 1996.

WATER-QUALITY ASSESSMENT OF THE TRINITY RIVER BASIN, TEXAS-GROUND-WATER QUALITY OF THE TRINITY, CARRIZOWILCOX, AND GULF COAST AQUIFERS, FEBRUARY-AUGUST 1994: USGS WATER-RESOURCES INVESTIGATIONS REPORT 99-4233, 2000.

\section{VICTORIA COUNTY}

ARTESIAN WELLS OF THE COASTAL PRAIRIE REGION AND TERTIARY BELT OF TEXAS: GEOLOGICAL SURVEY OF TEXAS, CHAPTER 2, 1893.

UNDERGROUND WATERS OF THE COASTAL PLAIN OF TEXAS: USGS WATER-SUPPLY PAPER 190, 1907.

RECORDS OF WELLS, DRILLERS' LOGS, WATER ANALYSES, AND MAP SHOWING LOCATION OF WELLS IN VICTORIA COUNTY, TEXAS: TEXAS BOARD OF WATER ENGINEERS MISCELLANEOUS PUBLICATION 287, 1940.

VICTORIA WATER SUPPLY: USGS OPEN-FILE REPORT (UNNUMBERED), 1941.

PUBLIC WATER SUPPLIES IN SOUTHERN TEXAS: TEXAS BOARD OF WATER ENGINEERS MISCELLANEOUS PUBLICATION 215, 1946.

PUBLIC WATER SUPPLIES IN SOUTHERN TEXAS: USGS WATERSUPPLY PAPER 1070, 1950.

AVAILABILITY OF GROUND WATER IN THE GULF COAST REGION OF TEXAS: USGS OPEN-FILE REPORT (UNNUMBERED), 1956.

GROUND-WATER RESOURCES OF VICTORIA AND CALHOUN COUNTIES, TEXAS: TEXAS WATER COMMISSION BULLETIN 6202, 1962

RECONNAISSANCE INVESTIGATION OF THE GROUND-WATER RESOURCES OF THE GULF COAST REGION, TEXAS: TEXAS WATER COMMISSION BULLETIN 6305, 1963.

INVESTIGATION OF GROUND-WATER CONTAMINATION OF COLETO CREEK OIL FIELD, VICTORIA COUNTY, TEXAS: TEXAS WATER COMMISSION LIMITED DISTRIBUTION REPORT LD-564-MR, 1964.

RECONNAISSANCE INVESTIGATION OF THE GROUND-WATER RESOURCES OF THE GUADALUPE, SAN ANTONIO, AND NUECES RIVER BASINS, TEXAS: TEXAS WATER COMMISSION BULLETIN 6409,1964

GEOHYDROLOGIC SIGNIFICANCE OF LITHOFACIES OF THE COCKFIELD FORMATION OF LOUISIANA AND MISSISSIPPI AND OF THE YEGUA FORMATION OF TEXAS: USGS PROFESSIONAL PAPER 569-B, 1970.

SUMMARY APPRAISALS OF THE NATION'S GROUND-WATER RESOURCES-TEXAS-GULF REGION: USGS PROFESSIONAL PAPER 813-F, 1976.

STRATIGRAPHIC AND HYDROGEOLOGIC FRAMEWORK OF PART OF THE COASTAL PLAIN OF TEXAS: USGS OPEN-FILE REPORT $77-712,1978$ 
STRATIGRAPHIC AND HYDROGEOLOGIC FRAMEWORK OF PART OF THE COASTAL PLAIN OF TEXAS: TEXAS DEPARTMENT OF WATER RESOURCES REPORT 236, 1979.

LAND-SURFACE SUBSIDENCE IN THE TEXAS COASTAL REGION: USGS OPEN-FILE REPORT 80-969, 1980.

REGIONAL HYDRODYNAMICS AND HYDROCHEMISTRY OF THE URANIUM-BEARING OAKVILLE AQUIFER (MIOCENE) OF SOUTH TEXAS: UNIVERSITY OF TEXAS, BUREAU OF ECONOMIC GEOLOGY REPORT OF INVESTIGATIONS NO. 124, 1982.

LAND-SURFACE SUBSIDENCE IN THE TEXAS COASTAL REGION: TEXAS DEPARTMENT OF WATER RESOURCES REPORT 272, 1982.

TEXAS GROUND-WATER RESOURCES, in NATIONAL WATER SUMMARY 1984: USGS WATER-SUPPLY PAPER 2275, 1985.

DIGITAL MODELS FOR SIMULATION OF GROUND-WATER HYDROLOGY OF THE CHICOT AND EVANGELINE AQUIFERS ALONG THE GULF COAST OF TEXAS: TEXAS DEPARTMENT OF WATER RESOURCES REPORT 289, 1985.

WATER USE, PROJECTED WATER REQUIREMENTS, AND RELATED DATA AND INFORMATION FOR THE METROPOLITAN STATISTICAL AREAS IN TEXAS: TEXAS DEPARTMENT OF WATER RESOURCES LIMITED PRINTING REPORT LP-201, 1985.

GEOHYDROLOGIC FRAMEWORK OF THE GULF COASTAL PLAIN: USGS HYDROLOGIC INVESTIGATIONS ATLAS HA-695, 1988.

HYDROGEOLOGY AND PREDEVELOPMENT FLOW IN THE TEXAS GULF COAST AQUIFER SYSTEMS: USGS WATER-RESOURCES INVESTIGATIONS REPORT 87-4248, 1988.

GROUND-WATER FLOW IN THE GULF COAST AQUIFER SYSTEMS, SOUTH-CENTRAL UNITED STATES-A PRELIMINARY ANALYSIS: USGS WATER-RESOURCES INVESTIGATIONS REPORT 89-4071, 1990.

HYDROLOGY OF THE TEXAS GULF COAST AQUIFER SYSTEMS: USGS OPEN-FILE REPORT 91-64, 1991.

PROPERTIES AND CHEMICAL CONSTITUENTS IN GROUND WATER FROM THE MISSISSIPPI RIVER VALLEY ALLUVIAL AQUIFER AND PERMEABLE ZONE A (HOLOCENE-UPPER PLEISTOCENE DEPOSITS), SOUTH-CENTRAL UNITED STATES: USGS WATERRESOURCES INVESTIGATIONS REPORT 91-4149, 1992.

PROPERTIES AND CHEMICAL CONSTITUENTS IN GROUND WATER FROM THE UPPER CLAIBORNE AQUIFER, GULF COAST REGIONAL AQUIFER SYSTEMS, SOUTH-CENTRAL UNITED STATES: USGS WATER-RESOURCES INVESTIGATIONS REPORT 91-4150, 1993.

PROPERTIES AND CHEMICAL CONSTITUENTS IN GROUND WATER FROM PERMEABLE ZONE C (LOWER PLIOCENE-UPPER MIOCENE DEPOSITS), COASTAL LOWLANDS AQUIFER SYSTEM, SOUTHCENTRAL UNITED STATES: USGS WATER-RESOURCES INVESTIGATIONS REPORT 91-4151, 1993.

PROPERTIES AND CHEMICAL CONSTITUENTS IN GROUND WATER FROM PERMEABLE ZONE B (LOWER PLEISTOCENE-UPPER PLIOCENE DEPOSITS), COASTAL LOWLANDS AQUIFER SYSTEM, SOUTH-CENTRAL UNITED STATES: USGS WATER-RESOURCES INVESTIGATIONS REPORT 91-4152, 1993.

PROPERTIES AND CHEMICAL CONSTITUENTS IN GROUND WATER FROM PERMEABLE ZONE E (LOWER MIOCENE-UPPER OLIGOCENE DEPOSITS), COASTAL LOWLANDS AQUIFER SYSTEM,
SOUTH-CENTRAL UNITED STATES: USGS WATER-RESOURCES INVESTIGATIONS REPORT 92-4103, 1993.

PROPERTIES AND CHEMICAL CONSTITUENTS IN GROUND WATER FROM PERMEABLE ZONE D (MIDDLE MIOCENE DEPOSITS), COASTAL LOWLANDS AQUIFER SYSTEM, SOUTH-CENTRAL UNITED STATES: USGS WATER-RESOURCES INVESTIGATIONS REPORT 92-4105, 1993.

PROPERTIES AND CHEMICAL CONSTITUENTS IN GROUND WATER FROM THE MIDDLE WILCOX AQUIFER, GULF COAST AQUIFER SYSTEMS, SOUTH-CENTRAL UNITED STATES: USGS WATERRESOURCES INVESTIGATIONS REPORT 93-4070, 1993.

AQUIFERS OF TEXAS: TEXAS WATER DEVELOPMENT BOARD REPORT 345, 1995.

\section{WALKER COUNTY}

UNDERGROUND WATERS OF THE COASTAL PLAIN OF TEXAS: USGS WATER-SUPPLY PAPER 190, 1907.

GEOLOGY AND UNDERGROUND WATERS OF THE SOUTHEASTERN PART OF THE TEXAS COASTAL PLAIN: USGS WATER-SUPPLY PAPER 335, 1914.

PUBLIC WATER SUPPLIES IN EASTERN TEXAS, V. 2, HARRISON COUNTY THROUGH WOOD COUNTY: TEXAS BOARD OF WATER ENGINEERS MISCELLANEOUS PUBLICATION 214, V. 2, 1945.

PUBLIC WATER SUPPLIES IN EASTERN TEXAS: USGS WATERSUPPLY PAPER 1047, 1948

GEOLOGY AND GROUND-WATER RESOURCES OF WALKER COUNTY, TEXAS: TEXAS BOARD OF WATER ENGINEERS BULLETIN 5003, 1950

WATER SUPPLY OF THE HOUSTON GULF COAST REGION: TEXAS BOARD OF WATER ENGINEERS BULLETIN 5101, 1951.

AVAILABILITY OF GROUND WATER IN THE GULF COAST REGION OF TEXAS: USGS OPEN-FILE REPORT (UNNUMBERED), 1956.

RECONNAISSANCE INVESTIGATION OF THE GROUND-WATER RESOURCES OF THE GULF COAST REGION, TEXAS: TEXAS WATER COMMISSION BULLETIN 6305, 1963.

RECONNAISSANCE INVESTIGATION OF THE GROUND-WATER RESOURCES OF THE TRINITY RIVER BASIN, TEXAS: TEXAS WATER COMMISSION BULLETIN 6309, 1963.

HYDROLOGIC SIGNIFICANCE OF THE LITHOFACIES OF THE SPARTA SAND IN ARKANSAS, LOUISIANA, MISSISSIPPI, AND TEXAS: USGS PROFESSIONAL PAPER 569-A, 1968.

GEOHYDROLOGIC SIGNIFICANCE OF LITHOFACIES OF THE COCKFIELD FORMATION OF LOUISIANA AND MISSISSIPPI AND OF THE YEGUA FORMATION OF TEXAS: USGS PROFESSIONAL PAPER 569-B, 1970.

HYDROLOGIC SIGNIFICANCE OF LITHOFACIES OF THE CANE RIVER FORMATION OR EQUIVALENTS OF ARKANSAS, LOUISIANA, MISSISSIPPI, AND TEXAS: USGS PROFESSIONAL PAPER 569-C, 1972.

HYDROLOGIC SIGNIFICANCE OF LITHOFACIES OF THE CARRIZO SAND OF ARKANSAS, LOUISIANA, AND TEXAS AND THE MERIDIAN SAND OF MISSISSIPPI: USGS PROFESSIONAL PAPER 569-D, 1975. 
SUMMARY APPRAISALS OF THE NATION'S GROUND-WATER RESOURCES-TEXAS-GULF REGION: USGS PROFESSIONAL PAPER 813-F, 1976.

APPROXIMATE AREAS OF RECHARGE TO THE CHICOT AND EVANGELINE AQUIFER SYSTEMS IN THE HOUSTON-GALVESTON AREA, TEXAS: USGS OPEN-FILE REPORT 77-754, 1977.

STRATIGRAPHIC AND HYDROGEOLOGIC FRAMEWORK OF PART OF THE COASTAL PLAIN OF TEXAS: USGS OPEN-FILE REPORT 77-712, 1978.

TEXAS GROUND-WATER RESOURCES, in NATIONAL WATER SUMMARY 1984: USGS WATER-SUPPLY PAPER 2275, 1985.

HYDROLOGY OF THE JASPER AQUIFER IN THE SOUTHEAST TEXAS COASTAL PLAIN: TEXAS WATER DEVELOPMENT BOARD REPORT 295, 1986.

APPROXIMATE POTENTIOMETRIC SURFACES FOR THE AQUIFERS OF THE TEXAS COASTAL UPLANDS SYSTEM, 1980: USGS HYDROLOGIC INVESTIGATIONS ATLAS HA-704, 1987.

GEOHYDROLOGIC FRAMEWORK OF THE GULF COASTAL PLAIN: USGS HYDROLOGIC INVESTIGATIONS ATLAS HA-695, 1988.

HYDROGEOLOGY AND PREDEVELOPMENT FLOW IN THE TEXAS GULF COAST AQUIFER SYSTEMS: USGS WATER-RESOURCES INVESTIGATIONS REPORT 87-4248, 1988.

GEOHYDROLOGIC FRAMEWORK OF THE GULF COASTAL PLAIN: USGS HYDROLOGIC INVESTIGATIONS ATLAS HA-695, 1988.

GROUND-WATER FLOW IN THE GULF COAST AQUIFER SYSTEMS, SOUTH-CENTRAL UNITED STATES-A PRELIMINARY ANALYSIS: USGS WATER-RESOURCES INVESTIGATIONS REPORT 89-4071, 1990.

NATIONAL WATER-QUALITY ASSESSMENT PROGRAM-THE TRINITY RIVER BASIN: USGS OPEN-FILE REPORT 91-158, 1991.

PROPERTIES AND CHEMICAL CONSTITUENTS IN GROUND WATER FROM THE UPPER CLAIBORNE AQUIFER, GULF COAST REGIONAL AQUIFER SYSTEMS, SOUTH-CENTRAL UNITED STATES: USGS WATER-RESOURCES INVESTIGATIONS REPORT 91-4150, 1993.

PROPERTIES AND CHEMICAL CONSTITUENTS IN GROUND WATER FROM PERMEABLE ZONE C (LOWER PLIOCENE-UPPER MIOCENE DEPOSITS), COASTAL LOWLANDS AQUIFER SYSTEM, SOUTHCENTRAL UNITED STATES: USGS WATER-RESOURCES INVESTIGATIONS REPORT 91-4151, 1993.

PROPERTIES AND CHEMICAL CONSTITUENTS IN GROUND WATER FROM PERMEABLE ZONE E (LOWER MIOCENE-UPPER OLIGOCENE DEPOSITS), COASTAL LOWLANDS AQUIFER SYSTEM, SOUTH-CENTRAL UNITED STATES: USGS WATER-RESOURCES INVESTIGATIONS REPORT 92-4103, 1993.

PROPERTIES AND CHEMICAL CONSTITUENTS IN GROUND WATER FROM THE MIDDLE CLAIBORNE AQUIFER, GULF COAST REGIONAL AQUIFER SYSTEMS, SOUTH-CENTRAL UNITED STATES: USGS WATER-RESOURCES INVESTIGATIONS REPORT 92-4104, 1993.

PROPERTIES AND CHEMICAL CONSTITUENTS IN GROUND WATER FROM PERMEABLE ZONE D (MIDDLE MIOCENE DEPOSITS), COASTAL LOWLANDS AQUIFER SYSTEM, SOUTH-CENTRAL UNITED STATES: USGS WATER-RESOURCES INVESTIGATIONS REPORT 92-4105, 1993.
PROPERTIES AND CHEMICAL CONSTITUENTS IN GROUND WATER FROM THE MIDDLE WILCOX AQUIFER, GULF COAST AQUIFER SYSTEMS, SOUTH-CENTRAL UNITED STATES: USGS WATERRESOURCES INVESTIGATIONS REPORT 93-4070, 1993.

WATER-RESOURCES DATA, TEXAS, WATER YEAR 1993, VOLUME 4, GROUND-WATER DATA: USGS WATER-DATA REPORT TX-93-4, 1994.

NATIONAL WATER-QUALITY ASSESSMENT PROGRAM-PESTICIDES IN THE TRINITY RIVER BASIN STUDY UNIT, TEXAS, 1968-91: USGS FACT SHEET FS-088-95, 1995.

WATER-QUALITY ASSESSMENT OF THE TRINITY RIVER BASIN, TEXAS-DATA COLLECTION, 1992-95: USGS FACT SHEET FS-095-95, 1995.

WATER-QUALITY ASSESSMENT OF THE TRINITY RIVER BASIN, TEXAS-PESTICIDES IN A SUBURBAN WATERSHED, ARLINGTON, 1993-94: USGS FACT SHEET FS-159-95, 1995.

AQUIFERS OF TEXAS: TEXAS WATER DEVELOPMENT BOARD REPORT 345, 1995.

WATER-RESOURCES DATA, TEXAS, WATER YEAR 1994, VOLUME 4 , GROUND-WATER DATA: USGS WATER-DATA REPORT TX-94-4, 1995.

WATER QUALITY IN THE SPARTA AQUIFER, EAST TEXAS: TEXAS WATER DEVELOPMENT BOARD HYDROLOGIC ATLAS NO. 5, 1996.

WATER QUALITY IN THE QUEEN CITY AQUIFER, EAST TEXAS: TEXAS WATER DEVELOPMENT BOARD HYDROLOGIC ATLAS NO. 6, 1996.

WATER-RESOURCES DATA, TEXAS, WATER YEAR 1995, VOLUME 4, GROUND-WATER DATA: USGS WATER-DATA REPORT TX-95-4, 1996.

ESTIMATED RATE OF RECHARGE IN OUTCROPS OF THE CHICOT AND EVANGELINE AQUIFERS NEAR HOUSTON, TEXAS: USGS FACT SHEET FS-179-97, 1997.

WATER-RESOURCES DATA, TEXAS, WATER YEAR 1996, VOLUME 4, GROUND-WATER DATA: USGS WATER-DATA REPORT TX-96-4, 1997.

WATER-RESOURCES DATA, TEXAS, WATER YEAR 1997, VOLUME 4, GROUND-WATER DATA: USGS WATER-DATA REPORT TX-97-4, 1998.

WATER-RESOURCES DATA, TEXAS, WATER YEAR 1998, VOLUME 4, GROUND-WATER DATA: USGS WATER-DATA REPORT TX-98-4, 1999.

WATER-RESOURCES DATA, TEXAS, WATER YEAR 1999, VOLUME 6, GROUND-WATER DATA: USGS WATER-DATA REPORT TX-99-6, 2000.

WATER-RESOURCES DATA, TEXAS, WATER YEAR 2000, VOLUME 6, GROUND-WATER DATA: USGS WATER-DATA REPORT TX-00-6, 2001.

\section{WALLER COUNTY}

UNDERGROUND WATERS OF COASTAL PLAIN OF TEXAS: USGS WATER SUPPLY AND IRRIGATION PAPER 190, 1907. 
GEOLOGY AND UNDERGROUND WATERS OF THE SOUTHEASTERN PART OF THE TEXAS COASTAL PLAIN: USGS WATER-SUPPLY PAPER 335, 1914.

GROUND-WATER RESOURCES OF THE HOUSTON-GALVESTON AREA, TEXAS: USGS OPEN-FILE REPORT (UNNUMBERED) (PRESS RELEASE), 1932.

GROUND-WATER RESOURCES IN THE HOUSTON DISTRICT, TEXAS: USGS OPEN-FILE REPORT, 1933.

RECORDS OF WELLS IN HARRIS, GALVESTON, WALLER, FORT BEND, BRAZORIA, AND GRIMES COUNTIES, TEXAS: USGS OPENFILE REPORT, 1935.

PROGRESS REPORT ON THE GROUND-WATER RESOURCES OF THE HOUSTON DISTRICT, TEXAS: TEXAS BOARD OF WATER ENGINEERS MISCELLANEOUS PUBLICATION 128, 1937.

PROGRESS REPORT ON THE GROUND-WATER RESOURCES OF THE HOUSTON DISTRICT, TEXAS: TEXAS BOARD OF WATER ENGINEERS MISCELLANEOUS PUBLICATION 129, 1938.

PROGRESS REPORT ON THE GROUND-WATER RESOURCES OF THE HOUSTON DISTRICT, TEXAS: TEXAS BOARD OF WATER ENGINEERS MISCELLANEOUS PUBLICATION 130, 1939.

RECORDS OF WELLS, DRILLERS' LOGS, WATER ANALYSES, AND MAP SHOWING LOCATION OF WELLS IN WALLER COUNTY, TEXAS: TEXAS BOARD OF WATER ENGINEERS MISCELLANEOUS PUBLICATION 289, 1939.

RECORDS OF WELLS, DRILLERS' LOGS, WATER ANALYSES, AND MAP SHOWING LOCATION OF WELLS IN BRAZORIA AND FORT BEND COUNTIES (EAST OF BRAZOS RIVER), GALVESTON, GRIMES, HARRIS, MONTGOMERY, AND WALLER COUNTIES, TEXAS: TEXAS BOARD OF WATER ENGINEERS MISCELLANEOUS PUBLICATION (UNNUMBERED), 1939.

GROUND-WATER RESOURCES OF THE HOUSTON-GALVESTON AREA AND ADJACENT REGION, TEXAS: TEXAS BOARD OF WATER ENGINEERS MISCELLANEOUS PUBLICATION (UNNUMBERED) (PRESS RELEASE), 1939.

PROGRESS REPORT ON THE GROUND-WATER RESOURCES OF THE HOUSTON DISTRICT: TEXAS BOARD OF WATER ENGINEERS MISCELLANEOUS PUBLICATION 132, 1940.

NOTES ON RECHARGE TEST WELLS-HOUSTON DISTRICT, 1-29-41 AND 1-31-41: USGS OPEN-FILE REPORT (UNNUMBERED), 1941.

PROGRESS REPORT ON THE GROUND-WATER RESOURCES OF THE HOUSTON DISTRICT: TEXAS BOARD OF WATER ENGINEERS MISCELLANEOUS PUBLICATION 134, 1942

GROUND-WATER RESOURCES OF THE HOUSTON DISTRICT, PROGRESS REPORT WITH RECORDS OF WELLS, PUMPAGE, WATER-LEVEL FLUCTUATIONS IN WELLS, AND WELL ANALYSES; HARRIS COUNTY AND ADJOINING PARTS OF FORT BEND AND WALLER COUNTIES, TEXAS: TEXAS BOARD OF WATER ENGINEERS MISCELLANEOUS PUBLICATION 133, 1942.

GROUND WATER AND THE RELATION OF GEOLOGY TO ITS OCCURRENCE IN THE HOUSTON DISTRICT, TEXAS: USGS OPEN-FILE REPORT (UNNUMBERED), 1942.

ESTIMATED INCREASE OF PUMPAGE AND DECLINE OF WATER LEVELS IN WELLS IN THE HOUSTON DISTRICT DURING 1943: USGS OPEN-FILE REPORT (UNNUMBERED), 1943.

GROUND-WATER RESOURCES OF THE HOUSTON DISTRICT, TEXAS: USGS WATER-SUPPLY PAPER 889-C, 1944.
PROGRESS REPORT ON THE GROUND-WATER RESOURCES OF THE HOUSTON DISTRICT: TEXAS BOARD OF WATER ENGINEERS MISCELLANEOUS PUBLICATION 137, 1944.

PUBLIC WATER SUPPLIES IN EASTERN TEXAS, V. 2, HARRISON COUNTY THROUGH WOOD COUNTY: TEXAS BOARD OF WATER ENGINEERS MISCELLANEOUS PUBLICATION 214, V. 2, 1945.

GROUND-WATER RESOURCES OF THE HOUSTON DISTRICT, TEXAS, PROGRESS REPORT FOR 1946, WITH SECTION ON RESULTS OF PUMPING TESTS AT NEW SOUTHWEST PUMPING PLANT: TEXAS BOARD OF WATER ENGINEERS MISCELLANEOUS PUBLICATION 138,1946

PUBLIC WATER SUPPLIES IN EASTERN TEXAS: USGS WATERSUPPLY PAPER 1047, 1948

MEMORANDUM REGARDING AVAILABILITY OF GROUND WATER IN AN AREA ADJACENT TO THE BRAZOS RIVER NEAR HEMPSTEAD, TEXAS: USGS OPEN-FILE REPORT (UNNUMBERED), 1950.

GEOLOGY AND GROUND-WATER RESOURCES OF THE HOUSTON DISTRICT: TEXAS BOARD OF WATER ENGINEERS BULLETIN 5001,1950

WATER SUPPLY OF THE HOUSTON GULF COAST REGION: TEXAS BOARD OF WATER ENGINEERS BULLETIN 5101, 1951.

THE HOUSTON DISTRICT, TEXAS, PUMPAGE AND DECLINE OF ARTESIAN PRESSURE DURING 1950-1951: TEXAS BOARD OF WATER ENGINEERS BULLETIN 5201, 1952.

WATER RESOURCES OF WALLER COUNTY, TEXAS: TEXAS BOARD OF WATER ENGINEERS BULLETIN, 5208, 1952,

PUMPAGE OF GROUND WATER AND DECLINE OF ARTESIAN PRESSURE IN THE HOUSTON DISTRICT, TEXAS, DURING 1951 AND 1952: TEXAS BOARD OF WATER ENGINEERS BULLETIN 5401, 1954.

PUMPAGE OF GROUND WATER AND CHANGES IN ARTESIAN PRESSURE IN THE HOUSTON DISTRICT AND BAYTOWN-LA PORTE AREA, TEXAS, 1953-55: TEXAS BOARD OF WATER ENGINEERS BULLETIN 5602, 1956.

AVAILABILITY OF GROUND WATER IN THE GULF COAST REGION OF TEXAS: USGS OPEN-FILE REPORT (UNNUMBERED), 1956.

RECORDS OF WATER-LEVEL MEASUREMENTS IN BRAZORIA, FORT BEND, AND WALLER COUNTIES, TEXAS, 1931 THROUGH JUNE 1958: TEXAS BOARD OF WATER ENGINEERS BULLETIN 5904, 1959.

RECONNAISSANCE INVESTIGATION OF THE GROUND-WATER RESOURCES OF THE GULF COAST REGION, TEXAS: TEXAS WATER COMMISSION BULLETIN 6305, 1963.

ANALOG MODEL STUDY OF GROUND WATER IN THE HOUSTON DISTRICT, TEXAS: TEXAS WATER COMMISSION BULLETIN 6508, 1965.

GROUND WATER IN THE FLOOD-PLAIN ALLUVIUM OF THE BRAZOS RIVER, WHITNEY DAM TO VICINITY OF RICHMOND, TEXAS: TEXAS WATER DEVELOPMENT BOARD REPORT 41, 1967.

DEVELOPMENT OF GROUND WATER IN THE HOUSTON DISTRICT, TEXAS, 1961-65: TEXAS WATER DEVELOPMENT BOARD REPORT 63, 1967.

GROUND-WATER RESOURCES OF AUSTIN AND WALLER COUNTIES, TEXAS: TEXAS WATER DEVELOPMENT BOARD REPORT 68, 1967. 
HYDROLOGIC SIGNIFICANCE OF THE LITHOFACIES OF THE SPARTA SAND IN ARKANSAS, LOUISIANA, MISSISSIPPI, AND TEXAS: USGS PROFESSIONAL PAPER 569-A, 1968.

COMPILATION OF RESULTS OF AQUIFER TESTS IN TEXAS: TEXAS WATER DEVELOPMENT BOARD REPORT 98, 1969.

DEVELOPMENT OF GROUND WATER IN THE HOUSTON DISTRICT, TEXAS, 1966-69: TEXAS WATER DEVELOPMENT BOARD REPORT 152, 1972.

GEOHYDROLOGIC SIGNIFICANCE OF LITHOFACIES OF THE COCKFIELD FORMATION OF LOUISIANA AND MISSISSIPPI AND OF THE YEGUA FORMATION OF TEXAS: USGS PROFESSIONAL PAPER 569-B, 1970.

HYDROLOGIC SIGNIFICANCE OF LITHOFACIES OF THE CANE RIVER FORMATION OR EQUIVALENTS OF ARKANSAS, LOUISIANA, MISSISSIPPI, AND TEXAS: USGS PROFESSIONAL PAPER 569-C, 1972.

HYDROLOGIC SIGNIFICANCE OF LITHOFACIES OF THE CARRIZO SAND OF ARKANSAS, LOUISIANA, AND TEXAS AND THE MERIDIAN SAND OF MISSISSIPPI: USGS PROFESSIONAL PAPER 569-D, 1975.

SUMMARY APPRAISALS OF THE NATION'S GROUND-WATER RESOURCES-TEXAS GULF REGION: USGS PROFESSIONAL PAPER 813-F, 1976.

STRATIGRAPHIC AND HYDROGEOLOGIC FRAMEWORK OF PART OF THE COASTAL PLAIN OF TEXAS: USGS OPEN-FILE REPORT 77-712, 1978.

STRATIGRAPHIC AND HYDROGEOLOGIC FRAMEWORK OF PART OF THE COASTAL PLAIN OF TEXAS: TEXAS DEPARTMENT OF WATER RESOURCES REPORT 236, 1979.

APPROXIMATE ALTITUDE OF WATER LEVELS IN WELLS IN THE CHICOT AND EVANGELINE AQUIFERS IN THE HOUSTON AREA, TEXAS, SPRING 1977 AND SPRING 1978: USGS OPEN-FILE REPORT 79-334, 1979.

APPROXIMATE WATER-LEVEL CHANGES IN WELLS IN THE CHICOT AND EVANGELINE AQUIFERS IN THE HOUSTON-GALVESTON REGION, TEXAS, 1977-80 AND 1979-80: USGS OPEN-FILE REPORT 80-337, 1980.

APPROXIMATE LAND-SURFACE SUBSIDENCE IN THE HOUSTONGALVESTON REGION, TEXAS, 1906-78, 1943-78, AND 1973-78: USGS OPEN-FILE REPORT 80-338, 1980.

APPROXIMATE ALTITUDE OF WATER LEVELS IN WELLS IN THE CHICOT AND EVANGELINE AQUIFERS IN THE HOUSTON AREA, TEXAS, SPRING 1979 AND SPRING 1980: USGS OPEN-FILE REPORT 80-579, 1980.

DEVELOPMENT OF GROUND WATER IN THE HOUSTONGALVESTON DISTRICT, TEXAS, 1970-74: TEXAS DEPARTMENT OF WATER RESOURCES REPORT 241, 1980.

APPROXIMATE WATER-LEVEL CHANGES IN WELLS IN THE CHICOT AND EVANGELINE AQUIFERS, 1977-81 AND 1980-81, AND MEASURED COMPACTION, 1973-81, IN THE HOUSTON-GALVESTON REGION, TEXAS: USGS OPEN-FILE REPORT 81-341, 1981.

SPRINGS OF TEXAS, VOLUME 1: (BY GUNNAR BRUNE), BRANCHSMITH, INC., FORT WORTH, TEXAS, 1981.

APPROXIMATE ALTITUDE OF WATER LEVELS IN THE CHICOT AND EVANGELINE AQUIFERS IN THE HOUSTON AREA, TEXAS, SPRING 1981: USGS OPEN-FILE REPORT 81-676, 1981.
APPROXIMATE WATER-LEVEL CHANGES IN WELLS IN THE CHICOT AND EVANGELINE AQUIFERS, 1977-82 AND 1981-82, AND MEASURED COMPACTION, 1973-82, IN THE HOUSTON-GALVESTON REGION, TEXAS: USGS OPEN-FILE REPORT 82-328, 1982.

GROUND-WATER WITHDRAWALS AND CHANGES IN WATER LEVELS IN THE HOUSTON DISTRICT, 1975-79: USGS OPEN-FILE REPORT 82-431, 1982.

APPROXIMATE ALTITUDE OF WATER LEVELS IN WELLS IN THE CHICOT AND EVANGELINE AQUIFERS IN THE HOUSTON AREA, TEXAS, SPRING 1982: USGS OPEN-FILE REPORT 82-559, 1982.

LAND-SURFACE SUBSIDENCE IN THE TEXAS COASTAL REGION: TEXAS DEPARTMENT OF WATER RESOURCES REPORT 272, 1982

REGIONAL HYDRODYNAMICS AND HYDROCHEMISTRY OF THE URANIUM-BEARING OAKVILLE AQUIFER (MIOCENE) OF SOUTH TEXAS: UNIVERSITY OF TEXAS, BUREAU OF ECONOMIC GEOLOGY REPORT OF INVESTIGATIONS NO. 124, 1982.

APPROXIMATE WATER-LEVEL CHANGES IN WELLS IN THE CHICOT AND EVANGELINE AQUIFERS, 1977-83 AND 1982-83, AND MEASURED COMPACTION, 1973-83, IN THE HOUSTON-GALVESTON REGION, TEXAS: USGS OPEN-FILE REPORT 83-150, 1983.

RECORDS OF WELLS, DRILLERS' LOGS, WATER-LEVEL MEASUREMENTS, AND CHEMICAL ANALYSES OF GROUND WATER IN CHAMBERS, LIBERTY, AND MONTGOMERY COUNTIES, TEXAS, 1975-79: TEXAS DEPARTMENT OF WATER RESOURCES REPORT 280, 1983.

APPROXIMATE ALTITUDE OF WATER LEVELS IN WELLS IN THE CHICOT AND EVANGELINE AQUIFERS IN THE HOUSTON AREA, TEXAS, SPRING 1983: USGS OPEN-FILE REPORT 83-529, 1983.

APPROXIMATE WATER-LEVEL CHANGES IN WELLS IN THE CHICOT AND EVANGELINE AQUIFERS, 1977-84 AND 1983-84, AND MEASURED COMPACTION, 1973-84, IN THE HOUSTON-GALVESTON REGION, TEXAS: USGS OPEN-FILE REPORT 84-140, 1984.

APPROXIMATE ALTITUDE OF WATER LEVELS IN WELLS IN THE CHICOT AND EVANGELINE AQUIFERS IN THE HOUSTON AREA, TEXAS, SPRING, 1984: USGS OPEN-FILE REPORT 84-436, 1984.

TEXAS GROUND-WATER RESOURCES, in NATIONAL WATER SUMMARY 1984: USGS WATER-SUPPLY PAPER 2275, 1985.

DIGITAL MODELS FOR SIMULATION OF GROUND-WATER HYDROLOGY OF THE CHICOT AND EVANGELINE AQUIFERS ALONG THE GULF COAST OF TEXAS: TEXAS DEPARTMENT OF WATER RESOURCES REPORT 289, 1985.

WATER USE, PROJECTED WATER REQUIREMENTS, AND RELATED DATA AND INFORMATION FOR THE METROPOLITAN STATISTICAL AREAS IN TEXAS: TEXAS DEPARTMENT OF WATER RESOURCES LIMITED PRINTING REPORT LP-201, 1985.

APPROXIMATE WATER-LEVEL CHANGES IN WELLS IN THE CHICOT AND EVANGELINE AQUIFERS, 1977-85 AND 1984-85, AND MEASURED COMPACTION, 1973-85, IN THE HOUSTON-GALVESTON REGION, TEXAS: USGS OPEN-FILE REPORT 85-158, 1985.

RECORDS OF WELLS, DRILLERS' LOGS, WATER-LEVEL MEASUREMENTS, AND CHEMICAL ANALYSES OF GROUND WATER IN BRAZORIA, FORT BEND, AND WALLER COUNTIES, TEXAS, 1980-84: USGS OPEN-FILE REPORT 86-68, 1986.

APPROXIMATE CHANGES IN WATER LEVELS IN THE CHICOT AND EVANGELINE AQUIFERS, 1977-86 AND 1985-86, AND MEASURED 
COMPACTION, 1973-86, IN THE HOUSTON-GALVESTON REGION, TEXAS: USGS OPEN-FILE REPORT 86-135, 1986.

APPROXIMATE ALTITUDE OF WATER LEVELS IN WELLS IN THE CHICOT AND EVANGELINE AQUIFERS IN THE HOUSTON AREA, TEXAS, SPRING 1986: USGS OPEN-FILE REPORT 86-306, 1986.

HYDROLOGY OF THE JASPER AQUIFER IN THE SOUTHEAST TEXAS COASTAL PLAIN: TEXAS WATER DEVELOPMENT BOARD REPORT 295, 1986

RECORDS OF WELLS, DRILLERS' LOGS, WATER-LEVEL MEASUREMENTS, AND CHEMICAL ANALYSES OF GROUND WATER IN BRAZORIA, FORT BEND, AND WALLER COUNTIES, TEXAS, 1980-84: TEXAS WATER DEVELOPMENT BOARD REPORT 303, 1987.

APPROXIMATE WATER-LEVEL CHANGES IN WELLS COMPLETED IN THE CHICOT AND EVANGELINE AQUIFERS, 1977-87 AND 1986-87, AND MEASURED COMPACTION, 1973-87, IN THE HOUSTONGALVESTON REGION, TEXAS: USGS OPEN-FILE REPORT 87-108, 1987.

APPROXIMATE ALTITUDE OF WATER-LEVELS IN WELLS IN THE CHICOT AND EVANGELINE AQUIFERS IN THE HOUSTON AREA, TEXAS, SPRING 1987: USGS OPEN-FILE REPORT 87-233, 1987.

GEOHYDROLOGIC FRAMEWORK OF THE GULF COASTAL PLAIN: USGS HYDROLOGIC INVESTIGATIONS ATLAS HA-695, 1988.

HYDROGEOLOGY AND PREDEVELOPMENT FLOW IN THE TEXAS GULF COAST AQUIFER SYSTEMS: USGS WATER-RESOURCES INVESTIGATIONS REPORT 87-4248, 1988.

APPROXIMATE WATER-LEVEL CHANGES IN WELLS COMPLETED IN THE CHICOT AND EVANGELINE AQUIFERS, 1977-88 AND 1987-88, AND MEASURED COMPACTION, 1973-88, IN THE HOUSTONGALVESTON REGION, TEXAS: USGS OPEN-FILE REPORT 88-168, 1988.

APPROXIMATE ALTITUDE OF WATER LEVELS IN WELLS IN THE CHICOT AND EVANGELINE AQUIFERS IN THE HOUSTON AREA, TEXAS, SPRING 1988: USGS OPEN-FILE REPORT 88-334, 1988.

APPROXIMATE WATER-LEVEL CHANGE IN WELLS COMPLETED IN THE CHICOT AND EVANGELINE AQUIFERS, 1977-89 AND 1988-89, AND MEASURED COMPACTION, 1973-89, IN THE HOUSTONGALVESTON REGION, TEXAS: USGS OPEN-FILE REPORT 89-057, 1989

APPROXIMATE ALTITUDE OF WATER LEVELS IN WELLS IN THE CHICOT AND EVANGELINE AQUIFERS IN THE HOUSTON AREA, TEXAS, SPRING 1989: USGS OPEN-FILE REPORT 89-237, 1989.

APPROXIMATE WATER-LEVEL CHANGES IN WELLS COMPLETED IN THE CHICOT AND EVANGELINE AQUIFERS, 1977-90 AND 1989-90, AND MEASURED COMPACTION, 1973-DECEMBER 1989, IN THE HOUSTON-GALVESTON REGION, TEXAS: USGS OPEN-FILE REPORT 90-132, 1990.

GROUND-WATER FLOW IN THE GULF COAST AQUIFER SYSTEMS, SOUTH-CENTRAL UNITED STATES-A PRELIMINARY ANALYSIS: USGS WATER-RESOURCES INVESTIGATIONS REPORT 89-4071, 1990.

RECORDS OF WELLS, DRILLERS' LOGS, WATER-LEVEL MEASUREMENTS, AND CHEMICAL ANALYSES OF GROUND WATER IN BRAZORIA, FORT BEND, AND WALLER COUNTIES, TEXAS, 1985-89: USGS OPEN-FILE REPORT 90-588, 1991.
HYDROLOGY OF THE TEXAS GULF COAST AQUIFER SYSTEMS: USGS OPEN-FILE REPORT 91-64, 1991.

APPROXIMATE WATER-LEVEL CHANGES IN WELLS COMPLETED IN THE CHICOT AND EVANGELINE AQUIFERS, 1977-91 AND 1990-91, AND MEASURED COMPACTION, 1973-90, IN THE HOUSTONGALVESTON REGION, TEXAS: USGS OPEN-FILE REPORT 91-094, 1991.

APPROXIMATE ALTITUDE OF WATER LEVELS IN WELLS IN THE CHICOT AND EVANGELINE AQUIFERS IN THE HOUSTON AREA, TEXAS, JANUARY-FEBRUARY 1990: USGS OPEN-FILE REPORT 91-240, 1991.

APPROXIMATE CHANGE IN WATER LEVELS IN WELLS COMPLETED IN THE CHICOT AND EVANGELINE AQUIFERS, 1977-92 AND 1991-92, AND MEASURED COMPACTION, 1973-91, IN THE HOUSTON-GALVESTON REGION, TEXAS: USGS OPEN-FILE REPORT 92-066, 1992.

PROPERTIES AND CHEMICAL CONSTITUENTS IN GROUND WATER FROM THE MISSISSIPPI RIVER VALLEY ALLUVIAL AQUIFER AND PERMEABLE ZONE A (HOLOCENE-UPPER PLEISTOCENE DEPOSITS), SOUTH-CENTRAL UNITED STATES: USGS WATERRESOURCES INVESTIGATIONS REPORT 91-4149, 1992.

WATER-RESOURCES DATA, TEXAS, WATER YEAR 1991, VOLUME 4 GROUND-WATER DATA: USGS WATER-DATA REPORT TX-91-4, 1992.

PROPERTIES AND CHEMICAL CONSTITUENTS IN GROUND WATER FROM THE UPPER CLAIBORNE AQUIFER, GULF COAST REGIONAL AQUIFER SYSTEMS, SOUTH-CENTRAL UNITED STATES: USGS WATER-RESOURCES INVESTIGATIONS REPORT 91-4150, 1993.

PROPERTIES AND CHEMICAL CONSTITUENTS IN GROUND WATER FROM PERMEABLE ZONE C (LOWER PLIOCENE-UPPER MIOCENE DEPOSITS), COASTAL LOWLANDS AQUIFER SYSTEM, SOUTHCENTRAL UNITED STATES: USGS WATER-RESOURCES INVESTIGATIONS REPORT 91-4151, 1993.

PROPERTIES AND CHEMICAL CONSTITUENTS IN GROUND WATER FROM PERMEABLE ZONE B (LOWER PLEISTOCENE-UPPER PLIOCENE DEPOSITS), COASTAL LOWLANDS AQUIFER SYSTEM, SOUTH-CENTRAL UNITED STATES: USGS WATER-RESOURCES INVESTIGATIONS REPORT 91-4152, 1993.

PROPERTIES AND CHEMICAL CONSTITUENTS IN GROUND WATER FROM PERMEABLE ZONE E (LOWER MIOCENE-UPPER OLIGOCENE DEPOSITS), COASTAL LOWLANDS AQUIFER SYSTEM, SOUTH-CENTRAL UNITED STATES: USGS WATER-RESOURCES INVESTIGATIONS REPORT 92-4103, 1993.

PROPERTIES AND CHEMICAL CONSTITUENTS IN GROUND WATER FROM THE MIDDLE CLAIBORNE AQUIFER, GULF COAST REGIONAL AQUIFER SYSTEMS, SOUTH-CENTRAL UNITED STATES: USGS WATER-RESOURCES INVESTIGATIONS REPORT 92-4104, 1993.

PROPERTIES AND CHEMICAL CONSTITUENTS IN GROUND WATER FROM PERMEABLE ZONE D (MIDDLE MIOCENE DEPOSITS), COASTAL LOWLANDS AQUIFER SYSTEM, SOUTH-CENTRAL UNITED STATES: USGS WATER-RESOURCES INVESTIGATIONS REPORT 92-4105, 1993.

GROUND-WATER WITHDRAWALS, WATER LEVELS, AND GROUNDWATER QUALITY IN THE HOUSTON DISTRICT, TEXAS, WITH EMPHASIS ON 1985-89: USGS WATER-RESOURCES INVESTIGATIONS REPORT 92-4180, 1993. 
PROPERTIES AND CHEMICAL CONSTITUENTS IN GROUND WATER FROM THE MIDDLE WILCOX AQUIFER, GULF COAST AQUIFER SYSTEMS, SOUTH-CENTRAL UNITED STATES: USGS WATERRESOURCES INVESTIGATIONS REPORT 93-4070, 1993.

APPROXIMATE ALTITUDE OF WATER LEVELS IN WELLS COMPLETED IN THE CHICOT AND EVANGELINE AQUIFERS IN FORT BEND COUNTY AND ADJACENT AREAS, TEXAS, JANUARY-FEBRUARY 1991: USGS OPEN-FILE REPORT 93-62, 1993.

APPROXIMATE ALTITUDE OF WATER LEVELS IN WELLS COMPLETED IN THE CHICOT AND EVANGELINE AQUIFERS IN THE HOUSTON AREA, TEXAS, JANUARY-FEBRUARY 1991: USGS OPEN-FILE REPORT 93-075, 1993.

APPROXIMATE CHANGE IN WATER LEVELS IN WELLS COMPLETED IN THE CHICOT AND EVANGELINE AQUIFERS, 1977-93 AND 1992-93, AND MEASURED COMPACTION, 1973-92, IN THE HOUSTON-GALVESTON REGION, TEXAS: USGS OPEN-FILE REPORT 93-086, 1993.

WATER-RESOURCES DATA, TEXAS, WATER YEAR 1992, VOLUME 4, GROUND-WATER DATA: USGS WATER-DATA REPORT TX-92-4, 1993.

APPROXIMATE CHANGE IN WATER LEVELS IN WELLS COMPLETED IN THE CHICOT AND EVANGELINE AQUIFERS, 1977-94 AND 1993-94, AND MEASURED COMPACTION, 1973-93, IN THE HOUSTON-GALVESTON REGION, TEXAS: USGS OPEN-FILE REPORT 94-346, 1994.

WATER-RESOURCES DATA, TEXAS, WATER YEAR 1993, VOLUME 4, GROUND-WATER DATA: USGS WATER-DATA REPORT TX-93-4, 1994.

STRATIGRAPHIC NOMENCLATURE AND GEOLOGIC SECTIONS OF THE GULF COASTAL PLAIN OF TEXAS: USGS OPEN-FILE REPORT 94-461, 1995.

WATER-LEVEL ALTITUDES 1995, WATER-LEVEL CHANGES 1977-95 AND 1994-95, AND COMPACTION 1973-94 IN THE CHICOT AND EVANGELINE AQUIFERS, HOUSTON-GALVESTON REGION, TEXAS: USGS OPEN-FILE REPORT 95-182, 1995.

WATER-LEVEL ALTITUDES 1995 AND WATER-LEVEL CHANGES 1990-95 AND 1994-95 IN THE CHICOT AND EVANGELINE AQUIFERS, FORT BEND COUNTY AND ADJACENT AREAS, TEXAS: USGS OPEN-FILE REPORT 95-183, 1995.

AQUIFERS OF TEXAS: TEXAS WATER DEVELOPMENT BOARD REPORT 345, 1995

WATER-RESOURCES DATA, TEXAS, WATER YEAR 1994, VOLUME 4 GROUND-WATER DATA: USGS WATER-DATA REPORT TX-94-4, 1995.

WATER-LEVEL ALTITUDES 1996, WATER-LEVEL CHANGES 1977-96 AND 1995-96, AND COMPACTION 1973-95 IN THE CHICOT AND EVANGELINE AQUIFERS, HOUSTON-GALVESTON REGION, TEXAS: USGS OPEN-FILE REPORT 96-163, 1996.

WATER-LEVEL ALTITUDES 1996 AND WATER-LEVEL CHANGES 1990-96 AND 1995-96 IN THE CHICOT AND EVANGELINE AQUIFERS, FORT BEND COUNTY AND ADJACENT AREAS, TEXAS: USGS OPEN-FILE REPORT 96-164, 1996.

WATER-RESOURCES DATA, TEXAS, WATER YEAR 1995, VOLUME 4 , GROUND-WATER DATA: USGS WATER-DATA REPORT TX-95-4, 1996.
WATER-LEVEL ALTITUDES 1997 AND WATER-LEVEL CHANGES 1990-97 AND 1996-97 IN THE CHICOT AND EVANGELINE AQUIFERS, FORT BEND COUNTY AND ADJACENT AREAS, TEXAS: USGS OPEN-FILE REPORT 97-180, 1997.

WATER-LEVEL ALTITUDES 1997, WATER-LEVEL CHANGES 1977-97 AND 1996-97, AND COMPACTION 1973-96 IN THE CHICOT AND EVANGELINE AQUIFERS, HOUSTON-GALVESTON REGION, TEXAS: USGS OPEN-FILE REPORT 97-181, 1997.

WATER-LEVEL ALTITUDES IN WELLS COMPLETED IN THE CHICOT AND EVANGELINE AQUIFERS, FORT BEND COUNTY AND ADJACENT AREAS, TEXAS, JANUARY-FEBRUARY 1990: USGS OPENFILE REPORT 97-784, 1997.

WATER-LEVEL ALTITUDES IN WELLS COMPLETED IN THE CHICOT AND EVANGELINE AQUIFERS, FORT BEND COUNTY AND ADJACENT AREAS, JANUARY-FEBRUARY 1992, 1993, AND 1994: USGS OPEN-FILE REPORT 97-785, 1997.

WATER-LEVEL ALTITUDES IN WELLS COMPLETED IN THE CHICOT AND EVANGELINE AQUIFERS, HOUSTON-GALVESTON REGION, TEXAS, JANUARY-FEBRUARY 1992, 1993, AND 1994: USGS OPENFILE REPORT 97-786, 1997.

WATER-RESOURCES DATA, TEXAS, WATER YEAR 1996, VOLUME 4 , GROUND-WATER DATA: USGS WATER-DATA REPORT TX-96-4, 1997.

WATER-LEVEL ALTITUDES 1998 AND WATER-LEVEL CHANGES 1990-98 AND 1997-98 IN THE CHICOT AND EVANGELINE AQUIFERS, FORT BEND COUNTY AND ADJACENT AREAS, TEXAS: USGS OPEN-FILE REPORT 98-095, 1998.

WATER-LEVEL ALTITUDES 1998, WATER-LEVEL CHANGES 1977-98 AND 1997-98, AND COMPACTION IN THE CHICOT AND EVANGELINE AQUIFERS, HOUSTON-GALVESTON REGION, TEXAS: USGS OPEN-FILE REPORT 98-096, 1998

APPROXIMATE LAND-SURFACE SUBSIDENCE IN FORT BEND COUNTY, TEXAS, 1943-87 AND 1973-87: USGS OPEN-FILE REPORT 98-383, 1998

WATER-RESOURCES DATA, TEXAS, WATER YEAR 1997, VOLUME 4, GROUND-WATER DATA: USGS WATER-DATA REPORT TX-97-4, 1998.

WATER-LEVEL ALTITUDES 1999 AND WATER-LEVEL CHANGES 1990-99 AND 1998-99 IN THE CHICOT AND EVANGELINE AQUIFERS, FORT BEND COUNTY AND ADJACENT AREAS, TEXAS: USGS OPEN-FILE REPORT 99-177, 1999.

WATER-LEVEL ALTITUDES 1999, WATER-LEVEL CHANGES 1977-99 AND 1998-99, AND COMPACTION 1973-98 IN THE CHICOT AND EVANGELINE AQUIFERS, HOUSTON-GALVESTON REGION, TEXAS: USGS OPEN-FILE REPORT 99-178, 1999.

WATER-RESOURCES DATA, TEXAS, WATER YEAR 1998, VOLUME 4, GROUND-WATER DATA: USGS WATER-DATA REPORT TX-98-4, 1999.

WATER-LEVEL ALTITUDES 2000 AND WATER-LEVEL CHANGES 1990-2000 AND 1999-2000 IN THE CHICOT AND EVANGELINE AQUIFERS, FORT BEND COUNTY AND ADJACENT AREAS, TEXAS: USGS OPEN-FILE REPORT 00-093, 2000.

WATER-LEVEL ALTITUDES 2000, WATER-LEVEL CHANGES 1977-2000 AND 1999-2000, AND COMPACTION 1973-99 IN THE CHICOT AND EVANGELINE AQUIFERS, HOUSTON-GALVESTON REGION, TEXAS: USGS OPEN-FILE REPORT 00-094, 2000. 
WATER-RESOURCES DATA, TEXAS, WATER YEAR 1999, VOLUME 6, GROUND-WATER DATA: USGS WATER-DATA REPORT TX-99-6, 2000.

WATER-RESOURCES DATA, TEXAS, WATER YEAR 2000, VOLUME 6, GROUND-WATER DATA: USGS WATER-DATA REPORT TX-00-6, 2001.

\section{WARD COUNTY}

WATER RESOURCES OF THE PECOS RIVER BASIN, VOLUME 1, PECOS RIVER JOINT INVESTIGATION-PART 3, REPORT B, GEOLOGY AND GROUND WATER: TEXAS BOARD OF WATER ENGINEERS MISCELLANEOUS PUBLICATION 209A, V. 1, 1941.

WATER RESOURCES OF THE PECOS RIVER BASIN, VOLUME 2, RECORDS OF WELLS AND SPRINGS AND ANALYSES OF WATER IN LOVING, WARD, REEVES, AND NORTHERN PECOS COUNTIES: TEXAS BOARD OF WATER ENGINEERS MISCELLANEOUS PUBLICATION 209A, V. 2, 1941.

WATER RESOURCES OF THE PECOS RIVER BASIN, VOLUME 3, RECORDS OF AUGER HOLES INCLUDING LOGS, RECORDS OF FLUCTUATIONS OF WATER LEVELS, WATER ANALYSES, AND MAPS SHOWING LOCATIONS OF WELLS: TEXAS BOARD OF WATER ENGINEERS MISCELLANEOUS PUBLICATION 209A, V. 3, 1941.

MEMORANDUM CONCERNING PUMPING TEST OF WARD COUNTY WATER IMPROVEMENT DISTRICT NO. 3 LARGE-CAPACITY WELL, 6 MILES NORTHWEST OF BARSTOW, TEXAS: USGS OPENFILE REPORT (UNNUMBERED), 1942.

OFFICE MEMORANDUM REGARDING THE DRILLING OF WELLS BY WARD COUNTY IRRIGATION DISTRICT NO. 1 NEAR BARSTOW: USGS OPEN-FILE REPORT (UNNUMBERED), 1946.

GROUND WATER IN WARD COUNTY, TEXAS: USGS OPEN-FILE REPORT (UNNUMBERED), 1947.

PUBLIC WATER SUPPLIES IN WESTERN TEXAS: TEXAS BOARD OF WATER ENGINEERS MISCELLANEOUS PUBLICATION 216, 1949.

RELATIONSHIP OF THE BARSTOW AREA TO THE RESERVOIR IN REEVES COUNTY, TEXAS: USGS OPEN-FILE REPORT (UNNUMBERED), 1951.

MEMORANDUM CONCERNING THE RELATIONSHIP OF PUMPING FROM WELLS IN THE ALLUVIAL RESERVOIR IN REEVES COUNTY, TEXAS, TO WELLS IN THE BARSTOW AREA IN SOUTHWESTERN WARD COUNTY, TEXAS: USGS OPEN-FILE REPORT (UNNUMBERED), 1951.

DEVELOPMENT OF GROUND WATER FOR IRRIGATION IN THE PECOS AREA, REEVES AND WARD COUNTIES, TEXAS: USGS OPEN-FILE REPORT (UNNUMBERED), 1951.

PUBLIC WATER SUPPLIES IN WESTERN TEXAS: USGS WATERSUPPLY PAPER 1106, 1951.

SUMMARY OF GROUND-WATER DEVELOPMENT IN THE PECOS AREA, REEVES AND WARD COUNTIES, TEXAS, 1947-51: TEXAS BOARD OF WATER ENGINEERS BULLETIN 5202, 1952.

RECORDS OF WATER-LEVEL MEASUREMENTS IN LOVING AND WARD COUNTIES, TEXAS: TEXAS BOARD OF WATER ENGINEERS BULLETIN 5408, 1954
SHALLOW FORMATIONS AND AQUIFERS OF THE WEST TEXAS AREA: WEST TEXAS GEOLOGICAL SOCIETY PUBLICATION 61-45 AND PERMIAN BASIN GEOPHYSICAL SOCIETY, MIDLAND, TEXAS, 1961.

RECONNAISSANCE INVESTIGATION OF THE GROUND-WATER RESOURCES OF THE RIO GRANDE BASIN, TEXAS: TEXAS WATER COMMISSION BULLETIN 6502, 1965.

COMPILATION OF RESULTS OF AQUIFER TESTS IN TEXAS: TEXAS WATER DEVELOPMENT BOARD REPORT 98, 1969.

WATER RESOURCES OF WARD COUNTY, TEXAS: TEXAS WATER DEVELOPMENT BOARD REPORT 125, 1971.

RECONNAISSANCE INVESTIGATION OF GROUND WATER IN THE RIO GRANDE DRAINAGE BASIN-WITH SPECIAL EMPHASIS ON SALINE GROUND-WATER RESOURCES: USGS HYDROLOGIC INVESTIGATIONS ATLAS HA-510, 1974

SUMMARY APPRAISALS OF THE NATION'S GROUND-WATER RESOURCES-RIO GRANDE REGION: USGS PROFESSIONAL PAPER 813-D, 1975.

SPRINGS OF TEXAS, VOLUME 1: (BY GUNNAR BRUNE), BRANCHSMITH, INC., FORT WORTH, TEXAS, 1981.

MAPS SHOWING GROUND-WATER UNITS AND WITHDRAWAL, BASIN AND RANGE PROVINCE, TEXAS: USGS WATERRESOURCES INVESTIGATIONS REPORT 83-4121-A, 1984.

MAPS SHOWING GROUND-WATER LEVELS, SPRINGS, AND DEPTH TO GROUND WATER, BASIN AND RANGE PROVINCE, TEXAS: USGS WATER-RESOURCES INVESTIGATIONS REPORT 83-4121-B 1984.

MAPS SHOWING DISTRIBUTION OF DISSOLVED SOLIDS AND DOMINANT CHEMICAL TYPE IN GROUND WATER, BASIN AND RANGE PROVINCE, TEXAS: USGS WATER-RESOURCES INVESTIGATIONS REPORT 83-4121-C, 1984

TEXAS GROUND-WATER RESOURCES, in NATIONAL WATER SUMMARY 1984: USGS WATER-SUPPLY PAPER 2275, 1985.

RECORDS OF WELLS, WATER LEVELS, PUMPAGE, AND CHEMICAL ANALYSES FROM SELECTED WELLS IN PARTS OF THE TRANSPECOS REGION, TEXAS, 1968-1980: TEXAS WATER DEVELOPMENT BOARD REPORT 301, 1987.

PUBLIC SUPPLY GROUND-WATER USE IN WESTERN TEXAS: TEXAS WATER DEVELOPMENT BOARD REPORT 311, 1989.

EVALUATION OF GROUND-WATER RESOURCES IN PARTS OF LOVING, PECOS, REEVES, WARD, AND WINKLER COUNTIES, TEXAS: TEXAS WATER DEVELOPMENT BOARD REPORT 317, 1990.

POTENTIOMETRIC SURFACE OF THE EDWARDS-TRINITY AQUIFER SYSTEM AND CONTIGUOUS HYDRAULICALLY CONNECTED UNITS, WEST-CENTRAL TEXAS, WINTER 1974-75: USGS WATERRESOURCES INVESTIGATIONS REPORT 89-4208, 1990.

WITHDRAWALS FROM THE EDWARDS-TRINITY AQUIFER SYSTEM AND CONTIGUOUS HYDRAULICALLY CONNECTED UNITS, WEST-CENTRAL TEXAS, DECEMBER 1974 THROUGH MARCH 1977: USGS WATER-RESOURCES INVESTIGATIONS REPORT 91-4021, 1991.

CONFIGURATION OF THE BASE OF THE EDWARDS-TRINITY AQUIFER SYSTEM AND HYDROGEOLOGY OF THE UNDERLYING PRECRETACEOUS ROCKS, WEST-CENTRAL TEXAS: USGS WATERRESOURCES INVESTIGATIONS REPORT 91-4071, 1992. 
HISTORICAL POTENTIOMETRIC SURFACE OF THE EDWARDS-TRINITY AQUIFER SYSTEM AND CONTIGUOUS HYDRAULICALLY CONNECTED UNITS, WEST-CENTRAL TEXAS: USGS WATERRESOURCES INVESTIGATIONS REPORT 92-4055, 1993.

HISTORICAL SATURATED THICKNESS OF THE EDWARDS-TRINITY AQUIFER SYSTEM AND SELECTED CONTIGUOUS HYDRAULICALLY CONNECTED UNITS, WEST-CENTRAL TEXAS: USGS WATER-RESOURCES INVESTIGATIONS REPORT 92-4125, 1993.

SIMULATIONS OF FLOW IN THE EDWARDS-TRINITY AQUIFER SYSTEM AND CONTIGUOUS HYDRAULICALLY CONNECTED UNITS, WEST-CENTRAL TEXAS: USGS WATER-RESOURCES INVESTIGATIONS REPORT 93-4039, 1994.

DISSOLVED-SOLIDS CONCENTRATIONS AND HYDROCHEMICAL FACIES IN WATER OF THE EDWARDS-TRINITY AQUIFER SYSTEM, WEST-CENTRAL TEXAS: USGS WATER-RESOURCES INVESTIGATIONS REPORT 93-4126, 1994.

GEOLOGIC HISTORY AND HYDROGEOLOGIC SETTING OF THE EDWARDS-TRINITY AQUIFER SYSTEM, WEST-CENTRAL TEXAS: USGS WATER-RESOURCES INVESTIGATIONS REPORT 94-4039, 1994.

WATER QUALITY IN THE EDWARDS-TRINITY (PLATEAU) AQUIFER, EDWARDS PLATEAU AND TRANS-PECOS, TEXAS: TEXAS WATER DEVELOPMENT BOARD HYDROLOGIC ATLAS NO. 3, 1995.

AQUIFERS OF TEXAS: TEXAS WATER DEVELOPMENT BOARD REPORT 345, 1995.

HYDROGEOLOGIC FRAMEWORK OF THE EDWARDS-TRINITY AQUIFER SYSTEM, WEST-CENTRAL TEXAS: USGS PROFESSIONAL PAPER 1421-B, 1996.

WATER QUALITY IN THE CAPITAN REEF AQUIFER: TEXAS WATER DEVELOPMENT BOARD HYDROLOGIC ATLAS NO. 8, 1997.

WATER QUALITY IN THE RUSTLER AQUIFER: TEXAS WATER DEVELOPMENT BOARD HYDROLOGIC ATLAS NO. 9, 1998.

CHANGES IN GROUNDWATER CONDITIONS IN PARTS OF TRANSPECOS TEXAS, 1988-1998: TEXAS WATER DEVELOPMENT BOARD REPORT 348, 1999.

AQUIFERS OF WEST TEXAS: TEXAS WATER DEVELOPMENT BOARD REPORT 356, 2001.

REGIONAL GROUND-WATER FLOW SYSTEMS IN TRANS-PECOS TEXAS, CHAPTER 4, in AQUIFERS OF WEST TEXAS: TEXAS WATER DEVELOPMENT BOARD REPORT 356, 2001

CENOZOIC PECOS ALLUVIUM AQUIFER, CHAPTER 9, in AQUIFERS OF WEST TEXAS: TEXAS WATER DEVELOPMENT BOARD REPORT 356, 2001.

THE GEOLOGY AND HYDROGEOLOGY OF THE CAPITAN AQUIFER: A BRIEF OVERVIEW, CHAPTER 11, in AQUIFERS OF WEST TEXAS: TEXAS WATER DEVELOPMENT BOARD REPORT 356, 2001.

THE DOCKUM AQUIFER IN WEST TEXAS, CHAPTER 12, in AQUIFERS OF WEST TEXAS: TEXAS WATER DEVELOPMENT BOARD REPORT 356, 2001.

HYDROGEOLOGY OF THE RUSTLER AQUIFER, TRANS-PECOS TEXAS, CHAPTER 15, in AQUIFERS OF WEST TEXAS: TEXAS WATER DEVELOPMENT BOARD REPORT 356, 2001.

\section{WASHINGTON COUNTY}

UNDERGROUND WATERS OF THE COASTAL PLAIN OF TEXAS: USGS WATER-SUPPLY PAPER 190, 1907.

GEOLOGY AND UNDERGROUND WATERS OF THE SOUTHEASTERN PART OF THE TEXAS COASTAL PLAIN: USGS WATER-SUPPLY PAPER 335, 1914.

GROUND-WATER RESOURCES IN THE BRENHAM-GAY HILL AREA, WASHINGTON COUNTY, TEXAS: TEXAS BOARD OF WATER ENGINEERS OPEN-FILE REPORT (UNNUMBERED), 1942.

RECORDS OF WELLS AND SPRINGS, DRILLERS' LOGS, WATER ANALYSES AND MAP SHOWING LOCATIONS OF WELLS AND SPRINGS IN WASHINGTON COUNTY, TEXAS: TEXAS BOARD OF WATER ENGINEERS MISCELLANEOUS PUBLICATION 290, 1943.

PUBLIC WATER SUPPLIES IN EASTERN TEXAS, V. 2, HARRISON COUNTY THROUGH WOOD COUNTY: TEXAS BOARD OF WATER ENGINEERS MISCELLANEOUS PUBLICATION 214, V. 2, 1945.

MEMORANDUM REGARDING TELEPHONE CONVERSATION WITH DR. HASSKARL OF BRENHAM ABOUT DRILLING NEW WELLS FOR THE CITY OF BRENHAM: USGS OPEN-FILE REPORT (UNNUMBERED), 1947.

PUBLIC WATER SUPPLIES IN EASTERN TEXAS: USGS WATERSUPPLY PAPER 1047, 1948.

RECONNAISSANCE INVESTIGATION OF THE GROUND-WATER RESOURCES OF THE BRAZOS RIVER BASIN, TEXAS: TEXAS WATER COMMISSION BULLETIN 6310, 1963.

GROUND WATER IN THE FLOOD-PLAIN ALLUVIUM OF THE BRAZOS RIVER, WHITNEY DAM TO VICINITY OF RICHMOND, TEXAS: TEXAS WATER DEVELOPMENT BOARD REPORT 41, 1967.

HYDROLOGIC SIGNIFICANCE OF THE LITHOFACIES OF THE SPARTA SAND IN ARKANSAS, LOUISIANA, MISSISSIPPI, AND TEXAS: USGS PROFESSIONAL PAPER 569-A, 1968.

COMPILATION OF RESULTS OF AQUIFER TESTS IN TEXAS: TEXAS WATER DEVELOPMENT BOARD REPORT 98, 1969.

GEOHYDROLOGIC SIGNIFICANCE OF LITHOFACIES OF THE COCKFIELD FORMATION OF LOUISIANA AND MISSISSIPPI AND OF THE YEGUA FORMATION OF TEXAS: USGS PROFESSIONAL PAPER 569-B, 1970.

GROUND-WATER RESOURCES OF WASHINGTON COUNTY, TEXAS: TEXAS WATER DEVELOPMENT BOARD REPORT 162, 1972.

HYDROLOGIC SIGNIFICANCE OF LITHOFACIES OF THE CANE RIVER FORMATION OR EQUIVALENTS OF ARKANSAS, LOUISIANA, MISSISSIPPI, AND TEXAS: USGS PROFESSIONAL PAPER 569-C, 1972.

HYDROLOGIC SIGNIFICANCE OF LITHOFACIES OF THE CARRIZO SAND OF ARKANSAS, LOUISIANA, AND TEXAS AND THE MERIDIAN SAND OF MISSISSIPPI: USGS PROFESSIONAL PAPER 569-D, 1975.

SUMMARY APPRAISALS OF THE NATION'S GROUND-WATER RESOURCES-TEXAS-GULF REGION: USGS PROFESSIONAL PAPER 813-F, 1976.

STRATIGRAPHIC AND HYDROGEOLOGIC FRAMEWORK OF PART OF THE COASTAL PLAIN OF TEXAS: USGS OPEN-FILE REPORT 77-712, 1978. 
STRATIGRAPHIC AND HYDROGEOLOGIC FRAMEWORK OF PART OF THE COASTAL PLAIN OF TEXAS: TEXAS DEPARTMENT OF WATER RESOURCES REPORT 236, 1979.

REGIONAL HYDRODYNAMICS AND HYDROCHEMISTRY OF THE URANIUM-BEARING OAKVILLE AQUIFER (MIOCENE) OF SOUTH TEXAS: UNIVERSITY OF TEXAS, BUREAU OF ECONOMIC GEOLOGY REPORT OF INVESTIGATIONS NO. 124, 1982.

TEXAS GROUND-WATER RESOURCES, in NATIONAL WATER SUMMARY 1984: USGS WATER-SUPPLY PAPER 2275, 1985.

HYDROLOGY OF THE JASPER AQUIFER IN THE SOUTHEAST TEXAS COASTAL PLAIN: TEXAS WATER DEVELOPMENT BOARD REPORT 295, 1986.

APPROXIMATE POTENTIOMETRIC SURFACES FOR THE AQUIFERS OF THE TEXAS COASTAL UPLANDS SYSTEM, 1980: USGS HYDROLOGIC INVESTIGATIONS ATLAS HA-704, 1987.

GEOHYDROLOGIC FRAMEWORK OF THE GULF COASTAL PLAIN: USGS HYDROLOGIC INVESTIGATIONS ATLAS HA-695, 1988.

HYDROGEOLOGY AND PREDEVELOPMENT FLOW IN THE TEXAS GULF COAST AQUIFER SYSTEMS: USGS WATER-RESOURCES INVESTIGATIONS REPORT 87-4248, 1988.

GEOHYDROLOGIC FRAMEWORK OF THE GULF COASTAL PLAIN: USGS HYDROLOGIC INVESTIGATIONS ATLAS HA-695, 1988.

GROUND-WATER FLOW IN THE GULF COAST AQUIFER SYSTEMS, SOUTH-CENTRAL UNITED STATES-A PRELIMINARY ANALYSIS: USGS WATER-RESOURCES INVESTIGATIONS REPORT 89-4071, 1990.

HYDROLOGY OF THE TEXAS GULF COAST AQUIFER SYSTEMS: USGS OPEN-FILE REPORT 91-64, 1991.

PROPERTIES AND CHEMICAL CONSTITUENTS IN GROUND WATER FROM THE UPPER CLAIBORNE AQUIFER, GULF COAST REGIONAL AQUIFER SYSTEMS, SOUTH-CENTRAL UNITED STATES: USGS WATER-RESOURCES INVESTIGATIONS REPORT 91-4150, 1993.

PROPERTIES AND CHEMICAL CONSTITUENTS IN GROUND WATER FROM PERMEABLE ZONE C (LOWER PLIOCENE-UPPER MIOCENE DEPOSITS), COASTAL LOWLANDS AQUIFER SYSTEM, SOUTHCENTRAL UNITED STATES: USGS WATER-RESOURCES INVESTIGATIONS REPORT 91-4151, 1993.

PROPERTIES AND CHEMICAL CONSTITUENTS IN GROUND WATER FROM THE LOWER CLAIBORNE-UPPER WILCOX AQUIFER, GULF COAST REGIONAL AQUIFER SYSTEMS, SOUTH-CENTRAL UNITED STATES: USGS WATER-RESOURCES INVESTIGATIONS REPORT 92-4102, 1993.

PROPERTIES AND CHEMICAL CONSTITUENTS IN GROUND WATER FROM PERMEABLE ZONE E (LOWER MIOCENE-UPPER OLIGOCENE DEPOSITS), COASTAL LOWLANDS AQUIFER SYSTEM, SOUTH-CENTRAL UNITED STATES: USGS WATER-RESOURCES INVESTIGATIONS REPORT 92-4103, 1993.

PROPERTIES AND CHEMICAL CONSTITUENTS IN GROUND WATER FROM THE MIDDLE CLAIBORNE AQUIFER, GULF COAST REGIONAL AQUIFER SYSTEMS, SOUTH-CENTRAL UNITED STATES: USGS WATER-RESOURCES INVESTIGATIONS REPORT 92-4104, 1993.

PROPERTIES AND CHEMICAL CONSTITUENTS IN GROUND WATER FROM PERMEABLE ZONE D (MIDDLE MIOCENE DEPOSITS), COASTAL LOWLANDS AQUIFER SYSTEM, SOUTH-CENTRAL
UNITED STATES: USGS WATER-RESOURCES INVESTIGATIONS REPORT 92-4105, 1993.

PROPERTIES AND CHEMICAL CONSTITUENTS IN GROUND WATER FROM THE MIDDLE WILCOX AQUIFER, GULF COAST AQUIFER SYSTEMS, SOUTH-CENTRAL UNITED STATES: USGS WATERRESOURCES INVESTIGATIONS REPORT 93-4070, 1993.

STRATIGRAPHIC NOMENCLATURE AND GEOLOGIC SECTIONS OF THE GULF COASTAL PLAIN OF TEXAS: USGS OPEN-FILE REPORT 94-461, 1995.

AQUIFERS OF TEXAS: TEXAS WATER DEVELOPMENT BOARD REPORT 345, 1995

WATER QUALITY IN THE SPARTA AQUIFER, EAST TEXAS: TEXAS WATER DEVELOPMENT BOARD HYDROLOGIC ATLAS NO. 5, 1996.

WATER QUALITY IN THE QUEEN CITY AQUIFER, EAST TEXAS: TEXAS WATER DEVELOPMENT BOARD HYDROLOGIC ATLAS NO. 6, 1996

GROUND-WATER AVAILABILITY IN THE CARRIZO-WILCOX AQUIFER IN CENTRAL TEXAS-NUMERICAL SIMULATIONS OF 2000 THROUGH 2050 WITHDRAWAL PROJECTIONS: UNIVERSITY OF TEXAS, BUREAU OF ECONOMIC GEOLOGY REPORT OF INVESTIGATIONS NO. 256, 1999.

\section{WEBB COUNTY}

ARTESIAN WELLS OF THE COASTAL PRAIRIE REGION AND TERTIARY BELT OF TEXAS: GEOLOGICAL SURVEY OF TEXAS, CHAPTER 2, 1893.

GEOLOGY OF THE EDWARDS PLATEAU AND RIO GRANDE PLAIN ADJACENT TO AUSTIN AND SAN ANTONIO, TEXAS, WITH REFERENCE TO THE OCCURRENCE OF UNDERGROUND WATERS: USGS 18TH ANNUAL REPORT, PART 2, 1898

UNDERGROUND WATERS OF THE COASTAL PLAIN OF TEXAS: USGS WATER-SUPPLY PAPER 190, 1907.

GROUND WATER IN THE WINTER GARDEN AND ADJACENT DISTRICTS IN SOUTHWESTERN TEXAS: USGS OPEN-FILE REPORT (UNNUMBERED), 1931

GROUND-WATER RESOURCES OF WEBB COUNTY, TEXAS: USGS OPEN-FILE REPORT (UNNUMBERED) (PRESS RELEASE, FEBRUARY 9, 1933), 1933

GEOLOGY AND GROUND-WATER RESOURCES OF WEBB COUNTY, TEXAS: USGS WATER-SUPPLY PAPER 778, 1937.

MEMORANDUM ON WEBB COUNTY TRIP: USGS OPEN-FILE REPORT (UNNUMBERED), 1944.

PUBLIC WATER SUPPLIES IN SOUTHERN TEXAS: TEXAS BOARD OF WATER ENGINEERS MISCELLANEOUS PUBLICATION 215, 1946.

PUBLIC WATER SUPPLIES IN SOUTHERN TEXAS: USGS WATERSUPPLY PAPER 1070, 1950

PRELIMINARY SURVEY OF GROUND-WATER CONDITIONS NEAR LAREDO, TEXAS: JACK R. BARNES, CONSULTING GROUNDWATER ENGINEER, AUSTIN, TEXAS, 1953. 
FINAL SUMMARY OF CONCLUSIONS REGARDING A GROUNDWATER SUPPLY FOR LAREDO, TEXAS: JACK R. BARNES, CONSULTING GROUND-WATER ENGINEER, AUSTIN, TEXAS, 1953.

DEVELOPMENT OF GROUND WATER FROM THE CARRIZO SAND AND WILCOX GROUP IN DIMMIT, ZAVALA, MAVERICK, FRIO, ATASCOSA, MEDINA, BEXAR, LIVE OAK, McMULLEN, LA SALLE, AND WEBB COUNTIES, TEXAS: USGS OPEN-FILE REPORT 57-77, 1957.

RECONNAISSANCE INVESTIGATION OF THE GROUND-WATER RESOURCES OF THE GUADALUPE, SAN ANTONIO, AND NUECES RIVER BASINS, TEXAS: TEXAS WATER COMMISSION BULLETIN 6409, 1964.

CARRIZO SAND APPRAISAL STUDY, MAVERICK AND WEBB COUNTIES, TEXAS: USGS OPEN-FILE REPORT, 1965.

RECONNAISSANCE INVESTIGATIONS OF THE GROUND-WATER RESOURCES OF THE RIO GRANDE BASIN, TEXAS: TEXAS WATER COMMISSION BULLETIN 6502, 1965.

WATER-LEVEL DATA FROM OBSERVATION WELLS IN THE NORTHWESTERN GULF COASTAL PLAIN OF TEXAS: TEXAS WATER DEVELOPMENT BOARD REPORT 70, 1968.

HYDROLOGIC SIGNIFICANCE OF THE LITHOFACIES OF THE SPARTA SAND IN ARKANSAS, LOUISIANA, MISSISSIPPI, AND TEXAS: USGS PROFESSIONAL PAPER 569-A, 1968.

GEOHYDROLOGIC SIGNIFICANCE OF LITHOFACIES OF THE COCKFIELD FORMATION OF LOUISIANA AND MISSISSIPPI AND OF THE YEGUA FORMATION OF TEXAS: USGS PROFESSIONAL PAPER 569-B, 1970.

HYDROLOGIC SIGNIFICANCE OF LITHOFACIES OF THE CANE RIVER FORMATION OR EQUIVALENTS OF ARKANSAS, LOUISIANA, MISSISSIPPI, AND TEXAS: USGS PROFESSIONAL PAPER 569-C, 1972.

RECONNAISSANCE INVESTIGATION OF GROUND WATER IN THE RIO GRANDE DRAINAGE BASIN-WITH SPECIAL EMPHASIS ON SALINE GROUND-WATER RESOURCES: USGS HYDROLOGIC INVESTIGATIONS ATLAS HA-510, 1974.

GEOHYDROLOGIC SIGNIFICANCE OF LITHOFACIES OF THE CARRIZO SAND OF ARKANSAS, LOUISIANA, AND TEXAS AND THE MERIDIAN SAND OF MISSISSIPPI: USGS PROFESSIONAL PAPER 569-D, 1975.

SUMMARY APPRAISALS OF THE NATION'S GROUND-WATER RESOURCES-TEXAS-GULF REGION: USGS PROFESSIONAL PAPER 813-F, 1976.

GROUND-WATER RESOURCES OF THE CARRIZO AQUIFER IN THE WINTER GARDEN AREA OF TEXAS, VOLUME 1: TEXAS WATER DEVELOPMENT BOARD REPORT 210, V. 1, 1976.

GROUND-WATER RESOURCES OF THE CARRIZO AQUIFER IN THE WINTER GARDEN AREA OF TEXAS, VOLUME 2: TEXAS WATER DEVELOPMENT BOARD REPORT 210, V. 2, 1977.

STRATIGRAPHIC AND HYDROGEOLOGIC FRAMEWORK OF PART OF THE COASTAL PLAIN OF TEXAS: USGS OPEN-FILE REPORT $77-712,1978$

VARIATIONS IN SPECIFIC YIELD IN THE OUTCROP OF THE CARRIZO SAND IN SOUTH TEXAS AS ESTIMATED BY SEISMIC REFRACTION: TEXAS DEPARTMENT OF WATER RESOURCES REPORT 229, 1979.
STRATIGRAPHIC AND HYDROGEOLOGIC FRAMEWORK OF PART OF THE COASTAL PLAIN OF TEXAS: TEXAS DEPARTMENT OF WATER RESOURCES REPORT 236, 1979.

SPRINGS OF TEXAS, VOLUME 1: (BY GUNNAR BRUNE), BRANCHSMITH, INC., FORT WORTH, TEXAS, 1981

STRUCTURE, TEMPERATURE, PRESSURE, AND SALINITY OF CENOZOIC AQUIFERS OF SOUTH TEXAS: USGS HYDROLOGIC INVESTIGATIONS ATLAS HA-654, 1983.

TEXAS GROUND-WATER RESOURCES, in NATIONAL WATER SUMMARY 1984: USGS WATER-SUPPLY PAPER 2275, 1985.

WATER USE, PROJECTED WATER REQUIREMENTS, AND RELATED DATA AND INFORMATION FOR THE METROPOLITAN STATISTICAL AREAS IN TEXAS: TEXAS DEPARTMENT OF WATER RESOURCES LIMITED PRINTING REPORT LP-201, 1985.

APPROXIMATE POTENTIOMETRIC SURFACES FOR THE AQUIFERS OF THE COASTAL UPLANDS SYSTEM, 1980: USGS HYDROLOGIC INVESTIGATIONS ATLAS HA-704, 1987.

GEOHYDROLOGIC FRAMEWORK OF THE GULF COASTAL PLAIN: USGS HYDROLOGIC INVESTIGATIONS ATLAS HA-695, 1988.

HYDROGEOLOGY AND PREDEVELOPMENT FLOW IN THE TEXAS GULF COAST AQUIFER SYSTEMS: USGS WATER-RESOURCES INVESTIGATIONS REPORT 87-4248, 1988.

DEPOSITIONAL AND GROUND-WATER FLOW SYSTEMS OF THE CARRIZO-UPPER WILCOX, SOUTH TEXAS: UNIVERSITY OF TEXAS, BUREAU OF ECONOMIC GEOLOGY REPORT OF INVESTIGATIONS NO. 175, 1988.

GROUND-WATER FLOW IN THE GULF COAST AQUIFER SYSTEMS, SOUTH CENTRAL UNITED STATES-A PRELIMINARY ANALYSIS: USGS WATER-RESOURCES INVESTIGATIONS REPORT 89-4071, 1990.

HYDROLOGY OF THE TEXAS GULF COAST AQUIFER SYSTEMS: USGS OPEN-FILE REPORT 91-64, 1991.

GROUND-WATER QUALITY AND AVAILABILITY IN AND AROUND BRUNI, WEBB COUNTY, TEXAS: TEXAS WATER DEVELOPMENT BOARD LIMITED PRINTING REPORT LP-209, 1991.

EVALUATION OF THE GROUND-WATER RESOURCES IN THE WESTERN PORTION OF THE WINTER GARDEN AREA, TEXAS: TEXAS WATER DEVELOPMENT BOARD REPORT 334, 1991.

GROUND-WATER QUALITY MONITORING RESULTS IN THE WINTER GARDEN AREA, 1990: TEXAS WATER DEVELOPMENT BOARD REPORT 335, 1992

PROPERTIES AND CHEMICAL CONSTITUENTS IN GROUND WATER FROM THE MIDDLE WILCOX AQUIFER, GULF COAST REGIONAL AQUIFER SYSTEMS, SOUTH-CENTRAL UNITED STATES: USGS WATER-RESOURCES INVESTIGATIONS REPORT 93-4070, 1993.

PROPERTIES AND CHEMICAL CONSTITUENTS IN GROUND WATER FROM THE UPPER CLAIBORNE AQUIFER, GULF COAST REGIONAL AQUIFER SYSTEMS, SOUTH-CENTRAL UNITED STATES: USGS WATER-RESOURCES INVESTIGATIONS REPORT 91-4150, 1993.

PROPERTIES AND CHEMICAL CONSTITUENTS IN GROUND WATER FROM THE LOWER CLAIBORNE-UPPER WILCOX AQUIFER, GULF COAST REGIONAL AQUIFER SYSTEMS, SOUTH-CENTRAL UNITED STATES: USGS WATER-RESOURCES INVESTIGATIONS REPORT 92-4102, 1993. 
PROPERTIES AND CHEMICAL CONSTITUENTS IN GROUND WATER FROM PERMEABLE ZONE E (LOWER MIOCENE-UPPER OLIGOCENE DEPOSITS), COASTAL LOWLANDS AQUIFER SYSTEM, SOUTH-CENTRAL UNITED STATES: USGS WATER-RESOURCES INVESTIGATIONS REPORT 92-4103, 1993.

PROPERTIES AND CHEMICAL CONSTITUENTS IN GROUND WATER FROM THE MIDDLE CLAIBORNE AQUIFER, GULF COAST REGIONAL AQUIFER SYSTEMS, SOUTH-CENTRAL UNITED STATES: USGS WATER-RESOURCES INVESTIGATIONS REPORT 92-4104, 1993.

AQUIFERS OF TEXAS: TEXAS WATER DEVELOPMENT BOARD REPORT 345, 1995.

STRATIGRAPHIC NOMENCLATURE AND GEOLOGIC SECTIONS OF THE GULF COASTAL PLAIN OF TEXAS: USGS OPEN-FILE REPORT 94-461, 1995.

HYDROGEOLOGIC FRAMEWORK AND GEOCHEMISTRY OF THE EDWARDS AQUIFER SALINE-WATER ZONE, SOUTH-CENTRAL TEXAS: USGS WATER-RESOURCES INVESTIGATIONS REPORT 97-4133, 1997.

QUALITY OF GROUND WATER IN WEBB COUNTY, TEXAS, 1997-98: USGS FACT SHEET FS-184-99, DECEMBER 1999.

\section{WHARTON COUNTY}

UNDERGROUND WATERS OF THE COASTAL PLAIN OF TEXAS: USGS WATER-SUPPLY PAPER 190, 1907.

GROUND-WATER RESOURCES OF WHARTON COUNTY, TEXAS: USGS OPEN-FILE REPORT (UNNUMBERED), 1934?

RECORDS OF WELLS, DRILLERS' LOGS, AND WATER ANALYSES, AND MAP SHOWING LOCATION OF WELLS IN WHARTON COUNTY, TEXAS: USGS OPEN-FILE REPORT (UNNUMBERED), 1935 .

RECORDS OF WELLS, DRILLERS' LOGS, WATER ANALYSES, AND MAP SHOWING LOCATION OF WELLS IN WHARTON COUNTY, TEXAS: TEXAS BOARD OF WATER ENGINEERS MISCELLANEOUS PUBLICATION 296, 1940.

PUBLIC WATER SUPPLIES IN EASTERN TEXAS, V. 2, HARRISON COUNTY THROUGH WOOD COUNTY: TEXAS BOARD OF WATER ENGINEERS MISCELLANEOUS PUBLICATION 214, V. 2, 1945.

PUBLIC WATER SUPPLIES IN EASTERN TEXAS: USGS WATERSUPPLY PAPER 1047, 1948.

GROUND-WATER RESOURCES OF WHARTON COUNTY, TEXAS: TEXAS BOARD OF WATER ENGINEERS MISCELLANEOUS PUBLICATION 297, 1948.

MEMORANDUM REGARDING THE AVAILABILITY OF GROUND WATER IN THE AREA NORTH OF THE GALVESTON, HARRISBURG, AND SAN ANTONIO RAILROAD IN JACKSON AND WHARTON COUNTIES: USGS OPEN-FILE REPORT (UNNUMBERED), 1950.

AVAILABILITY OF GROUND WATER IN THE GULF COAST REGION OF TEXAS: USGS OPEN-FILE REPORT (UNNUMBERED), 1956.

GROUND-WATER RESOURCES OF WHARTON COUNTY, TEXAS: USGS OPEN-FILE REPORT (UNNUMBERED), 1956.

RECORDS OF WATER-LEVEL MEASUREMENTS IN JACKSON, MATAGORDA, AND WHARTON COUNTIES, TEXAS, 1934 TO APRIL
1958: TEXAS BOARD OF WATER ENGINEERS BULLETIN 5804, 1958.

RECONNAISSANCE REPORT OF THE BISHKIN-MEYERS WELL NEAR PIERCE, WHARTON COUNTY, TEXAS (CONTAMINATION REPORT NO. 4): TEXAS BOARD OF WATER ENGINEERS MISCELLANEOUS PUBLICATION 210, 1958.

RECONNAISSANCE INVESTIGATION OF THE GROUND-WATER RESOURCES OF THE GULF COAST REGION, TEXAS: TEXAS WATER COMMISSION BULLETIN 6305, 1963.

RECONNAISSANCE INVESTIGATION OF THE GROUND-WATER RESOURCES OF THE COLORADO RIVER BASIN, TEXAS: TEXAS WATER DEVELOPMENT BOARD REPORT 51, 1967.

COMPILATION OF RESULTS OF AQUIFER TESTS IN TEXAS: TEXAS WATER DEVELOPMENT BOARD REPORT 98, 1969.

GEOLOGIC AND HYDROLOGIC SUMMARY OF SALT DOMES IN GULF COAST REGION OF TEXAS, LOUISIANA, AND ALABAMA: USGS OPEN-FILE REPORT 73-07, 1973.

SUMMARY APPRAISALS OF THE NATION'S GROUND-WATER RESOURCES-TEXAS-GULF REGION: USGS PROFESSIONAL PAPER 813-F, 1976.

STRATIGRAPHIC AND HYDROGEOLOGIC FRAMEWORK OF PART OF THE COASTAL PLAIN OF TEXAS: USGS OPEN-FILE REPORT 77-712, 1978.

GROUND-WATER RESOURCES OF COLORADO, LAVACA, AND WHARTON COUNTIES, TEXAS: USGS OPEN-FILE REPORT 79-212, 1979.

STRATIGRAPHIC AND HYDROGEOLOGIC FRAMEWORK OF PART OF THE COASTAL PLAIN OF TEXAS: TEXAS DEPARTMENT OF WATER RESOURCES REPORT 236, 1979.

LAND-SURFACE SUBSIDENCE IN THE TEXAS COASTAL REGION: USGS OPEN-FILE REPORT 80-969, 1980.

SPRINGS OF TEXAS, VOLUME 1: (BY GUNNAR BRUNE), BRANCHSMITH, INC., FORT WORTH, TEXAS, 1981.

GROUND-WATER RESOURCES OF COLORADO, LAVACA, AND WHARTON COUNTIES, TEXAS: TEXAS DEPARTMENT OF WATER RESOURCES REPORT 270, 1982.

LAND-SURFACE SUBSIDENCE IN THE TEXAS COASTAL REGION: TEXAS DEPARTMENT OF WATER RESOURCES REPORT 272, 1982.

TEXAS GROUND-WATER RESOURCES, in NATIONAL WATER SUMMARY 1984: USGS WATER-SUPPLY PAPER 2275, 1985.

DIGITAL MODELS FOR SIMULATION OF GROUND-WATER HYDROLOGY OF THE CHICOT AND EVANGELINE AQUIFERS ALONG THE GULF COAST OF TEXAS: TEXAS DEPARTMENT OF WATER RESOURCES REPORT 289, 1985.

GEOHYDROLOGIC FRAMEWORK OF THE GULF COASTAL PLAIN: USGS HYDROLOGIC INVESTIGATIONS ATLAS HA-695, 1988.

HYDROGEOLOGY AND PREDEVELOPMENT FLOW IN THE TEXAS GULF COAST AQUIFER SYSTEMS: USGS WATER-RESOURCES INVESTIGATIONS REPORT 87-4248, 1988.

FLOW PATTERN IN REGIONAL AQUIFERS AND FLOW RELATIONS BETWEEN THE LOWER COLORADO RIVER VALLEY AND REGIONAL AQUIFERS IN SIX COUNTIES OF SOUTHEASTERN TEXAS: USGS WATER-RESOURCES INVESTIGATIONS REPORT 88-4154, 1989. 
GROUND-WATER FLOW IN THE GULF COAST AQUIFER SYSTEMS, SOUTH-CENTRAL UNITED STATES: USGS WATER-RESOURCES INVESTIGATIONS REPORT 89-4071, 1990.

SALT-DOME LOCATIONS IN THE GULF COASTAL PLAIN, SOUTHCENTRAL UNITED STATES: USGS WATER-RESOURCES INVESTIGATIONS REPORT 90-4060, 1990.

HYDROLOGY OF THE TEXAS GULF COAST AQUIFER SYSTEMS: USGS OPEN-FILE REPORT 91-64, 1991.

PROPERTIES AND CHEMICAL CONSTITUENTS IN GROUND WATER FROM THE MISSISSIPPI RIVER VALLEY ALLUVIAL AQUIFER AND PERMEABLE ZONE A (HOLOCENE-UPPER PLEISTOCENE DEPOSITS), SOUTH-CENTRAL UNITED STATES: USGS WATERRESOURCES INVESTIGATIONS REPORT 91-4149, 1992.

PROPERTIES AND CHEMICAL CONSTITUENTS IN GROUND WATER FROM THE UPPER CLAIBORNE AQUIFER, GULF COAST REGIONAL AQUIFER SYSTEMS, SOUTH-CENTRAL UNITED STATES: USGS WATER-RESOURCES INVESTIGATIONS REPORT 91-4150, 1993.

PROPERTIES AND CHEMICAL CONSTITUENTS IN GROUND WATER FROM PERMEABLE ZONE C (LOWER PLIOCENE-UPPER MIOCENE DEPOSITS), COASTAL LOWLANDS AQUIFER SYSTEM, SOUTHCENTRAL UNITED STATES: USGS WATER-RESOURCES INVESTIGATIONS REPORT 91-4151, 1993.

PROPERTIES AND CHEMICAL CONSTITUENTS IN GROUND WATER FROM PERMEABLE ZONE B (LOWER PLEISTOCENE-UPPER PLIOCENE DEPOSITS), COASTAL LOWLANDS AQUIFER SYSTEM, SOUTH-CENTRAL UNITED STATES: USGS WATER-RESOURCES INVESTIGATIONS REPORT 91-4152, 1993.

PROPERTIES AND CHEMICAL CONSTITUENTS IN GROUND WATER FROM PERMEABLE ZONE E (LOWER MIOCENE-UPPER OLIGOCENE DEPOSITS), COASTAL LOWLANDS AQUIFER SYSTEM, SOUTH-CENTRAL UNITED STATES: USGS WATER-RESOURCES INVESTIGATIONS REPORT 92-4103, 1993.

PROPERTIES AND CHEMICAL CONSTITUENTS IN GROUND WATER FROM PERMEABLE ZONE D (MIDDLE MIOCENE DEPOSITS), COASTAL LOWLANDS AQUIFER SYSTEM, SOUTH-CENTRAL UNITED STATES: USGS WATER-RESOURCES INVESTIGATIONS REPORT 92-4105, 1993.

PROPERTIES AND CHEMICAL CONSTITUENTS IN GROUND WATER FROM THE MIDDLE WILCOX AQUIFER, GULF COAST AQUIFER SYSTEMS, SOUTH-CENTRAL UNITED STATES: USGS WATERRESOURCES INVESTIGATIONS REPORT 93-4070, 1993.

AQUIFERS OF TEXAS: TEXAS WATER DEVELOPMENT BOARD REPORT 345, 1995.

\section{WHEELER COUNTY}

THE GEOLOGY AND WATER RESOURCES OF THE EASTERN PORTION OF THE PANHANDLE OF TEXAS: USGS WATER-SUPPLY PAPER 154, 1906.

GEOLOGY AND GROUND-WATER RESOURCES OF THE SOUTHERN HIGH PLAINS: USGS OPEN-FILE REPORT (UNNUMBERED), 1935.

GROUND WATER IN THE SOUTHERN HIGH PLAINS: USGS OPENFILE REPORT (UNNUMBERED), 1937.
GROUND WATER IN THE HIGH PLAINS OF TEXAS: TEXAS BOARD OF WATER ENGINEERS MISCELLANEOUS PUBLICATION (UNNUMBERED), 1938

GROUND WATER IN THE HIGH PLAINS OF TEXAS: TEXAS BOARD OF WATER ENGINEERS MISCELLANEOUS PUBLICATION 119, 1940.

PROGRESS REPORT ON GROUND WATER IN THE HIGH PLAINS OF TEXAS: TEXAS BOARD OF WATER ENGINEERS MISCELLANEOUS PUBLICATION (UNNUMBERED), 1942.

PROGRESS REPORT ON GROUND WATER IN THE HIGH PLAINS OF TEXAS: TEXAS BOARD OF WATER ENGINEERS MISCELLANEOUS PUBLICATION 120, 1943.

PROGRESS REPORT ON GROUND WATER IN THE HIGH PLAINS OF TEXAS: TEXAS BOARD OF WATER ENGINEERS MISCELLANEOUS PUBLICATION 121, 1944

GROUND WATER IN THE HIGH PLAINS OF TEXAS, PROGRESS REPORT NO. 5: TEXAS BOARD OF WATER ENGINEERS MISCELLANEOUS PUBLICATION 122, 1945.

GROUND WATER IN THE HIGH PLAINS OF TEXAS: USGS WATERSUPPLY PAPER 889-F, 1946

GROUND WATER IN HIGH PLAINS OF TEXAS, PROGRESS REPORT NO. 6: TEXAS BOARD OF WATER ENGINEERS MISCELLANEOUS PUBLICATION 123, 1947.

GEOLOGY AND GROUND WATER IN THE IRRIGATED REGION OF THE SOUTHERN HIGH PLAINS IN TEXAS, PROGRESS REPORT NO. 7: TEXAS BOARD OF WATER ENGINEERS MISCELLANEOUS PUBLICATION 125, 1949.

PUBLIC WATER SUPPLIES IN WESTERN TEXAS: TEXAS BOARD OF WATER ENGINEERS MISCELLANEOUS PUBLICATION 216, 1949.

COST OF PUMPING WATER FOR IRRIGATION, TEXAS HIGH PLAINS, FIELD INVESTIGATIONS-1947 IRRIGATION SEASON: TEXAS BOARD OF WATER ENGINEERS MISCELLANEOUS PUBLICATION $124,1951$.

PUBLIC WATER SUPPLIES IN WESTERN TEXAS: USGS WATERSUPPLY PAPER 1106, 1951 [1952].

DEVELOPMENT OF WELLS FOR IRRIGATION AND FLUCTUATION OF WATER LEVELS IN THE HIGH PLAINS OF TEXAS TO JANUARY 1951: TEXAS BOARD OF WATER ENGINEERS BULLETIN 5104, 1951.

SUMMARY OF GROUND-WATER DEVELOPMENT IN THE SOUTHERN HIGH PLAINS, TEXAS: TEXAS BOARD OF WATER ENGINEERS BULLETIN 5402, 1954

GROUND-WATER DEVELOPMENT IN THE SOUTHERN HIGH PLAINS OF TEXAS, 1953: TEXAS BOARD OF WATER ENGINEERS BULLETIN 5410, 1954

WATER-LEVEL DECLINE MAPS, 1956 TO 1957, AND WATER LEVELS IN OBSERVATION WELLS IN 20 COUNTIES IN THE SOUTHERN HIGH PLAINS OF TEXAS: TEXAS BOARD OF WATER ENGINEERS BULLETIN 5705, 1957.

RECORDS OF WATER-LEVEL MEASUREMENTS IN COLLINGSWORTH, HEMPHILL, ROBERTS, AND WHEELER COUNTIES, TEXAS, 1937 THROUGH JULY 1958: TEXAS BOARD OF WATER ENGINEERS BULLETIN 5806, 1958.

WATER-LEVEL MEASUREMENTS AND MAPS, SOUTHERN HIGH PLAINS, TEXAS, 1958 AND 1959: TEXAS BOARD OF WATER ENGINEERS BULLETIN 5908, 1959. 
WATER LEVELS IN OBSERVATION WELLS, SOUTHERN HIGH PLAINS, TEXAS, 1959 AND 1960: TEXAS BOARD OF WATER ENGINEERS BULLETIN 6011, 1960.

WATER LEVELS IN OBSERVATION WELLS, SOUTHERN HIGH PLAINS, TEXAS, 1960 AND 1961: TEXAS BOARD OF WATER ENGINEERS BULLETIN 6101, 1961.

A SUMMARY OF THE OCCURRENCE AND DEVELOPMENT OF GROUND WATER IN THE SOUTHERN HIGH PLAINS OF TEXAS: TEXAS BOARD OF WATER ENGINEERS BULLETIN 6107, 1961.

WATER-LEVEL MEASUREMENTS THROUGH 1962 IN SELECTED OBSERVATION WELLS, SOUTHERN HIGH PLAINS, TEXAS: TEXAS WATER COMMISSION BULLETIN 6207, 1962.

RECONNAISSANCE INVESTIGATION OF THE GROUND-WATER RESOURCES OF THE RED RIVER, SULPHUR RIVER, AND CYPRESS CREEK BASINS, TEXAS: TEXAS WATER COMMISSION BULLETIN 6306, 1963.

A SUMMARY OF THE OCCURRENCE AND DEVELOPMENT OF GROUND WATER IN THE SOUTHERN HIGH PLAINS OF TEXAS: USGS WATER-SUPPLY PAPER 1693, 1964.

WATER-LEVEL DATA FROM OBSERVATION WELLS IN THE SOUTHERN HIGH PLAINS OF TEXAS: TEXAS WATER DEVELOPMENT BOARD REPORT 21, 1966.

GROUND WATER IN THE OGALLALA FORMATION IN THE SOUTHERN HIGH PLAINS OF TEXAS AND OKLAHOMA: USGS HYDROLOGIC INVESTIGATIONS ATLAS HA-330, 1969.

WATER-LEVEL DATA FROM OBSERVATION WELLS IN THE SOUTHERN HIGH PLAINS OF TEXAS, 1965-70: TEXAS WATER DEVELOPMENT BOARD REPORT 121, 1970.

GROUND-WATER RESOURCES OF WHEELER AND EASTERN GRAY COUNTIES, TEXAS: TEXAS WATER DEVELOPMENT BOARD REPORT 170, 1973.

MAJOR AND HISTORICAL SPRINGS OF TEXAS: TEXAS WATER DEVELOPMENT BOARD REPORT 189, 1975.

WATER-LEVEL DATA FROM OBSERVATION WELLS IN THE SOUTHERN HIGH PLAINS OF TEXAS, 1971-77: TEXAS DEPARTMENT OF WATER RESOURCES REPORT 228, 1979.

PRELIMINARY DATA DESCRIBING THE DISTRIBUTION OF FLUORIDE AND SILICA IN THE OGALLALA AQUIFER ON THE HIGH PLAINS OF TEXAS: USGS OPEN-FILE REPORT 80-349, 1980.

ANALYTICAL STUDY OF THE OGALLALA AQUIFER IN WHEELER COUNTY, TEXAS_PROJECTIONS OF SATURATED THICKNESS, VOLUME OF WATER IN STORAGE, PUMPAGE RATES, PUMPING LIFTS, AND WELL YIELDS: TEXAS DEPARTMENT OF WATER RESOURCES REPORT 266, 1982.

WATER TABLE IN THE HIGH PLAINS AQUIFER IN 1978 IN PARTS OF COLORADO, KANSAS, NEBRASKA, NEW MEXICO, OKLAHOMA, SOUTH DAKOTA, TEXAS, AND WYOMING: USGS HYDROLOGIC INVESTIGATIONS ATLAS HA-642, 1980.

EVALUATING THE GROUND-WATER RESOURCES OF THE HIGH PLAINS OF TEXAS: RESULTS OF SURFACE ELECTRICAL RESISTIVITY: TEXAS DEPARTMENT OF WATER RESOURCES LIMITED PRINTING REPORT LP-130, 1980.

SPRINGS OF TEXAS, VOLUME 1: (BY GUNNAR BRUNE), BRANCHSMITH, INC., FORT WORTH, TEXAS, 1981.
BEDROCK GEOLOGY, ALTITUDE OF BASE, AND 1980 SATURATED THICKNESS OF THE HIGH PLAINS AQUIFER IN PARTS OF COLORADO, KANSAS, NEBRASKA, NEW MEXICO, OKLAHOMA, SOUTH DAKOTA, TEXAS, AND WYOMING: USGS HYDROLOGIC INVESTIGATIONS ATLAS HA-648, 1981.

WATER-LEVEL AND SATURATED-THICKNESS CHANGES, PREDEVELOPMENT TO 1980, IN THE HIGH PLAINS AQUIFER IN PARTS OF COLORADO, KANSAS, NEBRASKA, NEW MEXICO, OKLAHOMA, SOUTH DAKOTA, TEXAS, AND WYOMING: USGS HYDROLOGIC INVESTIGATIONS ATLAS HA-652, 1981.

DISSOLVED SOLIDS AND SODIUM IN WATER FROM THE HIGH PLAINS AQUIFER IN PARTS OF COLORADO, KANSAS, NEBRASKA, NEW MEXICO, OKLAHOMA, SOUTH DAKOTA, TEXAS, AND WYOMING: USGS HYDROLOGIC INVESTIGATIONS ATLAS HA-658, 1982.

GEOHYDROLOGY OF THE HIGH PLAINS AQUIFER IN PARTS OF COLORADO, KANSAS, NEBRASKA, NEW MEXICO, OKLAHOMA, SOUTH DAKOTA, TEXAS, AND WYOMING: USGS PROFESSIONAL PAPER 1400-B, 1984.

EVALUATING THE GROUND-WATER RESOURCES OF THE HIGH PLAINS OF TEXAS, VOLUME 1: TEXAS DEPARTMENT OF WATER RESOURCES REPORT 288, V. 1, 1984.

EVALUATING THE GROUND-WATER RESOURCES OF THE HIGH PLAINS OF TEXAS, VOLUME 2, RECORDS OF WELLS, AND MAPS SHOWING WELL LOCATIONS, BASE OF AQUIFER, WATER LEVELS, AND SATURATED THICKNESS (ARMSTRONG, CARSON, DALLAS, DONLEY, GRAY, HANSFORD, HARTLEY, HEMPHILL, HUTCHINSON, LIPSCOMB, MOORE, OCHILTREE, POTTER, ROBERTS, SHERMAN, AND WHEELER COUNTIES): TEXAS DEPARTMENT OF WATER RESOURCES REPORT 288, V. 2, 1984.

TEXAS GROUND-WATER RESOURCES, in NATIONAL WATER SUMMARY 1984: USGS WATER-SUPPLY PAPER 2275, 1985.

DIGITAL SIMULATION OF GROUND-WATER FLOW IN THE HIGH PLAINS AQUIFER IN PARTS OF COLORADO, KANSAS, NEBRASKA, NEW MEXICO, OKLAHOMA, SOUTH DAKOTA, TEXAS, AND WYOMING: USGS PROFESSIONAL PAPER 1400-D, 1986.

SUMMARY OF THE HIGH PLAINS REGIONAL AQUIFER-SYSTEM ANALYSIS IN PARTS OF COLORADO, KANSAS, NEBRASKA, NEW MEXICO, OKLAHOMA, SOUTH DAKOTA, TEXAS, AND WYOMING: USGS PROFESSIONAL PAPER 1400-A, 1988.

PUBLIC SUPPLY GROUND-WATER USE IN THE SOUTHERN HIGH PLAINS OF TEXAS: TEXAS WATER DEVELOPMENT BOARD REPORT 328, 1990.

WATER-LEVEL CHANGES IN THE HIGH PLAINS AQUIFER OF TEXAS, 1980-1990: TEXAS WATER DEVELOPMENT BOARD HYDROLOGIC ATLAS NO. 1, 1991.

PUBLIC-SUPPLY GROUND-WATER USE IN THE NORTHERN HIGH PLAINS OF TEXAS: TEXAS WATER DEVELOPMENT BOARD REPORT 336, 1992.

EVALUATION OF WATER RESOURCES IN PARTS OF THE ROLLING PRAIRIES REGION OF NORTH-CENTRAL TEXAS: TEXAS WATER DEVELOPMENT BOARD REPORT 337, 1992.

THE HIGH PLAINS AQUIFER SYSTEM OF TEXAS, 1980-1990. OVERVIEW AND PROJECTIONS: TEXAS WATER DEVELOPMENT BOARD REPORT 341, 1993. 
WATER-QUALITY EVALUATION OF THE OGALLALA AQUIFER, TEXAS: TEXAS WATER DEVELOPMENT BOARD REPORT 342, 1993.

WATER-LEVEL CHANGES IN THE HIGH PLAINS AQUIFER-PREDEVELOPMENT TO 1992: USGS WATER-RESOURCES INVESTIGATIONS REPORT 94-4027, 1994.

WATER-LEVEL CHANGES IN THE HIGH PLAINS AQUIFER, 1980 TO 1994: USGS FACT SHEET FS-215-95, 1995.

AQUIFERS OF TEXAS: TEXAS WATER DEVELOPMENT BOARD REPORT 345, 1995.

WATER-LEVEL CHANGES IN THE HIGH PLAINS AQUIFER, 1980 TO 1995: USGS FACT SHEET FS-068-97, 1997.

WATER-LEVEL CHANGES IN THE HIGH PLAINS AQUIFER-PREDEVELOPMENT TO 1995: USGS WATER-RESOURCES INVESTIGATIONS REPORT 97-4081, 1997.

PLAYAS AND RECHARGE OF THE OGALLALA AQUIFER ON THE SOUTHERN HIGH PLAINS OF TEXAS-AN EXAMINATION USING NUMERICAL TECHNIQUES: UNIVERSITY OF TEXAS, BUREAU OF ECONOMIC GEOLOGY REPORT OF INVESTIGATIONS NO. 242, 1997.

UPDATED WATER-QUALITY EVALUATION OF THE OGALLALA AQUIFER INCLUDING SELECTED METALLIC AND NON-METALLIC INORGANIC CONSTITUENTS: TEXAS WATER DEVELOPMENT BOARD HYDROLOGIC ATLAS NO. 10, 1998.

\section{WICHITA COUNTY}

GEOLOGY AND UNDERGROUND WATERS OF THE WICHITA REGION, NORTH-CENTRAL TEXAS: USGS WATER-SUPPLY PAPER 317,1913

WATER RESOURCES OF WICHITA FALLS, TEXAS: USGS OPEN-FILE REPORT (UNNUMBERED), 1943?

GROUND WATER IN THE VICINITY OF WICHITA FALLS, TEXAS: USGS OPEN-FILE REPORT (UNNUMBERED), 1943.

PUBLIC WATER SUPPLIES IN CENTRAL AND NORTH-CENTRAL TEXAS: TEXAS BOARD OF WATER ENGINEERS MISCELLANEOUS PUBLICATION 213, 1947.

PUBLIC WATER SUPPLIES IN CENTRAL AND NORTH-CENTRAL TEXAS: USGS WATER-SUPPLY PAPER 1069, 1949.

RECONNAISSANCE INVESTIGATION OF THE GROUND-WATER RESOURCES OF THE RED RIVER, SULPHUR RIVER, AND CYPRESS CREEK BASINS, TEXAS: TEXAS WATER COMMISSION BULLETIN 6306, 1963.

MAJOR AND HISTORICAL SPRINGS OF TEXAS: TEXAS WATER DEVELOPMENT BOARD REPORT 189, 1975.

SPRINGS OF TEXAS, VOLUME 1: (BY GUNNAR BRUNE), BRANCHSMITH, INC., FORT WORTH, TEXAS, 1981.

TEXAS GROUND-WATER RESOURCES, in NATIONAL WATER SUMMARY 1984: USGS WATER-SUPPLY PAPER 2275, 1985.

WATER USE, PROJECTED WATER REQUIREMENTS, AND RELATED DATA AND INFORMATION FOR THE METROPOLITAN STATISTICAL AREAS IN TEXAS: TEXAS DEPARTMENT OF WATER RESOURCES LIMITED PRINTING REPORT LP-201, 1985.
EVALUATION OF WATER RESOURCES IN PARTS OF THE ROLLING PRAIRIES REGION OF NORTH-CENTRAL TEXAS: TEXAS WATER DEVELOPMENT BOARD REPORT 337, 1992.

AQUIFERS OF TEXAS: TEXAS WATER DEVELOPMENT BOARD REPORT 345, 1995.

\section{WILBARGER COUNTY}

GEOLOGY AND UNDERGROUND WATERS OF THE WICHITA REGION, NORTH-CENTRAL TEXAS: USGS WATER-SUPPLY PAPER $317,1913$.

GROUND-WATER RESOURCES IN THE VICINITY OF VERNON, TEXAS: TEXAS BOARD OF WATER ENGINEERS MISCELLANEOUS PUBLICATION 286, 1944

PUBLIC WATER SUPPLIES IN CENTRAL AND NORTH-CENTRAL TEXAS: TEXAS BOARD OF WATER ENGINEERS MISCELLANEOUS PUBLICATION 213, 1947

PUBLIC WATER SUPPLIES IN CENTRAL AND NORTH-CENTRAL TEXAS: USGS WATER-SUPPLY PAPER 1069, 1949.

GROUND-WATER RESOURCES OF THE ODELL SANDHILLS, WILBARGER COUNTY, TEXAS: TEXAS BOARD OF WATER ENGINEERS BULLETIN 5301, 1953.

RECORDS OF WATER-LEVEL MEASUREMENTS IN FOARD AND WILBARGER COUNTIES, TEXAS, 1936 TO JANUARY 1956: TEXAS BOARD OF WATER ENGINEERS BULLETIN 5614, 1956.

RECONNAISSANCE INVESTIGATION OF ALLEGED CONTAMINATION OF IRRIGATION WELLS NEAR LOCKETT, WILBARGER COUNTY, TEXAS (CONTAMINATION REPORT NO. 8): TEXAS WATER COMMISSION MISCELLANEOUS PUBLICATION 163, 1960.

RECONNAISSANCE INVESTIGATION OF THE GROUND-WATER RESOURCES OF THE RED RIVER, SULFUR RIVER, AND CYPRESS CREEK BASINS, TEXAS: TEXAS WATER COMMISSION BULLETIN 6306, 1963

INVESTIGATION OF GROUND- AND SURFACE-WATER CONTAMINATION NEAR HARROLD, WILBARGER COUNTY, TEXAS: TEXAS WATER COMMISSION LIMITED-DISTRIBUTION REPORT LD-365, 1965.

COMPILATION OF RESULTS OF AQUIFER TESTS IN TEXAS: TEXAS WATER DEVELOPMENT BOARD REPORT 98, 1969.

MAJOR AND HISTORICAL SPRINGS OF TEXAS: TEXAS WATER DEVELOPMENT BOARD REPORT 189, 1975.

OCCURRENCE, QUALITY, AND QUANTITY OF GROUND WATER IN WILBARGER COUNTY, TEXAS: TEXAS DEPARTMENT OF WATER RESOURCES REPORT 240, 1979.

SPRINGS OF TEXAS, VOLUME 1: (BY GUNNAR BRUNE), BRANCHSMITH, INC., FORT WORTH, TEXAS, 1981.

TEXAS GROUND-WATER RESOURCES, in NATIONAL WATER SUMMARY 1984: USGS WATER-SUPPLY PAPER 2275, 1985.

EVALUATION OF WATER RESOURCES IN PARTS OF THE ROLLING PRAIRIES REGION OF NORTH-CENTRAL TEXAS: TEXAS WATER DEVELOPMENT BOARD REPORT 337, 1992.

AQUIFERS OF TEXAS: TEXAS WATER DEVELOPMENT BOARD REPORT 345, 1995. 


\section{WILACY COUNTY}

UNDERGROUND WATERS OF COASTAL PLAIN OF TEXAS: USGS WATER-SUPPLY AND IRRIGATION PAPER 190, 1907.

WATER-TABLE SURVEY IN THE LOWER RIO GRANDE VALLEY, PART 1-WILLACY COUNTY, TEXAS: TEXAS BOARD OF WATER ENGINEERS MISCELLANEOUS PUBLICATION 174, 1937.

MEMORANDUM REGARDING WELLS IN WILLACY COUNTY: USGS OPEN-FILE REPORT (UNNUMBERED), 1943.

PUBLIC WATER SUPPLIES IN SOUTHERN TEXAS: TEXAS BOARD OF WATER ENGINEERS MISCELLANEOUS PUBLICATION 215, 1946.

PUBLIC WATER SUPPLIES IN SOUTHERN TEXAS: USGS WATERSUPPLY PAPER 1106, 1951.

AVAILABILITY OF GROUND WATER IN THE GULF COAST REGION OF TEXAS: USGS OPEN-FILE REPORT (UNNUMBERED), 1956

GROUND-WATER RESOURCES OF THE LOWER RIO GRANDE VALLEY AREA, TEXAS: TEXAS BOARD OF WATER ENGINEERS BULLETIN 6014, V. 1, 1961.

GROUND-WATER RESOURCES OF THE LOWER RIO GRANDE VALLEY AREA, TEXAS: TEXAS BOARD OF WATER ENGINEERS BULLETIN 6014, V. 2, 1961.

RECONNAISSANCE INVESTIGATION OF THE GROUND-WATER RESOURCES OF THE GULF COAST REGION, TEXAS: TEXAS WATER COMMISSION BULLETIN 6305, 1963.

WATER-SUPPLY LIMITATIONS ON IRRIGATION FROM THE RIO GRANDE IN STARR, HIDALGO, CAMERON, AND WILLACY COUNTIES, TEXAS: TEXAS WATER COMMISSION BULLETIN 6413, 1964.

APPENDICES TO B6413, WATER-SUPPLY LIMITATIONS ON IRRIGATION FROM THE RIO GRANDE IN STARR, HIDALGO, CAMERON, AND WILLACY COUNTIES, TEXAS: TEXAS WATER COMMISSION BULLETIN 6413-A, 1965.

RELATION OF PONDED FLOODWATER FROM HURRICANE BEULAH TO GROUND WATER IN KLEBERG, KENEDY, AND WILLACY COUNTIES, TEXAS: TEXAS WATER DEVELOPMENT BOARD REPORT 138, 1971

SUMMARY APPRAISALS OF THE NATION'S GROUND-WATER RESOURCES-TEXAS-GULF REGION: USGS PROFESSIONAL PAPER 813-F, 1976.

STRATIGRAPHIC AND HYDROGEOLOGIC FRAMEWORK OF PART OF THE COASTAL PLAIN OF TEXAS: USGS OPEN-FILE REPORT 77-712, 1978 .

STRATIGRAPHIC AND HYDROGEOLOGIC FRAMEWORK OF PART OF THE COASTAL PLAIN OF TEXAS: TEXAS DEPARTMENT OF WATER RESOURCES REPORT 236, 1979.

LAND-SURFACE SUBSIDENCE IN THE TEXAS COASTAL REGION: USGS OPEN-FILE REPORT 80-969, 1980.

SPRINGS OF TEXAS, VOLUME 1: (BY GUNNAR BRUNE), BRANCHSMITH, INC., FORT WORTH, TEXAS, 1981.

LAND-SURFACE SUBSIDENCE IN THE TEXAS COASTAL REGION: TEXAS DEPARTMENT OF WATER RESOURCES REPORT 272, 1982.

STRUCTURE, TEMPERATURE, PRESSURE, AND SALINITY OF CENOZOIC AQUIFERS OF SOUTH TEXAS: USGS HYDROLOGIC INVESTIGATIONS ATLAS HA-654, 1983.
WATER LEVELS AND SALINITIES OF WATER WITHIN THE EVANGELINE AQUIFER IN AN AREA SOUTHWEST OF CORPUS CHRISTI, TEXAS: USGS OPEN-FILE REPORT 82-174, 1983.

TEXAS GROUND-WATER RESOURCES, in NATIONAL WATER SUMMARY 1984: USGS WATER-SUPPLY PAPER 2275, 1985.

DIGITAL MODELS FOR SIMULATION OF GROUND-WATER HYDROLOGY OF THE CHICOT AND EVANGELINE AQUIFERS ALONG THE GULF COAST OF TEXAS: TEXAS DEPARTMENT OF WATER RESOURCES REPORT 289, 1985.

GEOHYDROLOGIC FRAMEWORK OF THE GULF COASTAL PLAIN: USGS HYDROLOGIC INVESTIGATIONS ATLAS HA-695, 1988.

HYDROGEOLOGY AND PREDEVELOPMENT FLOW IN THE TEXAS GULF COAST AQUIFER SYSTEMS: USGS WATER-RESOURCES INVESTIGATIONS REPORT 87-4248, 1988.

EVALUATION OF GROUND-WATER RESOURCES IN THE LOWER RIO GRANDE VALLEY, TEXAS: TEXAS WATER DEVELOPMENT BOARD REPORT 316, 1990.

GROUND-WATER FLOW IN THE GULF COAST AQUIFER SYSTEMS, SOUTH-CENTRAL UNITED STATES-A PRELIMINARY ANALYSIS USGS WATER-RESOURCES INVESTIGATIONS REPORT 89-4071, 1990.

HYDROLOGY OF THE TEXAS GULF COAST AQUIFER SYSTEMS: USGS OPEN-FILE REPORT 91-64, 1991.

PROPERTIES AND CHEMICAL CONSTITUENTS IN GROUND WATER FROM THE MISSISSIPPI RIVER VALLEY ALLUVIAL AQUIFER AND PERMEABLE ZONE A (HOLOCENE-UPPER PLEISTOCENE DEPOSITS), SOUTH-CENTRAL UNITED STATES: USGS WATERRESOURCES INVESTIGATIONS REPORT 91-4149, 1992.

PROPERTIES AND CHEMICAL CONSTITUENTS IN GROUND WATER FROM THE UPPER CLAIBORNE AQUIFER, GULF COAST REGIONAL AQUIFER SYSTEMS, SOUTH-CENTRAL UNITED STATES: USGS WATER-RESOURCES INVESTIGATIONS REPORT 91-4150, 1993.

PROPERTIES AND CHEMICAL CONSTITUENTS IN GROUND WATER FROM PERMEABLE ZONE C (LOWER PLIOCENE-UPPER MIOCENE DEPOSITS), COASTAL LOWLANDS AQUIFER SYSTEM, SOUTHCENTRAL UNITED STATES: USGS WATER-RESOURCES INVESTIGATIONS REPORT 91-4151, 1993.

PROPERTIES AND CHEMICAL CONSTITUENTS IN GROUND WATER FROM PERMEABLE ZONE B (LOWER PLEISTOCENE-UPPER PLIOCENE DEPOSITS), COASTAL LOWLANDS AQUIFER SYSTEM, SOUTH-CENTRAL UNITED STATES: USGS WATER-RESOURCES INVESTIGATIONS REPORT 91-4152, 1993.

PROPERTIES AND CHEMICAL CONSTITUENTS IN GROUND WATER FROM PERMEABLE ZONE E (LOWER MIOCENE-UPPER OLIGOCENE DEPOSITS), COASTAL LOWLANDS AQUIFER SYSTEM, SOUTH-CENTRAL UNITED STATES: USGS WATER-RESOURCES INVESTIGATIONS REPORT 92-4103, 1993.

PROPERTIES AND CHEMICAL CONSTITUENTS IN GROUND WATER FROM PERMEABLE ZONE D (MIDDLE MIOCENE DEPOSITS), COASTAL LOWLANDS AQUIFER SYSTEM, SOUTH-CENTRAL UNITED STATES: USGS WATER-RESOURCES INVESTIGATIONS REPORT 92-4105, 1993.

AQUIFERS OF TEXAS: TEXAS WATER DEVELOPMENT BOARD REPORT 345, 1995. 


\section{WILIAMSON COUNTY}

GEOLOGY OF THE EDWARDS PLATEAU AND RIO GRANDE PLAIN ADJACENT TO AUSTIN AND SAN ANTONIO, TEXAS, WITH REFERENCE TO THE OCCURRENCE OF UNDERGROUND WATERS: USGS 18TH ANNUAL REPORT, PART 2, 1898.

GEOGRAPHY AND GEOLOGY OF THE BLACK AND GRAND PRAIRIES OF TEXAS, WITH DETAILED DESCRIPTIONS OF THE CRETACEOUS FORMATIONS AND SPECIAL REFERENCE TO ARTESIAN WATERS: USGS 21ST ANNUAL REPORT, PART 7, 1901

RECORDS OF WELLS AND SPRINGS, DRILLERS' LOGS, WATER ANALYSES, AND MAP SHOWING LOCATION OF WELLS AND SPRINGS IN WILLIAMSON COUNTY, TEXAS: TEXAS BOARD OF WATER ENGINEERS MISCELLANEOUS PUBLICATION 298, 1942.

WATER SUPPLY AT GRANGER, TEXAS: USGS OPEN-FILE REPORT (UNNUMBERED), 1944

PUBLIC WATER SUPPLIES IN CENTRAL AND NORTH-CENTRAL TEXAS: TEXAS BOARD OF WATER ENGINEERS MISCELLANEOUS PUBLICATION 213, 1947.

AREAL GEOLOGY OF THE JOLLYVILLE PLATEAU AND THE REGIONAL GROUND WATER: UNIVERSITY OF TEXAS AT AUSTIN MASTER'S THESIS, 1948

PUBLIC WATER SUPPLIES IN CENTRAL AND NORTH-CENTRAL TEXAS: USGS WATER-SUPPLY PAPER 1069, 1949.

RECORDS OF WATER-LEVEL MEASUREMENTS IN HAYS, TRAVIS, AND WILLIAMSON COUNTIES, TEXAS, 1937 TO MAY 1956: TEXAS BOARD OF WATER ENGINEERS BULLETIN 5612, 1956.

QUALITY OF GROUND WATER IN CRETACEOUS ROCKS IN WILLIAMSON AND EASTERN BURNET COUNTIES, TEXAS (APPENDIX 2, RECORDS OF WELLS AND SPRINGS, WILLIAMSON COUNTY): UNIVERSITY OF TEXAS AT AUSTIN MASTERS THESIS, 1974.

GEOMORPHOLOGY AND HYDROGEOLOGY OF THE TAYLOR ALLUVIAL FAN, WILLIAMSON COUNTY, TEXAS: THE UNIVERSITY OF TEXAS AT AUSTIN, MASTER'S THESIS, 1974

MAJOR AND HISTORICAL SPRINGS OF TEXAS: TEXAS WATER DEVELOPMENT BOARD REPORT 189, 1975.

GROUND-WATER RESOURCES OF PART OF CENTRAL TEXAS WITH EMPHASIS ON THE ANTLERS AND TRAVIS PEAK FORMATIONS: TEXAS WATER DEVELOPMENT BOARD REPORT 195, V. 1, 1975.

MAJOR AND HISTORICAL SPRINGS OF TEXAS: TEXAS WATER DEVELOPMENT BOARD REPORT 189, 1975.

GROUND-WATER RESOURCES OF PART OF CENTRAL TEXAS WITH EMPHASIS ON THE ANTLERS AND TRAVIS PEAK FORMATIONS: TEXAS WATER DEVELOPMENT BOARD REPORT 195, V. 2, 1976.

SPRINGS OF TEXAS, VOLUME 1: (BY GUNNAR BRUNE), BRANCHSMITH, INC., FORT WORTH, TEXAS, 1981.

TEXAS GROUND-WATER RESOURCES, in NATIONAL WATER SUMMARY 1984: USGS WATER-SUPPLY PAPER 2275, 1985.

WATER USE, PROJECTED WATER REQUIREMENTS, AND RELATED DATA AND INFORMATION FOR THE METROPOLITAN STATISTICAL AREAS IN TEXAS: TEXAS DEPARTMENT OF WATER RESOURCES LIMITED PRINTING REPORT LP-201, 1985.
EDWARDS AQUIFER-NORTHERN SEGMENT, TRAVIS, WILLIAMSON, AND BELL COUNTIES, TEXAS: AUSTIN GEOLOGICAL SOCIETY GUIDEBOOK 8, 1985.

GEOHYDROLOGY OF THE EDWARDS AQUIFER IN THE AUSTIN AREA, TEXAS: TEXAS WATER DEVELOPMENT BOARD REPORT 293, 1986

HYDROLOGIC AND GEOLOGIC DATA FOR THE EDWARDS AQUIFER RECHARGE ZONE NEAR GEORGETOWN, WILLIAMSON COUNTY, TEXAS, 1986-87: USGS OPEN-FILE REPORT 87-691, 1987.

HYDROGEOLOGY OF THE EDWARDS AQUIFER, NORTHERN BALCONES AND WASHITA PRAIRIE SEGMENTS: AUSTIN GEOLOGICAL SOCIETY GUIDEBOOK 11, 1987.

REASSESSMENT OF THE GEORGETOWN LIMESTONE AS A HYDROGEOLOGIC UNIT OF THE EDWARDS AQUIFER, GEORGETOWN AREA, TEXAS: USGS WATER-RESOURCES INVESTIGATIONS REPORT 88-4190, 1988.

GEOHYDROLOGIC FRAMEWORK OF THE GULF COASTAL PLAIN: USGS HYDROLOGIC INVESTIGATIONS ATLAS HA-695, 1988.

SUMMARY OF HYDROLOGIC DATA FOR THE SAN GABRIEL RIVER BASIN AND EDWARDS AQUIFER, GEORGETOWN AREA, TEXAS, WATER YEAR 1988: USGS OPEN-FILE REPORT 89-226, 1989.

EVALUATION OF WATER RESOURCES IN PART OF CENTRAL TEXAS: TEXAS WATER DEVELOPMENT BOARD REPORT 319, 1990.

HYDROGEOLOGY OF THE NORTHERN SEGMENT OF THE EDWARDS AQUIFER, AUSTIN REGION: UNIVERSITY OF TEXAS, BUREAU OF ECONOMIC GEOLOGY REPORT OF INVESTIGATIONS NO. 192, 1990.

TEST WELL DRILLING INVESTIGATION TO DELINEATE THE DOWNDIP LIMITS OF USABLE-QUALITY GROUND WATER IN THE EDWARDS AQUIFER IN THE AUSTIN REGION, TEXAS: TEXAS WATER DEVELOPMENT BOARD REPORT 325, 1990.

EVALUATION OF WATER RESOURCES IN BELL, BURNET, TRAVIS, WILLIAMSON, AND PARTS OF ADJACENT COUNTIES, TEXAS: TEXAS WATER DEVELOPMENT BOARD REPORT 326, 1991

GROUND-WATER RESOURCES OF THE CARRIZO-WILCOX AQUIFER IN THE CENTRAL TEXAS REGION: TEXAS WATER DEVELOPMENT BOARD REPORT 332, 1991.

SUMMARY OF HYDROLOGIC DATA FOR THE SAN GABRIEL RIVER BASIN AND EDWARDS AQUIFER, GEORGETOWN AREA, TEXAS, WATER YEAR 1990: USGS OPEN-FILE REPORT 92-160, 1992.

WATER-RESOURCES DATA, TEXAS, WATER YEAR 1991, VOLUME 4 GROUND-WATER DATA: USGS WATER-DATA REPORT TX-91-4, 1992.

WATER-RESOURCES DATA, TEXAS, WATER YEAR 1992, VOLUME 4, GROUND-WATER DATA: USGS WATER-DATA REPORT TX-92-4, 1993.

WATER-RESOURCES DATA, TEXAS, WATER YEAR 1993, VOLUME 4, GROUND-WATER DATA: USGS WATER-DATA REPORT TX-93-4, 1994.

STRATIGRAPHIC NOMENCLATURE AND GEOLOGIC SECTIONS OF THE GULF COASTAL PLAIN OF TEXAS: USGS OPEN-FILE REPORT 94-461, 1995.

AQUIFERS OF TEXAS: TEXAS WATER DEVELOPMENT BOARD REPORT 345, 1995 
WATER-RESOURCES DATA, TEXAS, WATER YEAR 1994, VOLUME 4, GROUND-WATER DATA: USGS WATER-DATA REPORT TX-94-4, 1995.

THE PALEOZOIC AND RELATED AQUIFERS OF CENTRAL TEXAS: TEXAS WATER DEVELOPMENT BOARD REPORT 346, 1996.

WATER-RESOURCES DATA, TEXAS, WATER YEAR 1995, VOLUME 4, GROUND-WATER DATA: USGS WATER-DATA REPORT TX-95-4, 1996.

WATER-RESOURCES DATA, TEXAS, WATER YEAR 1996, VOLUME 4, GROUND-WATER DATA: USGS WATER-DATA REPORT TX-96-4, 1997.

GROUND-WATER AVAILABILITY IN THE CARRIZO-WILCOX AQUIFER IN CENTRAL TEXAS-NUMERICAL SIMULATIONS OF 2000 THROUGH 2050 WITHDRAWAL PROJECTIONS: UNIVERSITY OF TEXAS, BUREAU OF ECONOMIC GEOLOGY REPORT OF INVESTIGATIONS NO. 256, 1999.

CHANGES IN GROUNDWATER CONDITIONS IN THE EDWARDS AND TRINITY AQUIFERS, 1987-1997, FOR PORTIONS OF BASTROP, BELL, BURNET, LEE, MILAM, TRAVIS, AND WILLIAMSON COUNTIES, TEXAS: TEXAS WATER DEVELOPMENT BOARD REPORT $350,1999$.

\section{WILSON COUNTY}

UNDERGROUND WATERS OF THE COASTAL PLAIN OF TEXAS: USGS WATER-SUPPLY PAPER 190, 1907.

RECORDS OF WELLS, DRILLERS' LOGS, AND WATER ANALYSES, AND MAP SHOWING LOCATION OF WELLS IN WILSON COUNTY, TEXAS: TEXAS BOARD OF WATER ENGINEERS MISCELLANEOUS PUBLICATION 299, 1936.

GROUND-WATER IN THE VICINITY OF DILTZ FIELD, WILSON COUNTY, TEXAS: USGS OPEN-FILE REPORT (UNNUMBERED), 1943.

PUBLIC WATER SUPPLIES IN SOUTHERN TEXAS: TEXAS BOARD OF WATER ENGINEERS MISCELLANEOUS PUBLICATION 215, 1946.

POTH, TEXAS: USGS OPEN-FILE REPORT (UNNUMBERED), 1949.

PUBLIC WATER SUPPLIES IN SOUTHERN TEXAS: USGS WATERSUPPLY PAPER 1070, 1950.

SUPPLEMENTAL REPORT ON SURFACE-WATER AND GROUNDWATER SURVEYS, NUECES RIVER BASIN, TEXAS: USGS OPENFILE REPORT (UNNUMBERED), 1950.

RECHARGE TO THE CARRIZO SAND IN ATASCOSA COUNTY AND ADJACENT AREAS: USGS OPEN-FILE REPORT (UNNUMBERED), 1951.

GROUND-WATER GEOLOGY OF WILSON COUNTY, TEXAS: TEXAS BOARD OF WATER ENGINEERS BULLETIN 5710, 1957.

WATER-WELL CONTAMINATION IN THE SASPAMCO AREA, WILSON COUNTY, TEXAS (CONTAMINATION REPORT NO. 3): TEXAS BOARD OF WATER ENGINEERS MISCELLANEOUS PUBLICATION 300, 1958

RECONNAISSANCE INVESTIGATION OF THE GROUND-WATER RESOURCES OF THE GUADALUPE, SAN ANTONIO, AND NUECES RIVER BASINS, TEXAS: TEXAS WATER COMMISSION BULLETIN 6409, 1964.
HYDROLOGIC SIGNIFICANCE OF THE LITHOFACIES OF THE SPARTA SAND IN ARKANSAS, LOUISIANA, MISSISSIPPI, AND TEXAS: USGS PROFESSIONAL PAPER 569-A, 1968.

WATER-LEVEL DATA FROM OBSERVATION WELLS IN THE NORTHWESTERN GULF COASTAL PLAIN OF TEXAS: TEXAS WATER DEVELOPMENT BOARD REPORT 70, 1968.

COMPILATION OF RESULTS OF AQUIFER TESTS IN TEXAS: TEXAS WATER DEVELOPMENT BOARD REPORT 98, 1969.

GEOHYDROLOGIC SIGNIFICANCE OF LITHOFACIES OF THE COCKFIELD FORMATION OF LOUISIANA AND MISSISSIPPI AND OF THE YEGUA FORMATION OF TEXAS: USGS PROFESSIONAL PAPER 569-B, 1970.

HYDROLOGIC SIGNIFICANCE OF LITHOFACIES OF THE CANE RIVER FORMATION OR EQUIVALENTS OF ARKANSAS, LOUISIANA, MISSISSIPPI, AND TEXAS: USGS PROFESSIONAL PAPER 569-C, 1972.

HYDROLOGIC SIGNIFICANCE OF LITHOFACIES OF THE CARRIZO SAND OF ARKANSAS, LOUISIANA, AND TEXAS AND THE MERIDIAN SAND OF MISSISSIPPI: USGS PROFESSIONAL PAPER 569-D, 1975.

MAJOR AND HISTORICAL SPRINGS OF TEXAS: TEXAS WATER DEVELOPMENT BOARD REPORT 189, 1975.

SUMMARY APPRAISALS OF THE NATION'S GROUND-WATER RESOURCES-TEXAS-GULF REGION: USGS PROFESSIONAL PAPER 813-F, 1976.

GROUND-WATER RESOURCES OF THE CARRIZO AQUIFER IN THE WINTER GARDEN AREA OF TEXAS, VOLUME 1: TEXAS WATER DEVELOPMENT BOARD REPORT 210, V. 1, 1976.

GROUND-WATER RESOURCES OF THE CARRIZO AQUIFER IN THE WINTER GARDEN AREA OF TEXAS, VOLUME 2: TEXAS WATER DEVELOPMENT BOARD REPORT 210, V. 2, 1977.

STRATIGRAPHIC AND HYDROGEOLOGIC FRAMEWORK OF PART OF THE COASTAL PLAIN OF TEXAS: USGS OPEN-FILE REPORT $77-712,1978$.

VARIATIONS IN SPECIFIC YIELD IN THE OUTCROP OF THE CARRIZO SAND IN SOUTH TEXAS AS ESTIMATED BY SEISMIC REFRACTION: TEXAS DEPARTMENT OF WATER RESOURCES REPORT 229, 1979.

STRATIGRAPHIC AND HYDROGEOLOGIC FRAMEWORK OF PART OF THE COASTAL PLAIN OF TEXAS: TEXAS DEPARTMENT OF WATER RESOURCES REPORT 236, 1979.

TEXAS GROUND-WATER RESOURCES, in NATIONAL WATER SUMMARY 1984: USGS WATER-SUPPLY PAPER 2275, 1985.

DIGITAL MODELS FOR SIMULATION OF GROUND-WATER HYDROLOGY OF THE CHICOT AND EVANGELINE AQUIFERS ALONG THE GULF COAST OF TEXAS: TEXAS DEPARTMENT OF WATER RESOURCES REPORT 289, 1985

APPROXIMATE POTENTIOMETRIC SURFACES FOR THE AQUIFERS OF THE TEXAS COASTAL UPLANDS SYSTEM, 1980: USGS HYDROLOGIC INVESTIGATIONS ATLAS HA-704, 1987.

GEOHYDROLOGIC FRAMEWORK OF THE GULF COASTAL PLAIN: USGS HYDROLOGIC INVESTIGATIONS ATLAS HA-695, 1988.

DEPOSITIONAL AND GROUND-WATER FLOW SYSTEMS OF THE CARRIZO-UPPER WILCOX, SOUTH TEXAS: UNIVERSITY OF 


\section{Bibliography of Ground-Water References for All 254 Counties in Texas, 1886-2001}

TEXAS, BUREAU OF ECONOMIC GEOLOGY REPORT OF INVESTIGATIONS NO. 175,1988

HYDROGEOLOGY AND PREDEVELOPMENT FLOW IN THE TEXAS GULF COAST AQUIFER SYSTEMS: USGS WATER-RESOURCES INVESTIGATIONS SYSTEMS REPORT 87-4248, 1988.

GROUND-WATER FLOW IN THE GULF COAST AQUIFER SYSTEMS, SOUTH CENTRAL UNITED STATES-A PRELIMINARY ANALYSIS: USGS WATER-RESOURCES INVESTIGATIONS REPORT 89-4071, 1990.

HYDROLOGY OF THE TEXAS GULF COAST AQUIFER SYSTEMS: USGS OPEN-FILE REPORT 91-64, 1991.

GROUND-WATER RESOURCES OF THE CARRIZO-WILCOX AQUIFER IN THE CENTRAL TEXAS REGION: TEXAS WATER DEVELOPMENT BOARD REPORT 332, 1991.

GROUND-WATER QUALITY MONITORING RESULTS IN THE WINTER GARDEN AREA, 1990: TEXAS WATER DEVELOPMENT BOARD REPORT 335, 1992

PROPERTIES AND CHEMICAL CONSTITUENTS IN GROUND WATER FROM THE MIDDLE WILCOX AQUIFER, GULF COAST REGIONAL AQUIFER SYSTEMS, SOUTH-CENTRAL UNITED STATES: USGS WATER-RESOURCES INVESTIGATIONS REPORT 93-4070, 1993.

PROPERTIES AND CHEMICAL CONSTITUENTS IN GROUND WATER FROM THE UPPER CLAIBORNE AQUIFER, GULF COAST REGIONAL AQUIFER SYSTEMS, SOUTH-CENTRAL UNITED STATES: USGS WATER-RESOURCES INVESTIGATIONS REPORT 91-4150, 1993.

PROPERTIES AND CHEMICAL CONSTITUENTS IN GROUND WATER FROM THE LOWER CLAIBORNE-UPPER WILCOX AQUIFER, GULF COAST REGIONAL AQUIFER SYSTEMS, SOUTH-CENTRAL UNITED STATES: USGS WATER-RESOURCES INVESTIGATIONS REPORT 92-4102, 1993.

PROPERTIES AND CHEMICAL CONSTITUENTS IN GROUND WATER FROM THE MIDDLE CLAIBORNE AQUIFER, GULF COAST REGIONAL AQUIFER SYSTEMS, SOUTH-CENTRAL UNITED STATES: USGS WATER-RESOURCES INVESTIGATIONS REPORT 92-4104, 1993.

DEFINING THE EDWARDS AQUIFER FRESHWATER/SALINE-WATER INTERFACE WITH GEOPHYSICAL LOGS AND MEASURED DATA (SAN ANTONIO TO KYLE, TEXAS): EDWARDS UNDERGROUND WATER DISTRICT REPORT 93-06, 1993.

1994 REVIEW AND UPDATE OF THE POSITION OF THE EDWARDS AQUIFER FRESHWATER/SALINE-WATER INTERFACE FROM UVALDE TO KYLE, TEXAS: EDWARDS UNDERGROUND WATER DISTRICT REPORT 94-05, 1994.

STRATIGRAPHIC NOMENCLATURE AND GEOLOGIC SECTIONS OF THE GULF COASTAL PLAIN OF TEXAS: USGS OPEN-FILE REPORT 94-461, 1995.

WATER QUALITY IN THE SPARTA AQUIFER, EAST TEXAS: TEXAS WATER DEVELOPMENT BOARD HYDROLOGIC ATLAS NO. 5 , 1996.

WATER QUALITY IN THE QUEEN CITY AQUIFER, EAST TEXAS: TEXAS WATER DEVELOPMENT BOARD HYDROLOGIC ATLAS NO. 6, 1996

\section{WINKLER COUNTY}

REPORT ON THE PROPOSED WATER SUPPLY, KERMIT, TEXAS: USGS OPEN-FILE REPORT (UNNUMBERED), 1939.

RECORDS OF WELLS, DRILLERS' LOGS, AND WATER ANALYSES, AND MAP SHOWING LOCATIONS OF WELLS IN WINKLER COUNTY, TEXAS: TEXAS BOARD OF WATER ENGINEERS OPENFILE REPORT 301, 1941.

GROUND WATER IN THE VICINITY OF KERMIT, TEXAS: USGS OPENFILE REPORT (UNNUMBERED), 1947.

PUBLIC WATER SUPPLIES IN WESTERN TEXAS: TEXAS BOARD OF WATER ENGINEERS MISCELLANEOUS PUBLICATION 216, 1949.

PUBLIC WATER SUPPLIES IN WESTERN TEXAS: USGS WATERSUPPLY PAPER 1106, 1951.

GEOLOGY AND GROUND-WATER RESOURCES OF WINKLER COUNTY, TEXAS: TEXAS BOARD OF WATER ENGINEERS BULLETIN 5916, 1959.

SHALLOW FORMATIONS AND AQUIFERS OF THE WEST TEXAS AREA: WEST TEXAS GEOLOGICAL SOCIETY PUBLICATION 61-45 AND PERMIAN BASIN GEOPHYSICAL SOCIETY, MIDLAND, TEXAS, 1961

RECONNAISSANCE INVESTIGATION OF THE GROUND-WATER RESOURCES OF THE RIO GRANDE BASIN, TEXAS: TEXAS WATER COMMISSION BULLETIN 6502, 1965.

A REAPPRAISAL OF THE GROUND-WATER RESOURCES OF WINKLER COUNTY, TEXAS, WITH PARTICULAR EMPHASIS ON CONDITIONS IN THE VICINITY OF KERMIT: USGS OPEN-FILE REPORT 69-217, 1969

COMPILATION OF RESULTS OF AQUIFER TESTS IN TEXAS: TEXAS WATER DEVELOPMENT BOARD REPORT 98, 1969.

RECONNAISSANCE INVESTIGATION OF GROUND WATER IN THE RIO GRANDE DRAINAGE BASIN—WITH SPECIAL EMPHASIS ON SALINE GROUND-WATER RESOURCES: USGS HYDROLOGIC INVESTIGATIONS ATLAS HA-510, 1974.

SUMMARY APPRAISALS OF THE NATION'S GROUND-WATER RESOURCES-RIO GRANDE REGION: USGS PROFESSIONAL PAPER 813-D, 1975

MAJOR AND HISTORICAL SPRINGS OF TEXAS: TEXAS WATER DEVELOPMENT BOARD REPORT 189, 1975.

OCCURRENCE, AVAILABILITY, AND CHEMICAL QUALITY OF GROUND WATER IN THE EDWARDS PLATEAU REGION OF TEXAS: TEXAS DEPARTMENT OF WATER RESOURCES REPORT 235,1979

OCCURRENCE AND QUALITY OF GROUND WATER IN THE EDWARDS-TRINITY (PLATEAU) AQUIFER IN THE TRANS-PECOS REGION OF TEXAS: TEXAS DEPARTMENT OF WATER RESOURCES REPORT 255, 1980

SPRINGS OF TEXAS, VOLUME 1: (BY GUNNAR BRUNE), BRANCHSMITH, INC., FORT WORTH, TEXAS, 1981.

MAPS SHOWING DISTRIBUTION OF DISSOLVED SOLIDS AND DOMINANT CHEMICAL TYPE IN GROUND WATER, BASIN AND RANGE PROVINCE, TEXAS: USGS WATER-RESOURCES INVESTIGATIONS REPORT 83-4121-C, 1984. 
TEXAS GROUND-WATER RESOURCES, in NATIONAL WATER SUMMARY 1984: USGS WATER-SUPPLY PAPER 2275, 1985.

RECORDS OF WELLS, WATER LEVELS, PUMPAGE, AND CHEMICAL ANALYSES FROM SELECTED WELLS IN PARTS OF THE TRANSPECOS REGION, TEXAS, 1968-1980: TEXAS WATER DEVELOPMENT BOARD REPORT 301, 1987.

HYDROGEOLOGY AND HYDROCHEMISTRY OF CRETACEOUS AQUIFERS, TEXAS PANHANDLE AND EASTERN NEW MEXICO: UNIVERSITY OF TEXAS, BUREAU OF ECONOMIC GEOLOGY GEOLOGICAL CIRCULAR 88-3, 1988.

PUBLIC SUPPLY GROUND-WATER USE IN WESTERN TEXAS: TEXAS WATER DEVELOPMENT BOARD REPORT 311, 1989.

POTENTIOMETRIC SURFACE OF THE EDWARDS-TRINITY AQUIFER SYSTEM AND CONTIGUOUS HYDRAULICALLY CONNECTED UNITS, WEST-CENTRAL TEXAS, WINTER 1974-75: USGS WATERRESOURCES INVESTIGATIONS REPORT 89-4208, 1990.

EVALUATION OF GROUND-WATER RESOURCES IN PARTS OF LOVING, PECOS, REEVES, WARD, AND WINKLER COUNTIES, TEXAS: TEXAS WATER DEVELOPMENT BOARD REPORT 317, 1990.

WITHDRAWALS FROM THE EDWARDS-TRINITY AQUIFER SYSTEM AND CONTIGUOUS HYDRAULICALLY CONNECTED UNITS, WEST-CENTRAL TEXAS, DECEMBER 1974 THROUGH MARCH 1977: USGS WATER-RESOURCES INVESTIGATIONS REPORT 91-4021, 1991.

CONFIGURATION OF THE BASE OF THE EDWARDS-TRINITY AQUIFER SYSTEM AND HYDROGEOLOGY OF THE UNDERLYING PRECRETACEOUS ROCKS, WEST-CENTRAL TEXAS: USGS WATERRESOURCES INVESTIGATIONS REPORT 91-4071, 1992.

EVALUATION OF WATER RESOURCES IN PARTS OF THE ROLLING PRAIRIES REGION OF NORTH-CENTRAL TEXAS: TEXAS WATER DEVELOPMENT BOARD REPORT 337, 1992.

HISTORICAL POTENTIOMETRIC SURFACE OF THE EDWARDS-TRINITY AQUIFER SYSTEM AND CONTIGUOUS HYDRAULICALLY CONNECTED UNITS, WEST-CENTRAL TEXAS: USGS WATERRESOURCES INVESTIGATIONS REPORT 92-4055, 1993.

HISTORICAL SATURATED THICKNESS OF THE EDWARDS-TRINITY AQUIFER SYSTEM AND SELECTED CONTIGUOUS HYDRAULICALLY CONNECTED UNITS, WEST-CENTRAL TEXAS: USGS WATER-RESOURCES INVESTIGATIONS REPORT 92-4125, 1993.

SIMULATIONS OF FLOW IN THE EDWARDS-TRINITY AQUIFER SYSTEM AND CONTIGUOUS HYDRAULICALLY CONNECTED UNITS, WEST-CENTRAL TEXAS: USGS WATER-RESOURCES INVESTIGATIONS REPORT 93-4039, 1994.

DISSOLVED-SOLIDS CONCENTRATIONS AND HYDROCHEMICAL FACIES IN WATER OF THE EDWARDS-TRINITY AQUIFER SYSTEM, WEST-CENTRAL TEXAS: USGS WATER-RESOURCES INVESTIGATIONS REPORT 93-4126, 1994.

GEOLOGIC HISTORY AND HYDROGEOLOGIC SETTING OF THE EDWARDS-TRINITY AQUIFER SYSTEM, WEST-CENTRAL TEXAS: USGS WATER-RESOURCES INVESTIGATIONS REPORT 94-4039, 1994.

WATER QUALITY IN THE EDWARDS-TRINITY (PLATEAU) AQUIFER, EDWARDS PLATEAU AND TRANS-PECOS, TEXAS: TEXAS WATER DEVELOPMENT BOARD HYDROLOGIC ATLAS NO. 3, 1995.

AQUIFERS OF TEXAS: TEXAS WATER DEVELOPMENT BOARD REPORT 345, 1995.
HYDROGEOLOGIC FRAMEWORK OF THE EDWARDS-TRINITY AQUIFER SYSTEM, WEST-CENTRAL TEXAS: USGS PROFESSIONAL PAPER 1421-B, 1996.

WATER QUALITY IN THE CAPITAN REEF AQUIFER: TEXAS WATER DEVELOPMENT BOARD HYDROLOGIC ATLAS NO. 8, 1997.

CHANGES IN GROUNDWATER CONDITIONS IN PARTS OF TRANSPECOS TEXAS, 1988-1998: TEXAS WATER DEVELOPMENT BOARD REPORT 348, 1999.

AQUIFERS OF WEST TEXAS: TEXAS WATER DEVELOPMENT BOARD REPORT 356, 2001.

REGIONAL GROUND-WATER FLOW SYSTEMS IN TRANS-PECOS TEXAS, CHAPTER 4, in AQUIFERS OF WEST TEXAS: TEXAS WATER DEVELOPMENT BOARD REPORT 356, 2001

CENOZOIC PECOS ALLUVIUM AQUIFER, CHAPTER 9, in AQUIFERS OF WEST TEXAS: TEXAS WATER DEVELOPMENT BOARD REPORT 356, 2001.

THE GEOLOGY AND HYDROGEOLOGY OF THE CAPITAN AQUIFER: A BRIEF OVERVIEW, CHAPTER 11, in AQUIFERS OF WEST TEXAS: TEXAS WATER DEVELOPMENT BOARD REPORT 356, 2001.

THE DOCKUM AQUIFER IN WEST TEXAS, CHAPTER 12, in AQUIFERS OF WEST TEXAS: TEXAS WATER DEVELOPMENT BOARD REPORT 356, 2001

\section{WISE COUNTY}

GEOGRAPHY AND GEOLOGY OF THE BLACK AND GRAND PRAIRIES, TEXAS, WITH DETAILED DESCRIPTIONS OF THE CRETACEOUS FORMATIONS AND SPECIAL REFERENCE TO ARTESIAN WATERS: USGS 21ST ANNUAL REPORT, PART 7, 1901.

GROUND WATER IN WISE COUNTY: USGS OPEN-FILE REPORT (UNNUMBERED), 1937

SUMMARY REPORT ON THE LEAKAGE AT THE DAM OF THE TARRANT COUNTY CONTROL AND IMPROVEMENT DISTRICT NO. 1 NEAR BRIDGEPORT, WISE COUNTY, TEXAS: USGS OPEN-FILE REPORT (UNNUMBERED), 1943.

PUBLIC WATER SUPPLIES IN CENTRAL AND NORTH-CENTRAL TEXAS: TEXAS BOARD OF WATER ENGINEERS MISCELLANEOUS PUBLICATION 213, 1947

PUBLIC WATER SUPPLIES IN CENTRAL AND NORTH-CENTRAL TEXAS: USGS WATER-SUPPLY PAPER 1069, 1949.

RECONNAISSANCE INVESTIGATION OF THE GROUND-WATER RESOURCES OF THE TRINITY RIVER BASIN, TEXAS: TEXAS WATER COMMISSION BULLETIN 6309, 1963.

GROUND-WATER RESOURCES OF PART OF CENTRAL TEXAS WITH EMPHASIS ON THE ANTLERS AND TRAVIS PEAK FORMATIONS: TEXAS WATER DEVELOPMENT BOARD REPORT 195, V. 1, 1975.

GROUND-WATER RESOURCES OF PART OF CENTRAL TEXAS WITH EMPHASIS ON THE ANTLERS AND TRAVIS PEAK FORMATIONS: TEXAS WATER DEVELOPMENT BOARD REPORT 195, V. 2, 1976.

SUMMARY APPRAISALS OF THE NATION'S GROUND-WATER RESOURCES-TEXAS-GULF REGION: USGS PROFESSIONAL PAPER 813-F, 1976. 
WATER-LEVEL AND WATER-QUALITY DATA FROM OBSERVATION WELLS IN NORTHEAST TEXAS: TEXAS WATER DEVELOPMENT BOARD REPORT 198, 1976.

SPRINGS OF TEXAS, VOLUME 1: (BY GUNNAR BRUNE), BRANCHSMITH, INC., FORT WORTH, TEXAS, 1981.

OCCURRENCE, AVAILABILITY, AND CHEMICAL QUALITY OF GROUND WATER IN THE CRETACEOUS AQUIFERS OF NORTHCENTRAL TEXAS: TEXAS DEPARTMENT OF WATER RESOURCES REPORT 269, V. 1, 1982.

OCCURRENCE, AVAILABILITY, AND CHEMICAL QUALITY OF GROUND WATER IN THE CRETACEOUS AQUIFERS OF NORTHCENTRAL TEXAS: TEXAS DEPARTMENT OF WATER RESOURCES REPORT 269, V. 2, 1982.

TEXAS GROUND-WATER RESOURCES, in NATIONAL WATER SUMMARY 1984: USGS WATER-SUPPLY PAPER 2275, 1985.

WATER USE, PROJECTED WATER REQUIREMENTS, AND RELATED DATA AND INFORMATION FOR THE METROPOLITAN STATISTICAL AREAS IN TEXAS: TEXAS DEPARTMENT OF WATER RESOURCES LIMITED PRINTING REPORT LP-201, 1985.

OCCURRENCE AND QUALITY OF GROUND WATER IN JACK COUNTY, TEXAS: TEXAS WATER DEVELOPMENT BOARD REPORT 308, 1988.

EVALUATION OF WATER RESOURCES IN PART OF NORTH-CENTRAL TEXAS: TEXAS WATER DEVELOPMENT BOARD REPORT 318, 1990.

NATIONAL WATER-QUALITY ASSESSMENT PROGRAM-THE TRINITY RIVER BASIN: USGS OPEN-FILE REPORT 91-158, 1991.

SIMULATION OF GROUND-WATER FLOW IN THE ANTLERS AQUIFER IN SOUTHEASTERN OKLAHOMA AND NORTHEASTERN TEXAS: USGS WATER-RESOURCES INVESTIGATIONS REPORT 88-4208, 1992.

EVALUATION OF WATER RESOURCES IN PARTS OF THE ROLLING PRAIRIES REGION OF NORTH-CENTRAL TEXAS: TEXAS WATER DEVELOPMENT BOARD REPORT 337, 1992.

NATIONAL WATER-QUALITY ASSESSMENT PROGRAM-PESTICIDES IN THE TRINITY RIVER BASIN STUDY UNIT, TEXAS, 1968-91: USGS FACT SHEET FS-088-95, 1995.

WATER-QUALITY ASSESSMENT OF THE TRINITY RIVER BASIN, TEXAS-DATA COLLECTION, 1992-95: USGS FACT SHEET FS-095-95, 1995.

WATER-QUALITY ASSESSMENT OF THE TRINITY RIVER BASIN, TEXAS-PESTICIDES IN A SUBURBAN WATERSHED, ARLINGTON, 1993-94: USGS FACT SHEET FS-159-95, 1995.

AQUIFERS OF TEXAS: TEXAS WATER DEVELOPMENT BOARD REPORT 345, 1995.

UPDATED EVALUATION OF WATER RESOURCES IN PART OF NORTH-CENTRAL TEXAS, 1990-1999: TEXAS WATER DEVELOPMENT BOARD REPORT 349, 1999.

WATER-QUALITY ASSESSMENT OF THE TRINITY RIVER BASIN, TEXAS-GROUND-WATER QUALITY OF THE TRINITY, CARRIZOWILCOX, AND GULF COAST AQUIFERS, FEBRUARY-AUGUST 1994: USGS WATER-RESOURCES INVESTIGATIONS REPORT 99-4233, 2000.

\section{WOOD COUNTY}

UNDERGROUND WATERS OF THE COASTAL PLAIN OF TEXAS: USGS WATER-SUPPLY PAPER 335, 1907.

GEOLOGY AND UNDERGROUND WATERS OF THE SOUTHEASTERN PART OF THE TEXAS COASTAL PLAIN: USGS WATER-SUPPLY PAPER 335, 1914.

RECORDS OF WELLS AND SPRINGS, DRILLERS' LOGS, WATER ANALYSES, AND MAP SHOWING LOCATION OF WELLS AND SPRINGS IN WOOD COUNTY, TEXAS: TEXAS BOARD OF WATER ENGINEERS MISCELLANEOUS PUBLICATION 303, 1942.

GROUND WATER IN THE GLADEWATER-BIG SANDY DISTRICT, TEXAS: USGS OPEN-FILE REPORT (UNNUMBERED), 1942.

PUBLIC WATER SUPPLIES IN EASTERN TEXAS, V. 2, HARRISON COUNTY THROUGH WOOD COUNTY: TEXAS BOARD OF WATER ENGINEERS MISCELLANEOUS PUBLICATION 214, V. 2, 1945.

PUBLIC WATER SUPPLIES IN EASTERN TEXAS: USGS WATERSUPPLY PAPER 1047, 1948.

RECONNAISSANCE INVESTIGATION OF THE GROUND-WATER RESOURCES OF THE RED RIVER, SULPHUR RIVER, AND CYPRESS CREEK BASINS, TEXAS: TEXAS WATER COMMISSION BULLETIN 6306, 1963.

RECONNAISSANCE INVESTIGATION OF THE GROUND-WATER RESOURCES OF THE SABINE RIVER BASIN, TEXAS: TEXAS WATER COMMISSION BULLETIN 6307, 1963.

CITY OF HAWKINS, WOOD COUNTY, TEXAS: TEXAS WATER COMMISSION LIMITED DISTRIBUTION REPORT LD-162-MR, 1963.

GROUND-WATER RESOURCES OF WOOD COUNTY, TEXAS: TEXAS WATER DEVELOPMENT BOARD REPORT 79, 1968.

COMPILATION OF RESULTS OF AQUIFER TESTS IN TEXAS: TEXAS WATER DEVELOPMENT BOARD REPORT 98, 1969.

SUMMARY APPRAISALS OF THE NATION'S GROUND-WATER RESOURCES-TEXAS-GULF REGION: USGS PROFESSIONAL PAPER 813-F, 1976.

WATER-QUALITY DATA FOR AQUIFERS, STREAMS, AND LAKES IN THE VICINITY OF KEECHI, MOUNT SYLVAN, OAKWOOD, AND PALESTINE SALT DOMES, NORTHEAST TEXAS SALT-DOME BASIN: USGS OPEN-FILE REPORT 80-2037, 1980

GEOHYDROLOGY OF THE KEECHI, MOUNT SYLVAN, OAKWOOD, AND PALESTINE SALT DOMES IN THE NORTHEAST TEXAS SALTDOME BASIN: USGS OPEN-FILE REPORT 80-2044, 1980.

GEOLOGY AND GEOHYDROLOGY OF THE EAST TEXAS BASIN-A REPORT ON THE PROGRESS OF NUCLEAR WASTE ISOLATION FEASIBILITY STUDIES (1979): UNIVERSITY OF TEXAS, BUREAU OF ECONOMIC GEOLOGY GEOLOGICAL CIRCULAR 80-12, 1980.

GEOLOGY AND GEOHYDROLOGY OF THE EAST TEXAS BASIN-A REPORT ON THE PROGRESS OF NUCLEAR WASTE ISOLATION FEASIBILITY STUDIES (1980): UNIVERSITY OF TEXAS, BUREAU OF ECONOMIC GEOLOGY GEOLOGICAL CIRCULAR 81-7, 1981.

SPRINGS OF TEXAS, VOLUME 1: (BY GUNNAR BRUNE), BRANCHSMITH, INC., FORT WORTH, TEXAS, 1981.

TEXAS GROUND-WATER RESOURCES, in NATIONAL WATER SUMMARY 1984: USGS WATER-SUPPLY PAPER 2275, 1985. 
WATER USE, PROJECTED WATER REQUIREMENTS, AND RELATED DATA AND INFORMATION FOR THE METROPOLITAN STATISTICAL AREAS IN TEXAS: TEXAS DEPARTMENT OF WATER RESOURCES LIMITED PRINTING REPORT LP-201, 1985.

APPROXIMATE POTENTIOMETRIC SURFACES FOR THE AQUIFERS OF THE TEXAS COASTAL UPLANDS SYSTEM, 1980: USGS HYDROLOGIC INVESTIGATIONS ATLAS HA-704, 1987.

GEOHYDROLOGIC FRAMEWORK OF THE GULF COASTAL PLAIN: USGS HYDROLOGIC INVESTIGATIONS ATLAS HA-695, 1988.

PROPERTIES AND CHEMICAL CONSTITUENTS IN GROUND WATER FROM THE LOWER CLAIBORNE-UPPER WILCOX AQUIFER, GULF COAST REGIONAL AQUIFER SYSTEMS, SOUTH-CENTRAL UNITED STATES: USGS WATER-RESOURCES INVESTIGATIONS REPORT 92-4102, 1993.

PROPERTIES AND CHEMICAL CONSTITUENTS IN GROUND WATER FROM THE MIDDLE WILCOX AQUIFER, GULF COAST AQUIFER SYSTEMS, SOUTH-CENTRAL UNITED STATES: USGS WATERRESOURCES INVESTIGATIONS REPORT 93-4070, 1993.

AQUIFERS OF TEXAS: TEXAS WATER DEVELOPMENT BOARD REPORT 345, 1995.

WATER QUALITY IN THE QUEEN CITY AQUIFER, EAST TEXAS: TEXAS WATER DEVELOPMENT BOARD HYDROLOGIC ATLAS NO. 6, 1996.

\section{YOAKUM COUNTY}

GROUND WATER IN THE HIGH PLAINS IN TEXAS (1940): TEXAS BOARD OF WATER ENGINEERS MISCELLANEOUS PUBLICATION M119, 1940

GROUND WATER IN THE VICINITY OF POWER PLANT OF SOUTHWESTERN PUBLIC SERVICE COMPANY NEAR DENVER CITY, YOAKUM COUNTY, TEXAS: USGS OPEN-FILE REPORT (UNNUMBERED), 1943.

GROUND-WATER CONDITIONS AT SHELL OIL COMPANY GASOLINE PLANT NO. 2, NEAR DENVER CITY, YOAKUM COUNTY, TEXAS: USGS OPEN-FILE REPORT (UNNUMBERED), 1944.

RECORDS OF WELLS, DRILLERS' LOGS, WATER ANALYSES, AND MAP SHOWING LOCATIONS OF WELLS IN YOAKUM COUNTY, TEXAS: TEXAS BOARD OF WATER ENGINEERS MISCELLANEOUS PUBLICATION 304, 1945.

GROUND WATER IN THE HIGH PLAINS IN TEXAS, PROGRESS REPORT (1944): TEXAS BOARD OF WATER ENGINEERS MISCELLANEOUS PUBLICATION M121, 1944.

GROUND WATER IN THE HIGH PLAINS IN TEXAS, PROGRESS REPORT NO. 5: TEXAS BOARD OF WATER ENGINEERS MISCELLANEOUS PUBLICATION M122, 1945.

GROUND WATER IN THE HIGH PLAINS OF TEXAS: USGS WATERSUPPLY PAPER 889-F, 1946.

GROUND WATER IN THE HIGH PLAINS IN TEXAS, PROGRESS REPORT NO. 6: TEXAS BOARD OF WATER ENGINEERS MISCELLANEOUS PUBLICATION M123, 1947.

PUBLIC WATER SUPPLIES IN WESTERN TEXAS: TEXAS BOARD OF WATER ENGINEERS MISCELLANEOUS PUBLICATION 216, 1949.
PUBLIC WATER SUPPLIES IN WESTERN TEXAS: USGS WATERSUPPLY PAPER 1106, 1951 [1952].

WATER-LEVEL DECLINE MAPS, 1956 TO 1957, AND WATER LEVELS IN OBSERVATION WELLS IN 20 COUNTIES IN THE SOUTHERN HIGH PLAINS, TEXAS: TEXAS BOARD OF WATER ENGINEERS BULLETIN 5705, 1957.

WATER-LEVEL MEASUREMENTS AND MAPS, SOUTHERN HIGH PLAINS, TEXAS, 1958 AND 1959: TEXAS BOARD OF WATER ENGINEERS BULLETIN 5908, 1959.

WATER LEVELS IN OBSERVATION WELLS, SOUTHERN HIGH PLAINS, TEXAS, 1959 AND 1960: TEXAS BOARD OF WATER ENGINEERS BULLETIN 6011, 1960.

SHALLOW FORMATIONS AND AQUIFERS OF THE WEST TEXAS AREA: WEST TEXAS GEOLOGICAL SOCIETY PUBLICATION 61-45 AND PERMIAN BASIN GEOPHYSICAL SOCIETY, MIDLAND, TEXAS, 1961.

WATER LEVELS IN OBSERVATION WELLS, SOUTHERN HIGH PLAINS, TEXAS, 1960 AND 1961: TEXAS BOARD OF WATER ENGINEERS BULLETIN 6101, 1961.

A SUMMARY OF THE OCCURRENCE AND DEVELOPMENT OF GROUND WATER IN THE SOUTHERN HIGH PLAINS OF TEXAS: TEXAS BOARD OF WATER ENGINEERS BULLETIN 6107, 1961.

WATER-LEVEL MEASUREMENTS THROUGH 1962 IN SELECTED OBSERVATION WELLS, SOUTHERN HIGH PLAINS, TEXAS: TEXAS WATER COMMISSION BULLETIN 6207, 1962.

A SUMMARY OF THE OCCURRENCE AND DEVELOPMENT OF GROUND WATER IN THE SOUTHERN HIGH PLAINS OF TEXAS: USGS WATER-SUPPLY PAPER 1693, 1964.

WATER-LEVEL DATA FROM OBSERVATION WELLS IN THE SOUTHERN HIGH PLAINS OF TEXAS: TEXAS WATER DEVELOPMENT BOARD REPORT 21, 1966.

RECONNAISSANCE INVESTIGATION OF THE GROUND-WATER RESOURCES OF THE COLORADO RIVER BASIN, TEXAS: TEXAS WATER DEVELOPMENT BOARD REPORT 51, 1967.

GROUND WATER IN THE OGALLALA FORMATION IN THE SOUTHERN HIGH PLAINS OF TEXAS AND NEW MEXICO: USGS HYDROLOGIC INVESTIGATIONS ATLAS HA-330, 1969.

WATER-LEVEL DATA FROM OBSERVATION WELLS IN THE SOUTHERN HIGH PLAINS OF TEXAS, 1956-70: TEXAS WATER DEVELOPMENT BOARD REPORT 121, 1970.

SUMMARY APPRAISALS OF THE NATION'S GROUND-WATER RESOURCES-TEXAS-GULF REGION: USGS PROFESSIONAL PAPER 813-F, 1976.

ANALYTICAL STUDY OF THE OGALLALA AQUIFER IN YOAKUM COUNTY, TEXAS-PROJECTIONS OF SATURATED THICKNESS, VOLUME OF WATER IN STORAGE, PUMPAGE RATES, PUMPING LIFTS, AND WELL YIELDS: TEXAS WATER DEVELOPMENT BOARD REPORT 221, 1978

WATER-LEVEL DATA FROM OBSERVATION WELLS IN THE SOUTHERN HIGH PLAINS OF TEXAS, 1971-77: TEXAS DEPARTMENT OF WATER RESOURCES REPORT 228, 1979.

PRELIMINARY DATA DESCRIBING THE DISTRIBUTION OF FLUORIDE AND SILICA IN THE OGALLALA AQUIFER ON THE HIGH PLAINS OF TEXAS: USGS OPEN-FILE REPORT 80-349, 1980 
EVALUATING THE GROUND-WATER RESOURCES OF THE HIGH PLAINS OF TEXAS: RESULTS OF TEST-HOLE DRILLING: TEXAS DEPARTMENT OF WATER RESOURCES LIMITED PRINTING REPORT LP-129, 1980.

SPRINGS OF TEXAS, VOLUME 1: (BY GUNNAR BRUNE), BRANCHSMITH, INC., FORT WORTH, TEXAS, 1981.

BEDROCK GEOLOGY, ALTITUDE OF BASE, AND 1980 SATURATED THICKNESS OF THE HIGH PLAINS AQUIFER IN PARTS OF COLORADO, KANSAS, NEBRASKA, NEW MEXICO, OKLAHOMA, SOUTH DAKOTA, TEXAS, AND WYOMING: USGS HYDROLOGIC INVESTIGATIONS ATLAS HA-648, 1981.

WATER LEVEL AND SATURATED THICKNESS CHANGES, PREDEVELOPMENT TO 1980, IN THE HIGH PLAINS AQUIFER IN PARTS OF COLORADO, KANSAS, NEBRASKA, NEW MEXICO, OKLAHOMA, SOUTH DAKOTA, TEXAS, AND WYOMING: USGS HYDROLOGIC INVESTIGATIONS ATLAS HA-652, 1981.

DISSOLVED SOLIDS AND SODIUM IN WATER FROM THE HIGH PLAINS AQUIFER IN PARTS OF COLORADO, KANSAS, NEBRASKA, NEW MEXICO, OKLAHOMA, SOUTH DAKOTA, TEXAS, AND WYOMING: USGS HYDROLOGIC INVESTIGATIONS ATLAS HA-658, 1982.

EVALUATING THE GROUND-WATER RESOURCES OF THE HIGH PLAINS OF TEXAS, VOLUME 1: TEXAS DEPARTMENT OF WATER RESOURCES REPORT 288, V. 1, 1984.

EVALUATING THE GROUND-WATER RESOURCES OF THE HIGH PLAINS OF TEXAS, VOLUME 4, RECORDS OF WELLS, AND MAPS SHOWING WELL LOCATIONS, BASE OF AQUIFER, WATER LEVELS, AND SATURATED THICKNESS (ANDREWS, BORDEN, COCHRAN, DAWSON, ECTOR, GAINES, GARZA, GLASSCOCK, HOWARD, HOCKLEY, LUBBOCK, LYNN, MARTIN, MIDLAND, TERRY, AND YOAKUM COUNTIES: TEXAS DEPARTMENT OF WATER RESOURCES REPORT 288 V. 4, 1984.

GEOHYDROLOGY OF THE HIGH PLAINS AQUIFER IN PARTS OF COLORADO, KANSAS, NEBRASKA, NEW MEXICO, OKLAHOMA, SOUTH DAKOTA, TEXAS, AND WYOMING: USGS PROFESSIONAL PAPER 1400-B, 1984.

TEXAS GROUND-WATER RESOURCES, in NATIONAL WATER SUMMARY 1984: USGS WATER-SUPPLY PAPER 2275, 1985.

INVESTIGATION OF THE FEASIBILITY OF SECONDARY RECOVERY OF GROUND WATER FROM THE OGALLALA AQUIFER. A REPORT TO THE 69TH TEXAS LEGISLATURE: TEXAS WATER DEVELOPMENT BOARD LIMITED PRINTING REPORT LP-202, 1985.

DIGITAL SIMULATION OF GROUND-WATER FLOW IN THE HIGH PLAINS AQUIFER IN PARTS OF COLORADO, KANSAS, NEBRASKA, NEW MEXICO, OKLAHOMA, SOUTH DAKOTA, TEXAS, AND WYOMING: USGS PROFESSIONAL PAPER 1400-D, 1986.

SUMMARY OF THE HIGH PLAINS REGIONAL AQUIFER-SYSTEM ANALYSIS IN PARTS OF COLORADO, KANSAS, NEBRASKA, NEW MEXICO, OKLAHOMA, SOUTH DAKOTA, TEXAS, AND WYOMING: USGS PROFESSIONAL PAPER 1400-A, 1988.

HYDROGEOLOGY AND HYDROCHEMISTRY OF CRETACEOUS AQUIFERS, TEXAS PANHANDLE AND EASTERN NEW MEXICO: UNIVERSITY OF TEXAS, BUREAU OF ECONOMIC GEOLOGY GEOLOGICAL CIRCULAR 88-3, 1988.

HYDROGEOLOGY OF LOWER CRETACEOUS STRATA UNDER THE SOUTHERN HIGH PLAINS OF TEXAS AND NEW MEXICO: TEXAS WATER DEVELOPMENT BOARD REPORT 314, 1989.
PUBLIC-SUPPLY GROUND-WATER USE IN THE SOUTHERN HIGH PLAINS OF TEXAS: TEXAS WATER DEVELOPMENT BOARD REPORT 328, 1990.

EVALUATION OF GROUND-WATER RESOURCES IN THE SOUTHERN HIGH PLAINS OF TEXAS: TEXAS WATER DEVELOPMENT BOARD REPORT 330, 1991.

WATER-LEVEL CHANGES IN THE HIGH PLAINS AQUIFER OF TEXAS, 1980-1990: TEXAS WATER DEVELOPMENT BOARD HYDROLOGIC ATLAS NO. 1, 1991.

THE HIGH PLAINS AQUIFER SYSTEM OF TEXAS, 1980 TO 1990. OVERVIEW AND PROJECTIONS: TEXAS WATER DEVELOPMENT BOARD REPORT 341, 1993.

WATER-QUALITY EVALUATION OF THE OGALLALA AQUIFER, TEXAS: TEXAS WATER DEVELOPMENT BOARD REPORT 342, 1993.

WATER-LEVEL CHANGES IN THE HIGH PLAINS AQUIFER, 1980 TO 1994: USGS FACT SHEET FS-215-95, 1995.

AQUIFERS OF TEXAS: TEXAS WATER DEVELOPMENT BOARD REPORT 345, 1995.

WATER-LEVEL CHANGES IN THE HIGH PLAINS AQUIFER, 1980 TO 1995: USGS FACT SHEET FS-068-97, 1997.

WATER-LEVEL CHANGES IN THE HIGH PLAINS AQUIFER-PREDEVELOPMENT TO 1995: USGS WATER-RESOURCES INVESTIGATIONS REPORT 97-4081, 1997.

\section{YOUNG COUNTY}

GEOLOGY AND UNDERGROUND WATERS OF THE WICHITA REGION, NORTH-CENTRAL TEXAS: USGS WATER-SUPPLY PAPER $317,1913$.

PUBLIC WATER SUPPLIES IN CENTRAL AND NORTH-CENTRAL TEXAS: TEXAS BOARD OF WATER ENGINEERS MISCELLANEOUS PUBLICATION 213, 1947.

PUBLIC WATER SUPPLIES IN CENTRAL AND NORTH-CENTRAL TEXAS: USGS WATER-SUPPLY PAPER 1069, 1949.

CONTAMINATION OF SURFACE AND GROUND WATER IN SOUTHEAST YOUNG COUNTY, TEXAS: TEXAS BOARD OF WATER ENGINEERS MISCELLANEOUS PUBLICATION 305, 1956.

RECONNAISSANCE INVESTIGATION OF THE GROUND-WATER RESOURCES OF THE TRINITY RIVER BASIN, TEXAS: TEXAS WATER COMMISSION BULLETIN 6309, 1963.

RECONNAISSANCE INVESTIGATION OF THE GROUND-WATER RESOURCES OF THE BRAZOS RIVER BASIN, TEXAS: TEXAS WATER COMMISSION BULLETIN 6310, 1963.

OCCURRENCE AND QUALITY OF GROUND WATER IN YOUNG COUNTY, TEXAS: TEXAS WATER COMMISSION BULLETIN 6415, 1964.

TEXAS GROUND-WATER RESOURCES, in NATIONAL WATER SUMMARY 1984: USGS WATER-SUPPLY PAPER 2275, 1985.

NATIONAL WATER-QUALITY ASSESSMENT PROGRAM-PESTICIDES IN THE TRINITY RIVER BASIN STUDY UNIT, TEXAS, 1968-91: USGS FACT SHEET FS-088-95, 1995. 
WATER-QUALITY ASSESSMENT OF THE TRINITY RIVER BASIN, TEXAS-DATA COLLECTION, 1992-95: USGS FACT SHEET FS-095-95, 1995.

WATER-QUALITY ASSESSMENT OF THE TRINITY RIVER BASIN, TEXAS-PESTICIDES IN A SUBURBAN WATERSHED, ARLINGTON, 1993-94: USGS FACT SHEET FS-159-95, 1995.

SPRINGS OF TEXAS, VOLUME 1: (BY GUNNAR BRUNE), BRANCHSMITH, INC., FORT WORTH, TEXAS, 1981.

EVALUATION OF WATER RESOURCES IN PARTS OF THE ROLLING PRAIRIES REGION OF NORTH-CENTRAL TEXAS: TEXAS WATER DEVELOPMENT BOARD REPORT 337, 1992.

\section{ZAPATA COUNTY}

UNDERGROUND WATERS OF THE COASTAL PLAIN OF TEXAS: USGS WATER-SUPPLY PAPER 190, 1907.

PUBLIC WATER SUPPLIES IN SOUTHERN TEXAS: TEXAS BOARD OF WATER ENGINEERS MISCELLANEOUS PUBLICATION 215, 1946.

PUBLIC WATER SUPPLIES IN SOUTHERN TEXAS: USGS WATERSUPPLY PAPER 1070, 1950.

RECONNAISSANCE INVESTIGATIONS OF THE GROUND-WATER RESOURCES OF THE RIO GRANDE BASIN, TEXAS: TEXAS WATER COMMISSION BULLETIN 6502, 1965.

RECONNAISSANCE INVESTIGATION OF GROUND WATER IN THE RIO GRANDE DRAINAGE BASIN-WITH SPECIAL EMPHASIS ON SALINE GROUND-WATER RESOURCES: USGS HYDROLOGIC INVESTIGATIONS ATLAS HA-510, 1974.

SUMMARY APPRAISALS OF THE NATION'S GROUND-WATER RESOURCES-TEXAS-GULF REGION: USGS PROFESSIONAL PAPER 813-F, 1976.

STRATIGRAPHIC AND HYDROGEOLOGIC FRAMEWORK OF PART OF THE COASTAL PLAIN OF TEXAS: USGS OPEN-FILE REPORT 77-712, 1978.

STRATIGRAPHIC AND HYDROGEOLOGIC FRAMEWORK OF PART OF THE COASTAL PLAIN OF TEXAS: TEXAS DEPARTMENT OF WATER RESOURCES REPORT 236, 1979.

SPRINGS OF TEXAS, VOLUME 1: (BY GUNNAR BRUNE), BRANCHSMITH, INC., FORT WORTH, TEXAS, 1981.

TEXAS GROUND-WATER RESOURCES, in NATIONAL WATER SUMMARY 1984: USGS WATER-SUPPLY PAPER 2275, 1985.

APPROXIMATE POTENTIOMETRIC SURFACES FOR THE AQUIFERS OF THE TEXAS COASTAL UPLANDS SYSTEM, 1980: USGS HYDROLOGIC INVESTIGATIONS ATLAS HA-704, 1987.

GEOHYDROLOGIC FRAMEWORK OF THE GULF COASTAL PLAIN: USGS HYDROLOGIC INVESTIGATIONS ATLAS HA-695, 1988.

DEPOSITIONAL AND GROUND-WATER FLOW SYSTEMS OF THE CARRIZO-UPPER WILCOX, SOUTH TEXAS: UNIVERSITY OF TEXAS, BUREAU OF ECONOMIC GEOLOGY REPORT OF INVESTIGATIONS NO. 175,1988

HYDROGEOLOGY AND PREDEVELOPMENT FLOW IN THE TEXAS GULF COAST AQUIFER SYSTEMS: USGS WATER-RESOURCES INVESTIGATIONS REPORT 87-4248, 1988.
GROUND-WATER FLOW IN THE GULF COAST AQUIFER SYSTEMS, SOUTH CENTRAL UNITED STATES-A PRELIMINARY ANALYSIS USGS WATER-RESOURCES INVESTIGATIONS REPORT 89-4071, 1990.

NATIONAL WATER-QUALITY ASSESSMENT PROGRAM-THE TRINITY RIVER BASIN: USGS OPEN-FILE REPORT 91-158, 1991.

HYDROLOGY OF THE TEXAS GULF COAST AQUIFER SYSTEMS: USGS OPEN-FILE REPORT 91-64, 1991.

PROPERTIES AND CHEMICAL CONSTITUENTS IN GROUND WATER FROM THE UPPER CLAIBORNE AQUIFER, GULF COAST REGIONAL AQUIFER SYSTEMS, SOUTH-CENTRAL UNITED STATES: USGS WATER-RESOURCES INVESTIGATIONS REPORT 91-4150, 1993.

PROPERTIES AND CHEMICAL CONSTITUENTS IN GROUND WATER FROM THE LOWER CLAIBORNE-UPPER WILCOX AQUIFER, GULF COAST REGIONAL AQUIFER SYSTEMS, SOUTH-CENTRAL UNITED STATES: USGS WATER-RESOURCES INVESTIGATIONS REPORT 92-4102, 1993.

PROPERTIES AND CHEMICAL CONSTITUENTS IN GROUND WATER FROM PERMEABLE ZONE E (LOWER MIOCENE-UPPER OLIGOCENE DEPOSITS), COASTAL LOWLANDS AQUIFER SYSTEM, SOUTH-CENTRAL UNITED STATES: USGS WATER-RESOURCES INVESTIGATIONS REPORT 92-4103, 1993.

PROPERTIES AND CHEMICAL CONSTITUENTS IN GROUND WATER FROM THE MIDDLE CLAIBORNE AQUIFER, GULF COAST REGIONAL AQUIFER SYSTEMS, SOUTH-CENTRAL UNITED STATES: USGS WATER-RESOURCES INVESTIGATIONS REPORT 92-4104, 1993.

PROPERTIES AND CHEMICAL CONSTITUENTS IN GROUND WATER FROM THE MIDDLE WILCOX AQUIFER, GULF COAST REGIONAL AQUIFER SYSTEMS, SOUTH-CENTRAL UNITED STATES: USGS WATER-RESOURCES INVESTIGATIONS REPORT 93-4070, 1993.

AQUIFERS OF TEXAS: TEXAS WATER DEVELOPMENT BOARD REPORT 345, 1995.

\section{ZAVALA COUNTY}

UNDERGROUND WATERS OF COASTAL PLAIN OF TEXAS: USGS WATER-SUPPLY AND IRRIGATION PAPER 190, 1907.

SURVEY OF THE UNDERGROUND WATERS OF TEXAS: USGS PRESS RELEASE, 1931.

GROUND WATER IN THE WINTER GARDEN AND ADJACENT DISTRICTS IN SOUTHWESTERN TEXAS: USGS OPEN-FILE REPORT (UNNUMBERED), 1931

GROUND WATER IN DIMMIT AND ZAVALA COUNTIES, TEXAS: USGS OPEN-FILE REPORT (UNNUMBERED) (PRESS RELEASE), 1934.

RECORDS OF WELLS AND WATER-LEVEL FLUCTUATIONS IN OBSERVATION WELLS IN DIMMIT, ZAVALA, AND EASTERN MAVERICK COUNTIES, TEXAS: USGS OPEN-FILE REPORT (UNNUMBERED), 1934.

WELLS IN WINTER GARDEN DISTRICT IN DIMMIT AND ZAVALA COUNTIES AND EASTERN MAVERICK COUNTY, TEXAS (RECORDS OF WELLS, DRILLERS' LOGS, WATER ANALYSES, 
AND MAPS SHOWING LOCATION OF WELLS): TEXAS BOARD OF WATER ENGINEERS MISCELLANEOUS PUBLICATION 302, 1940.

PUBLIC WATER SUPPLIES IN SOUTHERN TEXAS: TEXAS BOARD OF WATER ENGINEERS MISCELLANEOUS PUBLICATION 215, 1946.

GROUND-WATER CONDITIONS IN WINTER GARDEN DISTRICT, TEXAS: USGS OPEN-FILE REPORT (UNNUMBERED), 1947.

RELATIONSHIP OF GROUND WATER TO THE DISCHARGE OF THE LEONA RIVER IN UVALDE AND ZAVALA COUNTIES, TEXAS: TEXAS BOARD OF WATER ENGINEERS MISCELLANEOUS PUBLICATION 284, 1947.

MEMORANDUM ON TEST FOR SALT WATER LEAK IN CRYSTAL CITY WATER WELLS: USGS OPEN-FILE REPORT (UNNUMBERED), 1948.

PUBLIC WATER SUPPLIES IN SOUTHERN TEXAS: USGS WATERSUPPLY PAPER 1070, 1950.

WINTER GARDEN DISTRICT DIMMIT AND ZAVALA COUNTIES AND EASTERN MAVERICK COUNTY, TEXAS (RECORDS OF WELLS, DRILLERS' LOGS, WATER ANALYSES, AND MAP SHOWING LOCATIONS OF WELLS): TEXAS BOARD OF WATER ENGINEERS BULLETIN 5203, 1952.

RECORDS OF WATER-LEVEL MEASUREMENTS IN DIMMIT, MAVERICK, AND ZAVALA COUNTIES, TEXAS, 1920, 1928 TO SEPTEMBER 1956: TEXAS BOARD OF WATER ENGINEERS BULLETIN 5617, 1956.

GEOLOGY AND GROUND-WATER RESOURCES OF THE WINTER GARDEN DISTRICT, TEXAS: USGS OPEN-FILE REPORT, 1957.

DEVELOPMENT OF GROUND WATER FROM THE CARRIZO SAND AND WILCOX GROUP IN DIMMIT, ZAVALA, MAVERICK, FRIO, ATASCOSA, MEDINA, BEXAR, LIVE OAK, McMULLEN, LA SALLE, AND WEBB COUNTIES, TEXAS: USGS OPEN-FILE REPORT 57-77, 1957.

GEOLOGY AND GROUND-WATER RESOURCES OF DIMMIT COUNTY, TEXAS: TEXAS BOARD OF WATER ENGINEERS BULLETIN 6003, 1960.

RECONNAISSANCE INVESTIGATION OF THE GROUND-WATER RESOURCES OF THE GUADALUPE, SAN ANTONIO, AND NUECES RIVER BASINS, TEXAS: TEXAS WATER COMMISSION BULLETIN 6409, 1964.

RECONNAISSANCE INVESTIGATIONS OF THE GROUND-WATER RESOURCES OF THE RIO GRANDE BASIN, TEXAS: TEXAS WATER COMMISSION BULLETIN 6502, 1965.

WATER-LEVEL DATA FROM OBSERVATION WELLS IN THE NORTHWESTERN GULF COASTAL PLAIN OF TEXAS: TEXAS WATER DEVELOPMENT BOARD REPORT 70, 1968.

HYDROLOGIC SIGNIFICANCE OF THE LITHOFACIES OF THE SPARTA SAND IN ARKANSAS, LOUISIANA, MISSISSIPPI, AND TEXAS: USGS PROFESSIONAL PAPER 569-A, 1968.

COMPILATION OF RESULTS OF AQUIFER TESTS IN TEXAS: TEXAS WATER DEVELOPMENT BOARD REPORT 98, 1969.

HYDROLOGIC SIGNIFICANCE OF LITHOFACIES OF THE CANE RIVER FORMATION OR EQUIVALENTS OF ARKANSAS, LOUISIANA, MISSISSIPPI, AND TEXAS: USGS PROFESSIONAL PAPER 569-C, 1972.

RECONNAISSANCE INVESTIGATION OF GROUND WATER IN THE RIO GRANDE DRAINAGE BASIN-WITH SPECIAL EMPHASIS ON
SALINE GROUND-WATER RESOURCES: USGS HYDROLOGIC INVESTIGATIONS ATLAS HA-510, 1974.

GEOHYDROLOGIC SIGNIFICANCE OF LITHOFACIES OF THE CARRIZO SAND OF ARKANSAS, LOUISIANA, AND TEXAS AND THE MERIDIAN SAND OF MISSISSIPPI: USGS PROFESSIONAL PAPER 569-D, 1975.

MAJOR AND HISTORICAL SPRINGS OF TEXAS: TEXAS WATER DEVELOPMENT BOARD REPORT 189, 1975.

GROUND-WATER RESOURCES OF THE CARRIZO AQUIFER IN THE WINTER GARDEN AREA OF TEXAS, VOLUME 1: TEXAS WATER DEVELOPMENT BOARD REPORT 210, V. 1, 1976.

GROUND-WATER RESOURCES OF THE CARRIZO AQUIFER IN THE WINTER GARDEN AREA OF TEXAS, VOLUME 2: TEXAS WATER DEVELOPMENT BOARD REPORT 210, V. 2, 1977.

VARIATIONS IN SPECIFIC YIELD IN THE OUTCROP OF THE CARRIZO SAND IN SOUTH TEXAS AS ESTIMATED BY SEISMIC REFRACTION: TEXAS DEPARTMENT OF WATER RESOURCES REPORT 229, 1979.

HYDROCHEMICAL DATA FOR THE EDWARDS AQUIFER IN THE SAN ANTONIO AREA, TEXAS: TEXAS DEPARTMENT OF WATER RESOURCES LIMITED-PRINTING REPORT LP-131, 1980.

SPRINGS OF TEXAS, VOLUME 1: (BY GUNNAR BRUNE), BRANCHSMITH, INC., FORT WORTH, TEXAS, 1981.

STRUCTURE, TEMPERATURE, PRESSURE, AND SALINITY OF CENOZOIC AQUIFERS OF SOUTH TEXAS: USGS HYDROLOGIC INVESTIGATIONS ATLAS HA-654, 1983.

TEXAS GROUND-WATER RESOURCES, in NATIONAL WATER SUMMARY 1984: USGS WATER-SUPPLY PAPER 2275, 1985.

APPROXIMATE POTENTIOMETRIC SURFACES FOR THE AQUIFERS OF THE TEXAS COASTAL UPLANDS SYSTEM, 1980: USGS HYDROLOGIC INVESTIGATIONS ATLAS HA-704, 1987.

GEOHYDROLOGIC FRAMEWORK OF THE GULF COASTAL PLAIN: USGS HYDROLOGIC INVESTIGATIONS ATLAS HA-695, 1988.

HYDROGEOLOGY AND PREDEVELOPMENT FLOW IN THE TEXAS GULF COAST AQUIFER SYSTEMS: USGS WATER-RESOURCES INVESTIGATIONS REPORT 87-4248, 1988.

GROUND-WATER FLOW IN THE GULF COAST AQUIFER SYSTEMS, SOUTH-CENTRAL UNITED STATES-A PRELIMINARY ANALYSIS: USGS WATER-RESOURCES INVESTIGATIONS REPORT 89-4071, 1990.

HYDROLOGY OF THE TEXAS GULF COAST AQUIFER SYSTEMS: USGS OPEN-FILE REPORT 91-64, 1991.

EVALUATION OF THE GROUND-WATER RESOURCES IN THE WESTERN PORTION OF THE WINTER GARDEN AREA, TEXAS: TEXAS WATER DEVELOPMENT BOARD REPORT 334, 1991.

GROUND-WATER QUALITY MONITORING RESULTS IN THE WINTER GARDEN AREA, 1990: TEXAS WATER DEVELOPMENT BOARD REPORT 335, 1992.

PROPERTIES AND CHEMICAL CONSTITUENTS IN GROUND WATER FROM THE LOWER CLAIBORNE-UPPER WILCOX AQUIFER, GULF COAST REGIONAL AQUIFER SYSTEMS, SOUTH-CENTRAL UNITED STATES: USGS WATER-RESOURCES INVESTIGATIONS REPORT 92-4102, 1993. 
PROPERTIES AND CHEMICAL CONSTITUENTS IN GROUND-WATER FROM THE MIDDLE CLAIBORNE AQUIFER, GULF COAST REGIONAL AQUIFER SYSTEMS, SOUTH-CENTRAL UNITED STATES: USGS WATER-RESOURCES INVESTIGATIONS REPORT 92-4104, 1993.

PROPERTIES AND CHEMICAL CONSTITUENTS IN GROUND WATER FROM THE MIDDLE WILCOX AQUIFER, GULF COAST REGIONAL AQUIFER SYSTEMS, SOUTH-CENTRAL UNITED STATES: USGS WATER-RESOURCES INVESTIGATIONS REPORT 93-4070, 1993.

DEFINING THE EDWARDS AQUIFER FRESHWATER/SALINE-WATER INTERFACE WITH GEOPHYSICAL LOGS AND MEASURED DATA (SAN ANTONIO TO KYLE, TEXAS): EDWARDS UNDERGROUND WATER DISTRICT REPORT 93-06, 1993.

1994 REVIEW AND UPDATE OF THE POSITION OF THE EDWARDS AQUIFER FRESHWATER/SALINE-WATER INTERFACE FROM UVALDE TO KYLE, TEXAS: EDWARDS UNDERGROUND WATER DISTRICT REPORT 94-05, 1994.
REGIONAL DISTRIBUTION OF PERMEABILITY IN THE EDWARDS AQUIFER: EDWARDS UNDERGROUND WATER DISTRICT REPORT 95-02, 1995.

AQUIFERS OF TEXAS: TEXAS WATER DEVELOPMENT BOARD REPORT 345, 1995.

EDWARDS AQUIFER GROUND-WATER RESOURCES: GEOLOGIC CONTROLS ON POROSITY DEVELOPMENT IN PLATFORM CARBONATES, SOUTH TEXAS: UNIVERSITY OF TEXAS, BUREAU OF ECONOMIC GEOLOGY REPORT OF INVESTIGATIONS NO. 238, 1996.

HYDROGEOLOGIC FRAMEWORK AND GEOCHEMISTRY OF THE EDWARDS AQUIFER SALINE-WATER ZONE, SOUTH-CENTRAL TEXAS: USGS WATER-RESOURCES INVESTIGATIONS REPORT 97-4133, 1997.

WATER QUALITY IN SOUTH-CENTRAL TEXAS-TEXAS, 1996-98: USGS CIRCULAR 1212, 2000. 
Prepared by the USGS Texas Water Science Center:

8027 Exchange Drive

Austin, TX 78754-4733

Information regarding water resources in Texas is available at http: //tx.usgs.gov/ 